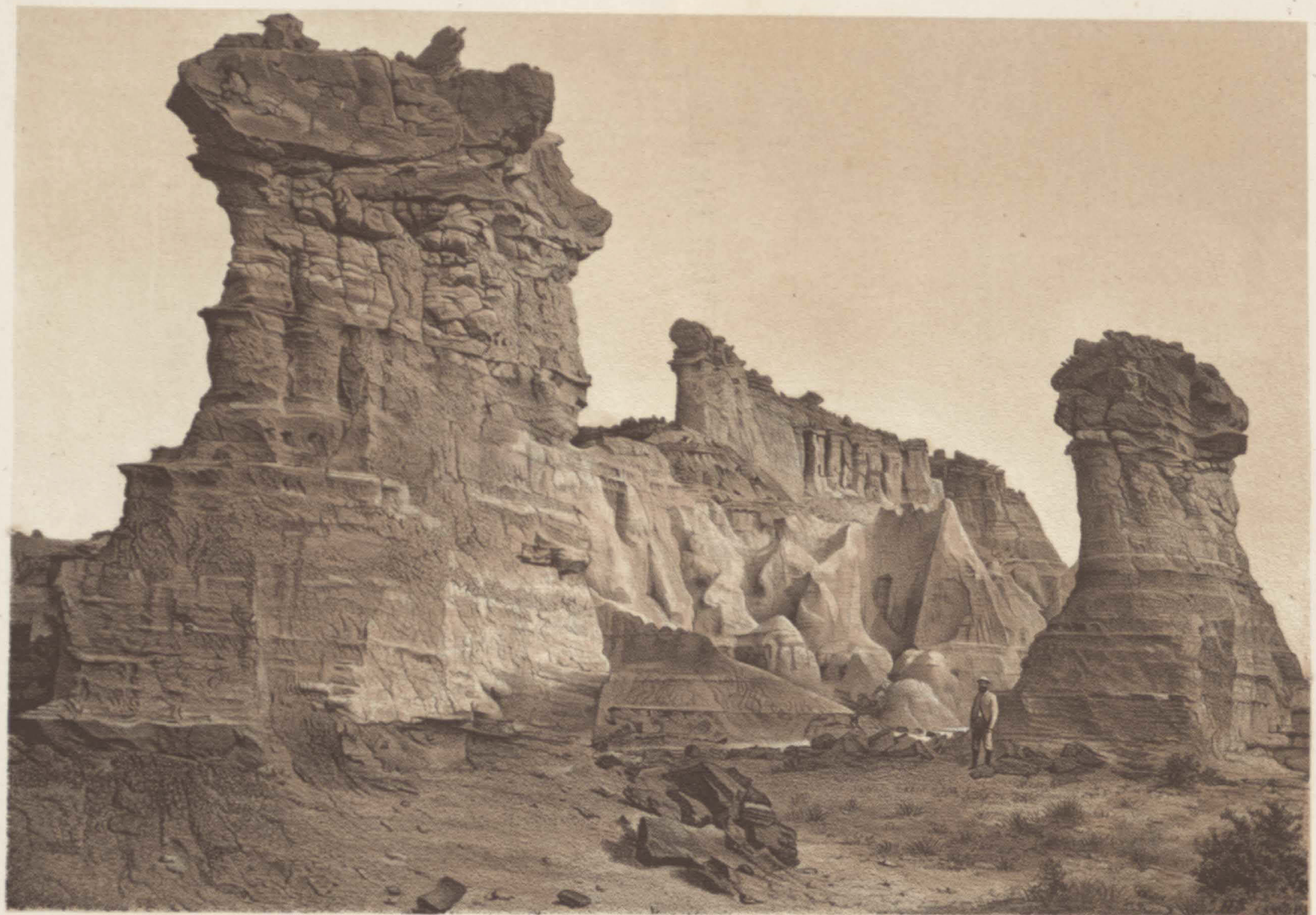




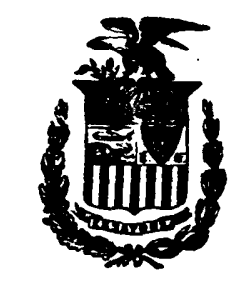

PROFESSIONAL PAPERS OF THE ENGINEER DEPARTMENT, U. S. ARMY. No. 18.

REPORT

OF THE

\section{GEOLOGICAL EXPLORATION OF THE FORTIETH PARALLEL MADE}

BY ORDER OF THE SECRETARY OF WAR ACCORDING TO ACTS OF CONGRESS OF MARCH 2, 1867, AND MARCH 3, 1869,

UNDER THE DIRECTION OF

BRIG. AND BVT. MAJOR GENERAL A. A. IIUMPHREYS, CHIEF OF ENGINEERS,

BY

CLARENCE KING.

U. S. GEOLOGIST.

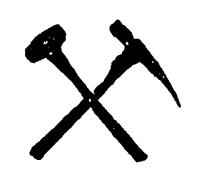


VOLUME II.

EI-IV 
UNITED STA'TES GIOLOGICAL EXPLORATION OF THE FORTIETH PARALLEL.

CLARENCE KING, GEOL.CGIST-IN-CHARGE.

\title{
DESCRIPTIVE GEOLOGY.
}

BY

\author{
ARNOLD HAGUE AND S. F. EMMONS. \\ SUBMITTED TO THE CHIEF OF RNGINEERS AND PUBLISHED BY ORDER OF THE SECBETART OP \\ WAR UNDER AUTHORITY OF CONGRESS.
}

ILLUSTRATED BY XXVI PLATES.

WASH I NGTON:

GOVERNMENT PRINTING OFFIOE.

1877 .

$$
\mathbf{v - v i}
$$




\section{TABLE OF CONTENTS.}

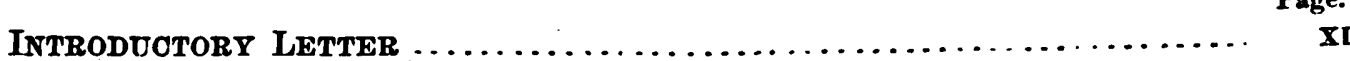

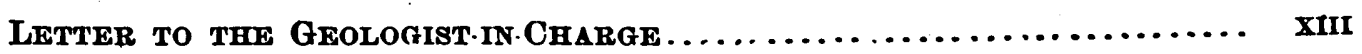

Chapter I. Rocky Mountains ............................... 1

Section I. Colorado Range. By ariold Hague...... 2

II. Laramie Plains. By arnold hague...... 73

III. Medicine Bow Range. By ariold hague... 94

IV. North Park. By ARNuld HagUe ........ 112

$\checkmark$. Park Range. By arnold Hague .......... 130

Vi. Cretaceous Region from como to Separa. TION. BY ARNOLD HAGUE.............. 142

VII. West of North Platte. By S. F. Emmons ... 156

VIII. Elkhead Mountains. By S. F. Emmons ...... 167

IX. VALleys of THE Yampa aND LTTTLE SNake

RIVERS. BY S. F. EMmons............... 181

Chapter II. Green River Basin. By S. F. Emmons............... 191

Section I. Physical Description................. 191

II. Generat Grology..................... 198

III. Descriptive GeOLOGX OF THE BASIN REgION.. 207

IV. Descriptive Geology OF THE MOUNTAN

REGTON.......................... 254

V. Terturies of the Utnta Valley ........ 307

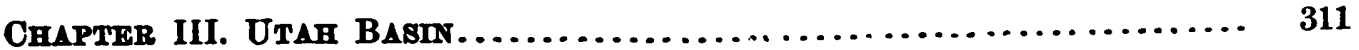

Sigotion I. Westrebe Uinta Range. By S. F. Emmons . 311

II. From Aspen to Echo City. By S. F. Emonons. 326

III. WaHsatch RaNGe. BY S. F. Emons...... 340

IV. NORTHERN WAHSATCH RegION. BY ARNOLD HAGUE $\ldots \ldots \ldots \ldots \ldots \ldots \ldots \ldots \ldots \ldots . . . \ldots \ldots$

V. REgion North of SALt LAKE. BY ARNold HAGUE $\ldots \ldots \ldots \ldots \ldots \ldots \ldots \ldots \ldots \ldots \ldots \ldots \ldots, 420$

VI. LAKE REgIon. BY S. F. EmMons ......... 431

VII. REgIon south of SALt Lake. BY S. F. Emmons .......................... 443

VIII. Desert Region. By S. F. Emmons ........ 462 


\section{Fifth Avenue, New York, January, 1877.}

SIR: We have the honor to present herewith our report upon the Descriptive Geology of the region examined during the years 1867 to 1873 .

The material has been treated under five general chapters, corresponding to the five geological maps of the Atlas, and proceeding, like them, from east to west. We each have written upon those regions with which we were most familiar, but, as our field-observations have not always been entirely independent, we have at times been obliged to use each other's notes, while always availing ourselves freely of your own fieldnotes and suggestions.

It will be readily understood by the reader, from the very title of the work, that this does not claim to be a systematic survey like those of Europe, based on accurate maps, but is rather a geological reconnaissance in an unknown and often unexplored region, where geology and topography had to go hand in hand, and that therefore, while details were often, from the necessities of the case, somewhat neglected, it was the general bearing of the leading geological facts that was most constantly in our minds.

In closing thus an official connection of ten years' duration, we cannot refrain from expressing our many obligations to you, not only for your advice and assistance in our early work, and your general supervision, but more especially for the unwearying kindness and consideration which have characterized your intercourse with us, often under circumstances rendered peculiarly trying to the patience by the obstacles which nature opposed to the successful accomplishment of the work you had so boldly planned.

Sincerely yours,

S. F. EMMONS.

ARNOLD HAGUE.

\section{Clarence King,}




\section{CHAP'TER I. ROCKY MOUNTAINS.}

Section I. COLORado Range-Physical aspech of the Great PlainsPhysical descrip'tion of the larame Hills-Archand geologyPhysical description of the Colorado archanan body-GeologyEASTERN FOOT-HILIs-PaLAfozoIC Formations-Triassio Formation-JUrassic Formation-Dakota Crhtaceous-Colorado Cretaceous-Descrip. TIVA GEOLOGY OF THE EASTERN FOOT-HILLS-CRETACEOUS PLAINS OF COLORADO-TERTIARY PLAINS OF WYOMING.

Section II.-LARAMIE PLAINS-Physical Description-General GeologyCOMO ANTICLINAL.

SECTION III.-MEDICINE BOW RANGE-PhYSICAL DESCRIPTION-GEOLOGICAL DESCRIPTION-CONCLUSIONS.

Section IV.-NORTH PARK-Physical Description-PaL fozoic and Mesozoig FORMATIONS-VOLCANIC ROCKS-TERTIARY BEDS.

SECTION V.-PARK RANGE-Physical DFscription-GEOlogical DESCRIPTION.

SECTION VI.-CRETACEOUS REGION FROM COMO TO SEPARATION-VAL. LEY of THE Medicine Bow River-Carbon Basin-Elk Mountain RegionValley of the North Platte River.

Section VII.-WEST OF NORTH PLATTE RIVER-Bridger's Pass Regionrawlings Peak uplift-Savory Plateau region.

SECTION VIII.-ELKUEAD MOUNTAINS-General DESCRIPTION-TRACHYTiC REGION-BASALTIC REGION.

ShCtion IX.-VALleys of The Yampa aNd Iattle SNake Rivers.

$1 \mathrm{DG}$ 


\author{
SECTION I. \\ COLORADO RANGE.
}

BY ARNOLD HAGUE.

Physical Aspect of the Great Plains.-To the eastward of the first range of the Rocky Mountains, the Great Plains stretch for several hundred miles, with gentle easy slopes, toward the Mississippi Valley. By reference to Map I, accompanying the report of the Geological Exploration of the Fortieth Parallel, it will be seen that the eastern boundary of the survey lies along the meridian of $104^{\circ} 30^{\prime}$ west from Greenwich, extending out upon the Great Plains only 30 to 55 miles beyond the foot-hills of the Colorado Range, so that only a comparatively narrow strip comes within the limits of our observation. To the eye, they present either a level, plateau-like country, or a broad, gently undulating surface, relieved only by low, smooth ridges, with abrupt bluffs along main drainage-channels, usually in an east and west course; or the ends of long horizontal table-lands, with escarpments from one to two hundred feet above the plain below.

Twenty miles from the base of the range, the slope is scarcely perceptible, and only within short distances of the foot-hills is the fall in any place very marked.

Between the mouth of Big Thompson Cañon, where the stream leaves the mountains, and the town of Evans, near the junction of the creek with the South Platte, there is a fall of about 600 feet in 20 miles, an average of 30 feet per mile, which represents very closely the slope of the plain in Northern Colorado.

In the region of Horse Creek, in Wyoming, 80 miles to the northward, and opposite the central portion of the Laramie Hills, the slope is shown, by barometric measurements, to fall off in 22 miles, 775 feet, or an average of 35 feet per mile. Taking the grade of the Union Pacific Railroad, which may fairly be regarded as indicating the rise of the land toward the mountains, it shows between Sydney, in Nebraska, and Cheyenne, a distance of 100 miles, an increase in elevation of nearly 2,000 feet, or 20 feet per mile. 
From Cheyenne westward, the grade becomes much more rapid, and between that town and Granite Cañon, which lies well up on the mountains on the Archæan rocks, a distance in a direct line of 18 miles, we have a rise of 70 feet to the mile; this, however, can hardly be regarded as giving the correct slope of the plains, owing to the position of Granite Cañon, which lies several hundred feet above what, in the other measurements, was considered the base of the range.

In a north and south line, the rise and fall in elevation is nearly as great, but is at the same time so gradual, and the configuration of the country such, that the nature of the slope is by no means so well recognized. Between Crow Creek and Horse Creek, about 30 miles to the northward, on the meridian of Cheyenne the plains have an average altitude of nearly 6,000 feet above sea-level, but fall off steadily in both directions. To the southward from Cheyenne the country slopes off, until at Evans near the lower boundary of the map, a distance of 52 miles in a direct line, the height above the sea is only 4,745 feet, a descent of 1,330 feet, or orer 25 feet per mile. North of Horse Creek, the slope is steadily to the northward, the descent being nearly 1,000 feet to the North Platte River, a fow miles beyond the upper limit of our map.

Numerous streams from the mountains between the Laramie River and the Big Thompson Creek, reaching ultimately the North Platte or South Platte River, cross the plains within the belt of our survey; but few of them, however, are of any considerable size. Along the elevated plateau already mentioned, the streams have a general east and west course, while to the north of Horse Creek and south of Crow Creek, conforming to the general configuration of the country, they run either northeast or southeast. These streams have cut for themselves, through the loose, friable sandstone formation, broad valleys of great uniformity of character and monotony of aspect, frequently 4 and 5 miles in width, but rarely depressed more than 100 or 200 feet below the general surface, although hemmed in by precipitous walls, sometimes several miles in length, without any marked break in their cliffs.

Although the Great Plains present but few striking physical features, in the detailed outlines they show great variety of form in the rounded 
hills and knolls and depressed basins and valleys, which evince a considerable amount of denudation in recent times. They are entirely destitute of any growth of trees, except in a few favorable localities, such as the more sheltered positions on the Chalk Bluffs, and along some of the larger water-courses, as the Cache la Poudre and Chugwater.

The characteristic features of the plain country extend, as already suggested, close up to the base of the Colorado Range, whose foot-hills rise up in a very abrupt and marked manner, presenting an exceedingly diversified physical and geological aspect of upturned sedimentary beds lying between the monotonous nearly level country to the eastward and the rugged central mass of the range.

Before proceeding with a description of the foot-lills and their relations to the later formations, a short discussion will be given of the leading topographical and geological features of the main mountain-range, or rather that portion of it that falls within the limits of our map.

Physical Description of the Laramie Hillos.-Several designations lave been given to the different groups of elevation making up the great mountain-chain which forms the eastern rim of the Cordilleras, and extends from New Mexico to the northern limits of the United States.

To that relatively depressed portion lying mostly within the limits of the 41 st and $42 \mathrm{~d}$ parallels of north latitude, the name Laramie Hills has been applied. Their natural boundary to the north is the Laramie River, which, after running northward through the Laramie Plains, turns somewhat abruptly, arrd breaks through the chain a few miles beyond the line of the map of the Fortieth Parallel Survey, while, to the southward, the North Fork of the Cache la Poudre may be considered their limit, giving them a length of about 80 miles and a width varying from 14 to 18 miles.

In their topographical features, the Laramie Hills present marked contrasts to the rugged groups both to the north and south, forming, as they do, a low mass between two higher members of the great chain. Their summit forms, in its general outline, a broad, undulating platean, with rounded, easy-sloping ridges falling away gradually to the eastward; the higher portion of the hills being invariably the western edge.

The average altitude of this broad summit varies from 7,800 to 8,300 
feet above sea-level, while rising above this height are but few prominent points, with probably only one that attains 9,000 feet.

Among the chief elevations are Sanders Peak, just north of the Cheyenne Pass wagon-road, and on the extreme western edge of the hills, 9,077 feet; Central Peak, 8,774 feet, about 5 miles in a northeast direction from the town of Sherman; Arrow Peak, 8,683 feet, at the head of the Chugwater; Sherman, a bleak, dreary summit-station, has an elevation of 8,271 feet, and is the highest point along the line of the railroad between the Missouri River and San Francisco.

The drainage from the Laramie Hills is all eastward. Six principal streams carry the waters from the mountains out on to the plains to the Platte Rivers; the Sybille, Chugwater, and Horse Creeks running into the North Platte, while the Lodge Pole, Crow, and Lone Tree contribute to the South Platte. In addition, two small streams, Dale and Box Elder Creeks, run southward and join the Cache la Poudre: the former, rising near Sherman on the western side of the hills, falls into the main stream before leaving the mountains; while the latter, on the eastern side, flows through a valley in the upturned Palæozoic strata on the flanks of the mountains, then turns breaking through the beds, and runs in a southeast course, until it joins the Cache la Poudre 8 or 9 miles out on the Great Plains. It is an interesting fact that no streams whatever run westward on to the Laramie Plains, although a few small springs near the base of the hills furnish a scanty supply of water.

Between the Chugwater and Crow Creeks lies the most elevated portions of the mountain mass. The cañons or valleys all trend eastward, similar in form, with gentle slopes, and many side-valleys supplying tributary streams. The divides between the streams are usually rounded ridges, broken by innumerable small hills and knolls of granite, giving a diversified and picturesque scenery, but by no means grand or rugged. To the north of the Chugwater, the plateau-like summit falls off gradually toward the Laramie River, and, for 3 or 4 miles before reaching the stream, becomes very much broken up, and loses its former character. To the south of Crow Creek, or rather to the south of the Pacific Railroad, the hills again fall away toward the Cache la Poudre, but gently, presenting 
broad table-like country, with here and there a few landmarks that have escaped erosion, rising above the general level for 400 or 500 feet. Signal Peak, near the head of Box Elder Creek, which presents a commanding view of the southern portion of the Laramie Hills and of the Colorado Range, is a characteristic point.

On the summit of the range, tree growth is very limited, although, over the entire area, there are on the slopes of the hills and under the shelter of the larger rocks many small groves of pine, sufficient to make the view picturesque, but not enough to be of much practical importance. In a few localities in the larger sheltered basins of Crow, Lodge Pole, and Horse Creeks are considerable bodies of good timber, but possessing no great vigor of growth. Saw-mills have been erected in one or two localities on Crow Creek. Aspen-groves add to the beauty of some of the upper basins. The streams are all too narrow to afford any good bottom-lands, and the only attempts at cultivation are one or two small ranches on Dale Creek.

In geological structure, the Laramie Hills form a single anticlinal range, one of the most marked to be found within the limits of this survey.

Its central mass, a heavy body of metamorphic granites and granitoid rocks of Archæan age, forms the axis, while on the flanks, dipping both east and west away from the range, rest heavy rock masses of sandstone and limestone of Palæozoic age.

These later beds, lying unconformably upon the older granites, are seen way up on the sides of the range, at altitudes higher than the old crystalline bodies. Nowhere over the entire area of the Laramie Hills are there any remnants or patches left standing of the Palæozoic beds; but there can be but little doubt that they formerly passed over the top and formed continuous strata. On the west slope of the mountains the Palæozoic beds present a somewhat monotonous, uniform, unbroken body in a north and south line, along the entire slope down to the Laramie Plains. The highest inclination of the beds observed was $10^{\circ}$; the lowest, $4^{\circ}$.

Upon the east side the contrast is quite marked, and, the diversity in occurrence as striking as is the uniformity on the opposite side. The continuity of the strata is frequently broken, the beds occasionally not appearing 
above the fresh-water Pliocene strata of the Great Plains. Again, the beds are observed in places as low hills, with gently-inclined strata; at others, they are carried up in abrupt, bold ridges, the inclination of the beds varying from a nearly horizontal position to abrupt walls standing quite vertical.

As seen just south of Wahlbach Spring, on the Cheyenne Pass road, they appear nearly horizontal, having been elevated nearly 1,000 feet above the plains, while immediately north of the main stream of the Chugwater they stand out, in curiously-moulded ridges with beautifully-curved outlines, at $88^{\circ}$, and at one locality pass the vertical position. What may be said in detailed description of the structural relations of the sandstone and limestone beds is deferred till after the discussion of the Archæan bodies, and are only mentioned here to give a general outline of their bearing upon the great mass of highly crystalline rocks that really make up the range. By reference to the upper section at the bottom of Geological Map I, eastern half, the structure may be seen. The section crosses the Laramie Hills in an east and west line, passes just north of Wahlbach Spring through Sanders Peak, and cuts the plain near Laramie City.

ARChæan Geoloły.-The Archæan rocks of the Laramie Hills, whilo presenting a considerable variety in texture and physical appearance, may nearly all be classed under granites, gneiss, mica- and hornblende-schists; and, of these, granites cover much the largest area. They probably belong to the very oldest rocks observed on the survey of the 40th parallel, and may be placed with but little hesitation in the Laurentian series; their petrographical structure, combined with certain lithological and mineralogical characters, strongly indicate, if they do not clearly establish, an equivalent age with the metamorphic granitoid rocks developed in Canada, New York, and Northern Europe.

This Archæan series consists of a central body of coarse-grained granite, made up of quartz, feldspar, and mica, but apparently with little structure. Above the latter, and forming the outer edges, dipping east and west away from the main mass, occurs a hard, compact, heavily-bedded series of reddish granitoid rocks composed of quartz and feldspar. At the north and south ends of the range, the granites gradually pass into a laminated structure, and the rock-masses become well-defined gneisses and schists. As already indicated, 
the central granites are. made up of coarsely crystalline material: their color is white or reddish-gray. Quartz and feldspars are the predominant minerals, while the amount of mica present is very variable, and in those localities where found abundantly gives, of course, a darker color to the rock. The quartz is granular, usually of a gray color, frequently colorless and translucent. The feldspars give the prevailing color to the granites. Both orthoclase and plagioclase are present, but the former is much more abundant. The orthoclase occurs in broad, tabular crystals, from microscopical forms up to those measuring one and a half inches in length; the larger crystals having usually a decidedly reddish tinge. The mica is most frequently found as a brilliant, dark biotite in small plates, and in the whiter granites quite well preserved.

In addition to the well-defined, essential minerals mentioned, the narrow crevices and fissures in the granite and the spaces between the crystalline particles seemed filled with a reddish, decomposed, hydrated oxide of iron. Owing to the coarse and friable nature of the granite, with the interstices occupied by a sort of ferruginous material, decomposition takes place easily ; and, where this latter ingredient is at all common, the disintegration proceeds with striking rapidity until the surface of the rock is protected from atmospheric agencies by a heavy layer of detrital matter, frequently to a depth of two or three feet. The ease with which this granite crumbles could be well observed, a few years ago, by studying the fresh railroadcuts and the surfaces of the ground that had been recently exposed by the workmen removing the coarse gravel for the purposes of the railroad-bed. This disintegration gives a marked character to the hills, and has left masses of rock that have withstood erosion, but carved in the most curious forms, which present rounded edges and a conchoidal weathering, with no angular fragments or blocks. Many of these masses have received names, such as Skull Rock, The Tower, Lighthouse Rock, from their supposed resemblance to the objects named.

There are many. localities in the central granite mass which differ somewhat from the above description; localities where the body of the rock is more compact and finer-grained, with no large feldspar crystals. In places, there appears to be a gradual transition from the coarser- to the 
finer-grained, while at others the change is quite sudden. In some localities, while the rock is still to be classed as a granite, it shows more or less tendency to a gneissic structure, particularly where the mica is abundant. The body of granite which extends to the eastward, and forms an outlying mass to the main range just north of the Chugwater, is more compact in character than the larger mass, although similar in its general features. Just north of the limits of the map, and north of the main stream of the Sybille, is another similar body of compact granite, rough and rugged in topographical character. So far as a somewhat hasty study of these granites in the field indicates, hornblende appears rarely to be a prominent ingredient, and only one or two localities were observed where this may be said to be the case; one on a small tributary of the North Fork of Crow Creek, and a second on Horse Creek, about two miles above the point where the stream breaks through the Palæozoic strata.

The granitoid rocks which form the flanks of the Archæan body of the Laramie Hills present many distinct features in contrast with the central granite. They are a compact, massive, and distinctly-bedded series of rock, composed of quartz and feldspar in small crystals, with but little if any mica. In color they are all dark with varying shades of gray and red. The rock is usually tough, breaking into sharp angular fragments, with but little disintegration, and withstanding atmospheric agencies much better than the central nucleus. These outer granites do not form a clearly-defined continuous body along the entire sides of the range. In some localities they appear to be wanting, and in others they form an intermediate rock between the two characteristic types, with the mineralogical composition of the outer beds, but with a physical habit somewhat resembling the older masses. On the east side of the range, they occur near Lone Tree Creek. They are well developed at Granite Cañon on the line of the railroad, and may be traced to Crow Creek. They are also well shown in the neighborhood of Horse Creek. On the west side of the range they may be followed for a long distance, where they form a low ridge extending northward from near the head of Dale Creek, and underlying Sanders Peak.

At the railroad-cut near Granite Canon, these rocks are well exhibited, and may be taken as typical of the series. They are exceedingly compact, 
of a decidedly reddish color, and composed of a granular, gray and red quartz, and small tabular crystals of red feldspar. The feldspars are chiefly monoclinic; the triclinic crystals, when observable by the unaided eye, are quite small. Biotite is rather more frequent than in most of the localities; it occurs in small black plates, and appears to be segregated in spots, while portions of the hand-specimens are macroscopically entirely free from it. There is also present a second variety of dark mica, which Professor Zirkel has determined by means of the microscope, to be allied to lepidomelane. Under the microscope, Professor Zirkel has shown that the quartz crystals carry liquid-inclusions, while several of them hold saturated salt-solutions, with fine cubic crystals of chloride of sodium. The quartz also contains fine laminæ of mica, so minute that fifteen hundred of them were estimated to be present in a space of one square millimetre. The feldspars also inclosed both quartz and mica.

On the west side of the range, near the head of Dale Creek, and about five miles northwest from Sherman, nearly identical rocks-occur. They have, perhaps, a somewhat more intensely red color, due to the ferruginous material in the interstices. The quartz grains have finely-colored varied shades of red, while the mica is not so prominent an ingredient. A chemical analysis of the two rocks shows a very marked similarity. The analyses were made by Mr. R. W. Woodward.

No. 1 is from the east side of the range. No. 2 is from the west side. Specific gravity in both cases is 2.6 .

\begin{tabular}{|c|c|c|}
\hline Silica $\ldots \ldots \ldots \ldots \ldots \ldots$ & $\begin{array}{l}\text { No. } 1 . \\
74.74\end{array}$ & $\begin{array}{l}\text { No. } 2 . \\
76.61\end{array}$ \\
\hline Alumina $. \ldots \ldots, \ldots, \ldots, \ldots, \ldots, \ldots$ & 12.06 & 12.45 \\
\hline Ferric oxide.... & 3.25 & 1.33 \\
\hline Lime ....... & 0.88 & 0.84 \\
\hline Soda........ . & 3.33 & 3.12 \\
\hline Potassa ..... & 5.32 & 5.42 \\
\hline Lithia . . . . . . . . . . . . & trace & trace \\
\hline Phosphoric acid $\ldots \ldots \ldots \ldots \ldots \ldots \ldots$ & trace & trace \\
\hline \multirow[t]{2}{*}{ Loss by ignition $\ldots \ldots \ldots \ldots \ldots \ldots \ldots$} & 0.61 & 0.53 \\
\hline & 100.19 & 100.30 \\
\hline
\end{tabular}


The low percentage in lime is quite remarkable. It would indicate that the triclinic feldspars cannot be either anorthite or labradorite. By the detection under the microscope of apatite in most of the Archæan rocks, and the presence of phosphoric acid in the specimens chemically examined, it would seem conclusive that at least a portion of the lime is present in the form of phosphate of lime.

Near the upper streams of the Chugwater, the granites gradually assume a laminated appearance, and pass into well-defined gneiss and schist. The minerals arrange themselves in thin parallel bands, or layers, which, however, are constantly subjected to alteration. In many places, this parallelism is best observed by studying the rock-formations at a distance. On the north side of the upper branch of the Sybille Creek, large heavily-bedded masses of a dark hornblende-gneiss form the cañon-walls. It is a fine-grained rock of quartz and light-colored feldspars, with fibrous hornblende as the predominant constituent. This rock forms a distinct feature of the gneissic beds of the north end of the Laramie Hills. To the south of the central granite body, as already mentioned, gneissic formations occur, and east of Signal Peak identical hornblende-gneisses make their appearance, and give the character to the east side of the range in the region of Lone Tree and Box Elder Creeks; they have a decided dip to the east, and nearly a north and south trend. The prevailing rock, however, is a pearl-gray gneiss with the minerals arranged in irregular, parallel zones, which pass imperceptibly into a granitoid rock, but always retaining more or less of the stratified arrangernent of the minerals. These granitoid masses appear to be interstratified between layers of gneiss.

A specimen from Signal Peak is a typical rock from this region. A compact, fine-grained, fresh-looking mass of gray quartz and light-colored orthoclase- and plagioclase-feldspars, with the mica mostly in very fine laminæ, in knots and bunches. Under the micrascope, minute zircons have been detected, and a chlorite-like mineral, which appears to replace the mica. Very similar rocks form the broad table between Dale and Deadman's Creeks, with the mica, however, somewhat more abundant. All these gneissic rocks present, in general, great uniformity of lithological structure; 
the zones and bands of minerals seem but little disturbed or twisted in comparison with the beds found to the south in the Colorado Range.

At Dale Creek, near the railroad-bridge, there occurs a granite mass, which, from its peculiar habit and contrast with the ordinary granites of the range, deserves special mention. It forms the cañon-walls of Dale Creek, which, at this point, rise abruptly for 125 feet above the stream-bed. It is a very coarse-grained, but compact rock, with an intensely deep red color. The component minerals are chiefly broad tabular crystals of orthoclase, with white and gray vitreous quartz, which seems to occupy the interstices between the feldspars. The mica is of a dull black color, similar to that observed in the granite from Granite Cañon, which has been referred to lepidomelane. Under the microscope, triclinic feldspars have been detected, and the quartz shown to contain but few liquid-inclusions. This granite develops no structural lines or divisional planes, and the minerals are brought together without any observable order in their association with each other. In contrast with the prevailing granite of the central nucleus, this one withstands the action of the weather remarkably well, and has been used to some extent for building purposes. The railroad-company quarried it in massive blocks for the piers of their bridge over Dale Creek. A similar granite, although somewhat finer-grained, occurs in the Adirondacks, near Boonville, Lewis County, New York.

At Iron Mountain, just north of Chugwater Creek, the granite is of interest, from its association with a large body of ilmenite. It forms the walls of the intercalated iron bed, while frequently large masses occur protruding into the iron, and almost completely surrounded by the heavy mineral. It is essentially an orthoclase-granite, with a few triclinic feldspars. The quartz occurs in small grains, well disseminated through the rock. Biotite in brilliant dark plates is much more abundant than is usually the case in the fine-grained granites of the Laramie Hills. It is a true granite, without any distinct evidence of structural lines. 
The following analysis was made by Mr. R. W. Woodward. Specific gravity, 2.6.

Silica.............................. 71.54

Alumina ............................... 15.04

Ferric oxide ........................... $\quad 2.45$

Lime............................. $\quad 1.40$

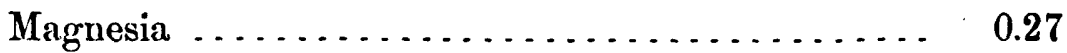

Soda ............................... $\quad 3.15$

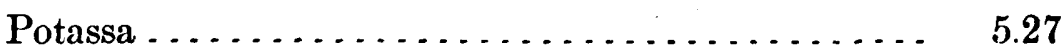

Lithia ............................. trace

Phosphoric acid ........................ 0.07

Loss by ignition...................... 0.90

100.04

The main chemical differences between this variety from Iron Mountain, and those previously given, is that the former stands a little lower in silica, with a corresponding increase in bases, and the presence of some magnesia, due to the biotite.

Among the highly crystalline rocks of this Archæan series is an interesting variety of gabbro, a rock the esssential ingredients of which are labradorite and diallage. Its presence in the Laramio Hills, so far as observed, is limited to the region east of Iron Mountain and of Chugwater and Horse Creeks, where it forms low, irregular-shaped domes and knolls, protruding through the granitoid rocks, which here show considerable variety in lithological habit. The gabbro is of a bluish-gray color derived from the prevailing labradorite crystals, which form by far the largest part of the mass, much of it appearing like a coarse granular feldspar, but for the finely-disseminated diallage. Much of the Iabradorite occurs in large broad crystals, two or three inches in length, the cleavage-surfaces presenting a lighly vitreous lustre. The play of color belonging to labradorite is quite brilliant, and the characteristic strix of triclinic feldspars frequently very well developed. The larger and well-defined crystals show a tendency to arrange themselves in parallel layers. Yollowish-green diallage is scattered through the feldspar, but it occasionally forms thin layers and seams. As 
accessory minerals there occur sparingly in the gabbro minute plates of yellowish-white mica, usually associated with the diallage. Ilmenite and magnetic iron are present in rounded grains; these are frequently decomposed on the surface, and give the rock a somewhat mottled appearance.

Under the microscope, the labradorite crystals show in a striking manner many of the minute structural peculiarities observed in the labradorites of the Scandinavian and German gabbros. For a detailed comparison of these resemblances, see Professor Zirkel's report, page 108 . In its mineralogical and chemical features, as well as in its geological occurrence, this gabbro bears a very close analogy to rocks described by Scheerer ${ }^{1}$ from Anabel and Hitteröe Islands and other localities in Norway.

Rocks with nearly the same habit have been mentioned as occurring in the Laurentian series of Canada by the geological survey of that country. A chemical analysis of the Iron Mountain gabbro, made by Dr. Wiedermann, in Leipsic, seems to indicate clearly that but little diallage can be present. It has nearly the composition of pure labradorite.

Below are given two analyses, for the purpose of comparison (No. 1, the Laramie Hills gabbro; No. 2, a rock described by Dr. T. Sterry Hunt ${ }^{2}$ under the name of labradorite, from Château Richer, in Canada):

\begin{tabular}{|c|c|}
\hline Silica . . . . . . . . . . . . . & $\begin{array}{l}\text { No. } 1 . \\
52.14\end{array}$ \\
\hline Alumina. . . . . . . . . . . . . . . & 29.17 \\
\hline Ferric oxide $\ldots \ldots \ldots \ldots \ldots \ldots \ldots$ & 3.26 \\
\hline $\operatorname{Lim} \theta \ldots \ldots \ldots \ldots \ldots \ldots \ldots \ldots$ & 10.81 \\
\hline Magnesia .................. & 0.76 \\
\hline Soda $\ldots \ldots \ldots \ldots \ldots \ldots \ldots$ & 3.02 \\
\hline Potassa $\ldots \ldots \ldots \ldots \ldots \ldots$ & 0.98 \\
\hline \multirow[t]{2}{*}{ Loss by ignition $. . . \ldots \ldots \ldots \ldots . . . .}$. & 0.58 \\
\hline & 100.72 \\
\hline
\end{tabular}

Iron Mountain, to which reference has already been made, is a mass of titaniferous iron, or ilmenite, and is situated just north of the Chugwater Creek, about $1 \frac{1}{2}$ miles above the point where the stream leaves the hills.

${ }^{1}$ Scheerer, Neues Jahrbuch für Mineralogie, 1843, 668.

2 Geological Survey of Canada, 1863, 478. 
The mountain rises about 600 feet above the stream-bed, is irregular in form, but has a somewhat oval-shaped outline. It occurs intercalated in the granite, standing nearly vertical, with the walls in places sharply defined; this is the case in the cañon, where the dark iron body resembles a broad dike, which rises to the top of the cañon-wall. Frequently large masscs of granite are nearly encased in the iron, and again the iron body puts out into the surrounding granite. The main deposit of iron is nearly a quarter of a mile in length, with a strike a little to the west of north and east of south. To the north the main deposit terminates somewhat abruptly; but southward it crosses the cañon, and may be traced cropping out through the granitoid rocks with the same general strike for nearly 2 miles, in the direction of Pebble Creek. These outcrops vary much in size, mostly mere narrow seams, and small irregular patches of iron, which disappear in the surrounding granite. St:ll farther to the south, just above Horse Creek, considerable deposits again make their appearance, but much smaller than Iron Mountain, and, like the latter, have been held for valuable mineral bodies; they are probably only a continuation of the larger one. The ilmenite occurs chiefly as a compact massive deposit, iron-black in color, with a submetallic lustre. It is frequently found, however, with a coarse granular structure. It is accompanied by small amounts of magnetite and hematite, which decompose and give portions of the mass a brownish-red appearance. Prof. O. D. Allen, of Yale College, examined specimens of the Iron Mountain ore, and found it to contain a mixture of ferrous and ferric oxide, which gave 50.83 per cent. of metallic iron, combined with 23.32 per cent. of titanic acid. Other samples of the ore, analyzed by Professor Richards, of the Institute of Technology in Boston, gave the following results:

Ferrous oxide........................ 24.55

Ferric oxide . . . . . . . . . . . . . . . . . . 48.97

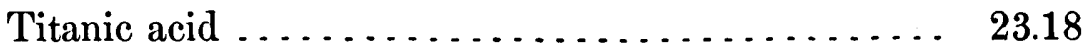

Sulphur. . . . . . . . . . . . . . . . . . . . . . $\quad 0.03$

Residue insoluble in acid ............... 2.15

Metallic iron..................... 53.33 
Samples of the coarse granular variety, collected from the deposits south of Iron Mountain, yielded Mr. R. W. Woodward the following:

Metallic iron ......................... 34.29

Titanic acid $\ldots \ldots \ldots \ldots \ldots \ldots \ldots \ldots \ldots \ldots, 49.47$

All the samples examined gave a very high, although a varying, amount of titanio acid.

This high percentage of so refractory a substance as titanic acid renders the vast deposits of iron of but little use for practical purposes in ironsmelting, which is to be regretted, as the beds in the Laramie Hills could be easily mined, and are so well located in reference to a market, and the known sources of iron in Wyoming are so limited.

The titanic-iron deposits of Canada and Norway would appear to possess very much of the same general characters, with equally varying amounts of titanic acid in their composition. An analysis of a specimen from Krageröe in Norway ${ }^{1}$ gave as high as 46.92 per cent. in titanic acid, and Dr. T. Sterry Hunt ${ }^{2}$ found 48.60 per cent. from similarly-situated beds at Bay Saint Paul, Canada. The ilmenite from Château Richer gave, titanic acid, 39.86 per cent.

This occurrence of ilmenite and gabbro, so intimately associated together in Laurentian rocks in widely-separated parts of the globe, each with the same physical habits, and, in the case of the gabbros of Wyoming and Norway, with the same minute microscopical structure and peculiarities, is most remarkable, and the causes evidently deep-seated.

Another mineral, graphite, common to the Laurentian series, is found on the west side of the hills in considerable quantities, in thin beds and seams. Two varieties are known: one a compact, hard mineral, made up of laminæ of graphite scales, and finely-disseminated pyrites in thin plates, which gives a bronze color to the mineral; it is very friable, and the pyrites on exposure undergoes a partial decomposition. A sample yielded 27 per cent. of iron-pyrites, rendering the graphite too impure to be of any economic value. The second variety crumbles easily to a fine granular powder, is iron-gray in color, and occurs mixed with fine quartz sand, which gives it somewhat the appearance of magnetic sand; the pure powder,

\footnotetext{
${ }^{1}$ Daua's Mineralogy, 1868, $145 . \quad{ }^{2}$ Geological Surrey of Canada, 1863, 501.
} 
however, is black, and unctuous to the touch : it contains but little ironpyrites. Deposits of sufficient size to be worked are said to occur, if the mineral were only of the requisite purity. The following analysis is by Mr. R. W. Woodward:

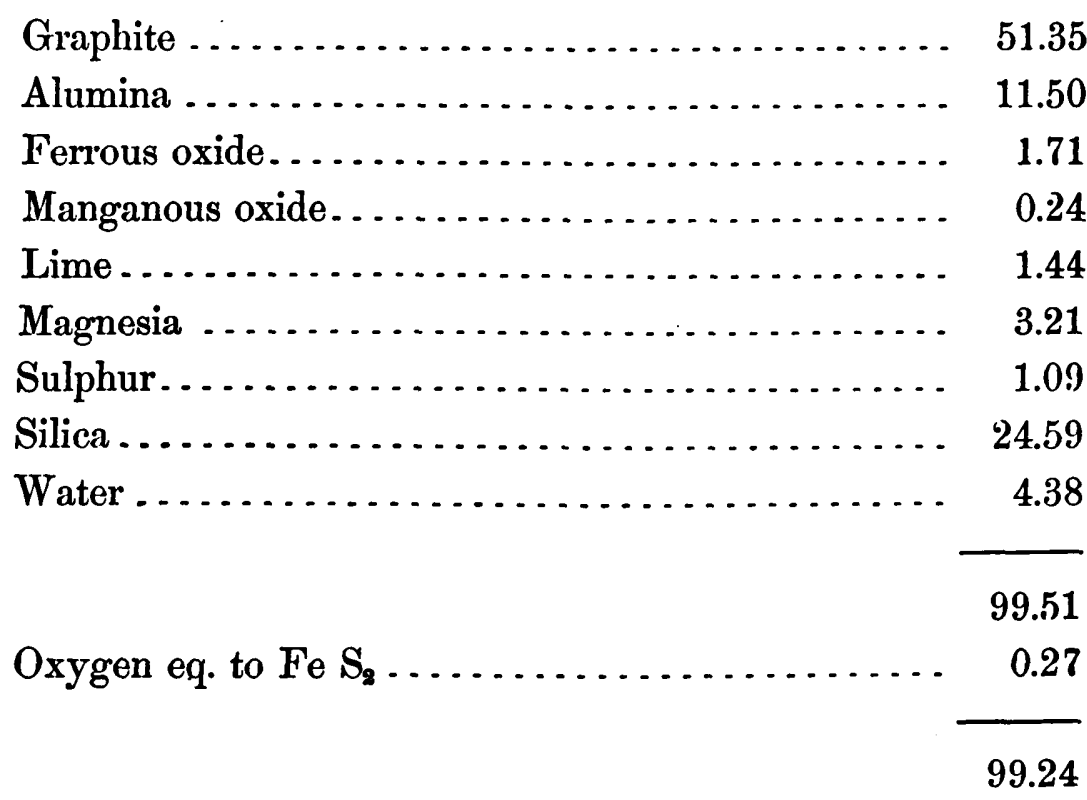

Besides the larger rock masses already mentioned, the hills are characterized by the presence of certain mineralogical features, and accidental minerals, which are developed more or less throughout their entire length, and are of importance in comparing the relations of the Laramie Hills with other well-defined Archæan ranges. Narrow veins of white vitreous or milky quartz are common, penetrating the granites, rarely more than a few inches in width, with a strike almost always a few degrees west of north, although there are some exceptions to this rule. Usually the quartz is quite pure, with the exception of small amounts of ferruginous minerals. Small quantities of compact yellowish-green epidote accompany the quartz, usually occurring on the side of veins or seams; it is never very abundant. It occurs on South Crow Creek, near where the road from Sherman crosses the cañon, and again on the plateau summit west of Iron Mountain. Magnetite and ilmenite also accompany the quartz veins in small, granular fragments, and may be traced for consid $2 \mathrm{D} \mathrm{G}$ 
erable distances. They also occur in the granitoid rocks. Medium-sized, irregular crystals of dark iron-garnets were observed in the coarse granite, while small red garnets occur in the gneissic strata near Signal Peak, and again near the head of the Sybille Cañon; both localities in the immediate neighborhood of observed hornblendic gneisses. Iron-pyrites occur, as already mentioned, in the graphite beds, and were observed in a narrow vein associated with quartz and the iron minerals. Although but little has been accomplished in the careful study of the field, it may be stated that the Archæan series of the Laramie Hills affords no very great variety in mineral species as compared with many localities of the same age. It may be well, however, to give, in a concise form, the species observed. The following are the essential minerals of the larger rock masses: Quartz, orthoclase, oligoclase, labradorite, biotite, muscovite, chlorite, hornblende, and diallage. As accessory minerals, there occur magnetite, ilmenite, graphite, pyrites, garnet, and epidote. Under the microscope were detected lepidomelane, zircon, and apatite. Large bodies of eruptive granites, such as have been observed in the Colorado Range to the south, probably do not occur in the Laramie Hills; indeed, the presence of eruptive rocks, younger than the Archæan, such as the porphyries, diabases, and diorites, were nowhere observed, and, if present, will most likely be found in the form of narrow dikes.

This is also true of the more recent volcanic rocks. Indeed, from the Laramie River southward, none of the volcanic rocks occur, either in the mountains or along the east flank of the range, within the limits of the survey. The first outbursts seen going southward are the well-known dikes of basalt at Valmont on Boulder Creek in Colorado, which break through the Cretaceous beds. At a short distance farther to the south occur the horizontal basaltic beds, capping the same strata near Golden City.

Physical Description of the Colorado Archanan Body.-But a small portion of the Colorado Range south of the Laramie Hills comes within the explorations of this survey, the southern boundary of the field-work not extending beyond the region of Long's Peak, about the line of $40^{\circ}$ $15^{\prime}$ of north latitude. It embraces then only about 30 miles in a north 
and south extension along the axis, but with the entire width of the range, which may vary from 25 to 30 miles.

Proceeding southward from the northern tributaries of the Cache la Poudre, the physical characters rapidly change, and offer very striking contrasts to the Laramie Hills. The mountains are higher, broader, more deeply cut by cañons, with greater diversity of outlines, and in every way built up on far grander proportions. They may be divided into three natural groups of mountain masses: the southernmost, the highest, and one of the grandest in the entire range, culminates in Long's Peak, (14,297 feet;) while between the waters of the Big Thompson and the Cache la Poudre lies the Hague's Peak (13,832 feet) group; and to the north and northwest of the latter stream is the somewhat lower, but broad, rugged region, with Monitor Peak (11,270 feet) as the highest point.

The trend of the culminating peaks, although somewhat irregular, is, in general, a few degrees west of north and east of south, showing a tendency to strike in the line of the Medicine Bow Range. The main summit lies some 20 or 25 miles back from the eastern face, presenting long slopes toward the Great Plains, with the western side much shortened, seldom more than 8 or 10 miles in width. On the eastern slope of the mountains, in the neighborhood of the alpine summits, the fall for the upper 2,000 or 3,000 feet, is generally quite abrupt, presenting grand escarpments, the walls of glacial-worn basins, which farther down become deep glacial cañons. But from the timber-line down to the Plains, the slope, although rough and diversified, may be said to be gradual and unbroken by any marked physical changes. Portions of the ridges between the deep cañons afford a gently rolling country, and others have a plateau-like character. Occasionally, there are open glades and sheltered valleys which have been designated parks.

Estes' Park, a very picturesque spot, north of Long's Peak, and cut through by the southern line of the map, is the best known, and probably the finest example. It lies 7,300 feet above sea-level; is 2 or 3 miles in length, by as many broad, althongh very irregular in outline. A fine stream, a tributary of the Big Thompson, runs through the bottom. The 
surface is undulating, dotted over with rounded knolls of granite, covered with pines.

Small lakes from one-half to one mile in length are characteristic of the upper mountain region. There are several in the neighborhood of Estes' Park, also in the region of the headwaters of the Big Thompson Cañon, and in the bottom of the larger eroded basins. The west side of the divide is much shorter, with the trough-shaped valleys cut deeply into the mountain-sides, stretching down to the interesting middle region between the Colorado and Medicine Bow Ranges. These ridges are generally narrower and sharper, with the rocks dipping steeper than on the opposite side.

This depressed middle region between the two great ranges is from 5 to 7 miles in width, a gently rolling country with a plateau-like character, that is on the summit between Hague's Peak and Mount Richthofen in the Medicine Bow Range, but to the north and south it soon passes into the broad glacial valleys of the Grand River and the Cache la Poudre.

Two principal streams, the Cache la Poudre and the Big Thompson, drain nearly all this entire portion of the Colorado Range.

The main branch of the Cache la Poudre rises on the west slope of Hague's Peak, runs northward between the two great ranges already mentioned, and just south of the line of $40^{\circ} 45^{\prime}$, making a great bend flows eastward; it is then joined by the South Fork, which comes down from the northeast side of the same peak, and carries much of the water of the eastern slope into the larger stream. A few miles farther down the river, it is joined by the North Fork, which, with its numerous lesser branches, including Fish and Sportsman's Creeks, drains the northern district. The resulting stream leaves the range just above the town of Laporte, runs southwesterly, and joins the South Platte near Greeley, 25 miles out on the plains.

A much narrower area is drained by the Big Thompson. Two main branches, the one rising on the east slope of Hague's Peak and the other in the Long's Peak Group, furnish channels for all the remaining waters of the higher summits. Soon after they unite, and just before leaving the mountains, the stream is joinc:d by Redstone Creek, a considerable tributary from the north, which drains the foot-hills left by the South Cache la Poudre. The Big 
Thompson also empties into the South Platte about 10 miles above the Cache la Poudre.

Most of the waters from Long's Peak, however, drain into the Saint Vrain's Creek, branches of which nearly encircle it on all sides.

A vigorous growth of coniferous forests, including several species, among them Pinus ponderosa and Abies Engclmanni, cover the greater part of the long eastern slopes. In the region of Monitor Peak and the broad level country to the north, reaching nearly to the Laramie Plains, the forests are quite dense, and have furnished large supplies of timber in the form of railroad-ties.

The limit of timber growth from Long's Peak northward may be placed at 11,000 feet above sea-level, although there doubtless are a few exposed localities where it does not quite reach that elevation.

GEoLOGY.-The main geological features of the Laramie Hills continue southward along the Colorado Range, which consists of an elevation of highly crystalline rocks of Archæan age, flanked by a series of later sandstones and limestones. In the latter case, however, the sedimentary beds occupy a much inferior position than they do to.the north. They seldom appear along the flanks of the foot-hills higher than 500 or 600 feet above the Plains, while the Archæan formation rises more than as many thousand feet, and occupies the broad area between the Plains and the Medicine Bow Range.

But while this higher region presents many points of resemblance with the Laramie Hills, the structure is in detail so much more complicated that a very considerable time would be required to work out with any degree of accuracy the stratigraphical relations of the different beds. The task would also be increased from the fact that all structural lines are frequently wanting, or difficult to follow, over many extended areas. It may be said, however, although with considerable hesitation owing to the limited observations in the field, that, in its general structure, this portion of the range presents a broad anticlinal axis, accompanied by many secondary folds and plications of strata between the summit and foot-hills. Although there are localities of westerly dipping beds along the east slope, they are usually quite steep, with the appearance of being limited in extent, while by far 
the greater number of observed dips was to the eastward. All the beds near the summit, where observed, seemed inclined at a low angle to the eastward. It may be stated that beds were noted dipping at all angles, from a few degrees above the horizontal up to $70^{\circ}$ or $80^{\circ}$. Where these high dips were seen, the strata were usually finely laminated dark schistose rocks.

No case of decided non-conformity was remarked in the entire series of beds, and their comparatively uniform character would indicate that they belonged only to one division of the Archæan rocks; while, from their similarity to other localities, they may be, without much doubt, referred to the Laurentian.

The rocks of the Calorado Range are almost exclusively made up of a series of crystalline, highly-metamorphosed granites, gneisses, micaschists, and sparingly of hornblende-schists, of varying lithological habit, but great uniformity of constituent minerals. The granites are made up chiefly of grayish-white granular quartz, rarely in large masses or crystals, orthoclase-feldspars, both red and white, some triclinic feldspars, but in very subordinate amounts, and particles of black mica, which, although never abundant, is most always present. In their plysical characters, the granites vary considerably in color, texture, compactness, and in their tendency to develop more or less of a parallel arrangement of their minerals, and to assume a gneissoid structure. Few localities would seem to offer a better field for the study of the gradual transitions from massive granites to welldefined gneissic schists, thinly laminated, and with a distinct bedding. Frequently, these gneissoid bodies will appear as lenticular masses, and as intercalated beds in the great granitic masses. On the other hand, the gneissic rocks will contain irregular zones and knobs of coarse granite. The rapid transition from the one to the other would appear to be of rare occurrence, except in the case of thin beds of mica-schists and slates in the massive granites. There are many rock masses in which the bedding is very indistinct, but which, nevertheless, show, in the quartz, feldspar, and mica, a tendency to arrange themselves in parallel bands.

The region of Long's Peak is a favorable one for the study of both the massive granites and those with a slightly-banded structure, but which must 
still be considered as granites. The granite of the summit is a typical one. It occurs inclined to the east at a low angle. It is coarse crystalline rock, of a light gray color and somewhat friable texture. Quartz and orthoclase-feldspar are the prevailing minerals; triclinic feldspars are rare and quite small. The quartz is of a dirty grayish-white color, while the orthoclase is pearl-gray, with a highly vitreous lustre. The mica is not abundant, but appears to be biotite in brilliant dark plates scattered through the rock, occurring in small segregated bunches and in minute scales adhering to the broad faces of the orthoclase crystals. Under the microscope, Professor Zirkel has detected, both in the quartz and feldspar crystals, long prismatic needles, which, from their crystallographic properties, he determined to be tremolite, although, to the unaided eye, no hornblende is visible. Apatite was also observed microscopically, and the quartz crystals carry fluid-inclusions. The same rock was examined chemically by Mr. R. W Woodward with the following results:

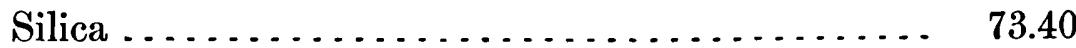

Alumina.............................. 14.53

Ferrous oxide $\ldots \ldots \ldots \ldots \ldots \ldots \ldots \ldots \ldots \ldots . . . \ldots .2 .25$

Lime . . . . . . . . . . . . . . . . . . . . . . . . 0.62

Magnesia ........................... 0.56

Soda............................. 2.63

Potassa ....................... 5.35

Lithia . . . . . . . . . . . . . . . . . . . . . . trace

Phosphoric acid ................... 0.22

Water ... . . . . . . . . . . . . . . . . . . . . . . 0.53

100.09

Specific gravity, 2.61, 2.77.

'This analysis is interesting, from the close resemblance to the analyses of the Archæan granites of the Laramie Hills, which is the more striking, as they differ from most of the granites in the ranges to the westward. The detection of phosphoric acid in sufficient quantity for estimation would indicate that the determination of microscopical apatite was a correct one, and 
that the mineral was well disseminated in this eastern Archæan upheaval. The low percentage in lime points to the conclusion that the triclinic feldspars are not labradorite.

The arrangement in parallel bands of the quartz and feldspar, already mentioned, is shown in this rock; it is, however, much better seen at a short distance in the field than in a hand-specimen. The rock appears to have undergone some movement since the formation of the bands, as the feldspars seemed curved and contorted, and frequently pressed together.

On the west side of Long's Peak, there occur beds of very coarse granite, the quartz of which seems segregated in large masses, accompanied by the other minerals in subordinate quantities. The feldspar also occurs in large, irregular-shaped bodies, when it is ordinarily white, with a pearly lustre. The mica present is also in segregated patches. There are also dikes, of what is sometimes called graphic granite, where the feldspar in massive form predominates, and has the quartz disseminated through it in small crystalline particles, which present the appearance of hieroglyphic figures and symbols. The associated mica is dark brown. Northward, on the lower flanks of the peak, rocks with a prevailing gneissic structure, and the mineral constituents finer-grained, are well developed. In the deeply-cut glacier-cañons of the higher portions of the peak are found excellent opportunities for observing many striking features of the metamorphosed strata; one, especially, on the east side, presenting a mural face nearly 3,000 feet high. Thin beds of compact, finely-laminated dark mica-slates, intercalated in the lighter granitoid beds, occur on the west flanks of the mountain, the prevailing constituent of which is mica, associated with quartz and feldspar. Under the microscope, large quantities of apatite prisms are detected, while in the quartz are thin plates, which Professor Zirkel has determined as muscovite. The regions of Estes' Park, the North Branch of the Big Thompson, and along the road leading from the Park to the Plains, is chiefly made up of coarse granular granite, with but little mica, and the feldspars for the greater part light reddish orthoclase.

Of the rocks in one or two other localities, special mention may be made.

The region drained by Sportsman's and Fish Creeks and the North 
Fork of the Cache la Poudre has, in general, a uniform lithological habit. It is a coarse granular, easily-crumbling granite. The prevailing color of the quartz is gray, while the feldspars, chiefly orthoclase, are in some localities white, and in others deep red. The mica is almost always biotite, but in varying proportions; in some localities, it seems nearly wanting. This region, as a whole, resembles, in many respects, the central granite of the Laramie Hills.

Northwest from the head of Sportsman's Creek, and south of the Laramie Plains, is a considerable body of granite, which, in some particulars, differs from the granite just described. It is more compact, more uniform in composition, with a larger proportion of mica, without the tendency to gneissic structure. The rock, in mass, is darker in color, and somewhat resembles the granites from Sheep Mountain in the Medicine Bow Range. Near the eastern base of the range, north of the Cache la Poudre, and east of Park's Station, stands quite a prominent hill of massive granite, compact in texture, and devoid of gneissic structure; it bears a close resemblance to the last-mentioned granite.

Mica-schists and slates occur in narrow beds, similar to the one already mentioned, interstratified in granites and gneisses: they occur also in a more massive form in a number of localities along the foot-hills of the range, and to the north, high up in the mountains. In the cañon of the Cache la Poudre, near the great bend, where it first cuts deeply into the beds, the walls are built up with heavy beds of dark, close-grained micaschists. On Dale Creek, there are schistose, laminated beds, standing nearly vertical. An interesting locality for the slates is to be found near the entrance to the Big Thompson Cañon, where they may be traced for a considerable distance in a north and south line. They are a very fine-grained admixture of quartz, feldspar, and mica, with a decidedly slaty cleavage. Under the microscope may be detected fine flakes of muscovite, as in the schist from Long's Peak.

Narrow dikes of intrusive rocks penetrate the Archæan series of this region. They appear, however, to be limited in extent, and to have caused but little topographical and geological change in the great surface features of the range. None were observed more than 10 or 15 feet in width; their 
general strike being north and south, with a tendency to the west of north and east of south. Those observed were chiefly feldspar- and quartz-porphyries, with both a coarse- and fine-grained groundmass. A typical feldspar-porphyry cuts the Archæan series, on the west side of Long's Peak. It is made up of a compact crystalline groundmass of feldspar, quartz, and hornblende, with all the constituent minerals present porphyritically enclosed. Both orthoclase and plagioclase are present, the former, however, most prominent. The hornblende occurs in short, fibrous, green prisms, while the quartz is in small, round grains. $\Lambda$ s an accidental mineral, a small quantity of white mica may be detected associated with quartz. Under the microscope, liquid-inclusions are seen, both in the quartz and orthoclase. Professor Zirkel has called attention to the differences in form between the inclusions in the quartz and those of the feldspar; while in the former they are chiefly globular, in the latter they are very irregular in outline. Other dikes occur, darker in color, and more basic, doubtless from the greater amount of hornblende present in the groundmass. The occurrence of hornblende, abundant in these intrusive porphyries, is of interest, as it appears to be an exceptional mineral in the Archæan beds here. Narrow veins of pure quartz traverse the range in a number of localities, but, so far as known, none of any economic value have as yet been found, although so abundant and rich in mineral species in Central Colorado. Dark iron-garnets occur somewhat sparingly, disseminated in the more schistose beds. They were observed on the upper part of Fish Creek in mica-bearing strata, and again near the mouth of Dale Creek. Magnetite, in small irregular particles, was seen in a number of localities; while it probably may be found scattered through all the beds, it was observed more frequently in the coarser-grained granites.

EASTERN FOOT-HILLS.-The sedimentary rocks which form the outlying ridges and foot-hills of the east side of the Colorado Range are made up of Palæozoic and Mesozoic strata, containing both sandstone and limestone beds. They form a very marked physical and geological feature, a narrow border region, lying between the massive Archæan rocks on the one side, and the broad level plains of the Upper Cretaceous series of Colorado and the nearly horizontal Pliocene Tertiary series of Wyoming on the other. 
In relation to the broad, elevated range of mountains, they appear to to occupy a very insignificant area, seldom rising more than 500 or 600 feet above their base in Colorado, and 1,000 feet in Wyoming; but from the Great Plains, looking westward, they rise so abruptly and with such considerable diversity of outline and structure, that the effect is very striking. This narrow region, bordering the Archæean rocks, varies in width from onehalf mile to ten miles, depending partly upon the inclination of the beds, and their detailed structure, and in part upon the height reached by Tertiary and Quaternary beds, which conceal over wide areas the upper members of the Mesozoic series.

From the extreme southernmost limit of the map northward to the Union Pacific Railroad, the continuity of these sedimentary ridges is unbroken. Still farther to the northward, all along the Laramie Hills, the Palæozoic beds may be traced for the greater part of the distance, but in places they become so depressed as to lie entirely beneath the Niobrara Tertiary beds, which abut against the Archæan rocks.

In their broader geological features, they represent a very simple structure, a series of sedimentary beds resting upon the flanks of the upturned metamorphic rocks, and dipping along the entire length of the range almost invariably away from the mountains; the beds as shown in the Laramie Hills being simply the eastern fold of a broad anticlinal axis. In the details of structure, however, they are much more complex, varying in their dip away from the range, being found lying at every angle from nearly horizontal to vertical. In general they may be said to possess, in the region of the Big Thompson and the Cache la Poudre, a gentle dip, and to increase in the angle of inclination to the northward until they reach at the Chugwater the vertical position. To this rule, however, there are many marked exceptions. These beds are everywhere found to rest unconformably upon the older Archæan crystalline rocks. Nowhere, however, for over 100 miles along the front of the range between the Laramie River and Saint Vrain's Creek, was any non-conformity in the entire series of Palæozoic and Mesozoic beds observed, while in many localities the relations of beds and their exposures along the streams were such as to show a perfect conformity of dip. In the Laramie Hills, the conformity 
from the lowest strata of Palæozoic rocks to the Dakota sandstone of the Cretaceous is well shown, while in Colorado the conformity from the Red Beds of the Triassic to the summit of the Laramie beds, at the top of the Cretaceous, seems equally evident.

The thickness of the beds of the various horizons changes considerably at different localities, but the average thickness of the series may be estimated with some degree of accuracy, at least for the strata exposed from the base of the Palæozoic to the top of the Cretaceous marls and clays of the Colorado group. Above the Colorado group, the Fox Hill and Laramie beds which extend out upon the plains with very low angles, accompanied by gentle folds, are usually so covered with soil and grass as to render any exact measurement of their thickness somewhat difficult. The thickness of the entire series may be estimated as at least 6,000 feet. It must be borme in mind, however, that this is not a continuous section, for nowhere within this region do we find both the lower and upper members of the series exposed in the same locality. Moreover, where the Palæozoic strata are best developed, the Triassic and Jurassic appear quite thin. And again, where the Colorado group is seen to the best advantage, the underlying and overlying beds do not appear so clearly defined.

In the following general section is given the estimated thickness for each of the formations represented in the series :

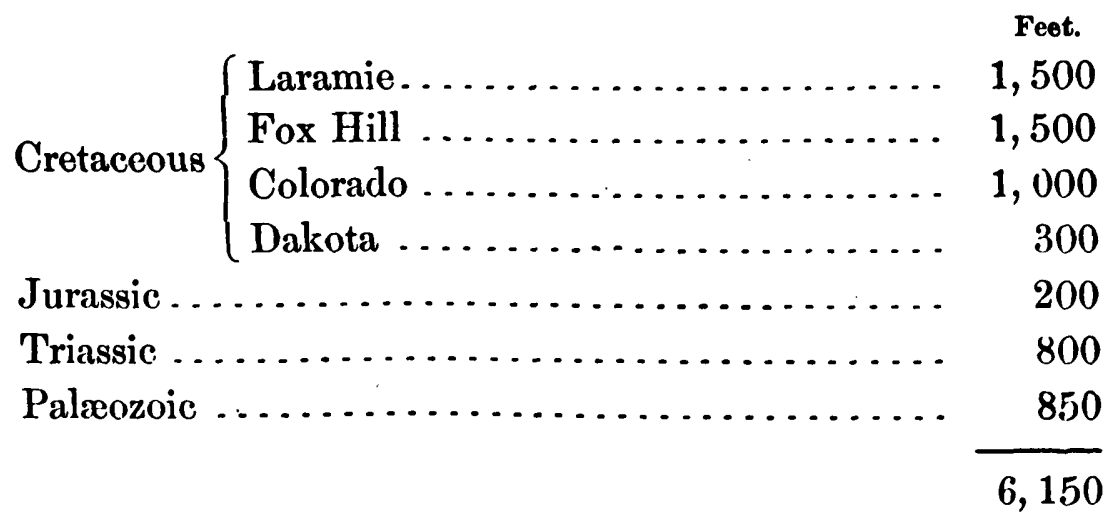

Wherever this conformable series rests upon the older rocks, along the front of the Laramie Hills, the Palæozoic strata may always be found at the base. But just north of where Box Elder Creek leaves the mountains, 
and a few miles to the southward of the forty-first parallel, Red Beds of the Triassic occur, lying directly upon the metamorphic rocks, and from that point southward, for a long distance, beyond the limit of our map, form the lowest member of the series exposed. According to the observations of Mr. A. R. Marvine ${ }^{1}$ and Dr. A. C. Peale, the Palæozoic strata do not re-appear again north of Colorado Springs. The persistency of the lower beds along the foot-hills for nearly 70 miles, and their sudden disappearance, not to re-appear again north of latitude $39^{\circ}$, is an interesting feature in the structural peculiarities of the range.

PaLeozorc Series.-By reference to Map I, east half, of the geological sheets in the accompanying atlas, it will be seen that the ridges, which are formed of the Palæozoic rocks along the east base of the Colorado Range, are represented in .but one color; the one employed on the other sheets to designate the Upper Coal-Measure limestone. So far as our observations in these ridges have been made, the rocks of the Coal-Measures are the only formations that have been definitely determined by palæontological evidence, and these occupy the greater part of the entire thickness of sandstones and limestones represented in the series, extending from the summit downward to within 150 feet of the base.

According to the published reports of Dr. F. V. Hayden ${ }^{2}$ and Prof. N. H. Winchell, ${ }^{3}$ and to the verbal communications of Mr. Henry Newton, of the Black Hills expedition of 1875, primordial fossils, representing Obolella and Lingulepis, have been collected in the lower coarse sandstones at the base of the series in the Black Hills to the northeast. The detailed sections from the Black Hills agree so closely with those made from the Laramie Fills that it would seem most probable that the entire series represented in one locality would be found in the other; and that the 100 to 150 feet of reddish sandstones at the base of the series in the Laramie Hills may yet yield the lower forms of life, as found farther to the north.

For this reason, the entire series of conformable rocks below the Triassic has been considered as compressed within the few hundred feet of Palæozoic

' United States Geological and Geographical Survey of Colorado, 1873.

${ }^{2}$ Geological Report of the Exploration of the Yellowstone and Missouri Rivers, F. V. Hasden, 1859-60.

${ }^{3}$ Reconnaissance of the Black Hills of Dakota, 1874, N. H. Winchell. 
strata found along the eastern slope of the mountains. They extend along the front of the range for nearly 65 miles, in a north and south line.

The Palæozoic beds vary somewhat in thickness, but in their extreme development were nowhere observed as over 1,000 feet. As already stated, their average thickness may be taken at 850 feet. The following sections made across the strata, beginning at the base of the series next the granite, give a general idea of the Palæozoic rocks.

At Table Mountain, between North Crow Creek and Lodge Pole Creek, the section gave as follows:

1. Pink and cream-colored limestone, alternating with thin sandy beds ..............

2. Bluish limestone, highly siliceous ......... 650 feet.

3. Thin bed of conglomerate..............

4. Gray and bluish arenaceous limestone .......

5. Red arenaceous limestone .............. 50 feet.

6. Reddish-white sandstone .............. 50 feet.

7. Campact fine gray sandstone, almost a quartzite, with some conglomerate............ 100 feet.

850 feet.

At Granite Canion, just north of the Union Pacific Railroad, the following section was obtained:

1. Light gray limestone, with arenaceous beds.

2. Massive blue limestone.

3. Brilliant red arenaceous limestone.

4. Compact reddish-gray sandstone, with fine pebbles.

East of Signal Peak, 3 or 4 miles south of the railroad, the section gave:

1. Blue limestone ...................

2. Thin bed of fine conglomerate......... 300 feet.

3. Red arenaceous limestone..............

4. Bluish-gray limestone................. . 4' 0 feet.

5. Red sandstone, with considerable variety in texture, and calcareous near the top........ 100 feet.

80 feet. 
The beds are made up almost exclusively of sandstones and limestones, and show but little evidence of slates, clays, marls, or mud-rocks. But, with the exception of the lower quartzite and sandstone, all the sandstone strata appear more or less calcareous, and the limestones, through most of the horizons, indicate more or less arenaceous material; while the heavilybedded massive limestones frequently carry intercalated narrow beds of sandrocks and fine conglomerate.

The lower sandstones are exceedingly variable, occasionally appearing as a hard compact rock, and in other localities developing a loose friable conglomerate, consisting of pebbles and fragments of older rock. They are, however, everywhere characterized by a prevailing reddish tint; the upper beds showing considerable persistency as a coarse, bright red sandstone.

In general, the limestones develop a dark bluish-gray color with bands of various colored beds. The upper limestones are usually lighter in color, frequently shading off into pink and white, and possessing a saccharoidal granular texture. The beds which form the steeper ridges, lying inclined at angles varying from $75^{\circ}$ to the rertical position, show all the divisions in the series much less distinctly marked than the less altered beds inclined with a gentle uniform dip. In many localities the limestones in these highlymetamorphosed ridges are so much altered, as to present a very marked difference in lithological character; the beds being changed into compact, hard, cherty strata, and the purer limestone, as in the ridge north of the entrance of the Chugwater Cañon, altered into a coarse white marble.

Dolomitic limestones appear to characterize the base of the formation; at least in the region of Granite Cañon the beds show the presence of more or less magnesia. They are marked by a compact very fine-grained texture, and uneven fracture. Fragments treated with dilute acids dissolve slowly, usually leaving a slight residue of silica in fine angular grains.

A small fragment of a nearly pure magnesian limestone from Granite Cañon was submitted to chemical analysis by Mr. B. E. Brewster, with the following result: 


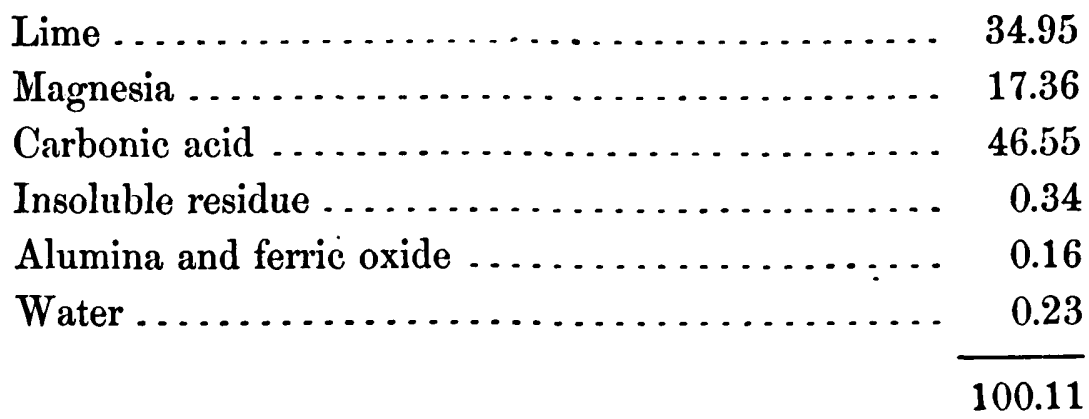

The uppermost stratum of limestone and the bed immediately underlying the Triassic Red Beds at Horse Creek is an exceedingly fine-grained homogeneous rock, of a deep flesh-red color. Scattered through it are small white crystals of calcite. This rock, as in a measure typical of the upper light-colored limestones, was also subjected to chemical analysis, and found to be a nearly pure dolomite, the impurity being a little silica.

It yielded as follows:

Carbonate of lime ..................... 60.09

Carbonate of magnesia . . . . . . . . . . . 39.20

99.29

The characteristic layer of red arenaceous limestone, near the base of the limestone series, is usually a well-defined bed. A specimen in our collection from near Granite Cañon presents a compact texture and a smooth even fracture. To the eye the rock shows a slightly-banded structure, which is somewhat more marked in the thin microscopic sections. Under the microscope, the rock reveals the presence of small crystals of calcite and numerous angular grains of sand.

As already mentioned, the only fossils found in these beds are such as are characteristic of the Coal-Measure formations. Numerous fragments of crinoid stems and highly-altered impressions of molluscan forms, too poor for determination, are found throughout the limestones in many localities; but well-preserved specimens are somewhat rare, or at least were not collected by our parties. They are all comprised within the Brachiopoda; the following being identified: 
Productus semireticulatus.

Productus cora.

Productus Prattenianus.

Athyris subtilita.

Of these forms, $P$. semi-reticulatus would appear to be the most abundant. In the palæontological report of Mr. G. B. Grinnell, ${ }^{1}$ accompanying the report of Colonel Ludlow, on a "Reconnaissance of the Black Hills of Dakota", he mentions finding, in one or two localities, Spirifer centronatus, Winchell, but does not state in what part of the limestone series they occur. This species, along the belt of the Fortieth Parallel Surwey, is a characteristic fossil of the Waverly group in the Wahsatch limestone, occurring in several localities in the Wahsatch and Oquirrh Ranges of Utah. Its presence along the east base of the mountains, where heretofore only Primordial and Coal-Measure species have been recognized, is of special interest.

Triassic formation.-Immediately overlying the Coal-Measure limestone occur the heavy sandstone beds that have been referred to the Triassic age. They are found all along the foot-hills of the range, the continuity of outcrop being broken in only a fer places, and, in most cases, simply by being concealed below the unconformable Tertiary beds.

They are characterized by a prevailing brilliant red color, which, however, shades off into yellowish and whitish tints, and, near the top and bottom of the series, show frequently reddish-gray bands. The deep brick-red color, however, is so persistent as to form one of the most clearly-defined geological horizons of the uplifted sedimentary beds.

In thickness, the Triassic beds vary very considerably; thinning out from 800 feet, as given in the general section, down to less than 300 feet. They reach their greatest development to the southward in Colorado, between the Big Thompson and Cache la Poudre, while north of the railroad, they appear much thinner, and, between Lodge Pole and Horse Creeks, reach their minimum. Still farther to the northward, in the region of the Chugwater, they again thicken, but scarcely attain the width of the beds in Colorado.

'Reconnaissance of the Black Hills of Lakota, 1875, 76 and 77. 3 D G 
The following sections, the one taken at the northern end of the map, near the Chugwater, and the other 55 miles to the southward, near where Box Elder Creek leaves the mountains, agree very closely in general outline, and serve to show the character of the Triassic rocks.

At the Chugwater, we have :

1. Redulish-5ellow sandstone.

2. Bluish.white cherty limestone, 6 to 10 feet.

3. Fine red sandstone.

4. Compact arenaceous limestone, 3 or 4 feet.

5. Red shales.

6. Fine red sandstone, with interstratified beds of clay.

7. Heavy massive red beds, with layers of fine conglomerate.

The entire section showing between 500 and 600 feet of strata.

At Box Elder Creek, we have:

1. Reddish-yellow sandstone $\ldots \ldots \ldots \ldots \ldots \ldots \ldots \ldots \ldots \ldots \ldots \ldots \ldots$

2. Fine-grained earthy sandstone, with layers of gypsum $\ldots \ldots \ldots \ldots \ldots \ldots$

3. Thin bed of blue limestone........................... 150 feet.

4. Laminated shales, with some red clays $\ldots \ldots \ldots \ldots \ldots \ldots \ldots \ldots \ldots$.

5. Yellowish-red sandstone $\ldots \ldots \ldots \ldots \ldots \ldots \ldots \ldots \ldots \ldots \ldots \ldots \ldots \ldots \ldots$ fect.

6. Massive red sandstone $\ldots \ldots \ldots \ldots \ldots \ldots \ldots \ldots \ldots \ldots \ldots \ldots \ldots \ldots$ feet.

7. Coarse red sandstone, with conglomerate.................. 100 feet.

It is evident, from the foregoing sections, that sandstones form by far the greater part of the entire series of strata. Even the conglomerates, shales, clays, and earthy beds, which occur interstratified throughout the formation, appear more or less arenaceous, and are really closely allied to true sandstones, only showing considerable diversity in texture and mechanical conditions. The conglomerates would appear to be much more prevalent near the base of the series, especially south of the Cache la Poudre, where they lie resting directly upon the Archæan body, and carry considerable detrital material, derived from the lower rocks. Shales and impure clays, which, in thin layers, may be found anywhere from the base to the summit, characterize the middle formations; while the upper beds are usually finer-grained, with an earthy appearance, and carry thin beds of limestone and gypsum. 
In the more compact and massive sandstones, transverse bedding forms a very prominent and marked feature of the Triassic Red Beds.

In addition to the well-defined limestone beds, many of the horizons in the upper impure sandstones appear highly calcareous, which is, however, not evident to the eye, but which, when they are treated with dilute acids, is indicated by a brisk effervescence. A typical specimen of the red sandstone in our collection, taken from near the entrance to the Big Thompson Cañon, and not far below the top of the Triassic series, presents a fine-grained friable texture, a deep red color, with a shaly, laminated structure. A fragment from this rock was subjected to chemical analysis by Mr. B. E. Brewster, with the following result :

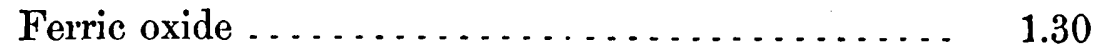

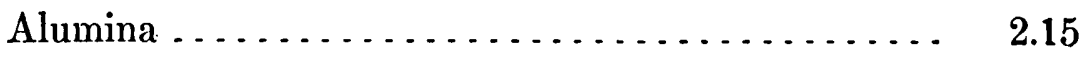

Lime............................. 6.07

Magnesia ........................... 4.40

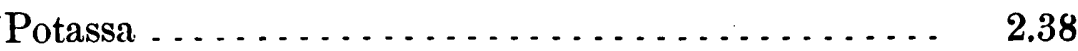

Soda.............................. 1.14

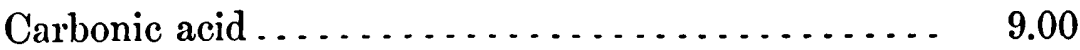

Water ............................ $\quad 1.62$

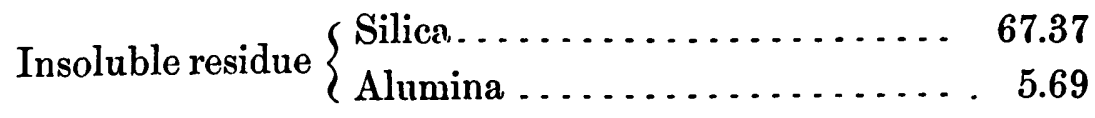

101.12

This analysis shows the presence of a large amount of soluble carbonates, including a high percentage of dolomite, and a considerable admixture of argillaceous materials. So large a proportion of carbonate, with no trace of gypsum, occurring in a formation in which many of the horizons are marked by the presence of heavy deposits of the latter salt, is not without considerable interest.

Underlying the shaly sandstone a short distance, occurs a deep red bed, somewhat coarser-grained, still more friable, and without any laminated structure, which, upon being treated with acid, gave no indication of the presence of soluble carbonates. Laminated impure shales, from a well- 
marked horizon on Horse Creek, and interstratified between coarse sandstones, were found on examination to contain a considerable amount of calcareous substance, which is probably, like the bed from the Big Thompson, largely dolomitic. They have a fine-grained arenaceous texture, with a deep reddish-yellow color.

The limestone beds in the Triassic series along the base of the Colorado Range are, in many localities, well marked, but do not appear to be persistent over very wide areas; at least, they were not always observed in crossing the formation, but, where noticed, always preserved the same general characters. Two distinct beds, but a few feet in width, are recognized. They are clearly defined north of the Chugwater, and are shown in the section already given, where the lower bed consists of a compact, siliceous, granular rock, and the upper one a bluish-white cherty band with a brittle fracture, not unlike the characteristic limestone stratum so persistent in the Jurassic beds.

The deposits of gypsum, which form so marked a feature of the Red Beds, are largely developed in many localities along the base of the Colorado Range. They occur in irregular beds, interstratified in the deep red sandstones and shales, and, although they may possess a wide range throughout the entire horizon, are much more prominent in the upper formations. Although quite distinct, and separated from the limestone strata by intervening sandstone layers, the heavier gypsum beds are usually at no very wide interval from the limestones. The deposits vary in thickness from 2 feet up to at least 25 feet; the heavier bodies frequently occurring as broad beds, with a considerable thickness in the centre, but thinning out toward the edges. The gypsum occurs both massive and crystallized; is nearly white in color, with a light reddish tinge, and frequently reddish-gray from the admixture of slight impurities; the lustre is usually pearly, and often brilliant. The compact massive gypsum, where not discolored by exposure, is generally snow-white, presenting a striking contrast with the brick-red dolomitic shales.

Gypsum from Red Valley, near the northern end of the Laramie Hills, is quite pure, possessing very nearly the required theoretical composition, an analysis yielding- 
Sulphate of lime ................... 78.11

Water ........................... 21.21

99.32

No organic remains have yet been found in the Triassic formations east of the Colorado Range.

JURASSIC FORMATION.-Intimately connected with the Red Beds occurs a series of loose friable sandstones, limestones, marls, and impure clays, presenting great variety in color and texture, and passing from one to the other by almost imperceptible grades. The entire series is usually composed of fine-grained material, and the clays and marls show a more or.less laminated structure. These beds have been referred to the Jurassic age.

While the prevailing character of the Triassic beds is a deep red sandstone, the overlying Jurassic rocks possess a slightly reddish tinge, but are marked by beds of orange, purple, and lavender-colored strata, which consist largely of argillaceous material. Narrow beds of limestone occur in both formations, while gypsum, which forms so prominent a feature in the Triassic, is found in thin, narrow seams, in what would appear to be several different horizons in the Jurassic.

The line which has been adopted as forming the boundary between the Triassic and Jurassic periods is a somewhat arbitrary one, not being based upon any broad structural or palæontological evidence, or, indeed, upon any clearly-defined lithological distinction. Where the upper formations of the Triassic period consist of the deep red compact sandstones, and the overlying strata are friable light-colored beds, the line of separation has been taken at the summit of the more massive red series. In many places, however, the top of the Red Beds possesses a yellowish shaly character, shading into the upper series, rendering a sharp line of separation somewhat difficult to establish. As the upper beds, however, are much. more easily decomposable, they have suffered considerably from erosion, and have been worn out into longitudinal depressions, or valleys, between harder layers of rock, forming a somewhat marked physical feature of the ridges, and at least offering a convenient division between the two series of

rocks. No organic remains sufficiently well preserved for specific deter- 
mination have been obtained from Jurassic rocks east of the Colorado Range; but as characteristic strata have been easily recognized, which are very persistent wherever the Jurassic occurs, and below which, on the Laramie Plains not far above the Red Beds, well-defined Jurassic fossils have been identified, it seems, for the present at least, desirable to place the line of separation at the top of the compact red sandstones.

In thickness the rocks, which have been referred to the Jurassic, vary from an extreme development of 250 feet, down to less than 75 feet. They attain their greatest thickness in Colorado in the region of the Big Thompson Creek. To the northward, their average width may be taken at 200 feet. In Wyoming, along Lodge Pole and Horse Creeks, they appear less clearly defined, being in part obscured by loose soil, and in part resembling the Triassic beds. Here they are probably represented in some places by only 75 feet of strata. Still farther to the northward, they expand again to at least 150 feet, showing most of the characteristic beds to be found in Colorado and Western Wyoming. The lowest beds in the Jurassic series are usually reddish-yellow sandstones and shales, passing into lightercolored beds, partaking more and more of a marly nature, with interstratified beds of hard sandstone and some limestones. The upper beds are friable sandstones interstratified in compact gray and cream-colored marls, with varying proportions of lime. In several localities, these calcareous marls would seem to be represented by well-defined beds of limestone.

At Box Elder Creek, near where the stream leaves the mountains, the following section was made across the Jurassic beds:

1. Fine friable sandstone.

2. Gray marls and clays.

3. White marls.

4. Yellowish calcareous sandstone.

5. Cherty limestone.

6. Orange sandstone with light-colored clays.

7. Gray marl with purple and reddish-brown bands of clay and thin layers of sand.

8. Gray arenaceous marl.

9. Reddish-yellow friable sandstone.

It represents a section of rock strata of from 200 to 250 feet in thickness. 
The limestones of the Jurassic strata appear to be of two distinct kinds; the one a hard, dense, cherty rock, carrying a considerable amount of silica, and usually of a characteristic gray color; the other less compact, exhibiting greater variety in color and texture, and in most localities probably dolomitic.

A specimen from the latter limestone, collected at the base of the mountains, near the old "Denver and Laramie Stage Road," shows a rather more than usually compact texture, and a pinkish-gray color. Scattered through the rock are numerous small crystals of calcite. Under the microscope may be seen minute grains of silica and crystals of quartz.

This rock was subjected to complete chemical analysis by Mr. B. E. Brewster, with the following result:

\begin{tabular}{|c|c|c|}
\hline Silica & 2.77 & 2.95 \\
\hline Alumina and ferric oxide $\ldots \ldots \ldots \ldots \ldots$ & 0.79 & 0.54 \\
\hline Lime $\ldots . . . . . . . . .$. & 29.90 & 29.89 \\
\hline Magnesia ........ & 19.31 & 19.36 \\
\hline Soda and potassa. . & 0.38 & 0.28 \\
\hline Carbonic acid .... & 45.05 & 45.14 \\
\hline Water....... & 1.35 & 1.30 \\
\hline & 9955 & 99.46 \\
\hline
\end{tabular}

Combining the carbonic acid with the bases we have very nearly the composition of true dolomite.

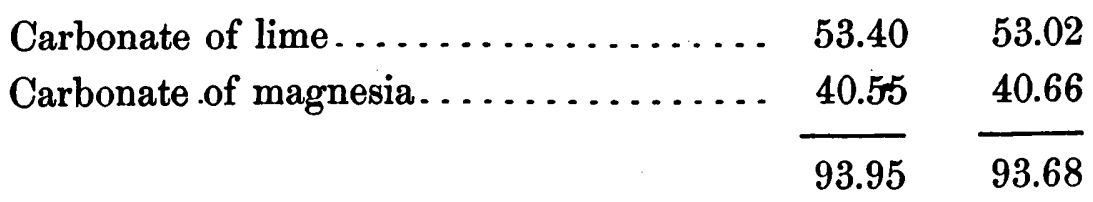

Dakota Cretaceous.-Although the base of the Jurassic is frequently obscure, the upper horizon, which has generally been adopted as separating the series from the Dakota sandstone of the Cretaceous group, is usually well defined and easily recognized along the entire base of the mountains. The Dakota beds are essentially a sandstone formation, and as they are usually hard and compact, frequently almost a quartzite, they form a well-defined horizon. Lying between the easily-eroded Jurassic 
marls and clays below and the overlying blue shales, clays, and soft crumbling rocks of the Colorado group above, the Dakota beds are usually a conspicuous feature in the ridges which form the foot-hills of the main range. Where the Palæozoic and Mesozoic rocks are found resting upon the Archæan masses at a highly-inclined angle, the Dakota group may usually be traced, forming the uppermost member of the steeper ridges; but where the angle is low, they frequently pass under, and are concealed by the overlying Tertiary beds.

In approaching the mountains from the Great Plains, the Dakota beds are especially prominent, as they form the outlying member of the series of upturned sedimentary beds, which rise so abruptly above the plain; for, although the overlying Colorado group is perfectly conformable, they never occur high up on the long ridges, which form a sort of barrier between the level country and the mountain region beyond.

As already mentioned, the Dakota is a sandstone formation, and presents but little variety in its physical features and composition along the base of the mountains. The bottom of the series is usually a fine conglomerate, passing into a hard brownish-yellow sandstone, distinctly bedded, and in many localities showing the presence of considerable iron scattered through the rock. Occasionally, the iron will appear in segregations, forming rounded patches or blotches of iron stain on the yellow sandstone in a very striking manner. Frequently, the upper members of the group are a loose friable rock, many of the beds being nearly a white sandstone. Thin seams of black clay, rich in iron and occasionally some carbonaceous matter, although somewhat rare, occur all through the upper part of the group. Along the Laramie Hills the Dakota formation in places develops a tendency toward a shaly structure, but in. general they are characterized by massive beds.

In thickness, the Dakota group may vary from 200 to 300 feet.

The following section in Northern Colorado will serve to show the general character of the lower member of the Cretaceous series, especially as represented between the Big Thompson and Cache la Poudre: 
1. Yellow sandstone

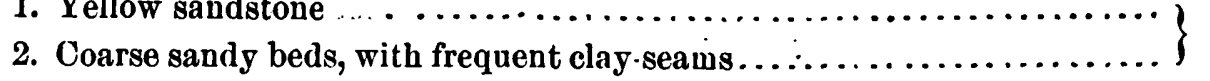

100 feet.

3. Yellowish-brown sandstone, almost a compact quartzite $\ldots \ldots \ldots \ldots \ldots \ldots$
4. Coarse jellow sandstone, passing into fine conglomerate........... 200 feet. 300 feet.

So far as examined, none of the sandstones would appear to carry any carbonate of lime: A specimen of the Dakota sandstone, taken from the prominent outlying ridge north of Wahlbach Spring, presents a fine-grained, even texture, with a yellowish-brown color. Under the microscope, with a high power, many of the quartz grains indicate the presence of glass cavities, while between the sand particles may be recognized an occasional fragment of hornblende, and a green mineral, which appears to be chlorite.

This rock was subjected to chemical analysis with the following result:

Silica.............................. 95.46

Alumina . . . . . . . . . . . . . . . . . . . . $\quad 2.69$

Ferric oxide $\ldots \ldots \ldots \ldots \ldots \ldots \ldots \ldots \ldots \ldots \ldots \ldots . \ldots \ldots$

Lime. . . . . . . . . . . . . . . . . . . . . . . . 0.14

Magnesia ......................... 0.06

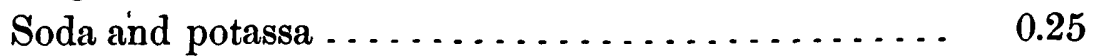

Ignition $\ldots \ldots \ldots \ldots \ldots \ldots \ldots \ldots \ldots \ldots \ldots \ldots . . \ldots \ldots$

99.96

Colorado Cretaceous.-The Colorado group embraces the Middle Cretaceous highly fossiliferous rocks, which overlie the Dakota sandstone, and, in turn, underlie the sandstones of the Upper Cretaceous. The group is essentially composed of clays, shales, marls; limestones, and some impure sandstone, which, taken together, form a well-defined series of beds, and include the three divisions of the Middle Cretaceous, of the section made by Meek and Hayden along the Upper Missouri River: the Fort Benton, Niobrara, and Fort Pierre beds.

Along the east base of the mountains, within the belt of our exploration, but more especially in Wyoming, it would appear almost impossible to indicate, with any degree of raccuracy, the divisions of the series, although their 
presence is very easily recognized, and in many localities either one or the other bed occurs well developed.

The Fort Benton beds, which lie next the Dakota, and are only exposed along the base of the abrupt ridges, consist of dark plastic clays, at times distinctly bedded, and frequently occurring as thinly-laminated paper-shales. The lower beds are always more or less arenaceous, with interstratified beds of purer clay, while the upper beds sometimes carry thin seams of argillaceous limestone, which, in many places, cannot be distinguished from similar beds in the Niobrara. In general, the beds are very uniform in lithological character. Along the Laramie Hills, they are somewhat difficult to recognize, as they are usually concealed by loose soil and débris from the steeper ridges to the westward, but in Colorado they may be traced for long distances in well-defined north and south lines.

The Niobrara beds, which occur just above the Fort Benton, although much thinner, are, from their characteristic colors and peculiar mode of weathering, more easily recognized. Where the upper beds of the Fort Benton are calcareous, it is generally difficult to separate the two series below the yellowish-white chalky limestone strata, which is so pronounced a feature in the Niobrara. They consist mainly of marls and impure limestone. The lower members are bluish-gray argillaceous limestones, with occasional beds of lighter-colored clays, all of them highly fossiliferous, passing up into yellowish-white or cream-colored marls, associated with gypsum, which occurs frequently in thin, irregular layers, and at times disseminated through the marls. Not far above this occurs a second bed of somewhat deeper yellow marl, which at the top passes into bluish-gray, soft, earthy beds.

The base of the Fort Pierre group is usually much obscured by overlying soil, and at times the lithological aspect of the beds blends so completely with those of the underlying Niobrara that any separation seems impossible; but in other localities the dark, almost black, thinly-laminated clay affords a very distinct horizon. The entire group, like the Fort Benton division, is made up of clay-beds, with but little variety in general character. The lower clays carry considerable amounts of carbonaceous material, and along the seams and cracks incrustations of gypsum and alkaline salts. 
Some of the richer carbonaceous shales along the Laramie Hills have been examined for coal, but without success. The apper beds are somewhat lighter in color, usually harder, and perhaps more siliceous.

Only at one locality north of the railroad, about 2 or 3 miles north of Horse Creek, do the Fox Hill beds, overlying the Fort Pierre, occur, and even these may prove to be the extreme upper members of the lower division; everywhere else the Pliocene Tertiary strata conceal the beds above the black clays. In Colorado, however, the Fox Hill beds extend along the base of the range, and the junction between the Fort Pierre and the next series above may be well seen. Here the more prominent clay-beds pass into coarse argillaceous sandstone, of a dirty brown color and crumbling texture, but carrying well-defined fossils, characteristic of the group.

The Colorado beds, like all the other sedimentary strata along the base of the range, vary somewhat in thickness, and appear to reach their greatest development in Colorado. No accurate measurement of their thickness was made at any one place, and it would be somewhat difficult to do so, as the group is more or less covered with soil, and the dip extremely variable. The lower members of the Fort Benton beds incline uniformly with those of the Dakota ; but, owing to their plastic, flexible nature, are likely to fall away to the eastward with a lower angle, which is not recognized until we find the more prominent marls of the Niobrara lying inclined at a reduced dip. The Fort Pierre clays would seem either still more flexible, or else, removed farther from the main range, to have undergone less pressure in the uplift of the strata, for we find the beds extending far to the eastward, flattening out with low angles, frequently inclined at from $3^{\circ}$ to $5^{\circ}$. In this way, they change from an abrupt angle of $30^{\circ}$ to nearly horizontal strata, rendering an estimate of their thickness a matter of some difficulty.

Their thickness may be best obtained by measuring at different points, where well exposed, the several members of the group, and from these estimating the entire expansion. Probably the extreme development of the Colorado beds will be found not to fall much short of 1,000 feet in Colorado; while, in Wyoming, the thickness will be somewhat less, but over the greater part of the area the upper members of the series are never seen. 
The following section was not made at any one point, but will serve to show the character of the entire group:

1. Interstratified beds of clay and sands, in many localities the clays ? predominating, and in others the sandy beds...........

2. Dark arenaceons clays $\ldots \ldots \ldots \ldots \ldots \ldots \ldots \ldots \ldots \ldots \ldots \ldots \ldots$

3. Grayish.black carbonaceous clays and shales.............

4. Bluish-gray, soft, earthy beds....................

5. Yellow marls and limestono $\ldots \ldots \ldots \ldots \ldots \ldots \ldots \ldots \ldots \ldots \ldots$

6. Whitish-gray marl ..........................

7. Yellowish-white and cream-colored marls and limestone, with

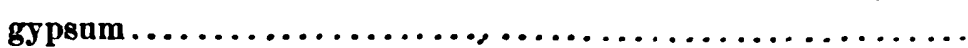

8. Light-colored marls............................

9. Blue argillaceous limestones......................

10. Clays, with the calcareous beds. $250-350$ feet.

11. Dark plastic clays, with arenaceons and ferruginons layers.....

$250-450$ feet.

$600-1000$ feet.

Although the beds show considerable variety, it is evident that they possess, in general, simple features; the lower members being clay-beds, more or less arenaceous, passing up into calcareous beds, and, still higher in the series, again becoming clays, with sands near the top.

It would be difficult in most places to separate the Fort Benton from the Fort Pierre group by lithological distinctions, but for the striking peculiarities of the brilliant-colored marls of the Niobrara; where the latter are concealed, and the beds are not defined by their organic remains, it becomes almost impossible to say to which series certain beds may belong. The Fort Benton clays, lying next the rigid sandstones of the Dakota, are easily eroded into broad shallow depressions, with the gray and yellow marls of the Niobrara forming low ridges to the eastward. These marl-ridges, although very insignificant in proportions, form one of the most striking features along the foot-hills, affording excellent geological horizons in travelling rapidly over the country. In many places, they show great persistency, and may be followed without any break in their continuity for many miles. They rise usually but a few feet above the surrounding level, standing out in a most marked manner above the dull earthy clays, presenting 
their steepest sides toward the range, and falling away gently to the eastward. Farther to the eastward the Fort Pierre clays produce a second slight depression, or valley, but frequently somewhat broader and less regular, showing low benches and occasionally isolated mounds or hills.

Organic remains characterize several well-determined horizons in the Colorado group east of the mountains, and in many localities appear very abundant, especially the genus Ostrea, which-frequently forms almost entire beds, held firmly together by a little calcareous cement. They show, however, but little variety in species. Many of the fossils in our collections are too poor for specific identification.

The following forms, which occnr in the Colorado group, have been found east of the mountains :

Inoceramus problematicus.

Inoceramus difiormis.

Inoceramus Barrabini.

Inoceramus incurvus.

Ostrea congesta.

Ostrea
Callista Deweyi.

Anisomyon sexsulcatus.

Pinna restituta.

Scaphites nodosus.

Baculites ovatus.

Ammonites —?

In addition to the above, many of the clay-beds are characterized by numerous small finely preserved fish-scales, lying parallel to the plane of stratification.

Descriptive Geology of the Eastern Foot-inlls.-In giving the general geological and lithological features of the main formations, which make up the belt of sedimentary beds along the base of the range, but little has been said of the details in any one locality, and scarcely anything of the structural peculiarities of ridges, showing the relations which they bear to each other, and to the older Archæan rocks. In the following pages some of the more salient features will be pointed out. Beginning with the northern end of the Laramie Hills, the first occurrence of Palæozoic and Mesozoic rocks south of the Laramie River is found at the head of Bush Creek, in a small bay-like depression in the Archæan rocks, known as Red Valley, just where they jut out to the eastward from the main body. Here the Palæozoic series rise somewhat abruptly in a short isolated ridge, while the Triassic beds are the only Mesozoic rocks represented. The latter lie nearly 
horizontal, covering the greater part of the valley, and resting directly against the granite. The chief point of interest in the formation centres in the immense deposits of gypsum, which appears to underlie the entire valley, just below the surface, cropping out everywhere and in many places, over wide areas, actually forming the surface itself. There would seem to be several beds, varying in thickness from a few feet up to 15 feet. It is mostly a clear white pure gypsum, and, if required for market, could be mined on a most extensive scale. On the south side of this projecting mass of granite, and north of Reschaud Creek, the Palæozoic rocks crop out for a long distance, dipping to the southward at a highly inclined but uniform angle. In places, the Mesozoic beds may be found overlying them, but the Tertiary beds lie high up on the range, concealing the greater part of the strata. South of Reschaud Creek, the Palæozoic limestones, standing at an angle of $70^{\circ}$ to $75^{\circ}$, extend in a nearly north and south direction for 3 or 4 miles, in an unbroken line, until reaching a small tributary of the Chugwater. In the region of the Chugwater, the outlines of the Archæan body are very irregular, and the sedimentary beds circle around the mass, conforming closely to all the lesser details of the older rocks.

Just north of where the Chugwater leaves the Laramie Hills, the Archæan mass projects to the eastward, and the later beds, influenced by the underlying body, turn in like manner in the same direction, presenting a great variety in structural features, and marked by abrupt changes in strike and dip. Within 7 miles, in an east and west line, the entire series of ridges, from the base of the Palæozoic to the top of the Colorado group, describe a complete letter $Z$. Immediately to the south of the Palæozoic beds, already mentioned as lying to the southward of Reschaud Creek, the entire series of beds occur, standing at a very high angle, and striking nearly due north and south, until just before reaching the Chugwater they turn off slightly to the southeast, curving around the Archran mass. Here the Palæozoic strata appear very prominently, rising nearly vertically, and reaching to the summit of the Archæan body. The Triassic and Jurassic strata, although inclined at a high angle, do not extend high up on the flanks; but the Dakota sandstone, on the contrary, rises in a very bold manner, forming a high wall, dipping at an angle of $85^{\circ}$ from the 
range. Beyond this sandstone wall, the Colorado group occurs, exhibiting its dark shales and yellow marls. This sandstone wall is cut by the Chugwater, showing a fine section through the entire Dakota beds. Immediately south of the Chugwater, the Dakota beds make an abrupt break, turning to the southwest, and, in a very short distance, are found with an almost due east and west strike. Indeed, all the beds turn in a very abrupt manner, inclined at high angles; the Red Beds standing at $55^{\circ}$ to $61^{\circ}$. Where the strata are found with an east and west trend, the dip falls off to $25^{\circ}$ and $30^{\circ}$. Here the Palæozoic limestones, with a uniform dip of about $25^{\circ}$, are found north of the stream.

The Red Beds, which are well exposed, occupy a very considerable area, forming a small valley, through which for a short distance runs the Chugwater, the stream having cut for itself a narrow channel in the upper red clays. A section across the Red Beds at this point has already been given. On the south side of the Chugwater occurs a long, low ridge, rising but a few hundred feet above the stream, at the base of which the Jurassic marls and limestones crop out, while the top is formed of the Dakota sandstones, which incline gently toward the plains, and are overlaid unconformably by the Pliocene Tertiary beds. Just west of the wagon-road occurs a somewhat prominent hill, in which is exposed a good section of the Jurassic beds. The base of the hill on the north side consists of the intensely red Triassic rocks, overlaid by the Jurassic marls, which in turn are capped by the Dakota sandstones, forming the summit of the hill. Immediately beyond the hill, the entire series of strata again trend to the northward, which, standing at a high angle, are seen compressed into a comparatively short space. They trend at first north and south, then east and west, and again curve around to the north and south, forming approximately three sides of a square scarcely 3 miles in width. The Palæozoic limestone extends high up on the flanks of the Archæan, while the Triassic and Jurassic rocks have been worn away by erosion, in many places several hundred feet, but the harder and more rigid Dakota beds are seen forming a somewhat prominent ridge. The clays and marls of the Colorado group occupy the centre of the square, but are largely concealed by loose soil and gravel. At the entrance to the 
Chugwater Cañon, the Carboniferous limestone presents a very marked appearance, rising almost out of the plain, for several hundred feet, in a nearly vertical position, its beds considerably metamorphosed. On the summit of the ridge occurs a limestone bed, altered into a fair variety of white marble.

A short distance south of the Chugwater, the Palæozoic and Mesozoic rocks become depressed, and disappear entirely beneath Tertiary gravels that have been referred to the Wyoming Conglomerate of the Bridger basin.

On the Chugwater, some 4 or 5 miles below where it cuts through the wall of Dakota sandstone, already mentioned, occurs a very considerable development of all three subdivisions of the Mesozoic rocks. Unfortunately, but little time was allowed for the examination of this group; it would appear, however, to derive its chief interest from the fact that, so far as known, it forms within the belt of our exploration the only occurrence east of the Laramie Hills of an outcrop of pre-Tertiary rocks, isolated from the main ridges of uplifted beds along the flanks of the range. Where they first rise above the surrounding Tertiary beds, the stream has cut a channel through the dark ferruginous shales of the Fort Benton division of the Colorado Group, beyond which the stream runs through a narrow passage in the Dakota sandstones. On the north side of the river, the Dakota beds form quite a high ridge, dipping at an angle of $25^{\circ}$ to $30^{\circ}$ to the southward, the entire series of rocks trending approximately east and west. North of the Dakota ridge occurs a narrow valley of the Jurassic marls, with the characteristic low ridge of Jurassic limestone in the middle, in turn underlaid on the north side of the valley by the Red Beds, which appear in a low bench, the bright red soil marking the outlines of the formation for long distances.

So far as observed, this group of upturned beds only extends for 3 or 4 miles, beyond which the Niobrara Tertiary covers all the older rocks, and the Chugwater widens out into a broad open valley, with high bluffs and walls of horizontal sandstone.

Returning to the foot-hill ridges, the entire series are again seen coming to the surface just above the northern tributary of Horse Creek. From 
here southward to the main valley, a distance of 3 miles, all the characteristic beds, from the Palæozoic to the top of the Colorado group, are well represented. The most striking feature, however, is the bold, abrupt bluffs of the Palæozoic rocks, which rise above the top of the Triassic beds from 50$.$) to 600$ feet, exposing almost sheer cliffs of Carboniforous limestone to the eastward, the strata standing at an angle of $70^{\circ}$. Three streams from the range nearly equally divide the limestone into three somewhat isolated ridges with curiously eroded summits, whose trend is a few degrees west of north. Numerous forms of the genus Productus are found here, but the only one that could be determined was $P$. semireticulatus.

The Triassic beds are, in general, fine-grained, somewhat shaly and argillaceous, with both deep red and reddish-yellow beds. The Jurassic occupies a shallow depression at the base of the Dakota sandstone, which, in many localities, appears to form a hard capping to the more easily eroded marls below.

Overlying the Dakota occur somewhat thin exposures of the lower dark clays, in turn overlaid by yellow and blue marls carrying immense numbers of the genus Ostrea, which, in places, almost makes up the rock. The upper dark plastic clays which carry numbers of Baculites ovatus would appear to be well developed, cropping out in low ridges and in occasional mounds and hillocks.

Not far north of Horse Creek, the dark clays of the Fort Pierre division of the Colorado group are overlaid by a series of beds, which crop out in long narrow lines, rising only from 12 to 15 inches above the plain. They consist of yellowish-brown sandstones, with seams of arenaceous clay, and soft friable sandstone with ferruginous concretions, and some vegetable remains. On the geological map, these beds have been referred to the Fox Hill group, but they may possibly belong to the upper members of the Fort Pierre. The only fossils found were a number of species of the genus Ostrea; but none of them have been specifically determined, and may not be characteristic of either formation. The beds strike considerably west of north, and $\operatorname{dip} 25^{\circ}$ to $30^{\circ}$ to the east. They occupy a very small area, deriving their chief interest from being, so far as observed, the highest members of the conformable series of pre-T'ertiary strata east of the Lara4. $\mathrm{D}$ C 
mie Hills. A short distance east of here they pass under the Tertiary plains.

Between Horse Creek and Wahlbach Spring, on the Cheyenne Pass road, the complete series of foot-hill strata are represented, presenting a rather uniform appearance. The Palæozoic rocks form high abrupt bluffs, somewhat resembling those to the northward, less bold and striking, but with the same cliff-like face to the eastward, having a dip angle from $55^{\circ}$ to $65^{\circ}$. At the base of the cliffs, red clays and soils reveal the Triassic sandstone, although they fail to show the unbroken continuity of well-defined strata that is exposed farther to the northward, while the Jurassic, which here would appear to be quite thin, is indicated by a slight depression in the formations, and a light clayey soil, capped by a light yellow sandstone.

In the Colorado group, the subdivisions are not always well defined, while the upper, or Fort Pierre beds, frequently lie concealed beneath the Tertiary. Where the Fort Pierre beds are exposed, they have suffered considerable erosion, and have been cut through by numerous streams and ravines, which offer good sections of the dark carbonaceous shales and clays.

Just north of Wahlbach Spring, the lower sandstones and limestones occur inclined at $15^{\circ}$ to $20^{\circ}$, possessing a much lower angle than the same strata to the northward. The relations of the several horizons to each other and their structural features are shown in the upper section at the bottom of Map I, east half: in the section, however, the Niobrara Tertiary beds jut up against the Dakota sandstone. A short distance to the northeast, the overlying Tertiary strata have been eroded, and the yellow chalky marls of the Colorado group are well exposed, carrying immense quantities of the genus Ostrea. Interstratified in the marls are thin layers, varying from 6 inches to 3 or 4 feet, of bluish clay-slates, with some gypsum.

Between the Cheyenne Pass road and the north branch of Crow Creek, a broad elevated table-mountain extends out from the main Archæan range to the eastward. On the east side it rises abruptly in nearly perpendicular walls, for nearly 800 feet, while toward the main range it presents a bluff nearly as precipitous, being separated from the granites by a deep cañon, which heads near the divide of Lodge Pole and Crow Creeks. This 
table-mountain consists entirely of sandstones and limestones, including probably the entire Palæozoic series found along the east base of the range, but here lying in a nearly horizontal position. The cause of this somewhat singular occurrence of the lower sandstones and limestone may be found in an irregular mass of rough granite, lying to the eastward of the table, which has elevated them to their present position, a level nearly equal with the summit of the Archæan body. Upon this mass of Archæan granite rest the later sedimentary rocks, dipping westward toward the main mountain-range, with an angle at their base of $8^{\circ}$ to $10^{\circ}$; while on the opposite side of the table, the same beds dip $5^{\circ}$ to $6^{\circ}$ to the eastward, forming a slight synclinal fold or depression, with the beds of the summit lying nearly horizontal. In addition to this synclinal, the limestones at both the north and south ends possess a gentle inclination toward the centre, producing a basin-shaped top. Upon the table, but little soil remains; young trees were entirely absent, yet there were numbers of decaying and dead ones of older growth, which still remained standing.

This is the only instance observed where any disconnected mass of Archæan granite occurs, lying to the eastward of the sedimentary foot-hill formations, which accounts undoubtedly for this singular and exceptional structure of the strata. It is the only instance observed of a synclinal fold in Palæozoic strata east of the mountains, and it is exceedingly interesting in dynamical geology to notice how the entire series of lower sandstone and limestone has been elevated in a horizontal position, and in a manner so entirely at variance with the upheaval of the same formations everywhere else along the mountain-slope, for a distance of one hundred miles. In this upheaval, the Mesozoic formations do not appear to have taken part, and they are nowhere recognized in the immediate region of Table Mountain. East of the mountain, the structure is entirely obscured by either Tertiary or Quaternary deposits, which rest close up against the granite. It would appear highly probable that the comparatively low dip of the beds just north of Wallbach Spring were in some way connected with this outlying body of granite, because a short distance still farther northward the beds occur at a high angle, and to the south of North Crow Creek, beyond the lower end of Table Mountain, they again exhibit a somewhat steep dip. 
Between the north and. south branches of Crow Creek, along the base of the range, the Palæozoic strata are the only rocks that occur well exposed, the later Tertiaries encroaching upon the upper nembers. Just south of the north branch occurs one of the ligh ridges or bluffs which is so characteristic of the Laramie Hills above Wahlbach Spring, the eastern face exposing the grayish-white Carboniferous limestone, which is always found at the top of the series, and may be so easily recognized for long distances across the plain. On the upper side of South Crow Creek, the beds of the Coal-Measure series stand nearly vertical, the lower rock, consisting of a hard compact conglomerate, separated from the red, dense granite by a short narrow cañon. The Palæozoic rocks appear quite thin, and it would seem as if the lower members were wanting; at least, the conglomerate closely resembles an interstratified layer high up among the Carboniferous limestones. In one or two localities, limestones may be seen lying in isolated patches directly upon the granite. Tertiary beds form the banks of Crow Creek Valley, extending close up to the Carboniferous rocks, resting directly against the conglomerate fornation, and, as these upper Tertiary strata consist of a hard coarse sandstone almost a conglomerate, the two sets of beds, lying nearly at riglit angles to each other, present a somewhat singular appearance. South of Crow Creek, the horizontal Tertiary rests directly on the Archæan.

Crow Creek has worn out for itself a broad valley, which has cut down deeply into the Pliocene strata, in several places exposing remnants of Mesozoic formations, probably Cretaceous, but which lack distinctive characters sufficient to determine their horizon. A pure white, soft, friable rock, cropping out near the stream-bed, indicated a strike of north $35^{\circ}$ east, with a dip of $20^{\circ}$ east. Occasionally the steep Pliocene bluffs along the valley will be cut by ravines and gullies, at right angles to the creek, formed by the washing-out of the soft sand rocks during heavy rains and torrents, leaving near the mountains the lower unconformable rocks exposed. In one of these ravines, Capt. A. L. Varney, U. S. A., procured some Reptilian remains, imbedded in hard, dusty-gray sandstone, which Prof. (). (.) Marsh identified as belonging to Lestosaurus, a genus of Mosasauroid Rep- 
tiles, abundant in the Upper Creaceous sandstone, through the Smoky Hill country, in Kansas.

But a short distance north of the railroad occurs an outlying ridge of Carboniferous limestone and the lower red sandstones, with a strike a few degrees west of north and a dip $30^{\circ}$ to the eastward. Here the lower reddish-gray sandstones, with the red arenaceous limestone, are well developed, overlaid by massive blue limestone, passing up into light-gray arenaceous limestone.

Along the inmediate line of the railroad, the Pliocene formation extends I1) to the Archæan body, but directly south the same red sandstones and blue limestone, which occur to the north, come again to the surface, with a dip of only $20^{\circ}$. The limestone has been quite extensively quarried for burning in kilns, and is said to furnish a very good quality of lime, which formerly supplied Cheyenne, Greeley, and the neighboring towns.

Coal-Measure fossils were found here; among them were identified-

Productus cora.

Athyris subtilita.

Still farther southward, the Palæozoic rocks occur inclined against the Archæan gneisses at an angle of $8^{\circ}$ to $10^{\circ}$. They appear to form an unbroken line nearly down to the old Denver and Laramie stage-road, presenting an abrupt wall to the main mountain mass, but falling off with gentle slopes toward the plain. The outlines of overlying formations are somewhat poorly defined, owing to the very irregular erosion of the Pliocene and accumulations of Quaternary deposits. South of the Wyoming and Colorado boundary-line, all the formations, including the Fox Hill beds, are well exposed, dipping at various angles; the Dakota Cretaceous capping the higher and more prominent ridges, and the Colorado Cretaceous, with the upper sandstones, stretching far out upon the plain.

The uplifts of Carboniferous limestone would appear to terminate near where Box Elder Creek turns and breaks through the sedimentary ridges, and from there southward the Triassic Red Beds occur lying next the Archæ:an. 
South of Box Elder Creek, the Triassic beds extend westward for 3 or 4 miles, in a broad, level table, occupying a depression in the Archæan body, overlapping it in a nearly horizontal position, dipping not more than $2^{\circ}$ toward the southeast. Lying next the granites occurs a bed of coarse, reddish-gray conglomerate, which underlies the bright red sandstone. It was not recognized to the north, but it is probably only a conglomerate bed in the Triassic, which here, owing to its position next the granite, appears somewhat coarser and more largely developed East of the Triassic table, the Upper Mesozoic formations dip with varying angles toward the Great Plains, showing considerable disturbance and displacement of strata. Where the stage-road enters the mountains, 3 or 4 miles north of Park's Station, the Cretaceous and Jurassic beds are seen occupying a small re-entering bay or depression. On the inside of this bay, the Jurassic and Dakota Cretaceous curve around, so as to form nearly a semicircle, while the softer beds of the Colorado group fill the central portion. On the north side, the Colorado beds strike north $45^{\circ}$ to $50^{\circ}$ east, with a dip $25^{\circ}$ to $30^{\circ}$ to the southwest; while, on the south side, they present an equally steep dip to the north, forming a sharp synclinal, with the strata contorted and pressed together in a very marked manner; the yellow and cream-colored marls forming so conspicuous a feature of the Cretaceous that the structure is easily made out. The light-colored chalky marls are here characterized by a great abundance of the genus Ostrea, associated with gypsum. From Park's Station southward to the Cache la Poudre, the ridges present a very uniform appearance, with a strike approximately north and south, and a dip varying from $15^{\circ}$ to $25^{\circ}$ east; the Dakota Cretaceous forming an almost unbroken wall of hard reddish-brown quartzite.

Along the base of this wall, all the subdivisions of the Colorado group may be recognized, especially as the Niobrara beds are well developed, although it would seem impossible to define either their lower or upper limits, as the calcareous beds, which are their characteristic lithological feature, pass gradually into both the Fort Benton and Fort Pierre divisions. The Fort Benton and Niobrara beds at Park's Station dip from $16^{\circ}$ to $18^{\circ}$ east, while the Fort Pierre clays to the eastward rapidly flatten out, indi- 
cating dipss of $6^{\circ}$ to $8^{\circ}$. Near Park's Station were found the following Colorado Cretaceous forms :

\section{Inoceramus problematicus.}

Inoceramus difformis.

Inoceramus Barrabini.

The lower geological section, which is given at the bottom of Map I, and crosses the Colorado Range and the Cretaceous plain, cuts the ridges nearly at right angles between 3 and 4 miles south of Park's Station. Here the Red Beds form a well-marked sandstone ridge, with a dip of $20^{\circ}$. The Jurassic marls, with the included limestones, occupy a slight depression at the base of the more elevated Dakota Cretaceous, which here consists of a hard, compact sandstone, inclined also at $20^{\circ}$ toward the plain, but presenting an abrupt wall on the western side. The Colorado group occupies a valley along the base of the Dakota wall, with the lower formation clearly represented.

From the Cache la Poudre to the Big Thompson, a distance of 15 miles, the ridges present considerable uniformity, both in structural and lithological characters. The general strike is a few degrees west of north, with an average dip from $18^{\circ}$ to $22^{\circ}$; both the Red Beds and Dakota sandstone maintaining the same average dip. Proceeding southward, the Red Beds would appear to increase gradually in thickness, and to display more variety in color toward the top, with a loose friable texture. The valley, or depression, which has been already mentioned as frequently lying between the Triassic and Dakota sandstone, and occupied by the Jurassic marls, here becomes a marked topographical feature, arising in part, no doubt, from the sandy, easily-eroded summits of the Red Beds, and in part from the nature of the rigid quartzite wall of Dakota sandstone. The Dakota beds here attain a development of nearly 300 feet, which is their maximum thickness east of the mountains. At the base of the Dakota the conglomerates, which form so persistent a feature, are exposed in a hard compact quartzite rock, which is overlaid by sandy saccharoidal beds, in turn overlaid by a second quartzite. All the divisions of the Colorado group crop out to the eastward, but with the same litho- 
logical and structural features that have already been noted north of Laporte. The bluish-gray argillaceous limestone at the base of the Niobrara. serves as an excellent geological horizon, as it crops out so characteristically and is so persistent.

A specimen of this rock, a fine-grained variety, in which were imbedded numerous specimens of the genus Inoceramus, was submitted to chemical analysis, yielding-

Carbonate of lime.

the residue indicating a fine blue clay. The lower members of the Colorado group maintain approximately the dip of the Dakota beds. An observation made just below Laporte gave, for the yellow chalk marls, an inclination of $16^{\circ}$, while the upper, or Fort Pierre beds, rapidly flatten out, and occur with as gentle a dip as $3^{\circ}$ to $5^{\circ}$. The upper member of the Fort Pierre beds consist largely of arenaceous material, which renders it difficult to separate them from Fox Hill beds. The line which has been followed, however, lies at the base of a long, low ridge of red ferruginous sandstone, which stretches far out upon the plain. In these lower beds, which have an earthy yellowish-brown color and loose texture, were found:

S'caphites nodosus.

Pinna restituta.

Inoceramus Barrabini.

Inoceramus incurvus.

Callista Deweyi.

Anisomyon sexsulcatus.

Ostrea ?

characteristic Fort Pierre fossils, which have likewise been found on the Upper Missouri River near the boundary line between the Fort Pierre and Fox Hill formations.

Several miles before reaching the Big 'Thompson Creek, a long spur or ridge of Archxan schists projects out, with a slight angle to the southwest, away from the main body of the Colorado Range, becoming gradually lower, finally passing away under the plain. As the great body of Archæan rocks still lies to the westward, this spur causes a sort of depres- 
sion, or hay, in the outline of the crystalline mass, around the lower end of which the sedimentary ridges curve somewhat sharply, following closely the Archæan boundary in all its details. In this way, the narrow spur forms an anticlinal axis, with sedimentary beds dipping away on both sides.

On the east side, the beds maintain the same dip as found to the northward, averaging from $18^{\circ}$ to $25^{\circ}$. Below the end of the $\Lambda \mathrm{r}$. sedimentary ridges extend, with an anticlinal structure, for some distance farther southward, the Dakota sandstone still forming the outer member of the upturned ridges. Near where the Dakota beds curve around to follow up along the west side of the Archæan spur, they dip at $45^{\circ}$. The westerlydipping beds have a general trend of north $35^{\circ} 40^{\prime}$ west, with all the formations standing at a much higher angle than upon the east side, many beds reaching nearly a vertical position, with the Dakota sandstones standing out from the main ridge in a most prominent manner. About 2 miles north of the crossing of the Big Thompson, the Mesozoic formations again curve round, this time doubling upon themselves, and resting directly on the main Archxan Range in a manner similar to the outer ridges next the plain. The beds thus dipping eastward from the main range form, with the westward side of the anticlinal fold, a broad synclinal valley within the bay or depression in the Archxan body, which at its broadest expanse measures nearly 3 miles across, gradually narrowing toward the north, until terminated by the coming together of the opposite sides of the fold in a continuous ridge. The Colorado Cretaceous, influenced by the abrupt bending of the underlying formations, circles around the Dakota sandstone, but, so far as observed, does not run up into the northern end of the synclinal, the Dakota forming the upper member exposed. At least, on the east side of the recess, Dakota beds occur standing nearly vertical, and on the west side inclined at a much gentler angle, with a considerable intervening space, so covered with accumulations of Quaternary material as to obscure all the underlying formations, concealing, if present, the Cretaceous marls and clays.

Where the Big Thompson Creek cuts through the outer or anticlinal ridge, it affords a very good exposure across the Red Beds, Jurassic, and 
Dakota Cretaceous. The Red Beds are characterized by heavy, coarse sandstones, of an intensely deep red color at the base, shading off into light yellowish-red near the top, both the Triassic and Jurassic carrying the lime-beds well developed, as limestone and gypsum. In the Triassic, calcarcous layers, more or less mixed with sand, would appear to occupy a thickness of 50 feet; both the thin beds of limestone, which characterize the Red Beds in other places, being well developed, rising above the sandstone in low, regular ridges. The gypsum deposit, a nearly pure white bed, here attains a thickness of at least 25) feet, interstratified in rark red sandstone. In the Jurassic, the light gray cherty limestone, which is a persistent and well-marked feature in the horizon, crops out in a bed nearly 10 feet in width, both underlaid and overlaid by fine, light marls.

The line of separation between Triassic and Jurassic, at best an arbitrary one, based chiefly upon lithological distinctions, is, at the entrance to the Big Thompson Cañon, somewhat difficult to follow, as the marly beds show a considerable vertical expansion, passing down gradually into the Red Beds.

Cretaceous Plains of Colorado.-The clays of the Fort Pierre division of the Colorado group become more and more arenaceous toward the top, and, by imperceptible gradations, pass up into well-defined sandstones of Upper Cretaceous strata. This great development of sandstone embraces both the Fox Hill and Laramie divisions. It covers by far the greater part of the area east of the Colorado Range, extending beyond the limits of our exploration both eastward and southward, forming the characteristic feature of the Great Plains. The lower member, the Fox Hill sandstone, lies directly upon the Fort Pierre clays, whose upper beds, flattening out to the eastward, are rarely seen inclined at a higher angle than $5^{\circ}$ or $6^{\circ}$, with an average dip of $2^{\circ}$ to $4^{\circ}$. The junction between the two formations is generally marked by a low ridge, 2 or 3 feet in height, presenting a mural face toward the mountains, but sloping off gently eastward. This wall, which constitutes a somewhat striking physical feature, is formed by the soft clays having been eroded into shallow longitudinal valleys, and irregular depressions and basins, partially filled in with detrital accumulations, leaving the overlying harder sandstone at a slightly higher 
elevation. Although these sandstones form by no means an unbroken ridge, they may be traced without lifficulty from Box Elder Creek far to the southward of the Big Thompson. From the top of this low ridge, the Fox Hill beds extend out upon the plains with considerable uniformity, falling away gently from the main range, and presenting a nearly level monotonous surface. Where best observed, they have in general a north and south strike, agreeing approximately with the conformable sedimentary ridges, which rest upon the Archæan body. Along the immediate base of the range, they afford but little variety or interest in structural features, lying at low angles, nowhere deeply cut by drainage-courses, with the surface planed down, and generally covered by vegetation.

Along the base of the Laramie Hills, the Fox Hill beds are buried beneath the unconformable Tertiary strata, and first reach the surface just below the boundary-line of Wyoming. Here the exposures are quite irregular, owing to the uneven erosion of the overlying beds and a somewhat local disturbance of the strata; but south of where Box Elder Creek enters the plains, the lower members of the series may be recognized.

In the low sandstone ridge mentioned above, organic remains, characteristic of the boundary between the Fort Pierre and Fox Hill divisions, may be collected in many localities. They were especially abundant just east of Park's Station, about a mile north of the Cache la Poudre, and between 3 and 4 miles southeast of Laporte. From the latter locality were collected numerous well-preserved specimens of the genus Inoceramus, including Inoceramus Barrabini, associated with Ammonites.

The Fox Hill beds east of the Colorado Range are characterized throughout by great uniformity in texture and physical habit, and consist of a coarse sandstone formation, showing only variations in color from reddishbrown to reddish-yellow. They are usually massive, carrying hard, compact beds, interstratified between layers of a more friable nature, which, in the uppermost beds, offer exposures far less numerous than in the lower, and have therefore been less searched for organic remains. We have at the top of the series several hundred feet of strata, whose beds have furnished no fossils; at least to our parties. The thickness of the Fox Hill strata is some- 
what difficult to estimate, owing partly to the impossibility of determining its upper limit, and in part to the uncertainty of dip.

The Fox Hill strata pass by imperceptible gradations into the Laramie series, offering no well-defined line of separation, both formations from top to bottom consisting of coarse sandstone. It is difficult to give a detailed description of either division which is not in some position in the series applicable to the other. In general, however, the two formations present some distinctions which are recognizable in the field over large areas. In the Fox Hill bede, the sandstones are usually more massive, with great uniformity of texture through a wide vertical range. The Laramie beds indicate more variety, with changes, within rertain limits, from coarse to fine layers, frequently interstratified with seams of argillaceous sandstone and of pure clay. In color also, the beds show more changes from rusty-yellow to deep red, with well-marked layers of whitish-gray sandstone. Another characteristic is the occurrence of beds of loose quartz-grains, like beach-sand, lightly held together by some ferruginous cementing material. The Laramie formation possesses even a less dip than the Fox Hill, and over wide areas dips only from $1 \frac{1}{2}{ }^{\circ}$ to $2^{\circ}$; in many places it appears perfectly horizontal. In one or two localities, far to the eastward, the beds indicate a slight inclination to the westward toward the mountains, as if there had been a gentle oscillation in the movements of the beds producing a wave-like structure. Such a structure, however, was not clearly shown. The Fox Hill and Laramie formations taken together have been roughly estimated, in Northern Colorado, as measuring 3,000 feet in thickness, allowing some 1,500 feet to each. In the Laramie formation occur the great deposits of coal, which have proved of such great economic value to Colorado. They form one of its most distinctive features, as in Northern Colorado, at least, no beds of coal have as yet been found in the Fox Hill beds. Through a wide vertical horizon, thin seams of coal and carbonaceous clays appear to crop out in the more elevated banks and ridges, but no attempt to give the numbers of such seams or their true positions in a section has as yet been made with any degree of accuracy. Within the limit of our survey, no coal deposits of any great value have as yet been opened, although a number of tumnels 
have been run, and shafts sunk in several localities without success; all the important deposits of workable coal lie to the southward.

Near what has been taken as the base of the Laramie formation occurs a bed of friable red sandstone, which may be followed for a long distance by a low bank or ridge. In this red sandstone, numerous beds of coal and carbonaceous clays outcrop, many of them having been more or less explored. $\Lambda \mathrm{t}$ the extreme northern limit of the Laramie formation, about 18 miles southwest from Cheyenne, and 5 or 6 miles west from Carr Station, on the Denver Pacific Railroad, in this same red sandstone, occurs one of the earliest discoveries of coal in Colorado.

It derives some interest from its being the most northern occurrence of coal, before the beds pass under the Tertiary deposits. At this locality, the sandstones dip between $10^{\circ}$ and $12^{\circ}$ to the eastward. $\Lambda$ tunnel has been run in on the coal for 100 feet. The seam of coal between the impure clays measures 3 feet.

The following section was made along the bank, beginning at the top:

1. Reddish-yellow sandstone.

2. Arenaceous clay . . . . . . . . . . . . . . . . . . . . . . . .

3. Blue clay $\ldots \ldots \ldots \ldots \ldots \ldots \ldots \ldots \ldots \ldots \ldots \ldots \ldots \ldots \ldots \ldots \ldots \ldots \ldots$ foot.

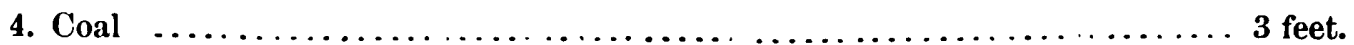

5. Black clay and impure coal $\ldots \ldots \ldots \ldots \ldots \ldots \ldots \ldots \ldots \ldots \ldots \ldots \ldots$ foot.

6. Red sandstone.

In the sandstone overlying the coal nay be collected large numbers of shells belonging to the genus Ostrea.

The coal appears to be of poor quality, and the mine was soon abandoned. It possesses a jet-black color, a somewhat resinous lustre, but crumbles readily on exposure to the air.

Following this red sandstone southward, the coal outcroppings may be traced for a distance of several miles along a shallow longitudinal valley, which trends a few degrees west of south. Along the eastern ridge, usually above the outcropping clay beds, the same shell of the genus Ostrea was found as already mentioned, but very poorly preserved. Still farther southward, the same sandstone rocks would appear to gradually assume a less dip until they are seen, nearly west of Park's Station, lying horizontally, terminating to the eastrard in abrupt escarpments, overlooking a 
nearly level grassy plain of Laramie sandstone. . Still farther southward, the same beds appear to extend nearly to the Cache la Poudre. Along the valley of the river, and upon the adjoining banks, Quaternary beds conceal in a great measure the underlying rocks, but the same series of beds would appear to lie upon both sides of the stream.

On Lone Tree Creek, near Carr's Station, may be seen the grayishwhite sandstone, which would appear to be characteristic of certain horizons in the Laramie formation. Along Lone Tree Creek, Owl Creek, and still farther eastward beyond the limits of our map, beds of undoubted Laramie age form the surface of the plains. In many localities, beds of argillaceous sandstones and carbonaceous clays, with indications of coal seams, crop out; while on Crow Creek, between 4 and 5 miles from its mouth, where it empties into the South Platte, occurs a thin stratum of coal cmbedded in reddish-gray sandstone, which lies approximately horizontal. So far as known, at the time our parties visited this country, in the summer of 1872, no shaft had been sunk in explorations for coal. Since that time, however, numerous openings have been made, which have cut coal seams varying from 2 to 3 feet in thickness, almost always lying nearly horizontal ; but in most cases, the shafts have been abandoned, the coal, besides heing a thin seam, having proved to be of little practical value.

All the specimens of coal which were collected in northem Coloradn, from the area under examination, and those which were shown to us from the immediate region, presented the same general characters, mostly jet black, with a bright lustre, when pure, and free from clay. Many of them carry thin films of pyrites. All of them would appear to crumble readily when exposed to atmospheric agencies.

In regard to the palæontological evidences of the Laramie formation, it may be said that none of the characteristic types of the Fox Hill beds, so abundant all along the base of the mountains, were found by our parties in the upper sandstones. But at several localities forms of marine invertebrata, which Prof. F. B. Meek has pronounced as undoubtedly of Cretaceous age, were obtained from a friable red sandstone which forms the overlying stratum of the Plains. They were found in the high bluff which 
lies between the Cache la Poudre and Big Thompson, west of Greeley and Evans; the most westerly occurrence being some 8 miles west of the former town in a bed which dips about $1^{\circ}$ to the eastward. They also occur on Lone Tree Creek. On Crow Creek, about 4 miles above the mouth, and between the two streams, several miles north of the South Platte.

The following species have been identified :

\section{Avicula Nebrascana. \\ Avicula cancellata. \\ Cardium speciosum. \\ Mactra Warrenana. \\ Nucula planimarginata.}

In addition to the above, Prof. J. J. Stevenson' has since obtained from near Evans and Platteville, just southeast from the map, the following species:

Ammonites lobatus.

\section{Mactra alta.}

Anchura -8

Still later, members of Dr. Hayden's ${ }^{2}$ corps have visited the region and collected most of the above species. It is evident that this group of fossils which occurs together in so many localities within such a limited area, in beds of precisely the same physical habit and composition, and lying approximately level, belong to the same geographical horizon. Indeed, the beds may be traced without much difficulty along the Big Thompson and Cache la Poudre Valleys, and then eastward up the valleys of the northern tributaries to the South Platte. These sandstones form the exposed banks along Crow and Lone Tree Creeks, and may be traced northward, passing under the Tertiary of Chalk Bluffs.

No organic remains were obtained from the beds in close proximity to carbonaceous clays and coal-layers east of the Denver Pacific Railroad, but the structural relations of the beds is such that there can be no doubt that the thin layers of coal occur under, or rather interstratified in, the red sandstones, with well-defined Cretaceous marine invertebrata overlying

${ }^{1}$ The Geological Relations of the Lignitic Groups, by J. J. Stevenson, 1875.

${ }^{2}$ United States Geological and Geographical Survey of Colorado, Washington, 1876. 
them. Although the Laramie beds in the extreme northern portion of Colorado have as yet furnished no coal deposits of great economic value, the region is of considerable geological interest from the occurrence of Cretaceous types lying in such close relation with the coal strata. Beyond the limit of the map, the Laramie beds were traced southward, and were found underlying the plains at Denver, and to include the valuable coal deposits at Frie, and the Marshall and Murphy mines north of Golden, extending from within one-half mile of the base of the range far out upon the Plains into Eastern Colorado.

The Laramie beds form the uppermost members of the great series of conformable strata that lie upturned against the Archran mass of the Rocky Mountains; all overlying strata resting unconformably upon the older rocks. South of Chalk Bluffs such beds cover very suborlinate areas, and are of but little geological importance. They are always found lying either horizontally or upon some sloping bed of deposition, and frequently occur filling depressions, the results of erosion in older formations.

Along the immediate base of the range, usually just outside tho Dakota sandstone, occur isolated patches of irregular terraces and benches, which consist of coarse gravel and smooth rounded boulders held together by ferruginous sands. To the southward, they are much better developed than in the extreme northern part of Colorado. In the region of the Big Thompson, they form a local but well marked feature, appearing on woth sides of the valley, having been cut through by the stream. They reach a development of about 200 feet in thickness, extending southward as far as the Saint Vrain's Creek. There is no positive evidence as to age of these terraces, and they may be either Pliocene-Tertiary or Quaternary; but, from their close resemblance to beds east of the Laramie Hills and to others westward on the Wyoming Plains, they have been referred provisionally to the Wyoming Conglomerate, the latest Pliocene beds of the Rocky Mountains. Out upon the Plains, away from the Colorado Range, the Iaramie sandstones are in places concealed by heavy accumulations of coarsc detrital material of Quaternary age, which consist of finer material than the well-marked terraces, but would appear to be largely derived from their decomposition. Such accumulations form quite a prominent feature in the 
region of the South Platte, and on the low bluffs between Evans and Greeley, and, indeed, in all the shallow basins worn out of the Cretaceous rocks. They lie scattered over the plains in irregular detached beds, and are not represented on the geological maps.

Tertiary Plains of Wyoming.-Between 5 and 6 miles south of the forty-first parallel, the Fox Hill and Laramie Cretaceous pass beneath the nearly horizontal beds of Tertiary strata. Abundant evidence has been furnished that these deposits are, without doubt, the sediments, filling the basins of the ancient fresh-water lakes, which formed so characteristic a feature of the Rocky Mountains through Tertiary times. East of the Rocky Mountains, these formations cover a very large area. From Chalk Bluffs they extend completely across the Territory of Wyoming, having been traced far northward into Dakota. To the eastward, they stretch far out upon the Nebraska Plains, their boundary in that direction having never been carefully determined; while westward the Colorado Range formed an effectual barrier.

Within the area of our survey occur both Miocene and Pliocene strata, with palæontological evidence of their age. To the beds of the Miocene lake-basin, the name, White River, first used by Dr. Hayden, has been applied, while, for the overlying Pliocene strata, the name Niobrara, first suggested by Prof. O. C. Marsh, has been retained.

White River Mrocene--As the White River formation is overlaid by the Niobrara, the outcrops of the former are necessarily somewhat limited, and the difficulty of tracing the outlines of the ancient Miocene lake is greatly enhanced. Within the area of our map, the only opportunity for studying the White River strata is to be found along the south and east face of Chalk Bluffs, where they protrude from beneath Pliocene beds. They rest unconformably upon the Laramie sandstones, and although the Cretaceous lies essentially horizontal, it has undergone considerable erosion before the deposition of the Tertiary, as the latter is found filling the uneven surfaces of the former. The Chalk Bluffs are but the abrupt terminations to the south and east of the Tertiary strata, which rise from the Cretaceous Plains by receding benches and terraces some 700 feet in height. From Cheyenne southward, the surface of the country is nearly level until within a short distance of the $5 \mathrm{D}$ a 
bluffs, where the country begins to fall off in low, gentle benches of Pliocene strata, overlying the more abrupt cliffs of Miocene which rest directly upon the Laramie sandstones. Along the face of Chalk Bluffs, numerous small streams, ravines, and gullies have worn out good exposures in the soft beds, producing a rugged, uneven surface of clays, marls, and sands.

From an examination of the country to the west of Chalk 13luffs, it seems evident that, while the Pliocene shore extended close up to within a short distance of the Archæan foundation of the Colorado Range, the waters of the Miocene lake, which undoubtedly stood at a much lower level, were hemmed in farther out upon the plains by the gently-rising Mesozoic beds, the beach-line being formed upon the Laramie formation. On the other hand, the Pliocene beds are found resting uncontormably upon all the divisions of the Cretaceous, Jurassic, Triassic, and Carboniferous.

The Miocene strata are exposed from near Carr's Station on the Denver Pacific Railroad, eastward across Owl Creek, the tributaries of Crow Creek, and stretch beyond our eastern boundary.

Between the Laramie sandstones below and clearly-defined Pliocene beds above, the Miocene presents a development of nearly 300 feet in thickness, with an altitude for the basin of about 5,800 feet above sea-level. Tho line separating the Miocene and Pliocene lake-basins is, however, a difficult one to determine, as both formations lie horizontally, and consist of beds with much the same lithological composition, with but little evidences of erosion between the two series. So far as the Chalk Bluffs are concerned, the line of junction between the two basins rests almost entirely upon palæontological evidence.

In general, the Miocene lake strata, in their lithological habit, are characterized by a rapidly-changing composition, with a considerable variety in texture, color, and compactness of beds, and are noticeable, in distinction from the Pliocene, for the fineness of sediment and absence of heavy layers of coarse, sandy material. They consist of alternating layers of marls and clays, interstratified with thin beds of fine sand, lousely held together without any cementing material. Occasionally, beds will be more compact from the presence of ferruginous layers, which make well-defined horizons. In 
color, the beds are all of light shades; the marls, which form the most prominent feature in the cliffs, suggesting the name of Chalk Bluffs.

From the exposures in the Chalk Bluffs, along the tributaries of Crow and Little Crow Creeks, Prof. O. C. Marsh has made large collections of vertebrate fossils, now in the museum of Yale College, which abundantly prove the Miocene age of the lower beds. Among the more important of these vertebrate remains obtained from this locality may be mentioned the following:

\section{Brontotherium ingens, Marsh ; \\ Brontotherium gigas, Marsh;}

two lugge mammals, nearly as large as an elephant, and exceeding in size any other extinct animal from this formation. These animals belong to an entirely new family, which Professor Marsh has designated the Brontotherida. They were as large as the Dinocerata, which characterize the Eocene lakebasins of Wyoming. They are most nearly related to the rhinoceros, but show some characters that indicate close affinities with the elephant.

Another large mammal, described from this region by Professor Marsh, was Elothcrium crassum, also about the size of a rhinoceros. In these same Miocene beds were also obtained many small mammals, carnivores, rodents, insectivores, and a few fragments of birds.

Niobrara Pliocene.-The upper 300 or 400 feet of the Chalk Bluffs consist of Pliocene strata, which cover the entire area of our map east of the Laramie Hills. The surface of the country is undulating, but generally so smooth and covered with loose soil as to present but few good exposures, except along the valleys of numerous streams and on the benches high up near the mountains. The valleys of Crow, Lodge Pole, Horse, and the Chugwater Creeks cut deeply into the underlying strata; the bluffs upon both sides of the streams presenting long continuous walls of bare rocks, from 100 to 200 feet in height. These streams, whose valleys vary from $\frac{1}{4}$ to 4 miles in width, usually erode through the soft strata till they reach some bed of hard, impervious clay, which forms their bottom. The surface of the Pliocene lake-basin, along the immediate base of the range, had an altitude above sea-level of at least 7,000 feet, and perhaps from 100 to 200 
feet more. For the entire thickness of the deposit, the beds would indicate from 1,200 to 1,500 feet.

As already mentioned, the beds are found lying unconformably upon the older uplifted strata and overlapping the area of the Miocene basin. South of the Union Pacific Railroad, they occur abutting against Mesozoic, formations; just north of Granite Cañon, they lie next the Archaan mass; and a short distance beyond, at the mouth of Crow Creek Canon, are found essentially horizontal against nearly vertical Palxozoic limestones. From Crow Creek northward, as indicated upon the geological map, they may be seen resting directly upon every formation, from the Archaran to the Fox Hill Cretaceous.

In general, the lithological aspect of the Niobrara Tertiary strata closely resembles that of the Miocene basin, as already described; but from the much greater area over which they occur, and from the many widely separated exposures, affords peculiarities not observed in the limited outcrop of the latter. The most prominent feature in the Pliocene, in distinction from the underlying formation, is the prevailing arenaceous nature of the beds, and the greater persistency in character, through a wider vertical range. Marls, clays, coarse and fine sandstones, conglomerates, with some nearly pure limestones, make up the strata. Of these, fine, marly sandstones are the predominant beds, while light-colored limestones are exceptional, and would appear to occupy only small areas, probably lenticular masses, filling shallow basins and depressions.

Over the greater part of these Tertiary plains, the upper layers are made up of coarse, hard sandstones, which near the mountains may be called a conglomerate, firmly held together by a fine cementing material, forming a sort of concrete. They consist of fine and coarse pebbles, crystals of quartz, and feldspar; chiefly material from the Archæan granites and gneisses, varying in size from a pea up to a foot in diameter. The upper stratum withstands atmospheric agencies remarkably well, and serves to protect the more easily eroded beds beneath. The character of these overlying conglomerates is well shown along the gently-sloping bench upon which the railroad reaches the mountains, and along the bluffs upon both sides of South Crow Creek, where it not infrequently overhangs, eaves- 
fashion, the softer rocks below, which have been washed out by the driving rains and storms. A peculiarity of this upper fine conglomerate is a tendency to split up into blocks and slabs from 6 to 12 inches in thickness. Near the mountains, these upper beds lie inclined at from $1 \frac{1}{2}^{\circ}$ to $21^{\circ}$, forming a most excellent railway-grade. Underlying the fine conglomerate along the railway-bench, and in the valley of Crow Creek, occurs another characteristic bed of the Pliocene basin, which consists of an exceedingly fine, almost impalpable, arenaceous marl, of a light cream color, and free from all inclosed pebbles, which mark both the underlying and overlying strata. Out upon the Plains, the upper stratum is usually somewhat finer than near the mountains, but of essentially the same nature-light-gray and ash-colored rocks, consisting of sands and Archæan pebbles. Below these are alternating beds of marls, clays, and calcareous grits, with thin seams of mud-rocks and belts of fine sand.

South of the railroad and west of Chalk Bluffs, the country falls off rapidly, and has undergone a very considerable amount of erosion, carrying away a great part of the Tertiary strata, and leaving a broken, irregular surface, with isolated hills and benches of Pliocene beds, which, where not covered by Quaternary detritus, offer exposures of considerable vertical thickness, but without any special geological interest. Erosion has, in several places, so worn away the overlying Tertiaries within the area colored on the map as Pliocene, between Box Elder and Lone Tree Creeks, as to expose, in a few localities, isolated patches of the underlying unconformable Cretaceous sandstones. About 12 miles south of Cheyenne, and 3 or 4 miles northwest from Carr's Station, the effect of erosion upon these horizontal strata is well shown at the "Natural Forts", where the reddishyellow sandstone is curiously worn away, leaving walls well arranged for purposes of defence. About 5 miles south of Cheyenne occurs a development of the light cream-colored limestone of the Pliocene basin. As it weathers slowly, it stands above the friable sands that here form the top of the plateau, and appears above the surface in a line of low, conical hills. It has a hard, cherty fracture, and is traversed by thin seams of quartz, which give the rock a somewhat more siliceous appearance than chemical analysis would indicate. Attempts have been made to burn it for lime, 
but they were soon abandoned, the lime made from the Carboniferous rocks at Granite Cañon proving much more desirable.

An analysis of the Cheyenne limestone yielded Mr. R. W. Woodward the following:

\begin{tabular}{|c|c|}
\hline Silica $\ldots \ldots \ldots \ldots \ldots \ldots \ldots \ldots$ & 1.49 \\
\hline Ferric oxide $\ldots \ldots \ldots \ldots \ldots \ldots \ldots \ldots$ & 0.37 \\
\hline Manganous oxide............. & 0.15 \\
\hline Lime . . . . . . . . . . . . . . . & 54.16 \\
\hline Magnesia . . . . . . . . . . . . . . . & 0.15 \\
\hline Carbonic acid and water..... & 43.68 \\
\hline
\end{tabular}

North of Crow Creek, along the bluffs of Lodge Pole and Horse Creeks, the beds retain much the characteristics of those already described, being light-colored, fine-grained sediments, largely arenaceous, with beds of marls and calcareous grits. The prevailing color of the sandstone is either ash or lavender, many of the beds suggesting fine pumice.

Near the mountains, between Lodge Pole and Chugwater Crecks, both the Tertiary and Cretaceous rocks have undergone considerable crosion, producing longitudinal valleys shut in by the Laramie Ilills on one side and abrupt walls of Pliocene Tertiary on the other. North of Horse Creek these walls, which are quite regular, and have been designated as Shelter Bluffs, rise from 250 to 300 feet in height. They consist of the same lightcolored marls as found upon Crow Creek. In places they are filled with small concretions of the same material, although harder, and carry thin beds of sandstone.

The Chugwater is, perhaps, the most characteristic valley, which cuts through the Tertiary basin, the stream running for over 50 miles through a nearly continuous line of bluffs, offering exposures of marls, grits, and clays capped by the hard sandstones. Fvery few hundred yards the bluffs are cut at right angles by ravines and gullies, which offer considerable diversity in form and outline, suggesting the "Manvaises Terres" of I)akota.

All through the marls and calcareous grits, but more especially abundant in the bluffs along the Chugwater, occur irregular segregations and 
thin lenticular seams of a jasper-like rock. This rock is traversed by narrow lines of calcareous spar and silica. It possesses a conchoidal fracture, a homogeneous texture, and in color is always some light shade of gray, green, or brown. In many localities, it is penetrated by dendritic forms of iron or manganese. Moss-agates are found scattered through the marls in small fragments and chips, which have been eagerly searched for by the inlabitants. In one or two localities, they occur so abundantly as to form an article of commerce. They were purchased by a firm of manufacturing jewellers, in Cheyenne, at a fixed price per pound, from which they obtained large numbers sufficiently clear and perfect to polish for ornamental stones. Most of the moss-agates which we see worn are obtained from the Tertiary plains of Wyoming. Many of them show a great variety of colors, with beautiful opalescent tints, and are frequently very rich in the enclosed dendritic forms of iron and manganese. Fine specimens have been found on the Chugwater, near the crossing, and again on Horse Creek, 12 miles east of the Military Road.

Silicified wood is also scattered through the Pliocene basin, but is a less marked feature than in the Tertiary beds of Nevadia.

$\Lambda$ s regards the life of the Niobrara basin, invertebrate remains would appear to be rare; at least, none were found by our parties. But of vertebrate fossils, Prof. O. C. Marsh has made large collections from numerous localities, especially from the upper beds at Chalk Bluffs, many of the species being identical with those found in the same formation from the "Mauvaises Terres".

Among the more important species obtained by Professor Marsh may be mentioned the following:

\section{Mastodon murificus, Leidy. Elephas imperator, $\mathrm{L}$. \\ Protohippus parvulus, Marsh. \\ Pliohippus, Hipparion.}

These forms show a warm temperate climate

Wyoming Cosglomerate.-Clearly overlying the Pliocene lakedeposits are found, along the base of the range, beds of both coarse and fine conglomerate, which hold a somewhat doubtful geological position. 
They are recognized only on the Sybille Creek and its tributaries, and in the region of the Chugwater and Pebble Creeks; localities where the Palæozoic and Mesozoic strata are wanting, the Tertiary formations abutting directly against the Archæan body. They are best developed on the Sybille, where they reach a thickness of 300 or 400 feet, made up largely of Archæan material, from rocks found in the Laramie Hills. The formation is cut through by numerous streams, which give it a bench-like terrace formation. That they overlie the Niobrara basin there can be no doubt, and at the same time are older than the loose Quaternary detritus that covers the plains all along the base of the range. Upon the geological map, they have been referred, along with somewhat similar beds on the Big Thompson, although at the latter locality they are not so well developed, to the Wyoming Conglomerate of the Green River basin. 


\section{SECTION II.}

\section{CARAMIE PLAINS}

BY ARNOLD HAGUE.

Physical Description.-To the westward of the Laramie Hills extends a broad expanse of open, nearly level country, known as the Laramie Plains, occupying the depressed area between these hills on the one side and the Medicine Bow Range on the other; the former a comparatively low uniform ridge, reaching scarcely more than 1,500 feet above the plain; the latter a high mountain mass rising between 3,000 and 4,000 feet. On the south, the plains are shut in near the forty-first parallel, the boundary between Colorado and Wyoming, by the coming together of the Colorado and Medicine Bow Ranges, and to the north by the Rattlesnake Hills, an irregular mountain group beyond the limits of this exploration. To the northwest, however, the plains are not entirely rimmed in, the open country stretching for a long distance without any marked geographical boundary. For most purposes, however, it will be well to regard the western boundary of the plains as limited by the Como Ridge, just north of the Medicine Bow Range, and situated at the extreme northwestern corner of the east half of Map I. As thus defined, the Laramie Plains measure at least 80 miles in length by about 30 miles in width.

In their broader general features, these plains bear many points of resemblance to the areas of depression along the Archæan Ranges of the Rocky Mountains, which stretch across Colorado southward as far as New Mexico, and have been designated the parks. In the case of the plains, they cover a somewhat larger extent of country, and are not in so marked a manner completely enclosed by high rugged mountains.

The Laramie Plains have an average elevation of 7,000 feet above sea-level, varying from 6,800 to 7,300 feet. The town of Laramie, on the 
line of the railroad, has an elevation of 7,143 feet, or a little more than 1,000 feet above Cheyenne, near the east base of the Colorado Range. The surface of the country is undulating, with slopes so gentle, and with such rounded outlines, that to the eye the greater part of the area seems 'practically level, and appears only to be broken by long bench-like ridges and occasional patches of sandstone, which have escaped the general erosion. Over the greater part of the area there is no elevation that could possibly be called a mountain or butte, only hilly ridges 100 or 200 feet above the general level.

The Laramie Plains are drained almost exclusively by the Laramie River, which, rising high up in the Medicine Bow Range, enters the plains near Sheep Mountain, flows a little north of east until it reaches the lowest part of the valley on the eastern side, then near Fort Sanders turns and runs north, with a very circuitous course, till beyond the limits of our map. No stream joins the river from the east, and from the south only two creeks, Willow and Antelope, reach the main stream. Numerous streams come down from the Medicine Bow Range on the west, but the Little Laramie, with its many tributaries, alone empties into the main river, the others either ending in lakes or sinking in sands, except in seasons of long-continued rains. The Laramie River is a fine, clear stream, with a rapid current and a broad alluvial bottom covered with grass.

Rock Creek, at the northern end of the Medicine Bow Range, after running out upon the plain, suddenly turns, flows westward around the Como ridge, and joins the Medicine Bow River; the only stream that does not drain toward the Laramie River.

Dotted over the surface of the plain occur numerous small lakes, lying in shallow basins in the nearly horizontal sandstones. Many of them are fresh-water lakes, or only slightly brackish; while others, especially the smaller ones, are strongly alkaline, and, in dry seasons, completely disappear, leaving incrustations of salines, admixtures of carbonates and sulphates. Deposits of these salts also occur on the plains, which may prove to be of considerable thickness and of economic value. The largest of the lakes is known as Cooper's Lake, lying in about the middle of the plains, just west of the railroad. It measures nearly 4 miles in length by 2 in width. 
Trees are wanting over the entire area, except along the broad valleys of streams; but the ridges, benches, and plain are well covered with a luxuriant growth of grass, offering fine grazing land.

General Geology.-In their geological aspect, the Laramie Plains are essentially a Cretaceous formation. All the beds of the Cretaceous recognized in other localities are represented, from the Dakota well up into the Fox Hill sandstones. The Colorado group, however, covers the greater part of the area, lying in a nearly horizontal position. Along the flanks of the ranges, the entire series of conformable strata exposed in the uplifted ridges east of the mountains occurs bordering the plains, resting unconformably upon the Archæan masses at varying angles, but always flattening out toward the valley. Rising above the plain, on the eastern side, occurs the broad belt of Palieozoic strata, which forms the western side of the anticlinal fold, already mentioned as passing over the Laramie Hills. From beyond the northern limits of our map, southward for 55 miles, these Palæozoic beds extend with an unbroken continuity of strata nearly to Harney Station, on the line of the railroad, where they are overlapped by Red Beds, which, from here southward, rest directly on the granite. Nowhere along the belt of the Fortieth Parallel Survey do the Carboniferous limestones present for so long a distance so uniform a ridge, with as little exhibition of marked flexures or folds, as along the west side of the Laramie Ilills. The strata everywhere dip with great regularity at gentle angles; the highest observed dip being $12^{\circ}$, with an average inclination from $5^{\circ}$ to $8^{\circ}$. High up on the hills, next the Archran rocks, the lower red sandstones occur, forming a low wall with a steep face toward the older formation, and sloping gently westward. The surface is usually so worn down, and the inclination of beds so slight, that the ridge offers but few localities for obtaining sections through the entire series. Only in one or two places have the limestones been cut by deep cañons, exposing any very great thickness of strata; the cañons just back of Laramie City and Fort Sanders probably presenting the best exposures, with abrupt walls several hundred feet in thickness. The Palxozoic series, on both sides of the Laramie IIills, show very great similarity in lithological habit. At the base occurs the coarse red sandstone, more or less compact, made up of fine quartz-grains 
and angular pebbles, in places passing into a hard conglomerate; but none of the beds observed exhibit the tendency to form quartzite, as on the opposite side of the range. The lower sandstones pass up into granular arenaceous limestone, with a reddish-yellow color, intercalated with layers of lighter shade, and in turn overlaid by heavy massive blue limestone, reaching to the top of the series. Probably, the narrow layers of sand-rock and conglomerate, which may be detected in the blue limestone along the east base of the range, occur here, but the opportunities offered for observing such details are by no means as good. In thickness, the Palæozoic beds west of the hills develop not far from 1,200 feet of sandstone and limestone strata.

All palæontological evidence obtained from these beds would tend to show that they belonged to the Coal-Measure limestones. No fossils were found in the upper members of the series, as on the east side; but, on the other hand, in several localities, within 200 or 300 feet of the base, characteristic Coal-Measure forms are abundant.

Near where the road which crosses the range, following up Sybille Creek from the east, passes over the Carboniferous limestone upon the west side, the beds which are found dipping from $5^{\circ}$ to $7^{\circ}$ consist of a hard, moderately fine-grained, bluish-gray limestone, carrying through a vertical range of 200 or 300 feet, and reaching at least within 200 fect of the base, the following Carboniferous species:

Productus Prattenianus.

Productus costatus.

Athyris subtilita.

Near the top of the Cheyenne Pass, in a very similar-looking limestone, and doubtless the same horizon, were found-

\section{Productus semireticulatus.}

Productus cora.

Athyris subtilita.

Bellerophon —?

Orthoceras —

Still farther southward, some 5 miles northwest of Sherman, the lower 
members of the series are well exposed, the lower red sandstone being quite characteristically but thinly developed, and overlaid by a slightly reddishgray limestone, possessing a strike of north 20 east, and a dip from $7^{\circ}$ to $9^{\circ}$ west. Near the base of this limestone were procured the following:

Productus Prattenianus.

Productus cora.

Along the gentle slope of the plain, directly overlying the Carboniferous limestone, occur the Red Beds of the Triassic. The junction between the two formations is not always so readily traced as east of the mountain, the surface-rock being generally concealed by loose soil, and is frequently only to be followed by the distinctly reddish tinge given to the gravel by the overlying sandstone. In a few localities, red sandstone beds stand out prominently in bench-like formations or bluffs, but usually appear planed down, conforming with other strata in the gentle slope toward the bottom of the valley, lying inclined from $4^{\circ}$ to a perfectly horizontal position, and offering but few good exposures. The best exposures of the Red Beds, including, as well, those of the Jurassic group, may be seen near Red Buttes on the railroad where the characteristic and peculiar forms produced by erosion on sandstones of horizontal Triassic beds has suggested the name for the station. Over a considerable area, immediately east of the station, sandstones, marls, and clays have been eroded into isolated hills and ridges, exposing the strata in many places for over 100 feet in nearly vertical walls, the heavier and more compact layers preserving the softer and more friable ones beneath from being worn down by atmospheric agencies. Near Red Buttes, the upper members of the Carboniferous are bluish-gray limestones, while the lowest red sandstones lack the intense color usually observed at the base of the series. They have a reddish-yellow tinge, with concentric spots of brick-red, and show more or less of a shaly structure. In composition, they appear to consist of fine grains of quartz, held together by a cementing material of carbonate of lime. All the beds are fine-grained, with occasional layers carrying coarser pebbles, and varying in color, but always exhibiting some shade of red, even up to the top of the Jurassic, the two formations being here very difficult to separate by the lithological 
distinctions observed elsewhere. In the upper part of the series, the most characteristic Jurassic limestone has a flesh-red color, with a uniform texture mixed with considerable fine, angular grains of sand. No well-defined organic remains were found, but the rock shows indistinct fossiliferous fragments.

This limestone was subjected to chemical analysis by Mr. B. E. Brewster, with the following result :

Silica .............................

Ferric oxide and alumina.

Lime..........................

Magnesia.

Carbonic acid

Water

which, when combined, yields-

99.890

Carbonate of lime.

76. 748

Carbonate of magnesia.

0.321

Along the east side of the plains, the Dakota sandstones may at times be recognized, cropping out above the accumulations of Quaternary débris, sufficiently well defined to trace their horizon. At the north, the beds appear to incline westward, with an angle of $2^{\circ}$ to $3^{\circ}$, but become horizontal to the south. They crop out just east of Lake Ione, and, so far as observed, are found only on the east side of the Laramie River till within 6 or 7 miles of Laramie City, which they appear to underlie as well as Fort Sanders, and to form the banks on both sides of the river; on the west side rising above the stream in a low rounded ridge, sloping westward.

The rock is a yellowish-brown, medium-grained sandstone, with some carbonaceous material scattered through the upper beds.

South of the railroad, the Triassic, Jurassic, and Dakota Cretaceous, following the boundary of the Archæan, curve around to the soutliwest, lying inclined at not more than from $1^{\circ}$ to $4^{\circ}$ toward the plain. The Triassic Red Beds rest directly on and overlap the granites, jutting up against 
the steeper slopes. All the beds fall away gently, with an occasional ridge formed by a layer of hard sandstone, capping softer beds, which presents a slight escarpment toward the mountain, and through which the streams have cut their channels, exposing portions of the strata. On Antelope Creek, the gypsum deposits are well shown, just north of the Willow Creek and North Park Road, interstratified in dark red sandstone. South of the road, about one mile, bordering the creek on both sides, the light-colored Triassic strata have been eroded into the most fantastic and fanciful forms, which very readily suggest the name, which has been applied to them, of the "Ruined City". They are neither as prominent, nor cover so large an area, as the similar formation at Red Buttes, but, on the other hand, are much more compact, with great diversity of outline, and suggest a variety of architectural designs.

A short distance west of Antelope Creek, the Triassic rocks occupy a re-entering angle, or depression, in the Archæan body, extending some twelve miles to the southward of the Colorado and Wyoming boundary, and westward to the Laramie River. Along the east side of the river is a narrow strip of Archæan rocks, upon which the Triassic beds rest. Here the Red Beds, and probably the overlying Jurassic marls and limestones, are well developed, exhibiting a series of nearly horizontal strata, between 1,000 and 1,200 feet in thickness, with perhaps a very slight inclination toward the north and northwest, the beds dipping away from the Archæan body. Facing the plains, the red sandstone presents an abrupt wall from 600 to 1,000 feet in height, showing in a marked manner the variegated beds, with the interstratified marls and limestones; while, on the east side, Sand Creek, which rises on the top of the plateau, cuts a deep, narrow cañon through the Red-Bed formation. These exposures exhibit a development of Triassic beds at least 1,000 feet in thickness, and are overlaid by the light-colored Jurassic strata, forming the summit of the plateau.

Resting upon the Archæan body, the lowest beds consist of coarse, friable, ash-colored sandstone, with pebbles and angular fragments, overlaid by a thin bed of hard, cherty limestone, which is, in turn, overlaid by reddish-gray sandstone. Above this comes the usual persistent red sandstone, passing up into clayey beds, more or less shaly, developing into a 
series of argillaceous sandstones, with thin layers of fine red clay and beds of gypsum, the latter varying in thickness from two or three inches up to several feet; the thickest deposit of pure solid gypsum, measuring 22 feet in width, lying between two beds of hard red sandstone. Nowhere in the region of the Rocky Mountains, within the belt of this exploration, are the gypsiferous deposits so well developed, at the same time so easily accessible from the railroad. Overlying the gypsum series, again occur the red sandstones, passing up into yellowish-red friable beds, shading off into white sandstones and marls, which may represent the base of the Jurassic series. Above the white sandstone occurs a bed of fine bluish-gray cherty limestone, which crops out prominently, and probably represents the stratum which is so persistent east of the Colorado Range; this, in turn, is overlaid by white and cream-colored sandstones and marls, passing into brownish beds, with layers of variegated clays and marls, and again overlaid by friable white sandstone, which appears to form, in many places, the summit of the plateau.

The following section represents more clearly the succession of strata, with estimated thicknesses, beginning with the Jurassic on the summit of the plateau, and descending to the base of the Triassic, which rests on Archæan rocks :

1. Friable white sandstone $\ldots \ldots \ldots \ldots \ldots \ldots \ldots \ldots \ldots \ldots \ldots \ldots \ldots \ldots \ldots$
2. Reddish.brown sandstone, with layers of variegated clays and

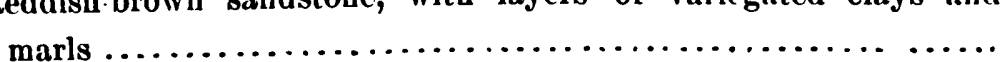

3. Cream-colored sandstones and marls $\ldots \ldots \ldots \ldots \ldots \ldots \ldots \ldots \ldots$

4. Bluish-gray cherty limestone.........................

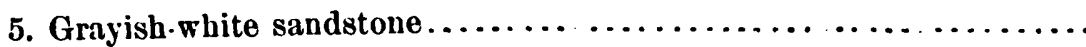

25 feet.

Triassic.

6. Yellowish-red sandstone

375 feet.

7. Fine deep-red sandstone.........................

8. Argillaceous sands and shales, with interstratified layers of fine clay and gypsum, including one bed of gypsum 22 feet thick .........

150 fect.

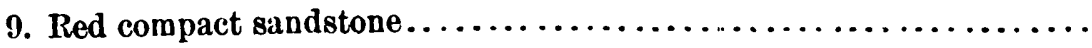

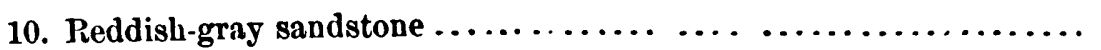

11. Thin bed of gray cherty limestone $\ldots \ldots \ldots \ldots \ldots \ldots \ldots \ldots \ldots$

12. Coarse, friable, ash-colored sandstone, witb pebbles............

225 feet.

1,200 feet. 
Near where the North Park road leaves the plains, going over to the Upper Laramie River, the Triassic and Jurassic formations jut up against the Archæan, which here occurs as a low, narrow ridge, only 300 or 400 feet in height, forming the east side of the Laramie Valley. On the opposite side of this ridge, in the broad river-valley, occurs an isolated body of Red Beds, the sandstones which formerly covered the ridge having been entirely eroded. 'The exposure of Red Beds, however, is limited, as a short distance below, where the road crosses the valley, the river runs through a narrow gorge in the Archæan rocks, west of Sheep Mountain. Under the characteristic red sandstones is found a narrow layer of blue limestone, only a few feet in thickness, below which occur white sandstones. Returning to the Plains again, we find that east of Sheep Mountain the beds of the Colorado group are the oldest formations found lying upon the Archæan body. The older rock-mass presents a steep slope toward the plains, around which curve the Cretaceous clays and marls, with a very varying strike and a somewhat varying dip. The line of junction between the two formations is very much obscured by detrital accumulations from the mountain, the clays presenting few well-defined outcrops. Approaching the mountain by the North Park road, the first outcrops that are seen, after leaving the nearly level plain and commencing to ascend the gentle grade, are a series of dark brown and black, thinly-bedded shales and clays, with interstratified layers of impure limestone, more or less mixed with coarse sand. In the limestone occur some fragments of organic remains, but too poor for specific determination, while the purer black clays carry thin seams of carbonaceous material, with occasional coatings and incrustations of gypsum. Underlying these dark clays, which have been referred to the Fort Pierre division, occur yellow and blue marls, which crop out in low, rounded banks, rising but a few inches above the level plain, but which mark very clearly the horizon of the Niobrara beds. They are characterized by the presence of large numbers of the species Ostrea congesta. Below the light-colored marls, the beds pass down into slate-colored mud-rocks, becoming more and more argillaceous, and apparently losing the calcareous character of the overlying strata; these clay-beds, in turn, are underlaid by (6 D G 
brownish, rusty sandstone, with occasional concretions of ferruginous inaterial. All of these beds dip at low angles, varying from $8^{\circ}$ to $15^{\circ}$.

On the north side of Sheep Mountain, where the Big Laramie River leaves the Medicine Bow Range, running out on to the plain, the entire series of sedimentary rocks again appears resting upon the Archæan body. The Carboniferous beds, here a light blue arenaceous limestone, stand nearly vertical, close up against the metamorphic rocks, and overlaid by the bright-colored Red Beds, with the fine gray marls of the Jurassic indicated by their characteristic soil and peculiar topography, lying between two formations of massive sandstone. Every formation, from the Triassic to the Niobrara division of the Colorado group, appears well developed along the south bank of the river, inclined at $16^{\circ}$ to $18^{\circ}$. Above the bank, the Fort Benton clays are somewhat concealed by overlying soil; but along the bluffs, where the river cuts the beds at right angles to their strike, the dark, almost black clays, passing up into slate-colored marls, are well exposed. The bluish-gray marls, which characterize the junction between the Fort Benton and Niobrara divisions, and form a prominent feature east of the Colorado Range in the region of Big Thompson Creek, are shown here, carrying the well-known Inoceramus problematicus. On the north side of the river, outcrops of the light-colored marls stand out prominently, but would seem to be quite thinly dereloped; at least, they rapidly pass into coarse, friable sandstones, which, in long, gentle, bench-like ridges, extend out upon the plains.

Between the Big and Little Laramie Rivers, east of Bellevue Peak, the Colorado beds are again found resting on the Archæan, as in the case of Sheep Mountain, but are still more hidden by overlying Quaternary deposits. At the northern end of Bellevue Peak, the lower sedimentary rocks again reach the surface, and adhere so closely to the Archean outline as to form a semicircular wall, with a diameter of less than 4 miles, showing all the formations, from the Carboniferous to the top of the Colorado group, curving around the older rocks. The Carboniferous beds lie 1,000 feet or more up on the sides of the mountain, inclined at varying angles, having, where they first appear on the east slope, a dip of $20^{\circ}$ to $25^{\circ}$ to the northward. These Carboniferous limestones possess a saccharoidal 
texture, and seem highly arenaceous throughout most of the beds. Of the Mesozoic strata, the Red Beds, Jurassic, and Dakota Cretaceous lie inclined from $20^{\circ}$ to $30^{\circ}$. Here the bluish-drab, cherty limestone of the Jurassic forms a prominent outcrop, rising slightly above the enclosing marls. Overlying the Dakota Cretaceous, the clays of the Colorado group incline at a gentler angle, affording few exposures, except the two low rolls of blue and yellow marls in the Niobrara division. Except in the latter beds, no organic remains were found in the entire series, and these were confined to the genus Ostrea. The Fort Pierre black clays dip away from the Niobrara beds with a slight angle, soon becoming nearly horizontal, and, so far as visited, appear to occupy the greater part of the circular basin north and west of Bellevue Peak, through which the numerous tributaries of the Little Laramie River run, and as these streams cut but little into the clays, their banks offer poor exposures of strata. It is possible that at the upper end of the basin older rocks than Cretaceous may be exposed resting against the Archæan range. 'The surface of the basin is quite level, and furnishes excellent grazing-land for large herds of cattle.

Along the broad valleys of the Big and Little Laramie River, and, indeed, over the greater part of the plains, long bench-like ridges form a characteristic feature of the region. Except on their edges, the benches present but few outcrops, and these usually exhibit coarse sandstone beds, lying in a nearly horizontal position. In numerous localities, organic remains have been found embedded in the sandstones, and have in every case been sufficiently characteristic to show that the beds belong to the Colorado group, without clearly determining the more limited subdivisions of the series. It seems evident, therefore, from our explorations, that the central portion of the Laramie Plains is underlaid by the Colorado group, and that all the beds may be present, but with more or less of an arenaceous texture. At the northern end of the plains, between Lake Ione and the Laramie River, in a yellowish-brown sandstone, was found the characteristic Fort Pierre species, Baculites ovatus, their surfaces being coated with exceedingly beautiful iridescent hues, associated with the genus Ammonites. At the southern end of the plains, near where the Laramie River crosses the western boundary of the Fort Sanders military reservation, the banks 
of the stream have exposed some arenaceous black clays, earrying interstratified narrow beds of purer sandstones, which dip about $1^{\circ}$ to the westward, and in their general habit closely resemble the Fort Benton beds. From these clays were collected Ostrea congesta, and minute but well-preserved fish-scales lying with their broader surfaces parallel with the stratification.

On the west side of the river, the Colorado group extends well up on the steeper slopes of the Medicine Bow Range, underlying the railroad as far westward as Como Lake, but affording few characteristic outcrops. Between Lookout and Miser Stations, beds of argillaceous sandstones are well exposed, from which were collected specimens of the genus Inoceramus. A short distance east of Miser, the railroad cuts through a heavy bed of brown sandstone, dipping slightly eastward, remarkable for its concretionary structure. These concretions consist of coarse, reddish sandstone, firmly held together by a ferruginous paste, which causes them to withstand erosion much better than the sandstone in which they are embedded. They occur of all sizes, from a few inches up to two feet in diameter, many of them quite smooth and symmetrical, and having weathered out from the bluff lie strewn over the surface of the plains. About one-half mile west from Miser Station, the railway cuts through another ridge of hard gray sandstone, also dipping east, in which were found large numbers of Colorado fossils, chiefly of the genus Inoceramus, but associated with Ammonites and Saurian teeth, the latter showing the enamel well preserved.

High up, along the gentle nearly uniform slopes of the Medicine Bow Range, overlying the Colorado group, occurs a very considerable development of Fox Hill beds. The junction between the two series is a very difficult one to trace out, the upper beds of the Colorado group being highly arenaceous, passing into the Fox Hill division of coarse, reddishyellow sandstone by alnost imperceptible gradations; a lithological difficulty enhanced by the absence of all marked physical boundaries, and the very general accumulation of detrital material derived from the elevated ridges of the range, which lies scattered over the slopes. The Fox Hill beds, resting unconformably upon the Archæan rocks, extend firom IIill Creek, a branch of the Little Laramie River, to the northern 
end of the range, circling around the spurs of Rock Mountain. They consist of coarse, friable sandstones, usually of a reddish-brown or yellow color, with occasionai layers of harder brown beds; all of them lying nearly horizontal, or with a gentle dip to the eastward. On the south bank of Mill Creek, not far from the Archæan mass, and almost completely surrounded by Quaternary deposits, occurs a body of brownish-gray sandstone, probably belonging to the Fox Hill group, which carries a layer of rich carbonaceous shales, with thin seams of coal cropping out along the exposed bluff; the shales exhibiting a thickness of 3 feet between the sandstone layers. These sandstones were searched for organic remains, bit they only yielded a few imperfect impressions of deciduous leaves. The strike of the sandstone is north $35^{\circ}$ to $40^{\circ}$ east, with a dip of north $55^{\circ}$ to $60^{\circ}$.

Between Mill and Cooper Creeks, numerous small stream-beds cut deeply into the sandstones, but offer no exposures of special interest. Cooper Creek, a very considerable stream, which debouches through a narrow cañon in the mountains, has worn out by erosion a broad valley in the softer Cretaceous rocks, leaving high banks upon each side, composed of coarse sandstones. The valley for several miles from the mountains is remarkable for the large amount of coarse detrital material, which everywhere covers the surface; the large Archæan boulders lying high up on the benches and ridges. At its lower end, the valley cuts through the Colorado beds, which, farther up the stream, are overlaid by the Fox Hill group. This formation apparently extends up to the Archæan ridges; at least, no structural or palæontological evidence was obtained of any later formations, all organic remains collected from a number of localities in the exposed banks being forms decidedly characteristic of the Fox Hill divisions, principally of the genus Inoceramus.

On the ridge, which forms the south side of Cooper Creek Valley, just above the upper wagon-road, and but a short distance from the Archæan foot-hills, was found a new species of the genus Axinaa, which Professor Meek, in his report, has described under the specific name of 
Associated with it, occurs the well-known form, Inoceramus Barrabini, which is also abundant in the long sandstone banks on the opposite side of the valley, which dip only $2^{\circ}$ to $3^{\circ}$ eastward.

Between Cooper and Rock Creeks, the country presents but little variety in its general features; the nearly horizontal sandstones terminating in abrupt walls toward the plains. At Rock Creek, the Fox Hill beds are well developed on both sides of the valley, lying close up against the Archæan body in flat-topped lills, rising 300 feet above the stream-bed, from which were collected several specimens of the genus Inoceramus. In the Fox Hill sandstones, between Cooper and Rock Creeks, layers of carbonaceous clays and shales occur cropping out along the benches, and carrying several thin beds of lignite. Of these coal outcrops, two have been to some extent explored,-the one known as the Cooper Creek, and the other as the Rock Creek coals. The Cooper Creek coal occurs on the north side of the valley, interstratified in a bed of hard clay, which is both overlaid and underlaid by sandstone. The beds have a gentle dip to the eastward. So far as known, no Molluscan remains have been found in immediate connection with the coal strata, yet it seems quite evident that they underlie beds characterized by Fox Hill species.

The coal possesses a lustrous black color, a moderately compact texture, and resembles that found east of the Colorado Range. An analysis of this coal was made by Dr. F. A. Genth, ${ }^{1}$ of the University of Pennsylvania, with the following result:

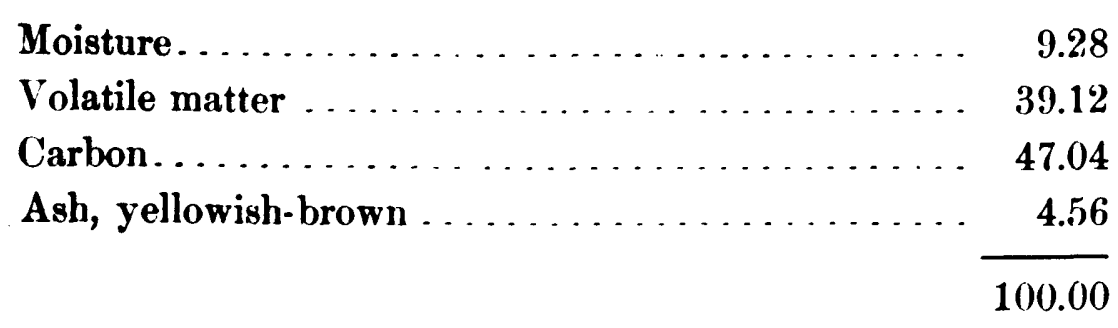

It contains 1.38 per cent. of sulphur, which is equal to 2.59 per cent. of pyrites.

The Rock Creek coal is situated about 6 miles southeast from the

${ }^{1}$ Report of U. S. Geological Survey of Wyoming, Dr. F. V. Mayden, 18i0, 185. 
Rock Creek Station of the old Overland Stage Road. Owing to some misunderstanding in regard to the directions for finding the deposit, it was not visited by our parties, but through the kindness of ranchmen living on Rock Creek, we were able to procure specimens of the coal, together with the overlying sandstone. It would appear from descriptions, and general structure of the country, that the coal beds occur in the Fox Hill formation in a somewhat similar manner to those on Cooper Creek, and in nearly the same geological horizon. The coal is said to occur in a rich carbonaceous clay, with a dip slightly to the eastward, and has been known for many years, having been used by the Overland Stage Company for blacksmithing purposes. Neither of these coal banks have been thoroughly opened, nor their true value and extent for commercial purposes made known, although they are situated within 15 miles of the railroad, with a gentle down grade for the entire distance.

Rock Creek, which has a broad open valley, is the most important stream north of the Little Laramie River, and drains, as has already been mentioned, into the Medicine Bow River north of the limits of the map. The upper valley runs through Cretaceous sandstones, stretching from the Medicine Bow Range, far out to the eastward. A short distance above Rock Creek Station, on the railroad, the soft clays and marls of the Fort Benton group reach the surface, the character of the country changing very greatly, while the broad valley narrows and cuts a deep channel through the easily-eroded clays. West of Miser Station, the sandstones give place to the argillaceous beds, and from there westward, nearly to Como Station, the Fort Benton and Niobrara Cretaceous occur as the surface formations. At Rock Creek Station, the Fort Benton beds are well shown on the high banks, and in the numerous narrow ravines and gullies, cutting through the clays at right angles to the main stream, which expose between 350 and 400 feet of dark plastic clays, with interstratified beds of sandstone and arenaceous clays. The Fort Benton formation is in many localities characterized by beds of ferruginous clays, which, when the iron is present in only small quantities, gives them either a black earthy appearance, or is indicated by a nodular and concretionary structure, with a considerable variety in color of the different layers, especially on exposed surfaces. 
The presence of iron in the clays frequently affects its physical appearance to such an extent as to suggest, when in doubt, to which group the clays may belong. In many localities, the lower clays are quite rich in iron, which forms marked layers or deposits of clay ironstone, cropping out for long distances. At Rock Creek, these clay ironstones are well developed, presenting a characteristic feature of the bluffs, which, owing to the great variety of color derived from the different degrees of oxidation of the iron, and its admixture with clay, gives, on the surface, the appearance of a volcanic formation of ash and scoria.

The iron deposits lie with the strata, and are found approximately horizontal, but with a thickness varying from a few inches up to 2 or 3 feet. In composition, they are argillaceous carbonates of a brownish-black color and compact texture, which, upon being treated with acid, effervesce briskly, leaving a residue of sand and particles of fine clay. They frequently appear considerably fissured, with the seams and cracks filled with crystallized spathic iron. They bear a close resemblance to other beds found in the same horizon on the Wyoming Plains, but especially to the deposits at Elk Mountain, where they are largely developed, and but for the fact that at the latter locality they are turned up at a high angle, show the same mode of occurrence. An analysis of the clay ironstone from Elk Mountain, which will be found in the description of the Cretaceous formation of that locality, probably represents the general character of the Rock Creek deposits.

In the dark-colored stratified clays, which overlie the carbonate of iron deposits, were found numerous small fish-scales, so characteristic of the Fort Benton division.

Beyond the railroad-station, Rock Creek runs through a narrow opening in the Colorado clays, which offers steep, almost impassable walls from the stream-bed to the summit, on the top of which the country presents a dreary parched plain, with scarcely any vegetation to relieve the clay barrens or dull monotony of surface features. The Cretaceous strata, which have been dipping eastward, here begin to show the influence of the dyingout of the Medicine Bow Range, and are seen encircling the northern Archæan flanks, gradually trending off to the westward, with east and west 
strikes and northerly dips. Six miles east of Como Station, the country presents a somewhat strange appearance; the arenaceous clays on the south side of the railroad being traversed by numerous cracks or fissures, which suggest earthquake-openings or crevasses in glaciers. They are, however, the courses of old stream-beds, now dry, except in seasons of unusual flood and freshet: some of them are but two or three feet wide, and at least 200 feet deep, with nearly precipitous walls of clay. On the north side of the railroad, a broader drainage-channel affords a good exposure of these beds, which, without doubt, belong to the Fort Benton division of dark blue clays, with layers of fine-grained, hard ferruginous clays and marls, carrying large numbers of fossils of the genera Inoceramus and Ostrea; while in the more fissile slaty beds imperfect remains of fish appear abundart at certain horizons.

On the top of the clay wall, close by the railroad, occurs a layer of brown medium-grained sandstone, which derives some interest from its laving been quarried at one time quite extensively by the railroad company for building as well as for construction purposes, and transported for long distances. The formation belongs to the sandstone strata, which characterize the Fort Benton division, and, although it in no wise appears superior as a building stone to other similar beds, it may, from its position and occurrence, be worked to great advantage. The lines of bedding are distinctly marked, the blocks quarrying from one to two feet in thickness, with the formation lying inclined at an angle of from $21^{\circ}$ to $3 \frac{1}{2}^{\circ}$.

Embedded in the sandstone are found numerous fragments of stems and deciduous leaves, most of them in a very imperfect state of preservation. It is possible, however, that a collection might be made sufficiently well preserved to allow of specific determination, which would be of considerable importance, as the sandstone, which is about 60 feet in thickness, lies between well-defined beds of the Colorado group.

The sandstones are overlaid by bluish-gray marls and clays, which probably belong to the Niobrara division; at least, the latter formation occurs not far distant, with the well-characterized yellowish-white chalky beds, and the sandstones cannot be far below the junction of the two groups. 
These yellow marls stretch off to the north with a low dip of $3^{\circ}$ or $4^{\circ}$; the Colorado group extending northward beyond the limits of our map.

Still farther westward, the Colorado group forms the surface formation, inclined at a gentle angle, and presenting but little of special interest. Between one and two miles east of Como Lake, they begin to show a higher dip, and to indicate the structural features produced by the Como Ridge, a somewhat singular uplift of the lower Mesozoic strata.

Сомо Anticlinal.-Como Ridge is situated in the extreme northwestern corner of the Laramie Plains, just west of the 106th meridian, and along the northern border of the map, the boundary-line cutting through Como Lake. The ridge, which takes its name from the lake, derives its importance solely from the geological interest which centres in the region, where it forms the southern side of a local anticlinal axis. The upper Cretaceous beds form the overlying strata of the plains over wide areas; but here, at Como, the lower rocks down to the Red Beds are exposed in a gentle uplift, the later beds dipping away in all directions. The main elevating force has acted approximately in an east and west dirèction, producing an anticlinal ridge, with its southern side again lifted up above the main axis of elevation. Directly along the axis of this fold lie the Jurassic marls and soft friable sandstones, which have undergone considerable erosion, leaving a shallow basin now occupied by the lake and a narrow anticlinal valley. On the south side of the lake, through the valley, runs the railroad, beyond which stands the main ridge, forming the south side of the fold. This ridge rises between 200 and 300 feet above the level of the lake, with a steep mural face toward the north, but falling off gently on the opposite side. On the summit, the ridge has a strike of north $60^{\circ}$ east, with a uniform dip of $20^{\circ}$ to $25^{\circ}$ to the southward. Southeast of the lake occur the lowest beds exposed, which consist of hard yellowish-red sandstones, and may belong to the uppermost members of the Red Beds, or may simply be a compact reddish stratum in the Jurassic. On account of this doubt, the Triassic formation is not represented on the geological map, although it is not at all improbable that the lower red sandstones should be so referred.

Directly overlying these red sandstones occur well-defined Jurassic strata, which form the northern face of the ridge, and are in turn overlaid 
by Dakota sandstone, which serves as the capping-stone to the ridge, and the overlying rock on the southern and gentler slope. Nowhere in the Rocky Mountain region, within the belt of exploration, are Jurassic rocks better defined, exhibiting all the characteristic strata which have heen observed in other localities, and at the same time associated with organic remains about the age of which there can be no doubt.

The following section along the bluff-face of the ridge was taken from top to base, in descending series :

Dakota Cretaceous.

1. Compact sellowish brown sandstone, forming the summit of the ridge.

Jurassic.

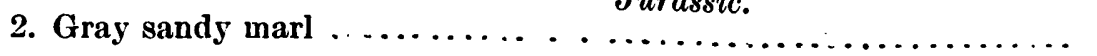

3. Cream-colored marls, with sandstone lajers $\ldots \ldots \ldots \ldots \ldots \ldots \ldots$

4. Bluish-drab cherty limestone.

$175-200$ feet.

5. Fine ash-colored marls, with thin bells of light-colored limestonc...

6. Gray and Orange 1narls, with coarse sandy material ...........

7. Reddish-yellow sandstone

8. Brick red compact sandstone.

Triassic?

The Dakota beds are a dense, tough series of sandstones, distinctly bedded, and breaking up into rough angular blocks in a similar manner as observed east of the Colorado Range. In the Jurassic, the bluish-drab limestone, which is everywhere so persistent a stratum, is here well developed, of a characteristic light drab color, flinty fracture, and carrying numerous small calcite crystals, scattered through the rock. Diligent search was made in this limestone for fossiliferous remains, but without success. In the marls and limestones, however, both above and below it, occur well-marked forms, which are sufficient to prove the Jurassic age of this horizon, although no very great variety in species has been identified.

The following species have been found by our parties:

CRINOIDS.

Segments of the column of Pentacrinus asteriscus

CEPHALOPODA.

Belemnites densus.

LAMELLIBRANCHIATA.

Tancredia Warreniana.

Trigonia quadrangularis, n. sp. 
About two miles east of Como Station, in the crean colored marls. were found a few small Lamellibranchiate shells, but not sufficiently well preserved to allow of specific determination.

It would seem somewhat remarkable, that while organic remains should be so difficult to find over wide areas of exposed Jurassic strata, here certain species, as P'entacrinus asteriscus and Belemnites densus, should prove to be so abundant. The latter type, pencil-shaped and of a dark slate color, occurs from 2 to 6 inches in length, and as they withstand atmospheric agencies remarkably well, and the marls in which they are embedded erode so readily, large numbers of them may be picked up along the foot of the bluffs, from which they have been washed out. As shown in the section given above, the well-defined Jurassic rocks have a thickness of nearly, if not quite, 200 feet. Only a limited development of red sandstones is exposed, consisting of yellowish-red beds, and compact mud-rocks, with but little local interest. East of the lake, on a gentle slope, they exhibit in a most marked manner the peculiar cracks and ripple-marks so characteristic of Triassic sandstones. Here we have deep symmetrical grooves occurring at intervals of 2 or 3 inches, for nearly 100 feet, covering the entire exposed rock-surface with the regularity of human workmanship.

On the nortl side of the lake, the Dakota Cretaceous forms a low but abrupt wall along the shore, dipping to the northeast at an angle of $35^{\circ}$ to $40^{\circ}$. At the extreme northeast corner beds of fine marl and coarse friable sandstone would indicate that the Jurassic beds occurred directly under the level of the lake. Along the anticlinal valley, on the east side of the lake, no outcrops are visible, the surface being covered with low, irregular sanddunes; but on the opposite shore it is hemmed in by a low bank of Dakota sandstone.

Como Lake, which is probably quite shallow, occupies the anticlinal valley, and measures about one mile in length by half a mile in width. It scarcely differs from the many other small lakes, which occur scattered over the Cretaceous and Tertiary plains of Wyoming, unless it be that the surroundings are somewhat more than ordinarily dreary and desolate. Irony certainly prompted the name for this sheet of water. The water possesses a mild brackish, alkaline taste, but deposits only a slightly saline incrustation 
along the shore during the dry season. A spring at the southeast corner, and one-fourth of a mile from the railroad-station, pours a considerable amount of fresh water into the lake.

It is not impossible that, scattered over the area of the Laramie Plains, may be found isolated patches of Tertiary strata; but none were positively recognized as belonging to beds older than the Cretaceous. In one or two localities, where rocks of Cretaceous age lie nearly horizontal, beds of coarse, friable sandstone cover the surface, whose age is perhaps doubtful, as they afford no palæontological or distinctive lithological evidence of their true position. Quaternary deposits occur along the steeper mountain-slopes and in the eroded basins and depressions of the plains, but are of such slight importance that, except along the broad river-bottoms, they have not been designated on the geological maps. 


\author{
SECTION III. \\ MEDICINE BOW RANGE.
}

\begin{abstract}
BY ARNOLD HAGUE.
Physical Description. - The Medicine Bow Range may be considered the second great range of the Rocky Mountain system. It extends from about the latitude of $40^{\circ} 15^{\prime}$ northward to latitude $41^{\circ} 40^{\prime}$, with a trend approximately northwest and southeast. The eastern slope borders on, and is closely connected with, the Colorado Range for some distance, but gradually trends off more to the westward, and forms the western rim of the Laramie Plains. The western side of the range shuts in the North Park on the east and north, and still farther northward forms the boundary of the North Platte Valley, which lies between it and the Park Range. As thus defined, the Medicine Bow Range is about 100 miles in length. In width, it varies very considerably, the southern end only measuring 10 or 12 miles from east to west, but across its broadest expanse, in the region of Medicine Peak, it reaches 30 to 35 miles.
\end{abstract}

The highest peaks in the range are: Mount Richthofen, at the southern end, nearly 13,000 feet high; Clark's Peak, at the northeast corner of the North Park, 13,167 feet; Medicine Peak, 12,231 feet; and Elk Mountain, 11,511 feet, at the extreme northern end, which stands out boldly as a prominent landmark, somewhat isolated from the rest of the range.

South of Mount Richthofen its trend is nearly north and south, a narrow serrated ridge, with short but deep glacial cañons putting out both east and west. Mount Richthofen rises above the surrounding peaks 800 or 900 feet; and from the Park Basin looking eastward, its summit presents a rugged, irregular mass of granite, with graceful outlines. North of the peak, the strike of the rock changes to a few degrees west of north, and it is of special interest that just where the change of strike sets in occurs the great flow of rhyolite that covers the western base of the range; the greater 
part of the slope of Mount Richthofen lying concealed beneath volcanic lavas. The east side of the mountain forms the divide between the waters that flow north and south. The main fork of Grand River, the great tributary from Colorado to the Colorado River, takes its rise on Mount Richthofen, flows south along the depression between the two ranges, and drains through the Middle Park. A branch of the Cache la Poudre also rises on the same mountain, draining the east side of the range, and joins the main stream near the bend.

At Clark's Peak, the culminating point, the range widens rapidly, and trends more decidedly to the northwest. The main crests form a high ridge, with an abrupt slope, along the edge of the Park, but falling off on the opposite side in a broken mountainous country. Here the longer and gentler-slopes are to the east, as in the Colorado Range, with the drainage consequently mainly eastward toward the Laramie River. Near the line of the forty-first parallel, where the range has a width of 25 miles, two welldefined ridges are developed, with a trend approximately parallel, which changes the entire character of the range to the northward. The eastern and lesser ridge borders the Laramie Plains; a fow miles above Bellevue Peak it suffers an abrupt depression where the Little Laramie River leaves the mountains, but it again rises, and continues unbroken for twenty miles, until the entire Medicine. Bow Range passes under the sedimentary beds. The western ridge, which is less regular in outline, culminates in Medicine Peak, a grand, broad central mass, at least 1,500 feet higher than the surrounding summits. Between these two ridges lies an elevated plateau country, nearly 10,000 feet above sea-level, gently undulating, but without any marked topographical features, covered with timber, and dotted over with open glades and numerous alpine lakes.

The Laranie River is the principal stream of the Medicine Bow Range; it has its source on Clark's Peak, in a small glacial lake at the foot of an escarpment, from 1,200 to 1,500 feet below the summit; it runs northward through the central portion of the mountains for 35 or 40 miles, and, finally rounding the northern base of Sheep Mountain, runs out on to the Laramie Plains. From the eastern slope, a considerable number of small streams reach the plain; but all with the exception of Mill Creek, which joins the 
Little Laramie River, end in small lakes or ponds, or else are lost in the sands before reaching the main river. On the opposite side of the range, six good-sized streams drain the waters into the North Platte River. Commencing from the south, they occur in the following order: Douglas, French, Brush, Cedar, Cottonwood, and Pass Creeks. On the east side of the Medicine Peak group, the waters, restrained from flowing eastward, drain north by the Medicine Bow River and Rock Creek; both streams, after a circuitous course through the sedimentary strata, emptying into the North Platte beyond the limits of our map.

On the southeast side of Medicine Peak, however, the creeks run toward the Little Laramie River, which, as already mentioned, cuts the eastern ridge. Elk Mountain, a comparatively small mass, standing isolated, sends out. no large strean, but numerous small creeks, which empty into the Medicine Bow River on the one side, and Pass Creek on the other. Thus, it will be seen that of the leading river features of the Rocky Mountain system, the North Platte, and the Laramie, which, however, ultimately falls into the North Platte, drain almost the entire area of the Medicinc Bow Range; that but a small proportion of the water seeks the South Platte, and an equally small amount is added to the Grand River.

All the higher regions exhibit well-marked evidences of glacial action. The summits of the main peaks are everywhere worn in a manner which shows unmistakable signs of ice erosion, and glacial boulders and detrital matter cover the lesser depressions and slopes. The valleys of Grand River, and the branch of the Cache la Poudre, which comes down from Mount Richthofen, are both examples of glacially-carved basins. At their upper ends, they are both somewhat similar in outline; but below, the Grand descends more rapidly, receives numerous tributaries, and the glacial phenomena are on a more extensive scale. Opposite Mount Clark, the Cache la Poudre receives a small tributary from the main peak, and near their junction is a fine glacial lake. From Mount Clark also descended the glacier of the Upper Laramie Valley, while on the south side short but deep trough-shaped cañons extend down to the North Park.

In the region of Medicine Peak, glaciers occupied all the upper valleys, and the amphitheatres, with mural faces 1,500 feet deep, cut out of 
pure white quartzite, are very striking. The valley of French Creek, on the south side, may be especially mentioned; here the escarpment is 1,500 feet in height, and the basin-shaped cañon, with its glacially-eroded lake-bottom, presents a fine example of ice action upon brittle, massive quartzite, which splits and breaks up easily into blocks under the action of frost and ice. There are ridges here entirely covered with huge blocks of quartzite, many tons in weight, piled up in the most irregular manner, and one may travel long distances without finding any rock in place.

Coniferous forests cover the greater part of the Medicine Bow Range, and there are many large areas, especially in the regions north and east of Medicine Peak and the headwaters of the Little Laramie River, where tree-growth is quite dense. Already much valuable timber has been cut. Abies Douglasii, a tall graceful tree, often over 100 feet in height; Abies Engelmanni, known as "white pine", and Pinus ponderosa, or "yellow pine", are among the species found. The timber-line, as in the Colorado Range, may be placed at 11,000 feet above sea-level.

Geology.-Like the Colorado Range, the Medicine Bow is made up almost exclusively of Archæan, highly crystalline rocks; but while in their general habit they resemble the formations of the eastern range, they exhibit certain mineralogical and petrographical differences, that are characteristic of the entire range. All the varieties of rocks observed may be classed under the following heads: granites, gneisses, hornblende-schists, mica-schists, dioritic schists, slates, argillites, quartzites, chert, hornstone conglomerates, and limestone. All the larger bodies of true granite appear to be confined to the southern end of the range, where it is closely connected with the Colorado Range and the borders of the North Park. Even these, however, show more or less tendency to bedding with the constituent minerals arranged in parallel bands and layers, and passing into a gneissic structure. A typical granite of the North Park ridge occurs on the summit northwest from Clark's Peak. It is a fine-grained compact rock, with a uniform texture, and a sharp angular fracture. In color, it is dark gray. It is composed of translucent quartz, white and pearlcolored feldspars, and dark thin plates of mica. Both orthoclase and plagioclase are present, the latter very abundant; deep red orthoclase, so 7 D G 
abundant in the Colorado Range, does not appear to be present. In this rock, the quartz and feldspars are intimately associated together, with some thin flakes of mica adhering to the feldspar crystals, in bands of grenter or less fineness. The mica, which is quite prevalent, occurs in well-defined layers.

Clark's Peak is a mass of true granite. It differs from nearly all the rocks of the range in showing but little, if any, tendency to bedded structure, and no parallelism in the arrangement of the constituent minerals. The rock in many respects resembles an intrusive body, and such, on further observation, it may prove to be. It is compact, moderately fine-grained, with no large crystals porphyritically enclosed, and resists atmospheric agencies remarkably well. In color, it is pearl-gray. Like the other rocks of the region, it is rich in triclinic feldspars. The quartz occurs in limpid white grains. Both orthoclase and plagioclase are present; the latter have a brilliant lustre and present the characteristic striæ well marked. The mica, probably a biotite, is finely disseminated through the mass without any apparent order. Hornblende, which is present in so many of the rocks of this range, is not observed in the specimens obtained on Clark's Peak.

Under the microscope, apatite may be seen, but no titanite; and the quartz carries many liquid-inclusions.

This rock is one of the finest granites in our collection, and would make an admirable building-stone if it were only accessible. In the immediate region of Clark's Peak there are some similar-appearing granites, which probably belong to the same formation, and it might be possible to trace their connection. In one, 3 or 4 miles southwest from the peak, near the base of the range, Zirkel detected the presence of zircon in red grains, closely resembling the minute zircons found in the syenites of Norway. The granite is lighter-colored than the Clark's Peak variety, and carries vitreous oligoclase crystals, an half-inch in length.

Due west from Clark's Peak, and separated by a low divide and two glacially eroded cañons, stands a prominent pẹak of gneissic rocks. Near the base occurs a typical variety of the region,-a fine-grained compact gneiss, composed of mica and orthoclase with much hornblende and plagio- 
clase; the feldspars are nearly white, and the mica and hornblende black. Under the microscope, apatite may be easily detected.

Near the base of the same peak are found outcrops of coarse-grained granite, which bear some resemblance to the granites of the Colorado Range, and probably belong to the older series. They are so covered by morainal detritus and soil, that their extent and relation to the surrounding rocks are very obscure. They carry no hornblende, but small white mica flakes, and are interesting for the large size and great activity of the liquid-inclusions contained in the quartz. Near the last-described locality occur granites, also coarse-grained, with the feldspar in large masses, and the quartz disseminated through it, producing the forms known as graphic granite.

North and west of the region just described, the rocks are almost entirely mica and hornblendic schists and gneisses. Along the crest of the ridge bordering the North Park, hornblendic rocks prevail, occurring both coarse and fine-grained, with varying amounts of quartz and mica. Many of them are characteristic diorite-schists. A typical rock, in the collection from this ridge, is made up of dark green hornblende and bluish-white plagioclase feldspars, many of them a quarter of an inch in length. A thin section, examined under the microscope, gave no indication of any monoclinic feldspar. Mica in black flakes and limpid quartz are present in very subordinate amounts. The mineral constituents are intimately mixed, and the bedding-lines are only seen when viewed at a distance in the field. At other localities in the same region, however, the green hornblendes never show broad faces, but are always present in long, narrow seams, or layers, which give the rock a gneissic structure. The narrow, deep cañon of the North Platte, which extends for 30 miles along the western edge of the range, everywhere exposes a series of dark hornblendic schists, with but little variety in constituent minerals, but great differences in the proportions of hornblende and feldspars present, the exposures occasionally showing beds carrying but little of the iron mineral. The beds are inclined at varying angles, most of those noted, however, standing very steeply. On the east side of the cañon, the prevailing dip appears to be easterly into the range.

Near the mouth of French Creek, the cañon of the Platte terminates, and the east side of the river presents a low, undulating country, rising 
gradually toward the higher portions of the range. On the west side, there are two prominent hills, which, from their isolated position, serve as landmarks in the valley. Bennett's Peak, opposite the mouth of Brush Creek, rises 600 feet, and River Butte, 5 miles below, at the mouth of Grand Encampment Creek, 900 feet above the river-bed. They are both made up of very dark, heavily-bedded hornblende-gneisses, dipping to the westward at a high angle. They are probably metamorphic diorites.

Between the Platte Cañon and the Laramie River, the country is either covered with a dense growth of forest, or else with soil and detrital matter, to such an extent that geological relations are difficult to make out. Along the Laramie and North Park road the rocks are chiefly coarse-grained, but showing more or less bedding. Hornblende appears to be a constant constituent, and the feldspars are usually light-colored. Between French and Brush Creeks, mica-bearing rocks prevail. A typical specimen, collected on the flat-topped ridge 2 miles north of French Creek, is a light-colored rock, crumbling easily, with a coarse, sandy texture. It is made up of limpid quartz, both monoclinic and triclinic feldspars, and small, minute flakes of dark mica. No hornblende was noticed, and our observations tend to show that it is somewhat remarkable to find mica present with so much plagioclase, and free from hornblende. The mica occurs in narrow layers, giving the rock a finely-banded appearance, but with the evidences of bedding much less marked than is usually seen in this region. The strike was from north $45^{\circ}$ to $55^{\circ}$ west. In this light mica-gneiss occurs interstratified a narrow belt, only a few feet in width, of diorite, which stands up prominently above the surrounding rock, and has much of the habit of an intrusive dike. In many respects, however, it closely resembles the finer-grained varieties of the metamorphic diorites; but a careful study of a specimen indicates certain mineralogical differences that have not been detected in the clearly metamorphic dioritic schists of the region. To the unaided eye, the rock presents an irregular admixture of a mass of hornblende and feldspar, of a dark gray color, with only a few long, acicular crystals of striated feldspar. Under the microscope, a thin section shows only hornblende, plagioclase, and a few orthoclase crystals, but no mica, quartz, or apatite. Zirkel calls attention to the singular arrangement of the groundmass. 
From Brush Creek northward for 15 or 20 miles, the same light-colored mica-gneisses and dark hornblende-schists, with occasional interstratified beds of vitreous quartzite, prevail. They form the higher ridges, as well as the long, gentle slopes that extend out toward the North Platte, until hidden under the later Tertiary sandstones. The geological relations of the beds are very complicated, varying greatly in both strike and dip, and but little could be made out as to their structure. South of Brush Creek, the prevailing strike appears to be northwest and southeast, with a southerly dip, while to the north of the creek the strike remains the same, with a northerly dip, thus indicating, in a general way, a broad anticlinal axis. The summit of Deer Mountain, at the head of Cedar Creek, is made up of the very lightcolored gneiss, similar to that already described from French Creek, except that it contains even less mica than the former, and the feldspars are unusually white and clear. Minute grains of red garnet were found in the rock, 100 feet from the summit. On the slopes of the mountain, hornblendic beds occur, largely developed, with the dark green hornblende, and both white orthoclase and plagioclase-feldspars, but they scarcely require mention here, except to note the large number of accessory minerals revealed in a thin section by the microscope, which include titanite, zircon, apatite, and an undetermined chlorite-like mineral.

From Deer Mountain northward, for 6 or 8 miles, the long slopes and ridges that jut out toward the valley afford excellent opportunity for observing and following the hornblende-gneisses that form the western foot-hills. $A$ recorded strike gave north $40^{\circ}$ west, with a dip of $60^{\circ}$ southwesterly. They vary from fine-grained up to heavy coarse beds, and from beds carrying but little quartz to those where the groundmass is largely composed of siliceous grains. The rock from the slope of Cedar Mountain bears a close resemblance in its external features to the diorite-dike already described from French Creek, although the former is undoubtedly a metamorphic product. It is a hard, compact rock, with no regularity in the arrangement of the constituents. Unlike the diorite from French Creek, however, the groundmass is composed of quartz and dark-green hornblende, while the feldspar is very minutey striated plagioclase. North of Cedar Mountain, our observations tend to show that the character of the rock changes, and the dark 
schists and gneisses, with hornblende as the predominating constituent, which have been so persistent along the entire western edge of the range, give way to lighter-colored mica-gneisses; still, however, carrying some hornblende. At Cherokee Butte, the connecting mass between Elk Mountain and the main range, occurs an altered Archæan granite, which is of special interest, as it differs from anything observed elsewhere in the range. It is a hard, medium-grained rock, composed chiefly of gray quartz and white and flesh-colored feldspars, both monoclinic and triclinic species being present. Micas, in minute plates, are scattered sparingly through the mass, but hornblende appears to be absent, at least in the specimens collected. Professor Zirkel has given a detailed description of the quartz under low magnifying power, which indicates worn fragments and rounded and polished grains, closely resembling the quartz-grains in the sedimentary gray wackes of Germany, which is especially noteworthy here, as the habit in the field is such as to suggest a metamorphic product. It has also many lithological characteristics like the granite from Granite Mountain, in the Pah-Ute Range, Nevada.

On the western slopes of Cherokee Butte is found a typical gray gneiss, the relations of which with the altered granite were not determined. It is of medium texture, somewhat friable, and finely laminated. Hornblende is present, but in a very subordinate amount; thin sections develop titanite.

As already mentioned, Elk Mountain stands nearly isolated from the main mountain mass, and has a higher elevation than any point in the northern end of the range, except Medicine Peak. The flanks of the northern portion are covered with the sedimentary beds, which rise in many localities to within 1,200 or 1,500 feet of the top, but the rest of the mountain belongs to the Archæan series. The summit, with four points of nearly equal height, is an irregular-shaped mass, which descends abruptly, but regularly, toward the valley of the Medicine Bow, while on the west side deep, rugged cañons penetrate the slopes. In lithological habit, there is considerable variety in the rocks, but they are all a hard compact, distinctlybedded series of gneissic strata. The recorded strikes of the beds differ somewhat, but all have a prevailing northeast and southwest direction; 
varying from north $45^{\circ}$ east to north $70^{\circ}$ east, with a dip always to the north, at angles frequently as high as $75^{\circ}$ and $80^{\circ}$.

The rock is chiefly made up of gray quartz, with both monoclinic and triclinic feldspars, but so fine-grained that it is difficult to form any correct opinion as to their relative proportions. There are also present what appear to the naked eye as exceedingly fine particles of dark brilliant mica, but which, under the microscope, Professor Zirkel considers as a chlorite-like mineral. It is this mineral which gives the banded gneissic structure; and although there is frequently but a small amount present, it is so evenly disseminated that it gives a decided character to the strata. Many of the finergrained beds show a vitreous aspect, and where thickly bedded, or where the bedding-lines are somewhat obliterated, suggest at first sight an impure quartzite.

In the specimens collected, hornblende does not appear to be present. One taken from the summit near the geodetic station, a dark, hard quartzose-looking rock, analyzed by Mr. R. W. Woodward, gave the following result :

Speoific gravity, 2.6.

Silica

Alumina 15.16

Ferrous oxide

Lime

Magnesia .

Soda.

Potassa

Lithia trace

Ignition

0.73

99.85

This shows a marked difference from the analyses of the Archæan series of the Colorado Range, and would seem to indicate that the feldspars are mainly triclinic. The percentage of lime present is also much higher than in the eastern range.

Medicine Peak is a mass of pure white quartzite, rising nearly 2,000 
feet above the surrounding country, and commanding a grand view of the Laramie Plains and the low country to the north, with a panoramic outline, 100 miles in length, of the Park Range to the west, while the peak itself suggests the prominent, bold quartzite summits in the descriptions of Scandinavian scenery in the Archæan regions of Northern Europe. The main ridge has a trend approximately north $20^{\circ}$ east, with what appears to be the strike of the rocks. The dip is to the eastward at a high angle. No accurate measurements of the thickness of the formation could be made, but it certainly is not much under 2,000 feet, while escarpments cut 1,500 feet deep through brilliant white rock. The quartzite is compact, brittle, with a uniform texture. It is traversed by thin, irregular iron seams, and in places is slightly stained a pale red from the oxidation of the iron. Crystals of quartz and feldspar are exceedingly rare.

Near the base of the formation, the quartzite has a pale bluish tinge, is somewhat coarser-grained, with interstratified beds of smooth and rounded quartz pebbles, many of them having been pressed and elongated in the direction of the strata since their deposition, showing conclusively their sedimentary origin. They vary in size from that of a pea to a hen's egg.

The rock from the summit yielded-

Silica ......................... 94.333

Ignition $\ldots \ldots \ldots \ldots \ldots \ldots \ldots \ldots \ldots \ldots \ldots \ldots \ldots .6 .269$

the residue showing considerable quantity of alumina, with traces of iron and lime. A large part of the alumina present in the quartzite would appear to be segregated, as nearly pure, simple silicate of alumina, in the form of cyanite, which was observed at rare intervals in narrow veins or seams a few inches in width. The cyanite occurs in long crystals of a pale-blue color, with a pearly lustre and hardness not above 5 . It is associated with colorless quartz, but free from all accumulations of iron.

Another marked feature of this formation is the number of narrow, well-defined dikes of dark intrusive rock, which penetrate it at a number of localities on the west side. The widest observed was 20 feet, with $a$ strike northwest and southeast, or against the observed strike of the beds. They are probably diorites. The only one from which a specimen was 
taken is a fine-grained crystalline rock, made up largely of hornblende and fine acicular crystals of brilliant triclinic feldspar.

At the head of the northern branches of French Creek, and directly under the great mass of quartzite which forms the summit of the ridge, is a series of thinly-laminated beds, which have not heretofore been met with in either the Archæan series of the Colorado or Medicine Bow Ranges. They consist of dark argillaceous slates and schists, underlying conformably the quartzite, and dipping eastward into the mountain. The upper beds consist of exceedingly fine iron-gray slates or fissile argillites, having a slight wave-like structure, and forming a sort of impure roofing-slate, with an imperfect cleavage. To the unaided eye, they exhibit only minute mica plates. They were estimated at about 400 feet in thickness. Directly underlying them, and passing from the one to the other, is a series of harder quartzose argillites, less thinly laminated, less uniform in character, with layers of ferruginous material between the beds, and with occasional narrow seams of quartz-grains.

Underlying this in turn is a highly crystalline schist, differing widely from the last-mentioned beds. There are no cleavage-lines, and the bedding appears to be in a great measure obliterated. It is dotted over with rounded nodules of hornblende, similar to the limestone concretions in the "knotenschiefer" of Germany, and is made up largely of highly-altered fibrous hornblende, of a bronze color, highly iridescent, with various hues of green, red, and purple. Very minute quartz-grains are visible in the mass of hernblendic rock; and in thin sections, under the microscope, may be seen minute crystals of feldspar. In places, the rock has somewhat of a reddish coloration, arising from the decomposition of the altered hornblende. The thickness of these beds and the nature of the underlying rock were hidden by the soil and débris of the mountain-slope, but there cannot be less than 600 feet in the entire series of slates, schists, and argillites.

Several miles farther down French Creek, on the ridge, just above the bed of the stream, occur outcrops of quartzose slates and silver-white micaslates. They strike north $15^{\circ}$ east, and dip as high as $70^{\circ}$ to $75^{\circ}$ to the eastward; apparently they were underlying a massive quartzite.

The south wall of French Creek Cañon, a high, almost unbroken ridge 
of quartzite, is probably the continuation southward of the Medicine Peak beds, which, if the observed strike of north $20^{\circ}$ east is correct, would follow the trend of the creek; and, in passing down the canon, we follow along the strike of the rocks. Now the argillites, slates, and fine schists observed at the foot of the quartzite mass, near the summit, may be closely related to the quartzose and mica slates noted farther down the stream, while the recorded strike indicates that such is probably the case. Still farther down the stream, and before leaving the rougher portions of the cañon, the heavy beds of light-colored mica-gneisses, which occur along the western ridges of the range, make their appearance, and continue down to the mouth of the cuñon.

Mill Peak, at the head of Mill Creek, is the culminating point of the eastern ridge, and is situated from eight to ten miles, a little north of due east, from Medicine Peak. Here the prevailing dip of beds is to the westward, as if forming a broad synclinal fold with the Medicine Peak group; the synclinal valley being occupied by the broad plateau, which separates the two ridges.

The eastern slope of Mill Peak is covered with a dense growth of timber, and loose soil, which conceal nearly the entire geological structure. The rocks appear, however, to be made up almost exclusively of reddishwhite vitreous quartzite, closely resembling in physical and lithological habit the Medicine Peak strata, but less free from foreign impurities, more discolored by the decomposition of iron secretions, and carrying beds holding more or less feldspathic material.

Not far below the summit, and directly overlying the white quarzite, rests a body of heavy, compact, red conglomerate. It varies considerably in texture, color, and character of the groundmass, and any description of one locality seems hardly applicable to other beds. The lower beds, however, are made up of pebbles and irregular-shaped pieces of both opaque and opalescent quartz, chert, and hornstone of various hues, held together by a siliceous ferruginous cement, making a mass which is exceedingly firm, and breaks with great difficulty under the hammer. Some of the quartz pieces are 3 or 4 inches in length, but penetrated by narrow seams filled with red ferruginous material. There are layers which contain much less iron in the cementing material, 
when the rock, of course, is much whiter; in other beds, it is finer-grained, but still made up of sharp angular pieces of siliceous minerals. It is described thus somewhat in detail, as in many respects it bears a close resemblance to what have been called the Red Jasper Conglomerates of the Huronian series, as observed in the region bordering the north shore of Lake Huron, by the Geological Survey of Canada. ${ }^{1}$ These red beds of the Medicine Bow Range, however, are not over 500 or 600 feet in thickness. They are overlaid by a thin formation of fine crystalline, almost amorphous quartzite, of a bluish-gray color, and traversed by seams of translucent quartz. The rock resemb'es the narrow siliceous belts interstratified in the Triassic, Star Peak limestone of Western Nevada. The interstices and cracks in the quartzite are everywhere filled with carbonate of lime. Thin sections, examined under the microscope, show minute calcite particles disseminated through t'ie rock in a manner, as Professor Zirkel has pointed out, that is exceedingly rare in highly crystalline quartzites.

The top of the peak is capped by patches of light gray and white siliceous limestone, that have escaped erosion. In texture and general habit, it resembles the underlying quartzite, and seems only to have passed from a prevailing siliceous bed to one of a calcareous nature. Weathering has produced very characteristic outlines, and the exposed surfaces are usually very rough from a confused net-work of minute ridges, formed by the preservation of red siliceous seams, while the surrounding limestone has been carried off, producing, when seen in the field, a most singular effect.

But little opportunity was afforded for an examination north of Mill Peak of the higher portions of the eastern ridge of the Medicine Bow Range, and it was therefore impossible to trace northward the white and ferruginous quartzites and limestone. For 10 or 15 miles along the foothills, and for long distances up Rock Creek, Cooper Creek, and the other large cañons, heavy dark schists and gneisses prevail. They all appear to be more or less distinctly bedded, with the same general lithological habit and forms of erosion as mark the rocks of the east side of the Platte Valley. South of the Little Laramie River, in the region of Bellevue Peak, 
mica-gneiss and hornblendic rocks characterize the ridge. The purely mica-bearing beds show a close ressmblance to the white gneissic rocks already described as occurring near the mouth of French Creek and on the summit of Deer. Mountain. A specimen taken from the north end of the ridge is a white or silver-gray gneiss, made up of translucent colorless quartz, bright pearl-colored feldspars somewhat altered, and a small amount of brown mica disseminated through the rock, but also segregated in bunches and nodules. These beds also contain minute red grains of garnet.

On the eastern and northern slopes, hornblendic beds prevail, usually close-grained, with the hornblende and feldspars sometimes intimately blended, at others separated by layers of either mineral more or less pure. These layers or bands vary in width: they are frequently lenticular beds of irregular shape, which give the hills and escarpments a highly-altered, metamorphosed appearance. South of the Laramie River, rocks of the same general character prevail. At Sheep Mountain, the rocks are distinctly bedded, and inclined toward the river. They are perhaps somewhat more coarsely grained than those to the north. At the river, near the crossing of the Laramie and North Park road, those of the high steep slopes seem generally less compact, decomposing more readily, and in physical habit seem to approach nearer to granite than the rocks already described.

In addition to the larger rock-masses which constitute the great mountain features, the Medicine Bow Range is characterized by the presence of certain accessory minerals, which are of importance in comparing the series of Archæan Rocks under consideration with those of the Colorado and other ranges; and, although but little was accomplished in this line of investigation, such facts as were noted should be mentioned.

Narrow veins of quartz penetrate the mica and hornblendic schists and gneisses. They are especially marked.along the western foot-hills in the neighborhood of Brush and Cottonwood Creeks. The quartz is usually quite pure, accompanied occasionally by fine particles of magnetite, and on Deer Mountain a vein was observed carrying small amounts of pyrites.

Epidote occurs massive, associated with quartz veins, in the interior of the range, in the neighborhood of the Laramie and North Park road. 
Small grains of reddish-brown garnets occur in several localities; where observed, they were always associated with the characteristic light-colored gneisses. They were seen on French Creek 2 or 3 miles above the mouth, near a small tributary coming in from the south; also on the summit of Deer Mountain. Gold in small quantities seems to occur in many districts throughout the range. For several years, miners have been at work washing for gold on Douglas Creek. At Rock Creek Cañon, fine yellow gold has been obtained, and it is said to have been found also in Cooper Creek Cañon, and on the smaller streams that come down from the southeast side of Elk Mountain.

It will be readily seen that the larger rock-masses which form the Medicine Bow Range present but comparatively few species among their essential mineral constituents, however varied may be the lithological habit of this great series of crystalline rocks. They embrace quartz, orthoclase, plagioclase, hornblende, mica, chlorite, and carbonate of lime. As accessory minerals, there occur garnet, epidote, magnetite, pyrites, cyanite, gold, and calcite. Under the microscope, in addition to the above, were detected zircon, apatite, and titanite.

Conclusions.-The Archæan series of the Medicine Bow Range presents many marked features characteristic of beds which have been referred to the Huronian formation on the shores of Lake Huron in Canada, and in various localities throughout the Appalachian chain. As these points of resemblance are in many respects so strong, the greater part of the uplift is referred to the same formation, with considerable hesitation, however, as they are widely separated from any beds distinctly recognized as of Huronian age, and such reference is based entirely upon lithological evidences. It is also possible that they may simply be higher members of the same great series with the Colorado Range.

The Medicine Bow Range also presents many features which are strikingly in contrast with the Laurentian rocks of the Colorado Range. Although but few mineral species occur in the rock-masses of the one range that are not found in the other, the relative proportions and differences of arrangement of the constituent minerals is very marked.

The Colorado Range, as already mentioned, is almost entirely formed 
of orthoclase-mica-granites, and gneisses, holding but little homblende, with the feldspars characterized by a prevailing reddish color.

On the other hand, the Medicine Bow Range is formed largely of plagioclase-hornblende and plagioclase-mica-bearing rocks. The feldspars of the granites, gneisses, and schists are either composed of triclinic species, or else they are present in such large proportions as to characterize the rocks in which they are found. In color, the feldspars are either white or of very light tints. Hornblendic gneisses and schists, which occur all through the Huronian series, predominate over large geographical areas in the Medicine Bow Range. They are usually compact and heavily bedded, many of them so free from orthoclase as to deserve the name of dioritic gneisses. The mica-bearing rocks differ entirely from those of the Colorado Range. They are very light in color, with a crumbling, sandy texture, and the mica usually present in subordinate amounts. A striking characteristic of this entire series of Archæan rocks, whether loose or compact in texture, is the banded and laminated appearance of the constituent minerals. Beds as hard and firm as any crystalline mass seem to show the same parallelism in arrangement as the typical gneisses, and it is especially noticeable in the alternate bands of dark green hornblende and white plagioclase-feldspars, which form the rocks that have been designated dioritic gneisses.

The other rock formations of the Medicine Bow Range which overlie the gneisses and schists are perhaps still more characteristic of the $\mathrm{Hu}$ ronian age as developed elsewhere. At the same time, they have no equivalent in the area of the Colorado Range included within the limits of this survey. They consist of the argillites, clay-slates, hornblendic iridescent schists, quartzites, conglomerates, and limestones, as described above with considerable detail.

Intrusive rocks of later age, if we exclude some of the granite bodies in the region of Mount Clark, seem to have penetrated this Archæan series only in narrow dikes. They do not appear to have produced any marked physical or geological changes in the leading surface features of the range. So far as observed, they are limited to dikes, with sharp well-defined walls, 
of fine-grained dark diorites, some of which have been described as occurring in the great white quartzite formation of the Medicine Peak group.

Volcanic rocks of Tertiary age were not observed, and probably do not occur within the Archæan belt. They do, however, occur, as previously mentioned, along the flanks of the range, on the east side of the North Park, where great flows of rhyolite have poured down from Mount Richthofen. Some details in regard to them will be found in the description of the North Park. 


\section{SECTION I V.}

THE NORTH PARK.

BY ARNOLD HAGUE.

Physical Description.-Of the great areas of depression lying west of the Colorado Range, known as the Parks, which form so characteristic a physical feature of the Rocky Mountains, the North Park is the only one that comes within the limits of this exploration, and, as its name would suggest, occupies the most northerly position of these basins.

The North Park is situated entirely within the Territory of Colorado; its northern rim lying about 5 or 6 miles south of the forty-first parallel, the boundary-line between Wyoming and Colorado. It lies depressed between two great Archæan uplifts, the Medicine Bow and Park Ranges, measuring at its widest expanse, from the base of the one to the foot-hills of the other, between 28 and 30 miles, but narrowing toward the north. To the northward, these two ranges come together; the former trending to the northwest, and the latter stretching out eastward, so as to shut in the Park basin on the north. In this way, the Park is enclosed on three sides by great walls of rugged Archæan rock, with clear, sharply-defined limits. On the south side, the boundary between the North and Middle Parks is by no means so prominent or so regular a feature, and is formed by a comparatively low cross-ridge of Tertiary volcanic outbursts, which stretch the entire width of the Park from Rabbit Ears in the Park Range to the slopes of Mount Richthofen in the Medicine Bow. The topographical divide of this southern ridge lies one or two miles beyond the limits of the map, but the northern slopes are well shown, furnishing the evidences as to both its physical and geological aspect. From north to south, the Park measures about 35 miles, being roughly quadrangular in form, with its meridional sides the longer.

Some of the structural details of the Medicine Bow Range have already been given, and those of the Park Range will be found under the proper 
division of this chapter. It is sufficient for present purposes to mention that the mountains on the east side attain an elevation of from 12,000 to 13,000 feet above sea-level; that they are massive and grand in outline, snow-capped for the greater part of the year, and descend with steep broken ridges to the basin. On the opposite side, the Park Range reaches nearly 12,000 feet, is more regular in its leading features, and falls away abruptly, with an almost precipitous wall, toward the east. The average altitude of the Park may be taken at from 7,500 to 7,700 feet above sea-level, presenting a sunken basin from 4,500 to 5,000 feet below the top of the high walls which surround it. An undulating surface characterizes the North Park, yet changes in level are so gradual, that a greater part of the area, when seen from any elevation that overlooks the basin, appears essentially a plain; only one or two points rising more than a few hundred feet above the Platte bottom. From the east side, a long low ridge of rhyolite projects into the Park, and from the opposite side, but with the same trend as the volcanic flow, a ridge of Archæan granite, nearly 12 miles in length, also extends out into the basin. The drainage-system of the North Park forms one of its most striking physical features, the entire waters finding their outlet through one stream, the North Platte, whose sources lie high up in the surrounding mountains. Numerous small streams descend from all the steep slopes, which, uniting below into larger creeks, flow out toward the centre of the basin, and make the three main streams, the East, Middle, and West forks, which at the extreme northern end come together, forming the North Platte, already a very considerable river, where it breaks through the Archæan wall of the Park. Along the slopes of the mountains, coniferous forests extend far down upon the outlying spurs, beyond which there may be generally found a narrow belt of deciduous trees, chiefly aspens; but over the entire area of the Park basin there is scarcely a tree to be seen, except along the alluvial banks of the broad streams, where there are many small willows and a few stunted cottonwoods. The valleys are unusually wide, and covered with an exceedingly rich growth of grass. If abundant streams of water and immense areas of grass-land are only to be considered, the North Park cannot be surpassed by any portion of Colorado for stock-raising purposes.

$8 \mathrm{D} \mathrm{G}$ 
Paleozoic and Mesozoic Formations.-Within the area of the North Park may be found strata representing all the sedimentary divisions, which occur east of the Colorado Range, from the Carboniferous limestone to the top of the Colorado Cretaceous, but which, unlike the beds bordering the Plains, are here associated with volcanic outbursts of trachytes, rhyolites, and basalts. Still later Tertiary beds, essentially horizontal, are found covering the greater part of the basin.

The upturned sedimentary ridges are all, from base to summit, conformable, and in their main features, as their mode of occurrence, their relation to the Archæan foundation, and topographical structure, closely resemble the same beds east of the mountains. They rest unconformably upon the Archæan, lying inclined at all angles from $50^{\circ}$ to $10^{\circ}$, but usually occur from $15^{\circ}$ to $30^{\circ}$; flattening out with less and less angle, away from the high ranges, until concealed beneath the Tertiary strata. At different localities, along the Archæan rim of the Park, beds of the Carboniferous, Triassic, Dakota sandstone, and Colorado Cretaceous may all be observed resting directly upon the older crystalline rocks, the underlying sedimentary beds failing to reach the surface, but the upper members of the series to the top of the Colorado group being usually well developed.

Carboniferous limestones were recognized at only one locality, and that upon the northeast side, where they lie up against the Medicine Bow Range, inclined at a low angle. They occupy but a comparatively small area, and derive their chief interest from being the single instance observed of Palæozoic strata within the Parks. No fossils were found; but there can be no doubt that the beds belong to the Carboniferous series, inasmuch as they underlie a very considerable development of Red Beds, and measure, at least, two or three hundred feet in thickness, which is far too heavy to represent one of the limestone strata included within the Triassic. Moreover, in their bedding and texture they resemble the upper members of the Coal-Measure limestone wherever seen below the red sandstones.

The Red Beds, although showing considerable variety in composition and color, possess prevailing deep reddish tints, and are made up of fine sands, with red clays and shales far less prominent than along the Colorado 
Range, while the calcareous and gypsiferous strata, although they may be detected in thin layers, are rarely exposed in sections along the creeks. Near the base, they show, in many localities, beds of fine conglomerate, which consist of small, rounded, siliceous pebbles cemented by a fine, ferruginous sand. At the top of the series, the sandstones pass gradually up into lighter-colored beds of Jurassic marls. In thickness, they vary considerably, but appear to have an average development greater than along the east base of the Colorado Range, attåining in several places nearly 1,000 feet. As, over long distances, the Red Beds rest directly upon the Archæan rocks, the great differences in thickness may in part arise from the lower beds failing to reach the surface. Although from the Jurassic beds of the North Park no well-defined organic remains have ever been found; they show too close a resemblance with undoubted Jurassic rocks, lying between the Red Beds and Dakota sandstone, to question their true position. The light-drab or dove-colored cherty limestone, which forms so characteristic a feature of Jurassic beds, seems a very persistent stratum in the North Park, and, as in many other places, stands out prominently a few inches above the surface of the more easily eroded, crumbling marls, which usually possess light cream and ash colors.

An analysis of this cherty limestone, made by Mr. B. E. Brewster, yielded as follows :

Silica.............................. $\quad 6.535$

Ferric oxide and alumina $\ldots \ldots \ldots \ldots \ldots \ldots \ldots . .60 .921$

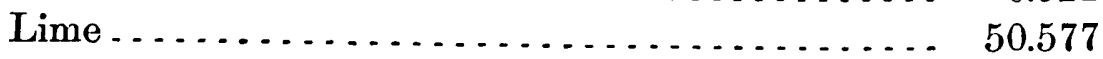

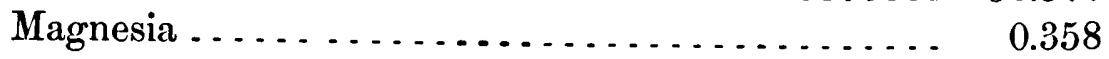

Carbonic acid....................... 40.177

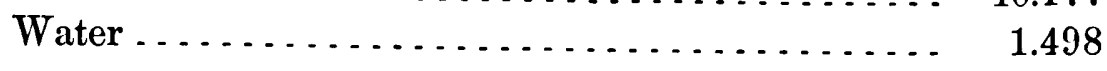

100.086

Combining the carbonic acid with the bases, we have:

Carbonate of lime ...................... 91.11

Carbonate of magnesia.................... 0.75

In thickness, the Jurassic beds were estimated at from 200 to 250 feet. As already mentioned, both the Dakota and Colorado groups of the 
Cretaceous are well represented in the North Park. The Dakota beds present identical topographical and lithological features with the corresponding horizon along the Colorado Range,-a prominent ridge or wall of yellowish-brown sandstone, frequently so well compacted as to form a hard quartzite, with well-narked bedding-planes, and with occasional layers of fine cherty conglomerate, so characteristic in many places of the Dakota sandstone. This lower division of the Cretaceous is estimated at 350 feet in thickness. Of the Colorado group, all the subdivisions, - the Fort Benton, Niobrara, and Fort Pierre beds,-which have been recognized east of the Colorado Range and on the Laramie Plains, may be recognized here, but not always so sharply defined. Beds of pure clays and limestones, although present, and giving character to the Middle Cretaceous rocks, are usually less thickly developed, being more arenaceous throughout the series, which would naturally tend to obscure all divisions. Nevertheless, the dark fissile clays, with the ferruginous layers of the Fort Benton, passing up into fine argillaceous limestones and variegated white, blue, and yellow marls, associated with gypsum and selenite, which mark the Niobrara, and in turn pass up into bluish clays, and sandy argillites of the Fort Pierre, may all be observed at numerous localities. At the junction between the Fort Benton and Niobrara beds, the limestones attain their greatest development, but are rarely more than 20 feet in thickness, and are marked by a fine, almost impalpable, texture, with sufficient silica in their composition to give them a conchoidal fracture when broken by the hammer. They emit a strong bituminous odor. A peculiarity of the horizon is, that while in many localities the overlying marls are easily recognized, in others the beds pass so rapidly into sandstones as to lose all lithological characteristics.

The uppermost members of the Cretaceous series represented in the North Park consist of heavy beds of yellowish-white sandstones, with a somewhat friable texture, and generally roughly bedded. They have all been included in the Colorado group, although the great thickness of nearly pure sandstones would suggest still later horizons, and it is not impossible that in a few localities they may prove to belong to Fox Hill strata. The reference, however, of the entire series to the Colorado group rests partly 
upon the great uniformity throughout, in composition and physical habit, and, in part, upon the palæontological evidence procured from the uppermost beds, at several places, before they passed under the Tertiary deposits.

Organic remains from this horizon are abundant all over the Park, and consist chiefly of the following forms:

Baculites ovatus,

Inoceramus Barrabini,

which may occur in the lower sandstones of the Fox Hill, but which characterize the Fort Pierre beds, even where the latter are made up of nearly pure black clays. It should be stated that all through this massive sandstone may be seen thin seams and partings of impure clays. The entire thickness of the Colorado group, from the top of the Dakota to the overlying Tertiary, has been roughly estimated at from 1,500 to 2,000 feet of strata.

On the north side of the Park, lying directly upon the Archæan spur of Bruin Peak, occurs an interesting development of the lower members of the Colorado group. They are well shown along the Platte River, which exposes a steep bank of marls and dark, earthy limestones, carrying a small species of Ostrea.

East of the Platte River, about 2 or 3 miles, and midway between the river and the Laramie and North Park road, lies Sentinel Hill. It stands out boldly, and somewhat isolated from the main range, and, rising from 1,200 to 1,500 feet above the river-bottom, forms a prominent landmark, plainly visible over the entire Park. This hill offers one of the most instructive sections across the Mesozoic strata to be found in the region, as all the strata are well represented from the base of the Red Beds well up into the Colorado Cretaceous. On the north side of Sentinel Hill, the bright-red sandstones of the Triassic occur, dipping into the hill. Overlying these are light-colored marls of Jurassic age, with the prominent drab limestone, in turn overlaid by more marl beds, which pass up into compact sandstone. The summit consists of Dakota Cretaceous, which also forms the greater part of the southern and outer slope of the hill, but near the base is overlaid by the bright beds of Colorado marls, which 
are soon lost beneath the later Tertiary strata of the basin. These conformable beds dip to the southward at angles varying from $22^{\circ}$ to $25^{\circ}$.

Just where the road from the Laramie Plains enters the North Park, the Dakota Cretaceous occurs, apparently resting next the Archæan foundation, and standing in bold characteristic ridges, with a mural face toward the mountains, and with a gradual slope in the direction of the plain. They occupy a slight rè-entering bay, or curve, in the Archæan mass, and dip with an angle of $18^{\circ}$ to $22^{\circ}$. A point of some interest in these ridges consists in the development of conglomerate, which forms so marked a feature over wide areas, at the base of the Dakota group ; it is only to be observed in most localities in cross-sections, but here the ridge-summits consist of conglomerate beds offering very excellent exposures. This conglomerate is formed of small fragments of worn and rounded quartz, associated with pebbles of dark chert, the mass held together by a cementing material of fine sand and ferruginous earth. A peculiar feature of the conglomerate is, that many layers are so extremely hard that under the hammer the rock fractures in lines across the chert, as well as through the binding cement. The beds $\operatorname{dip} 18^{\circ}$ to $20^{\circ}$. Still farther eastward, on Retreat Creek, just above the camp station, the probable line of junction between the Dakota and Colorado groups is well shown along the banks of the stream. Here the dark black clays lie directly upon the lower sandstones, both formations dipping with an angle of $17^{\circ}$ to $19^{\circ}$. The former rises abruptly in a high ridge, while the latter dies away in low, rolling benches. The low bench just south of the camp station probably represents the Colorado marls overlaid by the upper sandstones.

From Retreat Creek southeastward to Elk Camp, some 16 or 18 miles, the sedimentary ridges present a nearly uniform appearance that calls for but little mention, rising to about the same height above the plain, and with an average inclination of $20^{\circ}$ to $30^{\circ}$. Unlike the Mesozoic strata, however, of Northern Colorado, instead of forming long unbroken lines of upheaval, the beds show a constantly changing strike, which produces short broken ridges, between which small streams have found their way from the main range to the forks of the Platte.

From 1 to 2 miles east of Retreat Creek occur a number of prominent 
white hills, which have probably attracted the attention of all visitors to the North Park, whether for pleasure or exploration, on account of their striking contrast with the surrounding country. They are found to consist of loose quartz sands, collected here in a somewhat remarkable manner by the prevailing west winds. These sand-dunes rise from 100 to 200 feet in height, and, although constantly changing in form, are, from the position of the surrounding hills, kept together with but little variation in their main outlines.

Volcanic Rocks.-Along the east wall of the Park, from Elk Camp nearly to Good Pass, which goes over into Middle Park by the way of Willow Creek, the lower spurs and foot-hills of the Medicine Bow Range are entirely covered by immense flows of volcanic rocks, chiefly rhyolites. The central point of eruption would appear to be on the slopes of Mount Richthofen, near the change in strike of the Archæan rock-masses. Here they lie somewhat higher than at any other point, and the flows of darkcolored rhyolites contrast in a marked manner with the gray Archæan body. Long volcanic flows send out low ridges into the Park, 300 or 400 feet in height, between which numerous streams have cut broad valleys, more or less filled with coarse, detrital accumulations. These ridges present a rough, broken surface, and are for the most part covered with timber.

In their lithological aspect, they offer, so far as examined in the field, but little variety in texture and composition, and over wide areas present the same general features. They are, however, characteristic rhyolites, and, from their position as the most easterly outburst of a rock, which plays so important a part in the Tertiary volcanic phenomena of the Western Cordillera, deserve some special mention. They are usually composed of a fine-grained groundmass, in which small fissured crystals of sanidin, and broken grains of black and dark gray quartz, and occasionally black hornblende are imbedded. They also carry the globular grains, or sphærolites, which are often so marked a feature in rhyolites. In color, they vary from reddish to purplish-gray. At the head of Sioux Creek, rhyolites of a somewhat different type occur, the groundmass being more compact and lighter in color. The enclosed feldspars are larger, giving the rock more the appearance of a porphyry, and include opaque orthoclase crystals, as well as sani- 
din. Macroscopical quartz occurs in comparatively large grains, while the hornblendes, though small, are very abundant.

It has already been mentioned that the divide between the Middle and North Parks is composed of eruptive rocks, which stretch between the two great Archæan ranges. Although the summits and the greater part of the northern slopes are thus formed, this east and west ridge does not exclusively consist of eruptive material; the foot-hills in many places being made up of long ridges of Cretaceous sandstones, which have been elevated into their present position by the Tertiary volcanic outbursts. 'These volcanic rocks consist of both trachytes and basalts, and occur both as large, massive bodies, and as narrow dikes, penetrating the Mesozoic strata. The trachytes occupy by far the most considerable area, and have influenced to a greater extent the present form and outline of the ridge. Parkview Peak, the highest point along the divide, stands out prominently from the surrounding country, rising over 12,000 feet above sea-level. It is situated just south of the limit of the map, near the southeast corner of the Park, one of the tributaries of Sioux Creek draining its northern slope. Its summit consists of light-colored rocks, probably trachytes, which form, upon the northern side, long spurs and ridges extending down to the Park.

An instructive geological feature of Parkview Peak, and one rarely met with within the area of this survey, is the occurrence of heavy beds of Cretaceous sandstones, elevated by trachytic outbursts, and now found imbedded between large masses of volcanic rocks, and in places penetrated by dikes, frequently only a few feet in width, which, withstanding atmospheric agencies better than the enclosed sandstones, rise above the latter like abrupt walls, with a general strike of east and west. The sandstone beds appear quite hard, and somewhat metamorphosed, showing the effect of the intrusion of adjacent trachytes. All the observed beds dip to the northward, with varying angles, but their inclination is of little importance, owing to the irregular manner in which the trachytes have reached the surface. Of the age of the sandstones, no definite proof was obtained, although it would seem more than probable that they belong to the Colorado group, as very similar beds are found to the westward upturned by trachytic and basaltic outbreaks, whose age is undoubtedly that of the Colo- 
rado Cretaceous. These latter beds, which are of considerable geological importance, as indicating the age of rocks through which the volcanic outbursts have poured, extend for several miles along the foot-hills in regular ridges, rarely inclined more than a few degrees, stretching down to the Park Basin, where they are unconformably overlaid by Tertiary deposits.

At Ada Spring, this Cretaceous ridge is cut at right angles by a narrow ravine, exposing sandstone strata, and leading to the south side of the ridge, which presents a precipitous face to the main divide of the Parks. Here we have an exposure of some 400 or 500 feet, near the base of which crop out characteristic blue limestones and argillaceous marls, which form so marked a lithological feature of the junction between the Fort Benton and Niobrara divisions of the Colorado Cretaceous group. From the lower bed of limestone were collected a number of specimens of a small Inoceramus, together with an Ostrea, which Prof. F. B. Meek identified as belonging to the Fort Benton division, and similar to species found along the east base of the Colorado Range, and on the Laramie Plains, from the same horizon. The bituminous odor emitted from these limestones in many localities is here quite strong. These beds have a thickness of about 75 feet, and are overlaid by argillaceous shales of a yellowish-gray color, but very sandy in texture, which probably represent the Niobrara division, although no fossils were found, and the marls not very characteristically developed. They were estimated at 100 feet in thickness. Overlying the yellow-gray shales, and reaching to the top of the ridge, are beds of coarse, crumbling sandstone, with interlaminated beds of arenaceous clays; the latter occurring quite hard, and of a fine-grained texture. Several of the sandstone beds would appear to be derived directly from the decomposition of old crystalline rocks, as they are made up largely of fragments of feldspar, flakes of mica, and grains of quartz, firmly compacted together. On the summit of the ridge, the sandstones carry impressions and fragments of stems and leaves of a deciduous growth. To the southward of this ridge, the Cretaceous strata extend up the slopes of the main divide, until broken up and concealed by the volcanic rocks of the summit.

West of Parkview Peak, the summit of the divide is somewhat lower, and presents a plateau-like character, formed by a heavy mass of därk-gray 
trachytes, which extend westward nearly to the West Fork of the North Platte, where they end abruptly in steep cliffs. This trachytic area stretches over 20 miles, in an east and west direction.

In its lithological aspect, this area of intrusive rocks, lying between the North and Middle Parks, presents several features of special interest, which distinguish it from all others, and call for something more than mere mention. Indeed, none of the trachytes show the same physical habit which marks the outbursts of this species in Utah and Nevada.

Just beyond the limits of the map, and to the east of Parkview Peak, near the trail which goes over into Middle Park, occurs a number of isolated hills and cones of a somewhat peculiar composition. That the rocks are intrusive there can be no doubt, and at the time of their examination in the field were regarded as belonging to the trachytic family, both from their peculiar habit and general appearance, and from their mode of weathering, and association with related rocks. At that time, however, no definite evidence was obtained as to their age, as is the case with the eruptive rocks to the westward. Subsequent detailed study of hand-specimens threw some doulth upon the reference to the trachytes, and examinations of thin sections under the microscope led Professor Zirkel to place them among granite-porphyries. The arguments brought forward in favor of this latter classification are so strong that it would seem highly probably that they were older than any trachytic eruption. On these grounds, we have been led to regard them provisionally as granite-porphyries, possibly breaking through the Archaxan foundation, and occurring here as an outlier from the Medicine Bow Range.

With these rocks, Professor Zirkel has classed others from the summit of Parkview Peak, which, in most of their microscopical details, develop the same characteristics, but, in their field habit, present still more the aspect of trachytes; and, as to their age, it would seem quite clear that they have broken through Cretaceous strata.

The rock from the pass east of Parkview Peak possesses a deciderlly porphyritic texture, with large, well-defined crystals, chiefly feldspar, enbedded in a fine-grained, brownish-gray groundmass. It weathers in large angular blocks, and, in its broader outlines, shows great diversity of form. On the surface, it appears somewhat porous, owing to the decomposition of 
iron minerals, magnetite, and pyrites, the latter, on exposure, falling out from the rock. It is an exceedingly tough, dense mass, breaking with a rough, hackly fracture and angular edges. In its mineral composition, this rock, both macroscopically and microscopically, is exceedingly rich in species, the following being recognized by the eye: orthoclase, plagioclase, quartz, hornblende, mica, magnetite, pyrites. In addition, by aid of the microscope, numerous crystals of titanite and apatite are seen.

Orthoclase is the predominating feldspar, and, from the large size of many crystals, as well as from their abundance, gives character to the mass. Many opaque orthoclase crystals measure from $1 \frac{1}{2}$ to 2 inches in length, and are remarkable for the well-developed terminal planes, exhibiting forms heretofore entirely unknown in recent voleanic rocks.

The faces shown will be found in Professor Zirkel's report. ${ }^{1}$ But singularly enough, these rare forms are found again on Steves Ridge, in the Whitehead Peak trachyte region, west of the Park Range, in an undoubted sanidin-trachyte.

Plagioclase crystals occupy a much more subordinate position, are always small, but marked by a resinous lustre. Both quartz and hornblende play a secondary part. The former occur as clear, colorless grains, and the latter as small, brownish crystals. The mica, which is quite abundant, forms well-developed flakes of a brilliant bronze color. The cubes of iron pyrites on a fresh fracture present a bright-yellow color, and appear to be everywhere scattered through the rock-mass. Both the pyrites and the magnetite decompose so readily that the surface of the rock shows frequently a dirty-brown color. In the specimens collected from Parkview Peak, the rock presents a somewhat different appearance, although, as already mentioned, the microscopical analysis shows the same detailed structure. The latter rock possesses a much lighter color, with a slightly greenish tinge, and a characteristic trachytic texture. All the mineral ingredients found in the rock from the Middle Park Pass oecur here, but in different proportions; the individual crystals being smaller, with less of a porphyritic texture, and the bronze mica less prominent, being replaced by dark-green hornblende,

\footnotetext{
${ }^{1}$ Microscopical Petrography, vol. 6, 68.
} 
associated with a decomposed mineral, which, under the microscope, looks like epidote.

Professor Zirkel has given, with some detail, in his report, the reasons for regarding these rocks as granite-porphyries. Perhaps the most important one, next to those already stated, the forms of the monoclinal feldspars, and the occurrence of pyrites, may be mentioned the absence of glass and the presence of liquid-inclusions in quartz-grains. This distinction, no doubt, forms a sharp line, separating the two classes of rocks. Another point is, the presence of a considerable quantity of titanite, a rare ingredient in Tertiary trachytes, but nevertheless one of the component parts of trachytes from the Whitehead Peak region.

In this connection, it is not without interest to state that, upon the slopes of Whitehead Peak, is found a local occurrence of granite-porphyry too limited to be indicated on the map, which is entirely surrounded by trachytes. If further observations should lead to placing these rocks from the North Park region among granite-porphyries, it would be necessary to admit their outbreak as late as Cretaceous times, which is more recent than has generally been supposed.

The connection between the rocks of Parkview Peak region and the plateau-like mass of trachytes lying to the westward was not visited by our parties, the upper portion of the divide having been reached from $\Lambda$ da Springs. The contrast in topographical outlines between the two masses is very marked; the former occurring in cones and sharp peaks, as well as in long irregular dikes, while the latter is characterized by broal nasses, with steep acclivities, and deep mural faces. It is without doubt a trachyte, although it offers some marked peculiarities, which distinguish it from other regions. It is a fine-grained, dark gray rock, with few crystals observable to the unaided eye, except a white, glassy sanidin and minute flakes of dark biotite. The mineral ingredients of the groundmass consist of sanidin, augite, hornblende, biotite, and apatite. Under the microscope, the augite is seen greatly to predominate over the homblende in a sufficient degree to class it as an augite-trachyte, which is a somewhat rare occurrence within the belt of the Fortieth Parallel Survey. 
A specimen of this trachyte was subjected to chemical analysis by $\mathrm{Mr}$. R. W. Woodward, with the following result:

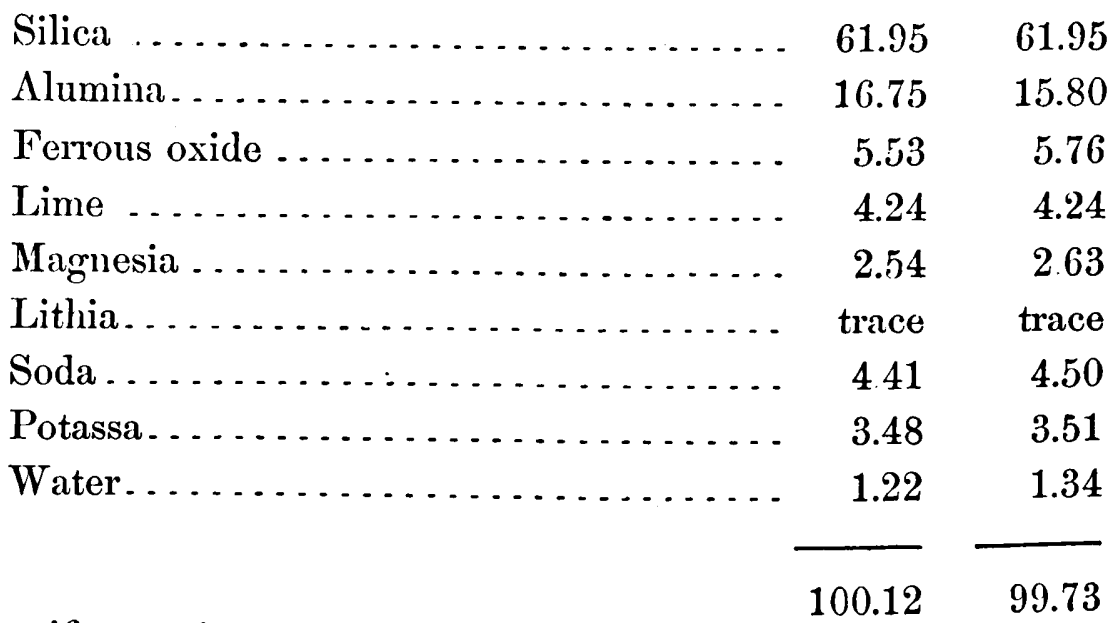

Specific gravity, 2.7, 2.6.

In this trachyte are enclosed fragments of unaltered, fine-grained granite and dark hornblende-rock.

Other trachytes from this same region present much the same physical habit, with the same mineral constituents, varying chiefly in the compactness of the rock and in color.

The basaltic formation, which enters into the structure of the divide between the two Parks, lies almost entirely westward of the trachyte region. It rarely attains the elevation of the older outbursts, but presents a more broken, irregular surface, with several outlying buttes and hills. These hills form a striking feature in the scenery, rising from 200 to 700 feet above the level of the Park basin, with a crater-like shape, that recalls the small cones which are frequently seen surrounding the base of large volcanoes. That they are connected a short distance below the surface with the main mass of basalt would seem highly probable, but are now separated by horizontal Tertiary strata, which abuts up against their steep slopes.

Buffalo Peak, just east of the west fork of the Platte, is the most prominent of these basaltic hills, rising nearly 700 feet above the stream-bed below, while its summit, a level surface, measures only some 300 feet across. The lithological character of all these basaltic hills is quite similar, being normal fine-grained basalts, varying from black to dark gray, and, with the 
exception of olivine, exhibiting no well-defined mineral constituents. A specimen from a hill southwest of Buffalo Peak, under the microscope, indicated triclinic feldspars, augite, olivine, and specular iron in an exceedingly fine groundmass.

From this same hill, Mr. R. W. Woodward analyzed the rock, with the following result:

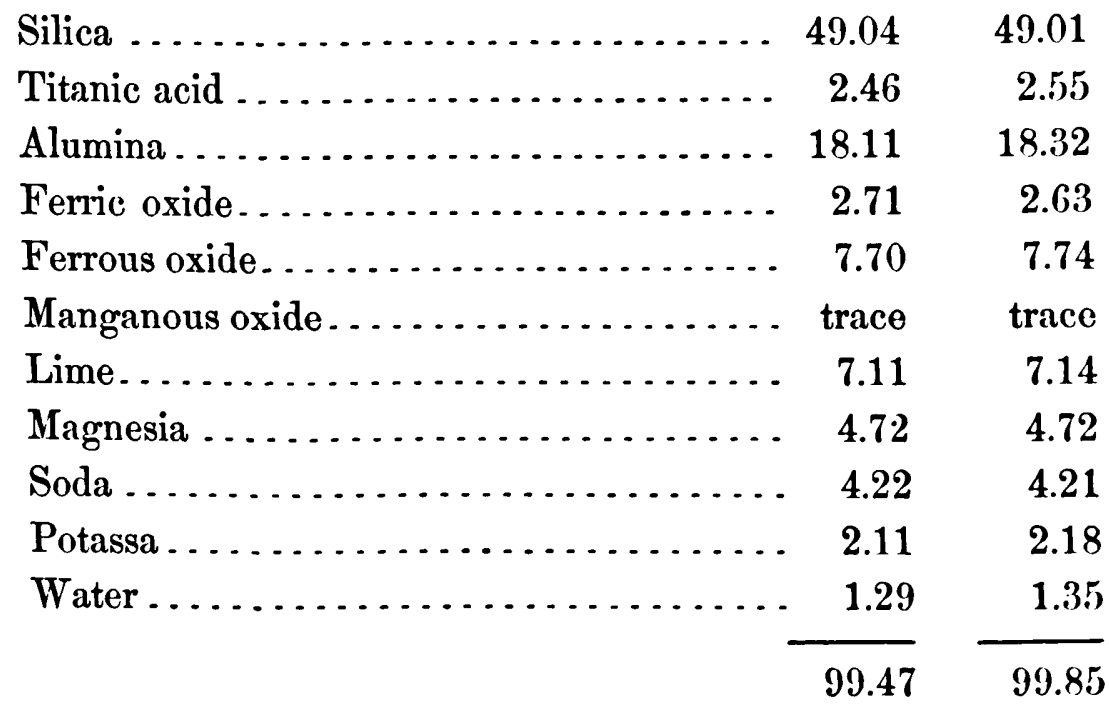

Specific gravity, 2.8, 2.7.

This analysis shows a typical basalt, containing, however, a large amount of titanic acid, which is of some interest, when we remember the occurrence of titanite in the eruptive rocks of Parkview Peak, as well as in the trachytes from Whitehead Peak.

East of Buffalo Peak occur some interesting dikes of basalt penetrating the Cretaceous strata like ramparts, and standing above the sedimentary beds in almost unbroken walls for long distances. Where observed, they strike north $40^{\circ}$ to $50^{\circ}$ west. They resemble the rock from Buffalo Peak, except that they appear richer in olivine. West of the Platte, very similar basalts extend to Rabbit Ears, a peak which rises with considerable prominence above the surrounding country in rough jagged points of darkgray vesicular basalt. It lies directly against the Archæan rock-mass of the Park Range, and forms the most westerly outburst of a most interesting 
group of volcanic rocks, stretching in an east and west line, between two great longitudinal ranges of highly-altered metamorphic schists and gneisses.

On the west side of the Park, north of the basaltic area, the only Mesozoic beds observed were Dakota sandstones and the Colorado group, and these are traced with difficulty, owing to the rough nature of Archæan foot-hills and great accumulation of glacial detritus, which not only conceals the Cretaceous strata, but renders travelling impracticable. The Dakota beds, resting upon the Archæan, dip at angles varying from $25^{\circ}$ to $50^{\circ}$. The Colorado clays incline much more gently, and stretch out into the Park basin, with a dreary arid appearance, with scarcely any vegetation, and dotted over with alkaline incrustations, chiefly sulphates of soda and magnesia, which permeate the argillaceous beds. Along the Archæan spur, which projects out from the main range and terminates in Crawley Butte, are found, on the north side, all the Mesozoic strata from the Red Beds to the top of the Colorado group, inclined at low angles; while, upon the south side, the horizontal Tertiary beds would appear everywhere to abut against crystalline strata.

Tertiary Beds.-Overlying the uppermost Cretaceous strata represented within the Park, occur the beds of approximately horizontal Tertiary deposits, to which allusion has already frequently been made. They were rarely observed inclined at a higher angle than $4^{\circ}$. They lie unconformably upon the older rocks, resting in places against every formation from Archæan to the top of the Colorado group, and are seen in an undisturbed condition, resting against the basalts. They extend over the entire Park basin, giving it the level, prairie-like aspect, which it presents from all the higher elevations. Through these beds, the many streams of the Platte drainage have worn their present channels, leaving everywhere long bench-like ridges, with steep sides, which, although offering numerous good exposures, appear in no case to have cut deeply into underlying strata, making any determination of their thickness uncertain. Within the Park, they probably do not exceed a few hundred feet. Lithologically, these deposits possess a somewhat local character, the material of which the uppermost beds are formed being derived exclusively from the relatively narrow limits hemmed in by the Park walls, rendering any comparison 
with other basins almost impossible, although they present certain features like the Niobrara Pliocene beds east of the Laramie Hills.

So far as known to us, neither vertebrate nor invertebrate forms have as yet been obtained from these deposits, so that palæontological evidence, so desirable in determining the age of Tertiary basins, is still wanting for the North Park deposits. It is quite probable that there may be found included within the Park two distinct Tertiary series. Some observations were made at the time of our explorations, which would tend in this direction, showing a lower set of unconformable beds, which, however, only reach the surface in a few localities, the greater part of the area being covered with more recent deposits. From the difficulty of sharply defining the two horizons of these beds, they have been given a local name, the North Park Tertiary, and a distinct designation upon the geological map. Partly from the general appearance of the strata, and in part from their relation to the basaltic rocks, they have been regarded provisionally as of late Pliocene age.

Lithologically, as already stated, these deposits within the Park develop a local character, the uppermost beds being invariably loose friable sandstones, formed from the comminuted detritus mixed with the re-arranged sands of the Colorado beds. Where the old crystalline rocks prevail, the sandstone is generally coarse, and of a gray color, while in the other beds yellowish-brown shades prevail. Beneath these overlying sands are finer beds, with interstratified layers of impalpable grayish-white and creamcolored marls, which cannot be told from similar beds east of the Laramie Hills, in the neighborhood of Horse Creek and Shelter Bluffs. Many of these cream-colored beds are exceedingly friable and rich in lime, and, upon being treated with dilute acid, give off a brisk effervescence. Under the microscope, the mass seems made up of exceedingly minute angular crystalline grains: other beds consist largely of trachytic and rhyolitic material. On the south side of Bruin Peak occur beds, which differ somewhat from those found in other parts of the Park, being made up of loose coarse crystalline detritus mixed with gravel and fine sand. Beyond the Park, the North Park Tertiary deposits extend down the Platte Valley, and may be traced northward between the two great ranges, along the Medicine 
Bow Range as far as Elk Mountain, and around the northern end of the Park Range. At the upper end of the valley, south of Grand Encampment Creek, they are quite thin, but appear to thicken northward.

On the lower geological section given on Map I may be seen the relation of the North Park and its sedimentary beds to the Archæan uplifts. The section is drawn through Crawley Butte, near the broadest expanse of the Park, and represents all the Mesozoic formations resting upon the Medicine Bow Range, and passing under the North Park Tertiary deposits, which lie horizontally against the Archæan island. To the west of Crawley Butte, the Dakota and Colorado Cretaceous alone, of the older series, come to the surface along the Park Range.

9 D G 


\section{SECTION V.}

\section{PARK RANGE.}

BY ARNOLD HAGUE.

Physical Description.-The Park Range forms the third and last great Archæan uplift of the Rocky Mountain system included within the limits of this survey, extending from about the latitude of $41^{\circ} 20^{\prime}$, in an unbroken line, far to the southward into Central Colorado. Within the boundaries of the map, the range embraces, in a north and south line, about 70 miles. In width, it varies considerably; the sonthern end, opposite the North Park, measuring only 12 to 15 miles from east to west, while to the northward, in the region of Pelham Peak, its broadest expanse, it reaches from 30 to 35 miles.

In its topographical features, the Park Range presents much less that is grand and rigged than the Colorado, and much less diversity of structure and intricate drainage than the Medicine Bow; and, while its general elevation is as high as the other ranges, the culminating peaks are much lower, only one, Mount Zirkel, attaining an altitude of over 12,000 feet above sealevel. The highest peaks in the range are Mount Zirkel, 12,126 feet, and Ethel Peak, 11,976 feet, on the western rim of the North Park; Pelham Peak, 11,524 feet, a picturesque, graceful summit, just north of the Colorado line, in the Territory of Wyoming; and Grand Encampment Mountain, 11,063 feet, in the northern end of the range, at the head of Battle and Savory Creeks.

From the southwest corner of the North Park, the trend of the range is nearly due north and south for 45 miles, with a narrow plateau-like summit along the eastern edge, falling off with gentle undulating slopes to the westward, but terminating in a somewhat abrupt wall toward the depression known as the Park. This wall, to the north of Mount Zirkel, is broken by a long narrow spur that puts out from the main ridge in a southeasterly direction into the Park, while a nearly parallel ridge, still 
to the north, forms a portion of the Park boundary, and connects the Medicine Bow with the Park Range.

North of Davis Peak, the range strikes off to the northwest in a broad flat-topped mass, presenting uniform unbroken slopes, with no prominent outlying spurs, and with a trend nearly parallel to the Medicine Bow Range.

The drainage-system of the range is remarkably simple. Streams at regular intervals from each other, having their sources high up on the axis of the range, drain both east and west in very direct courses. Only one, the Grand Encampment, an eastward-flowing stream, breaks through from the opposite side, receiving the waters from the western tributaries of the Pelham and Davis Peak group.

All the eastward-running creeks contribute their waters to the North Platte, while the western streams flow into the Little Snake and Yampa Rivers, the main eastern tributaries of Green River. The streams of the east side, enumerating from the south, are Cheyenne and Arapahoe Creeks within the North Park, and Grange, Beaver, Grand Encampment, Cow, Warm Spring, and Jack's Creeks, in the Platte Valley. On the west side, there are Moore's Fork and Elk River of the Yampa, and Battle and Savory Creeks of Little Snake River.

Traces of local glaciers, such as groovings and moraines, are abundant throughout these hills, as through most of the higher mountain-regions, and are shown also in the character of the topography.

In the southern end of the range, in the region of Mount Zirkel and Ethel Peak, the eastern face exhibits a number of remarkable glaciallyeroded cañons. The upper portions are large amphitheatres, with grand mural faces, which soon contract into deeply-cut trough-shaped valleys, with all the characteristic features of glacial erosion. These valleys are never more than 3 or 4 miles in length, and at their mouth, considering the limited size of the ancient glaciers, are found immense terminal moraines, which have undergone but little erosion in post-glacial times. It is as if the entire former contents of the cañon had been carried down and dumped at the entrance, and had never been disturbed.

In the northern portion of the Park Range, there are some secluded, 
open basins, shut in by high hills, which are usually filled with recent Quaternary deposits, and form a characteristic feature of the region. Encampment Meadow is a little mountain-valley, having some few acres of grassy bottom at the head of Grand Encampment Creek. Grange Valley, east of Davis Peak, is another basin of similar character.

The high ridges and mountain-slopes are generally covered with a good growth of coniferous forests up to about 11,000 feet, the average height in these latitudes in the Rocky Mountains, although varying somewhat with the exposure. The higher plateaus and summits are mostly bare. On the western slopes, the growth would appear to be quite dense, but perhaps not so vigorous as on the opposite side. The same species are found as characterize the Medicine Bow and Colorado Ranges.

Geological Description.-In its geological structure, the Park Range for its entire distance belongs, like the other great uplifts to the eastward, to the Rocky Mountain system of highly crystalline rocks of Archæan age. Rocks of later ages form but a very subordinate part of the uplift, and are found only along the lower flanks, seldom rising more than a few hundred feet above the plain, where they rest unconformably at varying angles upon the older series.

At the extreme southwest corner of the Park, Tertiary basaltic rocks conceal the spurs of the Archæan series; but in one instance only, at Rabbit Ears Peak, do they form any considerable part of the slope.

Farther to the north, between Cheyenue and Arapahoe Creeks, the Dakota sandstones occur inclined at a high angle. Still farther northward, rocks as low as the Red Beds of the Triassic, with the conformable series exposed, as high as the Colorado marls, are found uplifted against the granites, while near where the Platte River leaves the Park, the Colorado beds appear lying next the Archæan. Above these, the horizontal beds of the North Park Tertiary, which cover the Mesozoic rocks of the Park Basin, lie up against the Archæan, concealing the older rocks, and breaking the continuity of their exposures.

Over that portion of the Park Range north of the Park, the later sedimentary beds have never extended, except possibly in some lower portions, which cannot now be traced. To the north and east, the hori- 
zontal Tertiaries cover unconformably the Mesozoic beds, so that their angle of dip cannot be determined. On the west of the northern end are horizontal beds abutting against the flanks of the Archæan uplift, which have been referred to the Laramie group of the Cretaceous. As these beds, however, show no unconformity of dip, and no great difference of lithological character with the overlying Tertiaries, there is a possibility that they may be a lower, hitherto unrecognized member of these beds. South of the Little Snake River, in general, only outcrops of the Cretaceous rocks are exposed along the western flanks of the Park Range; in one instance only have rocks as low as the Triassic been found in contact with the Archæan. The structure of these sedimentaries, as well as could be seen under the great accumulation of volcanic material, is that of a series of secondary rolls, approximately parallel with the axis of the range, but showing no signs of having for any great extent covered the Archæan rocks, since their beds, never upturned at very steep angles, are as often inclined in an opposite direction to the slopes of the main Range, as with them.

In regard to the geological features of the Park Range, too little opportunity was afforded for working out with any degree of accuracy the detailed structural relations of the different beds. Only the broad leading features that characterize the range can here be pointed out, and even these may require considerable modification.

The narrow portion from the southern limit of the map northward to Davis Peak appears to have a nearly uniform monoclinal structure, with the prevailing dip of the beds to the westward, which on the summit, so far as observed, are inclined at low angles, falling off gently to the westward, while near the foot-hills they dip much more steeply, passing under the later rocks. The entire mountain-ridge suggests the western fold of a broad anticlinal axis, whose eastern side has been carried away either by erosion or downthrow. On the outlying spur which forms the northern rim of the Park, west of the Platte River, near Bruin Peak, the existence of this eastern side of the fold is indicated; north and south strikes being observed with easterly dips.

North of Pelham Peak, the axis of the main fold appears to undergo a somewhat abrupt change, curving round to the northwest, and striking 
approximately with the topographical trend of the range. This change in the direction of the geological axis produces a sharp bend on the eastern side of the range; the beds dipping in opposite directions toward each other, forming a synclinal fold, narrow near the angle of the bend, but widening to the westward.

This structure is first indicated by the rocks on the north slope of Davis Peak dipping distinctly to the northwest. Near where the Grand Encampment Creek leaves the mountains, the beds dip a little south of west, and strike west of north. In the higher portion of the range at this point, the prevailing strikes are east and west, while the basin-like depression of Encampment Meadows seems to occupy a synclinal trough, the beds to the south having a prevailing northwest dip, while to the north their inclination is generally southward.

Northward, the broad axis of the anticlinal passes through the region of Grand Encampment Mountain, with the sides of the fold falling off to the southwest and northeast at highly-inclined angles. At the bend of Snake Creek, below Camel Peak, the red gneissic beds dip as steeply as $45^{\circ}$ to the southwest. In the cañon on the spur between the forks of Battle Creek, the rocks are seen dipping $45^{\circ}$ a little west of south. To the east of the head of Jack's Creek, the strike is about north and south with a westerly dip, while at the northern end of the range the beds sink suddenly at an angle of $60^{\circ}$ to the north, with a strike of east and west.

In their lithological character, the highly crystalline beds of the Park Range vary considerably in texture, color, and habit; but all the prominent rock-masses may be classed under granites, micaceous and hornblendic gneisses and schists, and probably interbedded syenites and diorites. They differ in many respects from the beds of the Colorado and Medicine Bow Ranges, although they more closely resemble the former than the latter, and for that reason have been referred to the Laurentian. They are characterized by the presence of much structureless granite of a decided reddish tint, overlaid by gneisses and schists, similar to the series of the Colorado Range, but carrying more hornblende-bearing beds in the upper members. On the other hand, they are wanting in those rocks that are more especially 
characteristic of the Medicine Bow series, which was referred to the Huronian formation.

A characteristic granite from the southern end of the range is found upon the summit of Ethel Peak. It is a moderately coarse-grained rock of a reddish-gray color, and a somewhat friable texture, breaking up readily into small, irregular-shaped pieces. It is distinctly bedded, but without any lamination in the arrangement of its constituents, and closely resembles many of the granite bodies from the Colorado Range. It is composed of quartz, feldspar, and mica. The quartz is present in small angular grains, slightly tinged with gray; the feldspars, mostly orthoclase, are reddish in color, and frequently stained with an earthy, ferruginous coating, while the mica, in dark biotite plates, is not very abundant, but well disseminated through the mass, occasionally adhering to the broad faces of the orthoclase crystals. The outlying spur east of Arapahoe Creek, where observed, is a somewhat similar-appearing granite, a reddish, crumbling mass, with rounded outlines, which probably belongs to the same body. Separated from this spur by the broad valley of Arapahoe Creek, stands Crawley Butte, an isolated and prominent landmark in the North Park. It rises above the Tertiary plain some 1,000 or 1,200 feet. Geologically, it is closely connected with the spur, and the eroded forms and outlines are similar in both masses, being the result of the same agencies upon rock-masses of the same composition and texture.

On the northern rim of the Park, granites would seem to be the prevailing rock. From Bruin Peak, the highest summit of this ridge, were collected a number of interesting rocks. Coarse-grained graphic granite occurs, similar to that found in Grand Encampment Cañon, and on the west side of Long's Peak, in which the individual crystals of quartz, feldspar, and mica have frequently attained the dimensions of half an inch or more in diameter. The feldspar is chiefly orthoclase, of a bright red color, and the quartz massive and usually white. Both muscovite and black biotite are present, the plates of the former being much the larger. One variety of this rock is made up mainly of flesh-colored orthoclase, with but little quartz or mica, and these are usually present in segregated masses. Between the feldspar masses occur narrow fissures of yellowish-green epidote. 
It resembles the rock described by F. H. Bradley, ${ }^{1}$ from the Unaka Range, a part of the Blue Ridge, which forms the boundary between North Carolina and Tennessee. East of Bruin Peak, the granite assumes a more uniform character, composed chiefly of orthoclase and quartz, with beds carrying more or less hornblende or mica. Both hornblende and mica-gneisses are found here, the former, an exceptionally beautiful rock, being made up largely of crystals of dark, brilliant hornblende, with an admixture of white feldspar, which is, however, at times almost entirely wanting. Much of the feldspar is shown, under the microscope, to be well-developed plagioclase, while the quartz appears to be a subordinate constituent.

Hornblende also appears to be present in considerable amount in some varieties of the mica-bearing gneisses. These gneisses become so finegrained that they may be properly classed as mica-slates, consisting of minute grains of quartz, dark-greenish flakes of biotite, and some little white mica, probably muscovite. Under the microscope, thin sections disclose abundant grains of magnetite. Zirkel calls attention to the interesting manner in which the octahedral crystals of magnetite are penetrated by prisms of colorless mica.

On Mount Zirkel, a somewhat similar series of mica and hornblende beds occur, which are finely exhibited in the rock exposures of the glaciallyeroded cañons. Here the bedding is distinctly seen on a large scale, and presents a series of rock formations, highly altered, with an exceedingly variable lithological habit. Hornblende, associated with both orthoclase and plagioclase, forms the prevailing rock, while other beds are made up of mica and orthoclase, carrying some little hornblende and probably always a small amount of triclinic feldspar. They are characterized by a banded structure, in which the individual minerals are separated in layers, but varying greatly in width and outline, expanding from a mere line up to several inches, and again narrowing down to the former dimensions, and mingling in with the other constituents. Usually, the dark hornblende layers will be penetrated by small quantities of feldspar, and the feldspar bands, in turn, finely striped with hornblende. Segregations of the different minerals,

${ }^{1} \Lambda \mathrm{m}$. Jour. Sci., May, 1874, 519. 
especially hornblende and quartz, which are always present in varying quantities, in irregular-shaped bodies, are of common occurrence.

Along the trail which leads up Grand Encampment Creek, across the mountains to the westward, are found many excellent exposures of the Archæan rocks. At the mouth of the creek occurs a gneiss, the mass of which is largely quartz and feldspar, with the laminated structure very irregularly developed. The mica, which is mostly biotite, seems to occur in lenticular masses. The rock has little of the schistose structure of most gneisses, and passes into a coarse-grained rock, in which large masses of quartz and feldspar are enclosed in this gneissic material in a somewhat similar manner to the segregations in the beds on Mount Zirkel. Above this is a compact, dark-gray hornblendic rock, containing a slight admixture of white feldspar, which gives it a porphyritic appearance. Still farther up the creek occurs a large, interesting body of granite. It resembles, in its mineralogical habit, many of the features of the granites in the Colorado Range. It varies in texture and compactness, and is characterized by reddish orthoclase and quartz, with but little plagioclase or mica, and probably no hornblende; at least none was observed. The coarsegrained granites are one of the most characteristic rocks of this region, and show macroscopically what is usually only revealed by the microscope, that the feldspar crystals enclose masses of quartz filling the fissures, which often contain other feldspars, as well as well-developed crystals of mica. In these coarse-grained-beds, the crystals of flesh-colored orthoclase often attain a size of several inches. The coarse rocks pass again into the opposite extreme of granites, of which a specimen collected is a compact pinkish rock, composed chiefly of flesh-colored orthoclase and translucent quartz, with but little mica. Frequently, the mica is entirely wanting, or at least cannot be detected by the unaided eye; when present, it shows a tendency to gneissic lamination, its crystals almost always lying in parallel planes, even when irregularly disseminated. Zirkel has shown, in his examination of a thin section under the microscope, that the red color of the feldspar is in a measure due to fine laminæ of oxide of iron in microscopical fissures in the crystals; and that the mica is accompanied by a dirty green, strongly dichroitic, chloritic-like mineral. The quartz of all these granites is very 
poor in liquid-inclusions. It is an interesting fact that these microscopical observations hold equally well in the examination of the red granites from the Laramie Hills.

The slopes of Davis Peak, southeast from Encampment Meadows, present a series of hornblendic and micaceous gneisses, very similar in petrographical habit to those found on Mount Zirkel. The micaceous rocks are a very fine-grained admixture of black mica-flakes, reddish-gray orthoclase, and white, limpid quartz. Scattered through the gneiss are numerous small garnets of a deep-red color, mostly about the size of a pin-head, sometimes, however, as large as a pea. Under the microscope, no hornblende could be detected, and the quartz was poor in liquid-inclusions. Near the summit of the peak occurs a characteristic hornblende-gneiss, in which the lamination is very regular. It consists of alternating white layers made up mostly of plagioclase, and black ones in which hornblende predominates. As in the mica-gneiss no hornblende was detected, so in this rock no mica is visible. Under the microscope, minute apatite crystals are seen, while the quartz shows interesting double inclusions of liquid carbonic acid. In this gneissic series is sometimes seen the same zonal structure with alternating black and white bands, frequently an inch or more in thickness, as already noticed in the Mount Zirkel series. The very summit of Grand Encampment Mountain is formed of a mass of hard, compact, dark-green hornblende, which is almost entirely free from other constituents, but which carries interstratified a bed of white micaceous.quartzite; it may be classed as an amphibolite.

On both the east and west flanks of the range, the attitude of the beds is very similar, and in their larger general features resembles the rocks of the range already described. A few especially interesting characteristics should, however, be mentioned. At the north end of the Park Range, just north of the upper end of Jack's Creek, where the first Archæan rocks are found emerging from the horizental Tertiary beds which form the divide, occurs, interbedded in the hornblende rocks, a remarkable bed of pure white quartz, some 50 feet in thickness. Such is the dazzling whiteness of its mass that it was at first mistaken, at a little distance, for a snow-bank. It is a vitreous structureless mass, of a milky white, and at times almost limpid quartz. A thin 
section under the microscope reveals, in its interior, a series of lines and spots to which the milky appearance is due, a high magnifying power, showing them to be an aggregation of liquid-inclusions, carrying sometimes water with a moving bubble, and sometimes liquid carbonic acid containing a bubble which disappears with a slight elevation of temperature: the same phenomena are seen in the quartz of the accompanying gneiss. Associated with the gneisses of this region is a hornblendic rock, closely resembling that from Rawlings Peak, but in which the granitic structure predominates over the gneissic, and the hornblende shows a tendency to distinct crystallization. It is a compact, medium-grained rock, composed of hornblende, orthoclase, and plagioclase, with but a small amount of quartz. Orthoclase appears to be the prevailing feldspar. 'The rock has the mineral composition of a syenite, with much of the habit of an eruptive body. Closely related to this rock is another made up almost exclusively of feldspar and quartz, but carrying also some plates of white mica in subordinate quantities.

In the metamorphic series of Jack's Creek occur beds that in a marked manner resemble intrusive bodies, and in the hand-specimen it seems impossible to distinguish them from well-known eruptive diorites. A specimen in the collection may be described as a compact crypto-crystalline mass, with no observable regularity in the arrangement of the mineral constituents, with a rough, angular fracture, and of a dark-gray color. In mineral composition, it appears to be chiefly an admixture of dark-green hornblende and white plagioclase, the latter frequently present in long, acicular crystals, of a vitreous lustre.

The western slopes are generally densely wooded, and the exposures much less favorable for observation than on the eastern side. The predominating beds seem to be the hornblendic rocks, and but one or two localities require special mention. Under the lavas, at the head of Little Snake River, is exposed a rock, which is different from any of those already mentioned. It is a compact rock, having no schistose structure, but a peculiar banded appearance, owing to the parallel arrangement of the fine quartz and minute mica flakes between the feldspar crystals. Both orthoclase and plagioclase are present; the former, however, is the more abundant, and 
gives a decidedly reddish tint to the rock, while the latter is only observed in brilliant acicular crystals.

The following analysis was made by Mr. R. W. Woodward:

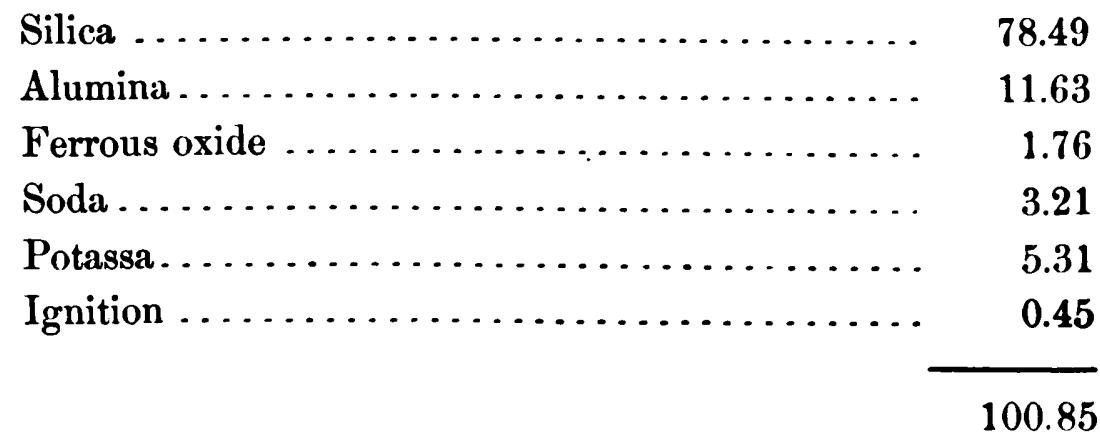

Specific gravity, 2.6.

This analysis is characterized by a somewhat high percentage of silica. At the bend of Little Snake River, below Camel Peak, the same red gneiss is exposed, interbedded with the hornblende-rocks.

On Buck Mountain, at the head of Elk River, on the west side of the range, occurs a compact dark-gray crypto-crystalline hornblende-rock, almost identical in lithological characters with the one described from the head of Jack's Creek; there is something in the physical habit of the groundmass which suggests that they may both be interbedded intrusive rocks.

The essential minerals which form the large rock-masses of the Archæan series of the Park Range are, so far as observed, like the minerals of the other great ranges to the eastward, limited in numbers. The list comprises quartz, orthoclase, plagioclase, biotite, muscovite, homblende, and epidote; as accessory minerals, garnet, magnetite, and gold. Under the microscope are detected, not already observed macroscopically, chlorite and apatite.

Epidote, as an essential constituent of the rock, was seen only at Bruin Peak in deep-red granite, where it occurs in considerable quantities. It is found, however, in one or two localities scattered through the coarser granites. Red garnets occur in the finer-grained mica-gneisses, usually very small, but on Davis Peak they were found of considerable size. Fine gold occurs in the stream-beds in the region of Buck Mountain, where miners have been engaged in washing for this metal for several years past. 
Chlorite was detected in the red orthoclase-granites, with an association and habit similar to that observed in the granites of the Laramie Hills.

Minute apatite crystals occur in the hornblende-gneisses of Davis Peak.

The red orthoclase, structureless granites, poor in mica, of the Park Range, bear a close analogy to the Colorado Range granites. The overlying mica-gneisses are, in habit, also more closely allied to those of the Colorado Range than to the Medicine Bow series. They are characterized in general by a somewhat compact texture, gray color, with broad mica flakes; while the Medicine Bow series have a much more friable and crumbling nature, are white or silver-gray in color, and the feldspars more decomposed. The mica is present usually in minute, thin plates.

Hornblendic beds, however, recall the Medicine Bow series. They are, indeed, the only rocks that indicate any very close analogy, and even these have some points of difference. In the Park Range occur beds of very fine-grained hornblendic gneiss, carrying considerable quartz, which resemble the beds in the Laramie Hills, in the Sybille Cañon, while the finely-laminated rocks, made up of fibrous hornblende and bluish-white plagioclase, which so characterize portions of the Medicine Bow Range, do not appear to form a marked feature of the Park Range. On the other hand, the massive white quartzites, argillites, iridescent slates, red conglomerates, and limestones are wanting in the Park Range.

Intrusive rocks later than the Archæan series do not appear to have penetrated the Park Range. At least, dikes or outbursts of such material were not observed. This, however, is not remarkable, as they play a very insignificant part in the other Archæan uplifts to the eastward. The later Tertiary volcanic rocks may also be said to be absent from the interior of the range, although, as already mentioned, they occur all along the west flank. 


\author{
SECTION VI. \\ CRETACEOUS REGION FROM COMO TO SEPARATION.
}

BY ARNOLD HAGUE

Valley of the Medicine Bow River.-North of the two great Archæan masses, the Medicine Bow and Park Ranges, Cretaceous strata are found over the greater part of the area, extending from the Laramie Plains westward to the limits of Map I, where they pass beneath the Eocene 'Tertiary deposits of the Green River basin.

Over this wide extent of country, the crystalline schists reach the surface at only one point, Rawlings Peak, while Palæozoic and Mesozoic rocks below the Colorado Cretaceous occupy nearly as restricted limits. The country presents a broken, undulating surface, varying in average altitude from 6,500 to 7,000 feet above sea-level. The structural features are somewhat complicated, consisting of a series of anticlinal and synclinal folds, with sharp, prominent ridges of Fox Hill sandstone, and basins and level plains of Laramie beds.

Between Como and Medicine Bow Stations, the country is overlaid by the Colorado Cretaceous, all the divisions being recognized. The Niobrara yellow marls would appear quite thin, although characteristically developed, and both the upper and lower clays seem highly arenaceous. Just north of the river, at Medicine Bow Station, the beds strike north $65^{\circ}$ to $70^{\circ}$ west, and dip $16^{\circ}$ to $18^{\circ}$ southwest. In the bright-colored marls were found Ostrea congesta associated with imperfect fragments of Inocerami. Below the Niobrara beds, in the sandy clays, occur Inoceramus altus, and in a low ridge or bench not far distant, but above the latter, were collected Scaphites Warreni.

The Medicine Bow River, after leaving the mountains, runs almost exclusively through beds belonging to the Colorado Cretaceous; its course being guided by the clays and marls, and the overlying Fox Hill sandstone. Beds of the former formation occupy a deep bay, or recess, penetrating the 
Archæan gneisses between Rock and Elk Mountains, through which the river cuts a narrow channel, trending in a nearly north and south direction, until reaching the overlying sandstones, when it turns abruptly eastward, following the line of junction between the two series of beds; the Fox Hill strata appearing as a long line of prominent bluffs upon the north side of the stream. To the eastward, where the overlying sandstones turn toward the north, the river also runs in the same direction, but, before reaching the railroad, makes a bend to the eastward, flowing through Colorado Cretaceous strata. A short distance west of Medicine Bow Station, the Colorado Cretaceous passes under the Fox Hill sandstone, and from here the latter formation occupies the surface for at least 5 miles to the westward, or to within 3 miles of Carbon.

All the beds appear to dip westward, but with a varying angle, and with a general strike of northwest and southeast, curving around somewhat to a north and south course as we proceed westward. The surface presents a gently rolling, barren country, with occasional edges of sharp sandstone rising a few inches, or, at best, a few feet, above the plain, but sufficient to indicate the position and inclination of the beds. Near the base of the series occurs a prominent but low ridge of sandstone, which strikes north $60^{\circ}$ west, with a dip to the southwest of $32^{\circ}$ to $37^{\circ}$. It consists of coarse, yellowish strata, interstratified with beds of ferruginous clay-shales and black carbonaceous clays, underlaid by deep-red ferruginous sandstones, passing down into gray and steel-colored beds. At the base on the west side of the ridge are found two springs, highly charged with sulphur and salts of iron, probably derived from the adjacent impure clay strata. Farther westward, observed strikes gave north $40^{\circ}$ to $45^{\circ}$ west, and a dip of $25^{\circ}$ to $30^{\circ}$ west. This ridge is followed by a broad, open country, without outcrops, and then other ridges still dipping westward, but at lower angles; the rocks presenting much the same general aspect. It was impossible to determine the thickness of these beds, but there must be at least between 4,000 and 5,000 feet of strata represented.

Carbon Basin.- The town of Carbon is situated directly on the line of the Pacific Railroad, 656 miles west of Omaha, and 83 miles to the westward of Laramie City. It lies 6,760 feet above sea-level, on a bleak, 
dreary plain of nearly horizontal sandstones. In an economical point of view, it derives its sole interest from the heavy deposits of coal underlying the town, which have been extensively mined for a number of years. Geologically, the place has also received considerable attention in examining the question as to the age of the Wyoming coals. There would appear to be but little doubt that the beds belong to the Laramie division of the Cretaceous sandstone. In determining the true horizon of these beds, however, it is necessary to trace out their relations with the great sandstone formation, which forms all the higher ridges of the region, and to compare the strata with other similar localities. The beds at Carbon occupy a broad, irregularly-shaped basin, the rocks on the west, south, and east all dipping in toward the centre, surrounding it completely on three sides. Fetween one and two miles west of Carbon, a high, prominent ridge of Fox Hill sandstones, known as Simpson Ridge, whose highest point, just south of the railroad, rises some 800 feet above the level of the town, shuts in the valley on that side. South of the railroad, this ridge, which is quite regular in outline, trends approximately north and south, but to the north falls away considerably, curving around to the northeast. Its structure is that of a very perfect anticlinal fold, whose axis passes through the high point already mentioned. The beds upon the east side of the ridge facing Carbon dip at $55^{\circ}$ to $60^{\circ}$, while upon the opposite side of the fold the same rocks dip westward at $35^{\circ}$ to $40^{\circ}$. In the axis of the fold lies a brilliant pearl-gray, mediumgrained sandstone, which is overlaid on both sides by a series of arenaceous and ferruginous clays, with the following subdivisions:

1. Thinly-lawinated arenaceous clay.

2. Rusty saudstoue, with ferruginous seans.

3. Ferruginous fine-grained cluystone, 4 feet.

4. Fine black clay, 50 feet.

5. Ferruginous claystone, 3 feet.

6. Crumbling rusty saudstone.

Overlying the latter are sandstones similar to those from the summit, but perhaps not quite so white, which are in turn overlaid by coarse red sandstones reaching to the base of the ridge. $\Lambda$ marked peculiarity of outline, seen upon both sides of the ridge, and one that adds a striking feature to the anticlinal structure, is the similar shallow valleys formed, high 
up on the slopes, by the erosion of the softer clay-beds, protected by the outer overlying sandstones. Along the east base of the ridge, the coarse sandstones may be traced northward to the railroad-cut. Here, one mile westward from town, a thin bed of coal is seen in a hard sandstone, which carries a large amount of half-carbonized bits of wood, and is overlaid by beds of arenaceous clays. A short distance farther north, on the west side of a low ridge, with all the beds still dipping eastward, occur similar clay and iron strata, as seen high up on Simpson Peak, associated with fine calcareous sandstones. The beds of Simpson Ridge, in passing eastward, shallow in dip, and may be traced passing conformably under the level coal-bearing strata of the valley. Leaving, for the present, the detailed description of the beds underlying Carbon, we find the strata for nearly 3 miles east of the town lying horizontally, and then gradually assuming a westerly dip, forming the opposite side of a broad synclinal fold from the Simpson Ridge beds. About 4 miles east of Carbon, near the first snowshed, rusty, yellow sandstones occur, dipping west at $25^{\circ}$, and carrying a thin stratum of impure coal. A short distance farther eastward are found very similar yellowish sandstones, with concretionary fragments of iron, black clays, and friable sands, with intercalated thin seams of iron, still preserving the same dip. South of Carbon, the beds incline gently northward, and would appear to be perfectly conformable with the basin strata. How far they extend southward was not carefully determined, but coal outcrops in very similar beds are said to occur 4 or 5 miles south of the railroad. Returning to the railroad, which crosses the synclinal basin near its centre, the strata appear approximately horizontal, although, immediately underlying Carbon, they are somewhat disturbed by local faulting, bringing the beds which carry the main coal seam to the surface a short distance west of the town.

In company with the superintendent of the mines, the following section was made of the beds underlying Carbon:

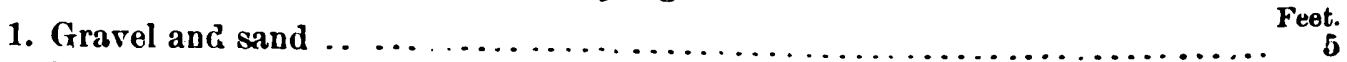

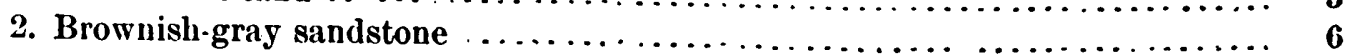

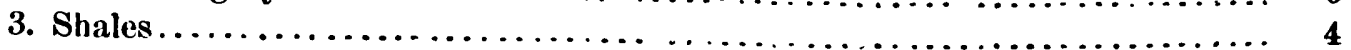

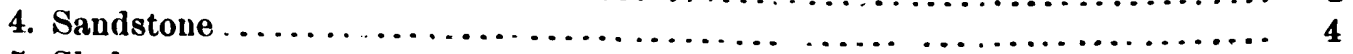

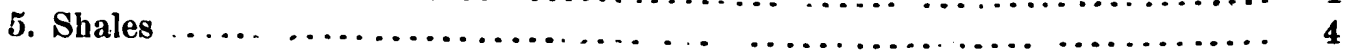

$10 \mathrm{D} \mathrm{G}$ 


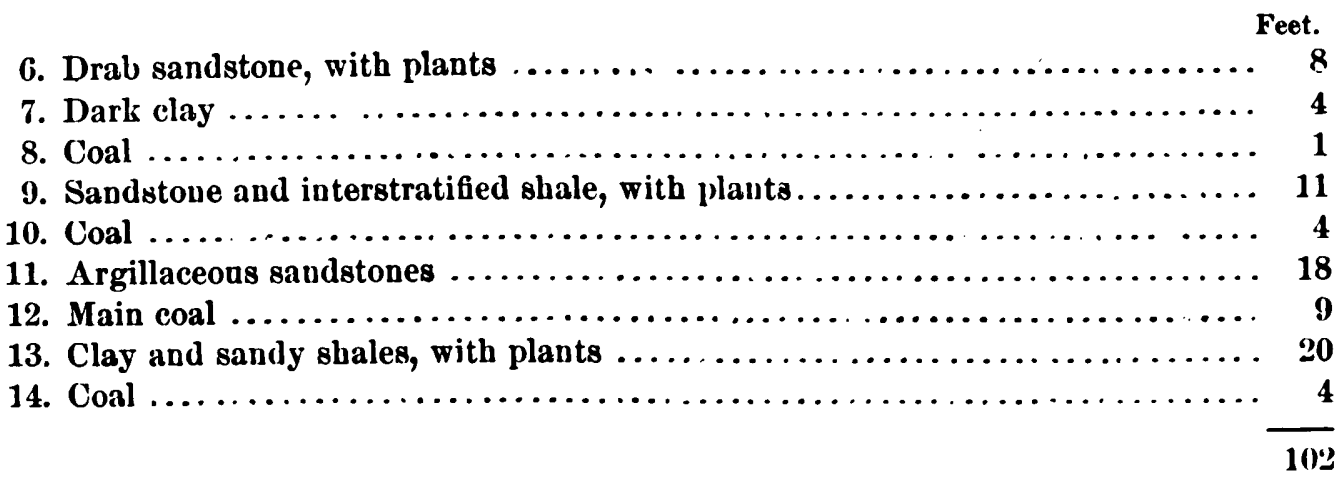

Below the lower coal, yellowish-gray sandstones occur, which were not estimated. The third stratum of coal, number 12 in the section given above, is the only coal that has been worked. In its physical appearance, it resembles the other Cretaceous coals of Wyoming, and is regarded as one of the best for railroad purposes. It is highly prized, although it carries narrow seams of earthy impurities and slate bands. In the cracks and fissures of the coal are thin layers, or films, of yellowish-gray carbonate of lime. It crumbles readily on exposure to the air, and takes fire spontaneously on the dumps. When burned, it yields a large percentage of yellowish-gray ash; but the amount of water present appears to be lower than most of the Wyoming coals From bed number 6, a fine-grained, calcareous sandstone, large quantities of fossil leaves of dicotyledonous growth have been collected, many of them well preserved; also, from bed number 9, below the first coal stratum, and from number 14, below the main workingseam, other collections were made.

Professor Lesquereux, who gathered a large suite of specimens from these beds, has determined fifty-six distinct species, and has come to the conclusion that the beds are, without doubt, of Miocene age. From this collection, eighteen species are identical with the Miocene flora of Europe, and thirteen with that of the Arctic regions. Among the species found here which Professor Lesquereux regards as indicating a Miocene flora may be unentioned the following: Betula Stevensoni, Acer trilobatum, Alnus Kiefersteini, and Equisetum Haydeni. Associated with these, however, in the same beds, are other species, subtropical types, which Professor Lesquereux says are 
characteristic of a much lower horizon; among them, a Smilax grandifolia, Rhamnus Goldianus, Cinnamomum Mississippiense, and Ficus tiliafolia.

At the time of our visit to this district, we made diligent search for Molluscan remains, but without success, and, so far as known to us, no vertebrate or invertebrate forms have as yet been found in the Carbon Basin, with the exception of a single imperfect and distorted specimen of a Viviparus, having no specific character.

The evidence as to the age of these deposits rests either upon the fossil plants which they contain, or upon their stratigraphical position, and, where such testimony disagrees, it would seem that the latter must necessarily receive the greater weight. This is especially the case where so much doubt has already been raised in other localities of the Rocky Mountains as to the importance of plant evidence in determining geological horizons between Cretaceous and Tertiary beds.

Professor Lesquereux, notwithstanding he feels so positive as to the Miocene age of the Carbon beds, does not hesitate to place them below the Green River series, giving them a position, in relation to the latter horizon, which few geologists will be disposed to dispute, and which the geological maps and sections accompanying this report conclusively prove. In the second chapter of this volume, it will be shown that the Green River beds are undoubtedly of Eocene age; that they are, moreover, overlaid by several thousand feet of Eocene deposits, and underlaid by a heavy thickness of the Vermillion Creek series, also Eocene; and that the latter overlies unconformably beds occupying the same horizon as the Carbon formation, which we regard as of Upper Cretaceous age.

West of Simpson Ridge, the Fox Hill sandstones pass under the Laramie beds, and the latter extend westward as far as Saint Mary's Peak, a distance of 15 miles, where they are again limited by the coming to the surface of the underlying sandstones. North of the railroad, the Laramie formation stretches beyond the boundary of our map, and its limits in that direction have never been determined; while, to the southward, it is hemmed in by outlying ridges of Fox Hill sandstone connected with the Elk Mountain upheaval. The rocks of the Laramie division are chiefly loose, friable sandstones, of rusty-yellow and reddish-brown colors, and in places carrying 
thin seams of clay. Occasionally, carbonaceous clays crop out in ravines and gullies, with indications of coal, but no workable deposits have as yet been opened. North of Saint Mary's Station, the berls strike north $70^{\circ}$ tu $i 5^{\circ}$ west, and aip $16^{\circ}$ to $20^{\circ}$ to the northeast ; near Dana, they strike noril $55^{\circ}$ to $60^{\circ}$ west; and, still farther eastward, strike north $35^{\circ}$ east, but with the same dip.

Over this area of Laramie strata are dotted, in the spring and early summer, numerous small ponds and lakes, which, in many cases, suffer complete evaporation during the dry season. As the country is very poorly drained, and the clays highly impregnated with saline matter, most of the waters are strongly alkaline, and leave behind considerable incrustations.

From the shore of one of these lakes, south of Percy, a quantity of salt was collected, which, upon being subjected to chemical analysis by Mr. R W. Woodward, yielded the following:

Soluble matter, 48.36 per cent.

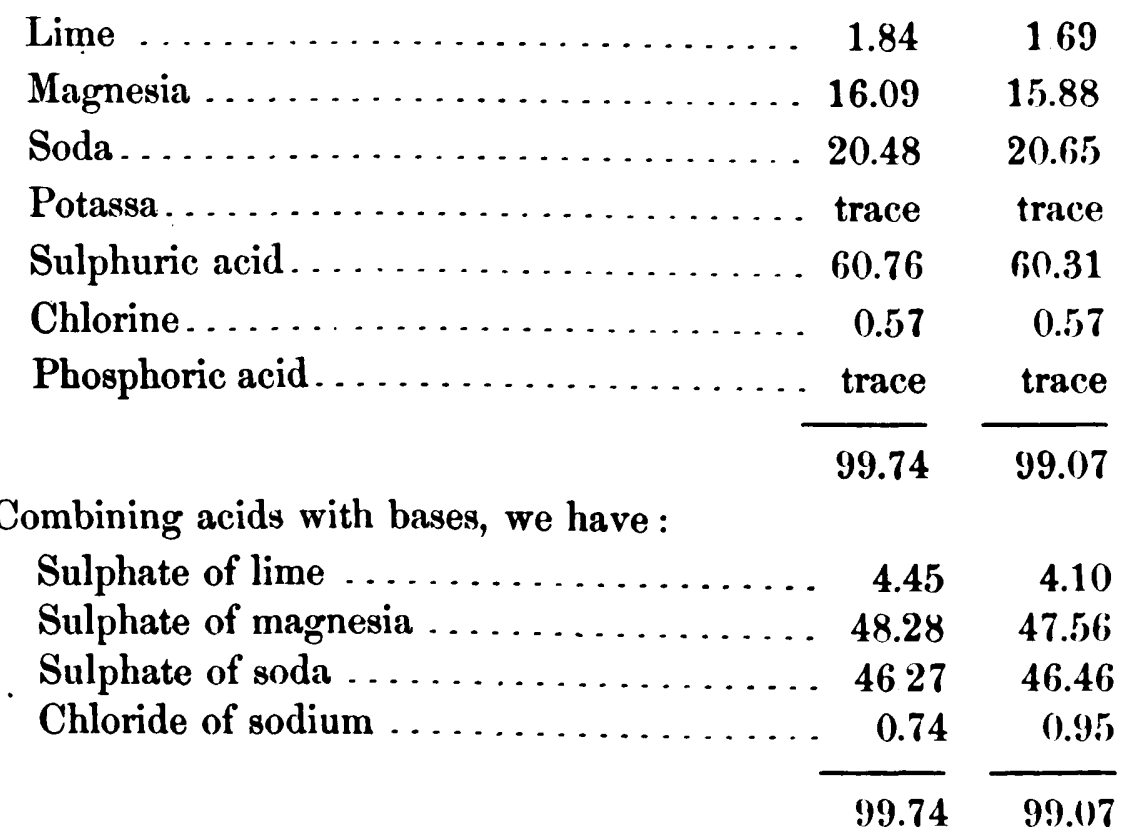

Elk Mountain Region.-Nine miles south of Percy lies Flk Mount,ain, the most northern point of the Medicine Bow Range. Some description of the schists and gneisses forming its main mass has already been given, but on its northern slopes are found all the beds from the Coal- 
Measure limestone to the Fox Hill sandstone, uplifted at high angles, lying against the Archæan foundation. All the geological divisions are well represented, in general exhibiting the same characteristics as seen elsewhere in the Rocky Mountains, and only a few salient features require special mention. Unlike the rigid beds east of the Colorado Range, which stand out from the main mass in unbroken lines of strata, the beds at Elk Mountain conform much more closely to the Archæan outline, and curve around the older rocks lying directly upon the sloping sides. All the later sedimentary strata are more or less disturbed, and show considerable crumpling and local displacement. The Carboniferous limestones lie high up on the mountain, in places reaching within 1,200 or 1,500 feet of the summit, and -extend from the first cañon east of Scotch Creek to the west side of Sheep Butte.

In the narrow cañon east of Scotch Creek, the limestones occur at the entrance in a steep cliff, then, rising up over the gneisses, form a covering 200 or 300 feet in thickness, concealing the crystalline rocks beneath; both formations, however, being distinctly seen from the cañon. These limestones would appear to be much more arenaceous than the same beds to the eastward. They all possess a coarse crystalline texture, more or less sandy, many of the beds consisting largely of siliceous material of a bluish-white color, interstratified with yellowish-white layers, and at the same time are not so characteristically bedded as the Palæozoic limestones of the Laramie Hills. At Sheep Butte, the arenaceous habit of the limestone is clearly shown. Here the beds stand at $80^{\circ}$, many of them almost pure sandstones of a bluish-gray color. The Red Beds, Jurassic, and Dakota Cretaceous all occur on the slopes of the mountain, but much lower down, and less regular in outline than the Carboniferous. East of Sheep Butte, they all conform with the latter beds in following the deep re-entering bay in the Archæan mass, and then curving around the northern side of the butte, completely encircling the projecting spur of Archæan rocks. Just east of the summit of Rattlesnake Pass, the Dakota Cretaceous stands out prominently, with its characteristic wall, above the softer Jurassic marls on one side and the Colorido clays on the other, at an angle of $85^{\circ}$, striking north $75^{\circ}$ to $80^{\circ}$ east. From here eastward, nearly to Foote 
Creek, the Colorado Cretaceous is well represented in a series of three or four low rolls, rising gently above the surface. The strata bend slightly in long gentle S-curves, with a general strike of north $65^{\circ}$ east, and dip $85^{\circ}$ east.

Overlying the Dakota, the Fort Benton black shales and bands, with brown earthy marls, appear quite prominently, the latter weathering light gray, with a peculiar dotted, speckled surface. In the marls occurs an undetermined species of a small Inoceramus. The Niobrara light-colored marls, although very characteristic, forming a low continuous ridge of purplish and yellowish beds, would appear to be hardly more than 100 feet in thickness, passing up into the overlying clays. North of Sheop Butte, along Rattlesnake Creek, the Colorado Cretaceous, which forms the creek-bed, may be well studied. Here the two lower members of the series crop out upon the south side of the stream, and the Fort Pierre sandy clays on the opposite side pass up into well-defined Fox Hill sandstones. These upper clays dip $55^{\circ}$ to the northeast.

East of Sheep Butte and south of the Rattlesnake road, the Fort Benton clays are characterized by an extensive development of the ferruginous beds, which, in many localities, mark the underlying clay strata in thin bands and nodular concretions. The clays have undergone a very considerable erosion, and are cut by narrow ravines and gullies, exposing the harder iron layers along the ridges for several hundred feet in length, but with a very varying thickness, and with interstratified beds of clays. The iron occurs both massive and in concretionary nodules, associated with rather striking and delicately-marked clay concretions. It presents a steel-black color, weathering to brownish-black, a very even crystalline texture, a conchoidal fracture, and a hardness about 4 . In the cracks and fissures and between the surfaces of the nodules occurs a secondary formation, caused by percolating waters, of crystalline spathic iron, and an occasional seam of carbonate of lime. The following analysis, made by Mr. B. E. Brewster, shows it to be an argillaceous siliceous carbonate of iron, with a trace of carbonaceous matter, and, like many of the English clay ironstones, containing a considerable amount of manganous oxide. 
ELK MOUNTAIN REGION.

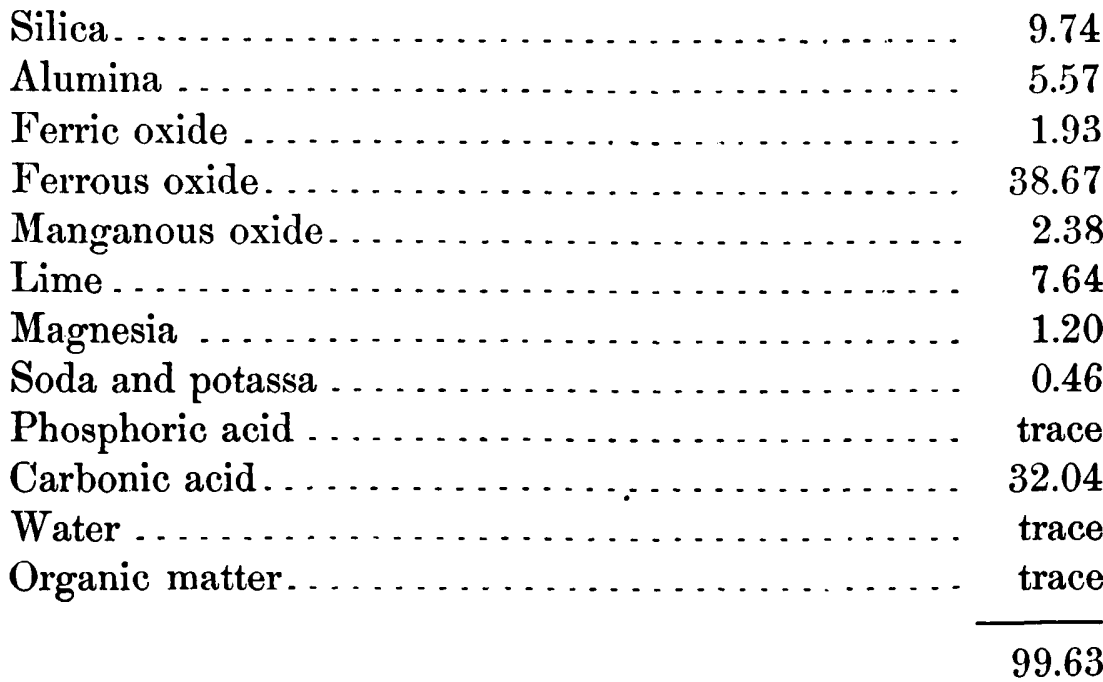

Although these clay ironstones of the Colorado Cretaceous have as yet nowhere been observed in extensive deposits, it is by no means impossible that they may be found near the railroad in close proximity to limestone bodies and lignite beds of the Laramie formation; in which case they may at some future time prove to be of practical value. One of the most marked structural features in the region of Elk Mountain is seen in the prominent ridges of Fox Hill sandstone, which lie just outside the eroded valleys of the Colorado Cretaceous. In many localities, the Colorado clays fall away in dip, and the overlying sandstones pass out upon the plain in low rolls with diminished dips. Here, however, along the face of the mountain, the Fox Hill presents very persistent ridges, with mural faces toward the range, and dipping at high angles. To the eastward of Elk Mountain, along the north side of the Medicine Bow River, these ridges extend in an east and west line. North of Scotch Creek, the beds are considerably broken up, and Simpson Ridge, a long anticlinal fold, trends off to the northward. West of Simpson Ridge, the west side of this fold curves round, striking east and west, until north of Rattlesnake Creek, when it bends off to the northwest in the direction of Saint Mary's Peak.

A recorded strike of the main ridge, north of Elk Mountain, indicates north $35^{\circ}$ to $40^{\circ}$ east, with a dip of $52^{\circ}$ to $57^{\circ}$ northwest. At the southern base of the ridge, the Fort Pierre beds pass up into brownish sandstones, overlaid by gray beds, and in turn passing up into others of a rusty-brown 
color, carrying argillaceous and ferruginous material, with impressions of decirluous leaves and stems. Above these occur massive white sandstones.

Valley of the North Platte.-Along the bluffs between Elk Mountain and Saint Mary's Peak occurs another anticlinal fold. To the northwest of Elk Mountain, along Pass Creek, the beds fall away gradually to the west and southwest, bending in strike as they go northward, until south of Wolcott Station, their dirction is a few degrees north of west and south of east, the course of Pass Creek roughly indicating the outlines of the uplift. Just north of Pass Creek occurs a very sharp, clearly-defined anticlinal fold, the beds on the upper side dipping north and northeast.

North of the railroad, and on the east side of the North Platte, the Fox Hill sandstones form a prominent monoclinal ridge, dipping northeast, which below Fort Steele determined the course of the river in a similar manner as beds of the same horizon have parked out the course of the Medicine Bow River. At the southern end of this ridge, at Saint Mary's Peak, the beds occur considerably disturbed, and metamorphosed into a hard sandstone, with a strike north $15^{\circ}$ east, and a dip $16^{\circ}$ east.

The ridge on the south side of the fold mentioned as north of Pass Creek crosses the North Platte River, in a nearly due east and west line, about 2 miles above Fort Steele. It is formed of sandstone beds, which dip $45^{\circ}$ to $50^{\circ}$ to the southward. This ridge presents singular narrow crests of the harder upright strata, forming straight ridges only a few feet in wilth, and enclosing narrow monoclinal valleys worn out of the more yielding beds. It extends to the westward in an east and west line for nearly 10 miles, forming the southern boundary of the open Quaternary valley west of Fort Steele, then gradually trends to the southward with a constantlydecreasing dip to the south and east, joining the Sage Creek Bluffs. The latter form the line of bluffs which border Sage Creek on the north, possessing an easterly strike and a dip northward, which gradually shallows passing eastward, until near the mouth of Sage Creek they are practically horizontal.

On the surface of the flat country to the north of this line of bluffs, where the soil accumulation is very slight, the jointing planes of these sandstones present a line of cracks of remarkable regularity; the grass 
growing in little ridges along these cracks gives to the surface the appearance of a planted field. These sandstones form the southern member of a broad, shallow, synclinal fold, which occupies the valley north of Sage Creek, the northern member of which, as already described, is very steep. On the opposite side of the Platte River, east and southeast from the mouth of Sage Creek, the Cretaceous beds, dipping from $1^{\circ}$ to $3^{\circ}$ to the northeast, rise in long level benches of friable coarse gray sandstone, stretching completely across the valley to Elk Mountain, where they again dip westerly, and may be traced to the beds, already described, on Pass Creek. Southward the limit of Cretaceous strata is less definitely determined, as; in a nearly horizontal position, they lie concealed beneath Tertiary deposits of similar lithological habit, which have been referred to the North Park beds. These Tertiary beds extend down the valley of the Platte as far as Cottonwood Creek, and rest in plateau-like ridges against the crystalline gneisses of the Medicine Bow Range. Near the mountains, in a number of localities, they may be seen lying unconformably upon the upturned edges of the Cretaceous.

As thus described, by the aid of the geological map it will be seen that the Fox Hill Cretaceous forms a remarkable synclinal basin, irregular in shape, but extending in an east and west line for 32 miles, and measuring across its broadest expanse about 16 miles in width. The persistency of the bluff-like formation of the Fox Hill beds over so wide an area is a marked feature in the geological structure of the region.

Perhaps equally noteworthy is the occurrence of the upper members of Colorado Cretaceous clays, which crop out along the base of the bluffs, as seen on the Medicine Bow River, at Elk Mountain, along the Sage Creek Bluffs, and at the Mount Steele Ridge, in all of which localities the beds of the lower series pass up gradually into the upper sandstones, both divisions being perfectly conformable.

In general, these Fox Hill beds are not rich in organic remains; but sufficient palæontological evidence was obtained at various points, in rude casts of Inoceramus and Baculites, and some characteristic plant-remains, to define their horizon as belonging to this group.

A number of sections were made through portions of the Fox Hill 
group. A section across the ridge, on the west side of the Platte, near the river, two miles south of Fort Steele, shows, in the lower 2,000 feet, principally beds of massive sandstone, 50 to 100 feet in thickness, with a few shaly seams at the base, overlaid by a thickness of about 1,500 feet of more thinly-bedded sandstones, in thickness varying from 5 to 10 and 15 feet, with interlaminated shales, sometimes bituminous, and two or three thin seams of coal. In the valley south of the ridge, the upper beds run into more reddish, iron-stained sandstones, which have been considered to represent a remnant of the lower beds of the Laramie group, in the trough of the synclinal. The whole thickness of the Fox Hill beds, which we estimate at between 3,000 and 4,000 feet in this region, is not exposed in this ridge, the lower beds being concealed beneath the Quaternary of the valley. Some of these beds can be seen on the low hills just west of Fort Steele, where there are indications of a narrow anticlinal fold having an east and west axis parallel to this ridge.

About 4 miles east of Fort Steele, in the railway gap, which cuts a high, prominent ridge, dipping about $16^{\circ}$ to $20^{\circ}$, the following section was taken in descending series:

1. Heary.bedded white

2. White and buff sandstones............................. 200

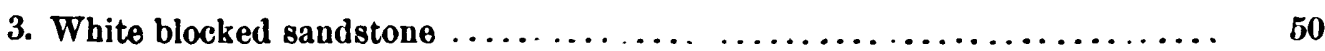

4. Yellow sandstone $\ldots \ldots \ldots \ldots \ldots \ldots \ldots \ldots \ldots \ldots \ldots \ldots \ldots \ldots \ldots \ldots \ldots \ldots$

5. Shale beds $\ldots \ldots \ldots \ldots \ldots \ldots \ldots \ldots \ldots \ldots \ldots \ldots \ldots \ldots \ldots \ldots \ldots \ldots \ldots \ldots \ldots$

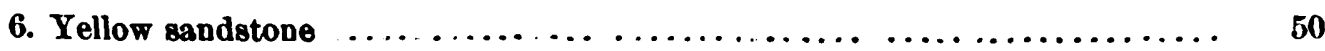

7. Brown sandstones.............................. 750

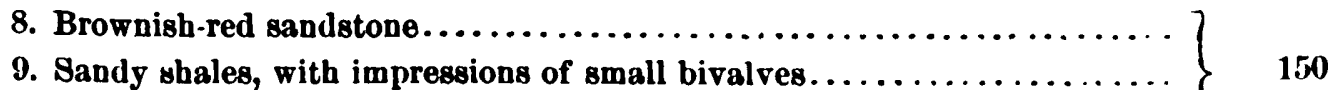

10. Coarse sandy shales $\ldots \ldots \ldots \ldots \ldots \ldots \ldots \ldots \ldots \ldots \ldots \ldots$

The North Platte River cuts through the nearly horizontal rocks of the synclinal basin, exposing along its bluffs many good, but limited sections, showing between 400 and 500 feet of strata. In general, they do not differ greatly from those already given. The following section, made near where 
the old overland stage-road crosses the river, was taken from the waterlevel to the top of the overlying bench:

1. Hard rusty-gray sandstone

2. Black shales, with thin sandstone layers, carrying Ostrea..... 50 fect.

3. Friable yellow sandstone, rich in the genus 0 strea......... 30 feet. 450 feet.

4. Reddish-yellow sandstone.

5. Grayish $\cdot$ white sandstoue

Of all the sandstone strata exposed in this region, those from Saint Mary's Peak appear the most compact, forming a hard, distinctly-bedded rock, of a steel-gray color, and carrying but little iron. An analysis of the Saint Mary's Peak sandstone was made by Mr. B. E. Brewster, with the following result:

Silica ............................ 94.76

Alumina............................. 2.99

Ferric oxide . . . . . . . . . . . . . . . . . . . 0.23

Lime ............................ 0.21

Soda................................ 0.13

Potassa . . . . . . . . . . . . . . . . . . . . . 0.41

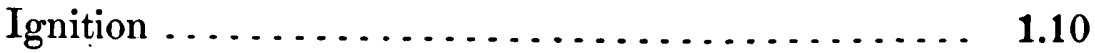

99.83 


\title{
SECTION VII. \\ WEST OF NORTI PLATTE RIVER.
}

\author{
BY S. F. EMMONS.
}

Bridger's Pass Regiov.-The valley of Sage Creek is an open, shallow basin, whose bottom is covered by a considerable accumulation of alluvial deposits; the few exposures along the benches bordering the stream showing only decomposed clay beds of the Colorado Cretaceous. $\Lambda$ t a re-entering angle of the northeastern face of the Savory Plateau are found, at the base of the bluffs, beds of coarse gravelly sandstone, striking little east of north, and dipping at an angle of $55^{\circ}$ to the east. In the valley, these beds curve rapidly to the westward, shallowing in dip, while in Bridger's Pass they are found with a northeast strike and a northwest dip, showing that the Tertiary beds of the plateau cover a quaquaversal uplift in the Lower Cretaceous rocks. A section taken in a northeasterly direction from the northern point of the Savory Plateau, diagonally across Sage Creek Valley, shows, above the gravelly sandstones, which represent the Dakota group, beds of blue clay-shales overlaid by thin-bedded sandstones and interstratified clays; these again succeeded by yellowish-brown sandstone, containing spherical concretions of more calcareous material. Above are about 100 feet of white and blue clays, containing thin calcareous seams full of Ostrea congesta. Above this is a seam of only a few inches in thickness of white shaly limestone, also containing abundant remains of Ostrea congesta, associated with thin seams of arragonite and selenite. These berls are exposed only on the upper slopes near the bluffs; their angle of dip decreasing with their distance from the bluffs. Through the middle of the valley, over an extent of nearly 4 miles, are found no exposures; but the character of the soil shows the underlying rocks to be made up mainly of the yellowish clays and marls of the Colorado Cretaceous. On the northeast border of the valley rises a bluff of massive white sandstones belonging 
to the Fox Hill group, at the base of which are found exposed a few beds of bluish clays, representing the upper line of the Colorado Cretaceous.

Bridger's Pass, which connects the valleys of the Upper Sage Creek and the South Fork of the Little Muddy, has been eroded out of the soft beds of the Colorado Cretaceous. Along the northern and western borders of this valley extends a ridge of white massive sandstones of the Fox Hill group, standing at angles of $10^{\circ}$ to $25^{\circ}$, and curving in strike approximately with the shape of the ridge. At the gap in the ridge, just below the forks of the Little Muddy, through which the stage-road passes, these sandstones bare a strike due north and south, with a dip of $15^{\circ}$ to the westward. To the south of the gap, they may be traced for some distance along the eastern face of the bluffs, and then disappear under the conglomerates which form the surface of the plateau. To the north, with a strike bending to the eastward, they form a continuous ridge about 15 miles in Iength, showing a bluff face to the southwest toward Bridger's Pass, at the base of which are exposed the clayey beds of the Colorado group. A thickness of 3,000 to 4,000 feet of heavy-bedded sandstones, mostly white and buff, with a fow included beds of shale and some thin seans of coal, dipping to the northwest at an angle of $10^{\circ}$ to $20^{\circ}$, are here exposed.

The flat-topped summit of this ridge, above Bridger's Pass, is covered by pebbles and boulders of micaceous gneiss and granite, with smaller pebbles of pure white quartz, which originate evidently in the Archæan beds exposed at the northern point of the Park Range. These result from the decomposition of the $\mathrm{Wyoming}$ Conglomerate, of which a thickness of about 40 feet is still found on the more sheltered portions of the ridge, where it consists of small pebbles about the size of a hazel-nut, of quartzite and crystalline rocks in a white calcareous matrix.

The higher beds along the northwest slopes of this ridge belong to the Laramie Cretaceous. As seen on the flanks of Separation Peak, they consist largely of sandstones of rusty colors, carrying considerable iron, and showing several coal-seams. One bed in particular is of so bright a red color that it might almost be mistaken for one of the Red Beds of the Triassic; it is, however, of generally finer grain, and is more thinly laminated.

The shallow valley skirting this ridge on the northwest, through which 
passes the road from the Little Muddy to Rawlings Station, seems to occupy a slight synclinal depression, which in the middle may be merely a slight faulting.

In going northward from a point on the Little Muddy, about 5 miles west of the Sulphur Springs, a thickness of between 3,000 and 4,000 feet of beds of the Laramie group, dipping northwest at an angle of $20^{\circ}$, is crossed. Of these, the lower 2,000 feet are composed of massive white and yellow sandstones, in which the shale beds are of subordinate importance. The upper sandstones are stained and striped in red by iron oxide, and form ridges with considerable clayey valleys between. In the upper 800 feet are several coal-seams, and near the top is a prominent bed of bright vermilion color, only a few feet in thickness, of fine-grained, hard, argillaceous material, abounding in well-preserved impressions of leaves. This is overlaid by a white sandstone about 200 feet in thickness, carrying a coal-seam, which in turn is capped by a thin-bedded brown sandstone, which weathers into flags about 3 inches in thickness; the dip of these upper beds has shallowed to $10^{\circ}$, and to the north the beds of the Laramie group are practically horizontal.

The heavy white sandstones of the Fox Hill group, which form the bluffs of the northern face of Bridger's Pass, bend in strike to the northward, east of Separation Peak, shallowing in dip at the same time to almost horizontal. On the east side of the low saddle, between Sage Creek Valley and Rawlings, they form bluffs facing westward, standing here with a dip of $10^{\circ}$ to the east, or, in other words, this pass occupies a low anticlinal fold, the southern extremity of the Rawlings Peak uplift.

For eight miles to the west of Fort Steele all traces of the underlying beds are lost beneath the soft clayey soil, characteristic of valleys which are worn out of beds of the Colorado Cretaceous. Just south of the railroad, about midway between Rawlings and Fort Steele, is a double line of low ridges, formed by thin-bedded sandstones and interlaminated clays, which join at the east and open out to the west, representing the anticlinal fold whose indications are seen near the latter point. Near the railroad section-house, in the northern of these ridges, was found in sandstones dipping $35^{\circ}$ with a strike $5^{\circ}$ north of west, a curious deposit of whitc 
crystalline gypsum. It apparently filled a fissure in the sandstones about 2 feet in width, running at right angles to the stratification. These sandstones probably belong to the upper part of the Dakota, or lower part of the Colorado group. The southerly-dipping ridges extend to the westward, with a trend parallel to the line of the Fox Hill Bluffs, until, under the influence of the Rawlings Peak fold, they curve to the north along the western flanks of that uplift. The northern ridges cross the railroad about 3 or 4 miles east of Rawlings, curving round to the northeast so as to enclose a slight synclinal crumple, and are lost under surface accumulations. On the slightly-rising ground about 4 miles east of Rawlings Peak, however, the characteristic conglomerate of the base of the Dakota group is seen, a line of boulders, as much as 6 feet in diameter, marking its line of outcrop, which forms a curve parallel to the base of the ridge. This conglomerate is made up of small pebbles, generally not larger than a filbert, in a siliceous matrix. The pebbles are mostly of black jasper or chert, while the matrix is largely made up of broken and partiallyrounded crystals of quartz. The boulders represent portions of the conglomerate, which have become so hardened and compacted by local metamorphism, that the matrix is as unyielding as the jasper pebbles, and the mass fractures with equal ease through either. The western faces of these boulders present the most remarkable instance of polishing by winddriven sand we have had an opportunity of observing. The surface of the otherwise rather light-colored rock has assumed a dark leaden-gray hue, and a polish equal to that of glass, while the sand has drilled irregular grooves and holes, often three-quarters of an inch deep, and not more than an eighth of an inch in diameter, through pebbles and matrix indifferently. In the finer-grained portions of the unaltered conglomerate are mixed, with the grains of limpid quartz, white earthy particles of kaolinized feldspar, generally too small to show any shape, but in some cases as large as a pea, when the general outline of the original feldspar crystal can be easily traced. Below the conglomerates are found a few outcrops of the Jurassic limestones, showing a comparatively small thickness of beds, and dipping like the conglomerates $8^{\circ}$ to $10^{\circ}$ to the eastward. Beyond these, to the westward, are the Triassic sandstones, whose presence is indicated by the 
character and color of the soil, though over the long, smooth slopes, extending to the foot of the Rawlings Peak Ridge, no outcrops were found.

Rawlings Peak.- In a direction a little west of north from Rawlings Station extends a double-crested ridge, which represents the remnants of an anticlinal or quaquaversal fold, enclosing a body of Archæan granite. Through the middle of this fold runs a little north and south valley, following the direction of the main axis, while at right angles to it the southern end of the fold has been cut through, and in part carried away by the erosion of a stream, now dry, which drained the region to the west and north of Separation Peak. There are thus exposed a series of conformable sedimentary strata, in which the lowest beds probably correspond to the Primordial sandstones of the Laramie Hills.

The granite is exposed by the erosion of this longitudinal valley, and is best seen toward its southern end; here, on the east side, its surface, being directly exposed to the west winds, has been beautifully grooved and polished by the desert sands. It shows quite distinct lines of bedding, which have an inclination of $45^{\circ}$ to the westward, while the overlying quartzites and sandstones of Rawlings Peak dip $10^{\circ}$ to the east. This granite, which has been classed by Professor Zirkel as a granite-gneiss, is a compact, greenish, rather fine-grained rock, which, although wanting in the distinctly crystalline structure of an eruptive granite, has none of the laminated structure of a gneiss. It is made up of quartz, homblende, and feldspars, with a decided predominance in the latter of plagioclase over orthoclase. Its greenish color is due to the prevalence of finely-disseminated hornblende through the mass. Under the microscope, both quartz and feldspars are seen to contain a great number of liquid-inclusions, which, particularly in the quartz, are remarkable for containing most perfectly-formed cubes of salt, a hitherto unusual occurrence in the quartz of Archæan granites. There are also observed in the liquid-inclusions of the quartz, besides the cubes of salt, green hornblende-microlites, which seem to have been taken up mechanically by the liquid.

The eastern and higher ridge is made up principally of the quartzites and sandstones, which slope approximately with the surface of the ridge, and curve somewhat with the spurs. They are well seen in section at the gap, 
through which the railroad passes. Their greatest thickness exposed cannot be less than 700 feet of beds, generally not more than a foot or two in thickness of gray-white quartzite and sandstones, having something of a reddish tinge on the weathered surfaces. The lowest bed found is a finegrained conglomerate, about 70 feet in thickness, made of small pebbles of white quartz in a siliceous matrix, while the upper bed is a ferruginous sandstone, about 15 feet thick. The only traces of organic life found in them were a few indistinct fucoidal remains, but their general lithological character, and position beneath well-defined Carboniferous limestones lead us to consider them representatives of the lower Palæozoic series of the Laramie Hills.

At the extremity of the eastwardly-projecting spur of Rawlings Peak is an interesting deposit of red hematite. It forms a body some 20 feet in thickness in the sandstones immediately underlying the lower limestone bed. The extent of the body in strike could not be determined; at the time of visit, however, it had already been extensively mined for use as a flux, and as a mineral paint, for which it is peculiarly valuable. The ore is remarkably free from impurities, and contains almost the theoretical percentage of iron; although its surface, when fresh, shows a metallic lustre, it is so soft and fine-grained that a very slight attrition reduces it to an almost impalpable powder of brilliant vermillion color. The horizon of this deposit is probably represented by the ferruginous band found in other parts of the ridge. Above the iron deposit at this point is a bed of some 50 feet of drab limestone, so compact and fine-grained as to resemble a lithographic stone. The same bed occurs capping the sandstones in the low hills south of the railroad gap, where they furnish large springs, and are overlaid by darker-colored limestone beds, all dipping $10^{\circ}$ to the southward, and soon disappearing beneath surface accumulations.

On the western ridge, a few miles northwest of the railroad station, the best section is obtained, where the beds $\operatorname{dip} 30^{\circ}$ to $40^{\circ}$ to the westward. A thickness of only about 150 feet of the underlying quartzites is exposed on the slopes of the valley. Above the ferruginous sandstone, which caps the quartzites, is 50 feet of fine-grained drab limestone, darker in color toward the base; over this 30 feet of white siliceous limestone, succeeded by a bed $11 \mathrm{DG}$ 
of varying thickness of dark-blue earthy limestone, from which was obtained Pleurophorus oblongus and some fragments of a strongly-curved Productus. Above the blue limestone is a bed of 40 feet of dark, earthy limestone, frequently of reddish color, followed by 40 feet of grayish granular limestone. This thickness of 200 feet of limestones is overlaid by 50 feet of arenaceous shales, beyond which is a gap of about 500 feet, showing only occasional outcrops of thin arenaceous shales, but including probably argillaceous and calcareous beds in the intervals covered by soil. A gap of some 400 feet now occurs before the ridges of the characteristic red sandstones of the Triassic are reached. Near the base of these, in a bed of lightdrab, fine-grained, semi-crystalline limestone, was found a Natica Lelia. Individuals of the same species were found in a similar position in a limestone of the Red Beds on the East Fork of the Duchesne in the Uinta Range. This species, being new, does not suffice to characterize the horizon, but is interesting as being the only one found between the horizons of distinctly Jurassic and Permo-Carboniferous types.

The beds thus far noticed occupy the higher portion of the ridge, whose surface is but little incidented. On this ridge there is evidence of one, if not two, slight displacements along a line approximately at right angles to the strike of the beds. From the fragments of granite seen along the principal line, it would seem probable that a sharp ridge branches out from the main granite body to the westward, which has determined the direction and position of the faulting. Along the western slopes, the harder or more massive beds of the Mesozoic formations stand out in monoclinal ridges, and are easily distinguished by their lithological habit. These upper beds where observed have a steeper dip than those nearer the axis of the fold; their angle being over $40^{\circ}$ to the westward, while that of lower beds is scarcely $30^{\circ}$. In general direction of strike, they follow the shape of the uplift, curving eastward toward the south, and toward the north assuming a trend of due north and south; the line of the ridges is, however, rather sinuous and irregular, following short re-entering and projecting angles, and consequently presenting varying dips.

The Triassic formation is represented by a thickness of about 600 feet of sandstones, of a light pinkish red and more massive habit in the upper 
portion, and of a deep Indian red, and frequently thinly bedded, and of much finer texture toward the base. About midway in these sandstones is a bed of about a foot in thickness of a pale greenish drab, compact, lithographic limestone, enclosed in beds of purple and green argillaceous clays and shales. This bed seems very persistent throughout this formation east of the Wahsatch Range. At the base of the series is a gray sandstone, rather thin-bedded, with very regular jointing planes. The red sandstones are overlaid by about a hundred feet of red and white, soft, argillaceous beds, including thin seams of arenaceous shales. Above these were found two outcrops of limestone, a dark, earthy bed of 10 feet, overlaid by 15 feet of gray, somewhat arenaceous limestone. In these were found the following

Camptonectes bellistriatus. extenuatus. pertenuistriatus.

Belemnites, sp. ?

Eumicrotis, sp.?

Astarte, sp. ?

Adjoining these limestones, the outcrops were too much covered to make it certain that 25 feet is the maximum development of Jurassic limestone here. No other outcrops were observed, though in the gap of nearly a hundred feet between them and the characteristic conglomerate of the base of the Cretaceous, which shows on the surfaces only fragments of thin sandstones and rusty shales, there may be some limestone beds hidden. Beyond the outcrop of the Dakota conglomerate, which is here white, the successive ridges are occupied by beds of the higher groups of the Cretaceous, still conformable, but with ever decreasing angle of dip. To the westward, the high plateau region is occupied by nearly horizontal beds of the Laramie group.

Along the line of the railroad, west of the gap near Rawlings Station, the first prominent outcrops are seen in low ridges of shales of the Colorado group, overlaid by white sandstone beds dipping westward, which, to the north, have a strike of nearly north and south, while beyond the railroad to the south they bend eastward, assuming a trend of south $70^{\circ}$ east. Above these, the series of heavy-bedded white sandstones of the Fox Hill group is 
crossed in section, dipping conformably westward. West of the divide toward Separation Station, the rusty sandstones and arenaceous clays, with their included coal beds, of the Laramie group, are crossed, dipping at first with the lower sandstones $10^{\circ}$ to $15^{\circ}$, but beyond the open shallow valley to the north they are seen to lie nearly horizontal, perhaps dipping $2^{\circ}$ to $4^{\circ}$ north. About two miles to the south of Separation Station, these rocks form parallel ridges running northeast and southwest, in which the beds dip $10^{\circ}$ to the northwest. The upper sandstones are full of impressions of deciduous leaves, and constitute the characteristic leaf-beds of the Laramie group.

From Separation, the beds flatten out to the west as well as to the north, and form a high barren plain country, in which the dry, shallow water-courses present but few exposures of rock. One can only distinguish that the stratification-lines occupy nearly horizontal planes, but of the character of the beds little definite idea can be formed. It is probable that the Laramie beds occupy the greater part of the surface of this region, though in some coarse sandstones are found plentiful casts of fresh-water shells, Lymna a, Viviparus, Goniobasis, which probably represent the same horizon as the beds found at the junction of the Little Snake River and Little Muddy Creek. They would then be remnants of the Vermillion Creek Tertiaries, which may doubtless at one time have extended as far east as the base of the Rawlings Peak uplift. About ten or twelve coal beds of various thicknesses can be distinguished in this region. None have been worked on account of the exposed and dry nature of the country; but the comparatively horizontal position of the strata presents a very favorable condition for the mining of coal on a large seale.

Savory Plateau Region.-From the depression of Bridger's Pass and the valleys of Sage and Little Muddy Creeks, southward to the base of the Park Range, extends an elevated platean region, cut through by deep cañon-like valleys, the higher portion of which, immediately adjoining these valleys, and which is about 8,500 feet above the level of the sea, has received the name of the Savory Plateau. This region is principally covered by horizontal beds of the North Park Tertiary, which, as proved by exposures in the deeper cuts on its northern edge, overlie the upturned edges of Cretaceous and earlier beds, while the higher portions of the ridges are capped 
by remnants of the Wyoming conglomerate. The best exposures of the Tertiary beds are found in the open valleys at the heads of. Savory and Jack's Creeks, and on the pass between the Archæan body of the Grand Encampment Mountains and the Savory Platean. A thickness of not less than 1,000 feet of these beds is here exposed, which is made up in the upper portion of a thickness of about 300 fect of a drab, earthy, somewhat porous, limestone, sometimes enclosing small pebbles, underlaid by beds, which grade off insensibly from limy sandstones into coarse gravel beds. In the lower part of bluff-exposures bordering the meadows, at the heal of Jack's Creek, was found a seam of greenish, indurated clay, containing streaks of fine, hardened gravel, in which are flakes of brown and white mica, deposited with their broad faces parallel to the lines of stratification. In the same bluff was a peculiar seam, a few inches thick, of dark-green, cherty material, which also contained a few scattered flakes of mica. To the west of the divide, at the head of Savory Creek, the Tertiary beds can be traced for some distance, and are found to cap the underlying Cretaceous sandstones, which are here almost flat, and show no discrepancy of angle. To the west of Savory Platean, however, and south of the Little Muddy Creek, is an open valley, whose surface is covered by detrital material and considerable accumulations of sand blown in from the open country to the west, in which no outcrops were found. It was impossible, therefore, to ascertain the stratigraphical relation of these Tertiaries with the different groups recognized in the Green River Basin; and no beds, corresponding lithologically to these, are found west of this line. Their angle of dip at the most westerly exposures would carry them apparently over the beds of the Vermillion Creek series, and the large proportion of limestone they contain would ally them with the overlying Green River group. They may, however, represent an entirely later series, and be a local development confined to the region of the North Park and the Platte River; for this reason, as has been already stated, they have been designated by a special color, and assigned provisorily to the Pliocene. They occupy the valley of the North Platte to the south of Jack's Creek, forming long, gentle slopes, extending up from the river to the flanks of the Grand Encampment Mountains, which, though so covered by recent Quaternary deposits that only few 
exposures of the underlying Tertiary are found, sufficiently show the continuity of their original deposition. Their beds may be traced along the line of bluffs bordering the valley of Sage Creek on the south and west. Here the upper member is a hard siliceous shale, more like an older rock, under which are seen the white limy sandstones; the lower beds being concealed beneath débris accumulations. 


\section{SECTION VII. \\ ELKHEAD MOUNTAINS.}

BY S. F. EMMONS.

General Description.-To the west of the Park Range, on the borders of the broad Tertiary plains of the Green River Basin, lies a singularly picturesque and beautiful group of high volcanic peaks, known as the Elkhead Mountains. Their steep, rugged slopes are covered for the most part to their very summits with a dense growth of pine forests, while the valleys which are enclosed between them present a pleasing variety of open glades and groves of quaking-asp and pine. The highest peaks, which attain an elevation of over 10,000 feet above sea-level, are arranged somewhat in the form of a cross, of which one bar is formed by the north and south trachytic elevations of Whitehead Peak and Steves Ridge, and the other by the east and west ridge of basalt, of which Anita Peak and Mount Weltha are the culminating points. Out of the gently-sloping plains in the northwest angle of this cross rise a number of isolated peaks and dike-like ridges both of trachyte and basalt.

From the few outcrops of sedimentary rocks exposed along the bases of these peaks, and in some cases high up on their slopes, it is evident that the eruptive rocks broke through and covered a pre-existing line of elevation of Cretaceous, and possibly also Tertiary beds, whose summits, and a portion of whose slopes, have thus been preserved from erosion by their envelope of more resisting volcanic rock.

From a mineralogical point of view, the eruptive rocks of this region form a remarkably interesting and peculiar group, being characteristically different from any of the widespread groups of volcanic rocks, which cover so large an area in the western portion of the region embraced within our explorations. They consist mainly of quartziferous trachytes and nephelinebasalts.

The trachytes, which belong essentially to the class of sanidin. 
trachytes, containing generally large, well-defined crystals of this feldspar in a rough, porous, and mostly crystalline groundmass, are characterized by the presence of a large amount of free quartz. They have, nevertheless, a physical habit which is not rhyolitic, but decidedly trachytic. The quartz occurs in rounded grains, which have a dull, greasy lustre, and are cracked and riven, like a glass which has cooled suddenly. While this quartz is evidently an unessential and accessory constituent, like tridymite in other trachytes, occurring only in grains large enough to be distinguished by the naked eye, and not, therefore, forming part of the groundmass or influencing the general aspect of the rock, the fact that it frequently contains glass-inclusions proves that it is a primary product, and not the result of later secretion. These trachytes, besides the normal constituents, sanidin, hornblende, and mica, contain also a relatively large proportion of augite, and in some cases considerable amounts of olivine, generally, however, where the rock has a decidedly basic character.

The basalts of the region are no less remarkable than the trachytes, being the only representatives of the group of nepheline-basalt found within the limits of our exploration.

The trachyte outflow forms, as we have seen, a north and south ridge, nearly parallel with the line of outcrop of the Archxan rocks of the Park Range, which, at the northern end of the ridge, it comes in contact with and partially covers. 'The dense forest, which covers it almost continuously, renders its exploration somewhat difficult. Its forms are generally rounded and dome-shaped ridges, with sharp conical peaks, in striking contrast with the prevailing flat-topped peaks and ridges of the basaltic outflow.

North of the east and west line of elevation, the trachyte-flows have been more deeply eroded, leaving sharp, jagged peaks, of which the most prominent is Hantz Peak, a comparatively regular cone, 10,906 feet in height, while a number of similar shaped peaks of less height form the projecting summits of Steves Ridge. In the angle of the two ridges, a line of sharp ridges and narrow dikes extend out in a northwest direction, partly covered by the more recent basalt flows, of which Crescent Peak and the Skelligs Ridge present the most striking topographical features. To the southward, the trachyte ridge has generally broad, gentle slopes. Its crest 
rises from the Yampa River northward, finding its culminating point in Whitehead Peak, a dome-shaped mountain-mass, abruptly escarped on its eastern side, whose summit has an elevation of 10,817 feet above sea-level.

Trachytic Region.-The trachyte of Whitehead Peak is one of the most interesting and curious of the remarkable group of trachytes of this region. It is a grayish-drab rock, having a tendency to split into thin laminæ, from half an inch to an inch in thickness. It is formed of crystals of sanidin, hornblende, and augite, with large rounded masses of cracked quartz, in a purplish-gray, fine-grained groundmass of a rough porous texture. Besides the hornblende and augite, it contains a few sparse grains of bronze-colored mica, while some portions of the rock are filled with reddish-brown spots, which the microscope shows to be half-serpentized olivine, "a mineral which," Professor Zirkel remarks " has never before been observed in a sanidin rock". He suggests, with regard to the occurrence of this mineral in connection with free quartz, that it almost seems as if the unusual secretion of free silica had been counterbalanced and neutralized by the introduction of so basic a mineral as olivine. Large sanidin crystals are frequently found in this rock measuring an inch or more in diameter, and showing a tendency to zonal decomposition. At Whitehead Peak, there is also an extremely local occurrence of granite-porphyry, which is too small to be indicated on the map. It contains both orthoclase and plagioclase-feldspars, with black mica and a large amount of black hornblende prisms, in a grayish felsitic groundmass. On the bold eastern escarpments of Whitehead Peak, the trachyte is seen to be underlaid by a very considerable thickness of white fine-grained sand-rock, often quite thinly bedded and shaly, with somewhat of the appearance of a volcanic ash. Under the microscope, however, the rock is seen to be made up of rounded grains, largely of quartz, with some colored jasper, and black grains, which may be magnetite. No angular crystals can be detected in the rock, and it may possibly be a remnant of some later Tertiary formation, which covered this region before the trachyte overflow.

To the south of Whitehead Peak, the trachyte-flow forms a high ridge, dividing Elk River from Elkhead Creek, on the spurs of which it spreads out, covering the underlying Cretaceous beds, nearly to the banks of the 
Yampa River. From the Sugar Loaf, an isolated flat-topped hill near the forks of the Yampa River, was obtained a gray sanidin-trachyte, which contained none of the grains of quartz, which are so unfailing an accompaniment of most of the other trachytes of this region. It has a more massive habit than the trachyte of Whitehead Peak, but contains like it large crystals of sanidin, imbedded in a gray porous groundmass. $\Lambda$ ssociated with the sanidin are numerous hornblendes and black biotites, while the groundmass is made up of micro-crystalline feldspar, and hornblende.

To the north of Whitehead Peak, an outlying western spur of Steves Ridge, which forms a secondary parallel elevation between the main ridge and Steves Fork of the Little Snake River, is formed of a still more charto the famicteriferous trachyte. This rock bears a remarkable resemblance well-defined crystals of the Drachenfels on the Rhine, containing large, in a rough, gray groundmass, hornblendes. Like the trachyte of whith crystals of mica and a few face of this rock is full of rounded of Whitehead Peak, the weathered surglassy quartz, in which it abounds, have, from which the grains of cracked, rock present a white color, with a porous, anten out. Some varieties of the the harder sanidin crystals can easily be separated texture, from which tals possess remarkably distinct, well-defined crystalline faces, having a dull, smooth, compact surface, and resembling the orthoclases of some of the porphyritic granites or felsitic porphyries. Under the microscope, no some titanite and apatite quartz could be detected. It discloses, however, well-defined glass-inclusions, and the in the dark quartz grains are seen particles. A thin section of the groundmass is made up of feldspathic made up of smaller crystals of of the larger sanidins shows that it is and also contains some hexagonal and with a few striated plagioclases, neither glass- nor fluid-inclusions. From the eastern spurs of

Snake River, was obtained a of Steves Ridge, toward the head of Little summit of Whitehead Peak, in which olivinest identical with that from the summit of Whitehead Peak, in which olivine is present, with a considerable 
development of bronze-colored mica. The large quartz grains and crystals of feldspar are somewhat less frequent than in the Whitehead rock.

Crescent Peak is a high, sharp ridge, having a somewhat curved outline, which is isolated from the main mass of the trachyte hills by the valleys of Slater's and Steves Forks. It is composed, however, of a trachyte, which is in every way analogous to the main body of Whitehead Peak and Steves Ridge. The rock of the peak itself has the same sherdy habit as that of Whitehead Peak. It consists of a light-gray groundmass, in which, to the naked eye, only crystals of sanidin, with occasional hornblendes and micas, and the peculiar rounded grains of cracked quartz, are visible. The microscope detects a few yellowish-brown augites, and around the quartz grains a peculiar greenish ring, made up of an interwoven mass of microlites. The quartz contains glass-inclusions, and the groundmass is made up of feldspar-microlites, with small prisms of augite and hornblende, and biotite plates in a brown, globulitic, amorphous base. To the north of Crescent Peak is a curious dike, called Skelligs Ridge. It is a wall of semicolumnar trachyte, in which the eolumns are arranged horizontally, from 20 to 50 feet in width, rising vertically out of the soft grassy slopes to a height of from 50 to 100 feet, and extending in a northwest direction for several miles. Its walls, especially on the southwest side, are almost perfectly perpendicular. The surface of this rock presents a peculiarly rough appearance, from the holes or cavities left by the weathering-out of the quartz grains. It resembles mineralogically the rock of Crescent Peak, but is more massive in habit, and is remarkable for the fine definition of its crystalline constituents, particularly the hornblende and mica. In this, as in all the other quartziferous trachytes, no more quartz can be detected by the microscope than by the naked eye.

On the low saddle and ridge, which extends to the northeast from the base of Crescent Peak, is found a rock of rather a different habit. It has, in general, a rather homogeneous groundmass, in which no crystalline ingredients are visible, but which contains still these same curious grains of cracked quartz. This rock has often a shaly texture, and weathers with an earthy-brown surface, so that, at first glance, it might be mistaken for a sedimentary rock. The quartz grains are frequently colored brown, appar- 
ently by a coating of ferruginous material, resulting from the decomposition of the surrounding rock-mass. To the naked eye, the groundmass has almost the appearance of a fine-grained sandstone, but is seen to be filled with minute dark crystals and flakes of mica. The microscope detects crystals of glassy sanidin, but neither hornblende nor olivine. Beneath the trachytic rocks, at the head of Steves Fork, was found a small outcrop of sedimentary rock, a compact, black, indurated clay, containing fossil impressions. The fossils could not be identified specifically, but were thought, when combined with the lithological character of the rock, to indicate the horizon of the Colorado Cretaceous, and the beds have been, therefore, colored as such on the map. The microscope detects in this rock some grains of quartz and fragments of long, slender, transparent crystals, together with a few opaque grains of magnetite.

Camel Peak, near the bend of the Little Snake River, is a remarkably sharp, wedge-shaped ridge, rising abruptly about 2,500 feet above the valley. It is composed of a light-gray, compact rock, somewhat resembling a basalt, but containing the same cracked grains of quartz which abound in the trachytes. These quartz grains often occur as little spheres, from the size of a pinhead upward, which stand out upon the fractured surfaces, covered with a greenish-white coating of decomposed material, and looking like amygdaloidal inclusions in a basalt. In the bluish-gray, homogeneouslooking groundmass, besides the quartz grains, only a few flakes of black mica and occasional hornblendes or augites are visible. The microscope detects the presence of small sanidins and much magnetite, with a prevalence of augite over hornblende. This rock, therefore, forms, as it were, an intermediate step between the basalts and the trachytes, but from its association it has been classed with the latter group. From the broad benchlike spur of Steves Ridge, to the east of Camel Peak, were collected a number of different specimens, whose general habit resembles this rock, which have, therefore, been also included in the trachytes. One of the specimens collected from this ridge has been classed by Professor Zirkel as a basalt. It is a dark-blue, compact rock, containing the usual large grains of quartz, together with crystals of augite, and a few of, what are apparently olivines, in an almost homogeneous groundmass. A second specimen, 
from the same locality, a rock of somewhat similar appearance, shows, together with the great number of large glassy quartz grains, a few sanidin crystals and a large proportion of brown biotite plates scattered through the mass. Under the microscope, considerable augite is seen, but no hornblende or olivine. These spurs were so densely wooded that it was impossible to determine the relations of these different flows of volcanic rock, but the occurrence of a well-defined basalt on the northern spur of Hantz Peak would seem to indicate that this series of rocks marked a gradual transition from the more acid trachytic flows to this final basic outburst, along the contact-line of the volcanic flows with the Archæan body. The Hantz Peak basalt body occurs on a densely-wooded ridge, running out to the northeast from this peak, in which few rock-outcrops are visible. The rock itself is a dark-blue, compact mass, rich in olivine, in which a few scattered crystal of plagioclase-feldspar could be detected. In this basalt, the microscope detects the presence, besides olivine and plagioclase, of augite, biotite, and apatite, while that of nepheline, though not distinctly recognized, is confirmed by the general resemblance of this rock to the nepheline-basalts found to the west, particularly at Bastion Mountain.

Hantz Peak is the highest and most prominent point in this region. Its summit is a very sharp cone, whose slopes to the south and east are extremely abrupt, falling off at an angle of nearly $40^{\circ}$. On the north shoulder of Hantz Peak, about 300 feet below the summit, is a remnant of sedimentary beds, consisting of horizontally-stratified sandstones, which have been much metamorphosed, and, in some cases, completely vitrified. Within these sandstones is a development of a fine-grained conglomerate, made up of small pebbles of black and greenish chert and jasper, which is quite identical with the characteristic and persistent conglomerate, which we find throughout this region at the base of the Dakota Cretaceous. For this reason, and from the fact that to the east of Hantz Peak, in contact with the Archæan rocks, is a sinall development of Triassic sandstone, these quartzites or sandstones have been referred to the Dakota group of the Cretaceous.

The trachyte which forms the main mass of Hantz Peak is a mauvecolored rock, which separates easily into sherd-like laminæ. It shows 
occasional grairs of rounded quartz, with white, decomposed feldspars, and considerable arrounts of black mica and homblende, in a grayish felsitic groundmass, and mineralogically belongs rather to the basic group of trachytes of Camel Peak. Singularly enough, however, the very summit of the peak is made up of a white porous rock, which has all the characteristics of a rhyolite, consisting mainly of grains of free quartz and crystals of sanidin-feldspar in a white, porous, felsitic groundmass. In it the microscope detects no plagioclase, hornblende, or biotite. Some of the quartz crystals of this rock are seen to contain very perfect dihexahedral fluid-inclusions containing a moving bubble. Fluid-inclusions occur also in the feldspars. As this is the only occurrence of a rhyolite found in this region, and its external habit is not essentially different from that of the trachytes around it, it has been considered merely a local deviation, and not designated by a special color.

The prominence of this peak and its peculiar shape have rendered it a point of attraction for the summer thunder-storms, which collect in these hills from the open country to the west, and the loose rock, which forms its top, shows shallow trench-like gullies, radiating out from the cairn on the summit, made by the passage of the electric fluid. $\Lambda$ singular result of the action of lightning was observed in a tin can, which had been placed on the end of a pole at the very highest point of the peak by some of the early explorers. When found by us, this can, which had been thrown to the ground, was found to be perforated with twenty or thirty holes, some as much as a quarter of an inch in diameter, whose rounded edges showed that the iron had been completely melted by the heat generated by the passage of the electric fluid.

At the eastern base of Hantz Peak is an open mountain-valley, having a considerable extent of meadow-land, to the east of which, in contact with the Archæan rocks, was a small development of bright-red sandstones resting directly on the Archæan schists and gneisses, which have been referred to the Triassic, though it was impossible to detect any outcrops of the overlying Jurassic limestones.

The Little Snake River, which rises in the hills bordering these meadows, runs for a distance of about 15 miles in a northwesterly direction, 
its bed marking approximately the line of contact between the volcanic and Archæan rocks. Below the meadows, it runs for a short distance in a deep rocky cañon, which opens out into a broad valley largely covered with recent detrital material. To the east of this valley rise the densely-wooded spurs of the Park Range. Its western slopes are covered by the gentlyinclined trachyte flows of Steves Ridge. In the deeper cuts, made by streams flowing from this ridge, are disclosed a few indistinct outcrops of fine-grained, gray, calcareous sandstones, containing minute black grains like magnetite, which are evidently of Cretaceous age, but afford no clue to the horizon they occupy in that formation. Some remnants are also found of a light-gray trachytic tuff, enclosing fragments both of trackyte and of Archæan gneiss.

Toward the northern end of Steves Ridge, a red, striped hornblendic gneiss, which has already been described, is found cirectly underlying the benches of the more basic trachytes already mentioned. The same red gneiss, enclosed in beds of dark-green hornblendic gneiss, is found exposed at the north base of Camel Peak, just below the bend of the river. It here forms a little rocky knoll overhanging the south bank of the stream, and to the north passes under the horizontal beds of soft sandy and clayey material, forming the plateau country to the north. Its strike is here north $30^{\circ}$ west, with a dip of $45^{\circ}$ to the southwest. A continuation of this outlying portion of the Archæan body is found at the forks of Battle Creek, where the beds form the face of the included spur, having a nearly east and west strike, with a dip of $45^{\circ}$ to the south.

On the low dividing ridge between the head of Slater's and of Steves Fork, and in a narrow gap at the mouth of the latter stream, is found a trachyte of somewhat distinct mineralogical character from those previously described, which, from its position, as well as from the external habit of the rock, would seem to represent an older eruption, or at least one which cooled at a greater depth below the surface. $\Lambda t$ the mouth of Slater's Fork, it forms a narrow ledge, only exposed by the deeper cuts of the stream-bed, and is capped by friable white sandstones, themselves in turn covered by flows of basalt. It is a reddish or greenish-gray, compact rock, having at times almost the texture of an older diorite or porphyry, which, in a cryptocrystalline felsitic groundmass, shows an unusual development of brown 
mica. In this respect, as in its general appearance, it resembles sonie of the lavas of the Leucite Hills in the Green River Basin. Besides the mica, no crystals can be distinctly recognized by the unaided eye; but the microscope discloses the presence, in the groundmass, of crystals of sanidin, with a few plagioclases, frequent augites, and a few olivines, but neither quartz nor hornblende. The characteristic mineral, however, is one which shows colorless rectangular sections, with fibrous borders, which resembles nepheline, though it wants its usually sharply-defined hexagons. As the rock, when powdered and treated with hydrochloric acid, gives a precipitate of gelatinous silica, there can be little doubt of the presence of nepheline, more especially as the basalts of the surrounding hills are all nephelinebasalts. A specimen of the rock from the head of Slater's Fork was subjected to chemical anal by Mr. R. W. Woodward "It has a high specific gravity, 2.7, and contains the following ingredients:

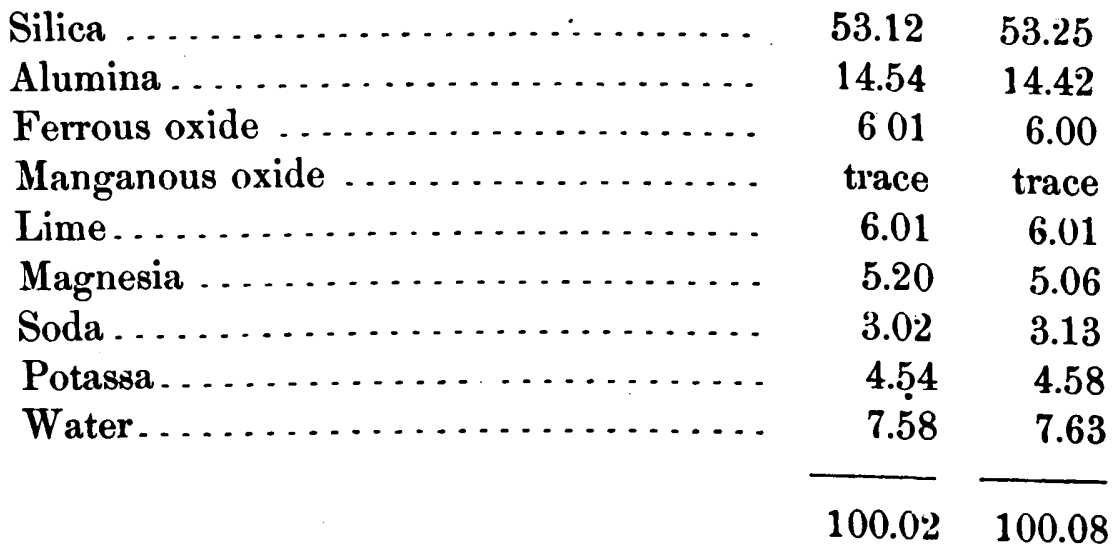

BASALTic Hills.-The basalts of the Elkhead Mountains belong, with few exceptions, to the group of nepheline-basalts, containing little or no feldspar, but in general considerable olivine, with augite and magnetite. They form the main east and west ridge west of Whitehead Peak, and numerous isolated, picturesque hills north of this ridge. The valley of Slater's Fork, which has been eroded out of the basaltic hills, discloses the sandstones, which underlie the flows, in a few isolated outcrops, but the forests are too thick to allow the tracing of the line of contact between these and the basalts with any great degree of accuracy.

In one exposure on the north face of Anita Peak, however, the white 
friable sandstones were seen in contact with a basaltic breccia, or ash, which rested on it with an unconformity of erosion, rather than of angle of deposition. Although these sandstones, where seen, show little to distinguish them, the occurrence of fragments of coal in the wash of the stream renders it probable that they belong to the same horizon as the beds observed along the banks of the Little Snake River.

Near the head of Slater's Fork, a dike of columnar basalt connects the main ridge with the sharp narrow peaks between this valley and that of the Little Snake River. Their flows cover the greater part of the surface of the country, and only in the deeper-cut valleys are the remains of the underlying sandstones exposed. These basalts are compact, rather crystalline rocks, of dark-gray color and even texture, in which can be distinguished, by the unaided cye, a great deal of olivine and augite; only by the aid of the microscope can the magnetite, nepheline, or plagioclase-feldspar be detected. Of these peaks, that east of Slater's Fork shows also a remarkably fine columnar structure, while, in a low flat-topped hill, opposite the mouth of Battle Creek, something of the shape of an ancient crater is suggested. Out of the flat mesas to the north of the Little Snake River rise two basaltic peaks. Of these, Watch Hill is a wedge-shaped mass, of no great height, standing close to the river, and in near connection with the flows on the south of it. Its rock is a dark-gray dolerite, containing plagioclasefeldspar, augite, olivine, and magnetite, as seen under the microscope, with a great deal of dark globulitic substance between the crystals.

Bastion Mountain is a flat-topped peak, whose horizontal outline, owing to a deeply-cut valley on the northeast side, has the shape of a $U$. Its summit is for the most part covered with forest, and its sides in the upper portion present precipitous walls, which in many places are inaccessible. The basalt of which it is composed is a light-gray porous rock, the cavities having, in the hand-specimen, a parallel arrangement, which give the effect of a wavy, rudely schistose structure to the rock. These cavities, which are very small, contain a fine yellowish incrustation of carbonate of lime. The augites in this rock are large and distinct, and olivine can be easily distinguished by the unaided eye. The microscope discloses as well biotite, magnetite, nepheline, and a comparatively large amount of plagioclase, and $12 \mathrm{D}$ G 
also yellowish undichroitic needles, which Professor Zirkel thinks may be gœethite.

Along the western flanks, the basalt has a coarsely vesicular structure, the round cavities being filled with white opaque carbonate of lime, having something of a concretionary structure. On the surface of the mesa, to the west of the mountain, is a greenish-gray tufa, looking like a palagonitetufa, enclosing angular fragments of this vesicular basalt. It is a granular mass, made up, as shown by microscopical examination, of fragments of yellowish glass, augite crystals, magnetite grains, rounded quartz with fluidinclusions, and the black needles characteristic of crystalline slates, together with decomposed orthoclase, in a calcareous matrix. It would seem, therefore, to be composed of the débris, partly of the basalts and partly of the neighboring Ärchæan rocks, which, however, have not been observed at the surface within 8 miles of this occurrence.

Along the benches above the south bank of the Little Snake River, below the mouth of Slater's Fork, are other little basalt knolls, which probably belong to the outflow of Navesick Peak. This is the only important basaltic peak which has a conical shape, and, although its altitude is considerably less than that of the adjoining mountain-mass of Mount Weltha, it forms a more prominent landmark when seen from the Tertiary plains of the Green River Basin. High up on its northern face are remnants of beds of fine white sands, whose débris fill the ravines leading northward.

The basalt of Navesink Peak is a dark-gray, finely crystalline rock, having the texture of an anamesite. Black augites and yellow olivines are the only crystals that can be detected macroscopically, but the microscope shows also magnetite, biotite, nepheline, and a little triclinic feldspar, while the augites and olivines abound in glass-inclusions.

An analysis of this nepheline-basalt was made by Mr. R. W. Woodward, with the following result:

Silica $\ldots \ldots \ldots \ldots \ldots \ldots \ldots \ldots \ldots . . .48 .60$

Alumina.................... 15.78

Ferrous oxide $\ldots \ldots \ldots \ldots \ldots \ldots \ldots \ldots . . \ldots 10.1$

Lime ........................... 8.34
48.46

10.31

8.33 
ELKHEAD MOUNTAINS.

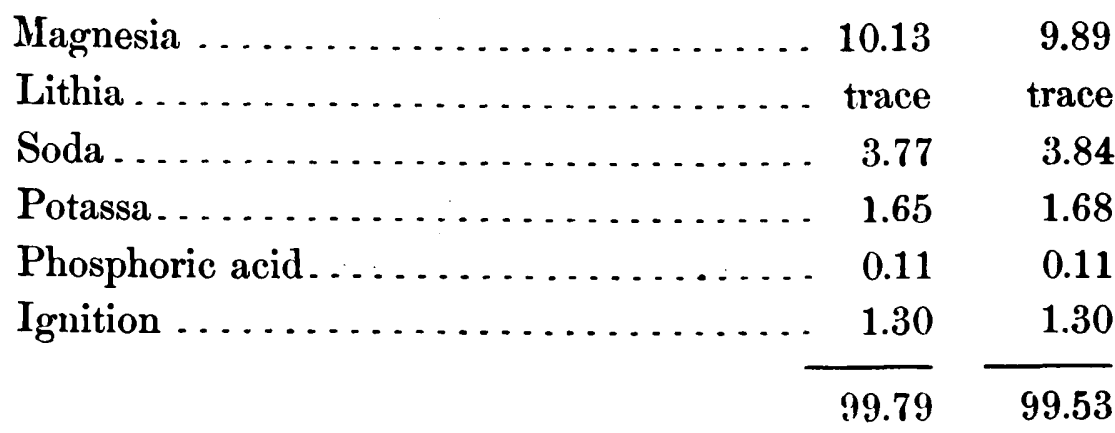

Anita Peak has at its summit a curiously-castellated knob, rising several hundred feet above the level of the main ridge, made up of very distinctly columnar basalt. The columns are very irregularly arranged, being sometimes horizontal, sometimes perpendicular, but in general having a somewhat radial arrangement. The rock of the peak has a strong influence upon the magnetic needle, which, at the summit, points east instead of north. The basalt, of which the peak is composed, is an almost black, rather compact rock, very rich in olivine, which occurs in very large, well-defined crystals, and, where decomposed near the surface, imparts a rusty color to the mass. Under the microscope, it is seen to have an amorphous glassy base, and to belong to the feldspar-basalts. It contains well-striated plagioclases, dạrk-brown augites, and magnetite grains.

The broad, flat-topped mass of Mount Weltha, though higher than any of these volcanic peaks, does not give the impression of so great altitude to the observer on account of its long, gentle slopes, and the absence of a sharp summit-peak. . The basalt presents much the same general character, but on its western foot-hills is more porous, of a somewhat lighter color, and has the texture of a dolerite. This rock is remarkably rich in olivine, and, under the microscope, is seen to contain magnetite, augite, and nepheline, with well-defined crystals of sanidin, sometimes in Carlsbad twins The nepheline is not crystallized, but forms a sort of base, as is generally the case with these nepheline-basalts. The presence of sanidin in this connection is very remarkable, especially as the rock contains no plagioclase at all.

From the extreme western foot-hills of Mount Weltha, there extends out into the red Tertiary plains, in a direction a little north of west, a curious wall, so straight und regular that it would seem to be built of masonry. It is 
from 3 to 4 miles in length, perfectly straight, and almost continuous, varying in height from 30 to 60 feet. It is 6 feet in width throughout, either side being perpendicular, while its summit presents shapes of square towers and bastions, whence its name, "The Rampart". It is made up of a columnar basalt, whose columns are arranged horizontally and at right angles to the length of the dike. This basalt is as remarkable as the dike itself, being a light-gray crystalline, rather porous, rock, full of fine crystals of black mica and having something the appearance of a trachyte. Under the microscope, it shows neither triclinic feldspar, hornblende, nor olivine, but a great quantity of yellowish-green augite crystals, and a colorless, unstriated ingredient which the chemical tests show must be nepheline, together with considerable apatite. Part of the colorless material is left untouched by acids after long digestion, and must therefore be sanidin-feldspar. 


\section{SECTION VIII.}

\section{VALLEYS OF THE UPPER YAMPA AND LITTLE SNAKE RIVERS.}

nY's. F. EMMONs.

The region of the southivest corner of this map, which is drained by the Yampa River and its numerous tributary streams, is in general a rolling country, of soft, rounded outlines, well covered with soil and grass, and, along the ridges, with a considerable growth of aspen, and a few pines. Along the waters of most of the streams are wide alluvial bottoms, which, on the Yampa River itself, afford considerable stretches of arable land, sometimes nearly a mile in width, and which support a growth of fine, large cottonwood trees. This region is occupied by the soft and easily-decomposed beds of the Cretaceous sandstones and clays, which, from the nature of their composition, as well as that of the country itself, present comparatively few outcrops. The general outlines of their structure can, however, be traced by the forms of the ridges, which follow closely the lines of geological uplift.

Near the flanks of the Park Range, however, where lower beds of the Cretaceous come to the surface, the outcrops are largely concealed by overflows of volcanic rock, and larger accumulations of detrital material, due to their proximity to high mountain-masses, and afford only vague suggestions as to the structure of the sedimentary formations. At the head of Elk River are broad openings in the forest, affording quite an expanse of meadow-land, which is occupied by a considerable thickness of detrital gravel, composed largely of débris of the soft sedimentary rocks, which have been exposed by the eroding-off of the volcanic flows, and toward the mountains by débris of the Archæan rocks. 'The fine gravels proceeding from the Archæan range, at the head of the eastern fork of Elk River, have been washed with considerable success for gold.

In the deep ravine at the head of the west fork of Elk River are found scveral outcrops of sedimentary rocks. At its mouth, where the stream 
emerges into the meadows south of Hantz Peak, a white quartzite having a northwest strike, with a dip to the eastward of $35^{\circ}$ to $40^{\circ}$, has been considered a continuation of that found on the north shoulder of Hantz Peak, and hence to represent the Dakota Cretaceous. Higher up the stream are some reddish sandstones, and, at the very head of the stream, on the divide between these waters and those of the Little Snake River, is found a body of about 100 feet in thickness of blue clay-shales, which resemble those of the Colorado Cretaceous. In the meadows below, in the cuttings made by streams in the Quaternary deposits, are occasional outcrops of sandstones and shales, too inconsiderable, however, to be indicated. On Milky Fork, so named on account of the amount of fine white sands suspended in its waters, which come from the sandstones on Whitehead Peak, is shown a reddish sandstone, which probably corresponds to that seen in the cañon above mentioned. These sandstones, however, do not resemble those of the Triassic. In the stream-cuts, at the forks of Elk River, are found a considerable body of clay-shales and some blue limy shales containing Ostrea and Inoceramus. These stand almost perpendicularly, with a strike about north and south, to the east of which is a conformable bed of metamorphosed white sandstone. The exposures are, however, altogether too inconsiderable to afford any definite outlines of structure, though the beds have evidently been compressed into sharp folds against the Archæan mass, which is exposed on the other side of the stream. Following down Elk River, for some 10 miles below the forks, the Archæan beds rise steeply on the east side, showing occasional outcrops on the west side of the river, while in the low, gently-sloping gravel benches of the western slopes are found frequent exposures of the blue and drab shales of the Colorado Cretaceous, generally dipping at a gentle angle to the westward, and, in some cases, overlaid by a grayish-white, fine-grained sandstone.

In the low saddle to the northeast of the Sugar Loaf was found an exposure of a dark, compact, rather siliceous limestone, evidently forming the crest of a gentle anticlinal fold. The round hill to the westward, enclosed within the bend of the river, is composed of yellowish and white, coarse sandstones, dipping $10^{\circ}$ to $15^{\circ}$ to the eastward, overlying the limestone formation, while at the base of the Sugar Loaf were found the same blue 
shales alceady seen, standing at a steep angle; they were also found near the river, dipping gently to the westward. Although no fossils were obtained which were sufficiently well preserved for specific determination, little doubt was felt that these limestones belong to the Jurassic formation, and that the sandstones and shales overlying them represent respectively the Dakota and Colorado groups of the Cretaceous. The shales form a region of soft, rolling hills, included between Elk River and Moore's Fork, where they are generally inclined at low angles, while along the flanks of the Archæan rocks are occasional outcrops of steeplydipping sondstones, which have been referred to the Dakota Cretaceous.

At the bend of Moore's Fork, the stream cuts through a ridge of white and buff, coarse sandstones, which are reddened by local metamorphism and oxidation of their ferruginous material. At this gap is a very interesting group of springs, whose waters are charged with carbonic-acid gas and sulphur. Unfortunately, we have no analysis of these waters, as the bottle, in which some was carefully collected at the spring, was broken in transit to the East. The presence of sulphur is, however, evident from the color of the water and its peculiar odor, as well as from slight deposits of sulphur around the edges of the springs, while the effervescence of the carbonic acid is not to be mistaken. - In the gravels on the eastern bank of the river is one large pool, about 20 feet in diameter, of clear, bluish water, out of the centre of which rises a little bubbling jet, several feet above the surface, which would lead one to suppose at first glance that it was a boiling spring. Several springs are found in the rocks to the west of the gap, sometimes only a few inches in diameter, out of which the water issues in a foaming jet, and in one instance having worn out a cave, of considerable size, in the soft sandstone. The water is cold, and not unpleasant to drink when freshly taken from the spring, though when warm the sulphur gives it a disagreeable flatness.

'To the south of the gap is a broad Quaternary valley, whose surface is covered with loose gravel and pebbles of the Archæan rocks. To the east of this valley, the spurs of the Park Range rise up steeply, composed of coarse gneisses and mica-schists, underlaid by granitoid rocks whose general strike is about north $15^{\circ}$ east, with a dip of $50^{\circ}$ to the westward. Just beyond 
the limits of the map, the river cuts a narrow cañon in a body of basalt which bas broken through the Archæan schists. The main mass is a dark, compact, fine-grained basalt, rich in brown crystals of olivine. It is apparently a feldspar-basalt, but so fine-grained that but few feldspar crystals can be distinguished, and no other individualized minerals. It contains frequent rounded cavities, which are lined with white crystalline carbonate of lime. Over the main body of the basalt is a flow of basaltic mud, or pumice, of a deep red color, carrying fragments of the solid lava in a vesicular, porous matrix, of which the vesicules are frequently filled by white carbonate of lime. Higher up the stream, beyond the limits of the map, are considerable flows of basalt; and a high table-land to the south, at the head of White River, which rises to a height of nearly 10,000 feet, is evidently capped by flows of basalt. The Archæan rocks are exposed in some of the hills in the middle of the valley, having apparently the same strike and dip with the main body, though much obscured by surface accumulations. The low, flat ridge to the west presents abrupt escarpments toward this valley, along the foot of which are occasional exposures of thin, red sandstones, overlaid by siliceons limestones, while the summit of the ridge is covered by the white and buff sandstones which are seen at the gap. These limestones and red sandstones evidently represent the Triassic and Jurassic at this point. Their thickness cannot be estimated, but would seem to be very much less than that observed to the north and west. On the low divide between the western branch of Moore's Fork and the valley next west, at the extreme southern limit of the map, are exposed the same siliceous limestones, here having a silky semi-crystalline texture, and containing imperfect casts of fossils; they dip at very high angles, and are succeeded to the westward by white sandstones somewhat metamorphosed, and the blue clays of the Colorado Cretaceous. The most easterly of these limestone exposures has a westerly. dip, while farther west the next observed dip was eastward, and there would seem to be here either a sharp synclinal, or, what is more probable, an inverted dip in the beds. The exposures are not sufficiently continuous to afford a satisfactory section. The strike of the beds is approximately north at this point, but bends to the eastward in the ridge farther north, where the dip also shallows out. In the broad, narrow valley to the west of this ridge, 
the few exposures that were seen indicate a synclinal fold open toward the south; the blue clays of the Colorado group, which are exposed near the divide, being overlaid by heavy beds of white, fine-grained sandstones, which dip to the westward, and closing around the northern point of the synclinal are upturned at Bear Ridge with a steep easterly dip of $45^{\circ}$ to $50^{\circ}$ east.

Bear Ridge represents an anticlinal fold, belonging to the system of secondary folds approximately parallel to the trend of the main crest of the mountains, which, like most of these folds, has a steeper side toward the mountains, and a more gentle slope away from them. In this instance, the eastern member of the fold dips $45^{\circ}$ to $50^{\circ}$ eastward, while the western beds slope at an angle of $15^{\circ}$ to $20^{\circ}$ westward. The axis of the anticlinal fold sinks toward the south and rises to the north, exposing the lower beds at the southern point of the Whitehead Ridge, where the anticlinal structure still continues, with a synclinal fold to the east between it and the exposures of the Colorado clays, at the junction of Elk River and Moore's Fork. The exposures of the Fox Hill Cretaceous as seen in Bear Ridge show a series of massive, white, fine-grained sandstones of several thousand feet in thickness. The upper beds are more thinly bedded, and show some interstratified clay seams, but the beds are characteristically different from the sandstones of the Laramie group. In the open country to the west, where these sandstones underlie the long slopes at a gentle angle, were found a few fragments of Baculites, which are quite characteristic of this group. At the southern end of Bear Ridge, the sandstones slope off more gently, bending in strike gradually round to the westward, and forming an east and west ridge, parallel to the main elevation of the White River divide, south of the limits of our map, in which the beds have a gentle northern dip.

The Yampa, therefore, runs approximately in the axis of a broad east and west synclinal fold, in which, however, may be seen the influence of gentle folds, whose axis runs north and south. The upper beds in this synclinal valley, which consist of yellowish and buff sandstones, sometimes stained red with oxide of iron, and containing considerable development of clayey beds, have been referred to the horizon of the Laramie group, although no 
coal seams characteristic of that horizon in this region were found. To the north of the river, these beds rise, approximately with the slope of the valley, toward the Elkhead Mountains, while in descending the river below the ford a series of gentle folds is crossed, whose axis is approximately north and south, forming slight undulations in the almost horizontal beds. The only fossils obtained from these upper beds were a few uncharacteristic species of Ostrea.

On the south bank of the river, between the ford and the mouth of Fortification Creek, is exposed a small body of nepheline-basalt, which resembles mineralogically the basalts of the Elkhead Mountains. In its physical habit, however, it is a more compact, close-grained rock, not at all vesicular, showing yellowish-brown crystals of olivine and black augites in a dark-gray, homogeneous groundmass. The summit of the ridge, between this point and the valley of Williams Fork, is covered with fragments and rounded pebbles of basalt, showing the probable existence of considerable basalt flows in the high ridge to the south, beyond the limits of the map, which divides the Yampa from the White River.

Fortification Peak is a little remnant of a basalt-flow from the Elkhead Mountains, which has protected its base of white sandstone from erosion, and stands out boldly above the low rolling country in a castellated hill, which rises some 400 to 600 feet above the general level. The beds of basalt which form its summit are only from 50 to 100 feet in thickness, and have preserved the general shape of the sandstone ridges which they covered, sliowing a remnant of a valley on the very summit of the peak. The basalt is a very porous and scoriaceous rock, and on its upper weathered surface is often colored a bright red, and has the ropy texture of a recent lava flow. In fresh fracture, it shows a dark, vesicular mass, in which, however, but few crystalline ingredients are visible to the naked eye. The vesicules have frequently a thin, blue, interior coating, and are sometimes filled with white carbonate of lime. Under the microscope, the rock is rather coarse-grained and rich in augitc; it contains also olivine, magnetite, and some triclinic fcldspar; a part of the colorless groundmass is proved to be nepheline. When treated with acid, the solution gives a precipitate of gelatinous silica, too voluminous to be due to olivine alone. Both olivines and augites contain 
glass-inclusions. Immediately under the basalt is a fine-grained grayish sandstone, which effervesces freely with acids, and is made up of rounded grains of colorless quartz, and of red and black jasper, with a calcareous cement. Some of the black particles look like grains of magnetic iron.

To the north and west of Fortification Peak extends a low, rolling country, covered with soft, earthy material of a prevailing red color, in which no outcrops are visible. The character of the soil; however, shows that it is probably made up of decomposed beds of the Vermillion Creek Eocene. These beds are found exposed on the western face of the Elkhead Mountains, at the bay-like indentation between Mount Weltha and Navesink Peak, where they consist of coarse, red sandstones, with intercalated beds of reddish and cream-colored clays and arenaceous marls. The limits of these beds are not well defined, on account of the character of the surface in this region, but their connection can be traced, over the broad plains to the west, which will be found represented on Map II, to characteristic outcrops, in such a manner that there can be little doubt as to the horizon to which they belong. Though they present here little difference of angle with the underlying Cretaceous beds, they are probably unconformable, as they are seen to be to the westward, and the lowest beds of the series cannot therefore be definitely determined. On the Little Snake River, at the western limit of the map, they are represented by yellow, coarse, gritty sandstones containing casts of Melania.

The country west of the Grand Encampment Mountains, just to the north of the Little Snake River, is a broad, high plain formed of horizontal beds of

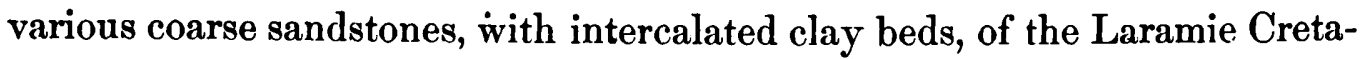
ceous, lying nearly horizontal, with a gentle slope to the westward, approximately the same as that of the general surface of the country. These plateaulike benches are covered with detrital material, and show comparatively few outcrops. The nature of the underlying beds can only be arrived at by occasional exposures along the bluffs of the cañon-like stream-beds which traverse it. The best exposures were obtained along the banks of the Little Snake River. The uppermost beds observed were coarse, white sandstones, forming a bluff on the south side of the river, near the point where the road from the Yampa crosses the Little Snake. At this point is an exposure of 
coarse, gritty, white sandstones, about 200 feet in thickness, containing some thin, dark-colored beds, hardened by the oxide of iron, and full of impressions of leaves of the elm and alder. These beds dip at an angle of $10^{\circ}$ to the south and west, and disappear under the overlying red Tertiaries. Along the north banks of the river, in ascending, a band of heavy, white and yellow sandstones, from 200 to 300 feet thick, is exposed, rising at an angle of $5^{\circ}$ to $10^{\circ}$, and which abound in impressions of deciduous lenves. Below them is a series of shaly beds carrying coal, which are best seen in section opposite the mouth of Slater's Fork. Here a thickness of about 100 feet is cxposed in a bluff marle up of thin beds of shales, more or less arenaceous, interstratified with gray sandstones from 2 to 6 feet thick, and carrying three to four beds of coal, of thicknesses varying from 1 to 3 feet. In these beds were found abundant impressions of leaves, and, in some of the clay seams, poorly-preserved fossil remains, whose aspect, as well as that of the lithological character of the beds, has a very close resemblance to the clayey beds observed in the railroad-cut near Bear River City, Utah, which contain fresh and brackish-water species of mixed Focene and Cretaceous aspect. These beds dip about $10^{\circ}$ to the west. Below them, a little higher up the stream, is a bed of heavy, white sandstone, which forms a pretty continuous outcrop nearly up to the mouth of Battle Creek. In Battle Creek, a sect:on of similar beds is exposed, showing sandstone with interbedded clays and some bituminous seams, but no coal. Higher up on the Little Snake River, the only rocks that can be recognized are uncharacteristic white sandstones, still dipping at a very gentle angle. Occasional exposures of sandstone are also seen along the valley of Slater's Fork, while at the eastern base of Crescent Peak, as we have seen, are found dark, clayey beds, upturned at a steeper angle, which have been referred to the Colorado group. The line of Crescent and Camel Peaks seems therefore to mark the first considerable folding of the underlying Cretaceous beds, while to the north and west they occupy a comparatively undisturbed position.

Muddy Mountain, which is a broad, flat-topped hill, rising 600 or 860 feet above the general level of the bench country, is made up of white and yellowish blocky sandstones, dipping $5^{\circ}$ to $8^{\circ}$ to the south and west, which belong to the upper beds of the Laramie Cretaceous. Its very summit is 
covered by the remains of a coarse conglomerate, formed of large, rounded pebbles of quartzite, lying perfectly horizontal, and unconformable to the underlying sandstones, which probably represents the Wyoming conglomerate. This formation, which is regarded of Pliocene age, is the latest deposit of the Tertiary waters in the Rocky Mountain region. It is a structureless conglomerate, made up of coarse pebbles of the more resisting rocks of the ranges near which it is found, generally loosely compacted by a gravelly or limy cement. The pebbles generally decrease in size with their distance from the mountains from whose rocks they are derived. Only rarely is any considerable thickness of this conglomerate found; but the larger pebbles resulting from its decomposition cover the higher flat-topped peaks and ridges wherever they have resisted the effects of erosion sufficiently to preserve the original surface of this latest Tertiary deposit. That it was in a measure a littoral or beach deposit is shown by the fact that it is more frequently found, and in greater development, in close proximity to the higher mountain-ranges; but there are evidences, particularly in the Green River Basin, which seem to show that it extended, though perhaps in a very thin sheet, to distances of 20 and 30 miles from the shore-line. 



\section{CHA P'TER II.}

\section{THE GREEN RIVER BASIN.}

BY S. F. EMMONS.

Section I.-PHYSICAL DESCRIPTION-Green River Basin-Uinta Ravge. SECTION II.-GENERAL GEOLOGY-THE UIN'TA UPLIFT-TERTIARY FORMATIONS. SECTION III.-DESCRIPTIVE GEOLOGY OF 'IHE BASIN REgION-WASH. akie Basin-Brown's Park aNd the YaMPa VALLEY-Vermillion aNd Red Creek Basins-Cretaceous uplift of Bitter Creek-Volcanic rocks-Bridger Basin-Cretaceous UPLIFT OF OYSTER RIDGE. Section IV.-DESCRIPTIVE GEOLOGY OF THE MOUNTAIN REgIONNorthern slopes of the Uinta RaNGe-Henry's Fork Basin-Red Creek archanan body-Owiyuku's Plateau-Vermillion Creek ValleyRegion east of the Uinta Range-Escalante Hills and Yampa PlaTEAU-SUMmit Region at Lodore Cañon and Westward-Ashlex Creek Basin-Southern flanks of the Uinta RaNge. Section V.-Tertiaries of tue UiNTa Valley.

\section{SECTION I.}

PHYSICAL DESCRIPTION.

Green RIver Basin.-The region represented on Map II comprises the southern portion of an enclosed area of Tertiary plains, called, from the river which drains it, the Green River Basin, together with its southern boundary, the great east and west range of the Uinta Mountains; it includes also, on its southeast corner, a portion of the Tertiary basin of the Uinta River, which forms the northern rim of the great Colorado River Plateau.

The Green River Basin proper is a rudely triangular area, embraced between the systems of elevation of the Rocky Mountains on the east and 
the Wahsatch Range on the west, and extending from the sources of the Green River, in the Wind River Mountains, on the north, to the base of the Uinta Range on the south. The northern portion of this basin, which extends nearly a hundred miles beyond the limits of our exploration, resembles so closely in physical features, as well as in geological structure, the Tertiary area represented on the map, that a description of the latter may answer to give a general idea of the whole basin.

From the western flanks of the Park Range to the outlying ridges of the Wahsatch, a distance of about 150 miles, extends a practically desert region, watered only by a few widely-separated streams and scattered springs of water often too impure to drink, whose surface is almost bare of vegetation, having neither the coarse grass that covers the plains east of the Rocky Mountains nor the abundant growth of desert shrubs which are characteristic of the valley plains of the Great Basin. 'The topography of the region is eminently suggestive of its geological structure, which is that of a comparatively undisturbed succession of Tertiary strata deposited on the bottom of an enclosed fresh-water sea. Its general appearance is that of a great plain, or succession of plains, which rise in low terrace-like steps from the centre of the basin toward its borders. In the western half, this effect is most striking, the flat-topped ridges rising with so gentle and regular a slope from the line of Black's Fork toward the base of the Uinta Mountains, that the peaks of this range seem like an island ridge rising out of a level plain, when in reality there is a difference of level of 2,000 to 3,000 feet between the middle of the basin and its border. On an east and west line, the slope of the basin is still more gentle, its present level rising only about 800 feet from the line of greatest meridional depression along Green Fiver to either shore. The topography of the eastern half of the basin is, to a limited degree, more varied than that of the western half, since, while in the latter, the horizon is always bounded by a perfectly horizontal line, among the prevailing mesa ridges of the former, are some of more irregular outline in the Cretaceous uplift of the region of Bitter Creek, which represents a system of elevation existing previous to the deposition of the sediment of the Tertiary seas.

The minor streams of the basin, which have cut broad, but compara- 
tively shallow bottoms through the soft, readily-disintegrated beds which cover the present surface, have followed in general the slope of the original basin, while Green River, into which they all flow, shows in the southern portion of the region an utter disregard of the present topography. This stream, whose name may have been suggested to the early explorers by the somewhat greenish tinge of its watars, or by the brilliant contrast, which the narrow fringe of grass and cottonwood trees along its banks makes with the glaring white and red colors of the desert plains, takes its rise in the Wind River Mountains, and flows in a southerly direction through the middle of the basin, at first in a wide, alluvial bottom, but south of the line of the railroad in a narrow cañon-like bed, cut a thousand feet or more through the horizontal Tertiary strata. Traversing the open valley of IIenry's Fork, it enters the Uinta Range at Flaming Gorge, following, in cañons cut thousands of feet into the hardest quartzite, an even more sinuous course than that which it had in the soft Tertiary plains.

'A striking illustration of the irregularity of this course is shown, immediately after its entrance into the mountains, when leaving the natural valley at the base of the line of cliffs, stretching westward from Flaming Gorge, it bends abruptly to the southwest, cutting a deep cañon throughi hard rock for a distance of over 2 miles, and, curving with a horseshoe bend, returns to the clayey valley at the base of the cliffs within a mile of the point where it left it. In the view in Plate I, looking southward from the edge of the cliffs near Flaming Gorge, these two sharp bends of the river are seen, and the low divide, scarcely 200 feet above its bed, which separates them.

At first its direction is at right angles to the trend of the range; then bending eastward, parallel to its geological axis, it emerges into the open Tertiary valley of Brown's Park, in which, however, it shows the same disregard of the present topography as before, occasionally leaving the soft beds of the valley to cut a gorge through some projecting spur of hard quartzite rock. $\Lambda$ fter pursuing an easterly course for a distance of about 40 miles, it bends again to the southward, leaving what would seem to be its most natural course through the low valleys, which extend around the eastern end of the Uinta Range, and cutting a narrow, winding gorge over 3,000 feet deep $13 \mathrm{D} \mathrm{G}$ 
transversely through the heart of the range, to emerge again into the open region south of the Colorado Plateau.

The sinuousness and irregularity of the course of Green River through the Uinta Range, and its independence of the present topographical features of the region, suggest that it must have been determined originally in rocks of an entirely different nature from those, through which it now lies; and a confirmation of this idea is found, as will be seen later, in the existence of undisturbed Tertiary beds at a level higher than the present walls of the different cañons of the river, and which must once have extended across, and in a great measure covered, that part of the mountains through which it flows.

Uinta Range.-The Uinta Range, which forms the southern boundary of the Green River Basin, is the only considerable mountain uplift within the limits of our exploration, and, indeed, with few exceptions in the whole Cordilleran system of the United States, which has an east and west trend. In its physical features, as well as in geological structure, it differs essentially from all of the mountain-ranges of the region examined by us, and in both respects is characterized by a grand simplicity and regularity of structure.

Its extreme length is about 150 miles, of which the western 25 extend beyond the limits of this map. Of this extent, the eastern third is somewhat irregular in form, but the main body of the range is a broad, straight ridge, whose crest, which has an average elevation of 10,000 to 11,000 feet, is a forest-covered region of rounded glacier-basins, studded by hundreds of shallow lakelets, and scored on either flank by deep, straight glacier-cañons. Out of the higher portion of this crest rises a series of narrow precipitous ridges and peaks, entirely bare of vegetation, whose principal summits attain elevations of over 13,000 feet.

The scenery of this elevated region is singularly wild and picturesque, both in form and coloring. In the higher portions of the range, where the forest-growth is extremely scanty, the effect is that of desolate grandeur; but in the lower basin-like valleys, which support a heavy growth of coniferous trees, the view of one of these mountain-lakes, with its deep-green water and fringe of meadow-land, set in the sombre frame of pine forests, the whole enclosed by high walls of reddish-purple rock, whose horizontal 
bedding gives almost the appearance of a pile of Cyclopean masonry, forms a picture of rare beauty. Seen from the Bridger Plains on the north, the apparent height of the range is dwarfed by the effect of the Tertiary beds, which extend up in gentle, even slopes on its flanks to a height of 10,000 feet; but from the south, where erosion has acted with greater effect, aided by the proportionately greater force of the sun, and the warm southwest wind from which the northern slopes are sheltered, the full grandeur of its rugged sides, rising over 7,000 feet from base to summit, is more apparent.

Owing to the precipitous and rugged nature of its peaks and cañons, the range is difficult to explore, there being only three trails by which it may be crossed with animals, and these up to midsummer are frequently rendered impassable by snow. The most prominent peaks of the range, seen from the north, are Tokewanna and Gilbert's Peaks, whose altitudes above sea-level, as determined by barometrical measurement, are respectively 13,458 and 13,687 feet; that of Emmons' Peak, the highest summit in the range. which is situated somewhat to the south of the main crest, is 13,694 feet. The topographical divide lies somewhat to the north of the middle of the range, so that the streams which flow to the southward have larger and more deeply-eroded cañons, but the intervening spurs descend very gradually, so that the southern face of the mountains, toward the Uinta Valley, presents a bold precipitous wall, cut through at intervals by deep narrow gorges, which form the gateways of the cañon-valleys of the streams. The growth of coniferous forests, which on the northern slopes only commences at about 9,000 feet, extends on the southern spurs below the base of the range into the upper portions of the Uinta Valley, to a level of less than 7,000 feet, while the upper limit of forest-growth in the range may be considered to be about 11,000 feet. The prevailing species among these forests are Pinus flexilis, P. ponderosa, Abies Menziesii, A. Engelmanni, A. Douglasii, A. grandis, A. amabilis, together with, on the lower levels, Juniperus Virginiana.

The eastern portion of the range beyond Marsh's Peak is much lower than the main crest, but preserves the same general character of a broad, elevated region of shallow, basin-shaped mountain-valleys whose flanks are 
scored by deep, narrow cañons. Plate II represents a view of this eastern summit region, looking westward across the cañon of Lodore from its eastern wall. What this portion of the range loses in height, it gains in breadth, since the Owi-yu-kuts and Yampa Plateaus may be considered properly to form part of the Uinta Range. The former, whose summits attain an equal elevation with those of the central ridge, viz., of over 9,000 feet, is separated from it by the deep valley of Brown's Park, whose walls are so steep, and present such close correspondence in outline, as almost to suggest that it was formed by the sinking of a portion of the crest.

Between the Escalante Hills, which is the name that has been used to designate the central ridge east of the Green River, and the Yampa Platean, lies a shallow, trough-like valley, through whose bottom the Yampa River has cut a narrow, winding cañon, which, though less deep, is proportionately narrower, and has more nearly vertical walls than the cañon of Lodore. Both of these two cañons, of which the one has a depth of 1,500 feet, the other of about 3,000 , are practically inaccessible from above, and can only be explored by boats, with which our parties were not provided. In Plate III, something of the respective character of these two cañons is seen. This view is taken from the northern wall of the Yampa Cañon at its junction with the Green River, looking across the western end of the Yampa Valley in a direction a little west of south. In the foregound, the Yampa River, is seen emerging from its narrow cañon into the little opening called, by Professor Powell, Echo Park. In the middle distance, it joins the Green River, which comes in from the right, and the two rivers flow due south for a short distance into the Yampa Valley, and then doubling on their course round a sharp knife-edge of rock, which cannot be distinguished, owing to the correspondence of stratification-lines, from the walls of the cliff in the background, flow westward to the north of this cliff, in the grander canon of the Green River, called Whirlpool Cañon, whose southern wall is seen in the upper right-hand corner of the view.

To the eastward, the Escalante Hills sink gradually, and end in the low valley of the Little Snake and Yampa Rivers. The course of the latter river in this valley shows the same peculiarity as that of the Green 
River in its cañons, since it cuts deep, narrow cañons through the hard rocks of the ridges of Yampa and Junction Peaks, instead of winding through the soft Tertiary strata, around their base, as with the present configuration of the surface it would have seemed most natural for it to do. Here also it is evident that its course was determined at a much higher level, when these peaks were buried beneath Tertiary beds, which have since been removed by erosion. 


\section{SECTION II.}

\section{GENERAL GEOLOGY.}

The Uinta UpLift.-The geological structure of the Uinta Range, like its physical structure, is in its main outlines remarkably simple and regular; its main mass was formed by the uplifting of an immense thickness of practically conformable strata, at the close of the Cretaceous period, in a broad anticlinal fold, having the form of a flat arch, or inverted U. The movement which produced this fold was accompanied by comparatively little fracturing and dislocation of the strata, and by no intrusion of eruptive rocks. By subsequent erosion, during Tertiary and recent times, there has been removed, from the crest of this fold, a thickness of not less than 20,000 feet of rock strata, whose upturned edges, in a great measure buried beneath the Tertiary beds which have been formed from their débris, encircle in parallel curves the present flanks of the range.

In the eastern part of the range, this simple structure was somewhat complicated by the presence of a preëxisting ridge of Archæan rocks, which, though probably covered by the conformable series which had been deposited unconformably around and over it, was more or less involved in the main Uinta uplift. Of these Archæan rocks, only a comparatively small. area is now exposed, and, of their structure, little can be learned except that it is extremely complicated. They consist, in general, of quartzites, white mica and hornblende-schists, with a local development of paragonite beds, and correspond most nearly to those classed as Huronian in the Rocky Mountains.

The conformable series of beds involved in the Uinta fold extend in geological horizon, as far as their age has been satisfactorily determined, from the Carboniferous up to the top of the Cretaceous. The Carbonifcrous formation, whose beds form the main mass of the range, is represented by the groups of the Weber Quartzite, Upper Coal-Measures, and PermoCarboniferous. The beds of the first of these form the crest throughout the greater part of its extent, lying nearly horizontal, or inclined at very low angles. They consist of a lower series of white and reddish, compact 
quartzites, a middle series of purple, coarse quartzites, and an upper of red and striped sandstones, in all of which no unconformity was observed; they are in general barren of all fossil remains, only two species of Spirifer obtained from quartzite débris having been found by us; but as they are quite conformable with the limestones of the Upper Coal-Measure group, which abound in well-defined fossil remains, they have been referred to the Weber Quartzite group.

Their thickness, as observed in different parts of the range, is from 10,000 to 12,000 feet, while, as their base is never reached, the actual thickness of the formation may be indefinitely greater. This fact might seem to throw some doubt upon the correctness of the assumption that they all belong to the Carboniferous formation, since the Weber Quartzite, in the Wahsatch Range, at a comparatively short distance to the west, attains a development of only 5,000 to 7,000 feet, and the general tendency of all the formations is to thin out to the eastward. Lithologically also the lower beds of this group resemble, perhaps, the Cambrian, rather than the Weber Quartzite of the Wahsatch, and it might be supposed that the upper portion of this group had been deposited over a shallow, rounding uplift of Cambrian rocks in such a manner as to show no appreciable unconformity of angle. ${ }^{1}$

The Upper Coal-Measure group is represented by a body of limestones and fine-grained sandstones of prevailing light-gray and drab colors, with some darker limestones at the base, in which the siliceous members seem proportionately more developed at the eastern end of the range. Their upper horizon is marked by a well-defined cherty limestone rich in fossils, above which a series of clays and calcareous shales, whose character is not well defined, though identified at one point by fossils, represents the PermoCarboniferous group. These beds are in general upturned at steep angles, forming flanking parallel ridges, and only in the lower portions of the range, east and west of the main elevation, are left in the comparatively horizontal position which they occupied in the arch of the fold.

\footnotetext{
${ }^{1}$ Since the above was written, there has been published, in the report of Prof. J. W. Powell, on the Geology of the Eastern Uinta Mountains (p. 144), sections made in the cañons of the Green River, showing an unconformity of deposition in these beds, which, if correct, would seem to prove the latter supposition to be the more correct.
} 
In its simplest form, the great Uinta fold may be likened to a flat arch, in which, by reason of too sharp a bend at either angle, the joints have been partly broken near the extremities, and the crest of the arch forced bodily upward, without dislocation in the centre. Actually the principal displacement has occurred on the line of the northern angle of the arch, that along the southern angle having been only local and of limited extent. The main geological axis of the range follows approximately the line of the northern face of the higher peaks. South of this line, the strata slope southward at a gentle angle, generally about $5^{c}$, but bend sharply downward at the southern extremities of the spurs, forming thus a second axis. Along the flanks of the range, where the denudation of the Tertiary covering has been of sufficient depth, are exposed the upturned edges of the younger portion of the conformable series, which once formed the crest of the arch, the Triassie, Jurassic, and Cretaceous formations.

The Triassic formation is represented by the Red Bed group in a thickness of about 2,500 feet, principally of sandstones. At its base is a series of clayey beds, over which are the characteristic red sandstones of the formation in a thickness of about 1,200 to 1,500 feet, about equally divided by a thin but persistent bed of limestone, the summit of the formation consisting of massive white and buff, cross-bedded sandstones, which gene:ally form prominent ridges. This formation is, as far as observed, barren of fossils, and its horizon has been determined by its stratigraphical position between well-defined fossiliferous strata.

The Jurassic formation, though thin, contains the only considerable development of limestone in the three groups. Its thickness, which varics somewhat in different portions of the range, averages about 600 to 800 feet, in which the maximum observed thickness of limestones, which are highly fossiliferous, was 200 to 300 feet, the remainder being made up of sandstones, shales, and clay beds, remarkable, where well exposed, for their bright, variegated colors.

The Cretaceous formation consists of over 10,000 feet of beds of sandstones and clays, carrying coal seams, which are most abundant in the upper part of the series. In the division of this formation into four groups, as carried into this region, the Dakota group consists of about 500 feet of rather 
thinly-bedded sandstones, with some clay beds, having at its base the persistent conglomerate carrying small pebbles of black chert. The Colorado group, of about 2,000 feet in thickness, is made up mostly of clays and yellow marls, with some sandstones at the base, which enclose one prominent coal seam; the outcrops of this group are generally occupied by valleys. The Fox Hill group consists of about 3,000 feet of heavily-bedded white sandstones, with a few coal seams and comparatively little clay. The Laramie group, whose actual thickness cannot be definitely estimated, since it is directly overlaid by an unconformable series of beds, consists also of gray and white sandstones, often iron-stained, containing a greater development of clay beds, and very rich in coal seams. In the fauna of this formation, brackish and, locally, even fresh-water forms, are found associated with marine types.

While throughout the greater portion of the range the folding, which has raised its crest, has been mainly produced by forces resulting from the contraction of the earth's crust acting on meridional lines, or at right angles to its longer axis, there has also been some, though considerably less, longitudinal compression, or contraction of the beds involved in the folding, in an east and west direction, producing minor, transverse corrugations, whose position and outline are indicated by the present curves and reëntering angles in the ridges, formed by the outcrops of these flanking formations.

In the eastern portion of the range, the longitudinal compression has been proportionately greater, and this, combined with the presence of an underlying ridge of unconformable Archæan beds, whose highest summit has been exposed by denudation around Red Creek, has produced a highlycomplicated structure. The crest of the main fold is much widened, and bent somewhat to the southward. Along its northern angle, lines of displacement were developed, whose movement has continued even into Tertiary times. There was probably also some fracturing in the crest of the fold, which determined the position of the great central valley of Brown's Park. To the south of the main fold, the region of Yampa Platean was uplifted bodily, developing a double anticlinal at its western extremity, which merges into a single fold at the east end, while the sharp, rectangular folds on either flank were accompanied by a certain amount of dislocation 
of the strata involved. Between the Yampa Plateau and the main fold, in the synclinal trough of the Yampa Valley, is a remnant of the Triassic beds, which has escaped erosion, while the western end of the valley is walled in by a faulted-up mass of Palæozoic strata, which separates it from the synclinal valley of Brush Creek.

Beyond the limits of the range to the eastward, the contracting forces produced two minor corrugations, which are represented by the anticlinal folds of Junction and Yampa Peaks, and, between these and the Archaen body of the Park Range, an irregular series of broad, gentle undulations. To the north of the Archæan body of Red Creek was also some disturbance of the conformable series of beds, resulting in a broad quaquaversal fold in the vicinity of Bitter Creek, and, on the western edge of the basin, a series of narrow, wave-like ridges were formed, having a direction resultant of that of the shores of the Uinta and Wahsatch Mountains, whose influences in the folding are seen in the two independent directions of strike found in these ridges.

Tertiary Formations.-The movements of this period of Cretaceous upheaval, which involved also the Colorado Range, and a second uplift in the Wahsatch Range, resulted in the cutting off from the ocean of a great area, of which the Tertiary basins represented in the map formed part, and which was afterward filled by fresh-water seas. At the close of the period of upheaval, the highest crest of the Uinta Range must lave stood about 30,000 feet above the bottoms of the surrounding basins; but this difference of level, by the abrasion of the rocks which formed the crests of folds; and the consequent filling up of the basins by the sediments resulting therefrom, has been reduced at present to about 7,000 feet. The great erosion, which took place previous to and during Tertiary times, was principally a gradual wearing away and planing off of the crests of the folds, of whose resultant forms little trace is seen in the present topography. The only well-defined relic of pre-Glacial erosion is seen in the deep axial valley of Brown's Park, whose general form, except for the filling in and levelling off of its bottom, must have been very much what it now is, in early Tertiary times. The principal deposition of straia in the Green River Basin took place during Eocene thmes; those of later times, of which the evidences 
now existing are not known with any great degree of certainty, must have been of extremely local character. The aggregate thickness of these Eocene formations is estimated at 7,500 feet, and they have been separated into three groups, the Vermillion Creek, Green River, and Bridger, so named from the localities in which they find their most characteristic development. They are remarkable for the abundant remains of vertebrates found in their beds, which, though distinct in these subdivisions, yet are considered as representing Lower Eocene types.

The beds of the Vermillion Creek series, which are chiefly arenaceous in character, were deposited in greater thickness than either of the other groups, and extended from the base of the Park Range to the flanks of the Wahsatch Mountains. They consist in the lower part of coarse sandstones, gravelly beds, and conglomerates, which, in the upper portion, pass into finer sands, with an increasing proportion of fine argillaceous material, the whole characterized by prevailing red and chocolate colors. Their fauna indicates a warm climate, the general coarseness of their material a troubled, stormy sea, while the time of their deposition, immediately subsequent to the folding of the strata, the absence of calcareous material, and their peculiar color suggest that they are composed of comminuted débris of the Mesozoic rocks, which are also characterized by an absence of calcareous material, and in which the decomposition of the iron, found in considerable proportion in the Cretaceous beds, would color the lower beds, while the red sandstones and clays of the Triassic would, by rearrangement, produce the peculiar clayey sandstones of the upper beds. At the close of the Vermillion Creek period, there was a slight movement in these beds, in general not sufficient to produce sharp flexures, but causing gentle undulations, and a local non-conformity of deposition with the beds of the succeeding group. This movement was greatest along the flanks of the Uinta Range, notably at Henry's Fork Valley, a slight movement of uplift probably continuing till near the close of the Bridger period.

The beds of the Green River series contrast with those of the other two groups by the relative prevalence of calcareous material, and the fineness of their sediments. They were deposited in quiet, probably deeper waters, and perhaps during the time that erosion was wearing away the limestones 
of the Upper Coal-Measures from the crests of the folds. They consist of a lower series of calcareous sandstones and impure limestones, containing some lignite seams, overlaid by a great thickness of remarkably fissile calcareous shales abounding in remains of fish and insects, which reach an aggregate thickness of about 2,000 feet, and are characterized throughout by their prevailing white color. The extent of the sea in which these beds were deposited was somewhat less than that of the previous period, a strip of land having been elevated above its level along the flanks of the Wahsatch, and probably also a narrower strip along the shores of the Park Range; its beds, however, were deposited continuously over the ridge of Vermillion Creek beds, between the Bitter Creek Cretaceous uplift and the Archæan body of Red Creek, and also probably connected, through the low gap of the White River divide, at the eastern end of the Uinta Range, with the region to the south, in which beds corresponding to these and to the Bridger beds have been recognized, although their direct connection has not yet been traced. There has been a slight local movement in these beds, previous to the deposition of the Bridger beds, along the flanks of the Uinta Mountains, but that this amounted to an actual non-conformity throughout the basin we have only the negative evidence, that while there are gentle undulations in the former, the beds of the latter, which have escaped erosion, bear no evidence of having been disturbed, except locally, along certain lines of fault.

The Bridger group consists of a thickness of about 2,500 feet of arenaceous beds, with a small development of calcareous material, of a prevailing dull greenish-gray color, characterized by the great quantity of vertebrate remains which have been buried in them. Its fauna, like that of the former group, indicates a warm, semi-tropical climate. Its sea was of still more limited extent than that of the previous period, and was probably divided into two separate basins by the ridge, which connected the Bitter Creek uplift with the Uinta upheaval at Red Creek. The level reached by the upper beds deposited during this period is higher than the present level of the Uinta Range along the course of Green River; but as no remnant of these beds has as yet been discovered in the region, the actual proof that they ever extended across the range at this point is wanting. 
That they had a connection to the south through the same gap with the Green River beds at the eastern end of the range is, however, probable

The later history of the Green River basin is still involved in some obscurity; no representative of the Miocene beds of the eastern slopes of the Rocky Mountains have been discovered within its limits, and no connection probably existed with the eastern Tertiary seas. When drained, it was probably to the southward, at the eastern end of the Uinta range. A local deposit of Pliocene strata is said to exist within the limits of the basin on the southern flanks of the Wind River Mountains. There is a possibility, also, that the upper beds of Brown's Park, which have been colored as Green River Eocene, may prove, on further investigation, to be of Pliocene age, which would heighten the probability that the North Park Tertiaries belong also to that period. If the basin was drained previous to Pliocene times, the erosion that took place afterward was of broad, general character, and had no relation to the present topography.

The last deposit that was made in this basin in pre-Glacial times is of a peculiar character, and has been so largely removed by recent erosion that the scattered remnants that now remain afford but meagre data for tracing the character and extent of its original deposition. This deposit is a structureless conglomerate, called by us the Wyoming Conglomerate, entirely barren of fossil remains, and made up of comparatively coarse, generally rounded, fragments of the harder rocks which form the present crest of the Uinta Mountains, cemented together by calcareous material. It is found in greatest thickness along the immediate flanks of the Uinta Range, and is in all cases horizontal, having evidently filled in and levelled off the valleys and ridges of the pre-existing topography. It was therefore, in some measure, a littoral deposit, and probably in a shallow sea, subject to great changes of level, at a time when great storms and floods prevailed. $\Lambda$ s indicated by the existing remnants, it extended as much as 20 or 25 miles from the shore-line, and covered the lower eastern portion of the Uinta Range, bordering the present course of Green River.

It was on the level surface left by this deposit, then, that the present sinuous course of Green River through the Uinta Range was determined, though the general direction of this course was probably governed by the 
previously existing topographical features. Some idea may be had, then, of the magnitude of the erosion which has taken place in this region since Pliocene times, of which the Wyoming Conglomerate is the latest representative, when we consider that the bed of the stream which represented Green River must have been at a level corresponding to a present elevation of between 8,000 and 9,000 feet above sea-level, and that a thickness of from 1,000 to 2,000 feet has been gradually removed from a great part of the area of the Green River Basin, and carried away by its waters through the ever-deepening cañons. The bulk of this material must have been carried away by the floods which followed the Glacial period, while at the present, day, under conditions of comparatively slight precipitation, the amount removed from the basin region by the actual agency of water is relatively slight. From this period also dates the present configuration of the mountain summits ; the shallow amphitheatre-shaped valleys between the higher peaks were carved out by nèvé-ice, while the shapes of the cañons of the principal streams, and the moraines found at their mouths, show that they were cut nearly to their present depth by glaciers. As indicated by the moraines, which have remained to the present day, these glaciers were, in many cases, over 25 miles in length, and extended down to a level of but little over 6,000 feet above sea-level. 


\section{SECTION III.}

\section{DESCRIPTIVE GEOLOGY OF THE BASIN REGION.}

WASHAKIE Basin.-In pursuance of the general plan followed in Chapter I, the detailed description of localities will follow the general idea of proceeding from east to west, and, in this case, commence with the broad area of Tertiary occupying the northeastern portion of Map II, which is included under the general name of the Washakie Basin, as distinguished from the Bridger Basin, to the west of Green River.

Over the greater portion of this region, only the comparatively undisturbed beds of the Eocene Tertiaries are exposed. Owing to the soft, friable character of the material of these beds, and the approximately horizontal position that they occupy, it were almost impossible, even with a much more careful study than our time permitted us to give, to define accurately the outlines of the different divisions of these formations. Those given on the map, therefore, are to be considered only as approximately correct. The northeast corner of the map represents a portion of an almost level desert country, extending from Rawlings Peak to the Bitter Creek ridges, bare of vegetation, and even without the dry water-courses, which are generally found on these plains. To the west of Rawlings Peak, as we have seen, the Cretaceous strata fall off with an ever-decreasing angle of dip, assuming to the north of the railroad, between Separation and Washakie, an almost horizontal position, and are gradually succeeded by the overlying and, in this region, conformable beds of the Vermillion Creek Tertiary.

It is probable that the latter beds extended much farther east than has been indicated on the map, and that remnants may still exist in the region included in the color of the Laramie Cretaceous, which, owing to the similarity of the lithological character of the two formations, and the absence of palæontological evidence, it has been impossible to distinguish. The line of division, as drawn between these two formations, indicates the western limit of well-defined exposures of the Laramie Cretaceous. On the line of the railroad, about six miles east of Washakie 
Station, are outcrops of a thin bed of fine-grained, siliceous argillites, which are casily recognized on account of their deep vermilion color. They are very fine-grained, splitting into laminæ less than half an inch thick, and are sull of very distinct impressions of deciduous leaves of the types common in the leaf-beds of the Upper Laramie Cretaceous. They form a well-marked horizon near the upper portion of this series, and are underlaid by sandstones which carry coal seams. The same beds are also found about 10 miles northwest of this point, capped by thin-bedded sandstones. In both localities, they occupy a nearly horizontal position, having a slight dip to the westward. The low, flat ridges, extending north and south from Washakie Station, show no outcrops of any characteristic rocks, being composed principally of sands and clays resalting from the decomposition of beds, which might belong to either of these formations. The tops of the ridges are generally capped by thin beds of harder sandstone, which have resisted the action of erosion.

About 16 miles, in a direction about east $20^{\circ}$ south from Washakie Station, was found, in a shallow valley, an exposure of beds of greenish marls and clays, weathering in peculiar round, smooth, dome-like forms, characteristic of similar beds in the Bridger series. None of the fossil vertebrates, which are so characteristic and widely spread through this formation, were found, however, in these beds, and they have, therefore, been included in the color of the Vermillion Creek group, to which horizon their stratigraphical relations most nearly relate them. They have a dip of about $5^{\circ}$ to the westward, which would carry them under the red beds of Cathedral Bluffs.

A few miles southwest from this point, the sandstones of the Laramie group are found, rising at an angle of $15^{\circ}$ to $20^{\circ}$, with a strike of northeast and southwest. The upper beds observed were a brown sandstone, underlaid by about 200 feet of friable sandstone, at the base of which are the characteristic bright red, leafy beds, already mentioned. Below these are various sandstones carrying coal seams, and a succession of heavy-bedded sandstones and clays, extending as far south as the Little Muddy, whose section has already been given in the description of Map I. The ridge on the south side of the Little Murdy, at this point, has not been visited, but on theoretical grounds has bcen assigned to the Fox Hill 
series. To the south of this ridge, an arm of the desert makes in, in which the underlying rocks are concealed by accumulations of sand, which have been driven in here by the prevailing west winds from the desert region to the westward. To the west, the Laramie beds, which were crossed in section north of the Little Muddy, bend in strike to the southward, with a low, westerly dip, and gradually disappear under the decomposed beds of the Vermillion Creek series.

The eastern border of the map, from this ridge as far south as the Little Snake River, represents the western edge of the bench-country, between the Little Muddy and the Park Range, which has already been described in Chapter I, and is formed of beds of the Laramie group, having a dip of about $5^{\circ}$ to the westward. The western foot-hills of this bench-country, along the east side of the Little Muddy, are occupied by a series of loosely-aggregated sand-rocks, of chocolate, buff, and gray colors, which represent the base of the Vermillion Creek series. The only fossil remains found in these beds were rough casts of Goniobasis and Viviparus, in a yellow sandstone, which was considered to represent the base of the series in this region.

On the western borders of the Little Muddy Creek, the characteristic upper beds of the Vermillion Creek series are exposed, weathering in castellated forms, and easily recognized even from a great distance by their bright pinkish and reddish coloring. They consist of an intimate admixture of sands, clays, and marls, in varying proportions, which are more or less colored by oxide of iron. The lines of stratification in these beds are indicated rather by difference of color than by change in the material of which they are composed. The colors vary from a greenish-white to a deep, almost brick, red, which give to the bluff exposures a peculiar striped appearance, characteristic of this formation. The soil which results from their decomposition is a light, clayey material, of a peculiarly red color, from which the sandy constituents seem to have been washed out. The best exposures of these beds are seen at Washakie Mountain and at Cathedral Bluffs.

Washakie Mountain is a flat-topped ridge, about 8 miles east of the Little Muddy, which attains an elevation of some 1,500 feet above the surrounding plains. It is capped by a remnant of the $\mathrm{W}$ yoming Conglomerate, 14 D $G$ 
which, as elsewhere, is wholly structureless, and marle up of con:ive pebbles of the quartzites and more compact schists of the Park Range. The uppor 500 or 600 feet of the peak are composed of brown sandstones and thin, blue, calcareous shales and clays of the Green River series, which are licro nearly horizontal. Below these, on the eastern face, are the striped beds; of the Vermillion Creek series, dipping westward at an angle of $4^{\circ}$ to 5 ? Fastward from the base of the mountains is a long stretch of the red clayey country, without outcrops, and just at the edge of the valley are other bluffs, of the pinkish striped beds of the Vermillion Creck series.

From the top of Washakic Mountain, which affords an extensive view over the country for 5,0 to 100 miles westward, the outlines of the different groups of Eocene Tertiary may be studied to great advantage. A line drawn through this mountain to Cathedral Bluffs, thence to Pine Bluffs, and southeastward through Cherokee Ridge, represents roughly the ontline of a rudely circular basin, marked by lines of bluffs, which slope back toward the centre, presenting their escarpments outward. The centre of this circle is probably the lowest point of the 'Tertiary sea, since the beds all dip toward it, and, except along the line of Cherokee Rilge, lave not suffered any plication since their original deposition. Erosion, in general, acts much faster upon the edgres of the strata than upon their surfaces, hence we find here that the deepest erosion has taken place around the outer edgres of this basin, where the strata, being slightly upturned, are exposed in section, while toward the centre the greatest thickness of the original beds is preserved. The central portion of the basin is occupied by a remnant of the beds of the Bridger series, which is encircled by ridges formed of the more resisting beds of the Green River group; while in the valleys and more deeply-eroded ravines, which lie beyond these ridges, are exposures of the underlying Vermillion Creek beds.

At Washakie Mountain, there is a discrepancy of angle of $3^{\circ}$ to $4^{\circ}$ between the beds of the Green River series and those of the Vermillion Creek group. From this and more definite evidence obtained in other portions of the basin, it is evident that there was a slight movement in the beds of the latter group before the deposition of the Green River shales. The question of a want of conformity between the beds of the Green River group 
and the Bridger beds, on the other hand, is one which is still involved in considerable obscurity. $\Lambda$ t no point was an undoubted discrepancy of angle between these formations observed. On the other hand, the fact that the Bridger beds have never been seen to dip at an angle of more than $3^{\circ}$, while the Green River beds are generally inclined at $5^{\circ}$, and in some cases as high as $25^{\circ}$, combined with the isolated position of the beds of the existing remnants of the former group, would seem to indicate that some slight movement may have taken place in the Green River beds previous to or during the deposition of the Bridger series.

The line of bluffs which extends from Washakie Mountain to Cathedral Bluffs is formed, like this mountain, of beds of the Green River series in the upper portion, with the red Vermillion Creek beds at the base, the line of division between the two formations, which can be distinctly traced by their differences of color, descending somewhat in horizon toward Barrel Springs, and ascending again beyond that toward Cathedral Bluffs. East of this line of bluffs, and north of Washakic Mountain, extends a broad, red plain covered with a light, clayey soil, resulting from the decomposition of the Vermillion Creek beds. This region, and that to the north of the railroad, between Washakie Station and the Bitter Creek Ridges, constitutes the "Red Desert", from which the railroad station takes its name. The northern portion is an almost unknown region, barren of vegetation, and almost without water, but said to contain several alkaline ponds. From a point a few miles west of Washakie Station, just south of the railroad, a line of low bluffs extends westward toward Red Desert Station, and southward toward Washakie Mountain, marking some of the middle beds of the Vermillion Creek series. They are composed of whitish clays, capped by thin flaggy sandstones, in exposures of about 250 feet in thickness. To the northwest of Red Desert Station, there rise out of the plain two isolated hills or buttes of rusty sandstones and calcareous shales. They have an elevation of only abont 800 feet, but form a conspicuous feature in the general monotonous level of the region, on account of their irregular precipitous outline. Their upper beds have been referred somewhat doubtfully to the Green River group.

To the south of Red Desert Station the country rises in a series of 
steps or terraces, the first of which is formed of the whitish clays and sandrocks already mentioned as extending parallel to the line of the railroad toward Washakie Station. About 4 miles south of these, a second line of bluffs of greater elevation is composed of the striped red beds of the Upper Vermillion Creek series. To this we have.given the name of Cathedral Bluffs, on account of the remarkable buttress-like forms into which their faces have been weathered. A thickness of about 600 feet of these peculiarly-variegated beds is here exposed, composed of fine clays of red, greenish, and purple colors, with a varying admixture of fine white sancl. These are capped by about 100 to 15 () fet, of an impure concretionary limestone of drab color, having at its summit a seam about 4 inches in thickness, of oölitic limestone, which has been, in a great measure, silicified, and changed into a dark-gray chalcedony. These upper calcareous beds represent the base of the Green River group. The oölitic seam is marle up of rounded. grains from one-thirtieth to one-tenth of an inch in diameter, of a concentric: structure, cemented by a crypto-crystalline limy matrix. Fxamined under the microscope, they show no evidence of organic origin, and are seen to be almost identical with the limy sands, which are found on the present beaches of the Great Salt Lake. A partial analysis of the agatized portion of this seam gave 74.818 per cent. of silica, the remainder being principally carbonate of lime, with some alumina, oxide of iron, and magnesia. The beds of Cathedral Bluffs have a dip of $3^{\circ}$ to $4^{\circ}$ to the south ward, while the surface of the plateau summit of the bluffs slopes off at a somewhat steeper angle, so that, in the depressions of the dry water-courses to the south, the underlying red beds have been exposed by denudation.

Westward from Cathedral Bluffs, as far as 'Table Rock, extends a less well-defined line of bluffs whose upper beds contain generally some calcareous layers, which are considered to be characteristic of the Green River formation. Table Rock itself is made up of sandstones, and sandy and calcareous shales, with some lignitic seams, and several thin beds of limestone almost completely made up of fresh-water fossils, Melanin, Viriparus, and Unio, together with the agatized oölitic seam already observed in Cathedral Bluffs. Only a thickness of about 500 feet of recognizalolo beds is exposed in its cliffs, the base rocks being concealed by débria. The 
beds have a dip of about $4^{\circ}$ to the southeast, ard strike north $45^{\circ}$ east. In the valleys, both north and south of this peak, the red clays of the Vermillion Creek series are exposed, which, as seen under the cliffs near the stage-road, to the south of Table Rock, seem to show a non-conformity of dip of $3^{\circ}$. They are overlaid by beds of a calcareous sandstone, formed almost entirely of an aggregation of fresh-water shells, which is sufficiently compact to have been used as a building-stone for the stations of the old stage-road. From the line of Table Rock and Pine Bluff westward to the Bitter Creek Ridges, in the neighborhood of Black Butte Station, is a low open country, in which the Vermillion Creek beds have been so thoroughly disintegrated that few exposures of rock are found. The presence of the upper reds beds of this group is characterized, along the base of the bluffs, formed by the calcareous beds of the Green River series, by the peculiar red tinge of the soil. The lower beds of this series, which are composed mainly of coarse sandstones, differ so slightly in lithological character from the underlying Cretaceous rocks that their line of separation cannot be accurately drawn, where, as here, there is no appreciable discrepancy of angle between the two formations.

The most characteristic development of the beds of the Green River series, in this region, is in the neighborhood of Pine Bluffs, which form a prominent landmark in the eastern basin. Their highest point is composed of about 400 feet of yellowish calcareous sandstone, dipping $4^{\circ}$ to $5^{\circ}$ to the south of east, with a strike a little east of north. Under these, as shown in the bluffs to the north, are soft, white, shaly beds of a thickness of several hundred feet. In the ravines, on the eastern slopes of the bluff, occasional thin sandstone beds are observed, but, in general, the underlying rock is completely obscured by great accumulations of detrital material. Near the springs, about 10 miles northeast of Pine Bluffs, at the source of Bitter Creek, are exposures of thin, blue, calcareous shales, which are peculiarly characteristic of the Green River series. They are extremely fissile, splitting up into laminæ whose thickness is scarcely more than that of a sheet of paper, and are generally more or less impregnated with carbonaceous material. Their weathered surfaces are generally white, or a pale bluish gray. They are found in the h:lls both to the east and west of the springs, 
but their best exposures are in the bluffs to the eastward, where they strike north $30^{\circ}$ east, with a dip of $4^{\circ}$ to the southeast. Interstratified with these calcareous shales are thin seams of arenaceous shales, which seem to increase proportionately as one ascends geologically; the higher beds to the south of the springs showing only outcrops of sandy shales and coarse, buff sandstones, which frequently contain rude casts of Unio. Occasional exposures of these southerly-dipping sandstone beds are found along the bed of Bitter Creek, above the springs, as far as its head. To the south of this is an open plain country, in which no outcrops are found for a distance of 8 or 10 miles, but which is evidently covered by débris of the Bridger beds of the Washakie Basin, which extend up on to the flanks of the bluffs formed by the beds of the Green River series.

To the east of the head of Bitter Creek, in the region of the old stageroad, as far as Barrel Springs, extends a region of low, broken ridges, whose beds dip slightly to the south, presenting bluff exposures to the north, and made up mainly of sandstones and calcareous shales, which have been referred to the horizon of the Green River series. At the southeastern point of the Cathedral Bluff Plateau, the striped clay beds of the Upper Vermillion Creek series are overlaid by about 200 feet of soft, light-colored limestones and marls, which are capped by a thin seam of chalcedony, made up almost entirely of casts of Goniobasis, whose form is very perfectly preserved. This seam probably corresponds in geological horizon to the fossiliferous limestones found south of Table Mountain. The local replacement of the calcareous material by chalcedony, probably the result of chemical transformation by soluble silicates, is a phenomenon of very common occurrence throughout all these Tertiary beds. The strata which immediately overlie these beds are concealed beneath the detrital accumulation and the wash of the dry stream-beds to the south of Cathedral Bluffs.

Along the stage-road, near Barrel Springs, are exposures of shaly beds, which seem to correspond to the horizon of the calcareous shales found at Bitter Creek. In the low ridges adjoining these springs are beds of thin white calcareous shales, with a considerable development of carbonaceous material, interstratified with arenaceous beds. The beds are too much disintegrated to afford any continuous exposiures, but seem to have abounded 
in fossil remains. Some layers contain a great number of fresh-water shells, both Unio and Goniobasis, and others abound in leaf-impressions, among which are fragments of tropical plants of the palm species. From the disintegrated material of some of the beds were obtained also a few fish-vertebræ. Among the shells were recognized

\section{Unio tellinoides. \\ Goniobasis tenera. \\ Goniobasis nodulifera. \\ Goniobasis Carteri.}

The beds are here nearly horizontal, having a dip of $2^{\circ}$ to $3^{\circ}$ to the southward, and are overlaid by more arenaceous beds, with intercalated clays, whose disintegration produces a light shifting soil, which conceals most of the outcrops.

To the south of the stage-road, west of Barrel Springs, is a narrow, east and west ridge, whose irregular, serrated outline forms a striking contrast to the usual level summit line of the bluff ridges of this region. It is composed of greenish-drab sandstones, containing some admixture of clay, which form the base of the Bridger Eocene in this region. This ridge rises toward the east, having its culminating point in Haystack Mountain, which has an elevation of about 900 or 1,000 feet above the surrounding plains. It is made up largely of coarse, loosely-aggregated sandstones, composed of quartz grains, reaching the size of a duckshot. Interstratified with the sandstones are clayey beds, which toward the base seem to predominate over the arenaceous material. Along the northern base of this line of cliffs are found fragments of turtles, which have been washed out of the decomposed strata. On the northern face of Haystack Mountain was found the petrified trunk of a large coniferous tree, lying across one of the narrow ravines, a length of about 15 feet being thus exposed, either end being still imbedded in the sandstone. It is about 3 feet in diameter where uncovered, which is probably a considerable distance above its base. The woody appearance is very well preserved, the exterior being whitened, so that the resemblance to the weathered trunk of a dead tree is almost perfect; portions of the bark are covered with yellow spots, apparently of exuding gum, retaining their original coloring. The interior is a black, 
compact siliceous material, and, where the heart of the tree has decayed out, is loosely filled by crystalline quartz, still preserving some of the general fibre of decayed wood. The position of the beds of this ridge, so high above the surrounding country, and their apparent horizontality, might at first lead one to suppose that they represented the highest portion of all the Tertiaries in this basin; but a dip of .only $2^{\circ}$ would carry them 1,000 feet below the surface in the centre of the Washakie Basin, whereas almost all the observed dips, where the bedding was distinct enough to determine them, were from $3^{\circ}$ to $4^{\circ}$ toward the centre.

The region to the south of Haystack Mountain, and west of Washakie Mountain, is occupied by a series of northwest and southeast ridges, formed by the beds of the Bridger and Green River groups, in which, as seen from a distance, erosion has cut sufficiently deep into the beds to give good exposures of the rocks which compose them; this region was not, however, traversed by our parties. In the western portion of the Washakie Basin, the upper beds of the Bridger series have been completely disintegrated, and have left an open level country in which are no rock exposures. Along the bluffline, from Pine Bluffs souihward, the calcareous beds of the Green River series form the summit of the ridge, while the striped beds of the Vermillion Creek group are exposed along the base, easily distinguishable by their characteristic color.

About 12 miles southeast from the head of Bitter Creek, to the east of Pine Bluffs, the first exposures of the characteristic green clays and marls of the upper beds of the Bridger group are met. After passing over a level country covered with sand dunes, one comes suddenly upon a series of infinitely branching ravines and gullies cut into the clay beds of this group, with narrow trench-like ravines from 50 to 100 feet deep, and often not more than 20 feet wide at the top, with perpendicular sides, which show the characteristic scenery of the Tertiary bad-lands. From here southwestward, this bad-land region extends to the dry stream-bed to the north of Cherokee Ridge, ending in an irregular line of bluffs, facing southward and having a northeast direction, which present the most remarkable forms of erosion. The characteristic rocks of this bad-land country are a series of greenish-drah clays and marls more or less 
arenaceous, interstratified with thicker or thinner beds of coarse gray sandstone. They are extremely loosely agglomerated, and the material of which they are composed is very fine-grained and homogeneous. The characteristic feature of their peculiar topography is the fact that the eroded faces are practically vertical, and without the usual talus-slopes which result from the disintegration of ordinary beds.

The explanation of this may be looked for partly in the loosely agglomerated character of the beds themselves, which seem to be, in great part, merely mechanical admixtures of clay and sand, but principally in the climatic conditions of the region, in which erosion, at the present day at least, is the result rather of the action of air than of water. The region is exposed to no continuous rains; during the summer months, there fall only occasional violent showers, while in the winter the snows, which accumulate upon the surface, are driven into sheltered spots by the violent winds which sweep across the plains, and in the early summer are suddenly melted, and send down violent torrents of comparatively short duration. The more clayey beds crumble and disintegrate in the dry air, and under the influence of the expansion and contraction produced by the great diurnal changes of temperature from midday to midnight. The sandy strata are thus undermined, and the waters of the intermittent rains only serve to sweep out and deepen the existing gullies, without degrading their sides.

The view given in the Frontispiece shows some of the characteristic forms of erosion of this region. Here the bed of coarse sandstone, some 15 or 20 feet in thickness, which probably was locally indurated, has preserved isolated remnants of the beds from degradation. The thickness shown in this view is a little under 200 feet; the aggregate thickness of these beds, however, it was impossible to estimate, owing to the horizontal position of the beds and their want of continuity. That of the Western or Bridger Basin, as will be seen later, is between 2,000 and 2,500 feet; it seems probable that in this region, however, the thickness is considerably less. Fron these beds, great quantities of vertebrate remains have been obtained, which have been made the subject of a special report by Professor Marsh in another volume of the series. Their horizon has been determined by him to be that of the Lower or Middle Eocene, and in general features to correspond with those 
obtained from the Western or Bridger Basin; but as a group they have certain specific differences, which seem to favor the idea that the Washakie Basin may have been isolated from the former.

As on the northwest, so to the south, the connection of these beds with the underlying Green River beds is broken by a broad gap covered by surface accumulations, in which no outcrops are found. The strata are practically horizontal throughout the basin, but at the southern extremity of the line of bluffs, near the Cherokee trail, some underlying beds of chalky, brittle, calcareous shales were found dipping $7^{\circ}$ to the northward; whether these belonged to the Bridger or Green River group it was impossible to determine; their angle is greater than any observed elsewhere in the Bridger group, and yet, lithologically, they do not resemble any of the Green River beds observed by us.

The line of elevation of the Cherokee Ridge, so called from the old Cherokee trail, which follows its summit for a considerable distance, marks a comparatively sharp fold in the beds of the Green River series, which has doubtless been accompanied with considerable faulting. The movement which produced this fold would seem to have been continued since the deposition of the Bridger beds, as indicated by the angle of $7^{\circ}$ at the southern edge of this basin already mentioned, if these beds really belong to the Bridger series The Cherokee Ridge is made up of drab thin-bedded sandstones, interstratified with buff calcareous sandstones, containing rough casts of Goniobasis, which pass into a semicrystalline, whitish-brown limestone. The ridge forms an anticlinal, whose axis has an east and west direction, and descends to the westward. On the southern slopes, the beds are very much broken, and present irregular dips as high as $25^{\circ}$ to $30^{\circ}$, while on the north the average dip is about $10^{\circ}$ to the northward. At the eastern end of the ridge, near Otter Gap, the underlying reddish clayey beds of the Vermillion series are exposed in the deeper cuts. From Otter Gap to Washakie Mountain, the higher ridges are covered by the arenaceous and calcareous beds of the Green River series, dipping westward, while in the deeper ravines, and on the eastern slopes toward the Little Muddy, the red sands and clays of the Vermillion Creek series give their oharacteristic color to the country. 
To the south of the Little Snake River, extending eastward to the foot of the Elkhead Mountains, is a dry region of low rolling hills about 25 miles in diameter, the interior of which was not explored by our parties. From the general color of the soil of the region, and the position and character of the beds on its circumference, it has been assigned without hesitation to the Vermillion Creek series.

From Otter Gap to Elk Gap, the course of the Little Snake River indicates roughly the dividing line between the Vermillion series and the Green River group. The beds of the former rise generally to the eastward. $\Lambda$ bout 12 miles from Otter Gap, the river cuts a cañon through hills of drab clayey beds, underlaid by reddish sandstones, which probably represent the base of the Green River series. The line of depression to the west of this point, occupied by the dry water-courses south of Cherokee Ridge, shows but few outcrops; toward the Little Snake River, however, the red Vermillion Creek beds are exposed, as indicated, by the color of the soil. To the south of this line, the strata rise gently to the broad plateau, which extends from Sunny Point to Vermillion Bluffs.

This plateau represents a gentle undulation, or broad, anticlinal fold, in the beds of the Vermillion Creek series, of which a section is given in the bluffs facing the depressions of the basin of Vermillion Creek on the west, and the Little Snake River on the east, from which the upper beds have been removed by erosion. From the summit of this plateau, the strata slope off very gently toward the north at an angle of not more than $1^{\circ}$ or $2^{\circ}$. To the south and west, they follow the general slopes of the topography, sinking into the shallow synclinal basin which lies between Elk Gap and Vermillion Bluffs, where a remnant of the beds of the Bridger group still remains. On the soft slopes of the cliffs which border the Little Snake River on the west, from the bend southward, the line of division between these two groups can be traced by the characteristic coloring of the upper beds of the Vermillion series; it is seen to rise from the bend toward Sunny Point, and from there southward to descend gradually, until, a few miles above Elk Gap, the Green River beds come down to the river's bank. A section, taken on the cliffs at Sunny Point by the aid of an aneroid barometer, gave a thickness of about 2,000 feet of beds exposed from the river to 
the summit of the cliff. Of these, the upper 950 feet have been referred to the Green River series, and the remaining 1,050 feet, whose beds were largely concealed by the débris accumulations of the slopes, have been referred to the Vermillion Creek series. The section, in descending geologically, is as follows:

Green River series.

Coarse brownish sandstone, with intercalated brown calcareons shales ....... 100

White calcareous shales, with half.inch seams of gypsum and a four-inch seam

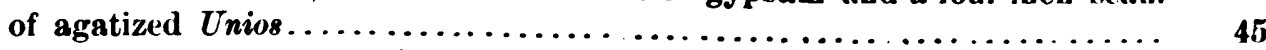

Drab concretionary limestone, with brown sandstone-shales $\ldots \ldots \ldots \ldots \ldots \ldots \ldots$.

White and brown argillaceous shales $\ldots \ldots \ldots \ldots \ldots \ldots \ldots \ldots \ldots \ldots \ldots \ldots \ldots \ldots \ldots$

Rusty arenaceous shales $\ldots \ldots \ldots \ldots \ldots \ldots \ldots \ldots \ldots \ldots \ldots \ldots \ldots \ldots \ldots \ldots \ldots$ 100

Beds of soft light.colored argillaceous aud calcareous shales, : ome of which are impregnated with carbonaceous material, and have a light.blne color on the weathered surface, containing also thin seams of gypsum . . . . . . . .

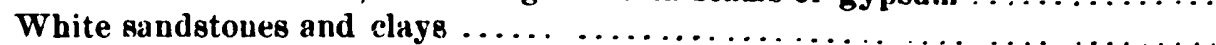

Vermillion Creek̉ seriex.

Reddish clayey arenaceous beds ........................ 1,050

About 7 miles south of Sunny Point, the dip suddenly becomes steeper, and the Green River beds reach the level of the river on its western side. From here to Elk Gap, there seems to have been a local disturbance resulting in the flexure and probable dislocation of these strata, as seen on the western side of the cañon through which the river runs at this point. 'The beds are mostly of loosely-aggregated grayish-drab sandstones, wanting in characteristic features. Just above the cañon, the dip changes for a short distance fromi south to north; but, at Elk Gap, the beds dip again to the southward at an angle of $10^{\circ}$. At this point exists a singular non-conformity. The lower beds, which have been considered to represent the upper part of the Vermillion Creek series, dipping at an angle of only $10^{\circ}$ to the south, are overlaid by a series of sandstones, having at the base a prominent seam of red shale, which dips $29^{\circ}$ to the south and west. Above these, at some little distance down the river, are apparently conformable beds of finc white calcareous and siliceous material, sloping off gently into the basin of the Lower Snake and Yampa Rivers, which forms the easterly continuation of the depression of Brown's Park.

Godiva Ridge is capped by white calcareous beds, containing the 
silicified scam made up of casts of Goniobasis, so prevalent throughout the 'Tertiaries to the north, which have n general dip to the sonthward, but on the spurs toward the river incline about $3^{\circ}$ to the northwest. They are underlaid by the red beds of the Vermillion Creek series, which are exposed along the northern flanks of the ridge, and extend out into the country to the east, where they have a general dip of $5^{\circ}$ to the northward. There is apparently a non-conformity of angle between the overlying beds and those of the Vermillion Creek Tertiary, though much less marked than that observed at Elk Gap. To the northwest of Elk Gap, the strata descend toward the basin, in which, according to geologists who have visited the region since our explorations of 1871 , there exists a remnant of the characteristic green clays and marls of the Bridger series.

The characteristic exposures of the beds of the Green River series are found in the Vermillion Bluffs, which bound the basin of Vermillion Creek on the southeast. At the most northeasterly point of these bluffs visited by us, about 15 miles from the canon of Vermillion Creek, they are capped by a remnant of the Wyoming Conglomerate, which here consists of a thickness of about 50 feet of structureless conglomerate, composed of coarse pebbles of red quartzite. Beneath the conglomerate is a thickness of 500 to 600 feet of calcareous beds, made up largely of the characteristic paper-shales of the Green River series; below, a thickness of about 800 feet of the characteristic red beds of the upper Vermillion series, underlaid by coarse sandstones and gravel beds of a grayish-drab color, which extend out over the basin, covering the upturned edges of the Upper Cretaceous strata. At this point, the beds dip only about $2^{\supset}$ to the east and south; but toward Vermillion Creek Cañon, the easterly dip gradually steepens to $12^{n}$. The dividing line between the Green River series and the Vermillion beds can be traced along the line of the bluffs, descending somewhat toward the cañon, while the summit of the ridge, which separates the basin of Vermillion Creek and Brown's Park, to the east of the cañon, is made up of beds of white calcareous Tertiary, which slope off on the south of the ridge into the basin of Brown's Park at an angle of $5^{\circ}$ to $7^{\circ}$. On the crest of this ridge, to the east of the cañon, where, by the denudation of the Tertiary beds, the underlying Triassic sandstones have been exposed, are 
patches of conglomerate containing pebbles of red quartzite, which have also been referred to the Wyoming Conglomerate.

Brown's Park and tri: Yampa Valley.-The valley of Brown's Park is a bay-like depression, from 6 to 8 miles in width, occupying the geological axis of the eastern end of the Uinta Mountains. It is the deepest valley of the Green River Basin, its average elevation being but little over 5,000 fect. Its surface is occupied by a series of flat Tertiary ridges, intersected by the broad alluvial bottoms of Green River and its tributary crecks. 'From the eastern end of the valley, these mesa-ridges rise gently to the eastward, attaining an elevation of about 1,000 feet above the level of Green River, on the divide between it and the Little Snake, and descend as gradually to the east. The continuation of this line of depression, in the valleys of the Iittle Snake and Yampa Rivers, extends as far as the upper canon of the Yampa River, and includes also the enclosed valley of Lily's Park at the base of the White River divide. The whole of this low region is occupied by a series of Tertiary beds of somewhat different lithological character from any of those hitherto described. The material of which they are composed is extremely fine-grained, very white in color, and contains a comparatively large proportion of carbonate of lime. From these Tertiary beds, no fossils were obtained by our parties which could determine their geological horizon. Their stratigraphical relations, as well as the predominance of calcareous beds, ally them most nearly to the Green River group, to which they have consequently been referred. Their extremely local development, their peculiar lithological character, and the fact of the decided non-conformity of their beds with the underlying Tertiaries, along the line of Elk Gap and Godiva Ridge, suggest the possibility that they may represent a local development of one of the later Tertiary formations. There can, however, be little doubt that the beds of the Green River group have occupied this region, and that, if these beds are later, the latter underlie them. These white Tertiaries occupy, in general, a nearly horizontal position, sloping a few degrees in approximate conformity with the slopes of the valleys which they occupy.

In the view, given in Plate IV, of Brown's Park, taken from the hills at the mouth of the canon of Lodore, looking across the valley in a northerly direction, the white line of the Tertiary beds can be distinguished on the 
opposite side of the valley along the cliffs which form the southern face of the Owi-yu-kuts Plateau.

At the base of the eastern portion of these cliffs, the white strata of the Brown's Park Tertiary are found resting against the quartzites, inclined at an angle of $25^{\circ}$ to the southward. The suddenness of this change of angle from the approximately horizontal position of the beds in the middle of the valley suggests a local displacement and sinking of the beds at the base of the cliffs since Tertiary times. This line of fault corresponds with that developed in the neighborhood of Elk Gap, in which the downthrow is also to the south. Owing to the obscurity which involves the correspondence of horizons in these Tertiary beds, the amount of displacement cannot be estimated with accuracy. The relative difference of level between the Tertiary beds of the western end of Brown's Park and the beds of the Green River group in the valley of Red Creek is not less than 3,000 feet; and, if the latter extended southward at their present angle to a direct superposition, this amount would be doubled. It is probable, however, that in this region of the valley the displacement has been much greater than farther eastward.

At no one point were the exposures of the Brown Park Tertiaries sufficiently continuous to give a definite idea of the thickness of the formation. We roughly estimate about 1,000 to $1,2(10$ feet still remaining above the lowest beds exposed. The best sections are obtained in the deep cuts made by Vermillion Creek at the eastern end of the Park. The most characteristic strata are composed of an extremely fine, white siliceous silt, enclosed in beds of coarse grayish-drab sandstone. A chemical analysis of the former was made by Mr. B. E. Brewster, with the following result:

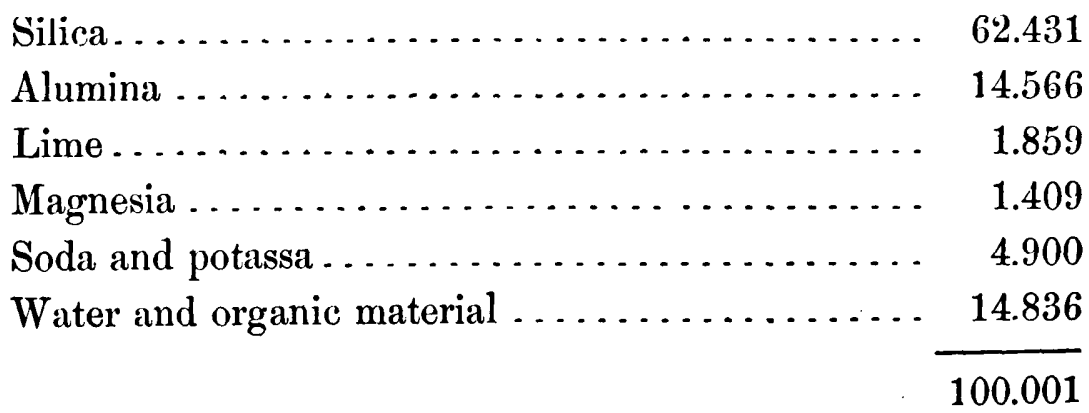

The drab sandstones consist of a loose aggregation of rounded grains 
and fragments, of quartz and feldspar, and minute black particles, which may be hormblende or mica. Another light-colored siliceous bed, which is more compact, though less fine-grained than the former, is characterizerl by a conchoidal fracture and a peculiar silky lustre, and is made up largely of small colorless acicular-shaped crystals. These siliceous beds pass through fine-grained white siliceous limestones into fine calcareous shales, which are extensively developed throughout the formation: With these are found thin beds of carbonate of lime, in which a singular concretionary structure is developed. The lower beds of the formation are of generally coarser material, and contain numerous gravelly beds which pass into a sort of conglomerate. This is more particularly the character of the upturned beds already mentioned along the northeastern edge of Brown's Park.' From the eastern end of Brown's Park, the strata rise gently toward the divide, and descend again with a still more gentle slope into the valley of the Little Snake, where the stream-beds are less deeply cut and the exposures more infrequent.

Throughout the valleys of the Little Snake and Yampa, the Tertiary beds have been more generally disintegrated than in Brown's Park, and form more rounded ridges, in which but little of the undecomposed rock can be found. The character of the beds is, however, apparently similar to that of those observed in Brown's Park. Along the western base of Yampa Peak, the Tertiaries are concealed beneath considerable accumulations of sand. In the basin east of Yampa Peak, where the streams have cut deeper into these beds, good exposures are found, and the material of which they are composed is seen to be quite similar to that in Brown's Park. They occupy an approximately horizontal position, but slope up slightly toward the flanks of the hills. On the northern face of the White River divide, to the southwest of Yampa Peak, is a considerable thickness of . sandy and gravelly beds, having a dip of $3^{\circ}$ to the northward, overlying the upturned edges of the Cretaceous strata which form this ridge. They here reach a height of 1,500 feet above the valley of the Yampa, and seem to be remnants of higher beds of the series, which have been entirely carried

\footnotetext{
${ }^{1}$ Since the above was written, it has been reported that fossils of a Pliocene type bave been found in the Tertiary beds of Brown's Park. If this be true, it is probable that these upturned bels mas represent a lower unconformable series, corresmonding in age to the Green River beds, to which the whole gronp had been referrel by na.
} 
away by erosion from the interior of the basin. Similar beds are observed to form the crest of the ridge which separates the Yampa and White River Valleys to the west of this point, where they are capped by a coarse conglomerate, which may possibly belong to the Wyoming Conglomerate. The connection of these beds with the Tertiaries of the White River Valley was not traced, but their position on the ridge proves that there existed a former connection between the Tertiary seas to the north and south of the Uinta Mountains. It is well known that, in the White River Valley, a series of calcareous shales, closely resembling lithologically those of the Green River series, has been discovered, which contain the same abundant remains of fish and insects that are characteristic of this group. The vertebrate remains discovered in the beds of the Uinta Eocene by Professor Marsh's parties are closely allied, as will be seen later, to those found in the Bridger beds. It is probable, therefore, that a connection once existed at this point between the seas, in which these two series of beds were deposited, on either flank of the range.

Vermillion aNd Red CReek Basins.-In the basin of Vermillion Creek, which is a region of flat terrace-like Tertiary benches, intersected by a complicated system of dry water-courses, the beds of the Vermillion Creek series have their greatest development. At the lowest portion of the basin, the beds which immediately overlie the upturned Cretaceous are a series of grayish-drab gravelly sandstones and clays, lying approximately horizontal. They rise gently to the east and north, and extend high up on to the northern flanks of the Owi-yu-kuts Plateau. The higher beds, exposed in the cañons of the western fork of Vermillion Creek, are coarse sandstones and gravels, which, in the upper portion, have the characteristic red color of this formation. It was on one of the broad benches between the branches of this creek, to the east of Ruby Gulch, that the originators of the famous diamond fraud of the summer of 1872 located their supposed discovery. An exposure of coarse iron-stained sandstone, on the surface of the mesa at the foot of Diamond Peak, was strewn by them with rough diamonds and rubies, which were ingeniously mixed with the soil around, so as to make it appear that they came from the decomposition of the sandstone. In the bluffs near this point, a few remains of $15 \mathrm{D} \mathrm{G}$ 
bird-bones were found in the gravelly strata, unfortunately not sufficiently well preserved to permit the identification of their species. In general, the beds of this formation, as far as observed, are singularly barren of fossil remains.

To the northwest of Diamond Peak, the 'Tertiaries reach a very considerable height, covering the edges of the Upper Coal-Measure limestones, and are capped by beds of the Wyoming Conglomerate, which also form the surface of the broad platean of Bishop's Mountain.

From a little west of Bishop's Mountain, whose meridian represents approximately the divide between the eastern and western Tertiary basins, the strata incline gently to the east, descending into the semicircular basin at the head of Red Creek. The beds exposed in this basin are largely coarse red and chocolate-colored sandstones, containing more or less admixture of clayey material. These beds form the base of the line of bluffs extending from Bishop's Mountain to Quien Hornet Mountain, which encloses the basin on the north. In the upper part of these bluffs, they are overlaid by the beds of the Green River series, which are probably nonconformable, although no direct discrepancy of angle was observed. The angle of dip of the Vermillion Creek beds in this basin is about $5^{\circ}$ to $7^{\circ}$ to the north, while the underlying Cretaceous rocks dip 25 ${ }^{\circ}$ at the gap of Red Creek. The Tertiaries extend high up on to the hills on either side of this gap, covering the edges of the Cretaceous strata, and in the high hills to the west of the gap have a dip of $10^{\circ}$ to $15^{\circ}$, which points to a probable movement in these beds in connection with the faulting of the Archaran body, which will be noticed farther on. From the basin of Red Creek northward to Quaking Asp Mountain extends a high plateau region, whose continuity is only broken by the deeply-cut valleys of Sage Oreek and the southern branches of Bitter Creek. Its surface is covered by débris resulting from the decomposition of the Wyoming Conglomerate, which, it may be supposed, once spread out as a sheet over this whole region, but which has been indicated on the map only at those points where its beds have been observed in an undecomposed state. It lies unconformably over the Tertiaries of the Green River and Vermillion Creek groups, as observed on the northern flanks of Quien Hornet Mountain, where the buff limestones of the former 
$\operatorname{dip} 4^{\circ}$ to the northward, while the conglomerates slope only $1^{\circ}$. Throughout this region, the beds of the Vermillion Creek series are exposed in general in the deeper cuts, as indicated on the map, while those of the Green River series, though not always recognizable, have been indicated as covering them on the higher benches, because their position and angle, as observed on the surrounding points where they could be distinctly recognized, would carry them over these benches.

On the eastern borders of the Cretaceous uplift of the Bitter Creek ridges, it has been impossible to trace with accuracy the dividing line between the Tertiary and Cretaceous formations, owing to the close lithological resemblance of the lower beds of the Vermillion Creek series with those of the Laramie group, and to the fact that in both are found coal seams, and that the difference of angle between the two, along this line, is scarcely appreciable. It is evident, however, that detached portions of the Tertiaries have been left overlying the Laramie beds; their continuity with well-recognized Vermillion Creek beds to the eastward being broken by erosion, and probably by some dislocation. To this fact, doubtless, is due much of the confusion in the minds of palæontologists with regard to the age of the coal-bearing strata, in which fresh-water forms have been found apparently mixed up with marine shells. To the northward, beyond the limits of the map, the Vermillion Creek beds sweep around the exposures of the Laramie series, and directly north of the Leucite Hills seem to be entirely covered by the light chalky beds of the Green River series, which come in contact with the latter, thus affording another argument in favor of the supposed non-conformity between these two groups.

Cretaceous Upliyt of Bitter Creek.-This is the main pre-Tertiary flexure in the basin country between the Rocky Mountains and the Wahsatch, and, as will be observed by reference to the map, is approximately on the same north and south line as the Archæan body of Red Creek, and the complicated system of folds and dislocations in the Uinta Range, along the lower cañon of Green River. This fact points to the probable existence of a north and south submerged Archæan ridge, or continuation of the Red Creek body, which has been the determining course of the flexures 
and dislocations produced by contraction in the overlying sedimentary beds along this line.

This uplift is an anticlinal, or rather quaquaversal fold, whose longer axis is approximately north and south; the beds involved in it having $a$ steeper dip toward the west and south, while to the east and north they slope off so gently as to present no non-conformity of angle with the overlying Tertiaries. These dips are about $5^{\circ}$ to $7^{\circ}$ on the east, as shown along the railroad from Black Butte Station to Salt Wells, and $12^{\circ}$ to $15^{\circ}$ on the west side, as seen along Bitter Creek from Salt Wells Valley to Rock Springs; while in the cañon of Little Bitter Creek, to the south of Quaking Asp Mountain, are outcrops of the sandstones of the Laramie series, which dip at angles of $25^{\circ}$ to $35^{\circ}$ to the southwest.

The open valley of Salt Wells in the centre of this fold is covered for the most part by clayey Quaternary soil, and presents no outcrops, with the exception of a little rounded hill of argillaceous beds in the mirldle of the valley, from which, however, no fossils were obtained. From the litholngical character of the few beds seen, and their position relative to the surrounding and overlying sandstones, it is evident that the upper beds of the Colorado series have here been denuded to a probable depth of 500 to 1,000 feet. The existence and relative position of these beds have been deduced rather from the angle of the overlying Fox Hill beds, which form the bluffs surronnding the valley, than from actual observation. Toward Quaking Asp Mountain, at the southern end of the valley, the anticlinal fold seems to close together with sharper dips, while, at the north, its beds pass under the Tertiaries at low angles, forming low circling ridges facing inward.

Capping the bluffs, which face the valley on its western edge, about six miles east of Rock Springs, is a bed of compact close-grained sandstone, almost approaching the nature of a quartzite, in which were found casts of fragments of Ammonites, and some small bivalves, possibly Cardium and Inoceramus. Although too fragmentary for specific determination, these remains were sufficient to identify the beds as belonging to the Fox Hill group. They have been therefore considered as marking approximately the dividing line between this and the Laramie group. They are enclosed, both below and above, in coarse gray sandstones, of no very distinctive 
lithological character. The beds dip here about $13^{\circ}$ to the westward, with a strike a little north of west. 'The upper section, AB, at the bottom of the map, which passes through this point, gives an exaggerated thickness to the beds of the Laramie series, from the fact that it does not cross the strike at right angles throughout, since at Rock Springs the Laramie beds strike nearly $30^{\circ}$ east of north. To the south, these sandstone ridges disappear under the horizontal Tertiary beds which form the bench-like spurs to the west and south of Quaking Asp Mountain.

This mountain is a sharp narrow ridge, made up of thinly-bedded brown sandstones, which strike to the northeast and dip to the southeast. They are, in general, much harder and more compact than the sandstones of the Fox Hill group, which is probably due to some local metamorphism. They may be considered to represent the opposite side of the fold from the rocks of the ridge just mentioned above, but their direct connection with these beds was masked by the Tertiary benches. In the deep ravines of South Bitter Creek, however, almost continuous exposures of the loose white sand-rocks of the Laramie series can be traced, which, with a dip of $14^{\circ}$ to the westward and a strike to the east of north, in the lower part of the valley near the railroad, gradually curve in strike to the westward as one goes south, and steeper in dip, till in the narrow ravines near the head of the creek, to the south of Quaking Asp Mountain, they are seen to $\operatorname{dip} 35^{\circ}$ to the south with a strike to the northwest. It may therefore be supposed that the beds which form Quaking Asp Mountain bend round in the same way under the Tertiaries.

On the eastern side of the valley, the lower sand-rocks, exposed in the parallel lines of bluff which enclose it, have been referred to the Fox Hill group, though the dividing line between this and the Laramie series is not easy to determine. Corresponding beds to those containing fragments of Ammonites, on the west of the valley, were found in the bluffs, about 6 miles northeast of Salt Wells Station. In lithological character, the distinction between the Fox Hill and Laramie groups is not very marked. In general, the sandstones of the former are more compact, frequently thinly bedded, and showing a tendency to split up into flags, or thin slabs. They are characterized by the presence of marine fossils, Ammonites, Baculites, and 
Inoceramus, and by the rareness of coal seams. In the Laramie, on the other hand, the marine fossils are mostly confined to the genus Ostrea. The sandstones are less compact and more frequently impure, and stained by oxide of iron, which also occurs in concretionary deposits of sufficient extent at times to constitute an ore bed. They are characterized by a greater development of clayey beds, and by the great number of coal seams, of which as many as fifteen to twenty can frequently be observed in $\boldsymbol{u}$ section of less than 1,000 feet, and by the presence of great quantities of leaves and plant-remains, especially in the upper portion of the series. The thickness given in the section for these two groups is about 3,000 feet for the Fox Hill and 6,00 / feet for the Laramie series. This thickness is deduced from the angle and width of outcrop of the beds, and may therefore be placed at rather a high figure, inasmuch as it is probable that there has been some faulting, which would make this width greater than it should be normally. On the other hand, owing to the unconformity of the Tertiaries, it is impossible to know how near the highest beds exposed may be to the top of the Laramie series.

In the region between Black Butte and Quaking Asp Mountain, and also that to the west of the Leucite Hills, along the northern edge of the map, there is a gap in our observations, and the outlines between the formations in these regions are based on rather distant observations of the apparent line of outcrop, a mode of geological study which gives a very fair approximation to the truth in a country so bare of vegetation, and where the topographical features are so dependent upon geological structure, as this. On the eastern side of the anticlinal, the beds of the Laramie group were observed principally in the region bordering the railroad from Black Butte Station to the Salt Wells Valley. This region consists of low, broken ridges of loose, friable standstone, having a general north and south trend, and eastern dip of from $5^{\circ}$ to $7^{\circ}$ within it are found local dips as high as $18^{\circ}$, which point to a certain amount of dislocation in the beds.

Owing to the generally low angle of inclination of the Laramie beds on this side of the anticlinal, direct evidence of their non-confornity with the overlying Tertiaries is difficult to obtain. Only two instances were observed, one in the bluffs to the east of the railroad, a little north of 
Black Butte Station, where there is distinct non-conformity between the beds at the base and those which form the summit of the bluff, and again to the north of Point of Rocks Station, where the discrepancy of angle is only $2^{\circ}$. The finding of fossils, of distinctly fresh-water types, in the vicinity of marine and brackish-water forms, may be explained by a nonconformity of erosion, where fresh-water Tertiary beds, of similar lithologi(al character, have been deposited in valleys eroded out of the rocks of the I aramie group.

From Black Butte Station to Point of Rocks, the course of Bitter Creek winds through low sandstone ridges, following, in general, their trend. The rocks exposed are grayish-white and rusty-reddish sandstones, with intercalated beds of sandy clays and carbonaceous shales, the latter frequently opening out into well-defined coal seams. The coal seams are not, however, continuous for any great distance, and do not, therefore, afford a means of tracing a correspondence of geological horizon. In many cases, the carbonaceous shales have, in former times, become ignited, and, having burned out, left a rusty-red ash-material in their place. The highest coal seams observed are those in the bluffs to the east of Black Butte Station and at Hallville, of which the former has a thickness of about $4 \frac{1}{2}$ feet, and the latter 6 feet; in either case capped by a well-defined clay seam. In this clay, above the Hallville coal, were found numerous remains of fresh-water fossils, among which were recognized Corbicula fracta, Corbicula crassatelliformis, and Unio (sp.?). Similar, and, in some cases, identical forms have been found by Professor Meek in the beds overlying the coal at Black Butte Station. These facts, taken together with the evidences of displacement observed at the Hallville coal-mine, render it probable that the two belong to the same horizon, and that the overlying beds, and, possibly, even the coal seam itself, if it be true, as reported, that coal has been discovered in the Vermillion Creek beds to the west of Rock Springs, may belong to the overlying Tertiary. The discovery by Professor Cope, since the completion of our field-work, of the remains of a saurian, in the neighborhood of Black Butte Station, proves the existence at the surface of well-defined Cretaceous strata as far east as this point. Great quantities of leaf-impressions and plant-remains are found also in 
the standstones near Black Butte Station, which, however, on account of their wide range and the want of direct correspondence in the flora of this region with that of the Atlantic coast, or of Europe, are of little value in the determination of the geological horizon.

To the west of Black Butte Station, the sandstone ridges, which, near the railroad, are degraded and much obscured by clayey and shaly débris, become gradually higher and more prominent. The peak of Black Butte, which is a prominent landmark in the region, attaining a height of orer 8,000 feet, is formed of one of these more massive sandstone beds, whose horizon corresponds with those exposed in the country to the west of Point of Rocks Station. It has apparently been preserved from erosion by local metamorphism. The summit consists of a huge homogeneous block of sandstone, some 50 feet cube, whose upper surface is thoroughly vitrified, while the lower part still preserves the soft friable nature of the sandstones of this region; this metamorphism only penetrates a few feet within the rock, and presents a regular gradation from a glassy state, almost like a slag, to that of a loose granular sandstone which crumbles between the fingers.

Along Bitter Creek, to the west of Point of Rocks Station, and in the dry stream-bed to the eastward, a more continuous section is afforded at right angles to the strike. Throughout this section there is little variety in the general lithological character of the beds. The exposures are principally sandstones, gray and brown, more or less stained by iron oxide. But, as shown in the section made by the artesian boring at the railroad-station, beds of clay and shale form no inconsiderable portion of the formation, though, being much more easily eroded, they are not seen on the surface. Some of the sandstones give slight effervescence with acid, but the amount of calcareous material is comparatively unimportant, and due probably to the percolation of waters charged with carbonate of lime. Throughout the whole section are found seams of coal, which, however, have been more explored in the upper part of the section in the neighborhood of the railroadstation. The coal beds carry a good deal of iron pyrites, to the decomposition of which is probably due the fact that almost all the springs in the vicinity are strongly impregnated with sulphur. There is a beautiful sulphur 
spring, whose waters are very cold and clear, at the point of the bluffs a short distance to the east of the railroad-station, and in the ravine northwest of that station there is a chalybeate spring which deposits salts of iron. To the northward, toward the Leucite Hills, the surface of the bluffs is plentifully covered by fragments of brown hematite of concretionary structure, which have been weathered out from the sandstone, and whose quantity renders it probable that careful search might reveal workable beds of ironore in this region. The fossils found along this section of the Laramie beds are principally confined to varieties of Ostrea, among which have been determined

\section{Ostrea glabra. \\ Ostrea Wyomingensis. \\ Anomia gryphorhynchus. \\ Cyrena cytheriformis.}

Specimens of Ostrea were obtained as far east as the line of bluffs bordering the dry water-course to the east of the Leucite Hills, which form the limit of our exploration in that direction. In the bluffs to the south of the sulphur spring, which have a height of about 350 feet, are exposed some seven seams of coal, from 1 foot to 7 feet in thickness, interbedded with beds of rusty sandstone from a few inches to 20 feet thick, and seams of sandy and clayey shales. At the base is a massive white sandstone 50 feet in . thickness, overlaid by brown sandy shales containing a seam of coal 3 feet thick, which dips $7^{\circ}$ to the eastward. The beds at the top have a dip of less than $5^{\circ}$, a difference of angle too slight to enable one to determine the exact point of non-conformity. A similar series of beds, in which the same condition of angle exists, is found in the bluffs to the north of Point of Rocks Station.

To the west of Point of Rocks, the sandstones are generally more heavily bedded, and contain a smaller proportion of shaly material, passing by insensible gradations into the beds of the Fox Hill group. In the sandstones of this latter group is found a thin bed of green compact argillaceous rock, very close-grained, and resembling similar beds at this horizon on the east side of the Platte at Fort Steele and in the Oyster Ridge. It has the appearance of an indurated clay, but contains some little calca- 
reous matter. The strike of the ridges along the line of the railroad is about $5^{\circ}$ to the west of north, but to the northward they curve rapidly to the west, and form a semicircular line of bluffs, which encloses the valley of Salt Wells on the north. Northwest of Point of Rocks is a higher platealllike region, which has been preserved from erosion by flows of volcanic: rock, which will be noticed further on. In the outcrops of sandstone scen a few miles before reaching Salt Wells Station, and in the low hills to the south and east of that point, the beds have an almost horizontal position, with a slight dip to the eastward. They are largely clays, with some thin intercalated beds of sandstones.

The axis of the anticlinal is probably still to the westward of these bluffs, and we may estimate about 1,000 feet of clayey beds exposed beneath the sandstones which form the bluff-line just to the east and south of Salt Wells Station. Owing to the want of outcrops, the actual point of change of dip in the beds cannot be observed; but at the entrance of the cañon of Bitter Creek, to the west of the valley of Salt Wells, the beds of massive sandstone dip $12^{\circ}$ to the westward. In the section exposed from here to Rock Spring Station are numerous beds of coal, whose correspondence with the strata on the eastern side of the fold cannot be determined with any definiteness; but it is probable that the seams here exposed have a lower horizon than any which have been worked at l'oint of Rocks or at Black Butte. The lowest seam observed is that of the Van I)yke mine, about 2 miles west of the Salt Wells Valley, which has a thickness of 4 feet of excellent coal, and is overlaid by a red iron-stained sandstone containing thin beds of limonite. This seam is considered to be near the base of the Laramie group.

From this point to Rock Springs Station the croppings of some ten different coal seams were noticed, but many must have escaped observation, since, in an artesian boring made at Rock Springs Station, no less than seventeen coal seams were crossed in a depth of 700 feet. The principal bed, which has been extensively mined by the Wyoming Coal Company about 2 miles east of Rock Springs Station, has a thickness of 9 to 11 feet, and stands at an angle of $15^{\circ}$. The strike of the ridges at this point is about $30^{\circ}$ to the east of north. The fossils found in these sandstones are few, and in general 
similar species of Ostrea and Corbula to those found on the east side of the fold. Owing to their steeper angle of dip, there is less liability of confounding them with the overlying Tertiaries, and no unmistakably fresh-water types have been recognized in them. The springs in this neighborhood, as to the eastward, are largely charged with sulphur.

To the west of Rock Springs, the sandstone ridges become lower and more infrequent, and are gradually concealed beneatlı surface débris. The highest outerop observed was that of a yellow, slightly calcareous sandstone. From these ridges to the base of the cliffs, formed by the beds of the Green River series, to the north of the railroad, the surface is covered by a lightreddish clayey soil, resulting from the decomposition of the upper beds of the Vermillion Creek series, which rest unconformably upon the Laramie beds. The unconformity is most distinctly marked, however, in the beds of the Greon River series, which dip only $4^{\circ}$ to the west, as seen in the bluffs north of Bitter Creek, a short distance west of the sandstone ridges of the Laramie group. To the north of the railroad, our observations extended but a little distance. To the south, the sandstone ridges of the Laramie group curve in strike to the eastward, being partially concealed beneath the horizontal Tertiaries which cover the flanks of Quaking Asp Mountain, and at the head of South Bitter Creek, as already observed, are found with a strike of north $30^{\circ}$ west.

- The study of the rocks of this region, while it only serves to confirm the observations on the beds of the Laramie group at other points, which show that they were deposited conformably over the older Cretaceous formations, and prior to the great period of plication and uplift in which the Recky Mountains and the Uinta and Wahsatch Ranges received their main elevation, and that they may therefore be properly regarded as of Cretaceous age, while the mingling of marine and brackish-water forms in their fauna indicate local shallowings in the seas in which they were deposited, where even fresh-water shells, brought down by rivers, may have been mingled with the remains of animals which actually lived in their waters, shows also that similar conditions of life existed during the early part of the Eocene Tertiary period, which immediately succeeded it, and that when the deposits of this period were laid in approximate or actual conformity 
with the underlying beds, and have since been disturbed in regions of preexisting movement, it is not always possible at the present day to draw a line of definite demarcation between the two formations.

VolCANIC Rocks.-The region of the Green River Basin is singularly poor in volcanic rocks, which, with the exception of the basalt of Fortification Peak, not designated by a special color on this map, were found in only two localities, namely, the Leucite Hills and Pilot Butte.

The Leucite Hills consist of a number of little conical peaks protruded through the beds of the Laramie Cretaceous, which form the plateau country to the north of the railroad, near the Point of Rocks Station. The form of some of these hills seems to indicate the outline of a former large crater, while to the north the lavas are spread out horizontally, capping the hills, and extend beyond the limits of our map, apparently forming the summit of North Pilot Butte. Although no well-defined Tertiary beds were found in actual contact with these eruptive rocks, it is evident, from their position directly over upturned Cretaceous sandstones, and adjoining Green Kiver beds, where the underlying, unconformable Vermillion Creek series is not seen, that they have been poured out, not only since the deposition of the latter Tertiaries, but since their partial removal by erosion.

This locality has a singular interest, not only from the fact of its being so far removed from any other occurrence of volcanic rocks, but still more, because it is, thus far, the only known locality of leucite-bearing rocks on the American continent. The leucite rocks are of a light-gray to greenishgray color, and have a porous feldspathic groundmass, in which the only crystals visible to the naked eye are plates of light-brown mica. The crystals of mica are arranged in almost parallel plates, giving to the rock a slight tendency to schistose structure.

Under the microscope, the felspathic-looking groundmass is found to be made up entirely of microscopic crystals of leucite, showing their characteristic octagonal sections, which become quite dark between crossed nicols. Within the leucite sections can be distinguished also small pale-green grains of augite and particles of glass with enclosed bubbles. No feldspar at all is found to exist in the rock, neither hornblende nor olivine; the only other ingredients, besides leucite and mica, being a small quantity of magnetite and a little 
apatite. The mica is notable for its very feeble power of absorption, so that when examined with one nicol its plates do not become black, but only reddish-brown. To the comparatively small proportion of augite and magnetite in these rocks may be ascribed their unusually light color as compared with the European leucite rocks. Associated with the more compact rock, which has some resemblance in texture to the older European rocks, is a porous variety, which gradually passes into a distinct pumice. An analysis of a medium-grained, somewhat porous specimen, made by Mr. R. W. Woodward, gave:

Silica

Alumina 13.37

Ferric oxide

Ferrous oxide

Lime

Magnesia 6.37

Soda

Potassa 10.73

Lithia trace

Carbonic acid 1.82

Water 2.76

99.58

The pumice is a very singular-appearing rock, consisting of a spongy mass of a light reddish-brown color, in which the cavities are generally lengthened out in parallel directions, while through the whole rock are innumerable minute flakes of a peculiar reddish mica, which occur in elongated plates.

Around the Leucite Hills, the eruptive flows seem to have had some slight metamorphic action on the underlying sandstones, and a bed of semi-crystalline white limestone was found under them to the north, which may probably represent the metamorphism of some of the beds of the Green River Tertiary. No fragments of this eruptive rock were found, except in the immediate vicinity of these hills, though the peculiar metamorphism of the summit strata at Black Butte would seem 
to suggest that this or a similar flow might once have extended in that direction.

Pilot Butte is a curious little conical, castle-like mound, rising about 400 feet above the surface of the plateau country, in the angle between BitterCreek and Green River, to the north of the railroad. It is a rudely circular mass, scarcely 1,000 yards in diameter, having abrupt faces on all sides, and composed of a rather singular volcanic rock, unlike any other found within the limits of the survey. It is evident that the soft Green River Tertiaries, which once surrounded and covered it, must have been eroded away in a similar manner to those around Fortification Rampart. The main mass is a dark-gray, rather porous rock, having at first glance somewhat the appearance of a basalt. Its fracture is, however, less conchoidal, and the pores have not the rounded vesicular shape characteristic of those of basalt. To the unaided eye, it presents an almost homogeneous mass, without distinguishable crystals. On the upper surface of the Butte, the rock is of a light-green color, showing plentiful little reddish specks, and its pores largely filled with white calcite, while the weathered surfaces are of drab-white color, and of a rough fleece-like texture, evidently altered at the time of outflow by contact with the enclosing Tertiary beds.

By the aid of the microscope, it is found that the feldspars, of which the mass is largely composed, are mostly sanidins; but among the smaller crystals are some which have triclinic striation. Besides the feldspars, it contains a little mica, whose decomposition has produced the reddish specks, but no hornblende; a more important and quite unusual constituent is found in small, exceedingly well-defined, colorless, six-sided crystals of augite, whose larger angle is $133^{\circ}$. The rock has also a glassy base, containing, besides opacite, numerous microlites, and may, therefore, be classed under the head of the augitic trachytes, though it presents a rather unusual occurrence among these comparatively rare rocks.

Bridger Basin.-In this basin, the Tertiary beds of the Bridger group are comparatively undisturbed, while those of the lower groups show none of the flexures and local dislocations, which have been noticed in the eastern basin, except along the inmediate base of the mountains in the valley of Henry's Fork. The beds of the former group slope off gently to the 
northward from the base of the Uinta Range at an angle not too great for that of their original deposition, while, on an east and west line, the slope of these beds toward the centre of the basin is too slight to be susceptible of angular measurement. As seen from the summit of Pilot Butte, whence an extensive view is obtained over the basin country to the west and north, the median line of greatest depression in these beds seems to extend in a direction a little east of north from about the junction of Ham's Fork, crossing the Green River, and extending up the valley of the Big Sandy, where its outlines are marked by the prevailing white color of the bluffs formed by the underlying beds of the Green River group. The outcrops of the latter formation find their greatest development along the eastern rim of the basin, while, on the west, they are comparatively thin and inconspicuous, especially toward the base of the Uinta Range, where they were probably cut off by a shallowing of the Tertiary sea, or deposited unconformably along the shore-line of slightly-raised beds of the Vermillion Creek series. 'That to the north the sea of this epoch extended much farther to the westward than the line of our exploration, is rendered probable by the reported discovery of beds, having a close lithological correspondence with those of this group, along Fontanelle Creek, a western tributary of the Green River, and in the valley of Bear River, beyond our northern boundary.

The outcrop of the beds of the Vermillion Creek series, on the other hand, which, throughout the region west of Green River, shown on this map, are, in general, deeply buried beneath these later formations, find their greatest development on the western rim of the basin, where they extend, as will be seen on Map III, high up on the flanks of the Wahsatch Range, increasing in thickness and in coarseness of material. Along the western flanks of the Bitter Creek Ridges, the beds of this formation are exposed by the denudation of north and south tributaries of Bitter Creek, but, in general, are much disintegrated, and show few good outcrops. They are, however, distinctly non-conformable with the beds of the Laramie group, but no distinct unconformity of angle was observed in these valleys between their beds, and those of the overlying Green River series. They are also exposed in the bottom of the upper portion of the valley of Sage Creek, and, as we 
have already seen, at the head of Red Creek. To the west of Red Creek, along the flanks of the mountains, they are upturned at a considerable angle, and show a very distinct non-conformity with the beds of the Green River series. In Henry's Fork basin, north of the Big Horn Ridges, they are represented by a series of red, somewhat clayey sandstones, which dip $25^{\circ}$ to the northward, at the base of a line of bluffs of buff calcareous sandstonse of the Green River series, which have a dip of only $5^{\circ}$ to the northward. These beds are continued to the west of Green River in a series of red banded sandstones, which form bluffs bordering the valley of Henry's Fork on the north, and which, to the west of Henry's Fork, are underlaid by coarse conglomerates dipping $25^{\circ}$ to $35^{\circ}$ northward, which represent the lowest beds of the series observed here. The red sandy and clayey beds are again found at the eastern base of Mount Corson, lying unconformably beneath the Tertiaries of the Bridger group. At no point in this region was a continuous section of the whole series of this group observed, nor, owing to their non-conformity with the Laramie beds, was the base ever determined, hence their thickness is not known, but is estimated at not less than 3,000 feet.

Green RIVEr Eocene.-The most characteristic development of the beds of the Green River Eocene is found in the hills along the west bank of the Green River in the vicinity of Green River City. To the north of the railroad, they form a plateau country, having a bluff face from 800 to 1,000 feet in height to the south and east along the valley of Bitter Creek and that of its northern tributary, and sloping off gently to the north and west. Through the western portion of this platean, the valley of Green River has been cut, exposing along its eastern bank a line of bluffs, about 600 feet in height, whose forms are peculiarly characteristic of the weathering of the beds of this group. They are represented in Plate $\mathrm{V}$, which gives a view taken from a mile above Green River City, looking southwestward down the valley of the Green River, along their base. To the south of the railroad, they form a peculiar series of steeply-rounded ridges, which have received the name of Alcove Ridges, from the shape of the deep, narrow ravines eroded out of their western face. The aggregate thickness of the beds exposed in this region is about 2,000 feet. They comprise a development of 800 to 
1,200 feet of calcareous shales, of white and brown colors, so thinly and regularly laminated that they have been called paper-shales. Within the shales are intercalated thin arenaceous beds, whose proportion increases in descending, while the base of the series is formed of more or less calcareous sandstones of white and buff color, and earthy impure limestones, with local developments of lignite. The upper member consists of a bed of about 100 feet in thickness of coarse brown sandstone, of massive structure, which caps the bluffs in the neighborhood of Green River City, where it seems to have been hardened by local metamorphism so as to have preserved from erosion the underlying, more easily-disintegrated beds. In Plate VI, which represents two peculiar tower-like columns about 150 feet in height projecting from the summit of the hills back of Green River City, the summit of the columns is seen to be formed of the massive sandstone, their base being in these peculiar fissile shales. The best exposures of the shales are found at the base of these bluffs, and in the railroad cuts, about four miles to the west of Green River City, and along the valley of Bitter Creek, to the east. From the shale beds at these localities immense quantities of fish remains have been obtained, together with a few fossil insects. Among the fishes, although individuals are so abundant, the number of species discovered is thus far comparatively limited. As described by Professor Cope, ${ }^{1}$ the genera Clupea, Asineops, Erismatopterus, and Osteoglossum are represented. In their affinities, they are closely allied to the Eocene Tertiaries of Monte Bolca in Italy. The living representatives of the latter genus inhabit generally fresh waters of warm, equatorial regions, while the presence of the first named, whose modern representatives are the herrings, indicate a probable connection of the sea with salt-waters.

The following species have been described from these beds:

FISHES.

Clupea humilis, Leidy.

Clupea alta, Leidy.

Clupea fusilla, Cope.

Osteoglossum encaustum, Cope. 


\section{Asineops squamifrons, Cope. \\ Asineops viridensis, Cope. \\ Erismatopterus Rickseckeri, Cope. INSECTS (COLEOPTERA). \\ Antherophagus priscus, Scudder. \\ Endiagogus saxatilis, Scudder. \\ Trypodendron impressus, Scudder. \\ Corymbites velatus, Scudder.}

The molluscan remains of this formation, however, found principally near the base of the series, are all distictly fresh-water types. $\Lambda \mathrm{s}$ far as observed, they are species of Viviparus, Goniobasis, and Unio, which cannot be specifically distinguished from those found in the other Tertiary beds of the basin. Throughout the shale series are numerous beds which are more or less impregnated with bituminous material, and which are characterized by the bluish-white color of their weathered surfaces. They are often sufficiently rich in carbon to burn readily, and yield on distillation a considerable amount of mineral oil. They are most frequent in the horizons which abound in fish remains, and it is from the decomposition of these that their carbonaceous material has probably been derived. The lithological character of the beds indicates deposition in still, comparatively deep waters. The material is a fine silt composed largely of carbonate of lime, the other constituents being mainly finely-comminuted sand. The following analysis of a specimen of the paper-shales was made by $\mathrm{Mr}$. $\mathrm{B}$. E. Brewster :

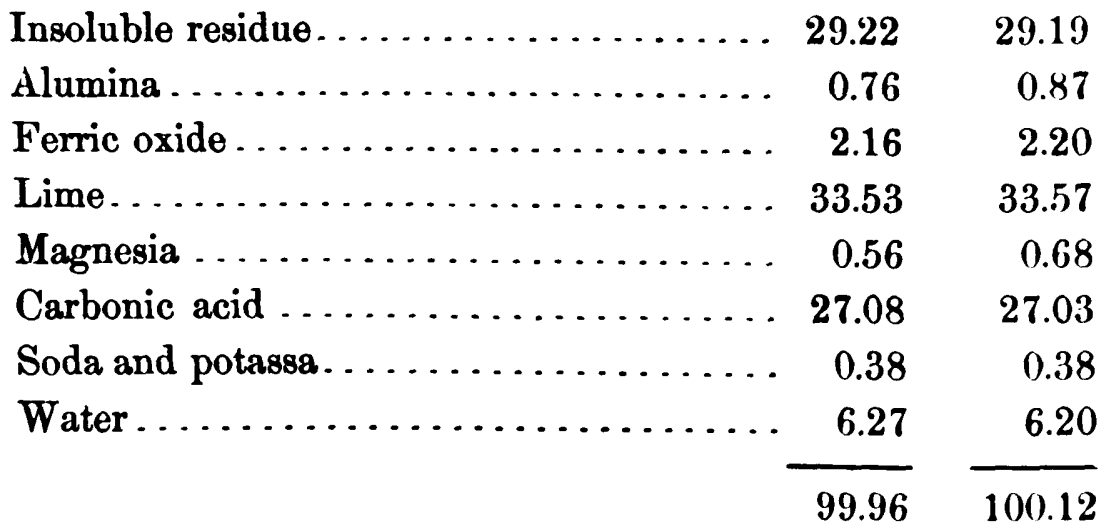


Insoluble residue :

Silica ............................... 23.47

Alumina .......................... 5.40

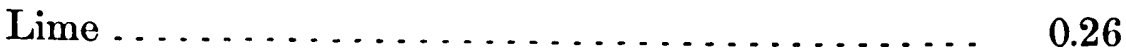

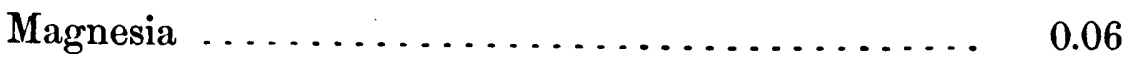

29.19

The dip of the beds, as seen to the east of Green River City, in the line of bluffs to the north of Bitter Creek, is very regular at an angle of $4^{\circ}$ to the westward. They are also exposed at the base of the bluffs, and in the ravines on the western side of the river opposite Green River City, where they preserve the same angle, but at the summits of the low flat ridges between Green River and Black's Fork are covered by thin-bedded drab sandstones, which form the base of the Bridger group, in general too much disintegrated to show distinct planes of bedding, but apparently dipping not more than $1^{\circ}$ or $2^{\circ}$ to the westward. The formation descends slightly to the northward, and the most northerly point, where a good exposure of the shale beds was found to the west of the river, is in the railroad-cut 4 miles west of Green River City. To the north of this point, the upper brown sandstone can be traced along the west bank of the river to a point about 12 miles above Green River City, where it crosses the river and disappears to the northward beneath the lower beds of the Bridger group.

Six miles south of the railroad, Green River enters a cañon-like gorge, cut through the lower beds of this formation, which was not explored by our parties. From this point south to the lower valley of Henry's Fork, the beds of the Green River series preserve a general inclination of $4^{\circ}$ to $5^{\circ}$ to the westward, forming flat mesa-ridges, which rise in a series of terraces from the Green River to the meridian of Quien Hornet Mountain, and a short distance to the west of the river are covered by the horizontal beds of the Bridger group. Along the flanks of the Uinta Range, they have locally steep dips to the north. On the northern face of Quien Hornet Mountain, as we have seen, the buff calcareous sandstones of the lower portion of the series are exposed, dipping $4^{\circ}$ to the northward, overlaid non-conformably by the beds of the Wyoming Conglomerate, and underlaid, in the basin of Red 
Creek, by the red and chocolate beds of the Vermillion Creek series, with no observed discrepancy of angle.

From Quien Hornet Mountain eastward to Green River, the buff calcareous sandstones and limestones dip $5^{\circ}$ to the northward, with a nomconformity of from $5^{\circ}$ to $15^{\circ}$ with the underlying Vermillion Creek Tertiaries. These beds form the gateway of the cañon of Green River, at its entrance into the lower valley of IIenry's Fork, dipping $5^{\circ}$ to the northward, while the underlying reddish sandstones and clays of the Vermillion Creek series dip $10^{\circ}$. They are traced along the lower flat spurs of Twin Buttes, between Green River and Henry's Fork, and, as exposed in the valley of Henry's Fork, contain some lignitic seams, one of which is of sufficient thickness to constitute a vein of coal. 'To the west of Henry's Fork, north of Deadman's Spring, they form low ridges, dipping 25? to the north, made up of yellow sandstones and whitish limestones, carrying casts of Goniobasis, and some interstratified shales. West of this point, they are covered by the soft soil resulting from the decomposition of the Briderer beds, no further outcrops having been observed on this side of the basin.

On the western side of the basin, the beds of the Green River series have been observed at comparatively few points. Near the railroarl-station at Piedmont are outcrops of white impure limestone and thin calcareous shales, from which were obtained a few indistinct remains of fishes similar to those found near Green River City. These outcrops are isolated by the Quaternary accumulations of Muddy Creek; but their geological horizon is sufficiently indicated, both by their lithological character and their position between the horizontal beds of the Bridger group, which form the bluffs on the east of this valley, and the slightly-inclined chocolate and red sandstones of the Vermillion Creek series, which rise to the west. They are represented to the northward by light calcareous beds, to the west of Carter's Station, which are immediately succeeded to the westward by the same underlying red and checolate sandstones. They extend to the northward in a line of low ridges, having a bluff exposure to the westward, and in the desert plains to the north, where, thongh not traced continuously, they occupy approximately the line of outcrop indicated on the map.

Bridaer Eocene.-The beds of this formation are found in their 
greatest development in the southern portion of the Bridger Basin. Throughout the basin, they occupy an approximately horizontal position, no steeper angle of dip being observed in them, even along the immediate flanks of the Uinta Range, than $4^{\circ}$. Their aggregate thickness in this basin is estimated at from 2,000 to 2,500 feet. As compared with the beds of the Green River series, they are characterized by an absence of calcareous material. The lower beds consist of a series of gray-drab sandstones, generally rather thinly bedded, with a varying proportion of argillaceous beds. The upper 1,000 or 1,500 feet of the formation consist of heavy beds of peculiar, loosely aggregated, but homogeneous clayey sandstone, of prevailing olivegreen color, containing thin, interstratified beds of harder sandstones, and in the upper portion of the series passing into marls, and at two horizons into impure limestones. The beds abound in siliceous and calcareous secretions; the latter form seams, about an inch in thickness, of crystalline carbonate and sulphate of lime, whose glistening fragments at times almost cover the surface of the ridges; from the former result the moss-agates, in which the region abounds, and singular cylindrical concretions, which in places have weathered out of the rusty-drab sandstones, resembling the broken trunk of a small tree, whose hollow interior is lined with crystals of quartz.

Along the line of the railroad and to the north only the lower beds have escaped erosion, consisting of thin-bedded drab and greenish sandstones and clays, forming a monotonous region of low flat ridges, whose surface is only varied by the shallow alluvial valleys of Black's Fork and its tributaries. To the south of the railroad, the country rises in a series of irregular, broad, flat terraces, in which each terrace represents approximately a higher bed of the series. At Church Buttes, the first exposures of the characteristic bad-land formation are found. These hills, which are isolated portions of the beds, which form the line of bluffs bordering the upper valley of Black's Fork on the east, have been so named from the peculiar architectural forms into which the green argillaceous sandstones of the upper part of the Bridger formation are eroded. The peculiar character of this erosion, which is similar to that already noticed in the Washakie Basin, and of which typical views are given in the colored illustrations of volume $I$, is best seen in the region of Grizzly Buttes, an irregularly semicircular line of bluffs, cut 
through by a labyrinthine system of dry water-courses, at the head of Cottonwood Creek. From the beds exposed in this region, and along the northern borders of the valleys of Henry's Fork, have been obtained most of the remains of Eocene vertebrates for which this basin is renowned. $\Lambda$ fresh undecomposed specimen of one of the peculiar green sandstones from these vertebrate beds is of a light bluish-green color, and consists of a mixture of fine grains of quartz and black mica with some decomposed feldspar, with a cement of greenish clay. Its analysis, made by Mr. W. R. Woodward, gives the following results:

\begin{tabular}{|c|c|c|}
\hline Silica & 66.17 & 66.42 \\
\hline Alumina . . . . . . . . . . . . & 14.95 & 14.73 \\
\hline Ferric oxide. . . . . . . . . . . . . . & 2.76 & 2.82 \\
\hline Ferrous oxide & 1.95 & 1.93 \\
\hline Manganese . . . . . . . . . . . . & trace & trace \\
\hline$\ldots \ldots \ldots \ldots$ & 3.87 & 3.89 \\
\hline Magnesia . . . . . . . . . . . . . . . . . & 1.88 & 1.97 \\
\hline Soda .... . & 2.84 & 2.97 \\
\hline Potassa . . . . & 3.77 & 3.61 \\
\hline Lithia . . . & trace & trace \\
\hline 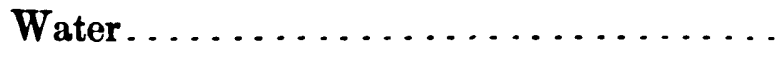 & 2.61 & 2.57 \\
\hline \multirow[t]{2}{*}{ Sulphuric acid } & trace & trace \\
\hline & 100.80 & 100.91 \\
\hline
\end{tabular}

The greatest thickness of continuous beds of the Bridger Eocene is found in the face of the bluffs which wall in the valley of Henry's Fork on the north. The higher portions of these ridges are still covered by deposits of Wyoming Conglomerate in an apparently conformable position, and in these places it is probable that the Bridger beds have suffered comparatively little erosion. On the plateau above Turtle Bluffs to the north, a thickness of some 200 feet of Wyoming Conglomerate still remains, composed of coarse gravel and boulders of quartzite, with a small proportion of limestone fragments, in a somewhat calcareous cement. At the Twin Buttes also, where the Bridger beds have an inclination of $2^{\circ}$ to the north and west, a thickness of about 40 or 50 feet of the Wyoming Conglomerate caps the 
summit. On the face of Turtle Bluffs, so called from the great quantity of fossil remains of this animal which have been weathered out of the beds of its slopes, the calcareous beds are easily distinguished. One of them is almost entirely made up of remains of Planorbis spectabilis. An analysis of a green calcareous narl from these bluffs, made by Mr. B. E. Brewster, gave :

\begin{tabular}{|c|c|c|}
\hline Silica ... & 31.28 & 31.45 \\
\hline Alumina . & 1.83 & 1.58 \\
\hline Ferric oxide.. & 0.22 & 0.21 \\
\hline Lime $\ldots . .$. & 34.20 & 34.18 \\
\hline Magnesia .. & 0.11 & 0.08 \\
\hline Soda...... & 0.18 & 0.28 \\
\hline Potassa. . . . . . & 0.33 & 0.33 \\
\hline 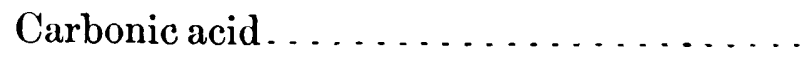 & 26.79 & 26.82 \\
\hline \multirow[t]{2}{*}{ Water $\ldots \ldots \ldots \ldots \ldots \ldots \ldots \ldots$} & 4.64 & 4.64 \\
\hline & & 99.57 \\
\hline
\end{tabular}

To the south of Henry's Fork, on the immediate flanks of the Uinta Mountains, which are largely covered by forest growth, the Tertiary beds are mostly disintegrated and concealed beneath the surface accumulations, and their actual contact with the upturned Carboniferous strata was not observed. That this line was deeply covered by the deposits of the Wyoming Conglomerate is rendered probable by the great thickness of these beds now existing on Mount Corson, where it amounts to nearly 1,000 feet. In the same way in the higher bench-ridges to the westward, the presence of Tertiaries is rather indicated by their shape than actual observation of the beds, the slopes of the ravines being covered by gravel, and the cañon-bottoms, toward the head, containing large accumulations of moraine-material. A considerable extent of the Wyoming Conglomerate is found on the surface of the flat ridge between Black's Fork and Bear River, called Concrete Plateau. On the northern edge of the plateau, it is exposed in a thickness of 100 to 200 feet, and consists of a white conglomerate made up of pebbles of white and red quartzite, and sometimes Carboniferous limestone in a calcareous cement. 
An analysis of this cement, made by Mr. 13. F. Brewster, gave:

Silica.

Soluble silica .................. 0.405

Alumina and Ferric oxide ............. 0.781

Lime..................... 47.007

Magnesia . . . . . . . . . . . . . $48 \ldots \ldots \ldots$

Carbonic acid................... 37.079

Water and organic matter............. 2.409

100.072

The insoluble silica doubtless comes from a mechanical mixture of fine sand. As the beds of the Wyoming Conglomerate, as far as observed, are entirely devoid of all organic remains, the only evidence of their geological age is obtained from their rolative stratigraphical position, from which it is deduced that they were deposited probably not long anterior to the Glacial period.

The molluscan remains of the Bridger beds, which are found principally in the lower part of the formation, hardly distinguish them in age from the other groups in this basin. Those which have been described belong to the following fresh-water species:

\author{
Unio Haydeni. \\ Planorbis spectabilis. \\ Planorbis spectabilis var. Utahensis. \\ Limnaa (Limnophysa) vetustus. \\ Limnaa similis. \\ Goniobasis Simpsoni. \\ Goniobasis arcta. \\ Goniobasis tenera. \\ Viviparus paludina, formis. \\ Viviparus Wyomingensis. \\ Pupa Leidyi.
}

The vertebrate remains, of which large collections have been made by Professor Marsh and his assistants, will be found specifically described by him in a later volume. They indicate a Middle or Lower Eocene horizon, 
and, in general, a warm semi-tropical climate. The following list includes some of the principal forms of the different families of vertebrates found by Professor Marsh's parties in the beds of the Bridger series:

$$
\begin{gathered}
\text { Primates .... } \\
\text { Carnivores.... }\left\{\begin{array}{l}
\text { Lemuravus distans, Marsh. } \\
\text { Hyopsodus paulus, Leidy. } \\
\text { Limnotherium tyrannus, Marsh. }
\end{array}\right. \\
\text { Bats ........ } \begin{array}{l}
\text { Uintacyon edax, Leidy. } \\
\text { Dromocyon vorax, Marsh. } \\
\text { Limnofelis ferox, Marsh. }
\end{array} \\
\begin{array}{l}
\text { Nyctitherium velox, Marsh. } \\
\text { Nyctitherium priscum, Marsh. }
\end{array}
\end{gathered}
$$$$
\text { Insectivores... }\left\{\begin{array}{l}
\text { Talpavus nitidus, Marsh. } \\
\text { Centetodon pulcher, Marsh. } \\
\text { Entomacodon angustidens, Marsh. }
\end{array}\right.
$$

Rodents..... $\left\{\begin{array}{l}\text { Sciuravus nitidus, Marsh. } \\ \text { Paramys delicatus, Leidy. } \\ \text { Tillomys senex, Marsh. }\end{array}\right.$

Dinocerata .... $\left\{\begin{array}{l}\text { Tinoceras anceps, Marsh. } \\ \text { Uintatherium robustum, Leidy. } \\ \text { Dinoceras mirabile, Marsh. }\end{array}\right.$

Perissodactyles . $\left\{\begin{array}{l}\text { Palaosyops paludosus, Leidy. } \\ \text { Hyrachyus agrarius, Leidy. } \\ \text { Orohippus agilis, Marsh. }\end{array}\right.$

Suillines...... $\left\{\begin{array}{l}\text { Homacodon vagans, Marsh. } \\ \text { Helohyus lentus, Marsh. }\end{array}\right.$

Tillodontia.... $\left\{\begin{array}{l}\text { Anchippodus minor, Marsh. } \\ \text { Stylinodon mirus, Marsh. } \\ \text { Tillotherium fodiens, Marsh. }\end{array}\right.$

Birds ....... $\left\{\begin{array}{l}\text { Bubo.leptosteus, Marsh. } \\ \text { Aletornis nobilis, Marsh. } \\ \text { Uintornis lucaris Marsh. }\end{array}\right.$

Turtles ....... $\left\{\begin{array}{l}\text { Trionyx guttatus, Leidy. } \\ \text { Baptemys Wyomingensis, Leidy. } \\ \text { Anosteira ornata, Leidy. }\end{array}\right.$ 


$$
\begin{gathered}
\text { Crocodilians ... } \begin{array}{l}
\left\{\begin{array}{l}
\text { Limnosaurus ziphodon, Marsh. } \\
\text { Crocodilus Elliotti, Leidy. } \\
\text { Crocodilus brevicollis, Marsh. }
\end{array}\right. \\
\text { Lizards ...... }
\end{array} \\
\text { Ophidians .... }\left\{\begin{array}{l}
\text { Glyptosaurus princeps, Marsh. } \\
\text { Thinosaurus leptodus, Marsh. } \\
\text { Oreosaurus lentus, Marsh. }
\end{array}\right. \\
\left\{\begin{array}{l}
\text { Boavus occidentalis, Marsh. } \\
\text { Lithophis Sargenti, Marsh. } \\
\text { Limnophis crassus, Marsh. }
\end{array}\right. \\
\text { Fishes ....... }\left\{\begin{array}{l}
\text { Amia Newberrianus, Marsh. } \\
\text { Lepidosteus glaber, Marsh. }
\end{array}\right.
\end{gathered}
$$

Cretaceous Uplift of Oyster Ridge.-Along the northwestern border of the Bridger Basin rises a series of low ridges, outliers of the Aspen Plateau, which forms the watershed between the waters of the Green and Bear Rivers. This line of elevation has been determined by a folding of the Cretaceous and underlying strata at the time of the main pre-Cretaceous uplift, and, as might naturally be expected from their position in the angle of the great Wahsatch and Uinta Ranges, the direction of the fold shows the combined influence of these two great shore-lines, whose waves sometimes cross, each preserving their independent strike, but in general take a direction which is the resultant of the two. Over the upturned edges of these folds, the beds of the Vermillion Creek Eocene have been deposited unconformably, here consisting of a series of coarse argillaceous sandstones, of banded chocolate and pinkish colors. The principal exposures of the Cretaceous beds are found where the erosion of the Tertiaries has been most considerable, viz, along the north and south valley of the Upper Littlo Muddy and Ham's Forks, and in the ridge which bounds it on the east, called, from the abundance of fossil remains of the genus Ostrea found upon it, Oyster Ridge, whose culminating point, Ham's Hill, rises about 1,600 feet above the adjoining plains. The strikes of the beds vary from north $30^{\circ}$ east to due north, while their dip is in general to the westward; it is evident, therefore, that a very considerable amount of erosion took place between the time of the folding of these beds and the deposition of the overlying Tertiaries, probably combined with some faulting, in consequence of 
which the eastern side of the fold has disappeared. In their parallelism, their generally steep angles, and the persistency of direction of their strike, these folds resemble those of the Appalachian system more than those generally observed in this region.

At the northern limit of the map, Ham's Hill is composed of white shaly sand-rocks and massive sandstones, having a strike a little east of north and dipping $20^{\circ}$ to the westward, which, from its general lithological character, is considered to belong to the Fox Hill group. A probable continuation of this fold to the northward has been observed by Professor Cope on Fontanelle Creek, where he notes a well-defined anticlinal fold, in which are exposed by erosion conformable beds as low as the Upper Carboniferous limestone. To the west of Ham's Hill, the eastern foot-hills of Aspen Plateau, as seen from a distance, are composed of almost horizontal beds of the pinkish gravels of the Vermillion Creek series. This region not having been thoroughly explored by our parties, it is not impossible that, in some of the deeper ravines, there may not be exposures of underlying Cretaceous rocks, which have not been indicated on the map.

At the point where the Little Muddy cuts through Oyster Ridge, similar sandstones to those found on Ham's Hill form the western edges of the ridge, with a dip of $20^{\circ}$ to the westward. The strike at this point is north $15^{\circ}$ east, but assumes a northern direction a few miles farther north. In the little circular valley just west of the ridge, at this point, are exposed some clayey beds, too much disintegrated to show a definite structure; but as they are succeeded on the east by the same sand-rocks, dipping $25^{\circ}$ to the eastward, with a strike of north $15^{\circ}$ east, they have been colored as belonging to the Colorado series. At no other point was the eastern member of this fold observed. The overlying striped red and white clays of the Vermillion series form a semicircular wall to this valley on the east, dipping eastward at an angle of $3^{\circ}$ to $4^{\circ}$.

In Oyster Ridge, south of the gap, the two strikes above mentioned are observed in conjunction. From the gap a few miles southward, the strike continues nearly north and south, and then bends to the westward, assuming a position of $30^{\circ}$ east of north, while the dip at the curve steepens to $45^{\circ}$ west. In the sandstone beds, which form the crest of this ridge, are found immense quantities of remains of Ostrea soleniscus, a long narrow shell from 8 to 12 
inches in length, a species which, as far as our observations go, has not been found higher than the Fox Hill horizon. Interstratified in these sandstones is a peculiar bed of green siliceous clay-slate, made up of fine grains of quartz in a green amorphous clayey matrix, which also seems somewhat characteristic of this horizon.

The southern portion of the valley of the Little Muddy occupics a synclinal fold in the rocks of the Fox Hill group. On the western sille of the valley, in one or two of the ravines, however, where the overlying Tertiaries have been eroded off, the crest of an anticlinal fold is found, whose members $\operatorname{dip} 45^{\circ}$ east and west, with the same strike of north $30^{\text {? }}$ east. To indicate this structure, a strip of Laramie beds has been colored on the map, although, owing to the close lithological resemblance of the Fox Hill and Laramie groups and the absence of characteristic fossil distinctions, it cannot be definitely determined that the Laramic beds are actually exposed here. At the extreme southern end of the valley, the folds become narrower and more abrupt, and the dip steeper, still preserving, however, the same trend of north $30^{\circ}$ east. At the upper end of the valley, the beds of the Fox Hill group, which form the synclinal, dip $60^{\circ}$ toward the centre. In a little ravine to the eastward are found $a$ series of beds of blue clay containing very perfect casts of Cardium pauperculum, a characteristic fossil of the Colorado group. Through these beds, borings have been made for oil, and a small anount of fair petroleum obtained. It was impossible to determine the exact horizon of the oil-bearing rocks, though they probably belong to the lower part of the Colorado series. The summit of the ridge is here capped by the beds of the Vermillion Creek group, dipping $2^{\circ}$ or $3^{\circ}$ to the eastward, and, at their eastern base in Pioneer Hollow, are found sandstones dipping $20^{\circ}$ westward, and carrying a 20-foot vein of coal. These rocks have been colored as belonging to the Fox Hill group, because the clays of the Colorado group on the other side of the ridge dip $45^{\circ}$ to the eastward, which would apparently carry them under these sandstones. It is possible, however, that there may be faulting in this region, and that the sandstones may belong to the Colorado group, in which case the coal seam corresponds to that found at this horizon on the south slope of the Uintas. 
Along the line of the railroad, Cretaceous strata are again found exposed near $\Lambda$ spen Station. Here are several hundred feet of bluish clay beds filled with fish-scales and oceasional impressions of bones and teeth, in which also some fragments of Ammonites were found, while intercalated in the clay beds are occasional beds of grayish limestone. These beds dip at an angle of $10^{\circ}$ to $15^{\circ}$ to the westward, and are overlaid on the summit of the ridge by a considerable thickness of white and gray sandstones, in which are found the Ostrea soleniscus of Oyster Ridge, for which reason they have been referred to the Fox Hill group, while the underlying clays undoubtedly belong to the Colorado series. All these beds have a close connection with the Cretaceous expostres on the west side of the divide near Bear River City, which will be seen represented on Map III. 


\section{SECTION IV.}

\section{DESCRIPTIVE GEOLOGY OF THE MOUNTAIN REGION.}

Northern Slopes of the Uinta Range.-From Concrete Plateau to Mount Corson the Mesozoic beds involved in the Uinta upheaval are, in general, deeply buried beneath the Tertiary and post-Tertiary accumulations of the Bridger Basin. The Tertiary beds, which attain an elevation of over 10,000 feet, extend high up on the flanks of the ranges as far as the Weber Quartzite, the lowest group of conformable sedimentary beds, which form its core, so that, seen from the interior of the basin, the range presents the appearance of a partially-submerged mountain-ridge. It is only in the deeper cañon-cuts of the streams flowing from the interior of the range that the upturned edges of the Mesozoic beds may be observed, and here, even, they are sometimes obscured, and their continuity broken by accumulations of gravelly material, glacial moraines, and débris of the Wyoming Conglomerate. In the eastern portion of this extent, the denudation has been greater, and a proportionately larger extent of outcrops of these older formations may be found. The siliceous limestone beds of the Upper Coal-Measure group can, in general, be more easily traced, as, on account of the resisting nature of their material, and the generally steep angle at which they stand, they have formed high, narrow ridges, which frequently project above the horizontal Tertiary beds, thus affording a guide to the general direction of the lateral flexures, which cause deviations from the general east and west strikes of the formations involved in the uplift. The difficulty of tracing the outcrops of the upturned beds is enhanced by the forest-covering, which extends over the upper portion of the flat, terrace-like spurs, commencing at an elevation of less than 9,000 feet, and stretching up to the bases of the high, castellated, rocky ridges and peaks of the interior of the range.

Along the steep banks of the canon-like valleys at the head of Black's Fork, good exposures are found of the Triassic sandstones and the PermoCarboniferous and Upper Coal-Measure limestones.

The ridge which forms the divide between these waters and those of Bear River is, as we have seen, in its lower part, a comparatively level 
plateau (Concrete Plateau), capped by beds of the Wyoming Conglomerate. At Lime Pass, the denudation of these beds has exposed the limestones of the Upper Coal-Measures, dipping $45^{\circ}$ to the northward, and striking about $15^{\circ}$ north of east. The better exposures are heavy, massive beds of grayish-blue limestone, which stand out in ridges, while the upper and more argillaceous beds have been worn away into low saddles and ravines, and covered up by surface accumulations and vegetation. On the eastern side of the west branch of Black's Fork, opposite Lime Pass, these softer beds are seen to consist of mud-rocks and slates, which probably correspond to the Permo-Carboniferous beds of this character in the Weber Cañon, while in the limestones were found a few Carboniferous fossils, among which only a Productus Prattenianus has been specifically determined. Overlying the slates and mud-rocks were found coarse-gray and reddish sandstones of the Triassic formation, whose exposures as observed were too limited to afford a continuous section of the formation. Doubtless, a more detailed examination might disclose also outcrops of some of the higher formations, which were hidden by the forest-covering from the general examination made by us. The lower beds of the Upper Coal-Measure group consist here of conglomerates, which, on the western side of the valley, are very coarse, while on the eastern ridge they have more the character of a coarse-grained gray sandstone, made up of grains of limpid quartz in a siliceous matrix, and sometimes stained by iron oxide.

A great thickness of the underlying beds of the Weber Quartzite group is exposed in section by the cañon-cutting of the upper valley of the west branch of Black's Fork. In the narrow ridge between the head of Black's Fork and Bear River, the dip gradually steepens from Lime Pass upward, from $45^{\circ}$ to $52^{\circ}$, without showing any non-conformity, and toward the head of the ridge shallows again to $16^{\circ}$, beyond which, in the axis, there seems to be a sudden break, and in the peaks near the head of the cañon the beds dip $5^{\circ}$ to the southward. The upper beds of this group (the Weber Quartzite) here consist mainly of coarse red sandstones, frequently characterized by a fine striping parallel to the beddingplanes. Below these is a great thickness of red and purple quartzites, made up of rounded grains of quartz, sometimes so large as to constitute a fine con- 
glomerate, and containing a varying admixture of broken feldspar crystals. Interstratified with these quartzites are several beds of greenish clays, from 50) to 100 feet in thickness, sometimes hardened into argillaceous slates, and containing a little mica. The lower beds consist, in general, of more compact, fine-grained quartzites, of a lighter color, passing into a white opaquo quartz-rock, which has only been observed in this part of the range.

On the eastern side of the canon, the immense mass of Tokewanna Peak, which reaches an altitude of 13,458 feet, is formed of beds of the purple and red quartzites, dipping $16^{\circ}$ north. The steeper dips of $52^{\circ}$, found on the Bear River Ridge, were not observed bere, though the Upper Coal-Measure strata reach $45^{\circ}$; and may probably be caused there by a local change of strike, or a curving in of the beds toward the axis of the range. The geological axis on this side of the cañon runs through the saddle in the ridge, beyond the second peak south of Tokewanna, while the main summits beyond this point are formed of similar beds, dipping $5^{\circ}$ to $6^{\circ}$ southward. The thickness of the upturned beds of the Weber Quartzite belonging to the northern member of the fold cannot be less than 10,000 feet at this point. The sudden character of the change of dip at the axis would seem to indicate a dislocation, and probable displacement along its line, but whether the downthrow be to the northward or southward can hardly be determined by the lithological character of the beds, which show only such very general distinctions at different horizons, that it is impossible to trace a correspondence of strata on these grounds without an exceedingly minute and detailed examination.

The main crest of the range is made up of beds of quartzite dipping $5^{\curvearrowright}$ to $7^{\circ}$ southward, which have been carved out by the action of nivé-ice into huge, shallow, semicircular basins, scantily covered by timber, and containing numberless little shallow lakes and ponds, which are inclosed by almost perpendicular walls and ridges, sometimes rising into peaks two and three thousand feet above their general level.

On the spurs between the east and west branches of Black's Fork, north of Tokewanna Peak, the beds of the Upper Coal-Measure group 'an be traced by the narrow ridges of limestone, projecting like walls above the general surface, here and there, and by the transverse depressions and 
widening-out of the stream-beds, resulting from the erosion of the softer beds. In the cañon of the East Fork, several outcrops of limestone are found, while lower down the stream sandstones, probably Triassic, are seen cropping out from under the gravelly slopes of its banks, overlaid at some little distance still farther north by an earthy limestone, which has been referred to the Jurassic formation. The strike of the Upper Coal-Measure limestones on these spurs is $15^{\circ}$ east of south, but must bend northward again to accord with its position on Smith's Fork, though, in the thicklytimbered and gravel-covered plateau between Black's and Smith's Forks, no sufficient outcrops were found to accurately determine their position. Near the forks of Sawmill Creek, to the north of Gilbert's Meadows, were found some loose fragments of limestone, evidently not far from their parent beds, which resemble lithologically those of the Jurassic beds. This probable position of the Jurassic beds accords with the idea of a sharp lateral flexure to the north at this point.

The western side of the valley of Smith's Fork, opposite Gilbert's Meadows, is occupied by an immense lateral moraine, now overgrown by forest, but easily distinguished by its peculiar topograplyy from the gravelly beds of the Wyoming Conglomerate. This, and some terminal morainematerial in the valley, obscure the outcrops of the Upper Coal-Measure limestones; consequently, the first exposures of the underlying rocks are quartzite beds, dipping $42^{\circ}$ northward. This dip holds, in ascending the creek, to the point where it forks, beyond which the dip flattens on the west side to $20^{\circ}$ for the distance of a couple of miles, and then, at a point marked by a side-ravine, changes suddenly to horizontal, and, farther up, to a dip of $5^{\circ}$ to the southward. This side-ravine seems to mark a line of faulting; but, from the want of any definitely recognizable horizon in the beds of the Weber Quartzite, it is difficult to determine whether the downthrow has been to the north or to the south.

The Indian trail, which crosses the range at this point, leading from Fort Bridger to the Uinta Reservation, affords a section which is characteristic of the general Uinta uplift, passing as it does along the western base of its mast lofty peaks. Above the steep dips of the northern side of the fold, already mentioned, the head of Smith's Fork is an amphitheatre-like $17 \mathrm{D} \mathrm{G}$ 
valley, surrounded by castellated peaks and ridges, formed of nearly horizontal beds of the Weber Quartzite, but having already a slight inclination of $3^{\circ}$ to $5^{\circ}$ to the southward. Jones's Pass, at the head of this valley, the lowest point in the divide from the western limit of the map nearly to Leidy's Peak, has an altitude of over 11,000 feet. From this saddle, the trail descends the cañon of the Ute Fork, in which the southerly dip increases very gradually, being less than $10^{\circ}$ at Emmons' Peak, while it is only near the southern flanks of the range that the steep angles of $40^{\circ}$ to $45^{\circ}$ are reached, and the overlying limestones of the Upper ConalMeasures found.

The form of the Tertiary ridge to the east of Smith's Fork, which is covered by the Wyoming Conglomerate, would suggest that this formation might resemble that of the Pliocene Conglomerate of California, in that it had filled an ancient stream-bed in the Eocene Tertiaries, which, owing to its being more resisting than the strata out of which it was cut, is left in the present topography as a ridge.

In the basin-like heads of Henry's Fork, next east from Sinith's Fork, which are thickly timbered, only quartzite formations are found; but the low, sharp ridges which enclose them on the north, are evidently, as farther west, outcrops of the harder limestones of the Upper Coal-Measure group. On the northern spurs of Gilbert's Peak, the quartzite beds are found dipping $42^{\circ}$ north, up to within a few miles of its base. The beds which form the peak itself have a slight southern dip, and are formed of purple quartzite, with several strata of greenish clayey beds, about 100 feet in thickness. These are entirely wanting in the upper 1,000 feet of the peak. From the summit of this peak, an excellent view is had of the interior of the range over the broad, shallow, glacier-formed basins at the head of the various creeks which flow to the north and south, and the steep, narrow ridges, formed of nearly horizontally-stratified beds of quartzite, whose slope, when.appreciable, is always to the south. From here, the axis of the range is seen to have a northeasterly direction from the Tokewanna Ridge to this point, probably bending outward still more to the north at Smith's Fork, while to the eastward it assumes a general east and west trend. The northern shoulders of the main ridge, to the eastward of Gil- 
bert's Peak, have a slight dip $3^{\circ}$ to $5^{\circ}$ northward, while at a point a little below the upper timber-line the dip falls off steeply into that of the limestone ridges to the north.

Burro Peak is formed of almost horizontal beds of quartzite, with an apparent dip of $1^{\circ}$ to the north. The steep wall of quartzite, forming the northern face of the higher portion of the range from Burro Peak eastward to Leidy's Peak, marking approximately the line of the main geological axis, is probably a line of faulting and displacement corresponding to that at the head of Smith's Fork. The range was crossed at Burro Peak and again on the Indian trail to the east of Leidy's Peak; but between these points, that is, from Island Pond to the head of Burnt Fork, there is a gap in our observations on the northern slope.

At the western base of Mount Corson lies the little valley of Burnt Fork, one of the tributaries of 'Henry's Fork, which is characterized by an unusually broad expanse of meadow-land, dotted by little clumps of pine. Toward the head of this valley may be seen low ridges, composed of strata of dark compact earthy limestone, having a strike of east $15^{\circ}$ south, and dipping $35^{\circ}$ to $45^{\circ}$ north. No fossil remains were found in them; but, from their position, the limestones doubtless belong to the same horizon as those, which are found to the east of Mount Corson, near Sheep Creek, carrying well-recognized Jurassic fossils. About 200 yards north of these are similar low ridges, showing indistinct outcrops of white sand-rock, having the same strike and dip, which probably represent beds of the Dakota Cretaceous. In the wooded region, at the head of this valley, and yet below the flanks of the Uinta Range proper, are curious ridges of bare rock, standing prominently out among the green valleys, formed of massive buff sandstone, in beds over 100 feet in thickness, in which the prevailing yellow color sometimes passes into a pink. These sandstones are formed of fine pure white quartz sand, owing their color to minute specks of iron oxide plentifully disseminated through their mass, and belong to the upper group of the Triassic sandstones, which, as will be seen later, are so characteristically exposed on the Flaming Gorge Ridge. The lower deep-red sandstones of this group were not distinctly traced here, owing to the covering of forest and surface débris, but are well 
exposed farther east in Connor's Valley. They correspond in dip and strike with the Jurassic limestones before mentioned.

Following the Sheep Creek trail, which passes up this vallcy, the flanks of the main Uinta elevation are found to consist at first of wooded ridges, running in general, parallel, to the strike of these rocks, and rising higher as one proceeds. Of these, the first seems to be formed still of the sandstones of the Triassic formation. The second and third ridges, however, show outcrops of the limestones of the Upper Coal-Measure group, beyond which, in a basin-like country at the head of Sheep Creek, are found the red sandstones and quartzites of the Weber group, still striking east and west, and dipping $30^{\circ}$ to $35^{\circ}$ north. This dip, however, soon flattens out to $10^{\circ}$ and $15^{\circ}$, and when the line of the main elevation, just north of Leidy's Peak, is reached, the strata have already their gentle southern dip, and in the sections exposed the greenish clay beds remarked at Gilhert's Peak and farther west can be distinctly traced. On the summit of the range, the trail crosses a broad basin country, extending from the eastern base of Marsh's and Leidy's Peaks nearly to Mount Lena, in which the almost horizontal beds of Weber Quartzite have been smoothed and furrowed by nèvés and glacial ice, their surface being now covered by dense forests, and numerous shallow lakes, too small and too much hidden by the trees to have been indicated on the map.

Returning to the northern slope, Mount Corson, which lies between the valley of Burnt Fork and that at the junction of Henry's Fork and Green River, which we call the Henry Fork Basin, is a remnant of Tertiary beds which has escaped erosion. It is a bread, flat-topped hill, whose summit, and the upper portion of its slopes, are covered with timber; at its southern base lies Connor's Valley, already mentioned. The main mass is composed of beds of the Bridger series, while the upper thousand feet are made up of the conglomerates of the $\mathrm{W}$ yoming group, $-\mathrm{a}$ more considerable thickness of this formation than has been observed at any other point. At its eastern base were found outcrops of coarse reddish sand and gravel beds, whose angle of dip, though indistinct, shows an evident unconformity with the horizontal Bridger beds of the main mass, and which have been referred, as before mentioned, to the Vermillion Creek 
series. Some buff and reddish sandstones carrying fresh-water fossils, which are exposed, dipping $25^{\circ}$ north, a few hundred yards north of Deadman's Spring in the Henry's Fork Basin, have also been referred to this group. They are overlaid, a little to the north, by white calcareous beds carrying numerous Melania, and again by a considerable thickness of shaly beds with thin sandstones, which may represent the Green River series at this point.

Henry's Fork Basin.-While along the higher northern flanks of the range thus far described, the upturned beds of the conformable series above the Carboniferous are still almost completely concealed by the overlying Tertiaries, in the vicinity of Green River, the region bordering the range on either side has been extensively denuded of its Tertiary covering, and the upturmed Mesozoic beds exposed, forming flanking monoclinal ridges, parallel with the strike, and separated by valleys of erosion. On the north lies the longitudinal depression called Henry's Fork Basin, which forms a long, narrow valley extending 15 miles in either direction, east and west, from Green River, with a width of about 3 miles, and whose average level is about 300 feet below the centre of the Bridger Basin proper. The still more extensive region of denudation on the south, called the Ashley Creek Basin, will be described later.

In the western portion of this basin, Quaternary accumulations separate the outcrops of the Cretaceous rocks, and obscure the outlines of the overlying Tertiaries. Near Deadman's Spring were found low ridges showing outcrops of a few hundred feet of loose yellow and white sandstone, in which is a bed of soft, yellow, fossiliferous limestone, striking east $20^{\circ}$ south, with a dip of $60^{\circ}$ north, whose general character relates it to the Colorado group of the Cretaceous, although the fossils obtained were too imperfect for specific identification.

South of this spring is a steep, narrow hill, or ridge, overlooking the gorge-like valley of Sheep Creek, composed of highly-metamorphosed sand-rocks, at times quite quartzitic, and standing at an angle of $50^{\circ}$ north, which have been considered to belong to the Dakota group, since, apparently underlying them, at the eastern base of the ridge were found outcrops of calcareous shales, highly fossiliferous, and carrying character- 
istic Jurassic forms, among which the following have been specifically determined:

\section{Camptonectes hellistriatus. \\ Myophoria lineata. \\ Gryphaea calceola. \\ Pentacrinus asteriscus. \\ Beleminites densus.}

Within the red Triassic sandstones in the canon are heavy deposits of gypsum, corresponding apparently in horizon to those found in $\Lambda$ shley Creek Basin on the opposite side of the range. The valley of Sheep Creek, from this point eastward, has been worn out of the clayey strata at the base of the Triassic formation, whose beds form almost perpendicular cliffs over a thousand feet in height on its northern side, while its southern wall is formed of the steeply-inclined strata of the Upper Coal-Measure group, through which, at this point, the main branch of this stream, entering it at right angles to its course, has cut a narrow, picturesque cañon. The steep angle of dip here is, however, evidently due to a local compression and lateral flexure of the beds, since it is not maintained to the eastward, and, for a short distance west, strikes of east $30^{\circ}$ south were observed. The ridge of Triassic sandstones, which form the northern wall of Sheep Creek and the southern boundary of the Henry's Fork Basin, stretches eastward in the direction of the strike of the beds, viz, east $15^{\circ}$ south, to the junction of this stream with Kingfisher Creek. It then bends outward toward the north, in a semicircular or bow-shaped curve, whose other extremity is at Flaming Gorge, the point where the Green River cuts through this ridge; it presents easy slopes on the north, and a steep bluff face to the south, overlooking a monoclinal valley, which would have seemed to be the natural course of Green River, but which, owing to causes before explained, this river has disregarded, as reference to the map will show, cutting instead a horseshoe-shaped canon in the hard limestones and sandstones of the Upper Coal-Measure group.

A continuous section of the Jurassic beds was not observed here by us, but the notes given by Professor Marsh' show a general correspondence in

'Amer. Joar. of Sci., Mar., 1871. 
thickness and lithological character with that found on the Flaming Gorge cliffs. He found a thickness of about 300 to 400 feet in the cliffs overlooking Sheep Creek, where the angle of dip was $25^{\circ}$ northwest, consisting largely of sandy and argillaceous shales and sandstones, which would probably underlie the beds mentioned above, and below them limestones, from which he obtained a numerous collection of fossils comprising the following genera:

Trigonia (two species).

Camptonectes.

Ostrea (small).

Volsella.

Neritella (like N. Nebrascensis).

Chemnitzia.

Pentacrinus asteriscus.

He also notes in the shales of the lower portion beds of gypsum from 1 to 6 feet in thickness. Below the Jurassic beds are the massive buff sandstones of the Triassic formation, underlaid in turn by the red sandstones of this formation.

This remarkable curved ridge, which has been called Flaming Gorge Ridge, presents a great variety of strikes and dips in the strata of which it is formed, the former varying from east $50^{\circ}$ north a little east of the junction of Kingfisher and Sheep Creeks, to east $20^{\circ}$ (and possibly even more) south at Green River, while the dips vary from $25^{\circ}$, to $45^{\circ}$ and $60^{\circ}$ at Camp Stevenson, and $90^{\circ}$ at Green River, and, in this variety of dips and strikes in a perfectly conformable series of beds, illustrates how easily apparent non-conformities may be caused by such secondary lateral flexures along the flanks of a great anticlinal fold.

In the sharp re-entering curve, at the point where Green River cuts this ridge, the beds are almost inverted by the suddenness of the flexure, and may doubtless have suffered a lateral dislocation, as may be seen in the view shown in Plate VII, which, looking westward, shows a natural section of the ridge. The perpendicular cliffs, here about 1,200 feet in height, are formed of the Triassic sandstones, having at their base an undetermined thickness of clay beds, while the extreme point on the north and 
west bank of Green River, in the foreground, is composed of sandstones of the Cretaceous formation, standing at $90^{\circ}$. The water at the extreme right represents the mouth of Henry's Fork, at its junction with Green River. Owing to the small scale of the map, the structure of this ridge has necessarily been much generalized, and the details of its structure are unavoidably lost.

A section of the beds exposed was made from Camp Stevenson to its highest point overlooking the Horseshoe Cañon of Green River (Plate I), and the general character of the beds and their approximate horizons are given descending geologically, but ascending the ridge from Henry's Fork Valley to the summit.

The outer wall of the ridge shows a thickness of 50 to 100 feet of gray flaggy sandstones, underlaid by a body of 100 to 150 feet of blue-gray clays and shales, carrying small fish-scales, and enclosing a prominent bed of coal, whose outcrops are too decomposed to give a definite thickness. Next the clays are about 150 feet of yellowish-gray sandstones, with carbonaceous seams, which form the base of the Colorado series.

At the top of the Dakota group are 150) to 200 feet of sandstones, which, in the upper portion, have a brownish color, growing whiter in the middle, and toward the base assuming a reddish hue, due to the oxidation of iron, which in some parts forms a perfect stockwerk of thin seams, standing out in reticulated lines upon the surface. Below these are 75 to 100 feet of striped clay beds, of pinkish and pale-green colors, succeeded by about 50 feet of impure sandstone, quite rich in iron oxide, and full of peculiar cavities, from which concretions have dropped out, which separates these from another series of variegated clays, of a great variety of colors, about 100 feet in thickness. Some of the clays of these beds are very pure, and the white ones have almost the consistency of a kaolin. At the base of these clays is a gravel conglomerate, characterized by small, rather angular pebbles of black chert, which is the base of the Dakota group.

The Jurassic formation, which was assumed to include all the beds between the gravel conglomerate and the massive, crossed-bedded, buff sandstone, was estimated to have a thickness of from 600 to 750 feet, where crossed, though the continuity of the beds was broken by some covered 
spots. The upper 150 to 200 feet consist of sandstones, with a varying admixture of colored clays, the former frequently having a shaly structure, and containing some calcareous seams with indistinct fossil remains. Below these is a body of bluish-drab limestones and calcareous shales, from the latter of which were obtained, Rhynconella Myrina, $R$. gnathopora, Lima (plagiostoma) occidentalis, Camp'onectes bellistriatus, and Gryphaa calceola. 'These limestone beds have a thickness of about 20") feet, and are underlaid by a deep Indian-red sandstone of 100 feet in thickness, running below into a series of sandstones and sandy limestones, which form the base of the series, containing thin beds of gypsum, but whose thickness could not be accurately estimated, as they were partially covered by surface débris.

In the Triassic formation the upper half consists of characteristic strata of massive buff or white sandstone, with remarkably well-developed lines of cross-bedding, and very thick beds, often nearly 100 feet without stratification-lines. They form the summit of the ridge, and are developed to a thickness of nearly 1,000 feet, a bed of about 50 feet of yellow, argillaceous sandstone dividing them into two nearly equal parts. The lower half of the Triassic, which forms the cliffs overlooking the Horseshoe Cañon of Green River, also nearly 1,000 feet in thickness, consists of an upper portion of pinkish-red sandstones relatively rather thinly bedded, the lighter color being due to an alternation of thin beds of nearly white color, and a lower portion of darker-colored and more heavily-bedded red sandstones, separated from the former by some argillaceous beds, and at the base running into clay beds with gypsum.

The valley of Green River, at the base of the cliffs, is eroded out of a series of light-colored beds, largely clays, of a prevailing greenish hue, whose thickness could not be estimated, and which have been considered to belong to the Permo-Carboniferous group.

Along the northern base of the Flaming Gorge Ridge are low outcrops of sandstones of the lower members of the Cretaceous, with narrow included monoclinal valleys, which follow the outlines of the main ridge, but in the open valley of the basin west of Henry's Fork the Quaternary covering conceals the earlier members. In following up this stream, then, the first outcrops' are found at the gap just where it emerges from the 
Tertiary benches. Here along the present bottom of the stream, sunk some 40 or 50 feet below the older and wider stream-bottom, are outcrops of white friable sandstones, with indications of coal seans, standing at an angle of $70^{\circ}$ north, and striking east and west, which must belong to the Laramie group.

On the surface of the triangular bench-country, included between the course of Henry's Fork below the gap and Green River, are seen numerous outcrops of sandstones of the Fox Hill group, running east and west, with an average dip of $45^{\circ}$ north, while, on the eastern bluff-faces of the benchcountry, where a point formed by these sandstones makes out, the underlying clays of the Colorado group can be distinguished, though, in general throughout this basin, as elsewhere, the easily-disintegrating character of their beds renders recognizable outcrops rare, and their presence is proved rather by induction than by actual observation.

The northern boundary of the valley, between these streams is formed, as already mentioned, by striped pinkish gravel and sandstone beds of the Vermillion Creek Eocene, dipping about $25^{\circ}$ north, overtopped farther back by the buff calcareous beds of the lower Green River group, which are best exposed in the gap of Green River at its entrance into the valley.

East of Green River, the prominent feature of the valley is formed by a peculiar double-crested ridge, called Bighorn Ridge, from the animals of this name, which frequent its precipitous sides, bare of vegetation with the exception of a few hardy junipers and pines growing on the very faces of the rock. It is formed of the coarse, gray sandstones of the Fox Hill Cretaceous, dipping $45^{\circ}$ to the north, and rises some 500 or 600 feet above the valley, extending with remarkable regularity from the Green River to the hills which form the watershed of Red Creek, a distance of 15 miles, with only a single break in its crests made by the narrow gorge of a stream dry in summer.

North of the Bighorn Ridge, the red argillaceous sandstones and gravel beds of the Vermillion Creek series are again recognized, dipping $25^{\circ}$ north, while the bluff line bounding the valley on the north is formed by the buff calcareous sandstones of the Green River group, dipping only $5^{\circ}$ to $10^{\circ}$ north, which would not necessarily prove an unconformity, as there is 
no direct superposition, and the same beds are found farther east, near Red Creek, to be quite conformable. It has already been seen, however, that sufficient distinct evidence has been found at other points to establish this unconformity.

On the south of the Bighorn Ridge extends a low valley of Colorado Cretaceous, showing occasional outcrops of yellow clays and marls, bounded on the south again by a high ridge or series of ridges forming the eastern continuation of the Flaming Gorge Ridge. These ridges, immediately east of Green River, are steep and narrow knife-edges of rock, formed by strata standing at angles of $45^{\circ}$ to $60^{\circ}$, of the same geological horizons as those of Flaming Gorge Ridge, and rise to a height of over 2,000 feet above the valley, but become lower farther east, where the trail to Ashley Park crosses them, forming simply projecting sandstone outcrops, which bound the northern edge of the plateau region, through which Green. River has cut its cañon from the Horseshoe Bend to Brown's Park.

Through the greater part of this plateau region, the red sandstones and quartzites of the Weber group are found, dipping at angles of $10^{\circ}$ to $15^{\circ}$ northward. After entering Flaming Gorge, as we have seen, Green River turns at right angles to cut its course through the hard siliceous limestones of the Upper Coal-Measures, in a cañon nearly 2,000 feet deep, and, bending again upon itself, returns to the base of the cliffs of red Triassic sandstone, about a mile west of the point where it had left them, as may be seen in the view represented in Plate I, where, however, the river, in its return course, is hidden from view by the low intervening clay ridge in the middle distance. The lower beds thus exposed are quite conformable with the overlying sandstones, but their angle of dip decreases somewhat as the horizon descends, until, as seen above, the Weber Quartzite is found to dip only at 15. After leaving the Flaming Gorge cliffs for the second time, the Green River cuts again through the Upper Coal-Measure limestones, and, in the Weber Quartzite, assumes a general easterly course, approximately parallel to the geological axis of the range, which, opposite Ashley Park, lies a little to south, at the base of the line of cliffs just north of Mount Lena. At its entrance into Brown's Park, therefore, the course of Green River is nearly in the actual axis, and the main elevation of the Uinta Range south 
of this valley is formed of beds of Weber Quartzite, having a gentle southern dip, varying from $5^{\circ}$ to $10^{\circ}$, along its northern face.

To the north of the river, at Ashley Park, and at the eastern end of the plateau region above mentioned, is a high table-topped mountain-mass, of crystalline schists and quartzites of Archæan age, which forms the western end of the Red Creek Archæan body. This body, which, as will be seen by reference to the map, is exposed over a comparatively small area, is composed of steeply-dipping beds of crystalline schists and white quartzites, which bear evidence of having suffered intense compression and distortion, and which are distinctly unconformable to, and of an older system than the conformable series involved in the Uinta uplift. The relations of these older rocks with the beds of the Weber Quartzite are clearly seen, as the latter are found along the southern base of this mountain, preserving their regular inclination of $10^{\circ}$ to $15^{\circ}$ north, in direct contact with the steeplyinclined beds of the crystalline rocks; and in one instance, near the mouth of Red Creek, on the face of the Archæan cliffs, overlooking the western end of Brown's Park, a detached fragment of the red quartzites remains, still dipping $15^{\circ}$ north, while the main mass of the cliffs is formed of beds dipping from $45^{\circ}$ to $70^{\circ}$ north.

It is thus evident that these and the succeeding conformable beds were originally deposited around the shores of an Archæan island, the highest peak of a submerged Archæan ridge, which was itself involved in the movement that raised the Uinta Range.

On the northern edge of the Archæan body, however, at the ridge forming the divide or water-shed between Henry's Fork Basin and the valley of Red Creek, the sandstones of the Fox Hill Cretaceous, the eastern continuation of the Big Horn Ridge, are found in contact with the Archæan rocks, standing at angles of $70^{\circ}$ and over, and showing signs of local displacement and faulting. The entire western limits of the Archæan body were not traced; but it is not probable that the Triassic or Jurassic formation comes in contact with the Archæan rocks in this region. The fact that beds of the Middle Cretaceous are thus found in contact with this borly on the north, opposite the point where the beds of the Weber Quartzite adjoin it on the south, presents a somewhat difficult structural problem. The solu- 
tion most in accordance with the observed facts is, that a line of fault, approximately such as is indicated on the map, has been developed by the uplift of the Archæan body and the adjoining Weber Quartzite beds, which has crossed the formations diagonally to their strike; that this has produced a displacement, such as is indicated by the steep dips of the Red Creek divide, and the want of correspondence in the dividing lines of the different formations generally, to the north of the Archæan body. The continuation of this line of faulting and displacement eastward, may be adduced as an explanation of the peculiar position of the rock on the Owi-yu-kuts Plateau, where, as will be described later, the flat dips along the main portion of the plateau, in the beds of the Weber Quartzite, are suddenly changed along the northern portion to steep angles of $50^{\circ}$ and $60^{\circ}$.

Red Creek Archean Body.-The best opportunity for studying the structure and character of this body is presented by Garnet Cañon, a narrow, precipitous, and winding gorge, which has been cut by Red Creek to drain the basin-like valleys, which have been worn out of the softer Cretaceous and Tertiary beds to the north. A fair transverse section of the body is thus exposed, which shows that its beds have been compressed into sharp, narrow folds, and so contorted that their structure is somewhat complex. The general plan of this structure seems to be that of a double anticlinal, whose axes converge and perhaps cross each other, one of which, the northern, has a direction of northwest and southeast, and the other of northeast and southwest. The dips observed in descending the cañon are first $70^{\circ}$ north, which changes a short distance down to $70^{\circ}$ south, forming the first fold, which has a northwesterly strike, and runs in the direction of the elevation north of Ashley Park. About the middle of the cañon, this dip changes again to $70^{\circ}$ north, forming a sharp synclinal, and the northern dip is continued to the mouth, decreasing, however, to $45^{\circ}$, while the beds have a northeasterly strike, which would produce the southern side of this fold along the foot-hills of Brown's Park to the east of the cañon-mouth.

The first rocks observed in descending from the Cretaceous valley below the gap of Red Creek are white quartzites of remarkable purity and great thickness. These pass, by gradations of quartzites containing a little white mica, into white mica-schists. Included in these beds, in the axis of 
the first anticlinal, are found interstratiGed beds of dark-green hornblendeschists, which, owing to their sharp contrast of color with the including rocks, and the steep angles and the contortions of the beds, have a slight resemblance to a dike of intrusive rock, for which, indeed, they might be mistaken by a careless or unpractised observer. These hornblende-schists were also found on the flat-topped hill to the westward near the Red Creek divide. To the unaided eye, the hornblende-schists seem composed exclusively of hornblende; but, under the microscope, the intervals between the hornblende prisms are found to be filled with colorless quartz and a few feldspar particles. They closely resemble those already described from Bruin Peak in the Park Range.

About midway in the cañon are found a series of fine-grained, white talcose mica-schists, containing large dodecahedral crystals of dark garnet, which resemble in a remarkable degree the well-known paragonite-schists of the St. Gotthard in Switzerland (found at Monte Campione near Faido). They contain disthene, or cyanite, in pale-blue crystals, like the European occurrence, and, moreover, large, well-defined crystals of staurolite, frequently crossed in twins. Under the microscope, the paragonite appears in colorless hexagonal laminæ, irregularly disseminated throughout the rock, as in the Swiss occurrence, but, unlike the latter, seems to contain no microseopical disthene or staurolite; it does contain, however, some microscopic tourmaline. The staurolite crystals are seen, under the microscope, to contain a large proportion of free quartz in rounded grains. On the cliffs to the west of the mouth of the cañon, as already observed, are some fragmentary beds of the Weber Quartzite, dipping $15^{\circ}$ nortl, resting unconformably on the upturned edges of the Archæan strata.

In the character of the quartzitic aid hornblendic strata, these rocks resemble the Archæans of the Rocky Mountains; but the paragonite beds have not before been observed, and the presence of white mica is also unusual. It has, however, been considered that they may be referred to the upper or Huronian portion of that formation. At the head of Willow Creek, some mineral-bearing veins have been discovered in these rocks, carrying red oxide of copper and some silver, but, at the time of our examination, had not been sufficiently opened to enable us to form an opinion of their probable value. 
The crescent-shaped valley to the north of Garnet Cañon is one, which has becin eroded out of the clay beds of the Colorado Cretaceous, and in which only a few exposures of yellow and blue clays with thin sandstone seams are found. As is generally the case with this formation, the surface is covered by clayey soil, and the exact relation of these beds with the crystalline rocks is consequently somewhat obscure. 'The valley is bounded to the north by another sandstone ridge, curving outward to the north like the Bighorn Ridge, which has been, from its position and lithological character, referred to the same group, namely, the Fox Hill series; a few fragments of Baculites and Inoceramus were found in the clays at its base. At Red Creek Gap, these heavy-bedded sandstones, showing a thickness of several thousand feet, dip $25^{\circ}$ to the northward, and may be traced continuously westward to their contact with the Azoic body on the divide between Red Creek and Green River, where, as already mentioned, they stand almost vertical. To the north of this point, a second high ridge is formed of yellowish-red and chocolate-colored sandstones and clays, dipping about $10^{\circ}$ northward, representing the overlying and unconformable beds of the Vermillion Creek series which are exposed in the upper basin of Red Creek.

In the bottom of Red Creek, just above the gap, are found other sandstone beds conformable with those at the gap, containing Mactra arenaria, which are considered to represent the lower part of the Laramie series. To the east of Red Creek Gap, these sandstone ridges disappear under red and chocolate clays and sandy beds, having a dip of $5^{\circ}$ to $7^{\circ}$ north, and forming the higher points overlooking these valleys, which are supposed to be the upper portions of the Vermillion Creek series. In the upper part of the Eastern Fork of Red Creek, along the northern slopes of Bruce Mountain, these Tertiary beds are concealed by forest growth and surface débris to such an extent that it was impossible to determine accurately the relations between Tertiary, Cretaceous, and Archæan formations; fragments of the latter are found in the débris of the valley-slopes, and the position of the Mesozoic beds farther eastward would indicate that they probably sweep well round to the northward, though their continuous covering of Tertiary renders this merely a matter of speculation.

Owi-yu-kuts Pl.1Teau.-Between Red and Vermillion Creeks is a pla- 
teau region about 8,000 feet above sea-level, surrounded on the east, north, and west by irregularly-distributed peaks and rounded hills, rising from 1,000 to 2,000 feet above it. The forest-covered hills between the heals of Willow Creek and of the Eastern Branch of Red Creek, overlooking the plateau from the west, are formed of drab limestones of the Upper Coal-Measure group, dipping $50^{\circ}$ to the northward, with a general east and west strike. Under these, to the south, are found the red sandstones and quartzites of the Weber group, conformable in dip, but gradually flattening out to the southward, until, on the edge of the cliffs which overlook Brown's Park, at the cañon of Beaver Creek, for instance, they have a dip of only $5^{\circ}$ nortl. This is the general structure of the plateau, namely, on its southern border overlooking Brown's Peak, consisting of beds of the Weber Quartzite, lying nearly horizontal, or with a slight dip northeastward, though, in one instance, at a projecting point near the eastern end of the cliffs, a local dip of $x^{\circ}$ to the southward was observed. The general surface of the plateau is too much covered with soil and trees to afford good continuous sections. Along the open valley at the northern portion, between the heads of Talanantés and Red Creeks, however, these same beds are found standing at angles of $50^{\circ}$ to $60^{\circ}$ north, with a strike of nearly east, which toward the eastern end bends to southeast. The change, in dip between the interior of the fold and its flanks, is even more abrupt and considerable than that already observed farther west, and points, as has already been remarked, to a continuation of the fault-line developed north of the Archæan body. It seems probable, also, that the whole region bordering Brown's Park has suffered subsidence since the formation of the main Uinta fold. Of the elevations bordering the plateau on the north and east, that next west of Diamond Peak, as well as could be distinguished under its forest-covering, was formed of nearly horizontal beds of the Vermillion Creek Tertiary, capped by the Wyoming Conglomerates. Diamond Peak itself, so called from the reputed discovery of diamonds along its northern slopes, which gave rise to the diamond bubble of 1872 , is composed of drab limestones and sandstones of the Upper CoalMeasure group, easily recognized by their position and lithological character, though no fossils were found hero by our parties. The beds are much broken, and the structure consequently somewhat obscure. Dips of $25^{\circ}$ 
northward were observed, and the strikes are very irregular, but generally east and west, with a tendency to the southeast. Along the southern base, the limestones, broken into huge blocks, have evidently fallen over the Tertiary beds, which have been deposited around it in the bay now occupied by the valley of Talmantés Creek. This valley itself would seem to have probably owed its position originally to a line of dislocation, since the strikes of the beds on either side show considerable discrepancy.

To the south of this valley extends a sharp, narrow ridge, which constitutes the eastern boundary of the Owi-yu-kuts Plateau, and which is formed by the upturned edges of the limestones and sandstones of the Upper Coal-Measure group, of which a section will be given farther on, having a strike of north $17^{\circ}$ west, and a dip of $31^{\circ}$ to the northeast. On the platean to the west of this ridge, the edges of the upturned beds of the Weber Quartzites are seen ribbing the surface, with a strike still more to the westward and a steeper dip. These outcrops extend close up under tho limestone cliffs, whose beds might seem to have been deposited unconformably over their edges. The evidence at this point, if considered by itself, might seem to favor the idea of a non-conformity between the Weber Quartzites and the overlying beds. We have been unwilling, however, to accept this evidence as final, from the fact that our observations elsewhere almost invariably point to the opposite conclusion, and would explain the apparent unconformity by a lateral dislocation, which has pushed the lower beds up at a steeper angle, and moved them somewhat to the northward and castward with respect to the limestone beds which form the cliffs. An evidence of this dislocation is seen in a break, about midway in the ridge, now occupied by the deep, narrow cañon of the dry bed of a stream which drains into the Lower Vermillion Creek from the north. As will be seen on the map, this faulting has had the effect of moving the southern portion of the ridge to the eastward. The strata of the upper formations are apparently continuous, however; owing, doubtless, to the greater elasticity of their beds, no actual break took place in them, but the effect of the movement is seen in the curved strike of the ridges which they form.

The cañon of Vermillion Creek, in the eastern continuation of this ridge, a narrow gorge, only a few hundred feet wille, with steep walls, which, $18 \mathrm{D} \mathrm{G}$ 
in the centre, rise 1,500 feet above its bed, gives an excellent section of the sandstones and limestones of the Upper Coal-Measures. The dip of the beds in this cañon is $27^{\circ}$ to the northeast, which is not quite as steep as that of the ridge to the north.

At the lower end of the cañon, some croppings of red quartzite are found under the Tertiary benches of Brown's Park; but in the cañon itself the main exposures belong to the Upper Coal-Measure group, of which a thickness of about 2,100 feet is shown. They consist of a lower portion of about 500 feet of drab limestones and sandstones, above which is a bed of pinkish sandstone of about 100 feet in thickness; and then 1,500 feet of lightcolored strata, very regularly and rather thinly bedded, consisting of limestones and sandstones, with intermediate grades, in which the siliceous material seems, in general, to predominate over the calcareous. Included in this series are numerous thin beds of cherty material, one of which, of about 4 inches in thickness, was particularly prominent by its black color, which gave it the appearance of coal; other seams contained considerable amounts of iron oxide. An analysis, made by Mr. B. E. Brewster, of one of the lower beds, a fine-grained drab limestone, having a fracture like a lithographic limestone, gave the following results :

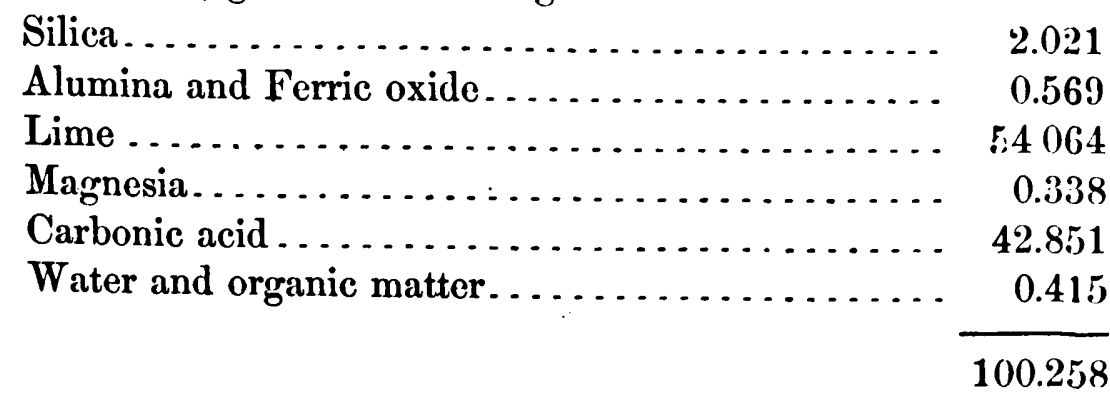

The upper gate of the cañon is formed by a bed of cherty limestone, whose surface is marked by abundant silicified casts of fossils. $\Lambda$ mong the collections made in this bed, the following have been recognized:

Bellerophon carbonarius.

Sedgwickia concava.

Nucula parva.

Pleurotomaria, sp.?

Fusilina, sp. 9 
This bed has been found to be very constant wherever a good section of the Upper Coal-Measure group in the Uinta Range, and has been considered as forming the dividing line between this group and the PermoCarboniferous. It is noticeable that in the beds exposed in a cañonsection like this, the siliceous members seem to predominate over the limestones; whereas, when found forming ridges projecting above the surface, the limestone beds are the more prominent. While it is evident that beds of the same horizon may change in character in very short distances, this may be also explained by the fact that the limestone beds are, in general, more massive, and present fewer bedding-planes than the siliceous beds, and are, therefore, better able to resist the action of erosion.

Vrrmillion Creek Valley.-Above the cañon of Vermillion Creek, and to the east of the ligh ridge which borders the Owi-yu-kuts Plateau, is a remarkable valley, in which, by the denudation of the overlying Tertiaries, the beds of the entire Mesozoic group, from Carboniferous to Upper Cretaceous, are exposed in a series of ridges running northwest and southeast, parallel to the.Owi-yu-kuts Ridge, but curving outward toward the centre of their exposure in the arc of a large circle. This curve, as we have seen before, is partly due to a flexure, which, in the lower and less elastic beds, has resulted in the dislocation of the beds of the Upper Coal-Measure group, but is partly also to be explained by the change of dip noticeable, which is less in the centre of the curve, and also in the outer or uppermost beds. This dip changes from $31^{\circ}$, as we have seen, in the Upper CoalMeasure series, to $25^{\circ}$ in the highest Cretaceous beds exposed.

Their section, in ascending order from the cherty Bellerophon bed, which forms the upper gate of the cañon, is as follows: $\Lambda$ gap of several hundred feet, in which the greenish clays and mud-rocks, which represent the Permo-Carboniferous, are too much eroded to afford a definite section; above these are several sandstone ridges, at the base colored red, and containing some conglomerate beds, in which is included a seam of compact, greenish-drab limestone, above which a second series of reddish sandstones, several hundred feet in thickness; then beds of massive buff sandstone, in thickness from 500 to 1,000 feet, corresponding to the cross-bedded sandstones of Flaming Gorge Ridge, above which a fine white and red sandstone, 
with some clay seams with a thickness of about 100 fect, making, in all, a thickness of about 2,000 feet for the Triassic formation. The ridges formed by these heary-bedded sandstones are here, as elsewhere, prominent topographical features. Above these 150 feet of limy shales and limestone of the Lower Jurassic, succeeded by several hundred feet of variegated clays, whose débris so covers the surface that, where examined by us, no definite series, corresponding to the arenaceous and calcareous shales elsewhere found, could be recognized.

Next, a rusty, white sandstone, having at its base a conglomerate containing pebbles of black and colored jasper, generally quite small and rather angular, the characteristic bottom rock of the Dakota Cretacoons, forms the commencement of that group, which also includes about 100 feet of blue clays, capped by 150 feet of buff sandstones, with included thin argillaceous beds. From these sandstone ridges, to the bed of the north branch of Vermillion Creek, which runs for a few miles in the strike of the formations, extends a series of low, rounded, clayey ridges of the Colorado Cretaceous. In this portion, no continuous section could be obtained near the creek, but the general character of a series of bluish clays below and yellow clays and marls above could be distinguished, the wholo carrying thin beds of sandstone and arenaceous shales. In the bed of this branch, and even for some distance beyond, the clayey character of the soil continues; but under the benches there soon appear outcrops of the white sandstones of the Fox Hill group, which was supposed, from the position of the sandstone outcrops, found along the base of the Tertiary cliffs on the cast of Vermillion Creek, to occupy approximately the position given on the map.

Of beds supposed to represent the Laramie group, there were found in the bottom of Vermillion Creek, northeast of the branch above mentioned, and at the base of the Tertiary benches included between its two northeastern parallel forks, beds dipping $25^{\circ}$ northeast, of impure sandstones, carrying seams of coal, one of which was found to be 25 fect thick. Occasional exposures of these sandstones are found in the bottom of these branches of Vermillion Creek, where the stream has removed the thick deposit of alluvial mud. The outlines of the two upper formations, as elsewhere, could not bo very definitely determined, and it is probable that more outcrops 
of the upturned Cretaceous could have been found in other stream-beds to the north had time permitted more extended exploration. The thickness of conformable beds, thus exposed from the Carboniferous upwards, cannot be less than 10,000 to 12,000 feet.

The upper portion of the basin of Vermillion Creek is, as we have seen, a bench-country, intersected by innumerable dry waterconrses cut through the horizontal lower beds of the Vermillion Creek series, bounded on the northeast by a line of bluffs extending southeastward from Pine Bluffs, and on the southeast by the line of Vermillion Bluffs, in which were recognized, as already stated, the upper red beds of the Vermillion Creck series, the limy shales of the Green River series, and a remnant of the Wyoming Conglomerate; the two former dipping to the southeast. Near the summit of the ridge, which extends to the southwest from Vermillion Creek Cañon, where the Tertiary beds have been removed, are found a few exposures of coarse red sandstone, which have been, from their position, referred to the 'Triassic, though lithologically they resemble very closely the Weber Quartzite. The summit of the ridge is, as has been scen, covered by a small remnant of coarse conglomerate beds, resembling the Wyoming Conglomerate, to which they have been provisionally referred.

East of this point, with the exception of the little outcrop of limestone and sandstone north of East Mountain, the northern member of the Uinta fold appears to be completely concealed by the Tertiary beds, which have filled the great depression of Brown's Park. The regular line of Weber Quartzite cliffs, which wall in this valley on the south, and whose beds have a uniform and gentle inclination to the southward, may be considered as properly belonging to the southern member of the main Uinta fold. Before proceeding to the description of this southern member, a brief sketch will be given of the structure and geology of the

Region East of the Uinta Range.-On the extreme southeastern corner of the map, the Cretaceous coloring covers the western continuation of the rolling, grassy country of the upper valley of the Yampa of Map I, in which few rocks are exposed on the surface, except in the cañons of the streams, notably that of the Yampa River itself. The general structure of this region is that of a series of gentle folds, having a north and south 
axis, whose beds, at the same time, rise toward the south to a region beyond the limits of the map, which may represent the geological continuation to the eastward of the Uinta plications. With the exception of a few specimens of Ostrea, no fossils were found here. The beds have been separated, therefore, in a general way, into a lower group of white, rather more heavily-bedded sandstones, and an upper series of red and pinkish sandstones. No opportunity offered for obtaining a continuous section of these beds, but their structure was easily traced by the difference of coloring of the two scries. The lower beds, as exposed in the deeper cuts of Williams Fork and Mill Creek, the next tributary of the Yampa River to the west, have, mainly on structural grounds, been included in the Fox Hill group. In the narrow ridge just east of Cañon Park, the rather steeply-dipping massive white sandstones represent the eastern side of the Williams Fork fold. The beds descend in Cañon Park, and are capped by the reddish strata of the Laramic group, which rise again to the west of Cañon Park in a gentle anticlinal, descending again to the westward beyond the mouth of Mill Creek; and near the point where the river emerges from the canon into the alluvial valley east of Yampa Peak, an upper series of beds is found containing coal and scattered deposits of iron-ore, with some shale beds, which resemble in lithological character those observed on the Upper Little Snake River. At the mouth of the cañon, the strata rise again slightly, with a gentle dip to the eastward, forming a bluff face to the valle $y$, against which its white Tertiary beds are deposited horizontally.

To the north, these upper beds slope off gently, and disappear under the rolling hills of the Vermillion Creck group between the Yampa and Little Snake Rivers. To the south of the Yampa River, the strata rise agrain, and are cut off abruptly in an east and west line of bluffs, which border the anticlinal valley of the upper part of Williams Fork and Mill Creek. Beyond this valley, on the foot-hills of the White River divide, the other member of the anticlinal is seen; the strata dipping southward into the hills. This seems to be the general structure of that portion of the White River divide included on the map, namely, that of the southern portion of a gentle anticlinal fold, from which the northern member has been cut off by erosion, and possibly also by some faulting, though no evidences of this were obscrved. 
Yampa Peak is an isolated mountain-mass, which may be considered to be, as it were, an eastern extension of the great terrestrial wave which uplifted the Uinta Range. It is composed of the drab limestones of the Upper Coal-Meisures; its structure being that of a double anticlinal, or quaquaversal, whose longer axis trends a little east of north. The Yampa River has cut a cañon, about half a mile in length, through the northern point of this ridge, exposing a section of about 1,500 feet of strata, mostly of limestone, with some sandstone. In the bluffs of the north side of this cañon, about the centre of the anticlinal, a slight north and south fault is observed, in which the downthrow is on the west. Near the summit of the peak, brownish-red quartzitic sandstones are found exposed in the deeper ravines, and on the steeper slopes, though a drab limestone caps the very summit. These were supposed to represent the Weber Quartzite group; but, as no great thickness was observed, they may possibly represent a red sandstone, which has been noticed in the Vermillion Creek section, included in the limestone beds, The strata on the east and south, dip much more steeply than on the west and north. No fossils were found on this peak, but the lithological character of its beds leaves no doubt as to their age. The white horizontal Tertiaries of Brown's Park cover the flanks of the peak on every side, so that no younger upturned beds were observed, though portions of the Permo-Carboniferous have been indicated on the map, to better illustrate the structure. The peak is connected with the hills of the White River divide by a Tertiary ridge, at the southern end of which were found sandstones dipping $31^{\circ}$ south, with an easterly strike, which, from their position under the coal-rocks, were considered to represent the upper portion of the Fox Hill group.

Coal Mountain, on the White River divide, south of Yampa Peak, is formed of soft, heavy-bedded sandstones of the Laramie group, which abound in coal seams. Six of these were passed in the ascent of the peak, and near the summit was found a 6 -inch seam of iron-ore. The structure of the ridge, as seen from this point, is to the eastward that of a gentle anticlinal, while on Coal Mountain itself the rocks dip $5^{\circ}$ to the south, and to the westward the axis of the anticlinal follows the higher part of the ridge, dipping $10^{\circ}$ southward on their southern slopes, while a synclinal fold is 
found on the no:thern spurs, the beds forming the lower extremities, dip, i:: : quite stceply to the south. The lower part of the second stream east of Coal Mountain cuts a narrow cañon through the outlying southerly-dipping beds, which here have the same angle of dip of $31^{\circ}$, in which is a spring, whose waters are highly charged with salts of iron. On the cliffs above this cañon, on the cast side, are seen a considerable thickness of sand and gravel beds lying almost horizontal, the observed dip being about $3^{\circ}$ to the northward, which extend high up on to the spur, and from their position are supposed to represent an upper portion of the Brown's Park Tertiaries. These same Tertiary beds are seen by the structure of the hills to form the summit of the White River divide to the westward; though from their - being easily degraded, on account of the incoherency of their material, no good exposures were found. In the deeper portions of the ravines, on the northern side of this divide, were found croppings of sand-rock, corresponding in dip and strike with those at the mouth of the cañon, and which have therefore been referred to the same group.

Junction Peak is the culıninating point of a high, narrow ridge, trencling a little east of north, near the confluence of the Little Snake and Yampa livers, cut through by the latter, near its southern end, in a deep, narrow cañon about 2 miles in length. Its structure is similar to that of Yampa Peak, representing a sccondary roll in the pre-Tertiary beds, which dip away from it in every direction. The inclination of these beds is steeper toward the north and west, and more gentle to the east and south, the strata at the summit being nearly horizontal, while on the east and west flanks they seem to have been broken, and fall off very abruptly, showing evidence of a similar folding and dislocation to that which has taken place throughout the Uinta Range. The general idea of this structure is given in the section CD at the bottom of the map.

In Lily's Cañon, an excellent section is shown of the Upper CoalMeasure limestones and a portion of the underlying red sandstones, forming an arch of tho general shape of an inverted $U$. At its eastern mouth, the white Tertiary beds rest directly upon the limestones of the Upper CoalMeasures, while at the western mouth of the canon the red and huff sandstunes of the 'Triassic formation are exposed in places, dipping west ward at 
an angle of $45^{\circ}$. In the decper-cut ravines of the Tertiaries, to the south and west of the ridge, toward Lily's Park, are found several exposures of sandstones, evidently belonging to members of the Cretaceous group, which form part of the Junction Peak fold. The surface of the southcrn portion of the Junction Peak Ridge shows only the beds of coarso gray, and compact whitish limestones of the Upper Coal-Measures. Its highest peak is capped by a flat mass of these limestones, dipping slightly west, while in the deeper ravines near the summit are found exposed tho brownish underlying sandstones of the Weber Quartzite, in general almost horizontal, or with a dip of a few degrees to the westward. To the north of the peak, the same rocks are found exposed, the strata showing signs of dislocation and faulting. At the northern point, the limestones dip $40^{\circ}$ northward, flattening out to $25^{\circ}$ on the extreme foot-lills.

The upturned edges of the higher members of this fold are mostly covered by the white Tertiaries, or obscured by drift material. On the western side of the peak, however, near the Little Snake River, at the northern part of Lily's Park, wher'e the stream cuts deeply into the Tertiaries, good exposures are found of these beds, showing the Triassic sandstones, the clays and limestones of the Jurassic, and some sandstones and clays of the lower members of the Cretaceous. In the section thus exposed, the beds strike north $45^{\circ}$ west, and dip $45^{\circ}$ to the southwest. Looking at these outcrops from the benches above the cañon of the Little Snake River, in the direction of tho strike, one would at first be led to conclude that there was a decided unconformity between these beds, and those which form the summit of Junction Peak, where the red quartzites overlain by drab limestones are seen dip to only $7^{\circ}$ westward, while the lowest exposures of the Triassic have a dip of $45^{\circ}$, as already stated. The sharp flexure and break on the edges of the central fold easily account for this apparent unconformity; and where the Tertiaries, which cover the benches of Lily's Cañon, have been denuded, the Upper Coal-Measure limestones may be found conformable with the Triassic sandstones. No fossils were found in the limestones of Junction Peak; but those on East Mountain, directly to the west of it, the lithological character of whose beds, and their relative position establish their identity, abound in characteristic Carboniferous fossils, among which 
were Fencstella, Zaphrentis, and casts of Orthoceras, too indistinct, however, for specific identification.

Escalante Hills and Yampa Plateau.-We now return to the flanks of the Uinta Range proper. 'The singular depression of Brown's Park, and its continuation to the eastward as far as the Little Snake River, lies, as we have seen, approximately in the axis of the main Uinta fold. The causes which have produced this depression are at the present day difficult to determine. From the position of the Tertiary beds, it is evident that it existed prior to their deposition, and is the result of forces acting between the close of the Uinta uphenval and the filling-up of these great Tertiary basins. One might suppose an engulfment of this portion of the rangre, and, indeed, the steep angle of the 'Tertiary beds on the north edire of Brown's Park proves that some movement of this kind has been going on since their deposition. On the other hand, the shape of the valley of Brown's Park, and its continuation to the castward, has much of the general outline of a glacial valley, and might be supposed to have been eroded by an immense ante-Tertiary glacier.

On the extreme western end of the escarpment which bounds the valley on the south, that is, in the upper part of Brown's Park, the beds of Weber Quartzite have a slight dip to the northward. In this region is found further proof that the course of the river was determined since the Eoceno period, in the fact of its leaving the softer beds of the open valley to cut narrow cañons in the spurs of hard quartzite on the soutl, as opposite the mouth of Red Creek and in Swallow Cañon. In general, as has been seen, the northern face of the hills, which bound the valley on the south, is formed of southerly-dipping beds of Weber Quartzite, whose angle of dip varies from $5^{\circ}$ to $10^{\circ}$.

A remnant of the eastern apex of the main Uinta fold is exposed, where the water-course, draining the eastern side of the divide between Littlo Snake River and Brown's Park, has cut a gap through the northeastern point of the Escalante Hills. In the little conical lill to the north of this gap are beds of red sandstone, overlain by drab limestones of the Upper CoalMeasures, dipping $45^{\circ}$ northeast, with a strike north $50^{\circ}$ west. In the hills to the south, this strike changes abruptly to southwest, and the northern face of East Mountain is composed of beds of coarse red sandstone, while its sum- 
mit and southern slopes are covered with the drab limestones of the Upper Coal-Measures dipping $35^{\circ}$ south.

On the southern flanks of the ridge, toward Lily's Park, the horizontal beds of the white Tertiaries cover the higher Mesozoic beds, but in tho deeper cuts the conformable red sandstones of the Triassic are exposed. $\Lambda \mathrm{t}$ the eastern end of Lily's Park are excellent exposures of most of these upper members, curving sharply around from a northeasterly strike, on the north side of the river, to north and south at the entrance of Yampa Cañon, bending to the southwest, south of the river, and curving again to the westward south of the White River divide. This curving strike is best marked by the upper bed of massive sandstone of the Triassic, always a prominent feature in the topography; the sandstone on the north of the river is of a yellowish-buff color, but, in the ridges to the south, the usual red hue predominates. On the White River Ridge, south of Lily's Park, the low divide has been worn out of the softer clay beds of the Colorado group, the sandstones of the Upper Cretaceous series to the east being in general concealed by the overlying Tertiaries. The re-entering curve of these outcrops suggests the structure of the hills immediately to the west, which is that of a double anticlinal fold enclosing the synclinal valley, through which the Yampa River now flows in a deep cañon.

The high plateau region of the Uinta west of this meridian is one of peculiar structural interest, all the details of which were not fully worked out. Its general outlines might be expressed by three meridional sections at different points : on the meridian of $108^{\circ} 30^{\prime}$, the section would be that of a single anticlinal fold; on the meridian of $180^{\circ} 45^{\prime}$, two anticlinal folds with an included synclinal; while on the line of the western edge of the east half of the map would be three anticlinal folds and two included synclinal folds. This general system of east and west folds has been much complicated by foldings at right angles, and by dislocations, more particularly in the vicinity of the Green River, all of which will be explained as far as observation has succeeded in unravelling them. The Escalante Hills, as we have seen, represent the southern member of the broad general fold of the Uinta Range. On their northern face, and in general along the plateau summit, are exposed the underlying beds of the Uinta quartzite dipping about $10^{\circ}$ to the soutliward. 'The beds of the Upper Coal-Measure limestones, over- 
lying these, form the southern slope of the ridge, dipping in general but very little steeper than the slope of the hills themselves; at Zenobia l'eak, their angle is $10^{\circ}$, the same as that of the underlying quartzite. Southward toward the Yampa River, however, the dip is somewhat steeper. The valley of the Yampa River from Lily's Park to its junction with Green River is a broad synclinal valley, whose northern borders are formed by the gentle sloping beds of the Escalante Hills, and bounded on the south by the more abrupt escarpments of the Yampa Plateau. 'Through the bottom of this valley, the Yampa River has cut a narrow, winding cañon 1,000 to 1,500 feet deep, through the beds of the Upper Coal-Measure group, which, in the bottom of the valley, are almost horizontal. The walls of this cañon are so steep, and its bed so narrow, that it is hardly visible until one is immediately on its brink. In the western portion of the valley, toward Green River, are some remains of the red sandstones of the Triassic, whicht have escaped erosion. From Tank Peak, whence was obtained the most comprehensive view of the structure of this valley, since owing to the depth of the cañons it was impossible to cross the Yampa River below lily's Park, these remaining Triassic beds can be very distinctly seen, ending on either side in prominent red bluffs. The flat-topped ridge, of which T'unk P'ak forms the eastern extremity, is capped by the drab limestones of the Upper Coal-Measures, dipping only $5^{\circ}$ to the southward. In the valley-bottom, at the base of this ridge, however, the same beds have a steep dip to the northward, which is $45^{\circ}$ at the foot of Tank Peak, and increases to $80^{\circ}$ near the western end of the Triassic beds. A line of bluffs to the west of the Triassic beds, which forms a continuation of the western wall of the cañon of Lodore to the south of the Yampa River, represents a similar line of sharp flexure and dislocation, the summit of the bluffs being formed of horizontal limestone strata, while at its eastern base the beds curve sharply downward at an anglo of from $80^{\circ}$ to $90^{\circ}$.

In the valley of Fox Creek, on the south of the Tank Peak Ridge, is a similar sharp flexure, where, on the southern border of the Yampa Plateau, the limestone beds dip again $70^{\circ}$ to the southward. On the hills south of Fox Creek, which represent a third broad fold, the Triassic sandstones still cover the surfice. East of Section lidge the southern flanks of the Yampa Plateau were not exanined, though the outlines of the formations could be 
distinctly traced in the open valleys of the White River by the monoclinal ridges, in which the variegated clays of the Jurassic and the sandstone ridges of the overlying Dakota Cretaceous could be distinctly recognized from a great distance. The ridges formed by the lower of these beds curve sharply in a re-entering angle to the northward at the base of Section Ridge, while the sandstone ridges of the Upper Cretaceous are seen to partake in a much slighter degree of this curve, and run approximately east and west, at a considerable distance from the flanks of the plateau. Section Ridge represents a sharp anticlinal fold, whose axis runs northeast and southwest, sinking abruptly to the southwest. Its summit is covered by the fossiliferous limestones of the Upper Coal-Measure group, dipping $20^{\circ}$ to the northwest, approximately with the slope of the hill, and forming abrupt escarpments to the southeast, at the foot of which the same beds are seen standing vertically, showing that this side of the fold has been dislocated, and perhaps suffered some faulting. The following fossils were obtained from these beds:

Nuculana bellistriata.

Schizodus curtus.

Bellerophon carbonarius.

Orthoceras crebrosum.

Naidites, sp.?

They have somewhat of a Permian facies; but as the general character of the fossils of this horizon, which has been so distinctly traced at every good exposure of the Upper Coal-Measure limestones in the Uinta Range, is rather Carboniferous than Permo-Carboniferous, they have been considered to mark the extreme upper bed of the Upper Coal-Measure group. Near the highest point of Section Ridge, the surface is partially covered by brown pebble-like accumulations of crystals of iron pyrites, colored brown by superficial decomposition. The bed, from which they probably came, is a dark, reddish seam, containing white fragments of calcite and quartz, the main mass being an admixture of quartz grains and iron oxide.

The interior of the Yampa Plateau north of Section Ridge was not visited. As seen from this point, its surface is generally level, having been formerly covered by the beds of the Wyoming Conglomerate, of which a remnant still remains on the northern point near the Green River. Doubtless, a careful examination of the ravines in this plateau might reveal other flexures 
and dislocations in the Carboniferous beds than those indicated on the map. Its northern point, lying between Island Park and the western end of the Yampa Valley, whose surface is, as shown on the map, capped by a remnant of the Wyoming Conglomerate, presents abrupt escarpments to the west, north, and east, and would seem to be the flat-topped arch of a fold whose east and western sides have suffered dislocation, the centre of the fold having been faulted up. The western wall toward Green River shows at its base the red quartzites of the Weber group, and apparently represents the line of a very considerable fault, in which the movement must have been some 4,000 or 5,000 feet at least, since, on the western side of the river, the red beds of the Triassic seem to approach very near the foot of the escarpment. In Whirlpool Cañon, where the Green River runs for a short distance due west in a continuation of the course of the Yampa River, a section of this anticlinal fold is given, in the centre of which, apparently, the rocks of the Weber group are exposed. Plate VIII represents a view of the cañon of Lodore, looking up the river, as it would be seen from the northeastern point of the plateau-region, south of Whirlpool Cañon, though the original photograph was actually taken from the eastern bank of Green River, just above the junction of the Yampa. The escarpment of the eastern side of the fold represents, as we have already seen, a sharp flexure, accompanied by some faulting similar to that of the southern edge of Section Ridge, in which the limestones of the Upper Coal-Measures, which, on the summit of the plateau occupy an approximately horizontal position, are abruptly broken down on the east, and stand along its eastern base in a nearly vertical position. Portions of this fold to the north, as exposed by the erosion of the Green and Yampa Rivers, are seen in section in Plato IX, which represents a view taken from the eastern banks of Green River, just above its junction with the Yampa, looking westward through Whirlpool Cañon and southward along this escarpment. In the left of the field of view are seen the more massive beds of the Upper Coal-Measure group of the Yampa Valley, while in the lower part of Whirlpool Cañon are exposed the upper beds of the Weber Quartzite.

In this somewhat imperfect sketch of the Yampa Plateau, it will have been seen that the system of flat-arched folds, with very sharp lateral flexures, often resulting in a partial displacement, which prevails in other parts 
of the range, is here represented in a most complex form, and combined with gentle rounded folds. Owing to inability to explore the region thoroughly, this description may be inaccurate in some of its details, but, in general, it is believed to represent correctly the main outlines.

The cañon of Lodore, as we have seen, cuts through the main body of the Uinta Range nearly at right angles to its trend, and exposes a section of the southern side of the main anticlinal fold. The general dip of the beds of red sandstone and quartzite at its mouth is about $10^{\circ}$ to the southward. In its deepest portion, the walls of the cañon are about 3,000 feet in height, and, on the western side particularly, almost vertical. An immense thickness of the Weber Quartzite is thus exposed. By calculation from the observed dip and the width of outcrop, on the assumption that in the whole distance there has been no faulting, there would be an aggregate thickness of more than 10,000 feet of strata exposed. The assumption of there being no faulting, lowever, is not consistent with the structure of the range as observed at other points, though, owing to the uniform character of the strata, it is difficult to determine any well-defined line of fault. The depression just north of a line drawn from Zenobia Peak to Ute Peak, which is approximately the line of outcrop of the beds of the Upper Coal-Measures which have escaped erosion, would seem to suggest the existence of such a fault at this point.

Zenobia Peak, the highest point of the Escalante Hills, is capped by the limestones of the Upper Coal-Measures, dipping $10^{\circ}$ to the southwest. In these limestones were found some casts of fossils, evidently Carboniferous, but too imperfect for determination. In one of the stream-beds of the southcrn slopes of the Escalante Hills, about 12 miles southeast of Zenobia Peak, were found in these limestones Spirifer lineatus and Spirifer opimus. The horizon of these fossils is apparently in the lower portion of the Upper CoalMeasure group, but it was impossible to determine at what distance from the bottom of the formation, from the fact that its line of contact with the Weber Quartzite is in a country, where the outcrops are obscured by soil accumulations and considerable growth of forest. 'The section exposed by the Yampa Cañon, as seen from its brink, shows beds of massive sandstone, much more heavily bedded than seen in the exposures of the Upper Coal-Measure group elsewhere. In the lower part of the section, the beds have a pinkish color, 
which, however, differs from the deep red of the Weler Quartzite, and may probably represent a larger development of the pink beds exposed in Vermillion Creek Cañon.

Summit Region west of Lodore Cañon.-To the west of the cañon of Lodore, the line of bluffs which forms the southern wall of Summit Valley presents approximately the northern limit of the remaining beds of the Upper Coal-Measures. In the lower portion of this valley, towarl the canion of Lodore, the existence of a fragment of Tertiary beds has been reported. They were not, however, found by our parties, and their ago or lithological character is not known. This fact suggests the interesting question, whether any other Tertiary besides the Wyoming Conglomerate ever covered this portion of the range. At Ute Peak, the most easterly point visited on this sirle of the river, an opportunity was had of observing the actual contact of the Upper Coal-Measures with the Weber Quartzite group. On the northern base of the peak, the upper beds of the Weber Quartzite are conrse-grained red sandstones, glistening on the surface, of loose texture, and weathering into large, massive blocks with rounded edges. In direct contact with the sandstones is a bed of reddish decomposed limestone, which has the external appearance of a porphyry, from the fact of its containing fragments of white crystalline calcite, some of which have a circular form, as if they had once been casts of corals. An analysis of this impure limestono was made by Mr. B. E. Brewster, with the following result:

Silica

Soluble silica . . . . . . . . . . . . . . . . . . $\quad 0.227$

$\left.\begin{array}{l}\text { Alumina } \\ \text { Ferric oxide }\end{array}\right\} \ldots \ldots \ldots \ldots \ldots \ldots \ldots \ldots \ldots \ldots . \ldots \ldots . . \ldots \ldots$

Lime. . . . . . . . . . . . . . . . . . . . . 39.542

Magnesia ........................... 0.287

Carbonic acid...................... 31.686

Water and organic matter............... 0.247

Carbonate of lime................... 70.610

Carbonate of magnesia .................. $\quad 0.603$ 
Above this are about 50 feet of coarse white sandstone, over which lie limestone-shales, and about 150 feet of fine-grained blue limestone, having almost a conchoidal fracture, very rich in fossils, from which, however, owing to the compactness of the rock and the smooth surfaces exposed, it was difficult to obtain good specimens. The fossils obtained here were:

Spiriferina Kentuckensis.

Athyris subtilita.

Meekella striato-costata.

With the exception of two mollusks found at the head of Bear River, Utah, these are the lowest fossils found in place in the Uinta Range.

Professor Marsh, ${ }^{1}$ in his exploration of these mountains in 1870 , found, at this horizon, and apparently very near this same locality, specimens of a Productus, Spirifer cameratus, Athyris subtilita, Hemipronites crassus, Zaphrentis (Stansburyi \%), and fragments of Fenestella and Phillipsia (?).

The dip of the beds at this point is about $15^{\circ}$ a little west of south, but to the eastward, toward the cañon, the beds apparently steepen, and dip $20^{\circ}$ to the southwest. In the hills to the west of Ute Peak are exposures of other limestones, apparently occupying a higher horizon than these, and yellow and purplish sandy shales, full of flinty concretions. In one seam of blue limestone at the base of these hills were found fragments of Syringopora, and a Spirifer, representing approximately the same horizon with the Ute Peak beds. Mount Lena is formed of the beds of the glistening red sandstone, dipping $7^{\circ}$ to $10^{\circ}$ south. The inclination of the Weber Quartzite beds decreases from here northward, and the northern axis of the range lies apparently just north of the divide, where the Indian trail descends into Ashley Park. Between Mount Lena and Marsh's Peak lies an open basin country, about 10,000 feet above the level of the sea, densely covered with forest. Of that portion lying between the two Indian trails indicated on the map, our knowledge is derived from distant observations and from the sections obtained on these two trails. All of the northern foot of the ridge which bounds this basin on the north has a gentle southerly dip, varying from $3^{\circ}$ to $7^{\circ}$. This gentle dip is more continuous here than in the range farther west, and extends southward into the portion covered by the beds of the 
Upper Coal-Mea ure limestones. The bedding of these limestones is concealed by surface accumulations, and, in general, can only be studied in the cuts of the deeper cañons. In the little peak, however, between the heads of Ashley Creek and Brush Creek, just west of the Sheep Creek Trail, the strata of Carboniferous limestone were found dipping nearly $25^{\circ}$ to the southward, showing signs of metamorphism in their red coloring, and indications of the presence of vein material in the fragments of mineralized quartz on the surface. This steep dip would seem to indicate some little local disturbance at this point; but south of the line of contact of the Weber Quartzite with the Upper Coal-Measures, from a little west of this point to a little east of Ute Peak, these beds seem to be approximately horizontal, forming a flat bench country, into which the streams flowing south have cut deep cañons. From the accumulation of rounded quartzite pebbles on its surface, it is probable that it was once covered by the beds of the Wyoming Conglomerate, but the only portion of this plateau where it was possible to prove the actual existence of this conglomerate was to the south of Cold Spring. Here on the bluffs overlooking Brush Creek was obtained a section, 200 to 300 feet in thickness, of a coarse gravel conglomerate, full of large rounded boulders of the Uinta quartzite, showing, as elsewhere, no bedding or structure-planes, and covering unconformably the upturned edge of the Mesozoic beds. Along the southern edge of this bench or plateau country, the Upper Coal-Measure strata, as exposed in the cañons cut by the streams flowing into Ashley and Brush Creeks, are seen to dip off steeply to the southward, this line of flexure marking approximately the northern limit of the Ashley Creek Basin.

On the surface of this bench region, near Geode Cañon, was found, in a pebble of red jaspery quartzite, a remarkably well-preserved specimen of Spirifer cameratus. From its position, its origin was evidently the Weber Quartzite beds of the interior of the range, and the character of the matrix would indicate that the stratum in which it was deposited belonged to the middle of the series. With the exception of a Spirifer imbrex found in débris from beds of the Weber Quartzite at the head of Bear River (Chapter III), this is the only palæontological evidence obtained as to the age of the great body of rock forming the core of the range. 
Ashley Creek Basin.-Under this general name are included the deeply-eroded valleys of Ashley Creek, Brush Creek, and Lower Green River, east of the Wonsits Ridge, the lowest portion of the region represented on this map. Probably nowhere in the world is a more excellent opportunity offered for studying descriptive geometry in its application to geology than in this basin. In it, the sandstone ridges of the various Mesozoic formations can be seen following the flanks of the higher hills in S-like curves; the more yielding clayey and shaly beds being cut into narrow monoclinal valleys, so that the system of three anticlinal folds, of which we have already spoken, is impressed upon the mind of the observer at a glance. As the observations made in this region formed the basis of the general grouping of these formations throughout the whole region shown in this map, a description of the various sections taken will be given somewhat more in detail than has been done heretofore.

The first line of section described will be that along the line of Ashley Creek, from Geode Cañon to the Quaternary valley of this creek. Geode Cañon is a narrow, picturesque gorge, in its deepest part about 2,000 feet deep; its upper portion being cut through horizontal beds of the light-colored siliceous limestones and sandstones of the Upper Coal-Measures. Near the mouth, it winds in and out between the beds, which here dip south at an angle of $29^{\circ}$. Among the upper beds which form the steep southern slopes of this bench country, the cherty fossiliferous seam, already mentioned, is prominent at the mouth of the cañon; in it were found the usual siliceous casts of Orthoceras, a smooth variety of Bellerophon, and the usual Bellerophon carbonarius, together with a Discina or Orbiculoidea. This bed is here about 50 feet thick, below which is found about 50 feet of yellow, compact cherty limestone abounding in geodes, containing beautiful crystals of calcite and small concretions of flint, some of which contain dendritic inclusions, and resemble the moss-agates of the Bridger Basin, and at its base a thin seam of green compacted sand and clay, which in places is very rich in oxide of iron. Below these limestones are massive bodies of white compact sandstone, more or less calcareous, and passing into siliceous limestones, which form the horizontal beds cut through in the upper cañon, of which, however, no detailed section was obtained. At the foot of the steep slopes on either 
side of the mouth of the cañon are monoclinal depressions, forming low saddles between the beds of the various creeks, and showing few rock-exposures, the surface being covered by soil and débris. This gap of several hundred feet is supposed to be occupied by the green and white clayey beds observed at the base of the Triassic formation in Flaming Gorge and Vermillion Creek, and which were assigned to the Permo-Carboniferous.

In the first line of ridges parallel to the steep slopes of the Bellerophon limestone, the escarpments of the northern face are formed of about 500 feet of coarse, massively-bedded sandstones of a deep-red color, with numerous intercalated clay seams, more or less impregnated with mineral salts, in which chloride of sodium appears to predominate. In the lower portion are thinlybedded sandstones, which are remarkable for their well-defined ripple-marks. At the base of these red sandstone cliffs, west of the mouth of Geode Cañon, on the divide between the two forks of Ashley Creek, was found an exposure of about 30 feet of solid white gypsum, overlaid by red and white clays. This gypsum is remarkably pure, containing 79.014 per cent. of sulphate of lime and 20.93 per cent. of water. Its beds are very massive on the exposed surfaces, and resemble a very fine-grained white marble, with a cloudy veining running through the mass. Doubtless, if opened by quarrying, these beds might furnish a very fair quality of alabaster. The red sandstone cliffs are capped by beds of harder compact grayish sandstone, above which a second line of cliffs is formed of 300 to 400 feet of lightercolored red or pinkish sandstones, with a gap of 100 feet or more between this and the deep-red bed, representing probably some clayey or shaly beds. These pink-red sandstones are capped by thin beds of flaggy sandstones, and a short line of cliffs is formed of 200 feet of yellowish sandstones, above which are heavy, white, cross-bedded, massive sandstones from 500 to 600 feet in thickness. These correspond to the massive buff and white sandstones already observed in former sections, and are noticeable for the persistency of the cross-bedding, which sometimes forms an angle of $30^{\circ}$ with the true planes of stratification. We have thus a thickness of about 2,000 to 2,500 feet of Triassic sandstones, in which, however, the thin limestone seam noticed in other sections was not observed.

To the south of the white sandstone ridges is an interval of clayey val- 
leys, representing the variegated clays of the lower portion of the Jurassic formation, which are more distinctly exposed in other sections. Forming a low ridge in the midst of this clayey interval, was found another deposit of gypsum about 25 feet in thickness, like the other; massive and compact, though of a more grayish color, and giving on analysis 76.736 per cent. of sulphate of lime and 21,512 per cent. of water. Neither of these gypsum deposits was found exposed for any great distance in the strike of the beds, and they probably are lenticular bodies enclosed in the clayey strata. The only other point at which they were found was on Sheep Creek, as already mentioned; but it is not at all unlikely that they exist in many other parts of the Triassic formation, since they would be easily concealed from observation by the disintegration of the clay beds which enclose them. A little to the south of this second gypsum deposit, a low ridge of coarse glistening sandstone is capped by about 50 feet of blue and drab limy slates and sandstone-shales, full of highly-characterized Jurassic fossils, among which were recognized-

\section{Gryphaa calceola var. Nebrascensis, Eumicrotis curta, Belemnites densus,}

together with two undetermined lamellibranchiate shells like Astarte.

To the south of this ridge another intervale occurs, which the character of the soil shows to be made up largely of red and purple clays, the latter being seen at the foot of the face of the next ridge under a white sandstone, whose base is a conglomerate, which is supposed to be that which forms the bottom of the Dakota group. The thickness of the Jurassic beds is difficult to estimate at this point, but seems to be greater than that observed on the northern slopes. Above the white sandstone are about 50 to 100 feet of blue clay-slates, the summit of the ridge being formed of compact brown sandstone, in which were found the following fossils of the Colorado group:

Inoceramus Ellioti (q).

Cardium, n. sp.

Lucina or Astarte (?).

Small mytiloid shell (q).

Several undetermined bivalves. 
On the southern face of this ridge, between beds of white and yellow sandstones, was found a seam of coal about 10 feet in thickness. This coal was apparently of remarkably good quality, having a brilliant lustre and conchoidal fracture, and was, as well as could be seen, remarkably free from clay seams. Unfortunately, the specimens obtained were lost in transitu, and no analysis has been made of this coal. To the south of this ridge, only a few hundred feet of 'sandstone ridges are exposed, which rapidly disappear under the clayey wash of the open valley. The average observed dip of the beds exposed in this section is about $20^{\circ}$ south. In general, it decreases in the higher beds and those at the greater distance from the axis of upheaval. To the westward of the main branch of Ashley Creek, the ridges bend off more to the northwest, closing up against the foot-hills of the range, and steepening somewhat in dip. At Obelisk Plateau, which forms the highest point of the Wonsits Ridge, the upper portions of these beds disappear under the Tertiaries, while the Triassic beds are seen to form the western faces of the cañon of the west branch of Ashley Creek, which runs approximately in the strike.

On the northern face of Obelisk Plateau, an abrupt escarpment, where the massive sandstone has weathered into obelisk-like shafts, or pinnacles, affords the following section. The summit is composed of conglomerate débris, obscured by surface degradation, from 150 to 200 feet below the highest point. In the next $25 \dot{0}$ feet were found some conglomerates and clays, with sandy shales, having somewhat of an oölitic structure, and carrying Jurassic fossils, among which were recognized Gryphaa calceola, already observed on Ashley Creek. The next 200 feet were hidden by débris; in their base were found some green and white clays, and the bottom of the cliff is formed of about 500 feet of the massive white crossbedded sandstone of the Upper Trias, dipping $29^{\circ}$ to the southwest. The strike of the sandstone is here about north $65^{\circ}$ west. To the west of this hill, the country is in general covered by benches of the Tertiaries of the Uinta Basin. The crest of the Wonsits Ridge apparently gives the present eastern limit of these Tertiaries, no remnants of them having been discovered within the basin east of this line. The Wyoming Conglomerate found on the Ti-ra-kav Plateau was apparently deposited upon the upturned 
edges of the Triassic and Jurassic beds. We may therefore conclude that the denudation of this basin has taken place principally since the time of the deposition of the Eocene 'Tertiary, and that a very considerable amount had already been accomplished previous to the deposition of the $\mathrm{W}$ yoming Conglomerate.

In the lower portion of the valley of Ashley Creek, and between this creek and Brush Creek, is found a country of low benches, made up, as proved by occasional exposures in some of the cuts, largely of blue and yellow clays, but in which no structure-lines could be observed. On the northern face of Wonsits Ridge, near Green River, were found, however, beds of yellow and white massive sandstone, with more shaly beds between, resembling, in lithological character, the rocks of the Fox Hill group, to which they have been referred, though it was impossible to form a very definite idea of their relative horizon. The beds exposed here are, at the base, several hundred feet of brown, shaly sandstone, overlaid by 100 feet of very white massive sandstone, 50 feet of partially bituminous sandstone, a bed of greenish coarse-grained sandstone, and 50 feet of highly bituminous sandstone, the whole covered unconformably by conglomerate and reddish gravelly Tertiary beds. This bituminous sandstone is rather a peculiar occurrence. On its weathered surface, it can hardly be distinguished from ordinary sandstone, but, in fracture, is perfectly black. The bituminous matter is not very inflammable, but is driven away in a very hot fire, with but little flame. It is probably a variety of asphalt. The specimens obtained from these beds give about 11 per cent. of bituminous matter and $85 \frac{1}{2}$ per cent. of silica. The sandstone strata have a strike at this point of east $20^{\circ}$ south, and dip of $20^{\circ}$ southwest, and are seen to form outlying ridges in the White River Valley, on the eastern side of Green River, running generally east and west, some distance to the south of Section Ridge. In their outline, the S-like curves of the lower beds have been generalized into one sweep around the outer edges of all these curves, while the interval between these and the harder sandstones of the base of the Colorado group, in which all structure has been obliterated by the decomposition of the clay beds, is supposed to be made up mostly of the heavy clayey beds of the Colorado group. 
To the east of Upper Ashley Creek, as far as Brush Creek, the ridges have a general strike of east $20^{\circ}$ north, while the dip flattens out in places to $5^{\circ}$, which gives a great width of outcrop. The actual line of the sandstone cliffs is much more varied than either the topography or the geological colors of the map express. Between the stream-beds, this line runs rapidly up toward the hills, in re-entering curves, bending out again in the deeper erosion of the valleys of the stream, giving a wavy line to the actual outcrops, which have necessarily been generalized on the map in consequence of the small scale on which it is drawn. To the east of Brush Creek, the sandstones of the Triassic and the variegated clays of the Jurassic formations are seen to run under the conglomerates of the Ti-ra-kav Plateau, appearing again at its eastern end. The outlines of the formations in the synclinal valley toward Island Park have been traced by observations made from the overlooking points of Ti-ra-kav Plateau and Split Mountain, as time did not permit the examination of this portion of the basin. Near the point where the Indian trail crosses Brush Creek, a coal seam is found, which probably corresponds to that already mentioned on Ashley Creek. Cretaceous fossils, such as Ostrea congesta, characteristic of the Colorado series, are found above these beds, and Professor Marsh mentions the discovery below it of cycloidal fish-scales, such as were found in the Flaming Gorge Ridge, Cretaceous turtles, and teeth of a Dinosaur; near this point also was found by Professor Marsh's party a fragment of the unique Cretaceous crinoid, the Uintacrinus socialis, Grinnell. We are here on the southern side of the synclinal, or near the point of the Split Mountain anticlinal, and the beds enclosing coal have a dip of $45^{\circ}$ to $50^{\circ}$ to the northeast. The coal seam here is also about 10 feet in thickness, but contains several dividing seams of sandstone and slate. There was the appearance of a second coal seam near this point, about 200 feet lower geologically, which, judging merely from the lithological character of the beds, would be within the Dakota group, perhaps near its base. No outcrops were found, however, sufficiently definite to determine its existence beyond a doubt.

In the singularly-curved ridges which form the western base of Split Mountain, the line of outcrop of the main coal seam is a narrow monoclinal 
valley only 15 or 20 feet wide, marked by an overlying sandstone bed containing remarkable spherical concretions. For miles along this line of outcrop they stand, freed from the loose sandstone in which they were enclosed, great spheres, from 6 to 10 feet in diameter, on whose surface little projecting ridges, of rectangular form, are so arranged as to give them roughly the appearance of parallels and meridians on a globe. Analysis shows them to contain about 45 per cent. of carbonate of lime, and considerable iron and alumina, which was, however, not quantitatively determined: they probably result, then, from a concentration of the limy material of the arenaceous beds, in which they occur.

The strata of the outer curved ridges on the western point of Split Mountain have a steep dip of from $40^{\circ}$ to $50^{\circ}$, and curve sharply round, as indicated on the map. The course of Brush Creek is cut through the clay beds of the Colorado group; near the ford were found some exposures in a deep ravine, showing blue plastic clays at the base, which are impregnated with salts of alum and alkalies, which crystallize out on some of the exposed surfaces. These clays seem to immediately overlie the spherical sandstones adjoining the coal. On the flat-topped benches of yellow marly clays, close to Brush Creek, the surface was found to be covered with conglomerate débris resembling the material of the Wyoming Conglomerate, though entirely decomposed. These curved ridges are so continuous as to make the ascent of Split Mountain from the west a very difficult matter, since they are rarely broken through, and the drainage follows, as will be seen by the map, their monoclinal valleys.

Split Mountain itself is a remarkable topographical feature, formed of the hard beds of the Upper Coal-Measures, dipping steeply north from $40^{\circ}$ to $50^{\circ}$; while at the extreme western point of the anticlinal the dip decreases to $15^{\circ}$, and on the south becomes as high as $70^{\circ}$; nearly through its centre the Green River has cut a V-shaped cañon in a southwesterly direction, bending at an acute angle to the eastward, and running for some distance in the strike of the steeper beds of the southern side of the anticlinal fold, through which it then suddenly breaks into the open alluvial valley of the Ashley Basin. In this cañon, the lower beds exposed have a distinctly red color, but it was not definitely determined that they belong to the Weber 
Quartzite series, and they have not, therefore, been indicated by a distinctive color.

In the synclinal south of Split Mountain, the red Triassic beds are seen to extend high up in the re-entering valley to the eastward, almost to the summit of the Yampa Plateau, in a U-shaped line of bluffs, presenting always steep escarpments toward the hills, while their surface slopes approximately with the dip of the beds toward the valley. On the northern slope of Section Ridge, these Triassic sandstones dip only $10^{\circ}$ to the northwest. So continuous a ridge do they form that it was found almost impossible to cross it with mules in order to reach the curved interior valley, in which are White Sulphur Springs. These springs come from strata near the base of the Triassic formation, and may probably get the sulphur, which deposits freely from their waters, from the same stratum in the Upper Coal-Measure series from which proceed the pyrites, already mentioned as occurring on the summit of Section Ridge. The width of the outcrops, indicated on the map, at the southwestern point of Section Ridge, is probably narrower than it should be, since the vertical distance of our grade-curves is so great that the topography here has been too much generalized to give sufficient accuracy in its delineation of the sandstone ridges. It is a matter of regret to the observer in this district that only a few days could be allotted to the study of this unique and interesting region, for the proper illustration of which a careful plane-table survey and several months' geological field-work would be necessary.

Southern Flanks of the Uinta Range.-West and south of the Wonsits Ridge, away from the immediate flanks of the mountains, the country is covered by the Tertiary beds of the Uinta Valley, which form gently-sloping terraces and plateau ridges between the valleys of the principal streans. In the bottoms of these valleys are broad stretches of alluvial land along the borders of the streams, while, in the bench country, near the cañons, through which the larger streams emerge from the mountains, are long ridges of moraine material overlying the Tertiaries. It is only along the steeper slopes of the mountains, and that where the streams have deeply eroded the Tertiary gravel beds, that the upturned older rocks can be observed. 
West of Obelisk Plateau, the first good exposures of the Mesozoic beds are found at the gateway-like entrance to Antero Cañon, through which flows the eastern branch of the Ute Fork. Between these two points, the upturned beds curve inward toward the centre of the range in a long, rounded curve, the upper branches of the West Fork of Ashley Creek running in general with the strike of the beds, while at Antero Cañon they bend outward in a sharp, narrow fold; in part obliquely, and in part transversely, this cañon has been cut through the beds involved in this fold, and the section exposed presents some striking complications of structure, which, taken by themselves, might look like nonconformities, except that, as is usual in the Uinta uplift, the flanking and more recent beds stand at a steeper angle than the older ones.

The gateway of the cañon, as of most of those of the southern slope, is formed by the massive cross-bedded sandstones of the Triassic, which, owing to their infrequency of bedding-planes, offer a greater resistance to erosion, when inclined at a considerable angle, than even the harder siliceous limestones of the Upper Coal-Measure group. On the eastern side of the gateway were found about 1,500 feet of white and brown sandstones, standing at an angle of $70^{\circ}$ south, in the upper part of which was a bed of bituminous sandstone, like that found on the Wonsits Ridge, having the same blackish-brown fracture and musky odor, containing, however, only 6 per cent. of carbonaceous matter, with 90 per cent. of silica. The summit of the ridges on either side of the cañon-gateway being formed of horizontal beds of Tertiary, the outcrops along the slopes are frequently concealed beneath their débris and cannot be followed continuously; but in the soft slopes, at a higher geological horizon than the sandstones, were found some limestones included in argillaceous strata, from which were obtained two undetermined species of Tancredia and an Astarte, not in a very good state of preservation, but sufficient to determine the horizon of the beds as Jurassic. Above these were a few indistinct outcrops of sandstones, supposed from their position to be Cretaceous. On the western side of the gateway, the outcrops of the same white and brown sandstones could be seen under the horizontal Tertiaries, standing at an angle of $60^{\circ}$ south, below which were the red sandstones of the Triassic, 
dipping conformably in the lower portion of the cliffs. Higher up, these red beds bend in an S-shaped curve from $60^{\circ}$ to a horizontal position, and then still higher on the cliffs assume an angle of $45^{\circ}$ south, the continuity of the beds being distinctly traceable through all these changes of dip, while their strike bends off $30^{\circ}$ to the north of west, almost at right angles to that of the strata on the east side of the canon, which is about southwest. Above the gateway of the cañon, separated by a gap without outcrops from the overlying Triassic sandstones, were found outcrops of the bluish-drab limestones of the Upper Coal-Measure; while the cañon above, which was not explored, runs nearly in the strike of the beds, and in it, as well as could be seen, the strata of Weber Quartzite stand at a much lower angle than the upper beds. From some blue limestones, apparently above the Jurassic outcrops mentioned above, but evidently not in place, were obtained the following Coal-Measure forms:

Streptorhynchus crassus.

Athyris subtilita.

Whether these were fragments, or whether, which seems hardly possible, there has been an inversion of beds, was not satisfactorily determined.

Where the next large stream to the west, the western branch of Ute Fork, emerges from the mountains, though the Tertiaries have been very considerably eroded, the accumulations of moraine material are so great as to cover almost all the outcrops laid bare by this erosion; and of higher beds than the Upper Coal-Measure limestones, the only indication found was an outcrop of white sandstone near an eastern branch of the main stream, which was supposed to belong to the Triassic formation. The narrow ridge separating this branch from the principal stream is formed by a huge lateral moraine. A short distance farther up this eastern branch, a blue limestone outcrop, dipping about $30^{\circ}$ south, closes up the basin-like head of this creek, while the steeper slopes near its source show outcrops of a whitish limestone, having a dip of but little over $10^{\circ}$, which would explain the apparently exaggerated width of outcrop of the Upper Coal-Measure group as indicated in the map at this point. The range was crossed here, coming from Burro Peak through the basin at the head of Antero Cañon, and over the spur which separates the two main branches of Ute Fork. On the surface 
of the lower part of this spur, little is to be seen of the structure, owing to the fact that it is covered with a dense forest, and the rocks are obscured by vegetation and fallen timber; the upper and barer portion to the west of the three lakes, at the head of Antero Creek, is formed of the striped red quartzites, which belong apparently to the upper part of the Weber Quartzite group, dipping $9^{\circ}$ southward; within them were found, however, some clay beds, about 100 feet in thickness, similar to those already observed on Gilbert's Peak, though their geological horizon should be considerably higher than the latter.

Eastward from this point, the almost continuous ridge forming the northern face of the higher portion of the range as far as Leidy's Peak, was seen to be formed of similar beds of approximately the same horizon, dipping from $5^{\circ}$ to $7^{\circ}$ to the southward, with a slowly-increasing angle toward the southern flanks. The basin at the head of the western branch of Ute Fork, to the west of this ridge, which is one of the largest of the characteristic amphitheatre-shaped basins which are found all along the crest of the range, has already been mentioned in the view from Gilbert's Peak; it is surrounded by the highest peaks of the range, Emmons' Peak on the west, with a ridge of scarcely less elevation, connecting it with the east and west crest of which Gilbert's and Burro Peaks are the prominent points. The exit to the south down the cañon of the west branch of Ute Fork was found impracticable for animals on account of the peculiar cañon-within-cañon structure common to many of the valleys of the southern slope, but remarkably well developed here. The peculiarity of this structure is that while the main valley is a canon-like gorge, having the characteristic U-shape of glacial valleys, the present stream has cut a still narrower cañon in its very bottom, scarcely wider than the stream itself, whose sides are perpendicular, and frequently overhanging, while its depth is in places 50 to 100 feet below the general level of the main valley-bottom. The cutting of such cañons through rocks as hard as the Weber Quartzite, is an additional proof of the great amount of post-Glacial erosion which has been already supposed to be necessary for the removal of such immense quantities of softer material from the Tertiary plains since the deposition of the Wyoming Conglomerate. 
The upper valley of the eastern branch of Lake Fork has the usual gateway at its mouth, formed by the closing together of the outcrops of Triassic sandstone; the valley above for a few miles is, however, wide and comparatively open, and the gateway less pronounced than that of Antero Cañon, so that the outcrops are more concealed by surface accumulations and afford a less continuous section. Through this valley runs the Indian trail from the Uinta Reservation to Fort Bridger, already mentioned as crossing the summit at Jones's Pass. From its mouth out upon the Tertiary plain, to the east of the stream, extends a long narrow ridge, formed by a lateral moraine, several hundred feet in height near the mountains, and apparently extending 5 to 10 miles away from them. The first outcrop found under the Tertiary beds in ascending the cañon was that of a bed of white sandstone of about 500 feet thickness, standing at an angle of $25^{\circ}$ south, with a strike nearly due east and west. Below this, with the exception of a 40-foot bed of harder, more compact sandstone, no outcrops were found till beds of 100 feet of blue limestone were found in the open valley above, while at the mouth of the side-cañon, coming down from Emmons' Peak, were several hundred feet of bluish-gray calcareous and siliceous shales. At the point where the canon bends again to the northward, the first outcrops of the Weber Quartzite were recognized, dipping about $20^{\circ}$. The same general series in these beds was found as elsewhere, namely, striped sandstones above, next purple quartzites with clay beds, becoming lighter-colored and more compact toward the base. Where the dip of these beds shallows to $10^{\circ}$, the same cañon-within-cañon structure, already noticed, is found, though less developed than on the Ute Fork.

The gateway of the western branch is more pronounced, the Triassic sandstones forming a narrow transverse ridge, enclosing the broad open valley above, which is some 15 miles in length. Some clayey beds above the sandstones were supposed to belong to the Jurassic formation. From 1,500 to 2,000 feet of Triassic sandstones are exposed in section here, dipping from $30^{\circ}$ to $35^{\circ}$ south, with a strike of north $65^{\circ}$ to $75^{\circ}$ east; their upper part is formed by about 500 feet of massive, cross-bedded, white sandstones, underlaid by a series of white and buff beds grading off into red sandstones, whose color becomes deeper as one descends. The broad val- 
ley above was not explored; but from Point Carbon, the culminating point of its western ridge, it was possible to distinguish the Upper Coal-Measure limestones forming the hills on its eastern border, with dips varying from $27^{\circ}$, near the lower end of the spur, to $14^{\circ}$ near its head. East of this gateway, remnants of Tertiary beds, dipping only $2^{\circ}$ south, are seen high up on the spurs, about 2,000 feet above the bed of the stream.

The valley of the next stream to the west, the east branch of the Duchesne Fork, presents the best and most continuous section of any of those west of the Ashley. Like Antero Cañon, its upper course runs partially with the strike of the beds, but below the bend, at Beaver Lake, it crosses them almost at right angles. Below its deeper portion, a moraine ridge covers the Tertiary beds of the eastern bank, as was seen to be the case at the eastern branch of Lake Fork, and the general shape of the cañon is glacial, though the height of these moraine ridges above its present bottom shows, in the absence of cañon-within-cañon structure, the work done by post-Glacial erosion.

On the western wall of the cañon are the best exposures found, the eastern slopes being broken and covered by débris below the bend. The beds here dip $25^{\circ}$ to $30^{\circ}$ south, and strike a little north of west. Those recognized going up the cañon were, first, in the saddle above the flattopped Tertiary hill at the lower end of this western ridge, a few outcrops of gray sandstones, which were referred to the Dakota Cretaceous; next, in a short side-ravine, evidently washed out of clayey beds, irregular outcrops of light-colored limestones and whitish calcareous shales, in which were found a few remains of Pentacrinus asteriscus, sufficient to designate their horizon as Jurassic. A short distance beyond these is the prominent cross-bedded white massive sandstone of the Triassic formation, 600 to 800 feet in thickness, underlaid by a yellowish sandstone 200) to 300 feet thick; next, 500 feet of pinkish-red sandstone, having at its base a thin bed, less than a foot thick, of greenish-white limestone, included in shaly beds, with 500 feet of deep-red sandstone beds forming the base of the series. Analyses were made of characteristic specimens from these beds by Mr. B. E. Brewster, with the following result. From the greenish-white limestone, a 
compact, fine-grained rock, in which, however, could be distinguished an admixture of occasional quartz grains, were obtained:

Silica

Alumina

Ferric oxide $\}$

Manganous oxide.

Magnesia

Carbonic acid.

Water and organic matter. 2.045

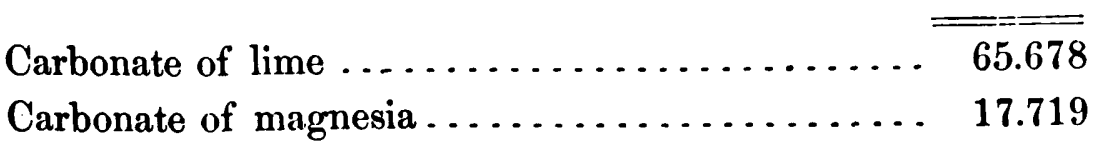

A specimen of soft deep-red sandstone from near the base of the series gave the following:

Silica

Alumina

Ferric oxide

Carbonate of lime

Carbonate of magnesia

2.04

Soda

1.15

Potassa

2.06

Water

0.70

99.08

No sulphuric acid was found, but the amounts of lime, magnesia, and alkalies contained in this rock are very suggestive.

In the limestone bed between the two red sandstones was found a Natica lelia, an identical form with that found at Rawlings Peak, though its horizon is here more definitely known. This occurrence is interesting as being the first fossil found in the Triassic beds east of the Wahsatch Mountains. From the red sandstones to the bend of the canon, the continuity of outcrops is somewhat obscured; apparently mud-rocks and limestones pre- 
dominate, and from one of the latter beds were obtained the following Permo-Carboniferous fossils:

Bakevellia parva.

Myalina (like the young of $M$. subquadrata).

Pleurophorus (like P. oblongus).

Myalina, sp.?

Macrodon, sp.?

These fossils present almost the only decided palæontological evidence of the existence of this formation in the Uinta Range, though it has been designated by a color, wherever the underlying and overlying groups are represented in juxtaposition on the map.

Above the bend, at Beaver Lake, as already mentioned, the cañon runs approximately in the strike of the beds, which, for a few miles up, are the limestones and sandstones of the Upper Coal-Measure group; in these beds on the west side of the cañon, just above the lake, was observed a short secondary roll, making a partial S-curve in the stratification-lines. Such secondary rolls, or crumples, in the southern member of the great anticlinal fold, are doubtless more common than can be actually proved by observation, and may account for the great width of outcrop which, especially in the Upper Coal-Measure limestone, is often larger than the angle of dip observed and their known thickness would warrant unless such intermediate flexures existed.

In ascending the western ridge from the lake to its summit, Point Carbon, so called, as being the highest point where Coal-Measure fossils were found, many isolated outcrops of light-colored limestone beds were crossed, dipping southward at generally low angles. The summit of this outlying peak, which is 11,443 feet above sea-level, is formed of a darkbluish thinly-bedded limestone, dipping $25^{\circ}$ south. These beds yielded some fossils, of distinctly Coal-Measure type, Productus and Spirifer, but which were not sufficiently well preserved for specific determination. Immediately under this limestone is a coarse-grained white sandstone, made up of large rounded grains of quartz similar to that noticed at the base of the Upper Coal-Measure group on Black's Fork. Following the ridge $20 \mathrm{D} \mathrm{G}$ 
toward the centre of the range, the red striped sandstones of the upper Weber Quartzite are crossed, whose angle rapidly flattens out to $15^{\circ}$ and $10^{\circ}$ south. An analysis of a specimen of these sandstones, of a deep-red color, with stripes of a darker coloring, about an eighth of an inch apart, and composed mostly of rounded grains of quartz, was made by Mr. B. E. Brewster, with the following result:

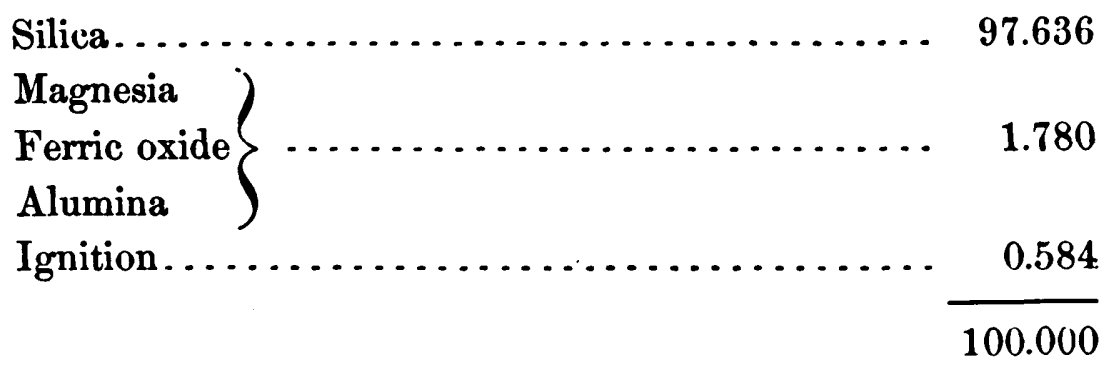

From Point Carbon, a comprehensive view of the southern spurs was obtained, and the general structure easily studied. In the region between the east and west branches of the Duchesne Fork, there is seen to be a re-entering curve in the strata toward the axis of the range, in consequence of which the steeper dips extend to a greater depth in the Weber Quartzite series; these beds can be seen lying at low angles high up on the dividing ridge near the head of the cañon, but bending down to the southward in conformity with the steep angles of the Mesozoic beds, without any appreciable break or want of continuity.

The red sandstones of the Triassic can be seen extending high up on the ridge, and forming the summit for some distance above the lake, their strike being to the north of west; in the valley beyond, to the westward, as will be seen in the description of Map III, they change in strike again, bending outward with a strike to the south of west. Unfortunately, there was a long interval between the time of observation of the two branches of the Duchesne, the western having been visited in 1869 and the latter in 1871 , and their correlation, with reference to the correspondence of beds, is not as satisfactory as could be wished. 


\section{SECTION V. \\ TERTIARIES OF THE UINTA VALLEY.}

The examinations of the Tertiary beds of this basin have been extremely cursory, being confined principally to the line of travel along the immediate foot-hills of the range. Our party found no fossils in any of these beds; but Professor Marsh and his assistants, who followed them from below the mouth of the Ashley Creek, up the valley of White River, south of the limits of this exploration, succeeded in securing a very valuable suite of vertebrate fossils from the latter locality.

The following are some of the principal forms collected and determined by him:

\section{Diplacodon elatus. \\ Orohippus Uintensis. \\ Orohippus gracilis. \\ Agriochorus pumilus. \\ Diceratherium advenum.}

Although some of the forms collected have a generic resemblance to those of the Bridger beds, others again have somewhat of a Miocene facies; the preponderance being in favor of the former, he has regarded the whole, while representing a later period than that of the Bridger beds, as probably of Middle or Upper Eocene age. Although the whole area has been designated by the one color of the Uinta Eocene, certain considerations, which will be more fully explained later, suggest the possibility that an older series of beds, probably corresponding in age to the Vermillion Creek series, may also have been deposited in this basin.

The lowest Tertiary beds observed are apparently those which rest unconformably on the upturned edges of the Fox Hill sandstones, on the southeastern end of the Wonsits Ridge. Here they dip from $8^{\circ}$ to $10^{\circ}$ to the southwest, and consist of a coarse sandstone containing beds of coarse structureless conglomerate, hardly to be distinguished from the Wyoming Conglomerate, being made up of rounded pebbles of Weber Quartzite and Upper Coal-Measure limestone, overlaid by several beds of coarse greenish 
sandstone, with alternate beds of reddish arenaceous material, not unlike the beds of the Vermillion Creek series on the Aspen Plateau; in all a thickness of perhaps 500 feet. These same Tertiary beds form the crest of the Wonsits Ridge as far as Obelisk Plateau. Some distance down the Green River could be distinguished red and chocolate-colored beds lying nearly horizontal, while those of the White River Valley, from which Professor Marsh's fossils were obtained, are represented as green and ash-colored argillaceous beds, eroded into bad-land forms, which might seem to be an unconformable and later series than the upturned conglomerates and sandstones; this non-conformity is, however, merely conjectural, and not supported by any actual observations.

At the Obelisk Plateau, as well as on the ridge east of Antero Cañon, the Tertiary beds are still capped by fragments of Wyoming Conglomerate, but of the character of the underlying beds, owing to their friable nature and consequent covering of loose material on the slopes, little could be seen in these higher ridges. The low terrace-ridges, which separate the valleys of the streams flowing into the Uinta, seem largely composed, however, of coarse sandstones and gravelly beds, of a general reldish color, having few strata of a consistency to afford good outcrnps. From the Ute Fork westward, the benches are covered near the hills by moraine ridges extending out into the valley from the cation-mouth of the principal streams, and reaching a height, in some cases, of several hundred feet. Between the Ute and Lake Forks were observed several exposures, showing from 200 to 500 feet of coarse red and yellowish sandstones, while the calculated thickness of Tertiary ridges observed would give a development of 2,000 to 3,000 feet of Tertiary beds above the present average level of the streams. The Tertiaries are, in general, much better exposed in the lower portions of the valley toward the Uinta River, but time did not permit of any extended examination in that direction. The most considerable body of Tertiary beds on this map is that between the forks of the Duchesne, near the western limits, where they form a flat-topped hill, capped by beds of the Wyoming Conglomerate. The thickness here is, as already observed, between 2,000 and 3,000 feet, the beds lying practically horizontal. By reference to Map III, it will be seen that the Tertiaries extend westward nearly 
to the slopes of the Wahsatch, here, as far as our observations showed, consisting generally of the coarse red and chocolate sandstones, with an everincreasing predominance of gravel and conglomerate material to the westward. They occupy relatively elevated positions, and correspond so much, in general lithological character, to the Tertiaries of the Wahsatch region along the Weber River and northward, which have been referred to the Vermillion Creek Eocene, that it seems possible that these western developments may belong to the same series, the more, as the present topography offers no evidence of any barriers between the seas in which they were deposited.

Between the east and west branches of the Lake Fork, on the very flanks of the Uinta Range, an exposure of Tertiary beds was found, of a very different character to those of the valley-terraces, which evidently occupy a higher horizon, and may belong to a later series. In this case, they would probably represent the western extension of the beds observed in White River Valley. At this point is a quarry-like opening, where the beds of the steep slopes, usually covered by vegetation and débris, have been denuded by the erosion of a little mountain-stream. A thickness of about 600 feet is exposed, of massive beds of coarse yellow sandstone, showing some concretionary structure, and worn out by atmospheric action into caves and round spire-like forms. The sandstones contain pebbles of saccharoidal quartzite, both rolled and angular. Some beds are very fine-grained, of white color, with a buff striping, running into very fine siliceous beds containing calcareous material, very like, in general appearance, certain strata observed in Brown's Park. At the base of the series are some reddish strata, but none of the red sandstone and gravel beds observed in the open valleys below. A singular regularity and persistence in the jointing-planes of these beds gave the appearance of a dip, at first sight, of $80^{\circ}$ to the south; but on careful examination, the existence of beds of clay and pebbles showed the actual planes of deposition to be nearly horizontal, with a dip of from $2^{\circ}$ to $5^{\circ}$ southward. To the west of this exposure, the Tertiary beds, distinguished by their horizontal stratification, could be seen to extend higher up on the spurs, to a height of not less than 2,000 feet above the stream-bed, at the gateway of the cañon, and 
were apparently capped by beds of Wyoming Conglomerate; though, as this idea was based on rather distant observations, the Wyoming Conglomerate color has not been indicated on the map.

The moraine ridges also deserve a more careful study than our time permitted. The principal lateral moraines observed were those on the west branch of the Ute Fork, and the east branches of the Lake and Duchesne Forks. In the two latter instances, they stand on the east bank of the present stream; in the first, on both banks. Smaller detached moraine-ridges were also observed between the streams, coming from shorter local glaciers. There is evidence of considerable erosion since the melting of these glaciers, shown by the depth of the present stream-beds below the base of their ridges, which, in the Lake and Duchesne Forks, is apparently from 500 to 1,000 feet in the readily-decomposed beds of the Tertiary. On the Ute Fork, it is comparatively small, which is probably due to the fact that the upturned beds, now largely concealed by recent detritus, come nearer to the surface, and have offered more resistance to erosion than the Tertiary gravels. 


\section{CHAPTER III.}

\section{U T A H B A S I N.}

SECTION I.-WESTERN UINTA RA.YGE-SOUTHERN FLANKS-TRACHYTE BODYNORTHERN FLANKS.

SECtion II.-FROM ASPEN TO ECHO CITY-UPPER BeAR RIVER VALleYRegion between BEAR AND Weber Rivers-Northern Bear River REgion. SECTION III.-WAHSATCH RANGE-GENERAI REMARKS-UTAH LAKE REGIONCOTTONWOOD REgION-FARMINGTON AND WEBER RIVER REgION.

SECTION IV.-NORTHERN WAHSATCH REGION-FroNT RANGE-OGDEN REGION-BOX ELDER REGION-EASTERN UPLIFT-INTERIOR VALLEYS.

SECTION V.-REGION NORTH OF SALT LAKE-PROMONTORY UPLIFT-ISLands-CURLew Valley-Terrace Mountains-Raft RIver Mountains.

SECTION VI.-LAKE REGION_GREAT SALT LAKE-Jordan VALLEY-TRaVERSE MOUNTAINS-UTAH LAKE VALLEY:

Section VII.-REgION SOUTH OF SALT LAKE-OquirRH MountainsTooelle and Rush VaLleys-Aqui Mountains-Islands.

Section VIII.-DESERT REGION-SKull Valley-Cedar Mountains-Lake side Mountains-The Great Desert.

\section{SECTION WESTERN UINTA RANGE.}

BY S. F. EMMONS.

Southern Flanks.-The western end of the Uinta Range, which projects about 25 miles into the region covered by Map III, differs in no essential respects from the main portion already described in Chapter II, and requires, therefore, no extended description. It has the same broad 
plateau-like summit, covered by dense growths of pine forest, out of which rise bare, steep ridges of horizontally-bedded quartzite. The extreme western end falls off somewhat in height, having an average elevation of less than 10,000 feet west of Bald Mountain, and hence is more densely wooded than the main crest, but shows the same broad amphitheatre-like basins at the heads of the streams, and similar glacier-cut cañons on its flanks. In geological structure, it preserves the same general character of one broad east and west anticlinal fold with axis near the northern edge, the southern member inclined gently over the higher portion, and dipping suddenly down on the southern flanks, while the northern member bends down at steep angles immediately north of the axis. The flanking Mesozoic beds are well exposed on either slope, but at the western end, where the range ends somewhat abruptly, in close proximity to the Wahsatch uplift, their outcrops are masked by a body of trachyte, which has poured out along the contact-line of the two ranges, and which, together with the Quaternary accumulations of several little mountain-valleys, so completely covers the present surface that but little can be learned of the structure of this interesting middle region.

In resuming the description of the southern flanks of the range, where left in Chapter II, the next cañon-section is found in the valley of the Duchesne Fork of the Uinta River, one of the most interesting and characteristic cañons of the range. This stream takes its rise between Bald Mountain (11,977 feet) and Mount Agassiz (13,000 feet), in an almost circular amphitheatre from 4 to 6 miles in diameter, studded with shallow mountainlakes, which occupy glacier-worn basins in the horizontal quartzites, with an average elevation of 10,000 feet above sea-level. It then flows for about 10 miles nearly due south through a deep U-shaped canon, cut from 2,000 to 3,000 feet into the hard quartzite strata, with almost perpendicular walls, which, when seen from below, with the bare summit of Bald Mountain at the head, gives an effect somewhat like that of the Yosemite Valley, so completely does it seem to be shut in. Reaching the steeper-dipping beds, its course is somewhat deflected, and, in the softer Mesozoic rocks, it has cut a broader valley, flowing through a wide alluvial bottom out into the region of Tertiary benches and plains. 
In this cañon, a section is afforded almost at right angles to the strike, and all the beds from the Weber Quartzite to the Tertiaries of the Uinta Valley and the Wyoming Conglomerate are shown with more or less distinctness. The shallow dips of $5^{\circ}$ and $10^{\circ}$ continue from the head of the cañon down to within about 3 miles of Stanton Creek, the main western branch of the Duchesne. On the broad flat surface of Rhodes' Spur, which forms the western boundary of the main cañon, the drab limestones of the Upper Coal-Measures are left for a considerable distance in the shallower dips. From them, the following Carboniferous species were obtained:

Chonetes granulifera.

Martinia lineata.

Syringopora multattenuata.

Syringopora?

Zaphrentis?

Lithostrotion?

Euomphalus?

Of these fossils, the two latter would seem to indicate a lower horizon than the Upper Coal-Measure series, having been found elsewhere only in the limestones of the Lower Coal-Measure group.

The line of change of dip from $10^{\circ}$ to $45^{\circ}$ south is marked by the east and west ridge, which borders Stanton Creek on the north, and the effect of this change of dip is seen in a bend of the cañon, where the stream has been deflected from its course by striking the face of a harder, more resisting bed. Stanton Creek runs approximately in the strike of the steep-lipping beds of the southern flanks, and is apparently worn out of the softer shales of the Permo-Carboniferous. The ridge to the south of this creek affords an excellent section of the massive buff and cross-bedded red sandstones of the Triassic, which are here also developed in an unusual thickness, dipping $45^{\circ}$ south, while the next parallel creek to the south is cut through the shale beds and limestones of the Jurassic. Beyond this, the lower beds of the Cretaceous, including the white sandstones at the base of the Colorado group, are found dipping conformably at $45^{\circ}$ to the south, and overlaid unconformably by the horizontal beds of the Uinta Eocene, which form the mass of Black-tail Mountain. In the curvings of the ridge, which separates this stream from 
the East Fork of the Duchesne, represented on Map II, are seen the topographical effects of the change in strike from $10^{\circ}$ north of west to $25^{\circ}$ south of west; the re-entering angle in the strata being produced by longitudinal compression of the Uinta fold. The upper part of Red Fork also runs parallel with the strike of the upturned beds, and has been cut in the line of a deposit of coal enclosed in a white fine-grained friable sandstone, which is considered to correspond to the coal seam found in the Colorado Cretaceous on Ashley Fork, though no fossils were obtained from any of the upper beds at this locality. The outcrops of coal were too much weathered and decomposed to afford any indications as to its economical value, consisting mostly of brown earthy carbonaceous material. Below the upper bend of Red Fork, a sulphur spring issues from the sandstones overlying the coal.

To the eastward, the beds of the Triassic, Jurassic, and Cretaceous pass under the almost horizontal Tertiaries of the Uinta Eocene, which cover the whole region along the headwaters of the Uinta. These Tertiaries are exposed in great thickness, and consist mostly of coarse buff and chocolate-colored sandstones and loose gravelly conglomerates, attaining a thickness of several thousand feet. They have been deeply cut through by the streams which flow into the Uinta River, and in some places, notably at the junction of Kern Creek and where the Uinta River cuts through the southern end of Kern Ridgre, beyond the limits of the map, isolated outcrops of unconformable upturned beds, limestones and sandstones, are found exposed, but too limited in extent to afford definite indications of their age. It would appear probable, however, that similar secondary flexures in the Mesozoic strata exist in this southern angle of the Wahsatch and Uinta Ranges as are found in the northern angle. The plateau-like summits of the highest of the 'Tertiary ridges are found to be covered by beds of coarse conglomerate, resembling in character those of the Wyoming Conglomerate observed on the north slopes of the range, to which formation they have therefore been assigned. The Tertiaries occupy the ridges which border Strawberry Valley, and those which separate the waters of this valley, which flow into the Uinta, from those of Hobble's Cañon flowing into Utah Lake. They doubtless extended at one time to the very flanks of the Walsatch; but the region west of Strawberry Valley, in the upper portions of Hobble's Canon, and 
the ridges to the south of Provo Valley, are so covered with forest growth and surface débris, that, in a somewhat hasty examination, it was impossible to determine definitely the present limits of the Tertiary beds. On general lithological grounds, and on account of their heightened dip, the beds immediately adjoining the Wahsatch on the east have been assigned to the lower Cretaceous formations, while outcrops of nodular limestone, which have a dip of $45^{\circ}$ to the eastward, overlying the red sandstone in Hobble's Cañon, though barren of fossils, have been considered as representing the Jurassic formation.

The thickness of the southern Tertiaries, like those to the north of the Uinta, seems to increase as it approaches the Wahsatch, and, like those also, to become more conglomeratic and be composed of coarser material generally; and it may be that these beds, like those to the north, represent only the lower members of the Tertiary formation, which farther east is covered by the more recent beds, from which were obtained the fossils which have led us to assign to this group a later age than that of the Bridger beds. Moreover, as already remarked in Chapter II, the high position of these beds, with no apparent barrier between them and the Tertiaries along the flanks of the Wahsatch to the north, which have been considered as belonging to the Vermillion Creek series, renders it probable that the seas, in which they were deposited, were originally connected, and that they are therefore of the same age.

The Provo River rises in a similar basin to that of the Duchesne at the southwest of Bald Mountain, and flows for a short distance across the strike; its upper valley, known to the settlers as Soapstone Cañon, then bends to the eastward, running approximately with the strike of the rocks, and marking roughly the line of division between the Weber Quartzites and the Upper Coal-Measure limestones. Croppings of the latter are found in the wooded hills to the south of this cañon, from which the fossils already mentioned have been obtained. They are much obscured, however, by surface accumulations and Tertiary and glacial débris, and near Kamas Prairie are lost under the beds of trachyte which form the hills between this valley and Provo Valley.

The plateau-like summit of the Uinta becomes narrower toward the 
west, descending gradually toward Kamas Prairic, while the outcrops of the upturned higher members of the fold close together, its geological axis nearly corresponding with the topographical, or following the line of the main crest to the west of Bald Mountain. The beds of the Weber Quartzite are exposed to the very edges of Kamas Prairie, where they disappear beneath the gravels and soil of the valley. In the ridge to the south of Kamas Creek, they already curve around with a northwest strike, dipping $20^{\circ}$ to the southwest; and south of the mouth of the upper Weber Cañon, the overlying beds of the Upper Coal-Measure are found striking north $55^{\circ}$ east, with a dip of $25^{\circ}$ to the northwest. The interval between the western end of the Uintas and the mass of the Wahsatch is occupied by the Quaternary Valley of Kamas Prairie, and the trachyte hills between that and Provo Valley, so that the exact relation of the beds of these two systems of upheaval cannot be definitely arrived at; but in the tendency of the flanking beds of the Uinta to close together at the western end, and in the finding of little outcrops of Carboniferous limestone and Triassic sandstone in ravines of the trachyte hills, we have sufficient proof that the Uinta upheaval is quite disconnected from that of the Wahsatch, and that the upper beds, at least as high as the Jurassic, probably once filled this interval. The existence of this trachyte body and other little bodies to the northward indicates a line of weakness and fracture nearly parallel with the main ridge of the Wahsatch, and crossing it diagonally farther north.

Trachyte Body.-The highest point at which the trachyte beds are found is at Heber Mountain, at the head of Heber Canon, where they form the three highest peaks between the headwaters of the Provo and the Uinta. Here they have apparently overflowed the conglomerate beds of the Uinta Eocene; still, this fact is not definitely proved, since these Tertiaries are only found to the south of the trachyte body, and nowhere directly under it. On the ridge to the east of Heber Mountain is a considerable accumulation of gravel and boulders, containing rounded fragments of both quartzite and trachyte, which is probably the remains of a glacial moraine, or may possibly result from the decomposition of beds of Wyoming Conglomerate, which covers the neighboring ridges at about this elevation. In the latter case, it would be an indication that the trachyte was at least of earlier 
origin than this formation. The trachyte flows have extended northward from this point, forming the mass of hills in the bend of the Provo River, between Provo Valley and Kamas Prairie, and extending up on to the flanks of the Wahsatch east of Clayton's Peak, while farther nc rthward they form the low, rolling hills between the Weber River and Parley's Park, and doubtless originally covered a very considerable extent of the Cretaceous beds exposed along the Wcber, being still found on the summits of the ridges to the east of it at Rockport, and forming the walls of the lower cañon of Silver Creek above Wanship.

These trachytes, while presenting considerable variety $m$ texture and appearance, have, nevertheless, a generic resemblance in all the various exposures. They are generally highly crystalline rocks, having a small proportion of groundmass with a large development of sanidin crystals, containing remarkably fresh hornblendes and micas, and particularly characterized by the frequent presence of augite and tridymite. Among the trachytes exposed in the cañon of the Provo River, between Kamas Prairie and Provo Valley, is found a rock of exceptionally porphyritic character. It has a reddish-purple groundmass, in which are small white crystals of sanidin, reddish-brown earthy hornblendes, with a very considerable development of specular iron. No mica is visible to the naked eye. Through the magnifying-glass, the groundmass is seen to contain crystals of plagioclase associated with the sanidin. A still more compact variety in the same locality shows occasional flakes of bronze-colored mica, with scattered crystals of sanidin and black hornblende, imbedded in a reddish, almost homogeneous groundmass.

About midway in this cañon are found beds of blue limestone, having a slight dip to the south and west, exposed for a distance of about half a mile along the edges of the stream, and apparently overlaid by the red sandstone of the Trias, of which fragments are found in the débris slopes, though the rock was not seen in place. The Triassic sandstones are, however, found cropping to the south of this ridge, on its flanks toward Provo Valley, just north of Heber City, where they have a distinct southwesterly dip of about $25^{\circ}$, with a northwest strike.

On the opposite side of this valley, at the mouth of the cañon of 
Snake Creek, just above the village of Medway, is a group of warm springs, the most important and considerable observed in this region, and which are of interest in connection with the trachyte body which they adjoin. They issue from conical or dome-shaped mounds, and deposit a great amount of calcareous tufa; many of the cones or mounds are now dry and choked up, or covered with soil and vegetation. The tufa deposits, which form a sort of low plateau, cover a very considerable area, probably 2 or 3 square miles, and over this plateau are dotted the active and extinct springs, varying in size from small orifices a few inches in diameter to cones and mounds built up 20 or 30, and even as much as 60 feet above the general level. Most of the extinct as well as active springs have the shape of a hollow truncated cone, the interior cavity being wider at the base than near the rim-that is, the tufa, which deposits on the rim as the water cools in contact with the atmosphere, builds up the inside of the enclosing crust faster than the outside; thus the orifice is continually closing together. Probably in the same way the lower channel, through which the water rises from below the surface, has become completely choked up in the case of the numerous extinct or dry cones. One of these may be seen in Plate XXI, Chapter V, which represents a dry tufa cone about 15 feet inheight, formed of layers of calcareous tufa having a rudely concentric structure. The interior cavity, which has been partly filled by soil and detritus, is 3 or 4 feet in diameter, and nearly 5 feet deep. It is less regular in shape than some of the active springs, its material yielding readily to atmospheric disintegration. The active springs are, however, more generally of a flat dome-shape, with a truncated top. Of these, the most perfect one observed is a mound about half a mile north of the town of Medway, rising probably 10 feet above the general surface. Its orifice is an almost perfect circle, 20 feet in diameter, filled to within a couple of inches of the brim with clear tepid water, having a temperature of $85^{\circ}$ to $90^{\circ}$ : from it is a slight seepage of water, through a little break in the otherwise perfect rim. The water is perfectly clear, and the bottom, which was apparently about 15 feet below the surface, could be seen with perfect distinctness; the diameter increases so rapidly in depth that a person holding himself vertically, at arm's length, with his hands on the rim, could scarcely touch the interior walls with his 
feet, when the legs were bent at right angles to the body. This rim is only about six inches in thickness. An analysis of the tufa of which it is formed was made by Mr. R. W. Woodward, with the following result:

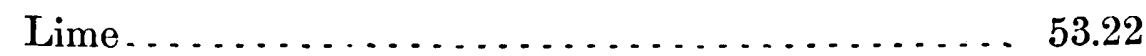

Ferric oxide........................... 0.22

Carbonic acid . . . . . . . . . . . . . . . . . . . 41.73

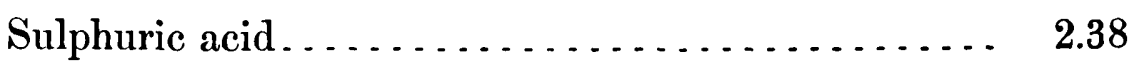

Insoluble residue $\ldots \ldots \ldots \ldots \ldots \ldots \ldots \ldots \ldots . . .4 .49$

100.04

No analysis was made of the waters, but, from the composition of the tufa, it is seen that the main constituents must be carbonate, with a little sulphate of lime. From some of the springs is a slight escape of carbonicacid gas; others, again, have a slight odor of sulphuretted hydrogen, which may probably arise from the decomposition of the sulphate in contact with organic matter. The amount of iron evidently varies considerably, as around some springs the surface is stained for a considerable distance with a deposit of hydrated oxide of iron, while at the above spring none was observable to the eye. In temperature, the springs are generally from $70^{\circ}$ to $110^{\circ}$, but in some instances reach nearly the boiling point. The temperature evidently depends more upon the amount of surface exposed to the air than upon a variation of the original temperature of the water as it comes from below.

On the foot-hills to the north of the town of Medway was found a bedded deposit of volcanic ash adjoining the trachyte body, which would seem to indicate that the valley was filled with water at the time of the trachyte outflow. In the valley-bottom, above the bend of the Provo, toward Silver Creek, is found a light-gray porous trachyte, which also has the appearance of having been ejected under water; it is composed of a white pumicelike groundmass, in which are large crystals of sanidin and needle-like prisms of black hornblende, together with mica. The divide between the Provo and the headwaters of Silver Creek is formed of a remarkably beautiful variety of trachyte, generally of reddish-purple color. It is made up very largely of well-defined crystals of sanidin, with black and somewhat 
altered hornblende, and less frequent crystals of plagioclase, in a compact, reddish, semi-vitreous groundmass. A still more beautiful rock in the same locality is of a bright grass-green color, containing the same predominant mass of sanidin crystals, with fresh unaltered hornblendes, the crystals of which, under the microscope, are seen to be ruptured in a most remarkable manner. On the walls of the pores or cavities of the rock, the microscope discloses a white siliceous deposit in stalactitic forms, which also penetrates the groundnass, as well as the feldspars and hornblendes, in small veins. Zirkel suggests that, as no tridymite is found in these rocks, this siliceous deposit may be considered to take its place. The groundmass is seen to contain some micro-felsitic base. The former of these trachytes is remarkable from the fact that the plagioclase crystals are seen to contain a moving bubble within the glass-inclusions, like the leucite lavas from Capo di Bove and Solfatara in Italy. This bubble was not absorbed when heated to $120^{\circ}$.

An analysis of the green trachyte, made by Mr. R. W. Woodward, gave the following result:

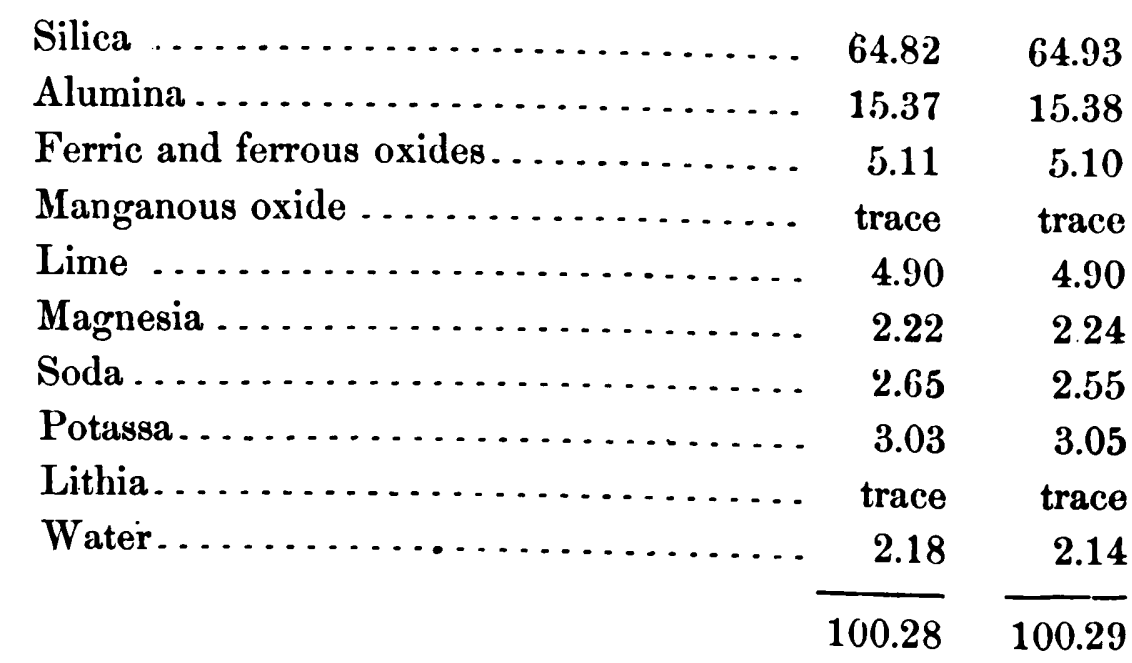

The trachyte from Silver Creek Cañon is a gray, rather finer-grained rock, rich in crystals of sanidin, plagioclase, and fresh brown hornblendes; the latter in needle-like prisms, often half an inch long. It also contains biotite, with augite, and occasionally tridymite. Under the microscope, the biotites are seen to be perforated by numerous apatites, and the feldspars to be rich in glass-inclusions. 
Nortulern Flanks.-The cañon of the Upper Weber runs approximately with the strike of the upturned beds, forming the northern flank of the Uinta upheaval. At the mouth of the cañon is found a body of drab limestones, forming its southern wall, having a dip of about $25^{\circ}$ to the northwest. They extend for a distance of $1 \frac{1}{2}$ miles to the south of the Weber River, along the foot-hills bordering Kamas Prairie. In these limestones were found the following fossils:

\section{Productus semireticulatus.}

Spiriferina pulchra.

Martinia lineata.

About 2 miles up the cañon, the red sandstones of the Triassic are found overlying conformably the upper shaly beds of these limestones, and in the north wall of the cañon are seen outcrops of the compact drab limestones of the Jurassic, which, to the westward, soon pass under the trachyte flows which cover the spurs on the north of Kamas Prairie. On the summit of the peak, 5 miles north of the mouth of the cañon, were found beds of white friable sandstone, dipping more gently northward, overlying conglomerate beds, which represent the continuation of the Dakota and Colorado Cretaceous as exposed in Weber Valley below Peoria. The upper portion of the cañon, to the point where it bends to the southward, has apparently been carved out of the softer beds of the Triassic; but, owing to its wide bottom and the soft gravelly slopes of the ridge to the north, which is capped by Tertiary conglomerates, no good exposures were found. To the south of the cañon, the hills are mainly formed of the upturned Carboniferous limestones, which are exposed in section in Berry Creek. The steep northern dips continue up this creek to near its head, exposing the Weber Quartzites lying con. formably under the limestones, while at the very head of the cañon the dip suddenly changes to a slope of $5^{\circ}$ to the southward, as is almost invariably the case on the northern edge of the Uinta. In one of the basin-like heads of this cañon, the green and purple clay beds, which have been noticed in other parts of the range enclosed within the quartzites, are shown in considerable extent. They are remarkably soft and uncompacted, being almost without structure-lines, although the quartzites in this region show much 
more metamorphism than in the eastern portions of the range, being generally white in color, and frequently of an almost vitreous texture.

Between the heads of the Weber and Bear Rivers, the ridges are covered with Tertiary conglomerates and glacial débris; and few exposures of beds higher than the quartzites, which form the core of the range, were found. At the head of Bear River itself are evidences of more extensive glacial action than at any point of the north slopes of the range. Here terminal and lateral moraines are found along the broad valley, down to within 10 miles of the railroad.

The main fork of Bear River heads in a similar amphitheatre to that of the Duchesne, but of somewhat less extent, under the northern slopes of Mount Agassiz. The general character of these high glacial basins and the effects of névé-erosion are seen in Plate $X$, which represents a view of Mount Agassiz, taken from the shores of Lake Lal, the eastern of the two little lakes at its northern base. This peak, which may serve as a type of most of the peaks of the range, consists of a sharp wedge-shaped ridge, whose summit is but a few feet in width, formed of horizontal beds of the Weber Quartzite, which have been cracked and broken by the combined action of sun and ice, and ground into fine sand by the trituration of its falling masses. The enormous extent of the débris falling from one of these peaks is shown in the talus-slopes along the northern face of the peak. The summit of this peak is formed of a coarse white quartzite, containing round pebbles, beneath which is a gritty zone 800 or 900) feet thick, containing quartz up to the size of a hazel-nut, the general hue of which is a pale green. Under this is a reddish-brown rock, containing similar pebbles, with beds of slate and shaly sandstone. The mud and shale beds are scarcely altered, and closely resemble the beds of the Connecticut Kiver sandstone. In the quartzites themselves are a few sheets, never over 3 or 4 feet in thickness, of green slates, which contain a little finely-comminuted mica.

From the débris of the quartzite beds, on the ridge to the east of Mount Agassiz, about 1,000 or 1,500 feet below its summit, was obtained a fossil, which, though not absolutely broken out from the quartzite beds in place, would seem necessarily to have come from these beds, being 
formed of the same quartzitic material, and having been found in a position which would hardly admit of its having come from any other beds, except under the rather improbable hypothesis that an Indian had placed it there. This is a half of a ribbed brachiopod, which has been described by Messrs. Hall and Whitfield as Spirifer imbrex. From the débris-piles in the basin was also obtained a quartz pebble, containing the impression of a Crinoid column. These, with the Spirifer cameratus, from near Geode Cañon, already mentioned, constitute the sum of the somewhat meagre palæontological evidence obtained as to the age of the quartzite beds of the Uinta Range; though it is worthy of remark that in the quartzite beds in general, as developed along the line of this survey, scarcely any organic remains have been found.

The bottom of the upper basin, directly under Mount Agassiz, shows quite a variety in color as well as in bedding: heavy beds of white quartzite divided by jointing planes into huge cuboidal blocks, pale-green solid quartzites, containing conglomerate pebbles up to the size of an egg, and dull-brown ferruginous beds, which are hardly compact enough to be called a quartzite, but are rather an indurated sandstone.

A partial analysis of one of these white quartzites gives $98 \frac{1}{2}$ per cent. of silica, the remaining constituents being iron and alumina. The rocks forming the summit, extending for three or four miles on either side, are in the position of a low flat arch. The summit rocks are nearly horizontal. Those to the south dip about $5^{\circ}$ south, and those to the north, about $8^{\circ}$ north. The cañon of Bear River descends toward the north more rapidly than the dip of the strata for about six or seven miles, when the beds are suddenly broken and flexed over to a dip of about $45^{\circ}$ to the north. From the broken and dislocated condition of this region of flexure, it is impossible to get at the true relations of the steeper-dipping part and the nearly horizontal beds higher up the cañon; but there is apparently considerable vertical displacement, and the steeper-dipping beds seem to have fallen down, so that, in estimating the thickness, it would not do to add to the thickness of the upturned beds that which is exposed in the horizontal ones. At least 4,000 to 5,000 feet of quartzites are exposed in the steeper-dipping series, and 3,000 to 4,000 in the horizontal beds. Over- 
lying the upturned quartzites, in the main cañon, is an obscure development of limestone, which is, however, so well covered with glacial débris and the Tertiary conglomerates that its position and relations are unknown. The conglomerates here have a dip of $8^{\circ}$ from the range, and are composed of remarkably coarse gravel, hardly showing the lines of deposition. West of Bear River, on the heights directly north of Weber Cañon, these conglomerates are exposed to a depth of 3,000 feet by sharply-eroded glacial cañons. They are there seen to have a dip of $5^{\circ}$ from the range, and to be composed of the very coarsest and most loosely-compacted conglomerate, quite devoid of distinct bedding. Their dip is only gotten by certain zones of finer material and shale, which may be traced through them. It is impossible here to draw the line between the Wyoming Conglomerates, which doubtless form the upper part of the series, and the Vermillion Creek series, which, in the vicinity of the Wahsatch and Uinta Ranges, develop such a great amount of conglomerate.

At La Motte Peak, to the east of the cañon of Bear River, the quartzites dip $16^{\circ}$ to the north. The rock is here a reddish-purple quartzitc, containing some fragments of decomposed feldspar, together with rounded grains of quartz, and a few broken fragments of crypto-crystalline quartz. Chemical analysis of this rock by Mr. B. E. Brewster gave the following:

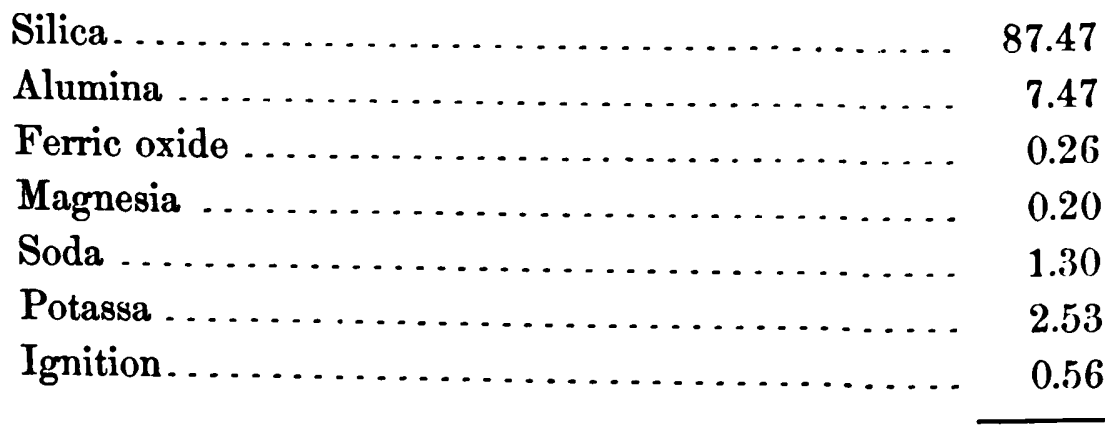

99.79

To the north of La Motte Peak, the dip of the rocks, forming the spur of which it is the culminating point, steepens more gradually and continuonsly than in the main cañon, and at the point of the spur the Carboniferous limestones arefound dipping $52^{\circ}$ to the northward. On the face of one of these spurs is found a conglomerate, made up of boulders, mostly as large as a man's 
head, of compact quartzite, many of them containing a good deal of specular iron, which seems to be conformable with the Carboniferous limestone. This, however, is the only locality in which any such conglomerate was found in the Upper Coal-Measure group, and it may possibly be a relic of the Tertiaries or the Wyoming Conglomerate.

In the ridge to the east of the right-hand fork of Bear River, as already seen, is a good section of at least 8,000 feet of quartzite, upturned at an angle of $45^{\circ}$ to $52^{\circ}$, underlying the limestones of the Upper Coal-Measures; and, on the low saddle between this fork and the head of Black's Fork, the limestones of the Upper Coal-Measures are well exposed, the Tertiary conglomerates, which form the ridge below, having been eroded off. On this ridge, also, is found the greatest thickness observed of undecomposed beds of the Wyoming Conglomerate at Concrete Plateau, where 100 to 200 feet still remain, consisting of pebbles of limestone and quartzite in a white calcareous matrix. The continuation of the ridge to the northward forms the divide between the waters of Bear River and those which flow through Muddy Creek into Green River. To what distance the Bridger beds extended in the upper portion of this ridge, it was impossible to determine, since the hills were covered with soil and débris. 


\author{
SECTION II. \\ FROM ASPEN TO ECHO CITY
}

BY S. F. EMMONS.

UpPer Bear River Valley.-Along the line of the railroad, from Aspen Station to a few miles west of Bear River City, there is exposed a great thickness of beds of the Cretaceous formations, having a general strike of north $30^{\circ}$ east, and dipping at various angles from $30^{\circ}$ to the perpendicular. These beds form a continuation of the uplift noticed on the valley of the Little Muddy, on Map II; but from the soft character of the rocks which compose them, and the fact that their outcrops can be traced only short distances, being covered by the horizontal beds of the Vermillion Creek Tertiaries, which overlie them, the exact details of their structure can hardly be arrived at. At Aspen Station is exposed a thickness of 300 to 400 feet of whitish and bluish shales, abounding in fish-scales, with occasional impressions of bones and teeth, and fragments of Ammonites. Within them are a few thin beds of grayish limestones. They dip to the westward about $10^{\circ}$ to $15^{\circ}$, and are overlaid by a series of gray and whitish sandstones. These beds were considered to represent the Colorado Cretaceous.

On the west side of the divide, near the bend of Sulphur Creek, the same overlying sandstones form a narrow ridge, having a trend north $30^{\circ}$ east, whose beds dip $30^{\circ}$ to the westward. They consist of 50 feet or more of light-colored shales and shaly sandstone, underlaid by a whitish sandstone full of remains of Ostrea soleniscus, beneath which is a light-colored shaly bed, and at the base 50 to 100 feet of heavy white sandstones. From the lithological character of these beds and their fossil remains, they have been considered to represent the Fox Hill group. Between this ridge and Bear River City, in the hills northeast of the railroad, is found a great thickness of beds of blue and gray shales, and some sandstones, which lithologically seem to represent the Colorado series. In general, these beds stand about perpendicular, and it may be supposed that a sharp fold has brought "p the 
Fox Hill group to the west of the ridge already mentioned, since the Ostrea soleniscus is also found in the vertical sandstones to the east of the clays and shales. At Bear River City, the hills to the north are formed of heavy standstone beds, containing several coal seams standing perpendicularly, and in some cases having a slight inclination to the westward. They contain plentiful casts of Inoceramus problematicus, and an Inoccramus dimidius has also been found in this vicinity. Both these forms are characteristic of the Colorado Cretaceous, so that, though lithological evidence would place the dividing line between Fox Hill and Colorado a little east of Bear River City, on palæontological grounds the sandstones and included coal seams at that point should be included in the latter group. West of Bear River City, along the face of the hills north of Sulphur Creek, are exposed outcrops of from 5,000 to 7,000 feet of strata, standing at angles of $85^{\circ}$ to $90^{\circ}$ west, and striking north $30^{\circ}$ to $45^{\circ}$ east, consisting of heavy white sandstones with conglomerate beds, and passing to the westward into reddishbrown sandstones with frequent clayey seams, which would include the entire Fox Hill and part of the Laramie Cretaceous.

The structure of the section thus exposed, from Aspen westward, would be first a broad synclinal, whose western member turns up abruptly at $80^{\circ}$ to $90^{\circ}$; then a sharp anticlinal in the Colorado beds, both of whose members stand quite vertical, and whose western member includes the Colorado, Fox Hill, and Laramie Cretaceous. From the prevalence of western dips in this section, one might perhaps be led to suppose that the Colorado beds, west of the sandstone ridge at the bend of Sulphur Creek, were simply faulted up; but their thickness exposed, which cannot be less than 5,000 to 6,(100 feet, makes a reduplication of the beds by folding necessary, while the structure, shown on the same line of strike at the head of the Little Muddy, renders it probable that the system of sharp anticlinal and synclinal folds shown there finds its continuation on this side of the divide.

About two miles west of Bear River City, a railroad-cut through a low ridge running out from the high ground, already described as forming the northeastern wall of the Sulphur Creek Valley, shows a section of about 150 feet of beds, quite distinct lithologically as well as palæontologically from any observed, though resembling in some respects those on the Little Snake 
Rivor near the mouth of Slater's Fork, described in Chapter I. 'Thry are separated by an interval, bare of outcrops, from the sandstones west of Bear River City, but correspond with them in strike, and stand nearly vertically, having an inclination of $70^{\circ}$ to $80^{\circ}$ to the southeast. They have evidently fallen over somewhat to the northwest, however, as the beds in the upper portion of the ridge, which thin out remarkably in a very short distance, have been completely bent over in that direction, so as to give the section almost the appearance of an anticlinal fold. They are formed of sandstones, marls, and clays, with a few bituminous and gypsiferous seams, and are remarkable for the fine definition of their bedding-lines, the strata varying from half an inch up to a foot or more in thickness. They abound in fossils of prevailing fresh and brackish-water types, of which the following forms have been described :

Unio vetustus.

Unio belliplicatus.

Corbula pyriformis.

Corbula Engelmanni.

Corbicula (Veloritina) Durkeei.

Rhytiphorus priscus.

Pyrgulifera humerosa.

Limncea nitidula.

Campeloma macrospira.

Campeloma, undet. sp.

Viviparus Conradi.

Ostrea?

These beds, from their stratigraphical position, evidently belong to the same conformable series as the Bear River City beds, being overlaid a short distance to the north by horizontal strata of the Vermillion Creek Eocene, and, on account of the number of fresh-water shells which they contain, have been frequently quoted as proving the Tertiary age of the coal-bearing rocks. Professor F. B. Meek's latest opinion, however, was, that the balance of evidence offered by their fauna, which have all been submitted to his determination, was in favor of a Cretaceous age. In any case, it would seem hardly advisable to give much weight to the evidence of beds of such ex- 
tremely local development, and which, from their position in the angle of the two high ranges of the Wahsatch and Uinta, have evidently been formed in an estuary at the mouth of some fresh-water stream, whose waters have spread them out conformably, for a considerable distance, over marine beds. Smaller outcrops of these estuary beds are visible at various points along the railroad, in fresh cuts, between Bear River City and Evanston.

To the south of Bear River City, in the shallow bottom of one of the tributaries of Sulphur Creek, is a spring of petroleum, near which a well was sunk for obtaining oil, with about the same result as at Judge Carter's oil-wells, already mentioned in Chapter II. It comes evidently from the Colorado beds, and probably from the same horizon as in the valley of the Little Muddy.

To the north, the upturned Cretaceous beds pass beneath the horizontal strata of the Vermillion Creek series, which form the main mass of the Aspen Plateau. These consist generally, as has already been seen, of alternations of coarse gray sandstones and reddish and cream-colored arenaceous clays and marls, giving to the bluff exposures a general striped appearance. The correctness of the conclusion, arrived at on broad grounds of corresponding lithological character and stratigraphical relations, that these Tertiary beds belong to the lowest series observed, and correspond to the Vermillion Creek group of the Green River Basin, has, since the completion of the field-work of this Survey, received confirmation by the recent discovery by Professor Marsh's assistants of an interesting series of vertebrate remains in the hills to the east of Evanston, which indicate the lower beds of the Eocene Tertiary. The most important forms recognized from this collection are those of the genus Coryphodon, an ungulate mammal characteristic of the London clay, and the lower portion of the argile plastique of the English and French geologists. The following are some of the most characteristic forms:

\section{Coryphodon lamatus. Coryphodon radians. Coryphodon semicinctus. Eohippus pernix.}

As no beds, which could be distinctly identified as corresponding to the Bridger series, were found to the east of the line of Aspen Plateau, this line 
of elevation may be considered to have marked the western limits of the Eocene lake in which they were deposited.

Along Bear River, from Bear River City to Evanston, the hills on either side are occupied by the nearly horizontal beds of the Vermillion Creek Eocene. On the east side of Bear River Valley, a short distance north of Evanston, the bluffs are formed of a series of coarse sandstones, not differing greatly in lithological habit from some of the beds of the Vermillion Creek series. They are, however, more compact in general, and $\operatorname{dip}$ from $13^{\curvearrowright}$ to $15^{\circ}$ to the northeast, with a strike of north $25^{\circ}$ to $35^{\circ}$ west. In these beds are valuable coal seams, one of which attains a thickness of 26 feet, which have been extensively worked by companies connected with the railroad. A great number of fossil leaves have been obtained from beds adjoining the coal, which have been considered by some fossil-botanists to indicate rather a Tertiary than a Cretaceous horizon. There is, however, no doubt, both from the stratigraphical position of the beds and their lithological character, that they belong to the coal series of the Cretaceous, and probably to the Laramie group; though, owing to the general indefiniteness of palæontological evidence and the isolated position of these beds, the latter statement is only conjectural. Within the mines, the dip of the beds steepens considerably, attaining angles of $25^{\circ}$, and even $35^{\circ}$; and the low dips at the surface, which have led some geologists to confound them with the overlying Tertiaries, may be simply due to a settling-down of the strata; the coal seam, which in the mine is 26 feet in thickness, for instance, shows at the surface only one foot of clear coal. In the valley to the east of the mines, as seen in the exposures of the stream-beds, the eastem dip is continued, though on the slopes of Medicine Butte, which is the highest point of the Aspen Plateau, there is some appearance of a westerly dip in the strata. In the little canon to the south of Medicine Butte, however, the series of Cretaceous sandstones is seen at the forks to have a dip of $45^{\circ}$ to the northeast, and higher up, where they disappear beneath the horizontal Tertiaries, there is apparently an even steeper dip.

Region between Bear and Weber Rivers. - The region to the west of Bear River, in the angle embraced between the Wahsatch and Uinta T From field-notes of Clarence King. 
Ranges, was formerly covered by a continuous sheet of very heavy Tertiaries, certainly not less than 7,000 feet in thickness, composed along the shore-lines largely of conglomerates, but having some heavy beds of sandstone. Passing away from the bounding ranges, the material of these beds grows finer and finer, and, the great mass of the formation being composed of loosely stratified red sands and sandstones, subsequent erosion on the lines of the present rivers and streams has laid bare narrow strips and irregular exposures of the older underlying rocks.

The Tertiaries to the north of Echo Cañon are nearly horizontal, and rise from the river-bed to a vertical height of 3,800 feet. They are chiefly of red sandstones containing some fine shale and clay beds, and limited sheets of conglomerate. In the neighborhood of Echo City, and to the south of Weber River, at the Narrows, namely, at the lowest horizons, the conglomerates have their greatest development. Southwest of Echo City a change is observable, from heavy conglomerates near the level of the river, which extend up 400 and 500 feet, into sandstones, mostly of a dark venetian-red, which form the summits of the cliff. The peculiar weathering of these sandstones is well seen in Plate XI, which represents the wall of Tertiary beds, bordering the railroad on the north, in Echo Cañon. A short distance to the south of Echo City, following up the Weber, the Tertiaries rise, exposing the underlying Cretaceous strata along its west side. The line of contact between the Cretaceous and Tertiary beds now trends back from the river, the lowest members of the latter being about 1,000 to 1,200 feet above the stream. This line of contact swings around, occupying the hills to the north of Silver Creek, and skirting the Cretaceous formations which lie along the northern side of Parley's Park.

From Wanship down to Echo City, the whole valley of the Weber is in Cretaceous strata, which strike diagonally across it, and dip to the northwest and north at varying angles, as will be hereafter described. On the east side of Weber Valley, to the south of Echo City, a belt, of about a mile or a mile and a half in width, of Tertiary conglomerates extends along the south of Echo Cañon up to about 10 miles from its mouth. To the south of this line, the Tertiaries have been eroded away, and the whole ridges, as far as two or three miles south of Chalk Creek, are formed of 
the Cretaceous. From Silver Creek, in the region of Wanship, all the way to Kamas Prairie, the upturned Cretaceous and Jurassic strata on the west side of the Weber Valley are overlaid by the trachyte-flows. These trachyte-flows cross the Weber just below Kamas Prairie, and overlie the Cretaceous on the east side of the river in the angle made by its great: bend. Just above the town of Peoria, the red sandstones of the Triassic and the overlying Jurassic are exposed, striking a little north of east, and dipping at a high angle, usually about $50^{\circ}$ to $60^{\circ}$ to the northward. The Triassic is here exposed for about 700 or 800 feet, the lower beds showing some white sandstone, while in the upper portion the characteristic crossbedding, identical in appearance with that at the quarry in the Lower Weber Cañon, is seen. These are overlaid by a fine gray lithographic limestone, breaking into rectangular fragments, intercalated with yellow earthy marls, not unlike those of the Lower Cretaceous, but containing numerous well-defined Jurassic fossils, among which were recognized Eumicrotis curta and Pentacrinus asteriscus. Above these marls and sandstones are a series of variegated shales, all conformable, and gradually lessening their steep dip, until they pass into soft calcareous sandstones and mauve-colored shales, which are immediately and conformably overlaid by the conglomerates of the Dakota Cretaceous. These are about 150 to 200 feet thick, and enclose pebbles the size of a cobble-stone. They are again overlaid by a series of yellow sandstones and about 1,000 feet of intercalated soft clay-rocks and dark shales. The dip at the upper part of these shales lessens to about $25^{\circ}$, which inclination is kept for a mile down the cañon, the series being made up of alternating beds of cream-colored and green sandstones, separated by passages of shales and inconspicuous sheets of conglomerate. In them, the remains of Fucoids are very frequent, and in one or two shale beds a few fragments of Inoceramus are found. The whole conformable northerly-dipping series of the Cretaceous cannot be less than 3,000 feet thick.

Following the easterly strike of these Cretaceous rocks up into the hills to the east, they seem to be overlaid, for a considerable distance, by the trachytes, which extend northward in a narrow neck overlying the Tertiary conglomerates. To the east of this neck is a triangular exposure of the Cre- 
taceous, including the Dakota conglomerates which are seen on the north slope of the Upper Weber Cañon, and the mixed beds of sandstone and shales of the Colorado group. Paissing eastward these are both overlaid by the nearly horizontal Tertiary conglomerates, which occupy the whole top of the ridge, forming the north wall of the Upper Weber Cañon. This great field of conglomerates extends down to within a couple of miles of Coalville, occupying the heights to the south of Chalk Creek and extending eastward all the way to Bear River. Chalk Creek itself, almost to its head, occupies a broad basin eroded out of the Tertiaries, in which are exposed the underlying Cretaceous. So also in Grass Creek, which runs parallel to Chalk Creek, a region of Cretaceous is laid bare, which is connected with that developed in Chalk Creek. There is here then a broad area of Cretaceous, which is bounded to the north by the Tertiary conglomerate ridge running parallel with the railroad on the south side of Echo Cañon, for about 10 miles from its mouth. At this point, the Cretaceous swings northward across the railroad, and occupies the lower 400 feet of the hills on the north side of the cañon. It is here seen to underlie the Tertiary with a clear unconformity, the inclined beds dipping about $30^{\circ}$ to $35^{\circ}$ to the northwest, while the overlying Tertiary has an inclination of not more than $5^{\circ}$ to $8^{\circ}$. Passing eastward, the Tertiary gradually encroaches on the Cretaceous again, and crosses the railroad about 2 miles below Castle Rock Station, occupying, with the exception of a few isolated outcrops like the "Needles" on Yellow Creek, the whole region from this point to Bear River.

The high tables and peaks of conglomerate which overlie the Cretaceous southeast of Coalville entirely obscure its structure. It is evident, however, in coming down the cañon from Kamas Prairie, that in the Colorado group there is a limited fold in which the rocks change their dip from a northerly to a southerly inclination, passing through a synelinal fold, and again dipping to the north and west. So that from Kamas Prairie to Coalville, with the slight exception of about 3 miles of southerly-dipping strata, the whole series dip north and west. With the exception of 300 or 400 feet, which may be reckoned in the Dakota group, at the base of the series, the whole formation from near Peoria to just below Coalville is embraced within the Colorado group. Where it directly overlies the Dakota beds, below Peoria, 
its strike is only $3^{\circ}$ or $4^{\circ}$ to the north of east; but where it passes over the local folds spoken of the strike swings around, and crosses the river in the region of Coalville at a sharp diagonal, in a nearly north and south direction. To the north of Coalville, again, the strike bends around to the direction of northeast, which it maintains for about 4 miles, when it swings into an easterly direction, dipping north, and occupies that position for about 4 miles farther. Then it bends again to the northeast with a westerly dip, which continues until it crosses the railroad and passes under the Tertiary conglomerates. From the base of the series, as exposed southeast of Coalville, there is exposed a little over 5,000 feet of cohformable northwesterlydipping rocks.

From Echo City to Lost Creek, as exposed along the base of the Tertiary cliffs, is a similar thickness, composed of the same series, dipping to the southeast. The uppermost beds of this series are represented by a series of coarse conglomerates, which might be confounded with the Echo Cañon Tertiaries, though wanting in their distinctive coloring and having a much more compact matrix; they stand, however, at an angle of over $20^{\circ}$, and, from their position, must be included in the Laramie group, though not elsewhere observed in this group, and very closely resembling the conglomerates at the base of the Dakota. As exposed in the Weber Valley, a short distance from Echo City, they constitute a prominent feature in the landscape, from the peculiar forms into which they have weathered, and, from a fanciful resemblance to the shape of an old woman, have been called the Witches' Rocks. Some of these peculiar forms are seen in Plates XII and XIII, of which the former gives a general view of the outcrops, and the latter, one of a single column 40 feet in height.

Echo City, therefore, represents about the position of a synclinal axis in the Cretaceous. At Lost Creek, these Cretaceous beds are apparently unconformable with the Jurassic. At Kamas, on the other hand, they are conformable with them. The northerly strike and westerly dip, which are observed at the head of Chalk Creek, are further to be seen in the limited outcrop at the "Needles", which also has a northerly strike, but in this case a nearly vertical position; in other words, there is developed in the angle between the Uinta and Wahsatch Ranges a broad and powerful fold in the whole Cretaceous system, which has a strike midway between the two 
ranges, in a general northeast direction. Were it not for the overlying trachyte and Tertiaries, the structure would undoubtedly be found to be this: Along the north flank of the Uinta, the Cretaceous would seem to be uplifted in conformity all the way with the Jurassic. This relative position is maintained eastward across Parley's Park, or, in other words, as far as the actual influence of the Uinta is felt. From that point, in contact with the earlier upheaval of the Wahsatch, the Cretaceous would be seen to be unconformable with the Jurassic; while between these two ranges, and occupying a resultant direction, would be observed a large anticlinal fold, with a northeast direction, whose rocks would pass down from its northern side with a northwest dip, and rise under the synclinal axis of Echo City, developing themselves between that point and Lost Creek; while on the southeast side of the fold they would pass under the synclinal, which is indicated in the local fold below Kamas, and rise again against the flanks of the Uinta. The positions exposed in Weber Cañon, Chalk Creek, Echo Cañon, and, as will be later seen, East Cañon Creek, entirely coincide with this reconstruction of the underlying structure. The winding strike which is observable for 10 or 12 miles in the Cretaceous beds to the east of Coalville is doubtless due to longitudinal compression. But besides this flexure in the strike, they are further complicated by a series of northwest faults, which have given rise to horizontal, as well as vertical, displacements. There is one broad block of country, included between two northwest faults, that seems to have been moved to the southeast. This faulting is quite complicated, and it is difficult to match the sides, owing to the duplication of similar beds of buff sandstone normally above one another in the series.

From the horizon of Coalville downward are, as exposed up Chalk Creek, a series of alternating dark shales and buff and gray sandstones, with a few yellow marl beds. At various points in this series, notably at Coalville, were obtained marine fossils, among which the following have been described by Prof. F. B. Meek :

Cardium subcurtum.

Anchura? fusiformis.

Mactra (Cymbophora)\& Utahensis.

Ostrea Wyomingensis (Coalvillensis).

Corbula, undet. sp. 
On Chalk Creek, above Coalville :

Anchura? fusiformis.

Gyrodes depressa.

Tellina? isonema.

Mactra (Trigonella)? arenaria.

And near Uptown:

C'ardium curtum.

Inoceramus erectus.

From the horizon of Coalville upward geologically for 4,000 feet, there is a series of varying sandstones, chiefly buff and gray in color, carrying here and there conglomerates, with a few beds of dark olive shales. On the summit of the third ridge north of Coalville, which forms the north wall of Grass Cañon, is a heavy buff and gray sandstone, underlaid by shales and clays, which carries coal, and is rich in fossils; here were found only Cardium curtum, Mactra, Inoceramus, and Ostrea ; but southeast of Coalville, near the Carrollton mine, Prof. F. B. Meek obtained from the same horizon great numbers of marine, brackish-water, and even fresh-water types. The sandstone is about 300 feet thick, and contains near its top vast numbers of Ostrea soleniscus. The coal-bearing beds here, therefore, may rather be included in the Fox Hill group, while, as has already been seen, the more eastern coal beds are generally of a higher horizon. The next ridge north, also composed of buff and gray sandstones, contains large species of Inoceramus and some Ostrea. These sandstones are unconformably overlaid by conglomerate beds of a pinkish color, containing a variety of pebbles of jasper chert and quartz, with occasional rounded fragments of limestone. The discrepancy of dip between them and the Tertiary beds is here only $10^{\circ}$, while, as we have seen 10 miles up Echo Cañon, the Tertiary is more nearly horizontal, and the discrepancy is $25^{\circ}$.

Near the head of Chalk Creek, and underlying the beds of shale and conglomerate, which form the high mountain northwest of the road, is a belt of conformable conglomerates, chiefly made up of pebbles not larger than a chestnut, containing some, however, 2 inches in diameter, which 
extends along the line of its strike a little east of north, for about 4 miles north of the creek, and 3 miles to the south. To the east, north, and south, it is bounded by the overlying Tertiary sandstones, which extend to Bear River. Upon the same strike, about 8 miles to the north of the point of its northern disappearance under the field of the Vermillion Creek Tertiary, outcrops a local development, known as the "Needles", of similar, though coarser, conglomerate, having a vertical position and a strike of a little west of north. This is, no doubt, a continuation of the same bed, and, from the position of the former, conformably under the black shales and yellow sandstones, they may be considered to be the bottom of the Cretaceous, or the Dakota group. This, therefore, represents the bottom of the western half of the Cretaceous fold, or a point very near the anticlinal axis; the upper part of the eastern member being represented perhaps by the Fvanston beds.

Northern Bear River Region.-Medicine Butte is, as has already been mentioned, formed of upturned Cretaceous sandstones, which are exposed on the western slopes and in the ravines to the north and south. On the east, coarse red conglomerates of the Vermillion Creek series rest unconformably on these sandstones, coming up to within a few hundred feet of the summit of the butte. To the north, the summit of Aspen Plateau is formed of the Tertiaries lying almost horizontal, or inclined $1^{\circ}$ or $2^{\circ}$ to the eastward. They consist of the same dull-red striped sandstones, with some interstratified beds of marl and argillaceous limestones. The underlying Cretaceous beds are exposed in some of the deeper-cut valleys, along the valley of the Little Muddy, as already mentioned, in Map II. In the valley of Bear River, about 7 miles north of Evanston, on the eastern side, the heavy compact sandstones of the Laramie group are exposed, dipping eastward into the foot-hills of the Aspen Plateau, and at one locality is a narrow seam of coal, accompanied by bituminous shales and clays.

About midway between Evanston and the Narrows of Bear River occurs an outburst of rhyolitic tufa, rising above the foot-hills of Aspen Plateau, which is of interest, since it is far separated from any other known occurrence of this rock. In its physical habit, it is a uniform fine-grained rock, of an arenaceous, pumice-like texture, crumbling readily, and having a prevailing lavender tint. The groundmass is an intimate admixture of $22 \mathrm{D} G$ 
fragments of feldspar and quartz grains, with thin lamina of lark biotite plates and some bronze-colored mica.

On the west side of Bear River, the Tertiary beds conceal all the underlying formation, the river itself, as far as the Narrows, running in a narrow valley of fluviatile Quaternary. Below the Narrows, this valley expands into an open level country, from 4 to 6 miles in width, entirely on the west side of the stream. On the east side, from the Narrows northward beyond the limits of our map, heavy dark-blue limestones come down to the water's edge in steep precipitous slopes, which present a rugged broken surface cut through by deep rough cañons. The formation rises some 2,000 feet above the river, extending to the eastward in irregular undulating ridges until concealed beneath the Tertiaries. At the Narrows the limestone falls off abruptly, the beds standing nearly vertical, and, on the west side of the river, the Vermillion Creek beds come close up to the limestones. The river, which has run due north for a long distance, is curiously deflected on reaching the limestone, and takes a due west course for 5 or 6 miles, then bending sharply to the north again, hugs closely the flanks of the hills. But little opportunity was afforded for the examination of this somewhat isolated body of limestone, and it has been referred to the Upper Coal-Measure limestone, on no palæontological or direct stratigraphical evidence, but solely from its relative position with regard to the Silurian and Cambrian bodies on the west side of Bear River Plateau.

The greater part of Bear River Plateau is covered with a considerablo thickness of the Vermillion Creek beds, which are here in general rather coarser, and more conglomeratic than those of the Aspen Plateau. Its summit varies in width from 2 to 4 miles, beyond which to the eastward these beds are well exposed by the deep cañons of Woodruff, Randolph, and Saleratus Creeks. They lie inclined at an angle of $1^{\circ}$ to $2^{\circ}$, and a probable thickness of 2,000 to 2,800 feet is exposed in the canons. They exhibit considerable differences in their lithological habit, but are characterized by a prevailing reddish-gray tint and coarse arenaceous texture. Most of the beds would be denominated sandstones, the fragmentary material being too small to be classed as a conglomerate. There are occasional beds of white sandstone, but even these are more or less stained by oxide of iron, 
while interlaminated in the series are strata of fine brownish-gray argillaceous sands and marls. On the divide between Saleratus and Lost Creeks, the beds have a somewhat coarser character, with a deeper red color, the steep slopes of Lost Creek resembling closely the conglomerate walls of Echo Cañon. Similar beds are found along the ridge of Red Creek, forming the divide between it and Lincoln and Duck Creeks, but of somewhat finer material, and covered with considerable vegetation.

.On the western edges of this great Tertiary plateau are found exposures of underlying Palæozoic and Mesozoic beds, which, as belonging to the great fold of the Wahsatch Range, will be described further on. 


\section{SECTION III.}

WAHSATCH RANGE.

RY S. F. EMMONS.

The Wahsatch Range forms one of the most important features topographically of the Cordilleran system, in the fact that it marks the central line of elevation of this great mountain region, and forms the divide between the arid interior basins of Nevada, and the high, relatively well-watered plateau country that drains into the Gulf of California. It is even more important from a geological point of view, inasmuch as there are found represented here all the principal formations, from the early Archaran to the latest Tertiaries, developed on a scale of unusual magnitude, while in its structure are seen the effects of dynamical forces, which have folded and twisted thousands of feet of solid rock as if they were as yielding as so many sheets of paper.

To the westward, it presents always a bold, abrupt escarpment, rising suddenly out of the broad, flat plains of the Utah Basin, and attains its greatest elevation within one or two miles of its western base.

To the eastward it slopes off very gradually, forming a region of broad ridges and mountain-valleys, from 15 to 20 miles in width, whose waters all drain into the Great Salt Lake, through cañons and gorges cut through its main western ridge. Its higher peaks attain altitudes of 11,000 to 12,000 feet; and the general mass of the main ridge has an average height of nearly 10,000 feet above the level of the sea, so that as late as midsummer the winter's snows remain unmelted along its summits, and the plentiful condensation of the eastward-moving atmospheric currents, produced by so high a mass, furnishes a continuous supply of water to the mountain-streams, from which the valleys along its western hase derive their exceptional fertility. The view of the range, as seen, for instance, from one of the islands of Salt Lake, presenting a mountain-wall of over 100 miles in length, of delicately-varied outline, the upper portion slightly covered by a thin mantle of snow, its slopes, while dotted with patches of pine, revealing all 
the intricacies of its rocky structure, and cut through, at short intervals, to its very base by deep canon-gashes, is one of rare grandeur and beauty. Though, from a distance, the mountains appear almost bare of forests, like most of the western ranges, they are well covered in their upper portion, where the character of the surface admits of it, with an open growth of pine and quaking-asp, while the lower spurs, especially toward Salt Lake Valley, often support a dense growth of a dwarf or scrub oak, which here attains an unusual altitude for trees of the oak family. Along the streams, where there is any alluvial accumulation, are willows and alders, and frequently cottonwoods. A striking feature is presented in the old lake-terraces which mark the former beach-line of the ancient Lake Bonneville, of which the uppermost is about 940 feet above the level of the present lake, and can be traced with but few interruptions from one end of the range to the other, often forming an almost level shoulder to the spurs, from 50 to 100 feet in width.

In its geological structure, the Wahsatch Range presents a type of extreme complication, contrasting strongly with the simplicity and regularity of its nearest neighbor, the Uinta Range. The simplest expression of this structure would be that of a sharp north and south anticlinal fold over pre-existing ridges of granite and unconformable Archæan beds, whose axis has been so bent and contorted by longitudinal compression that it at times assumes a direction approximately east and west. In connection with the folding has been developed a widely-spread system of faulting and dislocation, in a direction generally parallel with the main line of elevation, which has cut off and thrown down the western members of the longitudinal folds, and the western ends of the transverse folds, which are now buried beneath the valley-plains, while the detailed structure has been still further complicated by a system of transverse faulting, and, in the northern region, by the development of a second broad anticlinal fold to the east of the main line of elevation.

Like most of the great mountain-ranges of the Cordilleran system, it occupies the line of a former Archæan uplift, round which were deposited a thickness of from 30,000 to 40,000 feet of practically conformable beds, extending in age from the Cambrian to the Jurassic formation inclusive. 
There are indications that at the close of the Jurassic period commenced a general uplift and folding of these beds, while at the close of the Cretaceous period, after the deposition of an additional thickness of over 10,000 feet of strata in the seas which washed its eastern flanks, occurred a more general movement of upheaval, which produced the main elevation of this range. While the movements of these two periods are those of which the most evident traces are left, it is probable that there was a continental elevation at the close of the Carboniferous period, which cut off the Triassic and Jurassic seas from the region to the west of the Wahsatch, without producing any appreciable non-conformity in their deposits, and that less important movements have occurred in the range after the Cretaceous upheaval, even into late Tertiary times. An additional feature is presented by the occurrence of eruptive rocks of later date than the granites, which, in Mesozoic times, consisted of granite-porphyries and diorites, traversing the Palacozoic rocks in narrow dikes, and in Tertiary times of trachyte outflows, which covered considerable areas.

Before proceeding with a local geological description of the range in detail, it may be well to give a concise enumeration of the local groupings adopted for those formations, which are differently developed from corresponding horizons already described in the eastern region.

In the following table, the third column gives the names adopted in the Wahsatch region for the local divisions, made uccording to the predominating lithological characteristics of the beds. In the second column are given the corresponding letters used on the map to designate the several color-divisions, which indicate respectively the following geological horizons:

P. =Permo-Carboniferous limestones.

C. =Upper Coal-Measure limestones.

U. C. = Middle Coal-Measure quartzites.

L. C. = Lower Coal-Measure limestones.

S. C. = Sub- (or Lower) Carboniferous limestones

D. = Devonian limestones.

O. D. = Devonian quartzites.

S. = Silurian limestones.

Ca.=Primordial quartzites and slates. 


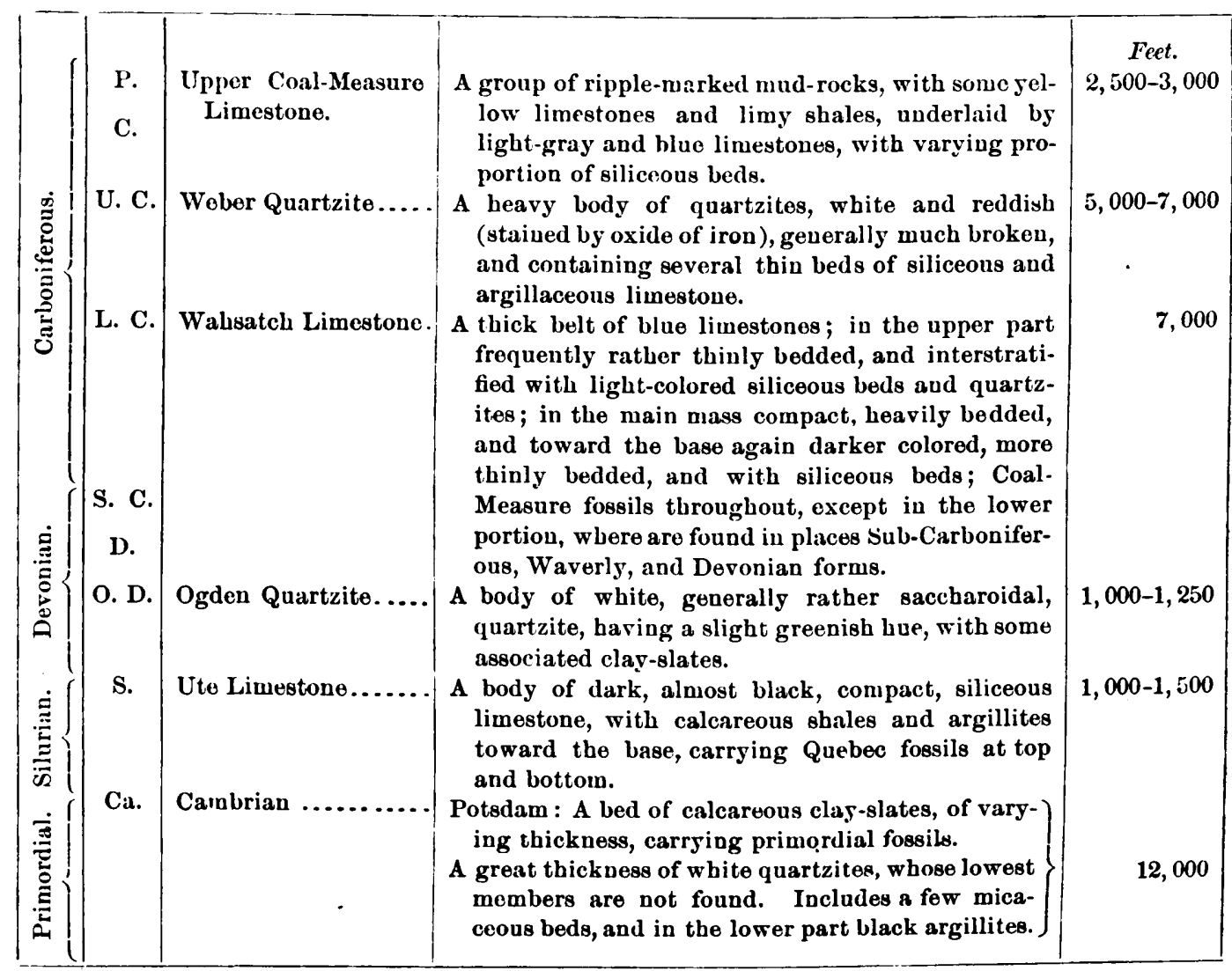

The Wahsatch Range may be subdivided topographically, in accordance with the different types of geological structure developed, into the following general divisions: The Southern Region, that opposite Utah Lake Valley; the Cottonwood Region, that opposite Jordan Valley; the Farmington and Weber Region, from Salt Lake City to Weber Cañon; and the Northern Region, north of the Weber River.

Utah Lake Region.-The southern limit of the Wahsatch Range proper is found at Mount Nebo, a sharp jagged peak, 12,000 feet in height, which is situated about south of Utah Lake, and 25 miles beyond the limit of the map. The structure of this peak is that of a sharp anticlinal, in which, contrary to what is the case in the main portion of the range to the northward, the western member is well-developed, and, indeed, forms its principal mass. The axis of the anticlinal is a little to the east of the summit, which is formed of thinly-bedded limestones and limy shales, 
having a strike of north $20^{\circ}$ west, and dipping $65^{\circ}$ to the west. (In the east of the axis, these beds dip still more steeply, and soon disalppear under gently-sloping sandstones of red and gray colors, which lie unconformably on the eastern flanks of the range, and are said to belong to the Tertiary formation. The rocks exposed on the western spur of the peak and in the cañon below are mostly blue and gray limestones, with some interstratified siliceous slates and argillites. Fossils of well-recognized Carboniferous types are abundant, the lowest found being Spirifer opimus. The dip of the western fold, although becoming somewhat less steep toward the western foot-hills, was nowhere observed to be less than $45^{3}$, so that a thickness of nearly 10,000 feet of strata is shown here in section, unless faulting shall have caused a reduplication of the beds. The obscrvations of this region were made at an early period in the work, when the subdivisions now adopted had not been clearly recognized, and were necessarily of somewhat hasty character, as they did not come within the province of the survey, so that, while it can confidently be asserted that those strata which form the main mass of the peak belong to the group called the Wahsatch limestone, and in age to the Lower Coal-Measures, it is uncertain whether the higher members of the Coal-Measures can be found here or not.'

From Mount Nebo to Utal Lake, the range bends gradually to the eastward, assuming opposite the southern end of the lake a position some twelve miles farther east than this peak, and, with a trend a little west of north, extends in a high narrow ridge to the granite body forming the mass of Lone Peak. Though once a continuous ridge, this portion is now cut through to its very base by the deep narrow cañon-gorges of Spanish Fork, Hobble's Creek, Provo River, and American Fork, which divide it into the separate groups of Spanish Peak, Provo Peaks, and Timpanogos Peak. The former of these does not come witlin the limits of the map, and will therefore not be described, though of the same general structure with the others. In this ridge is shown, in a most striking manner, the abruptness with which the range rises above the almost level valleys which border it

' Dr. (. A. White, in his report (Expl. W. of 100th Meridian, Lient. (1. M. Whecler, vol. iv, part i), describes a Productus Prattenianus from the top and a Memipronites crinistria from the cast side of Mount Nebo. 
on the west. In Timpanogos Peak, the average rise of its slope, from the foot-hills to the summit, is more than one in three for an elevation of 7,500 feet, while the upper 5,000 feet of the ridge rise almost one in one, presenting a wall so steep that, but for the shelf-like projections on its surface, resulting from the horizontality of its beds, it would be dangerous to climb.

It will be seen by reference to the map that the general shape of the western slope of the ridge is that of a pair of steps, the first rise being of about 3,000 feet to an outlying shoulder, from which the main ridge rises, about 2 miles farther back, in a steep, almost perpendicular, wall. Here again, as so frequently in the Rocky Mountain region, the physical structure gives the clue to the geological. Timpanogos Peak is formed of horizontally-bedded limestones, having at the most an inclination of $3^{\circ}$ east and $1^{\circ}$ or $2^{\circ}$ to the south. These beds are found to increase in dip a few miles farther east, and disappear beneath overlying members of the Carboniferous formation, to which they belong; but, on the west, their continuity is abruptly broken, nor could one imagine an erosion which would leave an abrupt wall of 7,500 feet in height on one side of a valley nearly 20 miles wide. The topography suggests that the line of junction of this lower shoulder with the face of the upper wall is that of a line of fault, and this idea is confirmed, as will be seen later, by the finding of faultings in the cañons of the Provo and American Fork, at either end of the ridge, in corresponding position.

In the ridge of Provo Peaks, the continuance of this line of fault is shown also in the topography, as well as rendered necessary by the thickness of the strata observed; while a second line of faulting along the very foot-hills, with the downthrow, as seems to be universally the case in this range, on the west, together with the sharp crushing of the strata into an $\mathrm{S}$-shaped fold, which has preceded and given rise to the dislocation, is shown in the section exposed in the little cañon of Rock Creek back of Provo City.

As the face of the hills on either side of Rock Cañon shows nearly horizontal lines of stratification, like that of Timpanogos Peak, the observer, on entering the cañon, and finding in its bottom clay-slates and quartzites standing perpendicularly, and even with a slight westerly dip, is at first led to believe that he has here a series of rocks entirely unconformable to the 
overlying strata of limestone. But ascending the canion, the beds are found, without showing any distinct break, to dip with an ever-diminishing anglo to the eastward, and soon beds, evidently conformable with the first observed, can be traced continuously along the cañon-wall, curving upward and westward from a dip of over $60^{\circ}$ east in the cañon-bottom, to an almost horizontal position high up on the spurs, and at times even with a slight inclination westward. There is here, therefore, a sharp S-shaped fold, the lower half of which is concealed beneath the surface, while the western front of the upper half has been broken down in a fault. The lowest beds exposed are a body of white granular quartzite, of a slight greenish tinge, about 800 feet thick, with greenish clay-slates, both above and below, the latter darker in color and more regular in cleavage. These beds represent the Ogden Devonian, as is determined by their position immediately below the large body of Wahsatch limestone, and the finding of a Spirifer centronatus and an undetermined Euomphalus, in some limestones in the western foot-hills which, from their position, must have been faulted down from the limestones immediately overlying these slates and quartzites. The Spirifer centronatus is elsewhere in the range found in beds of the Waverly period, but associated also with Spirifer alba-pinensis, which is also found in well-recognized beds of the Devonian age at White Pine, Nevada. This faulted portion, only seen in isolated pieces, consists of beds of light-colored quartzite, overlaid by limestones having a steep dip westward.

Rock Canon proper only exposes a section of the western shoulder of the main ridge, already mentioned as characteristic of this portion of the range, which here is much more developed than farther north at Timpanogos Peak. Above the Ogden Quartzite are found a series of blue and gray limestones, in general rather thinly bedded, sometimes semicrystalline in texture, with occasional thin beds of quartzite. About 1,000 feet higher in the series, an undetermined Spirifer was obtained, which may probably be Sub-Carboniferous. In the various limestones, in general rather more heavily bedded, between this and the head of the canion, where it opens out into the longitudinal depression at the foot of the main high ridge, which corresponds with the line of fault already mentioned in the western face of Timpanogos, are found only fossils belonging to the Coal-Measures, such as Spirifer opimus and Productus punctatus. Those which could be 
recognised came from a dark-blue, thinly-stratified, somewhat shaly limestone; the fossils from the more massive beds, in general, being too difficult to obtain, except from broken masses and boulders. The dip, as has already been said, gradually changes in ascending the cañon, from perpendicular to $45^{\circ}$, and finally to about $25^{\circ}$ east. In the longitudinal valley, at the head, the outcrops are obscured by soil accumulations, but, in the main ridge above, blue and gray limestones, generally rather lighter in color and less close in texture, are found dipping about $20^{\circ}$ to the east. From these were obtained other Coal-Measure fossils, which seem to indicate a somewhat higher horizon, though it may be remarked here, that in general the Coal-Measure fossils which are found extending through a vertical range of nearly 15,000 feet in this region, do not, as far as yet known, mark any horizon with sufficient distinctness to afford a sure guide, apart from the general stratigraphical and petrological considerations, which have been the main basis of the conclusions arrived at. The fossils obtained in this upper ridge were:

Streptorhynchus crenistria.

Productus Nebrascensis.

Spirifer lineatus.

Athyris subtilita.

Aviculopecten, sp.?

A thickness of over 10,000 feet of limestones would be given in this section but for the faulting in the longitudinal valley, whose amount, however, the conditions do not afford means of estimating. To the south of Provo Peaks, this upper faulting apparently disappears; and at the mouth of Hobble's Cañon, a simple monoclinal fold, with an eastern dip of $25^{\circ}$ in the Wahsatch limestones, is presented. On the eastern slopes of the ridge are found quartzites, whose position refers them to the Weber Quartzite; they are much obscured, however, by débris, and soon concealed by the unconformable Tertiary and Cretaceous beds, which, in this portion of the range, extend well up on its eastern flanks.

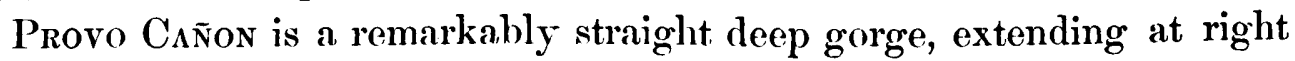
angles to the strike through the main ridge, and affording an outlet to the very considerable stream of this name, which takes its rise in the Uinta 
Range. The straightness of its walls, which on the southern side are almost perpendicular, and their general parallelism to the southern line of the Cottonwood Archæan body, suggest that its course has at least been determined by, and possibly its shape is largely due to, a fracturing of the strata which form the ridge, through which it is cut. The rocks forming the western shoulder of this ridge are so covered by detritus at the mouth of the cañon, that nothing can be determined as to its structure, though it presumably represents the northern point of the fold seen in Rock Cañon. About 2 miles up the cañon, the fault-line is represented by deep north and south ravines, bounded on the east by a straight wall of limestones, in which, on the southern side, the evidence of this faulting is seen in the curving of the strata, as is shown in Plate XIV. This view represents the wall of the cañon just west of one of the two beautiful cascades, which fall from the northern slopes of Provo Peaks into the cañon from the south; in this, though the volume of water is not great, the height from which it comes, falling over a ledge over 1,000 feet above the cañon-bottom, in one leap of about 600 feet, together with the lace-like appearance of its foaming waters as they ripple over the rugged edges of the strata of dark limestone, render it a most picturesque and pleasing addition to the grand but somewhat forbidding scenery of this alpine gorge. The other cascade, which is a mile or two above, still on the southern side of the cañon, is less prominent, but equally picturesque, being seen high up on the limestone walls, a silver fringe upon their background of deep blue.

Throughout the length of the canion were observed only beds of the Wahsatch limestone, though some of the lower groups may have escaped notice near its mouth. They are dark blue and gray in color, generally in heavy strata, though sometimes thinly bedded, and containing developments of slates and argillites. ${ }^{1}$ The beds dip eastward, generally at low angles, though in some places showing steep dips. No distinct evidences of extensive faulting east of the line of the cliffs represented in Plate XIV was,
however, observed.

${ }^{1} \mathrm{Mr}$. Henry Engelmann mentions the diwcorery of a frugment of Lepidodendron in slates, and of carbonaceons matter in bluish-black argillaceous slates in this cañon. He also obtained a Productus semistriatus and an undetermined Athyris from the cañon,
without defining the horizon. without defining the horizon.-(Capt. J. H. Simpeon, Expls. in 1850, 309, 369.) 
Above the narrow main ridge, the cañon opens out suddenly into Provo Valley, in which the ridges and hills are covered with soil and débris, and overgrown with grass and timber. Only isolated and detached outcrops of the underlying rocks, which were doubtless once covered by Tertiary, and perhaps also by Cretaceous beds, can now be found. In the lills immediately above the cañon-narrows, the presence of the Weber Quartzites is indicated by outcrops of light-colored sandstones and quartzites, while in the valley above, near where it opens out into the main Provo Valley, were found, to the north of the river, limestone strata containing rather poor specimens of Bakevellia, but which were sufficient, in connection with the overlying red sandstone, to determine the horizon as the Permo-Carboniferous, and the intermediate group of Upper Coal-Measure limestones has hence been colored upon the map inferentially.

The limestone strata rise gently both to the north and to the south from Provo Cañon. In the Timpanogos Ridge, this rise continues to the granite body of Lone Peak. Timpanogos Peak itself is a narrow ridge, only a few feet wide at its summit, falling off at a very steep angle for 3,000 to 5,000 feet on the east and west, composed of approximately horizontal strata of the Wahsatch limestone. A high spur extends from its highest point to the eastward, enclosing an ampitheatre-like basin, sheltered on the west and south by sheer walls over 3,000 feet in height, in which a large body of ice and snow remains probably throughout the year. The beds which form the upper portion of this ridge belong to what was first called the intercalated series, and consist of alternate layers of thin limestones and limestone-shales, with light-colored siliceous slates and quartzite. They form an easily recognizable horizon, indicating the upper portion of the Wahsatch limestone, and generally contain many well-preserved Spirifers, whose shells have been replaced by white calcite, which forms a strong contrast with the blue or gray matrix in which they are imbedded.

Among the fossils brought in from this horizon on Timpanogos Peak were:

\section{Spirifer cameratus.}

Athyris subtilita.

In the lower portion of the ridge, the limestones are generally of darker 
color, more compact, and heavily bedded. No fossils of a lower horizon than the Coal-Measures were found, though it is probable that along the base of the main ridge the Sub-Carboniferous beds of the Walsatch limestone could be detected by a more careful examination. The hills forming the outlying shoulder to the west are in general covered with soil and débris, and no details of their structure were obtained other than that the general dip of their beds is eastward, though toward the northern end of the ridge a western dip may be recognized in the extreme foot-hills.

AMerican Fork Cañon is a still more narrow and precipitous gorge than Provo Cañon, but its course is also more sinuous; in its central portion, the limestone walls tower up thousands of feet, almost perpendicularly, above its bottom. Since it was visited by our parties, a narrow-gauge railroad has been built through it to connect with the mines near its head, and much of the picturesque beanty due to the groves of poplar and pine, which nestled in its secluded nooks, doubtless destroyed. The upper portion of the cañon, beyond the main high ridge, runs approximately with the strike of the beds, but, in its lower portion, it crosses them almost at right angles. At its western mouth are found beds of massive, compact limestone, with others of a more shaly character dipping westward, and having a strike somewhat west of north. The western dip holds for about 2 miles up the cañon, when a body of white and pinkish saccharoidal quartzite is found, which forms the axis of a gentle anticlinal fold. This quartzite contains almost no lime, as is generally the case with those of the higher bodies. It gave, by analysis, nearly 90 per cent. of silica, the impurities being mostly alumina. To the eastward of this, the limestones come in again, dipping gently eastward, and showing on the face of the cliff evidences of the vertical movements, which must have lifted up the ridge of Timpanogos, in the contortions and dislocations which have twisted and broken beds of massive limestone, hundreds of feet in thickness. The fossil remains, fragments of Productus, Euomphalus, and Crinoid columns, obtained from these limestones, though too poor for specific identification, were considered sufficient at the time of our visit to determine the Carboniferous age of these beds. With the experience which has been since gained, a careful search, more particularly in the beds immediately overlying the quartzite, which is without doubt 
the Ogden Quartzite, would probably have yielded Devonian or Sub-Carboniferous forms.

The anticlinal structure disclosed in the American Fork section continues in the main ridge to the north, but the beds rise, and lower horizons are successively exposed until, at Dry Cañon, the granite body of the Cottonwood district is found at the surface, a spur of which doubtless underlies this whole ridge which we have been examining, and served to determine its direction. The contact of the lower beds with the granite body at Dry Cañon has not been actually observed, but the lines of division between the formations at this part of the range are based on observations from Lone Peak and the position of these beds in contiguous portions of the range. The limestone body north of American Fork Cañon has a general eastern dip in continuation of the Timpanogos Ridge, and preserves for some distance the same strike; but soon the strike of all the beds bends to the northeast, parallel in general to the southern line of the Cottonwood granite body. At the head of Deer Creek, the first northern branch of American Fork, the granite is seen to form the face of one of the spurs, while on either side it is covered by the steeply-dipping quartzite beds of the Cambrian, which, with a general inclination to the south away from the main body, also dip east and west on either side of the spur.

The cañon of American Fork above the first bend is still in the gentlyinclined beds of the Wahsatch limestone, which also forms the main body of the bounding ridge on the south, which stretches east from Timpanogos, and separates it from Provo Valley. It soon opens out, however, into a mountain-valley, with slopes obscured by soil and débris, in which it is difficult to determine the exact geological horizons. A breccia-like conglomerate, formed of small, rather angular, pebbles of green and white quartzites, enclosed in reddish, somewhat calcareous, matrix, which forms a low hill in the midst of this valley, may correspond to a conglomerate, which is found in about the middle of the Wahsatcl limestone at the head of the cañon. Above the second bend, the course of the stream is parallel with the strike of the beds, and, as near as can be determined, runs at the base of the Lower Coal-Measures. Its sides are covered for 50 or 100 feet from 
the bottom with moraine material, resulting from one of the local glaciers, which were very numerous in this high region.

At Forest City, the beds have a northeast strike, and dip $35^{\circ}$ to the southeast. Toward the summit of the ridge south of this point, the appearance of several interstratified quartzite beds indicates the horizon of the upper Wahsatch limestone, which here consist of light-gray and whitish limestones, with white, pink, and yellowish siliceous shales, the latter enclosing cherty seams. At their base were found

\section{Spirifer cameratus,}

Aviculopecten occidentalis,

so that the palæontological evidence confirms that of the pliysical character as to the correspondence of these beds with those which form the summit of Timpanogos Peak. These beds have a dip of $40^{\circ}$ on the southern slopes, while the ridge between this and Provo Valley is seen to be formed of the Weber Quartzites, of which the croppings are distinctly visible along the western slopes of the spur which runs south from just west of Medway. The Wahsatch limestones of the northern slopes of the ridge rise toward the north, and, at the upper bend of American Fork, 2 miles above Forest City, form a wall 4,000 feet in height. Here their strike bends abruptly to the northwest, with the direction of the canon.

The face of the spurs north of the stream, at Forest City, is formed of a dark, almost black, close, even-grained limestone, having in places a fetid odor, which stratigraphically corresponds to the Nevada Devonian; although careful search revealed no fossils sufficiently well preserved to confirm this palæontologically, the fragments of Euomphalus, Productus, and Crinoid columns obtained have a resemblance in general appearance to those of other well-determined localities, like Logan and Ogden Canions. In the ravine north of Forest City, the Ogden Quartzite is exposed in section, resembling the typical development at the head of Cottonwood Cañon in the conglomerate of large pebbles of limpid quartz, having a pinkish tinge in the matrix, which occurs near the middle, and in the body of purple and greenish argillaceous slates near its base. The lower rocks between this and the granite body have suffered very considerable dislocation and displacement, especially in the spur enclosed within the sharp bend of the 
strike, for which reason it has been difficult, in the absence of palæontological evidence, to define the position of the Ute limestone. The ore body of the Miller Mine, which is on a shoulder of this spur, is in the line of one of these breaks; the rocks, which enclose it, dipping sometimes a little north, though their general inclination is south. Like the majority of the ore bodies in this region, this deposit is enclosed within, and generally parallel with, the stratification. The hanging-wall is a light-colored quartzose rock, which passes into a white quartzite, while the foot-wall is a darkcolored siliceous rock passing into a blue limestone, probably the Ute limestone, which is found on the spur a little north of the mine. This limestone forms the head of the upper branch of American Fork, and can be traced across the head of Cottonwood Cañon, just below the town of Alta; it is much metamorphosed and singularly barren of fossil remains.

In the lower part of the Wahsatch limestone, at the head of American Fork Cañon, were found:

\section{Productus punctatus.}

Productus cora.

Productus semireticulatus.

Streptorhynchus crenistria.

Zaphrentis centralis?

Spirifer (opimus?).

Cotronwood Region.-That portion of the range which is included between Utah Lake and Emigration Cañon forms a geological whole, consisting of a series of sedimentary formations, flexed around a body of Archæan granite. Here the range no longer consists of a single ridge, as in the southern portion, but forms a broad mountain-mass, about 15 miles in width, and over 10,000 feet in average height, whose surface is deeply scored by a net-work of glacier-worn cañons and ravines, now debouching into the plain through narrow gorges, which recent erosion has cut down below the level of the old lake that once covered it. Seen from the valley, the most commanding points of this portion of the range are Twin Peaks and Lone Peak, each over 11,000 feet in height, but within the mass are still higher points, of which there are no less than five on the ridge extending from Lone Peak $(11,295$ feet) to Clayton's Peak (11,889 feet). The view of this portion of the range from Salt Lake City is well known to western tourists 
for its singular beauty, and will be found well represented in Volume I. The scenery of the interior of the mass is of a truly alpine character, especially in the spring and early summer, when the upper portions of the cañons are still decply buried beneath the winter's accumulation of snow.

While glacier-action has doubtless played an important part in the formation of most of the cañons and gorges, the traces of this action now remaining vary with the character of the enclosing rock, and the relations of their direction to the structure-lines. Where the rock is hard and homogeneous, as in Little Cottonwood Cañon, the evidences of glacier-action are apparent even to the uneducated eye. This canon is a long, almost straight gorge, whose cross-section would represent a $\mathrm{C}$-shaped depression, its bottom, especially toward the mouth, filled with huge rounded boulders of the granite out of which it has been carved, while its walls present smoothed and rounded surfaces. Big Cottonwood Cañon, on the other hand, while still showing some traces of glacier-action, and even large moraines, in its upper portion, is koward the mouth a narrow $V$-shaped ravine, whose course forms a zigzag line, running to and fro between the strata of quartzite, to find a more yielding point at which to break through them. The little tributary ravines on the south side of either of these canons, which occupy a much higher level, show traces of wearing by.ice at a very recent period, having rounded amphitheatre-like heads, and frequently little shallow glacierlakes. The most remarkable of these is the Three-Lake fork of Bigr Cottonwood, just east of 'Twin Peaks, where, over an extent of many acres, glaciers have grooved and polished the hard surface of a bed of dark argillaceous quartzite, and covered it with a thin weathered coating of a brick-red color. The three little lakes occupy three different levels in this glacier-hasin, and are connected by pretty cascades, of which the lower, being triple, is excecdingly picturesque.

The main system of glaciers, as is shown by the topography as well as by moraines and the shapes of the canons, radiated out from the high mass around Clayton's Peak. Most of these glaciers did not extend to a very low level. That of Iittle Cottonwood, however, as shown hy the regular shape of the cañon and the rounded boulders at the mouth, must have extended at least as low as the shore of the ancient lake which once filled the Utah Basin; that it actually protruded into the Jordan Valley is ren- 
dered improbable by the fact that no erratic boulders are now found there, too large to have been brought down by the force of a mountain torrent, though the waters of this lake might have levelled off or dispersed the accumulations of finer moraine material. In the little secondary glacier-basins, on the northern side of Lone Peak and of the ridge which extends eastward from this peak, large fields of névé ice, often with little glacier-ponds within them, may still be found even after midsummer.

The geology of this region may be described in a few words as follows:-A body of Archæan slates and granite is surrounded, and partly covered, on all sides except the west, by a conformable series of sedimentary rocks, of an aggregate thickness of over 30,000 feet, extending in age from the Cambrian to the Jurassic inclusive. The granite mass, though eruptive, has not been protruded through this immense thickness of overlying rocks, but their beds were deposited around and over a submerged mountainrange of granite surrounded by Archæan rocks; and subsequent elevation, flexure, dislocation, and erosion have produced the conditions represented on the map, where it will be seen that of this conformable series, now bent and twisted, different horizons from the Cambrian up to the Middle CoalMeasures are at different points in contact with the granite body. Of the immense arch which once covered this body, the western half has been faulted down, while the top of the arch, with its thickness of 30,000 feet of rock masses, has been broken up and worn away by atmospheric agencies.

Granite and Archean Rocks.-The Cottonwood granite body forms the main mass of the Lone Peak Ridge, toward the eastern end of which it disappears beneath the slates and quartzites, the base of the Twin Peak Ridge, and a northwestern spur of this peak which juts out toward the mouth of Big Cottonwood Cañon, and the bed of Little Cottonwood Cañon, from half a mile above its mouth nearly up to the town of Alta. Here it disappears under the Wahsatch limestone, but re-appears at the head of Big Cottonwood Cañon, forming the head of this and of the Snake Creek Cañon, and the mass of Clayton's Peak. The best exposures of this body are found in the lower part of Little Cottonwood Cañon, where it shows a conoidal structure, that is, has a tendency to weather in curved surfaces on a large scale, while the prevailing planes of cleavage have a dip of about $50^{\circ}$ to the westward. 
Plate XV, which represents a spur on the north side of the cañon minning out from the base of Twin Peak, gives a good representation of these fratures of its mass-structure, the general slope of the bedding-planes to the west, and the tendency of large masses to flake off, leaving rounded surfaces, which give the appearance of having been worn smonth ly glacieraction, as they doubtless have in part. From the immense boulders, often as large as a moderate-sized house, which are scattered through this part of the canion, the rock has been quarried, of which the foundations of the Mormon temple at Salt Lake are built. It is a remarkably beautiful stone, white and rather coarse-grained, dotted here and there with round black spots, where there has been a concentration of the dark-green homblende, which is a prominent constituent of the mass. This granite belongs to the class of dioritoid granites, which are of frequent occurrence along the Fortieth Farallel; thatis, it is a compound of quartz, bintite, hornblende, orthoclase and plagioclase feldspars, and titanite, with a relatively large proportion of plagioclase, homblende, and titanite. The crystals of titanite can be readily seen by the naked eye, and are frequently quite large and of very perfect form. By the aid of the microscope, pale-green hornblende microlites are found within all of these crystals; apatite is found to be alounlantly disseminated through the mass, and, in some varieties, plates of red oxide of iron; the larger hornblendes are also seen to be made up of accumulations of single prisms, and the quartz to be comparatively poor in liquid-inclusions. An analysis of this granite made by Prof. Thomas M. Drown gives the following constituents:

Silica. . . . . . . . . . . . . . . . .

Alumina

Ferrous oxide.

Manganous oxide.

Lime

Magnesia

Soda

Potassa ... . . . . . . . . . . . . . .

Ignition 
The granite of Lone Peak resembles this very closely, but shows also a porphyritical structure, carrying large crystals of dull white orthoclase in a crystalline matrix. In this, two principal sets of cleavage-planes, at right angles to each other, are prominently developed, giving the rock a tendency to separate into rectangular masses. Lone Peak itself is a narrow ledge, rising about 1,500 feet above the general surface of the ridge, having on its southern and western side a sheer perpendicular wall as straight as if built of masonry. This wall and the roche-moutonée basin which extends to the southward from Lone Peak are seen in the colored view of Lone Peak in Volume I. In the narrow ravine at the mouth of Big Cottonwood Cañon, where the granite spur of Twin Peak is denuded, a similar porphyritical granite is observed. It is rich in hornblende, biotite, and titanite, and under the miscroscope shows abundant fluid-inclusions, both in feldspars and quartzes, while the larger feldspars present an interesting manner of alteration in concentric zones, in the more decomposed of which the fluid-inclusions are the less abundant. This granite is in general, however, finergrained than the temple granite, and in some cases consists merely of quartz, feldspar, and white mica. These latter occurrences are comparatively rare, and associated with the lower mica-schists of the Archæan.

Along the western flanks of the granite body toward Jordan Valley are found some remnants of a series of Archæan quartzites and schists, which have a general strike northeast, and dip from $45^{\circ}$ to $60^{\circ}$ to the westward. Along the face of the Lone Peak Ridge, these rocks form only a thin shell, covering the ends of the spurs, and are mostly obscured by surface accumulations and soil. In a little ravine, at the contact of the Lone Peak granite with trachyte of the Traverse Mountains, is found a green decomposed rock, consisting largely of hornblende, quartz, and feldspar, which has been subjected to such great pressure that little of its original structure or composition can now be seen, but which doubtless belongs to this series of rocks. On either side of the mouth of Little Cottonwood Cañon, they consist of a body of quartzites about a thousand feet in thickness, which, on the south side, form a little spur running out from the main wall like a moraine ridge, and, on the north, cover the granite of Twin Peak for a considerable distance up the western slopes, without, how- 
ever, showing any very distinct bedding-planes. These rocks, though essentially quartzites, have a very distinct habit from the Cambrian quartzites of Big Cottonwood Cañon. They contain mica in very varying quantity, and, where this is abundant, have a laminated structure and approach a true mica-schist; toward the mouth, the mica is replaced by homblende, which gives to the rock a greenish tinge.

In the ravines on the west face of Twin Peak, between the mouths of Big and Little Cottonwood Cañons, a greater thickness of Archican rocks is found, probably not less than 2,000 feet, though, owing to the limited exposures and irregular position of the beds, it is not possible to make an accurate estimate. The strata are much contorted, and in one case completely surround a little knob of granite, which projects from a western spur of 'Twin Peak. In the lower beds is found a light-green homblende-schist, made up largely of quartz, the mass being penetrated by small bluish-green homblende prisms which give to the rock its schistose structure, and a little brown mica. With these are associated various slates and mica-schists, while the upper beds consist of light and darker-colored quartzites, among which a greenish schistose rock contains apparently a considerable anount of chlorite, and shows the effects of great pressure. A typical mica-schist is found in direct contact with, and in places penetrated by, the granite body already mentioned, which is exposed in the little side-caũon at the mouth of Big Cottonwood, and which marks the dividing line between the Archæan rocks and the Cambrian slates and quartzites of Big Cottonwood Cañon. The latter have a strike at right angles to them, or in a northwest direction, and dip steeply northeast, while the Archæans dip west and south and strike northeast. ${ }^{1}$

The Cottonwood granite body preserves the same mineralogical character throughout the greater part exposed; but, while that at the mouth of Little Cottonwood is composed mainly of large feldspar crystals, with

\footnotetext{
'Since the above was printed, Mr. J. E. Clayton has reported the discovery by
him; in the Archæan schists of the first small cañon north of Little Cottonwood, of a white mica-schist, containing well-defined crnciform crystals of staurolite, which would resemble the paragonite-schists of Red Creek, Uinta Range, together with a similar hornblende rock, which render more complete the resemblance of these two
Arcbæan bodies.
} 
hornblende and mica in general rather widely disseminated, giving to the mass a beautifully white appearance, and all these crystals are remarkably fresh and undecomposed, toward the east the rock becomes gradually finergrained and darker, owing to the closer arrangement and larger proportion of hornblende and mica, and the component crystals, especially the feldspars, are duller and more decomposed. The structure-planes also, which below are widely spaced and not prominent, about half-way up the cañon, at Tannersville, have become more frequent, and so regular as to give the appearance of lines of stratification.

Along the steep northern wall of the cañon, the dividing line between the darker Cambrian slates, which form the upper 2,000 feet of Twin Peak, and the white granite beneath, can be distinctly traced by the eye as one ascends the cañon. The slates are not conformable with this dividing line, but stand at an angle of $45^{\circ}$, dipping to the northeast; hence the ends of different series of beds are constantly seen as one ascends, and the dividing line reaches lower on the wall, until just below Alta the quartzites of the upper Cambrian descend to the bed of the cañon, and, crossing to the southern side, curve round and form the main ridge between this and American Fork Cañons as far west as the third high peak east of Lone Peak, whose summit is formed of metamorphic slates, while its northwestern face is in granite.

In the bed of the cañon above Alta, the granite has been again denuded, and in the divide between Big and Little Cottonwood Cañons, just east of this town, the ridge is formed mainly of granite, more or less covered by the Wahsatch limestone, whose continuity it breaks. This granite, as has been already remarked, closely resembles in general appearance and composition that at the mouth of the cañon. The very summit of Clayton's Peak, however, is made up of a rock which differs in external appearance very much from this rock : it is a dark, fine-grained, syenitic-looking rock, made up of quartz, orthoclase and plagioclase feldspars, mica, and hornblende; the latter is very abundant, and of a lighter green, and less distinctly crystallized than in the other granites. Under the microscope, it is seen to contain also titanite, of a darker brown than in the other granites, apatite in flattened crystals, and magnetite, while the quartz and feldspars contain 
many microscopical impurities, the latter, particularly, colored plates of red and black oxide of iron.

Resting on a spur of the granite mass, overlooking the lake at the head of Cottonwood Cañon, is a curious garmet rock, which may represent a portion of the Archæan body exposed at this point, if, as might naturally be supposed, the Archæan rocks surround the granite body. It is a coarsegrained quartz mass, of a greenish tinge, through which are disseminated abundant crystals of dark-brown garnet, with local concentrations of specular iron, often in large tabular crystals, and dark-green hornblende. Under the microscope, the greenish tinge is found to be due to a fibrous green epidote, and the garnet crystals to present a schistiform structure as if formed by the continuous superposition of layers.

In Big Cottonwood Cañon, about two miles below the bend, is a small exposure of granite, somewhat resembling the Clayton Peak granite, which itic sand. It is a fine-grained admixture of quartz, feldspar, black mica, hornblende, and titanite; the hornblende being generally fibrous and somewhat decomposed. In the feldspars, plagioclase is so largely predominant that the rock might almost be classed as a diorite. It is difficult to say
whether this rock should be considered as which it does not resemble very closely, or with the main granite body, granite-porphyries and diorites, which are found intersecting the sedimentary rocks of this region. These dikes of porphyry and diorite are very the mineralization of the beds has been niost developed; they are mostly of too limited extent to be represented on the map, and only a few typical granite or diorite body of Big Cottonwood be now described. Near this the upper part of the Wahsatch limestone, syenitic granite-porphyry, so classed by Zirkel, which resembles the granite in general appearance, having a rather coarse crystalline groundmass, in which plagioclase can be recognized by the naked eye, and containing, besides, quartz, orthoclase, mica, and hornblende ; its whole mass is impregnated with iron pyrites, which, as revealed by the microscope, penetrates 
in little filaments and veins the crystals of quartz and feldspar, thus proving it to be a later impregnation.

In the Cambrian slates of Twin Peak, on its northwestern slope, and partly interstratified, is an interesting porphyry, which, in the hand-specimen, has much the feel and general appearance of a trachyte. It is a reddish-drab colored rock, consisting of a rough-feeling, rather granular, finegrained groundmass, in which is imbedded an immense quantity of bronzecolored mica plates. By the naked eye, no other crystals can be distinguished; but, under the microscope, the groundmass is seen to be made up of crystals of a dull feldspar, the intermediate spaces being filled with quartz, small brown micas, and apatites, but no hornblende or titanite. The same rock, with perhaps even a larger proportion of mica crystals, is found cutting through the granite spur near the mouth of Big Cottonwood Cañon.

Another type of granite-porphyry is found north of the granite body of Clayton's Peak, on the divide between the headwaters of East Cañon Creek and of Big Cottonwood. It has a pale-green groundmass, containing large crystals of pinkish-white feldspar and.prismatic columns of dull-green hornblende porphyritically enclosed, while the whole mass is impregnated with pyrites. The hornblende crystals have frequently a radial grouping. The feldspar resembles, at first sight, orthoclase, but is seen to have the characteristic striations of plagioclase. Under the microscope, the color of these larger feldspars is seen to be due to a fine dust of oxide of iron, and that of the groundmass to epidote, resulting from the alteration of hornblende, while its feldspars are largely plagioclase.

Still another granite-porphyry is found in the Weber Quartzites east of Clayton's Peak, near their contact with the trachyte body at the head of Provo Valley. This is a gray granitoid rock, made up of quartz, feldspar, biotite, and hornblende, in grayish crystalline groundmass. The hornblendes are in long prisms of a dull-green color, and seem to be generally arranged in parallel directions. Here also, as in the granites, plagioclase is a prominent constituent.

On the divide between the southern head of Little Cottonwood Cañon and that of American Fork is a body of diorite, which occurs near the base of the Ogden Quartzite, and seems to be on a line with the break 
already mentioned at the Miller Mine. It is a dark-green compact rock, having on its weathered surface a porphyritical appearance, as the crystals of feldspar and hornblende show more distinctly thus than in the fresh fractures. By the aid of the microscope, it is seen that the fresher hornblendes contain magnetite grains, and within the groundmass is a certain amount of glassy base. This body, as do most of the intrusive dikes through this region, lies parallel with the stratification, and occupies the position of a band of metamorphic slates just above the Ute limestonc at Alta, which along the spur southwest of the town is seen to have a more and more felsitic character as one approaches the divide.

Palzozorc Rocks.-The Palæozoic beds of this region, which fold around and partly cover the granite body, have been subjected to intense compression and local metamorphism, twisted and contorted in cvery direction, faulted and dislocated, and penetrated by intrusive dikes and mineral veins. It does not come within the scope of this work to delineate these phenomena in all their details, but the main features of their structure have been determined with sufficient accuracy for purposes of general geology. The great belt of Wahsatch limestone, which forms the main stratigraphical landmark in these formations, crosses the head of Little Cottonwood Cañon in a northwest and southeast direction, having an average dip of about $45^{\circ}$ to the northeast, and bending, as has been seen, sharply to the southwest at the head of American Fork. It forms massive cliffs at the southern head of Little Cottonwood, and here already, in the mantling of white, through its general blue color, shows the commencement of the metamorphism which has marbleized its beds in great degree from here to the mouth of Mill Creek Cañon, where they disappear beneath the Salt Lake plain. This belt includes, as has already been stated, the three groups of Lower Coal-Measures, Sub-Carboniferous, and Nevada Devonian.

On the ridge which separates the head of Little from that of Big Cottonwood Cañon, these limestones have been eroded off, and the underlying granite exposed. On the west face of this ridge, however, just above and to the east of the town of Alta, a fragment of white limestone beds is still standing, while at the foot of the ridge the granite is again denuded in the cañonbottom, showing that this depression, which forms the basin-like head of the 
cañon, existed in the granite ridge before the limestones were deposited. On the west of this depression, between Little Cottonwood and American Fork, the east face of the cross-spur is formed partly of Ogden Quartzite and partly of the Ute limestone, continued to the westward by the underlying Cambrian slates and quartzites, all these beds standing at high and varying angles, and being much broken and contorted, as they come just in the apex of the great bend of the whole formation over the eastern point of the lower Cottonwood granite body.

The most distinct and char.cteristic section, however, is seen on the eastern continuation of the Twin Peak Ridge, opposite Alta, locally known as Emma Hill, where the erosion of the cañon has cut the formation at an oblique angle, its strike being northwest, while the ridge runs nearly east and west. Owing to the obliqueness of the section, the crumplings within the beds and over the protrusions of granite appear distorted, so that the prevailing dip of $45^{\circ}$ northeast is frequently seen to steepen to $60^{\circ}$ and more, and again to be as low as $30^{\circ}$. The contact-line of the granite body, on the north wall of the cañon below Alta, can be traced with the greatest distinctness, sloping irregularly to the eastward. The ends of a series of darker slates are seen to form the summit of the ridge, while along the contact to the bottom of the cañon a higher series of whitish quartzites, more or less iron-stained, follow in wavy curves the surface of granite. Above these are darker-colored siliceous slates, like the former dipping at $60^{\circ}$ and over, near the bottom of the cañon, and forming the upper 2,000 feet of the Cambrian body.

The Ute limestone projects out into the cañon, forming a precipitous spur half a mile below Alta, conspicuous by the cloudings of blue through its white mass. It is a semi-crystalline limestone, more or less siliceous, which, at times, becomes a quartzite, with a slight percentage of lime. It is very fine-grained, but, under the microscope, shows a distinctly crystalline structure, while small, rounded grains of quartz are seen to be disseminated through the mass; besides the quartz are many slender, needle-like, colorless crystals, which become brown under crossed nicols, and which resemble tremolite. The slates under this limestone should correspond to those in which are found, in other parts of this region, the 
Primordial fossils. The Ute body shows a thickness of about 1,000 feet, above which are from 100 to 200 feet of dark slates, containing fucoids, very much metamorphosed, and in places quite crystalline, which, with a body of white quartzite about 800 feet in thickness forming a saddle in the ridge, constitute the Ogden Devonian.

Emma Hill proper, in which are most of the important mines of the district, is formed of the lower part of the Wahsatch limestone, here a crystalline, generally white or whitish-blue rock, having a normal dip of $45^{\circ}$ to the northeast. Its beds are generally massive, and the limestone comparatively pure, though even the purest parts contain more or less silica, which is left in the form of sand after the lime has been dissolved out. It can also be detected by the microscope as forming small, rounded grains, as in the Ute limestone. The mineral deposits, though at this point more abundant in this limestone, are not confined to any particular bed or formation, and, in regard to their distribution, it may be remarked that they are mostly concentrated within a radius of 6 or 7 miles from Clayton's Peak. They have followed pre-existing fissures and cracks in the beds, generally in the neighborhood of lines of fault, and frequer,tly spread out in lenticular-shaped masses within the stratification.

The fossil remains obtained near Alta were mostly too indistinct for specific identification. They are:

\section{Spirifer cameratus. \\ Spirifer planoconvexus. \\ Spirifer, sp. $?$ (like S. disjunctus). \\ Syringopora, sp.? \\ Diphyphyllum.}

And from the bed above the Flagstaff Mine:

Spirifer lineatus.

Spirifer, sp.? (like S. disjunctus).

Athyris subtilita.

Euomphalus, sp.?

Zaphrentis, sp.? (like Z. centralis).

Which in general seem to belong to the Lower Coal-Measure horizon.

On the northern side of the ridge, east of the Reed and Benson mine, 
Mr. J. E. Clayton found, in a belt of dark limestone, a number of fossils, among which the following have been determined by Messrs. Hall and Whitfield :

Spirifer alba-pinensis.

Spirifer centronatus.

Athyris planosulcatus.

Athyris Claytoni.

Euomphalus Utahensis.

Terebratula Utahensis.

Cryptonella?

These have the same general aspect, and are many of them identical forms with those found in Ogden and Logan Cañons in this range and in Dry Cañon in the Oquirrh Mountains, and may be considered to indicate the Waverly horizon.

A peculiar belt of white calcareous quartzite in the limestones on the summit of the ridge above the. Flagstaff Mine, full of indistinct casts of fossils, among which a long cylindrical cavity, regularly ribbed in circles, parallel to the base of the cylinder, about one-eighth of an inch apart, is the most frequent, with also the interior mould of a Spirifer resembling $S$. cameratus, recalls a similar quartzite at White Pine, Nevada, occurring below the black shales which mark the dividing line between the Carboniferous and Devonian.

The Wahsatch limestone body can be traced by its white cliffs eastward to the ridge overlooking the head of Big Cottonwood, where it is more coarsely and distinctly crystalline, and its beds bent into $Z$-shaped folds, and traversed by dikes of syenite-porphyry about 20 feet wide. Of these, no less than three can be seen on one spur, the strata being abruptly curved at the contact-line, showing they have followed lines of weakness and fracture. One variety resembles that already described from Big Cottonwood, being very rich in hornblende and titanite, with mostly plagioclase feldspar, and but little mica. Another externally is more like the diorite from the American Fork divide, showing neither orthoclase, mica, nor titanite to the unaided eye.

The upper tributary cañons of Big Cottonwood run more or less in 
the strike of these beds, while that cañon itself, above the bend, has been carved out of the Weber Quartzite. No good section of this formation is, however, obtained here; various beds of white quartzite, and some of an iron-stained quartzitic sandstone, are exposed at various points on either side, but the cañon is encumbered with débris and moraine material. Near the bend, the latter forms a high ridge on its western side, through which the present course of the stream has been cut. On the ridges just north of this bend, in the continuation of the course of the old glacier-canon, heavy bodies of white quartzite are exposed; but, as at this point the formation makes a sharp bend to the westward, and the beds are consequently twisted and faulted, no opportunity for estimating the thickness is given. $\Lambda$ analysis of the pure white quartzite from this cañon gives nearly $9 \mathrm{t}$ per cent. of silica, the other constituents being lime, alumina, and a trace of oxide of iron.

Cambrian Formation.-In the section exposed along Big Cottonwood Cañon is afforded the best opportunity for seeing the rocks of the Cambrian formation, but even there it is difficult on the ground to form a satisfactory estimate of its thickness, as the cañon is cut so obliquely to the strike, and in part runs with it, while bending in every direction. In general, it may be described as a body of quartzites more or less argillaceous, having some fine-grained mica-schists in its upper portion, and, near the base of the part exposed, a bed of some 800 feet of dark-blue, almost black, finelylaminated argillites. Its thickness, as estimated from the distances between outcrops and the average dip, cannot be less than 12,000 fect.

In descending the cañon from the bend, a thickness of from $2,000()$ to 3,000 feet of white quartzite is crossed, containing some beds of limestone, then a series of white crystalline limestones, with some bluer strata, stiil crystalline, in the upper part of which are the dike and granite body, already described. Limestone exposures are found down as far as the mouth of a little cañon coming in from the north, where is the lowest body. of limestone found. The Ogden Quartzite is not distinctly recognized in the cañon, being obscured by surface accumulations. This limestone, however, resembles the Silurian of Little Cottonwood in containing needle-like crystals of tremolite, which are visible to the naked eye. On the ridge to 
the north of the head of this cañon is found the main body of the Wahsatch limestone, with the following characteristic Coal-Measure fossils :

Chometes granulifera.

Iroductus Nebrascensis.

Productus pertenuis?

Productus symmetricus?

It is, in general, much less crystalline than in the main cañon, and already strikes nearly west, with a dip to the northward.

In the main cañon, immediately below the Ute limestone, is a thickness of some 200 feet of schistose rock, quite micaceous near the bottom, then 2,000 to 3,000 feet of various quartzites, crossing the cañon at an oblique angle; that found in the Three Lake Cañon, which has been so largely polished and striated, contains only 60 per cent. of silica, the other constituents being mostly alumina, with a little lime and iron ; then, to the mouth of the cañon, argillites and quartzites, with every intermediate gradation, among which was observed, near the summit of Twin Peak, a bed of micaceous quartzite or mica-schist, in which the mica occurs rather sparsely in very fine specks, but sufficient to impart in places a schistose structure to the rock. The peak next east of Twin Peak is formed of dark-blue argillaceous slate, in which there is some development of bronze-colored mica in small crystals, not sufficient, however, to affect the character of the rock. In Plate XVI, a view taken about opposite Twin Peak in a bend of the main cañon, where its course has been deflected to the south by a body of harder slates, the characteristic forms of these rocks are well illustrated. The mass of Twin Peak is hidden by the spur in the left foreground, but the sidecañon behind these spurs leads up to its northern base. It is, however, almost inaccessible from this side, and more easily ascended from the east.

Near the mouth of Big Cottonwood, a body of dark-blue or black argillites crosses the cañon, and abuts up against the little granite body, in the side-cañon on the south. In the ridge which separates this cañon from that of Mill Creek, all these strata bend from a northwest to an east and west strike, with many folds and changes of dip, and are seen in section along the foothills of the range standing at a very steep angle, over $50^{\circ}$ to the north. The section of the Cambrian body as thus exposed, extending north from the mouth of Big Cottonwood a distance of about 4 miles across the strike, 
gives a better opportunity for estimating the thickness of the beds, but shows little other than quartzite and slate as the material of which they are composed.

Foot-hill Section.-The Cambrian body, along the line of the fonthills, extends northward from Big Cottonwood to a re-entering angle of the range at the cañon of a little creek next south from Mill Creek. 'The northern face of this angle is formed by a body of green clay-slates standing at $50^{\circ}$. A little distance up the cañon, on its north side, are found some blue limestones, which were at first thought to be Silurian, but their fossils provo them to belong probably to the lower part of the Wahsatch limestone.

Productus semireticulatus.

Spirifer?

Zaphrentis?

Crinoids.

The Ute limestone was not actually found therefore at this point, but may yet be there, or be concealed by a fault, as it can hardly be wanting. The Wahsatch limestone, which forms the greater part of the spur between this little creek and Mill Creek, has no good exposures along the foot-lills. The mouth of Mill Creek Cañon, however, as well as the greater part of its course above, is in the Weber Quartzite, which, at the mouth, is composed largely of beds of white quartzite, like those in Upper Big Cottonwood, and $\operatorname{dips} 50^{\circ}$ to $55^{\circ}$ north, corresponding in strike with the direction of the cañon. The beds, as exposed along the font-hills, are cridently very much compressed, and perhaps folded so as to be reduplicated, while higher up they spread out to the north, giving a much willer line of outcrop, due in part to a less steep dip, and in part doubtless to some secondary folds or faults which have not been noted.

About a quarter of a mile north of the mouth of Mill Creek Cañon, in a body of blue limestone above these quartzites, were found the following fossils, which were regarded as indicating the lower beds of the Upper CoalMeásure group :

Spirifer cameratus.

Spirifer octoplicatus.

Spiriferina pulchra.

Productus subhorridus. 
Above this blue limestone was a body of yellowish limestones and sandstones, with some red argillaceous strata, of a thickness of about 500 feet, succeeded by another blue limestone, very dark and compact, from which was obtained

\section{Rhynchonella Utahensis.}

In a thickness of about 1,000 feet of beds, largely blue limestones, next above, no fossils were found. Above this, in a bed of about 50 feet of limy shales, with greenish clays, were:

\section{Eumicrotis Hawni.}

Eumicrotis, sp.?

Next north were about 200 feet more shales, then blue and gray siliceous limestones, next, rather soft limestones with seams of white calcite, and more siliceous limestones, a thickness of about 300 feet, above which were obtained, from some clay-slates, two undetermined varieties of Aviculopecten and an Eumicrotis. From here to the mouth of Parley's Cañon, a thickness of about 500 feet is composed principally of limestones, generally soft, sometimes siliceous and broken, but in which no fossils were found. In these, the dip has steepened to $65^{\circ}$ north, with a strike due west. At the immediate mouth of Parley's Cañon is a bed of about 50 feet of white quartzite, with 100 feet of red sandstone, somewhat metamorphosed on either side, all dipping and striking as above.

North of this point, the dip shallows to $40^{\circ}$ north, and the beds strike north $40^{\circ}$ east. They consist of alternating siliceous, rather quartzitic beds, with various blue limestones and limy shales; the dip steepens again, and seems almost reversed, but beyond the limestones are found red and pinkish, rather loose-grained sandstones, with colored clays, characteristic of the Triassic, dipping south, showing that there had probably been some faulting. These sandstones sweep up on the spurs above, where the red beds can be easily traced from below, forming an anticlinal fold on the front of the spur between Parley's and Emigration Cañon, of which the western end has been cut off and eroded, and exposing again on the extreme foot-hills more Permo-Carboniferous forms in the little anticlinal of blue limestone and clay24 D G 
shales, which can be very distinctly seen both below and above the beachline. Here were found:

\author{
Aviculopecten Weberensis. \\ Aviculopecten curtocardinalis. \\ Aviculopecten McCoyi. \\ Aviculopecten parvula. \\ Sedgwickia concava. \\ Eumicrotis Hawni. \\ Myalina Permiana. \\ Myalina aviculoides.
}

At the mouth of Emigration Cañon are seen the dark-red sandstones and overlying pinkish-striped sandstones of the Triassic, which are capped by the drab limestones of the Jurassic, all dipping north, and forming the outlying northern member of the great anticlinal fold, whose southern side is seen, partly buried beneath the overlying Cretaceous or Tertiary, in Provo Valley. The thickness of the Triassic at this point cannot be readily estimated, but apparently does not vary much from that found where the section is more regular, as in Weber Cañon, viz, 800 to 1,000 feet.

In this foot-hill section, it is evident that the strata have been subjected to severe compression, and, besides the anticlinal between Parley's and Emigration Cañons, there may be other minor folds or faults, which have escaped observation, which, from palæontological evidence, are probably in the Upper Coal-Measures, since here the Permo. Carboniferous forms are found to have a much wider vertical range than in other sections, where they are generally confined to the upper 500 to $7(10$ feet of the series. The dividing line between the Permo-Carboniferous and Upper Coal-Measures, as drawn here, therefore, is one which cannot be distinctly defined in the field, since in lithological character the distinction of mud beds and limestones, which serve as a general division, cannot be followed, and the fauna is very much mixed through all, except the very lowest members of the latter. The theoretical thickness of beds, calculated from width of outcrop and dip, between the top of the Cambrian and that of the Triassic, does not, however, exceed very much that obtained from the combined average thick- 
ness of these beds, viz, about 17,000 feet, which, at an angle of $55^{\circ}$, would give a width of outcrop of nearly 4 miles, about that shown on the map.

Emigration Cañon marks approximately the line of the synclinal trough between the two great folds, that enveloping the Cottonwood granite, and that which curves over the Farmington Archæan body. In Red Butte Cañon, next north, the Triassic sandstones rise again from under the limestones of the Jurassic, having a more regular slope to the southward, and affording, in the evenness of their strata and the more compact nature of some of the beds, an excellent building-stone, which has been extensively used in Salt Lake City. The Jurassic rocks as seen in Emigration Cañon are drab, more or less argillaceous limestones, and clayey shales, having a conchoidal fracture, and breaking into little cuboidal rectangular blocks. Their beds are much broken and faulted, so that no continuous section is afforded. Their strike is, in general, nearly east and west, not, therefore, parallel with the direction of the cañon. About 5 miles from the mouth of the cañon, the Triassic sandstones are again exposed, and here the synclinal structure and basining-up of the Jurassic strata are more distinctly seen; but a short distance above this point, both formations are concealed by beds of a very coarse conglomerate, which, on stratigraphical and lithological grounds, has been considered to represent the lower bed of the Cretaceous. The Jurassic beds are exposed again, under the conglomerate, in a ravine near the head of the north fork of Parley's Creek.

The low divide where the road crosses from Emigration to Parley's Cañon, is in the line of the Jurassic synclinal, shown in the foot-hill section. The outcrops in general are much obscured by the unconformable conglomerate; but, on the north side of the divide, the red sandstone can be seen dipping $45^{\circ}$ to $50^{\circ}$ south, with some beds of light sandstones and limestones over them, while, on the south side of the divide, the same series can be recognized dipping northward, with a northeast strike, overlain by the lightcolored limestones of the Jurassic. In Parley's Cañon, the mud-rocks and limestones of the Permo-Carboniferous underlie the Triassic sandstones conformably, but show great irregularities in strike and dip. The Tridssic anticlinal of the foot-hill section can no longer be recognized; but the influence of the same folding which produced it is seen in the widening of the out- 
crops of the Upper Coal-Measure and Weber Quartzite series between Parley's and Mill Creek Cañons. 'The course of both of these cañons has evidently followed in general the strike of the beds, Mill Creek running nearly straight through the less distorted lower beds of the Weber Quartzite, while Parley's Creek has followed approximately the curving outline of the reddish mud-rocks and shaly limestones of the Permo-Carboniferous. Above the forks, however, its bed exposes the red sandstones of the Triassic, while its northern wall is formed of the thick conglomerate beds, from under which, here and there, appear outcrops of the Jurassic limestones. This conglomerate, which is composed of large pebbles, generally several inches in diameter, of quartzite and cherty limestone, in a somewhat limy matrix, has some resemblance to the coarser conglomerates of the Tertiary, but its matrix is so hard and compact that it fractures sharply through the hard quartzite pebbles, and at the head of Parley's Cañon it is found dipping $55^{\circ}$ north, almost in conformity with the Jurassic and Triassic strata, while its strike more nearly corresponds with the well-recognized Cretaceous beds exposed in East Cañon Creek. Its great thickness, and the size of its pebbles, exceeding so much that of the conglomerate, which usually marks the base of the Dakota Cretaceous, may be explained by its being formed along the shore of a high mountain-range, where the Cretaceous seas washed the east base of the Wahsatch.

On the divide between Parley's and East Cañon Creek, the Jurassic limestones are well exposed, thinly bedded, with seams of greenish clays. In the hills south are the red sandstones of the Triassic, with a coarse white grit at their base. The strike of these rocks is here north $35^{\circ}$ east for a short distance east of the divide, and then bends sharply to south $30^{\circ}$ east, the upper beds, or outer edge of the curve, crossing East Cañon Creek into the spurs of the group of hills north of Parley's Park. Parley's Park is simply a mountain-valley, about 6,400 feet above sea-level, consisting of some meadow-land at the head of East Cañon Creek, and a rolling sage-brush country between that and Silver Creek. Along the foot-hills of the high ridge, which forms the main divide, to the west of the meadows, the red sandstones are found striking due north and south, and sloping eastward under the valley. The body of the ridge is composed of the Upper Coal- 
Measure and Permo-Carboniferous series, having the same strike. A compact, gray, siliceous limestone, which is remarkably impure, from near the base of this series, obtained from the summit of the highest peak of the ridge, analysed by Mr. 13. E. Brewster, gave the following:

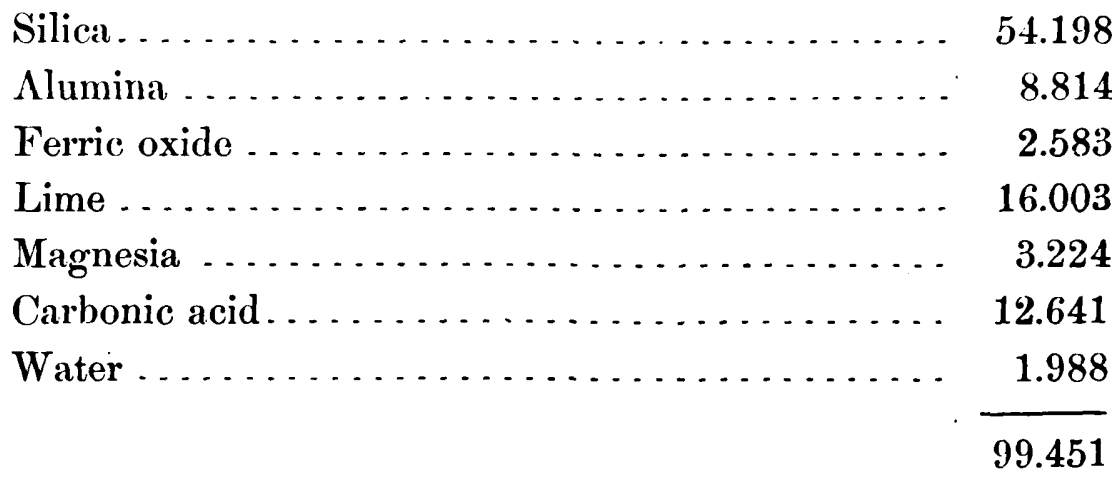

From near the head of Evans Cañon on this ridge, and, therefore, not very far from the base of the formation, since the Weber Quartzite forms the western slopes toward Big Cottonwood Cañon, were obtained a Bakevellia and Eumicrotis, showing that here, as in the foot-hill section, the PermoCarboniferous fauna had a comparatively wide range.

About 3 miles north of Clayton's Peak, the limestones bend to the eastward, and the main mass of hills surrounding the Clayton Peak granite body is composed of the Weber Quartzite, here an iron-stained, much-metamorphosed rock, in which the stratification-lines have become very indis-. tinct; the general strike is, however, east and west. In these quartzites, a number of valuable ore-deposits have been discovered, differing only from those of the limestones of Little Cottonwood in their chemical composition, in such a manner as might be expected from the difference of the enclosing rock. To the east of Clayton's Peak, the quartzites disappear beneath the trachytes of the Provo Valley, as has been already seen; their extension to the eastward points unmistakably to the influence of the Uinta upheaval; the several dikes of porphyry coming naturally in this line have already been mentioned. On the north, the Carboniferous limestones can be traced along the foot-hills bordering Parley's Park, striking eastward, until they also are lost under the trachyte body, while in the low hills of the middle of the 
valley occasional outcrops of the Triassic sandstones and Jurassic limestones are detected under the general covering of soil and surface débris.

Farmington and Weber Region. ${ }^{1}$ - This includes that portion of the range comprised between Emigration Cañon and Weber River; it is less high than either of the preceding, and consists of a single ridge, whose eastern slopes drain into the Weber River, while the cañons on the western face are not so long nor so deeply cut as in the Cottonwood region.

In general, its geological structure resembles that of the latter very - closely, being that of the same series of sedimentary rocks folding round an Archæan body, their western member having also been cut off by faulting and erosion; owing, however, to the very general covering of the edges of these beds by Cretaceous and Tertiary formations, the line of outcrops has been more difficult to follow, and the details of structure less completely obtained.

Immediately north of Salt Lake City, the foot-hill line of the Wahsatch extends westward about 4 miles from Camp Douglas, and sweeping round to the northward recurves again to the eastward into Mill Cañon, enclosing a broad mountain-projection; the central part of this mass is a high ridge, having a trend of about north $45^{\circ}$ east, which consists of strata of Wahsatch limestone overlaid by nearly horizontal beds of Tertiary conglomerate. On the foot-hills north of Camp Douglas, the limestones of the Upper CoalMeasures are found under the red Triassic sandstones of Red Butte Creek, but the underlying Weber Quartzites are mostly masked by the conglomerate. At the point, near the Hot Springs, the Tertiary beds have been eroded off, and, for a distance of nearly 3 miles to the northward, the ends of a series of limestone strata are exposed, dipping to the southeast at angles varying from $30^{\circ}$ to nearly perpendicular. The beds are from a few inches to 5 or 6 feet in thickness, and of color from buff to nearly black, with a prevailing dark hue; they are shattered in every direction by numerous planes of jointing, which, in some places, entirely obliterate the stratification-lines. A few obscure fossil corals and crinoid stems are the only organic remains that have been found here. Beyond these, to the north, the foot-hills are formed of a zone of quartzite, for the most part covered

' From field-notes of Clarence King. 
with recent soil, but outcropping sufficiently to indicate a thickness of about 800 feet of beds entirely conformable with the overlying limestones, which, from its position, is doubtless the Ogden Devonian. Under that, again, appears obscurely a mass of shaly gray limestone, earthy in places, of irregular dip, but occupying the position of the Ute limestone. Traced eastward on their strikes, all this series of Palæozoic rocks, within a distance of a mile, run under the rudely-bedded Tertiaries, which, although in general horizontal, show here a dip of $8^{\circ}$, and even $10^{\circ}$ and $11^{\circ}$.

These Tertiaries consist chiefly of conglomerates made up of pebbles of limestone, quartzite, and sandstone, among which the former is conspicuous, and a varying cement of a brick color, partly calcareous and partly siliceous. Unlike any others in the vicinity, they are more or less riven by deep cracks, and contain zones where the whole material is so confusedly crushed as almost to have lost the appearance of bedding.

In the cañon of City Creek, about two miles above its entrance, the bottom and the hills on either side for half a mile are occupied by a mass of trachyte; contemporanous erosion has so obscured the relations of this body with the Tertiary which surrounds it on all sides, that it was impossible to decide which is the later. The prevailing hue of the rock is a light reddish-gray, in some instances passing into an almost chocolate color, and in others, a true pure gray. It is very remarkable for the richness of its mineral ingredients. The feldspars are both sanidin and plagioclase, with a decided predominance of the latter; many brownish-black and bronzy-brown biotites occur, and black, well-preserved hornblendes up to a quarter of an inch in length. Under the microscope, the hornblendes are extremely interesting as containing fluid-inclusions with moving bubbles, and within an exterior coating of dark hornblende are nuclei of pale colorless hornblende. The rock is also rich in microscopic tridymite, almost equalling in its abundance the rock of Cerro de San Cristóbal in Mexico. It contains no quartz, but numerous apatites; augites, usually visible only under the microscope, but rarely visible to the naked eye. In many places, the biotites have suffered more or less decomposition, and are of a brilliant garnet color. The rock has decided affinities with the augite-andesites, 
although its whole habit and texture have the peculiar roughness of the trachyte.

The Tertiary which surrounds this trachyte mass continues up City Creek for about half a mile above it, and then gives out. Its eastern boundary then continues northward, and curves northwest down to the plain, cccupying the broad open spurs south of Centreville. To the east of this line, and south of the hills immediately bordering City Creek, the hills from near the mouth of City Creek Cañon, east of the grist-mills for about two miles, are occupied by a hard, irregularly-stratified quartzite, which is sometimes almost thinly bedded enough to be called a schist; at others it is in thick heavy beds, 3 and 4 feet through; this is the Weber Quartzite, which has here a strike of north $48^{\circ}$ east, with a dip varying from $30^{\circ}$ to $65^{\circ}$ to the southeast. It may be followed along the strike 10 miles in a northeast direction, to where it passes under the horizontal strata of the Vermillion Creek Eocene. Directly north of this, and conformable with it, lie the beds of the Wahsatch limestone, which occupy the summits at the head of Mill Cañon, and east of the Salt Lake Tertiary body. These beds here show an estimated thickness of about 6,000 feet, of heavy massive limestone, from which were obtained some Fusilina and other Carboniferous fossils. In their upper portion, the limestones seem more impure and siliceous than in the lower. A specimen from one of the beds, about 2,000 feet below the top of the series, a gray granular limestone, which weathers an earthy red on the surface, was analyzed by Mr. B. E. Brewster, with the following result :

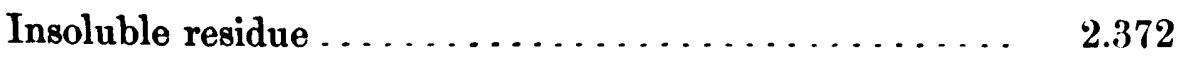

Ferric oxide and alumina ................ 0.246

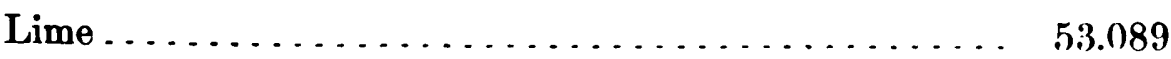

Magnesia . . . . . . . . . . . . . . . . . . . . . . 1.199

Carbonic acid ..................... 42.878

Water and organic matter............... 0.216

100.000

The dip decreases in passing north and east; from $45^{\circ}$ it sinks to $18^{\circ}$ at its extreme northeast limit. From stratigraphical position, though with- 
out the aid of fossils, the Sub-Carboniferous and Devonian formations have been included within this body. Directly underlying it is a zone of shaly quartzite, passing down into a solid white quartzite, the whole having a thickness of about 800 feet, and holding the position of the Ogden Devonian, as it has been colored. Under this again are 800 to 1,000 feet of highly crystalline limestones, which, being entirely conformable with the above, had been considered to represent the Ute limestone, on purely stratigraphical grounds. Since the completion of the field-work, there have been obtained from the lowest limits of these limestones on City Creek, in a bed of shaly limestone standing at a high angle, and immediately overlying quartzites and schistose rocks, three forms of Trilobites, of which the two following were sufficiently well preserved for identification, and probably indicate the horizon of the Potsdam group:

Ogygia parabola (also found at Ophir City, Oquirrh Mountains).

Crepicephalus (allied to Conocephalites (Crepicephalus) diadematus).

On the summit of the range directly east of Centreville, and underlying the Ute limestone, lies a conformable series of quartzites, the uppermost member of which is the same salmon-colored conglomerate-bearing quartzite which underlies the Ute limestone generally in the Wahsatch.

This series, with the exception of the underlying quartzite, which is considered as Cambrian, may be observed in the south branch of Mill Cañon above the saw-mill, and are here seen to rest unconformably upon an older body of Archæan schists. This body extends northward as far as the cañon next Mill Cañon, and consists of intensely metamorphosed material of an ashen-gray color, composed of quartz, orthoclase, and muscovite. It weathers with an excessively rough surface, developing curious wavy lines, and appears to have been a body of quartzitic schists, containing a little orthoclase and mica, which have undergone the most violent compression and crumpling, obliterating entirely the original bedding, and leaving only obscure traces of short, abrupt, and extremely irregular corrugations. To the northward, it probably passes unconformably under the main series of gneisses and schists, which form the main body of the range east of Farmington. Although the contact was not actually seen, yet the regular dip and strike of the gneisses and schists continue close down to this 
corrugated body; soil and a dense growth of scrub-oaks preventing observation of the exact contact. Yet, from the nature and position of the two bodies, there is no doubt that they are actually unconformable; and they may, therefore, be considered to represent the one the Huronian, and the other the Laurentian, member of the Archæan.

The whole sedimentary series, from the Weber Quartzite down, therefore, appears in the gap between the two masses of Tertiary, that which lies north of Salt Lake City, and the broad area east of the Wahsatch, which extends to the valley of the Weber. This latter Tertiary mass skirts the whole east slope of the range, and west of Morgan Valley rises to a height of 2,700 to 2,800 feet, resting unconformably against the eastern members of the Farmington Archæan. Its position is from horizontal to a dip of $14^{\circ}$ to the eastward; toward the base it is composed of beds of dark, brick-red sandstone, but in rising passes into heavy conglomerates interstratified with coarse sandstones.

Farmington Archean Body.-West of this Tertiary region, and north of the Laurentian Archæan body of Mill Creek, the whole Wahsatch, up to the Weber River, is composed of a conformable series of westerlydipping Archæan schists. As far north as Farmington Cañon, the strike is nearly with the range, $i$. e, about north $20^{\circ}$ west; but, near the head of Farmington Cañon, the strike bends rapidly to the east, and passes to $10^{\circ}$ east of north, which direction it keeps for about 4 miles, and then bends around conformably with the trend of this part of the range, viz, $15^{\circ}$ to $20^{\circ}$ west of north. In the axis of these two general flexures, the rocks are much broken, and the dip very irregular. As a general thing, the whole of this Archæan mass dips at about $15^{\circ}$ to $20^{\circ}$ to the west. There is, therefore, exposed from 12,000 to 15,000 feet of these schists.

The lowest exposed members are a great variety of mica and homblendic gneisses and schists, together with a few granitoid beds and some limited quartzites and slates. The main series is composed of a varying family of gneisses; the lowest of these are very coarse, composed of large crystalline masses of flesh-colored feldspar and partially-decomposed, earthy, brown mica, and large milky-white, irregular bodies of quartz. This rock is interesting, as showing the transition from an evenly-bedded rock into a 
structureless one. The original sheets of mica may still be traced through the rock, but they are twisted and broken and crowded into such positions that at first the rock looks like a very coarse granite. This same transition, between schists and structureless rocks, the result of pressure, is also noted in the East Humboldt Range, Nevada. Above the coarse mica-gneisses are a series of gray gneisses, in which the feldspar and quartz are both white, but which are firther interesting as containing freely-disseminated microscopic garnets, which, under the microscope, are seen to be rich in minute cracks, and to be more or less metamorphosed into chlorite; muscovite is the mica of this member. A little higher in the series is another gneiss, still containing a predominance of mica, but also a little hornblende; it is also rich in garnets, which likewise show the transition into chlorite. Above these are a heavy series of dark-green homblendic gneisses, containing little hornblende, but rich in feldspar and apatite; besides these minerals, they also contain a considerable proportion of zircon, never, however, large enough to be visible to the naked eye; the mineral, however, is distinctly the same that has been observed in other rocks, where its existence has been proved chemically.

The two general groups of which this Archæan body is formed, therefore, consist, first, of alternating quartzites and gneisses, in which micagneiss decidedly predominates, and which are further noticeable as containing garnet; and the second or uppermost zone is that of the hornblendic gneisses, containing zircon. The hornblendes in these latter are usually more or less fibrous, always dark green, and are arranged with the broader surfaces of the prisms parallel. Quartz and feldspar hold a very variable position in this series; at the top, the rock is really an amphibole rock, containing sparse grains of quartz, but no feldspar; a little lower, quartz partakes largely in the composition, but feldspar is quite rare. Lower still in the region of the mica-gneisses, feldspar forms a full quarter of the rock, but there is present with the hornblende considerable mica. Apatite seems to be a characteristic of those rocks in which the mica does not exist. Among the gneisses are zones varying from 50 to 100 feet in thickness. It would seem, from the results of irregular pressure, both here and in the East Humboldt Range, that the schistose structure can be easily broken up by 
lateral pressure, and that a distinctly-bedded rock may be easily compressed into one which possesses no evidence of bedding except its being bounded above and below by distinctly-stratified rocks, and thet the result of this compression may act very unequally on different zones of the same series, giving rise to the appearance of an eruptive rock lying between two members of a stratified series. That they are not eruptive rocks is clearly to be found by following them out on the strike, where they may almost always be traced into distinct stratification.

On the east slope of the range, directly east of Farmington, at the edges of the Tertiary strata, but separated from the Farmington Archaan by great masses of earth and Tertiary débris, is a body of peculiar dark purple quartzite, containing large pellucid grains of quartz, and rounded pebbles up to half an inch in diameter. In its dip and strike, it is apparently conformable with the Archæan schists, but, owing to the broken character of its beds, no great weight can be given to this appearance, and, from its close resemblance to almost identical bodies of quartzite found among the Cambrian rocks in other parts of the range, it is probable that it belongs to this series; it has not, however, been indicated on the map. An analysis of this rock gave:

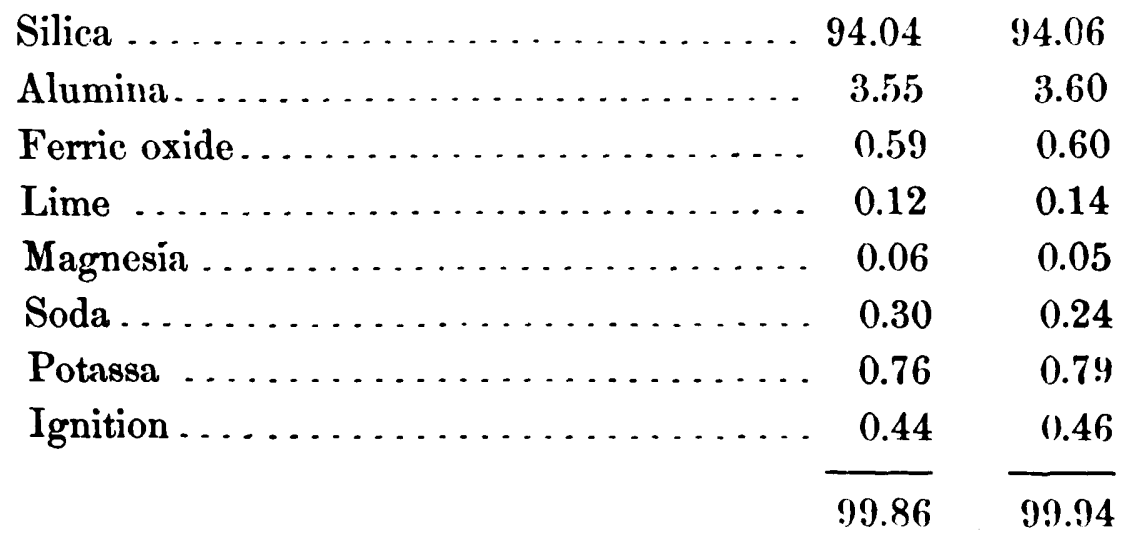

East Cañon Creek.-The area between the east slope of the Wahsatch and the valley-bottom of the Weber is occupied by a broad plateau of Tertiary sandstones and conglomerates, belonging to the Vermillion Creek series. Through this plateau is cut East Cañon, a narrow valley about 4,500 feet deep, whose flanks slope back with considerable regularity to the high hill-tops on either side; it is only in its lower portion, about 6 
miles south of Weber Station, that the cañon narrows very much. Around Morgan Valley, the Vermillion Creek series consists almost entirely of reddish-gray and brick-red sandstones, having a gentle dip toward East Cañon Creek from the west, and again toward it from the east. In the upper part, these beds consist of heavy conglomerates, containing pebbles of limestone, quartzite, and Archæan schist, which seem to be quite horizontal. There appears to be no unconformity, however, throughout the series, but a slight undulation, which reaches its maximum dip west of Morgan Valley.

Near the little village of Richville, about 4 miles south of Weber Station, the valley-bottom is occupied by a narrow area of gray trachyte, consisting of sanidin and biotite, in a very rough, gray, crystalline groundmass. This trachyte is little more than a tufa, and seems to have been deposited for the most part under water; it represents probably an eruption that has taken place after the greater part of the present topography had been marked out by erosion, and when Morgan Valley was occupied by a lake. Other evidence that Morgan Valley was a Pliocene lake is to be found in the friable white sand beds and argillaceous strata which occur on the immediate foot-hills on either side of the valley, outcropping indistinctly through the Quaternary. Their range is uncertain and their occurrence obscure, but they have been laid down on the map, since there is enough to warrant the belief that Morgan Valley, like Ogden Valley, was well covered with lacustrine Pliocene, which must have rested unconformably in a basin eroded out of the Eocene beds. Up East Cañon, above the trachyte outcrop, there is an exposure of olive-gray and cream-colored sandstones, having a considerable dip southeast or up the cañon, and apparently unconformable with the Tertiary beds which appear on the flanks of the hills higher up; these beds probably represent the edges of upturned Cretaceous strata, but, as they contain no fossils, their position is so uncertain that they are not indicated on the map. About half-way between Morgan Valley and Parley's Park, a broad open valley extends from East Cañon Creek in a northeasterly direction, quite through to the Weber Valley. The western half of this valley is undoubtedly formed of the Vermillion Creek Eocene, whose beds rise to the north and south of it in high mountains, 
while the eastern half cuts into the beds of the Fox IIill and Colorado Cretaceous.

Directly south of the westward opening of this valley, on the east side of the cañon, there is a second development of trachyte, which occupies the hill-slope for a distance of about 3 miles, but apparently does not cross to the western side. It occurs in bluffs with horizontal bedding, and it seems as if it might have broken out through the Tertiary, and outflowed after the formation of the cañon, or at least after the cañon was cut down almost to its present level. Petrographically, it is very similar to that in City Creek, is of a prevailing purplish-gray color, and, in rather a coarse groundmass, contains crystals of sanidin, hormblende, biotite, and augite. Like the City Creek trachyte, it is also rich in tridymite. The tridymite, it should be said, is not visible to the naked eye, and does not, according to Professor Zirkel, partake in the structure of the groundmass, but only occurs as an incrustation of the small cavities. At City Creek, the interior of the hornblende is colorless, while the exterior is black; here the interior is black, and the exterior yellowish-brown; the biotite is unchanged here, as is also the feldspar. The habit of the rock is decidedly like an andesite, but, although triclinic feldspars are not wanting, orthoclase certainly predominates, and the rock can therefore only be considered a trachyte.

The summits of the Wahsatch on either-side of the trachyte body are of the Vermillion Creek Eocene, lying nearly horizontal. Where the Mountain Dell trail crosses the main ridge, however, it is formed of coarse gritty sandstones, underlaid by heavy conglomerate beds, formed of pebbles of limestone and quartzite, having a strike of north $60^{\circ}$ east and a dip of $25^{\circ}$ to the southeast. This is evidently the same conglomerate which has been already mentioned as overlying unconformably the Jurassic and 'Triassic beds in Emigration and Parley's Cañons, and is considered to represent the lowest member of the Dakota Cretaceous. It here rests on the upturned edges of the Upper Coal-Measure limestones; these are very much obscured by drift and the disintegrated material of the Cretaceous, so that its position is somewhat uncertain. It is clear, however, that these supposed Cretaceous beds are unconformable with the Jurassic, Triassic, and underlying formation, and it seems also evident that they are 
unconformable with the Eocene beds, which appear round their northern and eastern flanks, being nearly horizontal, while the Cretaceous rise through them with a dip of $25^{\circ}$. The relation in this region between these three sets of unconformable strata, those from the Jurassic down, the conglomerate ridge, which has been referred to the $e^{\circ}$ Cretaceous, and the horizontal Tertiary, is much obscured by the enormous accumulations of débris and soil, and the ideas of non-conformity are to be arrived at rather by stratigraphical position than by acutal contact.

A short distance belọw Parley's Park, East Cañon is cut for a mile and a half through Cretaceous beds, which strike about east and west, and dip in the lowest member $60^{\circ}$ north, shallowing somewhat down the stream. The uppermost beds exposed are gray and cream-colored sandstones, interstratified with conglomerates, which form the summit of the upper members of the Colorado group. Fossils obtained from the sandstone here are of an altogether new species, and are of little value for identifying the exact horizon. They are, however, purely Cretaceous in type, and comprise the following forms, which have been described by Prof. F. B. Meek :

Cyprimeria : subalata.

Tellina modesta.

Tellina?? isonema.

Mactra (Cymbophora?) Utahensis.

Mactra? Emmonsi.

Cucullaa (Trigonarca?) obliqua.

The ordinary black shales of the Colorado group appear here in a very limited way, owing to the surface being deeply covered with earth; the sandstone and marls of this group outcrop very distinctly, leaving deep, soft valleys between them, which doubtless represent the soft shaly members; in several instances, sharp shale ravines, cut by recent erosion, display these black unctuous shales. Higher up the cañon, under the shales and sandstones, may be seen the coarse grits and conglomerates of the Dakota group, dipping more steeply north, and overlying the variegated shales and soft calcareous sandstones of the Jurassic, with no observed unconformity of dip. 
On the low foot-hills to the north of Parley's Park, enclosed within the bend of East Cañon Creek, and near Kimball's Station, is a small body of brick-red trachyte, mostly concealed by débris from the Tertiary rocks of the hills above. It has probably broken through the Jurassic or Cretaceous sandstones, which are found at the contact altered into quartzite. This rock mineralogically is like the usual type of the Wahsatch trachytes, being rich in crystals of sanidin, plagioclase, rather fresh brown hornblende, and biotite, often containing augite, and occasionally tridymite. One variety is extremely porous, almost pumice-like, and very rich in red bronze-colored mica, resembling somewhat in external appearance the pumice-like leucite rock from the Leucite Hills in Wyoming.

Weber Cañon.-In the mountain-mass immediately north of Morgan Valley, and in the cañon of the Weber River above this valley, another considerable portion of the Palæozoic and conformable series of rocks has been denuded of its Tertiary covering, so that the complete suite from Cambrian up to Jurassic may be followed almost continuously. 'The section afforded in Weber Cañon, being nearly at right angles to the strike, presents the best opportunity possible for the study of the series, and has served as the basis of the division of the formations adopted throughout the range. Tine mass of Morgan Peak is formed of beds of the Wahsatch limestone, having a general north and south strike, and dipping to the eastward. From the peak itself, about 200 or 300 feet below the summit, a few corals were obtained, generally too poorly preserved for specific determination. Among them the following were recognized:

Syringopora multattenuata.

Lophophyllum proliferum.

Diphyphyllum?

Zaphrentis?

The lower beds of the limestone body which forms this peak are generally of a dark-bluish gray limestone, with occasional cherty bands. Near the top, they are characterized by intercalated beds of granular limestone, some thin shales, and reddish calcareous sandstones, with one prominent narrow band of purplish-gray quartzite. Directly east of the summit, there is a slight depression, occupied by beds of a fine-grained, cream-colored 
sandstone, with a decidedly arenaceous habit, which is probably at or near the line of junction of the Wahsatch limestone and Weber Quartzite.

To the north and east extend flat plateau-like hills, formed in general of beds of the Vermillion Creek Eocene, in some of whose ravines are, doubtless, exposures of underlying rocks, which may not have been indicated on the map. In general, however, these beds close up around the flanks of Morgan Peak. On the west side of the peak, toward Morgan Valley, the slopes are generally covered with débris and soil. In some of the deeper ravines, however, the Ogden Quartzite could be recognized under the main body of limestone, represented by beds of pure white quartzite, whose thickness could not be determined, and forming the face of cliffs, under which the Ute limestone is exposed in a thickness of about 800 feet. Below this, though not actually in contact, is a body of greenish clay-slates, somewhat micaceous, underlaid by a body of yellow and pinkish, rather granular quartzite, representing the Cambrian. These rocks were observed in the foot-hills, a few miles north of Weber Station, having a strike of about north $35^{\circ}$ west. The lower members are soon lost to the westward beneath the valley-beds.

At Weber Station, the hills to the north present the ends of strata of the Wahsatch limestone, varying in strike a few degrees to the east or west of north, and dipping eastward at angles from $28^{\circ}$ to $40^{\circ}$. The beds are usually of quite pure limestone, some highly crystalline, others merely granular, and still others quite earthy, and containing well-preserved fossils of the Lower Coal-Measures, among which were recognized:

Zaphrentis Stansburyi.

Chonetes granulifera.

Productus symmetricus.

Streptorhynchus crassus.

Martinia lineata.

Spirifer opimus.

Spiriferina Kentuckensis.

Athyris subtilita.

Passing up the cañon, the same limestones form the hills on the north of the river for $2 \frac{1}{2}$ to 3 miles, a continuous series of about 5,000 feet $25 \mathrm{D}$ G 
of strata, dipping eastward toward the upper part as steeply as $50^{\circ}$, and in some instances reaching nearly the vertical. These steep dips are, however, extremely local, and are flanked to the east and west by the normal dip of $35^{\circ}$ or $40^{\circ}$. From the upper 1,000 feet of these limestones, the following Coal-Measure fossils were obtained:

\section{Spirifer opimus.}

2. Athyris subtilita.

3. Terebratula bovidens.

4. Productus Prattenianus.

5. Aulopora, sp. ?

Of these, Nos. 1 and 2 were from a gray granular limestone, about 300 feet down from the top, under which are dark beds, which frequently emit a very fetid odor on being struck by the hammer, and are intercalated with beds of yellow and impure arenaceous limestones. Nos. 2 and 3 are found also at about 500 feet from the top, and Nos. 3, 4, and 5 again at 300 feet below these. At 1,000 feet from the top comes in a series of thinly-bedded and heavily-blocked quartzites, which contain some sheets of small pebbles: these are, however, rather thin and localized. This quartzite, or, as it may more properly be called, indurated sandstone, occupies a belt of 150 feet. In general, the upper 1,000 or 1,500 feet of the series are made up of rather thinly-bedded and less pure rocks than the strata below, corresponding thus to the intercalated belt described in the southern part of the range. From the quartzite down to the Station are 3,500 to 4,000 feet of underlying and conformable limestones, varying constantly in purity and crystalline texture. Their color is generally very dark, and the beds heavy.

The fossils found in the strata to the east of the Weber Station and directly overlying the lime-kiln seem to represent that part of the section observed in Ogden Cañon, just over the Waverly, though no fossils of a horizon lower than Coal-Measures were found here. It is interesting to observe that the distortions of dip occur among the arenaceous beds near the top, in a position nearly corresponding to the Z-contortion in Ogden Cañon. It would seem that there must be something in the physical condition of these rocks, which renders it difficult for them to be compressed 
like the purer limestones below, which neither here nor in Ogden Cañon have suffered any interior contortions.

The very uppermost members of the series are reddened by oxide of iron. Overlying them, and for a short distance intercalated with them, are coarse red sandstones, quite conformable, and dipping about $40^{\circ}$ to the eastward. These represent the lower beds of the Weber Quartzite group. Among them are more or less conglomerates, of which the pebbles are quite small, and of white quartz. Their general texture is gritty, with a tendency to quartzite. Passing upward, the red zone, which is about 250 feet in thickness, is succeeded by a rather finely-laminated gray and white quartzite, above which the dip rapidly declines, varying from $20^{\circ}$ to $16^{\circ}$, and showing slight undulations in the strata. The curve from the steeper to the lower dip is very gentle, and occurs without dislocation or cracking of the strata. This low dip of $15^{\circ}$ to $20^{\circ}$ is held for about two miles up the cañon, the strata becoming thicker and more heavily bedded, while the texture of the quartzites grows more and more dense, and the occurrence of conglomerates less frequent, until a mile and a half from the base of the series there are no conglomerates at all, and the rock is a pure, compact quartzite, varying in color from white and greenish-white to brown and gray, and on its weathered surfaces being of a dark earthy brown. At the lower railroad-tunnel, a sharp double curve is described by the strata. They pass from the easterly dip of $16^{\circ}$, under a shallow synclinal, rising a hundred feet on a dip of about $20^{\circ}$ westward; then, passing over a sharp anticlinal, dip again to the east at a steep angle of about $50^{\circ}$ to $56^{\circ}$. Included in the strata of the quartzite, as displayed in the lower tunnel, there is a small development of what seems to be an interstratified limestone, quite black in color, and so siliceous as to scratch glass, yet effervescing freely under acids. It contains about 83 per cent. of silica and 5 per cent. of organic matter, the remainder being mostly carbonate of lime and magnesia. Above the upper tunnel are about 1,500 feet of massive quartzites, white and greenish-white, all having the easterly dip, and striking a little east of north. The strike of the beds seems to deviate a little more and more to the east of north as one ascends the cañon. In these solid white quartzites are peculiar cavities, like thsoe often left by decomposed fossils. They may 
possibly be organic casts, but, if so, are not definite enough to admit of specific determination.

Above the quartzite is a very large, heavy bed of limestone, 600 or 700 feet in thickness, which is much contorted, the dip-planes being in some places entirely obscured by metamorphism and local twists, but, in general, sufficiently developed to see that it is entirely conformable with the underlying quartzites. In these limestones, a fewill-preserved fossils were found, and are determined by Professor Meek to be distinctly Coal-Measure forms. These beds, then, mark the base of the Upper Coal-Measure group. The strike is north $16^{\circ}$ east, or north magnetic. On the hill-slopes to the north of the river, where they consist of cream-colored and gray, highly-altered limestones, reaching almost the whiteness of marble, they curve westward, up the ravine north of the upper tunnel, and are seen on the heights above to be conformable with the diminished dip of the quartzites. South of the river, they seem to be less altered and less contorted, and to possess a more regular and heavier bedding. A mile or more up the hills, near where they pass under the Tertiaries, they are seen to be interspersed with beds of pale yellow, fine-grained limestones. Overlying these are a series of yellow calcareous shales, about 175 feet thick, very brittle, and whose surfaces, instead of being smooth planes, are broken by little ridges and depressions, somewhat resembling ripple-marks, but wanting in their regularity. This is doubtless a peculiar result of pressure, and the shaly weathering due to the irregular surface of the crushed limestone. They are covered in many places with a sulphur-yellow oxidation-product. Search yielded no fossils. Above these calcareous shales are a series of sand and mud-rocks, chocolateand olive-colored shales, and red argillaceous sandstones, about 225 feet in thickness. These are peculiar, as displaying the very finest ripple-marks, the distance between the wave and trough being not over an inch to an inch and a half; alternating chocolate and olive shales form the lower 200 feet; the upper 25 feet being of a pretty solid sandstone. These are overlaid by about 100 fect of yellow and olive shales, which decompose very easily, and have a general earthy outcrop. Next in the ascending series are about 150 feet of gray-blue limestone, followed by about 20 feet of mud, hardly compacted into rock, showing here and there thin seams, which are stony. 
This is overlaid by about 75 feet of yellowish, brittle limestone, then 100 feet of light-colored, thinly-bedded limestone, and 100 feet of dark siliceous limestone, of which the following analysis was obtained:

Silica .............................. 59.753

Alumina............................. 8.595

Ferric oxide......................... 1.717

Lime .............................. 13.231

Magnesia ............................. 2.885

Phosphoric acid......................... 0.741

Carbonic acid .............................. 11.114

Water and organic matter ................ 1.379

99.415

Up to this horizon, in round numbers 1,600 to 1,700 feet above the quartzite, all the fossils whioh were found have belonged to the Coal-Measures. They are very few, but sufficient to determine the age. Above this, and up to the red Triassic sandstones, a thickness of about 700 feet, the fossils are all Permo-Carboniferous, and are found at three localities. The following have been determined:

\section{Aviculopecten McCoyi. \\ Aviculopecten occidaneus. \\ Aviculopecten, ? new sp. \\ Schizodus ovata. \\ Myacites (Pleuromya) Weberensis.}

Together with a Discina, which was found near the base of the series, and which has been figured by Professor Meek as of Triassic age.

Above the siliceous limestones are about 100 feet of chocolate and olive shales, carrying beds of argillaceous sandstones 3 and 4 feet thick, which also show beautiful ripple-marks, but much larger than those described below; then some 200 feet of mud-shales, containing limy bands with ripple-marks, and argillaceous limestones. Above these are 250 feet of buff and gray sandstones, with mud-shales, and over these a thin siliceous series, almost a quartzite, of about 70 or 80 feet in thickness. The dip through these Permo-Carboniferous shales has varied from $48^{\circ}$ to $60^{\circ}$, in some cases being as high as $70^{\circ}$. 
They are direstly overlaid by the red Triassic sandstones, estimated here to be from 800 to 1,000 feet in thickness. The same general distinction in color can be noted, as elsewhere, dividing them into a darker red series below, and a lighter above, though not as distinctly as in the Uinta, where the sandstones are much more loosely compacted and impure. A specimen of this rock gave 94 per cent. of silica, alumina being the principal impurity, and scarcely a trace of lime, while the specimen which was analyzed from the Uinta Range contained, as has been seen, 27 per cent. of carbonate of lime. The bedding of these sandstones is often extremely fine, especially in that portion which is quarried; some of the heavy beds are made of a finely-striped sandstone of brick-red and venetian-red color, banded with pale cream-color and white stripes. Much of the whole Triassic series shows remarkable cross-stratification, developing in section the arrowhendfigure and the flow-and-plunge structure. The average dip of these beds is from $70^{\circ}$ to $75^{\circ}$ eastward. Directly over the Triassic occur lime-beds, in which are found the following Jurassic fossils:

\author{
Myophoria lineata. \\ Pinna Kingii. \\ Cucullaa Haguei. \\ Myacites (Pleuromya) inconspicuus. \\ Myacites (Pleuromya) subcompressus. \\ Volsella scalprum var. isonema.
}

Of these, the Myophoria lineata, which is found in Europe in the Saint Cassian beds, was obtained from the limestone directly above the red sandstones of the Triassic; the others at different horizons in the calcareous shales. ${ }^{1}$

The lowest of these beds are quite thick, heavily bedded, and have an exceedingly fine texture, not unlike the true lithographic limestone. Over these, calcareous and argillaceous shales occur for a thickness of perhaps 80 feet, and, passing upward, are interstratified with lime-beds for some 600 feet. It is impossible to estimate definitely this thickness, as the hill-spurs upon

'Owing to a misunderstanding of the labels of fossils found in this cañon and in that of the Upper Weber River, Professor Meek, in Plate XII of his Report (Vol. IV), has associated Carboniferous with Jurassic species. 
which the outcrops occur are irregularly eroded and much covered with earth. Thence to the top of the series, where they pass under the Tertiary conglomerates of the "Narrows", the Jurassic series is entirely made up of alternating calcareous and argillaceous shales and sand-beds. Their average dip is $78^{\circ}$ to the eastward, and the prevailing bedding very thin and shaly: At various points, notably near the top of the series, there are extremely well-developed ripple-marks. The strike is about $16^{\circ}$ to $18^{\circ}$ east of north. The whole thickness cannot be less than 1,500 feet, and may possibly reach 1,800. Upon the hills to the south of the river, two bold blade-like outcrops of the edges of strata stand out conspicuously, and are known as the "Devil's Slide". The soft, intermediate, shaly strata have been worn down, leaving a steep, narrow passage-way between two high walls. From Morgan Valley up to the uppermost members of the Jurassic, we have about 18,000 feet of conformable rocks, and here the conformable series ends. There may be some few higher members of the Jurassic which are lost under the overlying non-conformable Tertiary conglomerates of the Narrows, but they cannot be either thick or important, as the whole series seems to be represented here which was found on the Upper Weber at Peoria, where it is overlaid by the conformable Cretaceous.

A short distance up the valley of Lost Creek, to the north of the village of Croydon, an obscure conglomerate is seen overlying the Jurassic beds unconformably, the latter holding their regular dip of $78^{\circ}$, and the former dipping only $25^{\circ}$ east, with a discrepancy also in the strike, the Jurassic striking about $16^{\circ}$ east of north, while the conglomerates trend $26^{\circ}$ to $\cdot 28^{\circ}$ east of north. Directly southeast of this, and across Lost Creek, there is an outcrop, lying parallel to the stream, and therefore conformable with the conglomerate above mentioned, which has also a dip of about $25^{\circ}$ to the southeast, and contains numerous Cretaceous fossils. This outcrop is partly of fine conglomerate, but chiefly of buff and cream-colored gritty sandstones. These are overlaid by black shales, which, with the sandstones, undoubtedly belong to the Colorado group. From their position underneath the Colorado beds, and unconformity with the Jurassic, it was concluded that these fragments of conglomerates represent all that is left in this locality of the Dakota Cretaceous. A half a mile up the valley, both the conglomerates 
and Jurassic beds pass under the nearly horizontal but slightly flexed beds of the Vermillion Creek Eocene, which in a northwesterly direction sweep round to the north and east of Morgan Peak.

From the point where the Tertiary beds first cross Lost Creek, about a mile above the village, their line of contact with the Cretaceous continues up the Weber River parallel with the valley, gradually descending until, about a mile below Echo City, the Tertiary beds form the entire bluffs on the east side of the river. Between the first ravine from the east to the north of Echo City and the mouth of Lost Creek, the lower foot-hills are formed of Cretaceous strata, which appear on both sides of the river, being overlaid at the height of from 400 to 500 feet by the nearly horizontal sandstones and conglomerates of the Vermillion Creek group. In the ravine above mentioned, fossils, both of the Colorado and of the lower Fox Hill horizons, were collected, in yellow sandstones dipping at about $25^{\circ}$ southeast. 


\section{SECTION IV. \\ NORTHERN WAHSATCH REGION.}

BY ARNOLD HAGUE.

Front Range.-To the north of the lower cañon of the Weber, the front ridge of the Wahsatch Range presents the same bold escarpment toward the west as it does farther south, but its summits are less elevated, and the ridge itself comparatively narrow, being bounded on the east by a series of deep, broad valleys. Geologically, however, the Wahsatch Range in this portion is much wider than to the south; the great conformable series of lower beds extending in broad anticlinal and synclinal folds into the elevated plateau country to the east of Cache Valley.

In the geological structure of the main front ridge, the same general type of an anticlinal fold, whose western member has been broken down and carried away, is maintained as heretofore; but the exposures of the underlying Archæan rocks are less considerable and less frequent, showing that the original Archæan body, like that of the present day, became gradually lower toward the north, and, instead of following the eastern borders of this body in comparatively continuous folds, the strata of the overlying, unconformable Palæozoic formations are broken by a series of numerous faults at right angles to the trend of the range, on the north side of which, as a general rule, the beds have been raised and moved back to the eastward. While the faults increase immensely the difficulties of tracing out the structure, in detail, of formations whose general petrological characters are so similar from one horizon to another, their general outlines may be detected by the eye trained in the study of geological structure, even from the Salt Lake Valley, at a distance of many miles from the range. Particularly is this the case in the extremely broken region back of Ogden City, where, on the face of the range, may be traced, by the breaks in the lines of stratification, the position of the principal fault-lines, which have been indicated on the map. 
In the lower cañon of the Weber River, a section is seen of the northern portion of the Farmington Archæan body, here consisting largely of gneisses, containing hornblende and pink feldspar, and frequently having a greenish color, due to the presence of epidote. These beds have here, as, indeed, wherever observed in the range, a westerly dip; the dip is, however, much steeper than to the southward, averaging about $40^{\circ}$, but frequently having a much higher angle, owing to local contortions of the strata. The sides of the cañon are extremely rugged and precipitous, and the scenery is of quite an alpine character, especially at the point known as the Devil's Gate, where, owing to a local fold, the stream makes a sharp curve to the northward, running a short distance with the strike of the beds. On the southeast face of the mass of hills north of the cañon, as seen from Morgan Valley, just above the entrance, is an appearance of an anticlinal fold in the strata where the Cambrian beds are seen dipping steeply to the northeast over the edges of the southwesterly-dipping Archæan beds.

Ogden Region.-Ogden Peak, which is one of the most prominent and picturesque peaks of this part of the range, and forms the culminating point of the mass of hills between the Weber and Ogden Rivers, is capped by quartzite beds belonging to the Cambrian formation, which lie unconformably upon the edges of the Archæan beds, exposed on its southern and western slopes. They dip steeply to the eastward, and strike north $15^{\circ}$ to $20^{\circ}$ west. Near the summit is a well-defined bed of compact conglomerate, containing flattened pebbles of polished quartz, corresponding to the bed found in Ogden Cañon, which will be described below. A detailed section of the strata on the east slopes of the peak was not obtained, owing to the dense growth of trees and shrubs; but the Wahsatch limestone was traced along the base for a considerable distance southward from the head of Ogden Cañon to where it runs under the red and buff sandstones, which have been referred to the Vermillion Creek series. On the northeast side of the peak is a broad amphitheatre, with steep, precipitous walls several hundred feet deep, which has been carved out of the quartzites. In the cañon below, glacial indications are everywhere to be seen in its polished walls, rounded basins with ice-markings and scratches, and well-defined moraines.

On the west face of Ogden Peak, evidence is seen of a powerful disturb- 
ance in the beds which make up this part of the range, resulting in the development of sharp folds almost at right angles to the main anticlinal fold, and in a faulting and dislocation which has lifted up and carried back the mass of Ogden Peak relatively to the rocks exposed to the north in Ogden Cañon, so that, as will be seen by reference to the map, the ends of the beds of Wahsatch limestone of Ogden Cañon come against the Cambrian quartzites of Ogden Peak. A sharp fold, whose axis follows generally the line of fault, could not, however, be indicated in the small scale on which the map is engraved. The evidence of this faulting is best seen in Fault Cañon, next south of Ogden Cañon, which heads directly under the west face of Ogden Peak. To the north of this point, the structure of the range is that of a series of easterly-dipping sedimentary formations from the Cambrian up, resting on an Archæan body which is exposed only along the extreme western foot-hills. Along the face of the hills, the edges of these overlying strata can be traced as an approximately horizontal line, descending somewhat in either direction from Ogden Cañon. To the north of the entrance to Fault Cañon, the Cambrian quartzites form the upper portion of the spur, with a slight inclination westward, while its base is masked by débris. The ridge on the south of this entrance is formed of beds of limestone, probably the Ute limestone, which, while sloping generally westward with the ridge itself, are folded sharply over it, dipping $70^{\circ}$ to the north and much more gently south. Curving up again along the southern foot-hills with a northern dip, they are succeeded by quartzites, also dipping north and east, which rest on the upturned edges of southwesterly-dipping Archæan strata. The head of Fault Cañon, under the base of Ogden Peak, is in the gneisses of the Archæan again, which are overlail non-conformably by the quartzites which form the summit of the peak, while in the bottom of the lower portion of the cañon are also obscure outcrops of Archæan rocks, the intermediate portions being filled by quartzite, which seem to dip into the cañon from the north. It is considered, therefore, that the limestones and quartzites to the south of the cañon are a faulted portion of the western member of the Ogden Peak fold, and that the crumpling of these beds has been caused by forces of compression acting in the direction of the axis of the range, which forces have produced a dislocation 
and downthrow of the whole mass to the north of the line of this canon, where the western member of the fold is lost beneath the plains.

The Archæan rocks, as exposed at the mouth of Ogden Canon, consist of a varying series of hornblendic and micaceous gneisses, having a strike to the north $20^{\circ}$ west, and a dip to the westward, and of a granitoid mass, in which no structure is observable. They present much that is worthy of special interest and study, in their gradual transitions from a compact to a decidedly schistose structure. As seen, on a large scale in the field, the bedding is distinctly marked by darker or lighter bands, characterized by the presence of either hornblende or mica as the prevailing constituent. Again, the beds are frequently marked by irregular, narrow bands of limpid quartz, or by nearly pure feldspar layers, usually accompanied by a little mica, while the rock masses also carry segregations of milky-white quartr, and in some places of dark green hornblende. In a hand specimen, many of the rocks develop a decidedly granitic structure, breaking with a sharp, angular fracture like a compact granite, but the gneissic tendency is, however, apparent in the general arrangement of the fibrous hornblendes in a direction parallel with the bedding of the rock. A typical specimen of the finer-grained masses is of a dark-greenish color, with a somewhat rough texture, and characterized by the presence of both hornblende and mica in considerable quantities. It is made up of minute crystals of delicate red orthoclase and white plagioclase feldspars, dark-green fibrous hornblende, with flakes of brown biotite, while quartz is present in subordinate amounts. With the magnifying-glass, particles are seen of what is apparently mica, with a distinctly yellowish tinge, and under the microscope considerable apatite has been detected, and what is supposed to be white mica. This rock passes into a coarser-grained variety, where the hornblende and mica are found less completely blended, and the feldspar plays a more important part. The rock with the least gneissic structure, from this locality, is a moderately fine-grained mass, composed chiefly of quartz, feldspar, and hornblende. Whitevitreous plagioclase is very abundant and intimately mixed with grains of quartz. Dark, shining plates of mica are present in small amounts. Another similar specimen, in a position not far from this, shows more of a tendency to the banded 
structure ; it differs in containing less quartz, or, if present, in a more finely disseminated state, which may be sufficient ground for the slight difference of physical habit. Still another variety, somewhat larger-grained, but with the same constituents, is of particular interest, as, in the microscopic sections, Professor Zirkel detected numerous minute crystals of a dark-brown mineral, which he regarded as zircon, from its mineralogical habit, and from the fact that he recognized the same microscopical forms in many of our Archæan gneisses and schists, rocks in which zircon is frequently found, but with us has never yet been observed macroscopically. In this rock, the minute microscopical crystals, determined as zircon, were so abundant that a portion of the small specimen collected was subjected, by Mr. R. W. Woodward, to chemical analysis, for the purpose of detecting, if possible, the presence of zirconia, - - a difficult problem where only a small amount of the earth is present. He succeeded not only in detecting the presence of zirconia, but in estimating the percentage contained in the rock The analysis was made in duplicate, giving the following results :

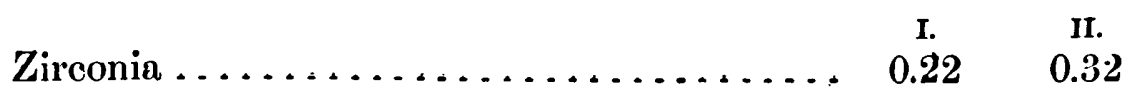

As the ordinary methods employed for the separation of zirconia were found not to be practicable in this case, Mr. Woodward devised a method based upon the fact that zircon is but slightly acted upon by hydrofluoric acid. The material supposed to contain zircon was powdered, and then digested with hydrofluoric acid and a small quantity of concentrated sulphuric acid in a large platinum crudible until the rock itself was thoroughly decomposed. After removal of the hydrofluoric acid by evaporation, the bases, which had been in combination with the volatilized silica, were brought into solution by protracted boiling with sulphuric acid and water, zircon remaining as an insoluble residue. This residue being fused for a long time with carbonate of soda, and the fused mass treated with water, the soluble silicates thus formed were dissolved out, leaving a sandy zirconate of soda insoluble in water, but soluble in hydrochloric acid. This is simply a concentration of the zirconia from a large quantity of the rock. The hydrochloric-acid solution gave all the characteristic reactions of zirconia, with none of those by which it might be mistaken for other sub- 
stances. Boiling the solution with metallic tin gave not the slightest reaction for titanic acid,-an important test, since titanic acid might be casily mistaken for zirconia. A specimen of the homblendic gneiss from Ogden Cañon, which was analyzed by Professor Robert Bunsen, gave the following results :

Silica

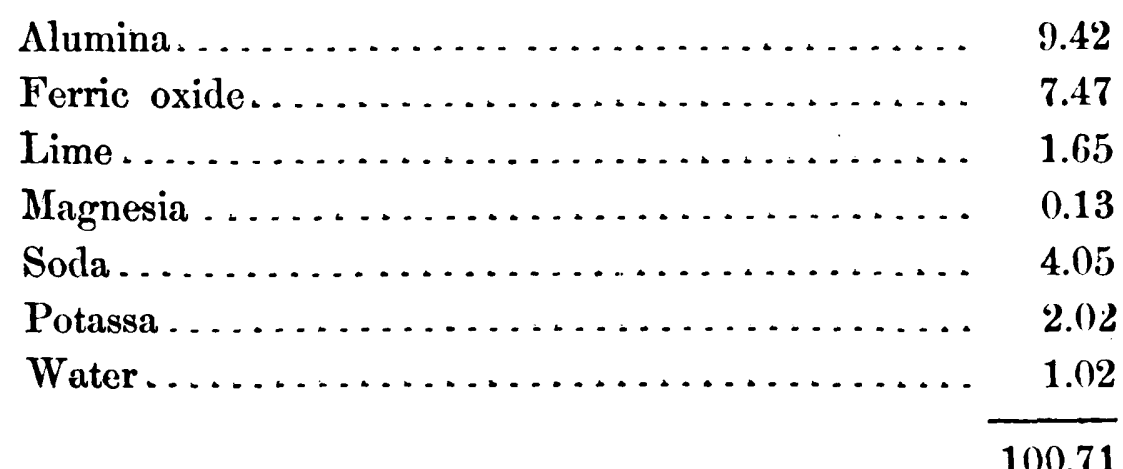

100.71

This rock is unusually low in the percentage of alumina present; lower than any other of the granites and crystalline schists that have been analyzed. On the other hand, it is very high in ferric oxide. The amount of soda present would indicate that it carrier a very considerable proportion of triclinic feldspar.

In Ogden Cañon, above this Archæan body, are exposed in section the entire series of Palæozoic strata, from the Cambrian up to near the top of the Wahsatch limestone. The strike in the lower beds is about north $30^{\circ}$ to $35^{\circ}$ west, with a dip of $60^{\circ}$ to $65^{\circ}$ to the eastward. The Ute limestone falls away gradually with less and less dip, until, near the well-defined junction of the Ogden Quartzite, it stands at an angle of $40^{\circ}$. This dip is preserved by the Ogden Quartzite and the lower beds of the Wahsatch limestone, but the upper portion of the great belt of limestone gradually assumes a lower angle, until, near the head of the cañon, it forms high precipitous walls, with a gentle inclination to the eastward of $7^{\circ}$ to $9^{\circ}$.

The Cambrian formation is represented by about 900 to 1,000 feet of quartzite, overlaid by about 100 feet of silicęous and argillaceous shales, which in their upper portion become calcareous. The quartzite is characterized, especially in the lower beds, by great uniformity in lithologi- 
cal habit and well-defined lines of bedding. It is a hard, compact rock, made up of minute grains of rounded quartz, with a somewhat friable texture, weathering like a more modern sandstone. It has a light-gray and flesh-colored tint, which is produced by the ferruginous material which is well disseminated through the beds, and prominent on the strata-planes, a characteristic feature of the Wahsatch Cambrian. Under the microscope, the puartz grains are seen to contain liquid-inclusions and minute slender microlitic forms. Near the upper part of the series are found distinct beds of conglomerate, with smooth and even highly polished pebbles of quartzite and jasper, of varying colors, mostly white. They sometimes reach two or three inches in diameter. In one of these beds, an interesting phenomenon is seen, showing the effect upon the enclosed pebbles of the great pressure to which the quartzite has been exposed. They occur flattened on the broader sides and elongated into almond-shaped bodies, and are frequently distorted and bent into curious forms. In several instances, two or more of the pebbles are so pressed together as to apparently form one mass, one having partially penetrated the other. These flattened pebbles appear to lie with their longer axes arranged in parallel planes.

Directly overlying the quartzite, with shärply-defined lines, occur 75 feet of nearly pure argillaceous shales, thinly laminated, of an exceedingly fine texture, and closely resembling beds from the same horizon underlying the great limestone formation of Ute Peak, at the two forks of Muddy Creek. Above these occur about 25 feet of nearly similar shales; but carrying more or less calcareous matter, which may be recognized under the microscope in minute crystals of calcite. These beds rapidly pass into the well-defined limestone-beds of the Silurian, which are from 1,200 to 1,500 feet in thickness. The lower beds are dark gray, with occasional bands of nearly black limestone. The limestones are usually fine-grained, and penetrated in every direction by thin seams of calcite. The rock is apparently siliceous. An attempt was made several years ago to burn it in kilns, but was abandoned, as the lime proved too impure. Several hundred feet above the base of the formation occurs a well-marked bed of argillaceous shale, about 20 feet in thickness, followed by limestone of a decidedly bluish tinge. This is in turn overlaid by a comparatively thin formation of white 
limestone, passing into a gray granular limestone, the upper portion of which is more or less characterized by shales. So far as known, no fossils have ever been found in the Ute limestone of the Ogden Cañon, except some fragments of Stromatopora, too much altered for specific identification.

The Ogden Quartzite immediately succeeds these calcareous shales, overlying them conformably, with a thickness which has been estimated at about 1,250 feet. It is a pale-reddish or yellowish-white quartzite, of medium-grained texture and conspicuous jointing planes. Under the microscope, occasional grains of quartz reveal the presence of small liquid-inclusions, with very mobile bubbles. Subjected to chemical analysis, it yielded 97.792 per cent. of silica. At the top of the formation are a few feet of olive-colored argillaceous shales, which separate it from the great body of the Wahsatch limestone.

This formation extends to the upper limits of the canon, exposing a thickness of not less than 4,000 to 5,000 feet. Most of the lower beds are coarsely crystalline, more or less silicoous and cherty in places, and carrying not unfiequently narrow bands of argillaceous muddy material. Near the upper limits of the cañon, a singular crumpling has taken place within the beds, by which 500 or 600 feet of strata are bent into the form of a $\mathrm{Z}$. The material of this crumpled portion is very black, fine-grained limestone, which is interrupted by frequent thin beds of impure siliceous and muddy material. A similar contortion is seen lower down on the south side of the cañon, near the edge of the stream. These contortions do not penetrate into the lower members of the group, nor do they affect the highest members seen in the cañon, the latter passing over the crumpled zone without following its waves. About 1,200 feet up from the base of the limestone was found a collection of fossils, which, while having a general Waverly aspect, also contain some distinctly Devonian forms, and may be therefore considered to indicate somewhere near the dividing-line between the Devonian and Sub-Carboniferous formations. The species determined by Messrs. Hall and Whitfield were :

Productus, sp.?, Spirifer alba-pinensis, Spirifer centronatus, 


\author{
Athyris planosulcata, \\ Iinomphalus (Straparollus) Utahensis, \\ Streptorhynchus equivalvis, \\ Streptorhynchus inequalis, \\ Proëtus peroccidens,
}

of which the two latter have a Devonian aspect.

From the upper beds of the Wahsatch limestone, near the head of the cañon, werc obtained portions of the interior of a Zaphrentis, showing evidence of a small curved species, but too poor for identification. Along the bottom of Ogden Cañon occurs an interesting formation of Quaternary gravel, which in places forms the bed of the stream, but is generally cut through to a considerable depth, sometimes as much as 150 feet. It is evidently a relic of the old Lake Bonneville, which once extended up into the cañon, under whose waters it was deposited. The coarser beds are made up of large quartzite boulders and pebbles held together by fine ferruginous gravel, forming a pudding-stone of considerable hardness, while the finer beds are composed of comminuted siliceous and feldspathic rocks, a variety of till derived from the material brought down by the stream. In the Ogden Quartzite, on the north side of the cañon, occurs a warm sulphur spring; which has a considerable flow of tepid water, and is highly charged with sulphurous vapors, the surface of the ground around being coated with a deposition of yellow sulphur. At the entrance of the cañon are two small thermal springs, which are slightly charged with salts of iron. They have a temperature of about $150^{\circ}$, and around one of them is a considerable deposit of calcareous tufa, which would indicate that the water came up through the limestone-beds which have been faulted down from the west face of the range. The old lake-terraces are particularly distinct in the neighborhood of Ogden, consisting mostly of uncompacted gravel and some beds of loose sand. In places, however, the calcareous cement has more or less consolidated the gravel into a loose conglomerate. No less than thirteen of these terrace-lines can be traced back of Ogden.

To the north of Ogden Cañon, the extreme foot-hills of the range are occupied by the Archæan body already noticed, above which the Cambrian quartzites and Silurian limestones can be distinctly traced by the different color 26 i) $\mathrm{G}$ 
of their beds. A short distance north of Ogden Cañon, a line of faulting is plainly visible, having a direction a little north of east, in which the northern beds have been thrown back and upward a few hundred feet. The effect of this fault can be distinctly traced through the lower quartzites and limestones, but is lost in the main body of the Wahsatch limestone. About four miles north of Ogden, the Cambrian outcrops extend down to the foothills, and back of the little town of North Ogden, or Ogden's Hole, the Ute limestone occupies the extreme front of the range, over which the light band of Ogden Quartzite can be distinctly traced. The low gap in the range at this point, called Eden Pass, marks another line of faulting. The Ute limestone ends abruptly, and its continuation to the northward is found several miles back near the summit of the pass, overlaid by the Ogden Quartzite, which slopes back to the eastward so nearly at the same angle with the hill-slopes themselves that no higher beds than this have been observed on the east slopes of the ridge north of this pass.

Willard Peak is a prominent summit of the range of equal altitude with Ogden Peak, and even more conspicuous, having abrupt escarpments toward the west, and sloping off steeply eastward into the parallel valley of the north fork of Ogden River. Its summit is formed of the beds of the Ute limestone dipping gently eastward, and distinctly traceable by their dark outline over the light quartzites of the Cambrian which underlie them. The western slopes of the peak are mainly formed of another Archæan body, consisting of the same pinkish hornblendic-gneisses and gray mica-gneisses which occur at Ogden Cañon, dipping here still more steeply to the westward, and striking about north $20^{\circ}$ west. The jagged outlines of this Archan borly can be distinctly traced, rising in points through the varying thicknesses of the overlying Cambrian strata. On the broad gravelly terraces which stretch out to the westward from the base of the peak, broken masses of quartzite and limestone are seen lying, sometimes flat, sometimes tipped up at steep angles, and dipping both east and west. It is evident that these are the remains of the Cambrian and Silurian beds which form part of the western fold; but the masses are too much obscured to afford any definite structure-lines which may give the clue to the position of the beds beneath the valley. Extensive hot springs are found in the quartzites of these terraces near the railroad, 
which leave a very considerable deposit of ferruginous salts. To the north of Willard Peak, the Archixan rocks gradually sink, and are lost beneath the plain and the débris which cover the slopes of the ridge toward Brigham City. In a narrow gorge north of this peak is a pretty cascade falling over a straight wall of Cambrian quartzite, which is here apparently deposited in a depression of the Archæan body. North of this point, and on the eastern slopes of the ridge, the hills are so thickly covered by débris and soil accumulation that no good outcrops were observed; but, from the prevalence of quartzite in the débris, it is evident that the upper limestones have been eroded away, and the quartzites themselves probably sink beneath the plain. As these same beds are, however, found in the range farther north, with the same easterly dip, but set back on a line to the east of the axis of the Willard Peak fold, and as no evidence was found of a synclinal fold to connect these two monoclinal ridges, we must suppose the whole northern ridge to have been faulted up in this region on a line corresponding with the valley of the north fork of Ogden River.

Box Elder Region.-In Box Elder Cañon, which connects Brigham City with a little mountain-valley, in which is the village of Copenhagen, the beds of the Cambrian are again exposed in section. They consist of quartzites and siliceous slates, with some micaceous schist, having a dip varying from $30^{\circ}$ to $70^{\circ}$ to the eastward, with a strike of about north $15^{\circ}$ west. The quartzite is very similar to that found in Ogden Cañon, a compact, fine-grained rock, with a somewhat granular texture and slightly reddish-yellow tinge. A specimen collected on the first high point north of the cañon possesses a vitreous lustre and conchoidal fracture, but it is so fine as to show but little tendency toward the granular texture. Under the microscope, its quartz grains reveal the presence of liquid-inclusions. To the north of Box Elder Cañon, the western foot-hills and the crest of the range for two miles are formed of these Cambrian quartzites, which then gradually sink toward the north, until, at Call's Fort, they disappear beneath the plains.

Directly east of the summit, in the low valley to the north of Copenhagen Valley, there occurs a heavy bed of dark limestone resting conformably upon the quartzite, which also forms a portion of the ridge to 
the west of this valley. The strike of the quartzite and limestone is approximately north $20^{\circ}$ west, thus crossing the range diagonally, so that the limestone body forms the summit of the ridge beyond the limits of the quartzite. With this direction continued southward, the limestone would strike across the head of Box Elder Cañon, where a characteristic Silurian coral, Halysites catenulata, is said to have been found. The limestone, probably of Silurian age, forms the west side of Copenhagen Valley, with a strike of north $30^{\circ}$ west. East of the valley, the range rises precipitously from 1,800 to 2,000 feet above the town, with short narrow cañons to the westward, and long gentle slopes toward Cache Valley. Brownish-yellow compact quartzite forms the western slopes, overlaid near the summit by heavy dark limestones which extend down to the base of the hills on the opposite side. These formations undoubtedly belong to the Ogden Quartzite and the Wahsatch limestone. The limestone is bluish-drab in color, usually fine-grained, but carrying beds that are more or less granular and sometimes gritty.

On the summit of the highest peak northwest of Copenhagen, in a dark gray medium-grained bed of limestone, were found forms of Ptypora, Aviculopecten, and Productus, not, however, specifically determined. To the southeast of the town, were found fragments of corals and species of Zaphrentis, together with some Productus, Spirifer, and Fenestella, all indicative of the Lower Coal-Measure horizon. The road which leads from Copenhagen to Wellsville in Cache Valley crosses the strata at a slight. angle, the upper bed striking north from $30^{\circ}$ to $35^{\circ}$ west, while the road has a direction only a few degrees west of north, until, near the base of Box Elder Peak, it turns abruptly westward, crossing the Wahsatch limestone at nearly a right angle. There would seem to be here some dislocation in the strata, which renders the structural relations somewhat obscure.

Box Elder Peak is the culminating point of the range west of Cache Valley. Its summit is formed of the upper beds of the Wahsatch limestone, which dip to the northeast $45^{\circ}$ to $50^{\circ}$, with the slopes of the range, and is more abruptly escarped to the west. In these limestones, the follow ing forms have been recognized:

Zaphrentis excentrica.

Zaphrentis Stansburyi. 
BOX ELDER REGION.

Cyathophyllum Nevadensis.

Lithostrotion Whitneyi.

Productus cora.

Productus punctatus.

The Lithostrotion Whitneyi found associated with the other forms in Box Elder Peak is of special interest. Professor Meek, in his report, says, speaking of this group: "Lithostrotion is a genus very abundantly represented by one or two species in the Lower Carboniferous, but unknown in the Coal-Measures of the Mississippi Valley." This genus is, however, found in several localities associated with Coal-Measure forms in Utah. The limestone of the summit possesses a dark bluish-gray color, with a compact and somewhat granular texture. On the peak next north occurs, stratified in the limestone, a bed of bluish-gray, slightly calcareous quartzite, which is a hard, compact rock, with the physical habit of quartzite; but dilute acids indicate the presence of a considerable amount of lime. Its chief interest lies in the fact that the same bed appears to have been recognized in a number of other localities of the range, and it probably forms a persistent and well-defined stratum in the upper members of the Wahsatch limestone.

'The cañons on the west side of Box Elder Peak cut deeply into the side of the mountain, affording fine exposures of the Palæozoic strata. The Wahsatch limestone extends down for 3,500 to 4,000 feet, which would be about two-thirds of the entire thickness of the belt. Below the limestone, the Ogden quartzite can be distinctly recognized on the face of the spurs, between the two limestone bodies, sloping gently to the north. At the mouth of the cañon, about seven miles north of Brigham City, near the little village of Call's Fort, in a body of dark blue argillaceous slates in the lower portion of the Ute limestone body, were found the following fossils of the Quebec group:

Dikellocephalus Wahsatchensis.

Dikellocephalus gothicus.

Crepicephalus (Loganellus) quadrans.

Lingulepis Ella. 
It is impossible to obtain here an accurate estimate of the thickness of these lower limestones, but in the continuation of the range to the north, beyond the limits of the map, and in the uplift to the east of Cache Valley, they are found with a thickness of nearly 2,000 feet, showing a very considerable increase in the amount of deposition over the beds of the same horizon observed in the southern part of the range.

To the north of Box Elder Peak, the beds slope gently to the northward, until, at the northern point, the ridge is completely occupied by the Wahsatch limestone, which passes under a deposit of Pliocene Tertiaries which have filled Cache Valley, and extended over the low pass at the "Gates" of Bear River into Salt Lake Valley. These Tertiaries consist here mostly of grayish-white limestones and sandstones, partly fine-grained and compact, and partly coarse and porous. Some of the beds are more or less oölitic, and some again are almost completely made up of aggregations of fresh-water shells of Pliocene and recent species. They are generally much obscured by the Quaternary gravels of the terraces, but, where sections can be obtained, are shown to have had a thickness of at least 350 feet. At the northern end of the range, where the narrow-gauge railroad crosses into Cache Valley, they are found to have been considerably uplifted, showing angles of dip of $10^{\circ}$ and $15^{\circ}$. An appearance of volcanic rock in the cañon of Bear River, at the "Gates", which, however, was not examined closely enough to determine definitely its character, suggests the possibility that this uplift may have been determined by a late volcanic outburst.

EAstern UpLIFT. - Cache Valley occupies a broad synclinal fold in the Wahsatch limestone, which, on the west, forms the flanks of the main range, while to the eastward, with a slight secondary roll, it occupies the broad mass of hills between this valley and Bear River Plateau, in the interior of which the lower formations gradually rise up from beneath it. In Logan Cañon, for a few miles above the entrance, the beds of the Wahsatch limestone dip to the eastward. This dip, which is $35^{\circ}$ at the mouth, rapidly decreases as one ascends the cañon, and opposite Logan Peak the beds are virtually horizontal, then rising again with a dip of $20^{\circ}$ to the westward. The lower beds, as exposed at the mouth of the canion, are generally of dark, rather siliceous, thinly-bedded limestones. About 1,500 feet above 
the lowest beds exposed were found the following fossils, which correspond closely with those obtained from Ogden Cañon:

Chonetes Loganensis.

Rhynchonella pustulosa.

Euomphalus latus var. laxus.

Spirifer alba-pinensis.

Spirifer centronatus.

Proëtus peroccidens.

Proëtus Loganensis.

$\Lambda$ the forks of the cañon, the beds rise more steeply, and a quartzite belt is seen which may correspond to the Ogden Quartzite. In the north fork of the cañon, fragments of granite indicate the probable existence of a granite core to this ridge beyond the limits of the map to the north.

While numerous small streams and cañons are found along the face of the range toward Caclie Valley, only two large streams to the south of Logan Cañon, Blacksmith's Fork and Muddy Creek, cut entirely through the ridge, coming from the still higher country of the Bear River Plateau. A short distance to the south of Logan Cañon the beds are found dipping into the range at an angle of $20^{\circ}$. Still farther south, back of the town of Providence, they seem to have a still lower dip. Ascending to the summit of Logan Peak from the valley, in crossing the eastern dips, the strata are seen to shallow out until they become perfectly horizontal; while on the summit the beds dip $12^{\circ}$ to the westward. The strata thus crossed are dark bluish-gray limestones, with many interstratified beds of calcareous grits, cherts, and highly siliceous limestones, together with beds of dark compact quartzite, always carrying some calcareous material. Occasionally, there occur narrow beds of argillaceous sandstone. Near the summit of the peak, in a dark-gray limestone, is a stratum of yellowish fine-grained sandstone, which appears to be nearly free from any calcareous matter. Fragments of corals too poor for specific determination were found on the slopes of the ridge associated with a small Productus. From the summit of Logan Peak were obtained at least two species of corals, Zaphrentis Stansburyi, and Lithostrotion too poor for identification. To the eastward of Logan's Peak the beds all appear to possess a decidedly westward dip. 
'The cañon of Blacksmith's Fork breaks through the range some seven or eight miles south of Logan Cañon. From where the stream leaves the mountains to the Bear Lake road, on the Cambrian Plateau, the cañon measures about twelve miles in length. It affords some of the most bealltiful cañon scenery to be found within the limits of this survey. Other gorges and passes possess doubtless more grandeur, and are built up of larger proportions, but few combine grandeur, picturesqueness, and varicty of outline to the same extent as Blacksmith's Fork. In width, the cañon is exceedingly narrow, with abrupt, precipitous walls rising from 2,000 to 3,000 feet in heavy masses above the stream-bed. At its entrance, the beds of Walisatch limestone are found dipping to the eastward. They gradually become horizontal, and then assume a westerly dip, forming a continuation of the synclinal fold seen to the north. The westerly-dipping beds seldom reach a high angle, inclining rarely more than $12^{\circ}$ to $14^{\circ}$. The limestone is a dark bluish-gray rock, compact in texture, with occasional beds more granular and of lighter color. The bedding-planes are distinctly marked, and the thickness of single beds sometimes reaches 20 or 30 feet. As the upper beds are never seen, it is impossible to estimate the entire thickness of limestone at this point: probably not less than 5,000 feet are exposed. The only fossils observed were a few indistinct impressions of coralline stems protruding from the surface on the walls of weathered limestone. Beyond the Wahsatch limestone occur the beds referred to the Ogden Quartzite and the cherty, siliceous strata of the Silurian or Ute limestone. Some eight miles above the entrance of the cañon, the Cambrian quartzites come in with a gentle dip to the westward, gradually flattening out to a horizontal position. Between Blacksmith's Fork and the canon of the Muddy, a distance of six to eight miles, the limestones lie nearly horizontally, the easterly-dipping beds occupying less and less area, and the little synclinal roll graduallydying out under the valley.

Muddy Cañon.-In its general features, the Muddy Cañon presents much the same character as Blacksmith's Fork, the dark heavy beds of bluish-gray limestone of the Wahsatch group forming the abrupt cañonwalls at its entrance. Here the beds are inclined at a low anglo to 
the westward, the minor fold along the foot-hills, as already mentioned, having disappeared. The dip gradually becomes steeper in ascending the cañon, reaching a maximum of $30^{\circ}$, and a thickness of nearly 6,000 feet is exposed in the Wahsatch limestones. Near the entrance to the cañon, the beds are more or less siliceous and impure, and at one locality occurs a thin stratum of compact bluish sandstone, containing but little calcareous matter. A thin section of this rock under the microscope reveals, in the interstices between the rounded grains of quartz, minute crystals and fragments of calcite. But few fossils were found along the section exposed in this cañon, and are mostly confined to fragments of corals, among which were recognized Zaphrentis and Syringopora. Underlying the Wahsatch limestone occurs a considerable thickness of quartzose beds, associated with some calcareous matter, which, from their position in the series, have been referred to the Ogden Quartzite. These trend across the cañon with a strike of about north $10^{\circ}$ to $15^{\circ}$ west and a dip of $20^{\circ}$ to $25^{\circ}$ to the westward, their lowest beds resting upon the western base of Ute Peak.

Immediately underlying the Ogden Quartzite occurs the Ute limestone, which includes here the entire series of calcareous and cherty beds exposed on the abrupt walls of Ute Peak, which has furnished the name for this great thickness of Silurian rocks, so characteristic of the lower portion of the Palæozoic section as developed in several widely-separated regions of the Wahsatch Range. Ute Peak is situated between seven and eightmiles above the entrance to the cañon, on its south side, just below the junction of the two forks; its steep slopes forming the southern wall of the main cañon and that of the south fork. It rises from 2,200 to 2,400 feet from the level of the stream, presenting, on its eastern side, a precipitous face, while to the west its slopes fall away gently, more nearly in accord with the inclination of the strata. The summit forms a broad, slightly-inclined table, the culminating point being but little higher than the long ridge that rises above the south fork. The beds of the Ute limestone cross the cañon with an observed strike of north $15^{\circ}$ to $20^{\circ}$ east and a westerly dip of $15^{\circ}$ to $18^{\circ}$. In the cañon-bottom of the south fork, the stream-bed has cut through the argillaceous slates and shales of the Cambrian series, which extend up the lower slopes of the peak from 30 to 50 feet, and are directly and conforma- 
bly overlaid by the beds of the Ute limestone. The line of junction at the top of the series, to the west of Ute Peak, between the Ogden Quartzite and the Silurian limestone, has not been well determined; but, as the entire western face of the mountain comes within the limits of the formation, it is evident that there are exposed here a thickness of not less than 2,000 feet of Silurian beds, which, from palxontological evidence, have been referred without hesitation to the Quebec group of Canada. As, however, the beds containing Quebec fossils are still overlaid by a considerable thickness of calcareous strata, the Ute limestone may yet be found to contain beds belonging to the Upper Silurian formations. Within the 2,000 feet of exposed strata of Ute Peak, there is presented a very great variety of lithological characters, dark, nearly black, compact limestones, coarse granular, lightercolored beds, carrying greater or less thicknesses of calcareous and argillaceous shales, sandstones, cherts, and grits, in color varying from black to grayish-white, with intermediate shades of blue. Occasionally, some of the finer-grained homogeneous beds develop a striped and banded mode of weathering. In general, it may be said that the beds are characterized by less uniformity of texture and color, while the arenaceous and cherty beds predominate over the purer limestones to a greater extent than is the case in the Wahsatch limestone.

Within 25 feet of the base of the series occurs a body of calcareous shales, interstratified with narrow beds of a dark, fine-grained limestone, which is filled with abundant remains of Entomostracea, containing new species of at least two genera :

\section{Dikellocephalus quadriceps. \\ Conocephalites subcoronatus.}

Two hundred feet above these beds, in a compact cherty black limestone, on the north side of the peak, was found an undetermined species of the genus Obolella. From the upper bluffs, some 200 feet below the summit of the ridge, in a coarse, gray, granular limestone, were found:

Euomphalus (Raphistoma) rotuliformis.

Euomphalus (Raphistoma) trochiscus.

\section{Maclurea minima.}


From the summit of the ridge, in addition to the Gasteropoda already enumerated, were obtained the following:

\section{Ophileta complanata.}

Raphistoma acuta.

Prof. F. B. Meek says, in his Report, referring to the genus Ophileta : "One of these is a small Ophileta, scarcely distinguishable from O. complanata of Vanuxem, as described from the Calciferous sand rock of New York"; and of the others, that they are "nearly allied to forms found in beds of the age of the Calciferous period in Minnesota, Wisconsin, and Texas".

A specimen of the grayish-black, cherty limestone from the base of Ute Peak was selected for chemical analysis. It is a compact, homogeneous rock, with a few grains of brilliant calcite scattered through it. The analysis was made by Mr. B. E. Brewster with the following result:

Insoluble residue 16.567

Soluble silica

Ferric oxide and alumina 0.601

Lime

Magnesia .

Phosphoric acid

Carbonic acid

Water and organic matter

100.230

The carbonic acid, with the bases lime and magnesia, would yield:

Carbonate of lime

76.82

Carbonate of magnesia

The insoluble residue gave upon analysis:

Silica

Alumina

16.567

These analyses show that the rock is a dolomitic limestone, rich in silica 
The .12 per cent. of phosphoric acid present would seem to be derived from shells of the genus Obolella and other minute forms. The sandstones in the Ute Peak beds occur mostly in thin layers, usually granular, and carrying a considerable percentage of lime, and are found throughout the entire series, while the shales and slates appear, for the most part, to be confined to the lower horizons. As already mentioned, the argillaceous and arenaceous slates, which have been referred to the upper members of the Cambrian, occupy the cañon-bottom. They are estimated at about 100 feet in thickness, and consist of exceedingly fine indurated clay-beds, interlaminated with layers of sand material of a brown earthy color, closely resembling the beds from the same horizon in Ogden Cañon. On the north side of the Muddy, no lateral cañon has cut through the slates, and there are found the Ute limestone and Cambrian quartzite forming a high cañonwall, exposing a fine unbroken section, dipping about $16^{\circ}$ to the westward. The two forks of Muddy Cañon offer a striking difference in structural features; the cañon of the south fork trending approximately with the strike of the rocks, and presenting on one side the high wall of the Ute limestone and on the other the Cambrian quartzite, the intermediate slates being almost entirely eroded off the steep slope. On the other hand, the north fork, running at right angles to the quartzite, cuts through 1,600 feet of the Cambrian rocks, forming a narrow impassable gorge, with precipitous and almost perpendicular walls.

Cambrian Plateau.-The large area of quartzite which underlies the Silurian limestone, and has been referred to the Cambrian series, occupies a very large superficial area. It extends from the northern limit of the map across Logan, Bंacksmith's, and Muddy Cañons, and as far south as Ogden River, occupying a belt of country from 6 to 8 miles in width. It forms a broad anticlinal fold, whose western side dips under the Ute limestone in the region of Logan and Blacksmith's Cañons, with a low angle, increasing, however, toward the Muddy, where it reaches an inclination of $16^{\circ}$. The Bear Lake road, as·shown on the map, appears to lie along the axis of the anticlinal fold, and here the quartzites are found quite horizontal, or else dipping under the influence of the eastern side of the fold $2^{\circ}$ or $3^{\circ}$ to the eastward. The eastern side of the fold is by no means as steep as the 
western, and the overlying limestones are found resting conformably upon the quartzites at the same angle of $2^{\circ}$ and $3^{\circ}$. In the region of Blacksmith's Fork, the beds lie horizontally in isolated hills, rising several hundred feet above the plateau level. An interesting feature in the scenery of the quartzite summit is formed by the picturesque falls and rapids found on the northern branch of Blacksmith's Fork before it enters the main cañon. There are several of these falls, the finest of which is about 30 feet in height, whose waters break over a ledge of quartzite, which is inclined $2^{\circ}$ or $3^{\circ}$ to the eastward, against the course of the stream, while rapids occur along the river between the more abrupt falls. The stream varies very considerably in width, running in narrow channels, and, in part, forming small lakes or ponds, surrounded by green meadows. The strike of the quartzite beds is approximately north $10^{\circ}$ to $15^{\circ}$ east. A thickness of from 1,500 to 1,600 feet is probably exposed beneath the Ute limestone, but the base is never reached. In lithological habit, these rocks present a close resemblance to the Cambrian quartzites, as seen in Ogden Cañon and other localities throughout the Wahsatch Range. The different beds vary somewhat in texture, but are mostly fine-grained, of a steel-gray color and slightly vitreous lustre where not concealed by the discoloration of ferruginous material. The presence of iron in considerable amounts would appear to be highly characteristic of the Cambrian formation. It occurs disseminated through the rock in thin seams or cracks, and in small concretionary masses, usually, however, decomposed into yellow ochreous earth. In the stream-beds of the north fork of the Muddy, and on the lower slopes of the ridges, were found fragments and rounded pebbles of specular iron; also, in the Cambrian quartzite on Mill Creek, which runs to Morgan Valley, similar fragments were found. It is not improbable that future explorations may discover iron masses of considerable economic importance.

In several localities in the Cambrian quartzite, but more especially in the region of Muddy Cañon, there were observed certain peculiar markings and groovings, suggesting imperfect borings and tracks of worms, such as usually have been described as worm-burrowings of the genus Scolithus. They do not appear to be abundant, but where noticed were generally in a 
vertical position, that is, at right angles to the bedding-planes of the rock.

On the Cambrian plateau, south of the Blacksmith's Fork, extending to the divide between the Muddy and Beaver Creek, occur isolated patches of Tertiary sandstone. The largest body is some 4 or 5 miles in length, lying between two branches of the Blacksmith's Fork, and rising about 500) feet above the level of the quartzite. Other smaller beds are found along the western base of the Bear River Plateau, which conceal the line of junction between the quartzite and the overlying limestone, forming frequently low hills or mounds, and stretching up the slope of the ridge for 200 or 300 feet. The same formation may be traced in small remnants over a considerable part of the plateau, within the designated area, although to the north of Blacksmith's Fork it was not recognized. These Tertiary beds have been referred to the Vermillion Creek series, partly from their close lithological resemblance, and partly from their apparent relation with the Tertiary series of the Bear River Plateau, although it is proper to state that no direct connection between these two formations was traced, and they may possibly be of later age. They generally consist of a coarse, sandy rock of loose, friable texture, colored bright red from the presence of a considerable amount of oxide of iron.

The easterly-dipping beds of the Cambrian pass under the Bear River Plateau, and are concealed beneath the overlying beds of limestone. The arenaceous and argillaceous slates, which are so well shown on the western side of the axis in Muddy Cañon, were nowhere observed on the eastern fold; the line of contact between the Cambrian and Silurian being very much obscured by remnants of Tertiary beds, and considerable accumulations of Quaternary detrital material, brought down from the plateau above.

Bear River Plateau extends for nearly 25 miles in an unbroken line from the northern limit of the map, rising 2,000 to 2,500 feet above the Cambrian summit. All along its western face, there is exhibited an abrupt precipitous wall, cut by a few deep cañons, whose streams are branches of Blacksmith's and the Muddy Fork. These cañons, or rather gorges, are very narrow, and cut deeply into the limestone down to the underlying 
Cambrian rocks. The most striking are perhaps those of the Blacksmith's Fork, which present perpendicular walls nearly 2,000 feet in height, offering fine sections of the limestone. From all the structural observations made in the field, there can be scarcely any doubt but that this great limestone belt represents the Ute formation, already described as resting conformably upon the Cambrian rocks of the west side of the fold, and which here forms the eastern side of a broad anticlinal axis, the strata being inclined at an angle of only $2^{\circ}$ or $3^{\circ}$ to the eastward. On the summit of the plateau, this limestone is mostly concealed beneath the Tertiary sandstones of the Vermillion Creek beds, or loose, sandy Quaternary soil, and is only exposed here and there in a few isolated localities. No fossils were found in place along the edge of the cliffs, or in the cañons, although it may be stated that only a cursory search was made, while a more careful examination may show the beds to be as rich in invertebrate remains as the formation on the opposite side of the fold. The thickness of this limestone is estimated as at least 2,000 feet.

Beaver Cañon lies entirely within the Cambrian quartzites. A variety of quartzite exposed here is of some special interest, as it differs from any beds observed in the region of the Muddy and Blacksmith's Cañons, but at the same time shows a close lithological resemblance with beds seen at other localities in the Wahsatch Range. It is characterized by purplish-gray color, vitreous lustre, and a tough, dense texture. The individual grains of quartz have a dark, smoky appearance, while the interstices between the grains are filled with crypto-crystalline, almost amorphous, quartz. Many of the beds develop a tendency to a schistose structure, containing interlaminated seams of thin, partially-foliated quartz, between layers of coarser material. Under the microscope may be recognized a few minute plates of mica, while the quartz grains reveal large numbers of liquid-inclusions with mobile bubbles. These purplish-gray rocks, by the absence of iron, present a marked difference from the white and brown quartzites of the Cambrian series. The recorded dips in the cañon are all to the eastward. Some 2 or 3 miles from the head of Beaver Cañon occurs a large deposit of calcareous tufa, formed by an old thermal spring, which has now nearly ceased running. 
The tufa is a compact, cream-colored rock, inclosing some minute shells and incrustations of stems and twigs.

On the south fork of Ogden River, just above the junction of Beaver Creek, heavy beds of nearly horizontal dark limestones occur, which there form the abrupt cañon-walls, until concealed beneath the Vermillion Creek beds. No fossils were found in the limestones, but, from their relative position, they have been referred, on stratigraphical grounds, with but little hesitation, to the Ute limestone. From the junction of Beaver Creek with Ogden River to the mouth of the upper cañon in Ogden Valley, the exposures are mostly in white or reddish-brown quartzites, whose walls rise between 1,000 and 1,500 feet above the stream-bed. The same purplish-gray beds which form so prominent a feature in Beaver Cañon occur here also, striking diagonally across the cañon.

The foot-hills along the east side of Ogden Valley, between the Upper Ogden Cañon and the base of Eyrie Peak, were not visited, but they present, from the valley, long, steep ridges, frequently broken by deep, narrow cañons, extending far back into the interior of the range. In crossing the divide, between Ogden and Cache Valleys, quartzite beds are passed over for the greater part of the distance, which, on the summit of the pass, attain an altitude of about 1,000 feet above the Tertiaries of Ogden Valley. Eyrie Peak, which lies to the eastward of the pass, rises still higher, nearly 3,500 feet, commanding a broad view in all directions. It is composed entirely of quartzite from base to summit, whose beds dip apparently to the northeast at an angle of $18^{\circ}$ to $25^{\circ}$, with a strike of north $30^{\circ}$ west. The top of the peak is composed of dark brownish-white beds, carrying considerable iron disseminated through them, and concentrated into thin seams or layers. Near the bottom of the series, the beds possess a decidedly bluish tinge, showing a marked resemblance to the purple beds of Beaver Cañon, with occasional layers of conglomerate made up of coarse sand, carrying smooth, round pebbles. Throughout the series are frequently found intercalated seams of dark shales and fine sand beds. This entire series of beds has been referred provisionally to the Cambrian quartzitespartly on structural grounds, and in part from strong, well-marked petro, 
graphical resemblance, though their connection with well-defined Cambrian strata has not been clearly traced out.

INTERIOR VALLEYS.-Of the great mountain-valleys which lie between the two crests of the northern portion of the Wahsatch Range, Cache Valley is the largest and most important. It occupies the great synclinal fold in the Wahsatch limestone already mentioned, and is overlaid by horizontal Tertiary beds of Pliocene age. They have been referred to the Humboldt Pliocene formation, inasmuch as they are probably of the same age as the beds which characterize such wide areas in the region of the Humboldt Valley in Nevada. They cover the greater portion of the southern end of the valley, except the broad fluviatile bottoms of the larger streams, and rest unconformably against the inclined strata of the Wahsatch limestone on all sides of the valley. The drainage-channels on the west side and to the south, in the region of Saw Mill Cañon, cut through the Tertiary, offering good exposures of a thickness at least of 350 feet of sandstones and limestones. The upper beds are friable sandstone, which weathers readily. A specimen subjected to chemical analysis yielded 94.44 per cent. of silica, the residue being chiefly iron and alumina, with considerable moisture. Below the red sandstones are found a series of fine-grained white and lavender-colored sands, interstratified with layers of calcareous sandstones. Near Wellsville occurs a body of soft compact sandstone, which is used as a building-stone by the inhabitants of the valley, as it is easily quarried and cut without difficulty. Other quarries have also been opened; and, from one near Mendon, a light porous rock was obtained, also much used in building. The beds of Mendon yielded a number of fresh-water shells, among which the genera Helix and Limnaa are well represented. Prof. F. B. Meek has described in his report a new species of the latter genus, found at Mendon, as Limnaa Kingii. In many localities, the Tertiary beds, especially among the steeper western foot-hills, are concealed by deposits of sand and coarse gravel, which belong to the Quaternary period. The terraced benches, which are so marked a feature on the western face of the Wahsatch, are also found along the foot-hills on both sides of Cache Valley, although not so broad as those observed in Salt Lake Valley. The entire southern portion of the former valley shows unmistakable signs 
of occupation by the waters of the ancient Lake Bonneville, which penetrated Cache Valley by the "Grates" at its northern end, just beyond the limits of the map.

Copenhagen Valley, so named from a little Danish settlement of that name, which lies at the head of Box Elder Cañon, has an elevation of about 5,000 feet above the sea-level, and 750 feet above the present level of Salt Lake. It was, therefore, covered by the waters of the ancient lake, although the terrace-lines are less conspicuous than in either Cache or Ogden Valleys. A large portion of its area is covered with recent Quaternary deposits of very unequal thickness, with exposures showing clearly the fine white sands and conglomerates of the Tertiary beds, which have been, like those of the other lake-valleys of the Northern Wahsatch, referred to the Humboldt Pliocene.

Ogden Valley, in its general features, is not unlike Cache Valley. It is, however, much smaller, measuring about five miles in width by six in length. The surface of the valley appears to have a much larger deposit of coarse Quaternary material than is found in Cache Valley, which may in part be owing to the quartzite slopes on the surrounding mountains, which have sent down an immense amount of rubble and fragmentary débris covering the surface of the ground, so as to render it for the most part unavailable for agricultural purposes. Beneath these Quaternary deposits, however, especially on the north and east sides, may be seen, underlying the sandstones and limestones, fine conglomerates, which bear a marked resemblance to the beds of Cache Valley, though it is necessary to bear in mind that, owing to the close proximity of these beds to the high mountain-ranges, they have in each case a somewhat local character. These beds also have been referred to the Humboldt Pliocene, although it should be stated that they are too far removed from any welldefined Humboldt formations to trace any direct connection, and palæontological evidence is yet too meagre to throw any important light on the question. The lake-terraces can here also be traced with more or less distinctness. The divide between Ogden and Morgan Valleys reaches an altitude of about 900 feet above the Weber River, measuring some 7 miles from valley to valley, with a width between the two high mountain- 
ridges on either side of 4 miles. In crossing from Huntsville to Mountain Green, but few outcrops are visible along the road, the hills being round and smooth, and covered with soil and vegetation. The rocks are chiefly sandstone, showing considerable variety in color and texture. The upper beds are in general more friable, possessing a reddish tint, many of them being fine conglomerates. The lower beds, though varying in physical habit, are much more compact, presenting under the hammer a decided tendency to conchoidal fracture, and similar to quartzose rocks which have a finely crystalline or amorphous base. Under the microscope, thin sections reveal the presence of fragments of triclinic feldspar, hornblende, and mica, and a few dark grains, which are probably magnetite. Many of the beds resemble in lithological habit the compact gray sandstones, which are so characteristic of the Cretaceous rocks in the region of the Wahsatch. The entire series of beds, however, the upper members of which also occur in Morgan Valley, have been referred to the Vermillion Creek formation. 


\author{
SECTION V. \\ REGION NORTH OF SALT LAKE.
}

BY ARNOLD HAGUE.

Promontory UpLift.-To the west of the northern portion of the Wallsatch Range lies a broad Quaternary plain, in part occupied by the shallow waters of an arm of Salt Lake, known as Bear River Bay, and in part by the valley of the Bear and Malade Rivers. Along the shores of the bay, and in the deeper cuts of these rivers, are exposed the fine mud deposits of the Lower Quaternary, which, over the greater part of the surface, are concealed by the more recent detrital material of the Upper Quaternary. Beyond the limits of the map, the valley of the Malade extends in a northerly direction, while Bear River, as already mentioned, has broken through the range at the "Gates", coming from the region north of Cache Valley, in a general southwesterly course, after having flowed from the Uinta Range through the Upper Bear River Valley, about 150 miles nearly due north. On the west side of the Malade River Valley, along the northern limits of the map, low rounded hills of limestone rise up above the Quaternary beds, presenting a broken undulating surface, and extending westward to the valley of Blue Creek. These limestone hills or ridges show a number of synclinal and anticlinal folds, with gentle dips, which can be traced from the Promontory Mountains nearly to Bear River. The first ridge to the eastward of Blue Creek has an inclination to the east, while the second ridge dips westward, forming a synclinal, followed by a second anticlinal fold to the eastward, the beds dipping under the valley, while in the small isolated hill to the west of Corinue, known as Little Mountain, the beds dip to the north at an angle of $18^{\circ}$. The northern end of these hills was not visited by our parties; but there would seem to be little doubt that they belong to the same horizon as the more southern hills, which have been referred to the Wahsatch limestone, from their close structural and lithological relations to the heavy limestone-beds of the Promontory Mountains.

This range extends from the northern limit of the map about 45 miles to the southward, forming a rocky promontory, which divides the two northern 
arms of Salt Lake, with a varying width from 4 to 7 miles, and reaching in its highest point 3,000 feet above the level of the lake. North of the railroad the range is comparatively low, with rounded outlines, the greater part of its surface being covered with loose soil and grass, and showing but few outcrops. The underlying formation, however, belongs to the Wahsatch limestone, and is evidently a continuation to the northward of the same beds which characterize the more important portions of the range projecting into the lake. The railroad passes through a low depression in the range, which, on the summit, attains an altitude 4,943 feet above sea-level, or over 700 feet above the level of Salt Lake. The old Pliocene lake, at its highest elevation, unquestionably occupied this pass, isolating the main portion of the Promontory Mountains, which formed an island of greater extent than either Stansbury or Antelope Island. This gap in the range, at its widest expanse, measures about three miles in a north and south direction, and everywhere shows the rounded forms and broad level benches produced by recent erosion and former occupation by the lake waters. On both the north and south sides of the gap, the upper terrace-lines of the old lake are quite marked, but perhaps less continuous than at other localities. All along the east and west sides of the Promontory Mountains, these old terraces and beach-lines may be traced with more or less distinctness, indicated by loose deposits of sand and gravel, or by benches cut in the hard mass of limestone. The elevation of the highest of these terraces is approximately 940 feet above the present level of the lake. To the south and west of the railroad, at Promontory Station, the range, which is quite narrow, consists of a series of limestones, of a prevailing gray color, in the lower part of which are dark heavy beds of nearly black limestone, all dipping to the westward at an angle of $38^{\circ}$. About four miles south of Promontory Station, the range widens rapidly to the westward, attaining a width of 6 to 7 miles, of which the western third is occupied by the same series of limestones, which here rise with an easterly dip, and overlie a limited outcrop of Archæan schists.

These Archæan rocks are exposed on the southwest corner of this projection of the range, and consist of quartzites and mica-bearing schists, closely resembling those described in the Archæan bodies of the Wahsatch. The main crest to the east of this western projection is occupied by con- 
formable strata dipping, as already mentioned, about $38^{\circ}$ to the west. They are much contorted, and show more or less faulting, so that their thickness cannot be accurately determined. It is, however, not less than 3,800 feet. About the middle of the series, there is an included zone of yellowishbrown sandstone, more or less calcareous, within which are several beds of gray limestone. Its lower portion is sharply defined from the underlying limestones; but, 300 feet above where it passes again into the limestones, it shades off gradually through shaly beds. The general strike of this portion of the range is north $28^{\circ}$ east.

Along the extreme eastern foot-hills, on the edge of the Lower Quaternary plain, which borders the lake-shore, are outcrops of easterly-dipping beds, which evidently show a portion of the eastern half of an anticlinal fold, of which the main mass just spoken of is the western member. This anticlinal fold appears very distinctly in the group of hills about 8 miles south of Promontory Station, of which Benada Peak is the culminating point. IIere a distinct northern axis cuts the range, and south of that point the rocks dip to the eastward. Through the pass, about $1 \frac{1}{2}$ miles north of Benada Peak, passes a synclinal axis quite parallel to the anticlinal, which lies 1 or $1 \frac{1}{2}$ miles to the west of it. Here the easterly-dipping members of the western anticlinal and the westerly-dipping parts of the eastern, or second anticlinal, meet. The second anticlinal passes through Benada Peak itself, and, as has been said, to the south of that point, for about 12 miles down the range, the greater part of the limestones dip uniformly to the east, at angles varying from $20^{\circ}$ to $40^{\circ}$. At Flat Rock Point, on the west side of the range, are found portions of the western members of this anticlinal fold, dipping at a gentle angle into the lake, and consisting, for the most part, of gray and drab limestones, among which are intercalated bands of yellowishbrown sandstone, similar to that described in the westerly-dipping mass south of Promontory Station.

From the westerly-dipping limestones, about 5 miles south of Promontory Station, near Antelope Springs, were obtained the following fossils:

Productus Prattenianus, Spirifer opimus, Athyris subtilita, Streptorhynchus (fragments); 
while the limestones farther south afforded:

\section{Zaphrentis Stansburyi.}

Productus semireticulatus.

These fossils are all clearly of Carboniferous age, though of themselves not distinctly characteristic, either of the Upper or Lower Coal-Measure limestones. The thickness of the series, and its relation to the underlying Archæans, however, as well as its general lithological character, all serve to ally it rather to the latter division.

About 14 miles south of Benada Peak, the Carboniferous limestones are found to abut unconformably upon a series of Archæan schists, which occupy the whole lower 7 or 8 miles of the range, with a strike north $30^{\circ}$ to $35^{\circ}$ west, and a dip to the northeast. The Archæan strata consist largely of siliceous schists and imperfectly-bedded hornblendic and micaceous gneisses, together with thick beds of quartzite and more or less interspersed argillaceous schists. Just west of the southernmost extremity of the range, the Archæan rocks come nearly down to the water's edge, presenting a cliff, some 50 feet in height, of dark argillaceous schist, which has apparently a dip of $25^{\circ}$ to the west. Along the cracks and fissures, this rock appears to decompose readily, and is found to be coated with an efflorescent substance, which, when applied to the tongue, gives the characteristic astringent taste of alum. The following analysis of this salt was made by Mr. R. W. Woodward:

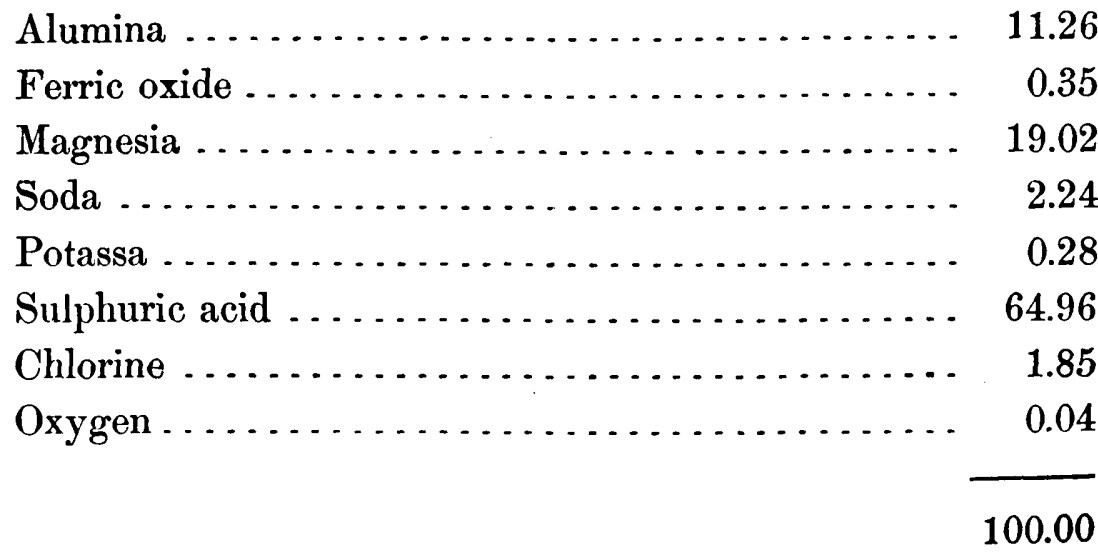

The analysis of this alum gives no water of crystallization. 
Prof. J. Lawrence Smith has published an analysis of an alum from this locality, ${ }^{1}$ with the following results:

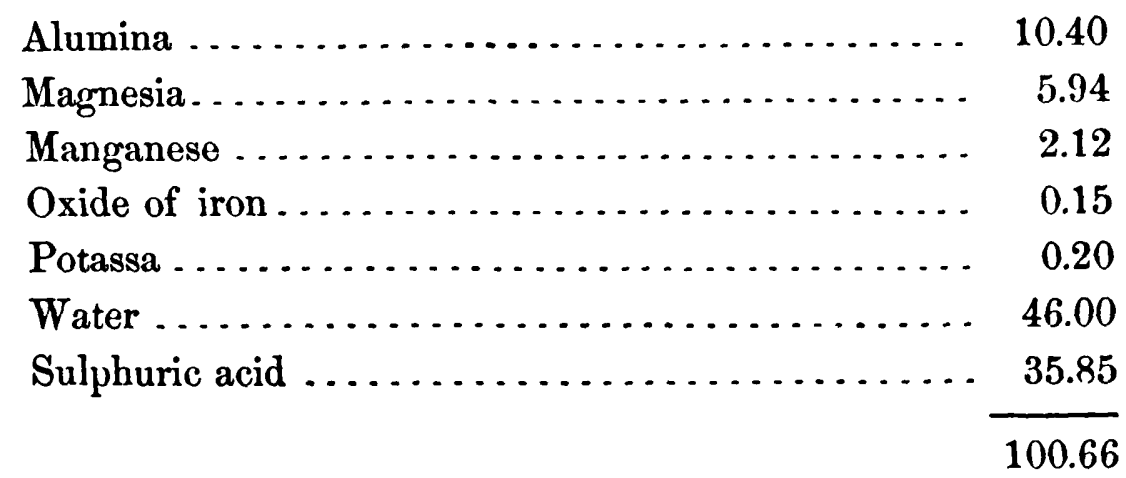

In the last edition of his Mineralogy, Professor Dana has classed this alum under the name of Bosjemannite, a mangano-magnesium alum. The analysis made by Mr. Woodward, however, shows no manganese, but a very large percentage of magnesia, and contains all the impurities gathered with the alum at the locality, which appears to be more closely related to pickeringite, a magnesium alum mixed with some epsom salt, while the needle-shaped crystals, analyzed by Professor Smith, were not procured at Alum Bay, but were a product of recrystallization.

Along the east side of the range, the cliffs in general come nearly to the water's edge, and there occur a great number of alkaline and brackish springs, which issue out of the limestone strata near the level of the lake. On the west side, the hills slope off more gently, and the lakeborders are occupied by a strip of Quaternary soil, which gradually widens toward the north. A few miles below Flat Rock Point is a fine spring of pure water. To the west of the railroad pass is a low north and south Quaternary valley, which is separated from the lake by a long low tableland of black basalt, extending about 10 miles in a northwest direction, and abutting upon the lake, at its northern extremity, in an abrupt low precipice. A similar basalt table-land rises slightly out of the Quaternary plain, and forms the southern end of the Hansel Mountains, to the north of Monument Station.

'Am. Jour. of Sci., 2d series, 18, 379. 
IsLANDS.-The Archæan uplift of the Promontory Range is continued to the southwest in the rocky summits, which lie above the level of the lake, forming Frémont and Antelope Islands. A small outcrop of Archæan gneisses is also found rising out of the mud plain at the Landing-rocks, to the west of Ogden, forming the extreme western point of the lake-shore line. Frémont's Island is made up of beds of dark-green hornblendic and micaceous gneisses, generally much contorted, in which the prevailing dip is about $40^{\circ}$ to the west, but on the western shore presenting a bold escarpment toward the lake. The old terrace-lines are very distinctly marked, as upon most of the islands of the lake. Antelope or Church Island, as it is sometimes called, is the largest of the rocky islands which dot the surface of Salt Lake, covering a superficial area of about 40 square miles. It has several fresh springs, and its slopes are covered with a good deal of grass, which have been used as common grazing-ground for the herds of sheep and cattle of the Mormon settlers. As seen from the shores of the lake near Farmington, in profile, the crest of the southern portion of the ridge is a perfectly horizontal line, evidently marking the level of one of the old lake-terraces. It is made up entirely of rocks of the Archæan series, mostly gneisses, with some quartzites and mica-slates. On the main peak is a thin stratum of not more than 20 feet of slates, which approach a limestone in composition These are the only calcareous beds that have been detected in the Archæan rocks of the Wahsatch Range. They stand in an almost vertical position, with a strike of north $45^{\circ}$ west, and are enclosed on either side in gneissic rocks, which form the main ridge to the south with the same strike. An outlying spur to the west of the main ridge shows a secondary fold, whose axis has an easterly and westerly direction, the beds dipping over $70^{\circ}$ to the south.

Curlew Valley.-To the west of the Promontory Mountains, the Rozel Hills and the southern end of the Hansel Mountains consist, as has been seen, of low, flat tables of dark, compact basalt, forming part, doubtless, of the same flow now separated by the Quaternary deposits of the valleys. To the west of the Hansel Mountains, the country north of the lake, as far as the Terrace Mountains, appears to be underlaid also by the basaltic formation, the southern extremity of the great outflow of basalt which covers an immense area to the north of the limits of the map. Much of the country here shown upon the map lies below the level of the upper 
terrace-lines, and presents everywhere marked evidence of having been submerged within recent geological time. The greater part of this area is more or less concealed beneath loose sand and basaltic detrital material of the Upper Quaternary. Only here and there, the presence of the underlying basalt is indicated by little hills and knolls which rise above the plain.

North of the Terrace Mountains, the basalts reach a somewhat higher elevation, forming low, broad tables with isolated domes. Of these, Red Dome, just north of the railroad, is the most prominent, presenting a conspicuous landmark in the region north of the lake. These basalts are characterized by a dense, fine-grained texture, but are occasionally quite porous, when they possess a reddish tinge, especially on the weathered surface, the color giving the name to the dome already mentioned. Wherever the slope of basalts was noted, it indicated a slight inclination to the southward, toward the desert. In a number of localities, at the head of the lake, salt springs occur on the desert, many of them quite cold and clear, all carrying considerable common salt in solution; many of them, in fact, being dense brines.

Between Red Dome and the Raft River Mountains lies an irregular mass of hills, which only in a few points attain an elevation of more than 1,000 feet above the desert-level. The greater part of these hills are below the well-recognized level of the old lake, and, like the hills to the eastward, everywhere show evidences of the recent occupation of the country by the lake waters. They are made up of dark-gray limestone broken through and partly concealed by heavy outbursts of basalt. Nothing can be said definitely of the structure of the limestones of these hills, as they are much disturbed by the Tertiary volcanic rocks, or else concealed by the still later loose Quaternary gravel. No fossils were found which determined accurately the horizons of these limestones, but there can be little doubt that they belong to the upper members of the Wahsatch limestones, which characterize all the mountain-ranges north of the lake. On the west side of Duff Creek, basalts find their greatest development in broad, heavy, tabular masses, lying inclined at an angle of about $2^{\circ}$ to the southeast, and presenting precipitous cliffs toward the creek. The rock is a compact black basalt, with a crypto-crystalline groundmass and uniform texture. On the basalt slopes west of Duff Creek, and on the south side facing the desert, the terrace-benches, which are so characteristic of the entire region, are 
beautifully shown. Seven well-defined, sharply-cut benches, several feet wide, were counted, one above the other, on the sides of the hard rock. Probably no locality in the region of Salt Lake affords a better opportunity for observing the broader and more permanent lake-terraces which mark the changes of level of the earlier bodies of water.

Terrace Mountains.-In their physical aspect, the Terrace Mountains bear a marked resemblance. to the other ranges of the Salt Lake Basin, especially to the Promontory Mountains on the opposite side of the lake. They measure about 20 miles in length by 4 to 6 in width, the culminating peak reaching 2,700 feet above the present water-level. Tangent Peak, the highest point in the mountains, affords on a clear day a most striking view of the arid gray desert and the blue lake stretching away to the southward and eastward as far as the eye can reach. The eastern horizon is bounded by a grand panoramic view, of over a hundred miles in length, of the Wahsatch Range, while to the westward the East Humboldt Range stands out in nearly equal distinctness, but with a more rugged and varied outline. The mass of these mountains, as far as visited, appears to be made up of beds of the Wahsatch limestone. The summit of Tangent Peak is occupied by a bluishgray limestone, below which occurs a dark, siliceous, cherty band, in turn underlaid by dark-gray limestones. The recorded strike is north $16^{\circ}$ east, with a gentle dip to the northwest. No fossils were found, except fragments of coral stems, too poor for identification. Just north of Tangent Peak, the spurs fall off somewhat abruptly, and a low saddle, with both east and west cañons, or valleys, separates the mountains into two distinct ridges. Both of these cañons are marked by broad, shallow basins, with. gentle sinpes between the limestone ridges. In both valleys, there is a very considerable development of horizontal Tertiary beds, extending nearly to the summit of the divide, which have escaped erosion and concealment beneath the Quaternary deposits. These beds resemble the fine sands, reddish gravels, and marls which form the Humboldt Pliocene beds of Eastern Nevada, and have been referred to the same horizon.

The terrace-lines, which form so characteristic a feature of the basin, are so prominent and well defined along the slopes and foot-hills as to have given the name to this range of mountains. They are remarkably well shown on the Tertiary strata, where seven broad, nearly level, benches may 
be counted, beaches of the more constant shore-line, while several others, not so well preserved, have left more or less indication of the receding waters of the basin. Barometrical observations were made at our camp in the Terrace Mountains, and from there careful instrumental determinations of the height of the upper beach-line. These observations were referred to our station-barometer at Matlin, and these again corrected by the railroadlevels as a base. This measurement agrees very closely with determinations made at Black Rock Point, where the position of the terrace was found, by a series of careful observations, to be 940 feet above the lakelevel. South of the railroad, for 5 or 6 miles, the depressions of the Terrace Mountains are in many places below the level of the old lake, the greater part of the range, like the Promontory, having stood as an island in the sea. In these low, narrow depressions, the action of the shallow water upon the shore is very clearly shown, with the beach-lines extending across the range from east to west. Considerable accumulations of Quaternary material skirt the base of the range, concealing the limestone slopes in many places for several hundred feet. It consists of beds of loose gravel and sand, and fine conglomerates, containing fragments of calcareous tufa, which also frequently serves as a cement, or binding material, for the conglomerate. The two groups of hills which rise out of the desert to the southwest of the Terrace Mountains, known as the Rocky and Desert Hills, were not visited by our parties. They have, however, been referred provisionally to the Lower Coal-Measure formation, on grounds of general analogy with the structure of this region, which is supported by the meagre facts with regard to the rocks which compose them, which it has been possible to obtain from those who have visited these almost inaccessible points. RAFT River Mountains.- In the southern end of the Raft River Mountains, a very considerable body of granite forms the central mass of the range. It measures 10 or 12 miles in a north and south direction, and 6 to 8 miles in width at its broadest expanse, culminating in Citadel Peak, a fine summit which rises nearly 2,500 feet above the level of the lake. On the south and west, it is covered by heavy beds of limestone, folding completely around its flanks, which have been referred to the Lower Coal-Measure formation; while on the east side it falls away gradually with easy slopes toward the valley of Clear Creek, until concealed by the 
recent Quaternary deposits. The rock is a nearly structureless, mediumgrained granite-mass, characterized by uniform texture and a pearl-gray color, and composed of the normal granitic constituents, quartz, feldspar, and mica. It decomposes readily; its surface being generally covered with detrital material, while the spurs and ridges everywhere present smooth, rounded outlines, with many fanciful forms of erosion.

The range to the north of the wagon-road was but cursorily examined. Next to the granite, to the north, are hard, compact, steel-gray slates, which pass into dark-bluish limestones, intercalated with cherty bands, in which no fossils were found. The main ridge to the north seems to be mainly composed of similar blue limestones, generally thinly bedded, with a large development of dark-colored argillaceous and calcareous shales, splitting into very thin laminæ, having a north and south strike, and dipping to the eastward. A microscopical examination shows that the dark color of these slates is due to a mixture of opaque black particles, probably of carbonaceous material. A few fossiliferous beds were observed, from which were obtained an Aviculopecten, whose species could not be determined. The western slopes of the range are covered high up on the flanks by heavy white beds, sloping gently toward the centre of the valley, composed of fine, white, pumiceous sands, loose sandstones, and fine conglomerates, which have been referred to the horizon of the Humboldt Pliocene, from their general resemblance to these beds as developed in the valley of the Upper Humboldt.

At the southernmost extremity of the mountains, and just below the granite body, occurs a somewhat isolated group of hills, which, in their geological character, differ somewhat from the formation surrounding the granite to the west, but which have, nevertheless, been referred to the same horizon. Their structure is evidently somewhat complicated, and was not made out very clearly. The same dark, steel-gray slates are seen as in the pass, and would appear to be the underlying rock. . Dark-brown quartzites carrying small amounts of carbonate of lime and dark bluish-gray limestones make up the series of the beds. These hills are traversed by dikes of fine-grained intrusive rocks, which, under the microscope, present an exceedingly fine crypto-crystalline base, filled with countless numbers of minute microlitic forms, fragments of triclinic feldspar, and a few grains of magnetite. Along the base of the higher ranges, and bordering the desert at irreg- 
ular intervals, west of the Terrace Mountains, are small isolated buttes and knolls of Tertiary volcanic rock. In exceptional instances, as at Desert Butte, they rise from 500 to 600 feet above the plain, but in general are small, low hills, mostly concealed by the Quaternary deposits. Several of the smaller outcrops occur along the south and southeast spurs of the Raft River Mountains, but occupy so small an area that they have not been designated on the maps. So far as examined, they appear all to be rhyolites, with considerable variety in texture and aspect, but in general more allied to the compact, porcelain-like kinds than to the rough, porous types. The rhyolite of Desert Butte, which is situated near the wagon-road, some 5 miles to westward of the Raft River Mountains, may be considered as a typical variety. In its physical habit, it is a dense, compact rock, exhibiting to the naked eye almost a homogeneous groundmass, and breaking under the hammer with a sharp angular fracture. In color, the prevailing tint is a light reddish-gray, shading off into white or salmon. The rock would be very uniform in texture but for the occurrence of rough spharulitic bodies and the characteristic lithophysæ. Narrow seams and lines of semi-transparent chalcedony traverse the rock in various directions. In a hand-specimen, the rhyolite somewhat resembles a quartz-porphyry, with small grains of brilliant white quartz and feldspar scattered through the groundmass; except that the minute feldspars have the characteristic lustre and habit of volcanic rocks. Under the microscope, the quartz-grains are seen to abound in glass-inclusions. Professor Zirkel has detected the presence of tridymite, occurring in hollows and cavities of the rock, and suggests that it is a secondary product, as it is often seen overlying iron-ochre and earthy ferrite, which are themselves of later origin than the rhyolite. Well-marked terraces form a prominent and somewhat curious feature of the Desert Buttes. The broad terrace measures 6 to 8 feet in width, being nearly level, and about 125 feet below the summit. This same terrace may be traced with a pocket-level for a considerable distance along the shore of the northern bay of the old lake, extending up the valley, west of the Raft River Mountains. Four distinct, plainly-marked terraces may be seen from this point, showing at favorable points level benches, 30 to 40 feet in width, cut in the solid rock, below which the slopes shelve off very abruptly. 


\section{SECTION VI.}

LAKE REGION.

BY S. F. EMMONS.

Great Salt Lake.-The Great Salt Lake of Utah is a broad, shallow sheet of water, occupying the lowest portion of the Utah Basin, 80 miles in length in its greatest extension in a northwest and southeast direction, and about 32 miles wide at its greatest average lateral expansion. Its bottom is evidently even more level than the broad desert-valleys which surround it, since at its deepest points its waters do not reach a depth of 50 feet, while a very large proportion of its area, comprising broad belts along the shoreline and the partly-enclosed bays, have less than 10 feet of water. The line of deepest depression is that extending northwest from Black Rock Point, between Stansbury and Antelope Islands, and to the west of the Promontory Mountains. This valley averages about 40 feet in depth below the present surface of the lake, while in no other portion of the lake, except in the immediate vicinity of Frémont's Island, are depressions of more than 20 feet found. It receives its supply of fresh water from four large streams, the Bear, Ogden, Weber, and Jordan Rivers, which, with a few minor mountain-streams from the western slopes, bring down the drainage of all the surface of the Wahsatch Range and the eastern portion of the Uinta Range, while a small but continuous supply of salt is furnished by the numerous springs which occur along its shores.

As it has no outlet, this great influx of fresh water would rapidly raise the level of the lake were it not for the enormous evaporation that takes place in this dry region, where the average difference in summer between the wet- and dry-bulb thermometers is from $20^{\circ}$ to $30^{\circ}$ (Falirenheit). The level of the waters of the lake is, therefore, subject to changes depending on oscillations in climate and variations in the condensing power of the atmosphere from year to year. It might naturally be expected that there would also be some variation in the level of the lake at different seasons of the year, but it is probably slight, and no data have been obtained 
with regard to it. Of the great climatic oscillations, traces are seen in the lake-terraces, which stretch along the flanks of the surrounding mountains, and show that at one period the waters of the lake were over 900 feet higher than at present. With regard to the changes in the height of the water-line from year to year, which are dependent on the varying relation of atmospheric evaporation to condensation, it is impossible to obtain absolutely accurate data, since up to the year 1869 no fixed datum-point had been established by which this height could be determined. It is known, however, from information obtained from the Mormon settlers and others, with regard to the water-line on different shoal portions of the lake, that during the eight years preceding the date of our survey of the lake (1869), there had been a general rise of about 11 feet in the level of the waters of the lake. The remarkable flatness of its immediate borders is well shown in the great increase of surface covered by the waters produced by this comparatively slight change of level. The superficial area of the lake, excluding the islands, as shown by this map, is 2,360 square miles, an increase of about 40 per cent., or 660 square miles, over that given by Stansbury's map, ${ }^{1}$ which is only 1,700 square miles. It is true that Stansbury's survey was made in 1849-5(), or 11 years earlier than the time from which the rise of 11 feet is dated; but it is evident, from the depth of water found at given points along his shore-line, that the level of the surface in 1861 must have varied but little, if any, from that of 1849 .

One of the most striking peculiarities of this lake is the great density and pungent bitterness of its waters. This is practically shown by the fact that the human body floats up entirely on the surface like a cork, and that the pain produced by water which enters the eye is almost blinding. It is generally stated by the Mormon settlers that during the early days of their settlement they used to obtain one barrel of salt from three barrels of water. The water obtained by Stansbury in 1850 contained 22.4 per cent. of mineral salts. In 1869 , the solution had become much diluted by the addition of so great an amount of fresh water, and it contained, as will be seen, only 14.8 per cent. of solid matter.

An analysis of several gallons of the water of Salt Lake, obtained by our parties in the summer of 1869 from near Black Rock Point, where the

'Stansbury's Expedition to the Great Salt Lake, 1852. 
influence of the fresh water from the tributary streams would not be felt, and made with the utmost care and thoroughness by Prof. O. D. Allen, of New Haven, gare the following results:

One thousand $(1,000)$ parts of water eraporated to dryness left a solid residuum of-

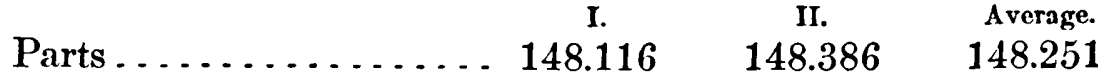

An analysis of this solid residuum gave:

\begin{tabular}{|c|c|c|c|}
\hline Magnesia.......... & $\begin{array}{l}\mathrm{I} . \\
6.477\end{array}$ & $\begin{array}{l}\text { II. } \\
.6 .126\end{array}$ & $\begin{array}{r}\text { Average. } \\
6.301\end{array}$ \\
\hline Lime $\ldots \ldots \ldots \ldots, \ldots$ & 0.369 & 0.344 & 0.357 \\
\hline Soda $\ldots \ldots \ldots \ldots \ldots$ & 66.789 & 67.168 & 66.978 \\
\hline Potassa .............. & 2.949 & 2.854 & 2.901 \\
\hline Sulphuric acid ......... & 8.090 & 8.340 & 8.215 \\
\hline Chlorine...$\ldots \ldots \ldots \ldots$ & 84.053 & 83.839 & 83.946 \\
\hline
\end{tabular}

Less oxygen of soda and magnesia ......... 18.758

149.940

Theoretically combining acids and bases, we have:

Chloride of sodium ...................... 118.628

Chloride of magnesium .................. 14.908

Sulphate of soda...................... $\quad 9.321$

Sulphate of potassa ..................... $\quad 5.363$

Sulphate of lime ..................... $\quad 0.858$

Excess of chlorine ...................... $\quad 0.862$

or, in 100 parts,

149.940

Chloride of sodium ..................... $\quad 79.11$

Chloride of magnesium................... $\quad 9.95$

Sulphate of soda ...................... $\quad 6.22$

Sulphate of potassa $\ldots \ldots \ldots \ldots \ldots \ldots \ldots \ldots \ldots, \quad 3.58$

Sulphate of lime........................ $\quad 0.57$

Excess of chlorine ...................... $\quad 0.57$

100.00

28 D G 
$\Lambda$ drop of the water, without concentration, gave spectra of potassa and lithia; a faint reaction for bromine and boracic acid was also obtained.

In this connection, it is interesting to note an analysis of the surfacesoil from a mud or alkali flat, not far from the lake-shores, between Salt Lake City and Black Rock Point. The material collected contained 16.40 per cent. of soluble matter, composed as follows:

\begin{tabular}{|c|c|c|}
\hline Calcium & 6.16 & 6.28 \\
\hline Magnesium . . . . . . . . . . . . . . & 2.22 & 2.16 \\
\hline Sodium $\ldots \ldots \ldots \ldots \ldots \ldots \ldots \ldots$ & 29.62 & 29.45 \\
\hline Potassium . . . . . . . . . . . . . . & 0.46 & 0.46 \\
\hline Chlorine........................ & 57.97 & 57.83 \\
\hline Sulphuric acid $\ldots \ldots \ldots \ldots \ldots \ldots$ & 3.72 & 3.44 \\
\hline \multirow[t]{2}{*}{ Oxygen equiv. $\mathrm{S}_{3} \ldots \ldots \ldots \ldots \ldots$} & 0.74 & 0.68 \\
\hline & eoretically combined: & 100.10 \\
\hline Chloride of sodium ............. & 71.43 & 71.05 \\
\hline Chloride of magnesium. ........... & 8.80 & 8.55 \\
\hline Chloride of potassium... & 0.88 & 0.87 \\
\hline Chloride of calcium ....... & 11.94 & 12.11 \\
\hline Sulphate of lime $\ldots \ldots \ldots \ldots \ldots \ldots$ & 6.31 & 5.84 \\
\hline \multirow[t]{2}{*}{ Excess of sodium $\ldots \ldots \ldots \ldots \ldots \ldots$} & 1.53 & 1.68 \\
\hline & 100.89 & 100.10 \\
\hline
\end{tabular}

In composition, these salts show a remarkable analogy to those of the waters of Salt Lake, from which, at no very remote period, they must have proceeded. The relative proportions of chlorides of calcium and magnesium remain the same, but a portion of each has been replaced by the lime of the soil. It is noticeable that in this soil, as in that of the Great Desert, the alkaline chlorides are present in great abundance, but the alkaline sulphates are wanting. It is interesting that in the waters of a lake containing so much mineral matter in solution, and which lies in a region of limestone rocks, so little lime should be found in solution as the above analysis shows. As the sulphates and carbonates of lime are, however, easily precipitated, it is probable that, in the solution presented by the waters of Salt Lake, they 
are unusually insoluble, and that those which are brought in by the tributary streams are almost immediately thrown down. That lime has been in solution in the waters is proved by the peculiar sands found on the beach at various points, notably at Black Rock Point and along the southern end of the Terrace Mountains. These sands are made up of little spherical grains of white, opaque carbonate of lime, up to one-tenth of an inch in diameter. An analysis made of them by Mr. R. W. Woodward gave the following results :

Ferric oxide and alumina . . . . . . . . . . 0.25

Lime

Magnesia .....................

0.82

1.02

So

Potassa.......................

$0.77 \quad 0.73$

Sulphuric acid .

$0.36 \quad 0.32$

Carbonic acid

0.52

Chlorine

40.74

40.74

Water.

trace

trace

Insoluble residue

$100.01 \quad 100.20$

Under the microscope, they are seen to have a rudely concentric structure, and may therefore be considered to be a concretion formed around some nucleus perhaps of organic origin, or perhaps some minute grain of siliceous sand. As has already been mentioned, similar deposits have been found in the Tertiary beds of the Green River Basin, compacted into a rock, and in some cases silicified.

The lake contains no fish, and was long supposed to be absolutely devoid of animal life, although the tributary streams abound in fresh-water fish, such as perch and trout, and the latter are even found in the Hot Spring Lake. Mr. Sereno Watson, of this Survey, has, however, discovered a minute crustacean which inhabits its waters, and which has been described by Prof. A. F. Verrill ${ }^{1}$ as Artemia fertilis. The shores of the lake 
are, moreover, covered in places, for a width of several inches, with the larve and pupæ of insects which live in its waters, among which have been described

\section{Ephydra gracilis, Packard.}

For the comparison of this great interior salt lake with those known in other parts of the world, the following table has been prepared, giving the analyses of the waters of some, whose physical conditions present points of resemblance with this, together with the composition of the water of the ocean, derived from a mean of nine analyses made of water taken from the Northern Atlantic and German Oceans, and one of the Mediterranean Sea:

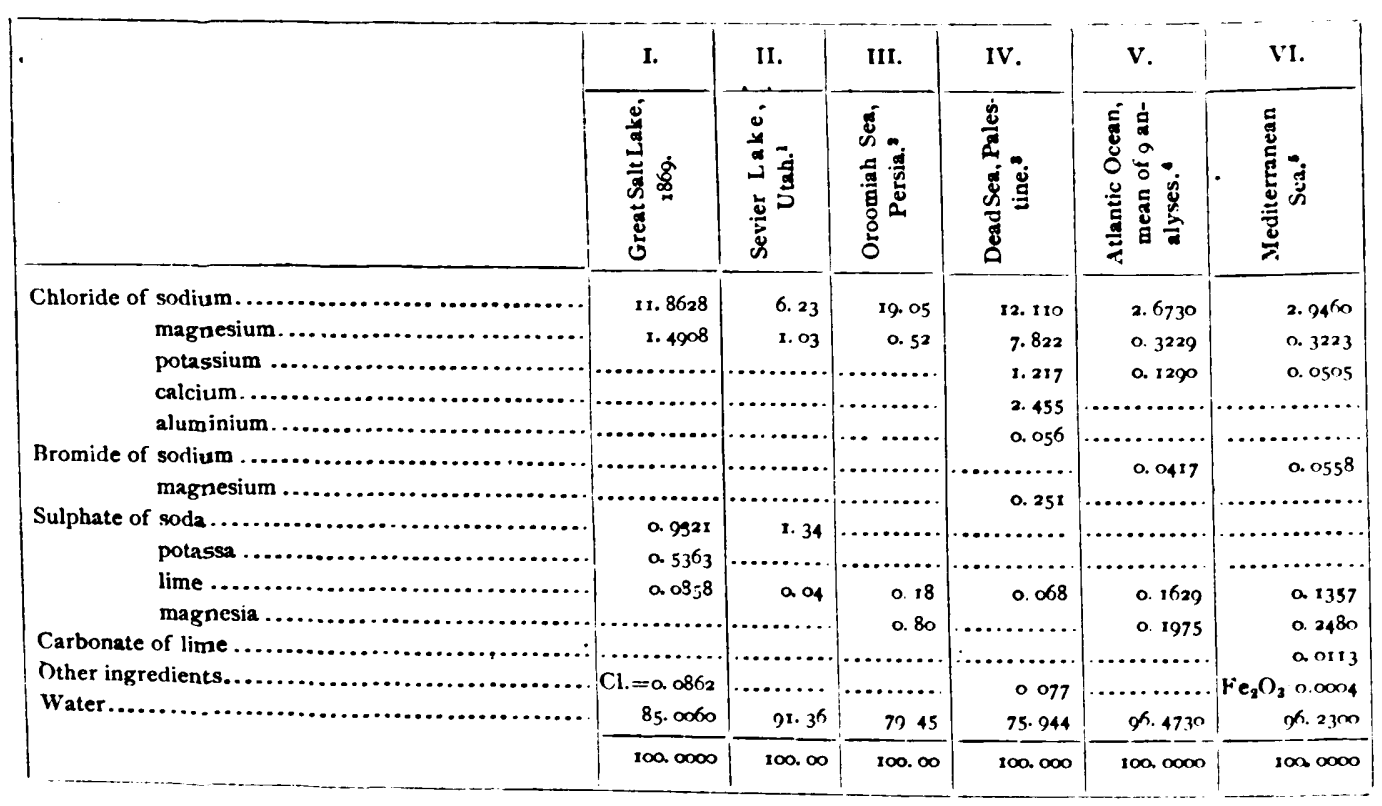

Of these, the Sevier Lake lies in the Utah Basin, to the southward, within the limits of the ancient Lake Bonneville, being fed by a single river, the Sevier, which reaches it after a comparatively long course through a desert region. Its superficial area is only about a tenth of that of Salt Lake.

The Oroomiah Sea of Northwestern Persia presents some remarkable

1 Wheeler, Expl. W. of 100th Merid., iii, 1875, 114.

${ }^{2}$ Bischoff, Chem. Geol., ii, 1864, 59.

${ }^{3}$ Bischoff, Chem. Geol., i, 1863, 313.

4 Bischoff, Cbem. Geol., ii, 1864, 33.

s Ramsay, Nature, vii, 313 . 
points of resemblance to Salt Lake. It is situated at 4,000 feet above sealevel, is 80 miles long, and 30 miles in average width. Its shores are very flat, and it is subject to annual variations of level of 3 to 6 feet. Its supply of salt is supposed by Edw. Hitchcock to be derived from Triassic sandstones, as there are salt streams flowing into it from them. Salt Lake, on the other hand, is not connected, so far as known, with any salt deposits by its tributary streams, which have no perceptible salt taste. Deposits of salt are known to exist, however, in rocks of the Jurassic age, which may have been connected with Lake Bonneville.

The Dead Sea of Palestine is 60 miles long by 15 miles wide, and has an extreme depth of 1,800 feet, while its surface is over 1,300 feet below the level of the Mediterranean Sea. The depression occupied by the Dead Sea and the Lake of Tiberias is supposed to have been once occupied by the Mediterranean, and, having been cut off, to have reached its present concentration of salts by evaporation. In this respect, it resembles Salt Lake, which is the concentration of Lake Bonneville. It is also subject to changes of level of 15 feet, and has extensive deposits of mineral salts on its borders, like those of the Great Desert. The water of Salt Lake differs from it principally in its smaller proportion of magnesia and lime.

In its relative proportion of soda and magnesia, it resembles more closely the composition of ocean salt than that of either of these two lakes.

The two shore-lines on the east and west sides of Salt Lake present the greatest contrast in appearance. On the west, the shallow waters of the lake merge almost imperceptibly into the flat plains of the Great Desert, which will be described in a later section. On the east, green meadows, intersected by mountain-brooks, stretch up to the foot of the rugged slopes of the Walssatch. From Ogden Point south to Salt Lake City, the immediate shores of the lake are occupied by varying widths of low marsh-land, which are continually being encroached upon by the rising waters of the lake. Along the flanks of the mountains are comparatively steep slopes of Quaternary gravel and soil, which sometimes extend out in terrace-like ridges, composed, as far as can be seen, of loosely agglomerated sandstones and gravel conglomerates. These are principally developed near Ogden City and to the south and west of the mouth of the Weber Cañon, and represent a formation, probably of Pliocene age, which once occupied the valley. 
At the point of the projecting spur of the Wahsatch, just north of Salt Lake City, a warm sulphur spring gushes out of the Wahsatch limestones, sending down a little stream, some 6 feet wide, of sulphurous waters, into the little arm of the lake called Hot Spring Lake. These waters, like most of the springs around the lake, contain chloride of sodium as their principal mineral ingredient. Between this point and the city is another warm spring in the limestone, whose waters contain some sulphuretted hydrogen. At this spring are baths, much used by the inhabitants. The following analysis of its water, made by Dr. C. T. Jackson, is exposed in the bathing establishment: "Three ounces of water, evaporated to dryness, gave 8.25 grains of solid matter.

Carbonates of lime and magnesia . . . . . . . . . 0.240

Peroxide of iron .................... 0.040

Lime . . . . . . . . . . . . . . . . . . . . . . . . 0545

Chlorine ........................... 3.454

Soda ............................... 2.877

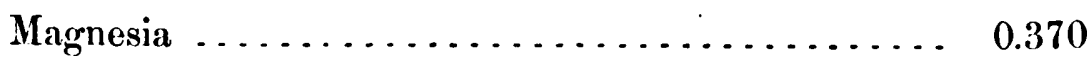

Sulphuric acid $\ldots \ldots \ldots \ldots \ldots \ldots \ldots \ldots \ldots \ldots . . .603$

8.229

"It is slightly charged with sulphluretted hydrogen and carbonic acid."

It is interesting to note the occurrence of these hot springs with those at Ogden and in Bear River Valley, occupying a line just west of the foot of the thountains, which is approximately that of the great system of faults which have thrown down the western side of the range, and nearly parallel with the line of volcanic outbursts on the eastern flanks.

Salt Lake City itself is situated upon the gently-sloping plains of Quaternary gravel, just at the base of one of the broader and more prominent, though by no means the highest, of the old lake-terraces. It is about 7 miles distant from the lake, which, owing to the flatness of the shores, cannot be seen from the level of the city. From the terrace above the city, however, a view is obtained to the westward over the lake to the mountain- 
ridges, which rib the desert beyond, while to the south lies outstretched the broad beautiful valley of the Jordan.

JoRdan VaLLey.-Jordan Valley is a broad Quaternary plain from 15 to 20 miles wide, which, on the eastern side, rises from the bed of the river in long, gentle slopes and gravel terraces, several hundred feet, toward the base of the mountains. In the alluvial bottoms of the streams, and in some cases on the gravelly benches, the Mormon settlers have cultivated their farms, utilizing the slope of the valley and the abundant supply of water furnished by the streams issuing from the Wahsateh Mountains for irrigating the fields, which the almost rainless summers of this region would otherwise dry up. Along the mountain-flanks, the different lines of the old lake-terraces can be distinctly traced, the highest of which rises 940 feet above the present level of the lake. The depth of the Quaternary gravels cannot be definitely determined, but must be very considerable in the centre of the valley, as shown by the thickness exposed where the Jordan River cuts through the Traverse Mountains, which amounts to several hundred feet. At the mouths of some of the cañons, where the mountain-streams have cut deeply into these gravels, stratified beds of loose, coarse sandstones and conglomerates are seen, which doubtless represent the Pliocene valley deposit, perhaps contemporaneous with that of Cache Valley. So little definite data were obtained with regard to these deposits, loweyer, that they have not been indicated upon the map. The best exposures of them in Jordan Valley are seen at the mouth of Parley's Cañon, where the erosion of the present stream has exposed a thickness of about 70 feet of horizontal, coarse, reddish sandstones. From the lake-terraces back of Salt Lake City was obtained the upper portion of the skull of a musk-ox, its horns and frontal bone well preserved and partially silicified, showing that the formation of these terraces was already in progress at the close of the Glacial period. On the west side of the Jordan, the slopes of the valley are more gentle and regular; but, owing to the smaller supply of water coming from the mountains on that side, there has been little cultivation of this portion of the valley, and it is principally used as a grazing-ground.

Traverse Mountains.-Jordan Valley is bounded on the south by a 
low range of hills called the Traverse Mountains, which form a partial connection between the Wahsatch Range and the Oquirrh Mountains. These hills rise only about 2,000 feet above the valley, and show but few good exposures of the rocks which compose them, their slope being generally covered with gravel and detrital material. They seem to be composed mainly of trachyte, thre flows of which extend close up to the flanks of the bounding ranges, and on the western side extend along the foot-hills of the Oquirrh as far as the mouth of Bingham Cañon.

It is probable that this trachyte-flow was preceded by an ejection of andesite, since among the specimens brought in from this range was one which a microscopic examination has proved to be andesite, though, owing to the fact that its locality cannot be well determined, this rock has not been indicated upon the map. It is a dark-gray rock, having a decidedly trachytic feel, the groundmass being very porous, and containing a few microscopical crystals of hornblende, with an occasional mica. Under the microscope, it is seen to be composed of plagioclase, with a little sanidin-feldspar, a large amount of dark-brown homblende in crystals, which show little alteration, and a small quantity of augite, while the groundmass, which is rich in gray glass, consists of an interwoven mass of microlites, which is characteristic of the andesites of the Wahsatch region.

The trachyte of the eastern end of the Traverse Mountains is a dark bluish-gray, sometimes reddish, crystalline rock, made up of large crystals of sanidin-feldspar and mica, with such a small proportion of groundmass that at a little distance it might be taken for gmite. While the larger feldspars are almost all sanidin, a considerable amount of plagioclasefeldspar can also be detected in the mass. It is also rich in hornblende, which is comparatively unaltered. Under the microscope, the fresher feldspars are seen to have a zonal structure, and to be rich in glassinclusions containing large bubbles. Considerable greenish-yellow augite and apatite are also detected, but no quartz. The groundmas is made up of felsitic microlites and magnetite grains inclosed in a glassy base. Near the point of contact with the granite mass of Lone Peak, there is found a greenish-white, earthy, decomposed rock, in which the only traces of crystallization left are white irregular spots of partially kaolinized feld- 
spar. Of the sedimentary rocks which underlie this trachyte flow, only a few exposures were found along the northern slopes of the eastern half of the Traverse Mountains. They consist of white quartzites, and, in a cut made by the railroad not far from the point of the hills, of a blue quartzite having the external appearance of a limestone. Their structure-lines were too much obscured to afford indications of their age on stratigraphical grounds, but, from their lithological habit, they have been provisionally assigned to the Cambrian quartzites, which they most resemble.

The trachyte of the western portion of the Traverse Mountains is a reddish rock, containing large crystals of sanidin and considerable bronzecolored mica, together with some hornblende. The groundmass is very vesicular, and contains some glassy base. In Rose's Cañon is found a lightgray trachyte, having a laminated structure, rich in crystals of hornblende and mica, showing comparatively few macroscopical crystals of sanidin. While the dark trachytes of the range belong rather to the normal sanidintrachyte group, this rock may be more properly classed among the hornblende-trachytes, and somewhat resembles the andesite above mentioned, which probably came from near the same locality. Near the mouth of Bingham Cañon was found a rock which, in the field, was considered a rhyolite, consisting of a breccia-like felsitic groundmass, containing grains of free quartz; but, as the specimens obtained have been lost, the occurrence has not been colored upon the map.

U rah LaKe VaLLEY.-Utah Lake is a beautiful body of fresh water, about 20 miles long by 4 or 5 miles in width, which receives the drainage of the southern portion of the Wahsatch Mountains and a portion of that of the southwest slopes of the Uinta Range. It is nearly 300 feet above Salt Lake, into which its surplus waters flow through the Jordan River. Like the latter lake, its shores are very flat and shallow, especially along the eastern side, where the valley-slope from the foot-hills of the Wahsatch Range to the water's edge is even less than in the Salt Lake Valley. The old laketerraces form prominent lines along the faces of the mountains which surround it, and are especially developed at the gap in the Traverse Mountains through which the Jordan River flows, and where they show immense accumulations of fine gravel. The upper terrace-line, which could be distinctly 
recognized on the soft slopes of the Traverse Mountains, was determined by barometrical measurement to be 870 feet above the level of Salt Lake.

The Pelican Hills constitute a low, flat-topped ridge which borders Utah Lake on the west, made up of thinly-bedded gray and blue limestones, with intercalated lighter-colored arenaceous beds and quartzites, closely resembling those which form the summit of Timpanogos Peak, to which the few fossil remains obtained from them, consisting chiefly of Spirifers and Crinoid stems, also ally them. They probably represent the upper members of the Lower Coal-Measure group. The strata are nearly horizontal; on the eastern slopes of the ridge having a slight inclination to the westivard; while on the west side they dip nearly $10^{\circ}$ to the eastward, showing a slight synclinal fold. This easterly dip is continued in the southern portion of the hills, beyond the limits of thə map. From the comparatively horizontal position of the strata, it would seem that this mass must have been faulted up. 
OQUIRRH MOUNTAINS.

\author{
SECTION VII. \\ REGION SOUTH OF SALT LAKE.
}

BY S. F. EMMONS.

Oquirri Mountains.-The Oquirrh Mountains are a high, steep mass of hills lying to the westward of Jordan Valley, about thirty miles in length and from five to ten miles in width, whose summits rise from 5,000 to 6,000 feet above the surrounding plains. They are composed mainly of beds of Carboniferous limestones and quartzites, which the forces of contraction, acting almost equally in either direction, have compressed into a series of complicated folds, in which the prevalent strike, however, is in a northwesterly direction. The folding of these beds has been accompanied by a very considerable metamorphism and by the injection of porphyritic dikes, together with subsequent mineralization in the more disturbed districts. The southwestern portion of the range, to the west of the main ridge, is a quaquaversal uplift in the Wahsatch limestones, in the centre of which, at Ophir City, a faulting at right angles to the longer axis of the uplift has brought up the upper beds of the Cambrian. From Ophir City, as a centre, these limestone strata all dip away, steeply toward the west, more gently toward the north, east, and south.

The main crest of the range, between Tooelle and Lewiston Peaks, is the remnant of the flat arch of an anticlinal fold, which descends both to the north and to the south, resulting at the south point of the range in two minor synclinal folds, in Pole Cañon and in the cañon south of Lewiston, and a similar synclinal fold to the north, in the region between Soldier Cañon and Tooelle Cañon. In the region between Tooelle Peak and Connor Peak, more particularly in Bingham Cañon, which is almost entirely in the beds of the Weber Quartzite, the structure-lines are much more difficult to follow, and evidently the general system of folding observed in the southern portion is much complicated by minor folds; but its structure is in general that of a synclinal fold in these beds, while at the northern point 
of the range, beyond Connor Peak, the beds of the Lower Coal-Measure group are found to be pushed up and crumpled together in short, sharp folds, giving, in an east and west section across the northern point, no less than three small anticlinals, while the tendency of all the beds is to dip steeply beneath the waters of the lake.

East Cañon is a deep, narrow gorge cut at right angles to the western anticlinal, or quaquaversal, already mentioned. At Oplir City, a steep wall of dark siliceous limestones rises perpendicularly on the south to a height of 2,000 or 3,000 feet, while in the opposite direction, about an eighth of a mile to the north of the cañon-bottom, a sheer wall of quartzite, from 300 to 400 feet in height, cuts off abruptly the tributary sidecañons from the north. Beyond and above this wall of quartzite is an amphitheatre-like opening, shut in by a semicircular wall, rising in places to a height of 2,000 feet, formed of outwardly-dipping beds of limestone. The line of faulting, so distinctly shown by this quartzite wall, has a direction of about north $30^{\circ}$ east, and discloses a thickness of about 400 feet of compact reddish-white Cambrian quartzites. Above these are about 100 feet of greenish-yellow clay-slates, in which were found numerous Trilobites and Primordial fossils, among which the following have been determined by Messrs. Hall and Whitfield:

Ogygia producta.

Ogygia parabola.

Ogygia, new sp.

Lingulepis, new sp.

Kutorgina, new sp.

Dikellocephalus, sp. 8

Dikellocephalus, sp.?

From their stratigraphical position, and their correspondence both in their horizon and fauna, with those found in the Wahsatch Mountains at City Creek, these beds evidently belong to the Potsdam group, although some of the above fossils have been assigned to the Quebec group by Messrs. Hall and Whitfield. In the limestones immediately above them, no fossils have, as yet, been found. But beyond the ridge to the 
north, at a geological horizon of about 2,000 feet higher, are found abundant Sub-Carboniferous and Waverly forms. ${ }^{1}$

In the intermediate 2,000 feet, however, no considerable body of quartzite can be recognized which would lithologically correspond to the Ogden Quartzite. The limestones contain numerous siliceous and cherty bands, but do not differ essentially from those of the Wahsatch group. It therefore remains, in some measure, an open question whether the Silurian or Ute limestone is represented here, or whether this Cambrian quartzite, with its overlying shales, has been faulted up as a wedge-shaped mass, and the limestone beds here all belong to the Wahsatch limestone. On account of the decomposable nature of the shale bed which overlies the quartzite, it cannot be definitely determined whether, to the north of the fault-line, the overlying limestones are conformable or unconformable with the Cambrian beds. The dip of the quartzites at the line of fault is only about $10^{\circ}$ to the northward. In the Miner's Delight Mine, whose whole ore-body was at first within the shale belt, an incline which has been sunk in a northerly direction, at an angle of about $15^{\circ}$, steepening in depth to about $20^{\circ}$, has, at a short distance from the surface, passed out of the shales into solid limestone. The fact that this incline seems to dip steeper than the stratification-planes indicates that the quartzite and shales have been faulted up as a wedge-shaped mass, otherwise it should have passed into quartzite instead of limestone beds. On this supposition, which is the one followed on the map, no lower beds are exposed in this cañon, with the exception of those brought up by the fault, than the Devonian limestone underlying the Waverly.

At the mouth of East Cañon, the limestones dip steeply to the westward, at an angle of $65^{\circ}$, striking nearly north and south. This dip is continued along the foot-hills of the range to the northward toward Dry Cañon, the next little cañon to the north; here the strike of the beds curves round somewhat to the east of north, while the dip of the beds shallows to $45^{\circ}$. In Dry Cañon, a considerable number of fossils of Sub-Carboniferous

${ }^{1}$ Dr. C. A. White describes an Olenellus Gilbcrti (Potsdam) from Ophir City, and Spirigera obmaxima, Euomphalus luxus, and a Conocardium (Snb-Carboniferous) from below Ophir Cits.-(Wheeler, Expl). W. of 100th Merid., Vol. IV, Part I, 44 aud 92 ct seq.) 
and Waverly types have been obtained by our parties, and, since the completion of our field-work, by Mr. J. E. Clayton. The vertical range of the fossils obtained from this cañon, which have all a Sub-Carboniferous or Waverly aspect, shows a much greater development of these beds in the Oquirrh Mountains than in the Wahsatch. From the westerly-dipping beds near the mouth of the cañon, in a blue limestone, were obtained the following Waverly forms:

Streptorhynchus inflatus.

Strophomena rhomboidalis.

Spirifer alba-pinensis.

Spirifer centronatus.

Rhynchonella pustulosa.

Euomphalus Utahensis.

Euomphalus (Straparollus) Ophirensis.

Michelina, sp.?

Zaphrentis, sp.?

By Mr. J. E. Clayton, from the ridge above, between Dry Canon and East Cañon, in a close-grained black !imestone, were obtained some of the same species, and:

Prö̈tus peroccidens.

Orthis resupinata.

Euomphalus latus var. laxus.

From the northern side of Dry Cañon, at a horizon, according to Mr. Clayton, about 1,200 feet higher, he obtained:

Trematopora.

Fenestella.

Polypora.

While farther to the north, on the ridge toward Soldier Canon, and still higher geologically, he found:

Productus lavicostus,

Productus elegans,

Productus semireticulatus,

Productus Flemingi var. Burlingtonensis, 
Spirifer striatus,

Spirifer setiger,

Spirifer Leidyi,

Athyris subquadrata,

which are regarded as Sub-Carboniferous.

To the south of the mouth of East Cañon, the strike of the beds curves round to the east of south, and, at Lewiston Cañon, is already nearly east and west, parallel with the cañon. Lion Hill, as the ridge between Lewiston and East Cañons is called, is a flat-topped ridge, consisting of a halfdome of limestone strata, cut off on the north by the fault of East Cañon, and sloping away with an ever-increasing dip east, south, and west. These beds are, toward the base, composed of dark, compact, fine-grained, more or less siliceous limestones, with some interstratified beds of shales and seams of black cherty material. On the flanks, toward Lewiston Cañon, there are found belts of a comparatively pure bluish limestone, which abound in remains of Spirifers, among which were recognized Spirifer opimus, the most abundant single species perhaps in this range. Between Lewiston and the southern point of the mountains, the beds of the Wahsatch limestone dip gently to the south and west, rising slightly to the eastward, until, in a line with the main crest of the ridge, they sink down again, passing under the shallow synclinal of Pole Cañon.

The section exposed in East Cañon would be somewhat as follows: Passing up through the steeply-dipping beds at the mouth for a distance of nearly a mile, the inclination of the beds gradually decreases, until, at Ophir City, they are on an east and west line, nearly horizontal, but have a slight inclination to the north and south. The cañon-walls are entirely in the limestones, the line of fault which has brought up the quartzite being to the north of the cañon. Above Ophir City, the beds are almost horizontal for some distance, and then slope off gradually to the east, the dip becoming steeper as one ascends the cañon until it reaches $45^{\circ}$. At the forks of the cañon, the limestones have a shaly appearance, owing to the frequence of thin interstratified seams of black chert. Above the forks, the dip shallows again, and near the head assumes a westerly inclination, forming a shallow synclinal, which can be traced to the south, following a line just west of 
the main crest, while all the beds have a general inclination southward. About midway between Ophir City and the forks, a branch-cañon from the south, by which the road to Lewiston passes, discloses a bed of soft black argillaceous shales, which follow the line of depression between the two cañons. From about this horizon, in Ophir Cañon, were obtained some specimens of Spirifer opimus. About a mile above this point were found, near the forks:

\section{Productus Prattenianus. \\ Spirifer opimus. \\ Naticopsis, new sp.}

From the head of the cañon, near the divide, were obtained:

Streptorhynchus robusta.

Chonetes granulifera.

Spirifer opimus.

Rhynchonella Osagensis.

The crest of the range between East Cañon and North Cañon is made up of limestone, with intercalated beds of sandstone and quartzite, resembling lithologically those of Timpanogos Peak, and abounding in excellent impressions of Productus Prattenianus and Spirifer opimus. These beds all dip at a very slight angle to the westward; the main ridge, from here north to the head of Tooelle Cañon, forming apparently the western member of an anticlinal fold. North Cañon cuts into the centre of this fold; but, as no fossils were obtained from this cañon, it is not known whether the SubCarboniferous and Devonian beds are here exposed or not.

From beds on the same line of strike to the southward, near Camp Floyd, the following fossils were obtained by J. E. Clayton:

\section{Orthis carbonaria, Streptorhynchus crassus, Productus Prattenianus, Productus multistriatus,}

which, however, only indicate a Lower Coal-Measure horizon, and re-affirm what the stratification-lines have already shown, that the beds gradually sink as a whole to the south of Lewiston Peak. 
At the mouth of North Cañon, the quartzite beds of the Weber group are found striking northwest and dipping to the eastward; their contact-line with the trachyte body of the Traverse Mountains following approximately the line of the road from Rose Cañon to Cedar Fort.

Northward from Dry Cañon, on the western side of the range, the anticlinal fold gradually sinks under the plain, and to the north of Soldier Cañon are found the lower beds of the Weber Quartzite, having a northwest strike, and dipping to the north and east. There seems to be here an insensible gradation from the beds of the Wahsatch limestone, which are intercalated with quartzite beds, into the lower beds of the Weber Quartzite, which contain interstratified beds of limestone.

In the quartzites on the foot-hills, between Stockton and Tooelle, is found an interesting occurrence of granite-porphyry, of which fragments are also found in the float coming down from Lewiston Cañon. It is a coarsely crystalline, grayish rock, containing large crystals of orthoclase, up to three-quarters of an inch in length, in a semi-crystalline groundmass, composed of quartz, feldspar, hornblende, and black biotite. It is remarkable for the distinct crystallization and fresh, unaltered condition of its constituent members; both hornblendes and micas show very sharply-defined hexagonal outlines, while the orthoclase is clear and translucent, having a delicate rose hue. The rock contains besides considerable titanite, which may be seen in comparatively large well-defined crystals within the larger crystals of orthoclase. A few of the orthoclases show a tendency to a zonal alteration. Besides titanite, these crystals contain also small hexagonal flakes of mica, and occasional crystals of homblende.

The beds of the Weber Quartzite, as seen along the foot-hills from Stockton to Tooelle, are mainly composed of a close, somewhat vitreous rock, stained by oxide of iron, and breaking easily into small fragments, so that the slopes are so covered with débris as to conceal the structure-lines. At the mouth of Tooelle Cañon, the quartzites are seen to have a strike nearly north and south, and to dip to the westward; the lower 1,000 feet being composed of a white compact quartzite. At the forks of Tooelle Cañon are exposed heavy limestone beds, lying conformably under these quartzites, which correspond to the upper members of the Lower Coal29 D G 
Measure limestone, as seen along the main crest, on a line due south from this point. The beds at the bottom of the canon are massive and somewhat argillaceous limestones, from which were obtained the following CoalMeasure fossils:

\section{Fienestella.}

Productus semireticulatus.

Productus Prattenianus.

Spirifer cameratus.

Spirifer opimus.

The limestone beds north of the fork bend in strike somewhat to the east of north with a dip to the northwest, and belong to the northern end of the eastern anticlinal fold, where it, to use the expression of the English geologists, "noses under" the overlying quartzites. The eastern member of the North Cañon fold, of which this is the northern point, has a much steeper dip and is less well defined than the western, and it seems probable that the folding has been accompanied with some faulting which has lifted up the western member; this would account for the character of the main crest of the range between Tooelle and Connor Peak, whose beds are nearly horizontal, and resemble in that particular the structure of the ridge of Timpanogos Peak. Passing up the north fork of Tooelle Cañon, the limestones soon disappear under quartzite beds; near the head of the cañon, already, a bed of yellowish-white quartzite seems to have a western dip, but this may be merely a local displacement.

On the divide between Tooelle and Bingham Cañons, occurs another body of granite-porplyry, somewhat similar to that already described on the western foot-hills. It is a light-green rock, in which the feldspar crystals are generally smaller and opaque, whereas, in the rock of the foot-hills, the feldspars are generally fresh and translucent. A few of the large translucent feldspars can be seen in this rock also. Its groundmass contains a much larger proportion of hornblende, which is of a dark-green earthy color, and almost no mica. No titanite was detected in this rock. Cnder the microscope, the hornblendes present remarkable phenomena of alteration, being changed into three distinct products, magnetite, epidote, and a leek- 
green fibrous mass, which will be found more fully described in Professor Zirkel's Report, Vol. VI, Plate III, fig. 2.

The mass of the range around Bingham Cañon, and to the south as far as the mouth of North Cañon, is occupied by the Weber Quartzites. The structure of this portion of the range is very obscure, owing to the broken and metamorphosed nature of the beds and the complicated position of the folds. On the eastern foot-hills of the range, opposite Lewiston Peak, the eastern dip is seen in the limestones of the Lower Coal-Measures as they gradually sink to the southward: the axis of the North Cañon fold passes through the low saddle on the spur to the south of the stream, showing that here, as in Tooclle Cañon, the eastern member of the fold is much the more abrupt. North of the mouth of North Cañon, the limestones pass by a gradual transition into the lower quartzites of the Weber group, which are seen striking northwest with a dip to the westward, forming the western end of the Traverse Mountains in contact with the trachyte body, and crossing the mouths of Rose and Butterfield Cañons into Bingham Cañon.

At the head of Butterfield and Bingham Cañons, they form the main crest of the range. In the latter, the easterly dip shallows near the forks, and steepens again below, while at the extreme mouth of the cañon the beds turn up steeply, and dip $60^{\circ}$ to the west. The section exposed in Bingham Cañon, therefore, represents in general a synclinal fold, whose eastern nember is short and abrupt; the whole series descends toward the north. In the north fork of Bingham Cañon, where the bedding of the quartzites is rendered more distinct by occasional interstratified calcareous beds, the observed strike was north $35^{\circ}$ east, with a dip $45^{\circ}$ to the northwest; while on the spur to the east of this fork, the strata curve around and assume gradually an east and west strike, and dip to the north and east. In Bingham Cañon itsclf, the quartzites are very much metamorphosed, broken, and stained with iron, and rich in silver-bearing minerals. Owing to the irregularity of the folds, it is almost impossible to estimate the thickness of this development of quartzite. It can hardly be less than that found in the Wahsatch Range, however, and seems to be much greater.

At the head of the south fork of Bingham Cañon is a diorite-dike, which 
resembles very closely that seen on the northwest face of Twin Peak. It is a fine-grained, grayish rock, containing black and bronze-colored mica and dark-green hornblende, in a fine-grained groundmass, made up largely of quartz and plagioclase-feldspar. The microscope discloses the presence of apatite, and the fact that the laminæ of mica are very much broken. 'This dike has a general northwest trend with the strike of the beds. The sides of Bingham Cañon, for a distance of several miles from its mouth, show the remains of gravel-terraces, made up of quartzite débris, which extend 50 to 100 feet above the bottom of the cañon, and show that, as in the cañons of the Wahsatch, the waters of the ancient lake formerly extended up into this cañon also. It was the finding of gold in these gravels that first directed the attention of the miners to the ore-beds in these mountains. In the quartzites of Bingham Cañon, Mr. J. E. Clayton succeeded in finding some fossil remains, among which have been recognized

\section{Archaocidaris, new sp., Martinia lineata, Polypora,}

and columns of Crinoids. The sharp synclinal fold on the eastern foot-hills is continued to the north of Bingham Cañon, and, at the eastern base of Connor Peak, quartzites are found striking north $15^{\circ}$ east, and dipping about $25^{\circ}$ to the westward. Some of the more thinly-bedded of these quartzites, of a compact cherty texture, show the effects of compression in the wavy undulating surface of the thinner sheets. Above these are reddish and yellowish limy shales, overlaid by blue siliceous limestones, whilo the summit of the peak is occupied by beds of soft, earthy, blue limestone, in which were found Spirifer and Productus, but too poor for specific determination. The dip of these upper beds is to the north and east. As palæontological evidence in this region offers no means of distinguishing between the limestone of the Upper and Lower Coal-Measures, this body has been ascribed to the Upper Coal-Measure group on purely stratigraphical reasons, from the fact that the quartzites of Bingham Canon apparently dip under the mass of Connor Peak. 
Owing to want of time, the structure of the range north of Connor Peak was not satisfactorily made out. Enough was seen, however, to show that the beds of this portion of the range had been plicated into east and west folds, as if they had been crushed against some unyielding mass at the northern point of the range.

At the extreme northwestern point, the beds dip $70^{\circ}$ northwest, with a strike of north $45^{\circ}$ east. These beds along the foot-hills are composed of white and iron-stained quartzites, which havo been designated by the color of the Weber Quartzite, though they may only represent some of the intercalated siliceous beds in the upper part of the Wahsatch limestone. Following the point of the mountain eastward, the beds assume a northeast strike, passing over a stoep anticlinal fold. From the limestones exposed opposite Black Rock at 800 to 1,000 feet below the uppermost beds shown, though it was impossible to determine at what depth below the quartzites already mentioned, were obtained the following fossils, whose general aspect is rather that of the lower beds of the Lower Coal-Measure group:

Productus semireticulatus.

Productus Prattenianus.

Streptorhynchus crenistria.

Spirifer opimus.

Fenestella.

Polypora.

Trematopora.

Within these limestones is an interesting bed of fine-grained white sandstone, of loose, friable texture, made up of rounded grains of limpid quartz, differing essentially from most of the siliceous beds, which are generally compact and almost vitreous. Passing still to the eastward, two nore short anticlinal folds are crossed, and at the northeastern point the limestone beds are overlaid by easterly-dipping quartzites, among which is one having the same curious cavities found in the quartzite beds of Weber Cañon, which are doubtless the cavities left by some organic remains. A yellow sandstone is also found among the quartzites. The outlying hills 
to the south are formed of the same quartzites, standing almost perpendicular. From the limestones of these eastern hills were obtained

Chonetes granulifera.

Productus Nebrascensis.

Productus longispinus.

Martinia lineata.

Athyris subtilita.

In the steeply-dipping limestones at the northeastern point is an interesting cave, over 200 feet in length and in places as much as 25 feet high, whose walls and roof are covered with a sort of tufaceous conglomerate, made up of pebbles of dark-blue limestone, cemented by a white calcareous tufa, while a similar tufa covers the floor. These are the remnants of one of the lower lake-terraces. In them were found a few recent shells of the genus Amnicola.

Along the steep front of the point of the mountains, which has an angle of slope of nearly $37^{\circ}$, the old lake-terraces can be traced with great distinctness, the upper one being marked by a line of calcareous tufa clinging to rock slopes. A careful measurement was made of the height of this terrace-line above the level of the present waters of the lake by a series of synchronous barometrical observations. 'The result gave 94!) fect. The little islet about a mile from the shore, which gives the name to this point, is composed of limestone strata, lying nearly horizontal, wlose weathered surfaces have become quite black.

Tooelle and Rush Valleys.-The broad plains to the west of the Oquirrh Mountains are divided by a low ridge, called the Stockton Hills, into two distinct valleys. Tooelle Valley, to the north, is a continuation of the present basin of Salt Lake, and on the borders of the lake consists largely of marsh-land and swamps, while along the stream-beds of the higher portions of the valley are considerable stretches of arable land occupied by the farms of Mormon settlers. On the flanks of the mountains, especially in the southern portion of the valley, the old lake-terraces are very distinctly marked, and at either cond of the Stockton Ilills form a broad, flat ridge, separating the two valleys.

Rush Valley, as the northern portion which is cut off by these lake- 
terraces is called, is in general a dry plain of Quaternary gravel and soil, supporting only a growth of sage-brush (Artemisia tridentata), but having along the bottoms of a few streams, especially that of Clover Creek, some alluvial soil. Rush Lake, a little sheet of water near the Stockton IIills, receives the surplus waters of the valley, and, though only existing as a lake since the time of the settlement of this region, its waters have already a slightly brackish taste. In the middle of the valley, near the southern limit of the map, is a low ridge, in which were found horizontal beds of a white limestone, with a silky texture. When treated by acid, this limestone leaves a pumiceous mass of glassy needles, which would indicate that it is a volcanic tufa which has been deposited under water and become impregnated with carbonate of lime.

Since the completion of the field-work of the Survey, it is reported that beds carrying coal have been discovered in the valley-slopes on the east side south of Rush Lake, where the Quaternary covering has been cut through by a stream-bed. From the description given of the beds, it is evident that they represent a southern extension of the beds of the Green River Focene, which were discovered, also carrying coal, on the edge of the Great Desert, at the eastern foot of the Ombe Mountains.

The low ridge of the Stockton Hills, between these two valleys, is made up principally of quartzites of the Weber group, but shows at the southeastern extremity a small development of limestone beds, which apparently form the northern point of the Ophir City anticlinal. Opposite the northern corner of Rush Lake these limestones strike northwest, dipping steeply to the southwest, and are overlaid in the hills farther west by quartzite beds, whose strike gradually changes to north and south, preserving a general westerly dip, as far as can be detected undor the accumulations of gravel and detrital material.

In the terrace-bench of the extreme eastern foot-hills of the Aqui Mountains, opposite the western end of the Stockton Hills, ridges of cherty white quartzite are seen striking a little west of north and dipping $75^{\circ}$ to the westward. These are supposed to be a continuation of the beds of the Weber Quartzite, with slightly inverted dip, inasmuch as the adjoining beds in the foot-hills of the Aqui Mountains, which have about the same strike and 
dip, assume gradually an eastern dip as one penetrates the hills. These beds belong without doubt to the Wahsatch limestones, and the upright quartzite beds must therefore represent the base of the Weber Quartzites, turned up steeply against the flanks of the Aqui Mountains.

Aqui Mountarns.-Beyond Tooelle and Rush Valleys, to the westward, rises a second high mountain-ridge, having a north and south trend, parallel to the Oquirrh Mountains, known by the Indian name of Aqui or Onaqui. Its central portion, of which the culminating point, Bonneville Peak, rises nearly 7,000 feet above the level of Salt Lake, is a broad mountain mass, some 10 miles in width, cut by deep cañon-gorges, and covered with a considerable growth of timber. To the north, it extends in a sharp narrow ridge, of gradually-decreasing elevation, to the shores of Salt Lake, the continuation of its line of elevation being seen in Stansbury and Carrington Islands. To the south of the central mass, it is a rather flat-topped ridge, having an elevation of only about 4,500 feet above the adjoining valleys, which extends beyond the limits of the map, connecting with the group of hills that enclose Rush Valley on the south.

The geological structure of this range, as well as could be determined by the limited observations made, is that of an anticlinal, whose axis, as far as a few miles south of Bonneville Peak, has a due north and south trend, in a line with the main crest of the ridge, bending, south of this point, slightly to the eastward. Along this axis, in the central portion of the range, a line of fault has been developed, resulting in an upthrow of the western member of the fold, which reaches its maximum of not less than 10,000 feet at Bonneville Peak, and gradually decreases to the north and south as the axis of the anticlinal descends.

The southern portion of the range, as seen on the map, is formed of limestones, having a gentle western dip, and striking diagonally across the range a little to the west of north. The higher beds of these limestones contain many arenaceous and sometimes quartzite beds, and would appear to correspond to the alternating beds of the upper part of the Wahsateh limestone. Beyond the limits of the map, to the southward, are seen bodies of quartzite, apparently overlying these, which probably represent the Weber Quartzite. Toward Reynold's Pass, the limestones become more 
massive and heavily bedded, still preserving a westerly dip of $15^{\circ}$ to $20^{\circ}$. The few indistinct fossil remains found here are of Carboniferous types, while the thickness of limestone beds which can hardly be less than 5,000 feet, makes it evident that they must belong to the great Wahsatch belt. To the north of the pass, the hills are formed of the same limestone beds, but with an easterly dip, forming the other side of a broad anticlinal fold. These easterly-dipping limestones were traced to the summit of the first ligh peak north of Reynold's Pass. The region between this peak and the head of South Willow Creek, on the eastern slopes of the range, was, however, not explored. On the western flanks, a body of westerly-dipping quartzites comes in, some 4 or 5 miles north of Reynold's Pass, and forms the main mass of the western ridge from here to a little distance beyond Grantville Peak. Here also the line of contact between the quartzites and limestones south of Bonneville Peak was not observed, and it is not known whether the latter wrap around the former with a western dip, as on the north end of the anticlinal, or are cut off by the fault, as the map would indicate.

In ascending Bonneville Peak from the west, a body of white quartzites of not less than 6,000 feet in thickness is crossed, whose average dip is about $25^{\circ}$ to the west, becoming somewhat less steep near the summit. The prevailing rock in these beds is a white, or yellowish-white, semi-granular quartzite. Occasional beds of conglomerate and one or two thin strata of a dark-green argillaceous rock, having an irregularly-laminated structure, with a development of minute spangles of white mica on the laminated surfaces, are found accompanying the quartzite. These imperfect micaschists, and a bluish-purple quartzite, like that found east of Farmington, containing also the flattened pebbles observed in Ogden Cañon, together with the general character of the quartzites, constitute a sufficiently close resemblance to the Cambrian formation of the Wahsatch to justify the assigning them to this horizon, while the fact that no other quartzite body of such thickness is found underlying a limestone belt of over 5,000 feet precludes the possibility of any other supposition. It must be stated, however, that in this range, as in the Oquirrh Mountains, it has not as yet been 
possible to identify, either lithologically or palaentologically, the ()gden Quartzite or the Ute limestone, but the explorations have not been sufficiently exhaustive to justify the conclusion that they are entirely wanting.

The east face of the Bonneville Peak Ridge presents an almost perpendicular wall of quartzite from 2,060 to 3,000 feet in height. The deep cañon under this peak at the head of South Willow Creek has the amplitheatrelike basin at its head, and the general shape in its upper part, of a glaciercañon. 'This cañon was only explored in its lower portion, where a heavy body of blue limestone, covered at the foot-hills by a flow of trachyte, is exposed in section, with a strike a little west of north. These limestones are much metamorphosed and dislocated, standing at such varying angles that it was difficult to determine their structure. But few imperfect casts of fossils were obtained from the lower beds exposed, among which the only one which has been specifically recognized is Zaphrentis multilumella. Their general character, however, and the thickness and general habit of the limestones are sufficient to determine them as belonging to the Wahsatch group.

Near the mouth of the cañon, a body of trachyte is exposed, which has apparently poured out between the nearly upright beds of limestone, while flows of volcanic ash of red and gray color, containing pebbles and angular fiagments of the lava, form the ridges on either side of the entrance, sloping $20^{\circ}$ to the cast, and apparently covering the flanks of the spurs to a considerable distance north and south. This rock is a light-gray hornblende-trachyte, containing abundant fine black needle-like crystals of homblende, with some black biotite, but no distinct crystals of feldspar. The mass is quite porous and rough to the touch, and has a low specific gravity. Under the microscope, the grayish-white porous groundmass is found to be made up largely of feldspar crystals, in which plagioclases are comparatively frequent, with abundant biotite in remarkably perfect hexagons and rhombs, while no microscopical hornblende was seen. The groundmass contains besides some apatite, and fine globulitic glass stains, which, on account of the colorless zone encircling them, might be mistaken for nosean.

The limestone beds in the upper part of the cañon have apparently a 
western dip, while in the narrow gorges a few miles from the mouth, the dip varies from perpendicular to $60^{\circ}$ to $70^{\circ}$ eastward. It may be supposed that the anticlinal axis here lies somewhat to the east of the main ridge, and that the break has followed a line a little to the west of it. Whether this supposition be correct or not, it is evident that in this portion of the range the forces of contraction and dislocation have acted most powerfully. It is worthy of remark that the line of the southern general section on the map crosses the Wahsatch, Oquirrh, and Aqui Mountains approximately at the points of the most violent disturbances in the sedimentary beds, and where the development, both of the older granites and porphyries and of the younger volcanic rocks, has been most considerable; it also indicates, in the two former, the region of the greatest concentration of argentiferous minerals; in the latter, these have not yet been developed.

On the western foot-hills of the range, the quartzites can be traced as far north as Hooper's ranch, where they form an outlying hill, the northern point of which is formed of steeply-dipping limestone beds, having a strike somewhat to the east of north. The limestone beds further north, on the west of Grantville Peak, were observed resting on the westerly-dipping quartzites, but thieir southern limit was not definitely determined.

Grantville Peak forms the crest of a sharp anticlinal fold, whose western member dips about $45^{\circ}$ west, while the eastern beds are upturned at much steeper angles, assuming at the extreme foot-hills a perpendicular position like those on the east of Bonneville Peak. The lowest beds exposed here are the same quartzites that were found at that peak, and likewise form the lighest portion of the ridge. The purple quartzite with flattened pebbles is particularly noticeable, forming the surface of the saddle north of Grantville Peak, and of the eastern slopes, where the force of the strong west winds, blowing from the desert, has laid bare and polished its surface, and worn away the matrix of the rock, leaving the harder pebbles standing out in rounded knobs. The whole series from the Cambrian to the Lower CoalMeasure limestone have been indicated here, as there was no evidence of any faulting. To the north, the beds sink, and the angle of dip becomes less steep ; to the northeast of Grantville Peak, the outlying foot-lills show limestone beds dipping from $25^{\circ}$ to $45^{\circ}$ to the east and north, while the 
narrow ridge which forms the extreme point of the range is made up of nearly horizontal beds of limestone, abruptly escarped on the west, but in which the dip seems to be rather west than east, though, in the little outlying limestone knob, called Pilot Rock, the beds have a well-defined dip of $20^{\circ}$ to the south and east. All along both flanks of the northern portion of the range, particularly on the Skull Valley side, are numerous springs, some of fresh water carrying considerable lime, but many of them highly charged with chloride of sodium. On the steeper cliffs, the line of the old lake-terraces is marked by a deposit of calcareous tufa.

IsLANDS.-Stansbury Island was formerly connected with the mainland by a low beach-line, which is now in great measure covered with water. The island itself is a rugged mountain-ridge, with precipitous slopes, which, though only three miles in width at its greatest lateral extension, rises nearly 3,000 feet above the lake-level. It is formed mainly of beds of the Lower Coal-Measure limestones, which form a sharp anticlinal fold, dipping $75^{\circ}$ in either direction, with a general north and south trend. These limestones abound in corals, among which has been recognized:

Zaphrentis Stansburyi.

Zaphrentis multilamella.

From a black limestone near the top of the peak was also obtained:

Euomphalus subplanus.

Underlying this black limestone is a bed of about 200 feet of lightercolored siliceous rock. Along the flanks of the hills, especially on the eastern shore, is a considerable development of light-colored beds, consisting of sandstones and quartzites, which have been referred to the Weber Quartzite, as at Black Rock Point, though they may only represent the upper impure beds of the Wahsatch limestone. These beds are both compact and heavily bedded, and thinly laminated. On the soutliern portion of the eastern shore, they have a strike of north $18^{\circ}$ east, showing a tendency to close around and cover this end of the anticlinal. The upper terrace-line on the island is marked by an abundant tufaceous deposit. In general, the geological structure of the island seems to resemble that of the Aqui Mountains, of which it forms a northern continuation en échelon, and perhaps may have a similar faulting, which has thrown up the western side of the fold. 
Carrington and Hat Islands evidently form part of the same uplift with Stansbury Island, and belong, like it, to the Lower Coal-Measure group. Associated with the limestones of Carrington Island is a considerable development of finely-laminated argillaceous slates, which contain little cubes of iron pyrites and some coarse conglomerates. The mass of Hat Island is principally made up of these slates and conglomerates. Between Hat Island and Frémont's Island is, as has been seen, the deepest portion of the lake, the bottom being over forty feet below its present surface. 


\section{SECTIQN VIII}

DESERT REGION.

IY S. F. EMMONS.

Skull Valley is a broad arm of the Salt Lake Valley, lying to the west of the Aqui Mountains. In its northern portion, it scarcely rises above the level of the lake, and is occupied by a great extent of marshes, which, for the greater part of the year, are almost impassable. It rises gradually to the south to about opposite the southern end of the Cedar Mountains, where an almost imperceptible divide throws the drainage of the country beyond westward into the Great Desert. This valley abounds in springs, which are most frequent along the eastern edge of its northern portion, where they are surrounded by very considerable extents of meadow-land, affording excellent winter-grazing for stock. In the southern portion of the valley, opposite Reynold's Pass, is a group of springs, in the midst of a swampy tract, covered by coarse grass and reeds. Only one of these springs, however, furnishes potable water, the others being too highly charged with mineral salts. The remaining dry portion is covered, as are all the valleys of the plateau region, by a scattering growth of sage-brush and little clumps of the nutritious bunch-grass. On the slopes of the Aqui Mountains, at Reynold's Pass, are great accumulations of fine quartz-sand, which have been blown in from the desert through the gap in the Cedar Mountains, and extend up many hundred feet on to the hills, choking up the bottoms of the smaller ravines.

Cedar Mountains.-They consist of a low range of hills, scarcely rising more than 2,000 feet above the adjoining talley, whose long gentle slopes are well covered with detrital material, and support a scanty growth of sage-brush and juniper (Juniperus occidentalis), with near the summits a few stunted pines. Like all the desert ranges, of which they are a fair type, they afford a very scanty supply of water, which is only found in a few widelyseparated springs. This fact, combined with the scanty data to be obtained, 
owing to the absence of deep-cut cañons or of extensive rock exposures, renders their exploration peculiarly unfruitful to the geologist.

The extreme southern point of the Cedar Mountains, as represented on the map, is mostly covered by the broad, flat gravel-terraces of the ancient lake, out of which rise.a few isolated hills of red iron-stained quartzites and limy shales, upturned at varying angles, but generally dipping to the north and east.

At White Rock Spring, the eastern foot-hills, forming a somewhat broken line of secondary elevation, are formed of beds of a coarse cherty limestone, abounding in cylindrical moulds of encrinites, like the calcareous quartzite found on Emma Hill in Little Cottonwood Cañon. These beds have a northwest strike, with a gentle dip to westward, and are succeeded higher on the foot-hills by limestone beds which are almost horizontal. They are partly covered by a flow of reddish breccia, which has occupied the stream-bottom between the spurs.

The White Rocks themselves are three very singular masses of grayishwhite quartziferous trachyte, the largest, about 300 feet high, having a rudely conical shape, with perfectly smooth sides, without cleavage-planes or cracks, and so steep that it is difficult to ascend to their summit. This trachyte is a coarsely crystalline, almost granitoid rock, made up of large crystals of sanidin, in a few instances an inch in length, with rounded, cracked grains of quartz, occasional prisms of hornblende and flakes of black mica in a crypto-crystalline groundmass. The groundmass is quite porous, and shows many rounded cavities, from which the quartz-grains have fallen out. Under the microscope, it is seen to be made up of a crystalline aggregation of feldspar, quartz, and augite, the quartz being unusually rich in glass-inclusions. This rock resembles in every respect the quartziferous trachytes of the Elkhead Mountains, except that it contains microscopical quartz in the groundmass. For this reason, it has been classed by Professor Zirkel in his report as a rhyolite.

The broad, flat-topped crest of the lills at this point is occupied by a flow of andesite, which extends for several miles to the northward, and forms an outlying hill to the west, which just rises abore the accumulations of desert sand. In external habit, this andesite cannot be distinguished 
from a basalt, flowing in thin sheets, with a rudely columnar structure, and becoming reddish-black upon its weathered surfaces. On the surfaces of fresh fracture, it shows a dark bluish-gray, somewhat porous groundmass, in which are imbedded crystals of augite and black mica, with occasional large crystals of plagioclase-feldspar. Under the microscope, it is seen to contain sanidin-feldspar, as well as plagioclase, some hornblende associated with the augite, and pale-gray glass. It has been classed, by Zirkel, with the augite-andesites, but, owing to the presence, unusual in these rocks, of mica and hornblende, it rather approaches the hornblende-andesites. It contains no olivine. An analysis made of this rock by $R$. W. Woodward shows more resemblance to the andesites proper than to the augite-andesites. The constituents are as follows:

Silica........................... 60.71

Alumina ......................... 16.00

Ferric oxide.................... 2.09

Ferrous oxide.................... 3.87

Lime . . . . . . . . . . . . . . . . . . . . . . . 5.17

Magnesia ........................ 3.07

Soda ............................. 2.74

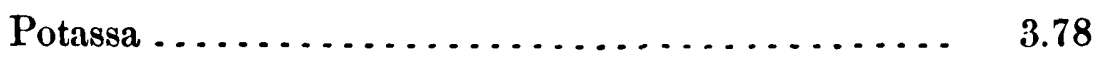

Lithia ....................... trace

Carbonic acid...................... 1.01

Water ......................... 1.48

99.92

To the north of White Rock Spring, linestones, generally lying at a shallow angle, form the main ridge as far as observed. Toward the north, opposite Hooper's ranch, a low ridge to the eastward of the main ridge is formed of limestones and shales, having a western dip, and incrusted with calcareous tufas of the lake-terraces, from one of which issues a large spring of limy water. At the point where the road to Pilot Rock crosses the hills, both the eastern and western slopes of the range are covered by flows of dark, compact basalt, inclining with the spurs in either direction. On the crest, whence the basalt has been denuded off, are exposed beds of limestone and 
siliceous shales, metamorphosed and blackened on the surface, in which are some indistinct impressions of encrinites and corals. On the western slopes, north of the pass, is a body of dark-blue limestone traversed by small veins of white calcite, also containing corals, which dips $85^{\circ}$ to the eastward. 'To the east of the limestones, and overlying them, are reddish quartzites, whose structure, as well as could be ascertained from the few exposures to be seen under the accumulations of surface débris, is that of a synclinal descending toward the north. These have been referred to the Weber Quartzite group; the main body of the range being evidently in the Wahsatch limestone.

Lakeside Mountains.-A similar low ridge of hills, en échelon with the Cedar Mountains, lying along the western shores of Salt Lake, is known as the Lakeside Mountains. Its southern foot-hills are formed of similar quartzites, resting on strata of dark-blue limestone, also carrying crinoid remains, having a Coal-Measure aspect, which form the southern peak of the range, with a strike of northeast and a dip of $45^{\circ}$ to the southeast. These limestones apparently form an anticlinal to the north, and are overlaid again by the quartzites at thelow pass in the middle of the ridge. The northern portion of these hills, as far as could be learned by the isolated observations of our parties employed upon the survey of the lake, are composed of the same heavy dark limestones, with occasional lighter siliceous beds, in broken, confused masses, and have been referred to the Lower Coal-Measure group. The island called Strong's Knob, which forms the northern continuation of this ridge, shows to the eastward almost perpendicular cliffs, several hundred feet in height, of dark-blue and black limestones, capped by a grayish limestone bed, containing corals, among which the following have been determined:

\section{Zaphrentis Stansburyi. \\ Zaphrentis multilamella.}

The same black and gray limestones are observed in Gunnison's Island, which is in the same line of elevation, and in Dolphin Island, opposite the Terrace Mountains.

The desert ridge to the west of the Lakeside Hills is but little known by actual observation. Its northern point shows similar limestone beds to $\dot{30} \mathrm{D} \mathrm{G}$ 
those forming these islands, and has, like them, been considered to belong to the Lower Coal-Measure group, while the southern point is said to be formed of a vesicular basalt.

The Great Desert.- To the west of Salt Lake and of the Cedar Mountains, stretches a wide desert plain, formerly the bottom of the broadest expanse of the ancient Lake Bonneville, and now known as the Great Desert. Over an extent of some 40 miles in width by over 80 in length, its surface is an almost absolute level, only broken by a few isolated ridges, forming rocky islands in the broad area. Its surface is covered by a deposit of the finest silt and mud, the sediment of the ancient lake, and is almost absolutely bare of vegetation. When dyy, this mud forms a hard level floor, almost like a pavement, but a comparatively slight fall of rain renders it so soft as to be practically impassable for horses or cattle. After a rain, the soluble salts, with which the soil is impregnated, are left in a thin film of white upon the surface, so that when looked upon from one of the bordering ranges at a time when the sun is near the horizon, so that its rays are reflected from the surface, the whole expanse seems to be covered by a mantle of pure white snow. Along the borders of the desert, these Lower Quaternary muds are covered by the more recent detritus of soil and gravel brought down from the neighboring mountain-ridges, and on its eastern side by the wind-blown sands, which have accumulated to great depths along the flanks of the hills which form the first barrier to the currents brought along by the prevailing west winds that sweep its surface. The difference of level between the mud plain and the present surface of Salt Lake is so slight that its determination by barometrical measurements must be received with some reserve. The elevation of the southwestern extremity, near Redding Spring, as determined by barometrical observations, is 4,256 feet, or 56 feet above Salt Lake; but it is probable that a rise of 20 or 30 feet in the waters of this lake would submerge almost the entire surface of the Lower Quaternary deposits.

As might naturally be expected from the composition of the mineral contents of the waters of Salt Lake, the salts which impregnate the soil of the Desert consist mostly of chloride of sodium; the surface incrustations of this mineral are sometimes of sufficient thickness to form beds, notably 
at the eastern base of Pilot Peak, just beyond the western limit of Map III, where the accumulations of crystals of common salt cover the surface to a depth of several inches over an area of many square miles. Some of the ordinary surface incrustation was taken from the desert to the west of White Rock Pass in the Cedar Mountains, and subjected to chemical analysis. It contained 97.43 per cent. of soluble matter, which gave by analysis :

\begin{tabular}{|c|c|}
\hline \multicolumn{2}{|l|}{ Soda $\ldots \ldots \ldots \ldots \ldots \ldots$} \\
\hline 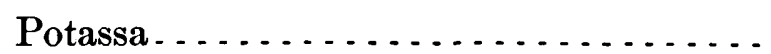 & trace \\
\hline Lime $\ldots \ldots \ldots$ & 0.10 \\
\hline Chlorine........... & 60.31 \\
\hline Sulphuric acid $\ldots \ldots \ldots \ldots \ldots \ldots$ & 0.18 \\
\hline & 99.65 \\
\hline
\end{tabular}

or, combined theoretically:

Chloride of sodium ............... $99.37 \quad 99.68$

Sulphate of lime................ $0.24 \quad 0.22$

Excess .......................... $\mathrm{SO}_{3}, 0.04 \mathrm{NaO}, 0.09$

$$
\begin{aligned}
& 99.65 \\
& 99.99
\end{aligned}
$$

A chemical examination was also made of the ordinary desert soil. The material analyzed was obtained from near the Dugway Station on the old Overland Stage Road, about 25 miles south of the limits of the map. That taken from the surface, an exceedingly fine, almost impalpable powder of a light brownish-gray color, known in the West as "alkali dust", was treated with warm water; only 0.5 per cent. of the mass was found to be soluble. This gave, on analysis:

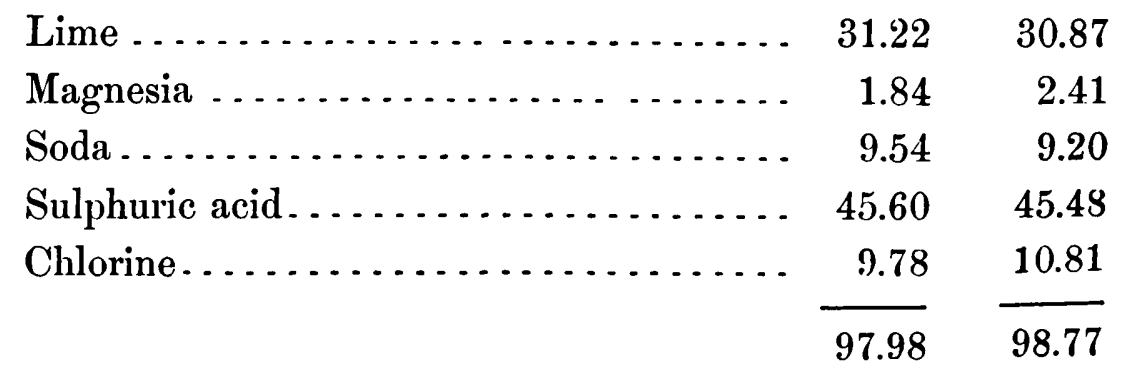


which, theoretically combined, give:

Sulphate of lime

$75.85 \quad 74.93$

Sulphate of magnesia............. $\quad 1.49 \quad 2.01$

Chloride of sodium . . . . . . . . . . . $16.10 \quad 17.71$

Chloride of magnesium . . . . . . . . . . . $\quad 3.16 \quad 3.00$

Excess ..................... NaO, $0.84 \mathrm{MgO}, 0.63$

$\overline{97.44} \quad \overline{98.28}$

A quantity of the soil was taken at the same locality from a depth of 2 feet below the surface, which presented the same appearance and texture as the former, but yielded, after digestion with water for a considerable length of time, 4.83 per cent. of soluble salts of the following composition:

Lime . . . . . . . . . . . . . . . . . . . . . . $3.84 \quad 3.76$

Magnesia . . . . . . . . . . . . . . . . . . . . . . . $0.0 .57 \quad 0.63$

Soda

$34.56 \quad 34.88$

Potassa ....................... trace trace

Sulphuric acid .................. $7.37 \quad 7.21$

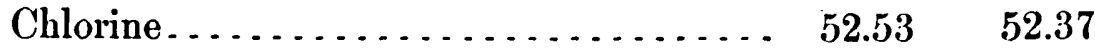

Oxygen equiv. $\mathrm{SO}_{3} \ldots \ldots \ldots \ldots \ldots \ldots \ldots \ldots . \ldots .14$

$99.01 \quad 98.97$

of which the theoretical composition would be:

Chloride of sodium............... $86.61 \quad 86.33$

Sulphate of lime.................... $9.32 \quad 9.11$

Sulphate of magnesia.............. $1.71 \quad 1.90$

Sulphate of soda.................. $1.31 \quad 1.05$

Excess of sodium $\ldots \ldots \ldots \ldots \ldots \ldots \ldots \ldots .0 .06 \quad 0.58$

$99.01 \quad 98.97$ 


\title{
CHAPTHR IV.
}

\author{
NEVADA PLATEAU.
}

SECTION I.-IBENPAII MOUNTAINS TO RUBY VALLEY-INTRODUCTORYIbenpail Mountains-WaChoe Mountains-Antelope Hills and Schell Creek Range-Egan Range-Ruby group-Franklin Buttes.

Section II.-OMBE MOUNTAINS TO EAST HUMBOLDT RANGE-OMbe Mountains- Peoquop and Toano Passes-gosi-Ute Range-Peoquop RANGE-LitTle Cedar Mountains.

SECTION I!I.-GOOSE CREEK HILLS TO TUCUBITS MOUNTAINS-GoOSE Creek Hills-Tonno Group-Fountain-head Hills-Tucubits Mountains. Section IV.-EAST HUMBOLdT RANGE-Region South of Frémont's PassRegion North of Fremont's Pass-Pliocene and Quaternary forma. tions-White Pine hountains.

Section V.-DIAMOND AND PIÑON RANGES-Diamond RaNge-Piñon RANGE-PALAEOZOIC FORMATIONS-VOLCANIC ROCKS-DIXIE GROUP REGIONPliocene formations-Robert's Peak-Wahweah Mountains.

Section Vi.-CORtez Range-Tenabo Peak region - Agate Pass regionCortez and Papoose Peak region-Pine Valley Pliocene-Region of the Cluro Hills-Palisade Cañon region-Region of the Carlin Peaks.

SECTION VII.-REGION NORTH OF HUMBOLDT RIVER-MALLARD HILLSBone Valley-Egyptian aNd Osino CaÑons-Elko aNd RIVER RaNGeSSeetoya Mountains-Northern Cortez RaNGE-SQUaW Valley RegronSHOSHONE MESA.

SECTION VIII.-SHOSHONE RANGE AND CARICO PEAK-NoRTHERN SHoshone Range-Carico Peak. 
BY s. F. EMMONS.

To the west of the Great Desert is a region of high narrow mountain-ridges, with a general trend of north and south, or else invariably a few degrees east of north and west of south. They are separated by broad, nearly level valleys, which present, but in a less pronounced manner, most of the arid desolate features of the Great Desert itself. These longitudinal valleys are, however, as compared with the Desert of Utah, relatively narrow, averaging, with a few marked exceptions, in general not more than 10 to 15 miles in width, but occupying a considerably higher level. Their elevation above the sea gradually increases to the westward from that of less than 4,300 feet of the Great Desert to over 6,000 feet, measured at the lowest point in the valleys near the centre of the region represented on Map IV. Of these valleys, Ruby Valley, along the east base of the Humboldt Range, is among the most elevated, retaining its high altitude for a distance of over 60 miles. From the desert westward, the mountain-ranges also increase in height and importance as far as the East Humboldt Range, a lofty mountain mass occupying the middle of the Nevada Plateau. This range now represents approximately the eastern boundary of all the westward-running waters of the Nevada Basin. To the west of this range, the valleys fall away gradually in altitude until, at the lowest levels of the Nevada Basin, they lie between 300 and 400 feet below the level of the Great Desert. The valleys west of the Humboldt Range contribute to the transverse drainage-system of the Humboldt River, their surfaces sloping upward from the river, both to the north and south, toward the east and west systems of divide, which correspond roughly with the north and south limits of the western half of the map. Many of the valleys, but more especially those east of the Humboldt Range, are regions of enclosed depressions, having no present outlet. In the bottoms of nearly every valley are either small lakes of fresh or slightly brackish water, fed 
by the snows of the neighboring high peaks, or else arid alkaline plains, containing, during the early spring, shallow pools, but dry during the greater part of the year, and frequently covered with incrustations of various salts. The composition of many of these salines will be found scattered through this report when speaking of the locality where they are found.

Although all these valleys are marked by the absence of any arborescent growth, they are for the most part, unlike the Salt Lake Desert, covered with some vegetation, either one or two species of grasses, or else a stunted development of shrubs and bushes. They present a monotonous, dreary aspect of a dull greenish-gray color, derived chiefly from the Artemisia tridentata, which usually stretches across the wide expanse of the valley.

In their geological aspect, they appear equally monotonous, and a description of one would, with but little variation, answer for the many. They are almost entirely covered by Quaternary deposits, made up of both coarse and fine detritus derived from the adjacent ranges, overlying and concealing, over the greater part of the area, the fine, impalpable, arenaceous clays and silts of the Lower Quatenary formation, which is usually only observed in the lowest portions of the valleys or along the banks of streams. Rarely, between the higher ranges, do formations older than the Quaternary reach the surface, so regular are the upheavals of the older sedimentary beds and so great the accumulations of the overlying detrital matter.

Taken together, the ranges of the Nevada Plateau present many features in common, especially as regards their topographical structure. As already mentioned, their trend varies but little, showing, as compared with other mountain-systems in the world, a remarkable parallelism, over such wide areas, in the lines of upheaval of the sedimentary ridges. This regularity of structure would be still more apparent, even to the superficial observer, but for the great outflows of Tertiary volcanic rocks, which, occurring along the old lines of upheaval, have spread out in all directions, concealing the older sedimentary strata. These ranges rise from 2,000 to 6,000 feet above the level of the adjacent valleys, presenting a mildly-serrated ridge, with culminating peaks every few miles. In width, they vary from 5 to 10 miles. In their transverse drainage-systems, and in their broader forms of erosions, making allowances for the differences in geological structure, they show 
many features that are common to all the ranges of the Nevada Platean. As regards their geological aspect, however, each mountain-range possesses much that is striking and distinctive, not only as related to their structural and dynamical features, but to the age of the beds exposed and their mode of occurrence. The salient features of each mountain-range will be given under the detailed description of each, beginning with those uplifted ridges that border upon the Great Desert, the Ibenpah and Ombe, and proceeding westward as far as the Shoshone Range, which lies just to the east of Reese River.

Ibenpah Mountains.-The first elevation to the west of the Desert, at the southern limit of the map, is that of the Ibenpah Mountains, a high commanding range, whose principal summits, just beyond the boundary of the map, attain a probable elevation of 10,000 feet or more. That portion of the mountains within the area of this exploration lies entirely in the Territory of Utah; the 114th meridian, the boundary-line between the State of Nevada and Utah, running through Deep Creek Valley, just west of the mountains.

This higher portion of these mountains, beyond the southeast corner of the map, was not visited, but shows to the east of the crest a body of granite, overlaid by heavy limestone formations. These are seen at the gap through which passes the old overland stage-road, where they show an anticlinal structure, folding over the underlying granite core. The limestones are generally dark-colored, passing from gray to blue, and considerably metamorphosed, while on the flanks toward the Desert they show some indistinct developments of arenaceous beds and quartzites.

Mount Horeb, the extreme northern point of the range, is formed of earthy blue and black limestones, dipping $45^{\circ}$ to the northeast. In none of the beds were any fossils found by our parties, but from their general lithological resemblance to the Wahsatch limestone, they have been referred to the Lower Coal-Measure horizon, while it is probable that in the lower exposures a careful search might reveal the Devonian and Silurian formations.

The lower portion of the eastern slopes of the range toward the Desert 
are very long and gradual, occupying a width of 4 or 5 miles in a descent of less than 1,000 feet. On these slopes, the ancient lake-terraces can be traced, from a little distance, with great distinctness, but, owing to the low angle of the slopes, their actual level is difficult to determine at any one point. The highest terrace which could be distinctly recognized stands at an elevation of 800 feet above the desert-level, and is composed entirely of loose gravel material. The pebbles consist principally of limestone, with some mixture of quartzite and granite. In this upper terrace was found no tufa. At the level of 500 feet above the Desert is a very well-defined terrace of calcareous tufa, filled with casts of recent fresh-water shells of the species common in the Lower Quaternary deposits of the Desert. Of this tufa, an analysis was made by Mr. R. W. Woodward, with the following result:

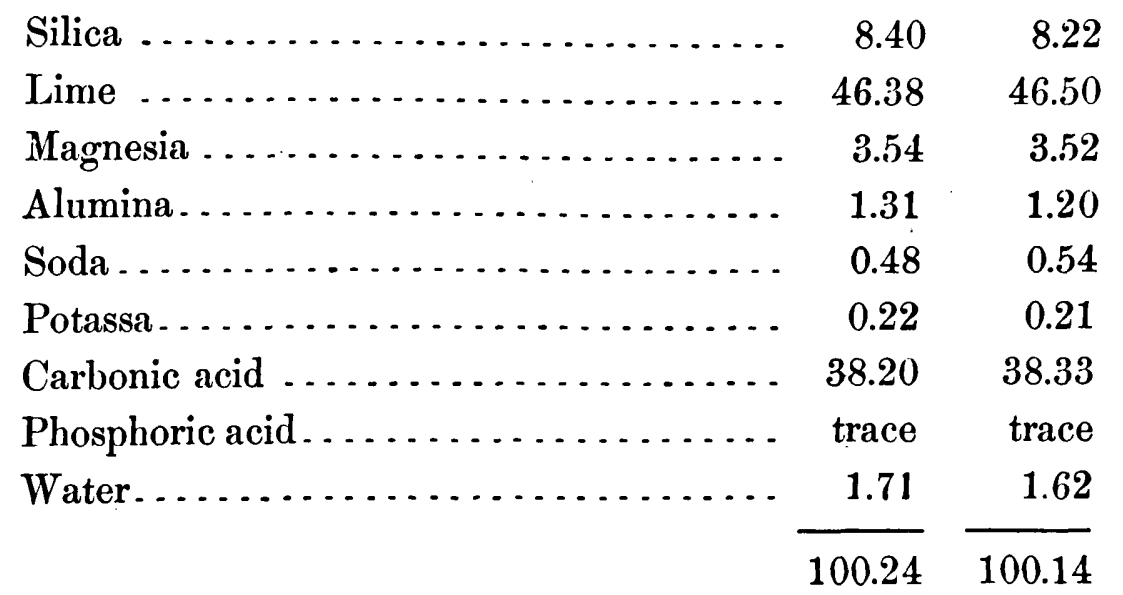

(Silica combined, and as free sand.)

A second prominent gravel terrace was found to be only 300 feet above the desert-level. Some ten or twelve distinct lines of intermediate terraces could be observed along the slopes of the range. These heights were all determined by barometrical measurements referred to station-observations at Redding Springs, a group of large pools of tolerably pure water, occupying the edge of the Desert, just east of the stage-road at the base of the extreme eastern slopes of the Ibenpah Range.

The valley of Deep Creek is traversed by a stream of this name, which takes its rise in the high peaks of the Ibenpah Mountains, to the south of 
the map, and flows north, through a gap in the limestone hills, out on to the Desert. In the neighborhood of the settlement, which has an elevation of 900 to 1,000 feet above the Great Desert, is considerable agricultural land, which has been occupied by Mormon settlers. As the stream approaches the Desert, its bed is cut deeper into the soft, muddy valley deposits, and its waters become impregnated with the soluble alkaline salts contained in the soil, which render it unfit to drink. In the spring and early summer, its waters form a shallow lake on the edges of the Desert, which, later in the season evaporating todryness, leave considerable deposits of alkaline salts. They form a thin, brittle crust, resting upon an exceedingly fine clay soil, largely derived from the neighboring rhyolites and Tertiary beds. A sample of this incrustation, mixed with some soil, yielded, upon being submitted to chemical analysis by Mr. R. W. Woodward, the following result :

\begin{tabular}{|c|c|c|}
\hline Sodium $\ldots \ldots \ldots \ldots \ldots \ldots \ldots \ldots \ldots$ & 16.50 & 16.37 \\
\hline Soda $\ldots \ldots \ldots \ldots \ldots \ldots \ldots \ldots$ & 26.47 & 26.39 \\
\hline Potassa $\ldots \ldots \ldots \ldots \ldots \ldots \ldots$ & 2.55 & 2.51 \\
\hline Sulphuric acid . . . . . . . . . . . . & 12.05 & 11.91 \\
\hline Carbonic acid. . . . . . . & 18.27 & 18.36 \\
\hline Chlorine.......... & 23.20 & 23.14 \\
\hline Boracic acid . . . . . . . & undet. & undet. \\
\hline & 99.04 & 98.68 \\
\hline
\end{tabular}

with a theoretical combination of

\begin{tabular}{|c|c|c|}
\hline Sulphate of potassa $\ldots \ldots \ldots$ & 4.71 & 4.63 \\
\hline Sulphate of soda... & 17.54 & 17.37 \\
\hline Sesquicarbonate of soda & 37.09 & 37.17 \\
\hline Chloride of sodium .... & 38.25 & 38.14 \\
\hline Excess of soda. & 1.45 & 1.37 \\
\hline
\end{tabular}

The deposit would appear to consist of an admixture of sesquicarbonate of soda with a large percentage of alkaline sulphates, and common salt, the usual impurities of the trona of commerce. The large amount of potassic salt present is of considerable interest. The presence of boracic 
acid was clearly shown. It is probably combined with the excess of soda, as borax. Somewhat similar incrustations are found in the Nevada Basin, and usually in close relation with regions of rhyolitic outflows. It would seem of interest that the occurrence here in Deep Creek Valley has the same geological surroundings.

To the west of the valley are long flat Tertiary ridges and narrow stream-beds cut through white beds of fine sands and marls, with some gravelly conglomerates. These beds have a general lithological resemblance to those of the Humboldt Pliocene, as developed in the valleys of the Upper Humboldt, containing, in particular, a bed of white, very finegrained material, having a rough feel like a volcanic ash, which is almost identical with some beds found to the north of Toano, and have, therefore, been referred to that horizon, though, as far as our observations extended, no palæontological evidence of their age was obtained.

The divide between Deep Creek and Gosi-Ute Valley is a low, rather flat-topped ridge, in which but few outcrops of underlying rocks were found. The evidence of fragments contained in the float shows that it is largely composed of eruptive rocks. These are mostly rhyolites. At one point, however, was obtained a rather singular rock, which has been colored as an andesite. On its weathered surface it has a light mauve color, and resembles a rhyolite, but in fresh fracture shows a dark-brown, compact, felsitic groundmass, in which are enclosed small white crystals of plagioclase feldspar and frequent brown micas, together with hornblende and occasional rounded grains of cracked quartz. The dark-green crystals of hornblende frequently show a zonal decomposition on the outer surfaces. The groundmass is extremely homogeneous and almost half-glassy. The feldspars, as far as can be seen by the unaided eye, are mostly plagioclase; while the quartz seems to be an entirely accessory constituent, and the rock has, therefore, been considered to hold the same relation to the normal andesite as the quartziferous trachytes do to the normal trachyte.

In the low hills to the north of Deep Creek Valley, and between it and the Desert, are occasional obscure outcrops of limestones, very much broken and dipping irregularly, associated with isolated flows of rhyolite. Theaccu- 
mulations of Quaternary detrital material are such that it was inpossible to obtain any definite ideas of the structural relations of these beds.

Wachoe Mountains.-To the south of the Gosi-Ute and Peoquop Ranges, rising out of the Gosi-Ute Desert, lie the Wachoe Mountains, an isolated body of hills of considerable geological interest. In both their topographical and geological features they offer a striking contrast to the long, narrow, north and south lines of Palæozoic ridges that characterize the surrounding ranges, and show instead an irregular group composed almost entirely of crystalline rocks, which include granites, later diorites, and quartz-porphyries, followed by andesites and rhyolites.

Of this group, granite forms all the more elevated portions, and gives the character to the main topographical outlines, and is at the same time the geological nucleus around which, at the southeastern end, is found a body of limestone, while at its base is spread out over a considerable area one of the most interesting outbreaks of Tertiary volcanic rocks of Eastern Nevada. It is an irregular shaped mass some 8 or 9 miles in length, and across its broadest expanse about 4 miles in width. From the westward, it rises somewhat abruptly, but with even slopes, nearly 2,000 feet above the Gosi-Ute Desert, while to the eastward it is more broken in outline, but falls away with gentler spurs toward the volcanic rocks below. In its physical habit, this granite is of special interest, as it presents marked differences from all the isolated granitic bodies of the Raft River, Ombe, Gosi-Ute, and Peoquop Ranges, which have many points of resemblance, and would appear to belong to the same group. The Wachoe granite is a very compact dense mass, with a comparatively uniform texture, weathering in rounded forms, but with regular monotonous outlines, all possessing the same gentle curves: it disintegrates slowly, the greater part of the hills showing but little soil and débris. Under the hammer, the rock breaks with great difficulty in irregular-shaped pieces, having a very uneven fracture. The minerals composing the rock show, as far as examined, no tendency to parallel arrangement, and have developed no regular lines of bedding. In color, it is dark reddish-gray, but with somewhat lighter tints on the northeastern spurs and foot-hills.

In its mineralogical features, this rock presents many peculiarities, and is marked by a composition as striking as are its outward physical 
characters, and equally at variance with that of most of the other larger granitic bodies, but more especially with those to the north and east. All the normal mineral constituents of common granite are here present, but not in the usual proportions. Quartz, orthoclase, plagioclase, and mica are the essential ingredients; in addition to these, as subordinate minerals, may be observed hornblende and a few dark specks, probably specular iron but which it would be difficult by the unaided eye to determine, but for the fact that in thin sections, under the microscope, it has been detected inclosed in the larger feldspar crystals. The quartz is present in very small quantities and always in fine grains, with a slightly gray tint. Both monoclinic and triclinic feldspars are present in considerable proportions; none of them have a brilliant color, but are more or less dull and opaque. A few of the larger crystals, which are frequently a half an inch in length, have a vitreous lustre. Mica plays an important part; it occurs in broad, shining plates, with a fresh, undecomposed appearance; there are also present some flakes of a bronze color, which are more or less altered.

Under the microscope, Zirkel has pointed out the presence of both titanite and apatite, the latter in short thick prisms, and carrying numerous liquid-inclusions, arranged in lines at right angles to the main axis of the crystals, as shown on Plate I, Fig. 8, accompanying his report. The liquid-inclusions of the quartz also carry minute crystals of chloride of sodium, while the larger feldspars hold specular iron.

The Wachoe granite was subjected to chemical analysis by Professor Thomas M. Drown, of Lafayette College, Pennsylvania, with the following result :

Silica .............................. 55.53

Alumina ............................... 18.65

Ferrous oxide ........................... $\quad 6.14$

Manganous oxide........................ 0.17

Lime ............................... $\quad 5.62$

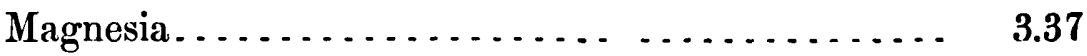

Soda............................... 4.84

Potassa . . . . . . . . . . . . . . . . . . . . . . . . 5.20

Ignition ................................ 0.65 
In its chemical constitution, this rock is one of the most remarkable granites in our collection. It stands from 12 to 20 per cent. lower in silica than the normal composition of granite, while at the same time it is but little higher in alumina, the increase being mainly in the other bases, iron, lime, magnesia, and alkalies ; the soda and potassa together constituting more than one-tenth of the entire rock.

Probably no decisive evidence will ever be produced to clearly show the age of this isolated granite body. It has, however, in general, in its mode of occurrence and structure, the character of an eruptive rock, while its mineralogical habit places it in close proximity with those other bodies in Western Nevada that have been regarded as of Jurassic age.

On the northeast side of the granite, and just below the summit of Melrose Mountain, occurs an intrusive rock of later age, an irregularlyshaped dike or body of fine-grained diorite, with a prevailing purplish-gray color. It is a dense rock, with an angular fracture and highly crystalline groundmass. Both orthoclase and plagioclase feldspars are present, but the latter appear to predominate, many of them occurring as brilliant acicular needles. The hornblende is found in small, fibrous, green crystals disseminated through the mass.

The limestone of Castle Peak is a gray, compact, somewhat siliceous rock, in which few fossils were found. The following Coal-Measure forms however, were obtained:

\section{Productus subhorridus.}

Athyris Roissyi.

Its beds in general dip easterly, resting directly against the granite body, but, in the ridge to the east, dip northward, enclosing a partial synclinal in Spring Cañon. It is traversed, near the summit of the ridge, by a dike of quartz-porphyry, having a north and south trend. This rock is a pure, white, felsitic mass, containing rounded crystals of quartz, and white feldspars porphyritically imbedded, its surface being stained with red, rusty spots, surrounding small particles of partially decomposed magnetite, which abound through the mass. The feldspars, which belong to the monoclinic group, are generally opaque, especially on the surface, but, in the interior, 
sometimes having a semi-translucent character. Under the microscope, the quartz is seen to contain great numbers of liquid-inclusions, within which are often remarkably perfect cubes of salt, some of which seem to be rounded on the edges. The groundmass is a crystalline aggregation of feldspar and quartz, isolated particles of which are also found included within the quartz.

The rhyolites which surround the limestone body of the Wachoe Mountains present considerable variety in appearance and structure. The most prominent rhyolite in Spring Cañon is a compact porphyritic variety, having somewhat the appearance of a hornstone. It contains, in a greenishdrab groundmass, crystals of dark, smoky quartz and occasional feldspars, but no mica. Through the mass are inclusions of jaspery-looking fragments, which seem to be pebbles entangled in the groundmass. Besides these are frequent green, earthy spots, apparently resulting from a partial decomposition of the felsitic groundmass. In the centre of some of the larger of such parts is found a greenish, granular substance, which effervesces with acids, around which the color of the groundmass shades off from a zone of green into the reddish hue of the unaltered rock. It would seem, therefore, that these greenish colors are due to the decomposition of included particles of limestone, which have reacted upon the groundmass of the rock. Under the microscope, the groundmass is seen to be made up of axial and central fibrations, and both quartz and feldspars to be rich in glass-inclusions.

A second variety of rhyolite from Spring Cañon is also a porphyritic rock of a brick-red color, in which, however, the groundmass is less compact and homogeneous. It contains, porphyritically-imbedded, white crystals of sanidin-feldspar and prisms of hornblende, but likewise no mica. Another variety from near the mouth of the cañon is a gray rock of a somewhat granitoid structure, rich in hornblende and feldspar, but showing no free quartz. The groundmass, which is in relatively small proportion in the rock, is of a leaden-gray color and compact felsitic texture. Under the microscope, this groundmass is seen to be a dense aggregation of almost colorless microlites, full of transverse cracks, along which it has become 
quite opaque. It is seen to contain, besides the sanidin and hornblende, an apparently large amount of plagioclase, with a little pale, yellowish augite.

At the very mouth of Spring Cañon, under the rhyolite flows, is an exposure of andesite, which also forms an isolated butte to the south of Last Chance Spring. Both these rocks have been classed by Zirkel among the augite-andesites. The rock at the mouth of the cañon has a dark-gray, compact groundmass, in which are crystals of black, fresh-looking hornblende and plagioclase-feldspar, with occasional black micas. Under the microscope, the groundmass is seen to have the glassy texture peculiar to the augite-andesites. There are also detected a few sanidin-feldspars and dark yellow augites, which are somewhat dichroitic. No olivine is found. This rock has all the external habit and somewhat greasy lustre of an andesite; that from the butte, however, is more like $a$ basalt in its external appearance. It is a dark, compact rock, with a conchoidal fracture, in which but few macroscopical crystals can be detected. It has a somewhat resinous lustre, and, under the microscope, is seen to be rich in plagioclasefeldspars and yellow-brown augites, both of which contain glass-inclusions, while the groundmass shows the characteristic interwoven network of microlites.

North of Spring Cañon, the volcanic rocks lie next the granite body, falling off gradually toward the Desert, with a rough, broken surface of hills and ridges quite characteristic of rhyolite regions. Of the only two volcanic rocks observed here, andesites and rhyolites, the latter occupy by far the greater area; the former, indeed, only reach the surface in one or two isolated hills, where erosion has apparently worn away the softer, superimposed rhyolites, leaving the compact andesite in bold outcrops. There are but few localities, if any, within our belt of exploration, where the relation between the two can be better observed than in the Wachoe Mountains. Here the contact between the two may be distinctly seen, the rhyolite flowing over and concealing the older basic eruptions.

A specimen of these andesites, in the collection from the northern end of the Wachoe Mountains, has some marked peculiarities. It possesses a 
dark steel-gray color, an oily resinous lustre, a compact, microcrystalline texture, with a decidedly conchoidal fracture, characteristics of andesites. It breaks readily under the hammer, with a fresh, bright surface, and withstands atmospheric agencies remarkably well. Mineralogically, that which first strikes the attention in this rock is the great number of brilliant biotite plates with which it is studded, and which protrude from the groundmass in a striking manner. The feldspar-crystals are all small, but show both sanidin and finely-striated triclinic forms, the latter especially brilliant. A few small acicular hornblende individuals are visible to the naked eye.

Under the microscope, Zirkel has shown that plagioclase is the prevailing feldspar, that hornblende is exceedingly rare, no augite being present, and that a few quartz-grains are scattered through the groundmass. $\mathrm{He}$ also calls attention to this rock as being "the mica equivalent of the hornblende-andesites".

This rock shows a strong family resemblance to the Spring Cañon group. Yet it is quite remarkable that it should be so rich in mica and free from augite, and the others characterized by the presence of so much augite as to deserve the classification of "augite-andesites". Geologically, they both bear the same relation to the rhyolites. This andesite, from the northern end of the mountains, has been carefully analyzed by Mr. R. W. Woodward, who obtained:

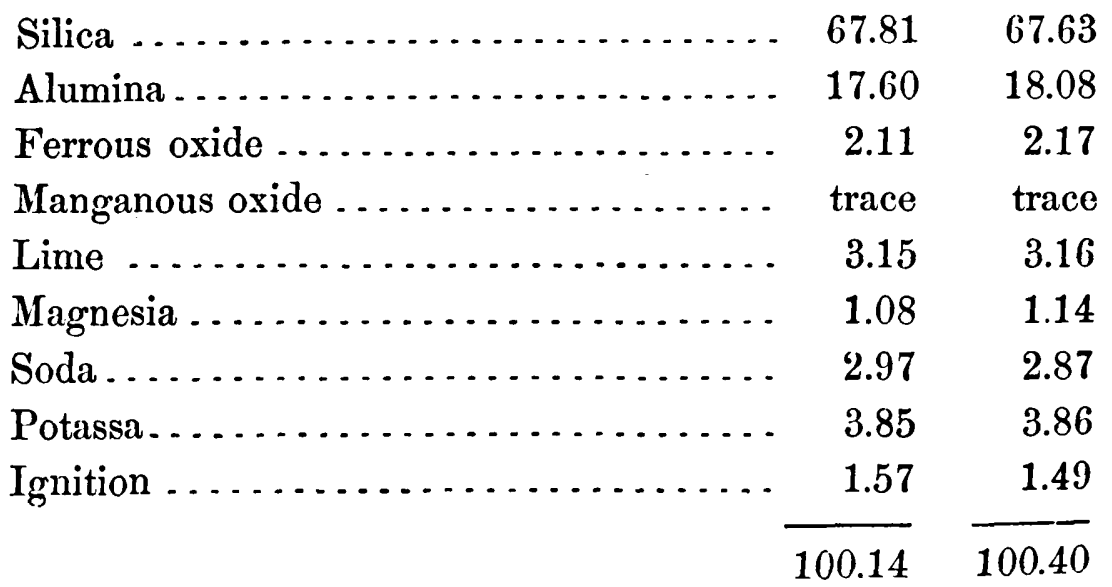

This analysis is really quite remarkable, and varies widely from the normal hornblende-andesites. It stands some 10 per cent. higher in silica 
than the typical andesites from Washoe, and, unlike the latter, the potassa is far in excess of the soda. All augitic andesites are apparently ligher in silica than the hornblendic group, but probably yield a much lower percentage than this rock from the Wachoe Mountains. A silica determination of the Spring Cañon augitic andesite gave 62.46 per cent.

In general, the rhyolites from the northern end of the mountains resemble those already described from the region of Spring Cañon. Few localities, however, within the same area, exhibit such an endless variety of rhyolitic forms, at least so far as superficial appearances are concerned. They mainly consist of rocks, with a fine microfelsitic groundmass, carrying small crystals of sanidin and quartz-grains, with an occasional hornblende. They occur in all shades of gray, red, purple, black, white, and cream-color, and varying from a fine-grained compact mass to a coarse, rough, vesicular texture. This variety in color is rendered still more striking by the presence of pumice, glassy, and half-glassy bodies of brilliant tints in a light-colored groundmass. One very characteristic rock is marle up of a light-red groundmass, through which occur blood-red bands of a jasper-like substance, frequently enclosing both quartz and sanidin, which suggests the lithoid variety of rhyolites from the Pah-Ute Range. These bands are arranged in a roughly parallel manner, giving the rock a somewhat stratified appearance.

Under the microscope, the quartz and feldspar are shown to be almost free from microscopical impurities. But in one of the quartz-grains, Professor Zirkel detected a number of liquid-inclusions, with mobile bubbles, a very surprising observation, as in no other known rhyolite has such an occurrence been noted. And it is probably no exaggeration to state that tho number of such quartz-grains that have been subjected to microscopical scrutiny must reach many thousands. Professor Zirkel also mentions that close by this grain of quartz occurs a decomposed feldspar, which closely resembles those found in granites, and suggests that both these minerals are bodies foreign to the rhyolite. This suggestion seems all the more plausible when we recall the close proximity of the later rock to the large body of Wachoe Mountain granite. 
On the south side of the Wachoe Mountains extend flows of rhyolite, forming low rolling hills, which stretch out westward nearly to the centre of Steptoe Valley, and connect at the south with the northern end of the Schell Creek Mountains. In their main features, they resemble the hills already described, but, in detail, have been little studied.

By reference to the lower section, at the bottom of the geological map, the structure of the Wachoe Mountains will be readily understood. The section is drawn on a due east and west line. It represents a central granite nucleus, forming the higher summits, with Coal-Measure limestones dipping away on both sides. On the eastern side, the limestone is traversed by quartz-porphyry dikes, and still later, on both sides, the palæozoic beds are concealed beneath the rhyolites, which, flowing out into the valleys, are, in turn, covered by Quaternary deposits. It is worthy of notice that few desert ranges of Eastern Nevada have such abundant springs of fresh water as are found upon the eastern side of the Wachoe Mountains, in the granite, limestone, and Quaternary beds.

Antelope Hills and Schell Creek Mountains.-Directly south of the Wachoe Mountains is a series of low ridges, forming the junction of the Schell Creek Mountains with the Antelope Hills. At their northern end, just north of Leech Spring, rises a low ridge, formed by westerlydipping beds of dark gray limestones and siliceous and argillaceous limy shales. To the east of this main ridge, is a second narrow ridge on the very edge of the Gosi-Ute Valley, composed of a core of granite, on which, to the west, rest some beds of limestone, while on the east of the granite is a peculiar series of interstratified beds of white dolomitic marble and flows or dikes of granitic porphyry, in which occur several veins carrying oxide of copper. From the miners who once prospected these veins, this region has received the name of the Kinsley District. 'The limestone beds of this region have been referred, like those of the Wachọe Mountains, to the Lower Carboniferous group. The association of beds of crystalline dolomite and granitic porphyry has been considered to represent the development of an Archæan body. They strike north and south and dip $25^{\circ}$ to the eastward. No less than six distinct beds of granite-porphyry, 
of thicknesses varying from 10 to 20 feet, were observed in a little hill just cast of the main ridge.

The marble is a remarkably beautiful, pure, fine-grained crystalline rock. Under the microscope, it is seen to have a crystalline-granular structure, the crystals of calcite having distinct twin striations, together with numerous fluid-inclusions containing a moving bubble which does not disappear at $100^{\circ} \mathrm{C}$. A partial analysis of a specimen of this limestone made by Mr. B. E. Brewster shows it to be a normal dolomite, containing 56.537 per cent. carbonate of lime and 41.119 per cent. carbonate of magnesia. It occurs in beds of varying thickness, some of which would furnish immense blocks, and are admirably situated for quarrying purposes. In general, they present the fine grain and purity of color of a statuary marble, but are sometimes shaded with wavy bands of bluish color running through the mass. The porphyries occur at comparatively regular intervals on the sides of the hill, seeming to be in every way conformable with the beds of marble.

This interesting group of porphyries, while having a general generic resemblance, presents in its extreme types considerable difference of appearance. The upper bed is a greenish-white felsitic rock, having much the appearance of a quartz-porphyry. It contains white, mostly opaque crystals of monoclinic feldspar and distinct rounded crystals of quartz in a light-green micro-crystalline groundmass. Only a few rare crystals of hornblende and mica can be distinguished through the mass, which, like the porphyry of the Wachoe Mountains, shows stains of iron oxide, though no grains of magnetite are visible; Zirkel refers the origin of these stains to the decomposition of hornblende. The other extreme is a dark-gray granitoid rock, rich in comparatively large crystals of hornblende and mica, and well-defined orthoclase crystals, while the quartz can with difficulty be detected by the naked eye. A middle member is more distinctly a felsitic porphyry, showing only comparatively few white feldspar crystals, and a fow sparse hornblendes and micas in dark-gray micro-crystalline groundmass.

Under the microscope, these exterior differences are lost in the closely similar mineralogical behavior of the rocks. The groundmass is seen 
to be distinctly crystalline, and made up of quartz, feldspars, mica, and hornblende, the latter often fibrous. Apatite and magnetite occur, the latter in very well-defined crystals. In the more granitoid varieties are some striated plagioclases and microscopical titanite. The quartz contains included portions of the groundmass, and both empty cavities and liquid-inclusions, among which are some with carbonic acid, but no glass-inclusions. In one of the more porphyritical varieties is seen a tendency toward felsitic porphyry in the presence of a few sphærulites. It contains well-defined titanites, and its hornblendes are not fibrous.

The numerous mineral veins which occur in these rocks have a general northerly strike, with that of the inclosing rock. They had not been opened at the time of our visit, but showed considerable green carbonate and red oxide of copper in the outcrops. The rock which forms the core of the main ridge, though having something of a generic resemblance to the porphyries, has been colored rather as a granite than a porphyry. It is a whitish, somewhat decomposed-looking rock, made ụp of quartz, feldspar, mica, and hornblende, in which the prominence of the latter and of the larger feldspars, in the distinctly macro-crystalline white mass of the rock, has somewhat of a porphyritic appearance.

The low hills to the south known as the Antelope Hills are made up of flows of various rhyolites. Of these, there is found directly adjoining the Marble Hill on the south a brick-red porphyritic rhyolite, somewhat resembling that of Spring Cañon. It contains white opaque feldspar, quartz, mica, and hornblende in a red compact felsitic matrix. The quartzes are sometimes associated together in lenticular bodies through the mass, and are found in very perfect crystals lining small druse-like cavities.

On the main ridge south of Leech Springs, so named from the abundance of these animals in its waters, is a reddish rhyolite containing large hornblendes, but no macroscopical quartz or mica, in a groundmass which shows very distinctly the characteristic banded structure of these rocks. Under the microscope, these bands are shown to be made up of alternations of sphærulitic fibrous material, with bands of an imperfectly granular nature, without tendency to fibration. The rock is seen to contain characteristic con- 
cretions of tridymite, with a little quartz, some biotite, apatite, and hornblende. Adjoining this is a rhyolite showing small white opaque feldspars, in a purple, somewhat rough-feeling groundmass, carrying small, green, fibrous hornblendes, but no macroscopical quartz. Under the microscope, no tridymite is found, but the sanidins are seen to contain glass-inclusions, having a peculiar serrated border not found in the inclusions of quartz. .

In the Schell Creek Mountains, which extend to the south from Leech Springs, forming the eastern border of Steptoe Valley, are limestones in which Primordial fossils have been found, overlying heavy bodies of Cambrian quartzite; the northern portion of the range is, however, entirely covered by flows of rhyolite, as far as has been observed.

Among the organic remains from this range, two new species have been identified:

\section{Crepicephalus (Loganellus) anytus.}

\section{Lingulepis Mara.}

Steptoe Valley has at its lowest point, where the waters which drain from the Egan Mountains form a little lake, an elevation of 5,730 feet aloove sealevel, already 600 feet more than that of Deep Creek.

Egan Ravgr.-That portion of the Egan Range which is represented on this map is a high, narrow limestone ridge, about 6 miles in width, having a north and south trend, whose most lofty peak rises nearly 5,000 feet abovo the sink of Steptoe Valley, while its average width is only about 6 miles from base to base. In topographical structure, it presents a double crest, a central line of depression being formed by a series of high, interior, longitudinal valleys, which drain to the eastward. Its general geological structure is that of an anticlinal fold, along whose crest erosive action has been the greatest, resulting in the formation of these longitudinal valleys, whose direction has doubtless been determined by a line of faulting along the axis of the fold. As compared with most of the desert ranges, it is unusually well watered, there being numerous large springs issuing from the limestones along its base, and considerable streams. running from the interior valleys; that from Gosi-Ute Cañon empties into the little lake at the sink of Steptoc Valley, and that from Pleasant Valley sends a stream of water for many miles out on to the desert, while its higher slopes and the interior 
valleys support a considerable growth of pine and mountain-mahogany (Cercocarpus ledifolius). At the northern point of the range, the fold is very flat, the eastern beds dipping only about $15^{\circ}$, the angle of the western fold being somewhat steeper. The basin of the little interior valley here is partially filled by an outburst of rhyolite of white earthy variety, so easily decomposable that but few fresh exposures of the rock could be found. The surface of the white soil resulting from its decomposition is dotted by curious little ant-heaps, often three and four fect in diameter, made up entirely of grains of limpid quartz, in most of which the crystalline outline, which is generally so well preserved in rhyolites, can be still distinguished. From Mahogany Peak south, the axis of the anticlinal fold, which is somewhat to the east of the main crest of the range, gradually approaches the eastern flanks of the range, and at Gosi-Ute Cañon the whole series of limestones are found dipping west at an angle of $10^{\circ}$ to $15^{\circ}$. As exposed in section in this cañon, they present a body of close-grained, gray, rather siliceous limestones, with distinct bedding and regular jointing-planes, having near the base a white crystalline bed. The higher portions which form the main ridge of Gosi-ute Peak are in general a grayish-blue, rather earthy limestone, traversed by thin scams of white calcite, with some interstratified shaly strata. From the upper beds only were any fossil remains obtained.

From the upper beds of Mahogany Peak were obtained:

Productus multistriatus,

Productus subhorridus,

Athyris subtilita (var. Roissyii);

from Gosi-Ute Peak were obtained:

Productus punctatus,

Campophyllum (frag.);

while from one of the lower beds in the cañon was obtained:

Diphiphyllum, sp.?

The aspect of these fossils and the great thickness of limestone exposed establish, beyond a doubt, the fact that these beds belong to the Wahsatch 
group of limestones. The whole body has been indicated by the color of the Lower Coal-Measure group; but the negative evidence of no lower fossils laving been found is by no means a conclusive proof that the Devonian formation may not be represented at this point. The finding of Silurian fossils in the limestones in the neighborhood of Egan Cañon, on the other hand, renders it certain that the Devonian limestones may be found, if not here, somewhat to the southward.

The range was not visited by our parties between Gosi-Ute Cañon and Egan Cañon, which lies some 8 or 10 miles to the south of the limits of the map. Here, at the point where the Overland Stage Road crosses the range, it is divided by a broad, open valley into two distinct ridges. The lower or western ridge is composed of limestones, dipping gently to the westward, which probably represent a continuation of those seen in GosiUte Cañon. In the eastern or higher ridge is seen a section of Cambrian quartzites and slates overlying granite, also dipping to the westward. Here the granite body forms the extreme eastern face of the range, and is overlaid by several thousand feet of quartzites and quartzitic schists, together with a 50 -foot bed of finely-laminated argillite, or roofing-slate. The main mass of quartzite is a compact, white, semi-translucent, thoroughly vitrified rock, showing little trace of granular structure. Within the series are thinner beds of dark-purple quartzite, showing evidence of having been submitted to great pressure, the surfaces being indented with impressions of coarse quartz pebbles, while in the interior there are developed occasional flakes of white mica. $\Lambda$ nother bed of light grayish-green rock shows a more fully-developed schistose structure, and is quite full of fine plates of white mica, though in hardly sufficient quantities to constitute a normal mica-schist. At the base is a bed formed of coarse rounded grains of quartz, in a matrix of green semi-crystalline quartz, which also has an occasional development of bronze-colored mica.

The granite is an even-grained, easily decomposable rock, containing a good deal of plagioclase, much magnesian mica, and some little hornblende, distributed in fine dust throughout the other constituents, with distinctly erystallized titanites. The rock also contains the zircon-like mineral which has been observed in the Archocan rocks of the Wahsatch 
Range. Its analysis was made by Prof. Thomas M. Drown, with the following result:

Silica............................ 70.46

Alumina .............................. 15.36

Ferrous oxide ......................... 2.93

Manganous oxide....................... 0.13

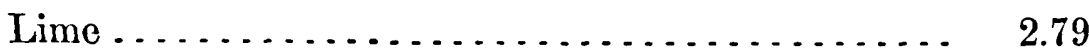

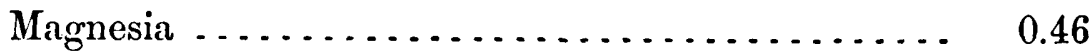

Soda .............................. 3.89

Potassa ............................ 3.98

Ignition........................... 0.45

100.45

The quartzite body doubtless represents a development of the Cambrian formation at this place. The direct contact of the overlying limestones with these quartzites was not observed, but the general structure of the intermediate portion of the range between this point and Egan Cañon shows a series of limestones dipping to the west, having a strike somewhat to the east and north, which would give room for the entire series of Silurian and Devonian limestones between this point and Gosi-Ute Cañon.

RUBY Group.-The broad low ridges constituting the Ruby Group, to the west of the Egan Range, are made up of beds of light-gray and drab limestones, whose structure is that of a broad synclinal, the angle of dip of the beds being rarely more than $10^{\circ}$. On the low ridge which forms the southern extension of Hamilton Butte, where crossed by the Overland Stage Road, the limestones are mostly concealed beneath surface accumulations and flows of basalt, which occupy the higher portions of the range, and once probably extended across the valley to the west to the foot-hills of the Ruby Group. Near the summit of the pass is a curious group of bare knolls formed of rhyolitic tufa, whose soft, gray, porous mass has been worn into curious shapes. Their surface is covered by little indentations or cavities, left by the fragments of included lava which have fallen out, giving them the appearance of a gigantic thimble or old-fashioned bee-hive; hence their name, "The Beelives". The mass of this tufa is of a light-gray color, 
in which are white spots of decomposed feldspars, the whole being filled with fine flakes of black mica and small crystalline fragments of quartz. Among the included fragments of undecomposed rock, the original rhyolite is seen to be a porphyritic variety, containing large crystals of greenish sanidinfeldspar, with a small amount of very fine mica and homblende, and largo rounded quartz, in a drab felsitic groundmass. This tufa, or breccia, is immediately overlaid by the flows of dark, compact, half-rylassy basalt, which form the summit, under which, on the eastern side, can be distinguished a few westerly-dipping, but nearly horizontal, beds of drab limestone, carrying the same fossils as those found in the western ridge. The rocks which constitute the basalt flow of this ridge and the one next west are in greneral dark, compact, fine-grained varieties, in which scarcely any distinct crystals can be distinguished by the naked eye. In general, they present a dull, greasy lustre and a semi-vitreous texture, breaking easily under the hammer into thin, curved fragments, which ring like glass. In these, a few minute feldspar crystals can be detected and some small, sparse grains of olivine. In the granular variety, which is a heavy, dark-gray rock, the color of the former being nearly black, no crystalline ingredients could be detected at all. These flows of basalt are comparatively thin, not more than 50 to 100 feet in thickness; their beds incline with the slope of the hills, and stand in isolated patches on the spurs which they have preserved from erosion.

The western ridge, which forms the eastern border of Ruby Valley, is made up of heavy beds of the same drab and cream-colored limestones, some of which are rich in fossils. The beds have a dip of $10^{\circ}$ to the eastward, and their western base is underlaid by calcareous and argillaceous shales. They probably represent the upper horizon of the Wahsatch limestone as developed in this region. Among the fossils obtained from these beds, the following were determined by Prof. F. 13. Meek :

Productus multistriatus.

Productus scmireticulatus.

Productus Nevadensis.

Spiriferina pulchra.

Athyris subtilita.

Athyris Roissyii. 
IIamilton Butte, which forms the northern end of these two ridges, is a broad, flat-topped hill, a little over 3,000 feet in height, measured from its base, with long, gentle, well-covered slopes, made up of limestone beds belonging to this same formation, lying nearly horizontal, but with an inclination of a fow degrees to the westward. The same fossiliferous stratum was recognized here as in the ridges to the south, in which was also found the Productus subhorridus of the Egan Mountains. In the northern end of Butte Valley, at the base of Hamilton Butte, are numerous large springs of fresh water, surrounded by considerable extents of meadow-land.

Franklin Buttes.-Out of the desert plain to the north of Hamilton Butte rise three little hills, known as the Franklin Buttes. With the exception of a little fragment of limestone on the eastern end of these hills, which has been referred to the Lower Coal-Measure limestones of the Egan Mountains, they are entirely made up of older eruptive rocks, which form a series quite as peculiar and very similar to those of the Kinsley district.

The rocks which form these little buttes present an interesting gradation from a syenitic granite, throughl granite-porphyry, into genuine felsiteporphyry. The western or smaller of the three has not been visited, but is colored like the main mass of the middle of the group. This butte consists of a long, narrow, north and south ridge of syenitic.granite, on whose eastern spurs are a succession of different beds, or dikes, of granite-porphyry, having also a north and south trend, though the hills are too low and too much covered by surface débris to show very definitely their structure. The eastern or higher butte shows a much more felsitic-looking rock, with less variety of structure; its main mass being a genuine felsiteporphyry.

The main rock of the middle butte is a crystalline aggregation of fleshcolored orthoclase, and greenish plagioclase-feldspars, quartz, and hornblende, in almost equal proportions, with some titanite. In places, it shows a porphyritic tendency in developing a partial groundmass, with somewhat rounded particles of quartz, and has been classed by Professor Zirkel from the hand-specimen as a granite-porphyry. The succeeding dikes, or beds, to the eastward, of which no less than six varieties were observed, are distinctly syenitic granite-porphyries. 
Those adjoining the main body consist of a micro-crystalline groundmass, having the flesh-color of the orthoclase-feldspar, with scattered crystals of dark-green hornblende and greenish-white plagioclase-feldspar porphyritically imbedded. The groundmass, as in all these rocks, is an entirely crystalline aggregation of quartz, feldspar, and hornblende, with no mica. In the more eastern members, the rock has a more felsitic appearance, the hornblendes are of lighter color, and more generally disseminated through the groundmass, and, with its varying proportion, the color of the rock varies from greenish-white to greenish-purple; the extreme member has the external appearance of a volcanic rock, breaking with a conchoidal fracture, and having a dark, semi-vitreous, weathered surface. In all of these, the crystalline ingredients predominate over the groundmass.

On the eastern butte, the rocks have a macroscopically homogeneous groundmass, of light color, with but few distinct crystals. IIere the graniteporphyries are of greenish-drab color, showing crystals of flesh-colored feldspar, scattered hornblende prisms, and a few flakes of black mica.

The felsite-porphyry of the main mass is a white homogeneous rock, with a few scattered black specks of hornblende and mica. Under the microscope, this latter rock resembles the Cornish elvan, the groundmass being an entirely crystalline aggregation of quartz and feldspar. The quartz contains glass-inclusions, which are not found in the neighboring graniteporphyries, and which are a rare occurrence in a wholly crystalline rock. The micas are seen to contain apatite.

In microscopical behavior, the granite-porphyries present the same greneral features. The micro-crystalline groundmass is comparatively coarse, showing rarely any sphærulitic tendency and no amorphous base. The quartz contains only liquid-inclusions, which are sometimes very abundant in the more granitic varieties, and consist, for the most part, of a saturated solution of chloride of sodium, with cubic crystals, two or more often appearing in the same cavity. Some of the larger quartzes also contain "stone-cavities", i. e., amorphous inclusions of microfelsiticallydevitrified substance. The amount of hornblende is comparatively large; apatite and titanite are both of frequent occurrence. 
Included in the granite-porphyries of the middle butte is a bed or dike of diabase, a heavy dark-green, amorphous rock, in which no crystalline ingredients are visible to the unaided eye: its association and physical habit suggest, however, the mineralogical character, which is confirmed by the microscope, of an older eruptive rock, consisting mainly of plagioclase and augite. 


\section{SECT I O N I I. \\ OMBE MOdNTAING TO EAST IIUMBOLdT RANGE.}

BY ARNOLD IIAGUE.

Ombe Monntains.-To the north of the Ibenpal Mountains, the Great Desert extends to the westward for several miles, with long, dreary slopes toward the Gosi-Ute Range; but farther northward, it is again cut off by the Ombe Mountains, which rise abruptly above the level plain of Lower Quaternary. The mountains are about 30 miles in length by not more than 4 or 5 in width, with a trend a few degrees east of north and west of south. The 114th meridian, the boundary-line between Nevada and Utah, runs just east of the main crest of the mountains, while the 41 st parallel crosses the lower slopes of Pilot Peak, at the extreme southern end. Pilot Peak, its most prominent elevation, forms one of the most commanding summits in this region of country, reaching an altitude of over 10,000 feet above sea-level, and rising at least 6,000 feet above the Desert. From its great elevation, abrupt slopes, and isolated position, it has always been, from the times of the earliest explorers and emigrants, a noted landmark in their journeys across the country; and, as it lies just west of the Great Desert, midway between the IIumboldt and Wahsatch Ranges, the summit affords one of the broadest and most instructive views to be obtained in Western Nevada.

Within the limited area occupied by this narrow range, there are found represented the older highly crystalline granites, heavy massivo quartzites and limestones, which have been referred to the Carboniferous, thinly-bedded, upturned calcareous and siliceous shales of the Green River Eocene Tertiary, and still later a considerable outburst of rhyolites and basalts, finally followed by the deposition of horizontal beds of Pliocene age. By reference to the geological map, it will be seen that there is only one body of granite represented, situated near the central portion of tho range; other bodies occur, but they are too small to be indicated. 
This granite body of the Ombe MIountains covers only a limited area, extending, however, across the entire width of the uplift, until the lower spurs on both sides are concealed beneath the Quaternary deposits of the valleys. It occupies the narrow, relatively-depressed portions of the mountains, known as Patterson Pass, which rises above Tecoma Valley, on the west side, with gentle slopes, some 2,400 fect, but falls away much more rapidly toward the Great Desert to the eastward, which lies nearly 3,000 feet below the water-shed of the pass. $\Lambda$ s thus defined, it measures about 4 miles in width, but scarcely more than 2 miles in a north and south direction, being overlaid by the heavy quartzite and limestone formations, which would appear to form an anticlinal fold, dipping away in opposite directions from the granite, the latter coming to the surface only along the axis of the fold. This granite is a medium-grained rock, somewhat friable in texture, and of a reddish-gray color, derived from an admixture of both red and white feldspars. The mineral constituents are chiefly quartz in small, translucent grains, associated with both monoclinic and triclinic feldspars. Mica, in thin brown flakes, frequently adhering to the broater faces of feldspars, is present, but in subordinate amounts. The white feldspars are often an inch in length, forming a strong contrast to the smaller, but more abundant, red crystals. $\Lambda$ determination of the alkalies in one of the large white feldspars gave: soda, 2.34 per cent.; potassa, 12.58 per cent. The other small outcrops of granite are found to the northward of Patterson Pass, in the limestone body, where they occur as irregularly-shaped masses and low, rounded hills.

Immediately south of Patterson Pass, resting unconformably upon the granites, and rising abruptly above them, occur the quartzite formations. They occupy the entire distance as far as the southern slopes of Pilot Peak, the mass of that mountain being formed almost completely of brilliant white quartzite beds. All the beds would appear to have undergone considerable lateral compression, many of them standing at high angles, producing a complicated structure, with local displacements; the main crumpling having produced both a synclinal and an anticlinal fold, with their axes striking diagonally across the topographical axis of the range. At Patterson Pass, the quartzites strike north $30^{\circ}$ east, with a steep dip to the southeast, but shallowing southward as far as a low break in the range, 
where they form the synclinal, the beds on the south side dipping northwest, but with the same strike as before. At Pilot Peak, there is an anticlinal fold, the beds striking north $15^{\circ}$ to $20^{\circ}$ east, and dipping $15^{\circ}$ both to the east and west; the greater part of the rock-mass inclined to the southeast.

This quartzite body, although its age has not been definitely determined, has been referred to the Weber formation. This reference is based upon its great thickness, at least 6,000 or 7,000 feet, its similarity to other great quartzite bodies which have been regarded as of Carboniferous age, and its probable relation to the overlying limestone strata found upon its southern flank. It is possible, however, that further examination may show that there are two distinct unconformable quartzites represented in the range. In its lithological aspect, this quartzite shows but little variety. It is all heavily bedded, with the divisional planes distinctly marked; it is mostly a fine-grained compact mass, with a conchoidal fracture and slightly arenaceous texture. Near the northern end, it has the prevailing bluishgray or brownish-gray color which characterizes the Weber Quartzite in Nevada.

At Pilot Peak, however, the rocks possess a somewhat different habit, closely resembling the massive quartzites of Bonneville Peak, Aqui Mountains, which have been referred to the Cambrian age, the upper beds being a pure snow-white body, underlaid by others of a deep bluish tinge, which appear less pure, carrying some feldspathic material, with occasional pebbles, and passing down into conglomerate beds, with quartz and jasper pebbles, showing considerable compression and flattening, and arranged with their broader faces parallel with the planes of stratification. Interstratified in this quartzite are narrow seams of silver-gray mica-schists composed of brown mica and quartz in exceedingly fine brilliant particles. A characteristic feature of Pilot Peak is seen upon the east side, where the entire slope is covered with huge blocks of quartzite, which have fallen down, and now completely hide the rock in place. This rock-mass is so exceedingly brittle, that, although formed of nearly pure silica, it has, under the influence of frost and ice, worn away with great rapidity, showing near the summit numerous rents and fissures with walls two and three hundred feet in height, standing out from the main mass, shattered and partially fallen 
down. A chemical examination shows the rock to be nearly pure silica:

Silica... . . . . . . . . . . . . . . . . . . . . 94.93

Water .......................... 0.17

95.10

with less than 5 per cent. of alumina and alkalies.

On the south flanks of Pilot Peak, the heavy dark-blue limestones, which rise between 1,500 and 1,800 feet above the valley, have been referred to the Upper Coal-Measure horizon. From these beds were obtained the following forms:

\section{Productus punctatus.}

Spirifer cameratus.

North of Patterson Pass, both the quartzites and limestones appear, lying conformably upon the granite body. Here, as well as on the south side, the beds stand up above the granites several hundred feet. At the pass, they dip gently to the westward, the limestone beds extending down to the valley-deposits. The quartzites strike a few degrees east of north; their boundaries, however, along the eastern base were not well determined, while the limestone body extends along the west side of the range for 5 or 6 miles, until it passes beneath the Tertiary volcanic outflows. It forms all the higher summits of the ridge. It is much disturbed and broken, having undergone considerable faulting and folding, and may be seen dipping in nearly all directions. Here may also be observed low, irregular hills and bosses of granite protruding above the limestone, the latter having suffered considerable erosion near the points of contact.

In this limestone have been found many well-defined but narrow veins of ore, and considerable time and money have been expended in exploring and opening the most promising mines. The ore is galena, carrying silver, associated with carbonates and other oxidized products, so frequent an occurrence throughout the mountain limestone formations of Nevada. Special interest, from a scientific point of view, however, is attached to this district, which has become quite famous as a locality for wulfenite (molybdate of lead). In other localities in Nevada and Utah, the presence of wulfenite in $32 \mathrm{D}$ G 
galena veins has been shown, but in none does it occur in such large quantities or in so well-crystallized specimens as in the Tecoma District, Ombe Mountains. The molybdate of lead frequently forms so high a percentage of the ore as to interfere seriously with its treatment in the ordinary leadfurnaces, rendering a modification of the methods employed very desirable. The crystallized wulfenite from the Tecorna Mine occurs in large masses, the faces of individual crystals having been observed from an inch to an inch and one-half in length. They possess a resinous lustre, a lemon-yellow color, and are frequently transparent and exceedingly brittle. In size and brilliancy, the finest specimens far surpass the famous wulfenite crystals from the limestones of Bleiberg in Carinthia. Associated with the wulfenite, adhering to the broad tabular faces, may occasionally be seen well-developed crystals of cerusite and anglesite (carbonate and sulphate of lead).

At another locality in the mountains occurs a quantity of bluish-green and brown chrysocolla (silicate of copper) associated with some oxide and carbonates of copper, but of no economic importance.

On the eastern slopes of the Ombe Mountains, about 10 miles south of the railroad, there are exposed, in the deeper cuts and ravines, sections of upturned sedimentary beds of Tertiary age, from which no fossils were obtained, but which, from their close lithological resemblance to beds of this age, as developed in Peoquop Pass and Elko Valley, have been considered to represent the Green River Eocene. They dip at an angle of $45^{\circ}$ to the eastward, with a strike of north true. They consist mostly of white, thinly-bedded calcareous and siliceous shales, remarkably fissile and frequently bituminous, carrying several thin seams, from 1 to 2 feet in thickness, of light coal. This coal, though black and lustrous, and apparently free from earthy matter, is, like that of Elko, very light, crumbles on exposure to the air, and will probably prove of little economic value.

Later Tertiary beds, lying approximately horizontal, probably of Pliocene age, occur at the northern end of the mountains, cropping out in a few localities, where exposed from beneath the Quaternary deposits. They consist, for the greater part, of fine siliceous rhyolitic material, interstratified with occasional fine sands. In color, they are light lavender and grayishwhite, showing an even texture, with but little variation in composition. 
Although quite friable, many of the beds split up readily into thin plates, with an almost fissile structure. Under the microscope, the rock shows its eruptive origin, and its glassy, pumice-like nature.

The volcanic outbursts connected with the Ombe Mountains neither cover an extensive area, nor have they apparently had much effect upon the present structural position of the older Palæozoic beds. They are found, for the most part, at the extreme northern end of the mountains, where the Carboniferous limestones plunge down beneath the plains, and would otherwise have formed the termination of the Ombe upheaval. At this point, both rhyolites and basalts occur, the former preceding the latter, and being in part concealed beneath the heavy basic rocks.

A noteworthy feature of these rocks, taken together, is found in the exceedingly glassy nature of the rhyolites, showing almost the extreme form of glass base, in which at the same time well-defined crystals of feldspar are abundant; while the basalts, which in Nevada are frequently characterized by a half-glassy base, are here found made up largely of a fine but distinctly crystalline groundmass. The main occurrence of rhyolite forms a rounded outlying hill, or butte, with steep slopes, rising some 300 feet above the valley, but falling away gradually to the eastward with an angle of $2^{\circ}$, and presenting much the appearance of fortifications or embankments. Lithologically, it more closely resembles many of the outbursts of the Nevada Basin than of the Plateau, and belongs, as mentioned, to the glassy and half-glassy varieties. A specimen in the collection from this hill is an exceedingly striking rock, made up of two kinds of glass, mainly, however, of a reddish-yellow or amber-colored one, with white sanidins and translucent quartz scattered through it. Imbedded in the sanidin are macroscopical inclusions of the same amber-colored glass, which makes up the base. In the report of Professor Zirkel, the microscopical structure of this glassy base is described at some length, and a thin section of the rock will be found illustrated in Plate 10, fig. 1, of his report. Another rhyolite from near the same locality shows much the same general character, but is lighter in color, and the glass appears drawn out in narrow bands and streaks.

The main mass of the basalt lies to the westward of the rhyolite, and 
covers a larger area, extending to the southward for two or three miles, where it forms a broad table-topped mass of dark-gray compact rock. It is a remarkably dense tough rock, breaking under the hammer with a hackly fracture, unlike those varieties rich in a half-glassy base. It has a finegrained groundmass, showing under the microscope feldspar and augite. Triclinic forms a quarter of an inch in length, and purely white, are imbedded in it; also what would appear as another species of triclinic feldspar with small bladed prisms, a brilliant lustre, and a very evident striation. Olivine, both macroscopical and microscopical, would appear to be wanting. The rock shows a good many cavities and druses filled or coated with carbonate of lime as a secondary product.

An analysis of this basalt made by Mr. R. W. Woodward yielded the following:

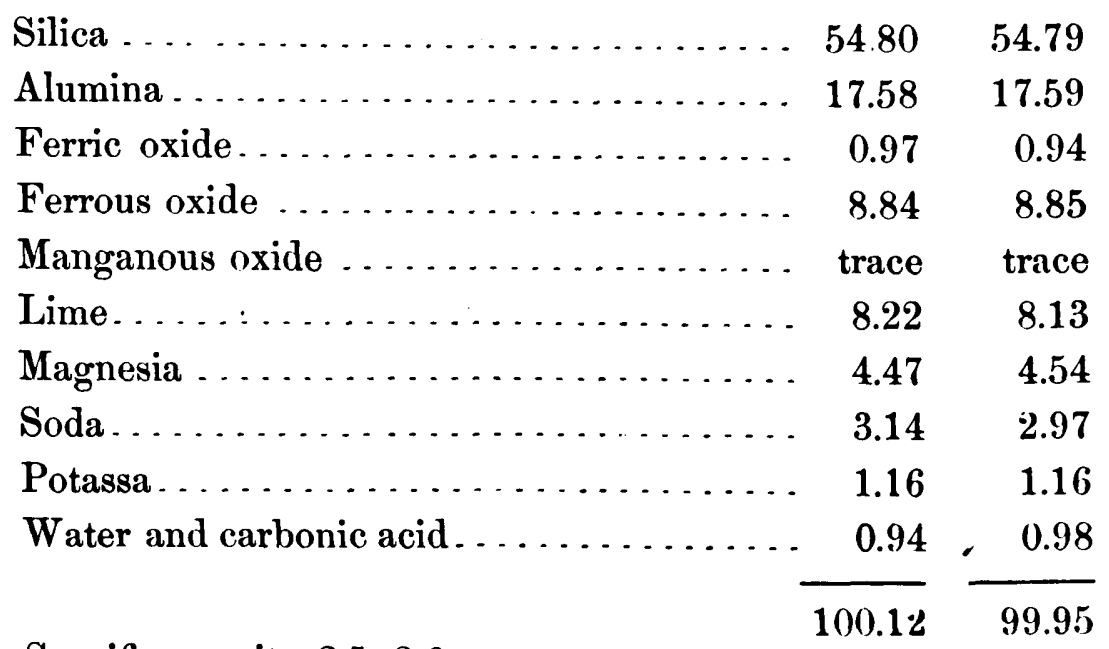

Specific gravity $2.5,2.6$.

It will be seen that the analysis runs very high in silica; indeed, no basalt analysed from our collection gave so large a percentage. It is correspondingly low in its specific gravity.

Along the east base of Pilot Peak, unrepresented on the map, occurs a small outflow of gray porous rhyolite.

In the Quaternary deposits that surround the Ombe Range, there is but little that is distinctive. On the east side of Pilot Peak, beyond the long slopes of Upper Quaternary accumulations, occurs a broad level plain, 
between 6 and 7 miles in width, composed of the Lower Quaternary fine clays and silts which characterize the Great Desert. In the dry season, over the greater part of this area, is found a heavy incrustation of quite pure common salt, derived from the beds below, which are evidently strongly impregnated, if, indeed, they do not carry a stratum of chloride of sodium. If necessary, there is no doubt but that this formation could be made to yield immense quantities of salt. From Pilot Peak, numerous streams run down beneath the débris of the slopes, coming to the surface near the plain in large springs. Many of them are quite fresh, but others, where the waters percolate through the Lower Quaternary strata before reaching the surface, are either brackish or highly charged with salt. At the Ombe Gap, north of the mountains, through which the railroad runs, occur alkaline deposits, consisting of an admixture of chloride of sodium and sulphate of soda.

Peoquor and Tonno Passes.-Directly north of the Little Cedar Mountains, Peoquop and Gosi-Ute Ranges, and on a line nearly due east from the termination of the East Humboldt Archæan mass, occurs an interesting break in the structure of the Palæozoic strata. The Carboniferous quartzites and limestones which form these narrow meridional uplifts are here thrown abruptly into a northeast and southwest direction, accompanied by considerable displacement, causing marked depressions and physical breaks in all three ranges, which may be easily recognized by reference to the geological maps. The railroad company have taken advantage of these gaps in constructing their line from the Salt Lake Basin to the headwaters of the Humboldt River. At Cedar Pass, the beds are much disturbed; at Peoquop Pass, the continuity of strata is broken, and a deep basin lying between the Peoquop Range and the Fountain Head Hills is occupied by Eocene Tertiary deposits; while, north of Toano Pass, the Carboniferous strata strike almost directly across the trend of the Gosi-Ute Range.

The Tertiary deposits which occupy Peoquop Pass extend in an east and west line for a distance of 8 miles, and rest unconformably upon the steep flanks of both sides of the gap. They strike northeast and southwest, and dip both to the north and south at angles varying from $6^{\circ}$ to $15^{\circ}$. The railroad-cuts and stream-beds expose a series of fine carbonaceous 
shales, marls, fine sandstones, and thin paper-shales. Thin, red, compact sandstones form the overlying beds, passing down into hard, red marls and shales, underneath which are more sandstones, banded red by oxide of iron, and in turn underlaid by finely-laminated gray shales, with thin beds of indurated clay. The peculiar carbonaceous zones, as well as the papershales, so closely relate these to the Elko shales that they have been referred to the Green River Eocene series. No organic remains of fish or insects, such as characterize the Elko beds, were obtained here, and the reference rests entirely upon lithological resemblances.

Overlying the upturned Tertiary beds are others approximately horizontal, and made up largely of comminuted volcanic material. They appear to extend westward across the valley, and to form the divide between the Gosi-Ute Desert and Thousand SpringValley, stretching southward as far as Toano Pass. At the pass, the depression is occupied by the latter deposits, mainly lavender-colored pumice-like beds, exceedingly friable, but distinctly bedded, and composed largely of rhyolitic, siliceous, and feldspathic material, in which are some sandy, earthy seams re-arranged and deposited under water. The town of Toano lies directly upon these Pliocene strata, and the more favorable beds are used to advantage for building purposes. The rock appears to harden upon exposure.

Gosi-Ute Range.-This range extends from Toano Pass southward to Mount Pisgah in an unbroken line of upheaval, with an almost true north and south trend. As thus limited, it measures about 65 miles in length, a narrow ridge scarcely averaging 6 miles in width. It presents the first long, continuous range west of the Great Desert, and forms the boundary of that great depression, its long slopes rising gradually above the plain on the eastern side, but falling away much more steeply on the other toward Gosi-Ute Valley, which lies 1,300 feet above the level of the desert. The range is one of extreme dryness and nearly barren of vegetation, there being but little soil either on the slopes or in the basins, while arborescent growth is confined to scattered dwarfed pines and stunted mountain-mahogany (Cercocarpus ledifolius).

Geologically, the Gosi-Ute Range is made up of granites, quartzites, and limestones; all the beds of the latter formations being referred to the 
Carboniferous age. The granite formations of the range occupy a very small portion of the area, and were observed with certainty in but two localities, one a mere outcrop in Toano Pass, and the other a much larger body in Middle Pass. The Middle Pass granite is an irregular-shaped mass, and, like the granite from the Ombe Mountains, extends across the range from valley to valley. It lies depressed between two large quartzite masses, portions of the great quartzite formation of the range, referred to the Weber beds, which, within short distances, tower above the summit of the pass, both to the north and south, at least 1,500 or 2,000 feet. On the west side, the granite rises only from 500 to 600 feet above the Gosi-Ute Valley, has a smooth, rounded summit, and falls toward Tecoma Valley, 1,500 feet below, in long, gentle slopes. This granite is coarse-grained, with a loose friable texture and a light-gray color. The constituent minerals show no order in their arrangement, and the rock appears to possess a normal granitic structure. All the ridges, outlying masses, and drainagebasins have gently curved and rounded outlines, sub-aërial action developing scarcely any sharp lines. The outcrop of granite mentioned as occurring in Toano Pass is found in the ravines north of the railroad, on the eastern slope, about two or three miles northeast from the town of Toano. So far as observed, it closely resembles the Middle Pass rock in physical habit and mode of disintegration, and is chiefly interesting from the indica. tion that it offers of a continuation northward of the same body of granite.

Between Toano and Middle Pass, the range is formed of the Weber Quartzite and the overlying Upper Coal=Measure limestone. Directly north of Middle Pass, the highest hills are of quartzite, but beyond, the summits are all capped by the limestone. South of the Toano Pass, the high group of hills forming the east half of the range are also formed of heavy beds of bluish-gray limestone, dipping $30^{\circ}$ to the east, and striking about north and south true. Near the west base of this series is a quartzite band, about 250 feet in thickness, which conformably underlies the main body of limestones. Underneath this again is a further development of limestone, whose thickness cannot be determined owing to the overlying Quaternary deposits. In the cañon of Owl Valley, the rocks are mostly quartzite, apparently dipping east, and underlying the limestone body. 
The quartzite mass, already referred to, north of Middle Pass, like the granite, stretches across the entire width of the range. It is distinctly bedded in heavy broad masses, striking north $3.4^{\circ}$ east, with a dip to the southeast. This quartzite is mainly white, with bands showing both bluish and grayish tints, and also carries beds of almost black quartzite. It appears to be made up of both large and small quartz-grains, metamorphosed and compressed into a dense compact rock. Many of the large grains are white and clear, while others appear to be flattened into thin flakes and sheets of quartz, with a decidedly schistose structure. Under the microscope may be seen minute flakes of white silvery mica, sometimes aggregated in layers; in the quartz are numerous fluid-inclusions. A small percentage of iron frequently colors the rock shades of brown and red.

South of Middle Pass, for a long distance, quartzite forms the main ridge, with the limestone overlying upon the flanks. In the region of Pine Mountain, where best observed, the limestone, of a light bluish-gray color, occurs dipping steeply to the westward. Near the summit, the following Coal-Measure species were collected:

\section{Spirifer opimus. Athyris subtilita.}

At Lookout Mountain, the culminating point of the range, which attains an altitude of 9,645 feet above sea-level, occurs an immense development of limestone. There are represented here between 3,000 and 4,000 feet of conformable strata, heavily-bedded, compact, blue limestone, with escarpments and walls varying from 30 to 100 feet in height. From Dondon Pass to the peak, the strata dip to the southward at an angle of $9^{\circ}$; along the main ridge of the peak the dip is $13^{\circ}$, and on the summit $9^{\circ}$. From the top of the mountain southward, there is a tendency to an anticlinal axis, and the beds which form the summit due west from Lookout Mountain dip sharply to the southwest.

The outlines of the limestone body to the northward and its exact relations to the quartzite formation were not worked out. The limestone has, however, been referred to the Lower Coal-Measure series of the Wahsatch limestone, partly on account of its great thickness, partly from its litho- 
logical resemblances, and in part to its relation to the other bodies of limestone in the adjacent regions. No organic remains that were capable of specific determination were collected; highly-altered specimens of Productus, associated with crinoidal stems, occur here, but of no special importance.

Mount Pisgah is a sharp, narrow, somewhat isolated limestone ridge south of Dondon Pass, whose beds resemble in lithological character those of Lookout Peak; their structure being that of an anticlinal fold, with a north and south axis, whose eastern member has been partly eroded. On the western foot-hills is a development of finely-laminated slates constituting part of the western fold, the entire structure being apparently in conformity with that of Lookout Peak. Our examinations at this point were extremely brief, and no fossils were found. By reference to the lower section, upon the geological sheet, the position of Mount Pisgah and its anticlinal structure will be readily seen.

Peoquop Range.-This range lies upon the west side of the Gosi-Ute Valley, and in many of its physical and geological features is almost a counterpart of the Gosi-Ute Range. As it rises, however, between two broad desert valleys of nearly equal elevation, it presents from the eastern side a much less bold and prominent appearance than does the Gosi-Ute Range. Its trend is almost due north and south, with a length of 52 miles, and is for the greater part of this distance even narrower than the range on the opposite side of the valley. It attains its culminating point in Spruce Mountain, which reaches an altitude of 10,400 feet above sea-level. Other prominent peaks are Grand Peak, 8,300 feet, at the southern end of the range, and at the northern extremity Orford Peak, 7,556 feet.

This range is one of extreme dryness, only one creek of any considerable length being known, and but few small obscure springs. As the strata along the northern end of the range for the most part dip easterly, there are along its eastern base numerous springs and ponds coming to the surface on the desert, just beyond where the strata pass under the valley-deposits. Along the great freight-road which runs from Toano southward, near the Peoquop foot-hills, a number of wells have been sunk in the desert Quaternary, yielding, after passing through sandstones, sandy shales, and clays, good water at a depth of 80 to 100 feet 
Geologically, the uplift embraces granites and Archæan schists, with the southern portion of the range consisting of Carboniferous limestones referred to the Wahsatch beds, and the northern portion of the range made up of quartzites and overlying limestones, regarded as equivalent to the Weber Quartzite and the Upper Coal-Measure limestones. In the region of Spruce Mountain, subordinate intrusions of diorites and porphyries appear through the limestones, crumpling and displacing the strata and complicating its structure.

In this range, granite is only known in one locality, at Holland Pass, and, like the similar occurrences in the Gosi-Ute and Ombe Mountains, occupies a low position or depression across the main trend of the uplift. At Holland Pass, the range reaches its narrowest dimensions, the granite apparently serving as a connecting link between two broader and more elevated masses of Palæozoic strata. It is barely two miles across the range from Gosi-Ute to Antelope Valley, with an elevation of not more than 500 feet above the Quaternary deposits. In its lithological character, as well as in its position, it closely resembles the granite bodies already mentioned in the Ombe Mountains and Gosi-Ute Range, which is all the more interesting, as it differs so widely from the granite mass of the Wachoe Mountains.

In a narrow ravine, on the east side of Spruce Mountain, occur outcrops of mica schists and slates, which probably belong to the older crystalline series. Their geological relations are quite obscure, and it would seem impossible, at least from present observations, to connect them with any series of beds in this region, as they are so isolated from other rocks of like character, and their outcrops cover such a limited area, but their physical and mineralogical habit is such as to suggest their Archæan age. At the same time, it may be stated, that they seem to be more closely related to the crystalline schist series of the Humboldt Range, from which they are only separated by a broad open valley without any intervening uplift than to those of any other large body of crystalline rocks in Western Nevada. These schists and slates are all very distinctly bedded and finely laminated. $A$ characteristic specimen in the collection of this slate represents a rock of a silvery-white color, and consisting of fine grains of white quartz and 
minute flakes of mica. The mica consists of both the dark magnesian biotite and white muscovite.

Under the microscope, Zirkel detected numerous crystals of zircon, which he has shown to be so abundant in the Archæan series of gneisses and schists along the Fortieth Parallel; and the biotite plates, but not the white mica or quartz, contain exceedingly minute microscopical needles, which he suggests may possibly be.referred to the same mineral Other beds are somewhat coarser in texture, less compact on account of the quartzgrains being larger, and the dark mica more abundant, with broader plates, rocks more closely related to what are usually designated as schists. The observed area of these beds is exceedingly small, and has not been indicated on the geological map. It is possible that more careful field-study would discover a number of such areas and would indicate clearly a much larger Archæan territory along the base of the mountain, and perhaps show an important Archæan foundation for the striking uplift of Palæozoic strata.

The entire northern end of the Peoquop Range would appear to consist of Weber Quartzite, overlaid by Upper Coal-Measure limestone. No estimate of the thickness of this quartzite was made, but it is at least several thousand feet, forming many of the higher summits and spurs. In places, it is capped by fragments of limestone, while, in others, the overlying rock may show a very great development. Directly south of Peoquop Pass rises a series of limestone hills with a strike varying from north $30^{\circ}$ to $40^{\circ}$ east, and dipping to the northwest at an angle of about $40^{\circ}$. There must be exposed here about 2,000 feet of limestones, which are conformably underlaid by heavy masses of quartzite, which are supposed to continue to the eastern foot-hills. The same masses of limestone which dip northwest curve around, and form the hills on the west side of the range. In the limestones south of the pass, not far above the quartzites, were obtained Carboniferous fossils, among which were the following:

Productus semireticulatus.

Spirifer cameratus.

Discina, sp. undet

On the east side of the range, Squaw Creek from the summit to the 
mouth of the cañon passes through quartzite. On the summit of Orford Peak rests an isolated body of gray limestone from 150 to 200 feet in thickness, thinning out to the northeast, all but this small fragment having been eroded. Beneath this limestone occurs a thin bed of dark, steel-gray quartzite, which, in turn, is underlaid by a somewhat coarse conglomerate filled with flint nodules and pebbles, and resting directly upon the massive quartzite. These beds strike north $28^{\circ}$ to $30^{\circ}$ east, and dip at an angle of $30^{\circ}$ to the northwest.

Large numbers of fossils were collected from this limestone, and the following species, among the Brachiopoda, have been recognized:

Orth is carbonaria.

Productus semireticulatus

Productus punctatus.

Productus Nebrascensis.

Productus longispinus.

Spirifer cameratus.

Athyris subtilita.

Athyris Roissyi.

Associated with them are corals belonging to the genus Campophyllum. A characteristic feature of the Carboniferous limestone of the northern end of the range are the interstratified beds carrying nodular concretions and fragments of flint, and black bands of siliceous cherty rock, with an exceedingly fine-grained texture, and a rough irregular fracture. They usually are marked by narrow bands of chalcedony, and give, when treated with acid, a slight reaction for carbonate of lime.

Directly north of Holland Pass occurs a body of limestone, forming the higher summits of the range, which has been but little studied, and, although its relation to the great quartzite body has not been observed, it is provisionally regarded as underlying it, and has therefore been referred to the Lower Coal-Measure series of the Wahsatch limestone. A recorded strike on the summit gave north $30^{\circ}$ west, with an easterly dip. South of Holland Pass, the range consists of nearly parallel ridges trending a few degrees west of north and east of south, that is, obliquely to the main trend of the uplift. 
The formation, like that of the southern end of the Gosi-Ute Range, consists of limestone, and has, in like manner, been referred to the Lower CoalMeasure series. The prevailing dip is westerly, and along the foot-hills, which rise above Gosi-Ute Valley, varies in angle from $8^{\circ}$ to $40^{\circ}$. Heavilybedded, dark-gray strata, many of them highly siliceous and seamed with calcite, characterize the hills; interstratified between them are frequent layers of calcareous and cherty shales and thin beds of quartzite.

A highly siliceous limestone, from the slopes of Grand Peak, on being submitted to analysis, yielded Mr. B. E. Brewster the following:

Insoluble residue

Alumina

Ferric oxide

Lime

Magnesia 27.769

Carbonic acid trace

Phosphoric acid . 1.249

Water 99.765

This indicates a carbonate of lime with 2.34 per cent. of carbonate of magnesia. Of the 34.912 of insoluble residue, 31.51 per cent. consisted of silica.

Organic remains of Brachiopoda, crinoidal columns, and fragments of stems and roots, highly metamorphosed, in general too poor for specific determinations, are abundant throughout the region, but only the two following forms have been recognized:

\section{Athyris subtilita. \\ Fusilina cylindrica.}

But for its intimate topographical and geological connection with the extreme southern end of the Peoquop uplift, Spruce Mountain, with its long ridge stretching to the northward, might almost be regarded as a separate range: As it is, the mountain, one of the loftiest in this region, presents, for a limestone summit, a striking appearance, rising steeply for nearly 4,000 feet above Butte Valley, and again falling away abruptly in the opposite direc- 
tion. Like the lower end of the main range, it consists chiefly of heavy limestone strata, which have been referred to the Lower Coal-Measure group. In its geological features, Spruce Mountain shows a very complicated structure, but in general would appear to be an anticlinal fold, the eastern side forming a synclinal with the beds of the main range. The occurrence of mica slates and schists would.indicate that the beds rested directly upon an Archæan foundation, while the crumplings and plications of strata, with their local displacements, are rendered still more complex by the intrusion of both small and large bodies of diorite and feldspar-porphyry, the more prominent ones only being represented on the map. From these crystalline rocks, the Palæozoic strata incline in all directions, with abrupt changes in both dip and strike, showing that their present position is largely dependent upon the intrusive bodies. On the southern point of the high ridge, the strata strike northwest and southeast, and dip easterly. On the saddle between the peaks, a diorite body disturbs the original position of the beds; but, on the northern and higher peak, the beds strike north $8^{\circ}$ to $12^{\circ}$ west, apparently at a slight angle obliquely to the trend of the uplift. The dip is about $15^{\circ}$ to the eastward. Northwest fiom here, and about 2,000 feet below the summit, occurs a large feldspar-porphyry body, to the west of which the strata mainly dip westerly, and from there northward to Blue Point Spring occur a number of minor folds and flexures. At Crawford Pass, a well-marked anticlinal fold in the hard siliceous limestone occupies the ridge, which is here not much more than 600 feet above the valleys. The axis of the fold strikes obliquely across the trend of the ridge, the beds upon each side dipping away at about an angle of $15^{\circ}$.

No measurement of the thickness of the Spruce Mountain beds was made, but it would seem highly probable that there are at least between 2,000 and 3,000 feet of Wahsatch limestone represented. Lithologically, the formation shows the same habit as characterizes the beds in other places, that is, heavily-bedded limestones, more or less siliceous, with occasional layers of calcareous shales and fine bands of quartzite. On the west face of the mountain, cropping out in several localities, occurs a well-marked bed of hard, black slate, carrying cubes of pyrites. A recorded strike gave north $25^{\circ}$ west. 
All the palæontological evidence obtained would go to show that only the Lower Coal-Measures were represented. It is by no means improbable, however, that a further search of the lower horizons may prove the existence in the uplift of both the Sub-Carboniferous and Devonian members of the Wahsatch limestone.

From the summit of Spruce Mountain, the following forms were collected:

\section{Productus costatus, Productus semireticulatus, Productus Nebrascensis, Eumetria punctulifera;}

from the ridge north of Spruce Mountain, and from a number of other localities, were obtained:

\section{Productus Nebrascensis, Fusilina cylindrica,}

crinoidal columns of large size, small disks of pentangular columns, together with slender forms of an undetermined

\section{Trematopora;}

on the ridge near Blue Point Spring were found large numbers of

\section{Fusilina cylindrica.}

The Spruce Mountain diorites observed are usually small, irregular bodies or narrow dikes. On the summit between the two prominent peaks occurs one that may be considered typical. It is a fine-grained dark rock with no large crystals, but made up of long, slender, black hornblendes, with both monoclinic and triclinic feldspars; the latter evidently predominating. The largest body of feldspar-porphyry is found on a saddle of the ridge northwest from the high peak. It is an exceedingly compact, tough rock, breaking with an angular fracture. In color, it is brownishgray, spotted with incrustations derived from iron minerals, which give it a somewhat dirty appearance. Macroscopically, the only minerals that are distinguishable are a few rounded grains of translucent quartz and fragments of feldspar imbedded in a felsitic groundmass. Under the microscope, 
the groundmass reveals no new constituents, but a purely sphærulitic structure, a detailed description of which will be found in Professor Zirkel's report, showing in an interesting manner a close analogy existing between these rocks and the Tertiary rhyolites. And yet while this microscopical analysis presents much that suggests such a comparison, no practiced fieldlithologist would ever mistake it for a late eruptive rock.

This region of Spruce Mountain forms a mining district, which, if not of great economic importance, possesses much that is of interest from a geological point of view, and worthy of detailed study. As the limestones have undergone considerable displacement and fracture, dependent upon the intrusion of crystalline rocks, so, in like manner, most of the ore-deposits show an intimate connection with both formations, usually occurring in the former, in close proximity with the latter. In places, they are found in seams and irregular breaks in the beds; at others, lying between the strata, and again as contact bodies between limestone and porphyry. All the ores would appear to be secondary products, such as carbonates and sulphates derived from the decomposition of galena and related minerals. Galena, although found in small masses, is not abundant; wulfenite occurs in small quantities.

Litrle Cedar Mountains.-This group of mountains lies midway between the Peoquop and Humboldt Ranges, and may be considered as a continuation southward of the Fountain Head Hills, connected by Cedar Pass. They rise abruptly above the valleys, and form but a small group nearly 12 miles in length by about 10 in width; the highest summits attaining an altitude of between 2,000 and 2,500 feet above the valley. Albion Peak, the culminating point, lies 8,391 feet above sea-level. The summits and higher slopes are well covered by a fair growth of coniferous trees, but the mountain mass is exceedingly dry, no stream being known, and probably not even a running spring.

But little opportunity was afforded for its geological study with any detail, and only the main features were gathered. Enough, however, was seen to recognize that the same geological horizons that are developed along the northern end of the Gosi-Ute and Peoquop Ranges re-appear here with the same characteristic structural and lithological behavior; that is, the 
range appears to be made up of beds of massive quartzite, occupying the central portion of the mountains overlaid by dark-blue limestones, the latter frequently appearing only in small patches on the flanks and ridges-fragments left by erosion. The general trend of the strata is north and south. Along the east flanks of the mountains, limestone is the prevailing formation, dipping at varying angles from $10^{\circ}$ to $22^{\circ}$, passing under the Quaternary valley, and apparently forming, with the west side of the Peoquop Range, a synclinal fold. Here were found crinoidal columns and fragments of bryozoans, together with

\section{Productus subhorridus.}

In a very similar limestone on the west side of the mountains, but dipping west at angles of $18^{\circ}$ and $20^{\circ}$, were found the following Coal-Measure forms:

Productus Prattenianus.

Athyris subtilita.

Syringopora multattenuata.

Chatetes, sp. undet.

On the summit of the ridge just north of Albion Peak occurs a body of highly-altered limestone, which, but for a small amount of fine quartzsand, has almost the theoretical composition of dolomite. It is a firm, compact rock, of a bluish-gray color.

Mr. B. E. Brewster, on subjecting it to chemical analysis, found the following constituents:

Silica.

Alumina and ferric oxide .................. 0.274

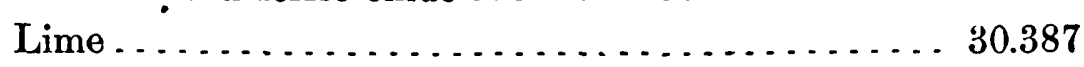

Magnesia ............................. 20.069

Carbonic acid. . . . . . . . . . . . . . . . . . . 45.726

Water ............................. 1.708

100.278

$33 \mathbf{D} G$ 
All the magnesia calculated as carbonate and the lime for the remaining carbonic acid gives :

Carbonate of magnesia................... 42.14

Carbonate of lime..................... $\quad 53.75$

Excess of lime ......................... 0.28

Coming out at the base of the limestones, along the east side of the mountains, are a number of both hot and cold springs, running a large amount of bright clear water. They leave no saline incrustation, and to the taste would seem to be comparatively free from mineral ingredients. 
GOOSE CIEEK HILLS.

\section{SECTION III.}

\section{GOOSE CREEK HILLS TO TUCUBITS MOUNTANNS}

BY S. F. EMMONS.

Goose Creek Hills.-This name has been given toa group of hills which lie directly north of the Ombe Mountains and form the southern continuation of a high range of mountains of the same name, extending north into Idaho, beyond the limits of the map. Immediately north of the hills, as represented on the map, extends a north and south ridge, having a general anticlinal structure, made up largely of white, close-grained quartzites, with blue and white, fine-grained, siliceous limestones. These rocks of the range show evidence of considerable metamorphic action and a large development of vein-material. The quartz veins have a general north and south trend, often being traceable for 6 or 7 miles, with a thickness of as much as 6 or 8 feet. In several localities upon the east side were found a new and undescribed species belonging to the genus Fusilina, associated with a poorly-preserved Productus, proving clearly the Carboniferous age of the limestone, while the quartzites have a general lithological resemblance to those of the Weber formation.

That portion of the hills which is included within the limits of the map is principally covered by rhyolite flows, beneath which are obscure outcrops of limestones, which have been referred to the Upper Coal-Measure group. The rhyolites present a great variety of texture and composition, and constitute a very interesting group of rocks. In an interior valley of the hills is an outcrop of granite-porphyry, showing a dome-shaped mass, only exposed in the lowest points of the valley. It is a greenish-gray rock, showing large crystals of pink-white orthoclase imbedded in a greenish-gray mass, made up of decomposed hornblendes in a gray felsitic groundmass. Under the microscope, the groundmuss is seen to be made up of hornblende, orthoclase, plagioclase, and quartz. The larger feldspars are altered into an opaque mass, in which, in some p!aces, traces are seen of a former triclinic striation. 
In some of the decomposed feldspars are colorless acicular crystals, which may be muscovite. The hornblende is remarkable for presenting, as a product of decomposition, black, opaque, angular grains like magnetite, which do not, however, occur in the fresher hornblendes. This body of graniteporphyry is immediately overlaid by calcareous shales.

To the east of the valley is a broad, table-shaped ridge, made up of flows of rhyolite, showing great variety in structure and composition. The main flow is made up of a grayish-white rhyolite, which has a rough trachytic feel. It consists of a very porous felsitic groundmass, in which can be distinguished only a few scattered crystals of free quartz, and long, thin sections of tabular crystals of feldspar, often showing a very beautiful twin development. The groundmass, examined closely, has a porcelain-like appearance. Under the microscope, it is seen to be a mixture of transparent polarizing particles and dull yellowish-gray bodies. Adjoining this rock on the east is a porphyritic rhyolite of reddish-purple color, still of somewhat porous texture, containing large crystals of quartz and sanidin, the former of which show frequently perfect pyramidal points; likewise no hornblende or mica. Under the microscope, the groundmass is seen to contain fibrous sphærulites, often as much as half a millimetre in diameter, which sometimes have a feldspar crystal in the centre. It also contains tridymite. To the eastward, these rhyolites pass into distinctly hyaline varieties, or pearlites. The first is a grayish porphyritic-looking rock, containing large grains of quartz the size of a pea, and very glassy sanidins, together with considerable hornblende and mica, in a gray pearlitic, and - somewhat granular groundmass. Under the microscope, the groundmass is seen to be made up of imperfectly dihexahedral quartz, sanidin, plagioclase, brown biotite, some yellowish-green augites, a few brown hornblendes and magnetite, together with pale yellow microlites, which are doubtless augitic. Both quartz and feldspars contain plentiful glass-inclusions. The mass between these ingredients shows an interesting arrangement of microlites, which appear to flow around the crystals, as will be seen in Volume VI, Plate X, fig. 2. The most remarkable of these hyaline rhyolites forms low rounded hills on the extreme eastern slopes, toward Surprise Valley. 
It is a dark-gray, almost black, pearlitic mass, containing crystals of sanidin and quartz, with a large development of reddish sphærulitic grains, which, when broken, are seen to be made up of concentric layers of sphærulitic material of a dull resinous lustre, often enclosing a nucleus of glass, quartz, and feldspar.

Tosno Group.-To the west of the Goose Creek Hills is a broad valley, narrowing rapidly to the northward, called Desert ${ }^{\circ}$ Gap, through which runs Passage Creek, a stream carrying the drainage of Thousand Spring Valley and the mountains to the north out into the desert country. To the west of the gap, the Toano Group forms an irregular mass of hills, a continuation northward of the Gosi-Ute Range, and separated from it by a low broad pass, known as Toano Pass, through which the railroad runs. The Toano Pass cuts the range at a point where the axis of upheaval has suffered an abrupt curve. That part of the range south of the pass has a strike nearly true north and south, which it maintains up to the pass, north of which it forms roughly a semicircular ridge, the strike of the beds following the curve of the ridge.

Between this pass and Ives' Pass, 5 or 6 miles to the northward, the hills form a somewhat isolated group, showing an interesting structure, with Fairview Peak both topographically and geologically the central point. On the northeast side of this ridge, the beds strike north $5^{\circ}$ to $10^{\circ}$ east, at Fairview Peak north $30^{\circ}$ east; while on the west side they strike northwest. The beds form an anticlinal fold, the axis occurring in the Weber Quartzite along the south slope of the hills, conformably over which lie heavy beds of blue and gray limestone. The high hills north of Toano are formed for the first 1,200 or 1,500 feet of Weber Quartzite, and then 800 or 900 feet of limestone, the latter forming the summit of the ridge, and the north side of the anticlinal axis. Fragments of limestone, which represent the southern half of the anticlinal fold, are found along the extreme foothills of Toano Pass, with a steep dip, reaching in places $60^{\circ}$. It is evident that both sides of the anticlinal have suffered a fault, and that the southern member, including both quartzite and limestone, has been depressed several hundred feet. On the opposite side, the Coal-Measure limestone also shows 
a fault of between 200 and 300 feet, and a considerable compression of strata, the beds occurring along the inside of the curved ridge, where they are found as a synclinal fold. By reference to the upper section at the foot of the geological sheet, this synclinal structure is shown, with the Weber Quartzite underlying the limestone.

Interstratified in the limestone near the summit of the ridge occurs a dark-brown cherty band. From this stratum, as well as both from the overlying and underlying limestone, large numbers of organic remains may be obtained, but without any great variety of species.

From the cherty band, the following Brachiopoda have been recognized:

Productus Rogersi.

Spiriferina pulchra.

from the limestone, in addition to the above species :

Productus Nebrascensis.

Streptorhynchus crassus.

Among Bryozoa, occurs an undetermined species of the genus Cascinium.

North of Ives' Pass, the hills rise in rounded masses, stretching to the northward for 15 miles, before again disappearing beneath the Quaternary deposits. The strata indicate considerable folding and crumpling, and the structure is nuch obscured. Just north of Ives' Pass, the prevailing dip would seem to be to the eastward, while in the northern end it seems to be in the opposite direction. South of Montello Creek, along the foot-hills, the beds dip $3^{\circ}$ east. The beds, so far as examined, are mainly limestones and calcareous shales, and have been referred to the Upper Coal-Measure series. No fossils were found in them. In these limestones are frequently seen beds and irregular bodies of bluish-black cherty matter, traversed by thin white seams of silica; the rock breaking with a rough, jagged fracture. Very similar rock appears to characterize the limestone in many localities, but its exact geological horizon was not clearly made out.

On the western wall of the Desert Gap, at the extreme northern end of the map, is a development of a remarkably interesting rhyolite, of a delicate purplish-gray color, which, on the larger surfaces of fresh fracture, has a wavy, lace-like structure. It is full of druse-like cavities lined with 
minute crystals of quartz. The groundmass shows stripes and bands of darker and lighter material, which encircle in wavy lines these druses, and the sanidins and quartz. Small crystals of free quartz and feldspar are visible throughout the mass. Some portions of the rock abound in comparatively large lithophysæ, cavities which resemble bladder-like swellings in the molten material of the rock, but which are generally regarded by microscopical geologists to result from a chemical and mechanical alteration of large sphærulites. Under the microscope, the stripes in the groundmass are seen to be made up of three characters of bands. The middle is of a grayish-yellow color composed of sphærulites and small fibres. On either side are dull gray zones of fibrous, rather homogeneous material, bounding which are third zones of colorless crystalline aggregations.

In a little group of hills to the west of the northern point of the Toano Group, which forms the southeastern border of Thousand Spring Valley, are similar shales and limestones, with an easterly dip. Here the development of limestone is heavily bedded, generally of a grayish-blue color, and seamed with white calcite. A very prominent zone of nearly black siliceous limestone has almost the hardness of quartz, although it effervesces freely with acids, leaving a black porous mass. Under the microscope, it is seen to contain crystals of white calcite and opaque black particles which are doubtless carbonaceous matter, to which the rock owes its dark color. These limestones have been assigned to the Upper Coal-Measure series, rather on account of their shaly character and relation to those of the Toano Group, than from any definite structural or palæontological resemblance to this series.

Thousand Spring Valley is a broad, shallow depression, covered with finely comminuted Quaternary material, which takes its name from the number of small springs found along the bottom and adjoining the bed of Passage Creek, which is itself dry during portions of the year in the greater part of its course. These springs present a great range of temperature, from the boiling-point of the hot springs at the upper part of Passage Creek, to a temperature of near the freezing-point in little springs which ooze out of the muddy bottom of Passage Creek, just north of the limits of the map. In the higher portions of the valley, along the borders of the 
bounding mountain-ridges, are considerable developments of white horizontal Tertiary beds, which have been referred to the Humboldt Pliocene. These find their greatest development in Holmes' Creek Valley, just beyond the limits of the map, whose waters drain into the Snake River. On the low ridge which forms the divide between this valley and Thousand Spring Valley, the upper bed is a drab-white, earthy, impure limestone, full of dendritic markings, and containing irregular-shaped cavities apparently left by no longer recognizable shells. As developed in Holmes' Creek Valley, the Tertiary beds seem to be largely made up of fine volcanic and pumiceous material. In this region, at least, their deposition seems to have been connected with a period of volcanic ejection of sand and ash. A peculiar castellated cliff on the east side of the valley, called Citadel Cliff, shows an exposure of a hundred feet or more of these beds, which are regularly stratified and for the most part made up of fine, white, friable sand, containing many small transparent glass particles, with a development of beds of fine breccia material, in which are grains of pumice; the most noticeable bed has a thickness of about 5 feet of a reddish-brown, nearly compact, glassy rock, breaking with a conchoidal fracture, which is composed of crystals of feldspar and quartz in a groundmass of red and black volcanic ash, consisting of thin splinters of obsidian partly fused together; under the microscope, the quartz is seen to have large glass-inclusions. The upper bed consists of a thickness of about 10 feet of soft, gravelly, creamcolored conglomerate. Within the beds is also a thin seam, a few inches thick, of a white, cherty material, banded with green, which breaks easily with a conchoidal fracture. Its hardness is less than that of quartz, and it probably contains a considerable mixture of felsitic material. A small conical hill not far from Citadel Cliff was found to be capped by a black, glassy obsidian.

The hills between Holmes' Creek Valley and Thousand Spring Valley, whose southern point extends into the region of the map, are made up of a body of limestone overlaid by quartzites dipping to the south and west, which have been referred respectively to the Lower Carboniferous and Weber Quartzite group.

Fountain Head Hills.-To the west of Thousand Spring Valley, the 
low, crescent-shaped ridge of the northern portion of the Fountain Head Hills is made up of quartzite beds, which have been assigned to the Weber Quartzite. Owing to the gentle slopes of these hills and the low angle at which the rocks lie, no considerable section of the beds was obtained. In them is a large development of a peculiar quartzitic sandstone or grit, which is very persistent through the Northern Nevada region, and considered characteristic of the horizon of the Weber Quartzite. It is a more or less fine-grained, reddish-gray rock, made up of angular fragments of flint and chert of various colors, in which black and red generally predominate, with a matrix of a granular siliceous material, often stained by brown oxide of iron and containing a very large amount of limpid quartz. It has a peculiarly rough feel, suggesting a porous texture, almost like that of a volcanic rock. It effervesces slightly under acids, and, under the microscope, is seen to contain small crystals of calcite, the matrix being made up of crypto-crystalline grains and rounded fragments of quartz. The structure of this ridge is, as far as can be seen, that of a gentle anticlinal, whose axis runs with the trend of the ridge.

Southeast of the quartzite occurs a body of limestone, extending southward as far as Cedar Pass. It appears to be made up of long ridges, varying much in direction, but with a general trend of northeast and southwest. One of the main ridges indicated a strike of north $25^{\circ}$ to $30^{\circ}$ east. The strata consist of heavy beds of grayish-blue earthy limestone, occasionally highly metamorphosed and in places impregnated with seams of white calcite. On Euclid Peak, the culminating point, the beds lie nearly horizontal, but have a sliglit western dip, and along their eastern base show outcrops of dark quartzite, which have been referred to the Weber formation. Fragments of this quartzite may be traced cropping out above the Tertiary and Quaternary beds, along the foot-hills from Euclid Peak to Cedar Pass, where it rises in ridges several hundred feet in height. Toward the pass, the structure is somewhat complicated, and the quartzite north of Indian Well, where the beds have undergone the greatest change in course, is seen striking north $60^{\circ}$ to $65^{\circ}$ west, with a dip of $12^{\circ}$ to $15^{\circ} \mathrm{E}$. Here the quartzite, a hard compact rock, is traversed, in a striking manner, by numerous narrow veins of pure quartz, but apparently of no economic 
value. In the region of Independence Spring are a series of low quartzite hills, which, in passing north, are overlaid by patches and fragments of limestone, which dip generally to the northwest.

As already mentioned, the quartzite has been referred to the Weber, and as the limestone, wherever observed, is seen invariably overlying it, the latter has all been placed in the Upper Coal-Measure series.

Organic remains, generally too poorly preserved for specific determination, but which undoubtedly belong to Coal-Measure forms, are found in many localities. The following species have been determined:

Productus subhorridus.

Athyris subtilita.

North of Independence Spring were also found, not over 100 feet from the quartzite, undetermined species of Bryozoa, belonging to the genus Trematopora.

East of Euclid Peak occurs a peculiar outburst of volcanic rock, which, although not a typical trachyte, has been regarded as belonging to that group. It stands remote from all other trachytic bodies, the other acidic volcanic rocks of the region, so far as observed, belonging to the rhyolites. It forms a long north and south ridge inclined to the eastward, and is cut through by Peoquop Creek, offering a good exposure of the mass. It is an exceedingly dense, tough rock, breaking with difficulty. In color, it is yellowish-brown, derived from the decomposed earthy material which makes up the base. Macroscopically, in its mineralogical composition, it shows only well-developed monoclinic and triclinic feldspars; the latter, apparently predominating, are brilliant and characteristic. Hornblende, very much decomposed, may be recognized from its form. The rock carries small cavities and druses, many of them completely filled by secondary products, as calcite and chalcedony. A chemical analysis was made of this rock by Mr. R. W. Woodward with the following result:

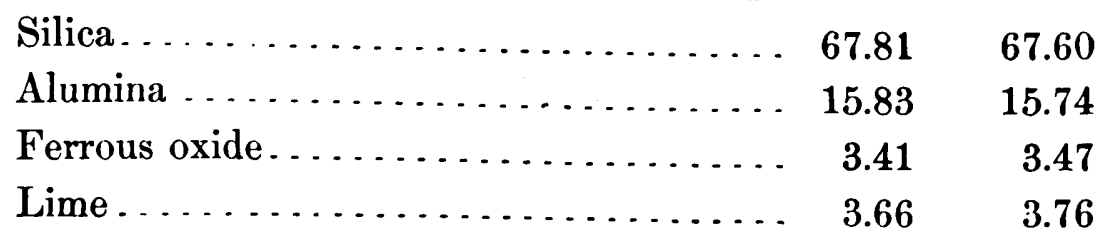


TUCUBITS MOUNTAINS.

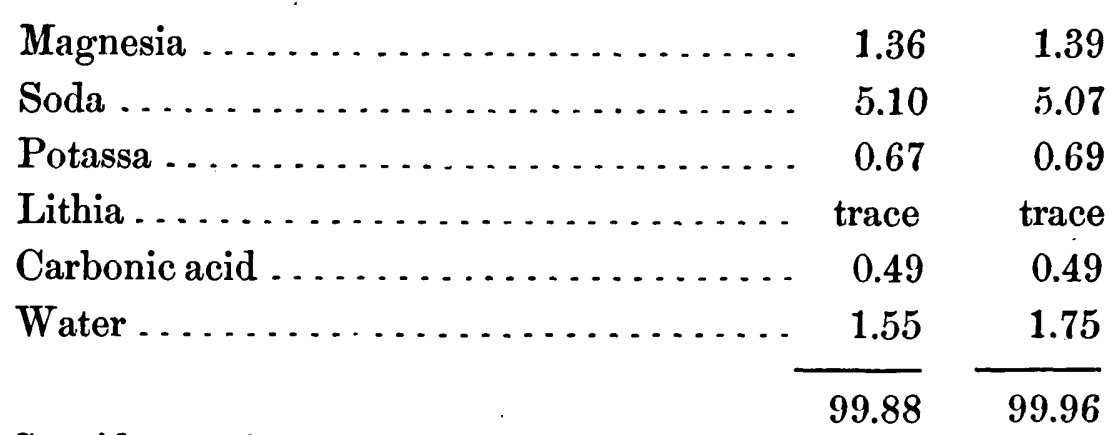

Specific gravity 2.5-2.6.

It will be seen that the rock stands rather high in silica for trachyte, but this is doubtless owing to the presence of the chalcedony. A marked feature is the large amount of soda and the correspondingly low percentage of potassa. The analysis would indicate a hornblende-oligoclase trachyte.

To the west of the Fountain Head Hills is a north and south valleylike depression in the quartzite, in which the westward-flowing waters of the Humboldt River and the easterly-running streams at the head of Passage Creek take their rise, suggesting the name for this group of hills. It consists of a series of low rounded hills, whose underlying rocks are masked by surface-accumulations of gravel and débris. The few outcrops shown indicate that it is probably occupied by the beds of the Weber formation.

Tucubits Mountains.-The Tucubits or Wild Cat Mountains form a northern continuation of the East Humboldt line of elevation. They consist of a mass of easterly-dipping quartzites and limestones, which, toward the southern end, have been much faulted and dislocated, so that it has not always been possible to trace the direct continuance of the beds. In its northern portion, as represented on the map, where some of the peaks attain a considerable elevation, it is formed mainly of bodies of quartzite, containing thin beds of curiously-banded cherty material, black and green in color, representing the horizon of the Weber Quartzite. Along the western base are exposed heavy bodies of blue limestone, whose strike is somewhat to the west of the trend of the range; greater thicknesses are observed as one goes south, and they were principally studied in the section exposed by the cañon of the Humboldt River called Emigrant Cañon.

In the exposures along the western face of the range, particularly at 
the head of the south branch of Forellen Creek, thicknesses of several thousand feet of limestones are found, generally dark bluish-gray, heavily bedded, and having a gentle dip of $20^{\circ}$ to $25^{\circ}$ to the eastward. No fossils were obtained, however, from these beds; but their general character is that of the Walisatch limestone. In the neighborhood of the mouth, or western end, of Emigrant Cañon, the beds stand at a steeper angle, dipping in some cases $45^{\circ}$ to the eastward, and have evidently been faulted, one line of fault being observed in a little side-ravine on the south side of the cañon, about a mile from its mouth, where the upthrow has been on the eastern side of the fault, and some of the eastern beds have been sharply bent downward at the line of fault. The line of this fault appears to be to the northeast. $\Lambda$ short distance above this point a section is exposed of several hundred feet of shaly beds, from which issues a considerable body of hot water. The beds shown here from the line of fault upward consist of 300 feet of lightgray limestone, overlaid by 100 feet of yellowish calcareous shales, above which are 150 feet of black, thinly-laminated, calcareous shales, abound ing in fossils; above the shaly beds are 200 feet of dark-gray limestones, followed by heavy beds of limestone about 1,500 feet thick, which could not be definitely determined on account of surfacc-accumulations. From the bed of black shales were obtained the following fossils, which have been considered to represent the Upper Helderberg group :

\section{Orthis multistriata. \\ Orthis, n. sp. \\ Spirifer Vanuxemi. \\ Atrypa reticularis. \\ Cryptonella, frag. \\ Crania, undet. sp.}

The slopes of the cañon above the Hot Springs are in general too much covered by detritus to afford a continuous section. Only a general idea of the rocks can be obtained here, from which it is seen that at least 4,000 or 5,000 feet of limy beds are cut, which, toward the upper part, show a greater proportion of shales, and are generally of much lighter color. Near 
the upper end of the cañon is an outcrop of about 500 feet of calcareous shales, having a purplish color on their weathered surface, overlaid by drab limestones, which, in turn, are overlaid by some blue siliceous limestones, carrying white seams of calcite containing crystals of pyrites.

In the hills to the eastward, beyond the upper end of the cañon, as has already been seen, only quartzites are observed, which represent the Weber Quartzite. The limestones extend much farther eastward at the immediate line of the cañon than they do either to the north or the south. In the low, rather broken hills which form the continuation of the range to the south of Emigrant Cañon, distinct outcrops of compact white quartzite are found along the eastern slopes, dipping about $25^{\circ}$ to the eastward and striking somewhat to the east of north. In general, but few exposures are found in these hills, but the surface is largely covered with débris of the peculiar dark-reddish quartzitic sandstone already observed in the Fountain Head Hills.

Directly south of the Hot Springs is a bare limestone hill, showing about 500 feet in thickness, of earthy blue limestones, plentifully seamed with white calcite, somewhat arenaceous in the upper part, and the beds generally from 15 to 20 feet in thickness. This is underlaid by several hundred feet of darker-colored, sometimes black, limestones, which, in the lower part, are very siliceous. These beds dip about $20^{\circ}$ to the southeast. No fossils were obtained from this outcrop of limestones. To the west of this hill, in a little ravine running northwest, just under the base of Tulasco Peak, was found exposed a series of thin-bedded limestones, from which were obtained a number of Coal-Measure fossils, whose aspect indicates a much higher horizon than the apparent position of the beds, which otherwise would have been supposed to be lower than the heavy-bedded limestones just mentioned. The bottom of the ravine is in dark-reddish limy shales. The lowest outcrop shown is 50 feet of white quartzite, overlaid by 100 feet of gray limestone with siliceous seams, above which 10 feet of a bluish-gray limestone carrying Fusulina, overlaid again by 30 feet of gray. limestone with cherty seams, above which 50 feet of shaly limestone carrying corals, while on the hills above are, though not in direct contact, apparently conformable beds of the quartzitic sandstones. These beds all dip $35^{\circ}$ to the 
eastward, with a strike of north $10^{\circ}$ west. From them were obtained the following Coal-Measure fossils :

Spirifer cameratus.

Spirifer Kentuckensis.

Athyris subtilita.

Rhynchonella, sp.?

$P$ seudomonotis radialis.

Pseudomonotis, sp. 9

Dentalium Meekianum.

Bellerophon carbonarius.

Chatetes.

Fenestella.

Trematopora.

The general aspect of these fossils, taken as a whole, together with the lithological character of their beds, shows that they doubtless represent the extreme upper portion of the Wahsatch limestone. Their relative position with regard to the Devonian beds exposed at the Hot Springs must be explained by a rather complicated system of faulting, which the character of the country and the limited time at our disposal did not permit us to work out in detail.

Tulasco Peak itself and the hills to the southeast and west, though showing few outcrops, are evidently occupied by beds of the Weber Quartzite, associated with which in the southern end are some flows of a brecciated rhyolite. In some cases, these peculiar quartzitic sandstones are so full of limpid quartz that they may be almost confounded with the rhyolite. They are, in general, the same reddish, rough-feeling rocks observed in the Fountain Head Hills, in which the proportion of granular matrix and of enclosed cherty fragments is very variable. The pores generally contain a great deal of brown hydrated oxide of iron, to which the color of the rock is somewhat due. In the neighborhood of the rhyolite outflows are found rocks which are made up largely of the same cherty fragments of black and green colors, in which the rock has a more compact and almost felsitic structure, its granular character having disappeared, and there being a more consid- 
erable development of grains of limpid quartz. These greenish breccias gradually lose all appearance of a granular groundmass, the whole mass seeming to be more or less felsitic, and pass into a porphyritic rhyolite, having something of a brecciated structure, which is full of crystals of limpid quartz, and carries some few feldspar crystals. In this range, it has almost the appearance of a quartz-porphyry, and may possibly be of older age than the rhyolites, though, as will be seen later, the same association is round with well-defined Tertiary rhyolites, of whose age there can be no doubt.

Out of the Tertiary plains, to the west of the Tucubits Mountains, rises a little group of hills called Forellen Buttes, which is composed of a somewhat similar brecciated rhyolite, having a rather compact, grayish-drab, felsitic groundmass, in which are large crystals of sanidin and quartz. Under the microscope, this rhyolite is seen to be made up of three different materials: first, broken crystals of sanidin and quartz, lying close together; second, fragments of dark-gray hornstone-rhyolite, rich in glass; and, third, bands of dull whitish rhyolite, enclosing angular fragments of quartz, which envelop the other ingredients in wavy lines. 
SECTION I V.

EAST HUMBOLDT RANGE.

BY ARNOLD HAGUE.

Region south of Frémont's Pass.-The East Humboldt is not only the main range of Central Nevada, but is also the most prominent uplift lying between the Sierra Nevada of California upon the one side and the Wahsatch of Utah upon the other. It extends from the southern limit of the map northward to the Humboldt River, a distance of 80 miles. It is a bold, single ridge, having a trend of about north $18^{\circ}$ to $\% 0^{\circ}$ east, with many rugged summits reaching over 10,000 feet above sea-level. Mount Bonplari $u$, the highest peak, a fine commanding point, at the northern end of the range, attains an elevation of 11,321 feet. The range, from its position and relative elevation, presents in its physical conditions much more of an alpine aspect, receiving at the same time a larger supply of moisture, in the form of both snow and rain, than any other of the Basin ranges. Its flora also suggests the higher elevations, the long slopes and glacier-carved cañon-basins being covered with scattered forests, including several varieties of pines and firs; Pinus flexilis would appear to be the prevailing species. The trees, however, are too short, being rarely over 50 feet in height, and too knotty to afford much valuable timber.

In general terms, the geological structure of the Humboldt Range represents a mass of Archæan rocks, which acts as the axis of an anticlinal fold, striking obliquely across the range, from which are inclined the Devonian and Carboniferous strata, resting unconformably upon the granites and gneisses of the crystalline foundation. The southeast side of the fold extends from the region of Frémont's Pass to Hasting's Pass, and consists of a single series of limestones conformably underlaid by quartzites, the latter appearing along the western base, while the entire summit and eastern face presents only heavy massive limestone. The eastern slope is 
broken by numerous cañons, many of them quite remarlable, which show characteristically the manner in which heavy bodies of limestone, when gently inclined, may be eroded into narrow, deep cañons, with nearly precipitous. walls. The photograph, reproduced on Plate XVII, represents this type of structure, as seen in Blue Cañon, with nearly sheer cliffs from 1,400 to 1,800 feet in height, standing out boldly above the Quaternary plain.

Wrapping around the granite mass, which occupies the whole of Frémont's Pass, are found the limestone beds, forming the extreme northern extension of the main body. On the eastern foot-hills, about a mile and a half north of the pass, the limestones stand nearly vertical, and appear as a mere thin bed, which rapidly dies out against the granite to the north Coming south of the pass, the angle of inclination decreases from $50^{\circ}$ to $40^{\circ}$, and falls off gradually to $22^{\circ}$, with a southeast dip. At the high peaks back of Cave Creek, a recorded dip gives $16^{\circ}$ to the southeast, and still farther to the southward the beds become nearly herizontal. They again rapidly rise in dip till, north of Hasting's Pass, and west of Fort Ruby, they reach an angle of $16^{\circ}$ to $20^{\circ}$; this time, however, inclined to the northeast. It will be seen, therefore, that, while the general dip is eastward, there is a gentle north and south synclinal structure.

About a mile south of Frémont's Pass, these limestones rapidly thicken, and are underlaid by 800 to 1,000 feet of white to brownish-white, highlylaminated quartzite. It is usually a compact, highly vitreous rock, the brown color being derived from the presence of small amounts of iron scattered through it, or else occupying thin, narrow seams. This whole series, the quartzite and overlying limestone, is distinctly unconformable to the granites. In the cañon next south of Frémont's Pass is seen a good exhibition of the conformable series, with the quartzites dipping $18^{\circ}$ to $20^{\circ}$ to the southeast. The transition from the quartzites to the limestones is made in a very short distance, without any noticeable interstratification of beds. The quartzites appear a little calcareous and the limestones somewhat siliceous, but the transition is made by a rapid passage from one to the other. The limestones are of a very light gray and grayish-buff, and these colors prevail for about 1,600 feet upward in the series, when the beds are usually of a dark-grayish hue, and the bedding nuch heavier than in the zones below. 
Thence to the top of the series limestone occupies the whole body, and here makes an exposure above the quartzite of not less than 6,000 feet.

In this great thickness of limestone occur beds exhibiting considerable variety in texture and composition. In the lower part of the series, thin calcareous shales, more or less arenaceous, are a characteristic occurrence, while higher up more compact beds of argillaceous material are found interstratified in the limestone. Near the summit of the ridge, beds of highly metamorphosed dolomites occur, of a bluish-white color.

Not far from one of the dolomitic zones, a bed of nearly white, saccharoidal limestone was observed, altered into a coarse marble. It has been analyzed by Mr. B. E. Brewster, with the following result:

Alumina and ferric oxide................ 0.363

Lime .............................. 54.513

Magnesia ........................... 0.273

Soda ............................. trace

Carbonic acid ....................... 43.130

Phosphoric acid...................... $\quad 0.349$

Water .............................. 0.109

Insoluble residue $\ldots \ldots \ldots \ldots \ldots \ldots \ldots \ldots \ldots, \quad 1.347$

100.084

Carbonate of lime...................... $\quad 97.345$

Carbonate of magnesia................... 0.573

97.918

Fragments of Coal-Measure fossils may be found scattered through the higher members of the series, but so far the lower members have yielded none: Stems of cyathophylloid corals, Bellerophon sections, and poorlypreserved forms of Spirifer are abundant; but the only species obtained that could be identified were :

Chonetes granulifera.

Productus Nebrascensis.

Fusilina cylindrica. 
So thick a series of limestones overlying a pure quartzite can be nothing else than the Wahsatch limestone, and it is not surprising that the only fossils obtained are Coal-Measure forms, procured high up in the series. The quartzite is referred to tho Ogden Devonian, and the section of beds seems to repeat that of the Piñon Range in the same latitude, with the exception that the limestone series is here continued much higher; the latter, in the Piñon Range, being eroded off down to the beds, which correspond to the Helderberg horizon in the New York State section, and which rise here in the Humboldt Range, 5,000 feet higher, embracing doubtless the narrow belt of Sub-Carboniferous and the enormous development of Lower Coal-Measure limestones.

The lower section, C-D, at the bottom of the geological sheet, cuts the Humboldt Range at Frémont's Pass, where only the upper members of the Wahsatch limestone are represented on the east side, lying steeply inclined against the granite. On the west slope, however, the Ogden Quartzite is shown resting next the granite, but without any overlying rock.

It is noteworthy that in this heavy and elevated limestone mass running streams are entirely wanting. The water, however, reaches the surface along the base of the range in numerous springs extending from Hasting's to F'rémont's Pass. These springs supply Ruby Lake. They are all clear, cold waters, with temperatures varying from $43^{\circ}$ to $48^{\circ}$. Cave Spring, about 6 miles to the south of Frémont's Pass, runs a considerable stream, coming out directly from the limestone through an opening sufficiently large to admit a man into an interior lake-chamber 10 by 12 feet and 10 feet in height. A narrow winding channel connects this chamber with still another and: larger one beyond, with its limestone floor covered with water. It is worthy of exploration, but, so far as known, has never yet been visited.

Not far north of Cave Spring occurs the only outburst of volcanic rocks observed in this portion of the range, and is of some special interest, as both macroscopically and microscopically it resembles a trachyte, and has been classed as such, although by no means a typical variety. Breaking through the limestone, which is considerably shattered, it forms a low, irregular hill of rough, gray rock with a medium compact texture. The 
mineral constituents are well developed, and consist of both monoclinic and triclinic feldspars, hornblende, biotite, and quartz. Many of the plagioclase crystals are quite large, and characterize the rock by their brilliant white faces. Thin flakes of black biotite are everywhere scattered through the groundmass, frequently adhering to the edges of the feldspars. 'The hornblende appears to be a deep dark green. Quartz-grains are rare, but are mainly in broken translucent masses; the rock forming no exception to most of the quartz-bearing trachytes in having the grains quite large, and in showing under a high power no microscopical ones. Minute apatite crystals are seen under the microscope in great numbers. $\Lambda$ markerl peculiarity of this rock is its coarse crystalline groundmass, to which it doubtless owes the somewhat characteristic fracture.

Region north of Frémont's Pass. - - The granite body which ends at Frémont's Pass agrees in trend with the general course of the range, and extends northward for nearly 15 miles, finally falling away toward Ruby Valley. In the pass, the granite possesses usually a coarse crystalline texture, weathering readily into picturesque forms of domes and pillars, with great diversity of outline, the whole more or less covered by granitic detritus. The feldspar and quartz are intimately blended, giving the rock a white or yellowish-white color, while the mica, although always present, varies greatly in amount. White Cloud Peak is the culminating point of the granitic mass, and here possesses in general the characteristics of an eruptive granite; that is to say, there are no distinct lines of bedding that would ally it with the gneisses. There are a series of divisional planes which strike apparently with the range, and dip west, dividing the granite into broad tabular masses 40 or 50 and sometimes 80 feet in thickness. These planes, although traceable by the eye, when looked at in detail are obscure or wanting, yet there is a further indication of parallel structure in the granite, which appears in a hand-specimen by the arrangement of micaflakes. The laminæ of the mica are by no means all parallel, but there is, however, in certain strata a prevailing direction. Among feldspars, orthoclase largely predominates, although plagioclase is present. In the quartz, liquid-inclusions are almost entirely wanting. Apatite prisms occur very

\footnotetext{
'From notes furnished by Mr. Clarence King.
} 
plentifully, extending lengthwise with the direction of the mica; they are sometimes flattened, and are occasionally broken, appearing in disconnected sections. Hornblende is entirely wanting. The most interesting characteristic is the microscopical crystals of zircon.

A little way down from the summit on the west side of White Cloud Peak, a change takes place in the rock, and the granite becomes overlaid apparently unconformably by a series of quartzites and hornblendic schists, which occupy the range to the western foot-hills, sinking under the overlying Pliocene beds. North of the granite body, these overlying schists curve around and occupy the entire width of the range, which they continue to do to its northern extremity, where it passes under the valley of the Humboldt River. They have a westerly dip, varying from $20^{\circ}$ to $45^{\circ}$, and toward the base of their series present a somewhat granitoid appearance. This immense thickness of gneisses and crystalline schists contains a few beds of white dolomitic limestone occurring in beds from 1 to 6 feet in thickness, separated from each other by micaceous quartzites and micaschists. The whole limestone series has only been observed in one or two localities on the summit of the ridge, at Mount Bonpland and Clover Peak, and is altogether embraced within a band of less than 60 feet thick. Over the limestones are further micaceous schists, and above these, forming the summit of the series, is a heavy development of quartzite. These quartzites form the summit of the ridges, which slope from Clover Peak westward.

The erosion of glaciers has excavated deep U-shaped cañons, which have cut through the quartzite, leaving it standing upon the lateral ridges, and exposing the lower schist series in the bottoms of the cañons. These quartzites are very well developed along the upper waters of Boulder Creek, and also in Clover Cañon. On Plate XIX, this erosion of pure quartzite by glacial action is well shown, exhibiting the steep escarpments of the summit, the narrow lateral ridges, and the manner in which the brittle rock splits up with a sharp angular fracture.

The quartzites of Clover Cañon are either white or stained a light yellowish-brown by infiltrated oxide of iron. They consist mainly of white quartz, which is at times milky and at times translucent in the same specimen. They also carry garnets up to the size of a large pea, numerous 
white flakes of mica, which are, in general, disposed parallel to the bedding of the quartzite, and, as a microscopical constituent, fine black threads of hornblende and minute dislocated prisms of actinolite. The quartzites of Clover Cañon represent the lowest part of the quartzitic series, and possibly a lower series than those exposed on the west side of the mountain, west of Clover Peak. They are distinctly fissile, and split with very smooth faces, upon which are clearly seen striations not unlike the slickensides frequently observed in mines. The surfaces of these laminac are more or less discolored and spangled with plates of pure white mica. Occasionally rare small crystals of feldspar appear on these smooth brownish faces. The appearance of striation is in no way referable to the presence of mica, but is an actual rubbing and grooving of the surface face from some early motion. In the quartzites of the entire group, this phenomenon is not uncommon, nor is it confined to the quartzites; but the mica-schists themselves show evidence of internal motion.

Along the west side of the range, in the vicinity of 'Thompson's Ranch, the quartzites are less milky and of a clearer gray tint; and although they still carry white mica, they have some black biotite. The same cleavagefaces are developed, but here they are decidedly corrugated and ribbed by mica, which enters the face at a diagonal; the whole appearance is as if the cleavage-face had been developed obliquely to a zone of parallel mica flakes. Besides the white mica in these last quartzites, there is a considerable amount of finely fibrous green mineral, which, in localities, is more or less penetrated by half-decomposed and almost wholly-decomposed white mica. This green mineral is doubtless a chloritic decomposition-product of the mica. Such behavior of the mica in these quartzites is of interest as illustrating the transition from well-defined crystalline schists with a parallel structure to granitoid forms, in which such structure is no longer observable. The lack of parallelism in the mica flakes, and the lack of continuity of the planes which carry mica, already suggest the granitoid structure. As in the Clover Cañon quartzites, so here also is there an appearance of severe horizontal rubbing. The chloritic mineral, the mica, and the quartz, all show evidences of powerful attrition and pressure.

No garnets are observed in the quartzites of the west side. Under the 
microscope, the quartz proves to be rich in fluid-inclusions and empty cavities. There are considerable zones, in which the quartz is a pure material, carrying neither mica nor garnet; but these zones rarely reach more than 20 or 30 feet in thickness, and are the exception rather than the rule. Beneath the quartzites is the narrow zone of dolomitic limestone already mentioned, and, under these, thin associated quartzites, and then the heavy mass of gneiss and gneissoid schist, which form the great bulk of the range. Of these, in the northern part of the range, there cannot be less than 5,500 or 6,000 feet.

In the region of Clover Peak, the gneisses are usually composed of quartz, orthoclase, brownish mica, and hornblende. They are varied by limited beds of dioritic schist, which are interesting from the number of minerals they contain. In them, plagioclase predominates over orthoclase, but both are always present. The mica is of a dark earthy brown, while the hornblende, always more abundant than the mica, is of a dark-green color. Titanic iron and apatite in unusually large quantities are present. Inclosed between the beds of gneiss, rich in orthoclase and poor in mica, are some sheets of pure amphibolite, noticeable as containing no foreign minerals, not even quartz. An unusually interesting gneiss is found underneath the quartzite on the west slope of the range below Clover Peak. It is a fine-grained, brilliantly-colored gray rock, in which the white particles of quartz and black mica form a decidedly granitoid arrangement, but the rock at large has a very distinctly fissile structure, and cleaves easily in fine sheets of an inch or more in thickness. Besides the black mica, there is a large proportion of a brilliant coppery-bronze-colored variety; the rock is further distinguished by containing, as shown by the microscope, a considerable amount of fine zircon, and the rock is considerably stained by infiltrated oxide of iron. The gneisses in the region of the dolomitic limestones are more or less enriched by crystals of carbonate of lime. Besides these, in the remoter gneisses, there are calcareous passages, where the crystals are irregularly distributed, never enough to give a distinct character to the beds, but still enough to cause it to effervesce under treatment with acids. Garnet is confined to the quartzites and the lowest members of the gneiss. Quartz, with the exception of the dioritic beds, invariably predom- 
inates over feldspar. In general, there is more orthoclase than placrioclase. The series is particularly instructive as illustrating the breaking-11p of the schistose structure and assumption of granite forms by the development of large feldspars, and by the compression which has been brought to bear in the direction of the beds. There seems evidently to be some connection between these two phenomena; for wherever the parallel structure of the mica and hornblende is broken up into wrinkles and waves, there the feldspars assume greater importance, and reach the size of large peas. The rock in such passages, in hand-specimens, is indistinguishable from a granite; and between this and the schist with parallel mica, in which no crystals of quartz or feldspar interrupt the sheets of mica, there is every possible transition.

A very instructive exhibition of these changes is to be seen directly east of the summit of Mount Bonpland, where an abrupt precipice of not less than 1,000 feet falls off to the east. Across the face of this precipice may be traced the parallel layers of the gneiss, which vary in tint from a pale gray, almost white, to nearly black, according as the mica or hornblende predominates. Across these planes of bedding is an irregular clouding, which looks upon the surface of the precipice almost like the presence of irregular intruded masses. Through these, however, the general lines and shades of the gneiss beds are seen to run; but the gneiss itself, within the limits of these vertical cloudings, has lost much of its schistose character, and is more granitic.

The whole summit region is profoundly riven with vertical crack:s parallel to the trend of the range, but to what depth is unknown. They are, however, seen more or less distinctly throughout the whole of the eastern precipitous face of the northern part of the range. Owing, no doubt, to this series of vertical fissures, the summit rocks are very peculiarly weathered into a series of tall pinnacles 50 or 60 feet high, with large rounded tops like mushrooms, formed of beds which have more successfully resisted erosion.

As already mentioned, this entıre series is conformable, and dips to the west, and overlies the White Cloud Peak body of granite, but overlies it 
in an obscure manner, so that their relation is not clearly made out; their position, however, is unconformable.

There is reason to believe that the gneiss of Sacred Pass is constantly descending in the series, so that the lowest members are reached at the southern end of the formation.

The granite of White Cloud Peak bears a remarkable similarity to some of the well-known Laurentian rock-masses of the Appalachians, while the overlying schists and gneisses, with their limestones and heavy micabearing quartzites, have a noticeably close resemblance to the eastern Huronian. Thus isolated from all other large Archæan regions, and with only the general petrographical outlines to decide from, no definite reference of this interesting Archæan body can at present be made; but since all its affinities lead toward the Huronian group, it is safest to refer it to that division.

The summits of the East Humboldt Range, from White Cloud Peak to the northern end, all show abundant evidences of glaciation. Very considerable glaciers existed in the elevated group south of Fort Halleck. From the region north of Lake Marian a fine view is obtained of the glacial cañon which forms the south branch of the South Fork of the Humboldt River. The glacier here was 8 miles long, and its cañon, presenting the characteristic U-shaped bottom, shows a depth of 2,500 to 3,000 feet. The whole range north of Frémont's Pass contains along its summit a series of deeplysculptured amphitheatres, with characteristic rounded bottoms, with roches moutonnées, and carries along the lines of present drainage an abundance of peculiar alpine glacial lakes. The rubbish of lateral moraines flanks the canons. The upper 50 miles of the range presents a pretty continuous field of glaciation.

All the cañons in the region of Clover Peak which descend to the west side of the range are cut at least 1,800 feet deep, and in many instances the glaciers flowed to the very edge of the plain. Upon the east side of the extreme north edge of the range, in the region of Mount Bonpland, the glaciers were short and steep, and have left abundant evidence of this in massive piles of terminal moraines. The evidence also is very convincing that since the Glacial Period erosion has been very insignificant. On Plate 
XVIII is shown one of the deeply-cut glacier-cañons which come down from Clover Peak.

A little north of where the main South Fork of the Humboldt River flows out of the East Humboldt Range, the Archæan mass makes out in a bold promontory, around whose base is wrapped a -series of unconformable overlying limestones. About a mile and a half north of the South Fork of the Humboldt, these beds have a north and south strike, and dip about $25^{\circ}$ to the west. 'This position is held for nearly 3 miles to the north, when they describe a curve, and finally strike north $40^{\circ}$ east, and dip northwest at about. $20^{\circ}$ to $25^{\circ}$. Nearly 4,000 feet of limestone are thus exposed, and at their base a varying amount of quartzites. At times, the Archæan comes directly in contact with the limestone, so that the intermediate quartzite, which has been referred to the Ogden group, is wanting, while in others, there is an exposure of 100 to 200 feet of quartzitic beds. The first 2,000 feet of limehave prevailing light colors, and among the light-gray beds are many of a buff tone. Above these come the dense blue-black limestones, carrying a number of well-defined Coal-Measure forms, comprising the following species:

Productus semireticulatus.

Productus longispinus.

Fusilina cylindrica.

Camarophoria.

From its thickness, the character of the underlying quartzite, the prevailing buff hue of the lower members of the series, and the character of the organic remains, there can be no hesitation in referring these beds to the Wahsatch limestone.

Back of the Overland Ranch, in among the schists and granites, in a cañon just to the north of White Cloud Peak, there is a fragment of limestone devoid of fossils, and so deeply fractured and metamorphosed as to be little more than an irregular mass of blocks. It is doubtless an accidental fragment left by the general erosion, and indicates the fact that, prior to the upheaval, much of the crystalline schists were overlaid by the Wahsatch limestone. Along the foot-hills south of Camp Halleck, occupying a similar position and unconformably overlying the schists, is a little pointed 
spur of limestone rising above the Quaternary of the valley. Upon the foot-hills, directly back of Camp Halleck; the limestones again recur, and here they wrap around a prominent mass of Archæan, curving into Sacred Pass and skirting the crystalline rocks for a distance of 6 or 7 miles. There is here no underlying quartzite, but the limestone rests directly on the Archaan, and has yielded, near the point of contact, the following CoalMeasure forms:

\section{Syringopora multattenuata.}

Productus costatus.

Athyris subtilita.

The limestone is much shattered and decomposed. It is of a prevailing light color, is characterized by more or less earthy beds, and is doubtless a much higher member than the black limestones directly north of the South Fork. Further down the range, north of Sacred Pass, on the same spur, there are obscure outcrops of limestone seen under the rhyolite, and for the most part covered with glacial débris. Observed dips gave $35^{\circ}$ and $40^{\circ}$ west. No fossils were found, but they probably represent a northern extension of the Coal-Measure limestones already described.

On the extreme northeast slope of the Archæan mass south of Wells Station, on the Central Pacific Railraod, are a number of small isolated patches of limestone resting upon the crystalline rocks in a manner similar to those already mentioned on the western side of the range, and with the same lithological habit. Imperfect forms of Coal-Measure fossils, too poor for specific determination, were found imbedded in a light-gray rock, dipping $25^{\circ}$ to the eastward.

North of the limestone in Sacred Pass, and extending northward until they rest against the Archæan body is a group of rhyolites, which are chiefly a pale olive-green tufa, in which are large crystals of vitreous sanidin. Last of Sacred Pass, the range is widened by the addition of an outlying mass, which projects southward as a promontory surrounded by the Quaternary of the valley. Between the promontory and the main range in Clover Cañon, the Archæan schists are broken through by a very peculiar black rhyolite, having a brilliant resinous lustre, and resembling externally many of the glassy andesites, except that it contains a very large 
proportion of rounded granules of quartz of an amber color, which are fissured into a perfect net-work by minute cracks. Both plagioclase and orthoclase occur, which, according to Zirkel, contain an enormous quantity of half-glassy inclusions. The quartz, on the other hand, contains no inclusions at all. It is remarkable that the rock also contains grass-green undichroitic augite and thick magnetite, but no biotite or hornblende. The groundmass is a brownish glass densely filled with both feldspar and augite microlites. This is another interesting instance of the remarkable association in one rock of free quartz, orthoclase, and augite, and especially so that they are found in an acid glass.

Pliocene and Quaternary Formations.-Throughout its whole length, the East Humboldt Range is skirted on the west by Pliocene strata, extending from the southern limit of the map northward to the Humboldt River. In Huntington Valley, they form a belt varying from one to two miles wide; but from the South Fork of the Humboldt to Trout Creek, the entire valley is filled with these strata, which, in the middle of the valley, are always horizontal, but have a slight dip of deposition along the foot-hills, away from the range, rarely amounting to more than $4^{\circ}$ or $5^{\circ}$. These strata doubtless represent a lake-basin which filled the whole Huntington Valley, and the valley of the South Fork down to the gap, where the latter stream breaks through the Carboniferous limestones of the Elko Range.

The Quaternary plain that occupies the depression east of the IIumboldt Range is divided into two valleys, known as Antelope and Ruby Valleys, separated by a low cross-ridge of limestones and basalts, extending from Spruce Mountain in a northwest direction to the Archæan body of the Humboldt Range. Its highest summit in the region of Spruce Mountain barely rises 600 feet above the valley, while its western end falls away in low, rounded hills. No fossils were found in the limestone, but there can be little doubt that it belongs to the Wahsatch limestone. The basalts, finegrained, black rocks, occur, breaking through the limestones in a number of places, and forming the summit for a considerable distance. In the southwest corner of Antelope Valley, between Eagle Lake and the main range, is found a large hot spring, so completely surrounded by the Quaternary deposits that it is difficult to recognize the formation through which it 
breaks. It runs a considerable stream of clear water toward the lake, but leaves, upon evaporation, a thin crust of alkaline salts.

This incrustation, upon being subjected to chemical analysis by $\mathrm{Mr}$. R. W. Woodward, yielded the following result:

Soda . . . . . . . . . . . . . . . . . . . . . 35.66

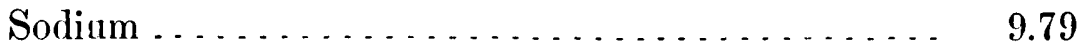

Potassa . . . . . . . . . . . . . . . . . . . . 1.04

Carbonic acid . . . . . . . . . . . . . . . . . . 15.27

Carbonic acid (excess over monocarbonate) . . . . 3.35

Sulphuric acid . . . . . . . . . . . . . . . . . . 19.99

Chlorine . . . . . . . . . . . . . . . . . . . 15.15

Boracic acid . . . . . . . . . . . . . . . . . trace

Phosphoric acid .................... trace

Combining bases with acids, we have:

100.25

Carbonate and sesquicarbonate of soda. . . . . . . . 39.04

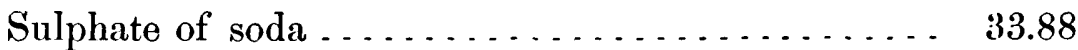

Sulphate of potassa. . . . . . . . . . . . . . . 1.94

Chloride of sodium . . . . . . . . . . . . . . 24.96

Excess of sulphuric acid . . . . . . . . . . . . . . . 0.43

100.25

In Ruby Valley, near the northeast shore of Ruby Lake, another hot spring reaches the surface, which deposits upon evaporation a siliceous sinter, a product of much less common occurrence from hot springs in Nevada than are the salts of the alkalies. This incrustation yielded $\mathrm{Mr}$. R. W. Woodward:

Silica.

Alumina ... . . . . . . . . . . . . . . . . . . .

Ferric oxide trace

Lime . . . . . . . . . . . . . . . . . . . . . 0.80

Soda . . . . . . . . . . . . . . . . . . . . . . . 1.06

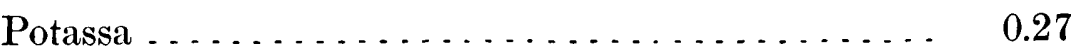

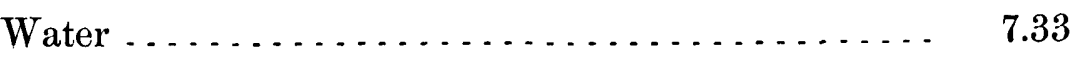

100.00

The analysis shows only 3.88 per cent. of basic elements. 
White Pine Mountains.-This somewhat isolated group, lying about 60 miles to the southward of the limit of the map, may be regarded as a southern prolongation of the East Humboldt Range. In volume III, ${ }^{1}$ of this series will be found a geological sketch of that well-known mining regrion, accompanied by a geological map. Since its preparation, however, the district has again been visited, and a hasty examination made of the heretofore unvisited portion on the west side of Pogonip Mountain, with the expectation, which was realized, of finding still lower formations than had previously been recognized. During this second visit, a large number of fossils were obtained from the different geological horizons represented, including several new species, as well as forms new to the locality.

In the narrow longitudinal uplifts, lying between the Sierra Nevada and the Wahsatch Ranges, the greater number of which, in general terms, consist of single anticlinal or monoclinal folds, made up of quartzite and limestone formations of great thickness, it is exceptional to find exposed in any one region a wide geological horizon. But here, at White Pine, the mountains, which have an average width of 12 miles from valley to valley. are formed of three distinct north and south ridges, two of which are monoclinal folds, with a sharp anticlinal lying between them, exposing, from the base of Pogonip Mountain on the western side, to the top of Mokomoke Ridge on the eastern side, strata from the Primordial shales to the CoalMeasure limestones.

Granite crops out in several small bodies along the base of Pogonip Ridge, but in only one locality was it observer in any large mass, where it occurs in a somewhat isolated hill as a coarse-grained homblendic rock with a friable texture. At the northern end of the ridge, apparently unconformable with the granite, are obscure outcrops of mica slates and black arenaceous and argillaceous slates and shales, in turn overlaid by an undetermined thickness of a compact vitreous steel-gray quartzite, closely resembling the Cambrian Quartzites of other Nevada localities. Above this quartzite, and forming the lower beds along the greater part of the ridge, occurs the Pogonip limestone, which extends to the top of Pogonip Momntain, with a thickress of from 3,000 to 4,000 feet of strata. 'They dip with

\footnotetext{
${ }^{1}$ Mining Industry, vol. iii, 4(m).
} 
an angle of $24^{\circ}$ to $30^{\circ}$ eastward. The lower beds are a fine-grained, somewhat siliceous, black limestone, varying considerably in compactness and bedding, and frequently passing into calcareous shales. Higher up in the series, they develop more of a dark-blue color, banded with layers of fine arenaceous limestones and occasional cherty bands a few inches in thickness.

From the large number of organic remains obtained in the hurried study of these strata, it is evident that the field is one that would well reward the palæontologist, who would make a careful search of the formation.

Messrs. Hall and Whitfield have described from these Pogonip limestone beds the following forms:

Crepicephalus (Loganellus) Haguei, n. sp.

Crepicephalus (Bathyurus) angulatus, n. sp.

Crepicephalus (Loganellus), sp. undet.

Crepicephalus (Loganellus), sp. undet.

Conocephalites (Pterocephalus) laticeps, n. sp.

Dikellocephalus Alabellifer, n. sp.

Dikellocephalus quadriceps, n. sp.

Ptychaspis pustulosus, n. sp.

Ptychaspis, n. sp. undescr.

Chariocephalus tumifrons, n. sp.

Agnostus communis, n. sp.

Lingulepis Mara.

Obolella, sp. undet.

Near the top of the Pogonip limestone, at the northern end of the ridge, were found the following forms, which have been referred to the Quebec group:

Ptychaspis pustulosus, n. sp.

Bathyurus Pogonipensis, n. sp.

Orthis Pogonipensis, n. sp.

Strophomena Nemia, n. sp.

Porambonites obscurus, n. sp.

Raphistoma acuta, n. sp.

Cyrtolites simuatus, n. sp. 
The section given in volume III, from Treasure Peak to the summit of Mokomoke Ridge, presents the following beds:

1. Dark bluish.gray compact limestone $\ldots \ldots \ldots \ldots \ldots \ldots \ldots \ldots \ldots \ldots \ldots \ldots \ldots, 1,500$

2. Thinly-laminated calcareous shales with interstratifed reddish-gray bands.. 125

3. Siliceous limestone with lenticular masses and uodules of chert......... 100

4. Black argillaceous shales, compactly bedded, with seams of bituminous

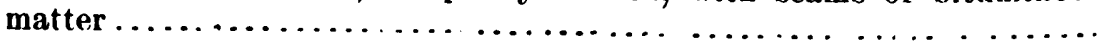

5. Black shales more arenaceous than No.4, with interstratified thin beds of

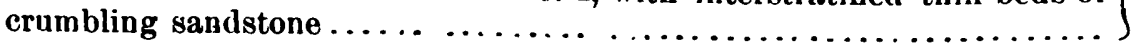

6. Reddish-yellow sandstone, fine-grained, even textnre . . . . . . . . . . 300

7: Light-yellow granular limestone, distinctly bedded, rich in Coal-Measure fossils. 1,500

Upon Treasure Hill are exposed at least 1,500 feet of blue limestone, the upper 800 feet of which have been shown, by palæontological evidence, to be of Devonian age, and the lower beds, although they have as yet yielded no organic remains, have been referred, in the absence of any direct evidence, to the same horizon, the Ogden Quartzite not coming to the surface along the base of the ridge.

The species obtained from these Devonian strata range, according to Messrs. Hall and Whitfield, from the Upper Helderberg to the Chemung horizons of the New York section.

From Treasure Hill were obtained:

Cladopora prolifica.

Diphyphyllum fasciculum.

Acervularia pentagona.

Ptychophyllum infundibulum

Naticopsis, sp. undet.

Orthoceras Kingii.

Strophodonta canace.

Productus subacvleatus.

Atrypa reticularis.

Rhynchonella Emmonsi

Pentamerus, sp.?

Spirifer argentarius.

Cryptonella, sp.!

Orthis, sp.?; resembles $O$. resupinata. 
Spirifer, sp.?; resembles $S$. striatus

Paracyclas peroccidens.

Bellerophon neleus.

Isoneina, sp.?

The collection from Babylor Hill included:

Syringopora Machuriis

Smithia Hennahii.

Favosites, sp.?

Atrypa reticularis.

Rhynclionella Emmonsi.

Pentamerus, sp. ?

Orthoceras, sp.?

Pterinea, sp.?

The only forms obtained from Mount Argyle belong to corals, and, although mostly fragments, Prof F. B. Meek has been able to specitically identify the following:

Alveolites multiseptatus.

Cladopora prolifica.

Smithia Hennahii.

Diphyphyllum fasciculum.

From the Blue Ridge, near the top of the series, we have:

\section{Spirifer Engelmanni.}

Productus subaculeatus.

Pleurotomaria, sp. $\dot{8}$

In the calcareous shales, no fossils have as yet been found. The siliceous limestone which caps Telegraph Peak contains large numbers of stems of Crinoidea, especially abundant in a fine-grained, white, cherty band, from which was also obtained a dorsal valve of a new species:

Spirifera alba-pinensis, H. \& W.

This fossil was taken from beds which evidently underlie strata of which there can be little doubt but that they belong to the horizon of the $35 \mathrm{D} \mathrm{G}$ 
Genesee slate; and although this is the only locality from which it has as yet been recognized in Nevada, it is known in the Wahsatch Range associated with the interesting groups of fossils from Ogden and Logan Canons, which show close affinities with the Upper Devonian, and at the same time are allied to the Waverly group of Ohio.

The black argillaceous shales which form so prominent a feature both in the geological and physical aspect of the district are but indistinctly recognized in other places, and without fossils. This may arise partly from the beds in neighboring ranges becoming more sandy or calcareous, thus losing their marked habit, and in part from offering exposures far less readily studied. There can be little doubt but that the horizon will be clearly identified at some future time in other Palæozoic uplifts of the Great Basin. Here at White Pine, the black shales have been somewhat roughly separated into two groups, the lower more argillaceous, the upper arenaceous, but divided more shäply by the association of species.

From the lower strata we have:

\section{Leiorhynchus quadricostatus.}

Aviculopecten catactus.

Lunulicardium fragosum (Posidonomya P).

Nuculites triangulus.

Goniatites Kingii.

Orthoceras cessator.

From the upper beds we obtained:

Streptorhynchus, sp.?

Spirifer, sp. ? (resembles S. disjuncta).

Productus semireticulatus.

This association of species from the lower beds with Leiorhynchus quadricostatus, a characteristic fossil from the Genesee slate, has naturally led Messrs. Hall and Whitfield to regard the horizon as Devonian, and the overlying upper series with the equally characteristic Spirifer resembling $\mathbf{S}$. disjuncta as of Sub-Carboniferous age.

The sandstone beds are mostly barren of organic remains, their chief interest being derived from the number of impressions of stems and leaves 
of Lepidodendron and Cordaites, vegetable remains being very rare in the Palæozoic sandstones of Nevada. Associated with them occur some crinoidal stems similar to those observed in the siliceous limestone below.

Next above the sandstone occurs the Carboniferous limestone of Mokomoke Ridge, highly fossiliferous and rich in well-known types of Coal-Measure forms of corals and Brachiopoda, so abundant in the ranges throughout the Great Basin. These beds yielded:

Diphyphyllum subcespitosum.

Zaphrentis, sp.?

Streptorhynchus crenistria.

Productus semireticulatus.

Productus Prattenianus.

Productus longispinus.

Productus, sp.? (resembles $P$. Wortheni).

Productus Nebrascensis.

Productus costatus.

Spirifer cameratus.

Spirifer Rockymontanus.

Spirifer planoconvexus.

Spiriferina spinosa.

Athyris subtilita.

Athyris sinuata.

Eumetria punctulifera.

Terebratula, sp.?

Eureka Mining District.-At Eureka, northwest from White Pine, and in the next range to the westward, an exposure of Pogonip limestone is again seen, which forms the immense development of strata of Prospect Mountain, with the same lithological habit as at White Pine, and carrying throughout the greater part of the formation Primordial fossils, showing beyond doubt that the two series of beds are the same and equivalent to the Potsdam sandstone of Wisconsin. Our collections include the following new species:

Crepicephalus (Loganellus) granulosus.

Crepicephalus (Loganellus) maculosus. 
Crepicephalus (Loganellus) nitidus.

Crepicephalus (Loganellus) simulator.

Crepicephalus (Loganellus) unisulcatus.

Dikellocephalus bilobatus.

Dikellocephalus multicinctus.

Agnostus Neon.

Agnostus prolongus.

Agnostus tumidosus

Lingulepis Mara.

Lingulepis minuta.

Obolella discoida.

Kutorgina minutissima.

Leptana melita.

The only other beds of the White Pine section definitely recognized at Eureka are the Coal-Measure limestones, also highly fossiliferous; many of the species being specifically identical with those from Mokomoke Ridge, although the beds are much darker and more compact than at White Pine. The list contains:

Fusilina cylindrica.

Trematopora, sp.?

Chonetes glabra.

Athyris subtilita.

Productus semireticulatus.

Productus costatus.

Productus cora.

Productus Nebrascensis.

Machrocheilus, sp.? 


\section{SECTION V. \\ DIAMOND AND PIÑON RANGES.}

BY ARNOLD HAGUE.

Diamond Range.-This uplift lies next west of the Humboldt Range, on the west side of Huntington Valley. It is a long single ridge, of which only about 14 miles, at the northern end, comes within the limit of the map, the range terminating abruptly at Railroad Cañon, about latitude $40^{\circ} 10^{\prime}$ It rises from 2,000 to 2,500 feet above the adjoining valleys, of nearly equal elevation above sea-level, in a number of rounded limestone summits with somewhat steep slopes. But little opportunity was afforded for the study of the range, which was crossed at only two points, Chokup Pass, a mile below the boundary of the map, and at Railroad Cañon.

Structurally, this portion of the Diamond Range would appear to be an anticlinal ridge, with the strata trending obliquely across the topographical axis of the range; that is, striking northwest and southeast, both sides of the fold being largely made up of dark bluish-gray limestone. This limestone has been referred to the Lower Coal-Measure formation, the upper member of the Wahsatch group. At Chokup Pass, a depression in the ridge, the limestones are seen dipping both east and west at high angles, the axis of the fold occurring along the summit. In the limestone occurs a belt of coarse, although compact, brownish-yellow sandstone, not unlike the sandstone body at White Pine, which lies at the base of the Coal-Measure limestone. It measures nearly 300 feet in thickness. No fossils were found.

At Railroad Cañon, the rocks, light cream-colored limestones dipping to the eastward, are much disturbed and plunge rapidly beneath the surface, where they are overflowed to the north by large fields of basalt. On the eastern edge of the hills is an obscure development of yellowish-white rhyolitic tufa, showing distinct strata-planes, and having feldspars greatly decomposed. Quartz is rare, and, when present, is in large pieces penetrated by 
many cracks. There are a few flakes of black mica. This outburst of volcanic rocks occurs, like so many others in Nevada, at the end of a long ridge, where the sedimentary strata come to an abrupt termination by plunging suddenly downward, with the break, which is evidently a point of weakness, and one of least resistance, occupied by intrusive material. From this light-colored limestone were collected a number of fossils, types of CoalMeasure species, nearly all identical with forms found in the Carboniferous limestone of White Pine. The following have been identified:

Chatetes, sp.?

Streptorhynchus crassus.

Productus semireticulatus

Productus Prattenianus.

Productus costatus.

Spirifer Rockymontanus.

Spiriferina spinosa.

From the southern end of the range, near Newark, in a bluish-gray limestone, were found :

\section{Chatetes, sp.? \\ Campophyllum, sp.? \\ Spiriferina spinosa.}

West of the Diamond Range, the Lower Quaternary plains occupy the central portion of the valley in a belt 4 or 5 miles in width. During the winter and early months of spring, they are usually covered by a few inches of water; but in summer, with the exception of small shallow ponds at the northern and lower end of the valley, they present a hard level floor like the Great Desert. These Lower Quaternary deposits are strongly impregnated with common salt, and, upon the evaporation of the concentrated waters at the upper end of the valley, exhibit broad fields of salt incrustation, which have for several years been a source of revenue to those engaged in gathering it for the purposes of silver extraction by amalgamation.

As the strata upon both sides of the valley dip toward each other, it is not surprising that numerous springs, both hot and cold, should be found encircling the valley along the base of the limestone hills. The waters are 
ustally free from saline ingredients. The temperature of several of the pools was taken, showing a variation from $51^{\circ}$ to $109^{\circ}$. At the base of the Piñon Range, on the line of the old Overland Stage Road, are found springs of clear but tepid waters highly charged with sulphur.

Piñon Range. ${ }^{1}$ - The range of mountains which lies next west of the Diamond Range, and to the north is separated from the East Humboldt Range by the broad plain of Huntington Valley, derives its name from the very considerable growth of coniferous forests that are scattered over its summits and slopes. It extends from Dixie Pass, just north of the line of $40^{\circ} 30^{\prime}$, where it terminates abruptly, southward to Swallow Cañon, near the line of $39^{\circ} 30^{\prime}$. The 116 th meridian west from Greenwich follows for a long distance the crest of its ridge. It is in general a well-defined single ridge, and for the greater part of its length barely averages six miles in width, having a varied broken outline, with isolated peaks rising between 3,000 and 4,000 feet above the valley, and then rapidly falling off into low depressions and easy passes.

Geologically, the Piñon Range presents several features which are of special interest, if not exceptional, in the structure of Great Basin ranges. Among these, the absence of granite throughout its entire length is worthy of remark, as but few ranges are seen in which granite or related rocks do not occupy more or less area, and to the influence of which the present structural features of the neighboring Palæozoic formations may not in part be traced. But on the other hand there are seen here the entire conformable series represented from the Cambrian schists and quartzites, through the great thickness of Silurian limestone, Ogden Quartzite, and nearly, if not quite, to the top of the Wahsatch limestone, lying highly inclined, and exposing about 14,000 feet of strata. In structure, we find, dipping both east and west, simple monoclinal ridges, gentle synclinal folds, and broad anticlinal axes. Everything later than the Wahsatch limestone appears to be wanting until Tertiary times, but of the latter deposits there have been recognized skirting the older upheaval the non-conformable upturned Green River Eocene, with the later nearly horizontal Humboldt Pliocene beds. The volcanic

\footnotetext{
${ }^{\prime}$ In part from notes furnished by Mr. Clinence King.
} 
activity of the Tertiary age is well shown in the broad areas of both acidic and basic rocks.

Paleozorc Formations of the Piñon Range.-South of Dixie Pass, at its extreme northern end, the range rises in an elevated group of peaks, the highest of which has been called the Raven's Nest. This is formed of a heavy body of grayish-blue limestones, with included strata of buff limestone, which trend diagonally across the Piñon Range, with a strike of about north $25^{\circ}$ east and a dip of from $25^{\circ}$ to $35^{\circ}$ to the northwest. Directly north of the Railroad Mining District, the ends of this limestone belt are covered by an overflow of trachyte. At the east base of Raven's Nest Peak, these beds are conformably underlaid by a thin bed of granular saccharoidal quartzite, which closely resembles the gray limestone above it, the one passing gradually into the other. The whole body of limestone is between 3,000 and 4,000 feet in thickness, and is made up of remarkably heavy beds. Toward the bottom, it is prominently siliceous, but toward the top is a very pure crystalline limestone, which has been much altered into marble, and, where unaltered, is reticulated with seams of calcite. This formation is overlaid by about 1,200 feet of finely-laminated and ironstained quartzites. The material of this formation is exceedingly fine: it carries no conglomerates; it has no gritty grains, but shows throughout a uniform compact texture. West of Raven's Nest Peak, it is much traversed by jointing planes, with a strike of northwest and southeast. It is altogether similar to the great quartzite formation which appears south of Pinto Peak in the region of Pinon Pass, and from the trend of the two bodies there is little doubt that they are the same. Directly south of Pinon Pass, the quartzite is overlaid by a heavy limestone, which contains Devonian fossils. West of Raven's Nest Peak, the quartzite body is also overlaid by a high conical hill composed of heavy dark beds of limestone, conformable with the quartzite, and dipping west at about $40^{\circ}$. A few crinoidal stems were all the fossil remains found in this upper series of beds. Its thickness is entirely unknown, but there are exposed at least 4,000 feet of strata. How much more lies to the west under the Humboldt Pliocene is, of course, uncertain.

From its position over the quartzite, from the heavy character of its 
dark-blue beds, and from the fact that a similar heavy body of limestone, above the quartzite at Piñon Pass, carries Devonian fossils, it has been referred to the Wahsatch limestone. It must necessarily be either the Wahsatch limestone or the Upper Coal-Measures. The underlying quartzite is neither thick enough nor coarse enough to be referred to the Weber beds, and without doubt it could not be the Ute limestone, when still underlaid by so heavy a body of limestone as that of Raven's Nest Peak. Moreover, the quality of the quartzite separating these two limestone bodies is quite simi lar to that of the Ogden Quartzite, so clearly shown in Ogden Cañon, Wahsatch Range. The thickness of 4,000 feet of underlying limestone is not too much for the Silurian and Primordial series, when we recall the thickness of the lower limestone, as seen at White Pine Mountains and at Robert's Peak. It is to be regretted that no organic remains were collected, in view of the fact that at Pogonip Mountain large collections of fossils were made throughout the series of nearly 4,000 feet of strata, the greater part of the beds yielding Primordial forms, overlaid by others carrying species identified as belonging to the Quebec formation.

Lithologically, the upper limestones at Raven's Nest do not resemble those of Moleen Peak, which carry, not far above the base of the series, Upper Coal-Measure fossils, and overlie the pebble-bearing, gritty, heavilybedded quartzite. The character of this latter formation is maintained in Moleen Cañon, and differs entirely from the Ogden Quartzite, which, throughout Central Nevada, is uniformly fine-grained and finely bedded, and carries no conglomerates.

Underneath the heavy Silurian limestone, and under the thin bed of saccharoidal vitreous quartzite, there occurs a heavy red and chocolate-brown quartzite, which forms the summit of Pinto Peak, retaining its conformity with the overlying series, and on the south edge of the Pinto Peak Ridge approaching a horizontal position.

These red quartzites to the north of Pinto Peak are underlaid by more or less of mica schists and quartzitic schists, which, from their position, inferior to the Silurian, and from their similarity to the Wahsatch Cambrian, are referred to the Cambrian age. They are roughly estimated at 5,000 feet in thickness. The section here exposed, therefore, is a conform- 
able series of about 14,000 feet in thickness, striking north $25^{\circ}$ east, at an angle, diagonally to the north and south trend of the range, and composed in an ascending series of the following beds :

1. Heary schists, grits, and quartzites (Cambrian).......... 5,000 feet.

2. Gray and bluish-gray limestones (Ute-Pogonip limestone) .... 3,500 to 4,000 feet.

3. Fine-grained and finely-laminated quartzites(Ogden Quartzite). 1,200 feet.

4. Dark blue limestone, with interstratitied beds, toward the base of the series, of cream.colored and whitish limestone (Wah. satch limestone) $\ldots \ldots \ldots \ldots \ldots \ldots \ldots \ldots \ldots \ldots \ldots \ldots \ldots \ldots \ldots, 3,500$ to 4,000 feet.

No fossils were found in any of these beds except the crinoidal stems above mentioned, and the reference of their horizons is therefore made entirely from stratigraphical evidence, which, besides the great similarity to other sections, is in this case rendered quite certain by the continuity of the Ogden Quartzite to the southward in the range. It is not considered certain that the whole of the body laid down as Cambrian is really such. There are two zones of quartzite, one of a gray saccharoidal form, the other brownish and distinctly laminated, which, as described, immediately underlie the lower limestone. Underneath these, the mica schists and heavy red quartzites of Pinto Peak may possibly be unconformable with the Cambrian quartzites, and represent an Archæan centre. The relations between the two are obscure, but the observations in the field tended to show that the whole outcrop is, as colored on the map, Cambrian. The lower beds of the limestone body, which has been designated on the geological sheet as Silurian, should probably liave been referred to the Cambrian, so as to include in the latter formation those strata which contain Primordial forms.

Trending southwest from Dixie Pass, the Ogden Quartzite becomes the foot-hill rock west of Pinto Peak, and, with slight interruptions where the Tertiary overlies it, may be traced upon a curved line of strike, until, in the region of Willow Creek, it trends south $50^{\circ}$ east, and dips southwest. At Willow Creek, the range has developed a complete anticlinal, of which the central part is formed of the lower limestone, which dips at an angle of about $16^{\circ}$ to the west and about $21^{\circ}$ to the east. This is overlaid on both sides of the range by the Ogden Quartzite, which, farther south, arches over the Ute-Pogonip limestone, and forms the axis of the fold, overlaid again on each side by the Nevada Devonian, or lower members of the.Walisatch limes. 
stone. The limestone, which makes its appearance, conformably overlying the quartzite, just north of Willow Creek, and to the south of it, and again upon Hot Spring Creek, is similar in all respects to the limestone west of Raven's Nest Peak, with the same predominance of earthy buff beds in the first 1,200 or 1,500 feet. The limestones from Willow Creek south do not rise so high in the series as at the north. Those at the north, upon purely structural grounds, from evidence obtained in so many other localities, are divided into the Devonian, Sub-Carboniferous, and Lower Coal-Measures ; or, in other words, all three divisions of the Wahsatch limestone. The SubCarboniferous, throughout our entire area, is such a narrow belt, that it is exceedingly difficult to recognize it; but, in such a conformable deep-water series, it seems highly probable, with the Sub-Carboniferous probably occurring at White Pine, that it should be represented here. The line between the Devonian and Sub-Carboniferous is drawn quite sharply at Hamilton and Eberhardt in the White Pine Mountains, but cannot with equal certainty be laid down in the region of Raven's Nest Peak. Farther to the southward in the range, evidence was obtained showing conclusively that about 1,200 feet of limestone, which overlie the Ogden Quartzite, contains organic remains, of which the Upper Helderberg marks the highest horizons. The occurrence of Devonian beds, as high as the Genesee slates, as well as the Upper Helderberg at White Pine, indicates that the summit of the Devonian series must be placed a few hundred feet above the Helderberg line. Accordingly, on the hills west of Raven's Nest Peak, the hypothetical line separating the Devonian from the Sub-Carboniferous is carried about 1,500 feet above the Ogden Quartzite.

The geological section across the Piñon Range represented at the baso of the geological map is made through the peak at the head of Pony Creek, and shows the flat anticlinal of Ogden Quartzite occupying the crest and higher summits, with the Devonian limestone dipping gently away both to the east and west. On the east side, the upper limestone beds are concealed by a heavy outburst of rhyolite, which extends to the plains, while on the west side the Humboldt Pliocene and Quaternary beds rest directly against the limestone. In the section, the Ute-Pogonip limestone and Cam- 
brian beds are drawn as forming a part of the anticlinal fold, but covered by the great arch of Ogden Quartzite.

This anticlinal axis, continuing southward, trends diagonally across the range at a strike of about south $25^{\circ}$ east. The easterly-dipping limestones of the anticlinal, 4 miles north of Piñon Pass, are covered by the body of rhyolite already mentioned, but on the west side of the anticlinal, however, they dip uniformly to the southwest for about 2 miles, when they pass under the synclinal axis, and rise again to the west, having an easterly dip, and exposing the Ogden Quartzite along the west base of the range. In the basin of this synclinal, the Sub-Carboniferous and Lower Coal-Measure formations have been introduced upon the geological map. It should, however, be distinctly stated that no palæontological evidence for such an assignment was obtained, but it has been made for the same reason as already given for the great thickness of beds in the region of Raven's Nest Peak. Near Mineral Hill, on the west base of the range, the UtePogonip limestone comes in below the Ogden Quartzite, extending southward for about 4 miles in low broken hills, until concealed beneath great flows of basalt. It forms the narrow entrance to Cave Cañon, where it appears in somewhat higher hills as a hard siliceous blue limestone, with a rough irregular fracture, and dipping under the overlying quartzite. The Ogden Quartzite is seen in low hills of exceedingly hard flinty rock of bluish and reddish tints and a vitreous lustre. Above the quartzite occurs the Devonian limestone, reaching to the summit of Fossil Pass, and forming the entire eastern slope. In color and texture, it resembles the lower members of the Wahsatch limestone already described, many of the beds possessing the characteristic buff color. The beds are slightly arenaceous, the siliceous grains being usually very fine, while certain layers are more or less dolonitic in composition. Under the microscope, the quartz-grains show frequent liquid-inclusions. The beds trend diagonally across the range, striking north $20^{\circ}$ to $25^{\circ}$ west, and dipping $28^{\circ}$ to $30^{\circ}$ to the eastward. At Pine Nut Pass, 14 miles to the southward and near the southern end of the map, the structure is much the same, a simple monoclinal ridge dipping eastward; the section, however, exposing only the Ogden Quartzite 
and Devonian limestone. The former occurs as rolling foot-hills, overlaid by ridges and walls of the latter, with a dip of $30^{\circ}$.

As regards the palanntological evidences of the age of the Piñon Range, it may be said that from only one locality have organic remains been found in the lower body of limestone, and these were confined to stems of corals too poorly preserved for specific determination. They were found in a blue cherty bed near the entrance to Cave Cañon, and, coming from the upper members, are of some special interest, as Prof. R. P. Whitfield regards them as belonging to the horizon of the Lower Helderberg of the New York section. From several localities in the range, however, the Wahsatch limestone has yielded fossils which have been referred to the Devonian age, the association of forms clearly indicating the Upper Helderberg beds. In one instance, there would appear to be a mingling of both Lower and Upper Helderberg forms; but, according to Professor Whitfield, all the forms might possibly occur in the Devonian beds. With Lower Helderberg fossils near the top of the underlying limestone, and Upper Helderberg forms near the base of the overlying limestone, the palæontological evidences certainly favor a conclusion that the Ogden Quartzite is the equivalent of the Oriskany sandstone in the New York section.

In the region of Hot Spring Creek, the limestone furnished the following forms :

Dalmania, sp.? (closely resembles D. anchiops

from the Schoharie Grit of New York).

Edmondia Piñonensis (associated on the same

block with Chonetes and Spirifer).

Orthis oblata.

Orthis, sp.? (resembles O. quadrans).

Strophodonta, sp.?

Spirifer Piñonensis.

Spirifer, sp.? (resembles S. arenosa)

Atrypa reticularis.

Rhynchonella, sp.?

Several species of Brachiopoda, found in the above list, were also collected from the summit of Fossil Pass. 
On the east side of the range, nearly due east from Chimney Station, were collected a number of fossils, chiefly corals, which, although they have not as yet been specifically identified, are closely related to Upper Helderberg forms.

Among them were the following:

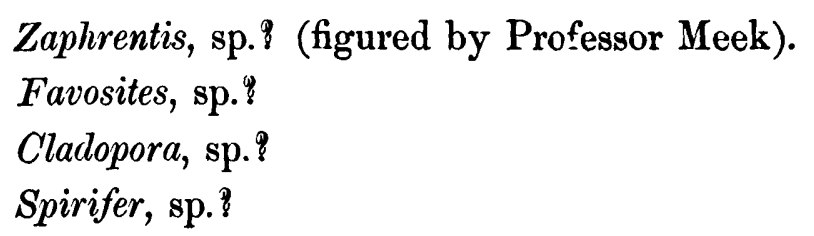

Mr. Henry Engelmann, who accompanied the expedition of Col. J. H. Simpson, obtained in Swallow Cañon, at the southern end of the Piñon Range, Devonian fossils, which Prof. F. B. Meek ${ }^{1}$ has described in a report accompanying that of Colonel Simpson.

The list comprises:

\section{Productus subaculeatus. \\ Spirifer Utahensis. \\ Spirifer Engelmanni. \\ Spirifer strigosus. \\ Atrypa reticularis.}

Professor Meek regards the group as closely allied to forms found in the Hamilton series of New York in a very similar rock. All of these species have since been found by us in the Devonian limestone of White Pine.

It is noteworthy, that while localities of Devonian fossils are as yet somewhat rare in the ranges of the Great Basin, and the Lower Coal-Measure forms of the Wahsatch limestone so abundant, here, in the Pinon Range, the palæontological evidences of the Devonian age of the lower members of the series should be so clearly defined, and exposed in so many localities on both slopes of the range along a north and south line of nearly 60 miles.

Volcanic Rocks of the Piñon Range.-Tertiary eruptive rocks are represented by trachytes, rhyolites, and basalts. From Dixie Pass south-

${ }^{1}$ Exploration across the Great Basin of Utah in 1859. Col. J. H. Simpson. Washington, 1876. 
ward, the stratified rocks are overlaid and cut off by irregular flows, which score the base of the range from its northern end to Pine Nut Pass. Notwithstanding these broad areas of volcanic rocks, it is noticeable that the Palæozoic ridge is never traversed by dikes or shattered by massive eruptions, forming prominent Tertiary peaks within the range; and although rhyolite hills in the region of Piñon Pass rise to considerable height, they lie to the eastward of the main uplift, and do not appear to have disturbed the broad anticlinal fold. From the region of Dixie Pass, the eastern foot-hills for about 12 miles are covered by successive outflows of trachyte, which, directly south of the pass, form rolling hills which abut against the ends of the Ute-Pogonip limestone, and trend southward until they flank the Cambrian quartzites, then continuing southward overflow the latter limestone on the east side of the anticlinal and also the Ogden Quartzite. This belt of trachyte widens out directly south of Dixie Valley for about six miles, and forms the material of a group of conical hills which, from their peculiar outlines, are conspicuous anywhere from the valley of Dixie Creek.

The overlying sheets and masses of trachyte, as well as all the prominent conical hills, are formed of a brownish and reddish-brown sanidintrachyte, in which the characteristic vitreous crystals of sanidin are riven with a multitude of cracks like those in the typical trachyte of Washoe. The groundmass is very coarse and rough in texture, and is formed of sanidin and brown magnesian mica. In a number of places where erosion has laid bare the lower members of the outflow, there is seen a gray trachyte rich in hornblende, and carrying a high proportion of plagioclase. This has a distinct bedding and a decided dip to the east, or away from the flanks of the range. In these gray hornblendic trachytes, the base is more compacted, and the rock has far more the habit of bedded andesites. It is not unlike the rock of the cross-spur at Washoe, and only differs from it in having rather smaller feldspar crystals. Mica, although present, is always in less quantity than the hornblende, and forms large black crystals, with a tendency to decomposition into brown earthy material. The less altered crystals cleave with very smooth and brilliant black faces. It is interesting to observe here, as in so many other places, noticeably in 
Washoe, this sequence of hornblendic trachyte, having affinities with andesite, followed by normal sanidin-trachyte. East of Pinto Peak, and a little to the north, in the middle of the trachytic zones are a series of north and south dikes of black vesicular basalt, which have small local outflows covering a group of hills with thin sheets. These basalts are poor in olivine and rich in acidic glass. They are also noticeable for the comparatively large size of the triclinic feldspars.

The contact between the sanidin-trachytes and the rhyolites lying farther to the south was not actually observed; but, from the contour of the hills and the peculiar southward slope of the trachyte surface, it seems most probable that it passes under the rhyolite. The volcanic rocks in the region of Piñon Pass are a light earthy rhyolite, having a very trachytic texture, containing, in a micro-crystalline groundmass composed of quartz, sanidin, and biotite, numerous dihexahedral quartz-grains, earthy, halfdecomposed orthoclase, and an unusually large proportion of biotite flakes. With the exception of the biotite, these minerals are not disseminated regularly through the mass, but oceur in isolated bunches, ten or twelve large quartz-grains appearing together, and, in others, groups of broken crystals of orthoclase. It is one of the richest in biotite of any rhyolite in the collection. But for the presence of quartz, both as a secreted mineral and in the groundmass, its general appearance and texture would unite it with the trachytes.

About 12 miles farther to the southward, at the base of the range, occurs another rhyolitic outflow, which forms low broken hills in contact with the Devonian limestone. This rock is a half-glassy hyaline variety, of uniform texture, and of a dark-gray color, with large sanidin feldspars imbedded in the glassy groundmass. Like many others of the same class, it withstands atmospheric agencies remarkably well, but erosion-outlines are usually sharp and angular. Between these two bodies of rhyolite are found small isolated patches of basalt, occupying the same relation to the Palæozoic strata as the rhyolitic masses. One occurs on the foot-hills near Fossil Pass, and is a hard, fine-grained, black rock. They appear simply as outlying bodies of the broad field of basalt, which borders the rhyolite east of Piñon Pass, and forms a continuous group of hills from the Piñon 
Range to Railroad Cañon in the Diamond Range, where it overflows the cream-colored Carboniferous limestone. These basalts connect the two ranges, completely encircling the northern end of Diamond Valley. It would appear to be a common mode of occurrence for both rhyolites and basalts, when coming to the surface along breaks in the sedimentary strata, or where the beds suddenly plunge downward beneath the surface, to strike, in massive eruptions, diagonally across the intervening valley to the base of the next range, dividing the depression into separate basins. The basalts of this long range of hills are rather uniform in character. Under the microscope, they appear to be unusually rich in grayish-black globulitic base. Augite is present in very fine grains, but the rock would appear to be remarkably poor in olivine.

On the west side of the Piñon liange occurs a very interesting basaltic table, which extends along the base of the range for 10 miles, abutting against the Ogden Quartzite, and completely obscuring the Ute limestone below. Along its east side, toward the range, it presents a moderately steep cliff, or wall, the main body dipping very regularly to the westward at an angle of $3^{\circ}$ toward the great basaltic flows of the Cortez Range on the opposite side of Garden Valley. The rock is distinctly bedded; deep black in color, and hard, but porous in texture.

One other locality of rhyolite connected with the Piñon Range, and found on the east side, some 8 miles south of the limit of the map, deserves mention. It presents a nearly white groundmass studded with large irregular grains of quartz and broken tabular crystals of glassy feldspar. There may also be detected a few small flakes of dark biotite. The groundmass has a coarse crystalline structure, which at once suggests to the fieldobserver, upon superficial investigation, a granite-porphyry, and yet a closer examination, together with its geological position, shows that it must be a Tersiary product. As rhyolite is simply the modern Tertiary type of the older granite-porphyry, this structural relationship between the two rocks is of interest. What adds greatly to this interest is, that Professor Zirkel finds, after a microscopical analysis of the rock, the same close resemblances, but concludes that the rock is undoubtedly a rhyolite. Professor Zirkel also finds in this rock minute grains of garnet, an exceed$36 \mathrm{D}$ G 
ingly rare but not a unique occurrence, they having been observed in rhyolites from both Hungary and New Zealand.

Dixie Group Region.-East of the foot-hills of the trachyte hills is an outcrop of uplifted Tertiary extending from Dixie Valley southward for 8 miles, and occupying a valley, or rather a low ridge, between the trachytes and a body of Lower Coal-Measure limestones to the east. For the most part, they are finely-bedded calcareous shales and marls containing carbonaceous seams and brown carbonaceous zones, which carry more or less coal. In the calcareous shales were noticed fragments of fossil fishes, but too obliterated for specific determination. They undoubtedly belong to the Elko shales, and are therefore referred to the Green River Eocene. They strike about north $20^{\circ}$ east, and dip $30^{\circ}$ to the east. This is the westernmost of the Green River outcrops, exposures of Eocene lacustrine deposits having never as yet been definitely recognized west of the Piñon Range.

To the east of this Eocene body, and penetrating it, lies a north and south ridge, detached from any mountain-range, about 8 miles in length, consisting of heavy beds of dark limestone, striking north $20^{\circ}$ east, and dipping to the east.

It contains the following Coal-Measure fossils :

Productus semireticulatus.

Productus longispinus.

It is evidently a part of the Wahsatch limestone, and directly to be connected with the fragments of Wahsatch limestone of a corresponding dip and strike, which lie to the east of the anticlinal north of Piñon Pass. The strike and dip of this limited body of limestone, which overlies the Ogden Quartzite, and is itself masked by overlying rhyolites, would, if continued, bring the Devonian beds directly under the Green River Eocene, at the west base of the limestone ridge. There can be little doubt, in connection with the fossils, that this is really the upper part of the Wahsatch limestone, and is the equivalent of the heavy beds of limestone which overlie the Ogden Quartzite west of Raven's Nest Peak; the rest of the

${ }^{1}$ Microscopical Petrograpby, p. 195. 
easterly-dipping part of the anticlinal having been covered over first by the Eocene deposits, and then subsequently by trachytes.

Pliocene Formations.-To the north, the eroded edges of the Green River series are overlaid by the soft friable beds of the valley Tertiary of the Humboldt Pliocene, which here, as elsewhere, are approximately horizontal. They extend to Dixie Creek, where they are, for the most part, covered by Quaternary detrital matter, and at Dixie Pass entirely concealed by accumulations of both trachytes and rhyolites. From the pass to the neighborhood of Cave Creek, the western foot-hills are skirted by a continuous band of Pliocene Tertiary, consisting of remarkably fine calcareous clays and sands. So much of the earlier rock of the range immediately underlying these Pliocene beds is of limestone, that it is not surprising to find so general a calcareous character in the Pliocene strata. In the region of Piñon Pass, they are mostly calcareous, where the beds, for a thickness of from 80 to 100 feet, are of white compacted lime-rock, in which is mingled about 10 per cent. of siliceous sand. These Tertiary lime formations are very chalky in texture and appearance, and are evidently made up of exceedingly fine material; in places, they are also more or less impregnated with alkaline salts, as if the lake in which they formed had been saline. Carbonates and chlorides predominate, but there are, at least in two cases; a little sulphate of soda and lime.

An analysis of this white lime-rock, from the Pine Valley Pliocene, by Mr. B. E. Brewster, yielded:

Silica. . . . . . . . . . . . . . . . . . . . . . .

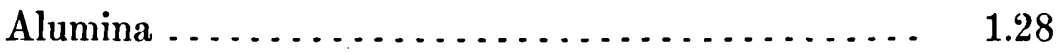

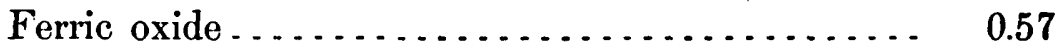

Lime . . . . . . . . . . . . . . . . . . . . .. 45.29

Magnesia ............................. 1.86

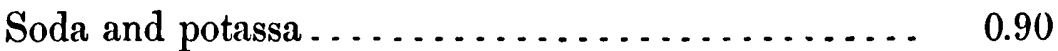

Carbonic acid..................... 36.23

Water ............................ $\quad 2.65$ 
Toward the northern part of the range, in the region of Pinto and Raven's Nest Peaks, a large amount of siliceous rock forms the foot-hills; the beds are in general more arenaceous, are far coarser, and carry thin sheets of pebbles. On the east side of the valley, and especially toward the northern end of the range, the Pliocene strata are prominently terraced, but on the west side they slope gradually, becoming a sort of inclined table cut by shallow ravines.

The depression of Dixie Pass represents a most remarkable point of dislocation. The Cambrian, Silurian, Devonian, and Carboniferous strata, all dipping west, come up to the pass from the south. The pass itself is obscured by trachytic and rhyolitic outflows, while on the hills to the north the outcrops are those of the Upper Coal-Measure limestone and Weber Quartzite, all dipping to the east, or in an exactly opposite position to the rocks south of the pass. It seems not improbable that the anticlinal south of the pass has been depressed and moved to the eastward, and that the line of fault is now obscured by the Dixie Pass volcanic outflows.

Robert's Peak.-Only the northernmost slopes of Robert's Peak come within the limit of the map; but the peak presents so much that is of interest that it will not be out of place to introduce here a few notes made during a hasty examination of the region. The mountain-group of which the peak forms the culminating point lies between the Piñon and Wah-weal Ranges, completely shutting in Keyes Valley to the north, and stands out prominently above the surrounding country, partly on account of its great elevation (10,136 feet) above sea-level, but in part also of its isolated position between two long, parallel ranges. The group consists almost entirely of limestone; and, from the fossils obtained, it is evident that the beds belong to the lower limestone belt. No careful estimate of the thickness of strata could be made, as the structure, somewhat obscure, was not clearly seen, but there must be at least between 2,000 and 3,000 feet of conformable beds which lithologically closely resemble the Pogonip series, compact, dark limestones, more or less siliceous, with interstratified beds of calcareous shales, and thin, cherty layers. So far as examined, the beds are inclined uniformly to the eastward, with a varying dip, and a strike northwest and southeast. Along the northern slopes, recorded strikes give from 
north $20^{\circ}$ to $25^{\circ}$ west, with a dip from $40^{\circ}$ to $50^{\circ}$ to the eastward, while the southeast foot-hills indicate a strike of north $8^{\circ}$ to $10^{\circ}$ west, and a dip of $18^{\circ}$ to $24^{\circ}$ to the eastward.

Organic remains were obtained from several localities, from the upper horizons on both the north and south slopes, yielding forms which may range from the upper members of the Quebec group to the Lower Helderberg of the Upper Silurian. It is one of the few localities in Nevada along the line of the Fortieth Parallel Survey where Upper Silurian fossils have been found.

The list embraces the following:

Cladopora, sp.?; resembles $C$. seriata.

Orthis, sp. ?; resembles 0 . hybrida.

Atrypa reticularis.

Atrypa, sp. ?; resembles $A$. nodostriata.

Rhynchonella, sp.?

Illanus, sp.?

The lower beds were not examined, but it would seem highly probable that they may be found to contain forms characteristic of both the Quebec and Primordial horizons, as found at White Pine and Eureka.

Overlying the Robert's Peak limestone, along the extreme northeastern foot-hills, occurs a dark-blue cherty quartzite, which, from its position and habit, has been referred to the Ogden Quartzite. It occupies but a limited area, being concealed both to the east and west by volcanic rocks, and derives its chief interest as indicating the relationship between the Robert's Peak limestone and the Piñon uplift.

Volcanic activity has had much to do in producing the displaced and shattered condition of the Robert's Peak beds, which, both to the east and north, have been broken through and buried beneath large outflows of both trachytes and rhyolites, but chiefly by basalts. These intrusive rocks frequently extend from the highest ridges down the long slopes of the mountain to the valleys below. Trachytes are found breaking through the Ogden Quartzites, where they occur as a dark-gray, rough rock, carrying shattered crystals of sanidin and some dark mica. The trachytes are overlaid by basalts, which, to the north, are connected with the basaltic table 
of the Piñon Range, and southward with the great dome-shaped masses stretching from Robert's Peak to the Piñon Range, forming a north and south line of eruption nearly 25 miles in length.

Rhyolites skirt the northern foot-hills, connecting with those of the Wah-weah Range, but the most interesting occurrence is found near the summit, just north of the main peak, where it breaks out through the limestone in a rounded dome-shaped hill. Rocks of precisely similar character to this were nowhere observed throughout the Great Basin, and, although of volcanic origin, it presents, in the field, a somewhat slaty schistose structure rarely observed in rhyolites. The groundmass appears quite uniform in texture, and of a dark bluish-gray color. Large feldspars are rare. Welldeveloped hexagonal plates of biotite are abundant, associated with occasional dark hormblende crystals. But for the large amount of finely-disseminated quartz in the groundmass, the rock, like the rhyolite from the east side of the Piñon Range, would show a close relationship with the trachytes. In this connection, therefore, it is of special interest to know that the microscopical analysis shows the same trachytic habit, but with many marked characteristics of rhyolite. Apatite may be detected in thin sections under the microscope.

WAH-weaII RANGE.-This range extends from Garden Gate southward for nearly 30 miles, and forms the western border of Keyes Valley. It separates Keyes from Cortez Valley, the latter lying between 400 and 500 feet below the level of the former. Only about 8 miles of the extreme northern end of the range is represented within the limits of the map, which consists mainly of granite and quartzite.

Granite occurs a few miles below Garden Gate, on the western side of the range, where it rises abruptly above the long slopes of Quaternary deposits of Cortez Valley, and forms a broken irregular-shaped mass for some distance, reaching an altitude nearly 1,000 feet above the plain. But little opportunity was afforded for studying this granite; it is, however, a medium-grained rock, resembling closely in its general outline the Mount Tenabo and Shoshone Wells body, and is probably simply an extension to the southward, with Garden Gate occupying a depression in the mass, which rises on both sides to a considerable elevation. Surrounding the 
granite on all sides, except toward the valley, occurs a heavy body of quartzite, which has been referred to the Ogden Devonian, although but little exsmined. Throughout Nevada, where large bodies of quartzite are found without any clue to their stratigraphical relations with an underlying or overlying limestone, the adjacent rocks being either granites or Tertiary volcanic outflows, it is exceedingly difficult, if not impossible, to definitely determine their true geological horizons. In many cases, lithological and structural resemblances will furnish a strong aid to such determinations, which, when followed up, will not infrequently throw the evidence in favor of one or the other of the great zones of quartzite; but unfortunately, in many cases, such resemblances are meagre, and the reference is made upon theoretical grounds, based upon slight evidence, or even personal impressions received in the field. The relation of the quartzite of the Wah-weah Range to the heavy body of limestone of Robert's Peak has not been worked out, but has been regarded as overlying it, and therefore has been referred, as already mentioned, to the Ogden formation. Geologically, the chief interest in the Wah-weah Range is found beyond the boundary of the map, where the quartzites give out, and are replaced by immense flows of trachyte and rhyolite, extending to the southern end of the range, and concealing the lower sedimentary strata. In one or two places, however, the quartzite comes to the surface, indicating that the intrusive rocks follow, as is so often the case, the longitudinal axis of the Palæozoic uplift.

Trachyte is the predominant rock, and forms the broad, table-like body which extends the width of the range. A number of small hills and peaks rise above the general level, and the mass is traversed by numerons deep cañons and ravines, exposing a great thickness of trachyte. It is, indeed, the largest body of trachyte observed in Central Nevada. East of the Virginia Range, trachyte outbursts are usually confined to narrow dikes, isolated hills, or cappings of older beds; the broader areas of acidic rocks being mostly of the rhyolitic variety. It would appear, however, probable that many large fields of trachyte have been poured out, and have since been buried beneath extensive flows of both rhyolite and basalt. It is also worthy of note that this trachyte mass lies slightly inclined to the westward, or toward the lower valley. 
Few localities afford a better opportunity for the study of the various modifications in form, texture, and mineral composition, of trachytes than the Wah-weah Range. There are represented here both the normal sanidin-trachytes and hornblende-oligoclase-trachytes. The former, which are generally the younger, are rough, porous, light-gray rocks, rich in sanidin and brilliant flakes of biotite. In the latter, the groundmass is more compact, more homogeneous, darker in color, and rich in triclinic feldspars, mostly oligoclase, associated with well-developed dark hornblendes. Between these two types are seen every variety, from those rich in either hornblende or mica to those in which both minerals would appear to occupy a very subordinate position. In one of the normal sanidin-trachytes, Professor Zirkel detected, under the microscope, the somewhat rare occurrence of blue haüyne. Associated in the same rock were also found minute forms of apatite. Quartz, which is a characteristic ingredient of rhyolite, also occurs in some trachytes, and Professor Zirkel has pointed out that the quartz of trachyte is almost always present, as a secreted mineral, in large macroscopical grains, while in rhyolites, in addition to the larger masses, it occurs in minute grains disseminated through the groundmass. Quartz-bearing trachytes are also well developed in the Wah-weah Range, and would appear to form no exception to the general rule, the rock possessing all the habit of trachyte with the addition of large grains of clear, colorless quartz. In the same region are also found augite-trachytes, the groundmass of which presents a dark-gray, uniform character, with a resinous, oily lustre, so marked in the augite-andesites. Scattered through this dark groundmass are numerous light-colored feldspars, which give the rock a decidedly porphyritic appearance. Brilliant striated plagioclase crystals are abundant. Apatite may be detected under the microscope, and the feldspars shown to contain some remarkable glass-inclusions.

The rlyyolites of the Wah-weah Range also play an important part in the volcanic activity, and are found skirting the hills both at the extreme northern and southern flanks, and also on the summit of one of the higher points. They all possess the same general habit, a bluish-gray microfelsitic groundmass, characterized by large numbers of irregular black grains of quartz and broken crystals of sanidin. In some localities, mica forms a 
prominent ingredient. Like the trachytes, the rhyolites under the microscope show the presence of apatite.

It will be seen that there are represented here a wide range of acidic types of volcanic rocks, embracing varieties from the extreme highly siliceous rhyolites, with their characteristic structure, through quartz-bearing trachytes, rough, light-gray, normal, sanidin-mica-trachytes, plagioclasehornblende-trachytes, to the augitic varieties, which show a marked mineralogical and physical resemblance to the rocks classed as augite-andesites.

In Cortez Valley, just east of the Wah-weah Range, occurs an interesting shallow alkaline lake, which, during the autumnal months, becomes dry, depositing a considerable amount of sulphate of soda and common salt. A sample collected in the month of July from the northern end of the valley contained:

Chloride of sodium $\ldots \ldots \ldots \ldots \ldots \ldots \ldots \ldots \ldots, 78.31$

Sulphate of soda...................... 21.11

99.42

The aqueous solution was neutral. It contained, in addition to the substances quantatively determined, minute traces of lime, potassa, lithia, and boracic acid. 


\section{SECTION VI.}

CORTEZ RANGE.

BY S. F. EMMONS.

Tenabo Peak Region.-The Cortez Range lies next west of the Piñon Range, and is separated from it by the narrow Pliocene basin of Pine Valley. It has a northeast and southwest trend; but, owing to the great accumulations of intrusive rocks, its boundaries are less clearly defined than are those composed mainly of sedimentary strata. To the south, the range terminates abruptly in Tenabo Peak, but to the north it stretches out in broad, irregular fields of rhyolite. The Cortez exhibits a marked contrast to the Piñon Range, the latter being formed of longitudinal uplifts of Palæozoic strata bordered by volcanic outflows, while the former, exposing but little of sandstone and limestone, shows intense activity of igneous rocks, not only in the broad accumulations of volcanic material, but in the great variety of rocks represented from quartz-propylite to the latest flows of basalt.

Tenabo Peak, at the extreme southern end, stands out somewhat prominently from the rest of the range, separated by the marked depression of Agate Pass. This peak, the highest in the range, has an elevation of $\Im, 240$ feet above sea-level, and rises boldly over 4,000 feet above the Quaternary plains of Crescent Valley. Tenabo, in the language of the Shoshone Indians, is said to signify "Lookout", a very appropriate name, as the peak affords one of the broadest and most commanding views to be found in Central Nevada. The greater part of the mountain is made up of a heavy body of granite, extending from the base up to within 900 or 1,000 feet of the summit, where it is overlaid by a limestone body referred to the Upper Coal-Measure series. This granite also forms the lower 2,000 feet of the precipitous western wall of the mountain down to Shoshone Wells, stretching westward so as to include the body making the divide between Crescent and Cortez Valleys.

Mill Creek and other lesser cañons cut deeply into the formation, and 
expose numerous walls, which offer fine views of the granitic mass. The granite is characterized by its tough, dense appearance, with but little tendency to crumble or wear away by exfoliation. It varies very considerably in texture, from a fine to a medium-grained rock, and from a pearl-gray to a rather dark-gray color, due partly to the differences in texture and in part to the more or less quantity of dark mica present. The granite is made up of quartz, in translucent grains, usually quite small, both monoclinic and triclinic feldspars, and dark biotite plates. In the region of Shoshone Wells, the rock is perhaps somewhat lighter in color than the main body of Tenabo Peak, but otherwise shows but little difference.

Between the forks of Upper Mill Creek, on the west side of Tenabo, occurs a rock-mass of later age than the granite just described, as it penetrates the latter as an intrusive body, with sharp lines of contact. It may probably be best classed as a diorite, but at the same time it presents many features of a fine-grained granite which has broken through the older body. It is a compact, dense rock, breaking with great difficulty under the hammer, with an uneven surface and angular fracture, behaving like a fine granite, or, more accurately, like a rock in which fine quartz is a predominant constituent of the groundmass. Few granites, however, possess so fine a texture as this rock, the groundmass being almost crypto-crystalline, with clearly-defined plagioclase and fibrous hornblende, while a more careful search indicates some orthoclase and quartz. The microscope reveals the presence of biotite in small flakes, and that the triclinic forms of feldspar prevail over monoclinic. So much hornblende with triclinic feldspar places the rock among the diorites, while on the other hand mica, associated with so considerable a proportion of quartz, would suggest a granite. It is of special interest that the diorite of the Agate Pass Region to the north also carries a large amount of quartz as an accessory constituent.

Resting upon the granite, and forming the summit of the peak, occurs a body of limestone which dips with an angle of $30^{\circ}$ to $35^{\circ}$ to the eastward, and strikes south $10^{\circ}$ east. The limestone extends but a short distance north of the summit, but thickens rapidly to the south. It is underlaid by a belt of pure white quartzite 420 feet in thickness, in turn underlaid by a second limestone formation. This quartzite has a saccha- 
roidal granular texture, resembling many varieties of marble. In the quartzgrains may be seen under the microscope large numbers of fluid-inclusions. Interstratified in the quartzite are thin seams or bands of black or steelgray quartzite, with the lines of contact between the two kinds sharply defined. A precisely similar bed of white quartzite, interstratified in limestone, with the same lithological features, both above and below it, has not been recognized in any exposures of the great belts of limestones. It may, however, represent some of the coarse yellowish-brown sandstones, or possibly some bed of arenaceous limestone, so frequently met with in other localities, notably the brown sandstone bed in the limestone of Chokup Pass, Diamond Range.

The limestone has an even, fine-grained texture, and a gray to grayishblack color. Disseminated through it are thin flakes and minute particles of iron pyrites. A specimen taken from near the summit of Tenabo Peak has been submitted to analysis by Mr. B. E. Brewster, with the following result:

Silica (chiefly sand) ..................... 19.899

Silica (soluble) ......................... 1.088

Iron pyrites ......................... 1.166

Alumina and ferric oxide ................. 1.088

Lime .............................. 39.765

Magnesia ........................... $\quad 2.799$

Carbonic acid......................... 32.799

Water and organic matter................. 1.059

This gives :

99.663

Carbonate of lime..................... 67.545

Carbonate of magnesia.................. $\quad 5.878$

A minute quantity of the alkaline bases was detected, the spectroscope indicating the presence of both soda and potassa.

No direct stratigraphical evidence was obtained as to the age of the limestones, as they rest high up on the granite, cut off from all other sedi- 
mentary formations, nor were fossils obtained. As heavy beds of quartzite and overlying limestone to the north of Agate Pass have been placed in the Weber Quartzite and Upper Coal-Measure limestone, the Tenabo Peak beds have also been provisionally referred to the horizon of the Upper CoalMeasures.

In the cañon through which the road passes, just north of Shoshone Wells, an isolated patch of limestone is found, also resting upon the granite, and dipping at a high angle to the northward, but which has not been indicated on the map.

In the Tenabo Peak limestone are a number of well-defined mineral veins, many of them having been extensively worked. The ores are rich in silver sulphurets, but combined with zinc, lead, and other base metals, requiring expensive metallurgical processes. A description of the Cortez Mining District will be found in "Mining Industry".1

Agate Pass Region. ${ }^{2}$-The Agate Pass depression trends northwest and southeast at right angles to the general course of the range. The western foot-hills of the range south of its mouth are formed of heavy-bedded darkblue limestones, which are locally more or less changed into marbles and invariably crystalline, and, as far as observed, contain no fossils. They have a strike a little east of north, dipping eastward, or toward the cañon. The thickness exposed may be 1,200 or 1,500 feet. On the eastern edge of their outcrop, they abut against a mass of diorite, which fills the bottom of the cañon for several miles, and extends northward, occupying the nortliwest foot-hills of the range for about 4 miles. This diorite is highly crystalline rock, containing very little groundmass, and is composed of wellpreserved triclinic feldspar, green hornblende, abundant quartz, and a high proportion of brown biotite, but, as far as observed, no apatite. The crystals of triclinic feldspar are in some instances a quarter of an inch long, and the hornblendes sometimes reach an eighth of an inch in length. The feldspars are more or less impurified by small inclusions of hornblende and mica, while the quartz crystals in general seem quite free from them.

${ }^{1}$ Mining Industry, vol. iii, 405.

${ }^{2}$ From field-notes of Clarence King. 
Its chemical constituents, as determined by Mr. R. IV. Woodward, are:

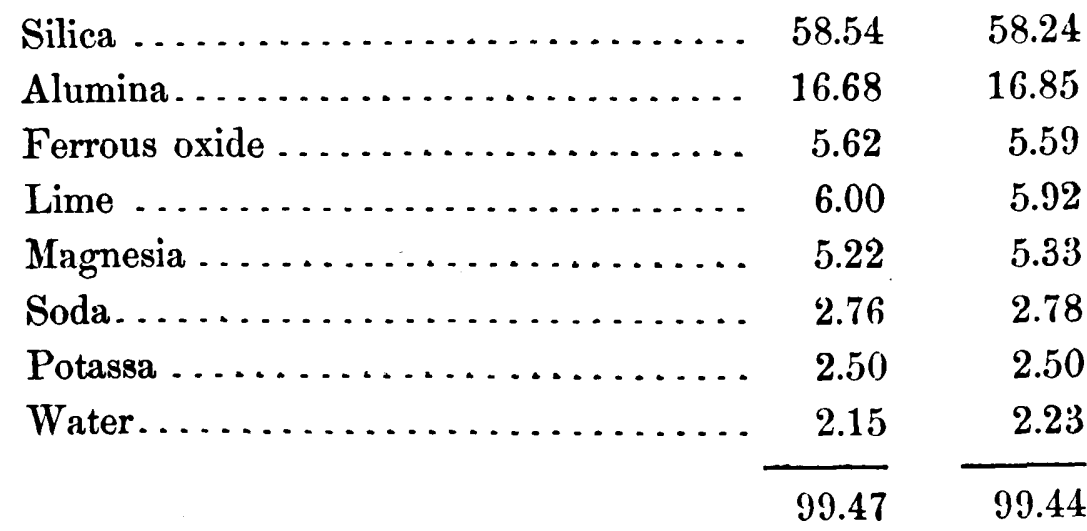

This diorite forms bold hills to the east of Agate Pass Road, through which are eroded gentle rounded cañons. There is singularly little dioritic débris, almost all the disintegrating material being readily ground up into fine sand, so that few boulders of diorite are found on the surface.

Directly to the east of the diorite is a very great thickness of siliceous and gritty beds, striking a little east of north, and dipping to the west, which in their composition and texture present a striking resemblance to the peculiar quartzitic sandstones already described from the Fountain Head Hills and Tucubits Mountains, though, in general, possessing a more massive habit. They consist chiefly of yellow and saffron-colored sandrocks, containing a considerable proportion of broken feldspar crystals, with here and there sheets of siliceous cherty pebbles, black, red, and white, both angular and round. They contain also a small percentage of carbonate of lime, which is due to the presence of microscopic crystals of calcite. The quartz-grains contain fluid-cavities with moving bubbles, and the feldspars are usually quite earthy and decomposed. A peculiar feature of this rock are the vugs lined with crystals of quartz and carbonate of lime. All the base of the rock is a fine clastic material, and a thin translucent chalcedony fills the interstices. Among the included pebbles and conglomerates are many of a small, brown hornstone or chert, which often occurs in the siliceous beds of the conglomerate, but have nowhere been found among the older rocks and clays. The angular condition of many of the included fragments is not surprising in view of the granite mass, directly to the north of 
these quartzitic sandstones, which is of the older type, and in all probability Archæan. The frequent outcroppings, through this deep sedimentary series, of granite and schist summits of the Archæan age are sufficient to account for the presence of angular conglomerates in any of the subsequent rocks.

The quartzite series and the before-mentioned limestone series dip toward each other at an angle of about $30^{\circ}$. Of the limestones, as has been seen, there are 1,500 feet exposed, and of the quartzites about 4,000. They represent the two sides of a synclinal, of which the western side has probably been faulted downward, and the diorite then burst up through the fissure. The quartzitic series, from its character and thickness, has been referred to the Weber Quartzite, and the limestones to the Upper CoalMeasure group. There is nothing, however, to prove that these do not represent the upper members of the Wahsatch limestone, in which case it must be the rocks to the east side of the synclinal that are depressed. Besides the yellow conglomerate beds, near the summit of the quartzite series, is a bluish-gray quartzite, made up of very fine grains of quartz, with very little orthoclase and a few crystals of calcite. This is, however, a very unimportant member of the series. There is a very close resemblance between the yellow conglomerates and grits of this series and those underlying the Upper Carboniferous limestone of Moleen Peak, which will be described in the next section.

At the summit of Agate Pass, the quartzite series is cut through by innumerable basaltic dikes, and overflowed by sheets of fine black basalt, which flow down the eastern slope, and mask the whole range, from the region of Mount Tenabo to Wagon Cañon, a distance of 28 miles. As observed along Agate Pass, these basalts are of a fine doleritic type, consisting of plagioclase, augite, olivine, and rather coarse magnetite, between which are small spots of dark bluish-gray globulitic base. There is considerable variety in these basalts, as to the coarseness of their crystalline ingredients, and the proportion of secreted crystals to the globulitic base. There are some specimens in the uppermost flows which are as fine-grained as hornstone, and have quite a resinous lustre in the fresh fracture. These contain a larger proportion of glassy matter, and their crystals are very minute. A characteristic of these basalts is the presence of a great quantity 
of large cavities filled with agates and chalcedonies. They range from the size of a pea to a foot in diameter; and the surface of the flat slopes toward Pine Valley is literally covered with lenticular masses of chalcedony, which have weathered out from the easily disintegrated basalt. It is only rarely that these chalcedonies entirely fill the cavities in the basalt. They usually form a lining from half an inch to three or four inches in thickness, with a botryoidal surface toward the interior. They are both of uniform chalcedony, and formed by repeated deposition of agate layers. On the lower sides of the cavity, there is found a considerable deposit of delessite, which sometimes plays a prominent part in the agate layers.

The erosion subsequent to the outflow of these basaltic tables has been comparatively limited: the ravines cut in them are of sloping sides, and not usually over a couple of hundred feet deep. Everything points to a very slight erosion since the basaltic period, whereas it is equally evident that the whole range had been subjected to severe changes or modifications of form before the volcanic period.

An obscure outcrop in the diorites of Agate Cañon, which, by the presence of quartz, biotite, hornblende, and feldspar, seems to be related to the diorites, proves, on examination, to be a granite, containing titanite, resembling, in this particular, the Jurassic granites of the Sierra Nevada. The hornblendes are peculiarly cleavable, and the biotite is present in proportions smaller than in the neighboring diorite. The feldspars are highly altered, so that the proportion between orthoclase and plagioclase is not to be recognized. Professor Zirkel says:" "The product of this decomposition is curious, consisting of broader or narrower colorless, prismatic rays, which are either massed confusedly together like felt, or are heaped together in the form of stars and bunches, presenting a beautiful aggregate polarization." 'The occurrence of this granite is very obscure. It is entirely surrounded with diorites, and may be either older or a Jurassic granite dike subsequent to the diorites. It is not to be connected with the heavy mass of granite which forms the north slope of the range about 4 miles northeast of $A$ gato Pass.

This is a broad mass of granite, extending 5 miles in a northeast and

${ }^{1}$ Microscopical Petrography, rol. vi, 48. 
southwes ¿ direction, and about 3 miles in width, which rises quite abruptly 4,000 feet from the plain. It is cut through by two sharp cañons, which expose its structure very clearly. It presents singularly few dividing plaues, and is remarkably solid, unbroken, and unseamed. It is composed of two feldspars, both entirely undecomposed, one of salmon-colored orthoclase, the other, a slender, white, triclinic feldspar, with quartz, which appears to be both translucent and of a milky whiteness, large white crystals of colorless orthoclase, long prisms of dark-green hornblende, and considerable biotite. There are not unfrequent veins and passages of granite, where all the constituents appear very large, the orthoclase reaching an inch and a half, and the quartz an inch in extent. The hornblende is here gathered into confused bunches of needles; and there is present a second mica, probably muscovite. The quartz contains fluid-inclusions: magnetic iron in small quantity and a little apatite are also present. The rock presents every variety of texture, from large pegmatite occurrences down to a fine, compact, salmon-colored mass, in which all the ingredients are too fine to be detected by the naked eye, the rock having a felsitic appearance, clouded here and there by a mere dusting of very fine hornblende and mica.

An analysis of a medium-grained variety of this granite was made by Prof. Thomas M. Drown, with the following result :

Silica . . . . . . . . . . . . . . . . . . . . . . 72.01

Alumina ............................. . 14.75

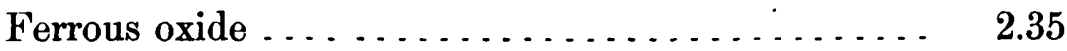

Manganous oxide.................... 0.17

Lime . . . . . . . . . . . . . . . . . . . . . 0.79

Magnesia........................... 0.65

Soda ........................... 4.21

Potassa . . . . . . . . . . . . . . . . . . . . . $\quad 4.49$

Ignition $\ldots \ldots \ldots \ldots \ldots \ldots \ldots \ldots \ldots \ldots \ldots \ldots .6 .61$

100.03

Cortez and Pappoose Peak Region. ${ }^{1-D i r e c t l y ~ t o ~ t h e ~ s o u t h ~ o f ~ t h i s ~}$ granite mass, and occupying the bold heights of Cortez Peak and the hill- 
tops to the north and south, forming a rude parallelogram, whose longer axis is with the range, about 8 miles in length, and whose shorter one is about 4 miles across the range, is a prominent occurrence of quartz-propylite. The prevailing type of rock is a fine, gray base, in which large, green hornblendes and brownish-green triclinic feldspars are imbedded. It shades into salmon color and green, also into drab-gray and brownish-gray tones, and varies from a coarsely crystalline texture to a fine, almost felsitic groundmass. The feldspars are very dull, and the hornblende more or less decomposed. The groundmass presents a crystalline aggregation of opaque feldspars, resembling those of granite, half-altered hornblende particles, and quartz which cannot be recognized by the naked eye. Under the microscope, the frequent presence of these fine particles of quartz gives a peculiar character to the section. The qnartz contains numerous fluidinclusions, among which some salt cubes were detected. The following note ${ }^{1}$ by Professor Zirkel is of interest:

"The large feldspar crystals are dull, but they still show that they have once been triclinic, the dimming lines, densely crowded together, crossing each other like lattice-work, or the bars of a grate, and leaving small, somewhat clearer, fields between them. The best-preserved porphyritical hornblendes are splendidly built up of long prismatic staffs, therein repeating the peculiarity which is shown as well in the quartzless propylites as in the older diorites. No dacitic hornblende has ever grown in such a manner. There is apatite and also some characteristic titanite."

An incomplete analysis of this rock, made in Leipsic, gave:

Silica

Alumina .......................... 16.13

Ferrous oxide.......................... 3.64

Limo ............................... $\quad 2.30$

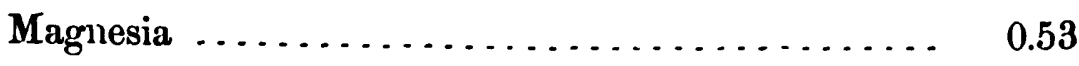

Ignition . . . . . . . . . . . . . . . .

The same great sheets of basalt which wrap around the east base of the quartzite series continue to occupy the east slope of the range, and

${ }^{1}$ Microscopical Petrography, vol. vi, 119. 
overflow the eastern boundary of the quartz-propylite mass. The rock is here, as at the head of Agate Pass, a very fine, green, more or less globulitic dolerite. All this portion of the range is very much steeper on the northwest side, where the older rocks are found, than on the southeast, where the subsequent flows of volcanic rocks occur.

With the granite, all the older rocks give out, and the range fiom Granite Cañon north to beyond the Humboldt River is entirely made up of eruptive rocks. Skirting the northern edge of the granite outcrop, and overflowing the northern extremity of the quartz-propylite, is a considerable field of rhyolite, which occupies the summit and north slopes of the range, and is deeply cut by sharp narrow cañons, which expose fine sections. These rhyolites, according to Zirkel, ${ }^{1}$ are distinguished from the others in the collection in the following points: "Their feldspars are, for the most part, altered into a dull, half-kaolinic substance; they lack evidence of any tendency to develop fibrous sphærolitic or axiolitic aggregations ; their groundmasses, which are in a very imperfect crystalline state, and are rich in ferrite, contain colorless feldspar-microlites, and they are absolutely free from biotite. Most of the rocks from this locality are rich in quartz, which is very pure, including only narrow lines of empty pores and beautiful isolated glass-inclusions."

In general appearance, the rock is of a buff, green, and purple color, and largely made up of a breccia, of which the fragments are applegreen, consisting of a very fine-grained, felsitic groundmass, containing a few decomposed feldspars and numerous large angular and rounded grains of quartz. These rounded grains of quartz are very peculiar, and possess the characteristic botryoidal surface of hyalite or chalcedony. The pellets are sometimes as large as a small.pea. The paste in which these fragments of green rhyolites are imbedded is a rhyolite rich in kaolinized feldspars and angular grains of quartz, which are sometimes dihexahedral, and sometimes simply angular fragments. They are all surrounded by a fine glazing, so that the cavities out of which the quartzgrains fall present a smooth, pearly surface. It is noticeable that there are also in the purple paste rounded quartz pellets, like those in the green frag-

${ }^{1}$ Microscopical Petrography, vol. vi, 194. 
ments; and this is another instance in which marked peculiarities are possessed in common by the breccia fragments and the including paste. It seems to be a general rule in all the breccias that the paste and fragments are precisely of the same material. To the east, the rhyolites fall off in long spurs, and are overflowed by sheets of fine-grained basalt.

In Wagon Cañon is a limited outcrop of reddish quartzitic sandstone, which is so similar to much of the rock in Agate Cañon, while resembling that of the River Range, that it has been referred to the Weber Quartzite. It is overflowed by a rough, gray sanidin-trachyte consisting of small sanidins, and laminæe of more or less decomposed biotite. The microscope reveals a large proportion of small particles of hornblende, entering prominently into the constitution of the groundmass, which consists as well of dull feldspars, and tolerably well-preserved hornblende crystals whose color was originally green. Both in habit and mineralogical constitution, this rock shows close affinity to propylite, and would be so classed, but that the orthoclase predominates over the triclinic feldspar: The peculiar look of the biotite which is noticeable in hand-specimens appears, under the microscope, to be due to the interposition, between the brown laminæ of its transverse sections, of colorless muscovite. A little apatite also occurs. $\Lambda$ somewhat fissile structure is given to the rock by the prominent parallelism of the biotite. This body of trachyte forms a narrow zone about half a mile wide and four miles long, lying between the foot-hill rhyolites and the body of quartz-propylite which forms Pappoose Peak. The question of age between the trachyte and the rhyolite, in the hills lying to the west of it, is obscure, but it seems probable that the rhyolite is the younger. The rhyolites of the foot-hills overlap the trachytes to the west and also the small body of quartzite which lies along the western edge of the quartzpropylite body, and connect with the rhyolites which surround the head of the valley; lying between Wagon Cañon and the Cluro Hills.

Beginning at Pappoose Peak, and extending along the middle of the range, across Wagon Cañon, and up nearly to the Humboldt River, is an irregular zone of quartz-propylite, probably part of the same eruption which occupies the crest of Cortez Peak, and which has been overflowed, to the south of Pappoose Peak, by the rhyolite body. It consists of a fine micro- 
crystalline groundmass of purplish-brown triclinic feldspar and green hornblende, in which are porphyritically enclosed earthy kaolinized feldspars, less decomposed than those of Cortez Peak, aggregations of crystals of green hornblende, and a few dark-brown biotites. Under the microscope, these latter contain between their laminæ interposed layers of calcite crystals, and apatite occurs in the groundmass and in the biotite.

This long ridge seems to be made up of repeated outflows, which have piled upon one another in thick masses, never showing the slightest tendency to overflow or spread out in thin sheets. The rock has the appearance of having been erupted in an almost solid condition, and possesses no evidence of flow whatever, which is not the case in the Washoe propylites. The lower exposures contain no biotites, and the feldspars and hornblendes both more closely resemble the rock of Cortez Peak. The biotite-bearing member is probably the last outburst, and is not represented at Cortez Peak. As in the Cortez quartz-propylites, the quartz is never or rarely visible to the naked ey.e, but under the microscope is seen to form a prominent element in the groundmass. In the rocks of Pappoose Peak, it is the hornblende that has suffered more decomposition than the feldspar, while at Cortez Peak the reverse is true. The actual proportion of biotite in the former rock is small, but its presence is conspicuous, because the flakes are very large, sometimes a quarter of an inch in diameter. The groundmass is also decidedly finer than at Cortez Peak. With these minor differences, the rocks are otherwise closely similar.

Lying to the east of the quartz-propylite body is a large development of dacite, which extends south from Wagon Cañon 8 or 10 miles, and descends to Pine Valley on the east. The prominent colors are dark-purple and dark-chocolate in the groundmass, in which are enclosed remarkably white, decomposed triclinic feldspars and numerous black, glittering quartz. Contained in the groundmass, and closely approximating to it in color and general appearance, are small angular fragments thickly scattered through the whole rock. These fragments contain secreted crystals of hornblende, plagioclase, and quartz, which are generally smaller than those secreted from the groundmass, but in other respects identical. The rock is, therefore, $a$. 
fine breccia, of which the included fragments are so small and similar to the paste that to the unaided eye it appears like one homogeneous rock. In certain of the larger feldspars, a metamorphism has taken place, resulting in a kaolin-like substance, penetrated in all directions by fine seams of chalcedony. Further evidence of alteration is observable in the cloudings of rusty-brown which traverse the purple groundmass. This results no doubt from the decomposition of the iron in the hornblendes, which conveys a stain to the plagioclases, and renders their edges and cracked portions a yellowish-brown. The mass possesses a general vertical structure, and never overflowed in tabular flows. This is common to all the dacites, whereas the andesite frequently overflows after the manner of the basalt, as at Washoe and Berkshire Cañon, Virginia Range.

Cropping through the dacite along the centre of the ridge is an obscure mass of dark-brown andesite, possessing, in a remarkable degree, the same earthy, half-decomposed modification, as described in the neighboring dacite. 'This is probably the crest of a ridge of earlier origin than the dacite, and represents a limited area uncovered by erosion. The rock has somewhat of a resinous lustre, and its feldspars are decomposed, and show a zonal structure. Under the microscope, their twin striation is visible, and the dark, yellow-brown crystals are seen to be augite, which brings this rock among the augite-andesites. The groundmass is much discolored, changing from the prevailing chocolate color to a rusty, iron-red and pale, yellowbrown, and is seen under the microscope to have a gray, rather than the usual brown, glass, which is probably caused by its proportionately greater richness in augite. It contains no olivine nor quartz. Its chemical constituents, as determined by Mr. R. W. Woodward, are:

Silica........................... 61.64

Alumina .......................... 17.44

Ferric oxide . . . . . . . . . . . . . . . . 0.82

Ferrous oxide....................... $\quad 3.99$

Manganous oxide $\ldots \ldots \ldots \ldots \ldots \ldots \ldots \ldots \ldots$ trace

Lime . . . . . . . . . . . . . . . . $5 . . . .8$

Magnesia........................ 3.05 
PINE VALLEY PLIOCENE.

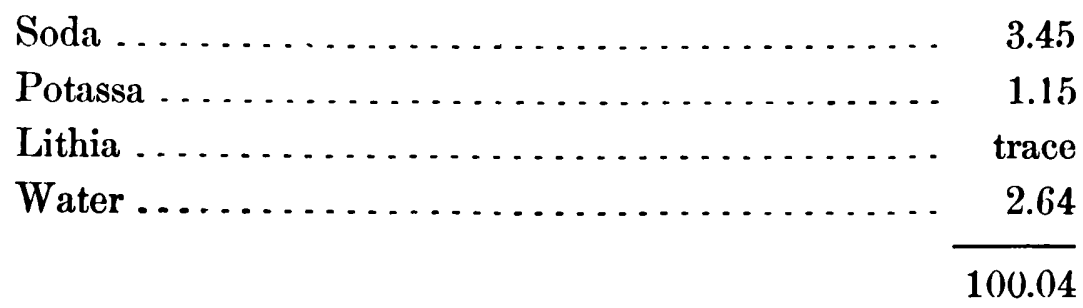

One specimen from this body contained some hornblende, which was apparently an accidental constituent.

Pine Valley Pliocene. ${ }^{1}$ - In the eastern foot-hills of the range, at the east base of Cortez Peak, the basaltic field is overlaid by a comparatively thick deposit of lacustrine Pliocene, in all respects like the Humboldt Pliocene. The beds are largely arenaceous, though toward the top there are fine clays, and singular beds composed of carbonate of lime and carbonate of soda in such proportions as almost to represent the composition of Gay-Lussite. There is no doubt that this formation formerly filled the entire area of Garden and Pine Valleys, and that the erosion of the draining streams has worn away a broad depression through the middle, which has been filled with Lower Quaternary and Quaternary.

On the east side of this valley, about four or five miles north of Mineral Hill, is an interesting exposure, where the Pliocene is worn into vertical bluffs 40 or 50 feet in height, of rounded and pinnacle-like shapes like the eastern bad-lands. The strata on this side are more calcareous than on the west, and contain beds which are almost limestone, but, as far as observed, are devoid of fossils.

The locality is particularly interesting as showing the relations between Pliocene and the Lower Quaternary. Usually the Lower Quaternary, as observed by us, has consisted of thin beds laid down conformably over the Pliocene, and occupying alkali flats, which, from their position in the very bottoms of the valleys, are not cut through and eroded by the streams. In this case, however, the main valley erosion took place, cutting out the broad valley bottom before the deposition of the lacustrine beds or Lower Quaternary, so that it occupies a position 40 or 50 feet below the top of the Pliocene, and skirts the base of the bad-lands, proving that the

\footnotetext{
${ }^{1}$ From field notes of Clarence King.
} 
Lower Quaternary, as laid down by us, is not necessarily the upper part of the Pliocene.

Region of the Cluro Hills.-On the west of the northern portion of the range, a small, detached, outlying group of hills, called the Cluro IIills, rises out of the plain, edged by Quaternary on the east and by a series of flanking deposits of Pliocene on the west. The hills themselves are composed of syenite, granite, and a quartzite body which has been, for convenience, referred to the Weber group. These hills are of interest as showing the only true old syenites of the collection. This rock consists of a fleshcolored monoclinic feldspar and greenish hornblende. Under the microscope, the feldspars resemble the orthoclase of granite. The hornblende proves not to be made up of homogeneous individuals, but every one of an association of light-green rays or prisms. This polysynthetic arrangement suggests the hornblendes of propylites. The rock also contains microscopical quartz, and a little plagioclase feldspar, whose striation is, however, very indistinct. Both these minerals have been generally considered not to occur in syenites, and their presence in this rock could not be detected but by the aid of the microscope. The granite of the Cluro Hills is similar to that already described in the Cortez Range.

To the north of Wagon Cañon, dacite forms the main crest of the Cortez Range, to the west of which is a body of hornblende-andesite, whose outcrops are somewhat obscure, and only exposed by erosion. This dacite differs somewhat from that to the south of Wagon Cañon in being less of a brecciated mass, though it still includes some breccia fragments. It is of a purplish-green color, and contains large, opaque, triclinic feldspars, with a good deal of fresh, brownish homblende, and some mica, in a micro-felsitic groundmass. The quartz crystals are not apparent to the naked eye, but under the microscope can be easily distinguished. The feldspars contain inclusions of a yellowish-gray glass, which sometimes almost replace the entire felspathic substance. The hornblendes are frequently decomposed, being altered into a pale-green substance, which sometimes has a mixture of calcite, but the biotites are always fresh. The andesite which appears on the slopes of the range toward the Cluro Hills is a dark, even-grained 
rock, containing but little hornblende. It seems, however, to be rather a hornblendic than an augitic andesite. It is full of very minute crystals of iron pyrites. The feldspars are generally of the same color as the groundmass, and can with difficulty be distinguished.

The syenite body of the Cluro Hills is partly exposed in an outlying peak to the west of the main crest. Between it and the andesite body is a syenite-porphyry, which is practically only a porphyritic modification of the main body of the Cluro Hills, but the rock is rather darker in color and more fine-grained. It is a dark-green rock with small flesh-colored feldspars, green hornblendes, and small quartz crystals, porphyritically imbedded in a groundmass, which, under the microscope, is seen to be composed of crystalline grains of feldspar, quartz, and altered hornblende. The rock contains more plagioclase-feldspar than the syenite, and the crystals of both feldspars are evidently fragments. The rhyolite which covers the syenite on the west, at this point, has a peculiarly shaly habit, splitting into thin laminæ only half an inch in thickness. It is stained by iron oxide on the surface, but, in the fresher fractures, shows a white, compact, felsitic groundmass containing only porphyritically imbedded crystals of quartz and feldspar.

Palisade Cañon Region.-In the neighborhood of Palisade Cañon, the andesite core of the range has been overflowed and mostly concealed by a flow of trachyte, which, in its turn, is covered by extensive flows of rhyolite, which mask the greater portion of the range north of the river. Most of the cliffs which border the cañon west of Palisade Station are composed of a dark-gray sanidin-trachyte. This rock contains but very little plagioclase or macroscopical biotite. Under the microscope, the groundmass is seen to contain a large quantity of very fine laminx of mica, together with decomposed hornblendes, and some apatite, but no augite. It has also a good deal of magnetic iron, which is frequently decomposed into dendritic fibres of ferric oxide. Apparently inclosed in this trachyte, on the south bank of the river, at the mouth of a little side-cañon, is a hill a few hundred feet in height, containing a large mass of iron-ore, remarkably fine-grained, and having a thoroughly con- 
choidal fracture. At a little distance, it might be mistaken for a basaltic rock. An analysis of this ore, made by Mr. B. E. Brewster, gave the following results:

Ferric oxide

Alumina .......................... 0.178

Manganous oxide..................... 1.454

Magnesia .......................... 0.472

Water ............................ 1.713

Insoluble residue....................... 12.518

Total ........................ 100.552

which would give a percentage of metallic iron 58.95. The occurrence of such a body of iron-ore in the midst of volcanic rocks is an interesting phenomenon, though it is probably too far from any source of fuel supply to be of practical value. It is, however, a remarkably pure ore, being entirely free from phosphorus or sulphur, though containing a rather high percentage of silica.

It may possibly have some connection with a peculiar rock which is exposed under the trachyte body on the opposite side of the river, forming the cliffs of the west side of a ravine which enters the cañon from the north. This has a very distinctly columnar structure, and is evidently of earlier age than any of the rocks around; but its relation to the other andesite bodies, on account of its isolated position, could not be determined. It is a heavy, fine-grained, crystalline rock, of a dark-gray color, whose constituents, with the exception of the plagioclase-feldspar, cannot be distinguished by the naked eye. Microscopic examination shows it to be a quartziferous augiteandesite, being made up of plagioclase, and a little sanidin-feldspar, augite, biotite, and some angular grains of quartz with glass-inclusions. Quartz crystals and some apatites are also found imbedded in the larger feldspars. It contains no hornblende or olivine, nor has it any glassy or amorphous base. Its chemical composition, as determined by Mr. Reinhard, at Leipsic, is: 
Silica............................ 62.71

Alumina .......................... 12.10

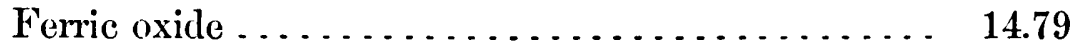

Lime . . . . . . . . . . . . . . . . . . . . . . 8.34

Magnesia ............................ 1.31

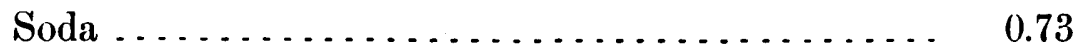

Potassa $\ldots \ldots \ldots \ldots \ldots \ldots \ldots \ldots \ldots \ldots . . .1 .15$

101.13

which is remarkable, not only for the high percentage of iron, but also for the absence of water and the small proportion of alkalies.

The trachyte which forms the main body of the hills to the north of Palisade Cañon, and the narrow gorge at the lower end of this cañon, is a somewhat different rock from that found along the south banks of the river, and apparently of later origin. It is a light-gray, quite porous sanidintrachyte, noticeable for the large earthy hornblende crystals, which occur in remarkably perfect hexagonal prisms, often as much as one-sixteenth of an inch in diameter. Casts of these crystals are found on the weathered surfaces of the rock, retaining perfectly the form of the original crystal. In general, the hornblendes are very much decomposed, and have imparted a somewhat reddish, rusty stain to the groundmass. Under the microscope, the latter is seen to contain some glassy base and also a little tridymite. The decomposition of the hornblendes is also very peculiar, and has often proceeded so far that the interior core of the crystals has been removed, and in part replaced by groundmass-material. In one specimen of this trachyte from the south bank of the river were found a few yellowish-brown crystals of augite.

Region of the Carlin Peaks.-North of Palisade Cañon, for a distance of about 20 miles, the surface of the Cortez Range is principally covered by extensive flows of rhyolite. A few obscure outcrops of sedimentary rocks show a pre-existing line of elevation, similar to that south of the river, whose form was probably determined prior to the volcanic period. These outcrops are, however, too isolated and indistinct to give any clue as to their structure, or any definite idea of the age of the rocks. The princi- 
pal exposures are in the deep cañons at the base of Carlin Peaks, whore is the greatest elevation of the range. Here, at the head of Annie Creek, was found a considerable body of siliceous and green argillaceous slates, enclosed in limestones having a westerly dip, while at the north of Carlin Peaks are also some few exposures of dark-blue and gray limestones, which are also seen at the gap of Maggie Creek, where, in direct contact with the rhyolite overflow, one bed of limestone has become marbleized. These sedimentary rocks, from which no palæontological evidence was obtained, have been referred, on grounds of general probability, to the Lower Coal-Measure group.

At Carlin Peaks, the range has a distinct double crest, of which the eastern portion doubtless represents the original sedimentary elevation, while the western crest is formed by a body of andesite, whose general direction is suggested by the isolated exposures of andesite from a little north of Wagon Cañon to the western of the Carlin Peaks. The two more northern bodies of andesite, that where the Emigrant Road crosses the range and that of the western of the Carlin Peaks, differ from the andesite found in Palisade Cañon, in containing some augite, and in having a more glassy base. They resemble closely the augite-andesite of the Wachoe Mountains.

That from the Fmigrant Road is a quite porous rock, with prevailing plagioclase, considerable sanidin-feldspar, and dark-brown hornblende, with a good deal of yellowish, decomposed augite. Under the microscope, the groundmass is seen to have something of the microlitic structure peculiar to the augite-andesites, and many of the hornblendes are somewhat decomposed, and have the characteristic black border.

The andesite from the head of Annie Creek is less porous. It is a dark-gray compact rock, rich in hornblende, containing also a good deal of yellowish-brown augite and some apatite. Under the microscope, the feldspars are seen to be mostly plagioclase, but with them are associated some schistiform, monoclinic feldspars and the groundmass to have the felt-like structure of augite-andesites. The feldspars are remarkable for containing inclusions of yellow glass, with a thick bubble, as shown in Vol. VI, Plate $\mathrm{V}$, fig. 3. This andesite forms a considerable mountain mass, and rests directly on the slates and limestones, while its flanks are covered by flows of rhyolite. 
The eastern of the Carlin Peaks is a high, flat, table-shaped mountain, made up of the typical red porphyritic rhyolite. The same character of rocks extends to the west of the upper part of Annie Creek, and covers the western slopes of the range where the Emigrant Road crosses it. Under it, near the river, is exposed an outlying portion of the trachyte body, and here the rhyolite itself very closely resembles the trachyte, but is distinguished from it by its containing a considerable amount of free quartz. With its prevailing sanidin-feldspar, it has also some finely-striated triclinic feldspars and black hornblende, but no mica, in a reddish-brown microfelsitic groundmass.

The rhyolites which form the eastern slopes of the range north of Palisade Cañon, in the neighborhood of the Emigrant Road, are grayish-red rocks, containing almost no macroscopical crystals, with the exception of a few sanidin and plagioclase-feldspars. The microscope discloses no quartz, but shows that the groundmass has a sphærulitic structure showing a radial fibration. The numerous cavities are seen to be lined by a light-gray crust, made up of fine layers of different-colored hyalitic opaline material. 


\section{SECTION VII. \\ REGION NORTI OF THE HUMBOLDT RIVER.}

BY S. F. EMMONg.

Mallard Hills.-The Mallard Hills form the southern continuation of a high range to the northward, whence comes the principal supply of water to Bishop's Creek, the main branch, properly speaking, of the Humboldt River. The higher portions of this range, as shown by the fragments in the wash of the streams, are formed of similar sedimentary materials to those of the Tucubits Mountains. The Mallard Hills, which are low, flat, rounded ridges, are made up almost entirely of flows of rhyolites, which are quite distinct in character from any observed in other portions of the region explored.

The rhyolite from Deer Cañon, the northern point of these hills, is a lavender-colored rock, which weathers into thin slabs, or laminæ, generally from half an inch to an inch in thickness. It resembles in many respects the quartziferous trachytes of the Elk Head Mountains. ' In a light-gray felsitic groundmass, it contains large crystals of sanidin and rounded grains of quartz, often as large as a pea, which are cracked in the interior and are surrounded by a ring of altered groundmass; it has, however, no mica or hornblende. Under the microscope, the groundmass is seen to be made up of a distinct aggregation of colorless plates, and black and colorless grains, while the ring which surrounds the larger crystals is an extremely fine, granular modification of this groundmass.

The rhyolites which form the main peak of these hills are generally of dark reddish-brown color. In some cases, they have the same laminated habit as those of Deer Cañon, and, like them, have something of a trachytic look. They contain also large crystals of quartz and sanidin in a felsitic groundmass, and have likewise apparently no mica or hornblende. They are sometimes extremely porous, the druse-like cavities being lined with botryoidal concretions of black glass and of chalcedony. Under the micro- 
scope, the rhyolitic character of these rocks is seen in the fact that the groundmass is spherulitic. The larger sphærulites consist usually of radiating fibrous material grouped around a dark centre.

In the valley to the north of these hills, whose waters run into the Snake River, is a Tertiary deposit, in which were found curious menilite-like fragments of white porcelain-like material, having a somewhat vitreous lastre, which, by the naked eye, can be seen to be full of little needleshaped fragments of black glass. In these, the microscope detects a tufaceous structure and the remains of diatoms. Along the northern slopes of the hills, just beyond the limits of the map, are numerous warm springs. The ridge which runs northwest from the Mallard Hills, forming the northeastern boundary of Bone Valley, is composed of the same dark brownishred rock found in the main group.

Bone VALLEY.-In Bone Valley, which forms an isolated interior basin, are deposits of white Tertiaries, which have been largely eroded away. On the surface of this valley were found a number of vertebræ and fragments of the jaws of fossil horses, evidently originating in these Tertiary beds, and which determine their age as that of the Pliocene.

These vertebrate remains were not found in place, but lying loose upon the surface of the valley; they were thoroughly petrified, but in general too imperfect for specific determination, although not water-worn, or showing any evidence of having been brought from a great distance; moreover, remains of light-colored limestone adhering to some of the specimens proved that they originated in the limestone beds of the Tertiary deposits of this enclosed valley. They were submitted to Prof. Joseph Leidy, who pronounced them identical with those obtained from the Pliocene Tertiaries of the Niobrara River. Those which were recognized and figured by him were:

Protohippus perditus, ${ }^{1}$ an extinct equine animal, represented, among the specimens collected, by a fragment of an upper jaw with two molars, fragments of the lower jaw with one molar each, fragments containing canine and incisors, some vertebræ, the end of a humerus, a pastern, and a coronary bone;

\footnotetext{
${ }^{1}$ Leidy, Extinct Mammalian Fauna, 1869, 275.
} 
Merychippus mirabilis, ${ }^{1}$ another equine animal, represented by an upper molar tooth; and

Cosoryx, ${ }^{2}$ represented by a peculiar furcate fragment of a horn-core, supposed to belong to an extinct family of antelopes.

The ridge to the west of Bone Valley is made up of quartzites and slates, striking a little north of east, and dipping about $25^{\circ}$ to the eastward, on whose flanks along the southern portion are some conformable limestone beds. No fossils were obtained from any of the beds, but from their association and position they have been assigned respectively to the Weber Quartzite and Upper Coal-Measure groups.

Egrptian and Osino Cañons.-The North Fork of the Humboldt, which here forms a considerable stream, takes its rise in the valley next west of Bone Valley, and, after leaving the open region of these two valleys, flows southward for 6 to 8 miles through a narrow canon-like gorge called Egyptian Cañon. In this cañon is exposed a peculiar rock, which, from its position, is apparently older than the surrounding rhyolites. It has been colored on the map as an andesite, although Professor Zirkel has, from a study of the microscopical sections, classed it among the basalts. In physical habit, it resembles the andesites. Its manner of weathering is rather peculiar, showing a rudely columnar structure, in which the columns are of cylindrical rather than prismatic shapes, and have a tendency to split into curved laminæ or sherds, at right angles to the axis of the cylinder. This peculiar weathering produces singularly picturesque architectural forms on the cliffs of the rock, which frequently show resemblances to ruined columns and remains of ancient temples.

The darker, more compact variety of the rock which is found at the lower end of the cañon is almost black, and shows only a few small crystals of feldspar in a semi-vitreous groundmass. Under the microscope, the groundmass is seen to be made up of. a mixture of fine microlites and grains of plagioclase, and augite. It contains, however, no olivine. Another variety, which shows the prevailing character of the rock, has a dark brownishgray groundmass, in which are imbedded large crystals,. often half an inch in diameter, of sanidin, rounded, cracked quartz, and also microscopical

\footnotetext{
'Leidy, Extinct Mammalian Fauna, 1869.

${ }^{2}$ Ibid., 172.
} 
crystals of plagioclase and augite. Both quartz and sanidins seem to be somewhat of an accessory ingredient like the quartz of the quartziferous trachytes. This rock likewise contains no olivine. Under the microscope, plagioclase is seen to be the predominating feldspar. The groundmass is a globulitic, half-glassy material, which contains peculiar crystalline products of secretion like those found in obsidians and artificial slags. The rock is also comparatively rich in apatite. The peculiar products of devitrification seen in a thin section of this rock will be found illustrated in Vol. VI, Plate XI, fig. 4.

Below the narrower portion of the cañon, which is cut through this dark, peculiar rock noticeable for its red, vitreous, weathered surfaces, spurs of reddish porphyritic rhyolite close into the river on either side for a few miles, and are succeeded by an open Quaternary valley, through which the North Fork flows in a broad, alluvial bottom as far as its junction with the main Humboldt. The hills to the east of this valley show a few outcrops of westerly-dipping quartzites, underlaid by limestones having a strike a little east of north, which were not closely examined, but have been referred to the Weber Quartzite and the Wahsatch limestone. They are covered high up on their flanks by the nearly horizontal white beds of the Humboldt Pliocene, while to the north the sedimentary rocks are concealed beneath the flows of rhyolite.

The rhyolite of Peko Peak, immediately adjoining the quartzite, has at first glance a strong resemblance to a sedimentary rock. It is, however, a distinctly eruptive body, but contains few crystals except those of quartz. It has a dull-gray, compact, felsitic groundmass, which in places encloses small fragments of green chalcedony, like those which make up the quartzitic sandstone already mentioned. In external appearance, it rather resembles an older eruptive rock. Under the microscope, it is seen to contain an enormous quantity of yellowish-brown grains of ferrite.

A mesa-like ridge of the white beds of the Humboldt Pliocene separates the lower part of the North Fork from the Elko Valley of the Humboldt River. Out of this, southwest of Peko Peak, rises a low rounded hill of white porphyritic rhyolite, whose groundmass has at times a somewhat earthy texture, but in general is very compact, almost like a porcelain. It abounds in small distinct crystals of quartz, which for the most part are $38 \mathrm{D}$ G 
smoky, and feldspar, with a small development of hornblende. The microscope also detects the presence of biotite, and shows that the groundmass is made up mostly of axially fibrous strings. The rock contains few angular fragments of quartzite.

At the southern end of this ridge, in Osino Cañon, is exposed a section of steeply-dipping quartzites and conglomerates, the latter showing the characteristic angular fragments of cherty material of the Weber Quartzite. Their general structure is that of a short synclinal fold, having a north and south axis, the beds being upturmed at high angles. Within the quartzites are also some black, apparently carbonaceous seams. The outcrops are very irregular, and are masked on the south of the river by the rhyolite flows of Upriver Peak. On the north of the river, at the eastern end of the cañon, is a body of light-gray, very crystalline rhyolite, having almost a granitic structure; containing sanidin, quartz, and mica.

In the broad valley of the Humboldt River, above Osino Cañon, are found in the dry season a number of saline incrustations, resting upon the fine impalpable Quaternary soil. From one of these deposits near Peko Station, a sufficient amount was collected for chemical investigation, the sample yielding 52 per cent. of soluble alkaline salts.

An analysis by Mr. R. W. Woodward gave the following:

Soda

Sodium .......................... 2.97

Carbonic acid......................... 30.78

Carbonic acid (excess over monocarbonate) ...... 10.07

Sulphuric acid ......................... $\quad 2.59$

Chlorine ......................... 4.58

Boracic acid ...................... $\quad 2.41$

The theoretical combination would give:

100.21

Carbonate of soda and excess of acid ......... 83.57

Sulphate of soda .................... 4.60

Borate of soda ...................... $\quad 4.49$

Chloride of sodium .................. 7.55 
Elko and River Ranges.-From Osino Cañon to Moleen Cañon, the Humboldt River runs through a wide bottom-land, which, to the southeast, extonds close up to the foot-hills of the Elko Range, but on the northwest is bounded by low, bench-like spurs of the River Range. The beds which compose these spurs are almost entirely of volcanic ash, generally of white color, and containing enclosed fragments of rhyolite. They slope off gently toward the centre of the valley. Along the foot-hills of the River Range, under these volcanic beds, which belong to the Humboldt Pliocene, are found occasional outcrops of upturned beds of the Green River Eocene. These are bost seen near Penn Cañon, at the northern end of the valley, where attempts have been made to develop their included coal-seams. $\Lambda \mathrm{t}$. the coal-mines, the strata dip $45^{\circ}$ to the south, with a strike a little north of east. They consist of beds of white, earthy limestone from six inches to a foot in thickness, with white, finely-laminated, calcareous and arenaceous shales, and seams of clay from two inches to a foot and a half in thickness. There have been found here three beds of coal: one of two feet in thickness, one of from five to six, and another of three. The coal is a very light lignite, black and lustrous, still retaining somewhat of a woody structure, and abounds in grains of yellow mellite. It is tolerably pure, and free from ash, but breaks up readily, on exposure to the air, into fine dust, and has thus far proved of little economical value. Adjoining the coal are beds of fine bituminous shales, which very closely resemble the brown paper-shales of the Green River series at Green River City in W soming. In them are found the same plentiful remains of fishes, and also occasional insects. Some of the shale beds have also abundant casts of deciduous leaves remarkably well preserved. It was impossible to make an estimate of the aggregate thickness of these beds, as they are concealed beneath the white Pliocene beds, which often so closely approach them in lithological character that they cannot be easily distinguished. A roughlymeasured thickness of 300 feet was obtained near the coal-mines, but, judging from the position of the outcrops and the dip of the beds, it would seem that as many thousand are probably represented. It is evident that these beds have suffered much more disturbance than those of the Green River Basin, since their angle of dip, which at the mines is $45^{\circ}$, shallows a little 
eastward to $25^{\circ}$, and in the ravine below the mines is found to be $65^{\prime \prime}$. About four miles to the northeast of the coal-mines a prospecting shaft has been sunk 100 feet, in a white, compact, fine-grained, volcanic ash, which doubtless represents one of the upper beds of the Humboldt Pliocene formation.

The northeastern foot-hills of the range, toward the North Fork, are covered, as has been seen, by flows of red and white rhyolite. On the spurs to the north of the coal-mines are found a great variety of lightcolored earthy rhyolites, from which one passes by insensible gradations, through compact, even-grained, structureless rocks, to the quartzitic sandstones, which form the main body of the hills. The rhyolites have sometimes a porous earthy structure, sometimes a compact felsitic groundmass, and enclose different-colored fragments of the same material, but show no distinct crystals, except very fine particles of quartz. The intermediate member is a compact felsitic rock, of a yellowish-white color, which, in the interior, is curiously striped by concentric bands of various colors, almost as fine and distinct as those of an agate. The colors are very brilliant and well defined, ranging from a deep purple, through brickred, into yellowish-white. Of these, Professor Zirkel remarks," "They are perfect likenesses of the felsitic tufas or clay-stones of the Lower Permian (Rothliegendes) in Germany, originating in the old felsite-porphyries; in every respect, the true precursors of the Tertiary rhyolites." In close connection with these curiously-striped rocks are found the fine-grained quartzitic sandstones, full of grains and crypto-crystalline fragments of limpid quartz and fine angular fragments of black and green chalcedony. It would seem therefore that these striped, compact rocks may represent here a tufa, which is contemporaneous with the Weber Quartzite; and the quartzitic sandstones, in contact with it, have been more or less altered, while the rhyolitic tufas, which co closely resemble it, and which are undoubtedly of recent eruption, have followed the same channels, and carried with them fragments of the older adjoining rocks. On the western slopes of the northern point of the River Range are bodies of westerly-dipping limestones, overlying the quartzites, which, from their stratigraphical position, have been

\footnotetext{
${ }^{1}$ Microscopical Petrography, 262.
} 
referred to the Upper Coal-Measure group, though no fossils were obtained from them. Their structure is shown in the upper section of the map.

In Penn Cañon, which is cut at right angles to the strike, nearly through the range, a thickness of some 3,000 to 4,000 feet of the beds of the Weber Quartzite is exposed. The structure is much obscured, but seems to be generally that of an anticlinal, whose eastern member is very steep and nearly perpendicular, while the main body of the range is formed of westerlydipping beds, whose angle in the centre of the range is only about $10^{\circ}$, steepening to $25^{\circ}$ on the extreme western foot-hills. The lowest beds exposed show a considerable thickness of black argillaceous shales and quartzites, which are overlaid by conglomerates, generally including a certain proportion of angular, cherty fragments, while the most prominent beds are the peculiar dark quartzitic sandstones already mentioned, which here are colored by hydrated oxide of iron. Microscopical examination shows that in both the quartzitic sandstones and conglomerates, the quartz-grains contain a great number of fluid-inclusions, and also small laminæ of mica, sometimes of distinctly hexagonal form. This fact also points to some preexisting uplift of crystalline rocks, from whose débris these were formed, which is now worn away, or concealed beneath the later formations. In the upper portion of the series is an included bed of limestone, underlying the upper conglomerate.

Immediately north of the cañon, the spurs are capped by a red porplyritic rhyolite of a type which is very widely spread throughout Nevada. It has a reddish-purple, compact, felsitic groundmass, and contains small crystals of sanidin and quartz, with a little hornblende and occasional flakes of black mica. It has a peculiar irregular fracture, and in a hand-specimen, but for the presence of quartz, might be easily taken for a trachyte. To the south of Penn Cañon, the range consists of low, rather broken lills, whose structure is masked by detrital material, but which, as far as observed, were composed principally of the greenish conglomerates and quartzite sandstones of the Weber group, having a prevailing dip of $10^{\circ}$ to the westward.

On the western slopes of the range, toward Susan Creek, are lightgray rhyolitic tufas, similar to those north of the coal-mines, being rather porous, and containing a few scattered crystals of feldspar and quartz in a 
porous earthy groundmass. Associated with these are gray semi-vitreous rhyolites, having a conchoidal fracture, which seem to be simply a more suddenly-cooled variety of the tufa. There also occurs here a dark-gray porphyritic rhyolite, having curious spherical balls, about an inch in diameter, of the same material, included in the mass, which is made up of distinct crystals of feldspar, quartz, and occasional hornblende and mica, in a compact, semi-vitreous groundmass.

At the extremity of one of the western spurs, toward Susan Creek, is a flow of earthy, flesh-colored trachyte, which contains scattered crystals of sanidin and mica in a micro-crystalline feldspathic groundmass. This rock resembles the European domite. Under the microscope, it is seen to have a light globulitic glassy base, in which is no microscopical biotite, hornblende, augite, or apatite. It contains, however, granular aggregations of red isotrope garnet, an occurrence never before observed in any trachyte except that from the island of Ischia in Italy. It contains also tridymite, and occasional small blue grains of a hexagonal shape, which are considered by Zirkel as haüyne. ${ }^{1}$

A tributary to Susan Creek, which runs down from the western slopes of the River Range, exposes under these rhyolites and trachytes a body of augite-andesite. On its weathered surfaces, this rock is of a greenish-gray color, but in fresh fracture almost black, having the resinous lustre peculiar to this type of rocks. In its half-glassy groundmass, one can distinguish crystals of feldspar and augite, the former being much more distinct on the weathered surfaces. By the aid of the microscope, magnetite grains are also found, but no olivine, and the groundmass is seen to be made up of yellowish-brown glass and the network of interwoven microlites peculiar to the augite-andesites. The glassinclusions in the feldspars and augites are very abundant, and almost replace the original substance of the crystal, as will be seen by reference to Vol. VI, Plate XI, fig. 2, where a thin section of this rock, showing a feldspar crystal included in glass, is illustrated.

A light-gray brecciated rhyolite, on the eastern slopes of the range, contains many fragments, which resemble the black and green jaspers of the conglomerate. It contains also fragments of rhyolite, while through

${ }^{1}$ Microscopical Petrography, 151. 
the mass are well-defined crystals of black biotite, the whole enclosed in a subordinate felsitic groundmass full of crystals of quartz. In the southern half of the River Range, the geological axis has a direction apparently about northeast and southwest, and south of the road from Elko the prevailing dip of the formation is to the eastward. Quartzites and conglomerates form the summit for some distance south of this point, showing occasional beds of limestone, while along the eastern slopes, toward Moleen Cañon, are found outcrops of light-colored earthy limestones overlying the quartzites conformably, which correspond to the Upper Coal-Measure limestones found at Moleen Peak, on the opposite side of the river. These are exposed in section at the entrance to the cañon, where the dip, at first shallow, gradually rises to $45^{\circ}$. A thickness of nearly 2,000 feet of buff, earthy limestones, with some included conglomerates, is thus shown, though not in continuous section, many of the beds bəing obscured by débris. The strike of the upper beds is considerably to the east of north, but in the cañon bends a little to the west of north, where the dip becomes steeper. In the Weber Quartzites, the river takes a sharp bend to the north, returning almost parallel to its course around a ridge of quartzite, whose beds stand almost vertical. In the upper portion of these quartzitus can be recognized the peculiar greenish and purplish conglomerates made up of angular jasper pebbles in a somewhat calcareous matrix, which resemble the conglomerates found along the range to the north, but are less metamorphosed. Although there is a decided appearance of unconformity at this point between the quartzites and limestones, it is probably due to faulting. Underlying the quartzites, on the south side of the river, and dipping about $45^{\circ}$ or $50^{\circ}$ to the eastward, is a zone of mixed slaty limestones and heavy blue limestones, which extend as far west as Carlin. These beds have a strike a little east of north. One of the mud beds above the main mass of limestone, but still some distance below the Weber Quartzites, contains a carbonaceous zone, carrying an impure anthracite.

These Lower Coal-Measure limestones to the north of the river disappear beneath the horizontal Tertiaries of the Maggie Creek Valley. To the south, they are covered by extensive rhyolite flows, which cover the mountain-mass at the northern end of the Pinon liange north of Dixie's 
Pass. The highest point of this mountain-mass, however, shows outcrops of the characteristic quartzitic sandstone of the Weber group, which here seem to be considerably metamorphosed, having a rough trachytic feel, and containing some crystals of quartz and a good deal of decomposed feldspar. The surfaces of this quartzite show a great deal of slickenside-polishing, evidence of a faulting, which the geological structure of the range renders necessary. The rhyolite, which is the red porphyritic variety alrealy described as common through Nevada, forms flat, table-shaped ridges, which extend down to the banks of the Humboldt below Carlin, and to the eastwarl obscure the contact between the Weber Quartzites and the Upper CoalMeasure limestones.

Moleen Pear.-The mass of Moleen Peak is made up of nearly horizontal limestones, having a dip of about $5^{\circ}$ to $10^{\circ}$ to the southeast, underlaid by quartzites, which have apparently been faulted up into their present position. Where the cañon of the South Fork of the IIumbollt cuts through the Elko Range, it exposes about 1,800 feet of these limestones of a prevailing gray and light-blue hue, but with many beds toward the bottom of an earthy buff color, and near the top some prominent members of included quartzite. At the three different zones, representing about equal distances through the 1,800 feet, were found the following Coal-Measure fossils :

From bed No. 1 :

Productus subhorridus.

Productus symmetricus.

From bed No. 2 :

Productus subhorridus.

Athyris subtilita.

Spirifer cameratus.

Zaphrentis Stansburyi.

From bed No. 3 :

Productus subhorridus.

Productus semireticulatus.

Productus Prattenianus.

Productus symmetricus. 
Streptorhynchus crassus.

Orthis carbonaria.

Eumetria punctulifera.

This limestone series is conformably underlaid along the north base by a series of quartzites and quartzitic conglomerates, carrying quartz and jasper pebbles, from the size of a filbert to that of an egg, resembling those exposed in Moleen Cañon. Their bedding is broad and heavy, and the colors green, yellow, and purple; the general texture of the quartzite is very coarse, closely resembling that of the Weber group. East of the cañon of the South Fork, the same limestones continue for about 8 miles on their strike, showing a little Weber Quartzite on their north base near the cañon, and considerable development of quartzitic strata high up on the series along the southeast foot-hills.

To the east of the Elko Range, the whole broad valley of the South Fork is a plain of horizontally-bedded Humboldt Pliocene, through which the narrow stream-beds are eroded. It is very difficult to get at the character of the beds, the best exposures being along the branches of the South Fork, where a couple of hundred feet of fine, siliceous, marly beds with occasional clay-seams occur. At the angle formed by Dixie Creek with the South Fork of the Humboldt, just southeast of Moleen Peak, there crops through the Tertiary plain a northeast ridge, or rather a low table of Carboniferous limestone of a prevailing light-blue color, banded with yellow and buff beds, like the neighboring limestones of Moleen Peak. This isolated outcrop is very much broken up, but possesses a general dip to the eastward, and is, without doubt, a fragment dislocated from the Moleen Peak mass.

Opposite the town of Elko, the limestones break off suddenly, and a low depression in the Elko Range is filled with beds of the Humboldt Pliocene, which, on the eastern side, have been eroded away, exposing upturned strata of the Green River Eocene, the northwestern foot-hills flanking the pass on either side being made up of flows of red porphyritic rhyolite. The beds of the Green River Eocene as exposed here have a strike due north, and dip $35^{\circ}$ to the eastward. They resemble closely those 
exposed at the coal-mines in the northern end of the ralley, consisting mostly of very thin shales, sometimes calcareous, sometimcs made up entirely of quite siliceous material, often bituminous, and in some cases containing several thin seams of brown coal. The Pliocene beds which overlie them non-conformably consist at the summit of the pass of white volcanic ash, very porous, and containing a good deal of fine black mica and hornblende.

The northern end of the Elko Range is, as we have seen, made up of red, porphyritic rhyolites, which extend continuously to Upriver Peak. These rhyolite flows seem to be generally rather thin, but, with the exception of points already mentioned at Osino Canon and south of the Elko Pass, no underlying sedimentary rocks were found exposed in the range. Along the western flanks of these rhyolite ridges are numerous hot springs, the most remarkable of which is that two miles south of the town of Elko, where a public bath has been established. Owing to the peculiar taste of its waters, this spring has been designated the "Chicken Soup Spring".

SeEtoya Mountarss. - The country represented on the northwest corner of the map, west of the River Range, is a region which has been the scene of great volcanic activity in later Tertiary times, and in which the older formations are generally concealed beneath extensive flows of rhyolite, which now cover the greater part of the surface of the country. It is intersected by broad valleys, whose waters run alternately to the south into the Humboldt River or northward into the Snake, which have generally been filled by Pliocene beds, composed largely of fine re-arranged volcanic material. The depression occupied by the valley of Susan Creek and the north and south tributaries of the North Fork of the Humboldt presents a type of one of these Pliocene Valleys. The streams run in broad Quaternary bottoms of fine mud and silt, resulting from the decomposition of the soft Tertiaries, and support considerable growth of native grass, while on either side are mesa-like benches of Tertiary strata, which extend up on to the flanks of the bounding ranges to a height of 600 to 900 feet above the valley-bottom, covered with a light gravelly soil, which only supports a scattered growth of sage-brush.

The southern portion of the Seetoya Range represents an uplift of sedi- 
mentary rocks around a core of granite and granite-porphyry, which in Tertiary times has been deluged by flows of rhyolite to such an extent that but little can be seen at present of the original structure of the range. Nannie's Peak, which is the central and most elevated point of this range, is a sharp, crescent-shaped ridge of granite, wrapped around by steeplydipping beds of the Wahsatch limestone, which are intersected and covered by flows of rhyolite. The granite, though distinctly an eruptive rock, has remarkably regular cleavage or bedding-planes developed in the strike of the ridge, whose summit is formed of projecting beds from 50 to 100 feet thick, dipping at an angle of $80^{\circ}$ to the westward, in conformity with the overlying limestones on the western flanks. It also shows a tendency to split up into narrow bands from one to three inches in thickness, which have a general conformity with this larger system of bedding.

The granite is a gray, coarsely crystalline rock, made up of quartz, plagioclase, and orthoclase, and large crystals of mica, but containing no hornblende. The orthoclase feldspar predominates over the plagioclase, and is generally decomposed and opaque, showing a zonal structure, while the latter remarkably is fresh and well preserved. Under the microscope, the quartz is seen to contain numerous fluid-inclusions, with well-defined salt cubes and sometimes grains of apatite. A tendency is observed, in the fine-grained aggregations of small quartz and feldspar crystals, to form a groundmass. Its chemical composition, as determined by Prof. Thomas M. Drown, is :

Silica............................ 70.77

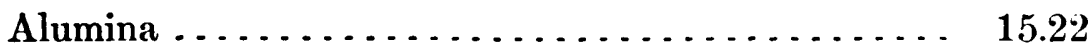

Ferrous oxide.......................... 2.65

Manganous oxide....................... 0.11

Lime ................................. $\quad 2.33$

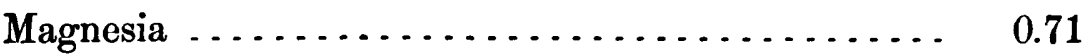

Soda ................................ $\quad 3.75$

Potassa ............................. $\quad 4.58$

Ignition $\ldots \ldots \ldots \ldots \ldots \ldots \ldots \ldots \ldots \ldots \ldots . .6 .52$ 
In some places, where the granite splits into thin slabs only about an inch thick, a little microscopical hornblende is found, and the plagioclase seems to predominate over the orthoclase.

On the southwestern point of the peak, at the contact with the overlying limestones, is a small development of felsitic porphyry, enclosing a vein of red oxide of copper. It has a fine-grained grayish groundmass, enclosing crystals of feldspar and large proportion of hexagonal plates of black mica and crystals of quartz. Under the microscope, the larger quartz crystals are seen to contain only liquid-inclusions, in some of which are cubes of salt. In the groundmass, which is generally micro-crystalline, there is a tendency toward a sphærulitic formation, which is particularly observable around some of the small quartz crystals, which are surrounded by radiating felsitic fibres.

On the western flanks of the peak, which are very steep, but well covered by detrital material, the limestones have a north and south strike, with a dip of $70^{\circ}$ to $80^{\circ}$ to the westward. Through them runs a curious dike or bed of rhyolite, which, on its weathered surface, at first glance has considerable resemblance to a felsite-porphyry. It is generally of a yellowish-gray color, showing large crystals of mica, hornblende, and quartz porphyritically imbedded in a dull, opaque, felsitic groundmass, whose fracture is very uneven and granitoid. In some cases, the groundmass has a greenish color, and is quite glassy, passing into a pearlite, and shows crystals of glassy sanidin. Under the microscope, the groundmass is seen to be distinctly sphærulitic, but without axial fibration.

The limestones seem to close completely around the granite body, and are best seen in section on Coal Creek, where they have an east and west strike, with a dip of about $45^{\circ}$ to the southward. A thickness of about 2,000 feet of limestones is here observed, the upper member of which is a conglomerate, which may probably represent the lower bed of the Weber Quartzite. In the cañon of Coal Creek, about a mile from its mouth, is a considerable development of black shales, in which in the creek bottom was found an exposure of about 15 feet of black anthracitic material, 
forming in places an impure anthracite coal. The section exposed is as follows :

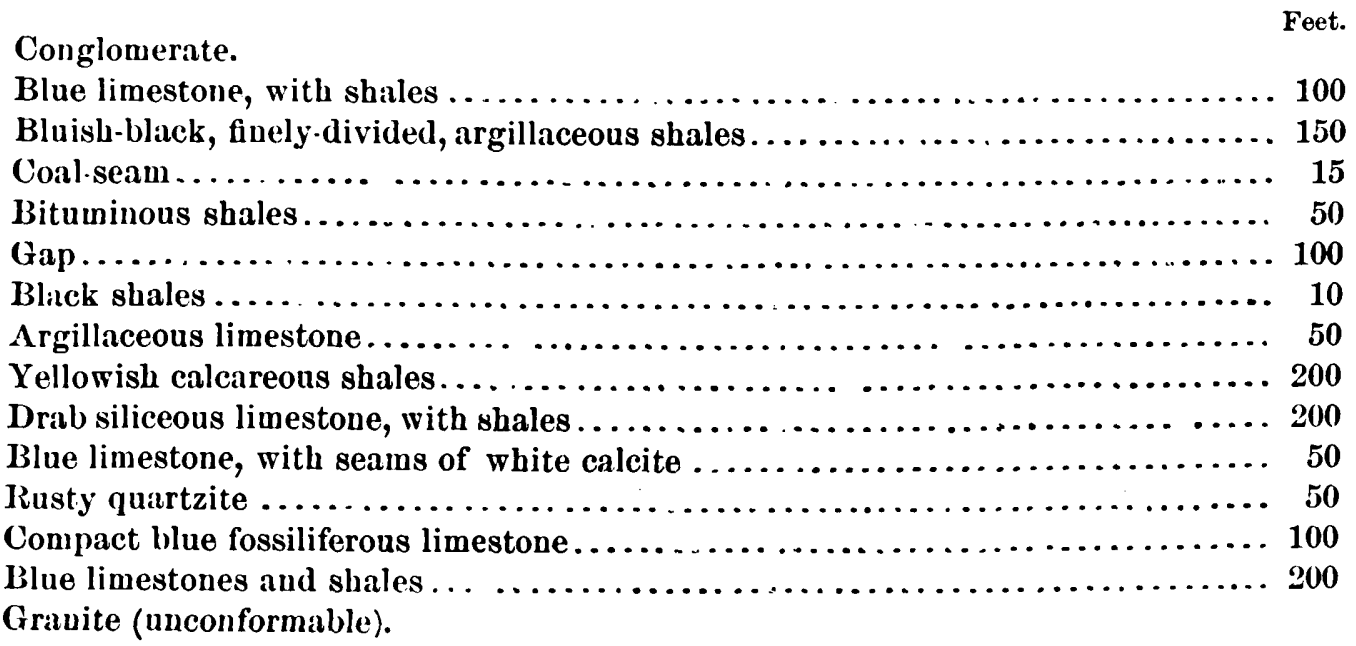

From the lower fossiliferous beds were obtained the following CoalMeasure fossils :

\section{Productus semircticulatus. \\ Syringopora multattenuata. \\ Cyathophylloid fragments.}

In these easterly-striking limestones, the same curious bed of rhyolite was observed as on the western slope. On the spur to the south of the mouth of Coal Creek is a body of gray trachyte, stained with streaks of iron oxide, which overlies a porphyritic decomposed rock resembling a rhyolite, but whose position would suggest that it may be an intercalated porphyry of Carboniferous age. If this be so, the interbedded rhyolites which encircle Nannie's Peak should have the same origin.

The trachyte is made up of sanidin and plagioclase-feldspar, with some little biotite, in a gray, somewhat porous, felsitic groundmass. Under the microscope, the groundmass is seen to be nearly colorless, and to contain feldspathic microlites, with very little ferrite, and also some little titanite. The porphyry or rhyolite has the same constituents as the trachyte, with addition of free quartz; but its groundmass has a peculiar half-glassy sphærulitic texture, as distinguished from the granular semi-crystalline texture of that of the trachyte. 
Maggie's Peak is made up of a granite similar to that of Nannic's Peak, but having a still more porphyritic texture. It has the same tendency to weather into thin slabs as that of Nannie's Peak. It is a gray, rather fine-grained rock composed of mica and hornblende, and relatively little quartz, with both monoclinic and triclinic feldspars. This rock has been classed by Zirkel as granite-porphyry. It is associated with a well-defined felsite porphyry, which closely resembles a rhyolite in physical habit, having the same tendency to separate into thin slabs, but carried to a much greater extent than in the granite. In a white homogeneous groundmass, it shows few crystals besides those of quartz, but under the microscope its groundmass is seen to be entirely crystalline, and the quartz to abound in fluid-inclusions, sufficient guarantees of its earlier origin. The rhyolites adjoining this porphyry, from which in the field it can be with difficulty distinguished, are whitish and red compact rocks, containing likewise only crystals of quartz. The exposed surfaces present beautiful botryoidal secretions of hyalite and opaline chalcedony.

At the extreme southwestern point of the range is a body of gray siliceous limestone, forming an outlying ridge, through which Magrie Creek has cut a narrow cañon. As far as observed, it was entirely barren of fossils, and, on account of its isolated position, no evidence was obtained as to its geological horizon. It has, however, been assigned, on general grounds, to the Lower Coal-Measure group.

The valley of Maggie Creek, like that of Susan Creek, is covered by white Pliocene beds. At the head of the valley, the low divide between it and that of the North Fork of the Humboldt is occupied by various flows of rhyolites, some white earthy varieties and some dark obsidian-like pearlites containing white feldspar crystals. To the north of this divide, the range is continued by a higher ridge, en échelon with the Nannie's Peak Ridge, which forms the eastern boundary of Independence Valley, and stretches northward beyond the limits of the map in a high important mountain mass.

This portion of the Seetoya Mountains is made up of heavy bodies of quartzite, which have been considered to represent the Weber Quartzite in this region, inasmuch as they are both underlaid and overlaid by limestones. The structure of the ridge is that of an anticlinal fold, whose axis 
is a north and south line running along the western flanks of the ridge. A vertical displacement along this line has exposed, on the western spurs, heavy beds of limestone in a thickness of 4,000 to 5,000 feet, which are much contorted. At the northern end of the limestone body, the beds form the complete arch of a sharp anticlinal fold, which descends or "noses under" to the north. In the middle of the exposure, the western member has been broken down, the eastern member of the fold forming steev, rugged spurs under the highest point of the range, in which the limestone beds dip at first about $20^{\circ}$ to the eastward, and gradually steepen to a perpendicular and even to a slightly western dip. At the southern point of the limestone exposure, in a little cañon just north of Seetoya Peak, the displacement is a simple faulting of about 100 to 150 feet, which can be very distinctly traced, where, in the upper portion of the limestone formation, a thickness of about 150 feet of dark limestone is bounded below by a body of black shales, and above by a blue quartzite, which can be traced on two adjoining spurs, both dipping about $20^{\circ}$ to the westward. Although palæontological evidence is wanting, there is little doubt that these limestones belong to the Lower Coal-Measure group.

The quartzites, which form the main crest of the ridge, consist mainly of white and blue saccharoidal quartzites, containing a few thin beds of interstratified limestones. Their average dip is about $25^{\circ}$ eastward, curving in strike from a little east of north at the southern portion to a little west of north toward the northern limits of the map. They abound in slickenside-surfaces, showing remarkably beautiful striation and polish. Along the eastern flanks of the ridge, overlying the quartzites, a few outcrops of limestone can be distinguished under the flows of rhyolite, which would represent the Upper Coal-Measure group. The lower portion of the quartzite body, as it approaches the limestones, has a large proportion of limy strata and beds of calcareous shales, interstratified in the quartzites. On the western slopes of Seetoya Peak is a quartzitic conglomerate, which apparently forms a portion of the western fold, though; owing to the displacement and faulting, it was not possible to fix definitely its horizon.

In a little cañon to the southwest of Seetoya Peak, the line of displacement is occupied by a dike of diorite or diabase cutting through the 
limestones, which are here exposed by the erosion of the ravine. The diorite is a fine-grained, dark-green variety, in which but few macroscopical crystals can be distinguished. It is made up mostly of plagioclase, mica, calcite, and a dark-green product of alteration, which Professor Zirkel thinks should be referred rather to augite than to homblende, which would place the rock among the diabases, although, from a macroscopical examination, it has been colored as a diorite. The line of the upper geological section at the bottom of the map cuts the range at Taylor's Creek, showing this dike, and the fault on the western slopes. To the southwest of Taylor's Creek, the low ridge which divides Independence Valley from Maggie Creek Valley is mostly occupied by flows of rhyolite, generally of white and red porphyritic varieties, which, as shown by the few outcrops and quartzite débris found in the ravines, have covered a pre-existing ridge of Weber Quartzite.

Northern Cortez Ranae. - That portion of the Cortez Range which bounds Maggie Creek on the west, and is connected by this ridge with the Seetoya Mountains, for the most part has not been covered by the rhyolite flows which have deluged this region. These hills are, however, remarkably thickly covered by detrital material, and show very few outcrops. From the not always reliable inferences to be drawn from fragments found in the ravines, the hills are mainly composed of quartzites, generally white, compact, and somewhat iron-stained varieties. At the Dalton Peaks are found almost the only good exposures of the sedimentary rocks, which make up the range. Here the eastern peak shows quartzites and siliceous shales, through which runs a black cherty vein, striking due north, and dipping $25^{\circ}$ to the eastward, while on the western peak are the peculiar greenish quartzitic conglomerates characteristic of the Weber Quartzite. These quartzites are very heavily bedded, and stand at a very steep angle, apparently with a slight dip to the westward. The structure here, then, as well as can be arrived at, is an anticlinal, whose western member is steeper, and has perhaps suffered displacement.

In the valley of Boulder Creek, to the west of Dalton Peaks, at White's Ranch, is a little isolated hill of limestone, overlaid by a greenishwhite quartzite, from which were obtained a collection of Lower Helder- 
berg fossils. The limestone is dark, fine-grained, and rather siliceous, thinly bedded, and interstratified with light-reddish siliceous shales, about onefourth inch in thickness, having some branching impressions like plant-roots. The beds from which the fossils were obtained are a series of thin-bedded limestones near the upper portion of the formation. The following species were determined by Messrs. IIall and Whitfield:

\author{
Atrypa reticularis. \\ Pentamerus galcatus. \\ Strophodonta, sp. (like S. punctulifera). \\ Orthis, sp. ? (allied to O. varica). \\ Trematospira. \\ Calospira (new sp.). \\ Rhynchonella, sp.? \\ Facosites, sp.? (allied to F. Helderbergi (). \\ Diphyphyllum (new sp.). \\ Campopliyllum, sp.?
}

$\Lambda$ thickness of 500 to 700 feet of limestones is here exposed. Their general dip is to the eastward, the beds lying nearly horizontal at the western face of the hill, and steepening in dip to the eastward. It would appear therefore as if this little body of limestone had been faulted up. The quartzites, which, from their stratigraphical position and general lithological character, have been considered to represent the Ogden Quartzite, are found along the eastern and southern flanks of the lill, conformably overlying the limestones. They also crop on the western side of Boulder Creek, at the foot of the bluffs formed by the flows of rhyolite and basalt of the Shoshone Mesa. The immediate foot-hills of the Cortez Range, in the neighborhood of Boulder Creek Valley, are covered by thick deposits of Quaternary gravel and soil, so that the structural relations of the outcrops of the Silurian with the Weber Quartzites of Dalton Peaks could not be definitely established.

From Dalton Peaks to Mount Neva, in the deeper ravines, are exposed frequent outcrops of quartzites having a general north and south strike, and the same lithological character with the Weber Quartzites of the Seetoya 39 D G 
Range, which, though too isolated and obscure to show clearly their lines of structure, give sufficient evidence that the Mount Neva mass is a preexisting elevation of Weber Quartzite, continuous with that of the Dalton Peaks Ridge.

Along the eastern flanks of this elevation, at Tuscarora, on the borders of Independence Valley, is a body of propylite, now largely covered by flows of rhyolite and Quaternary débris. Near the town of Tuscarora, the surface of this propylite is decomposed to a depth of 3 to 4 feet, and covered by as many feet of soil, which has been worked with considerable profit for placer gold. The propylite of Tuscarora has the characteristic physical habit of this rock, offering no prominent outcrops, and generally occupying a subordinate topographical position. It is a light greenish-gray, porphyritical rock, having something of an earthy texture, showing macroscopical crystals of opaque, somewhat decomposed orthoclase, and fresher plagioclase in a groundmass, which is characterized by a large admixture of light-green fibrous hornblende. There are also larger prismatic crystals of dark, fresh hornblende, usually characteristic of andesite, in the rock, but not in sufficient quantity to form an important element in its composition. 'The microscope detects in it no augite or biotite. The two varieties of hornblende, the green and the dark-brown, may be seen in Vol. VI, Plate IV, fig. 4, which presents a thin section of this propylite with its characteristic groundmass.

Another darker green, somewhat decomposed, variety, obtained from under the Quaternary accumulation of the slopes, has been classed by Zirkel,' from his microscopic examination, as an andesite, with the remark, however, that it contains a great quantity of hormblendes in an advanced stage of alteration into epidote, a rare occurrence with andesites. These hornblendes can be distinguished macroscopically in the feldspar crystals. The rock certainly has the physical habit and position of propylite rather than andesite.

A more well-defined andesite occurs on the foot-hills of the range, however, north of the town, where it has apparently poured out between the propylite and the underlying sedimentary rocks. It is a dark, com-

\footnotetext{
'Microscopical Petrography, rol. vi, 130.
} 
pact, heavy rock, having something of a columnar structure, of a dark reddish color on its weathered surfaces. Macroscopically, it shows only small plagioclase and black hornblende crystals in a dark-bluish, or sometimes greenish-gray, felsitic groundmass. Under the microscope, the hornblende has rather a greenish than the characteristic darkbrown color of andesite, and is somewhat fibrous. The groundmass is a yellowish-brown mass abounding in black trichites, containing some apatite, but neither augite, biotite, nor tridymite. These three rocks, which are so closely connected geologically, have, in their mineralogical composition, therefore, a similar interchange of characteristics.

The rhyolites which have covered these older volcunic rocks along the western borders of Indepiendence Valley are generally white, decomposed varieties, which are almost anorphous, the only traces of crystals being white outlines of kaolinized feldspar. By the aid of the microscope, they are seen to have soməwhat of a trachytic appearance, the groundmass showing no tendency to fibration or fluidal structure, and the presence of some altered hornblende and biotite, together with a good deal of quartz, is detected. On the extreme foot-hills of the range, about four miles north of Tuscarora, is a bed of dark rhyolite, in some respects almost like an andesite. It contains, however, almost exclusively sanidin feldspar in a dark, compact, felsitic groundmass, with mica in remarkably well-defined hexagonal prisms, and a little free quartz.

In the ravine a few miles south of Tuscarora, a body of augiteandesite is exposed under the rhyolite flows. It has a dark-gray groundmass, with somewhat of a resinous lustre, full of crystals of plagioclase and augite. The latter are remarkably well defined, while the plagioclases are seen to be full of fragments of yellowish glass. Under the microscope, the groundmass is seen to be made up of microlites in a glassy base of gray color, and to contain no olivine. The rhyolite adjoining this body of augiteandesite, and forming the foot-hills along the southern portion of Independence Valley, is a white porphyritic variety, containing a considerable development of mica, quartz, and sanidin in a somewhat decomposed felsitic groundmass.

The white amorphous rhyolites extend up on the eastern slopes of 
Mount Neva to its very summit, and evidently cover most of the northern slopes toward the Owyhee Valley, though these were not examined ly our parties. Doubtless, other outcrops of the older volcanic rocks mightit have been found by a more detailed search. Sufficient data were obtained, however, to show that this mountain mass consists mainly of a series of steeply upturned quartzites and slates, along whose eastern base there has been an outflow of propylite and andesite, the whole having been covered by thin flows of rhyolite, which have been sufficiently eroded in the deeper-cut ravines to expose the underlying sedimentary rocks.

In the deep ravine on the western face of Mount Neva, a considerable thickness of quartzites and dark siliceous argillites, with cherty seams dipping steeply to the westward, was observed. Their general character resembles that of the quartzite body of the Seetoya Mountains on the east side of Independence Valley, being that of rather saccharoidal rocks, of a bluishwhite color. One bed was noticeable for a wavy, vein-like, blue shading through the white mass, occasioned by accumulations of graphite in fine streaks through the rock. The lower end of the ravine is narrow and canonlike, its walls being formed of a dark-gray pearlitic rhyolite, liaving an unusually massive structure, and a tendency to columnar weathering. It is very rich in sanidin and mica, and contains also some plagioclase and a considerable amount of free quartz. The glassy groundmass is of a gray color, as seen under the microscope, and full of microlites in a great variety of forms, but contains neither hornblende nor augite.

Squaw Vathey Region.-The region to the west of the northern portion of the Cortez Range consists of a series of low rolling hills and east and west valleys, formed by flows of rhyolite and basalt, in which, with the exception of the isolated outcrop near White's Ranch, no sedimentary rocks were found. The valleys which occupy the lines of depression between these ridges are mostly filled with Quaternary débris, but in Squaw Valley and Rock Creek Valley there is a considerable development of stratified deposits composed largely of volcanic ash, which have been referred to the Humboldt Pliocene.

The more northern line of elevation, that of Owyhee Bluffs, presents a rather more abrupt face to the south and long gentle slopes to the north, 
and forms the divide between the waters of the Humboldt and those of the Owyhee River. The view to the northward from the summit of Rose Mountain, the most northern point visited by us, extends out over an almost limitless plain, whose horizon is as level as that of the ocean. The rhyolite which forms the summit of Rose Mountain shows the appropriateness of the name which has been given to this rock, signifying "thin flowing", since it is made up of sheets of lava only about an eighth of an inch in thickness. It is a red, compact, felsitic groundmass, containing only crystals of quartz, with an occasional development of sanidin-feldspar, the surface of each layer being colored by a red earthy coating, containing a few flattened crystals of feldspar.

$\Lambda$ considerable variety of rhyolites was found along the southern slopes of Rose Mountain. Among the most noticeable is a rhyolitic breccia, made up of pink and red angular fragments of earthy rhyolite, whose outline is generally rectangular, and which vary from half an inch to an inch or more in diameter. The banded structure of the rhyolite, from which these fragments are derived, gives to them the appearance of a structure like that of woody fibre, so that the rock has the appearance of a mosaic made of segments of wood. One variety of whitish, decomposed rhyolite is full of druse-like cavities, filled with prismatic crystals of quartz.

Along the lower foot-hills is a development of dark pearlitic rhyolite, not umlike that of Mount Neva, but less rich in crystals. Quartz and sanidin are its prominent crystalline ingredients, bnt the microscope discloses also some green angite. In this rock are found fragmentary inclusions of a darkgreen, rather finely crystalline diabase, which is remarkably rich in olivine, and shows well-defined tabular crystals of plagioclase and pale-brown augite. Under the microscope, a little globulitic base is detected and some titanic iron.

At Sunset Gap, in the eastern end of Squaw Valley, is a similar black pearlitic rhyolite, interstratified in a white porphyritic rhyolite containing small crystals of black hornblende and nica, with sanidin and a little quartz, in a white, rather earthy groundmass. The dark pearlitic rock contains, besides the sanidin, some little plagioclase and little green augite, but no quartz, hornblende, or biotite. These rhyolites show a decided dip to the 
eastward, and form north and south ridges, cropping out through the horizontal beds, which form the mesa-like benches through the middle of Squaw Valley: these are made up largely of re-arranged volcanic material, but along the eastern end of the valley contain also a considerable admixture of sedimentary débris from Mount Neva.

In the western end of Squaw Valley is a broad expanse of bottomland, which, at the entrance to the cañon which Rock Creek cuts through the ridge south of Squaw Valley, is occupied by a shallow fresh-water lake. On the summit of the ridge south of Squaw Valley is found a grayish-red, banded rhyolite, in which the bands consist of alternately predominating portions of a reddish felsitic .groundmass, and of aggregations of crystals of sanidin and quartz. The rock contains neither hornblende nor mica. Under the microscope, the groundmass is seen to have a very sphærulitic structure and radial fibration, and to abound in ferritic microlites, to the predominance of which in the sphærulites the reddish bands owe their color. The peculiar radial arrangement of the ferritic microlites is shown in the thin section of this rock, represented in Vol. VI, Plate VIII, fig. 3.

The main body of this ridge is made up of the ordinary reddish porphyritic rhyolite already described, which contains only a few crystals of quartz and sanidin, porphyritically imbedded in a red felsitic paste of peculiarly uneven fracture. The microscope discloses neither quartz, hornblende, or mica. Through this ridge, Rock Creek has cut a narrow winding cañon for a distance of about 4 miles, but in Rock Creek Valley runs in a broad Quaternary bottom, eroded out of the horizontal Pliocene beds. To the south of this valley, the rhyolites are covered by thin flows of of basalt, which form the surface of the broad table-shaped ridges of the Shoshone Mesa.

The hills to the west of Rock Creek Valley near the Warm Springs are composed of a peculiar decomposed rhyolite of a light pearl-gray color, which is almost identical in appearance with that which forms the little conical hills rising out of the Shoshone Mesa near its southeastern edge. This rlyyolite contains a large amount of small, gray, glassy sanidin crystals, and large cracked quortz-grains, but is almost devoid of homblende and mica. It is remarkable for containing a large amount of tridymite. Near the 
Warm Springs is also a small isolated remnant of basalt, which forms the foot-hills of this rhyolite ridge.

Shosione Mesa.-The Shoshone Mesa is one of the most singular topographical features of the Fortieth Parallel region. From Rock Creek Valley, the country rises to the southward in broad and even slopes, keeping approximately the same angle for a distance of 15 or 20 miles, and forming an elevated platean, bounded on its southern edge by perpendicular cliffs over 2,000 feet in height, which reach their greatest elevation at its extreme southern end, known as Stony Point. This eleration forms the southern of the three northeast and southwest ridges, or undulations, of the surface, which have been covered by the volcanic flows of the northern region.

Along the base of the cliffs, the lower thousand feet are seen to be made up of rhyolites, generally of rather dark color, while the surface of the table is composed of flows of dark, compact basalt. These basaltic flows have evidently covered the pre-existing rhyolite ridge, and flowed around the higher hills, which now project above its surface. The rhyolite which forms the base of the cliffs on the southeast, toward Rock Creek, is a dark-purple, thinly-banded rock, containing large crystals of sanidin and rounded quartz-grains in a compact, felsitic groundmass, which, under the microscope, does not show any signs of fibration except around the larger crystals. It constains a little plagioclase and considerable apatite, and the quartz-crystals are full of glass-inclusions, but the groundmass, although showing microscopically the fluidal structure peculiar to rhyolites, has rather a micro-crystalline development, and contains no micro-felsitic matter.

Associated with these, at one of the re-entering angles of the cliffs, is a peculiar dark pearlitic rhyolite abounding in large lithophysæ an inch in diameter, which are generally hollow, and look like a clayey mass, formerly filled with gaseous matter, which has burst forth, leaving a hollow interior. The rock abounds in large crystals of sanidin and quartz enclosed in an almost black, pearlitic groundmass, which has become whitened in contact with the lithophysæ. The centres of some of the lithophysæ are still filled by crystals of quartz and feldspar. In some of the larger feldspars, grains 
of mica can be detected macroscopically. Under the microscope, both mica, brown hornblende, and small dark-green augite grains can be distinguished. The gray, half-glassy groundmass contains sphærulites as large as a walnut, which develop by decomposition a concentric-layer structure. The most advanced stage of this decomposition closely resembles the larger lithophysæ, which would seem to sustain the opinion of J. Roth, that these lithophysæe are nothing but mechanically and chemically altered larger sphærulites.

About a mile from the edge of the cliffs is a little group of projecting hills having a rude semicircular shape, suggesting the form of an ancient crater, which are composed of a light pearl-colored rlyolite similar to that found near the Warm Springs. Under the microscope, it is seen to be less distinctly crystalline than that which forms the base of the cliffs, and to contain a large amount of tridymite. It also contains long prismatic bodies, which are apparently altered biotite.

At the base of the cliffs, at Stony Point, is a rhyolite which resembles macroscopically the typical porphyritic rhyolite, already so often mentioned, though this has rather a brownish-red color. It contains only crystals of sanidin-feldspar, with some little plagioclase, in a compact felsitic groundmass. The monoclinic feldspars seem to be a good deal decomposed, and are somewhat stained with iron oxide. Dark particles, apparently of specular iron, can be distinguished macroscopically in the groundmass. Under the microscope, this rock, with the exception of the absence of quartz, resembles that found at the base of the cliffs further north. The groundmass is a micro-crystalline aggregation of colorless particles, with grains of black opacite and brownish ferrite.

The basalt which forms the summit of the plateau at Stony Point is a rather remarkable rock, having a ligltt-brown color, through which are mottlings of a light-green material. The rock is a remarkably fine-grained variety, though somewhat vesicular, in which, by the unaided eye, no crystalline ingredients, with the exception of a few isolated feldspars and occasional grains of quartz, can be distinguished. Under the microscope even, the constituents are so fine as to be somewhat confused and difficult to distinguish. It is rather poor in augite, and contains small reddish-brown 
grains of olivine, which can hardly be distinguished from the magnetite grains, which have also a reddish, decomposed surface. Between the crystals, particularly those of plagioclase, is an amorphous base of the usual basaltic character. The quartz-grains are not seen under the microscope, and are quite an accidental occurrence, probably caught up by the basalt from the surrounding rhyolite.

The main rock of the mesa is a normal dolerite, very porous, often containing vesicules as large as a filbert, which are partially filled by carbonate of lime. It is a dark, rather coarse-grained rock, in which plagioclase, augite, and olivine can be distinguished by the naked eye, and, by the aid of the microscope, also magnetite and some apatite, with a little amorphous - base. Chemical analysis detects the presence of titanic acid, so that some titanic iron is probably associated with the magnetite. The analysis was made by Mr. R. W. Woodward, and gives the following constituents:

\begin{tabular}{|c|c|c|}
\hline Silica .... & 48.40 & 48.38 \\
\hline Alumina ........ & 17.95 & 18.95 \\
\hline Ferric oxide.... & 2.28 & 2.12 \\
\hline Ferrous oxide ... & 8.85 & 8.90 \\
\hline Manganous oxide . & trace & trace \\
\hline Lime....... & 10.05 & 10.32 \\
\hline Magnesia ........ & 6.99 & 7.02 \\
\hline Lithia .......... & trace & trace \\
\hline Soda.......... & 2.86 & 2.73 \\
\hline Potassa . . . . . . . . . . & 1.03 & 1.03 \\
\hline Titanic acid $\ldots \ldots \ldots \ldots \ldots \ldots \ldots \ldots \ldots$ & 0.24 & 0.24 \\
\hline Carbonic acid $\ldots \ldots \ldots \ldots \ldots \ldots \ldots \ldots$ & 0.84 & \\
\hline \multirow[t]{2}{*}{ Water $\ldots \ldots \ldots \ldots \ldots \ldots \ldots \ldots \ldots$} & 0.34 & 1.09 \\
\hline & & \\
\hline
\end{tabular}




\section{SECTION VIII. \\ SHOSHONE RANGE AND CARICO PEAK.}

BY ARNOLD HAGUE.

Shoshone Ravar.-The Shoshone Range rises from the valley of the Humboldt River in latitude $40^{\circ} 40^{\prime}$, and extends in a southeast direction until it passes south of the southern limit of Map V. Its general course is about north $25^{\circ}$ east or south $25^{\circ}$ west. Only about 40 miles of the northern portion of the range come within the limits of Map IV, embraced in the present chapter. Directly south of the railroad, at the northernmost extremity of the range, there occurs a large field of basalt, separated from the great Shoshone Mesa by the Humboldt Valley, which is here about 6 miles in width. This basalt flow extends south for about 16 miles, and consists of two gently-inclined tables, having a dip to the southeast, and separated from each other by a northeast and southwest valley, called Whirlwind Valley. These fields of basalt consist in general of fine-grained dolerite, made up of plagioclase, augite, olivine, and magnetite, with more or less of a gray globulitic base. Through these doleritic tables break out a great number of vertical dikes of fine-grained anamesitic basalt, containing a high proportion of brown glass, giving a very resinous lustre to the fresh fracture. In the gray dolerites, upon weathering, there is a noticeable tendency to the development of spherical forms. The ground is in some places strewn with basaltic balls a foot or more in diameter, with concentric shells weathering and peeling off under atmospheric agencies. On the face of the Whirlwind cliffs, overlooking the Reese River plains, these spherical forms are readily seen in the bluffs. There is also noticeable a rude columnar structure, which dies off into irregular jointing. These concentric balls seem to have something to do with the columnar forms, and they may possibly represent the remains of horizontal sections of the rude columns. The basalt here is covered with more or less hyaline incrustations, which 
are in some places a mere thin glaze, and in others a heavy coating nearly a quarter of an inch thick.

Along the west and north margins of this field of basalt, there outcrops a line of quartzites and quartzitic shales, which form for 15 miles the foothills and base of the mountains. Their prevailing strike is a little west of true north, with a dip of about $35^{\circ}$ to the east. They are mainly finelylaminated schists, which here and there in the lower horizons and at the base of the quartzitic series, apparently pass into blue quartzitic bands, with a little impure limestone. This quartzitic mass has great thickness, and, from the fact that, as developed to the southward, it is both underlaid and overlaid by limestone, has been referred to the Weber period. Further corroboration of this is the occurrence of a bed of impure anthracite in the lower siliceous zone, not far from Argenta, supposed to represent a horizon near the junction of the Weber Quartzite with the Lower Coal-Measure limestone.

The north and south belt of upturned quartzites, lying along the west side of the Whirlwind basalts, is about 2 miles wide. Continuing its strike to the south, the quartzites are seen to wrap around the east side of a mass of granite, which rises above the quartzite in a high plateau, crowned by several prominent hills. West of this granite, the quartzites for several miles are much broken, but appear to have a general dip to the west for about 4 miles west of the granite, when they curve into an east dip again, making a low, obscure synclinal. That part of the range covered by the Whirlwind basalts is lower and less prominent than the mass immediately to the southwest, from which it is nearly separated by a deep bay of Quaternary accumulations.

South of this narrow neck, the range has its broadest expansion, reaching about 16 miles in a direction transverse to its trend. For about 20 miles in the direction of the trend, the range is occupied by the quartzites already mentioned. They are covered along the east foot-hills by an overlying belt of rhyolite from 2 to 5 miles in width; and, west of Carico Lake, the entire range is overwhelmed by rhyolite. The granite mass, already mentioned, offers a good example of conoidal structure, on so large a scale that the rude layers might almost be mistaken for a sedimentary 
bedding. Lithologically the granite is composed of quartz, both monoclinic and triclinic feldspars in almost equal proportion, magnesian mica, a great deal of hornblende, and a little apatite. Under the microscope, the orthoclase is seen to contain fluid-inclusions. This rock seems alnost to occupy an intermediate position between normal granites and diorites, which contain quartz, hornblende, triclinic feldspars, and, exceptionally, monoclinic forms. It is very similar to the granite from the region of Ravenswood Peak, and only differs from it by carrying a less proportion of mica and hornblende.

Shoshone Peak, which here forms the culminating point of this portion of the range, is an immense outburst of gray and green dacite. It is the grandest and most elevated body of dacite to be found within the limits of the Fortieth Parallel Survey. Lithologically it is an interesting rock, from the large size of its included quartz-grains, which are present in the form of irregular globes, sometimes exceeding an eighth of an inch in diameter, and sometimes as rude dihexahedral crystals. Under the microscope, they show numerous inclusions of nearly colorless glass with a dark bubble. The quartz also contains hornblende-microlites, a rare phenomenon in dacites. The hornblende occurs as distinct green crystals, and as a fine earthy green element, intimately mixed with plagioclase to form the groundmass. Much of the dacite consists of a well-individualized groundmass, with large, partially decomposed plagioclase-feldspars, and pellucid grains of quartz, and small angular fragments of a finer-grained, less quartzitic dacite. There are passages where these included fragments become so numerous as to give to it strictly the character of a breccia, and again there are considerable regions where, in hand-specimens, there will be only one or two included fragments. They are always sharply angular and always of dacite, as is proved under the microscope by the presence of hornblende in glass cavities of the quartz. The dacite contains well-defined vertical jointing planes, and, in some instances, betrays a rude columnar structure. Crowning as it does a group of considerable elevation, Shoshone Peak has acted as a condenser of the snows of the Glacial period, and there is ample evidence of the presence of actual glaciers, both in amphithentre-structure and in actual glacial débris, as well as the striated surfaces at the base 
of the peak. That these glaciers were exceedingly short is proved by the character of the cañons a mile from the base of the peak, where, instead of the round ship-bottom curve, they are very sharp and V-shaped, and evidently the result of stream erosion.

The dacite from Shoshone Peak has been analyzed by Mr. R. W. Woodward, who reports the following composition for the rock:

\begin{tabular}{|c|c|c|}
\hline Silica .... & 70.17 & 70.25 \\
\hline Alumina $\ldots \ldots \ldots \ldots \ldots \ldots \ldots$ & 14.53 & 14.90 \\
\hline Ferrous oxide....... & 4.03 & 4.08 \\
\hline 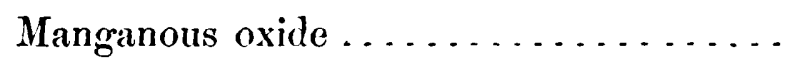 & trace & trace \\
\hline Lime....................... & 2.29 & 2.39 \\
\hline Magnesia ........... & 0.93 & 0.83 \\
\hline Soda . . . . . . . & 3.25 & 3.24 \\
\hline Potassa........ & 3.35 & 3.32 \\
\hline Lithia.$\ldots \ldots \ldots \ldots \ldots \ldots$ & trace & trace \\
\hline \multirow{2}{*}{ Loss by ignition $\ldots \ldots \ldots \ldots \ldots \ldots \ldots$} & 1.53 & 1.51 \\
\hline & $100.0 \mathrm{~s}$ & \\
\hline
\end{tabular}

Specific gravity, 2.54, 2.65 .

In this rock, the percentage of silica comes within the limits of that found in rhyolites, and but little lower than the amount usually obtained in rhyolites of Central Nevada. It is of special interest to note that the amount of potassa slightly exceeds the soda, as it does in other dacites from Nevada, as well as in many from European localities. ${ }^{1}$ The percentage of lime, which is also low, is, however, higher than in the dacites analyzed from the Washoe region.

A little northeast from Shoshone Peak, in the bottom of a deep cañon, is a small inconspicuous outcrop of diorite. This diorite bears some slight resemblance to the later dacite, especially in the occurrence of the numerous large grains of pellucid quartz. The groundmass, however, is distinctly crystalline, with a compact texture, which acts under the hammer like the older rocks. Triclinic forms of feldspar predominate, associated with some especially brilliant crthoclase crystals. In the groundmass are some minute

1 Microscopical Petrograpby, vol. vi, 136. 
forms of hornblende and mica. In addition to the above, the microscope reveals the presence of titanite and apatite. These three rocks, the granite, diorite, and dacite, form actual outcrops through the quartzite. The granite is evidently earlier than the quartzite, since the beds rest their upturned edges against the granitic flanks, while the diorite and dacite have broken through the quartzites subsequently to their upheaval.

In general, the quartzites have a southerly and easterly dip, chicfly easterly; but between the granite and dacite there is what appears to be a local and limited fold, producing a westerly dip. In general, the entire mass may be considered as one member, having an easterly dip. The uppermost layers of the quartzite are very compact and dark, and bedded in thin sheets, passing into fine, fissile, and argillaceous slates, both of which pass upward through a gradual transition into beds of fine argillaceous limestone. Diligent search was made in these latter beds for fossils, but to no purpose. There occur curiously flattened lenticular concretions, which may possibly represent some remains of animal life, but no distinct forms could be recognized. These limestones are very slightly developed, nowhere exceeding two hundred feet in thickness. They have been supposed to represent the lower members of the Upper Coal-Measure limestone. They are best developed on the heights south of Shoshone Peak at the head of Trout Cañon. Passing down Trout Cañon, an immense thickness of quartzites is seen, all conformable and dipping to the east, and varying from thick heavy gray beds to thin black fine-grained flinty quartzites, having a peculiar sulphur-yellow stain. There is a strong tendency in these fine beds to shrink up, leaving irregular open cracks along the planes of deposition.

Upon the outcrops of the siliceous schists on the ridges south of Shoshone Peak, wherever the rock-masses are prominently exposed to the air and sun, they become coated with a film of black metallic oxides, iron and manganese, but chiefly iron, which is as brilliant as a graphitic polish. It closely resembles certain basalts observed in Arizona. It was especially noticeable that the polish was less on the north side of the outcrops than on the south. This may be due in part to the abrading force of the snow and ice particles driven by the north winds of winter. Otherwise it would seem that the effect was purely a solar one, and it is difficult to understand 
the transportation of metallic oxides through the rock simply by attraction of heat.

The rhyolite, which scores the east base of the range, in the region of Shoshone Peak and to the southward, possesses a characteristic rhyolitic groundmass, with well-developed crystals of quartz and feldspar. In color, it exhibits various shades of lilac, light brown, and purple. The rock is full of seams, which give evidence of later solfataric action, and are stained with a slight deposition of sulphur and sulphate of lime. The quartz-grains in some localities are surrounded by a coating of maroon-colored ferruginous and siliceous material, which gives to the broken fragments of quartz the color of currant-jelly. In other localities, this coating is nearly black in color. In places, the groundmass has a peculiar crushed sugary appearance, and the small interstices are filled with a clear siliceous binding material, probably chalcedonic in nature.

In the large cañon which leads up into the range from about 4 miles north of Carico Lake are obscure outcrops, which appear over quite a wide area of country, of earthy-white and cream-colored rhyolite, which is composed of a homogeneous felsitic mass, containing no crystals, and revealing under the microscope scarcely any quartz or biotite. From the extreme fineness of the material and its earthy character, it would seem to be a tufa, and was probably ejected under a fresh-water lake, which formerly filled Crescent and Carico Valleys. Nowhere else along the belt of the Fortieth Parallel Survey has a tufa exactly similar been observed. It bears a close resemblance to some of the sandy beds of the Truckee Miocene, which are rich in infusorix, but under the microscope, with crossed nicols, it is clearly seen to possess a crystalline groundmass. Some of the rhyolitic tufas of the Truckee Miocene are of mixed origin, being composed partly of ejected trachytic material and partly of lacustrine sands, and it is not improbable that this Shoshone rhyolite also carries some fine detrital matter. It is characteristic of some of the finest-grained rhyolitic tufas that they show no planes of stratification, and indeed this is usually the case in the absence of much mica and hornblende. Where the tufas are chiefly felsitic, under certain circumstances of deposition they reach a considerable thickness, often not less than 50 or 80 feet, without showing any 
traces of bedding; and it is possible that they are actual ejections of fine mud. The white rhyolite tufas of this portion of the range are so nearly on a common level, that one is inclined to refer them to lake origin. It is not often that two types of rhyolites so distinct in habit as these two varieties can be observed so easily in the same locality.

The coarse porphyritic rhyolites which border the Shoshone liange extend eastward across the valley, and skirt the base of Carico and Railroad Peaks. In this way, rhyolitic formations completely encircle the northern end of Carico Valley and the southwestern end of Crescent Valley. Indeed, the two valleys are only separated by rhyolitic flows, which before the eruption formed evidently one long northeast and southwest depression. They are now connected by Rocky Pass, a narrow gap in the rhyolite, through which in wet seasons the drainage runs from Carico Lake into Crescent Yalley and thence northward into the Humboldt River.

Of the lithological character of the rhyolites bordering Carico and Railroad Peaks, little need be said, since they bear so close a resemblance to those already described, carrying in the same rough crumbling groundmass, broken crystals of sanidin and large grains of quartz. North of Railroad Peak, the rhyolites attain a considerable elevation, reaching an altitude of 1,500 to 2,000 feet above the valley, which in their mode of occurrence present more the outlines of rugged granite forms than is usually seen in rhyolitic masses. Here they form numerous sharp cones and pinnacles, with precipitous sides, and but little decomposed eartlıy débris.

Carico and Railroad Peaks. - These somewhat isolated peaks belong geologically to the same uplift and the same formation, attaining elevations between 8,000 and $\$, 500$ feet above sea-level. They appear in all respects quite similar, even in topographical details and modes of weathering. They form a broad mass, obout 14 miles in width, of nearly pure white quartzite, in places having a faint tinge of blue and in others a light brown. It possesses a dull vitreous lustre, a saccharoidal texture, and conchoidal fracture. The quartz-grains are visible to the unaided eye, and appear more or less rounded and with scarcely any base. Under the microscope, the quartzgrains reveal numerous liquid-inclusions with mobile bubbles. A specimen 
of pure white quartzite taken from near the summit of Carico Peak shows that it is made up largely of silica. It yielded:

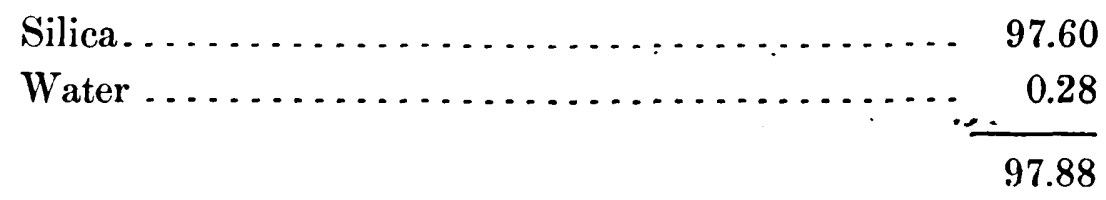

The other ingredients were alumina and iron. As to the geological horizon of these quartzites but little definite evidence was obtained, as they are either surrounded by volcanic material or Quaternary deposits; with no exposure of either an overlying or underlying limestone. It seems highly probable, however, that they belong to the same great series of quartzites that characterize the Shoshone and Toyabe Ranges, and have been referred to the Weber Quartzite.

$40 \mathrm{D}$ G 



\section{CHAPTER V.}

\section{NE V A D A B A S I N}

Section I.-REGION EAST OF REESE RIVER-Toyabe RANGE-SHoshone RANGE.

Section II.-FROM REESE RIVER TO OSOBB VALLEY-Sovthern Shoshone Range-Desatoya Mountains-Augusta Mountains.

Section I'I.-FISH CREEK AND BATTLE MOUNTAINS-Fish Creek Mountains-Battle Mountains.

Section IV.-HAVALLAH AND PaH.UTE RANGES-Havallah RaNGe-PaHUTE RANGE.

SECTION V.-WEST HUMBOLDT REGION-WEST HUMBOLdT RANGE-HILLS NORTH OF HUMbOLDT RIVER-HUMBOLdT VALLET-Carson DESERT.

Section VI.-MONTEZUMA RANGE AND KAWSOH MOUNTAINS-MontezUMa RaNGE-Kawsoh MoUntains.

SECTION VII.-REGION OF THE MUD LAKES-PaH-TSON MoUntains-KaMma Mountains-Black Rock Mountains-Granite Range.

SECTION VIII.-WINNEMUCCA LAKE REGION-PAH-SUPP MOUNTAINS-SAHwave Mountains-Truckee Range-Lake Range.

Section IX.-TRUCKEE RIVER REgion-Lower Truckee Valley-Virginta Range-Peavine Mountain region.

\section{SECTION I. \\ REGION EAST OF REESE RIVER.}

BY ARNOLD HAGUE.

Toyabe Range.-The main portion of the Toyabe Range lies to the southward of latitude $39^{\circ} 30^{\prime}$, beyond the limit of Map V. As the range has been one of considerable economic interest from the large number of 
mining developments centred there, a geological description of the most characteristic portion, extending from the town of Austin southward for 60 miles, was prepared, accompanied by a geological map, for "Mining Industry".

From Austin northward, the range extends about 25 miles, with a trend nearly north and south true. In the extreme southeastern corner of the map are found the northern outlying portions of the granitic bodies, which play so important a part in the structure of the range to the south. North of the granitic bodies, the range is made up of quartzites, slates, and limestones, which have been referred to the Carboniferous age, represented by the Weber Quartzites, and the overlying Upper Coal-Measure series, while flanking the Palæozoic formations on the east side are broad accumulations of rhyolite, through which, in the deep cañons and open basins, may be recognized the soft, friable beds of the uplifted Truckee Miocene.

The following description of the Austin body of granite is taken from the "Geology of the Toyabe Range":' "The $\Lambda$ ustin body of granite, which is particularly interesting as being the principal ore-bearing body of the range, forms the core of the main ridge of the Toyabe, which is here comparatively low for 5 miles south of Telegraph Pass. It is exposed mainly on the western slope of this ridge, where it is worn into the rounded spurs and open, shallow ravines, characteristic of an easily decomposed granite. This is a normal granite, consisting of quartz, feldspar, and mica; the feldspars of two varieties, a semi-translucent orthoclase, and an opaque, white variety, probably oligoclase; the mica, a dark magnesian variety; lornblende is found as an accessory ingredient, sometimes concentrated in bands or bunches. It forms the southern foot-hills of Telegraph Peak, underlying the metamorphic rocks, which are dark-blue siliceous limestone shales, dipping to the north and east at a low angle. At Telegraph Pass, it is exposed on the eastern slope of the ridge, where it is traversed by a dike, about 15 feet wide, of white granulitic rock, containing sparse crystals of mica, and black crystalline grains of tourmaline, concentrated in bunches throughout the mass. This dike has a northwest strike, which is in the direction of the principal veins of this neighborhood."

${ }^{1}$ Mining Industry, vol. iii, 328. 
In speaking of the granite body on the eastern side of the Park Basin, the same report says: "Directly east of Austin, forming the eastern watershed of the Park Basin, is a group of conical granite hills, having three principal peaks, rising about 1,800 feet above the neighboring valley, called the Park Mountains. Their entire mass appears to be of granite, which is in the main a compact, close-grained variety, in which the feldspars predominate; these are of two varieties, a fresh-colored orthoclase, and a greenish-white, probably oligoclase, besides which the granite contains quartz and magnesian mica, with some small green crystals, probably hornblende. $\Lambda$ narrow dike is observable on the slope toward Park Creek, having a northwest trend, corresponding to that on the east of Telegraph Pass. The rock of this dike is a white granulite, containing no mica, and the feldspar partially kaolinized."

The range, for the first 6 or 8 miles north of the granitic body,-forms a comparatively low and irregular mass of hills, which rise gradually toward the north, culminating in the Dome Mountain.

The Dome is one of the most singular mountains in Central Nevada. It derives its nane from the pecular outline of its summits, which form a broad, elevated mass, rising prominently above the surrounding country, with an elevation of over 11,000 feet above sea-level, while through the base it can hardly measure less than 10 miles in an east and west direction. It is characterized by long, easy slopes to the westward, which are so gentle that one can ride to the summit from almost any point. To the eastward, the slopes are much steeper, and in places almost precipitous. The cañons are deep, frequently opening out into broad basins or valleys, most of them being furnished with clear, running streams. Timber on the mountain slopes is both sparse and stunted.

Throughout the summer months, all the clouds in the region seem to gather over the Dome, apparently attracted there, not only by the elevation of the mountain, for there are others still higher, but by the immense mountain mass. While in this region abundant opportunity was offered for watching these clouds, which collected daily around the Dome, precipitating considerable quantities of moisture in the neighboring valleys, but leaving the country only a few miles distant in a dry and parched condi- 
tion. Driven by the southwest winds, the clouds would pass from the Dome across Cortez Valley to Mount Tenabo, and from there on to the high peaks of the Humboldt Range.

So far as examined, the Dome consists of nearly white quartzite beds. The rock is quite compact, with a slight arenaceous texture, has a vitreous lustre, and a brittle, splintery fracture. In places, it has more or less of a grayish tinge, and carries minute specks of oxide of iron, or ferruginous earth, scattered through it. In the hand-specimen, the rock cannot be distinguished from that of Carico and Railroad Peaks, the microscopical analysis failing to detect any points of difference. Liquid-inclusions in the quartz-grains are abundant, and easily recognized under the microscope.

The structure of this great quartzite body was not clearly ascertained, but it would seem most probable that it forms a broad anticlinal fold, with a low, gentle dip to the west, but inclined at a higher angle to the east.

Overlying the Dome quartzites, on the east side, occur a series of beds of siliceous and argillaceous slates, which pass up into compact gray limestones, considerably metaphorsed, and dipping to the eastward. It cannot be stated positively that the slate and limestone series overlie the quartzites conformably, although no apparent unconformity was observed; and inasmuch as in the same range to the southward nearly identical beds are seen resting conformably on massive beds of white and gray quartzites, it would seem more than probable that similar structural relations exist here in the region of the Dome. No fossils were found.

North of the Dome, the beds sink rapidly downward, and, with the exception of a long tongue of quartzite extending nearly to Carico Valley, the entire region, like so many others where the Palæozoic beds suffer a sudden depression, is deluged with vast accumulations of rhyolite. These rhyolites stretch westward to Reese River, rising in irregular-shaped hills between 1,000 and 1,500 feet above the valley.

In the eroded basins and valleys worn out in the rhyolite, noticeably on Silver and Boone Creeks, the underlying beds of Truckee Miocene are well exposed. These beds consist almost completely of cream- and ashcolored strata, made up of extremely fine, impalpable powder, so fine that when crushed and agitated with water the liquid will remajn turbid for days 
before becoming perfectly free from sediment. The beds are very soft and friable, split easily into thin fissile plates, and emit a strong odor of clay. Much of the rock, however, shows no trace of bedding through thicknesses of 20 or 30 feet. The material of some of the coarser beds, exanined under the microscope, reveals the volcanic nature of the beds, exhibiting particles of quartz, fragments of glassy feldspar, and black grains of hornblende or magnetic iron. A number of specimens treated with dilute acid gave no reaction, indicating the absence of soluble carbonates.

In the beds are frequent bands, seams, or irregular aggregations of chalcedonic material of variegated and beautiful colors, which, withstanding atmospheric agencies much better than the friable material, protrude in a marked manner beyond the face of the bluffs. That these beds are of the nature of lacustrine deposits would seem evident, not only from their general appearance, but from the presence of vertebrate remains found exposed in the bluffs. The bones collected were of too fragmentary a nature to admit of specific determination or to throw any light upon the age of the beds.

As already mentioned, the beds have been referred, like many other similar outcrops, to the Miocene Tertiary. It is evident that the beds are older than the great accumulations of rhyolite which have poured out and concealed them over wide areas. That they have been disturbed and upturned since their deposition, probably by the intrusion of volcanic rocks, is shown in many localities, and that they underlie unconformably Pliocene strata which are later than the rhyolite masses is equally evident.

In the extreme northern end of the quartzite body, near the head of Boone Creek, occur one or two local outbursts of propylite. In one instance, near the contact of propylite with the quartzite, a small dike of black vesicular basalt was observed, which formed a limited outflow, superimposed upon both the quartzites and propylites.

Shoshone Range.-The Shoshone Range, which trends about north $25^{\circ}$ east, or south $25^{\circ}$ west, lies for the greater part within the limit of Map V. The meridian of $114^{\circ} 55^{\prime}$, which forms the eastern boundary of the map, cuts the range at the northern end through the great quartzitic series in the region of Shoshone Peak. This formation, referred to the hori- 
zon of the Weber Quartzite, has already been described in its main structural and lithological features, and the reasons assigned for regarding it as of Carboniferous age. Within the limits of this map, the western slope, which is traversed by numerous deep narrow cañons, exposing the same beds, all dipping at high angles to the eastward, forms for 10 or 12 miles the eastern side of Reese River Valley. To the southward, the ridge falls away rapidly, causing a deep depression in the sedimentary strata, and in about latitude $40^{\circ} 10^{\prime}$ passes under the great accumulation of rhyolite.

At this point, the rhyolite, which has been traced along the eastern foot-hills, occupies the depression, stretching westward across the entire width of the range, and in Reese River Valley may be followed northward, flanking the older rocks, to within 3 miles of Trout Creek. Here, on the west side of the range, the rhyolites form a comparatively regular series of hills, with steep slopes, inclined to the westward, and broken through at intervals by drainage-courses. By reference to the geological map, it will be seen at a glance that the large body of quartzite to the north is separated from a smaller mass, which crops out through the general rhyolitic accumulations to the south; the gap between the two bodies being only about 3 or 4 miles in width. That this depression occupied by rhyolite is not filled up by the mere flowing of rhyolitic material in a viscous state is easily seen by the study of the topographical structure, but is rather a centre of massive eruption, the volcanic product seeking the surface along lines of greatest weakness in the older Palæozoic series.

Between the two quartzite bodies, the rhyolite forms a high prominent peak, nearly 2,500 feet above the neighboring valleys, falling off with easy slopes toward Reese River, but somewhat steeper on the eastern side. On both the east and west slopes, the peak is penetrated by long deep cañons, with the broad basin-shaped valleys near the top, so characteristic of rhyolite mountains. The rock is similar to the rhyolites already described from the range, a gray and reddish-gray felsitic groundmass, with large translucent fragments of quartz abundantly scattered through it. The smaller body of quartzite to the south follows the main trend of the range, rising above the rhyolite in a narrow ridge, about 7 or 8 miles in length: There 
can be no doubt but that it belongs to the same horizon as the larger body, although, so far as examined, it carries less quartzitic schists, and the rock has a reddish-brown color and vitreous lustre. It dips to the eastward, the planes of bedding being distinctly marked. Under the microscope, all the quartzite bodies of this region, including those from Carico Peak, Dome Mountain in the Toyabe Range, and localities in the Shoshone Range, present the same detailed structure and appearance, so much so that they can scarcely be told the one from the other.

Rhyolites score the ridge on three sides. They extend in low irregular hills to the Reese River Cañon, and toward the southeast connect the Shoshone with the Toyabe Range. These low hills hem in Carico Valley to the southwest.

Along the base of the Shoshone Range, in Reese River Valley, and nearly opposite the rhyolite spur from the Fish Creek Mountains, occur a number of hot and warm springs of considerable interest. They are scattered over an area of several acres, and are mostly surrounded by fine lightcolored soil derived from the rhyolitic detritus, which near the edges of the pools, where it can obtain moisture, is frequently covered by a somewhat luxuriant growth of alkaline grasses. Each spring forms a basin of clear transparent water, varying in temperature, in the open pool, from $85^{\circ}$ to $117^{\circ}$. When cool, the water is quite palatable, with only a slight taste of saline ingredients, and appears to deposit but a small quantity of mineral matter.

To the southward, about one-half mile from the main group, occurs an isolated spring of clear water, which comes to the surface at the base of a low mound, or dome, of rhyolite. At the time of our visit, the water, which was in a slight state of ebullition from the escape of gases, indicated a temperature of $90^{\circ}$. Coating the rocky walls of the spring 6 inches below the surface of the water was a soft, pasty, light-gray mass, apparently formed by the decomposition of the rock by the carbonated thermal waters. A stick forced into this pasty mass penetrated it with ease to a depth of 18 to 20 inches before striking the hard rock. A large quantity of the material was collected for chemical examination. 
The analysis was made by Mr. R. W. Woodward, who reported the following composition:

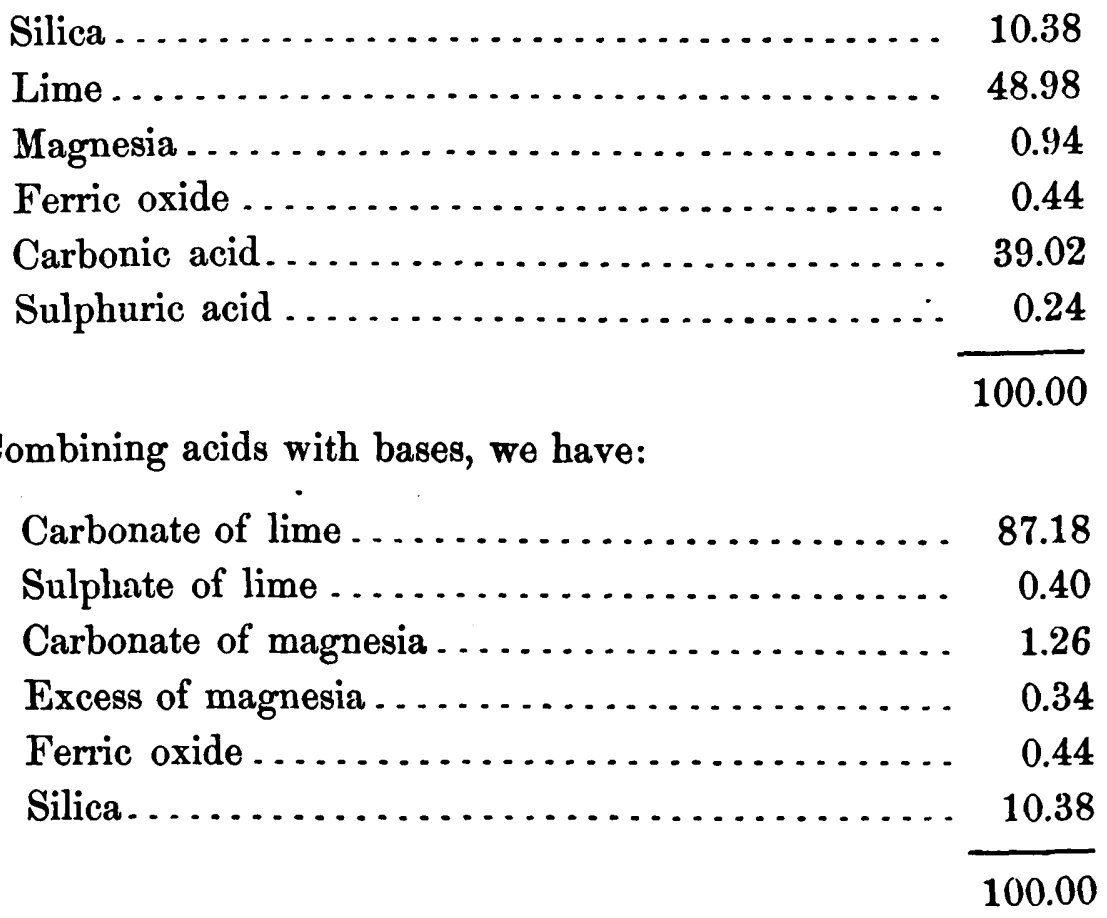

The rhyolite through which the spring reaches the surface is not only a very beautiful rock, but may be considered as typical of the region. It shows a very variegated coloring, from light-gray to reddish-gray, purple, and lilac. It has a fine microfelsitic groundmass, with a tendency to pass into a lithoidal texture. In a thin section under the microscope, the groundmass has a characteristic rhyolitic habit. The feldspars are mostly small and decomposed. The quartz is both abundant and large, and scattered in a most irregular manner through the rock.

The Upper Quaternary, through a great part of Reese River Valley, would appear to be extremely thin, and to give place rapidly to the Lower Quaternary, which consists of exceedingly fine argillaceous and arenaceous beds, forming almost an impalpable powder. In most years of moderate water-supply, the river, after leaving the canon, sinks in the broad basin east of the Fish Creek Mountains, the drainage-channels spreading out over a 
broad flat plain composed of thick plastic muds and fine sands. In the dry season, a thin efflorescence of alkaline salts covers the ground over extended areas. From a number of localities in the valley, in the region of rhyolitic hills, this fine surface soil was collected for examination, and found to be a highly arenaceous clay, charged with varying quantities of carbonate and sulphate of lime, and small percentages of soluble alkaline salts, chiefly sulphate and chloride of sodium. 


\section{SECTION II. \\ FROM REESE RIVER TO OSOBB VALLEY.}

BY S. F. EMMONS.

Southern Shoshone Range.-In the deep cut made by Reese River through this range, only a few exposures of sedimentary rocks are seen. The hills around are entirely made up of rhyolites, which slope toward the depression of this cañon. It is evident that the main erosion of the range had taken place previous to the outflow of rhyolite, and that this pass probably existed prior to that period. In almost all the Nevada ranges, where the oldest sedimentary rocks have been overwhelmed by volcanic flows, subsequent erosion lays bare what were the peaks, and it is on the higher parts of the range that we usually find the underlying rocks, whereas the passes, in spite of modern erosion, are generally occupied by the later rocks. From this, it appears that the great erosion is altogether prior to the rhyolite period. This is also evident from the moderate thickness of the Quaternary, and the proportionately greater thickness of the fresh-water Tertiaries, which antedate the rhyolite period. While the sharp post-glacial cutting has unquestionably modified the topography to a very great extent, yet the larger blocking out of the peaks and passes and the general shaping of the sedimentary masses were all done before the volcanic period.

The general structure of the Shoshone Range south of Reese River, as far as the few outcrops of older rocks indicate, is that of an original Archæan island of granite, wrapped around by fine-grained micaceous slate, which forms the main north and south ridge, to the east of which is a second line of elevation of later origin, represented by Ravenswood Peak and Jacob's Promontory; which is composed of series of quartzites and overlying limestones, which have been traversed and partially concealed by later eruptive rocks.

Archæan granite is exposed along the crest of the ridge for a dis- 
tance of 8 to 10 miles south of Ravenswood Peak, where it has a due north and south trend. This granite has remarkably regular bedding planes, apparently conformable to those of the overlying slates, which give it the appearance of being a stratified granite, though at the same time it traverses the slates in dikes. It is a white, fine-grained rock, made up of feldspar, quartz, and white mica, and containing neither hornblende nor titanite. The feldspars are mostly orthoclase, though there seems to be some little admixture of plagioclase. Under the microscope, the quartz-crystals are seen to be remarkably poor in fluid-inclusions, and the rock contains a little apatite, but no biotite whatsoever. In a dike which traverses the slates near the summit of the ridge, the rock is much coarser-grained, but shows the same constituents.

The slates have a north and south strike, and dip away from the granite body at an angle of about $45^{\circ}$ to the west, and to the eastward at a still higher angle, but are mostly obscured on this side by the rhyolite flows. They are fine-grained micaceous slates, very fissile, and having a glistening, nodular surface. Among these slates is a peculiar dark-purple, fine-grained rock, which is found largely developed in the Montezuma Range near Trinity Peak and in the Pah-tson Mountains. In a hand-specimen, it is so fine-grained that it might almost be taken for an anamesite. Under the microscope, however, it is seen to be made up of a fine crystalline mixture of quartz, and brown and white mica, with particles of black magnetite and some few grains of hornblende. The connection between this Archæan body and the other sedimentary bodies is obscured by the intervening flows of rhyolite.

In geological structure, the Ravenswood Peak mass is extremely complicated. It consists of a body of granite and porphyry, which has broken through an uplift of quartzites and limestones, all of which have been covered by an extensive flow of diorite, now forming the summit of the peak, and extending out for a considerable distance to the east and west. The granite is obscurely exposed in the cañon on the south side of the peak. It is essentially different from the Archæan granite, and evidently of later origin. It consists of milky orthoclase, with a little triclinic feldspar, large quartz-grains, which are pellucid and cracked like those of rhyolite, with a 
good deal of hornblende and biotite. But for the absence of titanite it would closely resemble the granites of the Sierra Nevada.

The porphyry, which also shows but a small outcrop in the same cañon, is a dark-greenish rock, containing white crystals of orthoclase feldspar and of hormblende and quartz porphyritically imbedded. Under the microscope, the quartz is seen to abound in fluid-inclusions, and to contain but very few glass-inclusions. The groundmass is mostly crystalline, and made up of feldspar and quartz-grains. It contains also a little amorphous base. The feldspars are remarkable for including distinct prisms of apatite, which is a rare occurrence.

The diorite of Ravenswood Peak is generally a fine greenish-gray rock, among whose uniformly fine crystals of plagioclase and hornblende occur large, tabular masses of triclinic feldspar, rendered more or less impure by included hornblende. The rock contains, moreover, some quartz, biotite and a little apatite, and is frequently impregnated with iron pyrites. In contact with the porphyry, the rock is considerably decomposed, the feldspars being more or less kaolinized, and the hornblendes being of a light-green color, while the biotite is more abundant.

The structure of the sedimentary rocks exposed in the cañons to the south of Ravenswood Peak is much obscured by the accumulations of débris and flows of rhyolite. The western bodies exposed near the summit of the ridge have a strike about north $20^{\circ}$ east, and dip steeply to the westward. They consist of greenish clay slates and white and blue quartzites, the upper member being a dark, nearly black, cherty quartzite. In the cañon immediately under Ravenswood Peak, these rocks, adjoining the granite, dip steeply to the eastward, and near the mouth of the canon are overlaid by a body of 500 to 600 feet of blue limestones. The same blue limestones are observed on the north spur of Ravenswood Peak, having a strike a little east of north, and dipping also to the eastward at a high angle, underlaid by similar quartzites. The limestones are considerably metamorphosed, and in some instances almost marbleized. In their upper portion is a body of reddish sandstone, while near the base are the same black, cherty quartzites observed to the south of Ravenswood Peak: No fossils were found in any of these limestones, nor is their lithological character very typical. 
Their general resemblance, however, points rather to the Carboniferous than the Triassic formation, and they have been considered to represent the Upper Coal-Measure group, while the underlying quartzites are supposed to belong to the Weber group so largely developed to the north.

An obscure outcrop of the same black quartzite is found along the base of the cliffs, about midway in Reese River Cañon, here dipping to the westward, and probably corresponding to that found near the summit of the ridge to the west of Ravenswood Peak. These outcrops in the neighborhood of Ravenswood Peak would therefore seem to be the remnants of a sharp anticlinal fold, whose axis runs a little east of north.

Under the Quaternary accumulations of the valley are exposed in various places Tertiary beds, which have been referred to the Truckee Miocene, as wherever the exposures have been such that the bedding could be recognized they are shown to underlie the volcanic rocks, and to have suffered disturbance previous to the volcanic period. It is probable, however, that there has been a Pliocene deposit in some of these valleys, whose material has been too soft and loosely agglomerated to withstand erosion, so that it is difficult to distinguish it from the Quaternary accumulations, or from the considerable beds of volcanic ash which border the hills, whose material in the field it is not always easy to distinguish from that of the Pliocene.

The rhyolites which have covered these older sedimentary and eruptive rocks, and built up the present outlines of the range, present an almost infinite variety of color and texture. The flows exposed in the Reese River Cañon are mostly rhyolitic breccias. They are sometimes a compact, hornstone-like material, of a dark bluish-gray color, striped and banded, and carrying well-defined crystals of glassy feldspar, but generally no free quartz. Another form of breccia is a rather earthy, porous rock, in which the feldspar crystals are largely kaolinized, but which contain a great quantity of black mica, which is entirely undecomposed, the included fragments being generally of the harder hornstonelike variety of rhyolite. Another rhyolite from the cañon resembles microscopically the typical porp'syritic red rhyolite, having a light purple color, showing some tendency to decomposition in bands. This rock under the 
microscope is seen to have a good deal of the character of a rhyolitic tufa, being composed of grayish bodies of a groundmass rich in ferrite, between which are bands and veins of colorless, granulated, hornstone-like material, which has filled up the intervals between these other bodies. This is the prevailing rock over the broad western slopes of Ravenswood Peak.

On the northern slope of Ravenswood Peak, between the diorites and the limestone body, the rhyolites are generally of dark color, and often so finely laminated and have so much of an earthy appearance that they might be mistaken for metamorphic slates. A careful examination, however, shows the peculiar banded arrangement of the groundmass of rhyolite and a considerable development of feldspar crystals. The rhyolites associated with these are of a dark reddish-purple color, generally containing a little free quartz, and feldspars which are much decomposed, while the groundmass shows microscopically a sphærulitic structure.

Along the eastern base of Ravenswood Peak is a great variety of flinty hornstone-like rhyolites associated with reddish rhyolitic breccias. The more compact of these rhyolites resemble very much the compact rhyolitic tufas found on the River Range, near the Penn Cañon coal-mines, having something of the same bands of various colors, though less well defined, and being entirely devoid of crystals. The mass seems to be an aggregation of fine fragments of rhyolite, cemented by a chalcedony-like material which surrounds them in agate-like bands. Among these rhyolites is the same dark purple-gray, hornstone-like variety found in Reese River Cañon, which contains crystals of feldspar and quartz. Within the rhyolites is a very considerable development of pure hornstone and flint of various colors, and the summits of the hills are almost covered with flint chips made by the Indians, to whom this has evidently been a source of supply for obtaining their arrow-heads. High up on the spurs is an imperfectly bedded deposit of coarse volcanic tufa, forming gravel-like beds made up of broken crystals of feldspar, quartz, and mica, in a sornewhat limy groundmass. Similar reddish breccia-like rhyolites occur along the ridge between Ravenswood Peak and the Archæan body, carrying only crystals of feldspar and quartz, but as a general rule no mica or hornblende, in a somewhat earthy, felsitic groundmass. 
The rhyolites along the western slopes of the Archæan body belong to the typical red porphyritic variety, already so frequently described, here containing considerable free quartz. They seem to overlie extensive deposits of white volcanic ash, which form the flanks of the range, and which can with difficulty be distinguished from the upturned Tertiary beds. These rhyolites all incline to the westward with the slopes of the range. The same prevailing red porphyritic rhyolite forms the summit of the range south of the Archean body, extending to the low gap west of Jacob's Promontory:

In the valley of Job's Creek, to the west of the range, and in the low, bench-like foot-lills, at the head of Lone Hill Valley, are exposures of Hiocene beds, consisting of brown and buff sandstones, dipping at an angle of $20^{\circ}$ to $25^{\circ}$ to the westward. As indicated by the fragments on the surface and in the stream-beds, these Tertiaries are underlaid by quartzites. Of the quartzites, a small, obscure outcrop is found at the head of Job's Creek, dipping to the west, which has been referred to the Weber group. The bluffs facing the low gap west of Jacob's Promontory are formed of beds of a dark-gray trachytic-looking rhyolite, which dip about $10^{\circ}$ to the westward. The rock has the rough, porous texture of a trachyte, and contains sanidin, hornblende, and mica in a dark-gray groundmass. The groundmass, however, has the fluidal structure of the rhyolite, and is seen to be full of very minute grains of free quartz.

$J_{A C O B}$ 'S Promontory is a group of low hills extending eastward, out into the Reese River Valley, from the Shoshone Range, made up of highly-metamorphosed dark-blue quartzites with cherty seams, which are exposed in the ravines, having a general north and south strike, but whose structure is very obscure. The quartzites are so blackened on the surface that they are easily confounded at a little distance with the volcanic rocks, which cover the greater part of the surface of the hills. They are much stained with iron, and apparently mineral-bearing.

The northern point of the hills, and the little outlying hill through which Reese River has cut its bed in a cañon-like gorge, as well as the southern foot-hills, are composed of a dark augite-andesite, having the resinous lustre peculiar to this rock. It has a columnar structure, and is $41 \mathrm{D} \mathrm{G}$ 
evidently older than the neighboring volcanic rocks. Its weathered surface is of a light-gray color, and shows distinctly the included feldspar crystals. The rock from the cañon at the north point of the hills is made up of plagioclase-feldspar and yellowish-green augite imbedded in a glassy groundmass, which, under the microscope, is seen to be made up almost entirely of brown glass, with no globulitic secretions, cementing microlites of plagioclase and augite, and grains of magnetite. It contains a little sanidin, which is mostly decomposed, but no olivine or hornblende. The larger plagioclases and the augites contain inclusions of brown glass, with rectangular bubbles. The augite-andesite from the southern point of the hills contains more sanidin, and also some little hornblende, which is sometimes found included in the sanidin crystals. A characteristic of these rocks is the fact that the augites occur in well-defined, perfect crystals, while the hornblendes are broken, and seem to be an accessory constituent.

On the western slopes of the hills is a rhyolite, which might at first be taken for an andesite. It has a similar dark-gray groundmass, but contains large sanidin crystals and comparatively few plagioclases, with fresh dark-green hornblendes. Under the microscope, the resemblance to andesite is still maintained in the fact that the groundmass is a dark-gray felt-like aggregation of microlites, but its crystalline ingredients are thoroughly rhyolitic, consisting of quartz, sanidin, a little plagioclase, and much dark hornblende with its characteristic dark border, together with a few light-green augites containing glass-inclusions. Associated with this rhyolite is a dark-gray sanidin-trachyte, which contains some little plagioclase, and also some augite, though with a large predominance of hornblende, in a micro-crystalline groundmass. The summit of the hills is formed of a dark, compact, fine-grained basalt, which has broken through and covered the quartzites. It belongs to the feldspar-basalts, and contains augite and plagioclase and very little olivine. In places, it is slightly vesicular, the cavities being partially filled by carbonate of lime.

In the low benches west of Reese River, near Jacobsville, is an exposure of from 50 to 100 feet of horizontal Tertiary beds, made up of gravel conglomerates and coarse arenaceous limestones, full of cavities, like the 
rude moulds of shells, which have been referred to the Truckee Miocene, though they may possibly be of later formation. The upper bed is a thin seam of curious green compact sandstone, made up largely of fragments of crystals of quartz, feldspar, and mica, enclosing angular particles of quartzite and jasper.

Mount Airy Hills.-The low hills between Reese River Valley at Jacobsville and Smith's Valley, in the neighborhood of Mount Airy stagestation, present an interesting succession of rhyolitic beds from 50 to 200 or 300 feet in thickness, which have a general dip to the northeast, presenting bluff faces to the southwest. The lower beds are generally of a light volcanic tufa or trass, varying in color from whife to a delicate mauve, made up of fragments of a pumice-like material, having a fibrous, woody structure, and particles of black volcanic glass enclosed in a porous ash,. which carries occasional crystals of sanidin. Associated with this are beds of a hard, rhyolitic breccia, made up of angular fragments of green and gray rhyolite, and crystals of quartz which are often broken, together with feldspar and biotite. The rock is frequently quite porous, and the cavities lined with a coating of fine, colorless crystals, which, under the microscope, are seen to present the form of a rectangular prism, with vertical striation on the prismatic faces, which Professor Zirkel ${ }^{1}$ thinks may be zeolites, either comptonite or thompsonite.

The rhyolitic lavas of these hills are reddish rocks, having an even, conchoidal fracture, whose groundmass has somewhat of an earthy texture, which are rich in crystals of quartz and sanidin, and contain little or no mica or hornblende. The quartz is frequently smoky, sometimes so darkcolored as to look like black glass. Under the microscope, the groundmass is seen to have a fluidal structure, presenting stripes of different material, some of which are axially fibrous, but with no tendency to sphærulitic forms, and the quartz and sanidin crystals have no foreign inclusions except glass.

The low hills at the head of Smith's Valley, which connect the Shoshone Range with the Desatoya Mountains, are composed of various flows of rhyolite, which have a general dip to the westward, away from the Shoshone

\footnotetext{
${ }^{1}$ Microscopical Petrograpby, rol. ri, 260.
} 
Mountains, and near the base of the Desatoya Mountains slope upward with an easterly dip. The flows consist generally of reddish porphyritic rhyolites, among which are some earthy varieties comparatively poor in crystals. Alternating with these are prominent beds of black pearlitic rhyolite, presenting all the gradations from a half-glassy rock containing crystals of sanidin to an almost pure obsidian, with only a few imperfect casts of feldspar crystals. Under the microscope, the groundmass of the latter is seen to consist of deep-brown glass, containing no product of devitrification, while the crystals of quartz, sanidin, and plagioclase-feldspars which occur in the mass contain inclusions of the same dark-brown glass. These darker bands are generally from 10 to 20 feet in thickness.

Desatoya Mountans.-Only the northern portion of this range is included within the map, whose most elevated portion is generally known as the New Pass Mountains, from the mining district which was once established at its southern base. This mountain mass, which is some six miles in length, and rises about 4,00J feet above the surrounding valleys, consists of a portion of an anticlinal uplift of Triassic limestones and sandstones representing the Star Peak and Koipato groups. The main mass of the hills is made up of heavy beds of green and purple quartzites and conglomerates, striking north $20^{\circ}$ east and dipping from $30^{\circ}$ to $35^{\circ}$ to the westward. Along the western flanks are exposed in the ravines heavy blue limestones resting conformably on these, which, toward the southern end of the range, bend in strike sharply to the east, with a dip of $70^{\circ}$ to the south, and soon disappear under the flows of rhyolite. Owing to the smooth, rounded slopes and comparatively few outcrops presented by the main mass of the hills, it was impossible to obtain a continuous section of the siliceous beds, which may correspond in Western Nevada to the lower red sandstones of the Triassic formation, as observed in the Rocky Mountain region.

In a section taken across the range from Gilbert's Crcek to Ammonite Cañon, shown in section C-Dat the bottom of the map, about 6,000 feet of the Koipato beds are crossed. The lowest exposures show strata of a greenish, somewhat cherty quartzite. Above these, forming the summit of the ridge, is a breccia-like conglomerate made up of greenish and purple cherty fragments, with a red cement, overlaid by a thickness of about 1,000 feet 
of quartzite and conglomerate, weathering with a peculiar yellowish-brown earthy surface. On the western slopes, immediately underlying the limestones, is a bed of purple, argillaceous roofing-slate. As exposed in Ammonite Cañon, there lies conformably above this a thickness of 1,000 to 1,500 feet of dark grayish-blue, compact, earthy limestones of the Star Peak group, which lithologically cannot be distinguished from the Carboniferous limestones. At the contact of the limestones with the quartzites is a band of yellow calcareous shales. Immediately above this are dark-blue, finely laminated, calcareous shales, rich in Triassic fossils, particularly in wellpreserved Ammonites. A second fossiliferous locality was found about 200 or 300 feet above the shales in a compact, fine-grained limestone. From the slates of the lower horizon were obtained the following forms:

Halobia dubia.

Pteria (Avicula), sp.?

Pecten deformis (frag.).

Myacites, new sp. (very small).

Orthoceras Blaki.

Ceratites Haidingeri?

Ammonites Billingsianus.

Goniatites (Clyodonites) lavidorsatus.

Ammonites (Gymnotoceras) Blakei.

Ammonites Ausseanus.

From the upper limestone beds were obtained:

Spiriferina Homfrayi.

Terebratula (minute sp., prob. new).

Chemnitzia?

From the limestones at the southern point of the range, near the head of South Cañon, were obtained also the following forms:

Halobia dubia.

Halobia (Daonella) Lommeli.

Modiolopsis (Modiomorpha?) ovata.

Modiolopsis (Modiomorpha?) lata. 
Lima (Clenoides) Gabbi.

Ammonites (Gymnotoceras) Blakei.

Acrochordiceras Hyatti.

Eutomoceras Laubei.

Lima (Limatula) crecta.

Of these Professor Meek regards the latter as indicating rather the horizon of the Lower Liassic.

Along the southeastern edge of the hills is a development of diorite, which also forms the country-rock of the mines at their southern point. This diorite is a dark-green, compact rock, with veinings of lighter green running through it, which, to the naked eye, presents an almost homogeneous mass. A few large greenish plagioclase-feldspar crystals can bo distinguished, and also occasional prisms of hornblende. Under the microscope, besides the hornblende and feldspar, magnetite, some apatite and a colorless mineral, which is probably tremolite, are also distinguished. The feldspars show vestiges of former twin striation, and are filled up with fine, needle-like fragments of hornblende, to which they owe their green color. The hornblendes are particularly interesting as showing the peculiar structure which has been figured by Professor Zirkel in his report.' 'They are made up of an aggregation of microscopical prisms arranged parallel to each other and in such form as to build up the macroscopical hornblende crystal.

This diorite body has been covered by the flows of rhyolite, which extend high up on to the flanks of the hills, and to the north cover completely the low ridge which connects these mountains with the Augusta Mountains. The rhyolite of this northern ridge is of the red porphyritic variety, very rich, however, in crystals of sanidin and apatite, and having the peculiar banded structure observed in the rhyolite of the ridge between Squaw Valley and Rock Creek Valley, to the north of the Humboldt River, in which the bands consist of alternately predominating portions of a reddish felsitic groundmass and of aggregations of crystals of sanidin and quartz.

Immediately adjoining the diorite is a peculiar rhyolitic breccia of light-

'Microscopical Petrographs, rol. vi, 88, und Plate I, fig. 11. 
green color, containing some pumice-like fragments, which themselves are of a darker green, approaching the color of the diorite. Associated with this is a rhyolite which contains breccia-like fragments of the adjoining quartzite and large crystals of quartz and mica, with well-preserved sanidin feldspars in a yellowish-gray, hornstone-like groundmass, which, under the microscope, is seen to contain microscopical biotite and apatite, and large sphærulites with a distinct centre, between which are axially fibrous bands of felsitic material.

At the head of the South Cañon, to the west of the mines, is a red, somewhat earthy rhyolite, also containing included fragments of a greenish decomposed rhyolite rich in crystals of sanidin and quartz. The groundmass contains large dark-yellow sphærulites, which in section show a concentric structure like the cross-section of a tree. On the western foot-hills of the range, adjoining the limestones, is a dark-red porphyritic rhyolite very rich in apatite, which, in contact with the limestones, is decomposed into an earthy variety, through which run seams of calc-spar and lenticularshaped aggregations of calcite crystals, which are evidently derived from the limestones. In the rhyolites of the eastern foot-hills are found in the quartz remarkably large glass-inclusions, having a peculiarly-shaped bubble, and included portions of the groundmass, which have assumed a hexagonal shape. The form of the bubble is shown in Vol. VI, Plate I, fig. 16.

To the south of the New Pass Mines, the Desatoya Mountains are represented by a narrow ridge having an elevation of only 1,500 to 2,000 feet above the valleys, made up of flows of different rhyolites. A section of the range is obtained in the New Pass, a cañon-like gorge, which cuts entirely through it, at right angles to the trend, to a depth of about 1,000 feet below the summit. A succession of rhyolites is found here similar to that seen on the Mount Airy Hills. In the centre of the ridge is a great thickness of earthy breccias, of colors pinkish-red above, white and green below. The thickness of these bodies cannot be less than 600 feet. The greenish breccia-tufa is a mass of a pale-green color, containing pumiceous fragments of a more intense green, enclosing frequently crystals of quartz and feldspar. A microscopical examination of this curious breccia-like tufa shows that it is 
made up of tivisted bands of pale-green glass, traversed by stripes of colorless glass, both straight and curved. 'The green glass is composed entirely of pale-green microlites, which are longitudinally arranged and almost continuous through the length of the band. The colorless glass contains both monoclinic and triclinic feldspars, and quartz crystals, which have as enclosures apatite crystals containing glass-inclusions. In the glassy material of which this rock is made up, no less than six different varieties of volcanic glass can often be distinguished at once.

To the west of these breccias is a body of pinkish porphyritic rhyolite, containing a very large proportion of crystals of quartz and sanidin-feldspar. Under the microscope, the quartz is seen to be full of well-defined glass-inclusions, and the crystals of sanidin, which are unusually clear and free from cracked or foreign interpositions, show the most remarkable blue colors, like the labradorizing feldspars from Frederiksvärn in South Norway. This phenomenon is a comparatively common occurrence in the rhyolites of this region. The blue color is even more intense than that of the Norwegian occurrence; but in the latter the peculiar shimmering light is due to the presence of strange bodies interposed between the lamina of the feldspar. In these, however, the sanidins are quite free from interpositions, and the phenomenon cannot be explained on this ground. In transmitted light, these sections are quite colorless, and are therefore not easily distinguishable from quartz, but the quartz is always characterized by dihexahedral glass-inclusions.

At the extreme western end of the canon is a mass of green rhyolitic breccia, not unlike that of the Mount Airy Hills, but remarkably rich in crystals of quartz, which form at least a third of the whole mass, and constitute almost the only macroscopical crystalline ingredients. 'The surface of the rock is covered by curious botryoidal concretions of opaline quartz, which also line the cavities of the rock. Under the microscope, the groundmass is seen to differ from that of most of the rhyolites of the Fortieth Parallel, in that it is non-polarizing, and made up of accumulations of small globules which are concentric but not fibrous, the whole being traversed by axially fibrous strings. These accumulations of globules have been named by Vogelsang "cumulites". 
To the west of the Desatoya Mountains is a broad, shallow Quaternary valley, in whose lowest portion, to the west of the centre, is a small alkali flat or deposit of Lower Quaternary silt. This flat is from 500 to 600 feet lower than the corresponding portion of Smith's Valley. It was evidently occupied at one time by an enclosed lake, whose drainage was to the southwest. This valley occupies a lower level than the valleys to the eastward, being but little over 5,000 feet above the sea. It is succeeded to the westward by a still deeper valley, the Osobb Salt Valley, whose lowest portions are from 3,300 to 3,500 feet only above the level of the sea. Between these two valleys rises one of the highest ranges of this portion of Nevada.

Augrsta Morntains.-This range south of the Shoshone Pass consists of a series of lofty peaks, whose summits attain an elevation of nearly 10,000 feet, and whose sides are deeply scored by sharp, narrow cañons. Its mass is made up almost entirely of eruptive rocks, ranging in age from the oldest granites to the most recent rhyolites and basalts, with a small development of sedimentary rocks of Triassic and Jurassic ages. The southern portion of the range, near the limits of the map, as far as Clan Alpine Cañon, is made up of an original elevation of diabase, which is exposed at the highest summit, and in isolated outcrops along the eastern foot-hills, which has been overwhelmed by successive flows of andesite, rhyolite, and basalt. The diabase is a compact, light-greenish to purplish-gray rock, made up of plagioclase and augite, with a very little quartz.

Clan Alpine Cañon, which heads in a high valley to the west of the main crest of the range, affords a section of an immense thickness of rhyolite, which has evidently come to the surface in mass, and shows no evidences of forming thin flows. The main crest of the range, at the head of the cañon, shows protruding points of andesite, which were not covered by the rhyolite flows. The andesite has a somewhat columnar structure, is of a dark color, containing a large development of slender, prismatic crystals of black hornblende. It is made up of plagioclase-feldspar and hornblende, in a groundmass which is seen microscopically to be an aggregation of minute colorless feldspars and brown hornblende-microlites. These long hornblende prisms have a general parallel arrangement through the rock, 
and even to the naked eye are seen to be very much broken, as if by a movement in the groundmass after their formation.

The rhyolites which immediately adjoin the andesite at the head of the cañon belong to the porphyritic variety, being of a pinkish-red color, rich in crystals of sanidin, mica, and quartz, and splitting readily into thin, sherdy fragments. Under the microscope, the groundmass of these rhyolites, which is of a brownish-yellow color, is seen to be fibrous, but is unaffected by polarized light. To the east of the summit is a compart porphyritic rhyolite, having almost the texture of an older porphyry, and containing, with the smoky quartz and sanidin-feldspars, dull, opaque, orthoclastic feldspars, and also a few plagioclase crystals.

Near the mouth of the cañon, the rhyolites are generally of white color, carrying no mica, but a great deal of smoky quartz and somewhat decomposed feldspar. With them are associated breccias made up of the same material, portions of whose groundmass scem to be rather crystalline, while other portions have a distinctly sphærulitic structure. Associated with these white rhyolites, on the western foot-hills, is a red porphyritic rhyolite, which contains angular fragments of diabase. It is rich in crystals of quartz, mica, and sanidin, and contains also some plagioclase. Under the microscope, the quartz crystals are seen to contain inclusions of pure glass, and also hexagonal zones of the half-fibrous groundmass. Among the whitc rhyolites, near the mouth of the cañon, is one which on the surface is tinged with a delicate rose color, and full of small cavities lined with minute crystals of quartz, upon which are deposited white, opaque, thin, hexagonal plates, resembling tridymite.

About 3 miles above the moutl of the cañon, a dike of dark, compact feldspar-basalt traverses the rhyolites, spreading out upon the spurs in flat, tabular masses. On the divide, at the head of Clan Alpine Cañon, and spreading out over the spurs to the west, is a dark, compact basalt, which belongs to that type which has a globulitic, glassy base. It contains some sanidin, with predominating plagioclase-feldspar; also augite and olivine. Under the microscope, the feldspars are seen to have a schistose structure, and abound in half-glassy included particles, and the olivines to have glass- 
inclusions that are of peculiar branching shape, with dark bubbles at the ends of the branches.

In the deep cañon-cuts to the east of Crescent Peak, in the central portion of the Augusta Mountains, is found a great variety of older eruptive rocks, associated with limestones and some fer quartzites. The sedimentary rocks are apparently wrapped around a body of granite, which is exposed at Granite Point, and of which traces are seen in the detritus of Augusta Cañon. 'Through these have poured successive outbursts of hornblende-porphyry, which have been succeeded by extensive eruptions of andesite forming the main body of the range, which in turn are covered by flows of trachyte, and the whole succeeded by rhyolite.

The granite of Granite Point is a fine-grained rock, containing quartz, feldspar, and biotite, with a little hornblende. Of the feldspars, orthoclase decidedly predominates, the plagioclase being present in small quantity. The mica is irregularly distributed through the mass in large hexagonal plates, while the hornblende is present in comparatively small quantities, and always accompanied by apatite.

The sedimentary rocks, as exposed in Crescent Cañon, and along the foot-hills as far as Augusta Cañon, have a dip of $55^{\circ}$ to the northeast, and strike north $40^{\circ}$ west. They consist of greenish clay-slates and dark-blue calcareous shales, with some development of limestone, but, as far as observed, contain no fossils. They probably represent the upper portion of the Star Peak Triassic. At Granite Point, these slates are found apparently resting against the granite body, though the structure is somewhat obscure.

The porphyry presents a remarkable resemblance to the well-known hornblende-porphyry from Potschappel near Dresden, both in external appearance and in interior structure and composition. It also presents remarkable points of resemblance with the andesite, which has followed it evidently through the same channels, since small bodies of the porphyry are found also under the western body of andesite in Antimony Cañon, though the outcrops are too limited to be indicated on the map. It is probable that in this part of the range the pre-existing elevation of Triassic rocks has been traversed and covered by flows of this porphyry, which havo been succeeded by the andesites, that now mostly conceal the 
original beds of porphyry. The porphyry is of a dark-gray or dark-purple color, containing only macroscopical crystals of hornblende. In the fresher varieties, the hornblende is black and glistening, but, in most of the rock, it is decomposed, of a light-green color, and almost earthy texture. In one variety of the porphyry, the homblende exists as light-green, almost white crystals, which might be mistaken for feldspar, their outlines being rudely rectangular, and the crystals being frequently half an inch in length. The same parallel arrangement of these hornblende prisms is observed in the porphyries as in the andesites which have succeeded them. In the hand-specimens, it is difficult to distinguish the fresher porphyries from the andesite. That at the head of Clan Alpine Canon, in the hand-specimen, might as readily be taken for hornblende-porphyry as an andesite. $\Lambda$ microscopical examination of these porphyries shows, in even more striking manner, their close resemblance to the Saxon occurrence already mentioned. Like this, they contain both plagioclase and orthoclase feldspar, the latter, however, decidedly predominating, and occurring both in single individuals and in Karlsbad twins. The hornblende plays a very unimportant part in the groundmass, which consists mostly of a yellowish-gray, amorphous and somewhat globulitic substance, including small feldspar prisms and aggregations of numerous black grains. It occurs mostly in larger crystals, which are generally broken and fragmentary, and do not present a regular crystallographical shape, but are encircled by a border of black grains, a phenomenon which is also frequently observed in andesites and trachytes, of the former of which it is a characteristic feature. This black, granular border, which is a result of superficial alteration of the crystal, is well shown in Plate IV, fig. 2, of Professor Zirkel's report, which presents a thin section of this rock. A further alteration has produced a bright-green substance, which is called viridite; and in the alteration of the black border, which occurs less frequently, a certain anount of calcite is formed, whose presence is shown by a slight effervescence in the hornblendes when treated with dilute acid. The porphyry contains some apatite but no augite.

The prevailing andesite of the region of Crescent Peak and Augusta Cañon is a light greenish-gray rock, containing large prismatic crystals of black hornblende porphyritically imbedded in a somewhat earthy ground- 
mass. This earthy character of the groundmass is all that distinguishes it in external appearance from the neighboring hornblende-porphyries. It resembles closely the andesite from the Walkenberg in the Siebengebirge. The hornblende prisms are remarkably ruptured, and are seen to be filled with the green viridite substance, which is also prominent in the groundmass. The phenomenon of the rupturing of the hornblende prisms is eren more remarkable in the andesites of this region than in those at the head of Clan Alpine Cañon. Under the microscope, they present also the characteristic black border, and the ruptured fragments of a single crystal can be traced with such distinctness that often one of the larger crystals is seen to be broken into thirty or forty pieces; a thin section of this rock, showing some fragments of crystals, has been illustrated by Professor Zirkel, in Vol. VI, Plate V, fig 2. The groundmass is an aggregation of minute colorless feldspar crystals, brown hornblende microlites, and black grains. Large masses of this earthy andesite are made up of breccia-like fragments of the same rock, which are only distinguishable from the enclosing andesite by slight differences of solor.

$\Lambda t$ the head of the South Fork of Augusta Cañon is found a different character of andesite overlying the earthy andesite, which shows macroscopically small white crystals of plagioclase-feldspar imbedded in a dark-gray compact groundmass. Its hornblende is not easily distinguished by the naked eye, but under the microscope is seen to be largely altered into a fibrous substance, of green color, though still preserving its original outline and the characteristic black border. The groundmass is made up of feldspar-microlites, which show a fluidal structure, and is very rich in minute brown grains of ferrite. The rock contains no augite, but the apatite which occurs in the rock is not colorless, as is generally the case, but of a light brownish-yellow.

Still another andesite, which may probably be of a later flow than this which occurs at the head of Crescent Cañon, contains augite as well as hornblende, though both in small proportions. It is a compact gray rock having an even, conchoidal fracture, and is rich in plagioclase-feldspar. The groundmass has a very uniform texture, and is seen, under the microscope, to contain a certain amount of amorphous base. This variety of andesite 
forms the base of Crescent Peak, and is overlaid by a trachyte which has a great deal of the external appearance of the andesites of this region. It is a dark-gray fine-grained rock containing slender crystals of black hornblende, which show the same products of alteration as the andesite. The feldspars of this trachyte are small and inconspicuous, but in them sanidin seems to predominate over plagioclase.

Near the head of Augusta Cañon, and extending across the ridgo which separates it from Granite Point Cañon, is a dike-like mass of columnar augite-andesite, which is almost identical with the augite-andesite of Jacob's Promontory. It is evidently a later outburst through the older andesites, and presents a remarkably regular columnar structure, the columns being generally very perfect pentagons, ranging in size from a few inches to a foot or more in diameter. The exterior surface of these columns is covered by a thin, regular coating, about one-tenth of an inch in thickness, of lightgreen color, which is evidently an alteration product of the groundmass, as the hornblendes and other crystalline ingredients of the rock which occur in it are unaltered. Beneath this green layer is a still thinner layer of reddish, rusty maierial. The dark groundmass of the rock has, in fresh fracture, a resinous, almost glassy lustre, and carries large tabular crystals of plagioclase-feldspar and some sanidin, together with greenish decomposed augites and crystals of hornblende, but no olivine. The microscope discloses also the presence of magnetite, and in the groundmass a base of brownish glass without globulitic secretions, which cements microlites of plagioclase and augite.

The same augite-andesite occurs on the western slopes of the range in Antimony Cañon, in thin, horizontal beds, which form the crest of the spur, and cover the underlying earthy and brecciated andesites, which in turn, as shown by occasional obscure outcrops, are underlaid by the older hornblendeporphyries. In the head of this cañon is also found an obscure outcrop of green clay-slates, which are very much broken and decomposed. The western slopes of the range south of Crescent Peak were not visited, but as seen from the summits are evidently largely composed of rhyolite flows, which cover so extensively the underlying rocks through the parts of the range which were visited. 
The rhyolite which immediately adjoins the granite body of Granite Point on the west is a white porphyritic rhyolite rich in quartz, which is accompanied by a white, somewhat earthy breccia, carrying small crystals of quartz, sanidin, and black biotite, and including, as breccia material, fragments of dark-blue quartzite, rounded crystals of orthoclase-feldspar, and opaque quartz, which evidently result from the decomposition of the granite, and which can easily be distinguished from the small, limpid quartzcrystals that belong to the rhyolite itself.

Along the foot-hills to the north of the granite body is a series of red rhyolites, among which were noticed a porphyritic rhyolite containing large crystals of fresh, glassy sanidin-feldspar, and opaque orthoclastic-looking feldspars, which may also be included fragments, resulting from the decomposition of the granite. A second rhyolite, a little distance from the granite body along the castern foot-hills, consists mostly of a red porphyritic groundmass, with comparatively few included crystals of quartz, sanidin, and mica, but no opaque feldspars. From fragments obtained in the débris of the cañon next north of the granite body, it is probable that the hornblende-porphyry extends at least as far north as this.

The main crest of the range between Granite Point and Antimony Cañon is made up of a drab rhyolite having the peculiar uneven fracture of the red porphyritic rhyolites. It contains only crystals of sanidin and quartz in a grayish-yellow felsitic groundmass, which, examined microscopically, is seen to consist almost wholly of longitudinal bands, showing a good axial fibration. This rhyolite, which occurs horizontally bedded, is underlaid by a bed of dark pearlitic rhyolite, containing crystals of sanidin and quartz, similar to those found between the Desatoya and Shoshone Ranges.

North of the line of Granite Point and Antimony Cañon, there is a broad depression in the range, in which it consists of a series of low ridges, forming a shallow basin, open toward the west. This portion of the range, which in ante-Tertiary times was scarcely elevated above the surrounding plains, is now occupied by extensive flows of rhyolite, which, for some distance north of Shoshone Pass, dip to the northwest, at first with an angle of $15^{\circ}$, but gradually shallowing out, and in general conforming in slope with 
the present topography; that is, they are generally inclined toward the centre of the basin, which lies between Shoshone Pass and Boundary Peak, called Soldier's Spring Valley. In estimating the thickness of these rhyolite flows, by crossing them on a northeast line from the ridgre which bounds Antimony Cañon on the north, one can reckon a thickness of over 6,000 feet of conformably superimposed beds of rhyolitic lavas. While these beds, which vary in thickness from fifty to a few hundred feet, are all of different external characters, there scems to be a certain sequence, which would indicate that there may be a repetition in the series caused hy faulting, so that this estimate cannot be definitely relied upon for their actual thickness. They have been very extensively eroded, and are in greneral of somewhat earthy character, so that they are easily acted upon by the forees of abrasion.

Shoshone Pass is cut along the line of strike of these beds, and at its lighest point is only a few liundred feet above the neighboring valleys. Along the pass are numerous springs of fresh, pure water, the most prominent group of which is called Shoshone Springs. Among the low lills to the north of Shoshone Springs are a few which can be prominently distinguished from a great distance by their dark color, in strong contrast to the prevailing light colors of the rhyolites. They are found to be formed of beds of darkblue limestone, which are bent into a narrow anticlinal fold, whose axis has a north and south direction, and of which the eastern member stands almost vertical, while the western beds slope off at an angle of $20^{\circ}$ to $25^{\circ}$. The aggregate thickness of these limestones could not be determined, as the outcrops are isolated by intervening accumulations of Quaternary material ; but an exposure of over 1,000 fect of limestone is shown, with interstratified beds of reddish, clayey, and arenaceous shales. Thie limestones have been very considerably metamorphosed by the action of the rhyolitic overflows, and aro very black and hard on their weathered surface, often covered with a thick, black coating, rich in iron. In one place, a considerable portion of the limestone has been changed into a white crystalline calcite, which is concretionary and bounded by a coating of carbonate of iron about an inch and a half in thickness.

In the hillss to the south of the spring is found an outcrop of conglom- 
erate, formed of greenish, cherty pebbles, in a reddish matrix, like the conglomerates of the New Pass Mountains, which would indicate the existence of the Star Peak Triassic body here, and that the anticlinal axis of the fold sinks to the northward. Some of the beds of limestone are very rich in fossils, but the rock is so much metamorphosed that it was very difficult to obtain good impressions. The lithological character of the limestone closely resembles that of the New Pass Mountains, but the fossils have a decidedly younger aspect, and have been assigned to the Jurassic horizon. Some of the forms have a facies which allies them to the Cretaceous or even to Eocene Tertiary formations; but the position and lithological character of the beds, and the fact that no Cretaceous or Eocene Tertiary beds have been found in this region of Western Nevada, preclude the possibility of their representing a later formation than the Jurassic. The following forms were determined by Messrs. Hall and Whitfield:

Terebratula Augusta, n. sp.

Septocardia Carditoidea, n. sp.

Septocardia typica, n. sp.

Aviculopecten (Eumicrotis ?) Augustensis, n. sp.

Pecten, sp. 8

Pecten, sp.?

Gryphaa, sp.?

Discina, sp.?

In a little ravine between the limestone hills was found a small outcrop, only a few feet in extent, of a curious rock, made up mostly of hornblende and quartz, with a little feldspar. The hornblende is extremely cleavable, and has somewhat of a parallel arrangement, which gives the rock at first sight the appearance of an Archæan schist. To the north of this point, under the rhyolite hills which bound Soldier's Spring Valley, on the west, are found considerable outcrops of a similar rock, much more decomposed, however, which was first taken for a syenite. A microscopical examination, however, shows that among the feldspars plagioclase decidedly prevails, and that the rock therefore belongs rather to the diorites. It is a rather coarse-grained diorite, and contains, besides hornblende and $42 \mathrm{D} \mathrm{G}$ 
the two feldspars, apatite and titanite, together with a compect mineral without cleavage, which Zirkel ${ }^{1}$ regards as tourmaline.

Of the almost infinite variety of rhyolites which make up this broad expanse of low hills, only a few of the more typical forms will be described. In crossing from Antimony Cañon to Shoshone Pass, at right angles to the strike of the flows, the following are the more prominent beds: The ridge north of Antimony Cañon consists of a light-reddish, very porous, porphyritic rhyolite, which contains some few brecciated fragments of red decomposed rhyolite. The rock itself has evidently been exposed to solfataric action, and contains, in well-preserved crystals, only mica and quartz. Of the cavities which abound in the mass, many retain the form of the original feldspar crystals which once filled them.

On the north of the ridge is a bed of white rhyolite, having a compact hornstone-like groundmass, and containing fresh crystals of sanidin-feldspar and quartz, together with occasional plagioclase crystals, but no mica. This rhyolite also contains included fragments of other rhyolites. Above this is a prominent bed of brilliant emerald-green rhyolite, which also has included breccia fragments, and is remarkably rich in quartz. Its groundmass has a compact hornstone-like texture, and under the microscope is seen to be made up partially of fibrous sphærulites, and of axially fibrous strings, which are surrounded by an imperfectly crystalline material.

Above this green rhyolite are various earthy rhyolites of delicate pink and yellowish-brown colors, which present no crystalline development, and which are succeeded by red porphyritic rhyolites rich in crystals of sanidin and mica, and containing comparatively little quartz, which have a peculiarly trachytic fracture. Interstratified with these red porphyritic rhyolites, as in the region between the. New Pass and Shoshone Ranges, are beds of dark, nearly black, pearlitic rhyolites, which have porphyritically-imbedded crystals of quartz and sanidin, and whose groundmass is largely made up of brown glass. Above the red porphyritic rhyolites are a series of earthy rhyolites, which present a similar succession of color to those already passed, namely, green below, succeeded by pink and yellowish-brown varieties. This green rhyolite, however, contains many crystals of sanidin, and some

${ }^{1}$ Microscopical Petrography, vol. ri, 8i. 
dark, fresh hornblendes, which are so strongly in contrast with the general decomposed character of the rock, that they would seem to have been mechanically included in the flow.

Beyond Shoshone Pass, to the north, are white rhyolites, having a green, conchoidal fracture, and containing an unusually large development of quartz crystals, which are frequently smoky, and of fresh, clear sanidin crystals, which often have the brilliant blue colors peculiar to these rocks. These are succeeded near the pass, at the northern end of Edward's Creek Valley, by red porphyritic rhyolites, which contain mica and hornblende, with rather opaque feldspars and very little free quartz. Under the microscope, the biotites are seen to be penetrated by numerous prisms of apatite. In the neighborhood of Shoshone Springs and the limestone body, similar earthy varieties of pink and green colors are found, associated with which is a gray, pearlitic rhyolite, enclosing fragments of the darker-colored pearlitic rhyolite and crystals of sanidin and quartz. Under the microscope, this rhyolite is seen to be made up of bands of colorless glass, alternating with partially opaque bands and stripes of light yellowish-gray microfelsite, which has an intermediate character between a true glass and a granular crystalline aggregation. In this groundmass are seen to be imbedded some broken quartz and feldspar crystals, many of which present the bluish opalizing colors already described.

On the spur to the southwest of Shoshone Springs is an isolated outcrop of rather light-colored, very vesicular basalt, which is so much decomposed that its mineralogical character can hardly be distinguished. Along the foot-hills, both to the east and the west of the Soldier's Spring Valley basin, are outcrops of upturned Truckee Miocene. In those bordering Lone Hill Valley, some coal-seams are said to have been discovered since the completion of the field-work, but no reliable data as to their character have been obtained. 


\section{SECTION I II. \\ FISH CREEK AND BATTLE MOUNTAINS.}

BY ARNOLD HAGUE.

Fish Creek Mountains.-The Fish Creek Mountains lie directly north of, and in the same trend with, the Augusta Mountains, and, like the latter, are made up mainly of rhyolitic outbursts. From the nature of the volcanic material, they form an irregular group of hills, a roughly diamond-shaped mass, the longer axis stretching northeast and southwest for 25 miles, while across their broadest expanse they measure about 18 miles. The more elevated portion is situated in the extreme southernmost end, culminating in Mount Moses, which rises in a conical peak, 8,725 feet above sea-level, and falls away in sharp ridges with steep slopes toward the west, south, and east. Northward the country passes into a broad undulating table, inclined gently to the southeast, with deeply-eroded cañons along its edges, penetrating for long distances into the main mass. On the north side, this table shows a somewhat remarkable wall of rhyolite, rising from 1,200 to 1,800 feet above its base, and extending across the width of the mountains, at right angles to the general trend. This wall divides the mountains into two distinct groups; the portion to the north being not only much lower, but presenting, for a rhyolite formation, a remarkably broad level country with few prominent landmarks; the lowest portion lying directly along the base of the wall, and affording an easy pass across the range.

Although the main portion of the monntains consists of Tertiary eruptive rocks, earlier formations are exposed along the western foot-hills, which derive their chief interest, and a very important one, from indicating clearly the existence of an older line of upheaval, along which the later volcanic rocks have found vent, reaching the surface in such vast accumulations as to conceal, except over a very small area, the underlying ridges. It is evident, in looking at the geological map and studying these older exposures, that the Tertiary outflows must have followed the lines of pre-existing 
ranges, even where the older ridges are now buried. If, indeed, such evidences were entirely wanting, it would be difficult to understand, unless guided by such upheavals, how volcanic masses like those of the Shoshone, Augusta, and Fish Creek Mountains should form ranges parallel with those of Palæozoic upheaval, and separated by the same meridional depressions which characterize the older formations. The remnants of the older range are represented by granites, followed by uplifted sedimentary quartzites, both having a general north and south trend, agreeing with similar exposures in the Augusta Mountains.

Granite was observed in the Fish Creek Mountains only along the western base, a little northwest of Mount Moses, where it forms the foothills and the entrances to the larger cañons; seldom, however, having an elevation of more than 300 or 400 feet above the valley. It is very irregular in outline, and may be traced for several miles either in prominent conical hills or low ridges and saddles, but the exposures would appear not to extend into the mountains for any distance. This granite is a hard reddish-gray rock, wearing, by atmospheric agencies, into smooth, rounded forms, with all the normal constituents well developed, including dark hornblende and black plates of biotite. It is a structureless mass, and, so far as our observations were made, would seem to be an intrusive body.

East of the granite body occurs the quartzite, where it forms a steep, sharp ridge, considerably broken up and displaced by volcanic intrusions. When unaltered, it is a compact gray rock, with a slightly vitreous lustre, but appears to be much decomposed, as if acted upon by solfataric agencies. Much of it is characterized by a ferruginous earthy material, which in some places acts as a sort of binding material for loose fragments of the original rock. No direct evidence as to the geological age of this quartzite was obtained; but as Triassic rocks are the only sedimentary beds exposed in the upheaval of the Augusta mountains to the southward, and as then somewhat resemble quarzite exposures to the westward, they have been referred upon the geological maps to the Triassic age.

Other isolated exposures of the older rocks may undoubtedly occur, but, so far as examined, the rest of the mountains consist of Tertiary volcanic material, represented by propylites, rhyolites, and basalts. Of these, 
propylite is the oldest, and presents but few outcrops. It is best observed in the basin of Storm Cañon, just east of the quartzite body, where several small lateral cañons, coming down from Mount Moses, unite, forming an open valley. From this valley, the rhyolites have suffered considerable denudation, leaving low, uncovered ridges between the lesser cañons, and irregular bosses of propylite protruding out of the great mass of surrounding rhyolite. That these propylite bodies are connected and represent an older eruptive mass, now buried, there can be no doubt. They are too small, however, to afford evidence of any considerable erosion of the older rocks before the pouring out of the later rhyolite.

This propylite is a characteristic rock, and its behavior, both in the field and in the hand-specimen, clearly indicates its eruptive origin. Under the microscope, the groundmass shows the same habit as the typical propylites of Washoe, and, like them, differs from the more recent rocks by the same resemblances to the older diorites. It has a greenish-gray color, occasionally shading off into yellowish-gray, due in part to the more or less decomposed condition of the hornblende. It presents a somewhat porphyritic appearance, owing to the feldspars, which are frequently a quarter of an inch in length, lying imbedded in a finer groundmass. This groundmass shows a medium-grained rock, compact, and breaking under the hammer with an angular or hackly fracture. A few monoclinic feldspars are associated with the triclinic forms. Hornblende, which has a fibrous structure, gives the prevailing greenish tint to the rock, and appears to be much decomposed. In some of the specimens collected, a few small flakes of biotite may be recognized by the unaided eye. Under the microscope, Zirkel has detected the presence of apatite, some sections of augite crystals, and, in the secondary products arising from the decomposition of hornblende, calcite, with rhombohedral cleavage, epidote, and a dirtygreen substance like viridite.

A careful chemical analysis of the Storm Cañon propylite was made by Mr. R. W. Woodward, who reports the following composition :

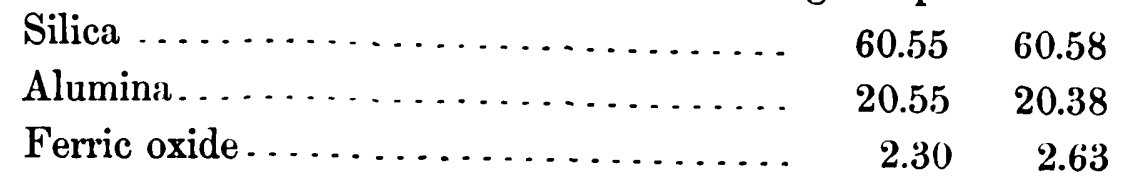


FISH CREEK MOUNTAINS.

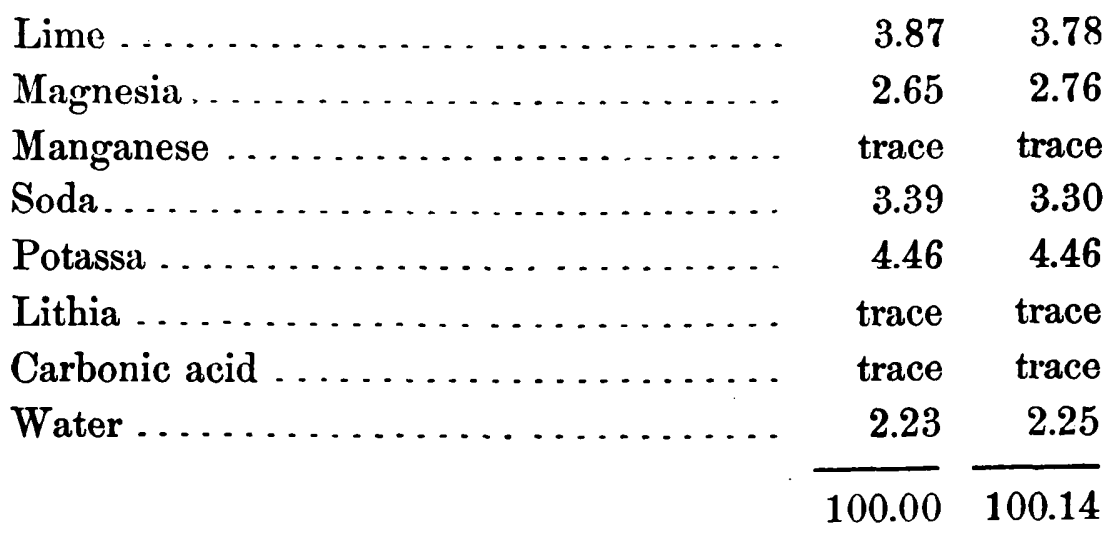

Specific gravity, 2.6, 2.66.

The percentage of silica agrees closely with the type-specimens from the Washoe district; but, at the expense of the lime, the yield of alkalies seems very high, with a somewhat surprising quantity of potassa for a propylite, indicating a relatively large amount of orthoclase-feldspar. It is interesting to note the detection of carbonic acid in the chemical analysis, the microscopical analysis revealing the presence of minute calcite crystals in the hornblende, as already described.

The rhyolite of Mount Moses and the hills to the north and east presents but little variety in its general aspect, and resembles the main mass of the Augusta and Desatoya Mountains. It extends westward in a low ridge to the Havallah Range, eastward to Reese River Valley, and may be traced to the Shoshone Range, being covered only by a thin deposit of Quaternary material in the valley of the river. The greater portion of the rhyolite is characterized by a crystalline granular groundmass, with prevailing gray and reddish-gray colors, more or less discolored by iron, which appears to be derived from minute grains of magnetite. In texture, the rock has a rough, porous habit, disintegrating readily. The most marked feature is the great number of large grains of black quartz scattered through the groundmass, whose color Professor Zirkel has shown, under the microscope, is due to the presence of oxide of iron filling microscopical fissures in the quartz. In general, the sanidin crystals are much shattered, and, where well preserved, appear quite small. As in the propylite, the triclinic forms are accompanied by some monoclinic ones; so here, in the rhyolite, the 
sanidins occur associated with some plagioclase. A specimen in the collection from the summit of Mount Moses may be regarded as a typical one, not only of the Fish Creek Mountains, but of this portion of Central Nevada. A careful study of the rock, together with its microscopical analysis, offers little in addition to what has already been written, though it may be well to state that the groundmass shows a tendency to develop a microfelsitic structure, that the sanidins are particularly well developed, while hornblende and mica appear to be wanting.

Mr. R. W. Woodward submitted the rock to chemical analysis, and obtained the following constituents :

\begin{tabular}{|c|c|c|}
\hline Silica & 75.44 & 75.55 \\
\hline Alumina .... & 13.98 & 13.67 \\
\hline Ferric oxide.... & 0.54 & 0.56 \\
\hline Lime . . . . . . . & 0.50 & 0.51 \\
\hline Magnesia. . . . . . . . . . . . & trace & trace \\
\hline Soda.... & 3.48 & 3.50 \\
\hline 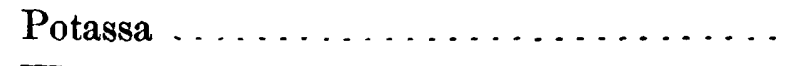 & 5.36 & 5.29 \\
\hline$\ldots \ldots \ldots \ldots \ldots \ldots \ldots \ldots$ & 0.77 & 0.85 \\
\hline & 100.07 & 99.93 \\
\hline
\end{tabular}

Specific gravity,2.48, 2.5.

Although the rock is rich in large quartz-grains, it does not show a higher percentage of silica than is found in many other rhyolites, in which the quartz is less prominent, but finely disseminated through the groundmass.

In the region of Dacie Cañon and the northern end of the mountains, the rhyolites present some features not observed at Mount Moses. Here they possess much less of a crystalline granular groundmass, and instead a microfelsitic one, with a more compact texture, showing a great variety of color. In crystalline secretions, they are comparatively poor, although the same black quartz and vitreous sanidin are easily recognized. In some of the reddish earthy varieties, dark magnesian biotite is also present.

Apparently underlying these more compact varieties may frequently be seen, exposed in the ravines which penetrate the edges of the table, alternating bands of gray, chocolate, red, orange, and purple rocks composed of 
fine ash and earthy beds colored by oxide of -iron. Skirting the western base of the table are a number of low rhyolitic hills and cones, scattered about in a most irregular manner, which are evidently of later origin than the great body of the rhyolite table. They appear to be local centres of eruption, crater-cones through which the last remnants of volcanic material have reached the surface. Two such isolated cones, rising out of the Quaternary plains, one of them nearly 300 feet in height, form prominent landmarks, a sort of gateway to the entrance of Dacie Cañon, and consist of light-gray rhyolitic ash and pumice, held together in a confused manner by a feldspathic binding material. Among these cones bordering the edge of the valley are a number of basaltic eruptions, rarely more than 200 or 300 feet in height, which are evidently later than the rhyolites, breaking through them and forming hard overlying beds. The relation of the basaltic outbursts to the immense mass of rhyolite is very interesting, as they play so small a part in the volcanic activity of the Fish Creek Mountains, only reaching the surface at intervals along a low narrow belt about 7 or 8 miles in length, directly superimposed upon the acidic rocks, and inclined gently toward the valley.

Nowhere is the later age of the basalt more strikingly shown than in two prominent crater-cones rising out of the volcanic débris slope about 5 or 6 miles to the southward of the extreme northern end of the mountains. These cones present a very symmetrical outline, with a nearly circular base, and steep, but regular, slopes. The lower two-thirds of the cones consist of light-gray rhyolite, while the summit is composed of dark basaltic rock, which, after the rhyolite had ceased to pour out, reached the surface through the same vents, building up the cone originally formed by the earlier flows. The contrast between the two varieties of rock is very distinctly marked, the basalt extending down the slope over the rhyolite in . well-defined beds. From the mouth of one of these craters, the last outburst has been a porous basaltic lava, which has not only poured down the sides of the cone, but has run out for a quarter of a mile on the plain. As the surface of the lava is free from all soil and vegetation, while the surrounding rhyolitic débris is partially covered with a growth of bnuch-grass and scrubby sage-brush, the impression received is one of very recent volcanic activity. 
From its mode of occurrence in direct contact with the acidic rhyolites, this basalt merits special mention. In its superficial physical aspect, it resembles an ordinary scoriaceous basaltic cinder, with a very cellular sponge-like structure and grayish-black color. When struck with a hammer, it emits a clear ringing sound, and fractures like a rock rich in a glassy or halfglassy base. The most striking lithological feature of the rock is the occurrence of large white vitreous feldspars an inch or more in length imbedded in the dark base. No other mineral constituents have been recognized by the unaided eye. Professor Zirkel has shown, under the microscope, in polarized light, that the large feldspar crystals are wanting in the characteristic striæ, and suggests that they may be sanidin. But, on the other hand, all the smaller microscopical feldspars are without doubt plagioclase, the base being made up of triclinic forms associated with augite. No olivine or other minerals can be detected, even under the microscope. The occurrence of such large, fresh sanidin crystals in a basaltic lava is in itself somewhat exceptional, but the interest is heightened by finding them in a rock which has poured through a rhyolite cone rich with secretions of the same feldspar. It seems highly probable that they may have been derived from the older rock, being caught up by the liquid lava and held intact as an accessory constituent, a view which finds support in their mode of occurrence.

There should be mentioned in connection with this volcanic region two localities of warm springs, situated in the valley to the westward of the Fish Creek Mountains, which come to the surface on the border of a broad Lower Quaternary plain. The water is clear, and, when cold, palatable; the temperatures were not ascertained.

Battle Mountains. - The Battle Mountains lie on the west side of Reese River Valley, directly west of the 117th meridian, and opposite the highest portion of the Shoshone Range. They occupy but a small area, and, although Sue Peak and Antler Peak rise nearly 4,000 feet above the Humboldt Valley, the group is not more than 16 miles in length by scarcely 12 in width, and both geographically and geologically stands in a somewhat isolated position. On all sides, the group is surrounded by broad, open Quaternary plains, which northward stretch far beyond the limits of the map. 
They are separated from the Shoshone Range by a wide meridional depression, and from the Fish Creek Mountains by a low arid valley.

Although the group thus occupies an isolated position, it lies directly in the trend of the Augusta and Fish Creek Mountains, and topographically would appear to be a prolongation along the same line of upheaval, forming but one range, a counterpart to the Shoshone, the next range to the eastward. As already described, the Shoshone Range in the southern portion is found to consist mainly of rhyolitic flows along a line of older crystalline rocks and sedimentary uplifts, and that in the neighborhood of Carico Lake they abut against a massive series of highly-inclined quartzites and quartzitic schists dipping to the eastward. To the westward, in the Augusta and Fish Creek Mountains, the same volcanic accumulations are found forming the great mass of the range, and concealing in a similar manner the older underlying rocks, which reach the surface in but few localities along a continuous line for over 70 miles. But to the north, the rhyolites, unlike those in the former range, terminate abruptly without reaching the Battle Mountains, which in many respects resemble in their geological structure the northern end of the Shoshone Range.

The Battle Mountains are for the most part made up of heavy beds of dark quartzites and quartzitic schists, slates, sandstones, and cherty beds, overlaid by beds of dark bluish-gray limestone.

These strata, wherever observed, dip to the westward, that is, in the opposite direction from the beds of the Shoshone Range, and the two masses would appear to form a broad anticlinal fold, whose axis lies in the depression now occupied by Reese River Valley. In their main lithological characteristics, the beds represented in the Battle Mountains resemble those from the Shoshone Range, although a close correspondence of the two series has not been worked out, and some peculiarities of composition recognized in the Battle Mountain rocks have not as yet been observed in the former range; but, as nearly all the strata are more or less altered and metamorphosed, an exact correlation of beds could only be obtained by careful examination. From the evidences derived from the structural position of these beds, and from the fact of finding in the overlying limestones several 
species of Coal-Measure fossils, the formations have been referred to the Weber Quartzite and Upper Coal-Measure series.

The main cañons of the Battle Mountains do not cut the formations at right angles to the strike, but obliquely, as at the northern end, or else parallel with them, as is the case with Willow Cañon and the cañon next eastward, thus offering exposures far less complete and satisfactory than is usually to be found in the Nevada Basin ranges. Willow Cañon and the cañon next to the eastward divide the southern end of the mountains into three parallel ridges, with distinct lithological features. To the north, in the centre of the mass, these ridges are united by low saddles, which connect with Antler Peak, a heavy mass of the overlying limestone. Beyond Antler Peak, to the north, the ridge-system is lost, and the hills are separated somewhat from the rest of the group by Elder Cañon, which trends off to the northwest between Antler and Sue Peaks, and heads in a broad open valley to the east of the latter summit.

Sue Peak and the high ridge to the eastward, with the steep slopes toward the Humboldt River, so far as examined, consist of dark fine-grained cherty quartzites, distinctly bedded, and dipping to the westward. They differ somewhat from the quartzite beds east and southeast of Antler l'eak, and may possibly belong to an older unconformable formation; but, as their point of contact was nowhere observed, and as the structural relations between them have not been traced out, it is impossible to state definitely the true relation of the two bodies. From the Battle Mountain mining settlement southward, the eastern ridge dips uniformly to the west, and is made up of brown and dirty-gray quartzites, speckled with bluish-black angular grains. They have a decidedly arenaceous texture and an irregular fracture. Under the microscope may be detected fragments of feldspar, which in some localities are of sufficient size to be recognized by the unaided eye. Associated with the quartzites are dark quartzitic slates and schists. Near the top of the ridge, the beds pass into sandstones of a dirty-brown color, more or less discolored by iron, and carrying numerous flakes of white silvery mica. A prominent stratum consists of a coarse conglomerate of quartz and jasper pebbles, held firmly together by a binding material of fine ferruginous sand. The middle ridge lying east of Willow Cañon has a strike about north 
$15^{\circ}$ west, the beds dipping at a high angle, and near the head of the cañon are much disturbed, and give evidence of having undergone considerable displacement. All the beds are highly siliceous, and are characterized by a bluish-black cherty quartzite having a conchoidal fracture and resinous lustre. They closely resemble similar beds, already described, from the Shoshone Range, in the region of Ravenswood Peak and Reese River Cañon, which were also referred to the Weber Quartzite.

The third ridge forming the western slopes of the mountains is much broken up by rhyolitic outflows, which have not only disturbed the strata through which they penetrate, but have in a measure concealed them below the heavy accumulations, thus destroying the continuity of the formations. The beds, which have a general strike of north $15^{\circ}$ west, with a dip of $40^{\circ}$ to $50^{\circ}$, consist of dark bluish-gray quartzitic schists and slates more or less argillaceous, of a compact texture, and usually thinly bedded. In the cañon directly west of Antler Peak and north of the large rhyolitic mass, these beds are well exposed, forming high abrupt walls, with a strike of north $15^{\circ}$ to $20^{\circ}$ west, and a dip of $35^{\circ}$ to $40^{\circ}$. A specimen from these quartzitic beds, subjected to analysis by Mr. R. W. Woodward, yielded the following:

Silica

Alumina

Ferric oxide

Magnesia ............................. 2.41

Soda................................. 0.31

Potassa . . . . . . . . . . . . . . . . . . . . . . . . 0.22

Water............................. 1.98

98.73

Overlying the quartzites occurs a narrow belt of dark-gray limestone, extending down to the Quaternary plains. A diligent search was made for organic remains, but without success.

Antler Peak is formed entirely of Carboniferous limestones. It occupies a somewhat singular position at the head of Willow and Duck Cañons, but its true relations with the surrounding quartzites were not clearly made out. All the limestone beds are inclined invariably to the westward, although 
apparently much broken up and folded; on the summit of the peak, they dip $30^{\circ}$ to $35^{\circ}$, while on the ridge, running out to the southward, recorded dips indicate in one locality $15^{\circ}$ and in another $20^{\circ}$. These beds extend from the summit of the peak to the very bottom of Willow Cañon in a nearly perpendicular wall, exposing about 1,200 feet of heavily-bedded dark-gray limestones, in places somewhat shaly and of lighter bluish-gray tints.

At the base of the limstone in Willow Cañon were found the following Carboniferous forms :

\section{Productus semireticulatus.}

Productus Prattenianus.

Eumetria punctulifera.

Athyris incrassata.

About 100 feet below the summit of the peak, and separated from the last locality by about 1,000 feet of limestone strata, were obtained several Carboniferous fossils, but of entirely distinct generic forms. The beds yielded:

\section{Fusilina cylindrica. Campophyllum, sp.?}

Organic remains belonging to Carboniferous horizons have been found, within the belt of this survey, in nearly every mountain uplift from the Laramie Hills westward to Battle Mountains, and it is of special interest to note here that the latter is the most westerly mountain group within the limits of the Fortieth Parallel Survey where a development of Carboniferous rocks has been identified, as from here westward to the Sierra Nevada in California no post-Archæan beds have been recognized as older than the Triassic.

In the same trend with the limestone belt that skirts the western foothills occurs a small body of limestone, lying out in the plain east of Elder Creek, which apparently forms a low dividing ridge between the Humboldt Valley and the valley to the south. This limestone is almost entirely concealed beneath the Quaternary detritus, and was only hastily examined. No fossils were found, but it has been, with the other limestones of the 
Battle Mountains, referred to the Carboniferous, although with some hesitation, as it lies so near the western limit of the Carboniferous formations.

Along the eastern foot-hill, the beds are traversed by a number of interesting mineral veins, which have been worked extensively in previous years. There would appear to be two distinct mineral belts, the one rich in argentiferous galena, with associated products of decomposition, together with some zinc and antimonial minerals, while the other is characterized by copper-bearing minerals, chiefly red and black oxides of copper, carrying some native metal. Blue carbonate and silicate of copper may also be recognized.

The volcanic outbursts of the Battle Mountains occupy a comparatively small area, but are represented both by rhyolites and basalts, breaking out both along the foot-hills, where the sedimentary strata rise abruptly out of the plain, and, what is somewhat exceptional, in the centre of the uplift, shattering and displacing the older Palæozoic ridges. Rhyolite, as in the broad area to the south, is the prevailing rock, and is also of the same normal type which characterizes the Fish Creek and Augusta Mountains. The most interesting locality is found on the west side of Willow Cañon, where it forms a broad table-topped ridge, showing precipitous walls toward the cañon, with no evidences of flow or bedding, and on the summit of the ridge no signs of domes or bosses, as is seen in the Fish Creek Mountains. The face of the cañon-wall presents a rather uniform appearance, with only the marked shadings and variations in color so characteristic of rhyolitic eruptions. In habit, the rock exhibits a compact microfelsitic structure, and in places develops a tendency to a lithoidal texture; in color, reddish-gray and pink are the prevailing tints, with irregular masses of a deeper purplish-red. Individualized minerals, with the exception of quartz, which occurs in large, broken, translucent fragments, are rare; the feldspars are nearly all fragmentary.

On the west slopes are one or two outbursts of rhyolite in the limestone, which would appear to be along a line of fissure parallel with the strike of the beds. The rock differs in no way from that already described. At the northeast corner of the Battle Mountains, a group of irregular rhyolite hills rises several hundred feet above the Humboldt River. They present but little of special interest either in structure or lithological aspect 
from the adjacent outbreaks, with the same colors and texture. In one or two localities, well-developed plates of black mica are abundant.

In the extreme southeastern corner of the mountains occurs a body of basalt which projects out in a prominent manner toward Reese River Valley. It forms a distinctly bedded, compact mass of a fine-grained black rock, in which, without the aid of the microscope, it is almost impossible to recognize the individual mineral constituents.

Near the entrance to Elder Cañon is found a small unimportant outcrop of diorite. It appears to be an isolated exposure, and derives its main interest from its relations to, and in some measure explaining the occurrence of, the cross-ridge connecting the Battle Mountains with the Havallah Range. It is of a dirty light-gray color, with a fine-grained crystalline groundmass, carrying but few well-developed minerals, and is by no means a characteristic diorite. Both monoclinic and triclinic feldspars are present, and, in the specimens collected, have a dull earthy appearance. Hornblende is abundant in long fibrous needles. Bronze-colored mica plates may also be detected. 


\section{SECTION IV. \\ HAVALLAII AND PAП.UTE RANGES.}

BY ARNOLD HAGUE.

Havallair Range.-This range, situated to the westward of the Fish Creek and Battle Mountain groups, is connected with the former by a narrow outburst of rhyolite, and with the latter by a low obscure ridge, apparently made up of Palæozoic strata. The range extends southward from the Humboldt River, a few outlying hills, however, appearing on the northern side, for over 60 miles, where it falls away in a long low point of volcanic rocks, running out toward the depression known as Osobb Valley. The southern portion forms a narrow single ridge along a nearly north and south line until opposite the lower end of the Battle Mountains, where it bifurcates, the main uplift extending to the northwest, while the lesser one trends a few degrees east of north, the two being separated by a high Quaternary valley 3 or 4 miles in width. Across its narrowest portion, the range, although having a high elevation, scarcely measures 5 miles in width, while its broadest expanse reaches, including the intervening valley, nearly 22 miles.

Signal Peak, at the northern end, is the culminating point of the range, attaining an elevation of 9,387 feet above sea-level. It stands out prominently above the surrounding country, and affords, from its summit, one of the most commanding views in all directions to be found in this portion of Nevada. Westward the view extends through a low gap in the Montezuma Range, across the Mud Lake Desert, to California; eastward, across the Shoshone Mesa, and up the valley of the Humboldt River; and southward to the extreme end of Osobb Valley.

Southward fiom Signal Peak, the ridge falls off gradually to Bardmass Pass, below which it gently rises, and, where the east and west uplifts come together, forms a bold mountain mass as far as Tobin Peak, just north of Golconda Pass. In comparison with most Western Nevada ranges, $43 \mathrm{D}$ G 
water is found in abundance, nearly every large cañon furnishing a considerable stream, which is due partly to the width of the more elevated regions, but, in part, to the great diversity of geological structure, with its folded and crumpled strata inclined in various directions. Timber is scarce even on the higher slopes.

Large masses of granite, probably of Archxan age, represent the oldest rocks of the Havallah Range. These are directly overlaid either by immense bodies of heavily-bedded quartzites, or else by still later beds of limestone, with some intercalated beds of quartzite and sandstone; the entire series, which constitutes nearly all the higher portions of the mountains, and forms a continuous body for 85 miles, being referred to the 'Triassic age, as no Palæozoic strata have been recognized west of the Battle Mountains. Breaking through the granites and Mesozoic formations are occasional narro'w dikes of diorite, and still later, more extensive outbursts of Tertiary volcanic rocks, represented by propylites, trachytes, rhyolites, and basalts.

The large granitic masses are confined to two distinct bodies, at the northern end of the range, separated by a broad Quaternary depression, at no point less than 3 miles wide, known as Ragan's Valley. On the east side of this valley, the granite forms a bold ridge nearly 15 miles in length, but barely more than 4 miles in width, with a trend approximately northeast and southwest. It rises from 2,500 to 3,000 feet above the recent beds, which surround its base, and is characterized by a broken serrated crest with great diversity of outline, quite unlike most of the granitic bodies of Central Nevada. To the northward, it falls away gradually, until concealed beneath the Quaternary of the Humboldt Valley; while to the southward it descends to Summit Springs, scarcely 500 feet above the plain, where it is overlaid by heavy sedimentary beds, which have been referred to the horizon of the Star Peak group, and will be described further on. The springs which give the name to the pass occur at the junction of the two formations.

This granite has much the physical attitude of many of the Archacan granitic bodies observed in the Colorado Range of Colorado and Wyoming. It is a structureless mass, without well-defined lines of bedding, of coarsegrained rock, with a loose friable texture, crumbling readily into irregular- 
shaped fragments. - The prevailing color is a dull earthy gray. It is made up of quartz, feldspar, mica, and some hornblende. The quartz occurs usually in small grains of a dark-gray color, well disseminated through the mass, brit rarely as prominent as the feldspar. Both monoclinic and triclinic feldspars are present, although the former are the more abundant; many of them are well developed, and measure 2 and 3 inches in length, with broad tabular faces and a brilliant lustre. Mica is present as biotite in small dark plates that decompose readily. The hornblende, always in small crystals, is dark green in color, but, in the greater part of the rock, is a very subordinate constituent. In the interstices between the larger crystals and on the broader faces of the feldspars are frequent coatings or thin layers of reddish oxide of iron, which give to the granite an altered appearance, and undoubtedly cause the characteristic weathering.

Under the microscope, Zirkel has detected in thin sections of the rock large numbers of minute apatites, and inclosed in other crystals particles of magnetite, and what he regards as probably muscovite. The microscopical examination of the feldspars of this granite is of special interest, and they present many striking and varied peculiarities in the composition and arrangement of the enclosed minerals and microlitic needles. A detailed description of these phenomena will be found in Zirkel's report, ${ }^{1}$ accompanied by illustrations. He also shows the close analogy in microscopical structure between these feldspars and those with a somewhat similar habit from a syenite in Southern Norway. The quartz crystals of this granite are of interest, as three distinct forms of liquid-inclusions have been observed: first, simple aqueous inclusions, with a bubble; second, simple carbonic-acid inclusions; third, those containing both water and fluid carbonic acid.

North of Summit Springs, and on the east side of the range, occurs a narrow dike of intrusive granite, which has cut through the older body, and is therefore evidently of later age. As already mentioned, the large body of granite appears to possess many features in common with the Archæan granite of the Rocky Mountains; but this dike, on the other hand, although we have no structural evidences of its age otherwise than its being subsequent to the main mass, bears a close resemblance to those eruptive bodies

${ }^{1}$ Microscopical Petrography, vol. vi, 45. 
that have been regarded as most probably of Jurassic age, and this reference is, in a measure, borne out by both the physical and mineralogical habit of the rock. This association of two distinct types of granite has consirlerable interest, as in our observations in Nevada the occurrences of one granite breaking through, and in close contact with, an earlier mass of very different composition was noticed in only few localities.

This granite dike is a comparatively fine-grained rock of a uniform texture, breaking with difficulty under the hammer with an uneven surface and angular fracture. The constituent minerals all have a fresh undecomposed appearance. In color, the rock is dark gray. It is made up of quartz, feldspar, mica, and considerable hornblende as essential minerals, while under the microscope may be detected distinct crystals of titanite. The rock, indeed, comes under the head of those classed as hornblende-titanite granites, so common in Western Nevada. The quartz is abundant in clear translucent grains. Both monoclinic and triclinic feldspars are present, the latter in a relatively large proportion, white in color, and of a vitreous lustre. Biotite and hornblende crystals are associated together; the former seem almost black, while the latter are dark green, with a fibrous structure. Under the microscope, the quartz crystals of this rock show an immense number of fine hair-like microlites, a common plienomenon, but very marked in this case. Zirkel has estimated that within the limits of one square millimetre, almost in the same plane, there are one hundred and twenty of these hairs, which would give, in the small space of one cubic millimetre, no less than ten thousand of these microlitic bodies, really a remarkable observation. Besides the above, the quartz holds many liquid-inclusions, carrying very perfect crystals of chloride of sodium, and in one section, figured on Plate 1, fig. 4, accompanying Professor Zirkel's report, may be seen both salt cubes and the dark microlites in the same inclusion. Narrow dikes of diorite also penetrate the large body of granite. Those observed were within two or three miles of Summit Springs. They are usually fine grained, and composed mainly of dark-green hornblende and triclinic feldspars, with but little variety either in texture or composition.

On the west side of Ragan's Valley, the granite occupies a somewhat smaller area than to the east, and attains a much lower altitude, reaching in 
but few isolated points 1,000 feet above the Quaternary gravels, which skirt the base. Both to the north and south it is overlaid unconformably by the sedimentary beds referred to the Star Peak Triassic. But little opportunity was afforded for the proper examination of this body; it may be said, however, in its general habit and modes of erosion to resemble the mass of granite upon the opposite side of Ragan's Valley, if, indeed, they do not form a continuous body broken on the surface by a thin deposit of fine Quaternary material. It is perhaps a little more compact, and of a deeper red color, owing to the prevailing dark tints of the orthoclase-feldspars, and shows distinct structural lines of bedding, with a dip toward the west.

At the southern end of this granite, and just north of Gold Run Creek, occurs a dike penetrating the older formation. It is between 20 and 30 feet in width, stands nearly vertical, with a strike approximately north and south, and in its habit resembles basaltic outbursts, which are found protruding through the granite in the same region. This rock has, however, a somewhat singular composition, differing mineralogically from all other eruptive rocks in our collection. 'It is very dense, with a high specific gravity, and develops but little tendency to decomposition. The cryptocrystalline groundmass is so fine that to the unaided eye it reveals scarcely anything of the interior structure, but scattered through it, porphyritically enclosed, are broad crystals of beautiful dark-green fibrous hornblende, with occasional segregated patches of minute mica flakes. The microscope shows that the groundmass is made up almost exclusively of fine quartz and hornblende, the latter frequently appearing as if distributed through a base composed of the former mineral. The presence of hornblende in so large proportions renders it impossible to relate the rock to any member of the basaltic group, while, on the other hand, the almost complete absence of feldspars makes its reference to any variety of eruptive rock equally insecure.

The basalts penetrating the granite are mostly small outbursts, which form narrow dikes or irregular-shaped bodies capping the older formation. Like the granite, the inclination of the basaltic flows is to the westward. $\Lambda$ specimen in the collection from here shows a tough dense rock, breaking 
under the hammer less readily than most basalts, with a rather sharp angular fracture. Under the inicroscope, the thin sections reveal but little glass-base, which is unusual in the basaltic rocks of Nevada, and accounts for its different physical habit. It has rather a fine-grained fresh-looking groundmass of augite and triclinic feldspar, the latter occurring as brilliant thin needles. There is some olivine in the rock.

One other locality of granite was observed in the Havallah Range; it is possible that others may be present, but, if so, they occupy a very limited area. This one occurs along the west base of the range, rising but a few hundred feet above the valley; it reaches the surface a short distance soutl of the entrance to Clear Creek Cañon in a conical hill, and from there may be followed along the foot-hills for 4 or 5 miles nearly to Bardmass Pass. It is characterized by a hard compact texture and a prevailing purplishgray color. It carries as essential mineral constituents both orthoclase and oligoclase, the latter less prominent, but frequently marked by very beautiful characteristic striæ, limpid quartz-grains of considerable size, and darkgreen hornblende, but proportionally little mica.

The post-Archæan sedimentary beds of the Havallah Range in many respects differ widely from those already described in the ranges to the eastward, but, on the other hand, are closely allied to formations found in the Pah-Ute and West Humboldt Ranges to the westward, the three ranges taken together forming quite a distinct geological province. Nowhere in Western Nevada have the Carboniferous and Triassic strata been recognized in direct connection with each other in the same uplift, and, in ranges standing as isolated as they do in the Nevada Basin, it is difficult to relate formations separated by broad valleys from 5 to 10 miles in width, and covered by Quaternary deposits. It is possible that Carboniferous rocks may be present in the Havallah Range, but they were not recognized as such, while there is no doubt that, at least in one locality, Triassic limestones form the foot-hills along the western base. With this exception, however, there has been as yet but little direct evidence obtained as to the age of these formations in the Havallah Range, and their reference to the Triassic is based more upon their broader, general features and lithological comparisons than upon either palæontological or structural proofs. In this connection, it is especially 
noteworthy that no Carboniferous rocks have been recognized west of the Battle Mountains and no Mesozoic ones east of the Havallih Range.

The granite body stretching out to the northeast on the west side of Ragan's Valley is overlaid about 3 or 4 miles south of the Humboldt River by a series of limestones and intercalated calcareous and argillaceous shales and slates. The strike of these rocks is about north $30^{\circ}$ east, and their general structure that of a synclinal, through whose axis there has broken out a mass of propylite. Microscopically, this propylite contains a little quartz, and has been classed by Professor Zirkel as a quartz-propylite, but the quartz seems to be a purely accidental ingredient, or else occurring in segregations, and is not generally diffused through the mass. A remarkable feature of the rock is the presence of liquid-inclusions in the quartz-grains. The rock closely resembles in habit and texture the hornblende-propylite of Washoe, and has therefore been colored as a propylite on the geological maps.

An analysis of this rock was made by Dr. Walter Kormann in the laboratory of the University of Leipzig, with the following result:

Silica.

Alumina

Ferric oxide

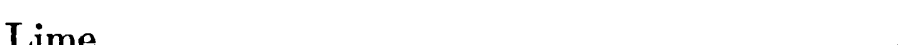

Magnesia .............................

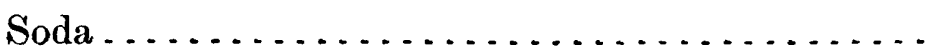

Potassa...............................

Carbonic acid.

W
66.336

14.803

4.068

2.991

100.809

It will be seen, by comparing this analysis with the well-known propylite from Washoe, that it stands at least 6 per cent. higher in silica, but is at the same time several per cent. lower than the normal quartz-propylites of the Virginia Range. The amount of carbonic acid and water present would indicate that the rock has undergone considerable decomposition. 
In the eastern member of the synclinal, irregular dips, twists in the strike, and all manner of local short flexures are observed in the calcareous shales and blue slates, which, however, have a general western dip. $\Lambda$ t their eastem base, to the south of the Emigrant Road, there is a tabular outcrop of black, vesicular basalt, which is highly crystalline, and contains unusually large cavities, which sometimes reach two inches in diameter. The westem member of the synclinal presents the same features of local contortion and irregular metamorphism, but has a prevailing easterly dip, with a strike about $15^{\circ}$ to $20^{\circ}$ east of north. The rocks of this series are best seen in the cañon of the Humboldt River between Iron Point and Golconda Stations. Here they dip at an angle of $45^{\circ}$ to the eastward, and cross the cañon diagonally, so that it is difficult to make an accurate estimate of the thickness exposed. The lower beds are fissile shales, generally of yellowish color, much stained by iron, of which there are about 500 feet in thickness exposed at the eastern mouth of the cañon. Above this are 50 feet of blue, earthy limestones, seamed with veins of white calcite. These are succeeded by 150 feet of partly calcareous, iron-stained shales, which are overlaid by 100 feet of black, compact limestone, and succeeded by another series of shales and other blue limestones, whose thickness could not be determined. No fossils were found in these beds; but, from their lithological character and position, they undoubtedly represent the Star Peak Triassic. Their general dip is $45^{\circ}$ to the eastward. They are underlaid in the hills to the north of the river by greenish clay slates, very much contorted, to a thickness of several hundred feet, below which is 1,000 feet of greenish-whito quartzite, in compact, heavy strata, referred to the Koipato series.

These quartzites are covered on the westem flanks of the range by broad, tabular flows of basalt, which slope gently to the westward. In the which, near the mouth of the of these hills are occasional outcrops of basalt, mucca, form a little cañon, through which the river flows beft of Winnemain stream. This rock is a rather porous, crystalline dolerite, having somewhat of a reddish tinge, and normal composition, together with numerous small crystals of olivine and magnetite. 'To the naked eye, it scems to be an entirely crystalline mass, but an examination with the microscope shows a 
fow globulitic, amorphous particles, like the basalt breaking through the granite already described.

The massive beds of the main portion of the range appear to have undergone considerable displacement and folding, producing a number of local synclinal and anticlinal axes, which renders the structure somewhat complicated and difficult to work out; the broader features, and many of the details, however, will be found in the following short description. West of Ragan's Valley, the main mountain-mass consists of the underlying quartzite, which forms the summit of Signal Peak, falling off rapidly to the north, but extending southward for about 15 miles in a roughly diamond-shaped body. It rises rapidly above the surrounding foot-hills, frequently with steep walls, and has a broad, gently inclined, table-like summit, which is divided into two ridges, separated by the cañon and basin of Clear Creek. The eastern ridge dips to the eastward, and the one on the opposite side, which is the higher, probably dips to the westward, although our observations are somewhat contradictory. Such a structure would give an anticlinal fold to the quartzite, the deep cañon of Clear Creek lying in the axis, and in a great measure accounts for the trend of the cañon being approximately parallel with the strike of the quartzite beds.

This quartzite, which is distinctly bedded, possesses a vitreous lustre, a compact texture, and a bluish to steel-gray color. It is an exceedingly dense, tough rock, breaking under the hammer with a conchoidal fracture. Under the microscope, the quartz-grains are seen to vary greatly in size, and to present smooth rounded surfaces. Specimens from two localities show that the grains carry large numbers of fluid-inclusions.

The beds have been referred to the Lower 'Triassic, or the horizon of the Koipato quartzites. It is not quite clear, however, that they underlie conformably the Star Peak Triassic, and they may belong to a much older formation, possibly of the same age as the dark quartzite beds of Sue Peak in the Battle Mountains, the true position of which is somewhat doubtful.

Overlying the quartzite body on all sides, forming the foot-hills, are the blue limestones, with the interstratified beds of sandstones, slates, and shales. On Gold Run Creek, between the quartzite and granite, the beds consist of highly metamorphosed siliceous slates, much folded and twisted, dipping 
into the range away from the granites. Higher up the ridge, and 2 or 3 miles to the southward, the beds in the region of a large trachyte outburst dip eastward. North of Gold Run Creek, the same beds are structurally of little importance, and are for the most part concealed beneath extensive flows of rhyolite, which have broken through them, and now terminate the range to the northward. The only mining operations in the range are centred in the region of Gold Run Creek, along a prominent quartz-vein, in the siliceous slates, which is said to have been traced for more than 3 miles. It dips to the westward at an angle of $30^{\circ}$, and, where developed, shows welldefined foot and hanging-walls, with marked uniformity of strike and dip. The ore consists mainly of oxidized products, with but few well-defined mineral species. A short description of the mining operations in the district will be found in "Mining Industry", Vol. III of this series.

At the extreme northwestern end of the range, due east from Winnemucca Station, the Triassic beds again come up from beneath the rhyolitic rocks, and at White's Cañon consist of limestones, with interstratified beds of calcareous shales and some white quartzites, having a strike of north $30^{\circ}$ east, and a dip of $45^{\circ}$ to the eastward. In Sonoma Cañon, very similar beds of slate, with bluish-white quartzites and siliceous felsites, are exposed, striking north $15^{\circ}$ west, and dipping $35^{\circ}$ to $40^{\circ}$ to the westward, but increasing in the angle of inclination toward the interior of the range, until just above the forks of the canion they stand nearly vertical. Above the junction of the two forks, the beds show considerable displacement, with an obscure structure, and have been fractured by intrusions of rhyolite. This latter rock presents an ash-gray color and microfelsitic groundmass, characterized by translucent quartz-grains, showing but little mica or welldeveloped feldspars.

In the foot-hills just north of Sonoma Cañon, the strata, which consist of dark-blue heavily-bedded limestone underlaid by fine-grained quartzite, are seen dipping eastward into the range, with a strike of north $8^{\circ}$ to $10^{\circ}$ west, and apparently forming a synclinal fold with the canon rocks. In this limestone was obtained the only fossil found in the range, Halobia dubia, a characteristic Triassic species, abundant in the Star Peak beds in the West Humboldt Range. Below Sonoma and Clear Creeks, the ridge 
exposes very similar interstratified beds dipping westward; but to the south of the latter stream, the small body of granite already described comes in, and the beds under its influence probably again dip toward the centre of the range.

From Bardmass Pass southward, the Upper Triassic beds, no longer subjected to the influence of the underlying rigid quartzite, extend from Grass to Ragan's Valley with low gentle rolls, forming a synclinal and anticlinal fold. At the western entrance to the pass, a gray compact sandstone overlaid by limestone is exposed, dipping eastward, which soon assumes a reverse dip, while along the eastern base an anticlinal axis exposes the sandstone in smooth, rounded, grassy hills with few outcrops, inclined again to the eastward, but with the limestone, which has been for the most part carried away by erosion, occurring only in small isolated patches.

On the opposite side of Ragan's Valley, the beds form a steep cliff to the west, but incline eastward with gentle angles, shallowing in dip till the limestones of the summit lie nearly horizontal. A short distance to the southward, near Pollard and Dale Cañons, the two distinct ridges come together, and form a single narrow range of highly metamorphosed slates, shales, and schistose quartzites, and in place are so much altered by twistings and flexures as to resemble eruptive masses in their great variety of color and rapid change in physical aspect. Many of the rocks have a scoriaceous cinder-like appearance, and might easily be mistaken for voleanic products but for their parallel and banded structure in broad masses, and the evidences they afford of transition from well-developed slates and quartzites. The strike of the beds agrees approximately with the trend of the range, varying from north $5^{\circ}$ west to north $10^{\circ}$ east. In dip, recorded observations gave from $15^{\circ}$ to $30^{\circ}$ to the west.

An interesting geological feature of the range, which is evidently closely related with the complicated structural conditions of the sedimentary strata, is the occurrence of numerous narrow dikes of diorite in the region of Dale and Pollard Cañons, standing at high angles, and nearly parallel with the strike. They vary considerably in texture and superficial aspect, but in mineral composition exhibit the same constituents, mainly plagioclase and more or less altered fibrous hornblende. One variety has a dark-green color, 
a uniform fine-grained groundmass; but with brilliant particles of iron pyrites scattered through the rock. Another dike exposed in the steep walls of Dale Canon presents a rather striking contrast with the one just described, having a light-green color, owing to the feldspar greatly predominating over the hornblende, which occurs in altered fibrous needles. There are some quartz-grains scattered through the groundmass. Under the microscope may be detected apatite in slender needles. Under the hammer, these rocks all exhibit much the same character, breaking with difficulty in a manner indicating a dense tongh groundmass rarely met with in Tertiary volcanic products, and quite unlike the microfelsitic rhyolites, or rocks like the basalts rich in amorphous glass-base. It is impossible for one familiar with the habit of rock-masses, and who has studied them in the field, not to recognize marked distinctions in the behavior of rocks under the blows of a hammer, distinctions which may be subtle and difficult to explain, yet subsequent analytical work shows that they were based upon fundamental differences in the rocks, and that the field impressions were correct.

To the Tertiary volcanic rocks of the Havallal Range, frequent allusion has already been made. They consist mainly of rhyolites, but there is one outburst of trachyte that calls for some sperial mention. It is situated just south of Gold Run Creek, high up in the range, at the junction of the older quartzites with the Star Peak beds, where it forms a north and south ridge 3 or 4 miles in length, with several peaks and cones rising above the general level. The inclination of the mass is to the eastward. The rock is a quartz-bearing trachyte. It possesses a light-gray color, a highly porous trachytic texture, and closely resembles the typical variety from the famous Drachenfels on the Rhine. The sanidin crystals are finely developed, frequently an inch and one-half in length, with broad tabular faces, but most of them are shattered and broken. Minute flakes of dark magnesian mica are everywhere scattered through the groundmass. The quartz appears to be segregated in large macroscopical grains as an acces-
sory mineral.

The main bodies of rhyolite are found at the extreme northern and southern ends of the range, coming to the surface where the long uplifts of Mesozoic strata plunge rapidly downward. Here, as if at points of greatest 
weakness, the rhyolites have been forced out in large massive eruptions in direct contact with the older beds, high up in the range, and extending down to the Quaternary plains below. At the north, they occupy the re-entering angle lying between the granite and the Triassic uplift, falling away in low broken hills to the Humboldt River. Wherever examined, the rock presented much the same general appearance in texture, color, and mineral composition, possessing a groundmass varying from microfelsitic to microgranular, with but little well-developed sanidin, mica, or hornblende. In color, it varies from light gray to reddish gray, the red tints appearing as if caused by some decomposition product, which the microscope shows to be derived from minute grains of ferrite.

West of Fairbank's Point, on the extreme northern foot-hills, near the Humboldt River, is an isolated outcrop of quite a singular rhyolite. It is a coarse-grained crumbling rock of light pearl-gray color, made up of large crystals of sanidin and cracked quartz, with scattered hornblende particles in a micro-crystalline groundmass. It may possibly be related to the quartzbearing trachyte south of Gold Run Creek, a reference which seems all the more probable as it bears a close resemblance to the quartziferous trachyte of White Rock in the Cedar Mountains of Utah. Under the microscope, its groundmass is seen to be entirely crystalline, and made up apparently of quartz and feldspar, containing also microscopical hornblende, mica, and apatite.

At the southern end of the range, the rhyolite forms a long narrow ridge rising in places nearly 2,000 feet above the level of the valley, which, across its broadest portion, scarcely measures four miles. The ridges follow exactly the trend of the main uplift, and a marked instance is afforded of the close relation existing between the older lines of upheaval and the volcanic activity of the Tertiary age; for it is indeed somewhat remarkable that such an immense mass of intrusive material, as is here exposed, should be thrown up and confined within such narrow limits. This rhyolite, wherever visited, scarcely differs in its general habit from those bodies already described in the range; it is, perhaps, more compact, with the fluidal structure in places well shown, and, as a result of this compactness, weathering has frequently produced sharper and nore angular forms, 
developing steep cliffs and precipices not unlike the outlines of many granites. The same reddish tints observed characterizing the rhyolites to the north may be seen here. The extreme southernmost end of the rarge was not visited, and other forms of rhyolite may exist there, with possibly isolated patches of the older sedimentary strata.

In crossing the range from west to east at Golconda Pass, a low depression in the rhyolitic body, there is seen at the entrance of the cañon an outcrop of bluish-gray limestone, so obscured either by the overlying rhyolite or by the coarse Quaternary gravel that its relations with other sedimentary beds are entirely wanting; it has, however, from its proximity to other beds in the range, been colored upon the map as belonging to the Star Peak Triessic. The rhyolite extends up to the summit of the pass and for some distance down the eastern slope, the entire mass having a gentlo inclination to the eastward.

Directly superimposed upon the rhyolite occurs a long north and south ridge of dark compact basalt, which form the eastern foot-hills. In places, it rises above the rhyolite in bold, prominent masses, presenting unbroken cliff-like faces several hundred feet in height, toward the line of contact, but falling away with even slopes toward the valley. The entire basaltic body, which is a massive eruption, inclines, like the rhyolite, to the eastward. Along the base of the basaltic ridge, skirting the valley, are some interesting stratified beds, which have been tilted up by the outbursts of the volcanic rocks, and consequently are of earlier age than the massive eruptions of basalt. They belong, undoubtedly, to the same geological horizon as the upturned sedimentary beds bordering the Augusta Mountains and Shoshone Range, and have therefore been referred to the Truckee Miocene. Although they are well exposed here in many of the ravines and basins, they offer no good sections across the beds, owing to their loose, friable nature and irregular modes of weathering. The upper stratum, which is about 4 feet thick, consists of light cream-colored beds of exceedingly fine volcanic ash, more or less compacted together and splitting into thin layers, below which is a bed, also 4 feet thick, of lavender-colored sands, so very friable as to crumble at the least blow into a fine pumice-like powder. This is in turn underlaid by strata of undetermined thickness, 
somewhat resembling the beds of infusorial silica, but more or less argillaceous, yielding, when subjected to chemical analysis, a considerable amount of alumina, which is undoubtedly derived from the decomposition of the feldspathic groundmass of trachytes and rhyolites. They have a grayishwhite color, stained bright red by ferric oxide in patches, or else in parallel bands or cloudings, which develop a tendency to concentric structure. None of these rocks when treated with dilute acids gave any indication of the presence of carbonate of lime. The average dip of the strata is $18^{\circ}$ to $20^{\circ}$ to the eastward.

There is another small outburst of rhyolite occurring as low broken hills along the western foot-hills of the range, two or three miles south of Bardmass Pass, which scarcely differs from those already described at the northern end of the range, but derives some interest from the group of thermal springs found near their base. The water flows out from the rock on gently sloping ground along the edge of the Quaternary valley, and about one-quarter of a mile east of the first prominent ridge. There are between twenty and thirty circular pools of water, varying from 1 to 12 feet in diameter, scattered over an area of several acres, and generally surrounded by a luxuriant growth of alkaline grasses. The brilliant green of the vegetation, with isolated patches of bare light-colored rock, together with clouds of vapor rising from the water, make the locality a prominent landmark for long distances. The waters from all the pools were remarkably clear, and when cold quite palatable, with a slight taste of sulphur. Thermomotric observations made in the open pools of four springs indicated temperatures varying from $155^{\circ}$ to $181^{\circ}$. But little mineral deposit was observed coating the walls of the springs, and what there is consists mainly of carbonate of lime, an analysis of which, made by Mr. R. W. Woodward, gave as follows:

Alumina .......................... 0.26

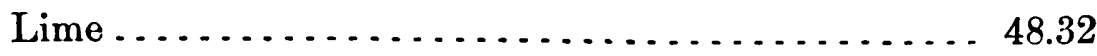

Magnesia............................... 3.98

Carbonic acid ...................... 39.07

Insoluble residue $\ldots \ldots \ldots \ldots \ldots \ldots \ldots \ldots \ldots . \ldots . . .68$ 
Two springs, situated side by side, differed from the others observed, in having a thin incrustation of hydrated oxide of iron upon the rock. About 8 miles to the southward, on the summit of the low divide separating Pleasant from Grass Valley, and closely related to the broad basaltic ficld stretching eastward from the Pah-Ute Range, are two small mud springs, which send out considerable water to the northward. The ground immediately surrounding the springs is quite soft, and shakes and trembles under the weight of a horse or mule. The mud from the springs has the composition of common clay.

Pah-Ute Range.-This range lies directly westward of the Havallah and Augusta Mountains, and forms one of the most prominent uplifts that rib the Great Basin of Nevada. It extends from the valley of the Humboldt River southward, with an unbroken persistent ridge for nearly 100 miles, passing beyond the limits of this exploration. Owing to the large masses of volcanic materialof Tertiary age, which, in so many places, have either broken through the older Mesozoic strata or filled up the breaks in their continuity, the range varies considerably in width, but for the greater part of the distance rarely measures more than 8 to 10 miles from base to base. From the southern boundary of the map to Granite Mountain, in latitude $40^{\circ} 15^{\prime}$, the trend is nearly northeast and southwest, beyond which it turns abruptly, becoming approximately north and south, parallel with the Havallah and West Humboldt Ranges. Below Table Mountain, the range rises abruptly on the west side, forming the eastern barrier of the ancient fresh-water lake-basin of Nevada, which stretched across the dreary Carson and Humboldt Desert westward to the Sierra Nevada Range of California, the elevation of the desert in the region of Carson Lake being about 3,800 feet above sea-level. Nowhere do the culminating points of the range reach any great elevation; but inasmuch as the adjoining valleys are relatively depressed, the difference in altitude is quite as well marked as in most of the Basin ranges, and the more rugged summits, owing to the limited lateral extent of the uplift, stand out even more boldly than in many other localities. Tarogqua Peak, the highest point in the Pah-Ute uplift, nearly opposite the lowest depressions of the adjoining valleys, has an altitude. of 8,751 feet above sea-level and 4,800 feet above the Quaternary plains. Chataya Peak reaches an eleva- 
tion of 7,766 feet, while the high basaltic mass north of Granite Mountain measures 6,804 feet.

Water is very scarce in the range, and is found only in springs, or else confined to small streams in the larger cañons, which in most cases become dry early in the autumn. Only over limited areas on the higher spurs and ridges is there any arborescent growth, and even here it is mainly made up of scattered and dwarfed pines.

In the main features of geological structure, the Pah-Ute resembles the Havallah and West Humboldt Ranges, exposing a nucleus of granite and granitoid rocks, probably of Archæan age, upon which rest unconformably longitudinal beds of quartzites, and overlying limestones and shales, of Triassic age, associated with large masses of coarsely crystalline diorites. Still later, in Tertiary times, the range has been subjected to great volcanic eruptions, represented by elevated masses and broad tables of trachyte, rhyolite, and basalt.

Granite Mountain.-Granite and highly crystalline Archæan masses form but a small portion of the exposed rocks of the Pah-Ute Range; and, of these areas, Granite Mountain is, both topographically and geologically, by far the most prominent. It rises above the plains over 3,500 feet, and presents a somewhat isolated appearance, stretching across the entire width of the range, and measuring 10 or 12 miles from the base of the long slopes that on both sides rise out of the recent valley deposit. In width, it varies from 4 to 5 miles, falling away to the north and south in steep spurs toward low passes, the southernmost of which, McKinney's Pass, is the most favorable place for crossing the range. On the lower slopes, wrapping around the greater part of the base of the mountain, but resting unconformably upon the upturned edges of the rock, occur the Triassic beds already mentioned.

One of the most interesting features structurally of Granite Mountain is that the crystalline rocks strike nearly east and west, while the uplifts of the later beds, where removed from the immediate influence of the mountain, possess a strike approximately north and south, varying only a few degrees either to the east or west. This is all the more noticeable, as where the strike of the larger masses of Archæan rock has been observed east of 44 D G 
the Havallah Range, they almost invariably approach more or less closely to a north and south course. This change in the strike of the beds, approaching a right angle to the main trend of the range, shows itself in a marked manner in the detailed topographical structure, where the main drainage-channels are developed in north and south lines, traversing the course of the beds, which are inclined at high angles. On the east and west slopes, the sulcations lying with the strike of the rocks are of only secondary importance, never reaching up as far as the higher summits and ridges. The present water-channels naturally follow the main cañons of the mountain to the base, where they turn, flowing toward the valleys along the inclination of the later Mesozoic beds.

It is worth observing here that the strike indicated by the mass of Granite Mountain is again hinted at by the recurrence of Archæan schists in Wright's Cañon, West Humboldt Range, where they have a strike of north $50^{\circ}$ east, and again in both branches of the Havallah Range, with a trend northeast and southwest. The granite appearing directly under the Koipato and Star Peak Triassic in all three of these uplifts, the Havallah, Pah-Ute, and West Humboldt, indicates either a broad granite range, or else a high granite plateau, during the period of deposition of the Triassic formations. There is some reason to believe that it was simply a high granite range, for the same conditions of direct superposition of the Triassic over the granites are not observed either to the northeast or southwest of these three ranges. In fact, with the limited exposures near New Pass in the Desatoya Mountains, one or two isolated localities in the Augusta Mountains, and the broken masses which rise above the general overflows of igneous rocks to the west, these three ranges form the entire development of Triassic rocks in this part of Nevada. That they extend southward beyond the limits of this exploration into the Ione region is known. They have been described as occurring in Plumas County, California, by Prof. J. D. Whitney, ${ }^{1}$ and have been observed by Mr. Clarence King in the Blue Mountains of Oregon. The most interesting problem connected with their occurrence is the cause of their discontinuance to the eastward beyond the Havallah Range Whether there has been an absolute unconformity between the Triassic of the Haval-

${ }^{1}$ Geological Survey of California, vol. i, 309. 
lah and the Carboniferous of the Battle Mountain group, or whether the Triassic actually passed conformably over the Carboniferous, and has subsequently suffered complete destruction by erosion, is a problem which cannot at present be definitely solved, although the former proposition seems most in accorlance with observed facts.

The crystalline rock-masses of Granite Mountain may, with scarcely any doubt, be referred to the Archæan series. The rocks which form the mountain are not, as the name would indicate, typical granite, but are allied to the granitic family, being made up chiefly of quartz and feldspar, with scarcely any mica or hornblende, a binary compound, which may perhaps be designated as aplitic granite. They are distinctly bedded, but without any observable regularity in the arrangement of the individual constituent minerals. The rock-masses vary somewhat in texture, but may be classed as medium-grained. Light flesh-red is the prevailing color; occasional beds are more or less stained with red oxide of iron, deepening the tint, but in general the feldspars present quite a fresh, undecomposed appearance. Orthoclase is the prevailing feldspar, usually dull and opaque; the quartz occurs in colorless translucent grains ; mica, when present, is found as dark biotite, and seems much more prevalent in defined zones, and is usually segregated into small bunches. In the interstices between the larger crystals are thin coatings of ferruginous material. Thin sections under the microscope show characteristic inclusions of carbonic acid, which disappear at a temperature of $31^{\circ}$ centigrade.

On the northern slopes of the mountain, in a ravine near the summit, and about one mile northeast from the geodetic station, are found minute brilliant-black crystals of tourmaline. Still further to the eastward, and in the region of the diabase dikes indicated on the map, occur small brown iron garnets, not much larger than a pin-head.

On the ridge east of the highest point occurs a narrow dike of typical feldspar-porphyry. It has a nearly east and west strike; where observed, it was well defined, but was not followed for any distance. In texture, this porphyry has an exceedingly fine-grained crypto-crystalline groundmass, breaking with a sharp angular fracture. The color is grayish-white, and but for the secretions of iron stains would be a beautiful rock. Brilliant 
feldspars, with rounded quartz-grains, are porphyritically enclosed in the groundmass. Mineralogically the composition would appear to be the same as the coarse-grained granite in which it occurs. Zirkel calls attention to an interesting point, "the microgranitic structure"-as brought out in the microscopical study of the rock. The quartz-grains carry fluid but no glass-inclusions.

Diabase penetrates the Archæan crystalline beds of Granite Mountain in several narrow dikes. They are especially noticeable, as the occurrence of diabase rocks cutting granite bodies has seldom been observed in our field of exploration. The dikes were seen on the northeast slopes, near the summit, with sharp straight lines of contact, striking approximately east and west. They are characterized by a fine-grained uniform texture and a darkgray color. They are exceedingly compact, breaking under the hammer with a rough, angular surface, free from all tendency to conchoidal fracture, with a habit peculiar to fine-grained rocks wanting in quartz and an amorphous base. Mineralogically the rocks are made up of triclinic feldspar and augite; many of the former are brilliant acicular needles, with a vitreous lustre, while the latter are rarely well developed. Small black grains are visible here and there, which are probably magnetite. Yellow particles of pyrite are occasionally seen as an accessory mineral. Under the microscope may be detected apatite prisms, and in the augites are several glassinclusions.

On the east side of the range, about 15 miles to the northward of Granite Iountain, occurs a very considerable body of granite. It extends in a north and south line for 8 or 10 miles, forming the water-shed along the main ridge for some distance, and falling off toward Grass Valley until concealed by Quatemary deposits. Here, as at Granite Mountain, the beds referred to the Triassic curve around the granite, resting upon it unconformably. Rounded conical hills, rugged, uneven spurs, with a great diversity of outline, characterize the topographical features of the region, the rockmasses possessing a hard, compact texture, with a prevailing light-red color.

Region south of Granite Mountain.'-South of Granite Mountain, for a distance of over 40 miles, no granite is known along the Pah-Ute

1 From field-notes furuisbed by Mr. Clarence King. 
Range, and, if any exists, it must be in very subordinate and unimportant bodies. Opposite Carson Lake, on the east side of the range, granite forms the lower foot-hills, extending southward for several miles, and rising abruptly out of the desert Quaternary sands. It is a rough irregular-shaped mass, with the slopes frequently and deeply sulcated by short rugged ravines; the principal cañon, known as Sommer's Pass, affording an accessible means of crossing the range. Still farther southward, and separated from the last-mentioned body by only a few miles, the granite again comes to the surface, stretching in an unbroken line along the foot-hills beyond the limits of the map. Neither of these granite bodies has been carefully studied. On the east side of the range, northeast from Tarogqua Peak, there is still another small body of granite at the base of the foot-hills, rising but a few hundred feet above the valley. Probably all these masses of granite belong to one body, but their connection is lidden by the heavy beds of Triassic quartzites and limestones, the older nucleus only appearing as already described. Granite Mountain may be regarded as roughly forming the axis of an anticlinal fold, dividing the range into two distinct parts, the later beds dipping away from its mass both to the northwest and southeast, and in the detailed observations to be given the rocks will be first described from Granite Mountain southward, and then from the north side of the peak northward to Humboldt Valley.

Directly south of the Archæan granite mass forming Granite Mountain are observed a series of quartzitic strata, similar, in most respects, to the inferior quartzites of the West Humboldt Range, which rest unconformably against the granite mass, having a northeast strike and southeast dip. These at the summit of McKinney's Pass are overlaid by limestones resembling the lower limestone belt of Star Peak, but so far as observed are devoid of fossils. They continue the northeast strike of the conformable underlying quartzites, and wrap around the granite mass, with a gradual change of strike, somewhat in the manner of the limestones of Wright's Cañon, West Humboldt Range. Curving to the south, this group of Triassic strata of about 4,000 feet thick reaches a north and south strike, which they preserve for about 15 miles to the point of their termination, where there is much faulting, local disturbance, and 
extreme metamorphism, and where the strata are encircled and abruptly cut off by the more recent volcanic rocks. As the strata assume a north and south direction, the dip becomes east, varying from $28^{\circ}$ to $40^{\circ}$. It seems to be essentially a monoclinal ridge, and to have been broken on a north and south line, and thrust up into its present position; no evidences being observed along the west base of any westerly-dipping beds. There is, however, at the extreme western base of Granite Mountain, in the narrow strip of Quaternary between the granite and the alkali flat, a low obscure outcrop of limestone, dipping west at an angle of about $30^{\circ}$, and striking a few degrees west of north and east of south. This probably represents the western connection of the monoclinal ridge already described. If it was a fold, the east half has been lifted at least 5,000 feet, and the same is true if it is a simple monoclinal block. In the valley between McKinney's Pass and Buffalo Cañon, West Humboldt Range, the structural problem is somewhat obscure, and is apparently this: whether the strata which dip down under the valley from Buffalo Peak rise again and form the western half of an anticlinal, of which the McKinney Pass mass is the eastern side, or whether the Buffalo Peak strata flatten out under the valley, and the McKinney's Pass ridge is simply broken up as a monoclinal block. The probability is given to the idea of a westerly-dipping mass under the valley by the outcrops spoken of, at the west base of Granite Mountain; but. in that case it is necessary to suppose a violent faulting along the axis, with such vertical displacement of the west half that the anticlinal lies fully below the valley, for it is entirely improbable that erosion could ever account for the absence of the west half of the fold. Much the same structure evidently occurs north of Granite Mountain and east of Star Peak, and the probability of an easterly-dipping set of strata, which are the prolongation northward of the Buffalo Peak side of the anticlinal, is rendered tenable by the actual existence on the east side of the West Humboldt Range, in the region of Indian Cañon, of easterly-dipping limestones. The Archæan mass of Granite Mountain appears to have played the part of a rigid centre, over which the folds and fractures have been developed.

Directly south of Granite Mountain, and rising out of the deep Quaternary recess, which here makes into the range on the west side toward 
McKinney's Pass, is a group of rhyolite hills extending about 4 miles north and south. It will be readily seen that their position occupies almost exactly the plane of what must have been the fault between the easterlyand westerly-dipping Triassic strata. This is only another instance of the rhyolites and other Tertiary intrusive rocks appearing along the old lines of dynamic action, which in recent times must necessarily have been the point of weakest cohesion. This rhyolite group forms a ridge slightly deviating from its south course toward the west, and reaching, at its highest. point near the middle, 1,200 feet above the valley. The rock has a yellowishgray groundmass, made up chiefly of long bunches containing numbers of ferritic needles and more or less sphærulites. The rock is peculiar, however, for the large number of pure crystalline secretions, both of quartz and sanidin, everywhere scattered through it. The sanidin appears exceedingly fresh and glassy, and almost as transparent as quartz, occurring as crystals up to one-eighth of an inch in length, which are noticeable for their frequent included glass-cavities. The quartz is present in well-developed dihexahedral forms carrying numerous glass-grains. Some rare black hornblende crystals and occasional flakes of biotite are seen macroscopically in the rock, but under the microscope do not appear to occur in the groundmass. It is somewhat uncommon to find an outburst of rhyolite, in which the rock is of so uniform a character throughout its entire mass as here at McKinney's Pass, and, inasmuch as it is a typical variety of this region of Nevada, has been subjected to chemical analysis by Mr. R. W. Woodward, who reports the following composition:

Silica. ........................ 74.00

Alumina ............................... 11.93

Ferric oxide . . . . . . . . . . . . . . . . . . $\quad 2.48$

Lime.......................... 1.56

Soda ............................ $\quad 2.64$

Potassa . . . . . . . . . . . . . . . . . . . . $\quad 5.65$

Lithia . . . . . . . . . . . . . . . . . . . .

Water ............................. 1.24

Specific gravity, 2.33 . 
It will be seen that the rock has the normal composition of a quartzsanidin-rhyolite rich in ferrite.

On the east side of the easterly-dipping Triassic limestones, south of McKinney's Pass, and lying directly upon the backs of the upturned beds, is a long outburst of diorite, and extending about 8 miles in a north and south line, forming what were at one time the foot-hills of the range. As in the Triassic rocks to the west of it, the lines of erosion strike northwest and southeast, dividing the dioritic mass into parallel ridges. The rock itself consists of a very coarse-grained combination of hornblende, biotite, a varying but small amount of quartz, and both monoclinic and triclinic feldspars. It is difficult, upon the first examination of this rock, to determine whether plagioclase or orthoclase is the prevailing form of feldspar, and, consequently, whether the rock is a diorite or syenite. The microscope, however, reveals more or less unchanged nuclei, which are distinctly striated in nearly all the feldspars, and the rock becomes a mixed hornblende, biotite, and quartz-bearing diorite. It bears a family likeness to the diorites farther south in the range, in the region of Chataya Peak, and only differs from them in the presence here of a considerable amount of biotite replacing a part of the hornblende.

Along its east margin, this diorite occurrence is overflowed by a broad mass of rhyolite, which overlaps it upon the north, coming in direct contact with the limestones. At the foot of McKinney's Pass, in the rhyolite, and very near the limestone, may be observed included fragments and boulders from Triassic beds, but they are very local and always within a few feet of the point of contact, showing conclusively, however, that the intrusive beds have come up through the. Mesozoic strata. These rhyolites form in general a more or less oval-shaped mass, 8 miles from north to south and 4 miles in breadth from east to west, and known as the Sou Spring Hills. The most striking feature of this group is its marked difference lithologically from the group on the west side of McKinney's Pass. There, in a microcrystalline groundmass, was a surprising amount of well-developed crystals of quartz and sanidin. Here the rock consists of an extremely fine base, which is essentially poor in crystallized minerals, being, in general, microfelsitic, and in places absolutely porcelainous. Such differences pro- 
duce, in the habit and mode of weathering of these lithoidal varieties, many sharp contrasts to the more crystalline and vesicular ones, inasmuch as they disintegrate less rapidly, develop scarcely any large feldspars or quartz-grains, and break with a smooth cherty fracture, affording steep slopes and abrupt walls. In the cañon which trends north from the Sou Hot Springs is a remarkable dark indian-red variety, consisting almost exclusively of a fine lithoidal base, in which are a few sharp, brilliantly defined, and entirely fresh crystals of sanidin and minute particles of quartz. Through this base are waving ribbon-like bands and strings of minute fibrous material, also more or less distinct aggregations of sphærulites, and narrow lines of devitrified glass. The latest of the flows, capping the others, contain well-developed sanidin, a few small biotites, and concentric radial sphærulites. The flows of middle age appear to be chiefly lithoidal, while the earliest of all are formed of brecciated material. Here, as in many other localities among the rhyolites, the included fragments are composed of the same material as the binding paste; the latter, however, is more finely felsitic, the crystallized minerals being very minute; whereas, in the included fragments, there are large dihexahedral quartz crystals, and sanidins oneeighth of an inch in length. A peculiar feature of this breccia is that the forms of the included fragments are rounded, and show, in the outer oneeighth of an inch of their section, decided caustic phenomena. In some instances, where the included fragments have been considerably fissured, and earthy decomposition has taken place, the sphærulites are destroyed, leaving spherical cavities; the whole mass being tinged reddish-yellow by the infiltration of iron oxides, which are probably developed from the ferritic needles in the groundmass. Here, also, it is noticeable, as in many other localities, that the breccia-flows form the earliest of the rhyolitic series. These lithoidal varieties of rhyolite differ so characteristically in their physical aspect from those found on the opposite side of McKinney's Pass, an analysis of which has already been given, that an analysis of the indian-red rock just described was made by Mr. R. W. Woodward, to determine, if possible, any marked distinctions of chemical or mineralogical composition. The two analyses agree very closely, showing less variation than may be found in any two highly crystalline rocks of the same species. In this rock, from 
the Sou Spring Hills, the silica is between one and one-half and one and three-quarters per cent. higher than in the other rock, at the expense of the lime and alumina, while the water, which undoubtedly in some manner plays an important part in the modification of the texture of volcanic rocks, is here only two-tenths of one per cent. lower than in the rhyolite from the west base.

The analysis of the rhyolite from the Sou Spring Hills yielded:

\begin{tabular}{|c|c|c|}
\hline Silica ............ & 75.65 & 75.70 \\
\hline Alumina...$\ldots \ldots \ldots \ldots \ldots \ldots \ldots$ & 11.52 & 11.48 \\
\hline Ferric oxide $\ldots . \ldots \ldots \ldots \ldots \ldots \ldots \ldots$ & 2.37 & 2.42 \\
\hline 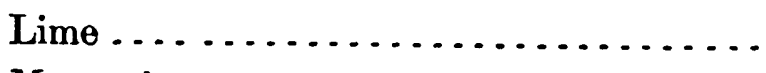 & 0.76 & 0.77 \\
\hline Magnesia . . . . . . . . . . . . . . . . . & trace & trace \\
\hline Soda . . . . . . . . . . . . & 2.91 & 3.00 \\
\hline Potassa............. & 5.93 & 6.09 \\
\hline Lithia . . . . . . . . . . . . . . . . . & trace & trace \\
\hline 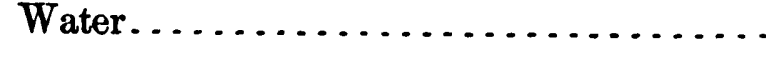 & 1.03 & 1.02 \\
\hline & 100.17 & 100.48 \\
\hline
\end{tabular}

Specific gravity, 2.44, 2.48.

The characteristic red color of the lithoidal varieties seems to be due to the quartz-grains of the microfelsitic varieties being dissolved in the feldspathic groundmass, producing a homogeneous porcelain-like base, in which the ferritic needles act much more energetically as a coloring matter. In general, in Central Nevada, where there is a mingling of crystalline and microfelsitic rhyolites with the lithoidal forms, the latter are almost always of a deeper red tint. It is certain that analysis shows but little essential difference, and that the amount of silica and iron present varies only slightly, although the one rock may be of a light-gray color and rich in large secretions of quartz-grains, and the other of a deep red, and carrying no macroscopical quartz.

Breaking through these rhyolites in a series of powerful dikes, and to a great extent overflowing them, occurs a subsequent formation of a dark steel-gray basalt, the greater part of which is finely cellular, though much of it is entirely compact and without pores. It is closely related in petro- 
graphical habit to one or two other basaltic outbursts, notably to the occurrence at the east base of Buffalo Peak, West Humboldt Mountains, by the absence of globulitic and glassy matter, and the consequent prevalence of crystallized minerals. Its aspect is more granular and more like diabase than most Western Nevada basalts, and, at the same time, is wanting in the vitreous lustre which is derived from included glass. The feldspars are all richly striated, the larger ones containing obscure inclusions; olivine occurs more or less decomposed.

Cottonwood Cañon, east of Table Mountain, exposes the southernmost limit of the Triassic mass already described, which here ends in a contorted and broken mass of marble. From there, for 12 miles to the south, the range on the east side is occupied by an outburst of rhyolite, of which all the loftier portions, and indeed down to within 300 or 400 feet of the plain, were formed by a series of sub-aërial ejections, while below that level they were poured out into and under water. These sub-lacustrine tufas are excellently stratified, and show the usual decomposition and infinitesimal crackings of the quartz-grains. It is doubtful if there is any place in the whole region of the exploration where the rhyolitic tufas are more interestingly displayed.

Lying to the west of this rhyolite body, and forming the summit of the range, is a north and south ridge of diorite, culminating in Chataya Peak. It forms a broad compact mass, cut by numerous cañons, and almost completely surrounded by the later volcanic rocks. These dioritic masses are beautifully crystalline, very coarse-grained, and, like the diorites of the Sou Spring group above described, contain a large amount of kaolinized feldspar, in this case revealing, under the microscope, scarcely any twin striation. The hornblende has so much parallelism of arrangement that the rock in some instances has a gneissic structure. There is a little free quartz, and the microscope reveals considerable apatite, with some titanic iron. In this diorite are certain clouded passages, which have a fine-grained compact arrangement, apparently of the same mineral constituenț, in which, however, some of the feldspars have remained pellucid, and show fine striation. This rock possesses no biotite. Considerable chemical change has gone on in the hornblende in some places. On the western foot-hills of 
the range, between 5 and 6 miles south from this mass, the hill-flanks for several hundred feet are composed of a rather finer-grained diorite, which is interesting as reproducing the occurrence of mica-diorite, the biotites in this case far exceeding numerically the hornblendes. Quartz is wanting, but apatite is abundant. There are in this range three types of diorites, one south of McKinney's Pass, containing biotite, hornblende, and quartz, with triclinic feldspar; the Chataya Peak group, which is essentially a true homblende-diorite, without mica, but rich in apatite; and the western foot-hill group, which consists, besides the numerous plagioclase-feldspars, of mica and hornblende, in which the mica predominates, considerable apatite, but no quartz.

Lying between the Chataya Peak diorites and the mass of rhyolite which lies to the east of it, and well exposed in Pine Nut Cañon, is an obscure trachytic mass having more or less affinity to the rhyolites. The relations between these two types of rock is well shown here, as in their mode of occurrence and general habit they resemble the trachytes, but in microscopical structure of groundmass, and in the amount of silica present, which is far too high for normal trachyte, are allied to the rhyolites. Although the silica in the rock analyzed reaches as high as 75 per cent., free quartz is almost entirely wanting. The rocks possess a reddish-gray color, a rough trachytic texture and fracture, and with no well-developed mineral constituents except feldspar, which gives the mass a porphyritic habit. In speaking of the groundmass of these rock, Professor Zirkel says: ${ }^{1}$ "One variety contains a groundmass which consists of undulating, twisted, and entangled axially-fibrous strings and bands, between which is a little felsitic substance that is nearly structureless, but rich in heaps of ferrite and opacite. This type of groundmass is as common in rhyolites as it is rare in trachytes. In another specimen, this structure is wanting; the groundmass being here, as in most other trachytes, an aggregation of feldspar, opacite, and ferrite, which are in the usual manner accumulated in little heaps with rounded outlines." Local solfataric action has attacked some of these trachytes decomposing the feldspars, the microscope revealing in the porcelain-like product grains of calcite with rhombohedral cleavage. The

${ }^{1}$ Microscopical Petrography, rol. vi, 149. 
chemical analysis of this rock differs but little from the analyses of the rhyolites of this range already recorded. It is interesting to observe the detection of carbonic acid, which in a manner determines the presence of calcite pointed out by the microscope.

Mr. R. W. Woodward, who made the analysis, reported the following composition :

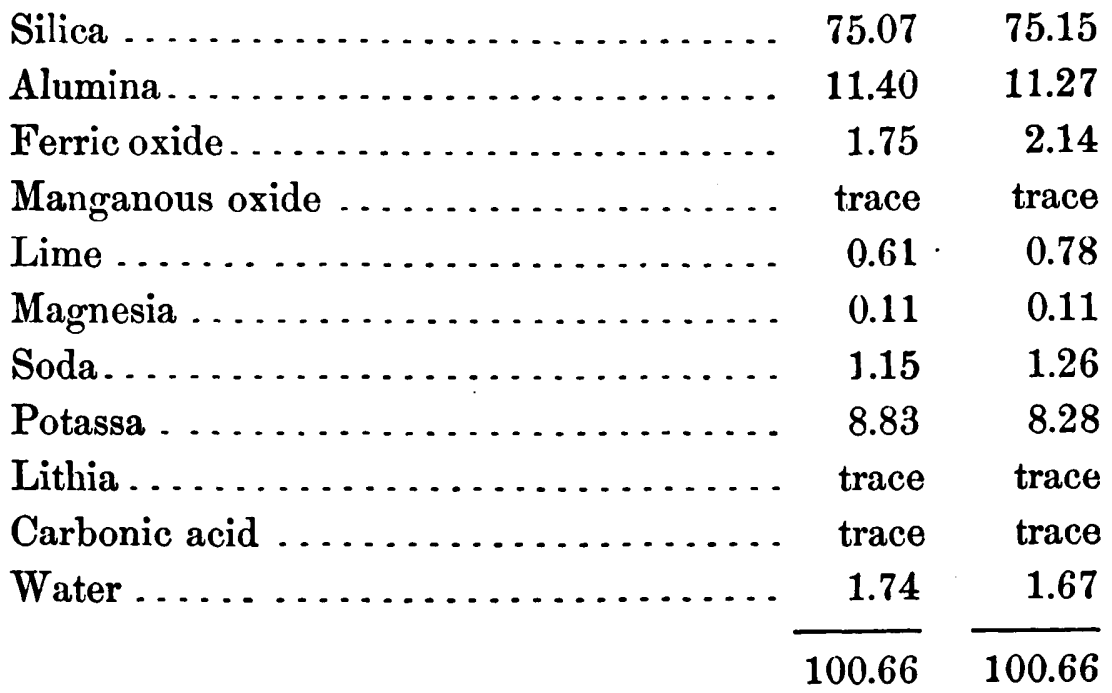

Specific gravity, 2.4, 2.3.

Breaking through and overwhelming these trachytes is a series of successive rhyolitic dikes, well exposed in Pine Nut Cañon. The same wide variety of texture is observable as at the Sou Spring Hills, dikes occurring here in which defined crystals amount to one-third or one-half of the mass. The sanidin crystals often form Carlsbad twins; the quartzgrains, which are abundant, contain good glass-inclusions. One of the most recent of these dikes which penetrate the older rock presents some peculiarities in the appearance of the feldspars that deserves special mention. The rock has a reddish-gray groundmass formed of quartz, sanidin, and biotite, containing free quartz in relatively large-sized grains. The sanidin possesses a most remarkable compactness of structure and a peculiar vitreous lustre, which give the fragments a very close resemblance to the associated quartz-grains. The larger crystals give out in refracted light the most beautiful blue colors, which are more brilliant than the most strik- 
ing labradorite, from their extreme delicacy of hue. It was hoped that a careful microscopical analysis of these feldspars would throw some light upon their composition; but Professor Zirkel," in his report, says: "The blue color is much more intense even than that of the famous 'labradorizing' feldspar from Frederiksvärn in South Norway. But while the luminous shimmer of the latter is connected with the numerous brown and violetblack laminæ and needles, which are microscopically interposed in its mass, the same strange bodies being also present in the proper labradorite from the coast of Labrador, and from Kiew, Russia, in the feldspars of these rhyolites, no strange particles can be detected, neither needles, nor plates, nor grains, nor a dust-like powder, nor glass- or fluid-inclusions. * * * The cause of this strange blue color must for the present, therefore, remain uncertain. It appears in the sanidin of some more eastern rhyolites. If the mineral which shows the color were plagioclase instead of sanidin, the phenomenon could easily be explained as a freak of polarization, produced by the passage of broken rays from one lamel into another whose planes of vibration do not correspond."

A sufficient amount of this iridescent feldspar was obtained by $\mathrm{Mr}$. R. W. Woodward for the purpose of chemical examination, the analysis yielding:

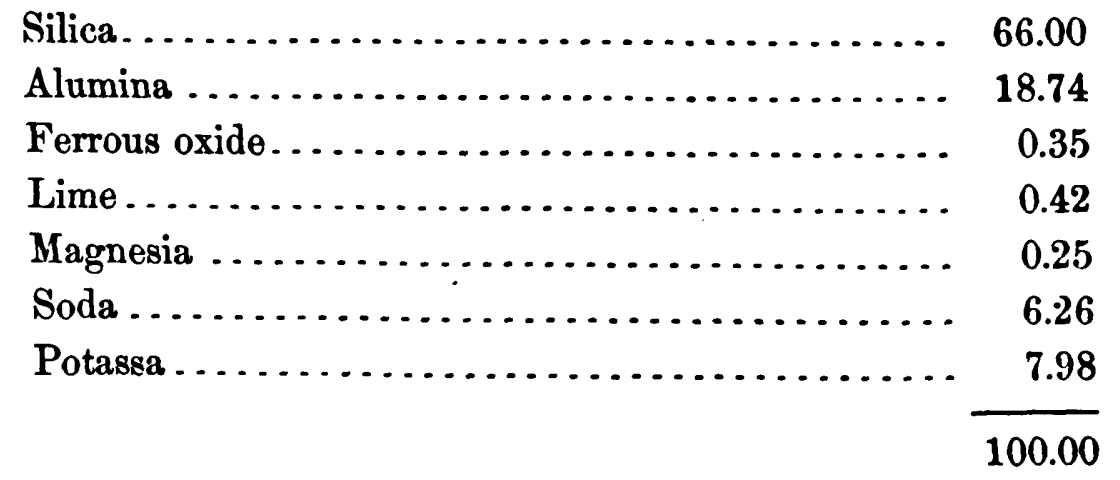

It is evident that the composition agrees closely with the common sanidin found in trachytes and rhyolites, with perhaps a somewhat large percentage of soda.

'Microscopical Petrography, vol. vi, 183. 
Farther down Pine Nut Cañon, below the mass carrying the iridescent sanidin, is a brown, earthy rhyolite, very rich in mica, somewhat porous, and of so decomposed a groundmass that only occasional sanidin can be detected, which in turn is overlaid at the base of the range by the rhyolitic tufas ejected under the lake.

South of the Chataya Peak group of diorites, rhyolites again cap the summit of the range, extending down on both sides to the plains below, and forming a broad band, crossing the range in a north and south line, about 4 or 5 miles in width. The outflows on the summit are tabular in general form, and closely resemble the sanidin-trachytes. Chemically, many of them appear rather low in silica, and might be classed as trachytes, but for the presence of more or less free quartz-scattered through the groundmass, and the characteristic rhyolitic structure revealed by the microscope. There is a remarkable regularity in the position of this rock, without the appearance of definite origin. Through a single mass may be traced unusual variations, certain specimens showing almost no quartz, and others running very high in that constituent. In general, where quartz increases, biotite increases also; so that some varieties are typical rhyolites, while others approach very closely to the trachytic forms. They are of a prevailing purplish-gray color, and contain two distinct kinds of feldspar, a very fresh undecomposed sanidin, and an earthy white isotrope substance, much like the feldspar in the decomposed neighboring diorite. The undecomposed sanidins so often occur in the middle of the earthy porcelainous mass that it seems probable that they represent unacted-upon portions, and that it has been a progressive decomposition from the outside of the crystals toward their middle, which, in some instances, has left considerable portions unattacked.

North and east of Chataya Peak, the range is overflowed by a broad and thick field of basalt, which has obscured all the underlying rocks. The summit north of the peak for 3 or 4 miles is occupied by a nearly level sheet of basalt, known as Table Mountain, which forms a prominent landmark, rising 4,000 feet above the valley. A portion of the same massive eruption extends from the base of Chataya Peak in a northwesterly direction quite across the valley, abutting against and overflowing the upturned Tertiary beds at the base of Buffalo Peak. This cross-ridge, which falls away 
gradually toward the west, reaches on the opposite side of the valley an elevation but a few hundred feet above the Quaternary gravels. It is of considerable interest, as it forms a divide across the valley, completely shutting in the Carson and Humboldt Desert to the south, and is one of the few prominent cross-ridges of Tertiary eruptive masses connecting the longitudinal ranges of the basin. Lithologically these basalts agree with those described from the Sou Spring Hills; a deep black, crystalline mass, with great uniformity of texture.

From Sonmer's Pass to the southern end of the map, the Pah-Ute Range consists essentially of a granite mass overlaid by sedimentary strata, which have a prevailing dip to the east. It has been less studied than any other portion of the range, but from the occurrence of porphyroidal rocks of great thickness, resembling the beds of the West Humboldt Range, and underlying dark limestones and marls, it has been provisionally referred to the Triassic.

South of the line of the map, basalt again comes in, covering a wide field and obscuring all the older rocks. It differs from the other basalts in having a characteristic glass base, which is indicated by its peculiar fracture under the blow of a hammer, and readily seen in thin sections under the microscope. It carries a few well-developed sanidins and some olivine. The glass base is much altered, as shown in Vol. VI, Plate XI, fig. 1, which represents a thin section of a specimen obtained from Mountain Wells Station, on the old Overland Stage Road, a few miles south of the limit of the map. Before returning to the region north of Granite Mountain, the thermal springs which lie at the eastern base of the range and the immense salt-fields of Osobb Valley require some special mention; the former are of interest from their evident association with the volcanic activity of the range, and the latter from the economic questions connected with the deposits.

Sov Hot Sprivgs.-Directly south of the rhyolite hills, which extend from McKinney's Pass, and about one-quarter of a mile from the foot of the slope, there rises a low mound of hot-spring tufa, covering perhaps 12 acres of ground. It has built itself up to a height of at least 60 feet above the plain, and has generally the figure of a broad, low dome rising out of the 
monotonous dreary valley. Scattered over the top are ten or twelve hotspring pools, almost circular in outline, varying from 6 to 60 feet in diameter, remnants of a much greater activity of thermal waters, and known as the Sou Hot Springs.

On Plate XX is given a general view of this group of hot springs, showing their position on the border of the valley with the Osobb Desert, stretching far away to the southward. The ground is covered with a loose alkaline soil, over which is a scanty vegetable growth, somewhat richer in the immediate neighborhood of the springs. In the illustration, only a few of the larger and more elevated pools are shown, the others either lying at a lower level or hidden by the inequalities of the surface. Around each spring there has been built up a secondary mound or rim of calcareous tufa, which in some instances has contracted as it formed, producing a perfect dome over the hot spring, with a vent of 2 or 3 feet in diameter. The temperature of the hottest of those observed varied from $160^{\circ}$ to $185^{\circ}$, although several of the largest springs have an agreeable temperature for bathing; indeed, a remarkable feature in connection with these springs is the very great variation of temperature within short distances. The waters are charged with chlorides and sulphates of the alkalies, together with small amounts of other salts, in which, however, the sulphate of soda largely predominates.

The residue obtained from the evaporation of the water from one of the largest, hot springs was subjected to qualitative analysis by Prof. $O$. D. Allen, of the Sheffield Scientific School, who reported the following ingredients: chlorine, carbonic acid, sulphuric acid, and soda, with traces of iron, lime, magnesia, and potassa.

A large amount of the alkaline efflorescence mixed with the fine, almost impalpable, surface-soil surrounding the same spring was collected from among the grass-roots, and submitted to Prof. O. D. Allen for the purposes of chemical examination.

Upon being treated with water, it left a very considerable residue, which consisted chiefly of sulphote of lime, with small amounts of silica, iron, magnesia, and a trace of phosphoric acid.

$45 \mathrm{D}$ G 
The mean result of two analyses of the soluble portion is as follows:

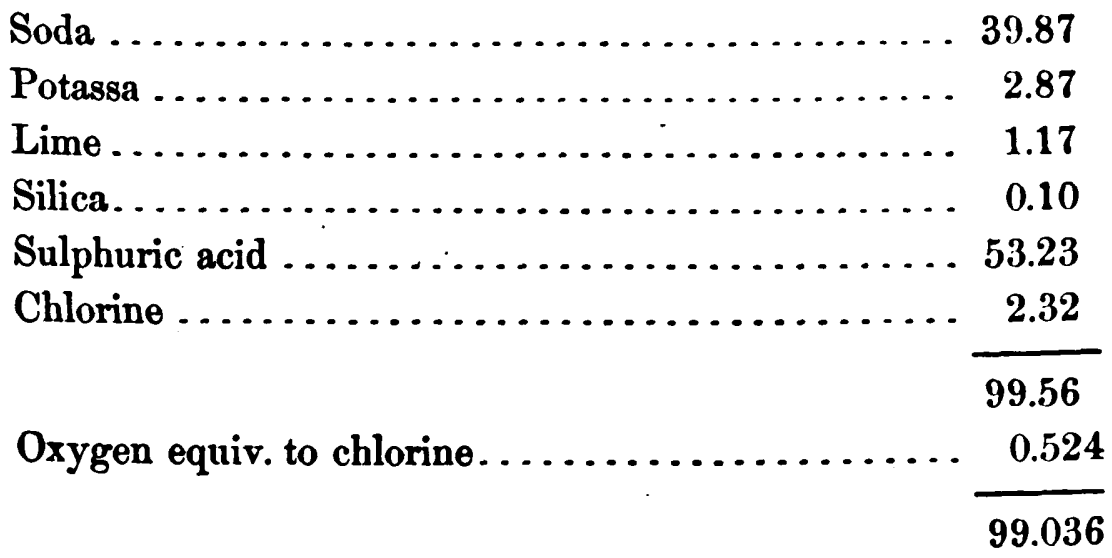

The theoretical composition of the constituents would give:

Sulphate of soda . . . . . . . . . . . . . . . . 86.664

Sulphate of potassa $\ldots \ldots \ldots \ldots \ldots \ldots \ldots \ldots \ldots .5 .307$

Sulphate of lime ................... 2.770

Chloride of sodium .................... 3.824

Silica........................... 0.100

Sulphuric acid in excess ............... 0.371

99.036

The solution of the soluble portion was feebly alkaline, and, in addition to the substances determined, indicated the presence of a trace of magnesia. With the spectroscope, it gave a strong reaction for lithia, and with turmeric paper one for boracic acid.

The lower view given on Plate XXI represents the opening of one of these springs around which no tufa cone has been formed, the surface of the water lying in nearly the same level as the ground, which is here partially incrusted with alkaline salts. The walls of the spring are funnel-shaped, and the pool so clear that the observer can look downward for 30 or 40 feet to the narrow orifice below, through which the water reaches the surface.

At the point of the diorite spur, but probably in close connection with the rhyolites, is a second group of hot springs, with a temperature of about 
$125^{\circ}$. They are strong brines, common salt being the chief ingredient. Several other saline springs are found bordering the valley.

Osobb Valley SaLt-FIelds.-The lowest depression of Osobb Valley, which lies between the Pah-Ute Range and Augusta Mountains, has an altitude, according to barometric measurement, of 3,360 feet above sealevel, which is by far the lowest point attained in the Great Basin within the limits of the Fortieth Parallel Exploration. It is occupied by a Lower Quaternary salt-field, which represents the bottom of a salt lake, which, at the period of its greatest saturation or smallest area, must have occupied a basin 18 or 20 miles in length along the middle of the valley. It is now. a solid field of white salt, covered with a thin layer of brine, which, in the extremely dry autumnal months, completely evaporates. The rains of winter and spring, however, accumulate on the surface of the salt, and form a briny lake, covering two-thirds or three-quarters of the salt-field. In the middle, the deposit of solid salt is $\mathbf{5}$ feet thick, and toward the west shore it is overlaid by fine saline mud, which is in turn capped by a thin, constantly-renewed, crystalline film of salt, about one-half an inch thick. In the salt mud, which thickens toward the west shore to an unknown depth, are found beautifully-modified octahedrons of salt, nearly pellucid, but containing always some discoloration from minute particles of clay that give the crystals a dark, smoky appearance. An analysis of this salt from the thick deposit yields nearly 97 per cent. of chloride of sodium, the remaining 3 per cent. being an admixture of carbonate and sulphate of soda, with slight impurities. The analysis gave Mr. R. W. Woodward the following :

Chloride of sodium .........., .......... 96.49

Sulphate of soda ...................... 1.91

Carbonate of soda...................... 0.96

Water .............................. 0.52

Insoluble residue...................... 0.12

100.00

The insoluble residue of 012 per cent. consists mainly of oxide of iron and a trace of lime. 
Underneath this thick crust of crystalline salt is another layer of fine saline mud and clay, also containing modified octahedrons of salt with clay impurities. This second stratum of mud has not as yet been fathomed, and it seems not at all improbable that there will be discovered other beds of alkaline salts. It is to be regretted that no vertical section has been made through the beds down to the Tertiary strata or underlying rocks, as it would be of considerable geological value. Already very large quantities of salt have been taken from this deposit to be used in the mills throughout Western Nevada in the amalgamation of silver-ores; but the field, if properly worked, is capable of furnishing immense amounts of nearly pure ehloride of sodium.

Region north of Granite Mountain.-North of Granite Mountain, heavy beds of dark quartzite, having in general a westerly dip, rest unconformably on the Archæan mass. They stretch northward for over 15 miles, forming all the higher portions of the western side of the range, and, wherever observed, extend down in broken, irregular ridges to the plain below. At Spaulding's Pass, where the formation was crossed, the entrance to the cañon on the western side is through a narrow ridge of westerlydipping beds, which open out into a broad rolling basin of quartzite hills, presenting a somewhat uniform character in both topographical features and lithological habit. Many of the beds have a decidedly schistose structure, in which the individual quartz-grains appear flattened out into flakes and pressed together in a compact mass, indicating a considerable amount of metamorphism. The rock has a prevailing bluish steel-gray color, a conchoidal fracture, and vitreous lustre. It is a dense, tough rock, breaking with difficulty. Lithologically it closely resembles the massive quartzite formation of the Havallah Range, and without much doubt belongs to the same geological horizon. It underlies the shales, limestones, and interstratified metamorphic rocks in the north of the range, and has therefore been referred provisionally to the lower quartzites of the Triassic age, which form so marked a feature in the West Humboldt Range. Unfortunately the point of contact with the Upper Triassic series to the north was not visited, and it cannot be definitely stated to underlie the latter beds conformably, the same doubt existing as was expressed in regard to the two forma- 
tions in the Havallah Range. But it should be stated that between the quartzites of the Havallah, Pah-Ute, and Humboldt Ranges, there is too much similarity in structure and position not to believe that they belong to one and the same geological horizon; and, in the latter range, the Koipato and Star Peak beds are clearly conformable.

East of the quartzite formation there occurs an immense outburst of basalt, which extends in a north and south direction for 15 miles, forming the more elevated portion of the range. It rises nearly 3,600 feet above the plain, falling off gently eastward in broad table-like ridges, which stretch across Grass Valley nearly to the Havallah Range. Several measurements of the angle of the basaltic flow were made, varying from $3 \frac{1}{2}^{\circ}$ to $8 \frac{1}{2}^{\circ}$, the average inclination being $5^{\circ}$. This heavy basaltic mass is cut in a number of places by deep cañons, which offer good exposures of the flows, showing a uniform mass of dark compact dolerite of normal composition. Outcrops of limestone are said to occur along the west base of the basalt, lying between it and the quartzite.

The relation of the basaltic field to the underlying quartzite and its position in the depression between the main uplifts of the Palı-Ute and Havallah Ranges is shown in the upper geological section at the base of Map V. North of the basalt, the granite body already described comes in, where it appears to form a barrier to the extension of the volcanic eruptions in that direction; but in the canon coming down from Spaulding's Pass, and lying between the two larger rock-masses, is a small body of fine-grained compact diorite not unlike some of the occurrences in the south.

Resting directly against the granite body on the west occur the Star Peak Triassic beds, which encircle around its mass to the northwest. Next to the granite are found heavy beds of blue limestone, highly crystalline and metamorphorsed, in places almost changed into marble, standing at a steep angle, and forming both walls of Upper Willow Cañon, which here has approximately 8 , north and south course. These strata underlie conformably the great series of beds that are well exposed throughout the entire length of Inskip Cañon, dipping always to the westward, but at very varying angles. They consist of quartzites, limestones, and some interstratified slates, passing up near the entrance to the cañon into thinly-bedded slates, 
shales, and marls, with a lithological habit like the beds to the westward that have been referred to the Jurassic age. No fossils were found in them, but, from their overlying the Star Peak horizons, and from their resemblance to the highly metamorphosed Jurassic strata of California, they have been referred to the same age.

In the lower portions of Willow Cañon, to the northward, the same beds are observed striking across the hills as seen in Inskip Cañon, with, however, a more easterly trend, owing to the tendency to follow the outlines of the rigid granite. The beds on the north side of the cañon are much contorted and twisted, showing considerable movement and fracture. In strike, they vary from north $20^{\circ}$ east to north $45^{\circ}$ east, and in places stand nearly vertical; the quartzites being so highly metamorphosed as to present a schistose structure, with blue, black, and purple bands.

To the northward, beyond the granite, there is a marked recess on the western side of the range, the uplift for nearly four miles becoming quite narrow and proportionately low, and then widening out again to its former dimensions. Quaternary deposits now occupy the recess, concealing the Jurassic strata, which are again well exposed in the Dun Glen Hills. As soon as the strata pass beyond the influence of the granite, the anticlinal structure of the uplift is developed, which it retains till the beds fall away beneath the Humboldt Valley. The axis of this fold lies upon the eastern side of the range, probably in the lower members of the Star Peak Triassic, so that the Jurassic strata do not appear among the easterly-dipping beds, but only along the western foot-hills. On the eastern side, the structure is quite simple, the beds inclining regularly toward the valley, with a strike approximately north $10^{\circ}$ east. They consist mainly of limestone, with some interstratified quartzites, mostly narrow belts, but with a lithological habit similar in compactness, texture, and color to the lower quartzites of the Star Peak series. Just east of the summit of the ridge, in the region of the Dun Glen Pass road, the beds are cut by narrow dikes of fine-grained diorites, with a strike approximately the same as the trend of the strata. They are of but little interest except as showing conclusively that they are later than the Triassic bed, through which they penetrate and in some measure accounting for the greatly disturbed condition of the strata on the 
west side of the fold. The summit of Dun Glen Pass is formed of a highly altered quartzose rock, with a strike of north $10^{\circ}$ east and a dip of $75^{\circ}$ to $80^{\circ}$ to the west, which is overlaid by heavy beds of dark bluish-gray limestone, still dipping west, but with. a much less angle of inclination. From here westward, the structure in places is very obscure and complicated, the beds showing considerable displacement, but in general possessing a westerly dip, with much the same series of strata exposed as seen in Willow and Inskip Cañons, together with the overlying slates and fissile shales of the Jurassic strata. North of Rose Cañon, and near its head, the Triassic limestones are well developed, lying at a gentle angle, and exposing several hundred feet of Star Peak beds. South of Dun Glen Pass, these same limestones form the summit of the ridge, with a dip of $80^{\circ}$ to the westward.

The only organic remains procured from the Pah-Ute Range were found in dark limestones in the region of Dun Glen Pass, and to the southward for one and one-half to two miles, along the main ridge.

The following forms, collected by our parties, have been described by Prof. R. P. Whitfield:

\section{Pentacrinites asteriscus. \\ Spiriferina Homfrayi. \\ Spirifera (Spiriferina?) alia, n. sp \\ Terebratula Humboldtensis. \\ Edmondia Myrina, n. sp.}

Of these forms, $\boldsymbol{P}$. asteriscus is generally regarded as a well-defined Jurassic species, at least in the Rocky Mountain region east of the Wahsatch Range, but here it is associated with Spiriferina Homfrayi and Terebratula Humboldtensis, species clearly recognized as belonging to the Star Peak beds in the West Humboldt Range. It should be stated also that these disks of Pentacrinites found in the Dun Glen limestone vary somewhat from the type-specimens, and are all of larger size, reaching one-fourth of an inch in diameter, while those of Jurassic age scarcely reach one-fifth of an inch. Professor Whitfield suggests that the Dun Glen variety may possibly be a new species.

This association of a Jurassic form with those of Triassic age is of special interest, because the Spirifera alia, also found here, is, in some respects, 
allied to Carboniferous types, and, but for its occurrence with characteristic Star Peak or Alpine Triassic fossils, would be regarded, at least, as an indication of Palæozoic rocks. In speaking of the S. alia, Messrs. Hall and Whitfield say," "We know of no species of Spirifera or Spiriferina in rock of this age resembling the one under consideration, or with which it can be confounded. The substance of the shell, like all those from the same locality, is badly exfoliated, and has apparently undergone some change, which has, to some extent, obliterated the natural features, so that we are not able to say definitely if it be punctate or not, consequently are in some doubt in regard to its generic relations."

From the same formation near Dun Glen, Professor Gabl ${ }^{2}$ has described the following species:

\section{Nautilus multicameratus. \\ Ammonites Homfrayi. \\ Mytilus Homfrayi. \\ Myophoria alta. \\ Rhynchonella aqviplicata.}

Mining operations have been carried on in several places along the Palh-Ute Range, but with little practical success, except perhaps in the region of Dun Glen, where there are a number of well-defined prominent veins, more or less worked, in general striking north and south, and dipping west in conformity with the structure of the range. A number of narrow quartz veins, known as the "Munroe series", situated a short distance southeast from Dun Glen, have attracted considerable attention from their yielding a relatively large amount of free gold and almost no silver; a rare occurrence in Central Nevada, where the ores are mainly sulphurets of silver and lead and their associated products of decomposition, the goldbearing veins being limited to a few localities like the "Munroe" and "New Pass Mines" in the Desatoya Mountains. In both these districts, however, active mining operations soon ceased, and the occurrence of so much free gold presented more that is of mineralogical and geological interest than of practical value.

\footnotetext{
${ }^{1}$ Volume iv, 282.

${ }^{2}$ Geological Snrvey of Oalifornia, Pulæontologs, rol. i, 1864.
} 


\section{SECTION V. WEST HUMBOLDT REGION.}

\section{BY ARNOLD HAGUE.}

West Humboldt Range. - - The West Humboldt or Koipato Range lies intermediate between the Pah-Ute and Montezuma Ranges, and extends from latitude $39^{\circ} 50^{\prime}$ to latitude $40^{\circ} 40^{\prime}$. Like the Pah-Ute and Havallah Ranges to the eastward, it rises somewhat abruptly above the Pliocene and Quaternary beds of the Humboldt Valley, and extends in a southwest direction for 70 miles, falling away in low volcanic hills, which jut out toward the Carson Desert, in the region of Mirage Lake. The range has its greatest expansion east of the town of Oreana, on the Central Pacific Railroad, where it is 15 miles wide, but to the north or south it scarcely reaches more than 12 miles. Directly east of Oreana, the range is seen to be divided by a valley diagonal to its strike, that is, having a northwest and southeast direction, which literally separates the range into two portions.

The northern half of the range has a nearly meridional trend, and is by far the more prominent portion, the summit being formed of a high, narrow ridge, with culminating points that attain elevations but a few hundred feet above the general crest. Star Peak, with an elevation of 9,925 feet above sea-level, is not only the highest point in the West Humboldt Range, but also of this portion of Nevada. Buffalo Peak, 20 miles to the southward, measures 8,387 feet, while Spring Valley Pass, the lowest depression in the northern half of the range, is at its summit 6,250 feet above sealevel. Topographically, it is a simple ridge, with the axis near the centre of the uplift, from which numerous cañons, with broad basin-like heads, becoming rapidly narrower as they descend, cut the mountain-slopes at nearly equal distances. Nearly all these cañons furnish constant streams, many of them on the eastern side, notably in Star, Coyote, and Buena Vista Cañons, running far out on the Quaternary plains. Timber is quite

\footnotetext{
'In part from notes furnished by Mr. Clarence King.
} 
scarce in the range, and indeed, from here westward to the Sierra Nevada of California, arborescent growth is scanty, even on the more elevated mountain-tops, and confined to a few scattered junipers and pines.

The southern half of the range is much more irregular in outline, varying in height from a few hundred to two thousand feet above the adjoining valleys, the sedimentary beds being less persistent in structure, and broken up by masses of volcanic rocks.

Geologically, the West Humboldt bears a close analogy to the Pah-Ute and Havallah Ranges, and, like them, is made up of an Archæan nucleus, although here but a small body, around which, and resting unconformably upon it, are Triassic strata of great thickness. These beds consist of quartzite overlaid by interstratified beds of limestone, quartzite, and felsitic rocks, which are in turn overlaid by Jurassic slates and shales. The Archrean and Triassic strata are cccasionally cut by dikes of intrusive rocks of Mesozoic age, those observed being chiefly diabase.

Along the base of the range, and wherever the strata have been weakened by displacement, by great flexure, or wherever they plunge rapidly downward, intrusive masses of rhyolite or basalt occur, confusing the local structure, and filling up great breaks in the Mesozoic depressions. Indeed, the range affords excellent opportunities for studying the relations between points of greatest weakness in the sedimentary uplifts and the outbursts of the Tertiary volcanic rocks. In one or two localities in the extreme foothills, the upturned Tertiary strata, referred to the Miocene age, crop out, but they are of little geological interest.

Northers Region.-The northern half of the West Humboldt Range, containing the oldest rocks and the best exposures of Star Peak Triassic beds, the local name being derived from their great development on the slopes of Star Peak, will be first described.

On the west side of the range, and rising nearly to the summit of the ridge, is a mass of granite about two miles in width, which is cut by two deep cañons, offering good exposures of the body. Throughout this granite, there is a series of structure-planes, striking northeast and dipping to the northwest; also, a series of occasional, nearly horizontal jointing planes, while in places there is noticeable a rough tendency to conoidal forms. It 
has a coarse friable texture, crumbling readily. Under the hammer, it breaks with difficulty into rough, irregular pieces. In color, it is dull gray, but mottled by segregations of dark mica. Both monoclinic and triclinic feldspars are present, but an opaque, cream-colored and white orthoclase is the prevailing species. The quartz occurs as translucent crystalline fragments, generally in masses of considerable size. Mica is abundant in segregated bunches of dark bronze color. A typical specimen of this granite collected from the first cañon north of Wright's Cañon has been analyzed by Prof. Thomas M. Drown, of Lafayette College, who reports the following composition :

Silica

Alumina ............................ 16.51

Ferrous oxide ...................... 2.52

Manganous oxide ....................... 0.11

Lime............................. 2.91

Magnesia . . . . . . . . . . . . . . . . . . . . . . 0.47

Soda ... . . . . . . . . . . . . . . . . . . $\quad 4.28$

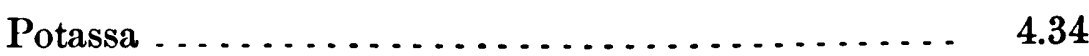

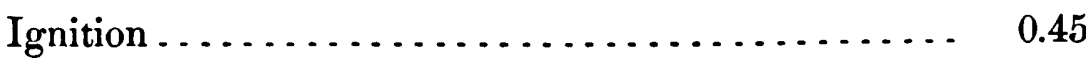

100.17

Along its northern and western edge, the granite mass is overlaid by a series of metamorphic schists and of light-colored mica-gneisses, in turn overlaid by a fine, white, knottea schist. The strike of these beds is north. $38^{\circ}$ east, standing nearly vertical. The contact of the granite and schists is extremely interesting, showing in horizontal plane an irregular angular intrusion of the former into the latter, outlying masses of schist lying in the granite and extending as promontories from the main mass of schist for 400 or 500 feet.

The line of demarcation between the two bodies is easily observed, and there seems to be no tendency of the schist to pass by gradations into the granite itself. The granite is here traversed by structure-planes having a strike parallel to the bedding of the schist; there is also another set of lines approximately at right angles to the former. These northwest planes 
are either vertical or dip $80^{\circ}$ to the southwest, while the northeast planes are quite vertical. The schists themselves are chiefly made up of quartz and muscovite, with a great quantity of infiltrated brown iron oxide. Occasional crystals of monoclinic feldspar and grains of crystalline quartz as large as a pea occur, around which the muscovite is bent, forming brilliant little knobs. A number of narrow dikes penetrate the granites and schists, including both diabase and Tertiary intrusive rocks. The former, so far as observed, follow the northeast lines of contact between the two older bodies, apparently agreeing roughly with the strike of the great Archæan mass underlying the Pah-Ute and Havallah Ranges to the eastward; the latter follow the northwest fissure-lines of the granite, and are evidently more recent than the northeast dikes. These Tertiary dikes, which play a very inconspicuous part, consist of a brown decomposed earthy material, too fine to tell by the unaided eye their true composition. In thin sections under the microscope, however, they are found to be made up of decomposed plagioclase and characteristic hornblende, with a groundmass having the structure of andesite.

Although, as has been already mentioned, the trend of the northern lalf of the range lies nearly north and south, the Triassic strata, which make up the greater part of the mountains, geologically form an anticlinnl fold whose direction is diagonally across the topographical uplift, having a strike about north $30^{\circ}$ east. The depression of Spring Valley Pass and Sacramento Cañon cuts across the anticlinal axis, which is here formed by a series of porphyroids, closely resembling erupted felsitic porphyries, but which are considered to be metamorphic products of the mixed quartz and feldspar rocks of the series of beds underlying the limestone of the Star Peak Triassic, and have been designated, after the Indian name of the West Humboldt Range, as the Koipato beds. They are regarded as of the same geological horizon as the lower members of the Red Beds of the Rocky Monntain region, although differing widely from them in their petrographical habit. These porphyroids are overlaid in some places, and in others underlaid, by normal quartzites and argillaceous schists, which are more or less metamorphosed. Directly and conformably overlying the quartzites are a series of intercalated formations, consisting in general of limestone, 
but carrying broad zones of quartzite. This limestone series is again conformably overlaid, in the northeast corner of the range, by a series of limestones and slates, which, for reasons expressed farther on, are referred to the Jurassic age. The contact beds of the inferior quartzites with the lowermost beds of black limestone are considered to be the dividing line between the Koipato and the true Star Peak Triassic.

On the west side of the range, and on the northwest side of the anticlinal, the Star Peak limestones first make their appearance near the mouth of Sacramento Cañon, where they form a feeble outcrop, standing vertically and striking with the anticlinal about north $30^{\circ}$ east. The strike, about a mile north of the mouth of Sacramento Cañon, makes a gradual curve around to the west, until it becomes north $35^{\circ}$ west, with a dip almost vertical, but a little to the southwest. Two and one-half miles north of Sacramento Cañon, it again describes a curve into parallelism with the axis, and makes a strike of north $30^{\circ}$ east, more and more of the formation cropping out from under the Quaternary deposits, until there appears a thickness of 600 or 800 feet. This northeast strike is continued until the limestones approach very close to the body of granite already described, where it is again curved to the northwest, and in extreme cases strikes due west, dipping soutl. At the entrance of Wright's Cañon, the prevailing strike is north $15^{\circ}$ to $25^{\circ}$ west, with a dip of $30^{\circ}$ to the southwest. Here in the canon, in the axis of this sudden change of strike, the beds are much contorted, folded up into loops, and in some cases thrown over into a reversed dip. The contact between the limestones and granites is more or less obscured by surface material and débris; enough, however, can be seen to found the belief that the granite was not an intrusive body, but that the strata were deposited over and around $i t$, and that the observed flexures in the strike were developed by the thrust of this hard granitic mass. Directly underlying these limestones, and quite conformable with them, all the way from Sacramento Cañon northward to Wright's Cañon, there is a variable zone of siliceous and argillaceous beds, having a more or less schistose structure, nowhere over 200 feet in thickness, and consisting of rocks with a prevailing felsitic base, but containing fragmentary crystals of quartz and feldspar, with occasional but rare white mica. In hand-specimens, and 
often in situ, they have distinctly the characteristics of atrue quartz-porphyry, but from their gradations into an argillaceous and arenaceous sandstone it seems clear that the extreme products are only phases of metamorphism. Directly under these beds, and also conformable with them and the limestones, occur heavily-bedded quartzites, which are very variable in composition, the same bed changing on its strike from a fine-grained microcrystalline quartzite to an argillaceous schist, and passing on into a coarse granular condition. Up to the region of the anticlinal axis, the structure of these argillaceous and quartzitic rocks is clearly conformable with the upper limestone, but, as they approach the axis, the planes of sedimentation become more and more obscure, the porphyritic character of the metamorphism more and more highly developed, until finally all structure-lines are obliterated, and the formation possesses many of the characteristics of an eruptive porphyry. Between the granite and the limestone in Wright's Cañon, the zone of porphyroids reaches 700 feet in thickness.

In the large cañon next north of Wright's Cañon, the limestone wraps around the western margin of the granite, and stands quite vertical. Near this locality is a somewhat obscure series of beds of quartzite, which, near the granite, is covered by débris. This quartzite, from its fine-bedded and fissile character, as well as from its position in the. limestone, is referred to the lowest zone of quartzite, which overlies the lowest of the Star Peak limestones on the east side of the range, and is observed above Buena Vista and Cottonwood Cañons to abut against the granite high up near the head of Wright's Cañon.

Where the limestones and underlying quartzites are wrapped around the northern boundary of the gneisses, they bend to the east and acquire a strike of north $40^{\circ}$ east and a dip of $50^{\circ}$ to the northwest. Here at the contact between the quartzites and limestones there is a transition series of 15 or 20 feet thick, formed, at quite regular intervals of 4 inches, of inchthick beds of quartzite and limestone. About one-half mile north of the northern termination of the Archæan schists, the limestones are observed to have a strike of north $35^{\circ}$ east, and a dip of $38^{\circ}$ to the southeast into the range, but this appears to be very local and due to faulting. The main limestone and quartzite formation from here north has a strike of about 
north $30^{\circ}$ east, with a dip declining toward the plain. In the region of the flexures around the northern end of the schist formation, there are seen numerous radiating and vertical fissures, besides a second series of faults developed in a northeast plane, or approxinately parallel with the line of strike. There does not seem, however, to be any considerable amount of displacement in connection with these fissures. In the limestones, in the region of Wright's Cañon and the large canion to the north, are irregular veins of feldspar, with occasional but rare masses of milky-white vein-quartz.

Diligent search was made in these flexed and altered limestones for organic remains, but the impressions found were too much obliterated for determination, with a single exception, that of an

\section{Ammonites Blakei,}

identical with those found in Star and Coyote Cañons on the east side of the range. All observations tend to show that the part played by this Archæan body has been, during the period of upheaval of the range, to push its way upward through the sedimentary strata, and bend them in a bold semicircular curve around the north and west side, lifting them from an average $30^{\circ}$ dip by waving curves up to the vertical position.

The westerly-dipping quartzites and porphyroids of the Koipato series, striking diagonally across the range, occupy the head and valley of Indian Cañon; thence northward they form the main ridge on both sides of Cottonwood Cañon, and the narrower portions of Buena Vista Cañon. Crossing Coyote and Bloody Cañons, they appear in the low hills near the entrance to Star Cañon, and die out in the plains a short distance northward. The thickness of these beds has been roughly estimated at 6,000 feet.

Star Cañon opens up from the plain through beds of dark slaty quartzite, having an irregular and imperfect cleavage. In certain layers, it is somewhat calcareous, and, in the lower members, shows much argillaceous material. This is the zone which prolonged southward continually underlies the lowest Star Peak limestone, gradually becoming thinner and more and more altered until it passes into the highly metamorphosed and true porphyroids. The siliceous zone directly under the limestone in the region of Coyote Cañon is, near the top, a fine-grained red and yellow marl, and passes downward through arenaceous and argillaceous beds into compact, 
more thickly bedded quartzites, below which the porphyroids come in well developed. On the long spurs in the region of Buena Vista and Cottonwood Cañons, the compact marls pass down into argillites, made up largely of admixtures of clayey mud and quartz sand, with interstratified bands of grit, impure jaspers, and chert, all well exposed, exhibiting a great variety of dull earthy colors.

A characteristic variety of argillite, possessing an- almost impalpable texture and homogeneous base, found on the northern ridge of Cottonwood Canon, was given to Mr. B. E. Brewster, for the purpose of chemical analysis, who reported the following:

Silica.

Alumina

Ferric oxide

Lime.

0.74

Magnesia

Soda. trace

Potassa

Ignition 3.20

99.62

Carbonate of lime is not present in this rock. The percentage of lime is also quite low. The large amount of potassa, associated with only a trace of soda, is of interest in connection with the analyses of other rocks of the West Humboldt Range. On the same ridge occurs a broad band of chert, which, from its withstanding atmospheric agencies better than the surrounding rock, occupies a prominent position. It has a light-drab color, a conchoidal, splintery fracture, and, under the microscope, presents a micro-crystalline texture, with minute grains of quartz disseminated through the mass. Mr. Brewster has also analyzed this chert, with the following result:

Silica

Alumina

Ferric oxide

Lime

0.27 
WEST HUMBOLDT RANGE.

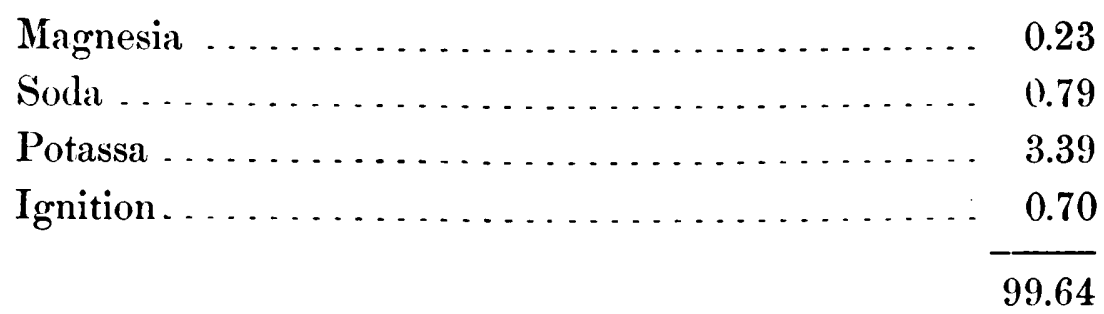

It will be seen that the interstratified chert band is about 15 per cent. richer in silica than the argillite, at the expense of all the-bases, except soda, and that the moisture is also very much less.

The porphyroids, as has been already mentioned, closely resemble in hand-specimens eruptive feldspar-porphyries, and in places also quartz-porphyries, but the study of their position and petrographical habit in the field indicates a gradual transition by metamorphism from the less altered arenaceous and argillaceous rocks up to the compact crypto-crystalline varieties, with a siliceous base, through which are disseminated broken and imperfect crystals of feldspar. It is evident, however, that metamorphism has been carried to such a degree as to have produced a class of rocks quite distinct in habit from those found elsewhere within the region of this exploration. They vary in color from light grayish-white to almost black, with shades of blue, brown, and green. They form dense, tough rocks, weathering with an angular surface, and possessing a rough, cherty fracture. In most cases, the texture of the rocks is so fine that they can only be studied to advantage in thin sections under the microscope, when they show chiefly quartz and feldspar in a siliceous base. The quartz-grains are frequently rounded, and enclose fragments of the base. Occasional flakes of mica and particles of magnetite occur. No hornblende or augite has been observed. In Coyote Cañon, there is a grayish-black variety, having a texture and lustre like lydite, through which run roughly parallel lines of narrow gray feldspar, giving the rock a distinctly banded structure. It appears, upon chemical examination, that the dark color is here due to carbon particles, so finely disseminated that even the thin sections are nearly opaque. Much the same banded structure is seen in Buena Vista Cañon, the feldspar also occurring in irregular aggregations. There are also small clusters of minute quartzgrains. In the region of Cottonwood Cañon, the porphyroids show a still $46 \mathrm{D}$ G 
more crystalline base, with the feldspars much better developed, irregularly scattered through the base, and giving the rocks more the character of true feldspar-porphyries. Most of the feldspars would appear to be triclinic. At Indian Cañon, where there is a great development of these lower rocks, they show still greater variety in superficial habit, but much the same mineral composition, in general being lighter-colored, with prevailing reddishgray tints. Rocks occur here in which the feldspars are poorly developed, but instead translucent quartz-grains appear scattered through the base quite like the porphyroids described from the region of Wright's Cañon, and resembling in hand-specimens true quartz-porphyries. In many of the rocks, the iron seems to be segregated in spots, and to occur as an ochreous substance, filling cavities and fissures. Near the summit of Indian Cañon occurs a porphyroid quite unlike those already described, as it carries considerable reddish-colored calcite. Under the microscope, the red color is seen to be due to the presence of oxide of iron. The calcite also encloses grains of quartz.

A specimen of one of the more coarsely-crystalline porphyroids from Cottonwood Cañon, and not far below the main limestone belt, has been subjected to chemical analysis by Mr. B. E. Brewster. The rock has a brownish-gray color, and carries both feldspar and quartz, the analysis yielding :

\begin{tabular}{|c|c|c|}
\hline Silica. . . . . . . & 74.74 & 74.72 \\
\hline Alumina...$\ldots \ldots \ldots \ldots \ldots \ldots \ldots$ & 14.14 & 14.10 \\
\hline Ferric oxide $\ldots \ldots \ldots \ldots \ldots \ldots \ldots$ & 0.79 & 0.81 \\
\hline Lime $\ldots \ldots \ldots \ldots \ldots \ldots \ldots$ & 1.51 & 1.51 \\
\hline Magnesia ... & 0.39 & 0.44 \\
\hline Soda .... & 0.92 & 0.75 \\
\hline Potassa .. & 5.29 & 5.42 \\
\hline \multirow[t]{2}{*}{ Ignition } & 1.88 & 1.83 \\
\hline & 99.66 & 99.58 \\
\hline
\end{tabular}

It is noticeable that in this analysis the low percentage of soda and the comparatively high percentage of potassa remain nearly the same as in the chert and unaltered argillite. The absence of homblende and augite, 
the presence of finely-disseminated carbon, and the tiansition from the highly-metamorphosed to the unaltered rocks place the sedimentary origin of these porphyroids beyond question.

Directly overlying the clays and slates of the Koipato series occurs the lowest limestone belt of the Star Peak Triassic. This limestone varies much in color near the bottom, consisting of dark, almost black, beds, passing up into grays and blues, and, north of Star Cañon, is much stained with red oxide of iron, at the same time showing a great amount of fissuring with the strike and dip. Organic matter appears to be present throughout the greater part of the series, and the black color in many of the beds is evidently due to the presence of carbon. Two analyses of limestone from this series, taken from widely-separated localities, have been made by $\mathrm{Mr}$. B. E. Brewster; No. 1 is from the lower beds in Star Cañon, a fine-grained black rock; No. 2 is from the ridge dividing Buena Vista from Cottonwood Cañon, and is a more crystalline lighter-colored variety.

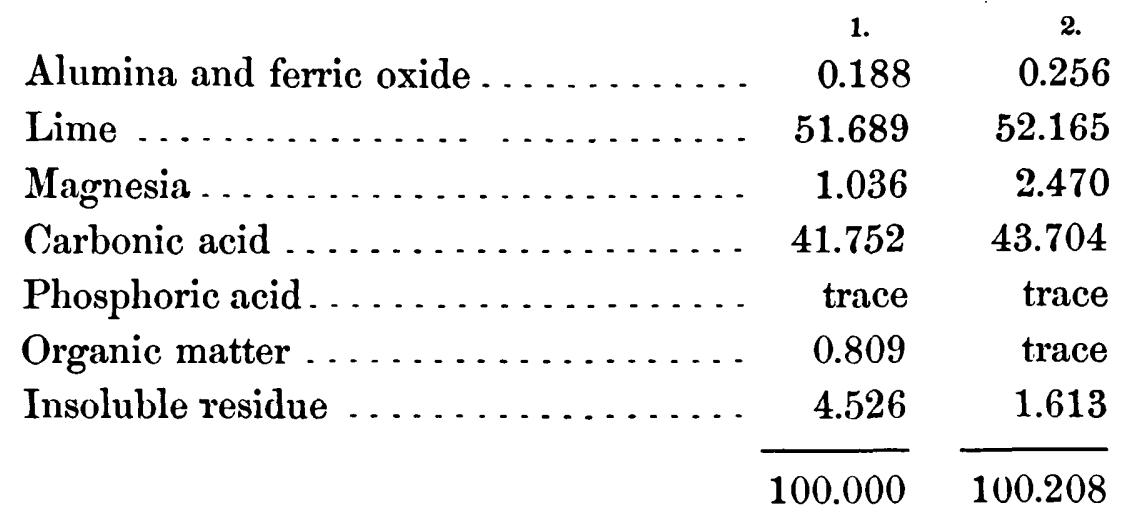

The lower beds of the series contain a great number of Triassic fossils characteristic of the Star Peak formation, which is undoubtedly the equivalent of the Alpine Triassic, not only the genera, but many of the species, being either identical with, or closely related to, well-recognized forms described from the St. Cassian and Hallstadt limestone beds of the Alps. Although the same species may be found scattered through the entire belt, there appears to be near the upper limits a second zone, rich in fossils, which carries with the other forms ribs of Vertebrata, too poor, however, for specific determination. 
Prof. F. B. Meek and Alpheus Hyatt examined the collection of Triassic fossils from this range, and identified the species.

From Cottonwood Cañon were obtained:

Halobia dubia.

Halobia (Daonella) Lommeli.

Orthoceras Blakei.

Eudiscoceras Gabbi.

Trachyceras Whitneyi.

Trachyceras Judicaricum.

Trachyceras Judicaricum var. subasperum.

Gymnotoceras Blakei.

Arcestes perplanus.

Arcestes Nevadensis.

Arcestes Gabbi.

From Buena Vista Cañon were obtained:

Modiomorpha? ovata.

Modiomorpha ? lata.

Posodonomya stella.

Sphara Whitneyi.

Arcestes perplanus.

Goniatites (Clydonites) lavidorsatus.

Gymnotoceras rotelliforme.

Fragments of Vertebrata.

In Coyote Cañon, but little search was made for organic remains; there were found, however, among poorly-preserved forms:

\section{Ammonites Blakei. \\ Rhynchonella, sp. 8}

In Bloody Cañon, a small ravine lying between Coyote and Star Cañons, were collected from the upper beds of limestone :

Ammonites, sp.?

Ribs of Vertebrata. 
Star Cañon furnished:

Ammonites Blakei.

Halobia dubia.

Arcestes perplanus.

In addition to the above, there have been described from Star Cañon, by Prof. W. M. Gabb, ${ }^{1}$ the following forms :

Spirifera Homfrayi.

Terebratula Humboldtensis.

Rhynchonella lingulata.

Posidonomya stella.

Monotis subcircularis.

Avicula Homfrayi.

And from Buena Vista Cañon:

Myacites (Panopaa) Humboldtensis.

The total thickness of this lower limestone cannot be less than 1,200 or 1,500 feet.

Overlying the limestones occurs a belt of siliceous rocks, which crosses Star Cañon just above Star City, and Buena Vista Cañon above the junction of the two main branches, where they strike about north $12^{\circ}$ east.

In Star Cañon, where the beds are well exposed, they present a varied group of slaty quartzites alternating with greenish schistose rocks having a resinous lustre and talcose habit, but apparently free from carbonate of lime, passing up, in the region of the Sheba Mine, into an earthy argillaceous rock with a distinct slaty bedding; and gradually becoming calcareous, with the calcite crystals plainly visible under the microscope. This series of beds is about 1,500 feet thick.

In thin sections, under the microscope, the green talcose rock reveals considerable chlorite scattered through it, and in places also frag-

\footnotetext{
'Geological Survey of California, Palæontology, vol. i, 1864.
} 
ments of feldspar. An analysis of this rock, made by Mr. R. W. Woodward, yielded:

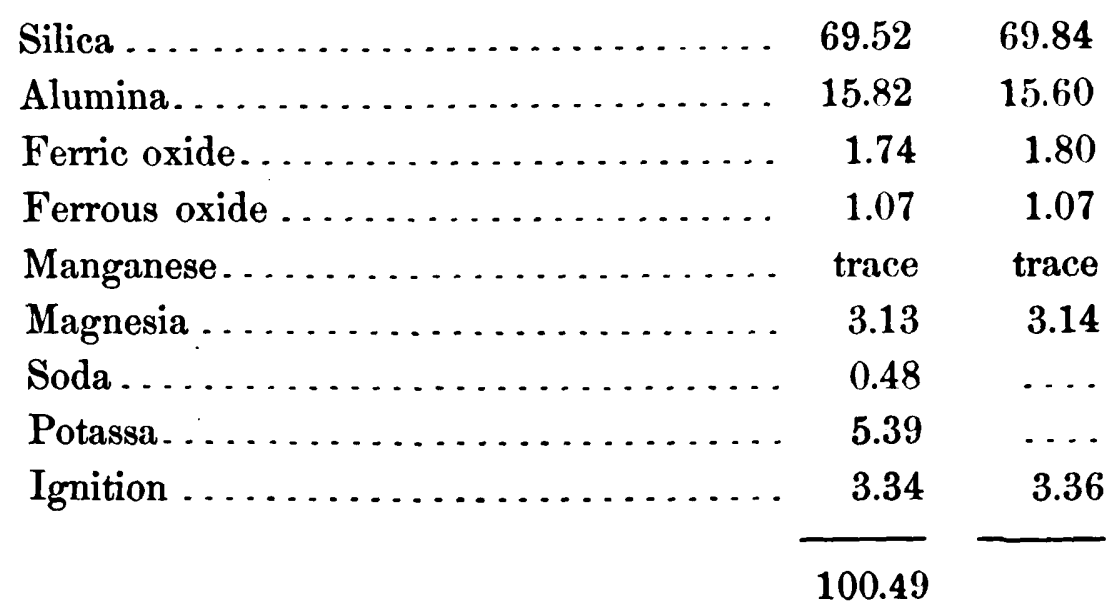

Specific gravity, 2.7.

In its chemical composition, the essential features of this rock are quite like the porphyroid, the analysis of which has already been given. It carries no lime; the percentage in iron is somewhat low, and, like the other rocks from the region, shows the same preponderance of potassa over soda.

This last formation is immediately overlaid by black arenaceous slates containing more or less calcareous material, which are but two or three hundred feet thick. They dip about $40^{\circ}$ to the west, and trend a few degrees east of north and west of south. These black slates are again overlaid by very thick limestones, which cannot be less than 1,800 or 2,000 feet thick. This is much fissured and stained by oxide of iron and traversed by narrow seams of calcite and quartz. It is highly metamorphosed, and in places is completely converted into white, coarsely crystalline marble. It has been less searched for fossils than the other belts, but those found have been recognised as belonging to the genus Ammonites, and probably to species already described. This series is again followed by another quartzite and interstratified siliceous slates, which form a steep bluff-like face on the east side of Star Peak extending nearly to the summit; but the actual top is formed of black and gray limestone. This is probably the same zone that occupies the foot-hills just north of Echo Cañon on the west side, and the 
summit of Santa Clara Peak just east of north of Star Peak. They have a dip of about $30^{\circ}$, sometimes going down to $20^{\circ}$, and, in the case of the actual summit, to $18^{\circ}$.

On the west side of the range, there occurs well exposed in Humboldt Canon a heavy body of distinctly bedded typical white quartzite, with cross-jointings breaking into coarse angular blocks, which forms the summit of the broad ridge northwest of Star Peak, and all the higher western slope. Near the summit, it has a dip of $25^{\circ}$ to $35^{\circ}$ to the west. This is, in turn, again overlaid by blue limestone, with dark bands near the top, so rich in carbon as to make a fissile rock, and to soil the hand when touched. It extends across the northwest corner of the range from Eldorado Cañon to Prince Royal, and is regarded as the lowest member of the Jurassic formation. The only fossils found came from the first small canon south of Humboldt Cañon, and belong to undetermined species of Montlivaltia and Cardium, both genera generally recognized by palæontologists as not occurring earlier than the Jurassic age. These limestones pass gradually into thinly-bedded almost fissile slates of a dull earthy color, with narrow bands of interstratified sandstone and bluish-gray limestone, the formation extending down to the plain.

The thickness of the formation, from the top of the porphyroidal rocks or Koipato series to the top of the overlying limestone on the west side of the range, has been roughly estimated at 10,000 feet; the section, as given in detail, consisting of broad, alternating zones of quartzites and limestones up to the base of the slates and shales of the Jurassic. It seems highly probable that the upper belt of limestone may at some future time be shown by palæontological evidence to consist entirely of Jurassic strata, the broad normal quartzite belt below separating formations of distinct geological age; but inasmuch as forms so characteristic as Montlivaltia and Cardium occur in the upper limestone, there need be no hesitation in placing the overlying shales in the Jurassic, although they have as yet proved barren of organic remains.

In the upper part of Humboldt Cañon occurs a diabase dike only a fow feet wide, penetrating the white quartzite at a high angle, in a line nearly parallel to the strike of the beds. It stands out prominently above 
the sedimentary strata, and, as it is a somewhat exceptional occurrence, deserves special notice. On a superficial examination, it resembles the dolerites breaking out along the base of the range; but a careful study in the field suggests, at least, that it is an older rock allied to the dikes found cutting the Archæan bodies of Western Nevada. Under the hammer, it is an exceedingly tough rock, breaking with a fine, hackly fracture, quite unlike basalts with globulitic base. It is a medium-grained crystalline aggregation of brilliant, needle-like feldspars and augites, no other mineral being recognized by the unaided eye. The microscopical sturly of this rock throws considerable light upon its geological relations, and reveals at once the presence of quartz-grains with liquid-inclusions, being, as Professor Zirkel' remarks, " an ingredient which has never been observed in any dolerite or basalt in the world". The rock recalls many varieties of the diabase of Northern New Jersey and Connecticut.

On the east side of the main anticlinal axis, which crosses the range obliquely at Spring Valley Pass, the quartzites of the Koipato series are seen to have a strike parallel to those on the opposite side, namely, about north $30^{\circ}$ east, but dipping to the east $30^{\circ}$. These quartzites have not the same lithological characteristics as those which underlie the limestones at the mouth of Star Cañon, but are more purely siliceous, thinner-bedded, and more irregular. Passing north from Spring Valley Pass, along the eastern foot-hills, a small hill of limestone lies at the entrance to Indian Canon, dipping easterly. Still farther north, other isolated patches occur in the region of Cottonwood Cañon, with the same dip, indicating the eastern side of the fold. From these limestone beds, a portion of a large belemnite was secured, which Prof. F. B. Meek has described under the specific name of Belemnites Nevadensis.

South of Spring Valley Pass, the foot-hills are formed of dark limestones, which overlie the quartzites. They also strike north $32^{\circ}$ east, and dip $45^{\circ}$ to the east. From this point southward, the Star Peak beds thicken rapidly, and for 8 miles the hills are covered by heavy masses of dark limestone, in which are found a few well-preserved fossils of the genus $\mathrm{Am}$ monites. The deeper cañons, as Buffalo Cañon and others, erode through the

${ }^{1}$ Microscopical Petrograply, vol. vi, 101. 
limestone, and display the underlying quartzitic schists of the interstratified Star Peak series. Local flexures in Buffalo Cañon throw the underlying quartzites around to a true north and south strike, which, however, they maintain only for a short distance; the dip in these local cuses rising as high as $60^{\circ}$ to the eastward. Along Buffalo Peak, the limestone is locally converted into marble, and is then entirely destitute of planes of stratification.

From field-notes furnished by Mr. J. D. Hague, the foot-hills south of Sacramento Cañon are found to consist of the Star Peak limestone, much broken up and irregularly bedded, having a general strike of north $15^{\circ}$ to $20^{\circ}$ west and dipping southwest. This conforms with observations on the same strike to the northward, and shows the limestone as turned up against the plane of the northwest and southeast fault, which has sundered the two halves of the range. South of this point, on the west side of the Buffilo Peak mass, in the American Mining District, Mr. J. D. Hague also found dark limestone beds dipping $20^{\circ}$ to $30^{\circ}$ to the east, and striking north $20^{\circ}$ west, underlaid by altered argillaceous limestones, passing down into quartzitic beds, which contain the crushed and half-obliterated remains of Nautili. From the limestones of American District were collected the following Triassic species :

\section{Halobia dubia.}

Trachyceras Whitneyi.

Ceratites Haidingeri.

Ammonites, sp.?

Ammonites, sp.?

Goniatites (Clydonites) lavidorsatus.

Wrapping around the southern extremity of Buffalo Peak occur some rather obscure outcrops of Tertiary strata, mainly consisting of thinly bedded calcareous sands and fine conglomerates, held firmly together by a fine binding material. As they lie turned up at an angle of $25^{\circ}$ to $27^{\circ}$, uplifted by the basaltic eruptions, they have been referred to the Miocene age.

Basalt is the only Tertiary eruptive rock recognized in the northern end of the West Humboldt Range, with the exception of the obscure 
andesitic dikes traversing the Archæan body. Their mode of occurrence appears to be quite similar in all cases, and they are found skirting the base of the range as massive eruptions, where the Triassic strata rise steeply out of the plain, seldom reaching more than a few hundred feet in altitude, although they frequently form nearly continuous masses for several miles. The largest exposures are found near Lldorado, Santa Clarn, and Buffalo Cañons, and, as might be supposed, along the main northwest and southeast fault, which nearly severs the range into two portions, and is evidently a line of great weakness. An interesting feature of these outbreaks is their close resemblance in general lithological habit. They are all finegrained, but distinctly crystalline, the only easily distinguishable mineral being olivine, which in places is very abundantly scattered through the groundmass. Under the microscope, the plagioclase and augite are characteristically shown. In a vesicular basalt directly east of Buffalo Peak, the feldspars are rendered quite impure by the presence of numerous glassinclusions. Professor Zirkel' calls attention to the microscopical structure of a variety of basalt from Eldorado Cañon, rich in olivine, containing well-developed crystals of picotite, a mineral abundant in the olivine of European basalts.

The northern end of the West Humboldt Range has in former years been the scene of considerable mining activity, mineral-bearing veins occirring throughout all the formations of the Star Peak Triassic, and being found on both sides of the range in nearly every canion. Those of the most importance thus far developed traverse the limestones, or the calcareous and argillaceous shales lying between the limestones and quartzites, and in general conform in dip and strike with the sedimentary strata. In "Mining Industry", ${ }^{2}$ Mr. J. D. Hague has given with some detail descriptions of the most important mining developments in the range up to the time of lis visit, showing the modes of occurrence, the amount of exploitation accomplished, together with the methods and costs of mining and milling. Mineralogically, these veins are of more than ordinary interest in comparison with most mining regions of Western Nevada, where usually the ore consists

1 Microscopical Peirography, vol. vi, 245.

${ }^{2}$ Mining Industrs, rol. iii, s018. 
mainly of the products of decomposition derived from the oxidation of sulphurets. IIere, however, although scarcely any study has been made of the vein products, good specimens have been obtained of native silver, argentite, stephanite, pyrargyrite, kerargyrite, galena, blende, jamesonite, bournonite, tetrahedrite, stibnite, anglesite, cerusite, malachite, azurite, calcite, quartz, iron pyrites, copper pyrites. Xanthocone in small crystals is said to have been found in the Manitowoc mine, on the ridge between Buena Vista and Cottonwood Cañons.

East of Buffalo Peak, and occupying the middle of the Quaternary plain, is an alkali flat, about 12 miles in length by 4 miles in breadth, formed of horizontal clay beds of the Lower Quaternary, which, along the edges and over a greater part of the surface, are covered by a heavy efflorescence of sulphates and chlorides.

Prof. O. I. Allen, of Yale College, who analyzed this salt, collected from near Buffalo Spring, found the following admixture:

Chloride of sodium . . . . . . . . . . . . . . . . . 70.81

Sulphate of soda ..................... 26.38

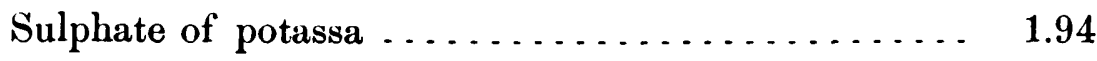

99.13

The aqueous solution was feebly alkaline, contained slight traces of lithium and calcium, and gave, after concentration, a reaction for boracic acid.

Southers Region.-The southern half of the range has been much less studied than the northern end, and it is even still more difficult to obtain definite ideas of its structure. Unlike the northern end, however, the geographical and geological axes approximately agree, the uplift, as before mentioned, having a northeast and southwest trend. In general, it seems to be a prolongation southward of the west side of the main anticlinal axis, made up for a distance of 20 miles of highly inclined and much metamorphosed strata, and plunging suddenly downward near the line of the Fortieth Parallel.

It consists of quartzitic schists as the lowest member, which only in the deepest points are laid bare by erosion. Over this, a heavy body of lime- 
stone comes in similar in, character to the Star Peak beds, from which one or two indistinct fossils of the genera Ammonites and Rhynchonella have been collected. Owing to the broken and deeply eroded state of the range, it is impossible to arrive at the thickness of this limestone; it probably, however, measures 1,000 feet.

Conformably overlying it, directly south of Oreana, is a quite heavy development of fine argillaceous slates, with interstratified bands of calcareous shales and fine arenaceous beds, the series, however, being prevailingly of very finely laminated argillites. They are without hesitation referred to the Jurassic slates, so largely developed in Humboldt Cañon.

Where the Triassic strata pass under the rhyolites, east of Humboldt Lake, they have a strike of about northeast true, and dip, so far as seen, to the northwest. About the middle of the uplift, they are broken through and overlaid by broad tables of basalt, which to a great extent mask the structure. Southeast of Lovelock's Station, there is a rapid bend of the entire formation into a north and south strike, with a dip to the west, which continues for about 6 miles, when, to the east of Lovelock's Station, and in the region of the little outcrop of Miocene strata, the whole body passes again into a northeast strike, which continues for 5 or 6 miles, until the range approaches the sharp valley dividing it from the northern end, where they are turned off into a northwest strike. The dip through all this region, with local exceptions, is toward the west, northwest, and southwest.

In the crumpled country lying directly south of Oreana, embraced between the dividing valley on the east and the Humboldt Valley on the west, there is a local double fold in the limestones and slates, which does not seem to penetrate deeply into the structure, the two half-folds upon which the strata dip to the east being very shallow and limited. Besides the folds, the strata are much disturbed by narrow dikes of vesicular basalt, having a strike a few degrees east of north, and, so far as observed, invariably dipping to the eastward. A peculiar feature of these basalts is the large amount of calcite formed in the cells of this extremely porous variety.

Directly south of the Jurassic slates below Oreana, the range foothills are occupied by an outburst of rhyolite, which continues north and 
south for about 4 miles, and directly beyond it occurs an outburst of basalt, which seems to break up between the Triassic slates and an unconformable overlying series of Tertiary sandstones, dipping to the westward at an angle of about $40^{\circ}$. These sandstones are composed of grains and pebbles of quartz, associated with some calcareous and argillaceous material, closely resembling those of the Kawsoh Mountains, and, from their inclined position, are referred to the Truckee Miocene rather than to the Pliocene series. They contain no fossils. The basalt has poured over them after considerable erosion, occupying the basin-like depression on the edges of the upturned beds, and following down the lines of Tertiary drainage. This furnishes another argument for referring them to the same age as the Miocene of Fossil Hill, Kawsoh Mountains. Along the western skirts of these basaltic hills, the characteristic calcareous tufas of the Lake La Hontan Basin are well shown. About a mile out from the foot-hills basalts, and rising out of the Quaternary, is another table of basalt, not unlikely a part of the same flow, which is altogether covered with the same tufa. South of the metamorphic uplift the country is occupied for about 10 miles by low, irregular, rhyolitic hills lying along the trend of the range. This group, although it has been but little studied, appears to resemble in its mode of occurrence and petrographical habit the Mopung Hills to the south, the only specimens of the rock obtained showing a similar groundmass of brick-red, white, and cream-colored bodies.

South of here for 8 miles, the range is again occupied by sedimentary rocks inclined to the south and southwest. They consist of highly metamorphosed quartzites and quartzitic slates, over which is a bed of highly altered limestone Neither in the quartzites nor limestones were any fossils discovered, and, since the body is entirely isolated from other sedimentary regions, there is no sure method of arriving at its age. The quartzitic schists, however, so closely resemble those which form the uppermost members of the Koipato series, that they have been referred to the same horizon, overlaid by the lowest stratum of the Star Peak limestone, although it is by no means impossible that hereafter some organic remains may be obtained referring them to some higher geological position.

Moruva Hills.-The Mopung Hills terminate the West Humboldt 
Range to the south, where they form a low group of rhyolitic rocks rising but a few hundred feet above the valley. Lying for the most part below the level of the old lake basin, they have suffered considerably from denudation, the retiring waters eroding them into the most rough and broken outlines, and leaving traces of the more permanent water-levels in the still remaining terraces. These rhyolites, as a group, differ considerably from those in the Pah-Ute Range, being far poorer in secreted minerals and revealing only small sanidins and both dark and colorless grains of quartz. Under the microscope may be detected, in a few cases, small flakes of biotite. Mineralogically, therefore, they present but little variety, but physically they offer one of the most interesting bodies of rhyolite in Western Nevada, showing the greatest possible differences in color, texture, and those peculiar structural forms so characteristic of rhyolite. In color, while they have a prevailing reddish tint, they vary from deep brickred, through brownish and yellowish shades, up to pink and salmon, producing the most marked and brilliant contrast, which is greatly heightened by the almost entire absence of soil and vegetation. The cause of this almost kaleidoscopic effect of color has been shown by Professor Zirkel to be due to the presence of ferritic needles and oxide of iron, filling the microscopical fissures in the groundmass after the development of the quartz and sanidin. In texture, these rocks vary from earthy, porous types, through infinite gradations and transitions, to compact masses, with a distinctly lithoidal character. In but few localities is the lamellated, banded structure more strikingly shown than here, even to the unaided eye the parallel lines running for long distances like narrow layers in sedimentary clays and sands, although much finer. But microscopically this structure is still more remarkable, and Professor Zirkel has given with some detail the results of his examination. ${ }^{1}$ He estimates that in some cases these lines are so extremely delicate that twelve of them taken together would not measure in thickness more than $0.03^{\mathrm{mm}}$.

The Mopung Hill eruptions are largely made up of breccia suspended in a fine felsitic groundmass, through which break later flows of white and

${ }^{1}$ Microscopical Petrography, vol. vi, 181. 
flesh-rolored rhyolites, and still later than these are others of a greenishgray pearlitic variety, the whole mass being penetrated by a powerfil series of north and south fissures, whose sides show the evidence of powerful motion.

A very interesting variety in the foot-lills directly to the south of the outlet of the lake has reddish-brown groundmass, containing beautiful chocolate-colored splmerulites, having a light, earthy nucleus. In this rock were (rystals of both orthoclase and plagioclase, but no quartz. Some purple varieties consist of round, half-pellucid grains, which have a concentric structure, the globules being flattened so as to give the rock a stratified appearance. Toward the extreme northern end of the foot-hills is a dark chocolate-colored rhyolite, containing much biotite, whose feldspar crystals are very largely decomposed, having a hollow nucleus partially filled with the groundmass. Still another interesting rhyolite in this group is a palered rock, with gray and purple bands. Crystals of sanidin pass through these narrow dark bands and penetrate the groundmass on both sides, while in other instances the groundmass diverges, surrounds the crystal, and converges beyond it.

In the most decomposed portions of these rhyolites is much carbonate of lime and some infiltrated salts incrusting the narrow fissures and cavities. In some places, a very considerable efflorescence of common salt covers the surface of the earthy rhyolites.

It is noticeable that in the breccias the entire mass of the included fragments is made up purely of rhyolitic material.

Two specimens of rhyolite from the Mopung Hills have been subjected to analysis, with a view to determine, if possible, if there exist any marked differences in chemical composition between these rocks and the granular, gray, porphyritic varieties that form the outbursts along the Pah-Ute Range.

No. 1 of these rocks has a characteristic lithoidal base, with well-developed but small sanidins scattered through it. No. 2 is a red, brecciated rock with few individualized minerals. 
Mr. R. W. Woodward, who made the analyses, reports:

\begin{tabular}{|c|c|c|c|c|}
\hline & 1. & 1. & 2. & 2. \\
\hline Silica & 76.80 & 77.00 & 74.12 & 75.34 \\
\hline Alumina......... & 11.64 & 11.54 & 11.96 & 11.68 \\
\hline Ferric oxide...... & 1.10 & 1.04 & 1.09 & 1.32 \\
\hline Lime . . . . . . . . & 0.43 & 0.43 & 0.36 & 0.49 \\
\hline Magnesia . . . . . . . & trace & trace & trace & trace \\
\hline Soda .......... & 253 & 2.45 & 2.26 & 2.20 \\
\hline Potassa. . & 6.69 & 6.72 & 7.16 & 7.35 \\
\hline Iithia . . . . . . . & trace & trace & trace & trace \\
\hline \multirow[t]{2}{*}{ Water ... . . . . . . } & 0.77 & 0.77 & 1.02 & 0.97 \\
\hline & 99.96 & 99.95 & 99.07 & $(19.35$ \\
\hline
\end{tabular}

Specific gravity, No. 1, 2.5 ; No. 2, 2.23.

Both of these analyses are remarkably alike, and chemically vary but slightly from the physically different rhyolites from the Pah-Ute Range, of which analyses are given on pages 695 and 698 . At the extreme southern point of the Mopung Hills, basalts again lreak ont, overlying the rhyolite, but occupying a very limited area.

Résumé.-Roughly the structure and dynamics of the West IIumboldt Range may be summed up in a few words. Its anticlinal fold strikes diagonally across the topographical trend, the axis of the fold being more or less influenced by the Archæan mass of Wright's Cañon, in the region of which there is some local displacement. The eastem side of the fold is faulted down on the plane of the axis, and is for the most part wanting, the position of the overlying limestone indicating that the northern continuation has suffered a powerful depression, leaving the western half high in tho air. A further remarkable peculiarity is the similar absence of the southern extension of the eastern side of the fold, the high summits in the region of Buffalo Peak falling off rapidly to the southwest without cliange of strike until they meet the line of the supposed northwest and southeast fault, and are there abruptly cut off, and do not re-appear on the southerly continuiltion of their strike. This cross-fault divides the range into the north and south halves just south of Sacramento Cañon, moved the southern end in 
a southeast direction until what would constitute the western side of the anticlinal is thrown into apposition with the axis. The necessary erumpling which would result from the originally folded condition prior to the faulting would make the southern end of the range complicated enough by itself; but it is rendered still more difficult to read by great local changes of metamorphism, and masked by the overlying masses of Tertiary rhyolites and basalts, which break out along the lines of greatest weakness, and wherever the strata plunge rapidly downward.

Hills Norti of Humboldt River.-North and west of where the Humboldt River makes its great bend to the south, and intermediate between the Havallah and Montezuma Ranges, lies a group of disconnected mountain masses separated by low depressions, which are occupied by Quaternary accumulations largely made up of drifting sands. These sand-beds are frequently of such an extent as to cover large areas and to form elevated dunes, more or less concealing the lower lills of the earlier uplifted strata. In general, the mountains present much the same geological appearance, with the same structural features, consisting of a nucleus of crystalline rock, against which rest unconformably a mass of uplifted slates with interstratified sandstones and limestones like the Jurassic slates of the Pah-Ute and West Humboldt Ranges. The prevailing dip is to the northwest, away from the course of the river; a number of recorded strikes and dips indicating from the southern end of the Eugene Mountains a gradual curving of the strata more and more to the northeast, until at Winnemucca Peak they strike a few degrees north of east, still dipping to the northwest. Structurally, therefore, they strike and dip quite unlike the north and south ranges south of the river, and doubtless are the determining cause of the great bend formed by the river, which wraps closely around the abrupt slopes of the Triassic uplifts.

From this region no organic remains have as yet been collected to aid in identifying the strata, and as the continuity of beds with the ranges to the south cannot be clearly made out, their reference to the Jurassic is based entirely upon lithological comparisons.

Winnemucca Peak.-The mountain mass of Winnemucca Peak is made up of highly metamorphosed blue limestones, seamed with white calcite, $47 \mathrm{Da}$ 
together with a considerable development of clay shales and siliceous, finely laminated slates, which strike a little north of east, and dip steeply to the northwest. Their lithological habit is not very characteristic, nor were any fossil remains found in them, but they have been referred for the reasons already mentioned to the Jurassic formation. They are underlaid by a body of syenitic granite, which is exposed at the western end of the peak, while along the southeastern foot-hills are found considerable exposures of diorite. In the neighborhood of this diorite body, the slates are traversed by numerous mineral-bearing veins, which have a strike and dip generally in conformity with the formation.

The syenitic granite, which has been indicated by the colors of both granite and syenite upon the map, is a fine-grained rock, made up of feldspar, hornblende, and mica. The feldspars are much decomposed, and their crystalline character so indistinct that it is difficult to say which is the prevailing form. To the naked eye, the hornblende appears to predominate, the mica, which belongs to the dark magnesian variety, occurring in large, isolated, hexagonal plates, which seem to be rather an accessory constituent, but under the microscope the mica is seen to rather predominate over the hornblende, for which reason Professor Zirkel has classed it as a granite rather than as a syenite. The diorite at the southwestern point of the hills, near the granite body, is a greenish-gray, rather crystalline rock, made up of plagioclase and hornblende, with some quartz. The hornblende is generally fibrous, and seems to be much decomposed, and, under the microscope, shows remarkable phenomena of alteration. The diorite from the eastern point of the hills is similar to this rock, but the plagioclase crystals are larger and fresher, which give to it more of a porphyritic structure. Under the microscope, it presents a beautiful instance of pseudomorphism of epidote ${ }^{\circ}$ after hornblende. It also contains titanic iron. The diorite from the centre of the mass is a more even-grained rock, having a less porphyritic structure, which is made up mostly of triclinic feldspar, hornblende, and quartz, with considerable macroscopical brown biotite. Under the microscope, the groundmass is composed almost wholly of quartz and hornblende. The quartz crystals contain a great many fluid-inclusions, which are of dihexahedral forms, and contain salt cubes like thuse found in the crystalline rocks from 
Rawling's Peak, Wyoming. The plagioclase crystals have in some places the same strueture as the labradorite feldspars from Paul's Island on the Labrador coast. They contain black needles and grains and brown laminæ in the same arrangement, which is an unusual occurrence in the presence of so much quartz as is found in this rock.

Southwest from Winnemucca Peak, along the banks of the river, are a number of obscure outcrops of light-gray limestones, considerably broken up by intrusions of basalt and partially buried in sand, which have on the map been colored as belonging to the Star Peak formation, although it is by no means improbable that they belong to the lower beds of the Jurassic.

BlaCr Butte derives its name from the color of the prevailing slates upon its summit. It forms an isolated mass, roughly circular in outline, between 3 and 4 miles in diameter, and rises over 2,000 feet above the valley of the Humboldt, presenting steep slopes on all sides, with deeplyeroded cañons. On the south side of the summit occurs a body of mediumgrained, light-gray crystalline rock, which, with some hesitancy, has been classed as a syenite. Where examined, it was found to be considerably decomposed, but appeared to carry both monoclinic and triclinic feldspars; the orthoclase of a flesh-red color, however, being the prevailing form. The hornblendes are usually quite small and of a greenish tinge.

The slates on the summit of the ridge strike north $50^{\circ}$ east, and dip from $50^{\circ}$ to $55^{\circ}$ to the northwest, and, although along the spurs the beds show considerable variation in dip, they are always inclined at high angles. It is evident that there are exposed here between 3,000 and 4,000 feet of conformable strata, mainly composed of thinly-bedded slates and shales, with occasional layers of compact brown sandstone and some bluish-gray limestone. In the slates may be recognized grains of pyrites, while the microscope reveals, under a high power, pale-greenish chlorite surrounding the quartz.

Eugene Mountains.-The Black Butte is connected with the Eugene Mountains by a low pass, in which are a number of obscure exposures of slates, standing at high angles and dipping northwest, serving to show the continuity of strata between the two main uplifts. The mountains extend from the Humboldt River for 12 miles, with a northeast and southwest 
trend, the highest points at the northern end attaining an elevation of over 3,100 feet above the valley. Although this group has been but littlo studied, there appears to be a nucleus of syenite cropping out in one or two places, and indicating a continuous body with that of Black Butte, which it lithologically resembles, and in like manner does not reach the higher summits.

Observed strikes of the slates vary from north $35^{\circ}$ to $45^{\circ}$ east, dipping steeply to the northwest. The low butte to the westward of the Eugene Mountains is formed of the same slates, having a strike north $45^{\circ}$ to $50^{\circ}$ east.

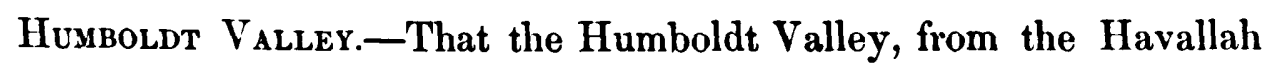
Range southward nearly to Humboldt Lake, is underlaid by horizontal Pliocene strata, seems evident from the great number of exposures in the immediate region of the river-banks, and from the thinness, wherever observed, of the overlying Quaternary material. Indeed, one noticeable feature of the valley is that there are no observations to warrant a belief in the great thickness of the Quaternary deposits; for wherever they are penetrated to any considerable depth, the upturned Miocene or horizontal Pliocene beds are soon reached. That all the older formations are more or less concealed by Quaternary is evident, but upon the mountain-slopes there are no such talus accumulations as are to be found elsewhere; the fine silts and gravels of the plain serve as a mere covering to the Tertiary, while the alluvial bottoms are not only thin but limited in extent. The reason of this thinness of Quaternary seems obvious: the whole region up to 500 feet above the level of Carson Lake, or about 4,400 feet above sea-level, has been so recently occupied by the waters of Lake La Hontan, which date back to the Glacial period. The thin series of clays and sands, which form the mud lakes and alkali bottoms, are of an altogether unknown thickness, and inasmuch as they represent the bottom of these Post-Pliocene lakes, the Upper Quaternary, which now covers the valleys, with the exception of these isolated areas, is, therefore, only the accumulation since the desiccation of this great sheet of fresh water. It is, therefore, evident that the very great accumulations of Quaternary could not be expected in a region which, during the longest portion of the Quaternary period, was submerged. 
For this reason, the Pliocene beds are represented on the geological map as forming a continuous belt along the river, although the outlines of formations are not definitely known.

Except in one or two places, where the river cuts a deep channel into the strata, there are no very good exposures, much better sections being found in the high bluffs on the Carson and Truckee Rivers. The best exposures, however, are seen east of Rye Patch Station, where the river for several miles flows in an exceedingly narrow channel, with nearly precipitous sides eroded in the Humboldt Pliocene beds, the walls having an average height of $200 \mathrm{feet}$, and in places reaching over 300 feet. The section shows a regular horizontal series of sands and finely-comminuted arenaceous clays, interstratified with indurated clays, but no beds of coarse conglomerate. Very similar bluffs occur just north of Oreana. No fossils were found. Directly west of Oreana, and extending thence southward to Lovelock's Knob, there is an exposure for 10 miles of the upper members of the Humboldt Pliocene, which here also are made up of clays and fine lands, as shown in the eroded ravines and basins. Abundant evidences are seen of the La Hontan Lake terraces, with a series of well-marked, successive beach-lines descending nearly to the level of the desert, scattered over which are fragments of the old lake tufas.

Organic remains are quite rare from the Humboldt Pliocene; the only vertebrate bones, so far as known, that have ever been found were taken from a cream-colored earth near Fairbank's Point, at the end of the Havallah Range, and have been pronounced by Prof. O. C. Marsh as belonging to the Pliocene horse. Invertebrate remains seem equally rare, and have only been observed in an isolated patch of light-colored limestone, which rests unconformably upon the Star Peak beds, just south of Mill City. Its relations with the other Pliocene strata are quite unknown, similar beds not having been recognized in the valley. Prof. F. B. Meek, to whom they were referred, regarded them as undoubtedly fresh-water Pliocene forms.

In the middle of the broad valley west of Humboldt Station, there is an interesting locality of basalt, rising out of which are numerous low domes and crater-like mounds of resicular basalt, having all the appearance of 
comparatively recent volcanic action. It is quite unlike any other basalt region in Nevada, and resembles more the immediate base of many large basaltic volcanoes. Directly connected with these basaltic outbreaks, but south of Humboldt Station, is a narrow vertical fissure, which has been filled with native yellow sulphur by solfataric action, long since extinct. It had been mined to some extent, but, at the time of our visit, had been abandoned, the yield being too small to be of practical importance. It may be well to mention here the occurrence of a somewhat peculiar sandstone, which appears to have been hardened and baked by the basaltic eruptions, forming an exceedingly tough rock with a vitreous lustre, composed of quartz-grains and particles of feldspar, and carrying secretions of jasper.

At the southern end of Humboldt Lake, there occurs the narrow crest of an anticlinal ridge, which strikes directly across the Humboldt Valley, and forms a dam, backing up the waters of the river into a broad lake, two or three miles in width. This anticlinal is perhaps 5 miles in length, and rises about 100 feet above Mirage Lake. The formation offers no good exposure of beds, but lies inclined at a considerable angle, and has therefore been referred to the Miocene age: The Lake La Hontan beach-lines are seen along the foot-hills on both sides of the valley, where large blocks and pebbles of basalt are cemented together by calcareous tufa. An outlying hill must have been an island during the period of the La Hontan Lake, as it is entirely surrounded by the old shore deposits.

Nowhere along the valley, from Fairbank's Point to Mirage Lake, have the Miocene and Pliocene beds been observed in direct contact, and nowhere on the river-bottoms are the Pliocene beds cut through to the older series. At one point, nearly west of Oreana, the two formations approach each other, but the direct contact is concealed by the Quaternary drifts.

Humboldt Lake is probably a shallow sheet of water, and, as it drains off through the Mopung Marshes into Mirage Lake, must have nearly the same saline ingredients as the lower portion of the river. It has a strongly brackish alkaline taste, but, owing to its free drainage, is less highly charged with soluble salts than most of the other interior lakes. A portion of the 
water collected in a cask was forwarded to Prof. O. D. Allen, of Yale College, for analysis. He reported as follows:

Specific gravity, 1.0007.

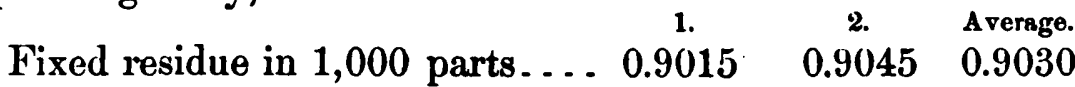

Constituents found in 1,000 parts :

$\begin{array}{lllll}\text { Corbonic acid } & 1 . & 2 . & \text { Average. }\end{array}$

$\begin{array}{lllll}\text { Sulphuric acid ................. } & 0.0257 & 0.0248 & 0.0253\end{array}$

$\begin{array}{lllll}\text { Phosphoric acid ............... } 0.00069 & \ldots . . & 0.00069\end{array}$

Chlorine .................. $0.2954 \quad 0.2949 \quad 0.2952$

Silica .................... $0.0320 \quad 0.0330 \quad 0.0325$

$\begin{array}{lllll}\text { Magnesia................... } 0.0281 & 0.0268 & 0.0274\end{array}$

Lime ..................... $0.0180 \quad 0.0172 \quad 0.0176$

$\begin{array}{lllll}\text { Sodium ..................... } 0.2786 & 0.2783 & 0.2785\end{array}$

Potassium................ $0.0612 \quad 0.0605 \quad 0.0609$

Lithia .................. trace $\ldots .$. trace

Boracic acid .............. trace $\ldots . . . \quad$ trace

Oxygen ................................ $\frac{0.04273}{0.88782}$

There is probably a loss of carbonic acid. The theoretical combination of bases and acids would give :

Carbonate of soda......................... 0.24944

Sulphate of soda . . . . . . . . . . . . . . . . . 0.04498

Chloride of sodium ..................... 0.39571

Chloride of potassium .................. 0.11617

Carbonate of lime........................ 0.03143

Carbonate of Magnesia.................... 0.05768

Silica ............................... 0.03250

Phosphoric acid ....................... 0.00069

Less carbonic acid added to the amount found.... 0.04254 
Near Brown's Station, opposite Humboldt Lake, a quantity of the saline incrustation found covering the ground was collected, mixed with the fine impalpable soil of the valley. On analysis, it yielded Mr. R. W. Woodward the following composition:

Soluble in water, 27.71 per cent.

Chloride of sodium ................... 49.67

Sulphate of soda $\ldots \ldots \ldots \ldots \ldots \ldots \ldots \ldots \ldots .20 .88$

Sesquicarbonate of soda ................... 18.15

Borate of soda ....................... 11.30

100.60

The Carson Desert.-In its general features, the Carson Desert resembles the depressed meridional valleys which lie between the parallel basin ranges, covering, however, a much larger area, and extending from the PahUte Range westward to the Kawsoh Mountains, a distance of 40 miles. To. the north and south, it is rimmed in by low volcanic hills connecting the main uplifts. Its average elevation may be taken at 4,000 feet, the lowest portion in the region of Carson Lake standing about 3,875 feet above sealevel, which agrees very closely with the elevation of Pyramid Lake and the series of Mud Lakes to the northwest. Both Humboldt and Carson Rivers empty into the Carson Lake; the former, receiving the drainage of $a$. large portion of Northern Nevada, brings down the greater part of the alkaline accumulations that are deposited in the lake, while the latter taking its rise in the snowy regions of the Sierras, although a very considerable stream, has a much less tortuous course across the arid regions of the basin. Carson Lake, which receives these streams, is about 20 miles long by 12 wide, and, although occupying a large superficial area, is undoubtedly a shallow sheet of water varying each year in its outlines. Its waters have never been analyzed, but are probably quite similar in composition to those of Humboldt Lake, except that having no outlet they possess a much greater density. Completely encircling the lake is a narrow belt of Lower Quaternary silts and fine gravels, which on the western side extend nearly up to the base of the West Humboldt Range, with scarcely any vegetation but alkaline grasses. On the opposite side of the lake is a chain of sand-dunes, formed of the sands which the prevalent westerly winds have blown from 
the Truckee Valley through the gap south of the Kawsol Mountains, and piled up in ever-shifting mounds on the eastern side of the desert.

Like the Nevada valleys, tree-growth is wanting on the desert, vegetation being still more limited than on the so-called sage-brush plains, and over a greater part of the area is restricted to a scattered growth of stunted alkaline shrubs, of which Halostachys occidentalis is the prevailing species, producing a monotonous dulness of mingled dull-gray plant-life and blinding white sands.

Over the entire area there is but a single elevation rising above the general level, and that one scarcely reaching 200 feet. It is situated midway between the Carson River and Mirage Lake, just east of the old Fimigrant Road, and stands up like an island in a sea of sand. From a hasty examination, it would appear to be a basaltic outburst, penetrating and uplifting the underlying Miocene Tertiary beds, which are exposed along the base. More or less encrusting the entire hill are heavy depnsits of the aqueous tufas, which have been eroded in the most curious manner; the rock upon which it was deposited weathering much more readily than the compact and homogeneous sediment, leaving the latter standing like a wall or fortification 3 and 4 feet in height and frequently 2 and 3 feet in thickness. In places, the tufa shows a concentric structure resting in dome-like masses • upon the underlying rock.

An analysis of this tufa was made by Mr. R. W. Woodward for the purpose of comparison with the similar deposits observed on the Truckee Desert and at Pyramid Lake, and was found to have an almost identical composition.

It yielded:

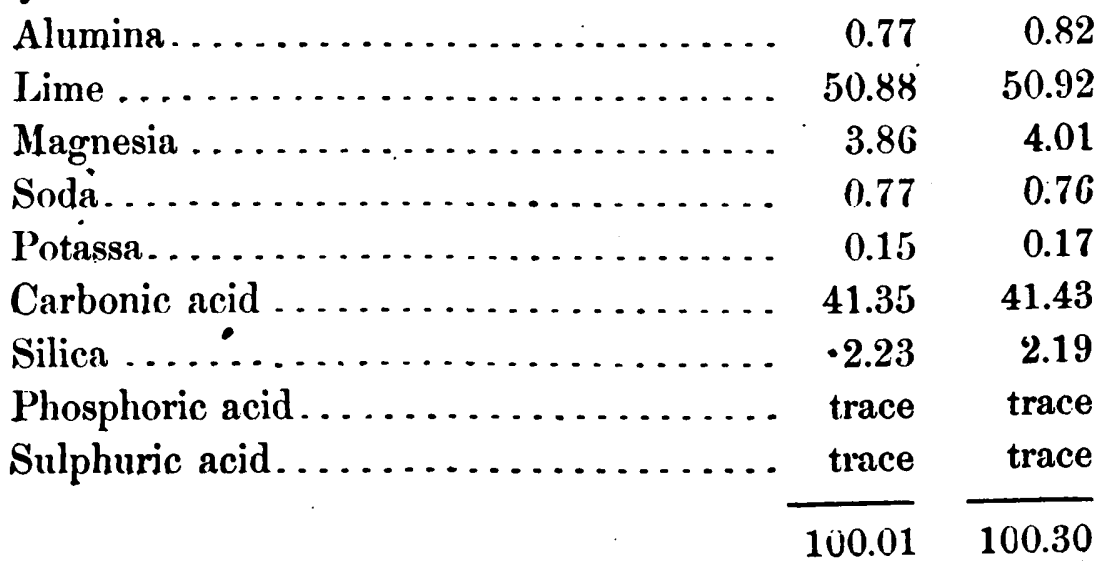


The silica exists partly in combination and in part as finely divided sand. Along the Carson River from Ragtown southward, the Pliocene formation, as seen in the Humboldt and Truckee Valleys, is well developed in broad bench-like tables, frequently standing one or two miles back from the river, which, upon the west side, are cut through at regular intervals by narrow ravines.

Everywhere along the borders of the desert, the La Hontan beach-terraces are easily traced, the highest one having an altitude, according to barometric measurements made at a number of points, of about 520 feet above the level of Carson Lake, below which elevation the hills and benches are more or less covered by fragments of calcareous tufa. These tufas are well shown in the neighborhood of Hawes Station, on the old Overland Stage Road, just south of the map, in longitude $119^{\circ} 10^{\prime}$, where both rhyolites and basalts are enerasted by a thin coating of yellowish-brown carbonate of lime.

The Soda Lakes; situated between 2 and 3 miles northeast from Ragtown on the Carson River, near the southern boundary of Map V, form one of the most striking features of the Carson Desert. The photograph reproduced on Plate XXII represents the smaller lake, the larger being shown in Vol. I, Plate XXVI. They lie depressed below the level of the plain, in what are probably ancient craters, and are not observed until just before reaching the brink. Upon the south side of the larger lake, the bank slopes somewhat gradually to the water's edge, with a fall of not more than 35 feet, but rising steadily on the east and west sides, until at the north it attains a height of $\mathbf{1 5 0}$ feet in nearly perpendicular walls. The lake has a clear blue color, is of round form, with a diameter estimated at five-eighths of a mile. It has no outlet, and is fed by a spring of cool fresh water on the northwest side, which breaks through a stratum of gravel outcropping just above the water-level. From the lake-border to the abrupt walls, the water is completely encircled by a narrow belt of level shore, composed of loose friable material, mainly small rounded basaltic pebbles, and coarse gravels held together by fine sands. A coniderable vegetation is found surrounding the lake, but one not specially rich in species. Mr. Sereno Watson collected near the fresh-wnter spring the following species: Erige- 
ron Canadensis, Solidago occidentalis, Epipactis gigantea, Juncus Balticus, known as "wire-grass" and considered valuable for hay and pasturage, Juncus nodosus, Juncus xyphioides, Phragmitis communis, Poa tenuifolia, one of the most common bunch-grasses of Nevada, and Avena sativa, or common oat, which, doubtless, escaped from some emigrant's wagon. From the more or less alkaline shore, Mr. Watson obtained: Ranunculus cymbalaria, Scirpus Kingii, a new species of rush, Sporobolus asperfolias, found also on the sands of Mono Lake, and Brizopyrum spicatum, a very abundant salt-grass

The water is highly charged with alkaline salts, and is so dense that the human body floats in it without exertion, and, after drying, the skin is left with a thin white coating. Wherever the water washes the shore, it leaves more or less residue upon evaporation. In the spring of the year, the water attains its highest level when there is but little deposit, and it gradually recedes until late in the autumn it reaches its greatest density, and there is left a very considerable amount of alkaline salts upon the shore.

In the month of August, a quantity of this water was taken from the south side of the lake for the purposes of analysis. Prof. O. D. Allen, who made the chemical examination, reports the following composition:

Specific gravity, 1.0975 .

Fixed residue in 1,000 parts, 114.7.

\begin{tabular}{|c|c|c|c|}
\hline Magnesia .............. & $\begin{array}{c}1 . \\
0.0230\end{array}$ & $\begin{array}{c}2 . \\
0.0230\end{array}$ & $\begin{array}{r}\text { Average. } \\
0.0230\end{array}$ \\
\hline Sodium $\ldots \ldots \ldots \ldots \ldots$ & 42.5990 & 43.0780 & 42.8380 \\
\hline Potassium . . . . . . . . . . & 1.5460 & 1.6480 & 1.5970 \\
\hline Chlorine $\ldots \ldots \ldots \ldots \ldots$ & 39.4100 & 39.3729 & 39.3914 \\
\hline Sulphur $\ldots \ldots \ldots \ldots \ldots$ & 0.0954 & 0.1002 & 0.0978 \\
\hline Sulphuric acid $\ldots \ldots \ldots \ldots$ & 9.4350 & 9.4286 & 9.4303 \\
\hline Carbonic acid.......... & 12.7440 & 12.5550 & 12.6490 \\
\hline Silicic acid ...... & 0.2050 & $\cdots$ & 0.2050 \\
\hline Oxygen $\ldots \ldots \ldots \ldots \ldots$ & & & 6.3465 \\
\hline
\end{tabular}

112.5780 
The combination of acids with bases gives:

Chloride of sodium

Sulphate of soda ................... 13.7626

Carbonate of soda .................... $\mathbf{2 9 . 2 4 8 2}$

Sulphide of sodium . . . . . . . . . . . . . . . . . . 0.2384

Sulphate of potassa. . . . . . . . . . . . . . $\quad 3.6515$

Carbonate of magnesia $\ldots \ldots \ldots \ldots \ldots \ldots \ldots \ldots . .60652$

Silica . . . . . . . . . . . . . . . . . . . . . . 0.2050

Excess of carbonic acid ............... 0.4658

112.5780

Before concentration, the water gave with tumeric paper a reaction for boracic acid; after crystallization, the spectroscope revealed the presence of lithia.

The northwest side of the lake being quite shallow, the receding waters - leave large fields of dazzling-white carbonate of soda, which by the autumn accumulates to such an extent as to become an article of commerce, 150 tons of the crude salt collected in one season from the two lakes having been freighted to Carson City, Nevada, and, it is said, sold at $\$ 40$ per ton to the soap-manufacturers.

An analysis by Prof. O. D. Allen, of a sample taken from the deposit, shows that it is quite a pure trona, or sesquicarbonate of sorla, mixed with small quantities of sulphate of soda and common salt. It yielded the following :

Soda

Carbonic acid. 36.86

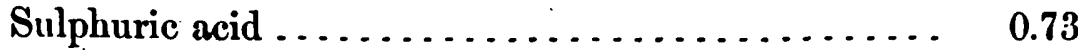

Chlorine .............................. 0.98

Water .......................... 19.90

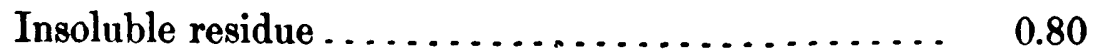

Oxygen eq. to chlorine . . . . . . . . . . . . . 0.22 
It contains also traces of phosphoric and boracic acid. The insoluble residue consists of fine sand and carbonate of lime.

Gay-Lussite is constantly forming in the waters, and is deposited in very perfect crystals, both on the small island which rises scarcely 2 feet above the water-level about 25 feet out from the northwest shore, and on small branches and twigs that are thrown into the lake. The branches, becoming saturated with water, sink to the bottom, and upon being brought to the surface are found encrusted with delicate yellowish-white crystals of Gay-Lussite. They are translucent, quite brittle, and of a characteristic vitreous lustre. An analysis of a crystal, by Professor Allen, gave the following constituents:

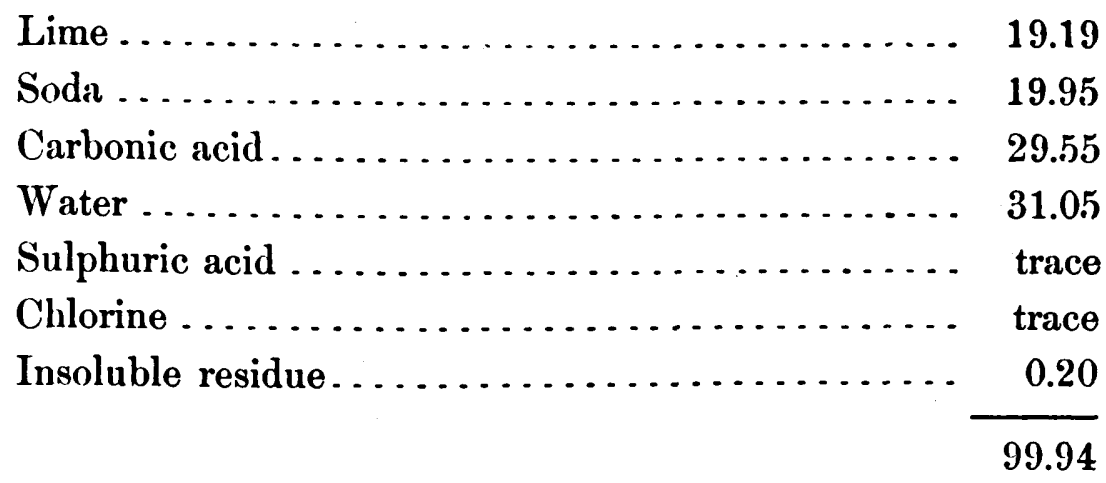

which, but for the admixture of small quantities of a sulphate and chloride, approaches closely the required theoretical composition.

The water appears to be wanting in animal life, with the exception of a minute fly, the larva of which is a small worm, accumulating in such large quantities as to form a belt a foot wide along the shore. It is occasionally gathered by the Pah-Ute Indians, and, after drying and pulverizing, made into a sort of meal or flour. In the autumn, when the water becomes somewhat dense, the larvæ are completely coated with carbonate of lime, and transformed into an irregular mass of mineralized matter.

The smaller of the two lakes, in most of its features, bears a close resemblance to the one just described, and from which it is separated by a narrow ridge only an eighth of a mile wide. It has the same crater-shaped basin, but the banks are not more than 60 or 70 feet in height, and the lake, even in spring, is scarcely more than one-fifth of a mile in diameter. There 
is no supply of fresh water from the surface, and at the time of our visit, in August, the water was much more dense than in the larger lake. Over a greater part of the surface was found a thick incrustation of trona strong enough to bear up a man, under which is a greenish slime and occasional pools of water. One characteristic feature of the shore is the green and purplish tints of the moist sands, which, upon being dried, present the usual earthy colors.

Gay-Lussite similar to that found in the large Soda Lake also occurs here, and is formed in the same manner.

The trona from the small Soda Lake, upon being subjected to analysis, yielded the following:

Sulphate of soda....................... 0.99

Chloride of sodium........................ 1.10

Carbonate of soda.......................66.27

Water and free carbonic acid................. 28.83

Insoluble residue $\ldots \ldots \ldots \ldots \ldots \ldots \ldots \ldots \ldots, 2.81$

100.00

It gave, after concentration by crystallization, in the spectroscope, both potassa and lithia. There is also present a trace of phosphoric and boracic acids. The insoluble residue is sand, with traces of lime, iron, and phosphoric acid. 


\section{SECTION VI. \\ MONTEZUMA RANGE AND KAWSOH MOdNTAINS.}

BY ARNOLD HAGUE.

Montezuma Ravae.-This mountain uplift lies to the westward of the West Humboldt Range and upon the opposite side of the Humboldt Valley, forming the first successful barrier to the westerly progress of the river in its long sinuous course across the State of Nevada. It extends from Mirage Lake northward for over 80 miles, passing beyond the limits of the map. From its southern termination to the Trinity Peak group, it agrees in trend with the lower half of the West Humboldt Range; and from there northward has a nearly due north and south direction. In width, the range rarely exceeds 12 miles, and in many places is contracted to 6 or 8 miles, the widest portions being in the region of Antelope Peak to the north, and at Trinity Cañon opposite the town of Oreana.

The range as seen from the valley, looking westward, presents a jagged and broken outline, which comes, however, more from frequent and abrupt changes in geological structure than from any real grandeur of topographical features. The serrated and sharp, pinnacled masses of granite, the rounded and smoothly-eroded forms of gray slate, the long black tables and rough domes of basalt, with the irregular outbursts of rhyolite, give an ever-changing and varied aspect as regards structure, form, and color to the entire range.

Commanding peaks nowhere characterize the range, the most elevated summits rising but a few hundred feet above others in the surrounding group. Trinity Peak, composed of granite, at the head of Trinity Cañon, and Antelope Peak, of Jurassic slates, 18 miles to the northward, attain an altitude of about 7,500 feet above sea-level; from both peaks the ridges falling off gradually toward Indian Pass, 2,500 feet below.

The drainage-channels of at least four-fifths of the entire mountain area fall toward the Humboldt Valley, a few secondary cañons from the steeper slopes carrying water derived from melting snows to the westward. The range, however, may be characterized as one of the driest in the 
Nevada Basin, inasmuch as in the main drainage courses throughout its entire length is there not only no perennial stream, but scarcely one running a hundred yards, a month after the close of the spring rains. A few small springs in Trinity and Black Cañons, and in the early season one or two others scattered through the granite belt, afford, when the necessary precautions are taken to prevent the water from running to waste, a sufficient supply for bands of stock.

Willow Spring, on the old Emigrant Road, in Rabbit Pass, is the only large one running all the year with any considerable strean of water. It is clear, cold, but slightly sulphurous, and comes from the Jurassic slates in the eastern foot-hills. Timber is scarce, only a few pines and junipers of dwarfed and stunted growth being found high up on the granite rocks, and in the more sheltered canons.

As a winter range for stock of all kinds, these mountains afford excellent pasturage. The easily decomposing granites and slates yield a good soil for a nutritious bunch-grass; and a moderate snow-fall, a mild climate, the shortness of the rigorous season, and the broken nature of the country, are all favorable for grazing purposes.

Geologically, the structure of the Montezuma Range in most of its broader features resembles the ranges already described to the eastward, between the Humboldt River and Battle Mountains; that is to say, it consists of Archæan masses composed of granite and crystalline schist, striking approximately northeast and southwest, forming the nucleus of the range, overlying which are Mesozoic strata, resting unconformably upon them. Breaking through the older formations are the Tertiary volcanic eruptions; in the northern portion of the range confined to small outbreaks mainly along the foot-hills, while to the south they have been ejected in such vast masses as to conceal, over the greater part of the area, nearly all traces of former rocks. The most distinctive feature of the Montezuma Range is, so far as observed, the entire absence of not only the Koipato quartzites, but also of the Star Peak series, the lowermost strata exposed consisting of slates referred to the uppermost beds in the West Humboldt uplifi. In the Havallah Range, the Koipato beds are largely developed, overlaid by Star Peak Triassic. In the West Humboldt, the Koipato formation is somewhat thinner, but overlaid by the enormous thickness of 10,000 feet of 
interstcatified Star Peak limestones and quartzites, in turn capped in places by Jurassic shales. But in the Montezuma Range, the Jurassic shales rest directly upon the granite, attaining a development of between 3,000 and 4,000 feet in thickness.

The granites and metamorphic crystalline schists of the Montezuma Range are, with the exception of a few small and inconsiderable outlying bodies, comprised within an area of 40 miles in a north and south direction, lying mostly between the parallels of $40^{\circ} 15^{\prime}$ and $40^{\circ} 45^{\prime}$. Within this limit, they occur in three large irregular-shaped masses, the trend of each body being northwest and southeast. They form nearly all the higher summits, falling away in low rugged hills until concealed beneath the inclined Jurassic slates, or the horizontal beds of the Quaternary. The largest mass of granite in the range is associated with a very heavy body of dark schists and slates, both of which have been referred with but little hesitation to the Archaan age. This Archæan group rises above the 'Truckee Miocene beds at Indian Pass, extending southward for nearly 25 miles in an unbroken line, where it terminates abruptly in an approximately east and west line, being covered by immense outflows of rhyolite and basalt. It occupies in the region of Trinity and Black Cañons, the entire width of the range, measuring over 10 miles across, with a general strike of north $40^{\circ}$ east and south $40^{\circ}$ west. The granite forms the axis of an anticlinal ridge, with the schists and slates resting unconformably upon it, all the higher points consisting of granitic peaks, which present a broken serrated ridge with great diversity of outline, while the overlying beds are exceedingly monotonous in form, with smooth rounded slopes and domeshaped summits, contrasting in a very marked manner with the granite and sharply defining the line of contact.

Where the granite was crossed, it appeared to be characterized, in general, by a uniform texture and habit. The specimens collected from the eastern foot-hills west of Rye Patch are a medium-grained rock, of a gray color and a somewhat altered appearance. All the mineral constituents of granite are present, but in small crystals or grains. Both hornblende and mica are well developed, the former in short, green, fibrous crystals, and the latter in brown hexagonal plates. Both macroscopically and microssopically the rock possesses the habit of the older series of eruptive AS $D \mathrm{G}$ 
gianites. Four or five miles northwest from Oreana, in the foot-hills of the range, occur small outcrops of granite surrounded by rhyolite. It is of some interest, as it forms the country-rock in which the "Montezuma Mine" is situated, a full description of which may be found in Mining Industry, Volume III of this series. That this granite belongs to the central mass, and is characterized by the same physical habit and mineralogical composition, there would seem to be no doubt.

On both sides of the anticlinal axis, the crystalline schists are well developed, and, as already mentioned, rest unconformably on the granite. They lie inclined at a very ligh angle; an observed dip in Trinity Cañon indicated $60^{\circ}$ to the eastward, while on the west side recorded strikes gave north $45^{\circ}$ east and a dip of $50^{\circ}$ to $60^{\circ}$ to the westward. It is evident that there are exposed here several thousand feet of conformable strata, of nearly uniform lithological character. In color, they vary from steel-gray to black, with considerable lustre. The groundmass is so exceedingly fine that it is almost impossible to recognize, by the unaided eye, any mineral constituent; but thin sections under the microscope develop an admixture of quartz and mica, with some grains of magnetite. Both biotite and muscovite are found. It is somewhat singular that no trace of feldspar is visible. In the region of Trinity Cañon, the slates are traversed by numbers of granitic veins cimilar in mineralogical character to the main body of granite.

South of the line of the great outbursts of Tertiary volcanic rocks, granites only appear along the Montezuma Range in one or two small outcrops, which derive their chief interest from the indications they offer that the granite probably underlies, at no great depth, a very considerable area of country. One of these localities, Lovelock's Knob, forms an isolated hill east of Lovalock's Station, which rises several hundred feet out of the Quaternary deposits of the Humboldt Valley, only the base of which, however, is of granite. Still farther to the southward, granites again come to the surface, projecting out eastward into the valley at Granite Point.

North of Indian Pass, along the east side of the range, and directly east of Antelope Peak, occurs the second large body of granite. It extends from Indian Pass to the mouth of French Cañon, measuring between 8 and 9 miles in length by 4 or 5 in width, and rising from 1, (:00 to 1,500 feet above 
the plain. In its field habit, modes of weathering, and geological relations, it closely resembles the more important body to the northward. This latter granite occupies the central mass of that portion of the Montezuma Range lying north of Antelope Peak. It is about 15 miles in length, and almost entirely surrounded by beds resting unconformably upon it, made up of fissile slates, calcareous shales, and limestones, referred to the Jurassic age. It possesses a medium-grained texture, a light-gray color, and the normal mineralogical composition, carrying considerable amounts of well-developed brilliant hexagonal plates of biotite.

North of Indian Pass, the Jurassic is the prevailing formation, wrapping around the granite bodies on the west and north, and dipping, except in local instances, to the west and northwest. The most favorable place for studying these beds is at Antelope Peak, where they reach a development of nearly 4,000 feet, exposed along the walls and slopes of French Cañon. The beds strike diagonally across the range, dipping, however, at very varying angles, owing to the intrusive masses of diorite and porphyry, which have thrown them up to $75^{\circ}$ and $80^{\circ}$, with a strike of north $25^{\circ}$ east. On the summit of Antelope Peak, they strike from north $25^{\circ}$ to $30^{\circ}$ east, and $\operatorname{dip} 35^{\circ}$ to $40^{\circ}$ to the northwest, the beds falling away gradnally toward Indian Pass. The slates and shales have a bluish-gray color, a thin lamination, and are frequently very brittle. In composition, they are generally arenaceous, passing into thin beds of compact sandstone. At times, the strata become gradually calcareous, and the rock passes into a well-defined limestone, rarely, however, more than a few feet in thickness, but of a deeper blue color than the slate rocks. West of Antelope Peak, the strata are considerably disturbed, curving around the southern end of the granite, beyond which they again dip to the westward, forming the main ridge. Here they follow a somewhat sinuous course, trending off to the northwest for about 12 miles, until beyond the influence of the rigid granite, when the ridge takes a nearly north and south direction, which it maintains beyond the limit of this exploration. The last fifteen miles consist almost exclusively of low hills of slate and shale, which rise hardly more than 900 feet above the eastern valley, toward which they fall off somewhat steeply, but more gently to the westward. Three miles below the upper limit of the map, the hills are separated by a low pass or depression 
in the strata extending westward to the Black Rock Desert. The strike of the beds is from north $20^{\circ}$ to $35^{\circ}$ east, and the dip where observed invariably to the westward.

In places, the strata are penetrated by narrow dikes of diorite and syenite, throwing the dip nearly vertical. The dikes, however, are on too small a scale and of too local a nature to be represented on the map. On the high hills just to the north of the granite, the slates stand but little below the vertical. Barren of vegetation, devoid of moisture, monotonous in outline, and of a dull gray color, the hills present a dreary, desolate aspect. It is to be regretted that no organic remains have been found in these beds, their reference to the Jurassic age being based solely upon structural grounds and their resemblance to Jurassic strata in California, as well as to the slates overlying Jurassic limestone on the opposite side of the Humboldt Valley in the West Humboldt Range.

To the southwestward, in the Truckee Range, and in Eldorado Cañon, Virginia Range, just south of the limit of the map, the Triassic formations have been identified, but in neither case are the overlying slates exposed, while from the Montezuma Range westward to the Sierra Nevada the Jurassic strata are found in isolated patches resting directly upon the granite, poorly exposed, except at the northern end of the Lake Range, and probably of no great thickness.

Breaking through the slates of the Montezuma Range is a body of porphyry, which, from its mode of occurrence and peculiar habit, requires some special mention. It occurs just south of Willow Spring on the north side of French Cañon, rising over 1,000 feet above the stream-bed in a beautiful conical-shaped peak, and is so entirely unlike the other outbreaks of the older pre-Tertiary rocks as to suggest a later origin. On the other hand, although it resembles some varieties of rhyolite, its groundmass is quite unlike those of the region, and at the same time none of the feldspars are sanidin. The geological position of the rock affords no clue to its age. The rock withstands atmospheric agencies remarkably well, and breaks with a rough, hackly fracture. It possesses a light coffee-brown color, with a fine crystalline feldspathic groundmass, in which can only be detected well-developed orthoclase and large grains of translucent quartz, frequently more than one fourth of an inch in length. The value of the microscope 
as an aid in determining doubtful rocks is well shown in this instance, as, in thin sections, both the quartz and feldspar are characterized by large liquid-inclusions, while glass-inclusions are entirely wanting, which settles the question definitely that the rock belongs to the older series of felsiteporphyries. At the mouth of Freuch Canon, a mile to the eastward of the porphyry, occurs an outburst of normal rhyolite, having a gray microfelsitic groundmass, rich in quartz-grains, which breaks out near the line of contact between the granite and slates.

Along the front edge of the granite, bordering the Humboldt Valley, are a number of outbreaks of fine-grained, black basalt, none of which, however, attain any great elevation above the Quaternary plain or present any features of mineralogical interest.

In the low depression of Indian Valley, and in the re-entering bay north of Black Cañon, the Truckee Miocene beds lie inclined at an angle of $1 \frac{1}{2}$ to $2 \frac{1}{2}$ degrees, with a thickness of over 700 feet. They cover a large superficial area, resting upon the granites to the south, the slates to the nortl, and extending eastward until concealed by the Quaternary deposits. Owing to their soft, porous, friable nature, they have suffered greatly from erosion, the streams having cut broad, deep channels through strata made up almost exclusively of volcanic material, consisting of coarse fragments of quartz and sanidin, imbedded in a fine comminuted ash. Many of the layers are quite compact and rock-like, while interstratified between them are others of nearly pure, lavender-colored punice and red earthy beds, crumbling in pieces at the slightest touch, the entire exposures showing the greatest variety in composition, texture, and stratification. That the formation is a subaqueous deposit there is abundant evidence, but the mode of occurrence would indicate marked changes in the rapidity with which the beds have been laid down, the depth and agitation of the supernatant water causing more or less sorting of the lighter and heavier particles, and the pressure of the overlying water and ash compacting the finelycomminuted feldspathic paste into thin, shaly beds. The colcr of the formation is very raried, with many shades of orange, red, yellow, purple, lavender, gray, and white. Din ectly overlying these beds are a number of horizontal tables of black, fine-grained dolerite, the longest of which, Table 
Mountain, rises 1,000 to 1,200 feet in precipitous walls above the bottom of the valley, and trends approximately northwest and southeast.

North of Black Cañon, bordering the Humboldt Valley, is an irregular group of rhyolitic hills, but a few hundred feet in height, through which protrude small bodies of granite, already mentioned, and obscure patches of Jurassic slates, the latter only being observed on the western side. This rhyolite is a gray, microfelsitic rock, in general poor in mineral secretions, but traversed by glassy hyaline varieties of obsidian, pitchstone and pearlite. One variety of rhyolite, in some of the hand-specimens, looks remarkably like trachyte, and yet in the field, and even under the microscope, shows the banded structure with the broken, undulating lines so characteristic of rhyolite. Macroscopically, the only mineral observed is sanidin. Still another variety is characterized by a lithoidal base, through which are scattered only fragments of sanidin and quartz. It has an appearance and fracture closely resembling porcelain, and a mottled surface like many variegated marbles. Although presenting marked physical differences from the microfelsitic and granular varieties rich in secreted minerals, a chemical analysis reveals much the same ultimate composition as the rhyolites from the West Humboldt and Pah-Ute Ranges, except that it may be a little richer in lime. In this case the silica seems to be dissolved in the magma, producing a porcelainous base instead of a microfelsitic groundmass rich in secreted quartz.

Mr. R. W. Woodward, who analyzed this rock, reports as ingredients :

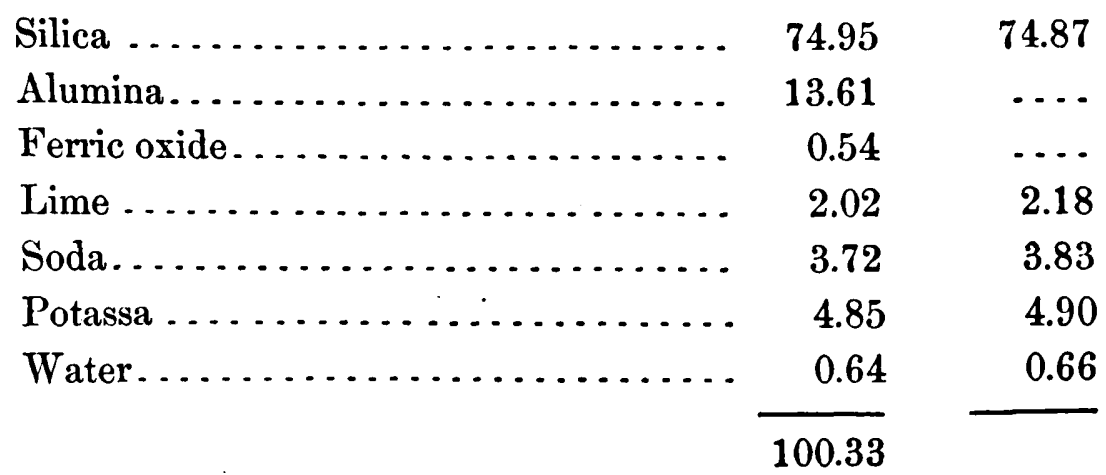

Specific gravity, 2.44, 2.55. 
It is worthy of mention here that the ore of the Montezuma Mine is of a peculiar character, consisting of a highly oxidized product derived from the decomposition of some antimonial lead mineral, probably jamesonite, as bright unaltered fragments belonging to the latter species have been found in the mine. The decomposed product, from its physical and chemical properties, has been identified as bindheimite, agreeing closely with the variety found in Cornwall, where it is also associated with jamesonite. It. has a fibrous structure, a yellow or yellowish-brown color, and gives a faint yellow streak. Prof. William G. Mixter, of the Sheffield Scientific School of Yale College, analyzed the mineral, and obtained the following composition:

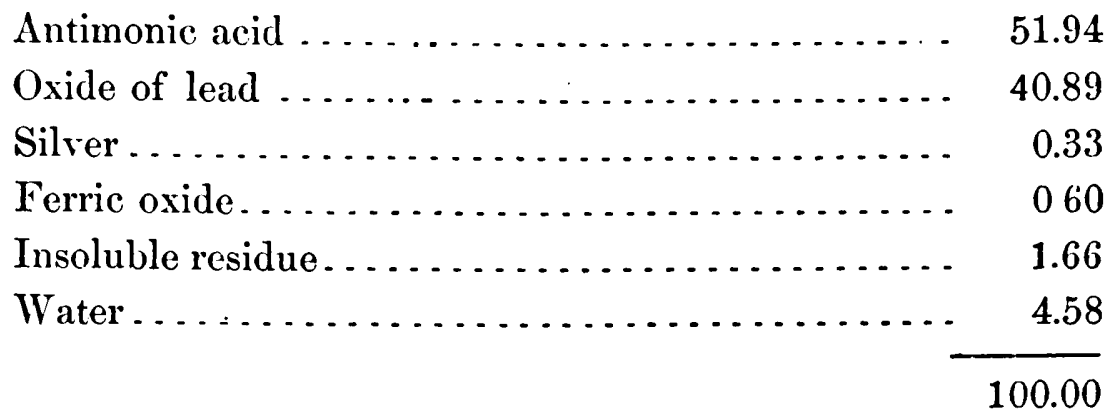

Volcanic region south of Trinity Peak. ${ }^{1}$ - As already mentioned, the southern end of the range, below the Trinity Peak Archæan region, consists mainly of volcanic rocks, and of these rhyolites and basalts form all the more prominent portions. Indeed, so far as known, with the exception of an outburst of propylite at the extreme southern end and a few doubtful rocks of obscure exposures, no other Tertiary eruptions were recognized.

- Valley Cañon, next south of Trinity Cañon, penetrates a wide area of low rhyolitic hills, having a great diversity of color and outline. About 3 miles up the cañon, there occurs a heavy outburst of rhyolite, of the pearlitic variety, more recent than the main crystalline fields, and forming quite regular hexagonal columns. In the gray, glassy base are observed a quantity of cracked sanidin crystals, frequently one-fourth of an inch in length, conside:able dark biotite, and some homblende. Free quartz would appear to

${ }^{1}$ In part from notes furvished by Mr. Clarence King. 
be wanting. Sphærulitic forms, so common in pearlites, are everywhere scattered throughout the gray glass.

About 4 miles south of Valley Cañon, and rising out of the plain, which is here formed of Humboldt Pliocene, thinly covered with Quaternary, is a mountain-mass 600 feet ligh, known as Lovelock's Knob. It is essentially a mass of granite, overflowed by rhyolite, which cover the greater part of the lill, and carry here and there fragments of included granite that were evidently picked up on the surface, since they are distinctly rounded and water-worn. These rhyolites present a great variety of colors, of which the more prevalent is a yellowish flesh-tint. There are also pale olive-gray varieties, containing pink brecciated masses ; still others are lavender and reddish-gray. In general, these rhyolites possess a microfelsitic groundmass, . with but few well-developed mineral secretions, and these mainly brilliant fragments of sanidin. It is quite remarkable that rocks in which chemical analysis detects scarcely any differences, with identical mineral composition, and apparently the same geological relations, should, in their physical aspects, vary so greatly within such limited areas. Under the microscope, these variations are, in a measure, explained by the great differences in the detailed habit of the groundmasses, which here present many of the characteristic structural phenomena of rhyolitic rocks.

On the northwest side of Lovelock's Knob is a small outburst of black basalt, penetrating both the granite and rhyolite.

From Granite Point, for. about 15 miles in a nortliwest direction, there is a long sheet of basalt, which has overflowed the rhyolite and covered even the summit of the range. These basalts cap heavy masses of Archaan rock, which occupy the cañon-bottom of the pass leading from Lovelock Station to Sage Valley. To the southeast, the basalts flow down to within a mile of the extreme point, in irregular fields, which are more or less eroded, showing grayish and purplish rhyolites along the western slope of the mountain promontory, and a large field of white rhyolite near the railroad. On the northeast side of Granite Point promontory, erosion, cutting deeply into the basalt, displays three considerable outcrops of granite, upon whose flanks rest highly metamorphosed slates, in general representing those of French Canon, the beds on the south side of the body dipping to the 
southeast, and those on the opposite to the northwest. From the large basaltic field southward, for 8 miles, as far as Karnak, rhyolites form the whole of the high summit of the range down to the plain on either side, with the exception of a few limited outflows of basalt at the base. Here, along the extreme foot-hills, and occasionally rising out of the Quaternary of the valley, are a number of small basaltic hills and limited regions, cut by interesting basaltic dikes, having a prevailing northwest and southeast direction.

$\Lambda$ bout 2 miles up Bayless Cañon, there is exposed a series of siliceous and argillaceous slates, of great thickness, having prevailing dark purplishblue and green colors, overlaid conformably by limestones roughly estimated at 1,500 feet in thickness. The transition rocks are highly laminated, and show frequent alternations between the siliceous and calcareous materials. The strike of the sedimentary series is from north $38^{\circ}$ to $40^{\circ}$ west, with a dip of $80^{\circ}$ to the southwest. They extend northeastward, running out into the plain in the region of Brown's Station, where they are broken through by black basalts, which stand out in isolated masses entirely separated from the main fields of basalt. These beds, consisting of slates and limestones, have been referred to the Jurassic from their lithological resemblance to the slates and limestone known to be Jurassic, in the West Humboldt Range, and from their similarity to certain California series. No fossils were found, and it is by no means certain that the beds do not belong to the Triassic formation, agreeing with those found upon the opposite side of the Humboldt Valley.

Directly above that part of Bayless Cañon which is occupied by the sedimentary strata, there occurs a rough broken country, out of which rise a series of high eruptive ridges, exhibiting a variety of rhyolitic forms. The highest and by far the most interesting part of this region is an exceedingly sharp broken ridge trending approximately north and south, and rising about 1,500 feet above the surrounding hills, and 3,000 feet above the Humboldt Valley, to which the name of Karnak has been given, from its resemblance to ruins. Along the crest of this ridge, the rhyolite forms a series of clusters of prismatic columns of all sizes, from three feet down to an inch in diameter. They show from three to seven sides, most frequently 
five, but in many cases the fifth side will be much longer than the other four, with a slightly curving outline and a tendency to develop a sixth side The four-sided figure would seem to be the least common. Usually they stand in an approximately vertical position, that is, above an angle of $60^{\circ}$, and are frequently diagonal to the beds in which they are developed, and, as might be expected, the steepest columns are, in general, near the crest where the slope of the ridge is greatest. The tendency to columnar structure shows itself in various degrees of perfection from the symmetrical prisin to a single set of parallel planes diagonal to the bedding of the rock. 'The most perfect prismatic forms are found near the summit, becoming less and less sharply developed farther down the slopes. As these columns readily break away and tumble down, the mountain-slope presents a huge débris pile of shattered prisms of all lengths and sizes.

On Plate XXIII is shown a northern and eastern view of the Karnak Ridge. Although columnar trachytes and rhyolites are by no means unknown, they are a much less common occurrence than the basaltic forms, and it is doubtful if there is any place in the world where they are developed on a grander scale than in the Montezuma Range; certainly not in Nevada, where rhyolitic modes of occurrence are so richly displayed.

The lithological characteristics of this rock are somewhat peculiar, consisting of a micro-crystalline groundmass, richer in secreted minerals than is usually found of the rhyolites of the Montezuma Range, and with a coarse rough texture and habit like many trachytes. Brilliant but small crystals of sanidin, black biotite, and long blades of dark hornblende are easily recognized by the eye, while scattered through the groundmass are occasional translucent quartz-grains. Under the microscope may be seen considerable apatite and plagioclase, but, what is somewhat singular, no quartz. The occurrence of so much plagioclase and the absence of microscopical, in the presence of macroscopical, quartz-grains, are marked features of some trachytes, but rare in rhyolites; while, on the other hand, the groundmass presents structural phenomena characteristic of rhyolitic types. Fragments of granite enclosed in the groundmass of the prisms have been observed.

The West Fork of Bayless Cañon exposes a great variety of bril- 
liantly colored red, yellow, gray, pink, and white rhyolites, having a tendency to horizontal bedding. The texture of most of these rocks is somewhat earthy and porous, passing into lithoidal varieties. In their topographical features and field aspects, they resemble those from the Mopung Hills on the opposite side of the Humboldt Valley, with the single exception that there are here many well-developed feldspars. Quartz-grains are present, although not very abundant, other secreted minerals being somewhat rare. A bright orange-colored .rhyolite having a comparatively homogeneous groundmass, through which are scattered numerous small feldspars, yielded to Mr. R. W. Woodward, upon chemical analysis.

\begin{tabular}{|c|c|c|}
\hline Silica ... . . . . & 70.29 & 70.15 \\
\hline Alumina $\ldots \ldots \ldots \ldots \ldots \ldots \ldots \ldots \ldots$ & 16.10 & 15.77 \\
\hline Ferric oxide $\ldots \ldots \ldots \ldots \ldots \ldots \ldots \ldots$ & 1.17 & 1.18 \\
\hline Lime............. & 1.09 & 1.12 \\
\hline Manganese... & 0.16 & 0.11 \\
\hline Magnesia ... . & 0.26 & 0.27 \\
\hline Soda.............. & 3.66 & 3.79 \\
\hline Potassa............ & 5.66 & 5.60 \\
\hline Lithia...... . . & trace & trace \\
\hline Water.$\ldots \ldots \ldots \ldots \ldots$ & 1.36 & 1.38 \\
\hline & 9.10 & 99.37 \\
\hline
\end{tabular}

Overlying these brilliantly colored rhyolites are broad masses of black basalt, which not only by their marked conirast of color, but by their great difference in topographical features, may be easily distinguished at long distances from the underlying rock.

In the low ravines eroded in the light rhyolite are several obscure outcrops of dark crystalline rocks, some of them resembling the augitic trachytes which break through the rhyolite at Truckee Ferry, Truckee Caũon, while others look more like propylite, and show hornblende in fine green spiculæ, scattered through the dark feldspathic groundmass. Although they have been but little examined, and their true relations to the surrounding rocks not well understood, they afford some interest as suggesting the 
existence of still older volcanic rocks, now for the most part concealed beneath immense accumulations of rhyolite.

Following up the cañon opposite White Plains to the centre of the range, the main rhyolitic mass is seen to be made up of a fine-grained groundmass, in which but few large and recognizable crystals are secreted.

The body of hard rhyolite, which is seen to break through the Tertiary strata in the vicinity of White Plains, is of two types: first, a distinctly heavily bedded gray and purplish-gray rock, whose beds stand upon end, with a dip of about $80^{\circ}$, and strike approximately north $55^{\circ}$ east. This consists of highly-laminated rocks, whose cross-sections show distinct lines of great fineness, which for the most part indicate a perfectly smooth parallel structure, but which are occasionally crumpled up into complicated scallops. All the darker lines are made up of what appears to be a colorless glass, but which, under the microscope, is found to be composed of fine polarizing grains. Rude jointings into rough columns and cuboidal masses characterize the rock. Crowding through this laminated mass is a more homogeneous and pearlitic variety, which consists of a gray glassy groundmass carrying abundant black mica and occasional unrecognizable feldspars. A peculiarity of this type of rhyolite is the resinous coating which forms upon all the exposed surfaces.

Pearlitic rhyolites, obsidians, and a great variety of glassy forms occur over large areas in the southern end of the range. The basalts, which break through and overlie these rhyolites of the southern end of the range, form most of the higher summits, and cap the long ridges jutting out in every direction. In general, they present a black resinous lustre, a vesicular structure, containing anygdules of olive-colored chalcedony, mainly spherical, and about the size of a small pea. They resemble the basalts found on both sides of the Truckee Valley, in the Virginia and Truckee Ranges, having a distinctly glassy base, rich in globulites. In texture, they vary from a rather coarse crystalline variety, in which the augite and plagioclase can both be detected, down to the finer glassy types. Olivine in quite large mass is found in several localities, in which, under the microscope, Professor Zirkel has detected, as in many European basalts, the presence 
of included grains of picotite. Microscopical apatite crystals and magnetite grains are also seen.

Skirting the southern flanks of the range are the upturned beds of Miocene strata, description of which will be found under the head of the Kawsoh Mountains.

At the extreme southwestern end of the range occurs the propylitic body already mentioned, where it serves as a depressed connection between the Montezuma and Truckee Ranges. It is found as a group of low hills, largely concealed by the drifting sands of the desert, and presents a gray-green, dense, tough rock, made up of plagioclase and decomposed hornblende.

An analysis of this propylite gave Mr. R. W. Woodward the following ultimate composition :

Silica

Alumina............................. 21.49

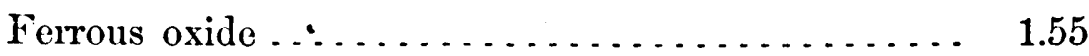

Manganous oxide ...................... trace

Lime................................. 3.73

Magnesia ............................. 4.01

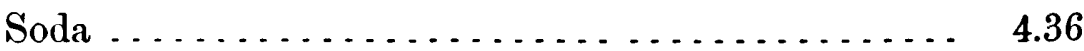

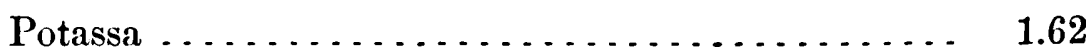

Water.............................. 3.13

Specific gravity, 2.66, 2.7

100.22

Geologically, the lower half of the Montezuma Range is made up of an intricate series of broad, heavy, massive, rhyolitic eruptions, having a northeast and southwest direction, breaking through which are powerful sheets of basalt, frequently capping the higher ridges. In few ranges are the direct relations between rhyolite and basalt so distinctly seen as here. Lithologically, the rhyolites of the Montezuma Range present an almost endless variety of forms, but, in general, they may be said to be poor in types containing secreted minerals, especially quartz-grains, in this respect differing widely from the rhyolites of the Pah-Ute Range and Augusta 
Mountains. On the other hand, they are rich in forms showing the peculiar phenomena of rhyolitic groundmasses.

Kawson Mountains. - The depressed region between the Montezuma Range and the outlying hills of the Kawsoh Mountains is occupied by an important development of disturbed Miocene rocks, which form a low but scarcely perceptible divide between the Humboldt Valley and the Hot Spring Valley to the westward. In the region of Hot Spring Station, although they are somewhat obscurely exposed, they appear to lie nearly horizontal, but, in passing northward toward Mirage Station, they become more and more inclined to the northwest, reaching a maximum dip of $25^{\circ}$. After a considerable erosion, which is subsequent to their upheaval, they have been overflowed by massive sheets of black basalt, which here, between the two ranges, occurs as isolated hills capping the sedimentary strata. In the hills about two miles north of the diorite outcrop, shown on the geological map at the northern end of the Kawsoh Mountains, there is a section of these Miocene rocks exposed to the thickness of about 700 fcet. Beginning at the top and following the series downward, we have :

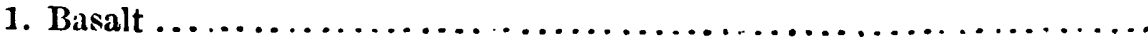

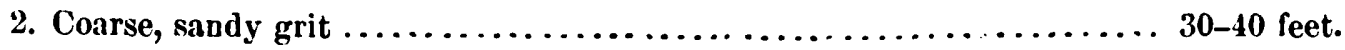

3. Saccharoidal cream-colored limestone, carrying fresh-water fossils....

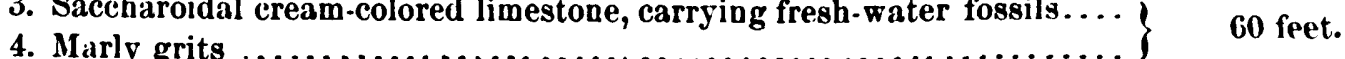

5. Fine grained friable sandstone $\ldots \ldots \ldots \ldots \ldots \ldots \ldots \ldots \ldots \ldots \ldots \ldots \ldots \ldots$ foet.

6. Formation concealed by Quaternary accumulations............. 100 leet.

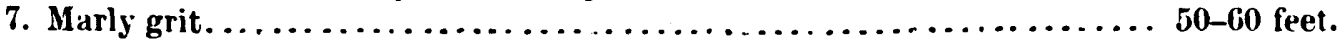

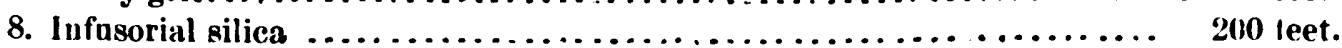

9. Palagouite tufa, base not exposed ....................... 250 leet.

At other localities skirting the northern edge of the Kawsoh Mountains very similar exposures are offered, in places the upper members being covered by basaltic masses, and in most of them the palagonite tufas by drifting desert sands.

At Fossil Hill, the cream-colored friable limestones abound in organic remains, of which the following specie; have been identified by Prof. F. B. Meek :

Carinifex (rortifex) Binneyi.

Carinifex (vortifex) Troyoni. 
Ancylus undulatus.

Melania sculptilis.

Melania subsculpt: is.

Spharum rugosum.

Spharum? Idahoense.

They are all of decidedly fresh-water types, and have been referred by Professor Meek to the Miocene or later formations, but on structural grounds, the reasons of which will be found in Volume I of this series, they are regarded with but little hesitation as belonging to the Miocene age.

Mr. B. E. Brewster, who has analyzed this limestone from Fossil Hill, reports the following composition:

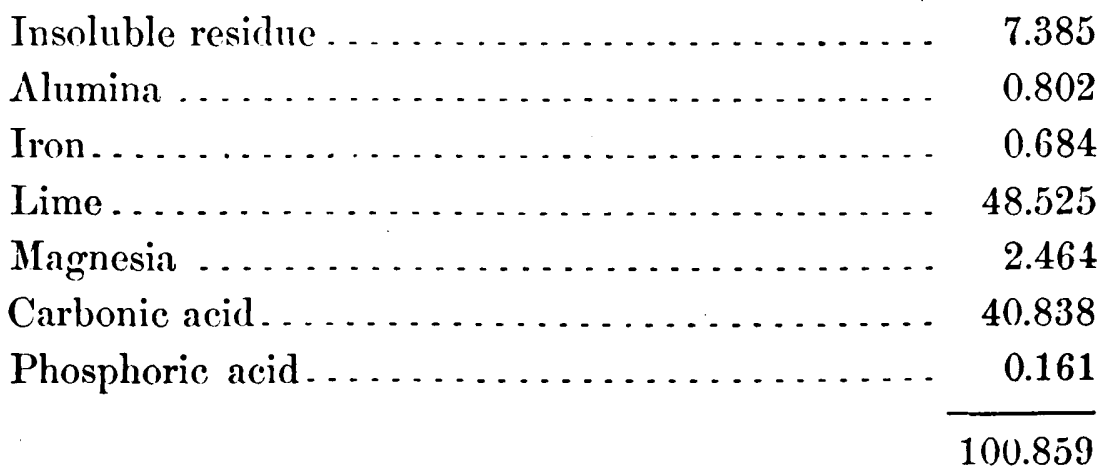

The underlying marls, grits, and sands pass into each other by almost imperceptible gradations, and are all characterized by light colors and friable textures.

Throughout the beds of infusorial silica, there is a general tendency to fine stratification, especially where rendered impure by argillaceous material, the purer and whiter beds usually underlying a series of yellow, more or less earthy ones near the contact of the overlying grits. The perfectly white bed has the color, texture, compactness, and general appearance of chalk. It is quite soft, cutting easily with the knife. It cleaves strongly to the tongue, and to the touch has the slight roughness of chalk, soiling the fingers. A number of specimens from different localites gave off no effervescence when treated with acid, although the overlying sand and grits and underlying tufas usually indicated the presence of some soluble carbon- 
ate. If gently heated, the rock assumes a slight grayish tinge, passing off at a higher temperature, which would suggest the presence of a small amount of organic matter.

Mr. R. W. Woodward subjected the infusorial silica to chemical analysis and obtained as a result :

\begin{tabular}{|c|c|c|}
\hline Silica .... & 86.70 & 86.91 \\
\hline Alumina. . & 4.09 & 4.00 \\
\hline Ferrous oxide $\ldots \ldots \ldots \ldots \ldots \ldots \ldots$ & 1.26 & 1.22 \\
\hline 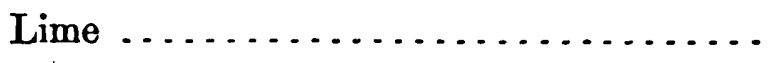 & 0.14 & 0.11 \\
\hline Magnesia .............. & 0.51 & 0.51 \\
\hline Soda...... & 0.77 & 0.80 \\
\hline Potassa $\ldots \ldots \ldots$ & 0.41 & 0.36 \\
\hline Phosphoric acid ................... & trace & trace \\
\hline \multirow[t]{2}{*}{ Water............................. } & 5.99 & 5.89 \\
\hline & 9.87 & 9.80 \\
\hline
\end{tabular}

Under the microscope, even with a moderate power, these siliceous beds are seen to be made up of innumerable fragments of Diatomacea. Dr. C. G. Ehrenberg, ${ }^{1}$ of Berlin, Prussia, to whom were sent a large number of specimens from this locality, has described no less than 33 distinct organic forms, one of which may belong to the vegetable world. Of these forms, 12 have been classed as Polygastera and 20 as Phytolitharia, the most abundant species being:

Gallionella granulata.

Gallionella sculpta.

Spongolithis acicularis.

Accompanying Dr. Ehrenberg's work is a plate giving the microscopical sections of the infusorial earth from this locality, together with others from the Truckee Valley and Salt Lake Desert.

The palagonitic tufas show considerable differences in superficial ap-

1 Über die wachsende Kenntniss des unsichtbaren Lebeus als feldsbildende Bacillarien in Californien, Berlin, 1870, 18. 
pearance, varying from a fine-grained, yellowish-brown volcanic ash, to coarse, scoriaceous, brecciated beds, highly altered and decomposed, the binding material being characteristic palagonite. The specimens collected from Fossil Hill are of the latter kind, containing many included basic fragments, completely surrounded by amorphous material. Portions of it, treated with acid, indicate the presence of soluble carbonates. Under the microscope, much of the material is clearly shown to be derived from the decomposition of augite. A specimen of the palagonite tufa from Hawes Station, on the Carson River, just below the southern boundary of the map, has been submitted to analysis by Mr. R. W. Woodward, who reports as the ultimate composition :

\begin{tabular}{|c|c|c|}
\hline Silica. . . . . . . . . . . . & 50.87 & 50.88 \\
\hline Alumina $\ldots \ldots \ldots \ldots \ldots$ & 14.86 & 14.37 \\
\hline Ferric oxide $\ldots \ldots \ldots \ldots \ldots \ldots$ & 13.02 & 13.30 \\
\hline Lime $\ldots \ldots \ldots \ldots \ldots \ldots \ldots$ & 6.08 & 6.18 \\
\hline Magnesia ..... . . . . . . . & 4.08 & 4.14 \\
\hline Soda.... & 1.76 & 1.86 \\
\hline Potassa $\ldots \ldots \ldots \ldots \ldots \ldots \ldots \ldots$ & 0.85 & 0.93 \\
\hline 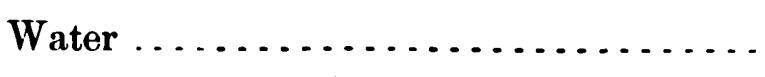 & 8.48 & - 8.34 \\
\hline
\end{tabular}

This Nevada palagonite contains a higher percentage of silica and less water than the tufa found in other portions of the globe, notably Iceland, Galapagos Islands, and Java.

For the purposes of comparison, there are subjoined here three analyses from these distant localities :

1. Palagonite from Iceland, collected between Thingvellir Lake and the Geyser (Bunsen).

2. James Island, Galapagos (Bunsen)1.

3. Dyampang-Kulon, Java (Prölss)2. 


\begin{tabular}{|c|c|c|c|}
\hline Silica . & $\begin{array}{c}1 . \\
41.28\end{array}$ & $\begin{array}{c}2 . \\
36.93\end{array}$ & $\begin{array}{c}3 . \\
37.57\end{array}$ \\
\hline Alumina & 11.03 & 11.56 & 15.18 \\
\hline Ferric oxide ... & 13.82 & 10.71 & 13.07 \\
\hline Lime .... & 8.75 & 7.95 & 6.02 \\
\hline Magnesia . & 6.49 & 6.28 & 5.58 \\
\hline Soda.... & 0.62 & 0.55 & 0.79 \\
\hline Potassa . . . . . . . . . . . . . . & 0.65 & 0.78 & 2.17 \\
\hline \multirow[t]{2}{*}{ Water $\ldots \ldots \ldots \ldots \ldots$} & 17.36 & 2524 & 19.61 \\
\hline & 100.00 & 100.00 & 100.00 \\
\hline
\end{tabular}

It is worthy of note that the palagonite from Java is described by Junghuhn as forming a stratum in the Tertiary sedimentary hills.

South of Mirage Station, there is a bold, conical hill that rises as an outlier on the northwest flank of the group. This is seen to be composed of infusorial silica, having a dip of about $18^{\circ}$ to the northwest; basalt lying in the eroded edges of the strata. At this point, the upper part of the infusorial beds consists of yellow sandy strata, which are underlaid by the clear white silica, and that again underlaid by a gritty sandstone, in which beds of more or less thickness of palagonite tufa begin to appear. The local erosion does not display the rock sufficiently to get at the solid beds of palagonite below. On the north side of the valley, at White Plains, the infusorial series outcrop in a ravine, striking northeast true, and dipping sontheast. In a ravine east of White Plains, at the bottom of the infusorial series, is again seen the uppermost limits of the palagonite. In the middle of the plain, a little west of Mirage Station, a well has been sunk, which cuts the lower beds of the infusorial silica, passing down into the palagonite.

Following northwest across the strike of these infusorial beds in the region of the sunken well, and rising constantly in the series of strata, there appear the coarse, gritty sandstones and the saccharoidal limestones, developed very thinly, and next above these a great series, attaining certainly 1,200 feet in thickness, of gray, vesicular, volcanic tufas, which are undoubtedly of the same age as the beds found in Indian Pass, Montezuma Range. Throughout the palagonite tufas are more or less infusorial beds. 
They are also found in coarse, gritty rocks overlying the main infusorial strata, and occur more or less abundantly all the way up to the limestone. None, however, have as yet been observed in the thick mass of gray acidic tufas above the limestone, but have again been recognized in a series of overlying cream-colored beds. In a stratum of compact grayish-lavender sands, carrying some feldspathic material, Mr. Charles E. Wright has recognized a number of forms described by Ehrenberg:

Gallionella?

Spongolithis acicularis.

Pinnularia incequalis.

Cascidoniscus radiatus.

Around the west end of the Montezuma Range, and through Caspar's Pass, the relations of the eruptive rocks with the sedimentary strata are obscured by the prevalence of Quaternary débris. At White Plains, however, it is clear that the pearlitic rhyolites actually break through them, and the basalts in the same region are later than the pearlites. The basalts of the Kawsoh Mountains are all subsequent to the upturning and erosion of the Tertiary, so that the period of deposition, probably carried back to the Miocene by the organic remains of Fossil Hill, is certainly placed anterior to the ejections of rhyolites and basalts. - The palagonite beds, which form the lowest exposure of the sedimentary series in this part of the country, require for their formation an augite-bearing eruption, and, as the augitic trachytes are an exceptional occurrence, and those of the Truckee Cañon are also later than the greater part of the rhyolites, it would seem necessary to refer these Tertiary palagonites to a period at least as early as that of the augite-andesites.

Among the gray tufas which overlie the infusorial silica are some beds of purely clastic sands, and one stratum of hard white crypto-crystalline quartzite, which presents a botryoidal appearance on the upper surface, the rounded protrusions being 5 or 6 inches in diameter. This seems to be a true stratum, and may very likely have been a siliceous product of a hot spring.

So far as observed, there is only one body of pre-Tertiary crystalline 
rock in the Kawsoh Mountains, which forms a group of low diorite hills at their northern end. It is a fine-grained, dense rock, of a dark-gray color, carrying a little quartz, and breaking with difficulty under the hammer. It is penetrated by a number of quartz veins striking north and south.

At the extreme northeastern corner of the mountains bordering the Carson Desert are exposed some bluffs of fine-grained, dark-gray sanidintrachyte, rising not more than 200 feet above the plain, and inclined gently to the northwest. The microscope reveals the presence of small secretions of tridymite. All the rest of the range, extending in a north and south direction for 20 miles, consists of basalt capping Tertiary strata. The latter are exposed along the base of the ridges and in the low interior valleys, one of which cuts completely across the mountains, having a broad interior basin, but offering no good section of the beds. These basaltic masses form long narrow parallel ridges, inclined toward the east, and presenting their steeper slopes westward. In lithological habit, they exhibit a great uniformity of character, varying somewhat in texture, as in all other localities of equal area, but in general are fine-grained, and in places quite porous. Macroscopically, few minerals can be distinguished, but microscopical analysis shows the normal plagioclase-augite composition of basalt, with the halfglassy globulitic base. . The rock from the highest peak is quite fine-grained, and has a reddish tinge, which appears to be produced by ferric oxide filling minute cavities and fissures. Mineralogically, the most interesting feature of these basalts is the finding, by Professor Zirkel, ${ }^{1}$ of hexagonal flakes of tridymite, arranged in a manner quite similar to those observed in the acidic volcanic rocks. It is noticeable that tridymite, which is of rare occurrence even in acidic rocks, has also been recognized in the sanidintrachyte from the extreme northern end of the Kawsoh Mountains. Olivine appears to be pretty well disseminated through the basalt, and may be easily recognized, even macroscopically.

The denuding action of drifting sands upon hard crystalline rocks, which is by no means an uncommon phenomenon in the arid regions of Nevada, is beautifully shown in the ravines and basins at the southern end of the Kawsoh Mountains, where the basaltic walls show polished, grooved,

'Microscopical Petrography, vol. vi, 239. 
and finely-reticulated surfaces worn by the constant attrition of loose sands driven by the prevailing westerly winds through the gap south of the Truckee Range.

Just east of Hot Spring Station, on the line of the railroad, and about 250) yards from a low basaltic ridge, occurs a group of six warm springs, which reach the surface through the nearly horizontal Tertiary strata. The waters are quite clear, palatable when cool, and free from any considerable amount of saline ingredients. The main pool, 3 feet below the surface of the ground, is nearly $3 \frac{1}{2}$ feet in diameter, and the only one having a temperature up to the boiling-point. Thermometric observations gave, for the remaining springs, temperatures varying from $189^{\circ}$ to $158^{\circ}$.

White alkaline efflorescences are found on the desert plains south of the springs. One of these, analyzed by Prof. O. D. Allen, yields :

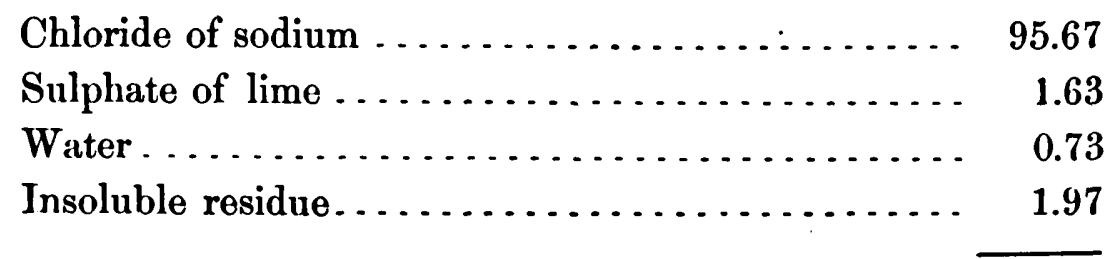

100.00

a quite pure salt, but the deposit is much too limited to be of any economic value, where others of almost unlimited extent are so easily accessible.

It seems evident that the sedimentary beds in the neighborhood of the springs, although obscurely exposed, belong to the Miocene strata, presenting the same finely-comminuted material of volcanic tufas, and more or less compact sands, in which the microscope detects the same Infusorice as are found in the beds at Fossil Hill.

South of the Kawsoh Mountains, and separated from them by a narrow pass connecting the Truckee Valley with the Carson Desert, lies an irregular group of hills, only the northern portion of which comes within the limit of the map. They border on the Carson River, and, at their widest part, measure about 9 miles.

Geologically, they represent a continuation southward of the same structure as the Kawsoh Mountains; an underlying sedimentary series of 
Miocene beds, broken through and for the most part capped by basalt, which forms the higher peaks and ridges. Characteristic Miocene strata, including the cream-colored limestone, infusorial silica, and palagonitic tufas, are exposed along the base of hills, concealed in a great measure by horizontal Pliocene beds and drifting desert sands. The palagonitic tufa is well shown southeast from Hawes Station, near the Carson River, where it appears somewhat finer and purer than at Fossil Hill. The best exposures of the sedimentary series are found south of the line of the map, in low hills below the ancient lake-terraces.

An analysis of the cream-colored limestone from the hills near Valley Wells yielded Mr. B. E. Brewster the following :

Silica

Alumina,

Ferric

Magnesia

Carbonic acid 29.165

Water

99.498

The basalts require but little special mention; in petrographical habit, they are allied to those of the Kawsoh Mountains and Truckee Valley. They are fine-grained anamesites, black and grayish-black in color, and rich in globulitic glass-base. In a deep ravine, opening out toward the Carson River, they are well shown in precipitous walls, 80 feet in height, of vesicular rock, in which the vesicles are lenticular in shape, and lined with a pale lilac siliceous secretion, many of them more or less filled with chalcedonic matter. These lenticular cavities, usually arranged horizontally, often reach an inch or more in length.

It may be well to note here. a thermal spring which rises out of the sedimentary beds, in the region of eruptive rocks, just south of the map, and near the road going from Wadsworth directly southward, by Valley Wells. It is a stagnant pool, 3 feet wide, having a temperature of $73^{\circ}$. It is said that the water for the past few years has been growing gradually cooler. 


\author{
SECTION VII. \\ REGION OF THE MUD LAKES.
}

BY ARNOLD HAGUE AND S. F. EMMONS.

Pah-tson Mountains.-This group, which trends approximately north $15^{\circ}$ east, measures about 24 miles in length, and across its broadest expanse nearly 6 miles in width, having roughly a diamond-shaped outline. It lies west of the Montezuma Range, and just south of its central mass is crossed by the parallel of $40^{\circ} 30^{\prime}$. In the central group, the main summits attain an elevation of over 3,000 feet above their base, rising in steep slopes both to the east and west, but falling away gradually in irregular hills and ridges to the north and south. Topographically, the structure is quite simple, being a single ridge with numerous deeply-cut cañons radiating out in all directions from the culminating mass. Few mountain groups of Western Nevada are more abundantly supplied with streams and copious springs of fresh water, and it has, in consequence, become a favorite pasturage for cattle and sheep.

Geologically, the Pah-tson Mountains consist almost entirely of granites and crystalline schists of the older rocks, followed by immense outflows of rhyolites and basalts.

The Archæan masses are represented by both granites and highly crystalline schists, the latter presenting much the larger area. Granite occupies a considerable part of the more elevated portions of the mountains, but it is of later age than that which has been classed as evidently belonging to the Archæan series, inasmuch as it penetrates the latter in several well-defined dikes. According to field-observations, the crystalline schists for a like reason would appear to be the oldest rocks in the group, as is evident by their being cut by the Archæan granite. These schists form the summit of Pah-keah Peak, and the high ridge which projects to the southward just west of Crusoe Cañon. Both in physical and mineralogical habit they show the closest analogy to the schists of Trinity Cañon, Mon- 
tezuma Range; and there can be no doubt of their similar origin and occurrence, the resemblance holding good even when the rocks are subjected to the careful scrutiny of microscopical analysis. They are composed of quartz, biotite, and muscovite, and in thin sections under the microscope Zirkel detected still a third mica in thin laminæ of an oil-green color. It is somewhat singular that neither in these schists nor in those from the Montezuma Range were traces of feldspar to be found. These beds may, perhaps, be best classed under the head of mica-schists, although they show but little tendency to develop a characteristic schistose structure or parallelism in the arrangement of the constituent minerals. They are, however, distinctly bedded, standing at a high angle, but so fine-grained as to present almost a homogeneous mass to the unaided eye.

Associated with the mica-schists occurs another rock, which, in its outward appearance, bears little resemblance to the beds of Pah-keah Peak, but which, nevertheless, seems to belong to the same series. It is found on the western ridge near the head of Crusoe Cañon. At first sight, it appears like is fine-grained quartzite, but on further examination one is led to doubt this hasty conclusion. Under the hammer, it shows a sharp, angular fracture, but is by no means brittle like most true quartzites. In color, it is a palegreenish white. Under the microscope, in thin sections, it shows a groundmass of quartz everywhere penetrated with innumerable minute crystals of hornblende. Feldspars appear to be entirely wanting as in the mica-schist. In this rock, hornblende would seem to replace the dark mica in the rock from Pah-keah Peak.

The granites, which have been classed as undoubtedly of Archran age, occupy but a small area on the surface of the Pah-tson Mountains, and were only observed near the head of Crusoe Cañon and in the deep cuts of the adjacent lateral ravines. It is very possible that they may be exposed in other localities to a limited extent, especially in the northern end of the mountains; but the great body of the formation is evidently buried beneath the later granite and the great accumulation of volcanic rocks. In the region of Crusoe Cañon occurs a characteristic granite. It has a very much altered, decomposed appearance, a rusty, earthy color 
and friable texture, and is composed mainly of white quartz, red opaque feldspar, and a silvery-white mica in thin laminæ.

These Archæan granites and schists are traversed by a number of interesting dikes of a somewhat peculiar mineralogical composition. As to their age, there is no definite clue, but they have been regarded as $\Lambda$ rchæan, partly from their petrographical attitude in the field, and partly from the fact that they were nowhere observed as penetrating the later granites. A dike in Crusoe Cañon consists of a fine pearl-gray rock, which serves as a kind of groundmass for a very coarse-grained pegmatite, in which are segregated a number of accessory minerals. Colorless quartz occurs, both massive and finegrained. The orthoclase crystals frequently measure 3 and 4 inches in length, of a brilliant lustre, apparently quite free from foreign ingredients. The amount of soda present in these feldspars is quite small, as shown by the following determination of the alkalies: Soda, 1.27 ; potassa, 13.45 per cent. All the micas are light-colored, both muscovite, in transparent flakes an inch or more in length, and thin laminæ of lepidolite being present. Tourmaline in long black needles, frequently well crystallized, occurs in segregated bunches, occasionally imbedded in quartz, when they seem to arrange themselves in short narrow lines or bands. Garnet, both massive and well crystallized, is found, usually of a brownish-red color, intimately associated with the colorless muscovite. No biotite or hornblende could be detected in this rock, even under the microscope.

Another dike penetrating the slates in the same region has a similar composition, but is finer-grained, with the associated minerals somewhat more disseminated through the mass. The tourmaline, especially, is so abundant and so well distributed that the dike may be classed as a schorlgranite. Running through the rock are bands of orthoclase, translucent colorless quartz, and black tourmaline porphyritically enclosed.

In the crystalline slates west of the summit of Pah-keah Peak occur several dikes of fine-grained white granite, which traverse the older rock in a northwest and southeast direction. They resemble the finer granite of Crusoe Cañon, and, if carefully examined, might be found to carry segregations of the coarser material with all the accessory minerals. In these 
granitic veins, however, are found fragments of the older crystalline schists, which were caught in the mass at the time of the formation of the vein.

As already mentioned, the later eruptive granites cover a considerable area in the Pah-tson Mountains. They form the central body situated nearly 2 miles northeast of Pah-keah Peak, and the western slopes extending down to the valley below. On the north and east, they are almost entirely encircled by the later eruptive rocks of Tertiary age, which give for the boundaries of the granite very irregular outlines. This granite differs in a very marked manner from the rocks described as Archæan, but, on the other hand, closely resembles nearly all the great bodies of granite that form the more prominent ranges and isolated ridges lying in the Nevada Basin between the Montezuma Range and the Sierra Nevadas of California, which have been regarded as most probably related to the Jurassic upheaval.

In texture, this granite is a medium-grained, compact rock, having a well-developed crystalline groundmass, which, however, is quite coherent, breaking with some difficulty under the hammer, and forming little soil where exposed to sub-aërial denudation. The prevailing color is a dark purplish-gray, shading off in places to lighter tints. The individual minerals have a fresh unaltered appearance, and the feldspars are free from coatings of ferruginous earthy material. It is composed of quartz, orthoclase, plagioclase, biotite, and hornblende. The quartz is in medium grains, colorless or of a slight gray tint. Both the monoclinic and triclinic forms are well disseminated through the rock in varying proportions, though the latter appear to be always abundant, and to give a decided character to the granite. Biotite is generally present in thin black laminæ, and is the only mica observed. Hornblende varies in amount in different localities, although it forms everywhere a striking feature of the granite; it is usually present in short dark-green prisms. Titanite plays so important a part in this granite, and is, at the same time, so uniformly disseminated through the mass, that it can hardly be regarded as an accessory constituent, but rather as an essential ingredient, although present in minute crystals and in subordinate amounts. It occurs in bright amber-colored crystals, of a slightly resinous lustre. It is abundant on the summit of Granite Peak, 
also near the head of Grass Cañon, and in the cañon descending to the eastward from Granite Peak, where it occurs well developed, but in very small crystals, in a rock apparently rich in triclinic feldspars. In thin sections, under the microscope, Zirkel has detected, in addition to the above, apatite, specular iron, and, in one instance, magnetite, completely surrounded by minute prisms of apatite.

The rock from the summit of Granite Peak may be taken as a typical granite of the region. It differs but little, if any, from the description given above, being, perhaps, somewhat lighter in color, as it contains less hornblende than is found in the greater part of the granite body. It has been subjected to chemical analysis by Prof. Thomas M. Drown, of Lafayette College, with the following result:

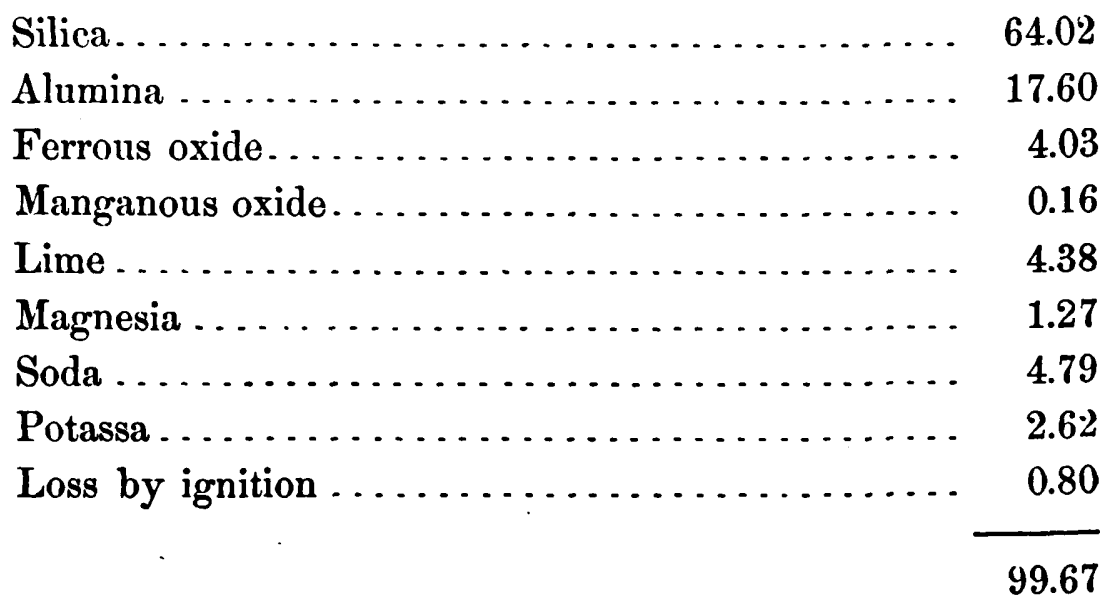

It will be noticed that, although standing within the usually prescribed limits of silica percentage, it is nevertheless a very basic granite, and that the large amount of soda present would indicate the predominance of oligoclase over orthoclase.

In the depression lying between the Pah-tson and Kamma Mountains occur several small isolated outcrops of granite, rising above the Tertiary and Quaternary deposits. Apparently they possess little geological interest except as indicating an extension of the granite body to the northward, now concealed beneath the andesites and rhyolites of the Kamma group.

The rhyolites of the Pah-tson Mountains are found along the highest 
portion of the main ridge, where they have broken through the granite, and spreading out thence to the north, east, and south, in the latter direction formed a southern continuation of the mountains, in a narrow ridge, set a little to the eastward of the main line of elevation. Through the rhyolites at various points, but generally in the line of the main crest, have broken out flows of basaltic rock, now found overlying the former, and capping the higher peaks at either extremity of the range.

These rhyolites present a most interesting series, showing types of all the principal varieties, from a compact porphyritic, almost granitic, structure, unusually rich in black mica, with earthy, porous varieties, without distinct crystals, to pearlites of most varied appearance, from those containing mica and occasionally other crystalline ingredients, to the most remarkable vitreous pearlites, without crystals, made up of sphærulitic concretions, and carrying in their mass rolled pebbles of the most pure black obsidian, accompanied by various chalcedonies and white pumiceous tufas and breccias.

The southern portion of the mountains, which seems to be an independent and later formation, is a steep narrow ridge, gradually descending to the south and west, with a few prominent breaks in its continuity, until it disappears beneath the Quaternary soil of the desert plains. It is principally composed of rhyolite of a rather massive habit, which weathers into tabular masses, with a dark reddish-brown surface, and forms abrupt escarpments to the north and west, its jointing planes having a general eastern dip, in some cases as high as $30^{\circ}$. It would seem as if the mass had been faulted up perhaps at the time of the basaltic eruption. The main rock of Aloha Peak, the culminating point of the ridge, is a porphyritic rhyolite of rough trachytic texture and reddish-gray color, showing glassy feldspar and a little mica as macroscopical crystals. In the felsitic groundmass, a tendency of the red and gray portions to arrange themselves in thin bands gives a striped appearance to the rock. On the dark-brown weathered surfaces of the cliffs, patches of bright lemon-yellow lichens present a pleasing contrast of color to the general sombre appearance of these volcanic rocks. Under the microscope, the ingredients of the rock are seen to be sanidin, frequently in Carlsbad twins, a little plagioclase and quartz, all with glass-inclusions, together with biotite, partly fresh and partly altered into a brown granular 
substance, while the microfelsitic groundmass contains microlites of an uncertain nature.

This rock forms the main ridge, with a southwest trend, while a second ridge to the west, with a north and south trend, which connects it with the main mass to the north, is composed of basalt, surrounding which is a gray rhyolite, very rich in black biotite, having rather a dull lustre to the unaided eye, but, under the magnifying-glass, showing a pearlitic structure and glassy lustre; this may be an alteration-product of the former variety. Under the microscope, the groundmass of this rock shows an abundance of products of devitrification in forms which seem to be peculiar to the pearlites; these are globulites arranged in long needles and tendril-like forms. Fine sections of brown hornblende crystals, sometimes in twins, are also disclosed. These peculiarities of structure are figured in Plate IX, fig. 2, of Vol. VI, which represents a section of this rock under polarized light.

A second body of basalt caps the eastern ridge of Aloha Peak, the saddle or gap between the two ridges being of the gray pearlitic rhyolite; this is probably a portion of the basalt flow, which has been separated from the main body by erosion.

These basalts belong to the class of feldspar-basalt, are dark vesicular rocks, showing macroscopically only white flecks, sometimes crystals of decomposed feldspar, in a homogeneous crypto-crystalline groundmass; that of the western ridge is much the more vesicular. Microscopically they belong to the same class as those of the Lower Truckee Valley, which will be more particularly described in a later section; they consist of crystalline elements in an amorphous glassy base, and are generally poor in augite. They contain more olivine than is usual in this type, and their feldspars, which occur in crystals and in thin lines in the globulitic base, have numerous brown glass-inclusions.

Rhyolites apparently form the eastern foot-hills of the mountains north of Aloha Peak, though they were not all examined in detail. In the long straight cañon, which runs eastward from Pah-keah Peak, the rocks crossed in section are as follows: At the head are granites, upon which rest the Archæan slates already described; to the east of these are rhyolites forming transverse ridges. These rhyolites are of two varieties, the one of a yellow- 
ish-brown color, looking in the mass like a fine-grained compact sandstọne, but disclosing, under closer examination, plentiful small crystals of glassy sanidin and quartz; the other is a porous, rough-feeling rock, of light mauve color, showing white opaque feldspars and some included fragments of other rhyolites. Under the microscope, the quartz and feldspars of the latter are seen to have glass-inclusions, and the groundmass to be a network of yellowish strings radially and concentrically arranged. In the cañon below these rhyolites, erosion has disclosed a body of blue limestone and shales, which, on grounds of general probability, but without palæontological or distinct stratigraphical evidence, have been referred to the Jurassic formation. The extreme eastern foot-hills at the mouth of the cañon are formed of a dark slate-colored rhyolite, whose weathered surface resembles that of a basic rock, but which in fracture shows the peculiar banded structure of rhyolites in wavy lines through the mass, in which can also be distinguished decomposed feldspars and a little free quartz.

On the main crest, just north of Pah-keah Peak, occurs a lavender-colored porphyritic rhyolite, of rough trachytic texture, and rich in small plates of black biotite, besides which can be detected only a few white feldspars, both glassy and opaque. The number of crystalline ingredients is not augmented by microscopic examination. The groundmass shows no fibrous structure, but only an undeveloped granular mass.

The central and highest peak of these mountains, just to the northeast of Pah-keah Peak, is of granite, to the north of which the next point is formed of a rhyolite, which is the heaviest, most compact rhyolite of the range, and has almost the appearance of an older porphyry. It is of a greenish-yellow color, and contains small but distinct crystals of quartz, feldspar, and mica in a compact felsitic groundmass, through which run occasional thin, reddish, vein-like seams. Under the microscope, the groundmass is seen to be formed of a network of peculiar linear aggregations of grains, between which is a concentric, radially fibrous structure like sphærulites. Glass-inclusions are found in both quartz and feldspar. A section of this rock, giving its peculiar structure, as shown under polarized light, is depicted in Vol. VI, Plate VII, fig. 2. Associated with this is a rhyolitic breccia, formed of angular fragments of greenish lithoidal rhyolites, 
in a compact felsitic groundmass, the whole so compact that it has a conchoidal fracture through the mass.

To the north of this peak, at the head of Grass Cañon, and adjoining the eastern body of granite, is a white rhyolite, full of cavities, colored in the interior by iron oxide, which, by their shape, would seem to have been left by feldspar crystals. In the white, felsitic groundmass can be distinguished also fresh glassy sanidins and quartz-grains. Through this rock run bands of a gray compact crystalline rhyolite similar to that justdescribed as forming the peak, and seeming to represent undecomposed portions of the mass. Associated with this is a rhyolitic breccia, formed of angular fragments of green and brownish lithoidal rhyolites, cemented by felsitic material containing free quartz, which is so compact and flinty that it has a conchoidal fracture, and rings under the hammer.

Grass Cañon, which is a long, narrow ravine running out at the northern end of the mountains, presents along its slopes the most interesting occurrences of volcanic rocks in these mountains. At its head, and along the upper walls, are gray pearlites of the crystalline type. A characteristic specimen (wrongly located in Vol. VI, 175, No. 375) is rich in black biotite, and contains macroscopical crystals of sanidin, plagioclase, and quartz. Under the microscope, the feldspar crystals are seen to contain great numbers of angular bubble-bearing glass-inclusions, sometimes so closely aggregated as to form entire portions of the interior of the crystals. Mica is most abundant in hexagonal laminæ, $0.008^{\mathrm{mm}}$ in diameter, while in the colorless glass-base are feldspar-microlites and pale-green needles, together with gas-cavities containing magnetite. This pearlite passes into one in which the crystalline ingredients are still present, but the groundmass is a colorless glass, in which are developed concentrically-curved cracks, giving a sphærulitic structure to the mass. Microlites are present as products of devitrification, and, as already stated, crystalline ingredients, feldspar and mica, which are difficult to detect with the unaided eye. Beyond the pearlites, on the west side of the canion, about opposite the North or Basalt Peak (not named on the map), is a peculiar greenish rock, having in general a granular structure, and showing no crystalline ingredients, through which run many bands, alternately quite porous, and again 
compact and lithoidal. The latter pass into chalcedony, which covers the weathered surface, and sometimes forms the mass of the rock in bands a foot or more in thickness.

At the head of a side-ravine, where, in a low saddle, the underlying rocks have been denuded, are disclosed a most interesting series of rhyolitic pearlites, chalcedonies, and tufas, which, from the occurrence of rounded obsidian balls within the pearlite layers, have been designated the Ball Rocks. The upper layers on either side of this saddlo are composed of the green rhyolite already mentioned, and layers of brown chalcedony, on whose weathered surfaces are curious rounded excrescences, of concentric structure, resembling the fungoid growths found on old tree-trunks. This similarity is heiglitened by the color and interior banded structure of the chalcedony, which resembles woody fibre. Within the chalcedony mass are frequent druses, lined with white banded opaline agate, and containing quartz crystals. Zirkel describes the microscopic structure of the chalcedony as consisting of concentric globules and botryoidal concretions in a seemingly colorless substance, which, by polarized light, is seen to be an aggregation of siliceous sphærulites. A section has been figured in Vol. VI, Plate XII, fig. 2.

On the saddle are exposed layers of pearlite, containing rounded obsidian balls, from half an inch to an inch in diameter, associated with a white pumiceous tufa, enclosing fragments, generally rounded, of the pearlite. The pearlite is of a blue-gray color, devoid of crystalline ingredients, with a tendency to form layers from an inch upward in thickness. It has a wavy appearance, and is entirely made up of sphærulitic concretions. The sphærulites have a concentric structure, and are formed of thin layers. Under the microscope, these layers are seen not to be complete rings, but to be grouped round the centre like the leaves of an onion, and the microlitic products of devitrification to be arranged in parallel wavy bands through the mass, quite independent of the concentric structure, from which Professor Zirkel concludes that this structure is merely a phenomenon of contraction. The pumiceous tufa, which is found abundantly along the slopes of the ridge, is a white porous mass, containing small fragmentary crystals of quartz and sanidin, and enclosing larger fragments of the gray 
pearlite, in contact with which the white frothy matrix is seen to be compressed and hardened, so that the surface of the cavities left by these fragments is smooth and hard like a plaster mold.

The obsidian balls, which have an almost perfectly spherical shape, and occur imbedded in a layer of pearlite near the summit of the saddle, are seen by microscopical examination to be remarkably pure, containing only a few trichites in a light-gray glass.

About a mile from the mouth of Grass Cañon occurs another white rhyolitic tufa or breccia, of much more compact mass than the above, and enclosing fragments of dark porphyritic rhyolite with free quartz, which forms quite high cliffs on the west wall of the cañon.

In this vicinity, also, is a considerable development of basaltic rocks, which have apparently poured out on the east side of the cañon, and have also covered the upper part of the ridge on the west. These basalts develop a columnar structure, particularly on the slopes of the peak on the east side, which has been called Basalt Peak, where they are remarkably perfect and arranged horizontally. They belong to the same general type as those of Aloha Peak. The main mass is a compact, dark, rather vitreous-looking rock, with conchoidal fracture and somewhat coarse texture, in which only small plagioclase crystals can be detected macroscopically. The microscope detects also olivine and augite, and in the groundmass an amorphous globulitic base.

The basalt from the very summit of Basalt Peak is more crystalline, showing, under the microscope, plagioclase, green augite, olivine, and magnetite, with a little brown, slightly globulitic glass. To the south of Basalt Peak, east of the head of Grass Cañon, and apparently underlying the basalt which forms the summit of the peak, is a considerable thickness of basaltic tufa, which macroscopically resembles the palagonitic tufas. It is very soft and crumbly, being simply a loose aggregation of finer or coarser particles of volcanic ash. Under the microscope, it is seen to be composed of splinters of brown glass, with a few fragments of brown augite and colorless feldspar. As the glass does not gelatinize after treatment with acid, Professor Zirkel proposes for it the name of hyalomelane-tufa.

Basalt forms the eastern wall of Grass Cañon throughout the greater 50 D a 
part of its extent, and at its mouth apparently extends also along the foothills to the west. The eastern slopes were not examined, but the basalt body probably connects with that of the low ridge, which connects these mountains with the Montezuma Range.

Kamma Mountains.-To the north of the Pah-tson Mountains, and on the western edge of the larger Mud Lake, or Black Rock Desert, as it is sometimes called, is an irregular group of hills, whose highest summits which rise from 2,000 to 3,000 feet above the desert are arranged in the shape of a crescent, called the Kamma Mountains. Through these hills runs the wagon-road from the bend of the Humboldt River to California laid out by General Lander, and sometimes known as Lander's cut-off. In the middle of the group, a few miles from the edge of the desert, is a group of springs, important because of the infrequency of springs in this arid region, and because they afford the last good camping-place before entering the desert region to the westward, known as the Rabbit Hole Springs. Their water is tolerably pure, having a slight flavor of sulphur, and of a temperature of about $60^{\circ} \mathrm{F}$. They were carefully walled in by General Lander, but the walls and adjoining stone house have largely fallen into ruin.

These mountains divide themselves into three natural groups, a southwestern, separated from the others by a dry water-course, which affords a more favorable route for a wagon-road to the Humboldt, except for its want of springs; a middle group, over which the present road runs; and a northern, bordering the desert. The southwestern group consists of a high, rounded ridge, whose slopes are unusually well covered, for this region, with soil and surface accumulations. Its main mass is of siliceous slates and quartzites, which were not sufficiently well exposed to show defined structure-lines. On the northern slopes, they stand nearly vertical, and carry several mineral veins. These rocks have been provisionally referred to the Koipato group of the Triassic. On the main crest is exposed a body of diorite of massive, rather tabular, structure, and conchoidal fracture, having a dark-brownish color on the weathered surfaces, but in fresh fracture showing a fine-grained crystalline mass of dark-greenisly color, in which, however, only small crystals of plagioclase can be distinguished by the 
unaided eye. Under the microscope, well-defined hornblende can be distinguished, associated with light-brown grains, which are probably epidote, while the fresh plagioclases are seen to contain hornblende dust, but no quartz has been detected.

In the desert, a mile or two beyond the western extremity of this ridge, is an obscure outcrop of a very characteristic dolerite. It is a rather fine-grained crystalline rock, of irregular fracture, and of a dark reddishbrown color on the weathered surface, in which crystals of augite up to a quarter of an inch in length and fine plagioclases can be distinguished. White calcite is deposited in crevices in the rock, and in some cases forms pellucid crystalline grains. The microscope detects also fine magnetite grains and hexagonal laminæ of specular iron, with a little olivine, while between the feldspars and augites is a little dark globulitic base. This dolerite is interesting on account of its rarity, the only other occurrence in this region being a small hill at Black Rock, which will be described later.

At the eastern extremity of the ridge,. in the gap of the dry watercourse already mentioned, is an outcrop of a rock that has been classed by Zirkel as a trachyte, but which, in general physical character and appearance, closely resembles the andesites, with which it is nearly connected. The dacite color, which is here indicated by mistake on the map, belongs to an outcrop found in the desert a little to the eastward. This latter is a finegrained rock, resembling in general appearance and structure a compact sandstone, of gray color. The only constituents to be distinguished in it by the naked eye are fine grains of limpid quartz. Under the microscope can be seen, besides the plentiful quartz-grains, well-striated plagioclases and altered hornblendes, in a groundmass of a somewhat rhyolitic nature. The trachyte at the gap is a greenish-gray rock, of moderately rough texture, containing, in a homogeneous-looking groundmass, white decomposed crystals of sanidin-felspar, occasional dark-brown hornblendes, with a few fresh plagioclases. The microscope detects also apatite and dendritic laminæ of specular iron, while the hornblendes are entirely decomposed.

The middle group consists mainly of andesitic rocks, which form sharp, jagged peaks on either side of the wagon-road, but to the south, 
in the long, flat spurs, are largely concealed by surrace accumulations. In the pass through which the wagon-road passes, the rocks seem to have a dip to the eastward. The easternmost mass closely resembles the trachyte above described, having yellowish, decomposed feldspars and dark-brown hornblendes in a rough-feeling groundmass, in which also small undecomposed plagioclases can be distinguished.

A yellowish-brown rock, having a conchoidal fracture, and less of the trachytic feel than the last described, forms the main mass of the peaks. Through the homogeneous-looking feldspathic groundmass are plentiful crystals of rather vitreous-looking feldspar and yellow-brown decomposed hornblendes. Under the microscope, the feldspars are seen to be mostly plagioclase, and the decomposed hornblendes present interesting peculiarities, which are described in the microscopical report. Apatite, which is found in all these rocks, occurs in broken prisms, presenting a peculiar arrangement of dust-like material in their interior, as shown in Vol. VI, Plate I, fig. 9.

These rocks present a peculiar type, being quite different in lithological habit from any other andesites observed in the region of the Survey, and, on the other hand, being distinctly trachytic in external character. In this connection, it is interesting to note the occurrence of another sanidin-bearing andesite in little isolated hills in the open region to the north of the Kamma Mountains, near the Indian Spring. It resembles the first of those described above, being of a dark greenish-gray color, and showing large sanidins and decomposed hornblende, but the groundmass is more compact and closegrained. On its weathered surface is a coating of reddish decomposed rock, containing silica in thin films.

At the northern end of the andesite hills are outcrops of purple, finely laminated, slightly calcareous, argillites, resembling those of the range next east, which have been, like them, referred to the Jurassic formation. From these, in a little side-ravine just south of the northern branch of the wagon-road, issues a little spring of remarkably pure cold water, called Lander Spring.

The northern group, which is somewhat lower than the two just described, is entirely made up of rhyolites and rhyolitic breccias and tufas, 
which occur in great variety, and give most brilliantly variegated colors to the hill slopes. Although presenting such great variety of color in the field, they present no great variety of mineralogical composition, being generally poor in crystalline ingredients. The breccias and earthy varieties predominate, and in color range from a white at the base of the hills, through delicate mauve and bright red, into yellow at the summit. A white rhyolite, in the dry water-course between these hills and the middle group, presents a finely banded structure in wavy lines, and abounds in small druses lined with quartz crystals. Under the microscope, its groundmass is seen to be neither microfelsitic nor distinctly crystalline, while the banded appearance is due to the arrangement of the grains and fibres of imperfectly crystallized material in the groundmass. The breccias, on the other hand, present in the angular fragments which are enclosed in them a great variety of micro-structure in the same rock.

The lower spurs of these hills are smooth and gently sloping, and covered with detrital material, so that little could be learned of their composition except that re-arranged rhyolitic material seems to predominate. A dark-brown outcrop about half a mile north of Rabbit Hole Spring, for instance, was found to be made up of fragments of various cherty rhyolites, carrying free quartz, cemented by a sort of argillaceous material.

Toward the desert, the Kamma Mountains present long gentle slopes, descending between 100 and 200 feet in the mile, in which, in places, notably along the slopes of the western group, deeper gullies disclose the presence of stratified beds of soft crumbly material, largely volcanic ash, which indicate a Tertiary deposit.

At the northern limit of the map is represented the southern point of a prominent range of mountains, which forms the eastern border of the Black Rock Desert, and whose culminating point, known as Mount Véry, reaches a considerable altitude, probably between 8,000 and 9,000 feet. Of the portion included within the limits of the map, the crest and eastern slopes are formed of trachyte, a fine-grained rock, of reddish-purple color and conchcidal fracture, in which no crystalline ingredients except minute feldspar crystals are visible to the naked eye. The microscope discloses no 
other crystals than the feldspars, which are seen to be sanidin, but in the groundmass are black opacites, which by their form should be magnetite.

In the cañon on the western slopes of this ridge are seen a considerable variety of rhyolites, and some Tertiary beds upturned at $20^{\circ}$, which, from their composition and angle, have been assigned to the Truckee Miocene. They consist of finely-laminated siliceous shales, of a whitish-drab color, resembling some of those of the Truckee Valley beds, but containing no diatoms in the specimens brought in. Over these are fine-grained conglomerates. The rhyolites exposed have evidently broken through these Tertiary beds, and walled them in on the side toward the desert. They are generally of white, porous, earthy varieties, showing only a few broken crystals of feldspar and quartz. One variety is a fine-grained purplish rock, containing no crystalline ingredients, but speckled all through the mass by fine white dots, which may be decomposed feldspars.

Other rhyolites and rhyolitic breccias presenting no specific differences from those already described occur in the low hills which dot the open region but little above the desert level, in the vicinity of Indian Spring. In general, the slopes toward the desert on this eastern side are so gentle, and are composed of such soft material, that no. distinct terrace-lines can be traced, although, as will be seen later, the ancient lakes probably extended well up on the slopes of the hills, and covered most of the interior valleys. The first distinct tufa deposits or outcrops are found about 3 or 4 miles west of the foot-hills on the Kamma Mountains, where they mark rudely the limit of the sagebrush-coveréd Upper Quaternary slopes, the desert beyond being occupied by the fine muds and silts of the Lower Quaternary, which in dry seasons present a hard mud flat as level as a floor, and which are practically without vegetation, supporting only here and there a sparse growth of the desert shrubs locally known as "grease-wood" (Halostachys occidentalis, Sarcobatus vermiculatus).

Black Rock Mountains.-The great Lower Quaternary plain of the larger Mud Lake, or Black Rock Desert, which occupies, in the region included in the map, an extent of about 60 miles in a northeast and southwest direction, extending still some distance to the north beyond its northern boundary, forms the sink of Quinn's River, a considerable stream, which 
rises in the mountains on the borders of Nevada and Eastern Oregon, and enters this valley through a break ia the Mount Véry Mountains, gradually losing its water by evaporation and absorption, until, where the road crosses it near the Black Rock, it is only about six feet in width. A western arm of the desert extends a short distance north of the limits of the map, between the Black Rock and Forman Mountains, where it is shut in by the hills which connect them, while the western Mud Lake, which lies between the northern end of the Lake Range and the Madelin Mesa, practically forms part of the same plain, being separated by a low, almost imperceptible ridge of Upper Quaternary, at the southern end of the Granite Range. These plains, which during the greater part of the year are so dry and hard that a wagon-wheel or horse's hoof scarcely leaves a perceptible track upon their surface, are frequently during the winter covered to a depth of several inches with water, which must render them practically impassable, since during our explorations in the months of October and November the occasional autumn storms had so softened the surface that mules would sink fetlock- and even knee-deep at every step, and the so-called "self-rising" portions, where the proportion of readily soluble salts in the soil is probably greater than usual, had to be carefully avoided, lest the animals might disappear altogether. Where the surface has been recently moistened by rain or spring-water, surface incrustations of soluble salts contained in the soil are found forming thin white films. Such were gathered from near the crossing of Quinn's River, and from near the so-called Hardin City, on the western arm of the desert, north of the limits of the map. They were analyzed by Prof. O. D. Allen, of Yale College, with the following result:

Quinn's River Salts.

Chloride of sodium .................... 85.27

Carbonate of soda ....................... $\quad 2.59$

Sulphate of soda ........................ $\quad 1.75$

Water .............................. $\quad 8.57$

Residue............................. $\quad 1.82$ 
Hardin City Salts.

Chloride of sodium . . . . . . . . . . . . . . 18.47

Carbonate of soda . . . . . . . . . . . . . . . $5 \mathbf{5 2 . 1 0}$

Sulphate of soda . . . . . . . . . . . . . 27.55

98.12

Of the latter, Professor Allen says: "It is reasonable to suppose that it contains an appreciable amount of borate of soda."

The general level of the Mud Lakes is about that of the lowest part of the Humboldt and Carson Deserts, from 3,850 to 3,900 feet above sealevel, while similar terrace-lines attest the former presence of the waters of the La Hontan Lake. The terrace-lines are in general more distinct on the western side, where a steeper wall was presented to the former lake, and later erosion has not so readily concealed them. Deposits of lacustrine tufa are abundant in the Black Rock Mountains, covering some of the lower outlying hills and extending through the lower passes. They are also found along the slopes of the Granite Range, and in greatest development along the basalt wall of the Madelin Mesa on the western side of the smaller Mud Lake.

The Black Rock Mountains form topographically a southern spur of the mountain mass north of the limits of the map, whose culminating point is known as Mount Lander, a peak of apparently 9,000 or 10,000 feet in height, which is probably connected with the northern continuation of the Granite Range uplift. The portion represented on the map consists of low broken ridges of rhyolite and basalt, in which these rocks are found quite regularly bedded, and presenting almost uniformly a bluff face to the west, with a gentle slope to the eastward, their bedding planes having as high an angle as $20^{\circ}$. As a rule, the basalt flows form the summit of these ridges, while on the western bluff faces are found, at the base, the outcrops of underlying rhyolites. In a few instances, however, rhyolites were found again, forming the capping beds, generally separated, it is true, by intervals of débris slopes from what appeared to be the underlying basalt flows. It seens probable that the present structure, and perhaps, also, the apparent 
superposition of rhyolite over basalt, is due to a general faulting and fracturing of the beds at the time of, or since the outflow of the basalts, and that in the one instance observed, where rhyolite seemed actually to overlie basalt, the latter might have poured out between previously formed rhyolite beds, as undoubtedly occurs at times in sedimentary rocks.

It is interesting to observe in this connection that the abundant hot springs which occur in these hills are almost invariably found on the edge of the desert along the western foot of the mountains. . Of these, the group of Warm Springs, locally known as the Double Hot Springs, about 6 miles from the southern point, consists of two adjoining pools about 15 or 20 feet in diameter, and apparently about as many deep, with other smaller pools in the vicinity, from all of which there is only a small overflow of water. The water has no perceptible taste, but it has a very high temperature, that of the larger pools at the surface being $165^{\circ}$ to $168^{\circ} \mathrm{F}$., while one of the smaller pools gave a temperature of $171^{\circ}\left(78^{\circ} \mathrm{C}\right.$.). Probably below the surface the temperature is very near the boiling-point.

This region possesses a weird interest, not only from its peculiarly desolate physical character, being, with the exception of the hot springs above mentioned, entirely without water, and utterly devoid of vegetation, not even supporting a growth of the almost ubiquitous sage-brush (Artemisia tridentata), but also from the large development of the more unusual accompaniments of volcanic rocks: concretions and geodes of chalcedony and agate are present in great quantity and of most varied forms and colors, while the occurrence of a persistent bed of decomposed basalt, perfectly honey-combed with amygdaloidal cavities filled with green earth, the fissures of the more compact portions being covered frequently with a thin dendritic coating of oxide of iron, has been the cause of leading hundreds of ignorant but enthusiastic miners into the belief in the presence of valuable argentiferous minerals. At the time of our visit in 1867 , this belief, fostered by fabulous reports, spread abroad in part by ignorant, in part doubtless by designing, persons during a series of years previous, the fear of hostile Indians and the inaccessibility of the region rendering trustworthy accounts difficult to obtain, had culminated in the establishment of a mining-town, called Hardin City, just north of the limits of the map, near some springs 
on the edge of the desert, and the building of two small mills, to work the so-called ore Had the vein, this bed of decomposed basalt, been metalbearing, it might have been the source of untold wealth, since, with a thickness of 40 to 60 feet, it could be traced almost continuously over an extent of thousands of acres; but a careful chemical examination revealed, as might have been expected, no metal other than a small percentage of iron.

The extreme southern point of the mountains is a rounded hill, rising about 500 or 600 feet above the desert, formed entirely of basalt, which, from the contrast of its blackened weathered surface with the white desertplains, has received the name of Black Rock, afterward transferred to the whole ridge. It is composed of a fine-grained rock, on freshly broken surfaces of a greenish-gray color, a conchoidal fracture, and sometimes rather granular texture, showing small crystals of fresh plagioclase and abundant yellow-brown augites; it contains also considerable calcite, which fills crevices, and sometimes forms minute crystals in the mass. From a little hill just north of this, at the southern end of the main ridge, was obtained a remarkably interesting dolerite, which was found alternating with a reddish, porous, fine-grained basalt. The dolerite is remarkable for its large tabular crystals of plagioclase; sometimes an inch in diameter. It is of a dark greenish-gray color, and resembles that found at the southwest end of the Kamma Mountains, but is much more coarsely-grained, and has a somewhat resinous lustre. In it can be distinguished crystals of dark-brown augite up to one-fourth of an inch in diameter. Under the microscope are detected, besides plagioclase and augite, olivine and magnetite, but no sanidin, quartz, or titanic iron. The crystalline ingredients are generally very fresh and unaltered, and a little amorphous base, in the form of wedge-shaped grains between the crystals, is present.

Basalt forms the mass of the hills for some distance north of the Black Rock. Among these basalts was found a deposit of basaltic tufa, a loose, gray, fine-grained mass, not to be distinguished by the unaided eye from that observed in the Pah-tson Mountains, but which, under the microscope, is seen to be made up, with the exception of some tabular crystals of feldspar, of fragments of the hyaline volcanic glass, called palagonite. The occurrence of palagonitic tufa here is particularly interesting, as being the 
only occurrence found, not directly connected with the Tertiary beds of the Truckee Miocene..

The rhyolites were principally examined in the neighborhood of Hardin City, where the mountains are wider than at the southern point, and the peculiar structure of the hills already noticed more prominent. These rhyolites are generally of earthy and brecciated varieties, and poor in crystalline secretions. Their groundmass is characterized microscopically by a medium character between the indistinct and the microfelsitic, as is shown in Vol. VI, Plate VII, fig. 1.

At the base of the cliffs east of Hardin City are outcrops of white loose-grained rhyolitic breccias, having a gravelly structure, and containing small pebble-like fragments of darker-colored rhyolites in a white felsitic groundmass. They have an appearance of bedding, and are exposed in a thickness of several hundred feet, showing varieties of texture, from the loose crumbly nature above described to a tolerably compact mass, having, however, the same gravelly composition. Above this occurs the so-called Snowstorm Ledge, a bed of decomposed basalt, from 40 to 60 feet in thickness. In its extreme form, this basalt is a greenish-drab earthy mass, rendered almost like a sponge by the quantity of amygdaloidal cavities running through it, which are generally filled with a green earthy powder. Where the decomposition has not proceeded so far, the basalt is of a light greenish-gray color, showing no macroscopical crystalline ingredients, its mass still full of smaller or larger rounded cavities, some of which are filled with the green earth, others again lined with botryoidal concretions of chalcedony, and in others still the botryoidal form is preserved, but a thin coating of hydrous oxide of iron only remains. The top of the cliff is made up of a fresh, black, lustrous basalt, with clean conchoidal fracture, ringing under the hammer, and of fine, even-grained textnre; this has also irregular crevice-like cavities, lined with a botryoidal coating of chalcedony, and in some cases containing a little calcite. On the slopes of the adjoining hills and ravines are innumerable geodes, lined generally with quartz crystals, and sometimes disclosing agates of great beauty. The green earth filling the pores of the decomposed basalt, being tested chemically, was found to 
consist principally of silica and alumina, with some alkalies, and a small percentage of iron. It is probably what is generally called seladonite. Microscopical examination of these basalts confirms the conclusions drawn from their external appearance. They are seen to be much altered, the magnetite is changed into yellow hydrous oxide of iron; there are no distinct olivines; the augites are pale and scarce; in the green powder is found titanic iron, which, when fresh, cannot be distinguished from magnetite. The peculiar structure of the augite-microlites is shown in Vol. VI, Plate I, fig. 19.

The highest point in this region, a little north of the bluffs above described, called Hardin Mountain, is capped by a light mauve-colored rhyolite, containing, in a rather porous felsitic groundmass, crystals of sanidin and quartz, and fragments of white and yellow pumiceous rhyolites. On the eastern flanks of this hill were found other outcrops of decomposed basalt, and in a ravine called Star Canon, running east and west across the mountains, at a considerable distance to the eastward, similar successions of basalt beds dipping eastward, underlaid by a variety of rhyolitic breccias, and in one case overlaid by a reddish, earthy, rhyolitic breccia. A rounded hill on the eastern borders of the mountains, known as Utah Hill, consists of a breccia-mass of hard flinty rhyolites containing free quartz, with very little cementing material between the fragments.

Among the interesting occurrences in this region is to be mentioned a deposit of pisolite, which is found as an incrustation round a spring in these mountains, about 15 or 20 miles north of the limits of the map. The specimens, brought in from this place by the miners, are aggregations of grains about one-fourth to three-eighths of an inch in diameter, perfectly white, of concentric structure, but having the form of very regular pentagonal dodecahedrons, which may possibly be a result of contraction or mutual compression. From the Forman Mountains, to the westward, was brought also a curious light-gray rhyolitic rock, interesting on account of its peculiar columnar structure, the columns being about an inch in diameter, and made up of an aggregation of very perfect little hexagonal prisms about an eighth of an inch in diameter each. The only crystalline ingredients visible are a little free quartz and a few feldspars. 
The Forman Mountains, as represented on the map, are the southern point of a range of mountains, in which both these and the Black Rock Mountains are probably merged to the north. They were only examined opposite the Cold Spring, a large spring of fresh cold water on the edge of the desert, near their southern point. Here they were found to consist exclusively of rhyolitic rocks, in which, as at Black Rock, the breccias play the most important rôle. Of the specimens of rhyolite obtained, one is a pure white felsitic mass, of conchoidal fracture, containing only white, halfkaolinized feldspars, with no other crystalline ingredients. Another variety is a reddish porphyritic rhyolite, with rough fracture, containing well-defined glassy sanidins, sometimes in Calsbad twins, and free quartz in a compact felsitic groundmass. With these occur breccias, which closely resemble the parent rock, being in no way distinguishable from it except from the fact that it shows a combination of angular fragments, all of the same composition and color, which is also that of the material which binds them together. Another white porous breccia is seen, however, to contain strange fragments of dark slate color, apparently of some older rock, which are too homogeneous, however, to offer definite characteristics.

Granite Range.-In the northwest corner of the map, the Granite Range appears as the first mountain uplift in Nevada east of the State of Califormia, its western base lying about 25 miles east of the 120th meridian, the boundary between the two States. The range rises abruptly above the Mud Lake Desert in about latitude $40^{\circ} 45^{\prime}$, but. projects in a low, narrow tongue of granite 3 or 4 miles still farther to the southward, toward the plain. To the northward, the range stretches far beyond the limits of the Fortieth Parallel Survey, and has never been thoroughly examined or mapped.

Within the limit of the map, the range extends in a north and south direction for 25 miles in bold, rugged mountains, which rise grandly for 4,000 feet above the level, floor-like plain of Lower Quaternary beds, the highest peaks attaining an altitude of 10,000 feet above sea-level. Only the southern portion of the mountains was visited, but, as far as examined, they appear to consist entirely of granite, with the later Tertiary volcanic rocks breaking out along the base. This granite, in its physieal habit, presents all the marked features which characterize the neighboring 
granitic masses of the Truckee, Pah-tson, and Sah-wave Mountains, but at the same time the range, being higher and more massive, develops certain aspects and modes of weathering which are not mo characteristically shown in the more subordinate, narrow ridges. The canons are deeply cut, but the ridges and spurs have in general a rounded outline, in distinction from angular forms, while the peaks, although standing out boldly, have curved, broad, and even dome-shaped summits, and are rarely seen in sharp pinnacles.

In general, the granite is characterized by a uniform texture, and shows little tendency to form either a fine or coarse-grained rock. It breaks readily under the blow of a hammer. It is made up of translucent quartzgrains, both monoclinic and triclinic feldspars, biotite, and hornblende. All the feldspars are light-colored, and the plagioclase, which is the prevailing form, frequently occurs beautifully striated and characterized by a brilliant lustre. Hornblende, as a constituent of the rock, varies very considerably in different localities as to the amount present, but is always a marked feature of the body. Amber-colored titanite, the variety designated as sphene, is very abundant, with well-developed crystalline faces.

It may be added that the rock-mass possesses a fresh, unaltered appearance, with no recognizable law in the arrangement of the mineral constituents. A specimen collected from the low hills west of Granite Creek Station may be taken as a typical rock. It was subjected to chemical analysis by Prof. Thomas M. Drown, of Lafayette College, with the following result :

Silica

Alumina

Ferrous oxide

Manganous oxide

0.29

Lim

Magnesia

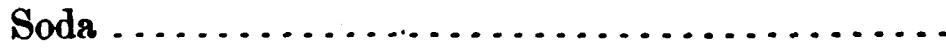

Potassa .

Loss by ignition 
This analysis bears a close resemblance to that of the Pah-tson Mountain granite, a resemblance which is equally well shown in the lithological characters of the two rocks.

East of Granite Creek, at the base of the range, occurs an outburst of basalt, rising but a few hundred feet above the desert. It forms smooth, rounded hills of black, compact rock, closely resembling in its geological occurrence the basaltic eruptions flanking the granite bodies of the Truckee and Lake Ranges.

About 3 miles southwest from Granite Creek Station, and near the southern end of the range, is a group of hot springs known as the Granite Croek Boiling or Mud Springs. Scattered over an area roughly estimated at 75 acres are a large number of pools, mostly circular, varying in size from 1 up to 25 feet in diameter, and surrounded by a luxuriant growth of brilliant green alkaline grasses, in marked contrast to the dull monotonous colors of the desert. The waters are clear and quite palatable. when cool. The largest one visited had a temperature of $194^{\circ}$ in the broad open pool; others indicated temperatures from $188^{\circ}$ up to the boilingpoint, and yielded large volumes of vapor that could be seen many miles across the desert. Along with these springs are a number of mud springs, or, as they are called, "Mud Volcanoes", round basins from 2 to 3 feet below the surface of the ground and varying from 6 inches to 6 feet in diameter. These were filled with mud and slime, the contents being thrown up and violently agitated at regular intervals, accompanied by puffs of steam. Several of these springs had built up cones of hardened mud, and all, with one exception, closed at the top. In this one, the aperture was about 2 inches in width, and emitted a very perceptible odor of sulphuretted hydrogen; it is said occasionally to throw out mud and water in all directions for a distance of 100 yards. Fragments of this ejected material were found by analysis to have the composition of clay.

From the base of the Granite Range westward, and west of the lesser Mud Lake, extends a broad plateau country made up exclusively of extensive flows of basalt, known as the Madelin Mesa, or Madelin Plain. It possesses the peculiar topography of the regions generally known in the West as lava beds, being cut through by deep, narrow, intricately branching ravines, 
with perpendicular walls, which render it peculiarly difficult to traverse, and well fitted to afford secure refuge to the scattering bands of renegade Indians, which frequent this region. Its physical aspect is most monotonous and dreary, and it presents no inducements for exploration or occupation, either for purposes of agriculture or of mining. The area represented on the map constitutes the eastern limits or walls of the immense flows of basalt, which extend more or less continuously westward into California, in the region of the Upper Pitt River, and thence northward through Oregon, east of the Cascade Mountains, and evidently stand in intimate connection in geological history with the great basaltic flows which have built up the Cascade Mountains, in the neighborhood of the Columbia River, and covered so much of the interior valleys of that great stream.

From beneath these flows, at intervals of 10 or 15 miles along their southern and eastern edges, issue springs, which are of more than usual importance on account of their rarity in this illy-watered region. The most important are, that just west of the southern point of the Granite Range, that at the Buffalo Station of the wagon-road, and the Sheep's Head and Rotten Egg Springs along the western edge of the Mud Lake. According to the Indians, there is also a spring of good water on the little basaltic butte in the midst of the western Mnd Lake. The Sheep's Head Spring is remarkably picturesque, being a stream welling out of a circular orifice of calcareous tufa about a foot in diameter. The Rotten Egg Spring, as its name suggests, emits an odor of sulphuretted hydrogen. 


\section{SECTION VII.}

\section{WINNEMUCCA LAKE REGION.}

BY ARNOLN HAGUE.

Pan-supp Mountains.-The Pah-supp group lies directly west of the Pah-tson Mountains, the depressed valley between them measuring scarcely more than 5 miles in width. The 119th meridian west from Greenwich passes through the central portion just to the westward of the main ridge, whose highest summits reach an altitude of 2,000 to 2,500 feet above the desert of the Mud Lakes, rising abruptly on the east side, but falling away gently to the westward. In a north and south direction, the mountains are about 20 miles in length, with a width of 12 miles from base to base. With the exception of the low foot-hills of slate skirting the eastern flanks, the entire mass of the Pah-supp Mountains consists of granite, whose physical attitude, as well as mineralogical composition, presents, wherever visited aiong the main ridge, a striking uniformity of character and a marked resemblance to the later granites of the Pah-tson Mountains, a resemblance seen even in the modes of weathering and in the detailed topographical structure of the higher slopes and valleys.

$\Lambda$ specimen of granite in the collection taken from the highest peak in the southern portion of the group, nearly due west from Pah-keah Peak, cannot be told from the rock in the region of Grass Cañon, Pah-tson Mountains. Both hornblende and mica are well developed, the crystals of the former being frequently one-half an inch in length, with broad faces of a dark-green color, while the thin laminæ of biotite seem fresh and unaltered. Plagioclase appears to be abundant, but in small crystals. No titanite was observed in the specimen collected. Under the microscope, in thin sections, the feldspars are shown to be impregnated with specular iron and hornblende dust.

Other specimens from the northern end of the ridge are somewhat ligliter in color, but have an identical mineralogical composition. The $51 \mathrm{D}$ a 
biotite is less prominent, and the quartz occurs in larger grains, remarkably clear and translucent. Under the microscope, the quartz is shown to be very rich in liquid-inclusions.

A characteristic feature of the mountains is the number of narrow quartz veins, rarely over a few inches in width, which traverse the granite, with here and there seams of fine-grained massive feldspar, with occasional grains of quartz scattered through it.

The slates already mentioned rest unconformably, at a high angle, upon the granite, where they occur, both at the northern and southern end, as a narrow belt of smooth, rounded hills between the crystalline rocks and the Quaternary deposits. No structural or palæontological evidence of the age of these slates was obtained, but, like the obscure outcrops of similar beds between the Humboldt River and the Sierra Nevada, have been referred to the Jurassic age.

Between 5 and 6 miles to the southwest of the Pah-supp Mountains, and connected with it by a low ridge nearly concealed by Quaternary accumulations, occurs a small, isolated group of hills composed of granite and the thinly-laminated Jurassic shales. The granite rises somewhat abruptly, but barely attains an eleration of 1,500 feet above the surrounding desert, extending in a north and south direction for about three miles. The chief interest derived from this body of granite is the proof afforded of the undoubted connection existing between the Pah-supp and Sah-wave Mountains, the two groups forming a nearly continuous line of upheaval, with low depressions barely covered by Quaternary beds. The granite of this isolated mass was but little studied, and only visited at the extreme northern end. It closely resembles, however, the rock from the Pah-supp Mountains, with the same texture, mineral composition, and mode of arrangement.

The overlying Jurassic beds extend eastward for 4 miles, nearly to the Pah-tson Mountains, in low, undulating hills and obscure outcrops, the surfaces of which are covered by loose fragments of extremely fissile gray slates; their relations to the rhyolites of the Pah-tson Mountains on the east and the granites on the west are clearly indicated in the upper geological section, at the base of Map V. These slates, which are highly metamor- 
phosed, like those of the entire region, have been examined microscopically by Professor Zirkel, who pointed out their resemblance to the Silurian and Devonian crystalline slates of Germany; but, while the similarity is quite marked, it should be borne in mind that it is only in the products of metamorphism, and, it would seem, might easily be found in strata as altered as the Mesozoic beds of Western Nevada. Quartz and extremely minute lamine of nearly colorless mica are the only minerals that could be recognized with a high power under the microscope.

SaH-wave Mountains.-The Sah-wave Mountains measure 20 miles in length by about 6 miles in width, and are but a continuation southward of the Pah-supp group, terminating near the line of the 40th parallel. They present their steepest slopes toward the east, the highest point rising over 3,000 feet above Sage Valley, and fall away in the direction of the Truckee Range, with which they are connected by a narrow depression. So far as examined, the granite resembles that of the Pah-supp Mountains, and is evidently of the same type. A specimen from the summit of the highest peak is of a light-gray color, owing to the small amount of hornblende and biotite present. The quartz has a slight grayish tinge. Under the microscope, in thin sections, the orthoclase crystals reveal the presence of included fragments of striated plagioclase.

On the flanks of the highest peak, the gray slates are exposed in the same manner as seen to the north, dipping eastward, upon which, resting unconformably, are the upturned Truckee Miocene beds, made up of lightcolored, variegated strata. Two or three miles to the southward, the Miocene is seen for a short distance resting directly upon the granite, beyond which it is in turn concealed by the Quaternary.

Truckee Range.-This range extends in a north and south line for 72 miles, and consists, for the greater part of the distance, of a single narrow ridge barely more than 5 miles from base to base, but widening considerably at the southern end, where it is made up of broad fields of Tertiary eruptive rocks. Its trend is almost due north and south, the meridian of $119^{\circ} 15^{\prime}$ cutting the crest of the ridge for its entire length, the culminating peaks being sometimes on one side of the line and sometimes on the other. Tutib Peak, at the southern end, Nache's Peak opposite Winnemucca Lake, 
and Kumiva Peak to the north, are the principal summits, rising from 2,500 to 3,000 feet above the plain.

Highly crystalline quartzitic schists and homblendic rocks, with both the older and later types of granites, are found in the Truckee Range. The intrusive granites and metamorphic schists, which have been referred with but little hesitation to the Archæan series, occupy but a small area in the range, outcropping at widely separated localities, yet are, from a geological point of view, of considerable interest. The later granites, however, form by far the greater part of the range, occurring probably in an unbroken line for 50 to 55 miles. So far as the limited observations in the range extended, the older granites were found only at the southern end, in the region southeast from Winnemucca Lake, where they occur in subordinate masses along the foot-hills, rarely rising to form the more elevated ridges. The time allotted for the examination of this portion of the range would not permit of accurately mapping the granitic outcrops, and, indeed, it would require a very considerable amount of labor to do so, as the formations have been very much disturbed by the outbreaks of diorites and diabase, and still later nearly concealed beneath immense flows of rhyolite and basalt.

Three or four miles southeast from the mouth of the Truckee River, at the extreme southern end of the lake, occurs a large body of the older granites, which is well exposed by a deep cañon cutting through the hills. One variety of this granite, an exceedingly dense, tougl rock, is made up almost exclusively of quartz and feldspar, with but little mica, and may be classed as an aplitic granite. The quartz appears in small translucent grains. Flesh-red orthoclase is the prevailing feldspar, while the observed plagioclase crystals are usually very minute. Mica occurs, somewhat segregated in thin laminæ, as muscovite. Another variety of granite from the same region is of some special interest, as it belongs to that class of rocks which have been designated as Archæan, yet in many points differs lithologically from the granite just described. It is a mediumgrained rock, with a decidedly crumbling texture, breaking with a rough uneven surface in irregular-shaped pieces. The constituent minerals develop no observable law in their mode of arrangement, while the rock is made up of quartz, feldspar, and mica in the proportions usually found 
in normal granite. The quartz-grains are relatively large and nearly colorless, protruding on the weathered surfaces of the rock above the easily decomposable feldspars. Both orthoclase and plagioclase are present, but the former are much more abundant, possessing a dull opaque surface of a decidedly flesh-red tint, which characterizes the entire rock-mass. All the feldspars have a more or less altered appearance, being frequently covered with an earthy ferruginous material, which seems to form a thin coat or film between the individual crystals, causing rapid disintegration where exposed to atmospheric agencies. The mica occurs as biotite well disseminated throughout the rock. It is worthy of special note that neither hornblende nor titanite could be detected. Under the microscope, in thin sections, a few small crystals of apatite may be seen; both the quartz and feldspar are rich in liquid-inclusions.

On the east side of the range, between 4 and 5 miles to the northeast of the granite locality, occurs a very considerable body of highly crystalline rocks. Among these, the rock from the summit of Nache's Peak deserves mention, as it is quite unlike any other in the collection from Nevada. It is an extremely hard tough rock, and possesses a crypto-crystalline groundnass, so fine as to render a determination of the mineral constituents with the ordinary magnifying lens quite impossible, while scattered through it are a few altered feldspar grains and decomposed hornblende crystals. Under the microscope, Zirkel has shown the rock to be made up of plagioclase and hornblende with a little quartz, and he calls attention to the close resemblance between it and the quarry-rock from Quenast in Belgium, so largely used in the pavement of the streets of Paris.

South of Nache's Peak are found the crystalline schists already mentioned as having been referred to the Archæan age. They form a series of dark-colored, thinly bedded mica-schists and light quartzose slates, which are here widely separated from any known beds of similar lithological habit. The former are composed of minute particles of quartz and both dark and bronze-colored micas, while the latter, presenting a considerable variety, show evidences of extreme metamorphism. One characteristic rock is so fine-grained as to suggest to the unaided eye a homogeneous mass, but, under the microscope, is shown to possess a micro-granular base, 
with the quartz-grains crushed and elongated in such a manner as to have their longer axes arranged in layers parallel to the plane of stratification. The rock contains a small amount of carbonate of lime. Dark and lightcolored bands give the beds a peculiarly striped appearance.

Directly east of Winnemucca Lake, the range is made up largely of granite, and was only cursorily examined; no areas of crystalline schists, however, were noticed, and indeed none were observed south of Luxor Peak. Two or three miles northwest from Luxor Peak, and at the base of the range, occurs a low rounded hill of altered slates referred to the Archæan, the exposures of which are mostly concealed beneath a thin layer of soil. It is surrounded by basaltic outflows and Tertiary sedimentary beds, completely preventing the formation from being traced for any distance. The beds lie inclined at a high angle, are thinly laminated, fine-grained, and of a dark iron-gray color. Nearly 10 miles still farther to the northward, and opposite the lower end of the Granite Range, occurs a second area of altered metamorphic beds, which have also been referred to the Archæan series. They are best shown in the deep cañons, but their geological relations, like the other locality, are much obscured by the heavy outburst of basalt that skirts the flanks of the Truckee Range.

Neither of these isolated outcrops have any special interest in themselves, but derive their chief value from the indications which they offer of the widespread occurrence of Archæan metamorphic rocks, along the Truckee Range. It seems highly probable that a more careful search in the range would discover numerous other outcrops of these same beds, which would tend to fill up the wide gaps and to show more clearly their connection with each other.

So far as observed, they reach the surface in only a few favored localities, lying for the most part concealed beneath enormous accumulations of later granites, which form the higher central masses, and numerous outflows of the Tertiary volcanic rocks, which break out along the foot-hills.

The later eruptive granites form the greater part of the Truckee Range, and, as already mentioned, probably extend in an unbroken line for over 50 miles. While it cannot be definitely stated that this great rock-mass belongs entirely to the later granitic formation, it may be said that wher- 
ever the range was visited the evidence would seem to bear out such a conclusion. A description of the physical outlines of this granite would be simply a description of the range. It forms all the higher summits and ridges, rising from 2,500 to 3,000 feet above the adjoining valleys, and stretches across the entire width of the mountains until covered along the base by the Quaternary deposits. In its lithological habit, in the details of surface-outlines, and in mode of weathering, it bears the closest resemblance to the rock-masses of the Granite Range, and is without doubt a part of the same formation, only separated by the narrow desert of the Mud Lakes.

This granite is characterized by its great uniformity of texture. It is medium-grained, with a fresh unaltered appearance, all the constituent minerals being well developed, with frequently sharp crystalline faces. Under the hammer, the rock breaks readily with an angular fracture. The prevailing color is light gray, varying somewhat from light to dark shades according to the amount of hornblende present. All structural lines seem to be wanting, the rock showing no tendency to parallelism in the arrangement of the minerals, even where the mica is present in considerable amounts.

Macroscopically the granite shows very clearly the following mineral constituents: Quartz, orthoclase, plagioclase, biotite, hornblende, and titanite. The quartz is well disseminated through the rock in limpid grains. Plagioclase seems the much more abundant form of feldspar, and is characterized by a brilliant lustre; both monoclinic and triclinic species are white in color. Titanite may be easily recognized by its yellowish-brown color, in small but perfect crystals. In addition to the minerals already mentioned, Zirkel has detected, in a thin section from a typical specimen found near the extreme northern end of the range, large numbers of microscopical apatites and some minute grains of magnetite; the quartz-grains are poor in fluid-inclusions. Professor Zirkel, in his report, ${ }^{1}$ gives, with considerable detail, the microscopical analysis of this granite, presenting some interesting observations on the structural features of the orthoclase feldspars, and on the peculiar manner in which all the larger crystals have

${ }^{1}$ Microscopical Petrography, vol. vi, 40. 
included within their border minute forms of nearly all the other mineral constituents of the rock.

This rock, from the northern end of the Truckee Range, may be considered as typical of the hornblende-plagioclase-titanite granites, which are so characteristic of the larger granitic bodies of Western Nevada, and both lithologically and mineralogically stand so far removed from the great rockmasses farther to the eastward, and from the smaller bodies of older granite which here and there crop out beneath the later variety.

Dikes or narrow veins of quartz and finer-grained granite traverse the coarser-grained rock of the Truckee Range in several places; they are frequently associated with massive black hornblende.

Two or three miles to the northwest of the Truckee Range is situated Hot Spring Butte, which properly belongs to the range; as it is only separated by a low depression occupied by Quaternary beds. It forms a very prominent landmark, rising over 1,000 feet above the plain, and derives its name from the large boiling springs at its base, which, from the earliest days of emigrant travel to Northern California and Oregon, have been the resort of camping-parties crossing the desert of the Mud Lakes. It is evident that it has been a favorite resort for Indians, and on the summit were found large numbers of flint and obsidian arrow heads and charms.

At the northwest base of Luxor Peak occurs a re-entering basin in the range, surrounded on nearly all sides by granite, but enclosed to the southwest by Archæan schists and Tertiary basaltic rocks. The basin proper is filled by sedimentary - Tertiary beds, p.rtially concealed by detrital material, which have been referred to the Truckee Miocene, not, however, from any direct evidence, but upon general grounds of more closely resembling the uplifted beds that skirt the ranges than the horizontal Pliocene strata found along the river-valleys. Stretching across the basin are beds of carbonate of lime and gypsum, which, upon the north side, have been washed away by the waters from the main canon of Luxor Peak, exposing a steep bank, 60) feet in height, of nearly pure white strata. The lowest stratum is a pearlcolored limestone, of a coarse, saccharoidal, friable texture, overlaid by others consisting of milky-white, fine-grained gypsum, carrying some minute crystals of calcite, and forming the top of a broad ridge or bench. Rising out 
of this bench are a number of conical mounds, formed of nearly pure selenite, from 6 to 12 feet in height and from 10 to 30 feet in diameter, and, in general, having a truncated top, the sides broken by radial lines, cutting the selenite into broad sections. On the top of many of these cones were apertures several inches in width, extending downward a long distance, at least as far as the eye could reach; others were closed, but gave, when struck with a hammer, a ringing, hollow sound. This selenite is remarkably clear and transparent, and so cleavable that thin sheets may be obtained 3 or 4 feet high by as many broad, a peculiarity taken advantage of by the early settlers of this portion of the State to replace the broken panes of windowglass in their houses. It is also exceedingly flexible, and, where exposed to pressure, presents a wavy, folded structure. That the formation is the result of thermal action, now extinct, there would seem to be no doubt.

Returning to the southern end of the range, opposite the southeast corner of Winnemucca Lake, where the granite bodies terminate, there are found resting upon them highly-altered limestones and quartzitic schists, which have been referred to the Triassic formation, although, it must be stated, without any positive evidence of their age. They have been but little studied, and indeed are so much disturbed by intrusions of the older series of eruptive rocks, probably diabase, and still later by immense masses of parti-colored rhyolites and black basalts, that their structural relations would seem to be of little importance. Facing Winnemucca Lake is a long ridge of these sedimentary beds, striking northwest and southeast, and dipping steeply toward the lake, while to the southward, resting upon an isolated body of granite, similar beds are found striking in the opposite direction, that is, northeast and southwest, and dipping eastward into the range. The limestone belt is several hundred feet in thickness, of a dark-blue color, and the specimen examined indicated the presence of but little magnesia. The low depression of Nache's Pass separates topographically the alreadydescribed portion of the range from the broad southern end, while the flow of volcanic material which occupies the pass cuts it off geologically from the 'Triassic region of Miner's Cañon.

Here at Miner's Cañon occurs quite a large area of thinly laminated quartzitic schists, slates, and metamorphosed argillites, carrying more or 
less feldspar, forming the summit of a prominent ridge, whose lower slopes are almost completely buried by basalt. The beds strike north $25^{\circ}$ to $30^{\circ}$ west and dip to the southward, apparently agreeing in direction with the beds bordering on Winnemucca Lake. Indeed, their chief interest consists in showing the extent of the Triassic formations, and their development to the southwestward from the great Triassic region to the north, since they resemble the metamorphic series of the West Humboldt Range. These beds are traversed by numerous dikes of preTertiary rocks, but most of them are so fine-grained or so altered, and present such a variety of physical habit, as to render it difficult to determine their species. Many of them are dense, tough rocks, with comparatively undecomposed mineral constituents; others break readily, possess an earthy appearance, and, to the unaided eye, have no well-defined characteristics. In thin sections, under the microscope, Zirkel' has shown that most of them are diabase, and composed of plagioclase, augite, quartz, magnetite, and apatite. In nearly all of them the augite is much decomposed, and an earthy, yellow base occupies the space between the crystalline minerals.

At the entrance to Miner's Cañon occurs a somewhat singular rock, and, unlike those just described, mainly consists of orthoclase and hornblende, with some small quartz-grains, both the principal minerals being well developed in a greenish-gray crystalline groundmass. It bears a close resemblance to the propylite of Kaspar Pass, just to the northward, and has been classed as a quartz-propylite, although field-observations as to its true position and age are wanting. Natrolite and stilbite associated with quartz are found in veins crossing Miner's Canon.

Except in one or two localities, including the more elevated summits and some low hills exposed by the inequalities of the flows, all the rest of the Truckee Range south of Nache's Pass is formed of black basalt. When observed in detail, the whole region is seen to consist of slightly rounded ridges separated by narrow ravines, the ridges being formed of successive curved beds of basalt, which seem to flow down from the middle on each side. The entire country has the appearance of resulting from a number of powerful dikes, which were erupted with great force along the

'Microscopical Petrography, vol. vi, $\mathbf{9 7}$. 
centres of the present ridges. The:e is little evidence of much steam accompanying these eruptions, vesicular basalts and the larger cavernous openings resulting from the expansion of considerable volumes of vapor being quite rare. Both physically and mineralogically, these basalts present much the same characteristics over the entire region. Black is the prevailing color. They are mostly so fine-grained as to defy mineralogical determination by the unaided eye, yet in sun-light are brilliant with minute faces of feldspar and augite. They have a decidedly resinous lustre, and break under the hammer with a conchoidal fracture and sharp edges, characteristic of the half-glissy amorphous base varieties. Under the microscope, they are readily shown to be normal basalts made up of plagioclase and augite, associated with magnetite, varying quantities of olivine, and some apatite. Beautiful specimens of clear botryoidal hyalite are frequently found as incrustations upon the joints and fissures of the basalt.

Diabase Hills.-About 6 miles from Wadsworth, along the west base of the Truckee Range, and about 300 feet above the upper limit of the Truckee Pliocene beds, occur two considerable hills of a light-gray diabase completely surrounded by black basalt. The rock is quite uniform in character, and presents a fine-grained crystalline appearance. It has to the feel almost the roughness of trachyte, but, upen microscopic examination, is found to be a true diabase, consisting of striated plagioclase, brownish-green augite, olivine, which is more or less altered into yellowish-brown serpentinous matter, some black grains, probably magnetic iron, and many colorless microlites, partly referred to apatite and partly to feldspar. No quartz was detected. Between the pale-gray diabases and the distinctly overlying black basalts, there is no possibility of confusion. Although microscopically composed of the same mineral ingredients, the diabase is entirely crystalline and wanting in groundmass, while the surrounding basalts are richly charged with an amorphous glassy base, a microscopical distinction which has produced striking differences in modes of weathering between the two rocks. Moreover, the older rock has suffered much more from erosion, and is more cut up by ravines and depressions, which at their base are now filled by the flows of basalt, showing conclusively their later age.

Although, in general, compact and having the superficial habit of gray 
trachytes, these diabases occasionally weather, on exposure, in a rough cellular mass along the joints and fissures of the rock, which, however, does not extend more than 6 or 8 inches below the surface. The sonthernmost of these two hills is penetrated by basaltic dikes with sharp lines of contact, and as they withstand atmospheric agencies better than the diabase, they form quite prominent ridges. The surrounding basalts are quite like those already described; some of them, however, are porous, and others have a peculiar brownish-red color difticult to explain, but which, under the microscope, is shown to be due to the color of the globulitic grains in the glass base.

Typical specimens of the diabase from Diabase Hills, and of the basalt from the immediate neighborhood, have been subjected to chemical analysis by Mr. R. W. Woodward, with the results as given below. In the first and second columns are given the diabase, and in the third and fourth the basalt:

\begin{tabular}{|c|c|c|c|c|}
\hline Silica ..... & $\begin{array}{l}1 . \\
54.52\end{array}$ & $\begin{array}{l}2 . \\
54.80\end{array}$ & $\begin{array}{c}3 . \\
53.94\end{array}$ & 53.98 \\
\hline Titanic acid. & trace & trace & $\ldots$ & \\
\hline Alumina..... & 19.10 & 19.10 & 17.05 & 17.05 \\
\hline Ferric oxide . . . . . & 2.83 & 2.67 & 2.93 & 3.00 \\
\hline Ferrous oxide ... & 5.89 & 5.90 & 7.15 & 7.09 \\
\hline Manganous oxide.... & trace & trace & trace & trace \\
\hline Lime $\ldots . . . \ldots \ldots$ & 7.25 & 7.26 & 7.41 & $\ldots$ \\
\hline Magnesia ........ & 3.92 & 3.78 & 4.67 & $\ldots$ \\
\hline Soda........... & 3.73 & 3.74 & 3.45 & 3.41 \\
\hline Potassa ........ & 2.30 & 2.30 & 2.19 & 2.23 \\
\hline Water.......... & 0.59 & 0.62 & 1.10 & 1.10 \\
\hline & & 100.17 & 99.89 & \\
\hline
\end{tabular}

In both cases, the specific gravity varied from 2.6 to 2.7 .

These analyses agree very closely, and it is interesting to observe that in their ultimate chemical composition, as well as in the individualized mineral constituents, they should show such a remarkable analogy, where the physical structure and geological relations of the two rocks differ so 
widely; the one being a true diabase, and the other, although perhaps not a typical dolerite, characteristic of a large area of Western Nevada. Chemically the chief difference appears to be in the higher percentage of iron in the basalt, at the expense of the alumina. The percentage of silica, 53.94, is somewhat high for a normal dolerite, but not above the average found in the glassy varieties of the Truckee Valley.

Besides the Diabase Hills, there is, in this southern portion of the range, but one other known outcrop which rises above the basalt. This occurs at the southern point of Tutib Peak, where it forms a gray rock often slightly decomposed, and is in all respects like the rock of the Diabase Hills, protruding through the basalt in a dome-shaped mass, showing a general rounded erosion, but no sharp ravines. The surrounding basalt shows no points of difference in its field habit from that already described.

No idea can be gotten of the extension of these diabase bodies underneath the basalts, but it would seem highly probable that they form a continuous body, now appearing only as insular hill-tops above the Tertiary eruptive masses.

To the northeast, the companion summit of Tutib Peak is formed of a dark-gray half-glassy rhyolite, which forms a dome-like top of about a mile in diameter, and is distinctly seen to underlie the surrounding basaltic field. As it is separated from the diabase by a broad sheet of basalt, the relative ages of the rhyolite and diabase could not be observed. In the prevailing dark-gray glass of the rhyolite are many monoclinic feldspars, a plentiful distribution of biotite, a little hornblende, but no quartz. This rock, under the microscope, in thin sections, affords a most interesting study of the globulitic devitrification of the hyaline varieties, and receives a detailed description by Professor Zirkel, ${ }^{1}$ who calls attention to the resemblance between this natural glass and the artificial furnace-products described by $H$. Vogelsang. Unlike any other rhyolite observed in the Truckee Range, it may be considered as an isolated outpouring, whose extent is obscured by the broad fields of basalt; it is, however, very closely allied to the semi-hyaline varieties near White Plains in the Montezuma Range.

${ }^{1}$ Microscopical Petrograpby, vol. vi, 206. 
LAKE RANGE.-This range, which measures about 50 miles in length, rises out of the arid plains of the Mud Lakes, and, continuing southward, divides the waters of Pyramid and Winnemucca Lakes. Its peaks attain an altitude of between 3,000 and 3,500 feet, with a base not more than 6 miles in width, the steep slopes on both sides reaching down to the water's edge, where they are fringed by a narrow border of Quaternary gravels and calcareous tufas.

Granites and Archæan rocks occupy a large area at the northern end of the Lake Range, and, but for the occurrence of small outbreaks of basalt that protrude through the granite and skirt the flanks on both sides, the entire upper portion of the mountains might be so referred. They extend in a north and south direction, with unbroken continuity, for over 30 miles, rising above the adjoining valleys in a very irregular ridge, culminating in Pah-rum Peak. South and east of Pah-rum Peak, the granite falls away rapidly, and is soon concealed beneath heavy beds of dark shale, which have been provisionally referred to the Jurassic age, while to the southwest basalts cover the older rock, extending to the shores of Pyramid Lake. Wherever this granite body was observed, it possessed, in texture, color, and physical habit, the general features of those of the Granite and Truckee Ranges.

At the extreme northern end of the range, extending out in a long tongue toward the northwest, occur a number of low, rounded hills, of a characteristic gneissic formation, which possess some interest, as it is quite unlike any other observed rocks in Western Nevada. It is to be regretted that time did not permit of their being more fully studied and their connection with the granite more satisfactorily made out. In their superficial habit, as shown in their mode of bedding, their action under atmospheric agencies, and arrangement of mineral constituents, these gneissic beds resemble closely the so-called primitive gneisses, but in mineralogical composition, even to the detailed microscopical structure, show a striking analogy to the predominant granite bodies of Western Nevada. They possess a very distinct gneissic structure, with the brown mica arranged in parallel planes through a fine admixture of feldspar and quartz. In color, they are brownish-gray. The feldspars are exceedingly fine, but, under the microscope, are shown to 
consist mainly of triclinic forms, associated with a little orthoclase. Quartz and hornblende are also present in considerable amounts. In thin sections, under the microscope, the presence of large numbers of apatite crystals are distinctly revealed, and the quartz-grains are shown to be very poor in liquid-inclusions; two characteristic features of the later eruptive granites of Nevada. The rock is essentially a mica-hornblende-plagioclase-gneiss, a composition that suggests the name of dioritic gneiss. Inasmuch as the rock so closely resembles the surrounding granites, it may be well to mention that neither macroscopically nor microscopically was the presence of any amber-colored sphene detected. All the mineral constituents seem to have a fresh, unaltered appearance.

The gray slate beds have been referred to the Jurassic solely upon theoretical grounds and from their resemblance to strata overlying wellrecognized Jurassic limestone in other localities. As they form smooth, rounded hills and domes, contrasting sharply with the more rugged granite and black basalts, the lines of contact are easily seen. They strike approximately northeast and southwest.

North of Winnemucca Lake, the range bifurcates, and there is a second ridge to the eastward, made up of a basaltic eruption, which inclines to the eastward with gentle slopes, being for the most part abrupt along the western face. Similar massive eruptions skirt the base of the slates, and break out along the granite flanks in isolated bodies, which, so far as observed, are all fine-grained compact rocks. At the northwest corner of Winnemucca Lake, there occurs a basalt differing somewhat from the others by the prominence of brilliant feldspar crystals in an almost homogeneous groundmass, and bright, fresh olivine grains. Under the microscope, the groundmass develops the characteristic glass-base, and the feldspars are shown to be exceedingly rich in foreign inclusions.

South of Pah-rennen Peak, the interior of the range has only been visited by topographical parties, the geological notes being obtained along the lake shores, where, for considerable distances, at least, acidic volcanic rocks appear from underneath massive eruptions of basalt. For this reason, the higher portions of the range have been provisionally colored on the geological map as basalt, and it is by no means improbable that on the ridges 
lying east of Pyramid Lake considerable bodies of older rocks may occur which have not been covered by the last of the volcanic products.

Basalts usually dipping slightly to the eastward form the extreme southern end of the range. In general, they resemble those described from the Truckee and Virginia Ranges, including both the fine-grained compact rock and the highly cellular porous variety. One specimen from this locality resembles the grayish-black rock found in the lills south of the Kawsoh Mountains, having the same horizontal lenticular cavities lined with the lilac-colored siliceous coatings. Brilliant acicular crystals of plagioclase characterize the rock, and are the only well-developed minerals observed. One other variety of basalt from here deserves mention, being quite unlike the surrounding rocks, and, under the microscope, is shown to be wanting in glassy base, although in other mineralogical and structural features resembling the normal basalts. 


\author{
SECTION IX.
}

TRUCKEE RIVER REGION.

BY ARNOLD HAGUE.

Lower Truckes Valley.-The broad valley of the Truckee lying between Wadsworth Station and Pyramid Lake, and hemmed in by the Truckee and Virginia Ranges, is formed of a series of horizontal arenaceous beds, through which alternate strata of more or less argillaceous material. These beds always present an undisturbed position, and are seen to rest unconformably on the basaltic hills, which enclose the valley to the eastward. Upon the west side, a short distance back from the river, they are overlaid by a deposit of Quaternary, which rises to the foot-hills of the Virginia Range, and thickens toward the mountain-flank.

Where the shallow lateral stream-valleys, as of Berkshire Cañon and the canon that comes down from Ormsby Peak, are most deeply eroded into the Quaternary, the top of the horizontal sand series is clearly seen. Through these beds, the Truckec River, in flowing north, has cut out a cañon from 200 to 200 feet deep, exposing the series, which are observed to possess a dip of not over $2^{\circ}$ toward Pyramid Lake, a dip altogether that of deposition. In the photograph reproduced in Plate XXIV, a view taken about 3 miles below the town of Wadsworth, these bluffs, which undoubtedly belong to the age of the Humboldt Pliocene, are characteristically shown, with the more indurated beds standing out prominently beyond the friable sands. The same illustration presents a fair view of the valley, with exceptionally large and fine trees along the river-banks, the flood-plain of the river varying from 100 to 2,000 feet in width. For 4 or 5 miles below Wadsworth, there is a fluviatile Quaternary formation about one-half mile in width, below which there are two or three gther basins where the cafron is quite broad, and which are occupied as farms.

At an elevation of 100 or 200 feet above the uppermost limit of the Pliocene strata, there may be traced along the basaltic flanks of the $52 \mathrm{D} \mathrm{O}$ 
Truckee Range, extending from Desert Station to Pyramid Lake, a belt of tufa terraces, showing the ancient water-levels of Lake La Hontan. These are formed mainly of blocks and boulders of basalt, and of diabase in the region of Diabase Hills, cemented together by a calcareous tufa, the tufa also occurring as a compact mass. The highest of these tufa terraces in the region of Wadsworth lies about 350 feet above the town, but there are indistinct traces at considerable elevation above this level of other beachlines formed before the waters were dense enough to deposit any large amount of tufa. They are indicated partly by slight beach-lines and in part by flat tabular lines of erosion in the rock.

About 12 miles down the river from Wadsworth, these tufa terraces on the east wall of the valley are quite thick, and the calcareous matter has piled up over the boulders and upon the rounded protrusions of the old shore to the thickness of 30 or 40 feet. Here are a number of pebble beaches, showing a rough stratification, each coated with a thin covering of tufa, cemented firmly to its neighbors by the same calcareous cement.

Near the northwest point of the chain of hills which walls in the valley on the east, this tufa formation develops itself in a well-defined stratum or sheet extending over a wide area of the valley-mesa. It is in some places a continuous bed, but for the most part occurs in ellipsoidal masses from 4 to 8 feet in diameter. The upper surface is quite smooth and very compact, but around the hollow underneath it is a mere network of crystalline fragments, tangled together and re-cemented by a further deposition of carbonate of lime. Among the forms of these detached masses are globes and flattened spheres, but more commonly a mushroom form, with a distinct stem penetrating the sands. There is one large area where these nushroom forms are seen lying as closely together as they can stand, the intervening spaces being occupied by a mixture of tufa and sand. These curious fantastic forms have frequently been mistaken for some variety of coralline growth.

Throughout this lime deposit are many small fresh-water shells. In the loose dry soil of the valley-mesas may be found an immense quantity of minute ostracoid shells, so light and delicate that they are drifted about by the prevailing winds, frequently carried long distances and strewn over the 
desert like ordinary sands and gravels. They have not as yet been carcfully studied, and their specific characters are unknown.

Another feature of the desert in the region of Wadsworth, where they never could have been brought by erosion, are large numbers of basaltic bombs, characterized by their general spherical form, some of which are as vesicular as a pumice, the whole body of the bomb being made up of the thinnest possible basaltic skeleton. Others again consist of dense, compact rock.

A specimen of the tufa from the Truckee Valley has been chemically cxamined by Mr. R. W. Woodward, who reports as follows :

\begin{tabular}{|c|c|c|}
\hline Alumina.... & 0.89 & 0.86 \\
\hline Lime $\ldots \ldots \ldots \ldots \ldots \ldots \ldots \ldots$ & 49.77 & 49.80 \\
\hline Magnesia $\ldots \ldots \ldots \ldots \ldots \ldots \ldots \ldots$ & 3.28 & 3.25 \\
\hline Soda......... & 0.79 & 0.88 \\
\hline Potalssa...... & 0.15 & 0.20 \\
\hline Carbonic acid . & 41.02 & 40.94 \\
\hline Silica ...................... & 3.01 & 3.10 \\
\hline Water $\ldots \ldots \ldots \ldots \ldots \ldots \ldots \ldots \ldots \ldots$ & 1.41 & 1.40 \\
\hline Phosphoric acid . . . . . . . . . . . . . . & trace & trace \\
\hline Sulphuric acid ... & trace & trace \\
\hline & 0.32 & 0.43 \\
\hline
\end{tabular}

It agrees closely with the analysis of similar tufas found at Pyramid Jake and on the Carson Desert.

Owing to the extreme softness of the Pliocene strata, erosion does not result in the forms of spires and pinnacles so common in the eastern Tertiary basins, but rather in rounded, terraced buttresses, separated from cach other by sharp re-entering alcoves.

Where the wall of basalt comes down from the north, on the east side of the valley, the river cuts a narrow sharp passage in the Pliocene, and in the canon-bottom is exposed the top of an underlying volcanic mass, which probably belongs to the purple dacites of the Virginia Range, and which evidently suffered very sharp irregular erosion before the laying-down of the Pliocene strata, since they enter and fill up all its carved-out depressions. 
About 5 miles above Pyramid Lake, the Pliocene formation falls away, and gives place to a Quarternary plain, which extends east and west, forming the shore-plain of both Pyramid and Winnemucca Lakes. As the river cuts deeper into the Pliocene strata, near the point where it emerges on the Quaternary plain, the material of the beds is found to be exceedingly coarse, and cross-stratification quite common. The escarpment of Pliocene forming the east wall of the Quaternary Valley leaves the Truckee River, and follows the Little Truckee toward Winnemucca Lake. About 2 miles south of the lake, on the east bank of the river, occurs an interesting outcrop of infusorial silica of the. Miocene Tertiary, coming up unconformably beneath the Pliocene. 'The latter are horizontal, while the infusorial beds strike about true north, and dip to the eastward at an angle of $35^{\circ}$, forming the steep river-bank, and probably continuing both under it and across it.

Lithologically the upper beds of the infusorial deposit closely resemble the same formation as already described in the Miocene series of Fossil Hill, Kawsoh Mountains, and under the microscope reveal the same profusion of siliceous Diatomacea.

Dr. C. G. Ehrenberg' ${ }^{1}$ examined a large suite of specimens from this locality, and has described in detail forty-six distinct forms, classifying twenty-eight of them under Polygastera and eighteen as Phytolitharia. Of these forms, the most abundant appear to be the same species as characterize the beds at Fossil Hill, namely:

\section{Gallionella granulata. \\ Gallionella sculpta. \\ Spongolithis acicularis.}

The lower portion of this series.of beds becomes almost fissile in structurc, and passes from pure white into buff, brown, and chocolate-colored beds. A few fragments of exogenous leaves and softer plant-stems are observed, but nothing sufficiently characteristic was obtained to aid in determining the age of the formation, although careful search might result in rich and important collections. The most extreme product of alteration of these infusorial beds is a gray flinty stratum having almost the look of

'Uber die wachseude Kenntniss des unsichtbaren Lebeus als felsbildende Bacillarieu in Californien, Berlin, 1870, 19. 
quartzite, the change in half an inch being almost complete from a porous earthy infusorial to a compact cherty stone.

A specimen of the brown fissile variety was submitted to chemical examination by Mr. R. W. Woodward, and found to have even a higher percentage of silica and less alumina than the pure white earth analyzed from the Miocene Tertiary of Fossil Hill.

The analysis yielded the following:

\begin{tabular}{|c|c|}
\hline Silica ....... & 91.43 \\
\hline Alumina..... & 2.89 \\
\hline Ferrous oxide & 0.66 \\
\hline Lime........ & 0.36 \\
\hline Magnesia .... & 0.25 \\
\hline Soda ........ & 0.63 \\
\hline Potassa...... & 0.32 \\
\hline Water...... & 3.80 \\
\hline
\end{tabular}

In the delta between the two lakes arises a ridge of limestone provisionally referred to the Triassic, which extends in a northeast and southwest direction nearly 3 miles, with a width from east to west of about a mile. It is separated from the Triassic formations of the Lake Range by a broad gap, which is filled with sand-dunes, and its assignment to the Triassic is based mainly upon theoretical grounds. The limestone is highly metamorphosed, in places having been altered to a fine crystalline white marble, which upon analysis yielded Mr. B. E. Brewster the following:

Alumina............................. 0.05

Lime............................ 55.16

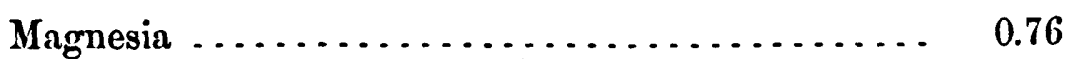

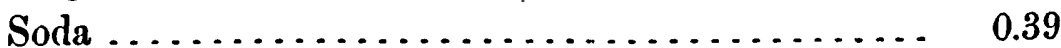

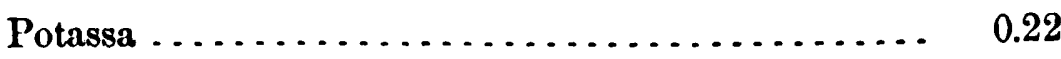

Carbonic acid.......................... 43.54

Insoluble residue....................... 0.04 
All over this delta group of hills may be traced the Lake La Hontan tufas, exposing a variable thickness, much of it having been carried away by erosion. It reaches a maximum thickness of perhaps 35 feet, and was obviously formed of a rude growth of crystals, which have been often cemented together, built upon, and partly enveloped in the amorphous tufa. Whenever and wherever this deposit is found, the traces of crystals abound through it in such a way as to leave no doubt that the formation was at one time mainly made up of them.

The Truckee River bifurcates and empties into both .Winnemucca and Pyramid Lakes, separated by the Lake Range, and as neither of them have any outlet, retaining by constant and rapid eraporation approximately the same level through a long series of years, their waters are necessarily charged with alkaline salts. The waters of Winnemucca Lake have never been analyzed, but inasmuch as their conditions are apparently the same as those of Pyramid Lake, the chemical composition of the two waters would probably show few points of difference. Winnemucca Lake is about 25 miles long by scarcely 4 wide, and, judging from the configuration of the shore and valley, is probably quite shallow. Everywhere along the shore and cliffs, below the level of the ancient Lake La Hontan waters, incrustations and fragments of calcareous tufa are abundant, but having the same habit as those found in the region of Truckee Valley and Pyramid Lake.

Pyramid Lake lies between the Virginia and Lake Ranges, and is almost completely encircled by high rugged mountains, frequently coming down to the water's edge in steep precipitous ridges with ever-varying outlines, which make the lake by far the most picturesque sheet of water to be found among the Nevada Valleys. It is 30 miles in length by 12 in width at its broadest expanse. It is crossed just below the centre by the 40 th parallel, and the extreme western shore lies 15 miles to the eastward of the California State boundary. Barometric measurements place the altitude of Pyramid Lake at 3,890 feet above sea-level, which varies but little from the level of Carson Lake and the Mud Lakes to the north. Above the present water-level, the terraced benches of La Hontan Lako are easily followed, cutting deeply into the volcanic rocks, four of them standing out prominently and more boldly than the others. Careful measurements by 
means of the pocket-level were made of these; the highest and most sharply defined was found to be 498 feet above the lake, the others standing respectively at 324,259 , and 97 feet above the present water-mark. As the low divide of volcanic hills between Pyramid Lake and the Mud Lakes lies below the higher elevations of the ancient lake, it is evident that the waters of the former were at one time connected with the broad open waters to the north. Incrustations of calcareous tufas, deposited by the receding waters, line the shore, adhering to the rocks in broad bands frequently two and three feet in thickness. Many large masses of rock are so completely covered with tufa as to suggest, at first sight, a solid mass of carbonate of lime, formed by thermal action around some hot spring.

The pyramid which gives the name to the lake is a tufa-encrusted island, rising abont 400 feet above the level of the lake, and has a warm spring about half-way up its slopes, while the "Tufa Domes" are large botryoidal-shaped masses of tufa, from 50 to 60 feet in height, extending out from the shore in the direction of the pyramid, and in one case quite isolated, as seen in the view presented in Plate XXV. The terraced. beaches are also indistinctly brought out on the pyramid.

These calcareous tufas have a light-brown color, and vary from a compact homogeneous rock to a rough porous entangled mass of rudely formed crystals. An analysis of tufa, taken from one of the "Tufa Domes", yielded Mr. R. W. Woodward the following:

\begin{tabular}{|c|c|c|}
\hline Lime $\ldots \ldots \ldots \ldots \ldots \ldots \ldots$ & 47.27 & 47.48 \\
\hline Magnesia $\ldots \ldots \ldots \ldots \ldots$ & 2.89 & 2.50 \\
\hline Alumina. . . . . . . . . . & 2.14 & 2.54 \\
\hline Soda........... & 0.51 & 0.48 \\
\hline Potassa . . . . . . . . . & 0.22 & 0.19 \\
\hline Carbonic acid . . . . . . . & 38.23 & 38.52 \\
\hline Silica $\ldots . . . \ldots \ldots \ldots$ & 7.27 & 6.90 \\
\hline Phosphoric acid.. & $\operatorname{trace}$ & trace \\
\hline Sulphuric acid $\ldots \ldots \ldots \ldots \ldots \ldots \ldots$ & trace & trace \\
\hline \multirow[t]{2}{*}{ Water...$\ldots \ldots \ldots \ldots \ldots \ldots$} & 1.20 & 1.20 \\
\hline & 99.73 & 99.81 \\
\hline
\end{tabular}

The silica occurs both combined and as free sand. 
$\Lambda$ naho Island lies 3 miles from the eastern shore, and rises somewhat boldly out of the water. A measurement made by Mr. J. D. Hague with a pocket-level places the summit at 507 . feet, and the highest observed deposit of tufa at 470 feet above the lake. As terrace-lines have been seen nearly 500 feet above the water's edge, it seems highly probable that the top of the island may at some time have been submerged beneath La Hontan waters. Geologically the island consists of dark-gray trachyte, possessing a fine-grained groundmass, scattered through which are large crystals of feldspar and occasional fragments of hornblende, the rock breaking with a rough hackly fracture.

Prof. O. D. Allen examined the water collected from Pyramid Lake, and reported the following:

Specific gravity, 1.0027.

Fixed matter in 1000 parts, 3.275.

Constituents determined in 1000 parts :

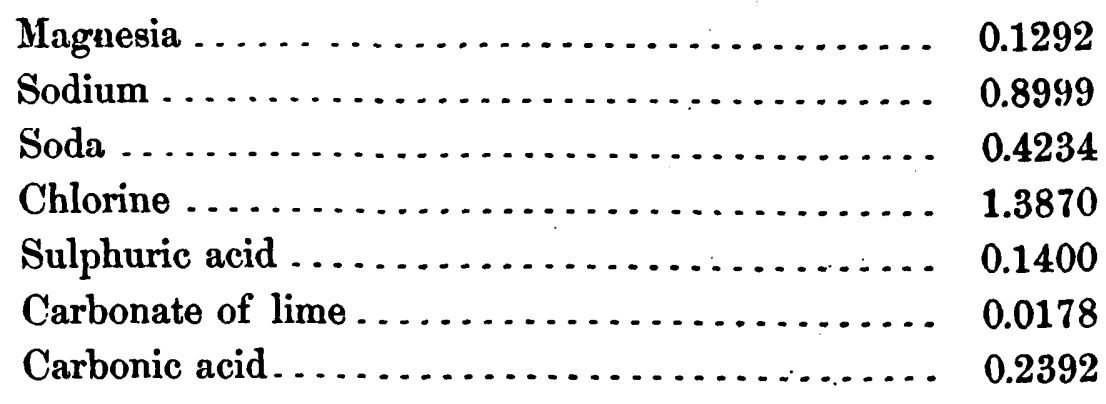

3.2365

There are present in small quantities, but not quantitatively estimated, potassa, lithia, silica, and boracic acid.

Virginia Ravae. - Within the belt of the Fortieth Parallel Survey, the Virginia Range forms the first. of the great series of meridional ranges lying to the eastward of the Sierra Nevada, which so characteristically rib the basin, and presents, with the exception of the Pah-Ute Range, a more continuous and unbroken ridge than any of the other mountain uplifts. It rises abruptly from the plain in latitude $38^{\circ} 10^{\prime}$, extending

' In part from notes furnished by Mr. Clarence King. 
northward for 150 miles to about latitude $40^{\circ} 15^{\prime}$, where it falls away in low volcanic hills bordering upon the Mud Lake Desert. Only the northern balf of the range, lying north of the Carson River, comes within the limit of this exploration, and the following observations therefore are restricted to this area. Immediately beyond the southern boundary of the map occurs an elevated and distinct group, lying between the broad valley of the Carson River and the deep narrow caūon of the Truckee, with Mount Davidson, a mass of diorite, as the centre, having an elevation of 7,827 feet above sealevel, and as the celebrated Comstock Lode occurs along the eastern slope of the mountain, the surrounding region has become one of great scientific and economical interest. In "Mining Industry", Vol. III of this series, will be found a detailed geological description of the Washoe Mining District, with a careful study of its typical volcanic rocks by Mr. Clarence King, accompanied by an elaborate account of the Comstock Mines by Mr. James D. Hague.

That portion of the range included within the map is built up, so far as known, with the exception of some Pliocene beds in the Truckee Canon, exclusively of crystalline intrusive masses, and of these pre-Tertiary rocks occupy a very limited area. Granite, although reaching the surface in large masses in the Pine Nut Region to the south, and in obscure outcrops at the base of Mount Davidson, has never been observed north of the Truckee Cañon, and, if ever seen, will probably be found in some deeply eroded cañon.

The range has been pre-eminently one of great activity throughout the volcanic period, as nearly all varieties of Tertiary intrusive rocks known in Nevada have been recognized here, many of them affording typical specimens. Propylites, quartz-propylites, andesites, dacites, hornblendetrachytes, augite-trachytes, rhyolites, and basalts have all been poured out along this line of upheaval, and, as might be expected, the more recent rocks, breaking through the earlier bodies, occupy the largest areas, capping the elevated ridges and concealing the older flows.

Steamboat Springs are situated a short distance to the south of the limit of the map, on the western side of the range, and near the base of a volcanic hill. . They cover an area about one-quarter or one-third of a mile in length by 800 to 1,000 feet in width. The surface of the ground is covered by a deep accu- 
mulation of siliceous sinter, the deposit of the evaporated spring-water. Running lengthwise with this deposit are a number of parallel fissures oropen seams from two inches up to one foot in width, having a general trend of north $8^{\circ}$ west. These fissures are generally continuous, though sometimes filled at intervals with débris that has fallen in and choked up the passage. All along the length of these fissures are seen jets and clouds of steam rising, and the sound of water boiling violently may be heard at short distances below the surface, although concealed from view. Where the fissure is perpendicular, a depth of 10 or 15 feet may be seen, and in some instances water is at the bottom. In several places, the steam issues in puffs, with a noise like that from a steam-boiler, and jets of hot water are thrown up, with more or less force, frequently 10 and 20 foet in height, while in other places the water is raised with just sufficient force to bubble up above the surface and run off. In the whole area, there are but one or two small basins where water is at all times standing. In several places, there are elevated conical mounds built up by the sinter deposited from the boiling waters. The water flowing from these sources runs away partly over the surface of the deposit and partly through channels concealed from view a short distance below the surface, and probably finds its way to the Truckee River. The sediment, or rather. deposit, from these waters is quite friable, and lies.in thin strata; it is occasionally porous and cellular, almost resembling coral. Sulphur occurs coating the other portions of the deposit. . The steam-also emits the odor of sulphurous gas.

An analysis of this siliceous sinter has been made by Mr. R. W. Woodward, who reports the following composition:

\begin{tabular}{|c|c|c|}
\hline Silica $\ldots \ldots \ldots \ldots \ldots \ldots \ldots$ & 92.67 & 92.76 \\
\hline Alumina and ferric oxide ..... & 0.80 & 0.65 \\
\hline Lime $\ldots \ldots \ldots \ldots \ldots \ldots \ldots$ & 0.14 & 0.18 \\
\hline Magnesia ........ & 0.05 & 0.05 \\
\hline Soda...... & 0.75 & 0.99 \\
\hline Potassa........ & 0.18 & 0.15 \\
\hline Loss by ignition . & 5.45 & 5.47 \\
\hline
\end{tabular}


Trucker Cañon.-The Truckee Cañon cutting deeply into the very core of the range, affords an opportunity for the study of volcanic outburst, scarcely excelled anywhere in Nevada. The entrance to the cañon near Glendale is an east and west gap of erosion, flanked on the north by a high mass of trachytic rock rising abruptly to an elevation of 1,800 feet above. the river-bed, while the hills on the south are formed of an accumulation of successive outpourings of andesite and andesitic breccia reaching a height of 1,200 to 1,500 feet, presenting a distinctly bedded appearance, and a prevalent dip toward the cañon. In this group of andesites, there is the most remarkable range of texture as well as of mineralogical composition. Solid olive-gray masses occur, in which the triclinic feldspar and hornblende appear distinctly in a gray micro-crystalline groundmass, and which in every case appear to underlie a second series of reddish-brown and yellowishbrown cellular andesites having almost the scoriaceous habit of trachyte. A remarkable feature of the rock is the presence of both bornblende and augite, the latter frequently in crystals one-eighth of an inch in length. According to the microscopical observations of Zirkel, the two minerals are never present in equal proportions, but one always predominates, and the other occurs as a very subordinate accompaniment. Following this mixed group of hornblende and augite-andesites, and closing the series, is a mass of breccia containing together angular fragments of the two preceding groups, but for the most part made up of the augitic variety, with whose ejection there must have been an immense accompaniment of water. In some of these later breccias, the angular fragments of the earlier series have been much decomposed, leaving irregular earthy masses, but carrying well-defined crystals of augite. Nowhere among the andesites of the Fortieth Parallel Survey is there any such approximation to the trachytic texture; nowhere such a well-marked occurrence of large individualized augite crystals.

On the hills south of this andesite group, in the continuation of the range toward Mount Davidson, but lying beyond the boundary of Map V, there occurs a great development of propylite, which is intersected by numerous dikes of compact, gray hormblende-andesite, which here and there overflows it in sheets, as at Washoe. The parallel is still further 
noticeable by a large distribution of decomposed earthy forms Upon other outcropping masses of andesite, on the hill-tops, were found numerous sheets of lyyalite, existing as an incrustation, from one-sixteenth to one-eighth of an inch in thickness, and following the irregularities of the surface. The appearance of these hyalites, as well as of those found incrusting the trachytic and basaltic rocks of the neighborhood, would seem to indicate a formation by secretion upon the present rock surfaces.

Directly north of the river, and lying opposite to the above-described andesites, is a large body of sanidin-trachyte, forming a compact heavy structure, of a chocolate-red color, and a distinctly bedded occurrence. Back from the river, about 2 miles, are found certain outcrops having the fine parallel laminæ characteristic of the rhyolite group, but otherwiso with the habit of trachyte. The rock carries only 56.74 per cent. of silica.

About 2 miles below the entrance of the canon, and occupying two ravines which open north and south on both sides of the river, is found an exposure of an older rock, of a prevailing dark-purple color, probably a porphyry, in which are plentifully scattered the decomposed crystals of triclinic feldspar. These feldspars are frequently decomposed and replaced by calcite; in others, they exist as a calcareous earthy clay. Here and there are green masses, probably delessite. The entire groundmass of the rock has suffered such chemical decomposition that it is impossible to detect, without the aid of the microscope, whether it is hornblendic or augitic in origin. The prevalence of calcite and delessite, and the mode of decomposition, would refer it to the rock classed as melaphyr, found in Berkshire Cañon; but large, well-characterized feldspars in the groundmass give a preponderance of evidence of its being more nearly related to the porphyries. In a railroad cut on the north side of the river, there is an excellent exposure of this rock, where it is seen to be divided into rough, rectangular prisms by vertical and horizontal planes, so that the forms of rude steps are quite noticeable.

Directly east of the andesite and trachyte masses, the canion for 8 miles down the river, on both flanks, is made up exclusively of basaltic rocks. On the south side of the cañon, descending in some places quite to the riverbank, the basalt occurs in long flows, having its origin on the high ridges 
several miles back from the river, and falling away in broad, uneven steps. It. is an unusually coarse-grained rock. It contains little or no olivine, but possesses a large proportion of a curious dark-green, fibrous substance, resembling, as Professor Zirkel suggests, the characteristic anamesite of Steinheim, and, like.the latter, shows, under the microscope, the presence of apatite. The basalts on the opposite side of the cañon extend northward for many miles, and in general differ from the others by presenting a finer texture, and by the presence of passages of very vesicular rock, in which the pores often reach a half-inch in diameter. Mineralogically, the rock is relatively rich in olivine, but, in the specimens examined, the apatite crystals found on the opposite side of the river are wanting.

It is evident that the Truckee Cañon, for the first 4 miles of its descent, represents something more than a valley of erosion, or at least than that modern erosion which has existed since the basaltic period. The evidence of narrow, limited flows down the lateral walls of the north flank of the valley is very clear, and the entire surface of the broad, open area from the narrows, near the above-described porphyry outcrop, down nearly to Clark's Station, shows a topography altogether dependent on the original basaltic surface. Over the fields, as one ascends from the valley-bottom, there is seen but a slight accumulation of soil, much of the rock being as bare as at the time of its original flow. The immediate river-valley here, as above, is occupied by Quaternary sands and gravels, overlaid by the present accumulations from the valley-walls.

About 3 miles above Clark's, on the north side of the valley, occurs an isolated body of trachyte, overflowed by basalt on the west, and by rhyolite on the east.

Antoine's Cañon, which joins the Truckee Valley from the north, bringing down the drainage of Spanish Peak, is cut altogether in rhyolite. This rock makes a large display, having its culminating point on Spanish Peak, and descending thence in all directions. Its central body is a fine-grained felsitic mass, showing but few individualized crystals of feldspar. Specimens in the collection from here afford characteristic instances of the finely striped and laminated rhyolitic structure, the lines and bands appearing alternately of a pale-brown and a pale-lilac color. Mineralogically, the rock 
is also notable as being rich in microscopical tridymite and rounded sphærulites. Although a true massive eruption, this rhyolite field frequently shows bedding planes.

In the bottom of Antoine's Cañon, about 2 miles above its mouth, is an isolated body, designated basalt on the geological map. .After a careful microscopical analysis, Professor Zirkel has shown that in its mineralogical composition and habit this rock must be placed with the augite-andesites, possessing among the feldspars a preponderance of sanidin. It contains wellcrystallized augite, but no hornblende, while half-decomposed olivine again suggests its relation with the basalts. Geologically, it would appear to be one of those augite-andesites more closely allied to basalts than to true andesites, inasmuch as the impressions received in the field at the time of our examination were such as to suggest an outburst later than the adjoining rhyolites.

A short distance farther down Truckee Cañon, on the north side, and connected in general with the already described mass of rhyolite, occurs a glass-bearing rhyolite, full of sanidin crystals and small quartz-grains, which is distinctly overlaid by a pure, black basalt, having a rude columnar structure. It appears to be the end of a flow descending from the heights west of Sheep Corral Cañon, and is an extremely fine micro-crystalline basalt, one of the most compact in texture of any in the collection. No mineral constituents are visible to the eye, but the rock is apparently rich in globulitic glassy. base; at least, it stands unusually high in silica, yielding $\mathbf{5 5 . 7 9}$ per cent. On the higher ridges, the texture is more coarsely crystalline, olivine and triclinic feldspars being visible.

The rhyolites directly underlying the end of this flow are light-colored and somewhat tufaceous, partly the result of accumulation of white rhyolitic rapilli, and partly the flow of fine tufa. It is excellently bedded, and contains more or less angular fragments of the Spanisli Peak rhyolite. Mica, irregular grains of quartz, and some large crystals of both fresh and decomposed sanidin are found in it.

From this point to the end of the canon, 12 miles to the eastward, there outcrops a continuous line of sanidin-trachytes appearing in low hills on both sides of the river. On the south side they are soon concealed by 
enormous fields of gray basalt, while to the north they connect with the great body of trachyte, which overflows the Virginia Range, extending from the valley north of Spanish Peak across to Pyramid Lake; but whether this normal sanidin-trachyte belongs to an earlier or later flow than the trachytes at the head of Sheep Corral Cañon has not been determined. Lithologically, the trachytes of Clark's Station are to be classed with the true sanidin-trachytes of Washoc.

Clark's Station is situated about midway in the Truckee Cañon, in an enclosed basin, shut in on all sides by eruptive masses. A mile to the westward of the station, and at an elevation of about 4,300 feet above sea-level, the basin is occupied by a series of soft white Pliocene sand-beds, which overlie and are more recent than the trachytes, rhyolites, and basalts. They may be considered as marking the point of superior limit in the deposition of Humboldt Pliocene beds in the Truckee Valley. From the well-determined altitude of these beds in the Nevada Basin, it would seem most probable that the lake-waters extended throughout the entire Truckee Cañon; that the valley of Glendale was a bay of the lake, receiving the waters of the Truckee River somewhere in the region of Reno; but this little group of Pliocene beds, which fills the valley near Clark's Station, is the only relic of the formation in the cañon, and either marks the limit of deposition of the sediment, or else, as is most probable, that portion of the deposit lying up the river from this point has been eroded, as it certainly lias been for the lower 8 miles. The strata are quite horizontal, and are largely made up of granitic materials, brought down, without doubt, from the Sierra Nevada. They contain a few fragments of minute fresh-water shells of the same species that are found in the Lower Truckee Valley.

About 4 miles below Clark's Station, the cañon widens out, leaving the basaltic hills overlying the trachyte about a mile and one-half to the south of the river. The open valley is occupied partly by trachytes and rbyolites and in part by basalts, but largely by exposures of a decomposed older rock, which is, with some hesitation, referred to propylite. It is of a dull olive-green color, contains much carbonate of lime, is everywhere marked by green, earthy masses the size of a pea, which appear to be decomposed augite. Less decomposed passages occur here and there, with well-recog- 
nized augite and triclinic feldspar, together with occasional though rare grains of quartz. The habit of the rock, and its position inferior to the trachytes, as well as its close resemblance to the decomposed forms of augite-propylite at Silver Mountain in California, has determined its reference provisionally to propylite, and it is so designated on the geological sheets. It is proper to state, however, that augite-propylite is a somewhat rare occurrence, and the rock may prove to be geologically more closely allied to the porphyry described from the upper end of the canon, and to the melaphyr in Berkshire Cañon. There are but two points discernible in its geological relations: one, that it is younger than the diorite bodies of the cañon; the other, that it is older than the Tertiary volcanic series, since the trachytes, rhyolites, and basalts all overlie it.

About 4 miles above Wadsworth, directly on the river-bank, in an exposure made by a railroad-cut, there is a body of quartzose diorite, which underlies the propylite. Under the microscope, these diorites have been shown by Professor Zirkel to contain plagioclase, but nearly no orthoclase, dark-green hornblende, quartz, apatite, biotite, and magnetic iron. Associated with this is a diorite-porphyry, consisting of a fine groundmass, with imbedded crystals of plagioclase and hornblende. A similar outcrop occurs near the head of the cañon, just south of Sheep Corral Cañon, and about 3 miles north of the Truckee River. This latter diorite is a little more quartzose than in the first-named locality. It is overlaid by the Sheep Corral Cañon trachytes, and the basalt mass to the south. This basalt field extends from the diorite outcrop down nearly to the railroad, and is essentially a part of the field lying directly west of it. These two outcrops of diorite, each about a mile in extent, together with the porphyry at the upper end of the canon, probably form the oldest rocks of the region; but, owing to their wide separation, there is no means of judging of their relative age. Taken together, they probably represent all that is left in the canon of the original Virginia Range prior to the Tertiary volcanic period.

Overlying the decomposed propylite mass of the Lower Truckee Canon upon its south flank, which is in turn concealed by basalt, is a rather thin bed of a light-colored trachyte, characterized both by individualized crystals and by glassy matter; sanidin, hornblende, and biotite appearing promi- 
nently throughout the light-gray groundmass, while the microscope reveals angite, magnetite, and apatite. This occurrence of both sanidin and augite is to be specially noticed.

Directly north of the Truckee Ferry lie some low purple hills, which consist also of sanidin-trachyte, with many small grains of magnetite, but no augite. It is an unusually dense, dark-colored trachyte, and the long sanidin crystals stand out very prominently.

An analysis of this rock by Mr. R. W. Woodward yielded the following:

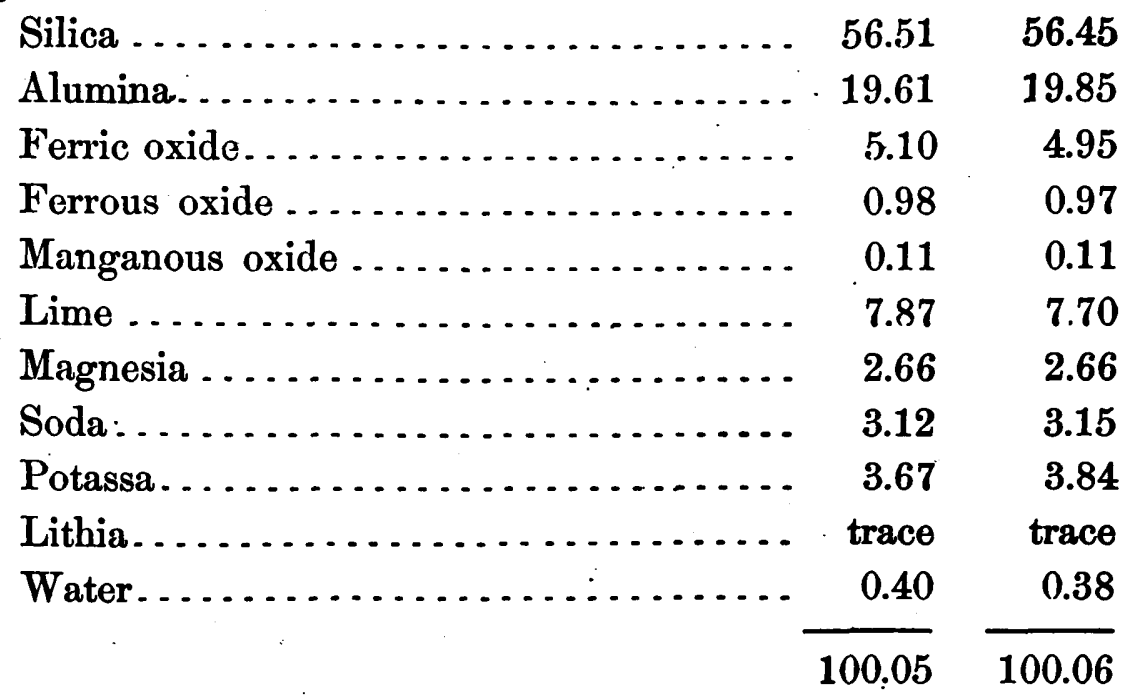

Specific gravity, 2.5, 2.6.

Overlying these sanidin-trachytes are horizontal beds of trachytic breccias of a very dark and basic appearance, which are in turn directly overflowed by dark-gray augite-trachytes, consisting, as shown by the microscope, of sanidin, a little plagioclase, some brown hornblende, and a considerable portion of pale-green augite. Far richer in augite than the trachyte which underlies it, it approximates much more closely in its mode of jointing and weathering to the basalts, and presents a series of mural faces in all respects like the latter rock.

An analysis of this augite-trachyte was made by Mr. R. W. Woodward, who reported as follows:

Silica ......................... $50.36 \quad 50.03$

Alumina....................... $17.00 \quad 16.99$

$53 \mathrm{D} G$ 


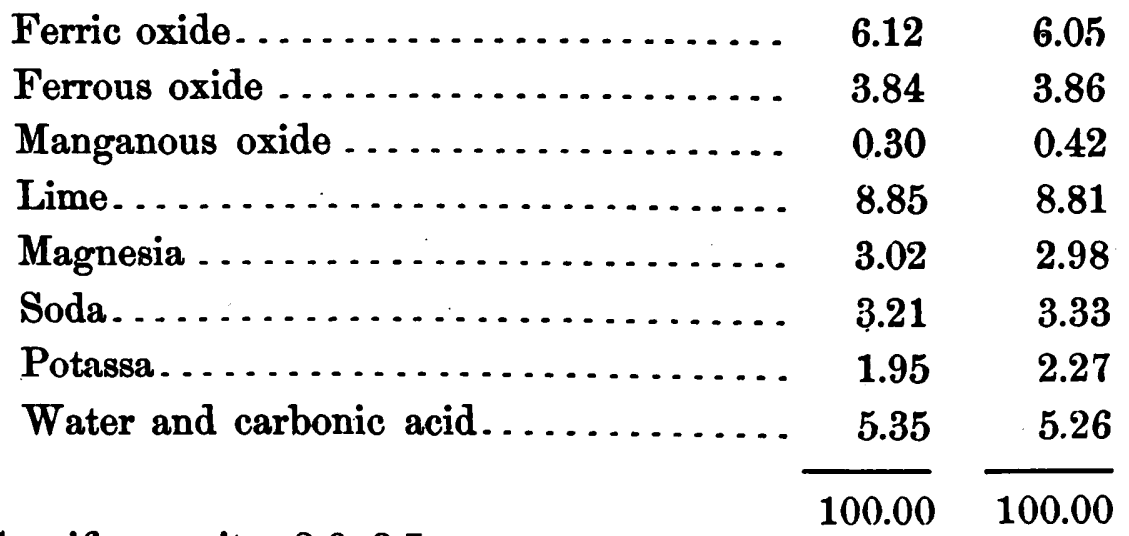

Specific gravity, 2.6, 2.7.

Trachytes of a similar composition form the detached hills between Wadsworth and Sheep Corral Cañon. Here the rock is dark brown to nearly black; it overlies propylite and carries large crystals of both sanidin and augite associated with a little hornblende. Although different in texture from the heavy flows of augite-trachyte north of the Purple Hills, and showing considerable mineralogical distinctions, such as carrying conspicuous black hornblende crystals, the occasional occurrence of brown mica, and a large proportion of glass, these rocks are doubtless derived from a common source, and from their relations to the other trachytes are probably also of the same age.

.In the open basin country just north of the Truckee Ferry are some hills of light-colored rhyolite presenting various shades of brown, yellow, reddish-yellow, light brick-red, and purple, the purple tints in general decidedly predominating. All these colors, although very brilliant, occupy but small local patches in a prevailing white field of rhyolite. The purple and green masses seem to belong to an earlier eruption than the white. Directly over the white rhyolite lies a bed 150 feet thick, of dark trachytic breccia, which, in passing upward, becomes more and more solid and compact, merging finally into a gray augite-trachyte. Indeed, this breccia is the first part of the augite-trachyte eruption. In a microfelsitic groundmass appear well-developed crystals of sanidin, biotite, and occasional large clear grains of quartz. The latest flows of purple rhyolite are slightly brecciated, the fragments which they contain being of the same material as the rock itself. It is evident that these rhyolites pass under, and therefore antedate the 
augite-trachyte breccia beds and the compact gray augite-trachyte, which rise in the high bluff wall to the northward. The rhyolites themselves are penetrated by two sets of dikes, one of a nearly black, very compact augitetrachyte, which contains in the micro-crystalline groundmass crystals of onehalf inch or more in length of sanidin. According to Professor Zirkel, the groundmass is a crystalline admixture of feldspar and pale brownish-yellow augite, many of the feldspars being striated, yet the prevailing forms are monoclinic. Short black lines of hornblende occur, although sparingly. No olivine was detected. So far as observed, these dikes all dip to the west and strike west of north.

Where these black trachyte dikes break through the rhyolite, there are contact phenomena of exceeding interest, the latter, and in this instance older, rock being converted into a dark chocolate-brown glassy mass, in which only a few feldspars and biotite flakes still retain their integrity, the product having almost the habit of obsidian. From this extreme form, there is a gradation through 3 feet of less and less glassy product into the normal rhyolite of the adjoining region. Professor Zirkel ${ }^{1}$ has described with some detail the microscopical characteristics of these hyaline varieties, illustrating in Plate VIII, fig. 4, a remarkable obsidian. But for the fact that on each side of these black trachyte dikes the glassy forms of rhyolite pass gradually into the crystalline varieties, it might not seem conclusive that the dikes had been the agents of this glassy modification; but since the same phenomenon is repeated at the contact of several of them, it seems improbable that the form could have existed in the first instance, and the dikes have, by accident, followed the course of the glassy bands. This fusion of rhyolite into glass is no more remarkable in contact with the molten dikes of trachyte than is the fusion of trachytic mountain-points by lightning, and the two phenomena would appear to bear a close relation to each other. In this locality, therefore, occurs a marked exception to the law enunciated by von Richthofen of the sequence of rhyolites over trachytes, for here the trachytes have undoubtedly broken through in dikes and overflowed the earlier rhyolites, both in the form of breccia and compact material, in the instance of the gray tabular hills to the north. It is, however, a marked fact that while

${ }^{1}$ Microscopical Petrography, vol. vi, 206. 
these trachytes hold in time the period of the basalts, they show also an affinity with that group by the presence of augite. In a geological sense, though not petrographically, they may be considered as basalts with the olivine left out, and sanidin substituted for a portion of the plagioclase. Besides the dark trachyte-dikes above described, there is also another set, having a north and south strike and a nearly vertical position, but with very limited overflows. They consist of black vesicular basalts, and are characterized by frequent coatings of hyalite, varying from one-quarter of an inch in thickness down to a mere siliceous glaze.

On the river-mesa, near the east end of the Truckee Cañon, and east of the diorite outcrop, are four isolated hills of normal sanidin-trachyte, having a great similarity to the brown variety on the summit of Sheep Corral Cañon.

The large fields of basalt which lie to the south of the river and cap the higher summits have never been entered or examined by our parties, and it is quite probable that in the deeply eroded canions may be found many outcrops of the earlier volcanic rocks. At the base of the range, just south of Wadsworth, partially buried by drifting sands and tufas, is a group of low hills, which cannot at first sight be distinguished from genuine basalts, yet which even in the field present certain peculiarities of form and texture that distinguish them from the surrounding rooks. They are compact fine-grained rocks of a resinous lustre, and varying from black to grayishblack in color. Except minute feldspars, scarcely any mineral constituents can be determined by the naked eye. The value of methods brought to bear by the microscope in the analysis of rocks is well shown in the study of this group. Professor Zirkel' regards them as augite-andesites, and has given a detailed description of their structure and composition. Mineralogically they appear to hold both sanidin and plagioclase in equal proportions, but the minute crystals are mainly triclinic. Augite, however, greatly predominates over hornblende. A determination of silica in one of these rocks gave 59.99 per cent., an amount much too high for normal basalt, but within the limits admitted for augite-andesites. Geologically, their true

'Microscopical Petrograpíy, vol. vi, 224. 
relation to the neighboring basalts is not clearly made out, but it would seem most probable that they appear as dikes penetrating the genuine basalts.

Some idea of the immense volume of the volcanic series is obtained from the study of so long and deep a cañon as this transverse valley of the Truckee. Upon either side, the hills rise from 1,200 to 3,000 feet. Much of this cañon-depth cannot be attributed to erosion, but certainly throughout the lower portion it would seem as if a very considerable part must have been produced in this manner. The cañon therefore exhibits a deep cut across the Virginia Range, and it is somewhat remarkable that so little of the earlier formations have been exposed. A cut through the range in the region of Washoe must have exposed a very considerable amount of stratified rocks, and a large body of diorite. Here at the Truckee Cañon, there are but two small patches of diorite and a band of porphyry to represent the older rocks, all the rest being of Tertiary volcanic age, conveying some idea of the immense development of these comparatively recent outbursts.

At the bend of the river, near Wadsworth, the Truckee having followed a course a little north of east through the cañon, suddenly describes a semicircle having a diameter of 8 miles, and thence flows in a northwest direction until it pours into Pyramid Lake. North from the intricate group of eruptive rocks along the Truckee Cañon, the Virginia Range is overwhetmed and masked by an immense flood of trachyte, which occupies nearly the entire distance to Mullen's Gap, with the exception of a belt along the east flank extending from Sheep Corral Cañon for 10 miles to the northward.

Shiege Corral Cañon.-The walls of this cañon expose mainly heavy beds of dark-brown trachyte. Scattered through a glass-base are occasional crystals of sanidin and biotite, the microscope also revealing the presence of plagioclase, while within the glass-base various forms of devitrification have taken place, resulting in a variety of micioscopic products, largely microlitic. Upon the summit-ridges, there is an unusual development of hyalite, covering many of the volcanic blocks to the thickness of onequarter of an inch. Where the normal botryoidal hyalite is wanting, the blocks are incrusted with a thin film of siliceous material. The rock is also characterized by frequent cavities lined with crystalline sinter, which rises 
in points one-sixteenth of an inch in height, and each point is crowned with a transparent globule of hyalite. A distinct horizontal bedding is frequently noticed in these trachytes. Their limit to the westward is not accurately known, but they are supposed to extend down to the valley west of Ormsby Peak.

The gray, glassy augite-trachytes which break out along the foot-hills just south of Sheep Corral Cañon are supposed to be later than the sanidintrachytes; a decision, however, which does not depend upon any superposition, for they have not been seen in any immediate contact, but rather upon field impressions, and because the gray trachytes rise in bold hills with a much fresher and less weathered appearance.

Dr. Anger, of Leipsic, who made an analysis of this augite-trachyte, found the following constituents :

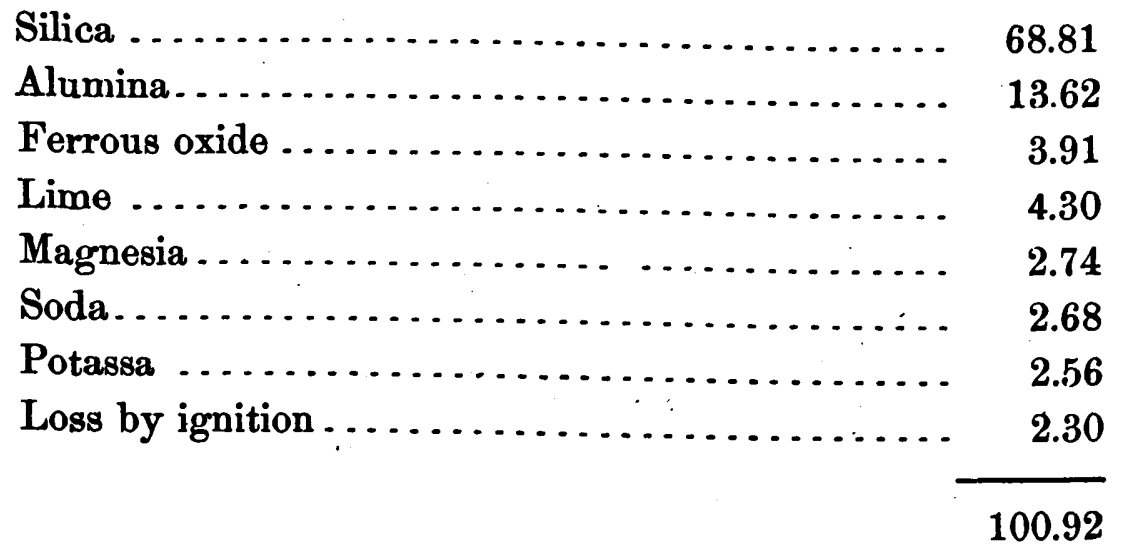

This rock stands over 18 per cent. richer in silica than the augite-trachyte from the hills back of the Truckee Ferry, and is unusually acidic for a rock so full of augite, having an amount of silica equal to that found in many varieties of rhyolite, while the Truckee Ferry Hills approach more nearly in chemical composition to basalt.

The propylite at the entrance of Sheep Corral Cañon is a greenishgray rock, closely resembling the typical body of Washoe, except that it carries a few grains of quartz. It is a dense, tough rock, with well-developed feldspars and occasional hornblendes. The microscope reveals the presence of apatite and magnetite. 
An analysis of this rock was made in the laboratory of Professor Wiedemann, in Leipsic, with the following result:

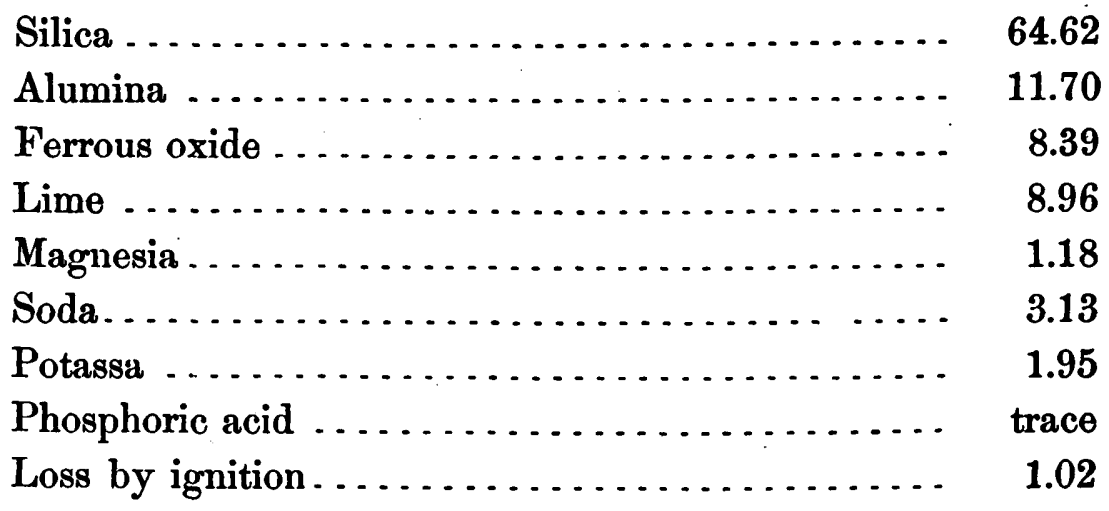

100.95

Directly to the north of Sheep Corral Cañon is observed the southern end of a bed of massive dacite, which occupies the extreme foot-hills of the range for about a mile, and then trends slightly into the range on a direction about north $20^{\circ}$ west. At the point where it trends into the range, the foot-hills are occupied by an outburst of rhyolite, which flanks the range for 8 miles along the Lower Truckee Valley, both rocks being.well developed in Berkshire Cañon, 3 miles to the northward.

Berkshire Cañon.-About $3 \frac{1}{2}$ miles up Berkshire Cañon, from the mouth, there occurs a heavy mass of a somewhat peculiar rock, which has been recognized nowhere else within the limits of the Fortieth Parallel Survey, and which has been classed as melaphyr, from its close resemblance in microscopical habit to rocks thus designated in Germany. Of its age here in the Virginia Range nothing is definitely known, except that it underlies the propylite, the oldest of the Tertiary volcanic products. . These melaphyrs extend from the head of the cañon in a northwest direction about 4 miles, and to the west, north, and south are overlaid by the summit rocks already described, and on the slopes of the range to the eastward are again concealed by propylites and andesites. They are, in general, deeply eroded in transverse ravines prior to the later outflows. In texture, they are extremely varied, passing from a fine-grained, compact, dark-green, or 
dark-brown rock, in which are no recognizable crystals, up to a coarsegrained mass, through which decomposed crystals of feldspar are very thickly scattered. The prevalent color is dark green, and in general the texture rather earthy. Under the microscope, Professor Zirkel found them to consist of triclinic feldspars, decomposed augite, a little hornblende, and considerable olivine. Many of the outcrops at the head of the canion, near the summit of the melaphyr body, are characterized by green spots the size of a pea, partly formed of delessite, and partly of well-crystallized calcite. Nearly all the feldspars in the upper portion are more or less converted into carbonate of lime. There are present impure crystals of carbonate of lime half an inch long, rendered opaque by green earth and some small, gray grains, whose nature is not known, probably referable to augite.

A little lower down the cañon occurs a chocolate-brown variety, in which the feldspars are mainly converted into carbonate of lime, but which is characterized by spherical amygdules from one-half inch downward until they are too small to be visible. The surface of these amygdules has a pitted appearance, like the smooth interior of certain empty cavities in basalt. They were evidently, in the first place, filled with green earth, which has been subsequently more or less converted into calcite. Only a few feldspars are still preserved in anything like their original condition, and under the microscope these all appear to be triclinic. About a mile down from the head of the cañon is the most altered zone in the melaphyr body. Here the entire mass is decomposed, and apparently consists of delessite and carbonate of lime, while the amygdules no longer show their spherical form, but are broken and run together until the rock is little more than a network of carbonate of lime, rendered impure by streaks and grains of delessite, with a general filling of impure delessitic matter, in which are the faint traces of feldspar, and brown earthy material, probably representing the augites. In this zone are found also large siliceous amygdules, which are in fact quartz geodes surrounded by a variable coating of carbonate of lime and green earth. In some instances, in the hollows of the calcareous amygdules, is a secondary growth of quartz crystals.

Descending the cañon, the first rock which is found to break through and overlie the melaphyrs is a pinkish-gray body, colored on the geologi- 
cal map as a propylite. It consists of a micro-crystalline groundmass of feldspar and brown undecomposed hornblende, in which the feldspar largely predominates. In this groundmass are imbedded clear, undecomposed, black and brown hornblende, a few biotite flakes, and both orthoclase and plagioclase, the latter slightly outnumbering the former. This rock, however, has much the habit of a trachyte, and in reality represents an intermediate condition, where, although plagioclase slightly predominates and carries the rock under the name of propylite, at the same time the proportion of orthoclase is so large as sensibly to affect its habit. Geologically it appears to be a trachyte, but lithologically a propylite. From its geological relations to the neighboring rocks, it was impossible to arrive at any definite conclusion as to its place in the volcanic series. It is younger than the melaphyrs, and older than the sanidin-trachyte which overflows it to the north, so that its position in time, so far as known, would coincide as well with propylite as with hornblende-plagioclase-trachyte. It builds up conical hills 600 feet in height, which show no bedding planes or other structural lines, and would appear to be a dense homogeneous mass without indications of successive flow.

Just to the south of these propylite hills is a series of dikes of light greenish-gray rhyolite, which are seen to cut through the melaphyr and to overflow the base of the trachyte hills. This rhyolite is an extremely fine-grained rock, of a shaly structure, and is composed of a micro-crystalline groundmass, in which are observed a few partially decomposed orthoclase crystals and a little altered mica.

A short distance farther down the cañon, apparently breaking through the propylite body, is a broad dike, several hundred feet in width, of typical hornblende-andesite. Brown, unaltered hornblende, prevailing plagioclase, many crystals of sanidin, and a few biotite flakes are seen everywhere dispersed through the grayish-brown groundmass. Perhaps this rock should be classed with the above-described propylites, for it only differs from them mineralogically in the proportion of sanidin and an increase of hornblende. It is noticeable that the fragments of hornblende lie for the most part in parallel layers through the groundmass. Unlike the propylite, however, it has the true geological habit of andesite, with the peculiar smooth, 
flinty fracture. These two rocks together, although assigned in one case to propylite and in the other to andesite, have a strong affinity with the trachytes.

The andesite zone extends for about 6 miles north and south, and is accompanied along its entire eastern edge by a belt of dacite. This dacite body averages about a mile in width, and consists of clouded masses of purple and bluish-gray rock. In general, the purple variety occurs in the most easterly beds, and seems to be the earliest of the dacite belt. It presents sometimes a compact, fine-grained purple base, without any minerals recognizable to the naked eye, but under the microscope reveals the presence of triclinic feldspars and quartz grains. The main part, however, of the purple zone is a micro-crystalline base of feldspar and a decomposed brown mineral, probably hornblende. The feldspars themselves show every grade of passage into carbonate of lime. Breaking through this purple dacite are brecciated masses, which are characterized by a larger proportion of mica and quartz than is found in the earlier body.

An obscure outcrop of gray brecciated propylite was observed, partially concealed by dacite, but no connection with any other rocks could be traced. Later than the purple breccias, a great outburst of pale-green dacite took place, in which also the feldspars have suffered considerable decomposition, resulting partly in carbonate of lime and partly in a soft kaolinized mass; but, where decomposition has not proceeded too far, they show, under the microscope, distinct striation. The quartz is in some instances crystallized in double pyramids, a not infrequent occurrence in dacites, and especially noticeable in the rock from Shoshone Peak, Shoshone Range. This green daeite extends south as far as Sheep Corral Cañon, where it is found to overlie a typical greenish-gray propylite already mentioned, but occupying too small an area to be represented on the geological map.

Breaking through the purple dacite, and in some instances crossing in dikes through the green dacite, is a long and powerful outburst of rhyolite, which occupies the foot-hills from within a mile of Sheep Corral Cañon to within 4 miles of Pyramid Lake. The main mass of the rhyolite in the region of Berkshire Cañon comes up through a broad vein, making a dike nearly 400 feet in width, and overflowing the dacites, forms a bold group 
of hills conspicuous from the surrounding country by their great variety of brilliant colors. They are white, salmon-color, yellow, pale green, pale lilac, gray, brown, olive, red, and deep purple, and present an equally varied texture. It is decidedly a massive outburst, and shows no tendency to bedding, the various colors appearing as cloudings in one mass, and by no means as a succession of ejections. In mineralogical composition, the variation seems quite as well marked. Near the top of the hills, it forms a pure white porcelainous rock of a fine microfelsitic groundmass, through which wind translucent siliceous bands, shading off into the more homogeneous mass. There are large areas which show no inclosed crystals. Following the same mass, either north or south, it is found to contain clear, transparent grains of crystalline quartz, and some sanidin. Gradually the sanidin and quartz crowd together, and make up nearly the entire material of the rock, leaving but little space to be filled with felsitic groundmass In such instances, the sanidin is largely decomposed, while the quartz, surrounded by a thin coating of ferruginous material, has the color of garnet. Much of the quartz occurs in irregular fragments, having no crystalline boundaries, although in some a definite angle may occasionally be observed; but there are no such crystals as characterize the green dacites. In a salmoncolored rhyolite were noticed some large cavities, in which were crystals of carbonate of lime imbedded between coatings of siliceous sinter. Occasionally can be noticed an appearance of fusion of the walls of the cavities, resulting in an obsidian-like substance. Besides this, there occur, in the salmon-colored rhyolites, passages of very fine, highly siliceous, jasper-like material. Decomposed sphærulites abound, and it is not impossible that these larger cavities may have resulted from the destruction of groups of sphærulites, though they do not show the structure of lithophysæ. Some of the largest of these jasper masses reach 5 and 6 inches in lengtli, and contain minute snow-white globules of apparently colorless jasper, scattered irregularly through the red and green jasper bodies. The substitution of carbonate of lime in the place of feldspars, noticed in the earlier volcanic rocks, continues through the rhyolites. A few of the very clear-and undecomposed orthoclase crystals possess the "labradorizing" quality, and are 
conspicuous by the iridescent play of light, but hardly to the same extent as observed in the rhyolites of the Pah-Ute Range.

Directly west of the highest point of the Berkshire Cañon rhyolites occurs a small dike of black, compact basalt.

There are then represented here in this section the exposures of seven types of eruptive rocks. Of these, melaphyrs are the earliest, followed by small outcrops of propylite, which, however, have a trachytic affinity; next the hornblende-andesite and the zone of purple and green dacites. As between the andesites and dacites, the evidence is not conclusive as to age. After the dacites come the trachytes, but the relation between the latter and the rhyolites was not observed here, although the sequence has been noted in too many other localities to leave any reasonable doubt as to their relative positions. The rhyolites, however, are clearly later than the dacites, and the basalts later than the rhyolites. All these rocks, with the exception of basalt, have at some period been subjected to a uniform process of decomposition, in which the feldspars have been more or less replaced by carbonate of lime, and, in the case of the melaphyrs, the olivine has been converted into a serpentineous product.

That all these rocks have been subjected to considerable sub-aërial action before the outbursts of basalt would seem highly probable.

The section $\mathrm{C}-\mathrm{D}$, at the base of the geological sheet, crosses the Virginia Range in the region of Berkshire Cañon, and the intricate structural relations of the different volcanic outbreaks are indicated as well as it is possible with the scale of the map and the geological data at hand.

Region west of Prramid Lake.-Opposite the southern end of Pyramid Lake, where the trachyte flow terminates, a broad sheet of tabular basalt, rising in nearly perpendicular walls, forms the highest peaks, and caps all older volcanic flows, beyond which the hills fall away toward Mullen's Gap. The gap cuts the Virginia Range at right angles to its trend, and, in a measure, isolates, topographically but not geologically, the northern end from the portion already described. On both sides of the gap, the hills rise gradually in a broken, irregular mass of ridges, cones, and pinnacles, of an interesting volcanic rock, presenting some peculiarities of habit. It is regarded as belonging to the quartz-propylites, and has been represented as such on 
the geological maps, although microscopical analysis indicates that it is more closely allied to dacites, the quartz-bearing variety of the andesites. The rock has the characteristic greenish-gray groundmass of the typical Washoe propylite, with the same arrangement and structure of the plagioclase and hornblende, and the same general field aspect. Its groundmass is exceedingly fine-grained, through which are scattered many well-preserved flesh-colored feldspars, occasionally one-half of an inch in length, and dark-green fragments of fibrous hornblende. Mica is present as sparse dark plates of biotite. Unlike the normal propylites of Washoe, the rock is characterized by the presence of a very considerable amount of translucent quartz-grains, all of them more or less cracked and fissured. Under the microscope, in thin sections, the quartz is shown to carry liquid-inclusions, which is a characteristic feature of quartz-propylites.

A chemical analysis of this rock yielded Mr. R. W. Woodward the following result :

\begin{tabular}{|c|c|c|}
\hline Silica $\ldots \ldots \ldots \ldots$. & 68.45 & 68.46 \\
\hline Alumina $\ldots \ldots \ldots \ldots \ldots \ldots$ & 16.97 & 16.85 \\
\hline Ferrous oxide... & 1.36 & 1.43 \\
\hline Manganous oxide. & trace & trace \\
\hline $\operatorname{Lime} \ldots \ldots \ldots$. & 3.07 & 2.92 \\
\hline Magnesia ..... & 0.73 & 0.75 \\
\hline Soda............ & 3.60 & 3.60 \\
\hline Potassa ........ & 3.99 & 3.98 \\
\hline Lithia . . . . . . . . . . . & trace & trace \\
\hline Carbonic acid $\ldots \ldots \ldots \ldots \ldots \ldots, \ldots$ & 0.59 & 0.59 \\
\hline \multirow[t]{2}{*}{ Water............................ } & 1.42 & 1.45 \\
\hline & & \\
\hline
\end{tabular}

Specific gravity, 2.38, 2.44.

It is interesting to note the presence of carbonate of lime, as under the microscope may be detected minute crystals of calcite, derived from the decomposition of feldspars.

As the area occupied by these quartz-propylites has not been carefully determined, it is possible that they may be represented on the geological 
map as covering too broad a field, and that within the territory so colored other volcanic outbursts may be found. They occur, however, along the shore of Pyramid Lake on both sides of Mullen's Gap, rising from 1,200 to 1,500 feet above the water-level. The only other volcanic rocks recognized in the region were rhyolites and basalts, both overlying the quartzpropylite, the former in low hills bordering the gap, and the latter capping the higher summits.

Geologically the most notable feature of these rhyolites is found in the great variety of structure which they present in such a comparatively limited area. Rhyolites from the same hill or outflow may show great differences in color, texture, and superficial appearance, but, in general, are characterized, even over large regions, by much the same structural habit of the groundmass and arrangement of mineral constituents. There are found here in Mullen's Gap rhyolites, having a microfelsitic groundmass rich in secreted minerals, others in which the groundmass is distinctly lithoidal and homogeneous, associated with pearlites, pumicestones, light-colored tufas, and coarse rhyolitic breccias and ash. The microfelsitic varieties, which have apparently broken through the quartz-propylites, have a purplish-gray color, a rough texture, and hackly fracture. Quartz and sanidin are the prevailing mineral secretions. The rock shows a tendency to pass by gradual transitions into the lithoidal varieties, not unlike the rhyolites from the Sou Spring Hills, Pah-Ute Range, which they closely resemble in general habit. In this connection, it is interesting to note that the rhyolites from Mullen's Gap, which are characterized by a lithoidal groundmass, possess a brilliant Indian-red color, also very similar to rocks described from the Sou Spring Hills, a similarity, which is still further shown by the behavior of the well-defined fresh crystals of sanidin and the occasional particles of quartz. It would seem as if the segregated fragments of quartz in the microcrystalline and microfelsitic varieties had become dissolved in the magma, and, uniting with the ferritic material of the groundmass, had formed, during the period of solidification, a homogeneous, porcelain-like, red rock, which presented physically, although not chemically, a totally different product from the rough, purplish-gray types.

The pumicestones and pearlites are remarkably light and porous, 
resembling those found in the southern end of the Montezuma Range and at Mono Lake. They have the characteristic lavender and gray colors, a rough, fibrous texture, with a tendency to develop half-glassy rocks. Crystals of sanidin are abundant. Associated with these rocks are grayish-white and cream-colored tufas, made up of siliceous and feldspathic material, so extremely fine as to crumble into powder at the slightest blow. They are of interest as showing the intimate connection between the ejection of rhyolitic products and the stratified lacustrine deposits, which, carrying remains of an extinct Tertiary fauna and flora, have necessarily been classed as of sedimentary origin.

There occurs here, on the north side of Mullen's Gap, a small obscure mass of an uninteresting, dirty, ash-gray breccia, very little being known of its mode of occurrence or immediate associations, but a specimen of it was collected in the field solely as showing the great variety of rhyolitic material to be found at the locality. The inclosed brecciated fragments exhibit considerable variety, but are all apparently of a rhyolitic nature. Small sanidins are the only crystals observed macroscopically. In thin sections, under the microscope, this rock becomes one of great interest and importance, the gray brecciated fragments exhibiting peculiar phenomena, which Professor Zirkel ${ }^{1}$ has described with considerable detail. Among the most striking features of the rock is the occurrence of liquid-inclusions in glass, and the presence also in the glass of minute crystals of apatite carrying glass, which also contains a fluid-inclusion. In Plate XII, fig. 1, accompanying Professor Zirkel's report, these phenomena are beautifully shown.

Between Mullen's Gap and the northern end of the Virginia Range, all the higher portions consist of broad, massive tables of black basalt, which incline gently to the eastward toward the lake or away from the granitic body of the Sierras, the volcanic masses evidently breaking out along the flanks of the older crystalline range. The deeply-eroded cañons of the basalt have never been explored, and it is possible that there may be exposed in several of them some of the older volcanic rocks, especially as trachytes and rhyolites occur along the shore of Pyramid Lake and to the north of the basaltic table.

'Microscopical Petrography, vol. vi, 265. 
West of Black Mountain, at the head of Louis Valley, occurs a body of rhyolite, lying between the granite and the main mass of the Virginia Range, which has escaped the great flow of basalt. It is a reddish-gray rock, with a microfelsitic groundmass, and the characteristic banded structure of rhyolites. Sanidin and mica are the prevailing constituents, the latter being remarkably well developed in minute flakes. Hornblende appears to be wanting. A thin section of this rock has been illustrated by Professor Zirkel, in Plate VI, fig. 4, accompanying his report, showing the marked manner in which the mica flakes have been broken and twisted. It is interesting to note that on the opposite side of the range, a little north of east, there crops out from beneath the basalt a very similar looking rock, having the banded fluidal structure of the groundmass remarkably well developed; indeed, there are few specimens in the collection that show this structure as well. The rock is more porous than the one from Louis Valley, and there is no macroscopical mica, but instead a few minute black hornblendes.

North of the basaltic body, the Virginia Range terminates in a group of low hills, which border Pyramid Lake on the northwest, and connect with the southern end of the Madelin Mesa. Astor Pass cuts through these hills, connecting Pyramid Lake with Honey Lake Valley of California, and lies below the level of the ancient La Hontan Lake, the calcareous tufas covering the flanks of the hills, and showing conclusively the flow of those alkaline waters westward beyond the boundary of Nevada.

On the geological map, these hills are colored as trachytes; it is probable, however, that rhyolites are represented here; indeed, the entire group belongs to that class of rocks which stand on the border line between these two types of acidic rocks. They are characterized by reddish-brown and gray colors, a decidedly crystalline texture, with the individual minerals usually well developed. One of the most striking rocks of the region, and one characteristic of Astor Pass, is found near the entrance of the pass, and about 4 miles northwest from Pyramid Lake, where it forms broad tablelike masses. The prevailing color of its groundmass is brownish gray, in which, forming the greater part of the rock, are porphyritically enclosed crystals of feldspar, mica, hornblende, and quartz. Many of the feldspars 
have a dull white color, quite unusual in rhyolites, and are frequently threequarters of an inch in length, carrying impurities, which may be recognized by the aid of an ordinary magnifying-glass. Mica is very abundant and of a brilliant black color, while the hornblende, which is also black, plays quite a subordinate part. The quartz-grains are large, but by no means frequent, and resemble those usually found in that somewhat limited group . known as quartz-trachytes; that is to say, they appear more. like an accessory mineral than a primary constituent of the rock. They are quite clear and colorless, and apparently free from microscopical impurities. Under the microscope, minute crystals of apatite may be recognized. The presence of quartz and the microscopical structure of the groundmass relate this rock to the rhyolites.

Peavine Mountain Region.-That portion of the Truckee Valley lying directly west of the Virginia Range is a broad open basin covered by a thick deposit of Quaternary. sands and gravels obscuring all the Tertiary strata below; these appear, however, farther up the valley, just above the town of Reno, and extend thence westward to the California boundary. These Tertiary beds line the valley on both sides of the river, and form a distinct deposit quite unlike those described from the Lower Truckee Valley. They lie inclined at angles varying from $10^{\circ}$ to $15^{\circ}$, in general dipping to the southward away from Peavine Mountain, but considerably disturbed by local outbursts of volcanic rocks. Inasmuch as the beds are so highly inclined, and are older than many of the intrusive rocks of the region, they have been referred to the Miocene age, although they differ somewhat in lithological character from the Miocene strata of the Kawsoh Mountains and Montezuma Range, having much less volcanic material in their composition. They consist mainly of sandstones, with interstratified beds of friable sands, clays, and thin shales of prevailing light colors. So far as known, no animal remains have as yet been found in these beds, although stems, leaves, and partially carbonized vegetable matter are abundant in certain layers of shale. Perhaps the most characteristic feature of the basin, and one that suggests the Green River beds of the Elko region, is the presence of a number of seams of impure coal and carbonaceons shales. Outcrops of coal occur on both sides of the river north of the town of Verdi, $54 \mathrm{D}$ G 
dipping to the southward $10^{\circ}$. Another coal-seam has been opened a long time on Dog Creek, a short distance north of Crystal Peak, but, so far as known, none of the deposits have as yet proved of any economical importance. No accurate measurements of the thickness of these Tertiary strata have been made, but there cannot be less than 500 or 600 feet of conformable beds.

A short distance south of the river, the Tertiary is hemmed in by masses of dark-gray sanidin-trachyte, to the south of which, in the region of Verdi, are outlying masses of Sierra granite.

On the opposite side of the river, and lying just within the borders of the State of Nevada, is situated Peavine Mountain, an outlying ridge, or rather peak, belonging properly to the Sierra Nevada Range of California. It stands somewhat isolated, forming a prominent landmark in the immediate region, partly on account of its commanding elevation, and partly from its striking outlines, which offer marked contrasts to the forms of Tertiary volcanic outbursts, which characterize the Virginia Range and the country to the eastward. It attains an elevation of 8,217 feet above sea-level and about 3,700 feet above the river, rising in abrupt but long regular slopes to the summit.

Geologically, Peavine Mountain is formed of a series of highly altered quartzites and fine-grained feldspathic rocks, which have been referred to the Archæan series; but their definite relations to other crystalline rockmasses has not been made out, nor can they be referred to any beds of precisely similar petrographical habit. They stand at a highly inclined angle, with a strike varying from north $50^{\circ}$ to $65^{\circ}$ east, agreeing approximately in strike with the Archæan rocks of the West Humboldt and PahUte Ranges, but quite at variance to the direction of the Mesozoic uplifts. The entire series of beds is characterized by a fine-grained texture, and all the beds seem more or less decomposed, the purer quartzites being penetrated by fissures and cracks filled by ferruginous material. In the quartzites are also minute grains of magnetite and occasionally a little yellowishgreen epidote. In the feldspathic beds, similar iron seams are even much more abundant, and many of the rocks are stained bright red from the discoloration produced by the ferruginous earth, rendering the lithological 
study of the rocks quite difficult. On the north slope of Peavine Mountain, near the Bevelhymer ledge, occurs, intimately associated with the series just described, a rock which has a much. fresher appearance, with the individual minerals more clearly defined. It is a compact dense rock, breaking with difficulty under the hammer, presenting a sharp angular fracture. It carries considerable dull opaque orthoclase, a little plagioclase, with both hornblende and mica. It would seem to be related either to the diorites or syenites. On the north slopes of Peavine Mountain, the beds are traversed by quartz veins.

East of Peavine Mountain, a low group of volcanic hills, rising but a few hundred feet above the valley, stretches out toward the Virginia Range, and closely connects the intrusive rocks of those mountains with the Sierra Nevada.

Lithologically, these rocks present somê features of interest, as they bear a close resemblance both to basalts and to augite-andesites, and, if classed with the latter, belong more to basalts than to normal andesite. They possess a bright fresh appearance, a conchoidal fracture, a grayishblack color, and a resinous lustre, characteristic of andesite. Scarcely any crystals are of sufficient size to permit of determination by the unaided eye, yet the groundmass is brilliant with faces of feldspar crystals. Under the microscope, the feldspars are seen to be mainly triclinic forms associated with augite. It is evident that the rock is not a true basalt by the large amount of silica present, a quantitative determination yielding 62.67 per cent., which is somewhat higher than is usually found in augite-andesite. As to the position of these rocks in regard to other volcanic outbursts, there is no evidence.

Granite Hills.-Along the western border of the map, lying between the Virginia Range and the California State boundary, occurs a large area of granitic rocks. They extend from the southern limit of the map northward to Honey Lake Valley, a distance of 40) to 45 miles, with an undulating surface, not forming one continuous range, but broken into numerous ridges, separated by irregularly shaped valleys that are now filled by Quaternary deposits. These valleys everywhere show conclusive evidence that they are merely shallow depressions in the great granite 
formation, and that the latter beds are composed simply of granitic detritus from the surrounding ridges. 'To the eastward, this granitic group is topographically closely connected with, but geologically quite distinct from, the Virginia Range, the volcanic outbursts of the latter resting as it were upon the flanks of the granitic body, although rising to a much higher elevation. In their physical attitude, the granite hills present but little that is of special interest, the ridges being long and narrow, of monotonous forms, and showing great uniformity of outline. State Line Peak is, however, an exception to this rule, rising grandly above the surrounding country, nearly 4,(;0) feet above Honey Lake Valley.

This granite may in general be characterized as a compact, dense, medium-grained rock of a prevailing dark-gray color. So far as observed, the rock-masses show no law in the arrangement of the mineral constituents, which usually present a fresh undecomposed appearance. Both hornblende and triclinic feldspars seem to play an important part in the composition of the rock.

In the ridge opposite Spanish Spring Valley occurs a rock which may be properly classed as granite-porphyry, the groundmass being so exceedingly fine-grained that the individual minerals cannot be recognized by the unaided eye, but at the same time it carries well-developed crystals of all essential ingredients of granite. In the rock under examination, quartz, of all the normal constituents of granite, is the least readily recognized, although here and there are some well-defined clear grains. Both monoclinic and triclinic forms of feldspar are well developed; the latter frequently beautifully stratified. The biotite is in general much better crystallized than the hornblende, which is, however, thoroughly disseminated through the rock. Under the microscope, the rock reveals the presence of considerable apatite, and the quartz-grains seem poor in liquid-inclusions. Both of these observations in the microscopical analysis are of some interest, as Zirkel has shown them to be characteristic of the later granites of Western Nevada. It may be added that this rock, in its physical habit, resembles closely the surrounding granite, but is somewhat more compact, from the character of the groundmass.

Just east of Spanish Spring Valley, the granite-porphyry is penetrated 
by a narrow north and south dike of rhyolite, which, inasmuch as such dikes are of a somewhat rare occurrence in granitic bodies, requires a special detailed description. It is found just below the crest of the ridge, standing almost vertically, with the lines of contact between it and the granite-porphyry sharply defined, and showing scarcely any indication of alterations or contact-products. A remarkable feature of this rock is its superficial resemblance to the main body of granite-porphyry, which, however, even a cursory examination dispels, revealing a fundamental difference in the structure of the two rocks. This rhyolite varies from light brown to a dark cream color, possesses a characteristic rough texture, and, under the hammer, breaks much more readily and with a totally different fracture from the granite-porphyry. Small but brilliant sanidin feldspars are the only mineral secretions observable by the unaided eye, which are scattered through a microfelsitic groundmass. To the sonthward of the rhyolite is a dike of black vesicular basalt, also standing at a high angle, and striking approximately north and south. 
NOTE.

Generalized section of sedimentary formations, with the local groupings adopted by the Geological Exploration of the Fortieth Parallel.

In order to enable the reader to readily understand the local names of the different series of strata used in the foregoing report, the following table has been prepared, in which are grouped together all the divisions of sedimentary rocks observed in the region explored, with the geological horizons to which they belong.

The character and relative thickness of each group are deduced from the most characteristic developments which have been studied; and as these are embraced in the wide region lying between the Great Plains and the Sierra Nevada, it will be readily understood that this table does not represent a section shown at any one point. The aggregate thickness given for each of the larger subdivisions is estimated in general from the maximum developments of the individual groups. 


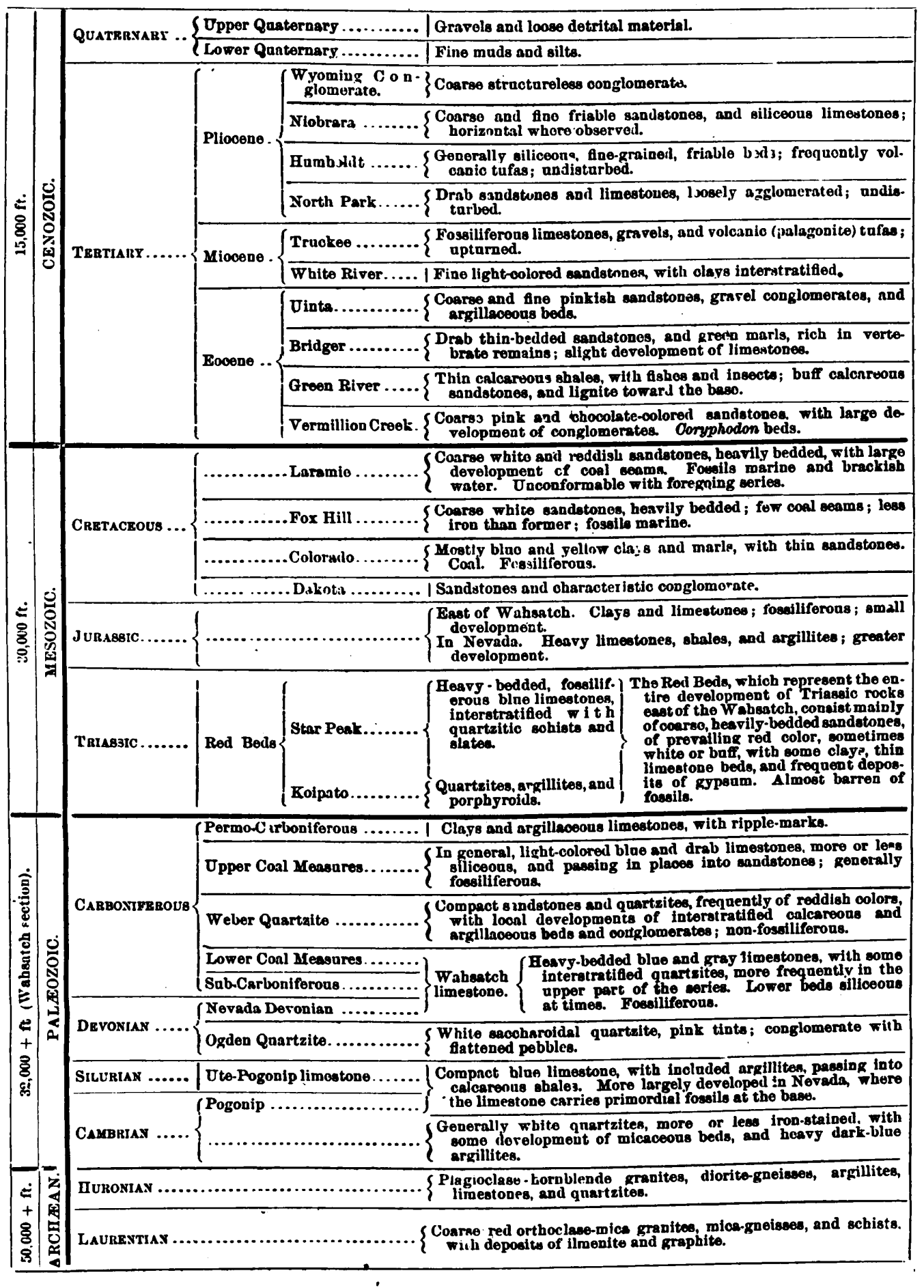





\section{N D E X .}





\section{GENERAL INDEX.}

[Small capitaln denote headings of chaptern, sections, or sub-sections.]

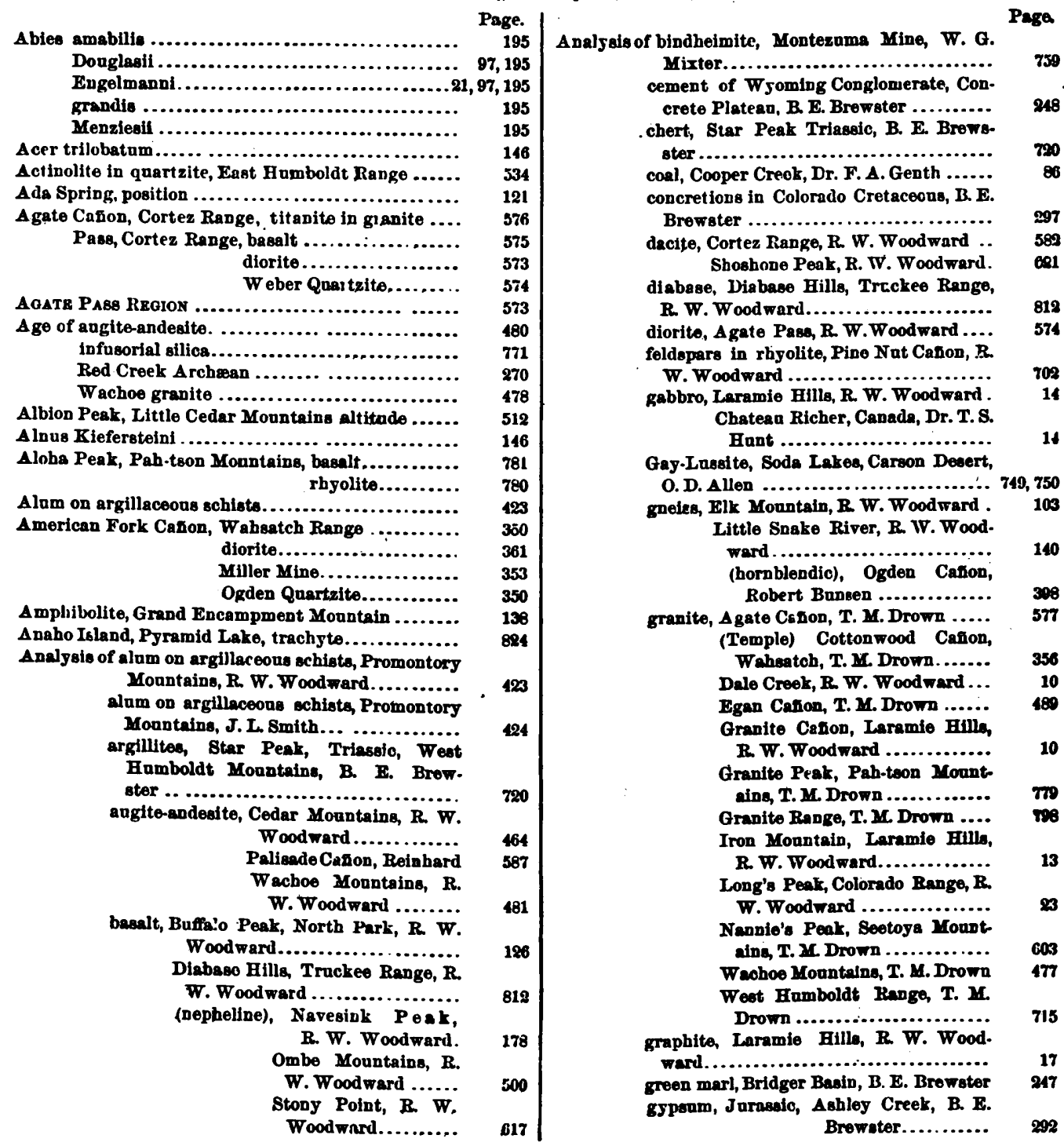


Anslysie of gypanm, Triassic, Ashley Creek, B. E. Brewster.

Laramie Hills, B. E. Brewiter ...

ilmenite, Iron Monntain, O. D. Allen ...... R. II. Richards.. IR. WV.Woodward infusorial silica, Kawsoh Monntains, $\mathbf{R}$. W. Woodward ........ Truckeo Valley, R. W. Woodward.

Iron ore, Palinade CaIIon, B. E. Browater . iron-stone (clay), Elk Mountain, B. E.

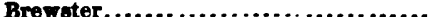
lencite rock, Leucite Eills, Wyoming, $R$. W. Woodward

limestone, (dolomitic), Archæan, Kinsley district, B. E. Broweter....

Carboniferone, Albion Peak, B. E. Brewater Granite Canon, B. E. Brewster Horse Creek, B. E. Brewster .

Hamboldt Pllocene, l'ine Val. ley, B. E. Brewster

Jurasein, eastero foothills, Col. orado Range, B. E. Brewater.

Laramie Plaine, B. E. Brewster ... B... North Park, B. F Brewater...........

IowerCoal-Measure,FastHum. boldt Range, B. E. Brewster

Lower Coal-Measure, Granil

Peak, B. W. Brewster........

I.ower Coal-Merente. Mill Canon, Wahsatch, B.E. Brewster.

Niobrara Pliocene, R.W.Wodward

Oölitic, Green Kiver Eoceno, B.

E. Breweter ..............

Trianalc, eastern foothine, $\mathrm{Col}$. orado Fange, IB, E.

Brewater ...........

Ducbesne Valloy, Uinte Range, B. E. Brewster ...........

Truckeo Valler, I. E. Brewater ........... West Humbold Range, B.E.Browater

Truckee Miocene, Kaw soh Mountains, B. E. Brewster... Truckeo Miocene, Valley Welle,

B. F. Browster. .

Upper Coal.Menure, Parley's

Park, B. E. Brevater .........

Upper Conl-Meanure, Tenabo

Peak, B. E. Browater ........

Upper Coal-Mesonre, Ute Peak,

Dinta Range, B. K. Brewater.

Opper Coal.Measure, Vermil

lion Crcek, B. F, Brevister,.

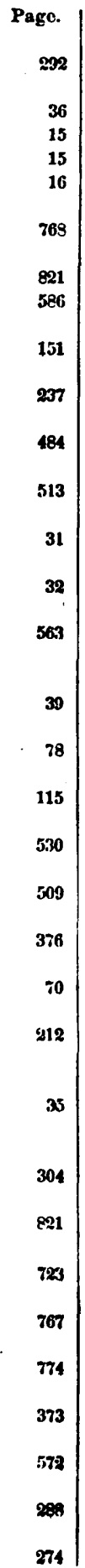

Analysis of limestone, Upper Coal-Mcasure, Wube

Cafion, B. I. Brewater.

Ute, Ute Peak, Walasatch

Range, B. E. Brewater ....

paper-8bales, Green Rircr City, Wyoming

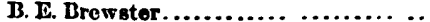

porphyroid, Triasoic, West Humboldt

Range, B. F. Brewater . ................

propylite, Пavalloh Range, Dr. Walter

Korman ......................

Monteznma Ranqe, P. W. Wood ward ...................... Shcep Corral Canoon, Prof. Wit deman................ Storm Cañon, R. W. Woolward (quartz), Cortez Peak, Prof. Wic

deman ............. Mollen's Gap, R. W Woolwarl..........

quartaite, Cambrian, Big Cottonwool, B. E. Brewater. Farmington, Wah satch, B. E. Brew ster ............

Oglen, Ámerican Fork CaIion B. E. Brewster................
Weber, Battle Mountains, Ni. vada, B. E. Brewater. Bear River, Utah. B. E. Brewster ............. Big Cotton wood, Wah eatch, B. E. Brewster.

La Motte Peak, Cinta Range, 13. E. Brewstor ................

Point Carbon, Cinte llange, B. E. Brew ster $\ldots \ldots \ldots \ldots \ldots . \quad 300$ qrartzitic echist, Star Peak Triassic, B. F Brewster..........................

rbyolite, Bayless Cáfon, Joutcznms Range, $R$. W. Woodward ..... Black Canoln, Montezuma Range R. W. Woolward ............. MaKinney's Pass, Pab.Uto Rango, 1i. W. Woodward...... Mopuog Hills, West Inumboldt Rapce, R. W. Woodward...... Mount Moses, Fieh Crenk Moun.

tains, R. W. Woodward ....... Sou Spring Hilts, R. W. Wood-

vard ......................

ealt incrustations, Antclope $\mathrm{V}$ alloy Springs, IR. W. Woodward ..........

Buffalo Spring, O. D.

Allen............... Cortez Valley, R. W. Woodward .......... Graso Valley Bpring R. W. Woodward... Bardin City Flato, 0 . D. Allen............. Enmboldt Valley, 0 . D. Allon ............
Page 389 411 242 72 c7D 765 839 C6I 578 845 367 380 350 
Analysis of salt incrustations, Osobb Valley, R. W. Wondward .........

Peko Station, R. W. Woolward

Percy Station, $\stackrel{\text { R. W }}{\text { W }}$

Woolward ..........

Qninn's River Sink

O. D. Alleu .

Reere River Springs,

I. W. Woolward.

Ruby Valley Springs

R. W. Woodward.

Tıuckeo Desert, O. D

Allen.........

cands, Selt Lake Beach, R. W. Wood

ward

sandstone, bitunivons, Wonsits Ridge, $B$.

E. Brewster

Antero Cañon, $B$

E. Brewster ...

Bridger Eocene, B. E. Brewster.

Dakota Cretaceous, Laramie

Hills, B. E. Brewster

Dakota Cretaceoug, St. Mary'

Peak, B. E. Brewater ........

Triassic, Ducliesne Valley,

Uinta. B. E. Brewster........

Triassic, Weber Cañou, B. E.

Brewster .....................

ainter, Steamboat Springs, R. W. Wood wril

surface-soil, Jordan Valley, R. W. Wood ward ..................

Deep Creok Valler, R. W. Woodwaid ................ Great Desert, Dugway Sta. tiou, R. W. Woolward

Great Desert, Whito Rock Pasa, R. W. Woodward ....
Tertiary, Brown's Park, B. E. Brewster... trachyte (angite), North Park, R. W.

Woodward :

Sheep Corral Canon.

Dr. Anger ...........

Truckee Ca ñon, R. W.

Woodward.......

Euclid Peak, R. W. Wuodward

Pino Nut Cañon, R. W. Wood

ward .

Proro and Silver Creek Divide,

I. W. Womisard

Slater's Fork, Elkhead Moun.

tains, R. W. Woodward

Truckee Cañon, R. W. Wood.

wnrd ...................

trona, Large Sodia Lake, Carmon Desert,

O. D. Allen ................

Small Soda Lake, Carann Lesert,

O. D. Allen

tufa, Lake Boueeville, Reddiug Spring,

R. W. Woodward.

Lake La IIontan, Carson Desert, $R$ W. Woodwarl .. Pyranid Lake, $\mathbb{R}$. IV. Woodward ..

Page. 304 390 826 494 474 467 467 22:3 125 838
Apalysis of tufa, Lake La Hontan, Truckeo Valley, $R$. W. Wondward ..................

Medway Spring, Provo Valley, R. w. Woodward (palagouite,) Dyampaug-Kulon, 0. Pı̈̈lse................ Galapagos Islanda, Rob-

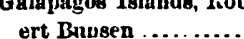
ort Busen ............
Hawes' Station, Nerada R. TV. Woodward .....

Icelaud, Robert Bunsea.
vater, Atlantic Ocenn..................... Dead Sēa...................... Hot.Spring, Salt Lake City, Dr. C. T. Juckmon ................... Huwboldt Lake, O. D. Allen....... Mediterravean Sea............... Oroomiab Sea, Pereia ............. Pyramid Lake, 0. D. Allen ........ Sevier Lake, Utah ............... Great Salt Lake, $\mathrm{Otah}$, O. D. Al len .......................... Sodla Lake, Carmon Demert, O. D.

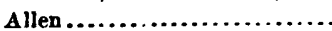
Sou Hot Springs, 0. D. Allen ......

Page.

819

31!

770

768

770

430

40

138

743

1.50

436

433

747

705

Andesite (aupite), age of . Andie Creek ................... 588 Antiuony Cañon................. C5 Angusta Cañon................... 65 Cedar Mountains........... 4 G3 Jacob's Promontory ............ 641 Palisnde Cafion (quartziferous) ... 586 Peavine Monntain ............... 83 Spring Gañon (montb) ........... $\$ 80$ Susen Creek ................... 598 Trackee Cafion.................. 8.0 Tuscarora..................... 611 Anguta Cafion ........................ C53 Berkshire C.ñon ...................... B41 Carlin Peaks......................... 5z8 Cellar Mountains ...................... 16. Clan Alpive Cañon .................... 640 Crescent Peak........................... Deep Creek Valley ...................... 175 Egsptian Cofion . Kampana Muntaing North of Wagon Cabon................. North of Wagon Cabon................ quartz in ............................. $\quad \mathbf{4 4 0}$ (a) Tuscarira ........................... $\quad 610$ Anglesite West Humboldt Range................. A ito Peak, Elkbeal Monntains, columnar besalt.. • 170 magnetic attraction of jasalt........... 179 Annie Creek, Cortez Ranga, angite-a ndesite........ $5 飞 8$ Antoine's Canion, Virgivia Rango, rhyolito .......... E2S. tridymite in rbyolite............ 8.830 Axtelope Hills and Schell Creek Mountaive.... 483 Antelope Island, limestove in Archean ........... \$25 Pcak, Montezuma Range, sltitude ........ 751 Springs, Promontory Monutains.......... 422 Valley, Thermal Springs ............... Antrro Caffon, Uints Range, bituminous sandstone.. 299 exposare of Mesoxuic 
INDEX.

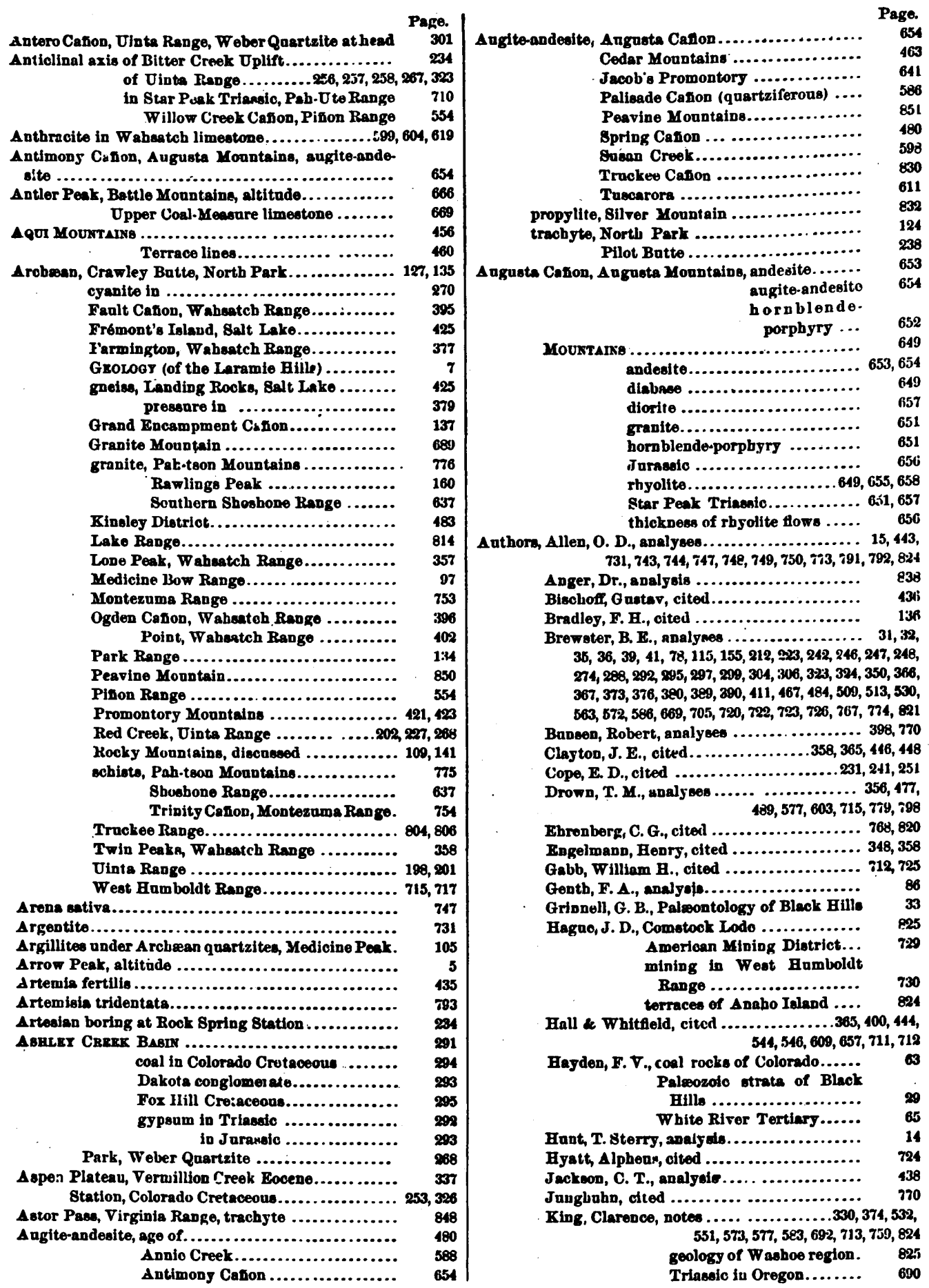




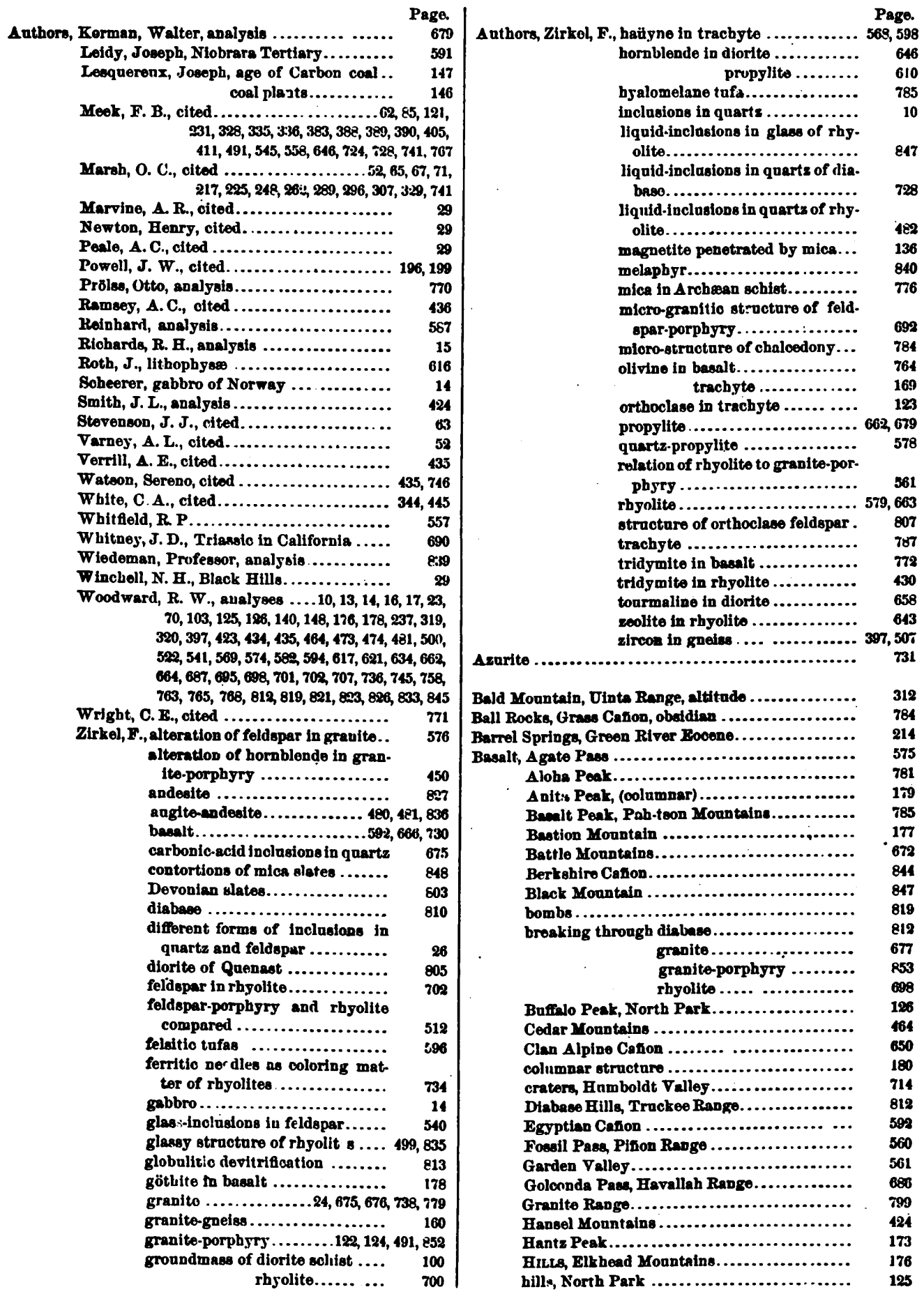




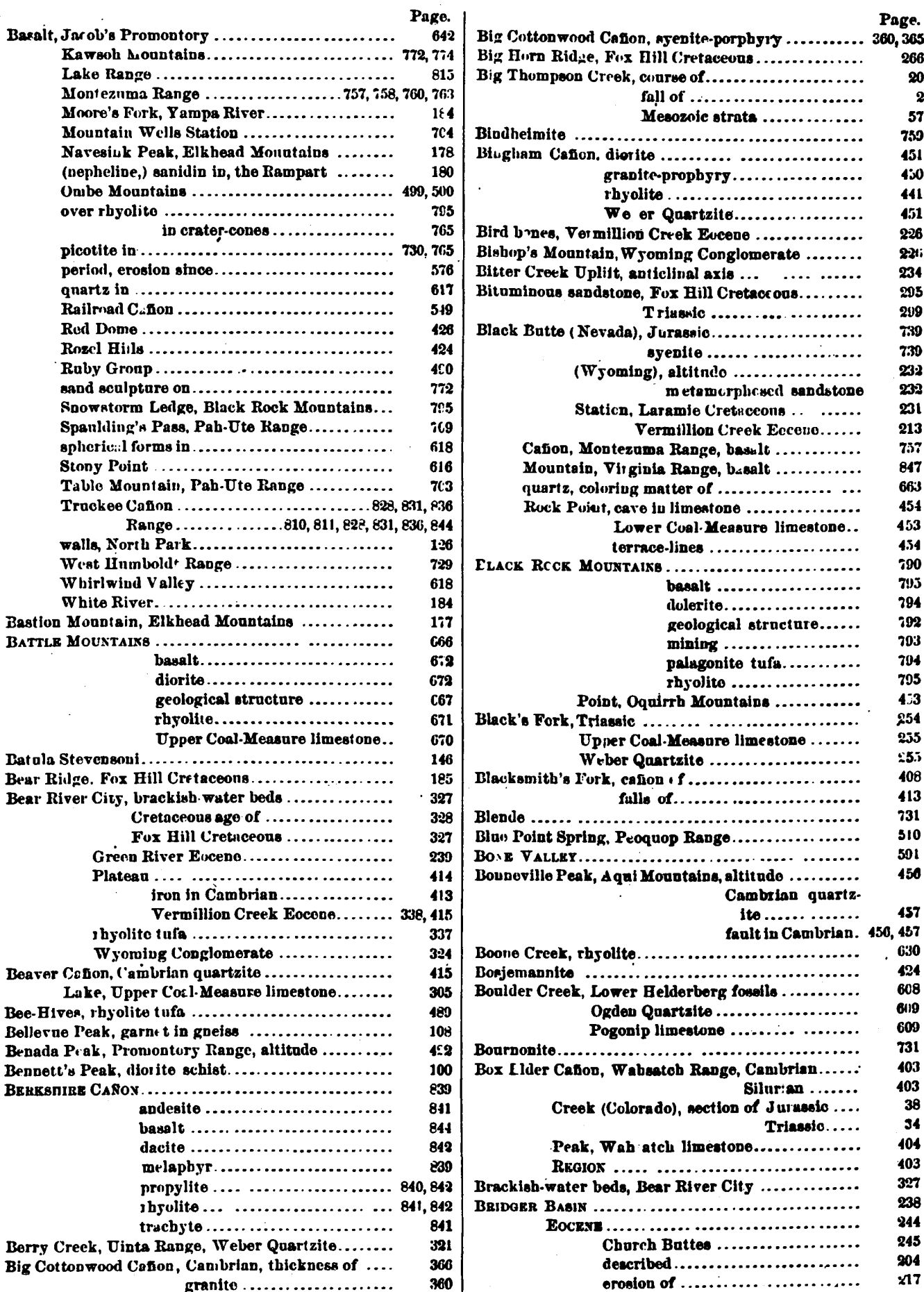


Buidger Eocono,

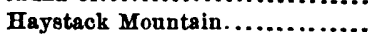

moss agates in ...................... thickners of................. 204, 217, 945

Pass, Fox Hill Cretaceous.................. Regios...............................

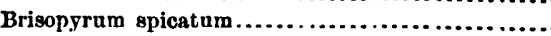

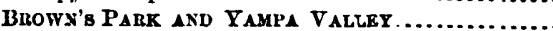
altitude described fault in Tertiary ..................... origin of $201,202,272,282$ Tertiary, Pliocene fossils ............ thick ness of Yampa Valley

Bruin Peak granite

Brush Creek, Medicine Bow Range, hornblende schist ....

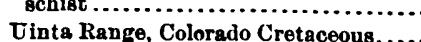

Buffalo Peak, Weet Humboldt Range, altitude..... North Park, described

Burro Peak, Weber Quartzite

Cache-la-poudre River, conrse of

Cache Valley, Humboldt Pliocene ...........406, 417 sandstone for building ................. terrace-lines

estode........

Cambizlax Formation, Big Cotton wood Cañon...... Beuver Cafion Bonneville Peak.

Bex Elder Canion. Cambrian Platenn.

City Creek Canon .............. conglomerate in ............399, 457,

Egan Canon. Grantrille Peat, anti.......

Muddy Canon, shale

Pinon Range .

Pogonip Ridge, White Pino

Schell Creek Mountains ..... Uinta Range .................

Cambrian Plateat................................ Camel Peak, Elkhead Mountains, red gneiss ........ 140, 175

trachyte......... 172

Camp Floyd, Carboniferous fossils ............... 148

Canon of Yampa River ........................ 284

Cañon-within-cañon structure..................... 301, 302

CARBON Ba

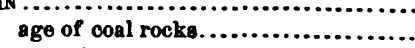

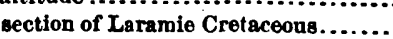

in clays of Colorado Cretaceous

in Star Peak Triassic.

Carbonate of copper, Kinsley district

Carbonic açid in quartz of granite

Carboniferous limestone, Cheyenne Pass :............

Elk Mountain..............

North Park.

Sybille Creek .................

sandstone, plant remains in .........

Carico and Railroad Peaks

Curico Valley, rhyolite tufa .......................

Carlin Perks, Cortez Range, andesite

rhyolite
8

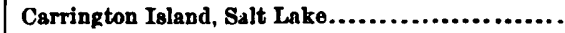

Carr Station, Colorado, Coal strata..................

White River Miccene .......

Cargon Degert

Lake La Hontan terraces.............

Lower Quaternary................

Truckee Miocene.

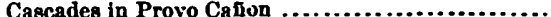

Cathedral Bluffe, section of Vermillion Creek Eocene.

Castle Peak, Wachoe Mountains, quart z-porphyry .

Wahsatch lime-

stone............

Cave in Wabsatch limestone, Black Rcck Point....

Cave Spring, East Hnmboldt Range.................

Cedar Mountain, diorite schist......................

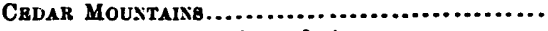

augite-andesite...................

basalt.

Central Peak, altitudo ..................

Cercocarpus ledifoling . 487, 509

Cerngite

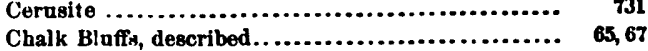

Chalk Creek, Colorado Cretaceons .................. 330

Chalybeate Springs ............143, 233, 401

Changes cf level in Salt Lake ..................... 432

Chataya Peak, Pah-Ute Range, altitude...............

diorite .............. 699

mics-diorite ........

Cherukee Butte, Medicine Bow Range, granite........ 102

gray gueiss.... 10: 10:

rounded quarts

in granite...

Ridge, Green River Eucene................ 218

Chejenne, eltitude.............................. 3

Pass, Carboniforous limestone ........... 76

Chicken Soup Spring, klko Valley .................

Chlorite in gneise, Deer Monntain ................. 101

Elk Mountain................. 10:3

Park Range...................... 140,141

Chokup Pass, Diamond Range.................. 549

Chrysocolla....................................... 498

Chugwater, described............................. $\quad 70$ section of Trisesic ...................

Church Buttes, Bridger Eocene................... 245

Cinnam onum Mississipplense..................... 147

Citadel Peak, Raft Riror Monntains............... 428

City Creek, Waheatch Range, Potedam .............. 377

tridymite in trachyte $\quad 375$

Vormillion Creek

Eocene ........... $\quad 875$

Clan Alpine Cañon, Augasta Mountains, andesite... G.. G19

basalt ...... 650

Clark's Paak, Medicine Bow Range, granjolite... 650 granite.......... 98

Clay-irunstone in Fort Benton Group.............. 87, 88

Clayton's Peuk, Wabsatch Range, altitude.......... 353

garnet in Archren $\quad \mathbf{3 6 0}$

granite......... 359

granite porphyry. $\quad 301$

Weber Qnartzite. 373

Clear Creek Cafion, Havallah Range, granito ....... 678

Cluro Hills, granite ............................ s84

rhyolite ..............................

eyenite ............................. 58

$55 \mathrm{D} G$ 
Coal Creek, Seetoys Mountains, Wahsatch limeston6.

in Colorado Cretaceous .. ....... 85, 86, 252, 327, 33 ...244, 455, 498, 595, 60 Laramie Cretaceous...........61, 62, 64, 146, 164, 230, Truckee Miocene . 231, 232, 233, 234, 276, 279, 330. 339

Measure fossils, geographical distribution ....

Mountain, While River divide, Laramie Cretaceons ...

of Carbon Basin described

Cosivillo, Itab, Colorado Creteceone...co.

Colorado Creteceons, Aspen Station

Bellevue Peak (east of ).........

bi nminous sandstone in ......

Brush Creek.

carbon in clays.................

coal in

Cosiville .

concretionary sandstone in . .83, 156, 297

Deadman's Spring

dinosanr in

Bast Cañon Creek

Llk Mountain

Elk River...................... 182

flishes in ...................89, 296, 326

gypsum in...........50,54, 81, 156, 159

limestone in ..................

Medicine Bow Range, east base 84, 85

North Park..................

of thr Colorado Ravge....

Oyster Ridge ..................

petrolenm in ................. 252, 32

railroad cat near Miser ........

Red Creek Vulley..............

sanian teeth in.

Sheep Mountain (east of).....

Stove's Fork

Sulphor Creek, anticlinal ......

thicknese of ..............28, 43, 116, 20

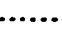

turtes in

Uinta Range..................

Vermillion Cruek Valley......

Colorado Rakgr................................ Colorado Crotaceous base, Furt Benton Group........ Fort Pierre Gronp... Jurassic limestone... limestone in Triasele. thickness of strata ex. posed ................ thickness of Palæozoic strata.

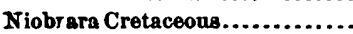
garnets in Archæan...............

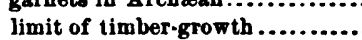
limit of timber-growth .............................. mica schist. .

prophyry dikes......................

Coloring matter of litholdal rbyolites ............. 698, 846 Culumnar structure in bakalt ................... 179, 180

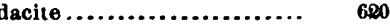
rh solite................761, 296, 830 trachyte.................. 171
Como Anticlisal, Dakota Cretzceous............ 91,92 Como Lake described ......................... 90, 92 Ridge described $. . \ldots \ldots \ldots \ldots \ldots \ldots \ldots \ldots \ldots, \quad 90, \ldots$

Jurassic ............................ section of Meeozoic................... 91 Concrete Platean, Wyoming Cunglomerate........ 247 Concretionary sandstone in Colorado Cretaceous . . 84, 156, 29 ? Conglomerate in Cambrian..................... 399 Connecticnt diabare............................ 728 Convor Peak, Oquirrh Mountains, Upper Coal-MeasConoidal struct are in granite..................... 356, 619 Cooper Creek, Fox Hill Creteceous.................. 86 Lake described........................ 7t Copenhagen Valley described..................... 118 Copper vein, Battle Mountains.................. F71 Cohtez and Pappoobr Prak Regiox............. 577 Cortez mining district ......................... 5

Peak, quartz-propylite.................... $57 \%$

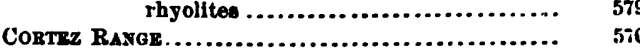
andesite $\ldots \ldots \ldots \ldots \ldots \ldots \ldots \ldots \ldots \ldots \ldots \ldots \ldots \ldots \ldots \ldots \ldots \ldots \ldots \ldots \ldots, 586,588$ basalt $\ldots \ldots \ldots \ldots \ldots . .575$ dacite............................ 5t1, 582, 584 diorite ............................ 571, 573 granito ............................. 576 propylite.......................... 610 quartz-propylite.....................5 577, 550 rhyolite $\ldots \ldots \ldots \ldots \ldots \ldots \ldots \ldots \ldots .579,585,589,612$ syenite-propbyry................... 58.5 thickness of Palmozoic ................ 575 t achy to.........................580, 585, 587 Cotton wood Cañons, Wahsatch Range, glacial erosion 354, 356 Rrolov Cnyote Canon, West Humboldt Range............ 719, 721 Crater cones, basalt orer rhyolite.................. 665 Crawford Pass, Peoquop Range, anticlinal.......... 510 Crawley Butte, Nortb Park, Arcbæan............ 127, 135 Crescent Peak, A ngusta Mountaing, an jesite ........ 652 Elkbead Mountains, trachyte ....... 1i Cretaceous age of Bear River City deponits........ 32. between Uinta and Wabatch, etructure. Plains of Colorado ................. 58 Rkgiox frox Como to Siparation .... 149 thickness, Uinta Range ................ 200 UYLIFT OF BITTR CREEK.............. 227 OYgter Rivge............. 250

Crow Creek described ........................... 52 Croydon, Dakote conglomerate.................. 391 Crusoe Canou, Pah-twon Mountains, Archæan granite 776 Curlew Vallex ............................ 425 Cyanite in Archæan, Red Creek .................. 270 quartzites, Medicine Bow Range........ 104

Dacie Cañon, Fish Creek Monntains' rhyolite....... 664 Dacite, Berkshire Ganon ........................ 843 columnar struoture ....................... 6:0 Cortez Range .......................... 582 dihexahedral quartz in................... $\quad 680$ Kamma Mountains....................... 787 north of Wagon Cañon .................... 584 Pappoose Peak, Cortez Range............. 581 Sheep Corral Cañon..................... 839 Showbone Peak 
Dagota Cretacrous. Colorado Range..............

(conglomerate), Asbley Creek Croydon .......
Hantz Piak... Hautz Piak...
North Park.. Rawlinge Peak Como anticlinal ............... eastern foot-hills, thickness of Elk Mountain.

ferruginous of gregations in.. Flaming Gorge Ridge........ Fort Sanders.

Laramie Plains

Mountain Dell Pass .............

North Park

Parley's Cañon ................

eection in Colorado...........

Sheep Creek.................

Valley of Burnt Fork ....... 250,264

Vermillion Creek Valley ....

Yampa River

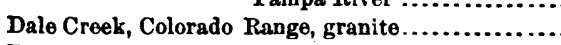

Dalton Peaks, Cortez Range, Weber Quartzite.........

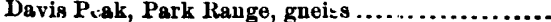
liquid carbonic acid in

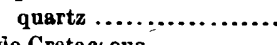

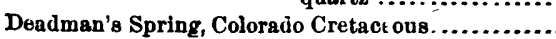
Vermillion Creak Eoceno........

Dead Sea. .

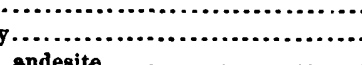

Humboldt Pliocene..............

Deer Canon, rhyolite.

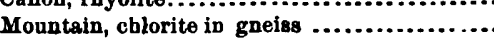
gstrnet in gneise

Delessite in feldspar-porphyry

Density of water, Salt Lake.

Degatoya Mouatalss .........................

D

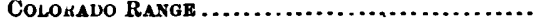

Descript.ve Geology, (Unta) Mountain Region..

Desert Butte, rhyolite. terrace lines . tridymite in rhyolite. .

ap, lithophysw in rhyolite................... rhyolite

Degert Region

Devonian, Furest City, American Fork Cairon ....... limestone, Egan Range ................... Oquirrh Mouutaing...

Piñon Range.

8.........................

White Pine.
Devil's Slide deecribed

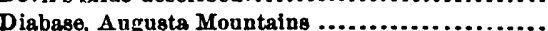

Connecticut Valley ........................

Diat ase Hills ..........................

fragments in rhyolite

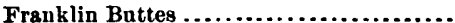

Granite Mountain, Pah. Ute Range ..........

Miner's Cañon, Truckee Rango

pyrites in

Tatib Peak, Truokee Range.

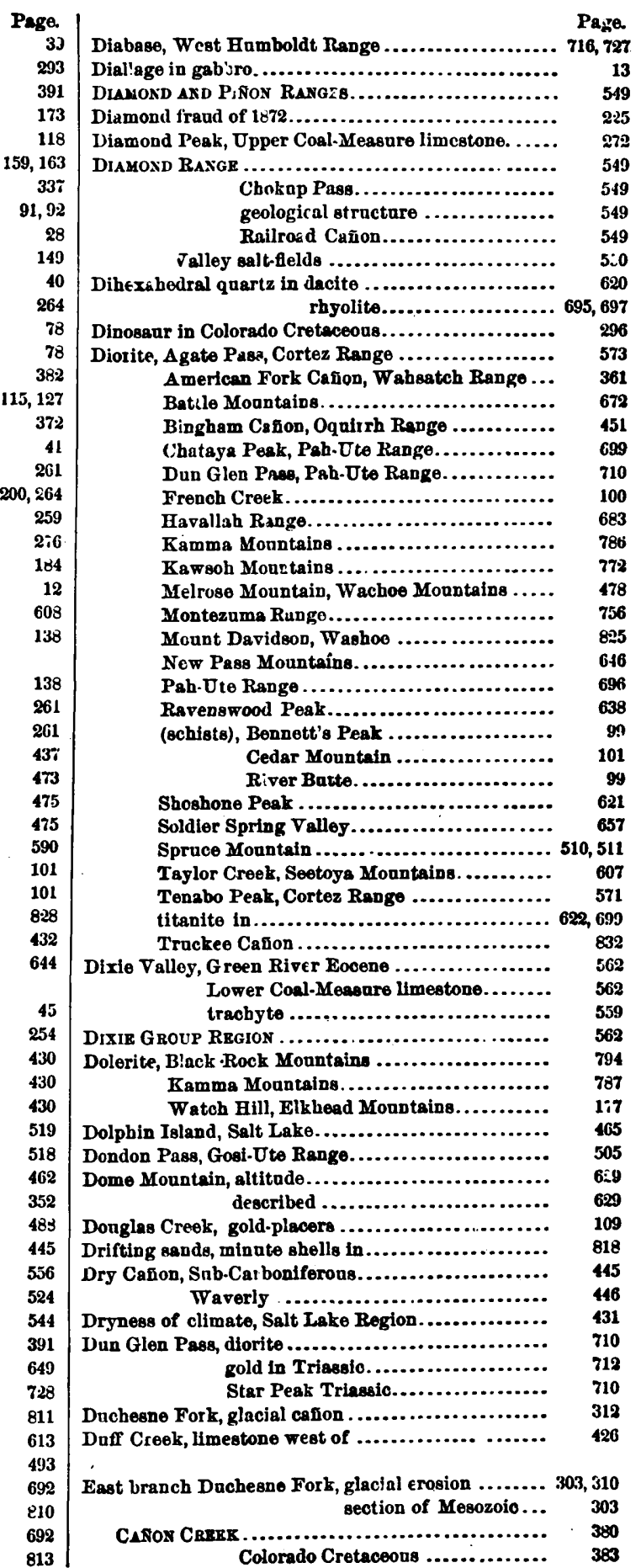




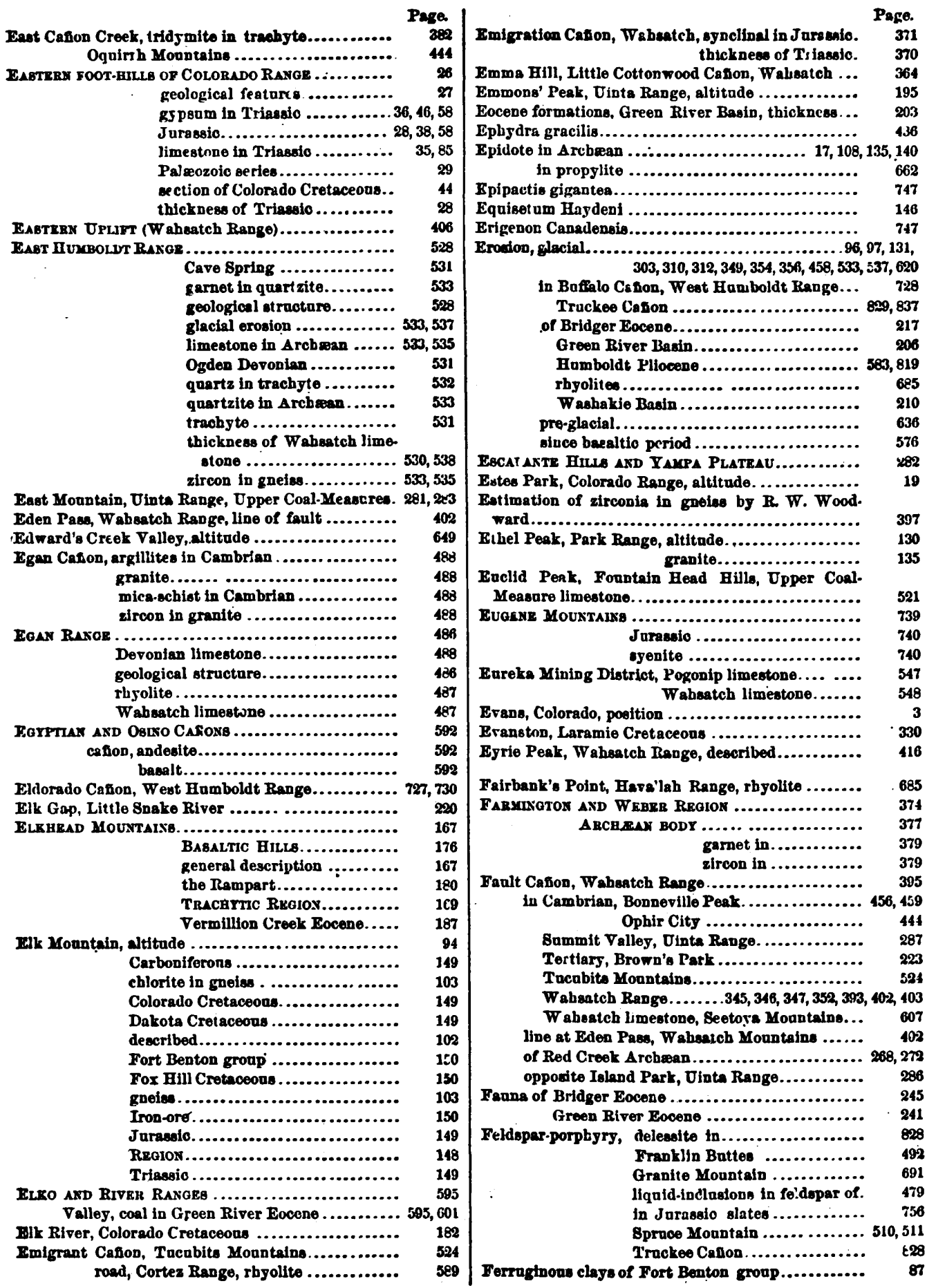


INDEX.

Fermginous segregations in Dakota Cretaceous.... Ficus tilimefolia

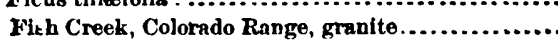
MOUNTAIN8.

$$
\begin{aligned}
& \text { granite } \ldots \ldots \ldots \ldots \ldots \ldots \\
& \text { Koipato Triassic.............. } \\
& \text { propylite } \ldots \ldots \ldots \ldots \ldots \\
& \text { rhyolite } \ldots \ldots \ldots \ldots
\end{aligned}
$$

sapidin in basalt .............

wcales in Fort Benton group....................

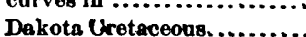

gypsum in Jurassic ...........

Tria

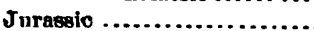

section of Mesosoic ...........

Permo-Carboniferoue .........

Triassic.

Flat Rock Point Spring .

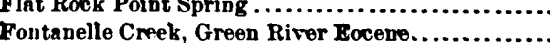

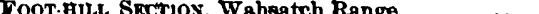

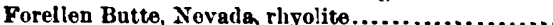

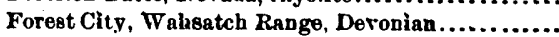

Forman Mountains, columber rhyolite.

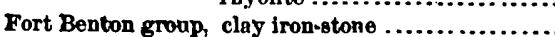
eastern foot.hills Colorario Range.........................

Elk Mountain ....................

ferruginous clays . ...............

Gsh-ecsles in....

Laramie River.

(n).............

reareg in

Rock Creek

enndstone for building

Fortification Peak, Yampa Voiloy nepheine baselt.

Fort Pierre claye, Little Laramie basin gronp, eastern foot-hills, Colorado Range

Sanders, Dakota Cretaceous

Steule, Fox Hill Cretaceons .

Fosilis, Acerrularia pentagons

Acrochordiceras Hyatti.....................

Agnostus communis .

Agnostus prolongus

A gnostus tumidosus ........................

Agriochwerus pumilis

Aletornis nobilis......

Alveolites multiseptatus...........................

Amia Newberrianus

Ammonites

$24,229,253,326,724,726,728,729,731$

Ammonites Billingsianns ................... 615

Ammonites Blakei .............645, 646, 719, 724, 725

A mmonites Homfrayi..................... 712

Ammonites lobetas........................ 63

Amnicole... ........................... 454

Anchippodus minor...................... $\quad 249$

Anchara ................................ 63

Anchura fusitormis ...................... 335, 336

Ancylus undulatus ....................... 767

Anisomyon sexsukatus.

45,56
Page 1 Page

Foesilo, A nomia gryphorhynchns..... Rage.

Anosteira ornata.......................... 249

Antherophagus prisous..................... 218

Arcestes Gabbi ............................ 721

Arcestes Nevadensis....................... 724

A rcestes perplanus ...................... 724, 725

A rehoocidaris ............................ 452

Asineops squamifrons.................... 242

Asineops viridensis ........................ 242

A starte .................................

Athyris Clartoni ......................... 365

Athyris ivcraseats .......................... 670

A thyris planosulcatus .................... 365 Athyris Roissyi......................t78, 487, 490, 508

Athyris sinuat ............................ 548

Athyris subquadrats..................... 447

A 1 hy ris subtilita ...33, 53, 76, 289, 300, 347, 349, 364, 385,

$389,422,451,490,504,508,509,522,526,509,547,548,600$

Atrypa nodostriata....................... 565

Atrypa ret:cularia .........524, 544, 545, 557, 558, 565, 600

Anlopora ................................

A ricule cancellate ..........................

A vioula Homfrayi ........................ 725

A vicula Nebrascane ........................ 6

A viculopecten ..................347, 368, 389, 404, 420

A ricnlopevten A ugustensis................. 657

A viculopecten catactus ..................... 546

A viculopecten curtocardinalis .............. $\quad 370$

A viculopecten McCoyi........................ 370, 389

A vicnlopecten occidenous ................... $\quad 389$

A viculopecten occidentalis................... 359

A viculopecten purvula...................... 370

$\Delta$ viculopecter Weberenais.................. 370

Axines ................................... 85

Axines Wyomingensis.....................

Baculites..................................153, 185, 271

Baculites ovatus ........................45, 49, 83, 117

Bakuvellia ................................. 342, 373

Bgkevellia parva ........................... 305

Baptemys Wyomingensis .................. $\quad 249$

Buthyarus Pogonipensis ................... 543

Belemnites................................. 163

Bekemnites deneus .....................91, 92, 262, 293

Bolemnitos Nevadendis..................... T280

Bellerophon ..............................76, 291, 530

Bellerophon carboenarioe.............274, 285, 291, 528

Bellerophon nelens ...................... 545

Bosvus occidentalis ........................ 250

Brontotherium gigas........................ 67

Brontotherium ingens....................... 67

Bubo leptostens........................... $\quad 249$

Cellists Deweyi............................ 45,56

Camarophoria............................. $\quad 338$

Cumpeloma ............................... 328

Cempeloms macrospira .................... $\quad 328$

Campophyllum..................487, 508, 550, 609, 670

Camptonectes ........................... 2

Camptonextes bellistriatas.................163, 262, 265

Cardium $\ldots \ldots \ldots \ldots . . .228,293,727$

Cardium curtam ......................... 336

Cardinm panpercalum .................... $\quad 252$

Cardiam speciosnm ...................... 63

Cardinm subcurtam ....................... 335

Carinifex Binneyi........................ $\quad 266$

Carinifex Trojoni ........................ 768 


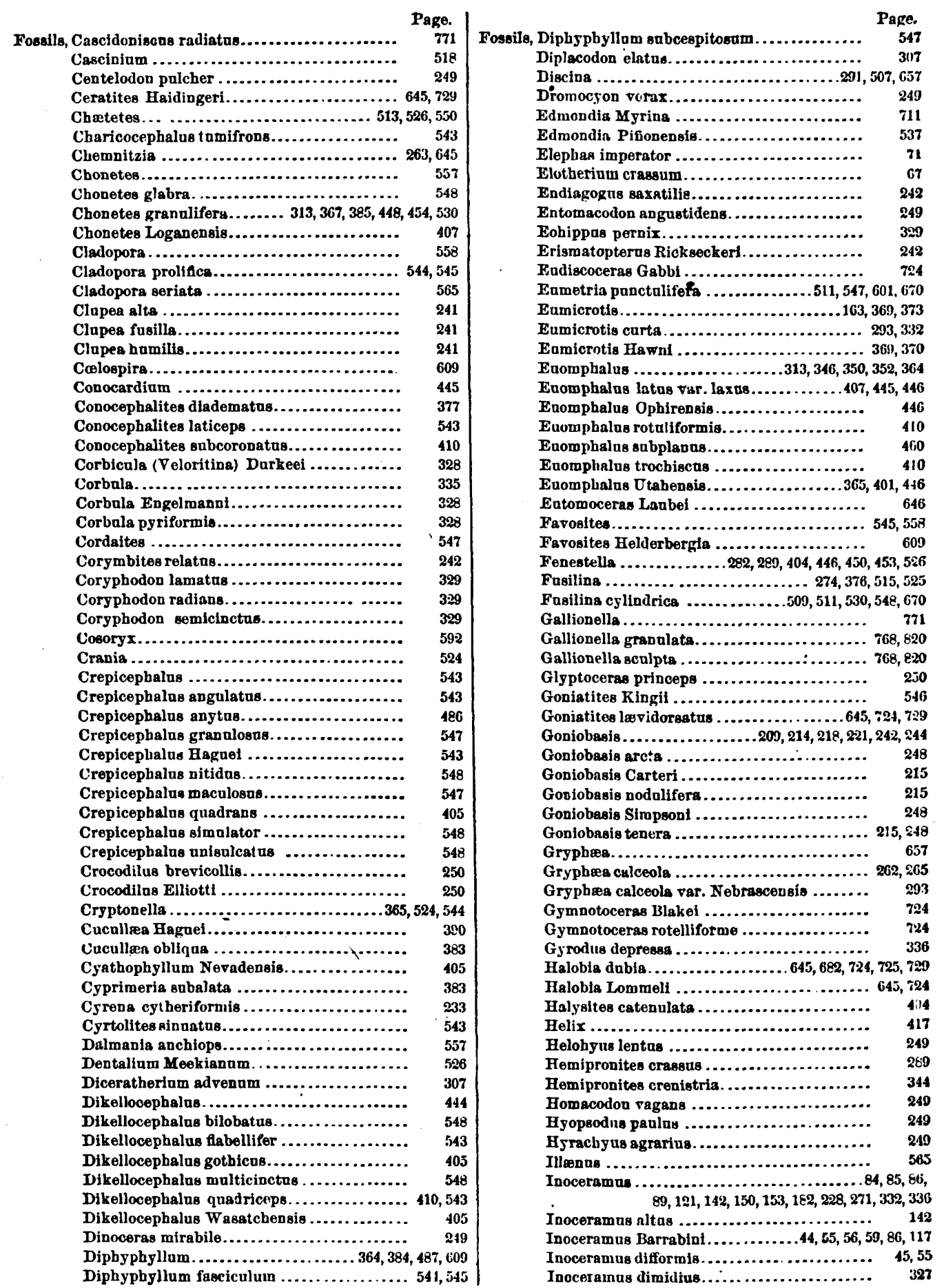


INDEX.

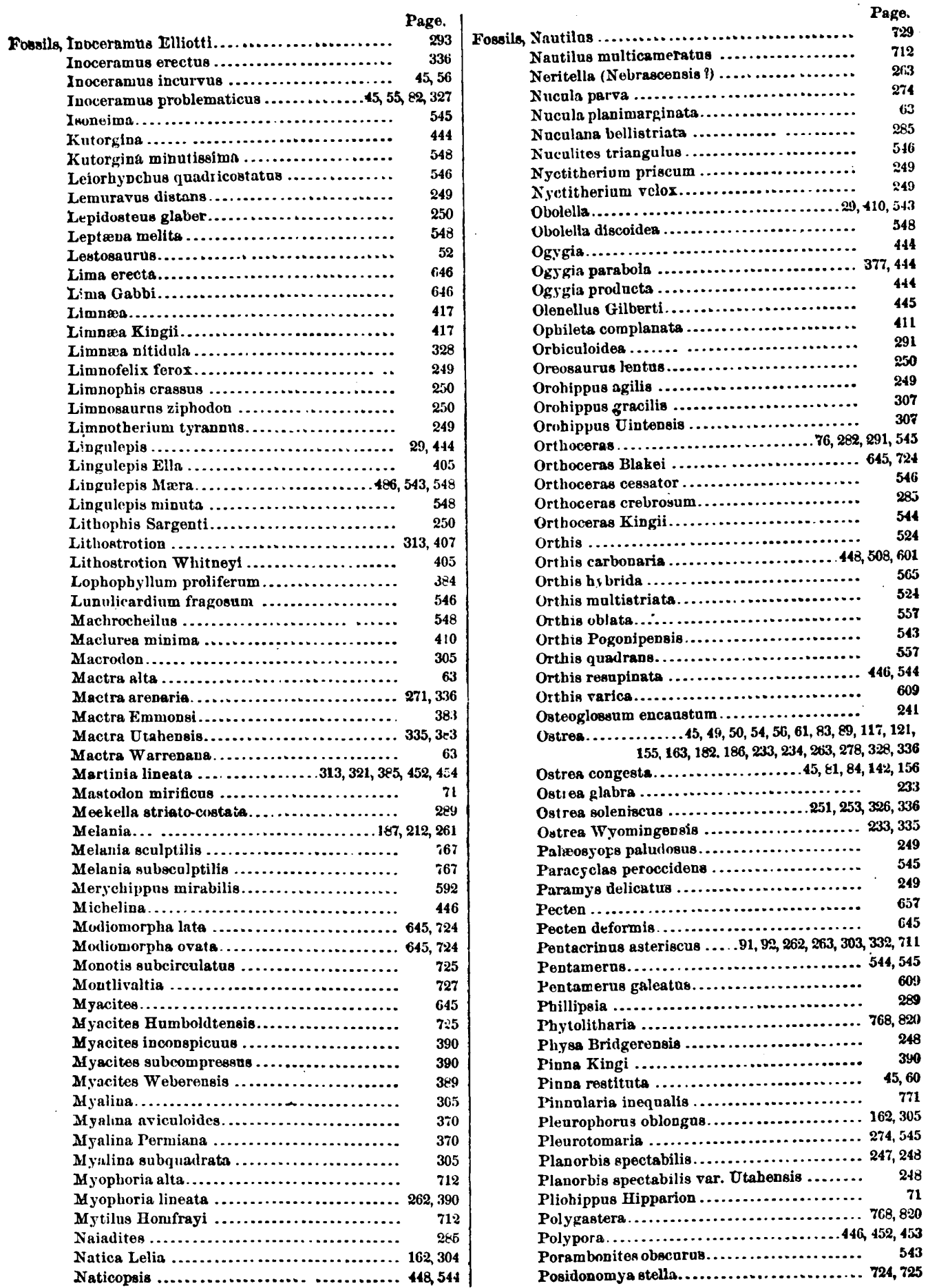


Page.

Fowells, Productas ..............................162, 289, $305,350,352,400,404,407,452,505,51$ Productus cora ..............33, 53, 76, 77, 353, 405, 548
Productus costatus...........76, 511, 539, 547, 548, 550 Productus costatus............76, 511, 539, 547, 548, 550 Productns Flemingi var. Burlingtonensis ... $\quad 446$ Proluctus levicostatus .................. 446 Productus longispinus ..........454, 508, 538, 547, 562 Productus multistriatus ................448, 487, 490 Productas Nebrasceneis............ 347, 367, 454, 490, $508,511,518,530,547,548$

Productus pertennis ...................... $36 \mathrm{it}$ Productus Prattenianus.......... 33, 76, 77, 255, 344,
$386,422,448,450,453,513,547,550,600,670$ Productus punctatus..........346, 353, 405, 486, 497, 508 Productus Rogersi $346,353,405,486,497,508$

Productus semireticulatus ..................33, 49, 76, $321,353,368,423,446,450,453,490,507,508$, $511,538,546,547,548,550,562,600,605,670$

Prodnctus semistriatus

Productus subaculeatro.................544, 545, 548 Productus subhorridns....368, 478, 487, 491, 513, 522, 600 Productus symmetricus ..................367, 385, 600 Productue Wortheni ......................... 547 Proëtus Loganensis ......................... 407 Proëtus peroccidens.....................401, 407, 446 Protohippus parvulus................... 71 Protobippas perditas ..................... 591 Pseudomonotis.

Psendomonotis redislis..................... 526

Pteria (avioula) .......................... 645

Pterinea ................................ 545

Ptychaspis ............................. 543

Ptychaupis pustnlosas

Ptychophyllam infandibulam.............. 544

Ptypora.................................. 404

Pupa Leidyi .............................. $\quad 248$

Pyrgulifera hnmerosa....

Raphiatoma acuts ............. 411, 543

Rhytiphorus priscus ..................... 328

Rhyncbonelle.................526, 557, 565, 609, 724, 731
Rhyucbonella wquiplicats .................. 712

Rhynchonells Emmonsi................... 544, 545

Rhynchonella lingulata .................. 725

Rhynchonella Osagensis ................... 448

Rhynchonella pustuloss.................... 407, 446

Rhjnchonella Utahensis .................. 369

Scaphites nodosus......................... 45,56

Scaphites Warreni...................... 142

Sciuravns nitidus........................ $\quad 249$

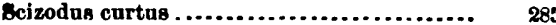

Scizodus ovatus........................... $\quad 389$

Scolithus................................. 413

Sedgwickis concava....................... 274, 370

Septocardia Carditoildea................... 657

Septocardia typica ........................... 657

Smithia Hennabi ........................ 545

Bphørs Whitneyi ......................... 724

Sphæram Idahoep*e.............. 76

Sphørum rugowam ..................... 767

Spirifer......289, 305, 346, 368, 404, 442, 452, 530, 557, 558 Spirifer albapinensis ... .......346, 365, 400, 407, 446, 545 Spirifer alia.

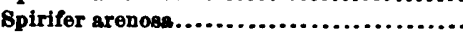

Spirifer argentarius.
Fossils, Spitifor cameratas................289, 290, 349, 352, $364,365,368,450,497,507,508,526,547,600$ Spirifer centronatus ..........33, 346, 365, 400, 407, 446 Spirifer disjonctus...................... 364, 546 Spirifer Engelmanni .................... 545, 559 Spirif or imbrex ........................ 323 Spirifer Leidyi ........................... 4417

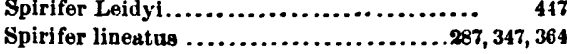
Spirifor octoplicatus ...................... 368 Spirifer opimus ...................... 287, 343, 346, $353,385,386,422,447,448,450,453,504$

Bpirifer Pifionensis ..................... 55 Spirifer planocnnvexus..................... 364,547 Spirifer Rockymontanns ................. 547, 550 Spirifer etiger .......................... 447 Spirifer striatus ........................ 447,547 Spirifer otrigosus ........................ 558 Sptrifer Vtahensis ....................... $\quad 558$ Spirifer Vanuremi....................... 524 Spiriferina Homfrayi ..................645, 711, 725 Spiriferina Kentuckensiø ...............284, 3e5, 526 Spiriferina pulchra ................321, 368, 490,518 Spiriferida apinose ...........................547, 530 Spirigera obmaxima ..................... 445 Spongolithis acicularis................768, 771, 8:0 Streptorbjnchus....................... 422,546 Streptorhynchus crassus.......300, 385, 448, 518, 550, 601 Streptorbynchus crenistria...........347, 353, 453, 547 Streptorhynchus equivalvis ................ 401

Streptorbynchus inequalis ................. 40

Streptorbynchus inflatus.................. 446

Streptorhynchus robusta................... 448

Stromatopora ........................... $\quad 400$

Strophodonta canace ...................... 54 t

Strophodonta punctulifers .................. 609

Strophomena Nemia ...................... 543

Strophomena rhomboïdalis ................. $\quad 440$

Stylinodon mirns ........................ 249 Syringopors .....................289, 313, 364, 409, 539 Syringopora Macluril .................... 545 Syringopora multattenuata...........313, 314, 513, 605 Talpavns nitidus.......................... 240 Tancredia ................................ 299 Tancredia Warrenana..................... 91

Tellina isonema......................... 336, 383

Tellins modeste

Terebratula........................... 547, 645

Terebratula Augasta ..................... 657

Terebratnla bovideos ...................... $\quad 386$

Terebratula Bumboldtensis................ 711, 725

Terebratula Utabensis ..................... 365

Thinossarns leptodus...................... $\quad 250$

Tillomys senex ........................ 248

Tillotherium fodiens..................... 219

Tinoceras anceps ......................... 249

Trachyceras jadicaricum .................. 724

Trachyceras judicaricum var, subasperum. $\quad 724$

Trachyceras Whitneyt................... 724, 729

Trematopor a ..................453, 511, 522, 526, 548

Trematospira ............................. $\quad \mathbf{6 0 9}$

Trigonia ................................ 263

Trigonis quadrangularis................... 91

Trionsx gnttatus ........................ $\quad 249$

Trypodendron impressus ................... 248

Uiutacyon odax. ......................... $\quad 240$ 
Page. Uintatherium robustum

Uintornis lucaris........................... $\quad 249$

Unio ................................212, 214, 242

Unio belliplicatus........................ . 328

Unio Haydeni ......................... 248

Unio tellinoides........................... 215

Unio vetustus ........................... $\quad 328$

Viviparus.........................147, 209, 212, 242

Viviparus Conradi ........................ 328

Viviparus paludinæ............................

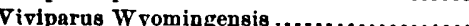

Volsella ocalprom var, isionema.

Zaphrentis ..282, 313, 368, 384, 401, 404, 409, 446, 547, 558

Zaphrentis centralis .................... 353,364

Zaphrentis excentrica ................... $\$ 04$

Zaphrentis multilamella ...............458, 460, 465

Zaphrentis Stansburyi .. . .889, 385, 404, 423, 460, 465, 600

Fossil Hill, Kawsoh Mountains, Truckee Miocene... 766

in Weber Quartzite........................

Pass, Piñou Range, basalt ....................

Fountain Head Hills ... ......................

Weber Quartzite

Fox Hili Cretaceous, Asbley Creek

Bear Rilge, Yampa Valley.....

Bear River City

Big Horn Ridge .................

Bluff etructure

Bridger's

characterized ...........59, 229, 233, 252

sulphur in coal of

Colorado ...................

eastern foothills, Colorado

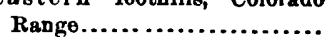

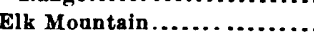

Ham's Hill, Green River Bagin

Laramie Hills ...............

Medicine Bow Range, erst

base.

Medicine Bow Valley...........

Mount Steele Ridge

North Platte.

Oyster Ridge, Green River

Basin

Rewlings Peak

thickness of......28, $60,143,154$,

Uinta Range

Vormillion Creek Valley .....

Wonsits Ridge, bituminons

sandstone in.

Yampa Valley

Frankum Butrks ...........

feldspar-porphyry

granite-porphyry

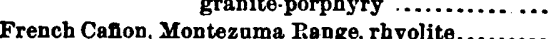

Creek, Medicine Bow Range, diorite.

placial erosion.

gneiss.

mica-schists...

Fremont's Island, Salt Lake, Archæan.

Pass, East Humboldt Ravge, granite.....

From Aepen to Echo Citr

Frontispiece. Eocene Bad-lands, Washakio Basin, described
Page

Wiatch ........................ 393

Fucoids in Cretaceous.......................... 332

Galbro, ilmenite in .......................... 14 Laramie Hills ........................... 13

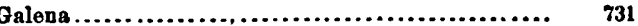

Garden-Gate, Wah-weah Range.................. 566 Valley, basalt ............................. 561

Garnets in Archæan ..........................18, 28, 101, granite ............................ 777

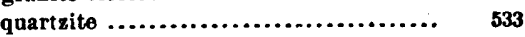
rhyolite............................... 561 trachste ............................ 598

Gay.Lnsbite in Plioceno, Pine Valley............. 583 Soda Lakes, Carson Desert .......... 749

General Gkologx of the Laramie Plains........... 75 UINTA UPLIFT ........... 198

Generalized section of the sedimentary rocks of the Fortieth Parallel

Geode Caĩon, Uinta Range, Upper Coal-Measures... Geograph cal distribution of Coal-Measure fossils....

Geologjcal description of Pakk Range ........... 13\% structure of the Wahsatch Range ...341, 393, 406

GrologY of Colorado RANGE .................... 21 MEDICINE Bow RANGE ................ 97

Gilbert's Peak, altitude........................... Weber Qnartzite....................

Glacial action on quartzite...................... 97 erosion, Cot ton wood Cañona, Wahsatch Range 354, 356 Duchesne Fork, Uinta Range ....... 312 East branch of Duchesne Fork...... 303, 310 East Humboldt Range ..............553, 537 French Creek, Medicine Bow Range. 97 Laramie Valley ....................... Park Range....................... 131 Shoshone Peak.................... 6\% Timpanogos Pesk, Wabsatch Range. $\quad 349$ Willow Creek Cañon, Aqui Mount. ains.......................... 45 moraines, Uinta Range................257, 300, 310 period in Green River Basiu................ 206

Gneiss, Clark's Peak, Medicine Bow Range........ 98 Davis Peak, Park Range ................... 138

Deer Mountain, Medicine Bow Range....... 101

Elk Mountain, Medicine Bow Range........ 103

French Creek, Medicine Bow Range ......... 101

(bornblendic), Medicine Bow Range......... 09

Lake Range............................. 814

Little Snake River...................... 139, 175

Mount Bon pland, structure of............. $\quad 536$

Ogden Cañon, Wahsatch Range............ 398

Sheep Mountain, Medicine Bow Range...... 108

Signal Peak, Color ado Range ............... 11

titanite in............................... 101, 102

West Bumboldt Range .................... 715

Götbite in bacalt.............................. 178

Golconda. Pass, Havallab Range, basalt............ 686 rhyolite........... $68 \mathrm{GH}$ Truckee Miocene.. 686

Gold in Archæan, Medicine Bow Range............ 109 Park Range................... 140, 181 Triassic, Dun Glen, Pab-Ute Range........ 712 Weber Quartzite, Oquirrh Mountains....... $\quad 452$ Goosk Creek Hills ........................... 515 


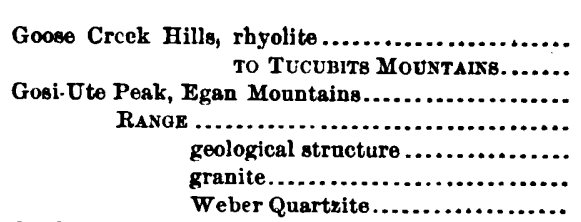

Grade of Union Pacific Railroad

Grand Encampment Mountain, altitude amphibolite.......... Archæan

Peak, Peoquop Range, altitude.

(n.............

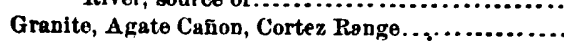
AND ARCHEAN Rocks, Cotron WoOd REglo (Arcbrean), Pah-tson Mountains Rawlings Peak ................ Sonthern Shoshone Range ...... as building-stone Big Cottonwood Cañon, Wahsatch Range .. Bruin Peak, Park Range. ..................

Cañon, granite. position pection of $P$ aleozoic.

corbonic acid in quarta Cherokee Butte, Medicine Bow Range....... Clark's Peak, Medicine Bow Range

Clayton's Peak, Waheatch Range

Clear Creek Cañon, Havallah Range.......

Clnro Hills...............................

conoidal structure in.....................

Dale Creek, Laramie Hills .................

dikes in granite...........................

Egan Cañon, Egan Range ..................

enclosed in rhyolite, Karnak ..............

Ethel Peak, Park Range

Fish Creok, Colorado Range.

Fish Creek Mountains ...................

Frémont's Pass, East Humboldt Range .....

Gosi-Ute Range.

Granite Cañon, Laramie Hill

Granite Point, Angusta Monntains ........ Montezuma Range.

Granite Range ..........................

HiLls granite-porphyry

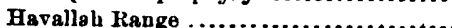

Iron Monntain, Laramio Billo..............

Lake Range.

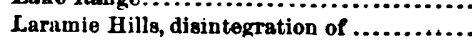
Little Cotton wood Cañon, Wahsatch Range.

Lone Peak, Wahsatch Range

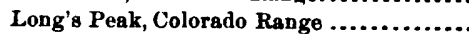
west side..

Lovelock's Knob

Maggie's Peak, Seetoya Mountains.........

Muuntain, Pab-Ute Range. altitude

n..............

diabase

feldspar-porphyry

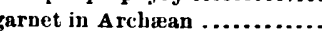
tonrmaline in Archegn

Nannie's Peak, Sectoya Moantains.........

\begin{tabular}{|c|c|c|}
\hline Page. & & Page. \\
\hline 516 & Granite, Pah-keah Peak, Pah-tson Mountains ........ & $7: 8$ \\
\hline 51.5 & 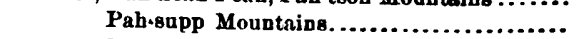 & 801 \\
\hline 487 & Patterson Pass, Ombe Monntains ............ & 495 \\
\hline 502 & Peoquop Range..$\ldots \ldots \ldots \ldots \ldots \ldots \ldots \ldots \ldots$ & 506 \\
\hline $50: 2$ & Pogonip Ridge, White Pine .................. & 54:2 \\
\hline 503 & Point Cañon, Augusta Mountaine, rhyolite. & 6.55 \\
\hline 503 & porphyry, Bingham Cafion ................ & $4: 0$ \\
\hline 2 & Cluyton's Peak $\ldots . \ldots \ldots \ldots \ldots \ldots \ldots$ & 361 \\
\hline 130 & Franklin Buttes ................. & 491 \\
\hline 138 & Goose Creek Hills ............... & 515 \\
\hline 137 & Granite.Hills $. . . . . . . . \ldots \ldots \ldots . . .$. & 8.52 \\
\hline 505 & Kinsley district ................. & 423 \\
\hline 95 & Parkview Peak.................. & 123 \\
\hline 576 & salt cubes in quartz of ........... & 402 \\
\hline 355 & Stockton, Oquirrh Mountains..... & 44? \\
\hline 775 & titanite in ...................449, & 85,491 \\
\hline 160 & 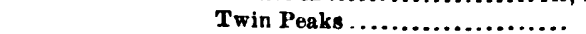 & 361 \\
\hline 637 & Whitehead Peak ................ & 169 \\
\hline 12 & Rart River Mountaing . ................. & 429 \\
\hline 360 & 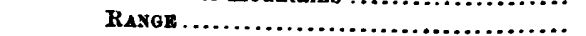 & 797 \\
\hline 135 & ultitnde $\ldots \ldots \ldots \ldots \ldots \ldots \ldots \ldots$ & 797 \\
\hline 9 & basalt.............................. & 799 \\
\hline 3 & granite $\ldots . . . \ldots \ldots \ldots \ldots \ldots \ldots \ldots \ldots$ & 998 \\
\hline $\mathbf{3 0}$ & Mud Volcanoes $\ldots \ldots \ldots \ldots \ldots \ldots \ldots \ldots \ldots$ & 799 \\
\hline 691 & Ravenswood Peak, Shoshone Range ........ & $6: 37$ \\
\hline 102 & Rawlings Peak $\ldots \ldots \ldots \ldots \ldots \ldots$ & 160 \\
\hline 97 & rounded quartz-grains in $\ldots \ldots \ldots \ldots \ldots \ldots \ldots$ & 102 \\
\hline 359 & salt-cubes in quartz of $\ldots \ldots \ldots \ldots \ldots \ldots \ldots \ldots$ & $03,7: 38$ \\
\hline 678 & 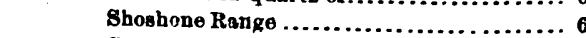 & 19,637 \\
\hline 584 & 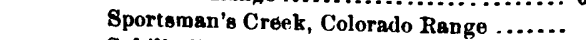 & 25 \\
\hline 355,619 & Sybille Creek, Laramie Hills ............... & $\mathbf{9}$ \\
\hline 12 & Tenabo Peak, Cortez Range ................ & 571 \\
\hline 675 & 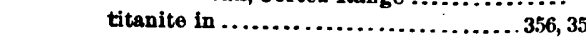 & , 359, \\
\hline 488 & $360,477,576,676,738,778,7$ & 8,807 \\
\hline 762 & tonrmaline in $\ldots \ldots \ldots \ldots \ldots \ldots \ldots \ldots \ldots \ldots$ & 777 \\
\hline 135 & Toyabe Runge................................... & 628 \\
\hline 25 & 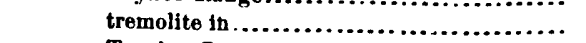 & 23 \\
\hline 661 & Truckee Range...$\ldots \ldots \ldots \ldots \ldots \ldots \ldots \ldots$ & 806 \\
\hline 532 & 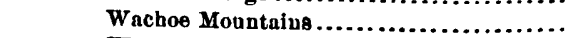 & 476 \\
\hline 503 & 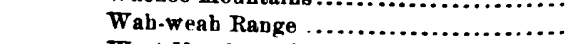 & 566 \\
\hline 9 & 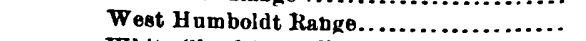 & 714 \\
\hline 779 & White Cloud Peak, East IIumbolilt Range. & 532 \\
\hline $\mathbf{6 o s} 1$ & Grantville Peak, Aqui Mountains, Canibrian auti. & \\
\hline 754 & 1 ................... & 459 \\
\hline 798 & Graphite in A rchæan, Laramie Hills.................. & 16 \\
\hline 851 & 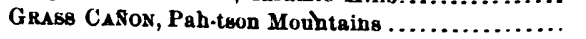 & 783 \\
\hline 852 & byalomelane tufa & 785 \\
\hline 674,678 & pearlite........ & 783 \\
\hline 12 & rhrolite tufa.... & 784 \\
\hline 814 & Utah, coal in Fox Hill Cretaceous.... & 7,336 \\
\hline 8 & Valley, Mud Springs . . ...................... & 688 \\
\hline 355 & 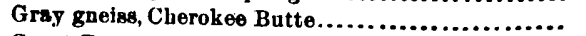 & 102 \\
\hline 357 & Great Desert, altitude $\ldots \ldots \ldots \ldots \ldots \ldots \ldots \ldots \ldots \ldots \ldots \ldots$ & 466 \\
\hline 22 & 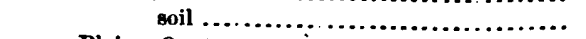 & 466 \\
\hline 24 & 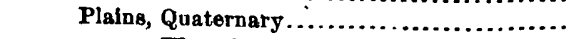 & 64 \\
\hline 754,760 & Wyoming Conglomerate..............64 & 71,72 \\
\hline 606 & 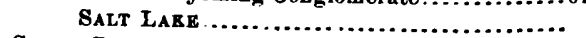 & 431 \\
\hline 689 & Greten River Babin & 191 \\
\hline 689 & Deschiptive GEOLOGY of ..... & 307 \\
\hline 689 & erosion of ..................... & 206 \\
\hline 69 & in Glacial period................. & 206 \\
\hline 681 & 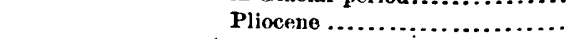 & 205 \\
\hline 691 & Vermillion Creek Eoceno....203, & 9,250 \\
\hline 691 & Wyoming Conglomerate....... & $\$, 258$ \\
\hline 608 & City Bluffe.......................... & 241 \\
\hline
\end{tabular}


INDEX.

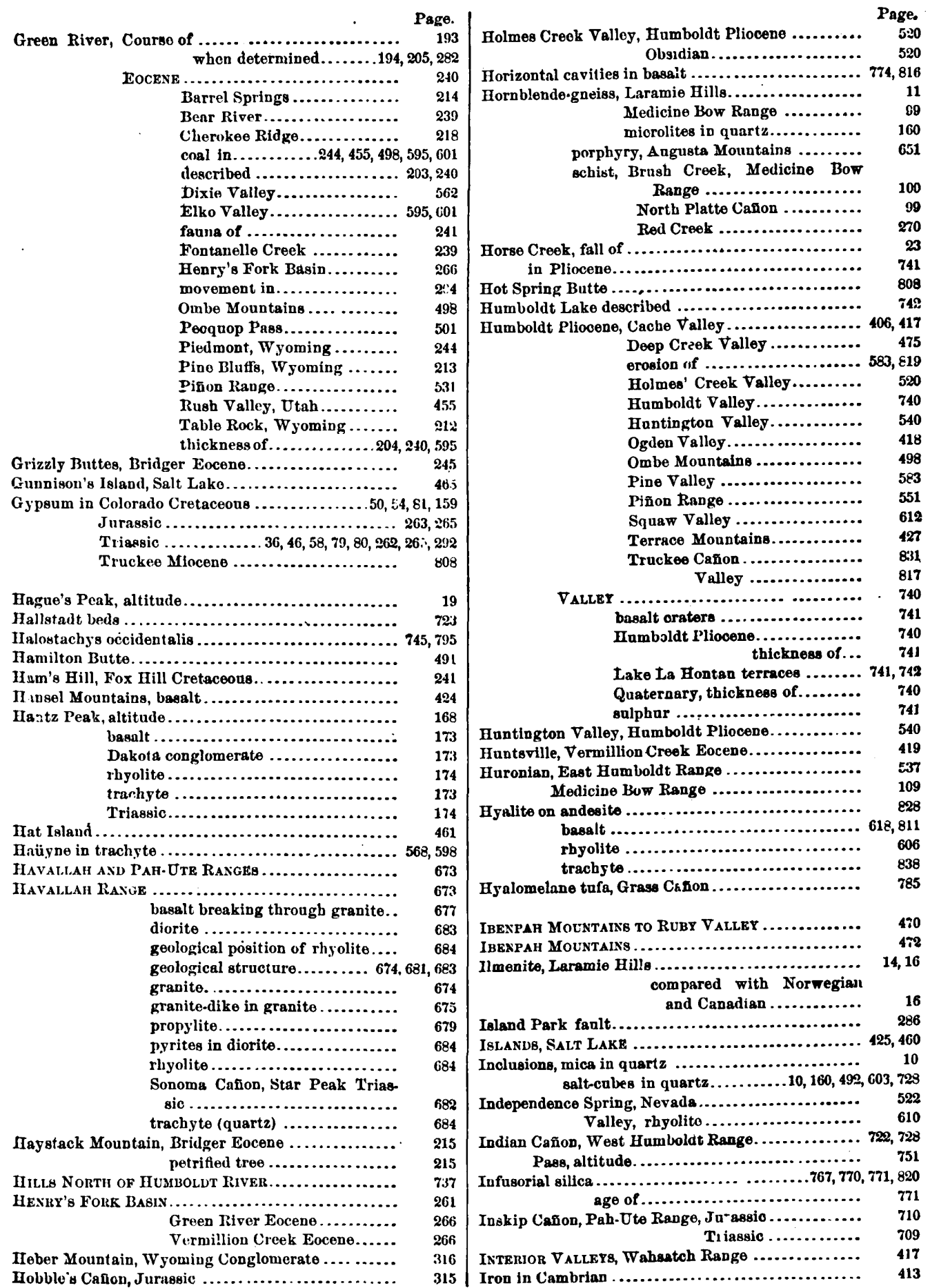


1NDEX.

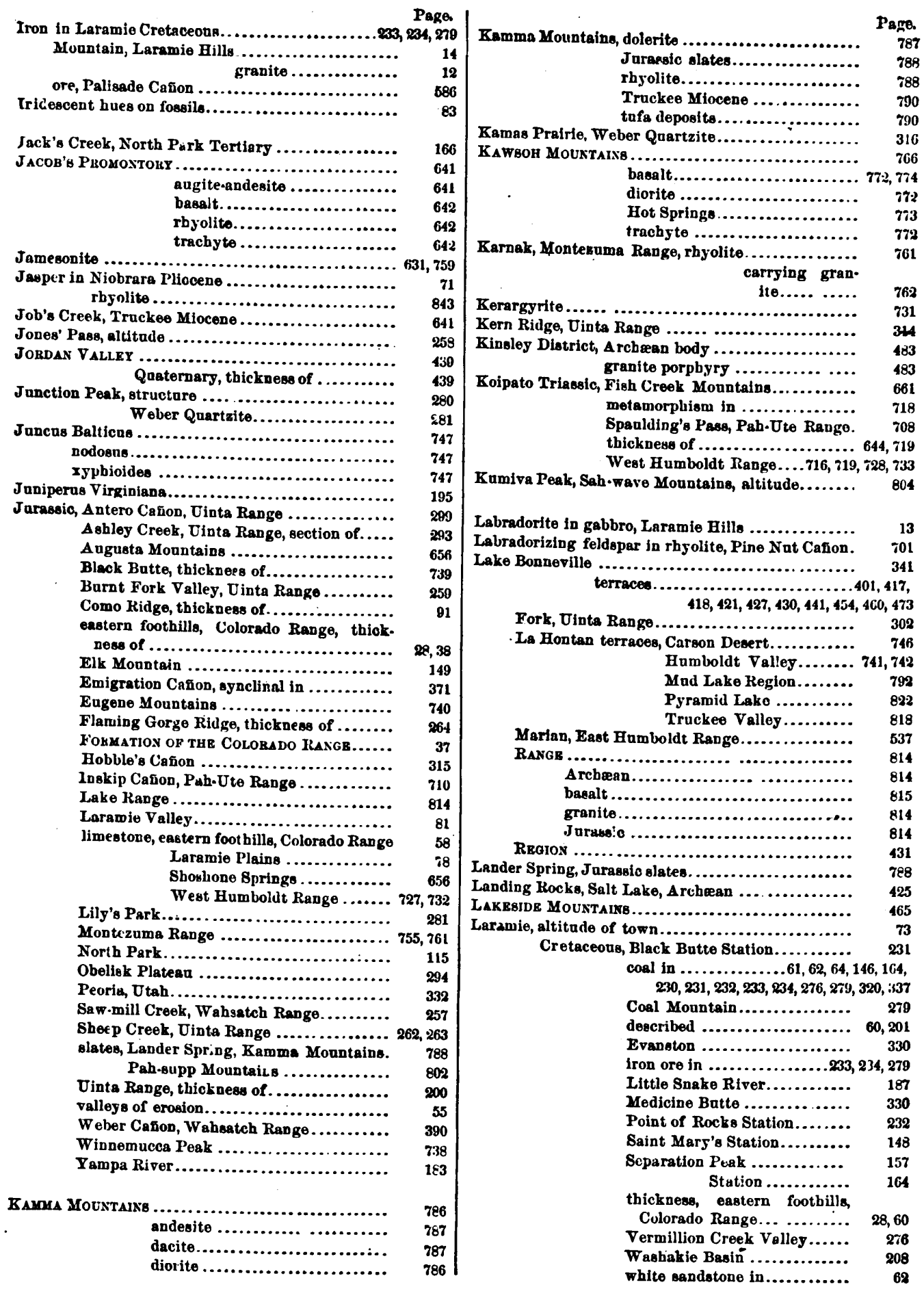


Laramie Cretaceons, Yamps Valley ............... Hille, altitude

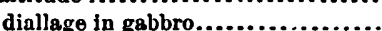
drainage of ..........................

epidote in Archæan .................

Fox Hill Cretaceous.................

garnet in A rchæan.

geological structure of .

graphite in Archæan...............

gypsam in Triassic ..................

hoi nblende gneiss.

ilmenite in gabbro

Laurentian rocks of.................

magnetite in

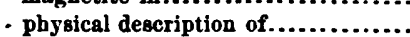

pyrites in Archæan .................

Table Monntain....................

thickness of Palæozoio on west side.

Plaixs, altitule

coal in Fox Hill Cretaceons.

Colorado Cretaceous ...............

Cooper Creek, valley of erosion ...

Dakota Cretaceous...................

drainage of.......................

erosion of Triassic ................

Jurassic limestone ................

lakes on..........................

Palæozoic strata .................

Quaternary .....................

section of Jurassic and Triassic...

Tertiary

thickness of Triassic ..............

Triassic.............................

River, course of.

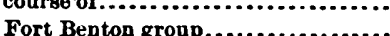

Bource of

Valley, glacial erosion in ...................

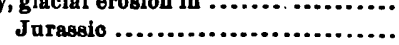
Triassio

Last Chence Spring

Laurentian of the Laramio

Wabsach Ra.....................

$$
\text { Wahsatch Range }
$$

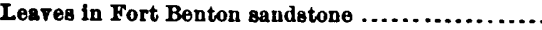

Leech Spring, Antelope Hills, tridymite in rhyolite.

Leidy's Peak, Uinta Range, Weber Quartzite .......

Lepidodendron

Lepidolite in granite. .

Lepidomelare in granite.

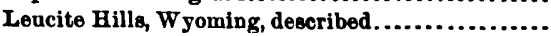

Lewiston, Oquirrh Mountaine, Wahsatch limestone.

Life in Niobrara Pliooene

Salt Lake

Soda Lakes, Carson Desert

Lightning (effects of), Hantz Peak.

(O)

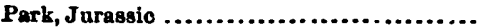
Triassio.............................

Limestone (bitnminoue), in Colorado Cretaceons . .

Niobrara Pliocene................... Red Beds

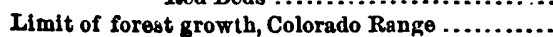
Medicine Bow Range ...... Park Range................ Uinta Range.
Page. Limit of Uinta Tertiary, Wonsits Rtdge ............ Lion Hill, Oquirih Monntains, Wahsatch lime. Liquid carbonic acid in quartz, Davis Peak........... Liquid carbonic acid in quartz, Daris Peak.........
quartzite, Jack's Creek .... inclusions in feldspar of porpbyry......... 479 quartz of rhyulite...........174, 482, 486

Lithophrem in rhyolite Len

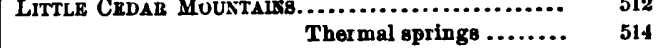
Cottonwood Cafion, granito ................ 355 Ogden Quartzite ......... 363 Oto limestone........... 363 Wahsatch limestone.... 362 Waverly limestone...... 365

Laramio Basin, Fort Pierre clays ........... 83 Maddy Creek (east), Laramie Cretaceous... 159

(west), Vermillion Creek Eo-

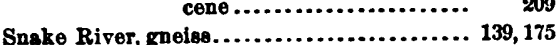
Laramio Cretaceous........... 187 Long's Peak, Colorado Range, altitude ............. 19 granite.............. 22 phospboric acid in granite............. 23

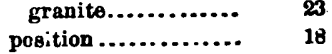
tremolite in granito.

Lodore Corion, Uint Renge, depth................ 196, 2\&7 Logan Cañon, Wabsatch Range, synclinal........... 406 $\begin{array}{cr}\text { Logan Cañon, Wahsatch Range, synclinal........... } & 406 \\ & 407\end{array}$ Lone Peak, Waheatch Range, altitude ............. 353 Archæan ............ $\quad 358$ granite............. $\quad 357$ Lookout Mountain, Gosi-Uto Range, altitude ........ 504 Louis Valley, rbyolito ........................... 848 Lovelock's Knob, granite....................... 754, 7CO rhyclite....................... 760 Station, 'Truckee Miocene ............. 732 Lower Coal-Measures, Black Rock Point........... 453 Dixio Valley............... 56 Enreka Mining District .... 548 Lookont Mountain.......... 504 Spruce Mountain ........... 510 Stanebury Island ........... 160 Strong's Knob .............. 654 Tooelle Cañon.............. 450 $34 \geq, 547$ 777

4

7

8

5

4

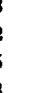

9

7

3

7


McKinney's Paes, rhyolite hills ................... Medicise Bow Raker Colorado Cretaceous........... diorite-schist drainge of epidote in Archean Fox Hill Cretaceons........... garnet in A rchæan. glacial erosion................... gold in A rehm. hornblende-gneiss limestoue in Archxan........ Medicine Bow Peak, altitude. masnetite in Archæan ....... pyrites in Archæan .......... red jasper conglomerate in Archrean. River . But te, Aspen Platean, Cretaceous.......... Peak, argillite under quartzite

cyanito in quartzito compressed pebbles in quartzite ..... Medway Hot Springs, Provo Valles.

Menilites in Tertiary

Mespzoic strata, Big Thompson Cañon. Sentinel Hill North Park ..........

Metamorphism in Koipato Triassic

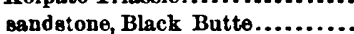

Mica-diorite, Chataya Peak. schist in Arcbæan, Colorado Range............. Medicine Bow Range ..... Pahkeah Peak. Shoshone Range

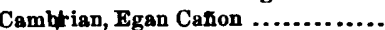
Spruce Mountain..................... Microlites in quartz

Micruscope, velue in determining rocks .............. Mill Cañon, Waheatch Range, Ogden Quartzite..... Creek Cañon, Wahsatch Range, Weber Quartzite. Laramie Plains coal in Fos Hill Cretaceou

Miller Mine, American Fork Cañon, Wabsatch Range Miner's Cafion diabase ............................. propylite. Triasaic.

Mining, Black Rock Mountains

Miocene Lake Basin, altitade of .....................

Miser Railroad Cut in Colorado Cretaceone..........

Moke-moke Ridge, White Pino .

Moleen Cañon, section of Carboniferous...................

Moleen Peak

Monitor Peak, altitude of ............................. MontbzULA RANGE AND KaWbOH MoUNTaIss ....... MONTEZUMA RANGe

Arcbæan...................... basalt ...................757, 758, 760, 76 diorite. feldapar-porphsry in Jurassic geological structure Granite Point granite. Juraesic.
Page. 85,86 109

90

109

99
107

9

94
108

108

106 onteznm\& Range, Juraselc, thickness of .......... Karnuk Ridge .................. 76 pearlite ........................ 759 propylite ...................... 765 pyerrite........................ 750

Moore's Fork, Yampa River, Sulphur Springs.......

Mopusa Huls . rhyolite................................

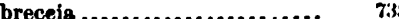
salt on rhyolite..................... 735 Morgan Peak, Wahsarch Range, Wahsatch limestone

Morgan Valle y, Humbolat Pliocene.................. trachy to ......................... 381 Vermillion Creek Eocene............ Mose agates in Bridger Eocene ...................... Niobrara Pliocene ...................

Mountain Dell Pase, Dakota conglomerate ........... 389 Wells Station, Pah. Ute Range, basalt....... 704 Mount Agassiz, Uinta Range, altitude of ............ 312

Weber Quartzite..... 32

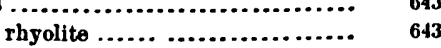
Bonpland, East Humboldt Range, altitude... 528 structnre of gneiss............... 536

Clark, altitude of .........................

Curson, Wyoming Conglomerato........... 247

Davidson, altitude of...................... $\quad 825$ diorito 825

Horeb, Ibenpah Mountains, Wahsatch lime-

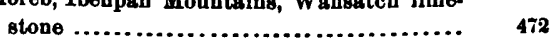
Lander, altitude of ........................ 792 Lena, Uinta Range, Weber Quartzite....... 289 Moses, Fish Creek Mountains, altitude....... . $\quad 660$ rhyolito...... 663 Nebo, Wahsatch Range, altitude........... structure ........... 3

Neva, Cortez Range, rhyolite............. 612 Weber Quartzite...... 610,612

Pisgab, Toano Range, antislinal atructare.. Riehthofen, Colorado Range, altitude ........

described ......

119

Vóry altite, Fox Hill Cretaceous...........

Welthe, Elkhead Monntaing, baselt

Zirkel, Colorado Range, altitude of........... 120 described ..........

Cambrian shales.................. 409, 412 Ogden Quartzite................. 409 Wahsatch limestone, thickness of... 409 Ute limestone, thickness of ......... $\quad \mathbf{4 1 0}$

Mountain, W yoming Conglomerate.......... 189 Mnd lakes, altitnde of ........................... 792 described.

springa, Grass Valley pearlites............ 846 quartz-propylite..... $\quad \mathbf{8 4 4}$ rhyolite ........... 846 breccia...... $8+7$

Mushroom forms of calcareons tufa............... $\quad 818$ 
Nache's Peak, Truckee Range, described

Nannic's Peak, Seetoya Monntains, granite rhyolite........

Narrows, Bear River, Upper Coal-Measures.......... Native silver

Natural forts, Niobrara Pijocene.

Needles, Dakota conglomerate

Nephtline-basalt, Bastion Mountain

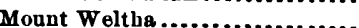

Yampa Valley .................... in trachyte.

NEVADa BastN.

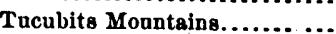
Fossil Pass, Piñon Range........ Forest City, Wahsatch Range. Oquirrh Mountains.

White Pine Mountaing Whe............................

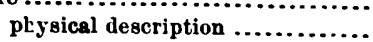

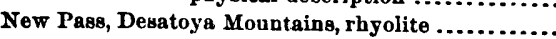
Mountains, diorite. geological structure ............. rbyolite

Niobrara group, eastern foothills, Colorado Niobraka Pliccene

Bone Valley ...................... cream-colored marls of......... jasper in.

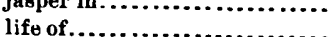
limestones of.............. mose-agates in.

ailicifled wood in

thicknese of

North Cañon; Oquirrh Mountains, Wahsatch lime

stone .........................................

Northelk Bear River Region ......................

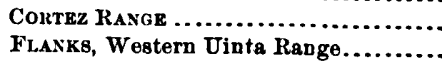

Region, West Humboldt Range.........

Slopes of Uinta Raver.........

WaHSATCH REGION.....................

Nolth Park

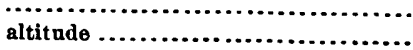

augite-trachyte........................

basalt ............................. 125,

Buffalo Peak

Carboniferons limestone............

Colorado Cretaceous....................

Dakots Cretaceous .............. 115, 118

drainage of. ...........................

Jurassio

hysical description of

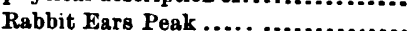

Rabbit Ears Peak ...................

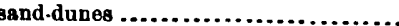

Sentinel Hill, Mesozoic strata ........

Tertiary described ................... Jack's Creek

Savory Creek

thickness of Triassic.

Platte Cañon, hornblendic schists.

River, section of Fox Hill Cretaceous sources of.
Page.

805

603

604

$\mathbf{3 3 8}$
$\mathbf{7 3 1}$

179

180

556

352

544
469

470

646

644
646
42
Obelisk Platean, Page WyomingConglome

rate ..............

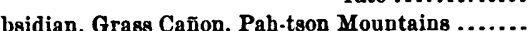
Holmes Creek Valley................... 520

gden Cañon, Wahsatch Range, Archæan...........

Cambrian ........... 398

Ozden Quartzite ... $\quad 40 \mathrm{~J}$

Quaternary ....... 401

terrace lines ........ 401

Ute limestone....... 390

Wubsatch limestone. $\quad 400$

Waverly Beds ...... 400

zircon in Archæan . $\quad 397$

Quartzite, American Fork Canon............ $\quad 350$ Boulder Creek.................. 609 East Humboldt Range ............ 531 Little Cottonwojd Cañon .......... 363 Mill Cañon........................ 377 Muddy Cañon.................. 409 Ogden Cañon..................... 400

Rock Cañon...................... $\quad 346$

RRGion

Valley, described......................... 418 Humboldt Pliocene................. 418

terrace lines....................... $\quad \$ 18$

Olivine in trachyte, Slater's Fork................ $\quad \mathbf{1 7 6}$ Steves Ridge................. 170

Ombe Mountaing ............................... 494 basalt ........................ 499, 500 coal in Green River Eocene ....... 498 geological structure............ $4 y 4$ Humboldt Pliocene.............. 498 Thyolit t....................... 499 to EAst Humboldt RaNGE ...... 494 Ophir City, Oquirrh Mountains, Potsdam.......... 144 OQuirkh Mountalss ........................... $\$ 43$ Devonian................... 445 fault in Cambrian geological structure......... $\$ 43$ North Cañon ............... 448, 451

Ore deposits, Sprace Mountain................... 512

Orford Peak, Peoquop Range, altitude............ 505 Upper Coal-Measuses. $\quad 508$

Origin of rhyolitic tufa........................ $\quad \begin{aligned} & 623 \\ & 436\end{aligned}$ Oroomiah Sea, northwestern Perais ... Orthoclase crystals in trachyte, OSOBB VALLEY EALT FIRLDS ..................... 707 Osino Cañon rhyolite........................... 594 Weber Quartzite .................. 594

Owi-yu-kuts Plateau......................... 271 altitude ................. 196 Vermillion Creek Eocene..... $\quad 225$

Owl Creek, White River Miocene

$\begin{array}{ll}\text { Valley, Gosi-Ute Range, Weber Quartzite...... } & 503 \\ & 513\end{array}$ Oyster Ridge, Colorado Cretaceous.................. 251 Fox Hill Cretaceous ................. 251

Pahkeah Peak, Pah-tson Mountains, granite......; 778 $\begin{array}{lr}\text { mica-schist..... } & \mathbf{7 7 6} \\ \text { rhyolit } 3 . . . \ldots . . . & \mathbf{7 8 2}\end{array}$ Pah-supp Mountains ......................... 801 granite..................... $\quad 801$ Jurassic slates ................ 802 


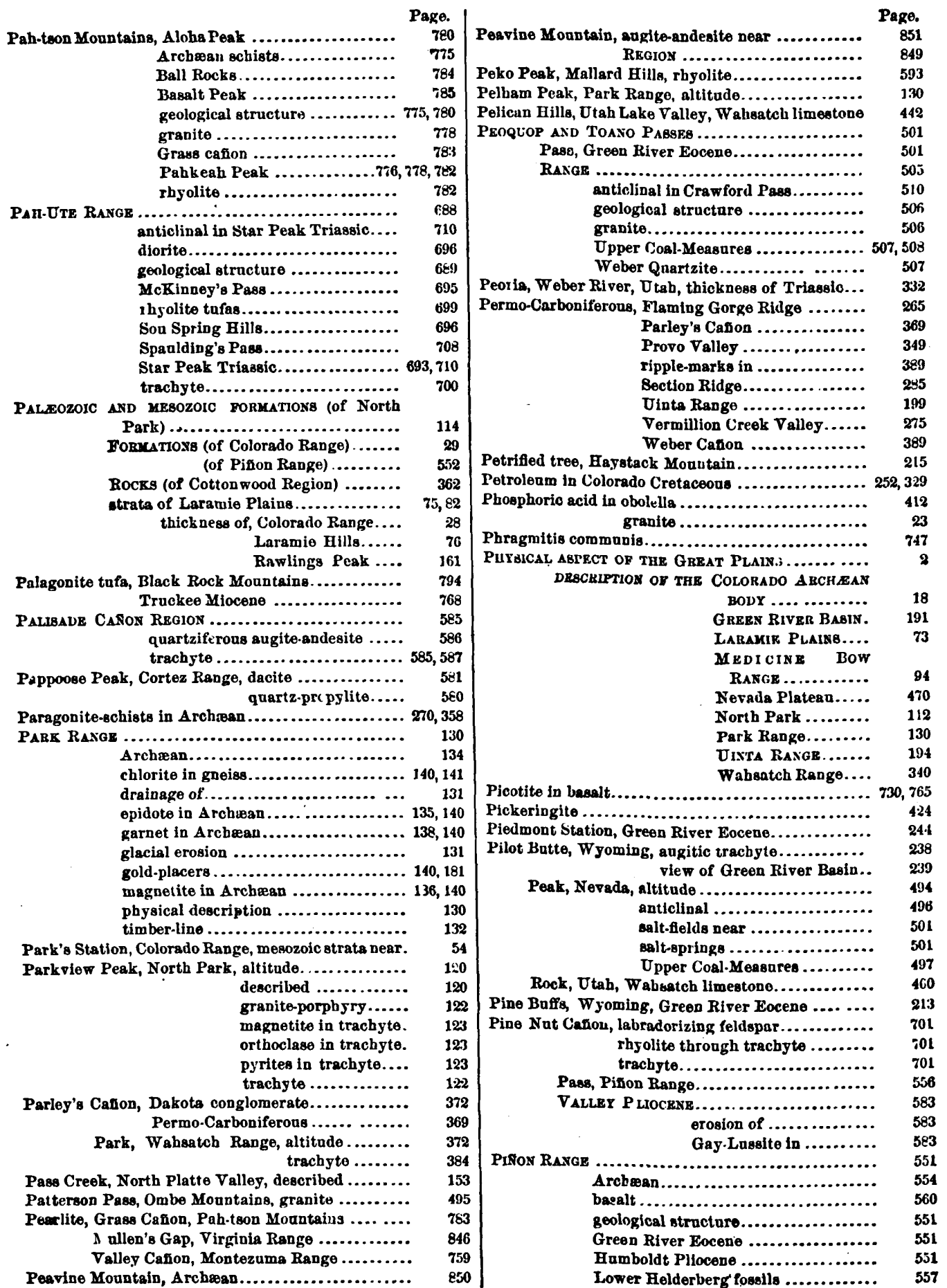


INDEX.

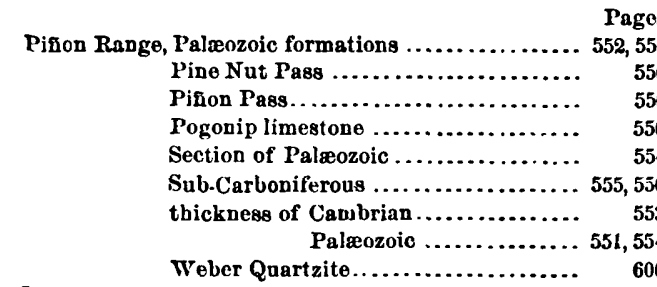

Pinto Peak, Piñon Range, deacribed.................

Pinus flexilis ............................. 195, 528 ponderosa....................... 21, 97, 195

Pioneer Ilollow, coal in Fox Hill Cretaceous. .......

Pigokte ................................. 796

Plant remains in Carboniferous sandetone .......... 546

Plate I. Horse-Shoe Curre, Green River, described $\ldots \ldots \ldots \ldots \ldots \ldots \ldots \ldots \ldots 193,267$

II. Summit Va!ley, Uinta lange, de. scribed .........................

III. Junction of Yampa and Green Rivers cescribed.......................

IV. Brown's Park from canon of Lodore described......................

V. Tertiary Bluffs, Green River City, described ..........................

VI. Tertiary columns, Green River City, described...

VII. Entrance to Flaming Gorge described.

VIII. Cañon of Lodore described.

IX. Carved Carboniferous strata, Yampa and Green Rivers, described.

X. Agassiz A mphitheatre described.....

XI. Echo Canon, Utab, described ........

XII. Witches Rocks, Weber Valley, do scribed.

XIII. Conglomerate column, Weber Valley, described............................

XIV. Wabsatch limestone. Provo Valley described...

XV. Granite, Little Cottonwood Cañon, de scribed ...................................

XVI. Cambrian, Big Cottonwood Cañon, de scribed.

XVII. Blno Cañon, East Humboldt Range, described.

XVIII. Glacier Cañon, East Humboldt Range, described......................

XIX. A rchæan quartzite, East Humbold Range, described.

XX. Sou Hot Springs, Osobb Valley, de scribed.

XXI. Tufa Cone, Provo Valley, Utab, de ocribed ..............................
Sou Spring tufa, Osobb Valley, de scribed..

193,267

Poa tenuifolia

Pliocene foesils, Brown's Park Tortiary

224

horse, Humboldt Valley ................ 74J

in Green River Basin ................ 205, 224

Morgan Vall y...................... 381

Salt Lake Valley ................... 489

lake basin, altitude of ................... in

Point Carbon, Uinta Kange, gltitude.................

Point of Rocks Station, Laramie Cretaceous..........

Pogonip limestone, Eureka Mining District......... 547 Mineral Hill, Piñon Range ........ 556

Roberts Peak ................. 564

White Pine.................. 543

Ridge, White Pine, Cambrian ............. 542

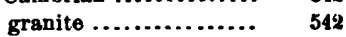

Porpbyroids, West Hunboldt Range .............. 721

Porphyry-dikes, Colorado Range.................. 25 (feldspar), delessite in .................. 828 Franklin Buttes ............... 492 Granite Moantain ............ 691

Montezuma Range............. 756

$\begin{array}{ll}\text { Montezuma Range.............. } & 756 \\ \text { Ravenswood Peak ............. } & 638\end{array}$

Seetoya Mountains............604,606

Spruce Mountain ............ 510,511

Truckee Cañon ................ 828

(hornblende), A ugusta Mountains ........ 651

(granite), Bingham Cañon .............. 450

Clayton's Peak ................ 361

Franklin Buttes ............... ' 491

Goose Creek Hills .............. 515

Granite Hills .................. 852

Kinsley district ............... 483

Parkview Peak................ 122

Stockton.................... $\quad 449$

stone-cavities in ................ 492

Twin Peaks $\ldots \ldots \ldots \ldots \ldots \ldots . . . .361$

Whitehead Pesk ............... 169

(quartz), Castle Peak ................. 478

(oyenite), Big Cottonwood Cañon.......... 365 Cluro Hills ................. 585

Potassa in dacitẹ.............................. 621

Potsdam, City Creek, Wahsatch Range............. 377

Ophir City, Oquirrh Mountains.............

Pre-glacial érosion.............................

Pressure in Archæan gneiss ................... 379

Priuce Royal Cønon, West Humboldt Range........ 727

Promontory Mountains, Antelope Springs ........... 428 Archæan................. 121, 423 geo.ogical structure........ 120,422 terracelines.

Station, altitude..................... 421

UPL'FT ............................ 420

Propylite (augite), Silrer Mountain ............... Berksbire Cañon...................... 840,842 epidote in ............................ 662 Fish Creek Mountains.................. 662

Havallah Range....................... $\quad 679$

Miner's Canon ........................ 810

Montezuma Range..................... 765

Sheep Corral Canon.................. 838

Truckee Cation..................... 827, 831

Tugcarora ............................ $\quad \mathbf{6 1 0}$

(quartz) Cortez Peak .................... 577 Mullen's Gap................. 844 Pappoose Peak............... 580 


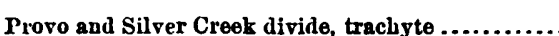

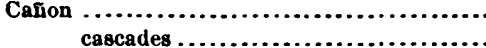
River, tridymite in trachyte.................

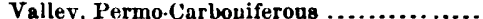
Pu:ple Hills, trachyte.

Pyramid Lake, altitude of . analysis of water Lake La Hontan terraces.............

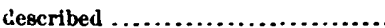

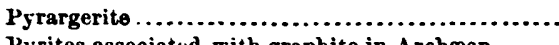
Pyrites associated with graphite in Archran.......

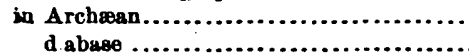

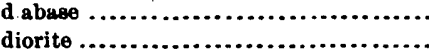
trachyte

Upper Coal-Measares

Quartz (dihexahedral) in dacite

$$
\text { rhyolite }
$$

hornblende in escribed...... Steves Ridge.

Quartz in andesito basalt .

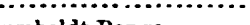
oldt Rang Havallah Range.

Quartzite in Archæan, East Humboldt Rnnge...... Merlicine Bow Range

Truckee Miocene.

Quartz-porphyry, Castle Peak, Washoe Mountainz. propylite, Cortez Peak, Cortez Range. Mullen's Gap, Virginia Range... Pappoose Peak, Cortez Rance...

Quaternary gravels, Ogden CaIion, Wahsatch Range. Great Plaius Laramio Plait

Qninn's River, width of

Rabbit Ears Peak, North Park

Hole Springs desctibed

Taft River Mountaing granito

Railroad Cañon, Diamond Raugo, bssalt Rauunculus cymbalaria. liaven's Nest Peak, Piñon Range... Ravenswood Peak, Shoshone Range, Carboniftrous diorite granito......... porphyry ..... rbyolite........

Rawling's Prak

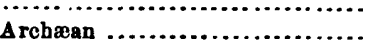
Dakota conglomerate.............. Fox Hill Cretaceous ............... hornblendo microlites in quartz ...

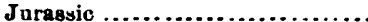
Palæozoic, tbickness of . ............. Red hematite .................... .........159, 162, 163 Red Beds ................28, 33, 77, 79, 81, घ:2, 92, 115, 149, 157, $162,163,174,184,200,254,259,281,283,284,292,299,302$ Red Crefk abchasan body Red Creek $\Delta$ rchæan rocks.............202, 227, 268, 269, 270

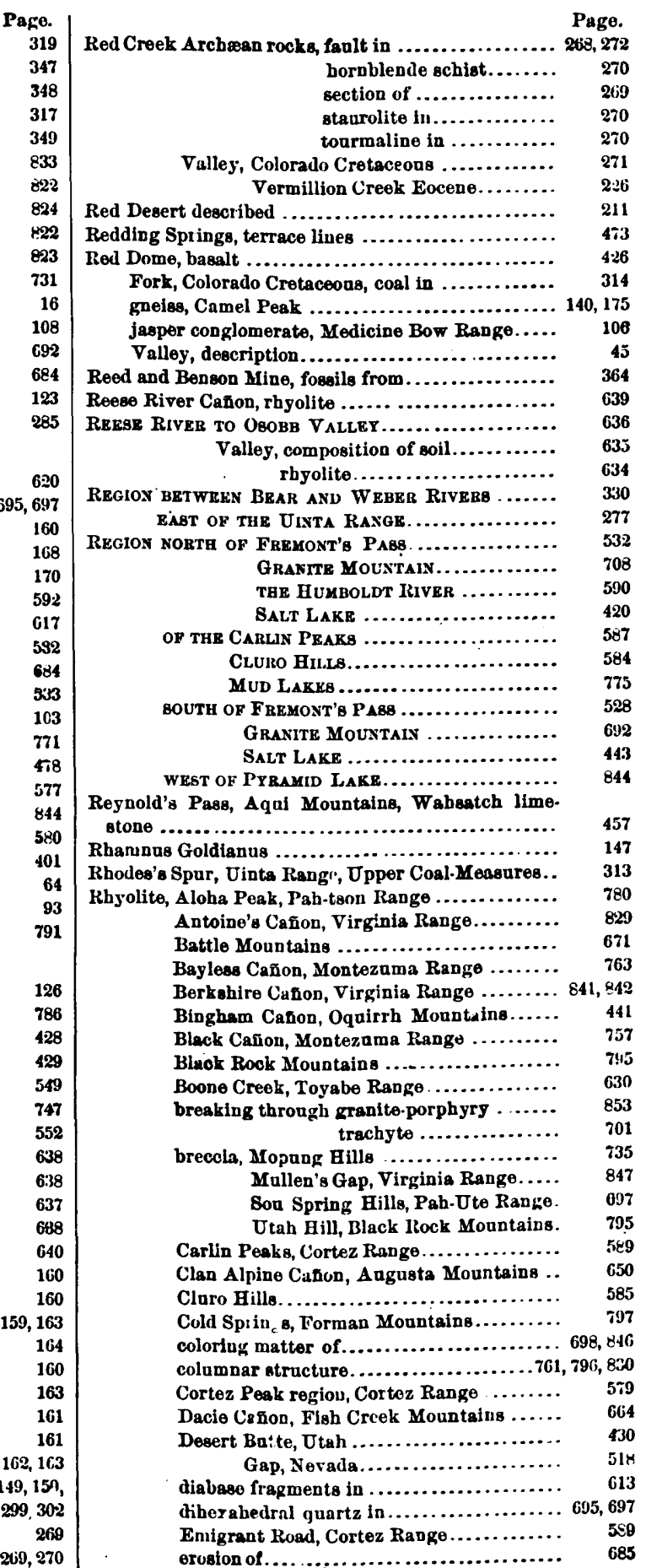



River Range, rhyolite...................... 596, 598 Wober Quartzit9 .................. 58 56

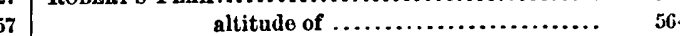
. Pogonip limestone ................... 56 trachyte ....................... 56 Roc's Cañon, Wabsatch Range, Ogden Quartzite..... 34 Sub-Carbouiferous .. 340

Creek, Laramie Plains, clay ironstones........ 88 coal, Laramio Plains, described......... $\varepsilon 6$ coal in Fox Hill Cretaceous ........... $\quad \varepsilon$

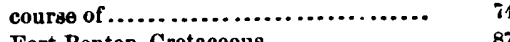

Fort Benton, Cretaceons Spring Station, Artesian boring $\ldots \ldots \ldots \ldots \ldots \ldots . .234$ Rocky Mountains ........................... 109, 14! Rozel Hills, basalt ............................ 42 Ruby Grour ............................... basslt........................... 490 Bee-Hives, rhyolite.................. Ruby Valley thermal springs................... Rush Lake................................ Valley, Green River Eocene................ Sacred Pass, East Humboldt Range, rhyolite........ 539 604 Wahsatch lime stone........ 530 Sage Creek Valler, North Platte, described......... 152, 150 Colorado Cretace. ous.............. 150 SAH-Wave Mountains ........................ Salt-cubes in quartz of granite ...............10,160, 603, 738. granite.porphyry ........... 492 Diamond Valley ......................... 55 Osobb Valley......................... 707

Salt Lake, changes of level....................... City, position ........................ 438 Thermal Springs .................. 37 composition of water.................. density of water ....................... 43? life in .............................. 435

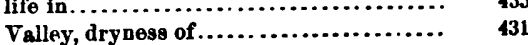
Pliocene........................ S.lt on rbyolite, Mopuug Hills................... 735 Springs, Pilot Peak ....................... 501 Saint Cassian fussils ........................... Suiut Mary's Station, Laramie Cretaceous........... 148 Sanders Pedk, Laramie Hills, altitade of........... 5 Sand-dunes in North Park ....................... 119 Sund-sculptare on basalt ....................... 77 granito....................... 160 conglomerate................... 159 Sandstone for building, Cache Valley Tertiary...... 117 Fort Benton group, Rock Creek .....................

Sanidin in basalt, Fiah Creek Monntains............ Sanidin in basalt, Fine-basalt, the Rampart ........... Santa Clara Peak, West Humboldt Range, limestone. Sarcobatus rermiculatus.

Saurian teeth in Colorado Cretaceous

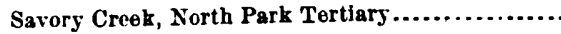

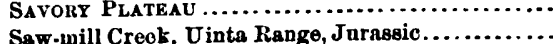




\begin{tabular}{|c|c|c|c|}
\hline & ge. & & nge. \\
\hline Schell Creek Mountains, Cambrian ................. & 485 & Shoshone Range, rbyolite........................623, 6 & \\
\hline 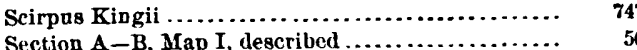 & $\begin{array}{r}747 \\
50\end{array}$ & $\begin{array}{l}\text { Weber Quartzite...............619, 622. } 68 \\
\text { Springs, Augusta Mountains, Jurassic ... }\end{array}$ & 656 \\
\hline $\begin{array}{r}\text { Section A-B, Map I, described } \ldots \ldots \ldots \ldots \ldots \ldots \ldots \ldots \\
\text { II, described } \ldots \ldots \ldots \ldots \ldots \ldots \ldots \ldots\end{array}$ & $\begin{array}{r}50 \\
\wp 9\end{array}$ & Signal Peak, Harallah Range, altitude ............. & \\
\hline $\begin{array}{l}\text { II, described } \ldots \ldots \ldots \ldots \ldots \ldots \ldots \ldots \\
\text { IV, described } \ldots \ldots \ldots \ldots \ldots \ldots \ldots\end{array}$ & 608 & 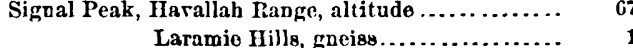 & 673 \\
\hline $\begin{array}{l}\text { IV, described } \ldots \ldots \ldots \ldots \ldots \ldots \ldots, 6,60 \\
\text { V, described } \ldots \ldots \ldots \ldots \ldots \ldots \ldots, 709,80\end{array}$ & 80.2 & $\begin{array}{r}\text { Laramio Hills, gneiss..................... } \\
\text { section of Palæozoic.... }\end{array}$ & 11 \\
\hline 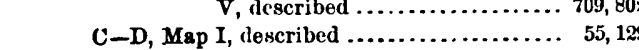 & 129 & $\begin{array}{l}\text { secrion of Palæozorc.... } \\
\text { zircon in gneiss ......... }\end{array}$ & 11 \\
\hline II, described.................. $2 \varepsilon$ & 280 & Silicifled wood, Niobrara Pliocene.................. & 71 \\
\hline IV, described ...........483,505,531, 55 & 555 & Silurian in Box Elder Cañon ..................... & 403 \\
\hline$\nabla$, described $\ldots \ldots \ldots \ldots \ldots \ldots \ldots 644,84$ & 844 & Silver Creek, Toyabe Range, rhyolite .............. & 630 \\
\hline (generalized) of sedimentary rocks of For- & & Wabsatch Irange, tridymite in tracbyte & 320 \\
\hline tieth Parallel ................................ & 855 & Simpson's Ridge, altitude...................... & \\
\hline of Archxan, Red Creek.................... & 269 & anticlinal........................ & 144 \\
\hline Colorado Cretaceous...................44, 156, 26 & 264 & section of Fox Hill Cretaceons..... & 144 \\
\hline Dakota Cretaceous .................... 40,26 & & Skelligs Ridge, Elkhead Mountains, trachyte ....... & 171 \\
\hline Fox Hill Cretaceous ..................144, 154, 15 & & SkULL VALLEX $\ldots \ldots \ldots \ldots \ldots \ldots \ldots \ldots \ldots \ldots \ldots \ldots \ldots \ldots \ldots \ldots \ldots \ldots$ & 462 \\
\hline 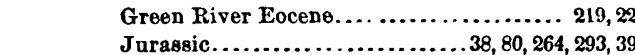 & & 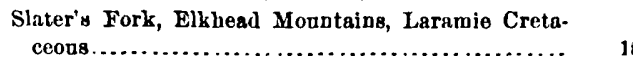 & \\
\hline $\begin{array}{l}\text { Jurassic } \ldots \ldots \ldots \ldots \ldots \ldots \ldots \ldots \ldots \ldots . \ldots, 80,264,293,39 \\
\text { Laramie Cretaceous } \ldots \ldots \ldots \ldots \ldots \ldots \ldots 61,145,158,18\end{array}$ & 188 & Slater's Fork, Elkhead Monntaics, olivine in tracbyte & 188 \\
\hline $\begin{array}{l}\text { Laramie Cretaceous } \ldots \ldots \ldots \ldots \ldots \ldots \ldots 61,145,158,18 \\
\text { Mesozoic strata.......................... 91, } 27\end{array}$ & 275 & $\begin{array}{l}\text { Siater s Fork, Eikhead Mountaics, onvine in trachyte } \\
\text { Smilax grandifolia } \ldots \ldots \ldots \ldots \ldots \ldots \ldots \ldots \ldots \ldots \ldots \ldots \ldots\end{array}$ & 176 \\
\hline $\begin{array}{l}\text { Mesozoic strata......................... 91, } 27 \\
\text { Palæozoic strata } \ldots .30,343,346,385,398,405,544,5\end{array}$ & 555 & $\begin{array}{l}\text { Smilsx grandifolia } \\
\text { Snowstorm Hill, Oquirrh Mountains, Carboniferous }\end{array}$ & \\
\hline $\begin{array}{l}\text { Palæozoic strata } \ldots .30,343,346,385,398,405,544,5 \\
\text { Triassic } \ldots \ldots \ldots \ldots \ldots \ldots \ldots \ldots \ldots \ldots \ldots \ldots .34,265,292,30\end{array}$ & & 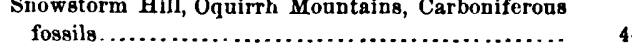 & \\
\hline $\begin{array}{l}\text { Triassic } \ldots \ldots \ldots \ldots \ldots \ldots \ldots \ldots \ldots . . . \ldots, 265,292,30 \\
\text { Truckee Miocene, Fossil dill } \ldots \ldots \ldots \ldots \ldots .\end{array}$ & 766 & & 446 \\
\hline & & Soapstone Cañon, Uinta Range........................ & 315 \\
\hline Upper Coal-Measures ................ 291, 59 & 599 & Soda Lakes, Carson Desert, described .............. & 746 \\
\hline Vermillion Creek Eocene .............. 212, 27 & & Gay-Lussite in.......... & 749 \\
\hline Wahsatch limestone, Coal Creek ......... 60 & 604 & life in $\ldots \ldots \ldots \ldots \ldots$ & 749 \\
\hline Weber Quartzite, Weber Cañon .......... & 387 & Soil, Reese River Valley, composition of ........... & 6.35 \\
\hline Ridge, Yampa Platean, anticlinal........... & 285 & Soldier Cañon, Oquirrh Mountains, Weber Quartzite & 449 \\
\hline Permo-Carboniferous & 285 & Solidago occịlentalis ............................ & 747 \\
\hline Seetoya Mountans..... & 602 & Sou Hot SPRINGs $\ldots \ldots \ldots \ldots \ldots \ldots \ldots \ldots \ldots \ldots \ldots \ldots \ldots \ldots \ldots$ & 704 \\
\hline diorite $\ldots \ldots \ldots \ldots \ldots \ldots \ldots$ & $\mathrm{cot}$ & Sou Spring Hills, basalt breaking through rhyolite.. & 698 \\
\hline fault in Wahatch limestone ... 6 & 607 & 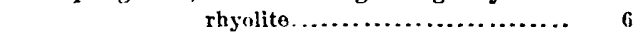 & 696 \\
\hline feldspar-porphyry $\ldots \ldots \ldots \ldots \ldots 604,6$ & 606 & breccia............................ & 697 \\
\hline gravite $\ldots \ldots \ldots \ldots \ldots \ldots \ldots \ldots$ of & 603 & SOLTHERN FLANKS OF THE UINTA RANaE......... 298,3 & 311 \\
\hline rbyolite..................... & 604 & RfGion, West Humboldt Range .......... & 731 \\
\hline te $\ldots \ldots \ldots \ldots . . . . . . . . .$. & 605 & SHoBhoNe RaNGE $\ldots \ldots \ldots \ldots \ldots \ldots \ldots$ & 636 \\
\hline Sedimentary formations, table of local names ....... & 855 & Sonthern Shoshone Range, $\Delta$ rchæan ............... & 637 \\
\hline (n....................... & 796 & Spanish Peak, Virginia Range, trachyte........... & 831 \\
\hline Selenite in Colorado Cretaceons .................... & 156 & Spaulding's Pass, Pah- Ute Range................ & 708 \\
\hline Separation Peak, Laramie Cretaceous .............. & 157 & basalt $\ldots \ldots \ldots \ldots \ldots$ & 709 \\
\hline 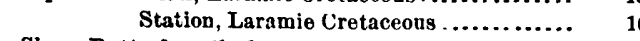 & 164 & Koipato-Triaseic .. & 708 \\
\hline Sheep Butte described ............................... & 140 & 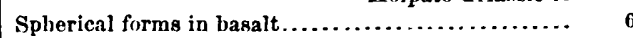 & 618 \\
\hline 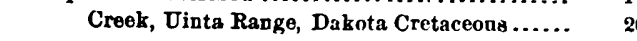 & 261 & Split Monntain, Uinta Range, anticlinal ............ & 297 \\
\hline gsp8am $\ldots \ldots \ldots \ldots \ldots 262,2$ & 263 & Sporobolug asperfolins ............................ & $\mathbf{7 4 7}$ \\
\hline Jurassic ............. 262,2 & & Sportsman's Creek, Colorado Range, granite ....... & 25 \\
\hline trail, Uinta Range. Upper Coal-Measures 2 & 290 & Spring Canon, Wachoe Mountains, angite-andesite.. & 480 \\
\hline 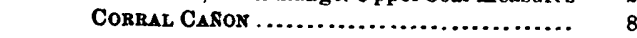 & 837 & rhyolite $\ldots \ldots \ldots$ & 479 \\
\hline 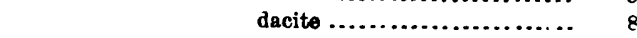 & 839 & Valley Pass, West Humboldt Range........ & 713 \\
\hline lite ..................... & 838 & Spruce Mountain, altitude $\ldots \ldots \ldots \ldots \ldots \ldots \ldots \ldots \ldots$ & 805 \\
\hline trachyte $\ldots \ldots \ldots \ldots \ldots \ldots \ldots .802,8$ & & diorite $\ldots \ldots \ldots \ldots \ldots \ldots \ldots$ & \\
\hline edicine Bow Range, gneiss ....... 1 & 108 & feldspar-porphyry ............ & 511 \\
\hline s................................. & 818 & Lower Coal-Measures............. & 510 \\
\hline 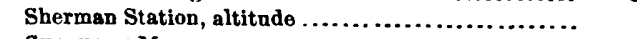 & 5 & mica-schist $\ldots \ldots \ldots \ldots \ldots \ldots \ldots$ & 506 \\
\hline 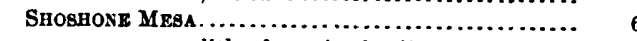 & 615 & position of ore-deposits.......... & 512 \\
\hline byعæ in rhyolite................ & 615 & thickness of Wahsatch limestone. & 510 \\
\hline te $\ldots \ldots \ldots \ldots \ldots \ldots \ldots \ldots \ldots \ldots \ldots, 614$ & 615 & wulfenite.................... & 512 \\
\hline Pass, Augusta Dtountains, rbyolites ....... & 658 & zircon in mica-schist & 506 \\
\hline Peak, dacite ............................ & 630 & Squaw Valley, Humboldt Pliocene................ & 612 \\
\hline diorite $\ldots \ldots \ldots \ldots \ldots \ldots \ldots \ldots$ & 621 & 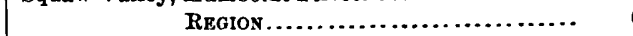 & 612 \\
\hline glacịal erogion...$\ldots \ldots \ldots \ldots \ldots \ldots$ & 620 & Ridge, rhyolite $\ldots \ldots \ldots \ldots \ldots \ldots$ & 614 \\
\hline 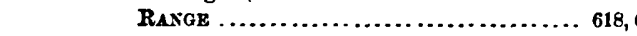 & $6: n$ & Stansbury Island, Salt Lake, Wabsatch limestone... & 460 \\
\hline and Carico Prak $\ldots . . . \ldots \ldots \ldots$ & 618 & Stanton Creek, Uinta Range, Triassic .............. & 313 \\
\hline Archæan granite ................. & 637 & Star Cañon, Wret Humboldt Range ................. & 719 \\
\hline & 637 & Peak, West Humboldt Range, altitude ......... & 713 \\
\hline 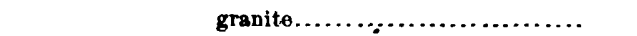 & 619 & Triassic, A ugusta Mountains .......... 651, & \\
\hline
\end{tabular}


Star Peak, Triassic, carbon in ................... Dun Glen Pah. Ute Range.

Sonoma Cañon. thickness, New Pass Mountains. West Humboldt Range.....717, 718, 723, $725,726,732,733$

White's Cañon, Havallah Range State Line Peak, altitude Staurolite in Archæin Steambont Springs, Washoe Valley, described ... Stephanito Steptoo Valley, altitude. Stibuite. Steves Fork, Elkhead Mountains, Colorado Creta. ceons. Ridge, olivine in trachyte.................. quartz-trachyte.

Stockton Hills, Weber Quartzite. Oquirrh Mountaing, titanito in porphyry ........................... Stone cavity in granite-porphyry.. Stony Point, altitude rbyolite

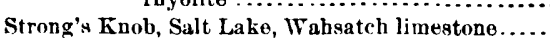
Sub-Carboniferous, Dry Cañon, Ołuirrh Monntains..

$$
\text { Piñon Range .................. }
$$
Rock Cañon, Wahsatch Range. Sne Peak, Battle Mountaius, altitude Sugar Loaf, Fampa Valley, trachyto ............... Sulphur Creek, Colorado Cretaceous ................ Hnmbolit Valley Hnmbollt Valley ....................... Springs........................143, 183, 232, $235,298,401,438,550,687,752,786,8,0,830$

SUMMIT REgION WEST OF LODORE CANON.......... 28. Valley, Uinta Range, fanlt ............... 287 Tertiary in..............

Sunny Po'nt, section of Green River Eocene... .... Sunset Gap, Squaw Valley, rhyolite.

Susan Creek, kiver Range, augite-andesite ......... rhyolite ..................

Sybille Creek, Laramie Hills, Carboniferous ......... granite $\ldots \ldots \ldots \ldots . . . .$.

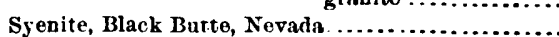
Clnro Hills, Nevada ....................

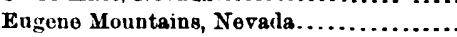
Montezuma Range

Winnemucce Peak

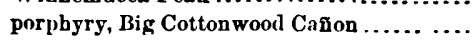
Cortez Range

Table Mountain, Laramie Hills, described aection of Palaozio of local names of the sedimentary formation of the Fortieth Parallel

Rock, Green River Encene..................

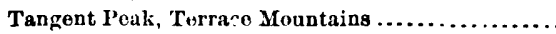
Tank Peak, Yampa Plateau

Tarogqua Peak, altitudo of .........................................

Taylor's Creck, Seetoya Monntains, diorito ........

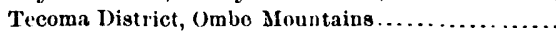
Tenabo Peak, altitule diori'e

825

486

731

\begin{tabular}{r|} 
Page. \\
723 \\
710 \\
693 \\
682 \\
645 \\
18,723, \\
732,733 \\
682
\end{tabular}

274,358

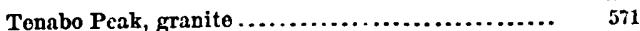
Lmestone ....................... 572 IFGION......................... 55

Terrace lines, Lake Bonneville........... 401, 417, 418, 4:1,$$
\text { Ia Hontan .... }
$$

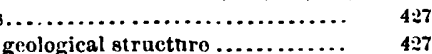
Humboldt Pliocene............. 497 terrace lines .................. 427

TEnTIARIES OF the UNTA VALLEY................. 307 Teitiaky beds of Nonth Palik ............... 127 Forimationi of GieEN River Basix ...... 202

Laramic Plains...................... 93

Plaixs of W Yosing ..................... 65

seas north and soutl of Uinta Range con.

Tetrabedrite

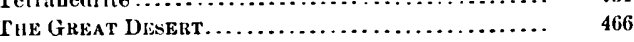

Thermal Springrs, Autelope Valley............... 540 in faulted regions ...........401, 438, 524 volcanic regions ...602, 614, 633, 666, 687, $704,706,773,774,793,825$

Kawsoh Monntains ............. 773 Little Cedar Mountains.......... 514 Ruby Valley................. 541 Salt Lake City ................... 374 Thickness of Bridger Eocene ... ..............204, 217, 245 Brown's Park Tertiary ............. 223 Cambrian ...............366, 398, 412,413, 553 Colorado Cretaceous ..............28, 43, 116,3:34 conformable strata, Wabsatch Rayge . 341, 370 Cretaceons, Uinta Range............. 200 Dakota Cretaceous...........28, 116, 264, 333 Eoceno formationa, Green Rirer Basin. 203 Fort Benton Cretaceous ............ 87 Fox Hill Cretaceous ..... 28, 60, 143, 154, 157, 201 Green River Eocene ................ 204, 240 Uumboldt Pliocene ................ 741 Huronian, Wabsatch Range........... 3is Jurassic, east of Walisatch Range....28, 38, 80, $91,115,200,263,264$ west of Wabsatch Range.... 739, 753 Koipato Triassic .................. 644, 710 Laramie Cretaceous................ 28,60 Nevada Devonian .................. 544, 554 Niobrara Plioceno................... 68 Ogden Quartzite..................... 400, 554 Palæozoic strata.....28, 76, 149, 161, 551, 554, 575 Permo-Carboniferous................ 389 Pogonip limestone ...............533, 542, 609 Quaternnry .................... 439, 740 Red Beds Triassic ............. 28, 33, 79, 80, $115,292,332,370,390$ Star Peak Triassic..............645, 7.27, 732 strata exposed in eastern foot bills, Col-

orado Ringe .................... 28 Truckee Miocene ................. 757, 766 Dinta Eocene................... 308 Upper Coal-Heasure limestone ....199, 274, 670 Ute limestone.................364, 385, 399, 409 Vermillion Creek Eocene ......... 240,331, 338 Wabsatch limestoue ........... 375, 386, 400, $409,510,524,530,538,607$ Weber Quart zite ...... 199, $956,287,323,325,387$ Whate R.ver Diecene............. 
Page.

Thickness of $W$. sming Conglomerate........72, 157, 246, 247 Thonsand Spring Valles, described....

, Vacier bain

structure $\ldots \ldots \ldots \ldots \ldots \ldots \ldots \ldots . .345,349$
Tirakav Plateau, Wyoming Conglomerate $\ldots \ldots \ldots \ldots . .290,294$ Titanite in diorite

granite ...356, 357, 359, 360, 477, 576, 676, 738, 778, 807 gravite-porphyry ................449, 485, 491

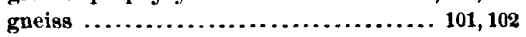

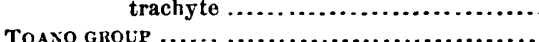
geological structure.

Tokewanna Peak, altitude of...................... Weber Quartzite

TOOELLE AN D RUSH VALLEYS.

Cañcn, Lower

Tourmaline in granite .....................270, 691, 778

Torane Ravge...

$$
\text { granite. }
$$

(n....................

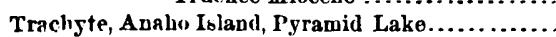
Axtor J'asa, Virginia Rango

(augite), North Park

Pilot But to Berkshire Caũon. Virginia Range........... hOUY OF WESTERX UINTA RANGE

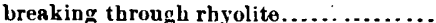

Camel Peak, Elkhead Mlountaing ........

City Cretk, Wahsatch Range...

Coal Creek, Seetoya Mountains

Crescent Peak, Elkbead Mountains....

divide between Provo and Silver Creeks.

Dixie Valley.

East Cañon Creek

East Humboldt Range.

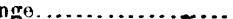

Elkhead Mountains ......................

Euclid Peak, Focntain Head Hills .......

IIantz Peak, Eikhead Mountains.........

Hä̈ $\zeta \boldsymbol{n}$ in $\ldots \ldots \ldots \ldots \ldots \ldots \ldots \ldots \ldots \ldots .568,593$

lornblende prevaiking over sanidin.......

Jacob's Promontory

Kawsol Mountaics.

Kimball's, Parley's Park ...............

like rhyolite.

Morgan Valley .......................

Palisade Cañon, Cortez Range .............

Parkview Peak, North Park..

Pine Nut Cañon, Pah-Cte Ringe .20...

Purple Hills, Virginia Range .

(quartz), Care Creek, East Humboldt Range

Havallah Range

Steves Ridge, Elkhead Mountain

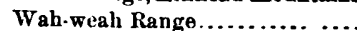

White hocks ......................

Roberts' Peak.

Cañon, Virginia Rango ...... 832, 837

Skelligs Ridge, columnar structure of .... 171

Spanish I'eak, Virginia Range............. 831

Sugar Loaf, E.khead Mountains ..........

texture of andtrite.

titanite in .

Traverso Mountains................... 440

tridrmite in ..............317, 320, 382, 334, 375, 598

Truckee Cañon, Virginia Range ......... 827, 828,

Wagou Cañon, Cortez Rang* .......... $830,831,834$
Trachyte, Wal-teah Pance Page.

Wbitekeal Peak, Elkhead Mountains....

Willow Creek Cañon, Piñon lange ....... 458

Transition from garnet to chlorite ............... $\quad 379$

TRAVERe Mountaix

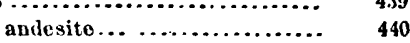
trachyto................... 440

Tremolite in granite, Long's Peak.............. 23

Triassic, Antero Cañon, Uinta Range ............. 290 Ashley Creek, Uinta lange, section of..... 292 Black's Fork........................ 254 eastern foothills, Culorado Range .......... 28 Elk Mountain, Wyoming ................ 149 Flaming Gorge Kidge, thickness of......... 265 Forsiation of the Colorado Range ...,.... 33 Inskip Cañon, Pah-Ute Range........... 709 Lake Fork, Uinta Range............. 31,2

Larsmie I'laius...................... 77,82 erosion of ............... 77,99 tbickness of ............ 79 Valles...................... 81 Lily's Park .......................... 281, 283 liniestone in, Colorado Range........... 35, 58 Koipato...........644, 708, 716, 716, 719, 728, 733 Miner's Cañon, Truckee Range .......... 809 near Hantz Peak ...................... 174 North Park, thickness of ............... 115 Rawlings Peak, Wyoming ............159, 162, 163 Ripple-marks in .................... 92 Stanton Creek, Uinta lange............ $\quad 313$ Star Peak.......... 651, 657, 682, 693, 718, 723, 732

Uinta Range, described................. 200 thickness of ................ 200 Upper Fampa River.................. 184 Valley of Burnt Fork................. $\quad 259$ Yampa Valley ....................... $2 \times 4$ Tridymito in rhyolite ...................430, 485, 516, 8;0 trachy te ..............317, 320, 375, 382, 384, 598 Trinity Cafon, Montezuma Range, Archæn schists, $\quad 8.54$ Peak, Montezuna Range, altitude of....... $\quad 7.51$ Trona, an article of commerce................. 748 ThuCKeE Cason .................................. $8: 27$ andesite ..................... 827 angite-andesite................. $\quad \mathbf{8 3 0}$ basalt.......................828, 831,836 columbar structure in rhyolite.... 830 diorite ....................... $\quad 832$ feldspar-porphyry .............. 828 Humboldt Pliocene .............. \&3! propylite....................... 827, 831 rhyolite.................... 831,834 trachy to ..............827, 828, $830,831,834$ Mioceno-Carson Desert............... 745 Dog Creek, cual .............. Golconda Pass ................ $\quad 686$ gypsum in ................. 808 Humboldt Valley ............ 740, 742 Humboldt Valley ...............
infusiorial silica............... 770,820 -Job's Creek .

Kanıma Mountains ........... 790 Kawsoh Mountaing ............ 760 Lone Hill Valloy, coal in....... Lovelock's Station (east of) .... Luxor Peak (base)............ palagonite tufa in ............. quartzite in ............... 77 
Page.

Tr uckeo Miocene-Shoshone Range...........639, 640,642 Toyabe Rango............... 631 Truckes Valley, coal in ......... White Plains vertebrate remains in ......

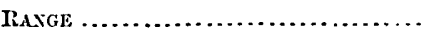
A rchean ...................... 804, $>06$ loasalt ....................... 810,811

diabase ...................... 811,813 granite...................... $\$ 06$ rhyolite ...................... 813 Tutib Peak ......................

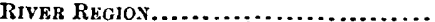

Valley, Humboldt Pliocene .................... Lake La Hontan terraces ........... Truckeo Miocene

Tucubrts Mounialns.

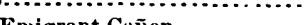
fault in Walusatch limestone.

Tulasco Peak ................ Upper Felderberg fossils .....

Tufa deposits, calcaruous. Tulasco Peak, Tucubits Mountains, Lower Coal. Measures. rhyolite....

Turtle Bluffs, Wyoming Conglomerate

Turtles in Colorado Cretaceous Tuscarora, Independence Valley, andesite. ......... propylite .........

Tu-tib Peak, Truckee Range, altitude diabase ................ rhyolite.

Twin Peaks, IVabaatch Range, A rchæan Cambrian .......... Granite-porphyry...

Uinta Eucene, age of. Kern Ridge. 307,31 thickness ........................ $\quad 308$

Range, amount of crosion in............... 198, 202 anticlinal axis of...........256, $257,558,267,323$ Archæan........................ 198, 201 Cambrian ....................... 199 Cretaceous....................... 200, 201 conrse of Green River in ..........194, 205, 282 difficulties of exploration .............. form of folds .............200, $201,283,286,32 ;$ Jurassic ......................... 200 limit of forest.growth............. 195 moraines.......................257, 300, 310 Permo-Carboniferous ............... 199 relation to the Wahsatch Range....... ' 316 thickness of Mesozoic formations..... Weber Quartzite........199, 256 $287,323,325$

Tertiary seas north and sunth of...... Triassic. Upper Coal-Measures ...............

199 Carboniferons and Triassic : $n$ Novaca $\quad 690$ Cretaceous and Eocene ...226, 2:29, 231, 235, 239, $313,331,336,392$

Cretacoous and Jurassic, Wahsatch Range...................315, 371, 382, 391
Unconformity, Green River and Bridger Eocene 211,

Green River Eocene and Ilmuboldt

Pliocene .................... 502

Truckce Miocene and IIumboldt Plio-

ceue .......................... 820

Vermillion Creek and Green River

Eocene...............210, 213, 220,227, 210 Wyoming Conglomcrate and Eocene.

Jper Brate Riveis Valley..................... 326

Uprer Cual-Measures, Battle Mountains .......... 609

Bear River Narrows ........ 338

East Branch of Duchesne... $\quad 305$

Black's Fork (head)......... 255

Connor Peak............... 452

conglomerate in ............. 325

Diamond Peak............ 272

East Mountain .............281, 283

Euclid Peak .............. 521

Lily's Cañon .............. 280

Orford Peak .............. 508

Peoquop Range ........... 507, 508

Pilot Peak ................. 497

pyrites in ................ 28

Ravenswood Peak ..........

Rhodes's Spur .............. 313

Section Ridge.............. 285

Sheep Creek trail ............ $\quad 290$

Tank Peak................ 284

Uinta Range, described..... 199

Ute Peak, Uinta Range ...... 288

Upper Weber Cañon......... 321

Vermillion Creek ........... 27

Weber Cañon.............. 388

Tampa Cañon.............. 287

Yampa Peak.............. 279

Zenobia Peak .............. 287

Helderberg fossils, Emigrant Cañon.......... 524

Ogden Cañon, Ute limestone................ $\quad 416$

Weber Cañon, Cpper Coal-Measures .......... 321

Yampa River, Moore's Fork, basalt ...........

Jurassic.......... 183

Triassic......... 184

Up.River Peak, Elko Range, rbyolite............ $\quad 602$

Utall Basin .............................. 311

Hill, Black Rock Mountains, rhyolite-breccia . 795

LAKE REGION .............................

VALLEY ......................... 441 terrace lines ................. 441

Uie Fork, Uinta Range, caūon within caũon ....... 301 glacial woraines...........300,310

limestone, Bear Rivur Plateau, thickness....... 415 Call's Fort, Wahsateh Range....... 405 Little Cottonwood Cañon........... 363 Muddy Cañon..................... 410

Ogden CaĨon .................... $\quad 399$

Upper Ogden Cañon ............... \$16

Peak, Wabsatch Range, described............ . 409

Uinte Range, Weber Quartzite .......... 288

Valley of B urnt Fork, Dakota Cretaceous ......... $\quad 259$

Jurdesic ................... 259

Triassic ................. 259

erosion of Cooper Cretk ................ 85

of the MediciNe Bow River ............ 142

North Platte.................. 159 


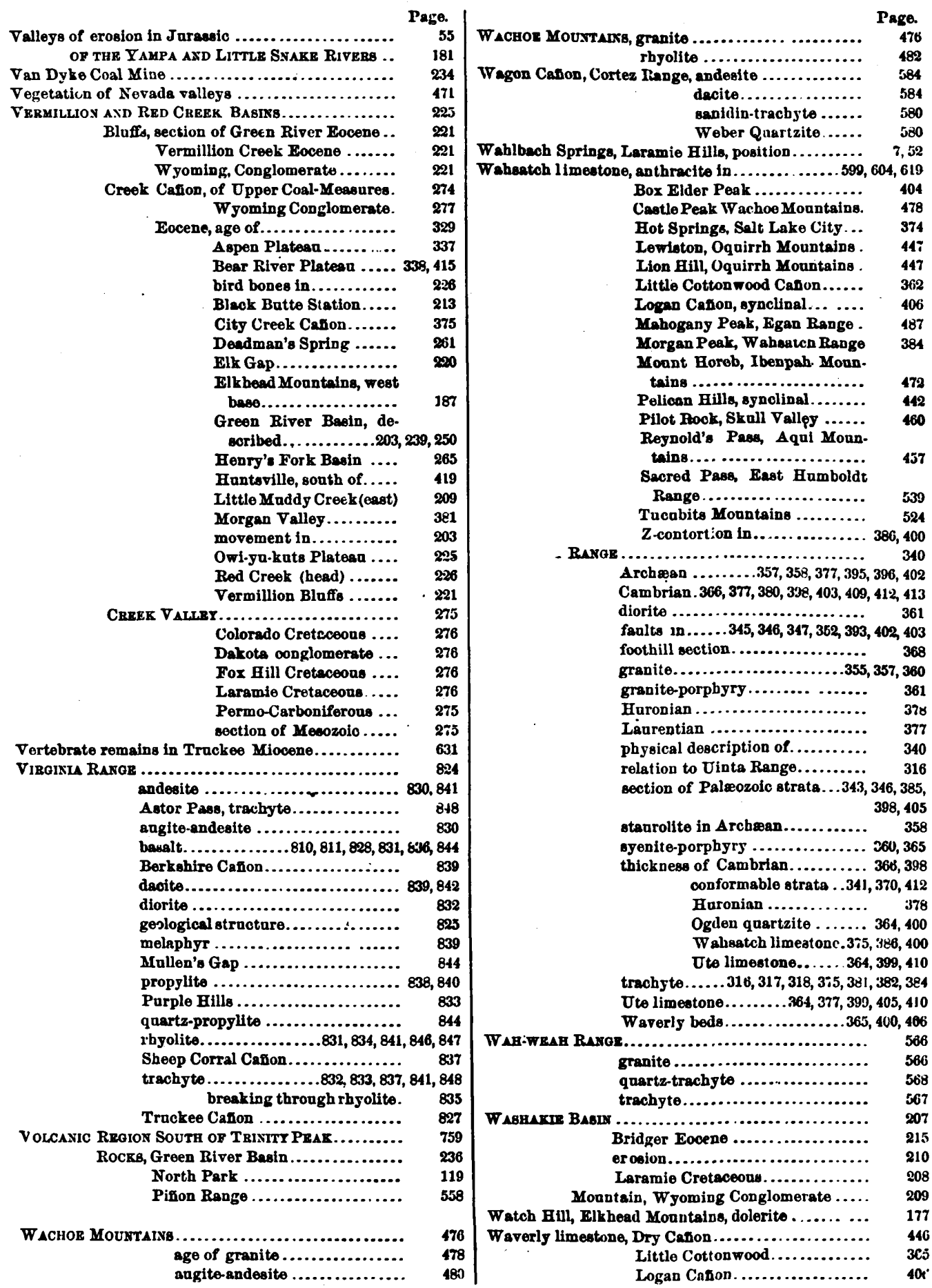




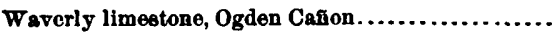
Webrr Caso Jurassic section................... Permo-Carboniferous section.........

Triassio section .....................

Upper Coal-Measures ..................

Weber Quartzite section

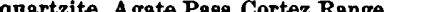
Antero Creek, Uinta Range...... Ashley Park, Uinta Range ...... Berry Creek, Uinta Range . ...... Biugham Cañon, Oquirrh Mountains.

Black's Fork, Uints Range ... ..... Burro Paek, Uinta Range........ Clayton's Peak, Wabsatch Range Dalton Peaks, Cortez Range . .... fossils in ...................200, Fonntain Head Hills . Gilbert's Peak, Dinta Range .....

Gosi-Ute Range .................. Junction Peak, Uinta Range...... Kamas Creek, Uinta Range ....... Leidy's Peak, Uinta Range.

Mill Creek Canon .................

Mount Agassiz, Uinta Range..... Lena, Uinta Range ........ Neva, Cortez Range.......610,6 Osino Cañon - 504 Peoquop Range ................. 507 Pinon Range ..................... River Range................... Shoehone Range. Soldier Cañon, Oquirrh Mountains Stockton Hills.................... Tokewanna Peak.

Uinta Range discussed ........... Wagon Cañon, Cortez Range ...... 580 Whirlpool Cañon, Green River....

River, thickness of Colorado Cretaceons..... Dakota Cretaceous ....... 333

WEgTERN UINTA RANGR..........................

W Rat HUMBOLDT RANGE ........................ endesite ........... 716 Archæan................ 715, 717 basalt .................. 729 Coyote Cañon ............ 719, 721 diabase $\ldots \ldots \ldots \ldots \ldots \ldots \ldots .716,727$ orosion in Buffalo Cañnn .. geological structure of ...714, 716, 736 gneiss. granite.................. 714 Jurasuic limestone ........ 727, 732 Koipato Triassic....716, 719, 728, 733 thickness.

porphyroids................

Prince Royal Cañon.......

Star Cañon................... Triassic ..717, 718, 723, 725, $\begin{array}{rr}\text { Wright's Cañon........... } & \mathbf{7 1 7} \\ \text { REgion } . . . \ldots \ldots \ldots \ldots \ldots \ldots \ldots \ldots & 713\end{array}$ age.

White Clond Peak, East Humboldt Range, granite.. 532

Whitehead Peak, Elkhead Mountains, altitude...... 169

porphyry..... $\quad 169$

trach to $\quad 169$

Whitr Pine Mountaivg granite ................. 542 Mokemoke Ridge .......... 547

Nevada Deronian, thick.

ness .................... 54 section of Palrozoic.......... 54 Pogonip limestone .......... 543

White Plains, Nevada, rhyolite.................... Trucke Miocene ............. 770

River, basalt at head of .................. 184 divide, Coal Monntein ................. 279

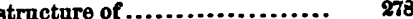

WuIT Riven

near Carr Station........... Owl Creek

thickness of

thickness

Rocks, Cedar Mountains, quartz-trachyte ... sandatone in Laramie Cretacebus.

White Snlphur Spring

White' Caglon Harallah Range ...2. Whirlpool Caxion, Groen River, Weber Quartzite ... 286

Whirlwind Valley, brealt......................... 618 Willard Peak, Wahsatch Range..................

Willow Creek Ceñon, Piñon Range, anticlinal ...... 55 Aqui Mountaing, glecial arosion Aqui Mountains, trachyte.....

Springs A..............................

Winnemnces Lake described ..................... RhGION ........................

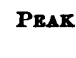

Wonsits Ridge, limit of Uints Elocene...............

Wright's Cañon, West Humboldt Rango .............

Wulfenite ........................................

Wyoming Coal Company..........................

Conglomerate, Bear River (head)........ Bishop's Mountain......... 220 Concrete Platesu, thickness 247

Great Plains, Colorado :.... 64, 71 thicknees 72

Green River Baoin ........ 205, 25

Heber Mountain........... 316

Mount Corson, thickness ... 247

Muddy Mountain.......... 189

Obelisk Platean ........... . 308

Ti-ra-kav Plateau.......... 290,29

Tartle Bluffs, thickness.... , 246

Vermillion Bluffs ........... 221

Vermillion Creek Casion... 27

Washakie Mountain .......

Yamps Platesn............ 285

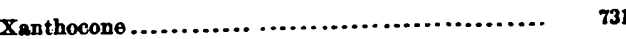

Yampa Canion, depth of ......................... . 196 Upper Cosl-Measures................ 287

57 D G 

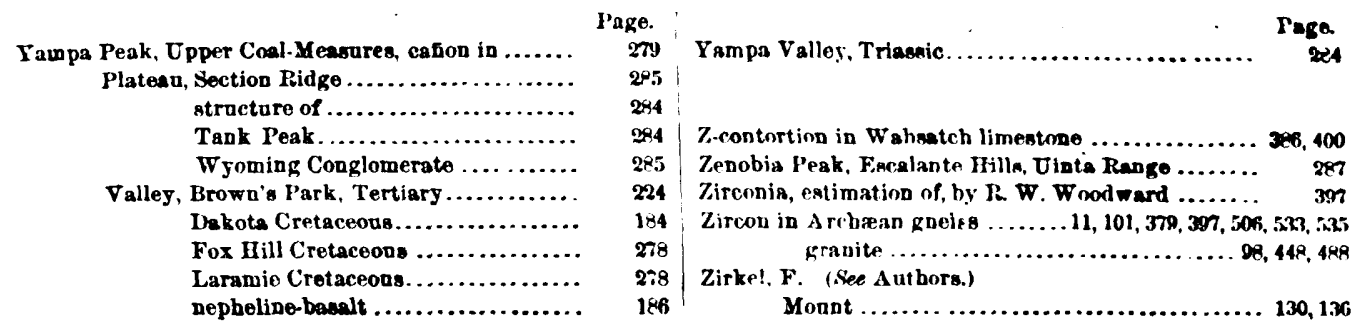


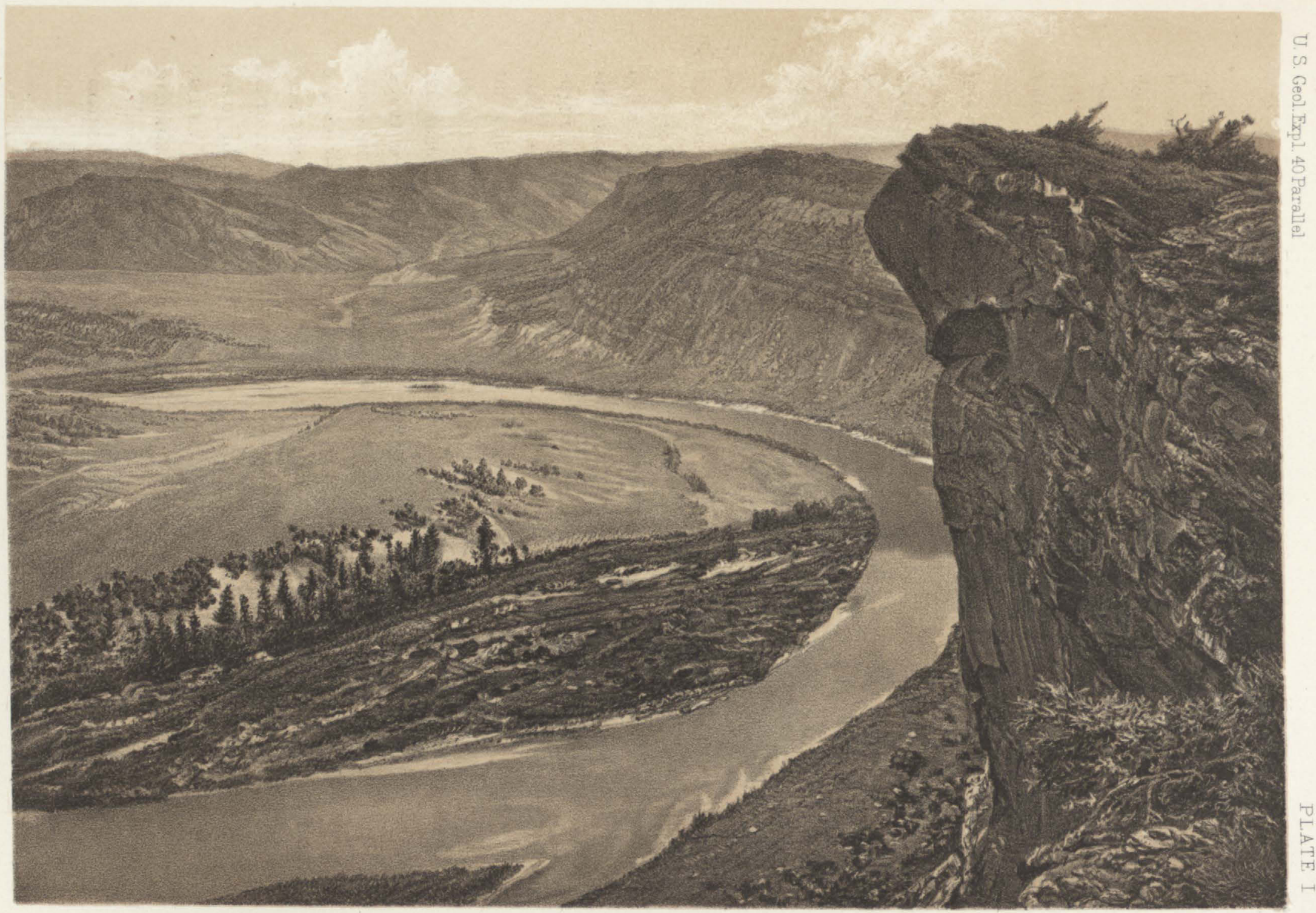

HORSE SHOE CURVE - GREEN RIVER - WYOMING 


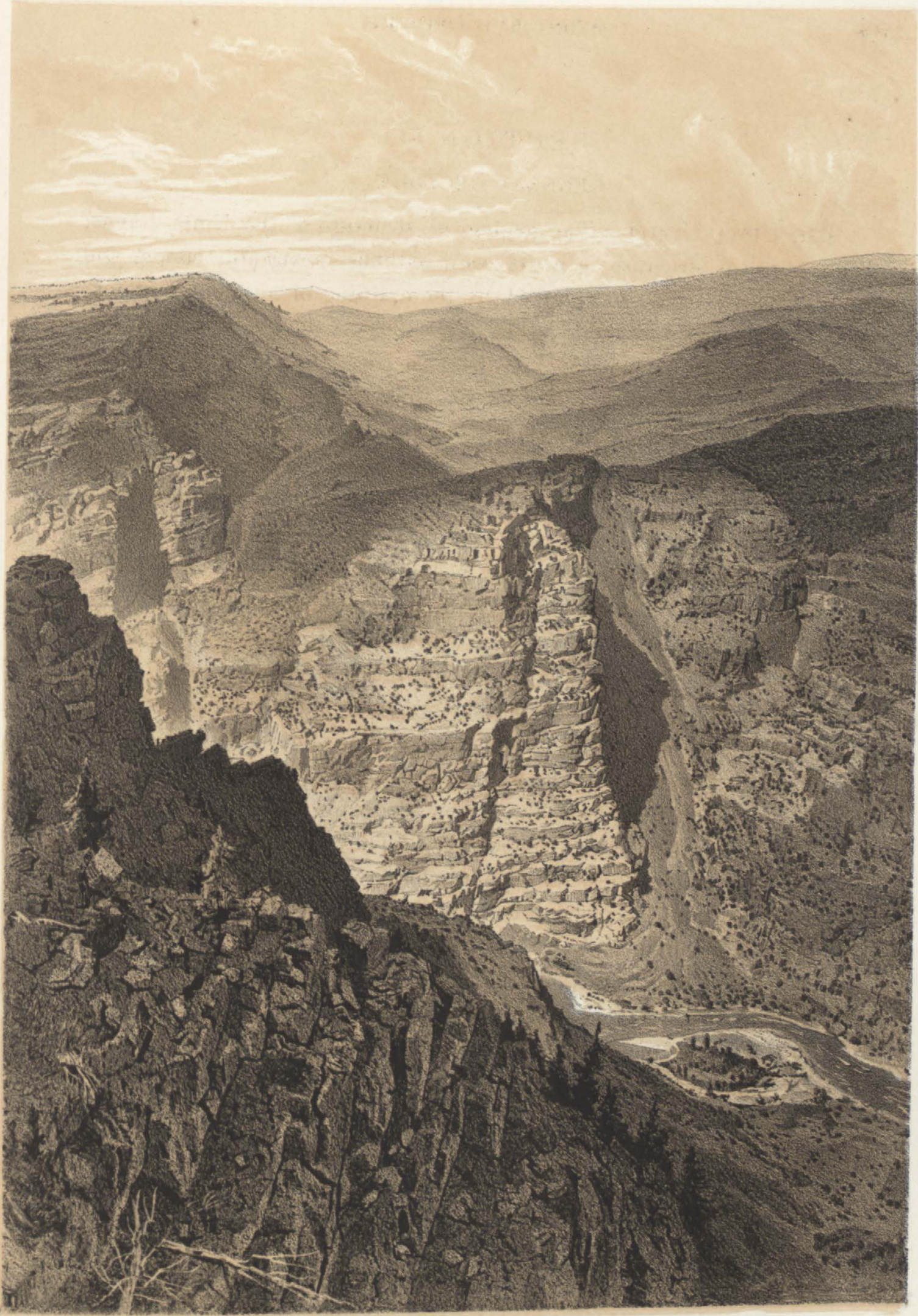




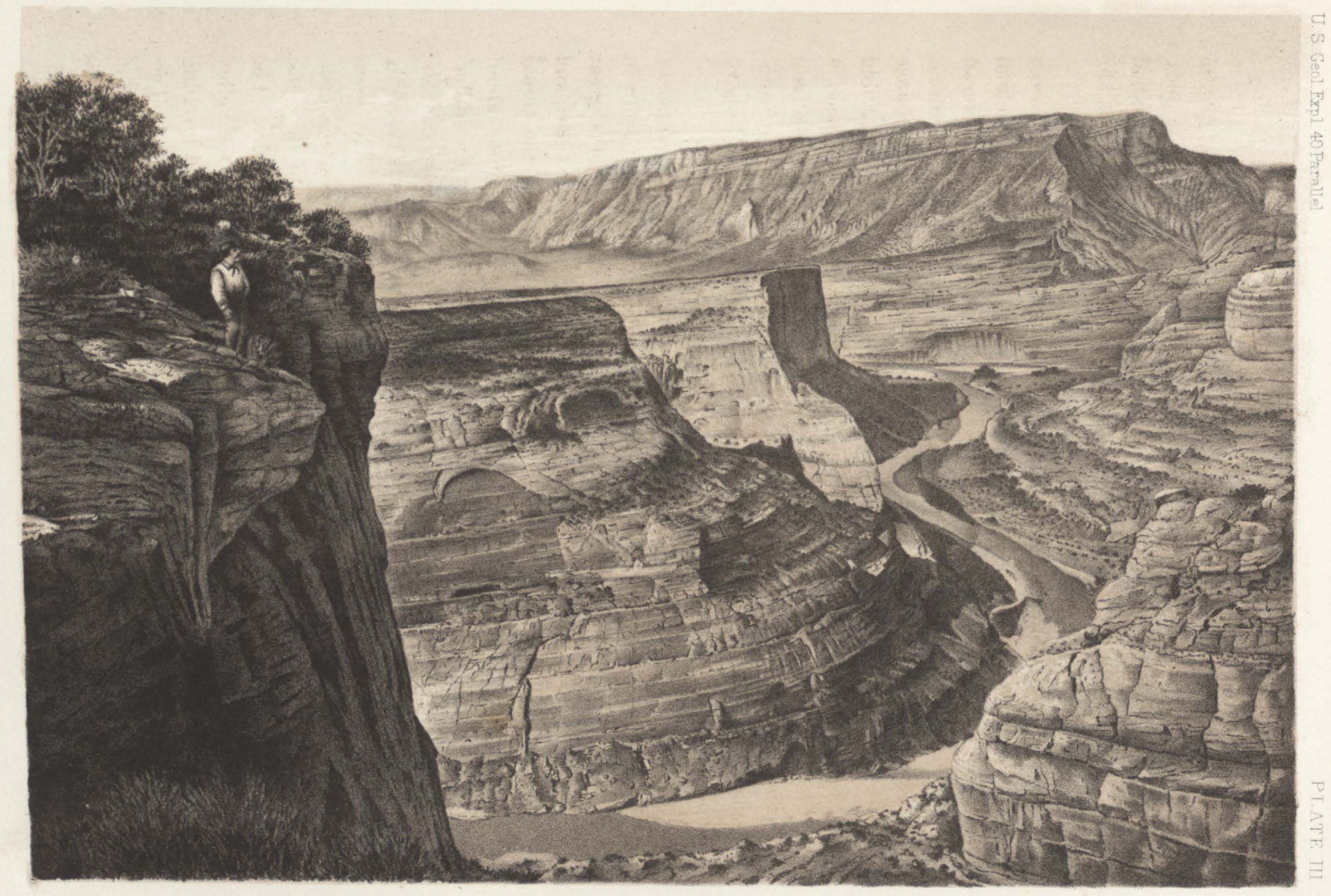

CANON OF THE YAMPA.NEAR JUNCTION WITH GREEN RIVER _ UINTA RANGF 


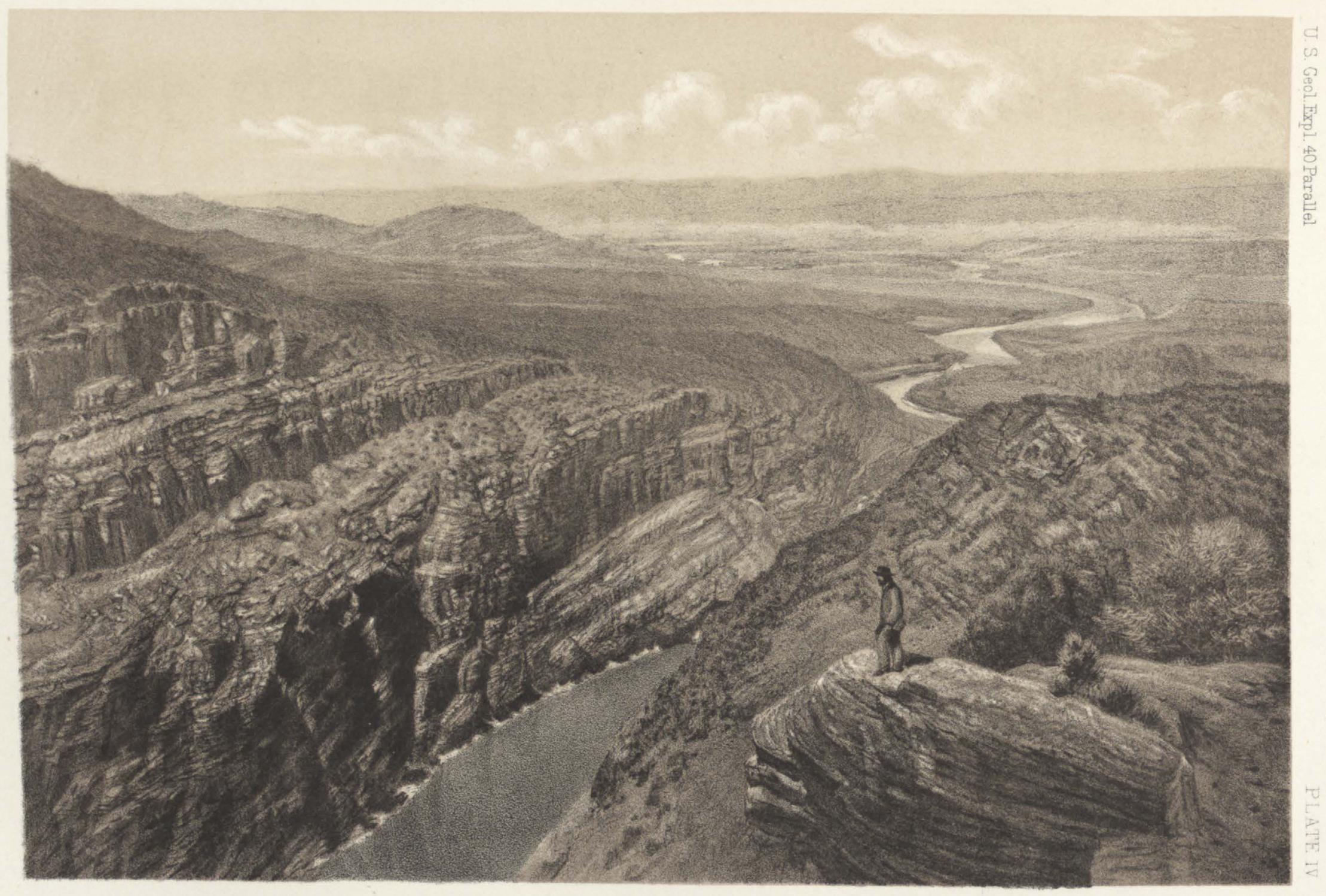

BROWNS PARK FROM THE ENTRANCE TO CANON OE LODORE - UINTA RANGE 


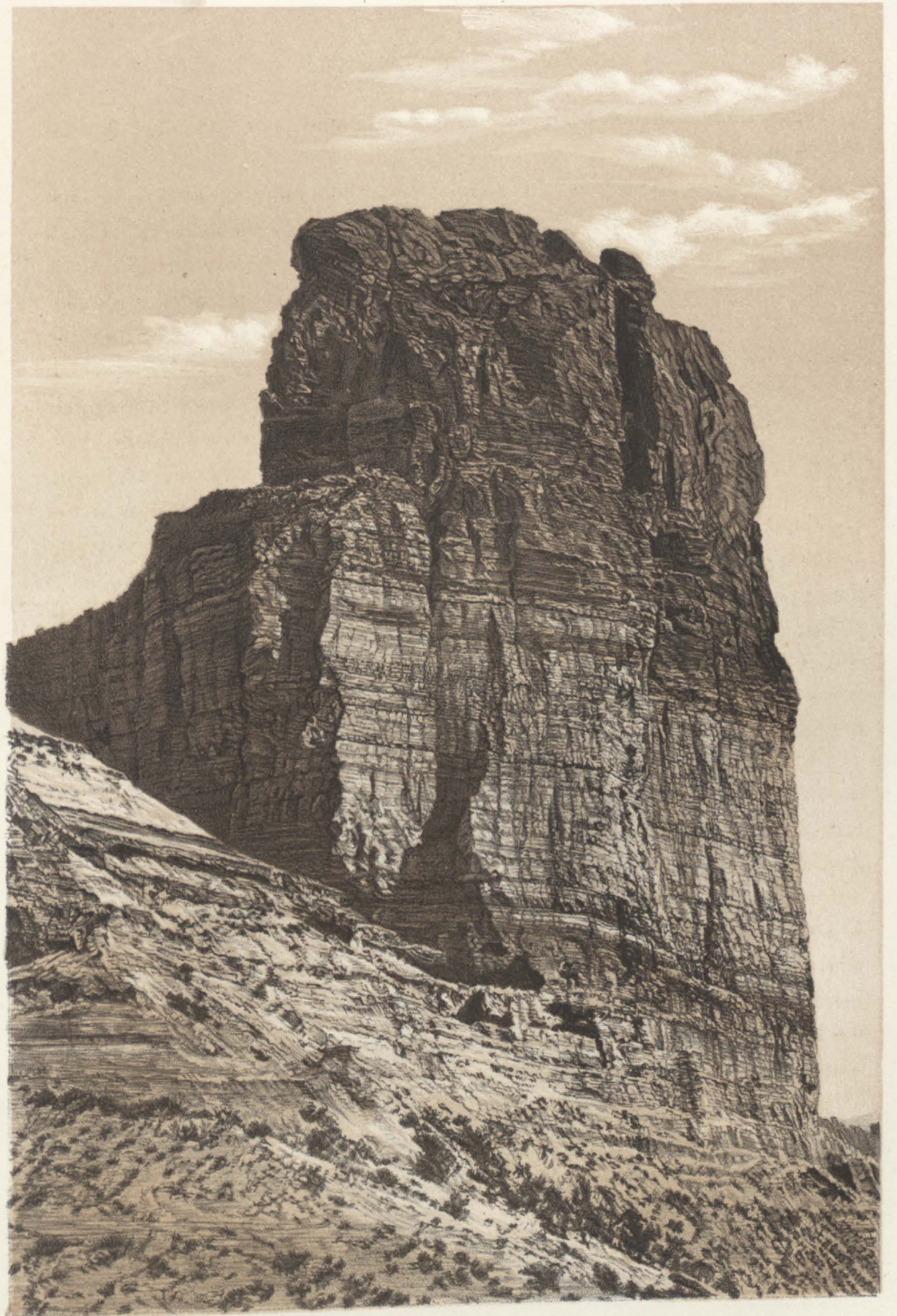




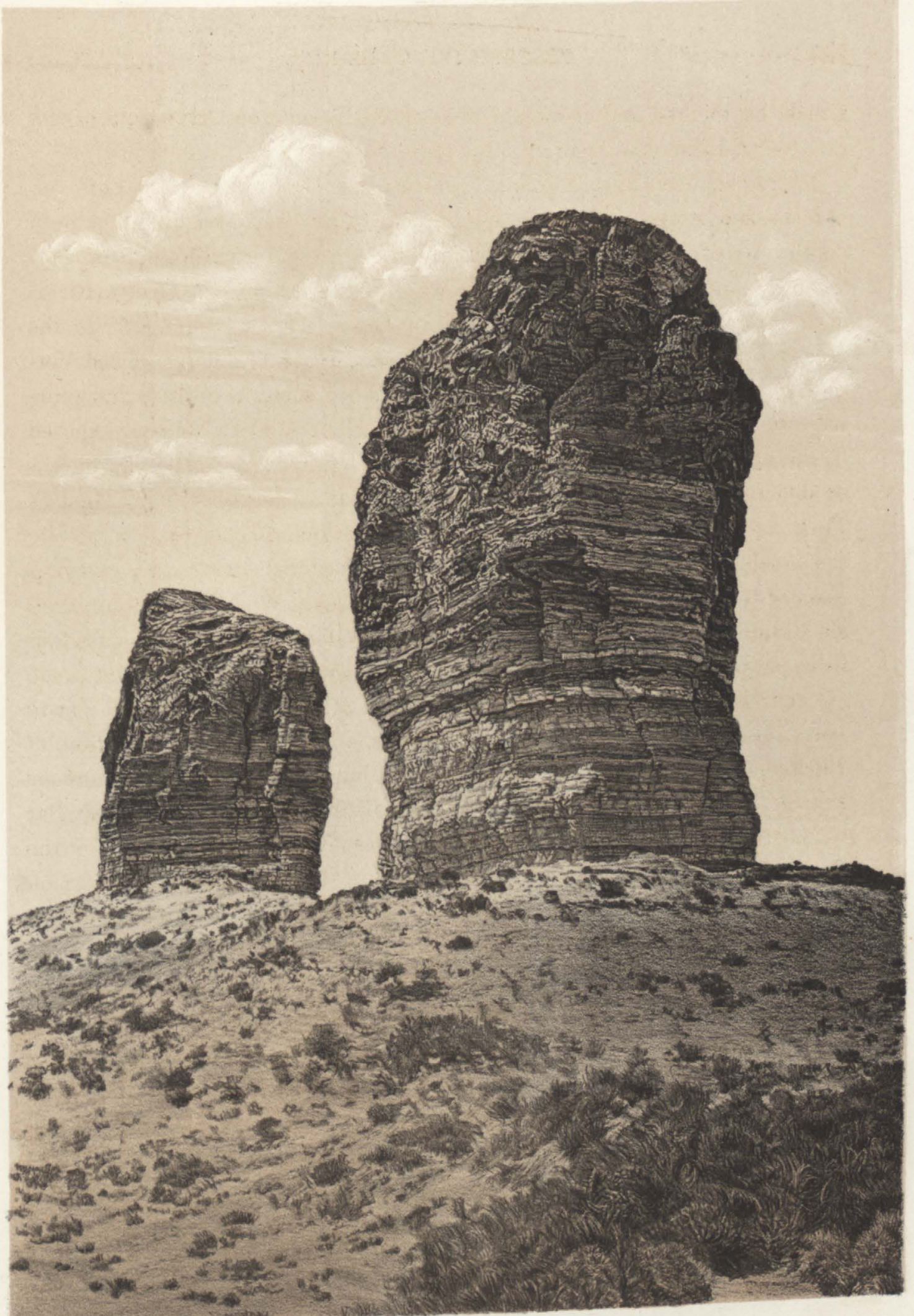

TERTIARY COLUMNS _ GREEN RIVER CITY - WYOMING 


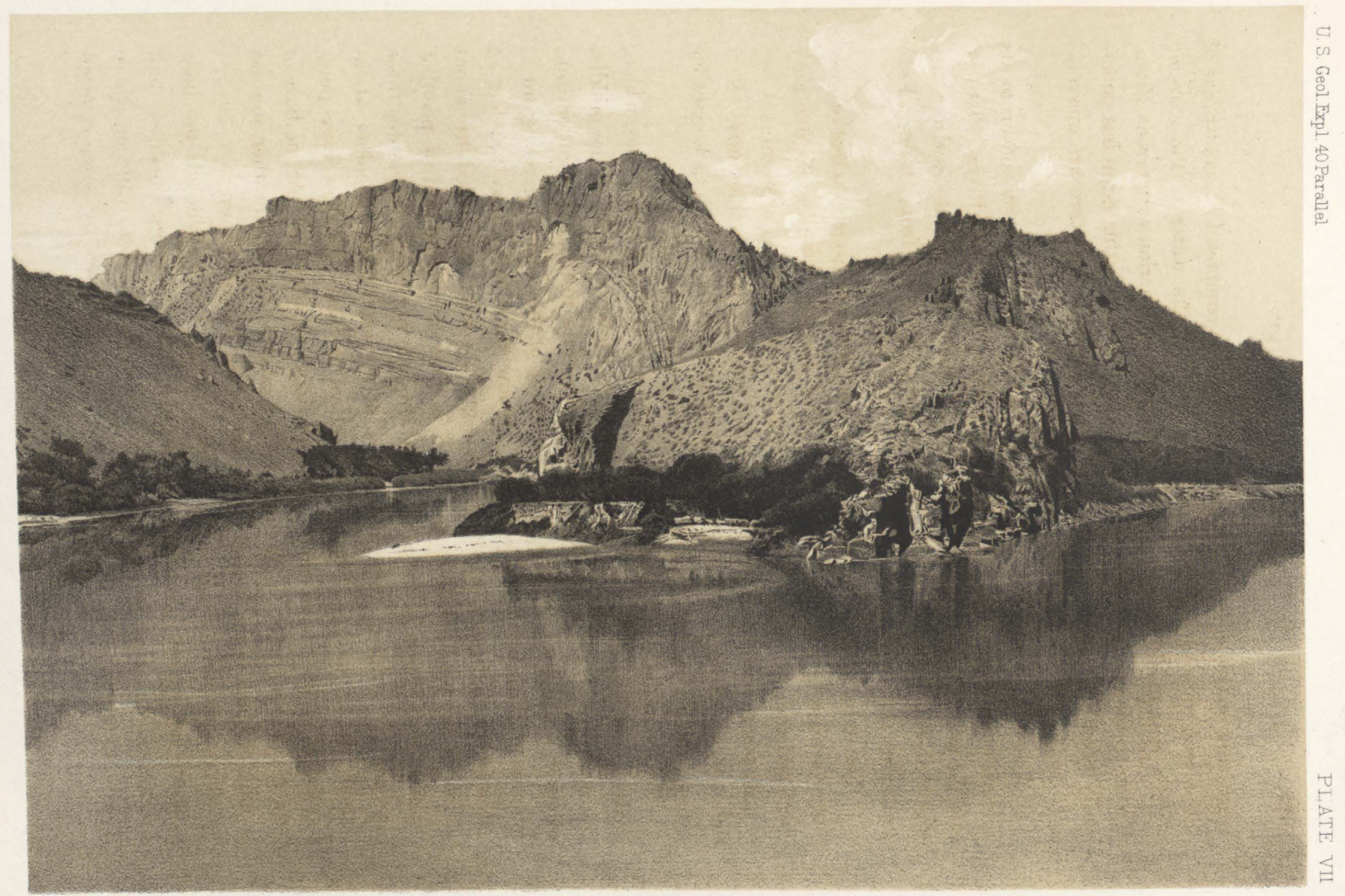




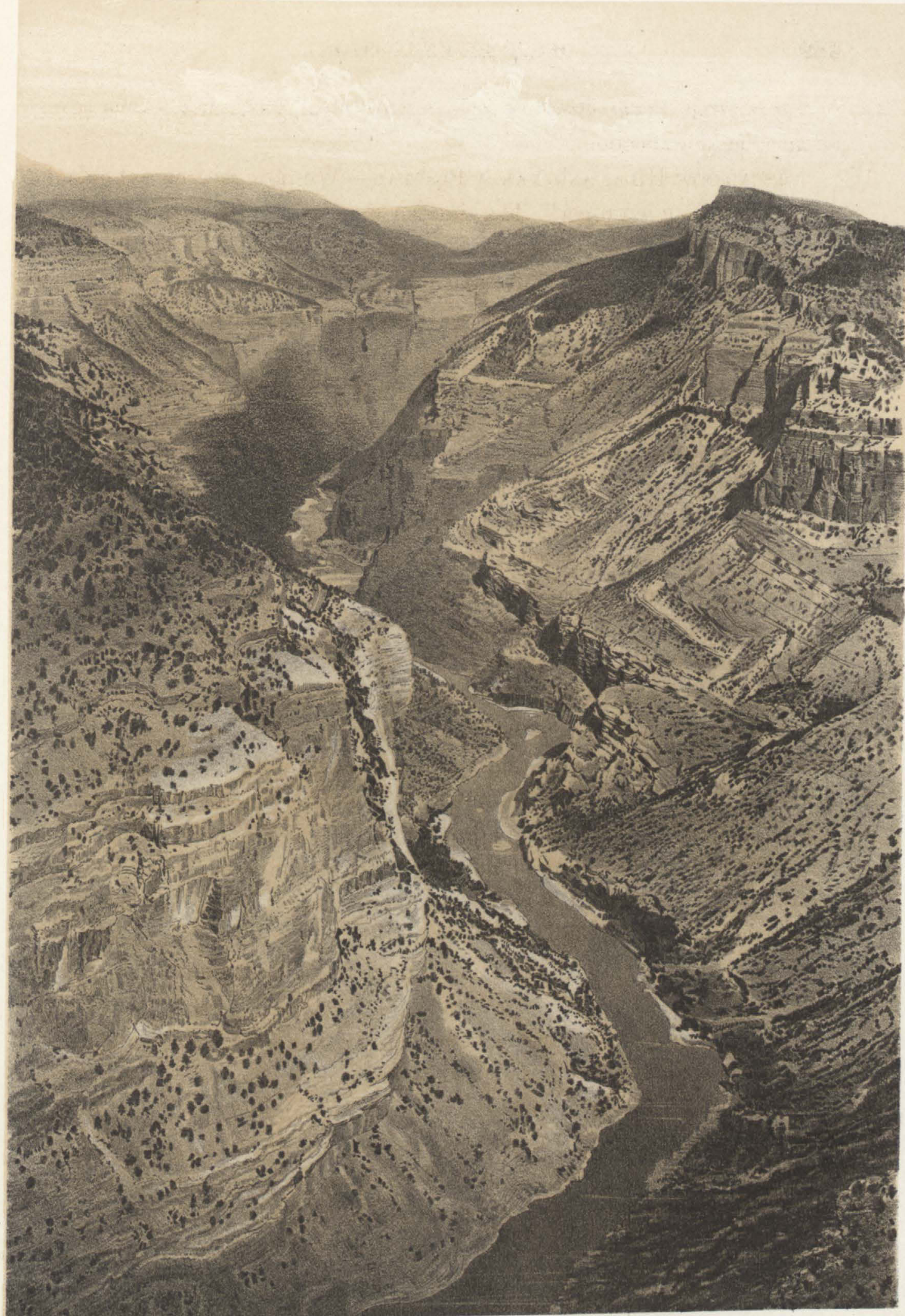




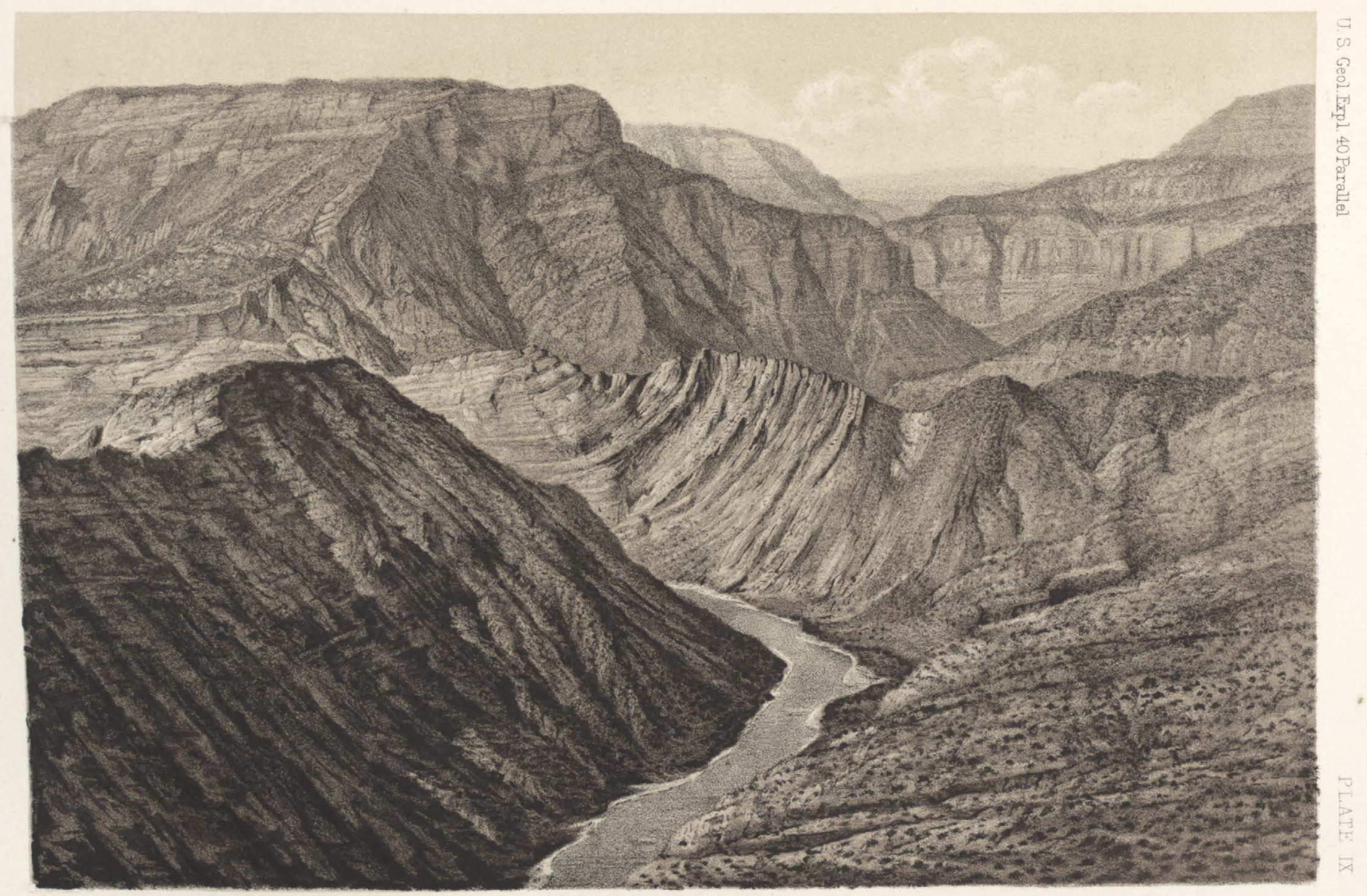

CURVED CARBONIFEROUS STRATA AT JUNCTION OF YAMPA AND GREEN RIVERS - UINTA RANGE . 


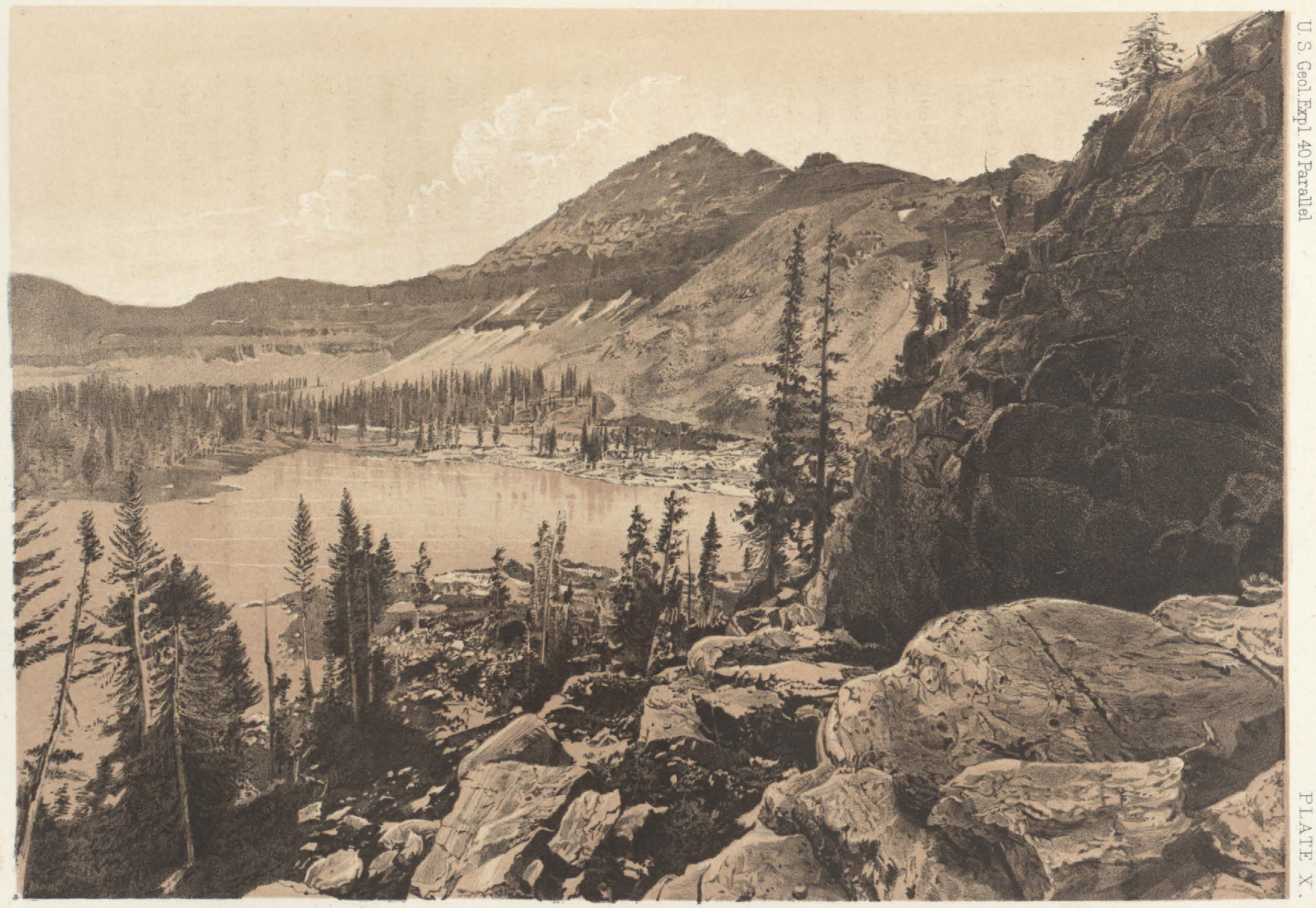

AGASSIZ AMPHITHEATRE _ UINTA MTS 


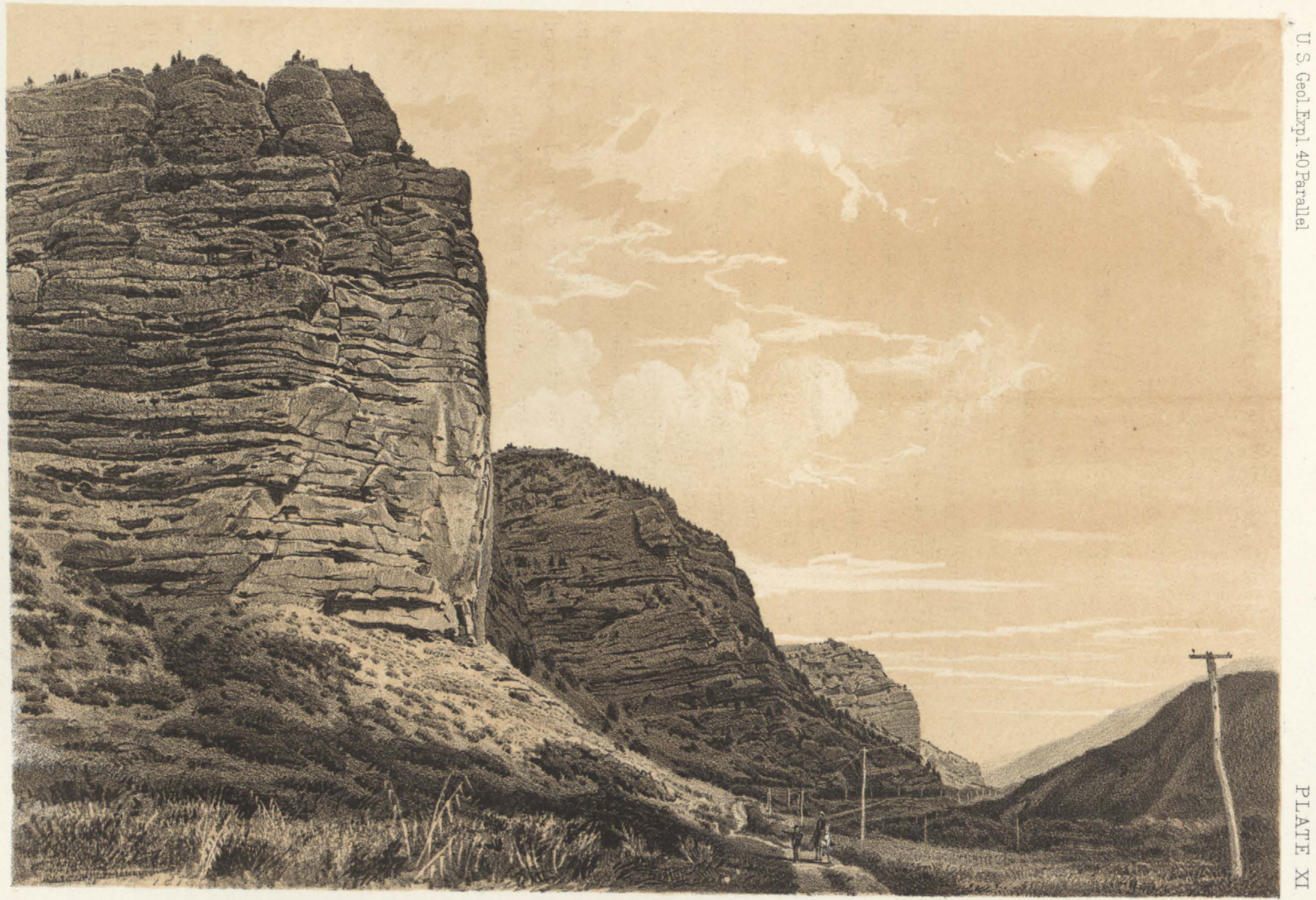

ECHO CANON - UTAH 


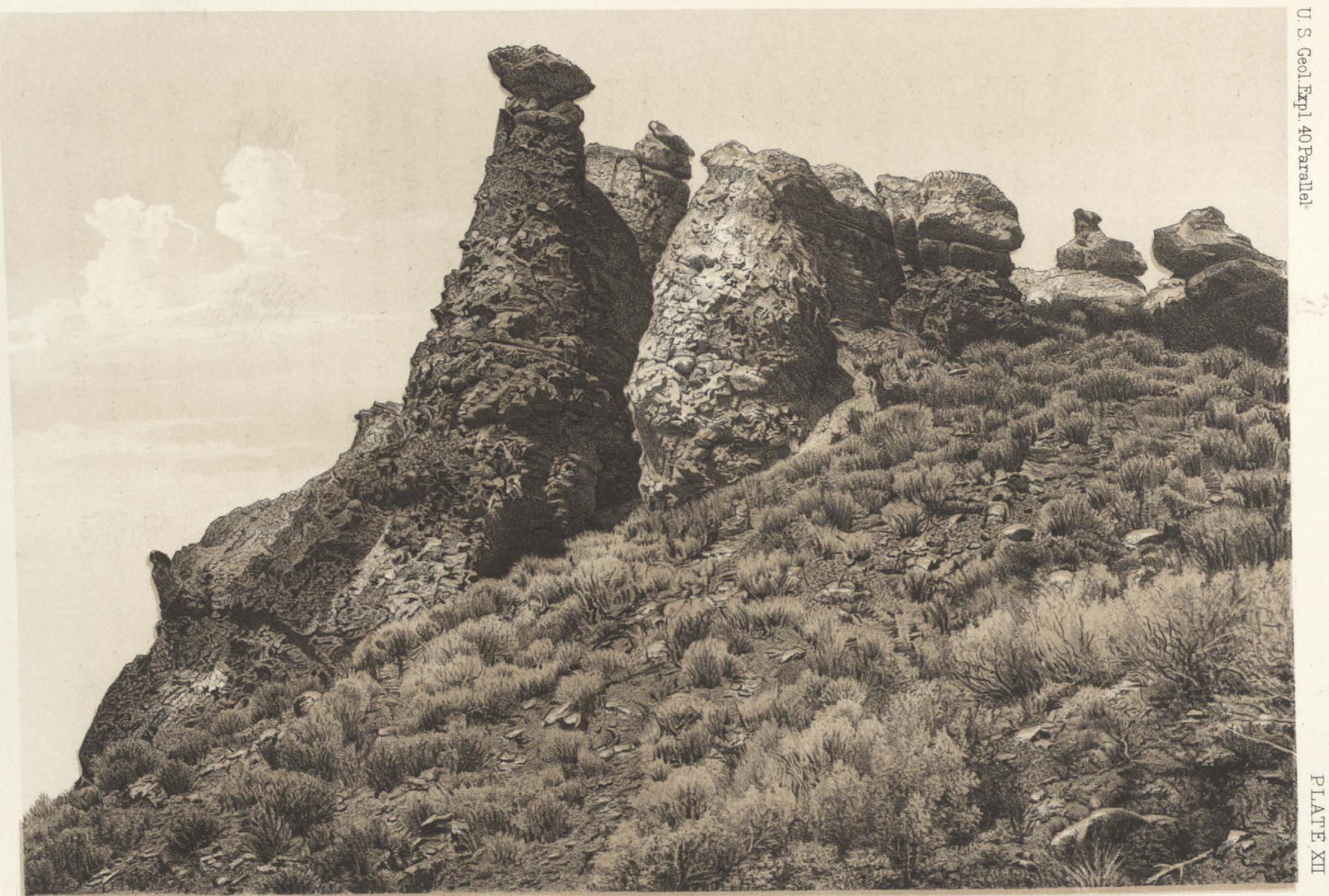

WITCHES' ROCKS - WEBER VALLEY_UTAH 


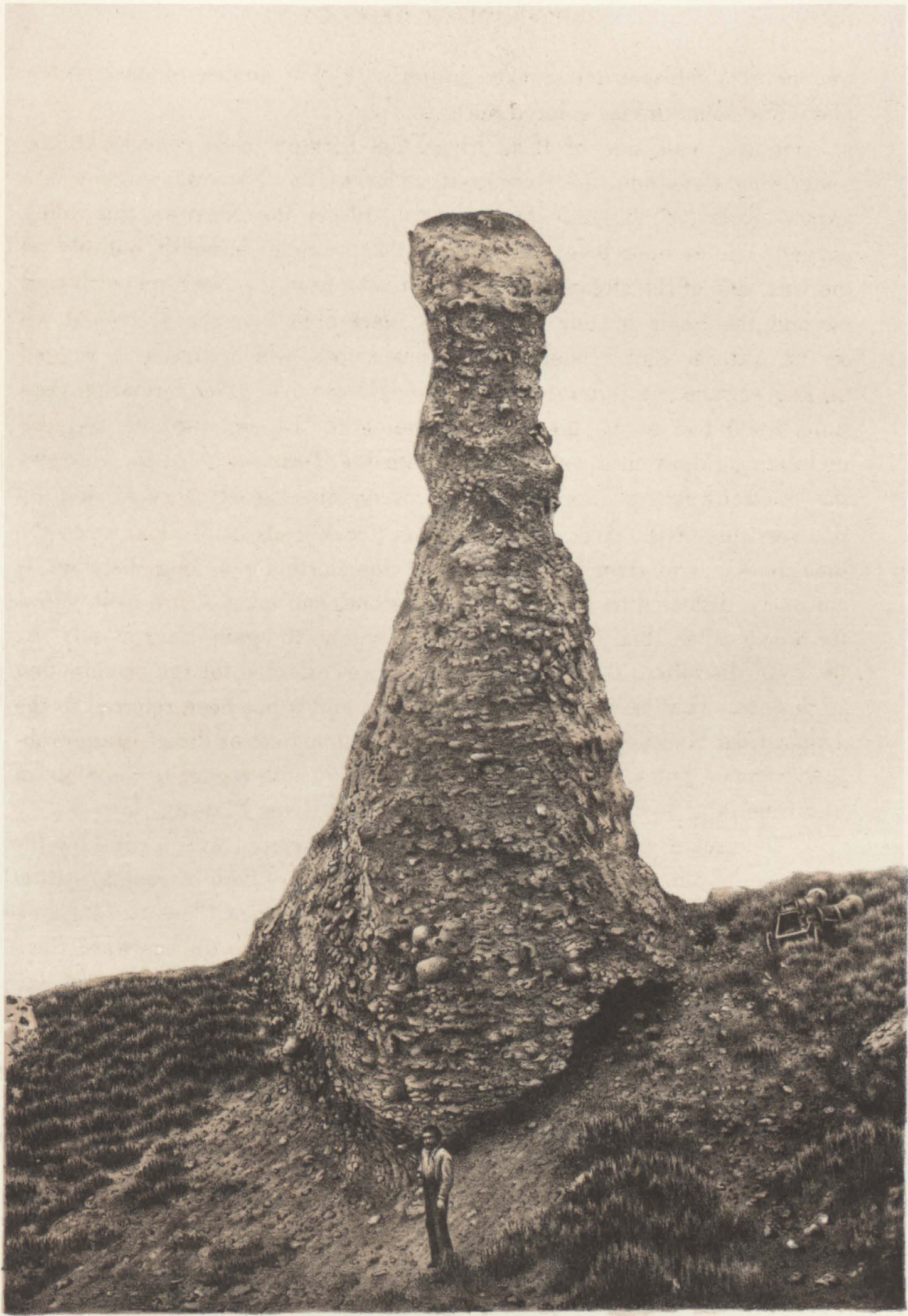




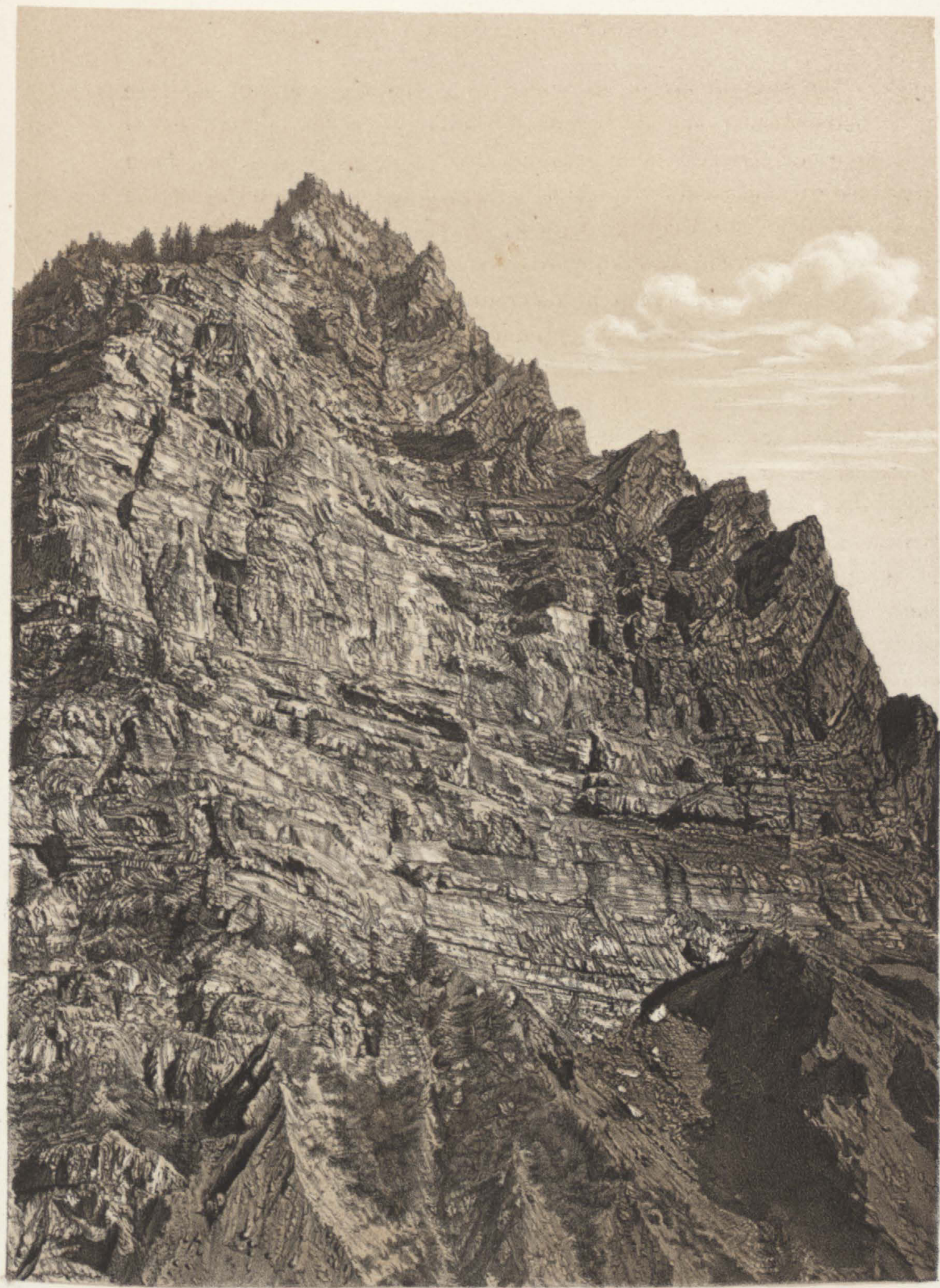




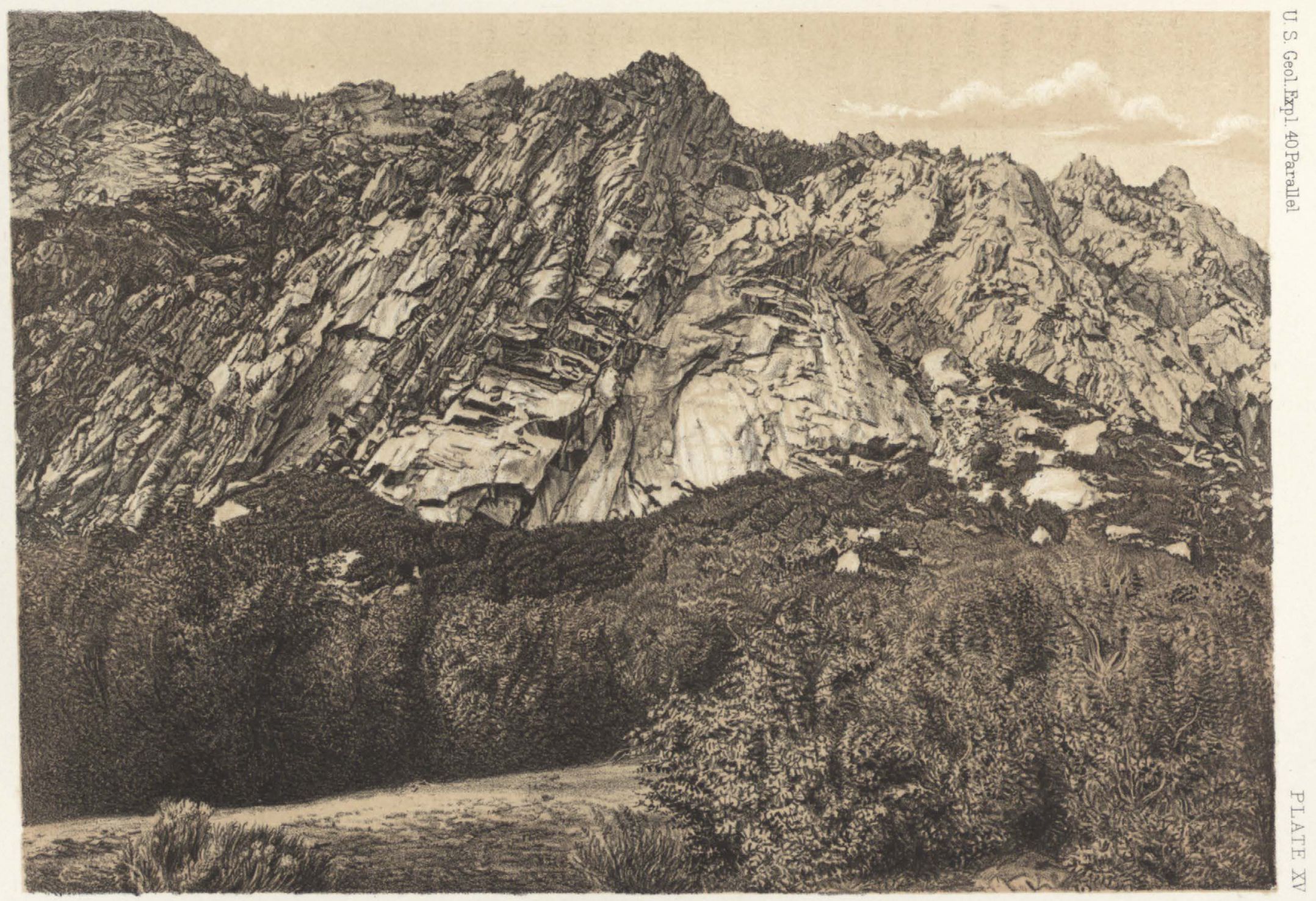

GRANITE LITTLE COTTONWOOD CANON WAHSATCH MTS 


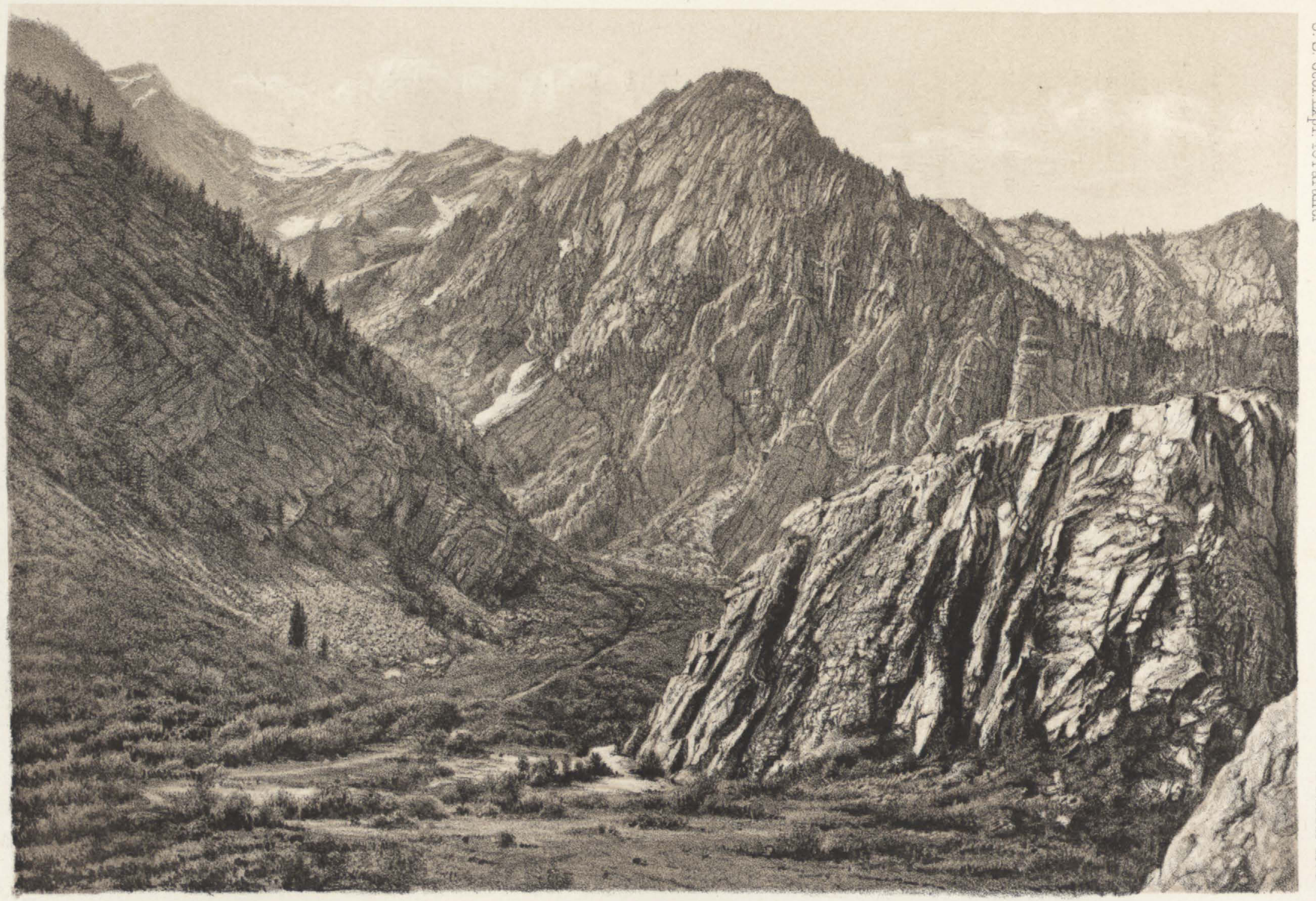

C.AMBRIAN ROCKS OF BIG COTTONWOOD CAÑON - WAHSATCH R.ANGE 


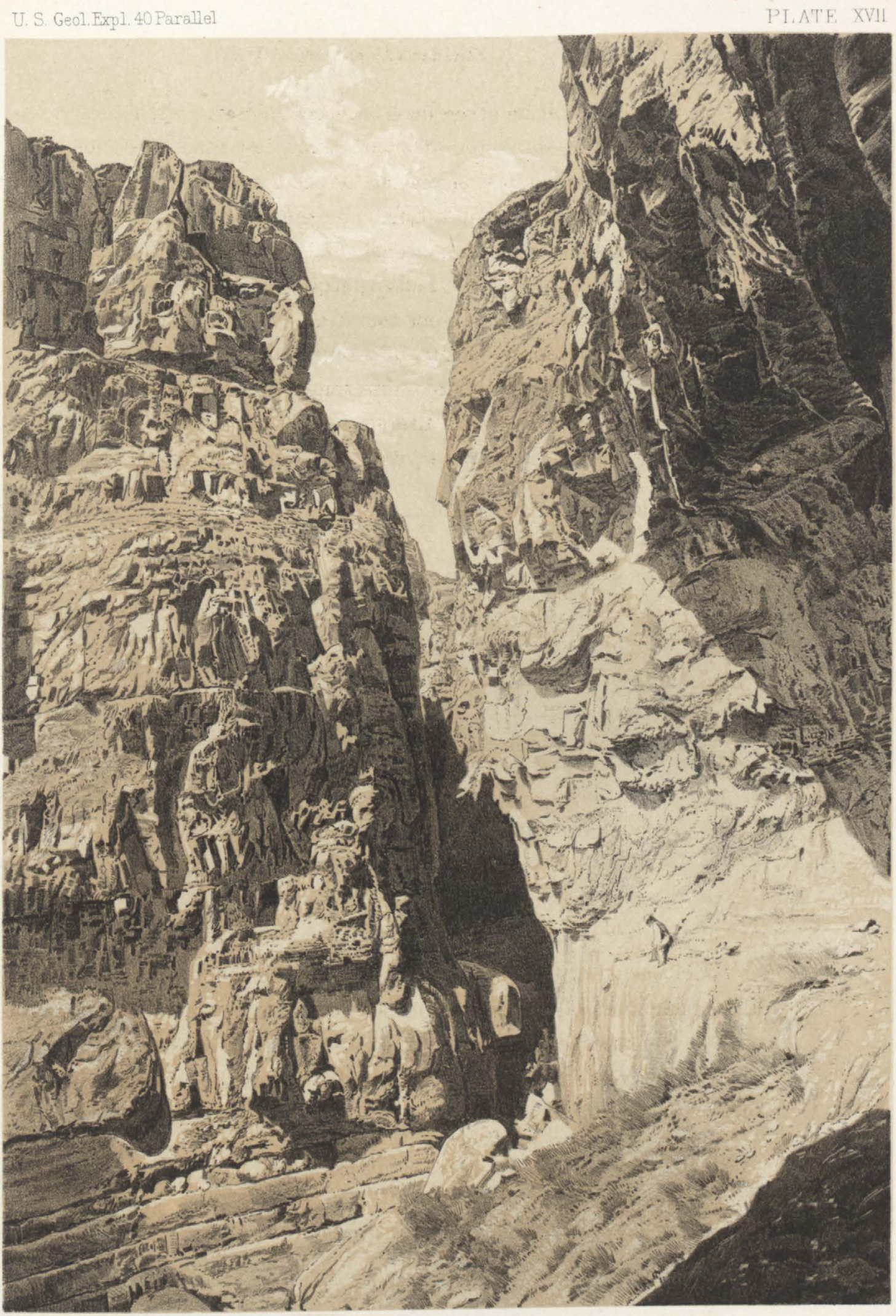

CAÑON IN LIMESTONES _ EAST HUMBOLDT MTS - NEVADA 


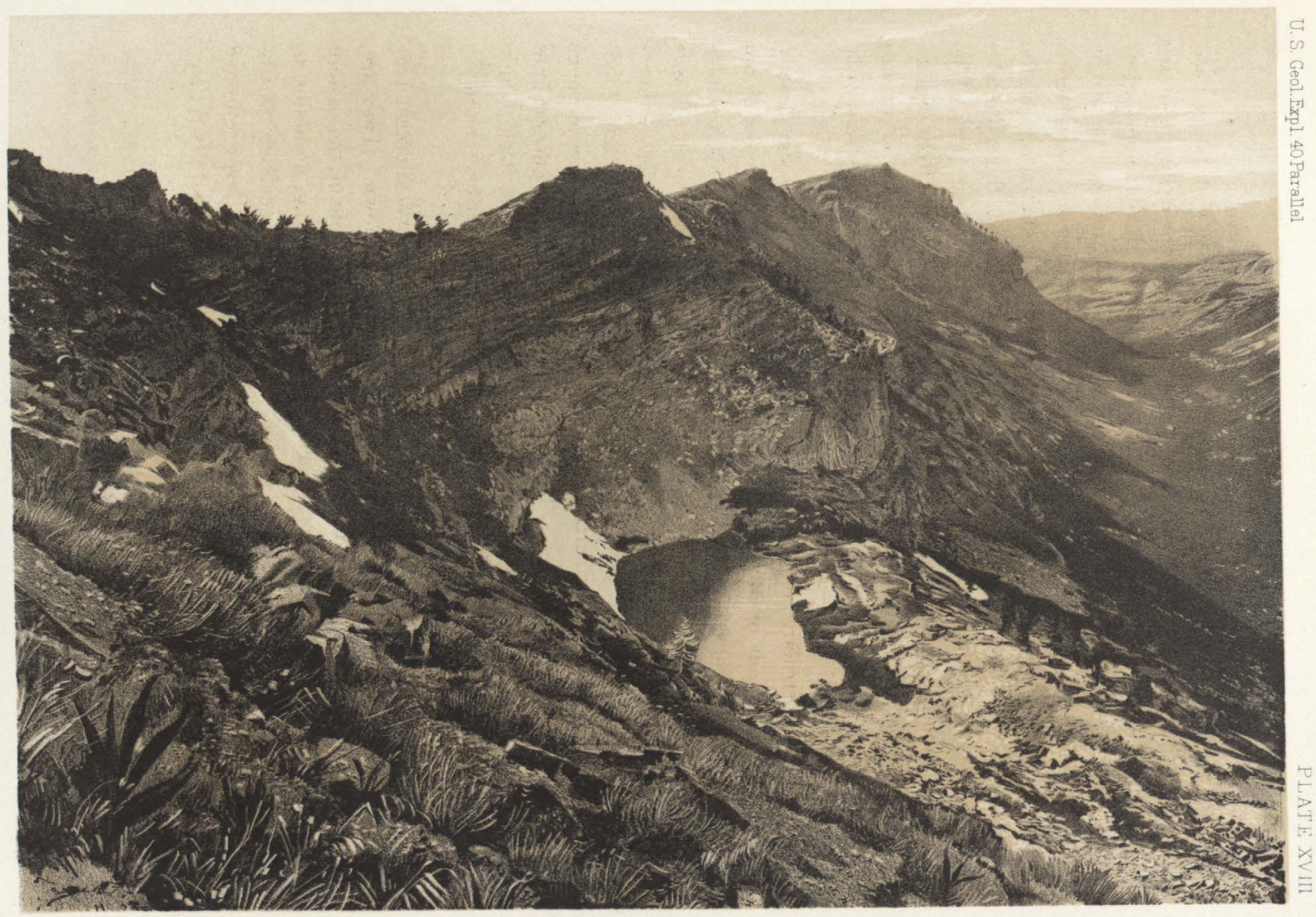

GLACIER CAÑON HUMBOLDT MTS _ NEAR CLOVER PEAK 


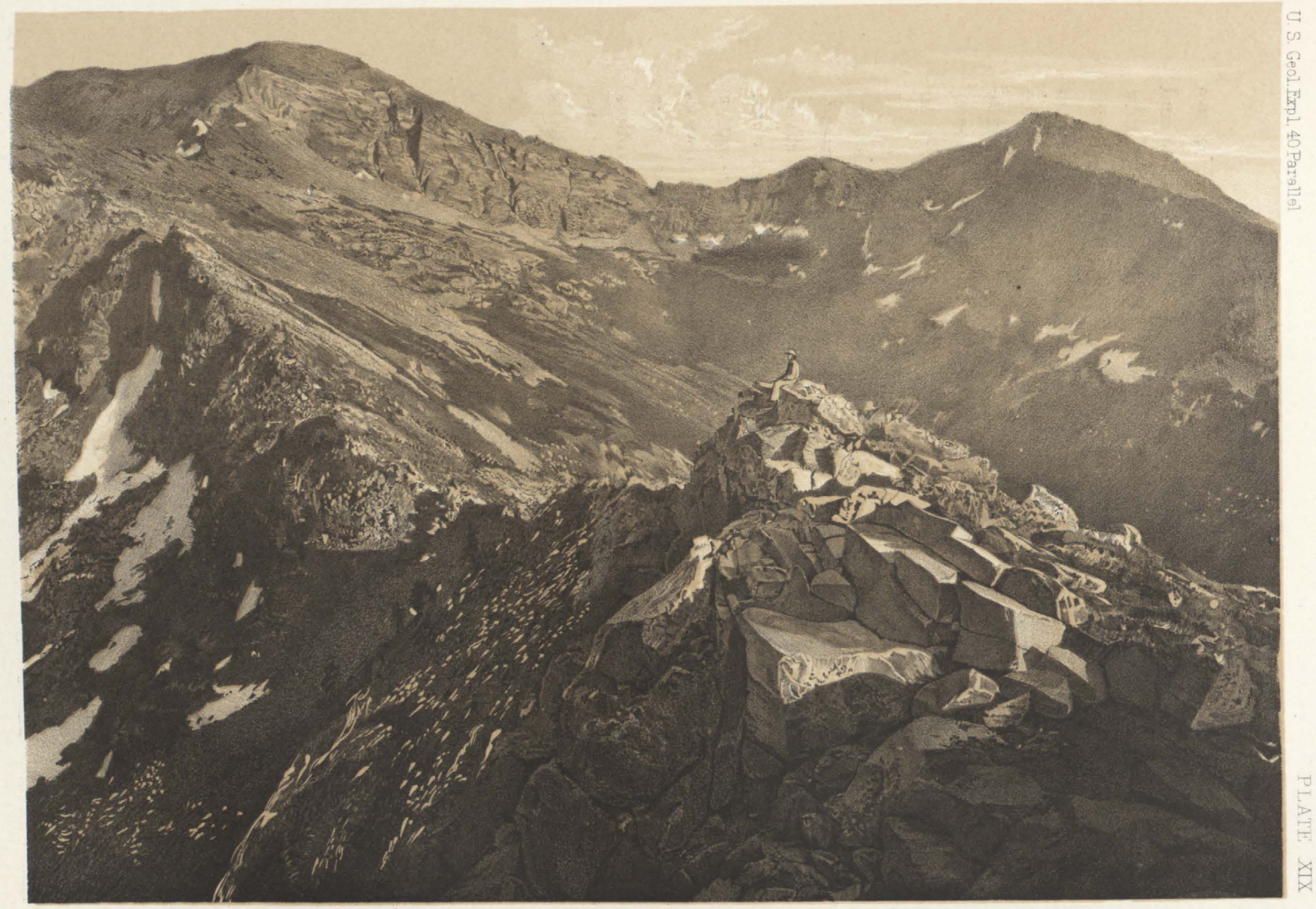

RIDGE OF ARCHAEAN QUARTZITE__HUMBOLDT RANGE 


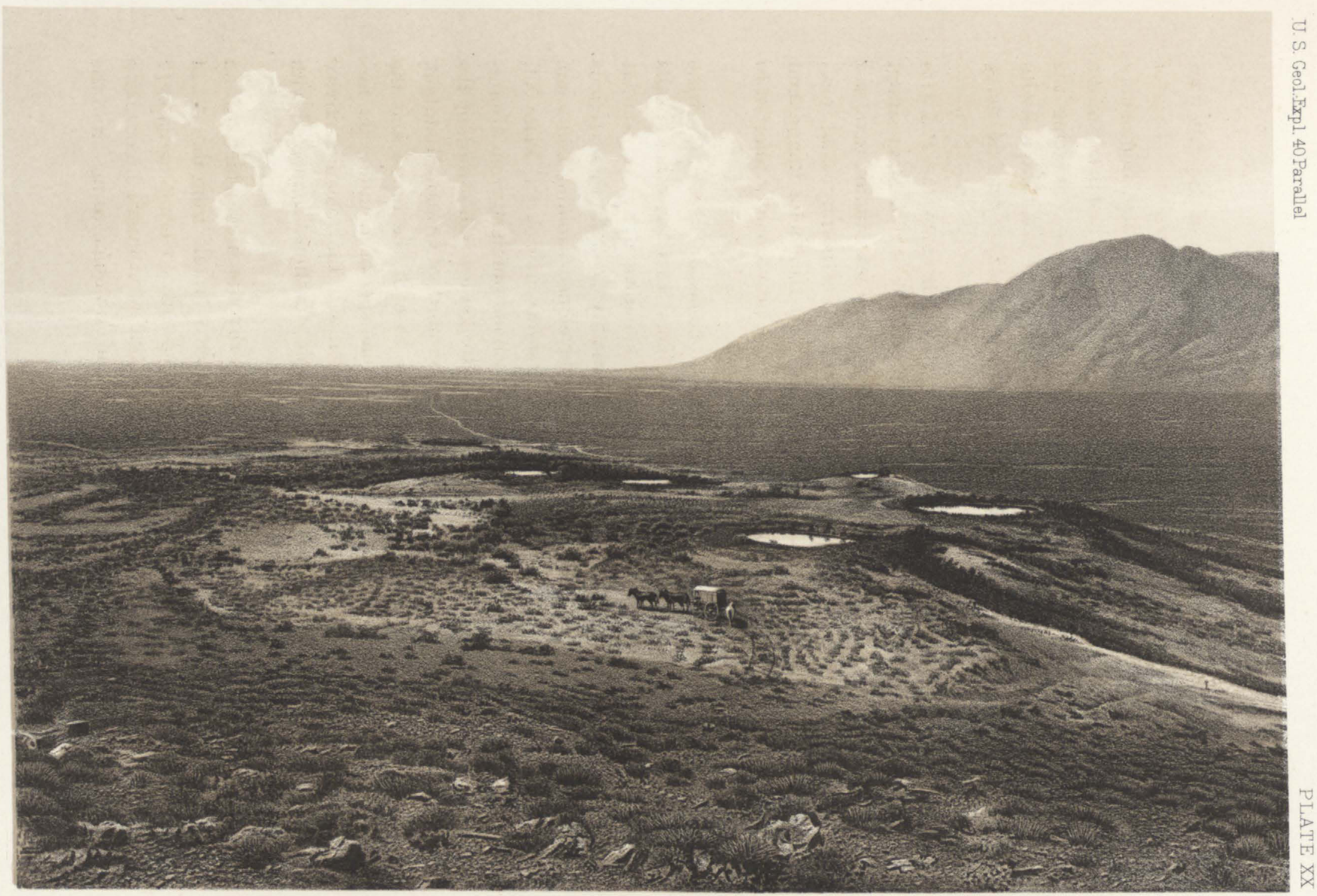

SOU SPRINGS _ OSOBB VALLEY _ NEVADA 


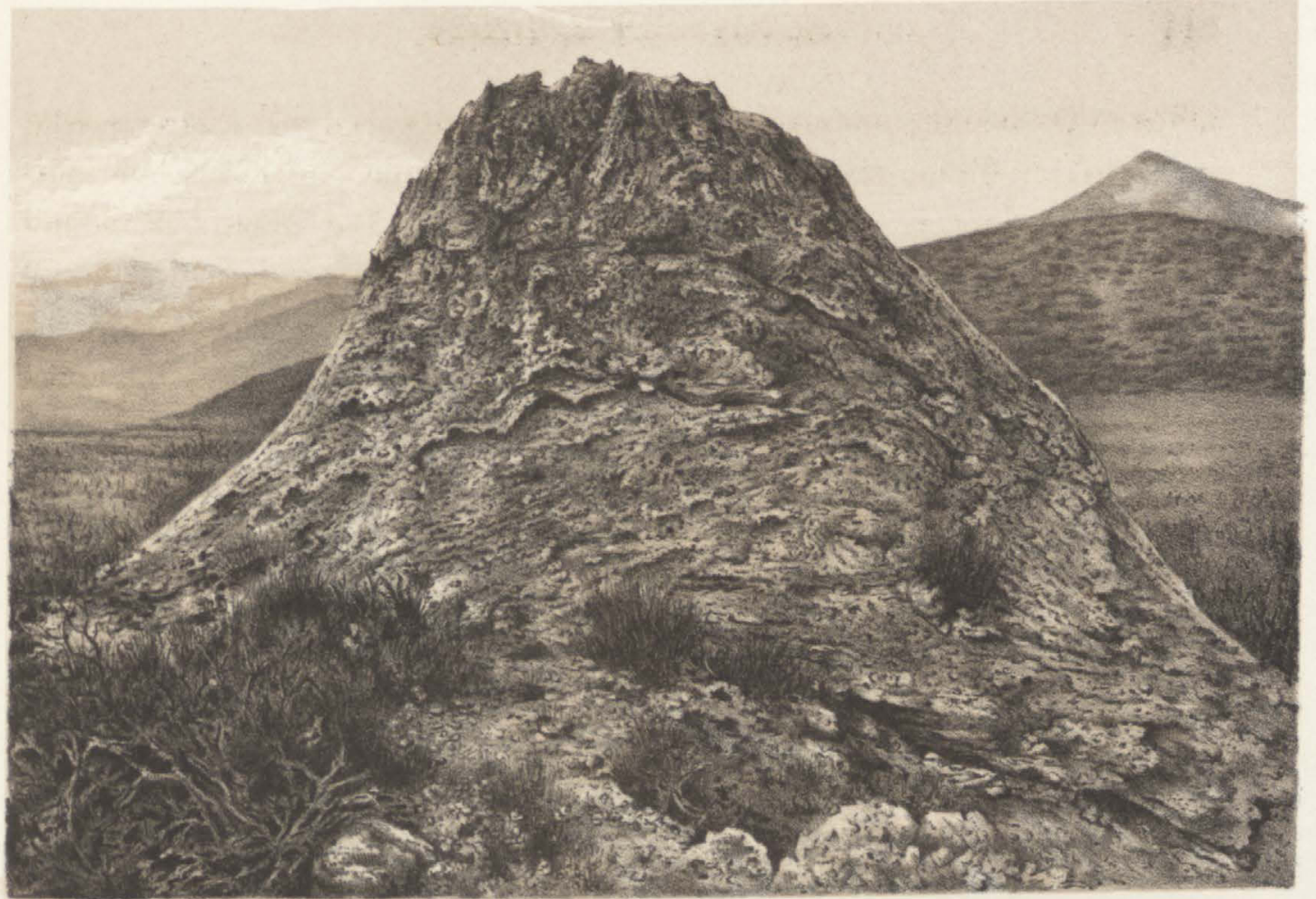

HOT SPRING TUFA CONE_PROVO VAIILEY - UTAH

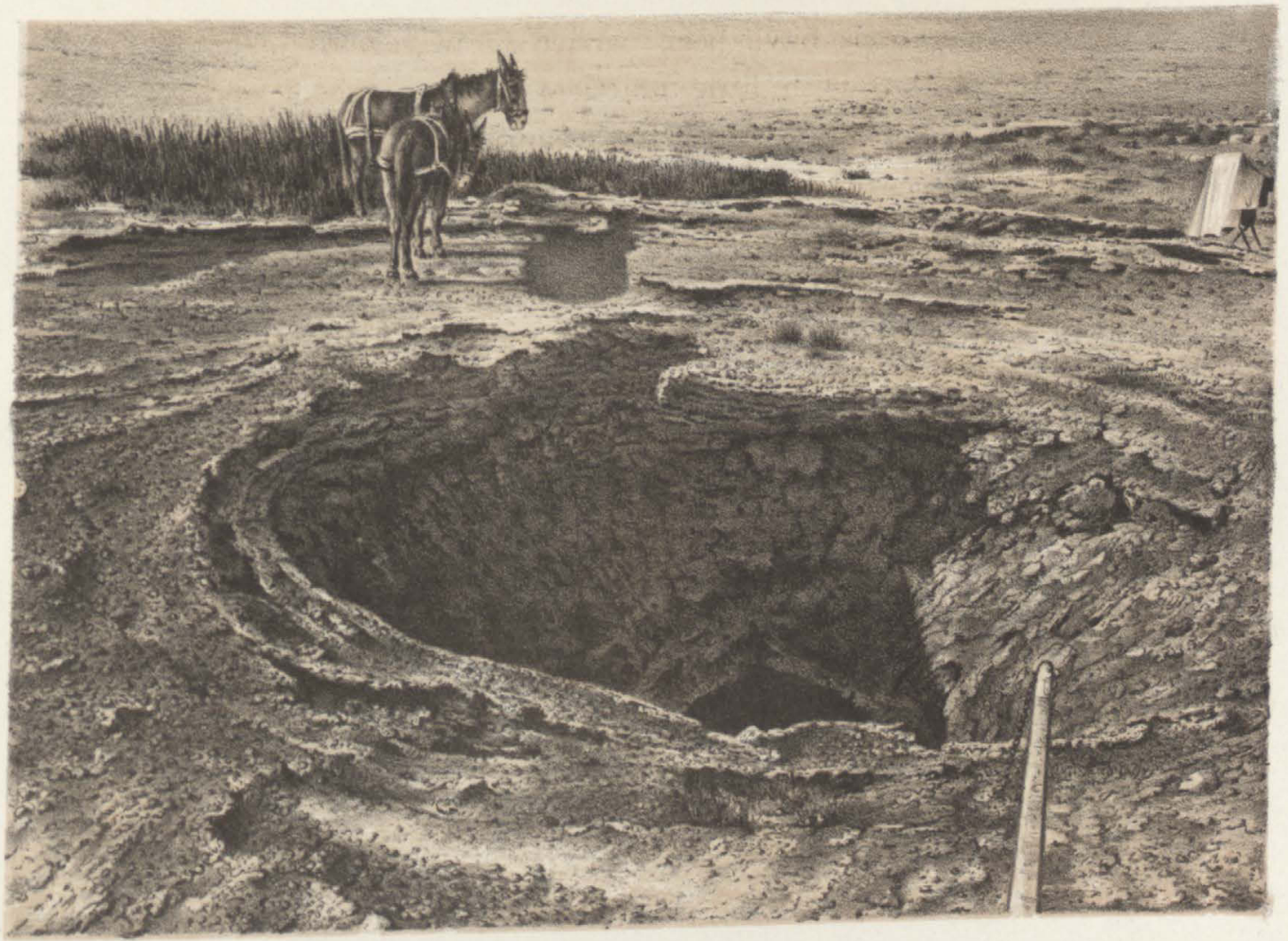




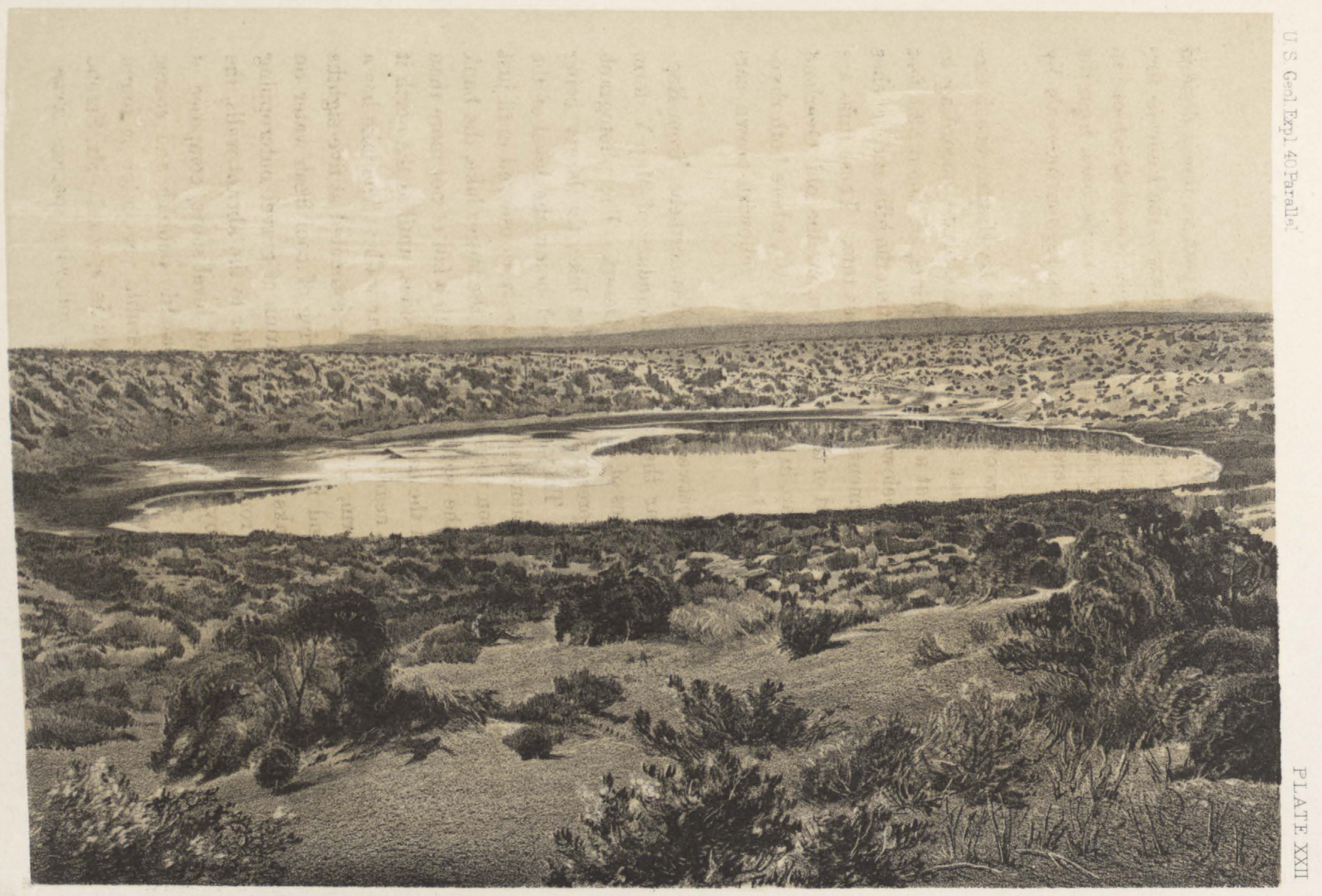

SODA L.AKE - CARSON DESERT - NEVADA . 


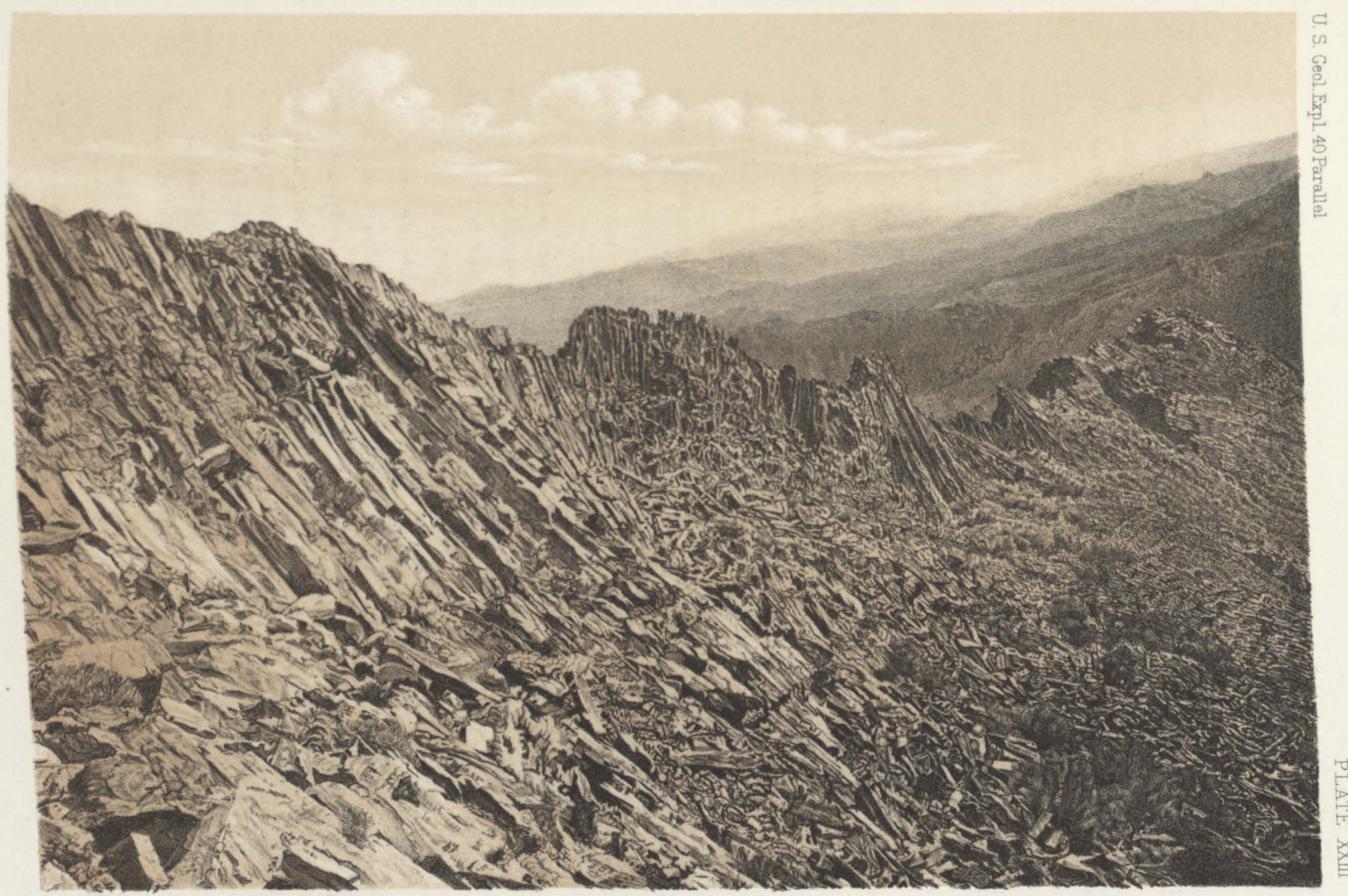

COLUMNAR RHYOLITE: KARNAK NEVADA 


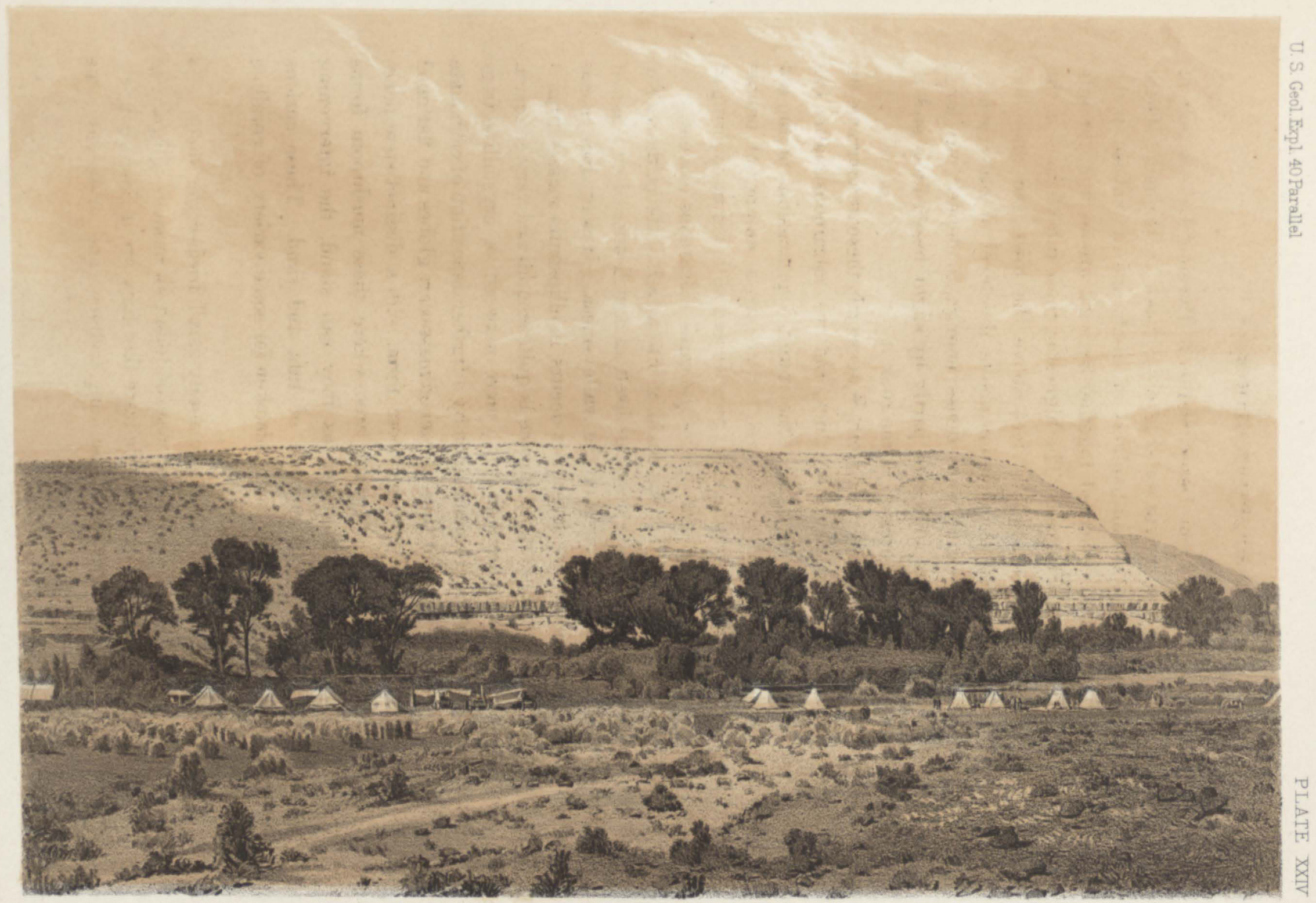

PLIOCENE BLUFFS - TRUCKEE RIVER, BELOW WADSWORTH - NEVADA 


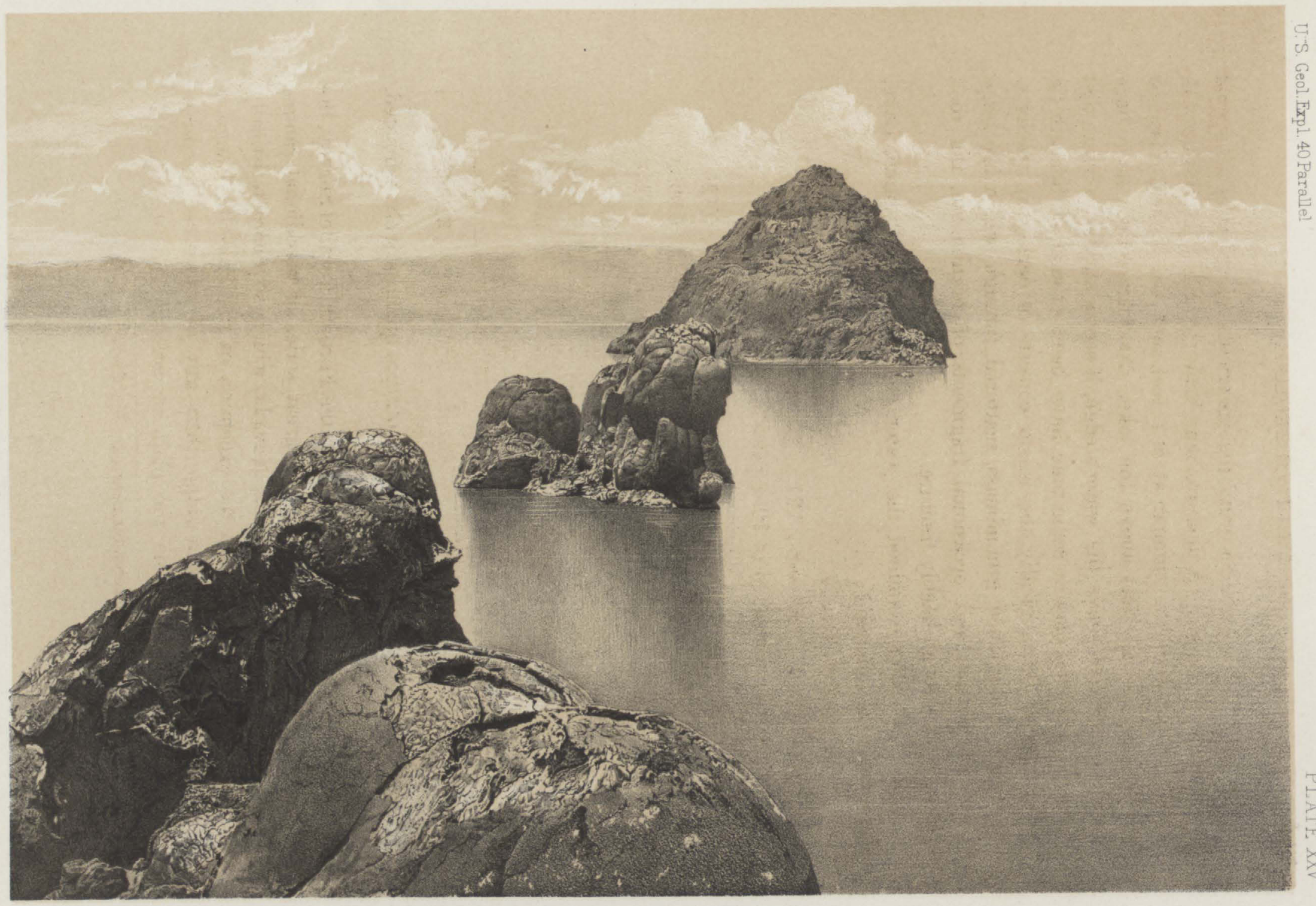

PYRAMID AND TUFA DOMES _ PYRAMID LAKE - NEVADA 